UNIVERSIDADE DE SÃO PAULO

INSTITUTO DE PSICOLOGIA

KAREN SCAVACINI

O suicídio é um problema de todos: a consciência, a competência e o diálogo na prevenção e posvenção do suicídio

São Paulo 
KAREN SCAVACINI

O suicídio é um problema de todos: a consciência, a competência e o diálogo na prevenção e posvenção do suicídio

Versão original

Tese apresentada no Instituto de Psicologia da Universidade de São Paulo, para obtenção do grau de Doutor em Psicologia.

Área de concentração: Psicologia Escolar e do Desenvolvimento Humano

Orientadora: Profa. Dra. Maria Júlia Kovács

São Paulo 
Scavacini, Karen

O suicídio é um problema de todos: a consciência, a competência e o diálogo na prevenção e posvenção do suicídio / Karen

Scavacini; orientadora Maria Júlia Kovács. -- São Paulo, 2018. $271 \mathrm{f}$.

Tese (Doutorado - Programa de Pós-Graduação em Psicologia Escolar e do Desenvolvimento Humano) -- Instituto de Psicologia, Universidade de São Paulo, 2018.

1. Suicídio. 2. Prevenção. 3. Posvenção. 4. Tabu. 5. Consciência. I. Kovács, Maria Júlia, orient. II. Título. 


\section{FOLHA DE APROVAÇÃO}

Nome: Scavacini, Karen

Título: O suicídio é um problema de todos: a consciência, a competência e o diálogo na prevenção e posvenção do suicídio

Tese apresentada ao Instituto de Psicologia da Universidade de São Paulo para obtenção do título de Doutor em psicologia

Aprovada em:

\section{Banca Examinadora}

Prof. Dr(a) Instituição:

Julgamento: Assinatura:

Prof. Dr(a) Instituição:

Julgamento: Assinatura:

Prof. Dr(a) Instituição:

Julgamento: Assinatura:

Prof. Dr(a) Instituição:

Julgamento: Assinatura:

Prof. Dr(a) Instituição:

Julgamento: Assinatura: 
Dedico esse estudo a todas as pessoas que foram tocadas pelo suicídio e aquelas que mesmo diante de tanta dor e sofrimento, continuam, dia após dia, a renascerem.

Dedico à minha amada filha e ao meu marido, que mesmo com a ausência sentida, entendem amorosamente o caminho que escolhi trilhar. 


\section{AGRADECIMENTOS}

Agradeço à minha querida orientadora, Maria Júlia Kovács, que acreditou no meu projeto, aceitou a mudança de tema, me deu liberdade de escrever e criar, pacientemente esperou os textos e competentemente me acompanhou nesse trajeto. Muito obrigada pelo carinho, compreensão e leitura cuidadosa desse estudo;

À minha amada filha Sofia e ao meu maridão André, que compreenderam a importância desse trabalho para mim e me apoiaram incondicionalmente, aguardando o término desse período. Que trazem sentido para os meus dias e me desafiam a ser cada vez melhor;

Aos meus pais, Laura e Sergio, que me deram a vida e me ensinaram tantas coisas, que me mostraram a importância das pessoas e o significado da empatia e compaixão;

À minha irmã gêmea, meus sobrinhos, e todos aqueles que vieram antes, que fazem parte da minha história e estarão sempre comigo;

Aos meus amigos queridos, que nunca deixaram de acreditar que seria possível, que me estimulam para sair da vida sedentária, me ajudam a esquecer o trabalho e celebrar à vida;

Ao meu terapeuta, figura querida, que tanto me ajudou, ouviu pacientemente minhas lamúrias sobre as dificuldades encontradas e vibrou comigo as conquistas no caminho;

Aos meus colegas de supervisão, pessoas especiais, unidas em torno de produzir pesquisa da melhor qualidade e com a bagagem cheia de sonhos e ideais. Obrigada pela ajuda;

Aos meus pacientes e aos participantes dos grupos de apoio, que confiam no meu trabalho, me deixam testemunhar suas histórias e dividem comigo sua dor e sua esperança;

A Mariana Cacciacarro, achado ímpar nesse trajeto, que me ajudou a desvendar a Teoria Fundamentada nos Dados segurou minha ansiedade enquanto desacreditei que o método funcionaria; 
A Rebeca Simão, revisora atenta e cuidadosa, que gosta de ajudar os outros a transformar em sentenças claras as ideias confusas que são colocadas no papel;

A Jussara Nathale, que transcreveu os grupos focais com empenho e em tempo recorde, para me ajudar a dar andamento ao trabalho;

Aos membros da banca de qualificação, Neury e Maria Helena, que olharam com cuidado o trabalho e gentilmente lançaram alguns desafios e ofertaram caminhos para que eu conseguisse chegar ao objetivo desse estudo;

A Luciana Cescon, que incansavelmente veio de Santos para São Paulo, por duas noites, para observar os grupos focais e me brindou com sua percepção aguçada;

À equipe do Instituto Vita Alere (Elis, Luciana e Izabela), que seguraram as pontas enquanto eu finalizava esse estudo e aceitaram navegar nesse mar agitado que é a prevenção do suicídio. Preparem-se, temos muito trabalho pela frente;

Aos amigos da diretoria da ABEPS, que dividem o mesmo ideal e trabalham unidos para mudar a situação crítica do suicídio no Brasil;

Agradeço a toda equipe do Espaço Natureza do Ser, gente iluminada que se uniu para fazer o bem e promover a cura, que acolhe e recebe a mim e a meus pacientes em São Paulo;

À banca de defesa por terem prontamente aceitado o convite e gentilmente cedido seu tempo para avaliarem esse trabalho;

Aos grupos de estudo, cursos, congressos, conversas... a todos aqueles que já cruzaram o meu caminho e trouxeram vida, significado, aprendizado, compartilhamento, união, bons momentos, risadas, amizade ... e amor!

Finalmente, aos colaboradores dessa tese, meu agradecimento especial, sem a gentil, corajosa e dolorosa abertura de suas histórias, esse trabalho não aconteceria. Minha grande admiração por toda a trajetória e ressignificação após o tsunami que é passar por um suicídio. 


\section{Alvará de demolição}

$\mathrm{O}$ que precisa nascer tem sua raiz em chão de casa velha. À sua necessidade o piso cede, estalam rachaduras nas paredes os caixões de janela se desprendem. o que precisa nascer aparece no sonho buscando frinchas no teto, réstias de luz e ar.

Sei muito bem do que este sonho fala

e a quem pode me dar peço coragem.

(Prado, 2011, p 37) 


\section{RESUMO}

Scavacini, K. (2018). O suicídio é um problema de todos: a consciência, a competência e o diálogo na prevenção e posvenção do suicídio (Tese de Doutorado). Instituto de Psicologia, Universidade de São Paulo, São Paulo.

O suicídio é um fenômeno complexo que constitui um grave problema de saúde pública, mobilizando estudos e programas de prevenção pelo mundo. O tabu impede que o suicídio seja tratado abertamente pela sociedade, ocasionando consequências negativas. $\mathrm{O}$ aumento da consciência é uma das maneiras de diminuí-lo. Partindo de grupos focais com sobreviventes enlutados pelo suicídio, objetivou-se compreender como o tabu, o estigma, a comunicação sobre o suicídio e a conscientização podem colaborar ou prejudicar a prevenção e a posvenção; com base nesses aspectos propomos procedimentos que possam aumentar a consciência sobre o assunto. Essa pesquisa, a partir da Teoria Fundamentada nos Dados (TFD), apresenta reflexões e sugestões de atuação para a ampliação da consciência da problemática do suicídio. Por meio da análise dos dados, três grandes temas foram encontrados: a compreensão (condição), a conscientização (interação) e a ação (consequência) que integram a ideia central de que o suicídio deve ser um problema de todos. O aumento da consciência pode gerar aumento da demanda por atendimento qualificado, sendo que é tarefa essencial encontrar locais acessíveis e habilitados para atender pessoas com ideação, tentativa de suicídio e familiares enlutados. Aumentar a consciência pública não é só prevenir suicídio, mas também promover mudança de atitude; para muitos, o suicídio continua sendo ficção até acontecer. Campanhas constituem uma das várias formas de atuação, mas devem ter objetivos claros. O aumento da conscientização (awareness) juntamente com o desenvolvimento da competência (suicide literacy) e a promoção do diálogo compõem os pilares necessários para a "tríade da mudança", que deve ser multifatorial, multissetorial e multidisciplinar. Foram apresentadas propostas envolvendo os 6Cs: Conscientização; Campanhas; Capacitação; Competência; Conversa e Conexão e as sugestões de intervenção foram separadas em: a) Conteúdo; b) Veículos para comunicação; c) Como; d) Quando; e) Por quem; f) Para quem; g) Provedores ou interessados; h) Desafios; i) Facilitadores; j) Outras ações. Essas propostas devem ser culturalmente adaptadas, planejadas e integradas com um plano abrangente de prevenção, sendo avaliadas por indicadores, além das taxas de mortalidade. Os colaboradores evidenciaram que ainda há muito tabu relacionado ao assunto, o que pode tornar-se um impeditivo para o cuidado e um multiplicador de estigmas e de preconceito, que estão em concordância com pesquisas internacionais sobre o tema. Além das propostas supracitadas, também sugerimos a utilização das caixas de medicamento como veículo para o aumento de consciência, o desenvolvimento dos grupos de apoio, o empoderamento das pessoas com a experiência vivida (lived experience), a criação de uma Associação Brasileira de Sobreviventes do Suicídio e de uma revista especializada no tema. Identificamos que aumentar a comunicação responsável, que faça sentido para as pessoas, tem importância fundamental para a sociedade e para aqueles que foram tocados por essa tragédia. No momento que a sociedade compreender e engajar-se em mudar esse fenômeno, novas estratégias de prevenção e de posvenção podem ser desenvolvidas.

Palavras-chave: Suicídio. Prevenção. Posvenção. Tabu. Consciência. 


\begin{abstract}
Scavacini, K. (2018). Suicide is everyone business: awareness, literacy and dialogue in suicide prevention and postvention. (Tese de Doutorado). Instituto de Psicologia, Universidade de São Paulo, São Paulo.
\end{abstract}

Suicide is a complex phenomenon that constitutes a serious public health problem, mobilizing studies and prevention programs around the world. The taboo prevents suicide from being openly treated by society, leading to negative consequences. Raising awareness is one way to reduce it. Starting from focus groups with suicide-bereaved survivors, the aim was to understand how taboo, stigma, suicide communication and awareness can collaborate or impair prevention and postvention; based on these aspects we propose procedures that can increase awareness on the subject. This research, based on the Grounded Theory (GT), presents reflections and suggestions for action to broaden the awareness of the problematic of suicide. Through the analysis of the data, three main themes were found: understanding (condition), awareness (interaction) and action (consequence) that integrate the central idea that suicide is everyone business. Increased awareness can generate increased demand for qualified care, and it is essential to find accessible and qualified places to assist people with ideation, suicide attempt and suicide loss survivors. Increasing public awareness is not only preventing suicide, but also promoting attitude change; for many, suicide remains fiction until it happens. Campaigns are one of several forms of action, but they must have clear objectives. Increasing awareness along with the development of the suicide literacy and the promotion of dialogue constitute the necessary pillars for the "triad of change", which must be multifactorial, multisectoral and multidisciplinary. Proposals were presented involving the 6Cs: Consciousness; Campaigns; Coaching; Competency; Conversation and Connectedness and the intervention suggestions were separated into: a) Content; b) Vehicles for communication; c) How; d) When; e) By whom; f) For whom; g) Providers or interested parties; h) Challenges; i) Facilitators; j) Other actions. These proposals should be culturally adapted, planned and integrated with a comprehensive prevention plan and evaluated by indicators, in addition to mortality rates. The collaborators showed that there is still a lot of taboo related to the subject, which can become an impediment to care and a multiplier of stigmas and prejudice, which are in agreement with international researches on the subject. In addition to the aforementioned proposals, we also suggest the use of medicine boxes as a vehicle for raising awareness, developing support groups, empowering people with lived experience, creating a Brazilian Suicide Survivors Association and a specialized journal in the subject. We have identified that increasing responsible communication, which makes sense to people, is of fundamental importance to society and to those who have been touched by this tragedy. The moment society understands and engages in changing this phenomenon, new strategies of prevention and of postvention can be developed.

Keywords: Suicide. Prevention. Postvention. Taboo. Awareness. 


\section{LISTA DE ILUSTRAÇÕES E DIAGRAMAS}

Figura 1 - Diagnósticos de transtornos mentais em casos de suicídio .....

Figura 2

Prevalência do comportamento suicida a cada 100 habitantes da cidade de Campinas

Figura 3

Principais fatores de risco para suicídio alinhados com intervenções relevantes

Figura 4

Crescimento estimado no número de sobreviventes enlutados pelo suicídio no Brasil de 2002 à 2012

Diagrama 1

- Compreensão

Diagrama 2

Esferas do Tabu

Diagrama 3

- Categoria Visão

Diagrama 4

Visão da sociedade

Diagrama 5

Comunicação

Diagrama 6

- Conscientização.

Diagrama 7

Ação

Diagrama 8

Campanhas

Diagrama 9

- Diálogo .

Diagrama 10

Quem

Diagrama 11

Categoria central

Figura 5

- Tríade da mudança

Figura 6

- Modelo de saúde pública

Figura 7

- Níveis de intervenção necessários em programas de conscientização

Figura 8 6C'S para aumentar a conscientização, diminuir o estigma e

Figura 9 prevenir o suicídio

Figura 10

- Como é dividido o "para quem" os conteúdos devem ser passados ..

- Protocolo para mensagens de sucesso

Diagrama 12

- Resumo das soluções propostas por esse estudo 


\section{LISTA DE IMAGENS}

Imagem 1 - Programa MAXQDA18 ………………………………….......... 72

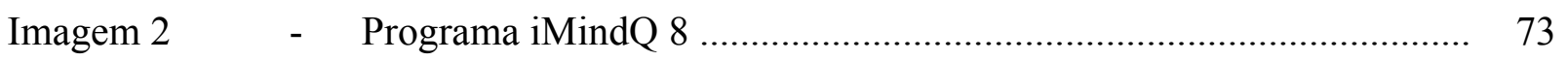

Imagem 3 - Visão geral das anotações .............................................................. 74

Imagem 4 - Codificação Axial I ………………………………………………. 74

Imagem 5 - Codificação Axial II .................................................................. 75

Imagem 6 - Codificação Axial III ...................................................................... 75

Imagem 7 - Codificação Axial IV …………………………………………... 76

Imagem 8 - Codificação Axial V ................................................................... 76

Imagem 9 - Codificação Axial VI .................................................................... 77

Imagem 10 - Codificação Axial VII ..................................................................... 77

Imagem 11 - Codificação Axial VIII ................................................................... 78 


\section{LISTA DE TABELAS}

Tabela 1 - Fatores de risco do comportamento suicida ..................................... 33

Tabela 2 - 10 Estados brasileiros com as maiores taxas de suicídio em 2012 .... 36

Tabela 3 - Metas e objetivos das Estratégias ...................................................... 44

Tabela 4 - Participantes do Estudo ...................................................................... 66

Tabela 5 - Exemplo de codificação aberta ........................................................... 70

Tabela 6 - Subcategorias, categorias e tema COMPREENSÃO ........................ 85

Tabela 7 - Conceitos e Subcategorias do Tabu ................................................... 86

Tabela 8 - Conceitos e subcategorias da Visão ................................................ 98

Tabela 9 - Experiência ........................................................................................ 121

Tabela 10 - Conscientização .......................................................................... 128

Tabela 11 - Consciência ............................................................................... 129

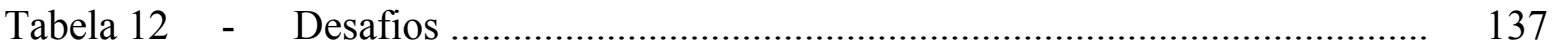

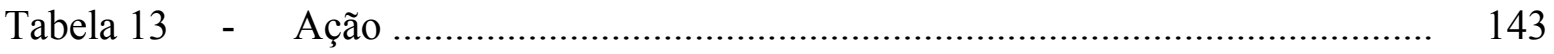

Tabela 14 - Conceitos e subcategorias do Diálogo ........................................... 151

Tabela 15 - Valores investidos em pesquisa no ano de 2013 nos Estados Unidos 180

Tabela 16 - Números de artigos com a palavra-chave suicídio nos jornais Folha de São Paulo e Estado de São Paulo; Revista Veja ............................ 191

Tabela 17 - Número de reportagens com a palavra chave suicídio por década, no Jornal "O Estado de São Paulo"

Tabela 18 - Componentes das Estratégias Nacionais de Prevenção do Suicídio ...

Tabela 19 - Conteúdos e/ou mensagens ............................................................ 215

Tabela 20 - Em que lugar ou veículos para comunicação ................................... 217

Tabela $21 \quad$ Sugestões de conteúdo para serem utilizados nas embalagens ........... 218

Tabela 22 - Como ou de que formas ................................................................. 220

Tabela 23 - Agentes ou pessoas que transmitem os conteúdos ........................... 220

Tabela 24 - Quando ou periodicidade …............................................................. 222

Tabela 25 - Esferas para conscientização ........................................................... 223

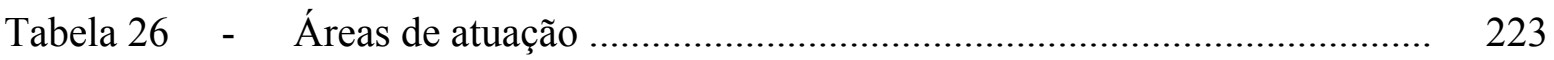

Tabela 27 - Público alvo ........................................................................... 225

Tabela 28 - Provedores e/ou interessados em aumentar a consciência pública ..... 226

Tabela 29 - Desafios para aumentar a consciência ............................................. 226

Tabela 30 - Facilitadores da conscientização ......................................................... 227

Tabela 31 - Outras ações para o aumento da consciência pública para o suicídio 227

Tabela 32 - Lista de controle para avaliação de campanhas .................................. 233 


\section{LISTA DE SIGLAS E ABREVIAÇÕES}

KI Karolinska Institutet

TOEFL Test of English as a Foreign Language

NASP Nationellt centrum för Suicidforskning och prevention av psykisk ohälsa

OMS Organização Mundial da Saúde

AIDS Aquired Immunodeficiency Syndrome

CVV Centro de Valorização da Vida

TFD Teoria Fundamentada nos Dados

GT Grounded Theory

IS Interacionismo Simbólico

CID Classificação Estatística Internacional das Doenças

MS Ministério da Saúde

OPAS Organização Panamericana de Saúde

SPRC Suicide Prevention Resource Center

UNICAMP Universidade Estadual de Campinas

AFSP American Foundation Suicide Prevention

GBD Global Burden of Disease

DAYL'S Disability Ajusted Life Years

YLL Years os Life Lost

IHME Institute of Health Metrics and Evaluation

IPEA Instituto de Pesquisa Econômica Aplicada

IASP International Association for Suicide Prevention

AAS American Association of Suicidology

IASR International Academy of Suicide Research

AFSP American Foundation for Suicide Prevention

ASR Archives of Suicide Research

UN Nações Unidas

REBRAPS Rede Brasileira de Prevenção do Suicídio

ABEPS Associação Brasileira de Estudos e Prevenção do Suicídio

TCLE Termo de Consentimento Livre e Esclarecido

LGBT Lésbicas, Gays, Bissexuais, Travestis, Transexuais e Transgêneros

SL $\quad$ Suicide Literacy

MHL Mental Health Literacy 
HL Health Literacy

IL Information Literacy

NESP National Estrategy for Suicide Prevention

USFSPP United States Fource Suicide Prevention Program

ELA Esclerose Lateral Amiotrófica

SOSS Stigma of Suicide Scale

CAPS Centro de Apoio Psico Social

SUS Sistema Único de Saúde

UPA Unidade de Pronto Atendimento

UBS Unidade Básica de Saúde

CRP Conselho Regional de Psicologia

USP Universidade de São Paulo

TCC Trabalho de Conclusão de Curso

SAVE Suicide Awareness Voices of Education

ENPS Estratégia Nacional de Prevenção do Suicídio

YAM Youth Aware of Mental Health

SEYLE Saving and Empowering Young Lives in Europe

IML Instituto Médico Legal

ONGS Organização Não Governamental

ASEC Associação pela Saúde Emocional da Criança

QPR Question, Persuade and Refer

APOIAR Aprender, Perguntar, Incluir, Agir, Reconectar

IA Inteligência Artificial

SOQ Suicide Opinion Questionaire 


\section{SUMÁRIO}

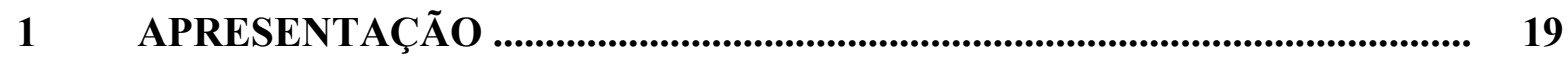

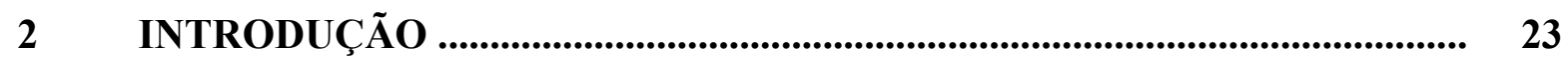

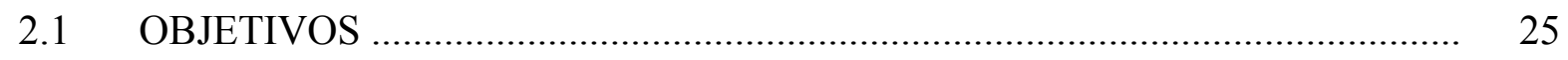

2.2 ORGANIZAÇÃO DESSE ESTUDO ……………....................................... 25

3 FUNDAMENTAÇÃO TEÓRICA ................................................................. 27

3.1 CONCEITOS E DEFINIÇÕES DE SUICÍDIO .................................................. 27

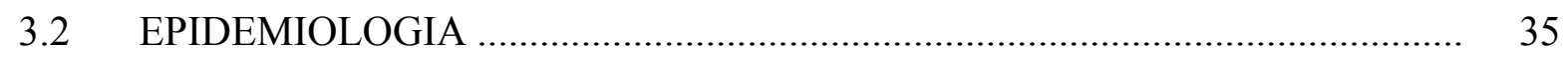

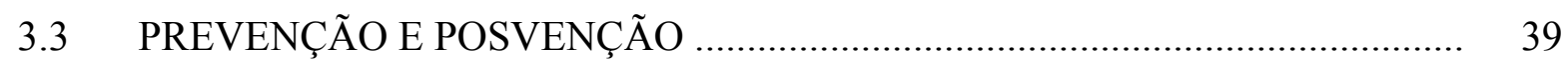

3.3.1 Prevenção ................................................................................................ 39

3.3.2 Prevenção do suicídio ..................................................................................... 41

3.3.3 Luto por suicídio ................................................................................... 46

3.3.4 Posvenção ............................................................................................. 49

3.4 TABU, ESTIGMA, PRECONCEITO E DISCRIMINAÇÃO ............................. 52

3.5 CONSCIÊNCIA (awareness) ...................................................................... 54

3.6 COMPETÊNCIA (literacy) ........................................................................ 55

$4 \quad$ MÉTODO _.......................................................................................... 57

4.1 REFERENCIAL TEÓRICO: INTERACIONISMO SIMBÓLICO (IS) .............. 58

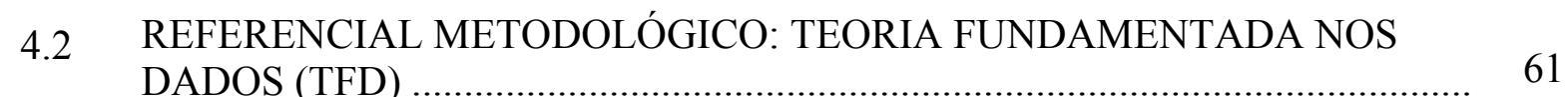

4.3 PROCEDIMENTO METODOLÓGICO …………………………………….... 63

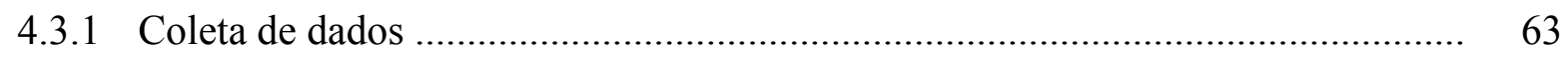

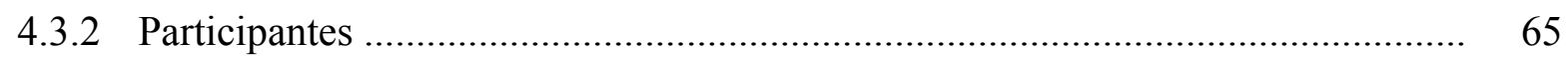

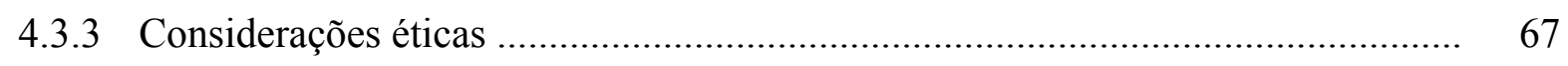

4.4 PERCURSO METODOLÓGICO: CODIFICAÇÃO ........................................... 69

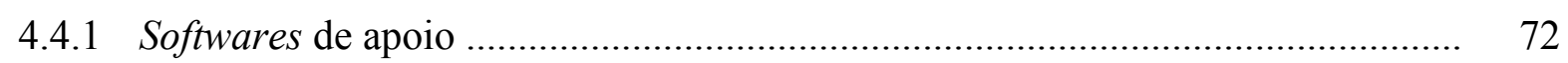

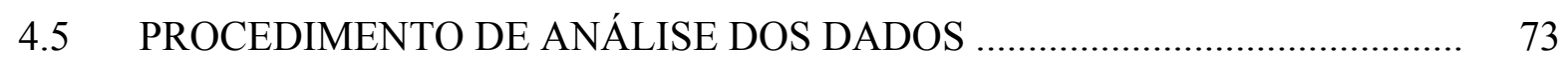

4.6 DIÁRIO DE BORDO METODOLÓGICO …………………………………...... 78

5 ANÁLISE DOS DADOS OU TEORIA EM CONSTRUÇÃO ......................... 83

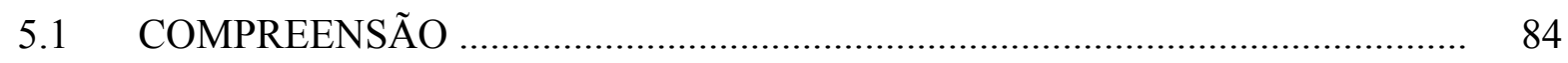

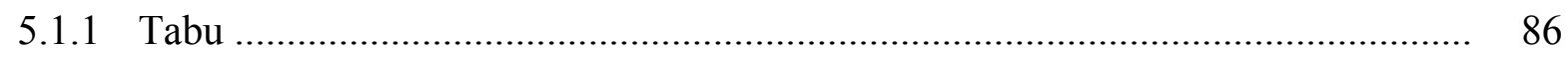

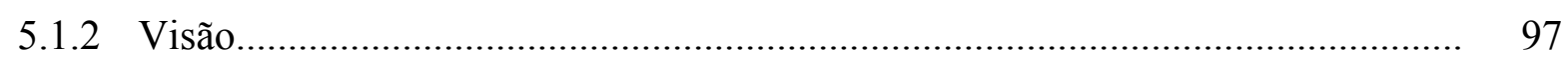

5.1.3 Comunicação .............................................................................................. 105 


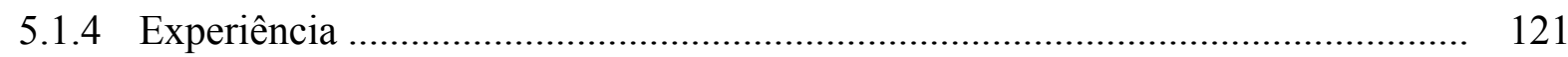

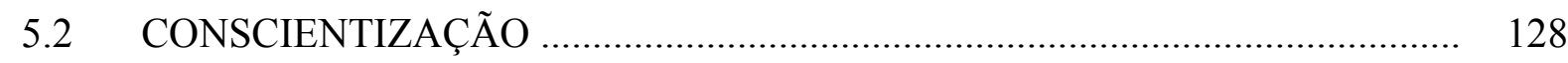

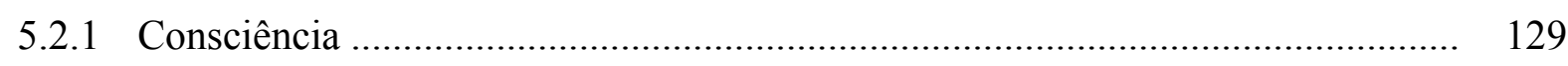

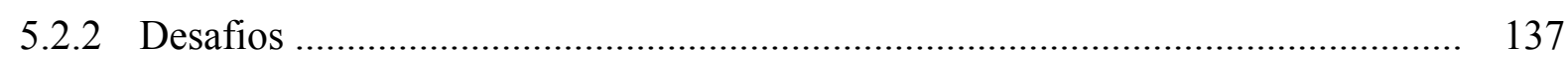

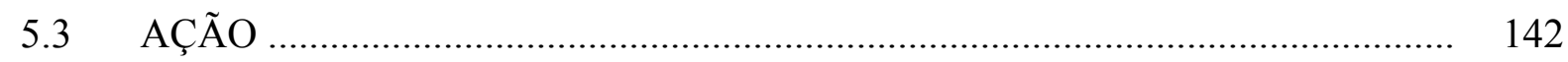

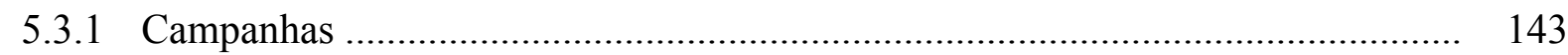

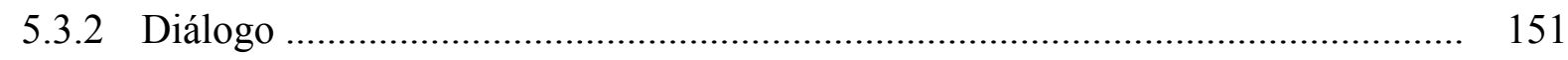

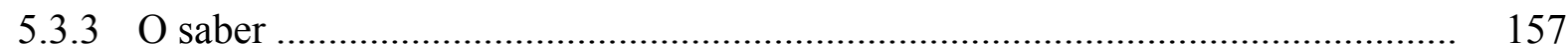

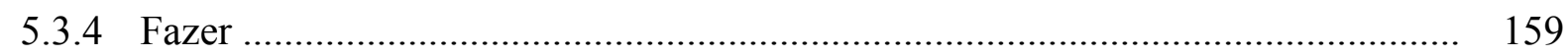

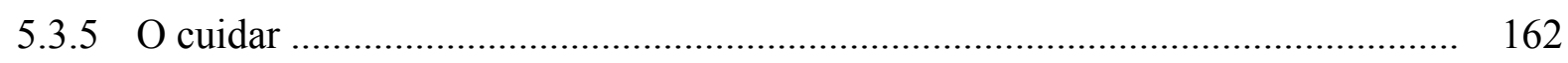

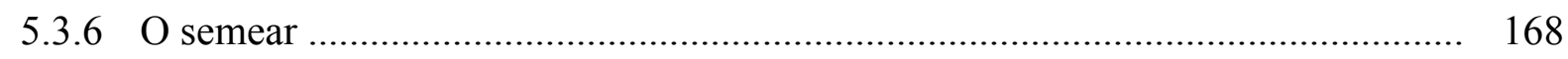

6 TEORIA FUNDAMENTADA NOS DADOS ................................................... 171

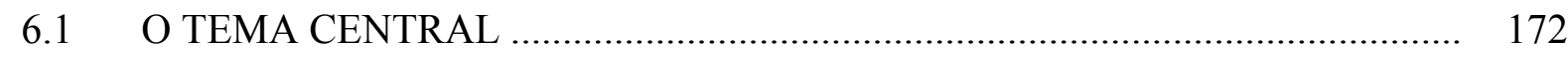

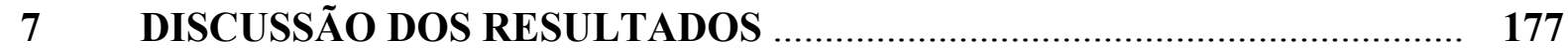

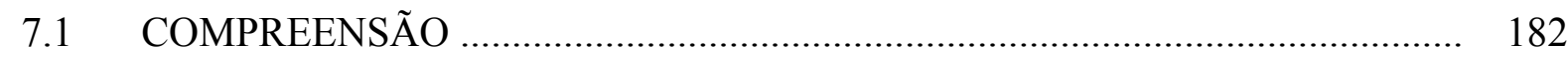

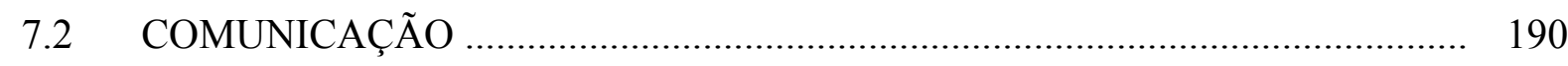

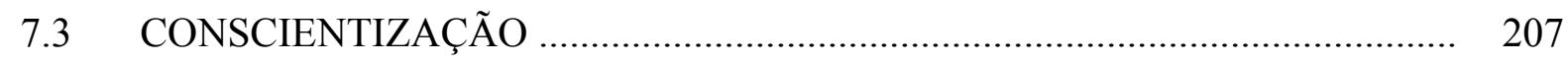

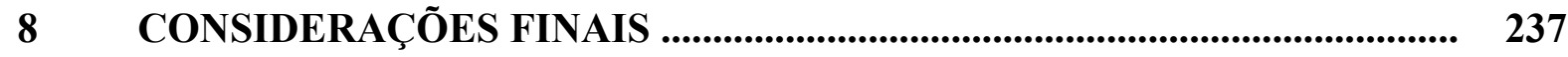

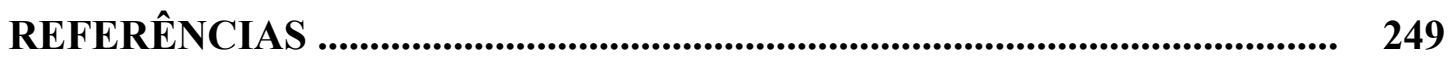

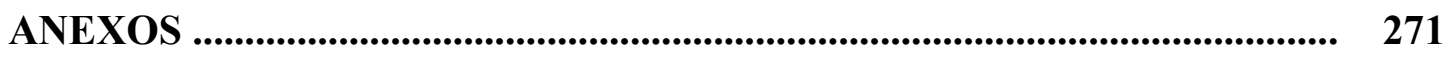

Anexo A - Roteiro Norteador do Grupo Focal . ............................................ CD

Anexo B - Termo de Consentimento Livre e Esclarecido (TCLE) ……............. CD

Anexo C - Transcrição do Grupo Focal encontro 1 .......................................... CD

Anexo D - Transcrição do Grupo Focal encontro 2 …................................... CD

Anexo E - Roteiro de Perguntas C1 ......................................................... CD

Anexo F - Roteiro de Perguntas C9 …...................................................... CD

Anexo G - Transcrição da entrevista piloto para qualificação ............................. CD

Anexo H - Relato da Observadora …………................................................. CD

Anexo I - Codificação Grupo Focal 1 .......................................................... CD

Anexo J - Codificação Grupo Focal 2 ........................................................... CD

Anexo K - Codificação Roteiro de Perguntas C1 ............................................ CD

Anexo L - Codificação Roteiro de Perguntas C9 ............................................. CD

Anexo M - Visão Geral das Anotações (memos) .............................................. CD 
Anexo N - Tabela dos Códigos ................................................................ CD

Anexo O - Diário de Bordo ........................................................................ CD

Anexo P - Segmentos Codificados ............................................................. CD

Anexo Q - Colaboradores .................................................................. CD

Anexo R - Parecer Consubstanciado do CEP .................................................. CD 


\section{APRESENTAÇÃO}

$\mathrm{Na}$ tentativa de contextualizar os objetivos dessa pesquisa e os caminhos que me trouxeram até ela, conto um pouco da minha trajetória.

No ano de 2008 fomos morar na Suécia, meu marido teve uma proposta de trabalho interessante e resolvemos encarar o desafio pela segunda vez, pois já havíamos morado em Estocolmo em 2001. Seria um bom período para cuidar da nossa primeira filha que havia nascido em julho 2007. Finalizei os atendimentos no consultório, dei à luz e com uma bebê de seis meses chegamos ao inverno sueco. Como todo estrangeiro em uma terra diferente, a adaptação não foi nada fácil.

O tempo passou e como escreve Camus "e no meio de um inverno eu descobri que existe em mim um invencível verão" (1991, p. 169), havíamos nos adaptado ao novo lar. Quando nossa filha entrou na escolinha, comecei a pesquisar o que poderia fazer profissionalmente na Suécia, então conheci o Mestrado em Saúde Pública do Karolinska Intitutet (KI), que era ministrado em inglês.

Foi um bom tempo me dividindo entre os cuidados com a casa, família e os estudos para o Test of English as a Foreign Language (TOEFL) - uma prova extensa para avaliar o nível de inglês de candidatos estrangeiros e obrigatória para a seleção do mestrado. TOEFL aprovado, apliquei para a seleção, algumas semanas depois, recebi a tão esperada notícia que havia sido aprovada para o mestrado na área de prevenção do suicídio e promoção de saúde mental. Foi um momento de intensa alegria e emoção, a profissional poderia renascer após a maternidade.

O curso seria oferecido pela Faculdade de Saúde Pública em associação com o "Nationellt centrum för Suicidforskning och prevention av psykisk ohälsa” (NASP, Centro nacional de pesquisas sobre o suicídio e prevenção da doença mental, tradução nossa). Éramos doze alunos de várias nacionalidades, somente eu era do Brasil.

Depois de recebermos os conhecimentos básicos em saúde pública com os alunos das outras áreas, o mestrado tinha mais duas "especialidades", nutrição e economia em saúde; começamos a aprofundar-nos no assunto com professores que eram referência em toda a Europa. Tínhamos aulas em uma casinha vermelha perto de um bosque, na biblioteca do NASP, um local muito simpático, no qual o cheio de café da copa perfumava as aulas de tempos em tempos, com uma grande mesa oval no meio. Em volta havia paredes cheias de livros sobre suicídio e luto, ao mesmo tempo cheio de vida, ideias e esperança. Éramos estudantes com vontade de fazer a diferença. Estávamos no auge da crise econômica da Europa, quando a Organização Mundial da Saúde (OMS) organizou, juntamente com o KI, o simpósio sobre 
suicídio em tempos de recessão econômica, no parlamento de Estocolmo, no qual pudemos compreender um pouco mais sobre os aspectos multifatoriais do suicídio e conhecer profundamente a extensão do problema, os esforços para entendê-lo e as atividades propostas para diminuir os índices, ajudar as pessoas e países a lidarem com essa situação.

Conforme fui aprofundando os estudos, comecei a ficar cada vez mais interessada e intrigada com o fato de não ter tido uma aula sequer de prevenção do suicídio na faculdade. Durante um exercício proposto, foi pedido que lembrássemos o que sabíamos sobre o suicídio, que histórias escutamos. Lembrei-me das pessoas que eu havia conhecido ou que havia ouvido falar, que tinham se matado, além de uma cliente que tentou o suicídio no meu consultório, que, por estar em um ambulatório médico, foi atendida a tempo. Lembro-me da minha reação e todo o nervosismo que senti quando ela foi embora, também quando voltou na sessão seguinte. Ficou evidente a minha falta de preparo para lidar com a situação.

Comecei a perguntar a meus colegas se eles já tinham conhecido alguém que havia se matado e para o meu espanto, absolutamente TODOS já tinham conhecido ou ouvido falar. Perguntei sobre homicídio, muitos não conheciam ninguém que tinha sido assassinado, mas conheciam pessoas que tinham tentado ou se matado. Para minha surpresa, lembrei de pelo menos umas seis pessoas que tinham cometido suicídio, a meu ver esse não era um número baixo. Continuei fazendo essa pergunta para muitas pessoas em grupos, cursos e em congressos, a resposta era sempre muito parecida, praticamente todas as pessoas sabiam de casos de suicídio e menos da metade de casos de homicídio. Compreendi então como esse fenômeno está tão mais perto de nós que imaginamos e nem sequer tocamos nesse assunto.

Em um dia comum de aulas, uma elegante senhora chegou à sala de aula, preparou os materiais, começou a se apresentar, era uma neurocientista que conduzia diversas pesquisas na universidade. Após falar uns cinco minutos sobre sua carreira acadêmica, disse: "mas não estou aqui pelo o que fiz, estou aqui porque perdi uma filha por suicídio há quinze anos, que teve diversas tentativas, de todas as maneiras que vocês possam imaginar por mais de dez anos", finalizou. Ficou sabendo do suicídio da filha ao receber um telefonema do hospital, perguntando se ela aceitava doar os órgãos, porém até aquele momento ainda não sabia que a filha havia morrido. Ela nos descreveu o choque devido à morte e à forma como a notícia foi dada.

Fiquei imaginando como foi para a família lidar com aquela situação e o comportamento da filha por tantos anos. Fiquei muito tocada ao perceber que mesmo após quinze anos, aquela senhora ainda tremia e sua voz ficava fraca ao nos contar o que aconteceu, mais ainda ao saber que mesmo dentro de uma universidade de ponta na área da saúde, somente dois colegas de seu departamento, que contava com mais de vinte pessoas, foram conversar com ela e ofereceram 
apoio pelo acontecido. Foi então que tive a certeza de que queria trabalhar e direcionar minha pesquisa para compreender o processo de luto por suicídio. Para mim, eles eram parte fundamental e comumente esquecidos da história, pela sociedade e também pela comunidade científica.

Iniciei meus trabalhos com a dissertação de mestrado, entitulada "Atividades de posvenção e serviços de suporte para sobreviventes do suicídio - Disponibilidade de serviços e um plano de intervenção para o Brasil”, em que pesquisei a diferença do processo de luto por suicídio e outros tipos de morte, quais os programas para enlutados haviam no Brasil e no mundo, quais eram os serviços de posvenção, termo que até então eu não conhecia, nem no âmbito brasileiro. Fiquei impressionada ao ver como praticamente nada tinha sido feito no nosso país para o tratamento e cuidado com essas pessoas. No final da dissertação, fiz uma sugestão para a criação de um centro de posvenção do suicídio e tudo que seria necessário para que saísse do papel, tornando-se a missão mais difícil de todas, tirar as ideias do papel e transformá-las em realidade.

Havia, porém, mais uma decisão importante a tomar, o contrato do meu marido havia acabado, precisaríamos escolher entre ficarmos pelo menos mais cinco anos na Suécia ou voltarmos para o Brasil. A asma forte de minha filha e minha vontade de trabalhar com o assunto no país foram pontos decisivos na escolha de sair da Suécia. No entanto, meu marido precisou voltar antes do mestrado acabar e eu não iria desistir de tudo ali, então fiquei mais seis meses na Suécia, somente com a minha filha, para finalizar o curso, um período intenso de dedicação aos estudos e cuidados com uma criança pequena.

Ao voltar para o Brasil, desembarcava junto comigo um sonho, o de trabalhar e fundar um instituto de prevenção e posvenção no país, que já estava idealizado na minha cabeça desde os dias sombrios de inverno sueco.

Voltar não foi tão fácil quanto pensei, percebi que eu havia mudado depois de anos fora. Com o tempo, acabei desenvolvendo um curso específico na área de prevenção e de posvenção do suicídio, que teve sua primeira turma em 2012 e foi o pioneiro ao tratar diretamente da posvenção, termo que era praticamente desconhecido no país. Depois de muito trabalho, juntamente com dois sócios, o Instituto Vita Alere de Prevenção e Posvenção do Suicídio foi fundado em agosto de 2013, repleto de ideias e ideais. De lá para cá houve muitas mudanças, os sócios saíram e passei a coordenar o Instituto sozinha. Desde que voltei da Suécia ministrei diversos cursos e palestras sobre o assunto, oferecendo consultorias, elaborando projetos, participei de congressos, criei um grupo para sobreviventes enlutados, publiquei um livro, alguns capítulos, tornei-me representante da Colcha da Memória Viva no país, integrei a 
diretoria da Associação Brasileira de Estudos e Prevenção do Suicídio, organizei um simpósio e um concurso literário, entre outras tantas atividades. Sei que fui uma das pioneiras em relação ao uso do termo posvenção no Brasil, pelo menos até onde eu sei, fico contente ao ver que tantas pessoas passaram a utilizá-lo.

A partir da minha experiência profissional percebi que não adiantava saber o que há de melhor no mundo em termos de posvenção e o que seria ideal para o Brasil, havia sim a necessidade de conhecer as necessidades das pessoas e o que seria proposto. Assim nasceu o primeiro projeto, pesquisar quais eram as necessidades dos enlutados pelo suicídio em seu processo de luto. Decidi então ingressar no doutorado para continuar a pesquisa do mestrado.

Entretanto, algumas mudanças foram feitas no meio do caminho ao tomar conhecimento que esse tema também seria pesquisado por outra pessoa. Queria trabalhar em um assunto novo, então após refletir e observar os pacientes que atendo e os grupos de sobreviventes que facilito, percebi que uma das questões mais difíceis para eles era poder falar sobre o assunto, seja comigo, em casa ou na rua.

Foi então que essa pesquisa foi definida, se a Síndrome da Imunodeficiência Adquirida (AIDS) e o câncer também foram assuntos tabu e hoje se fala mais livremente sobre esses temas, pensamos que o mesmo poderia ser proposto para a questão do suicídio. Queria saber como aumentar a consciência pública do comportamento suicida e do luto por suicídio.

Durante o período de estudos dessa tese, muito começou a ser feito no país nessa área. Diversos eventos ligados à temática iniciaram-se e a campanha setembro amarelo, proposta pelo Centro de Valorização da Vida (CVV) ganhou força e notoriedade.

Ainda que muitos dos esforços sejam feitos, não havia até então programas compreensivos e integrados de aumento da consciência pública voltados para o fenômeno do suicídio. Esse foi um dos motivos que inspiraram essa pesquisa, oferecer ferramentas e conhecimentos nesse tema tão denso e proibido, sem esquecer aqueles que mais precisam - os que têm ideação suicida, tentam matar-se ou perdem pessoas queridas por suicídio. 


\title{
2 INTRODUÇÃO
}

\author{
O suicídio demonstra que na vida existem males maiores do que a \\ morte (Orestano, 1913, p. 54)
}

Falar sobre o suicídio, é trazer para a consciência, para a discussão um tema sobre o qual a maioria das pessoas não quer falar, não quer pensar ou lembrar que existe ... é revelar que há muitas pessoas que escolhem a morte. É necessário falar sobre suicídio? Essa parecer ser a pergunta silenciosa e silenciada da sociedade. Sim, definitivamente, precisamos!

É um tema que não pode ser distanciado, sempre há impacto ao se falar ou pensar sobre o suicídio. Quando nos perguntam qual o tema do estudo, ao citar a palavra suicídio, sempre há reações... essas reações vão do... 'Jura? Porque?' Ao... 'puxa, deve ser pesado, hein'.... o fato é que é muito difícil que não ocorram reações a esse tema.

Há a crença de que para trabalharmos nessa área, ou escolhido esse tema para pesquisa deveríamos ter vivenciado o suicídio de alguém próximo. Não é o nosso caso, e assim como quem passou por essa experiência ficamos sensibilizados com a dor e o desespero daqueles que nos procuram em razão da ocorrência de um suicídio.

Percebemos a dificuldade de se falar sobre o suicídio em vários âmbitos, em grupos diferentes, mas de maneira geral, as pessoas que passaram por essa dor são os que têm mais abertura para falar, às vezes, com uma ânsia e necessidade para se expressarem livremente sobre a morte auto infligida. Essa comunicação ocorre, na maioria das vezes, ao perceberem que não há medo, preconceito ou julgamento quando sentem que há acolhimento, permissão e abertura para ouvir.

Quanto mais trabalhamos com o suicídio, mais nos surpreendemos ao ouvir as diversas histórias sobre esse tema. Alguns anos atrás, estávamos em uma farmácia e a operadora do caixa leu a apostila que estava em nossas mãos de ponta cabeça, nela estava escrito "Curso de prevenção e posvenção do suicídio". Tínhamos acabado de dar um curso numa cidade do interior sobre o tema. A moça leu e ficou e olhando, e então falou: "Nossa... suicídio.... que é isso que você tem aí", falamos então sobre o curso oferecido e ela perguntou se o curso já havia terminado. Ao respondermos que sim, ela disse: "Minha avó se matou quando eu tinha 6 anos, se enforcou no lustre da sala, em cima da mesa de jantar... fui eu que achei o corpo... nunca me esqueci daquela cena... minha família nunca falou sobre isso... acho que nem eu... acho que essa é a primeira vez que eu falo isso assim para alguém...". A narrativa nos surpreendeu, por se tratar de um relato que geralmente não é expresso tão diretamente. A nossa reação foi de acolhimento e diálogo e perguntamos se alguém tinha falado com ela sobre aquela situação, ela 
respondeu que não... e então perguntamos como se sentia ao contar essa história... ela falou..."'Estou bem... pelo jeito vocês não tem medo de falar sobre isso né... é bom poder falar para alguém assim", e a conversa seguiu por alguns minutos.

Esse diálogo nos faz refletir sobre as histórias que não são contadas, ao tabu que, muitas vezes, se inicia na própria família; à memória daqueles que se foram e a lembrança daqueles que ficaram; à dificuldade de encontrar pessoas dispostas a ouvir, sem preconceitos sobre o que significa o suicídio e a dor que carrega consigo. Provavelmente a moça viu naquela apostila, uma abertura, uma oportunidade de poder falar sobre a sua vivência.

As pessoas, muitas vezes, querem falar sobre o suicídio, mas não encontram eco... não sabem como e onde. Aos alunos que fazem cursos sobre prevenção do suicídio é dito que a partir do momento que escolheram aprender mais sobre o assunto, abriram uma porta para escutar histórias relacionadas ao tema. As histórias vão chegar, pois as pessoas se sentem seguras para contarem suas histórias para quem consegue escutá-las.

Como podemos começar a falar sobre o suicídio? O que nos impede de falar sobre o tema? Será medo? Preconceito? Será um tabu coletivo? Familiar? Individual? Como devemos falar sobre o suicídio? O que pessoas que foram tocadas por esse acontecimento gostaria que fosse falado? Essas foram algumas das questões nos acompanharam durante o desenvolvimento do projeto dessa pesquisa.

Optamos por usar como método, a Teoria Fundamentada nos Dados (TFD) ou Grounded Theory (GT). A primeira vez que tivemos contato com esse método foi durante o mestrado e achamos interessante ter a alternativa de basear a pesquisa nos dados obtidos, pois não queríamos realizar um estudo dedutivo, de provar se o que está na bibliografia em conjunto com hipóteses estava certo ou errado. Não queríamos provar teorias. Queríamos gerar ciência utilizando um método, que priorizava as histórias e vivências dos colaboradores, pessoas enlutadas pelo suicídio.

O desafio era mesmo considerando interessante construir uma teoria com a ajuda dos colaboradores, tínhamos pouca experiência com o método. A pesquisadora Mariana Cacciacarro, nos orientou na complexa tarefa de construir uma teoria fundamentada nos dados. Então essa pesquisa tem uma concepção diferente da tradicional em que a teoria é apresentada antes dos dados. A partir dos depoimentos apresentados pelos colaboradores nos grupos focais e da análise dos dados, que a fundamentação teórica foi desenvolvida, conforme explicaremos a seguir.

A relevância desse estudo está na necessidade da sociedade falar abertamente sobre o suicídio, de entenderem como oferecer ajuda e acolhimento, de profissionais aprenderem como 
cuidar de pessoas com comportamento suicida ou sobreviventes enlutados pelo suicídio, e, encontrar maneiras para diminuir o tabu e o estigma relacionado ao suicídio, colaborando para a prevenção e posvenção.

\subsection{OBJETIVOS}

Objetivo primário: Geral

Verificar como a comunicação sobre o suicídio e a consciência pública podem colaborar com a prevenção e posvenção do suicídio.

Objetivos específicos

Pesquisar como o tabu e o estigma sobre suicídio influenciam na sua prevenção e posvenção.

Conhecer procedimentos que possam aumentar a consciência pública sobre o tema.

Propor formas de aumentar a consciência pública em relação ao suicídio.

\subsection{ORGANIZAÇÃO DESSE ESTUDO}

$\mathrm{Na}$ apresentação e introdução expusemos os motivos e os objetivos da pesquisa, destacando sua relevância para a sociedade e para os colaboradores, pessoas enlutadas pelo suicídio.

No Capítulo 3, faremos uma breve revisão de literatura, destacando os fundamentos teóricos, que apresentam os conceitos básicos necessários para o entendimento do estudo, relacionados ao: suicídio, epidemiologia, prevenção e posvenção, consciência, tabu, estigma, preconceito, discriminação e competência. Por se tratar de uma pesquisa utilizando a TFD, a revisão de literatura foi feita após a análise dos dados, para que pudéssemos nos basear nesses dados e não em teorias sobre o tema, considerando a forma proposta pelo método e em concordância com os objetivos da pesquisa.

No Capítulo 4, traremos os aspectos metodológicos e a estratégica de investigação adotada, incluindo o referencial teórico (Interacionismo Simbólico - IS), o referencial metodológico (Teoria Fundamentada nos Dados - TFD), o procedimento metodológico (Local, ética, participantes, etc.), o percurso metodológico (codificações), o procedimento de análise 
dos dados (com imagens sobre as etapas de codificação), apresentando a configuração do estudo para o aumento da transparência do trabalho e credibilidade dos resultados encontrados.

Um diário de bordo com observações da pesquisadora a respeito das escolhas metodológicas estará destacado no final do capítulo.

No Capítulo 5 apresentaremos a análise dos resultados, com os conceitos, subcategorias, categorias e temas encontrados. No Capitulo 6, será apresentado o modelo teórico, que foi criado fundamentado nos dados colhidos.

No Capitulo 7 faremos uma discussão dos resultados encontrados. Optamos por separar a análise dos resultados da discussão para deixar mais claro o processo de análise dos dados. Assim, na discussão, faremos uma revisão dos conceitos e compararemos com a literatura, apresentaremos sugestões e reflexões de como podemos trabalhar para ampliar a consciência pública. Sugestões de trabalho desenvolvidas com base na análise dos resultados serão apresentadas e discutidas.

No Capítulo 8 apresentaremos nossas considerações finais e as sugestões para futuras pesquisas.

No Anexo, que está localizado no arquivo digital em CD, junto a contracapa, traremos as transcrições, codificações, memorandos, diário de bordo, roteiro norteador, termos e aceite da comissão de ética. 


\section{FUNDAMENTAÇÃO TEÓRICA}

\subsection{CONCEITOS E DEFINIÇÕES DO SUICÍDIO}

Bertolote (2012) afirma que a palavra suicídio vem do grego autófonos, que significa "que mata a si mesmo", traduzida para o inglês (suicide) e posteriormente para outras línguas. A palavra suicídio é conhecida desde o séc. XVI, sendo utilizada pela primeira vez em 1643 pelo médico inglês Thomas Browne em seu livro Religio Medici (A religião de um médico tradução nossa), que dividia o suicídio na forma "heróica" ou "patológica". Na Europa até então utilizava-se a expressão felo de se ou criminoso de si mesmo (Bertolote, 2013). Do ponto de vista etimológico o termo suicídio vem do latim sui (próprio) e caederes (ação de matar) com o significado de "a morte de si mesmo - matar a si mesmo".

O comportamento suicida por sua vez pode ser visto desde os primórdios, consta na mitologia de inúmeros povos e na maioria dos livros antigos, como a Bíblia, relacionado a uma forma heroica para salvar um povo ou relacionado à fuga, com o intuito de escapar de uma situação sem saída (Bertolote, 2012).

O significado que é dado a uma palavra ou conceito influencia como a sociedade e como o indivíduo relacionam-se com ele. Há crenças enraizadas no coletivo que estão ligadas à definições antigas, por exemplo, nos dias atuais ainda se relaciona o suicídio à fraqueza ou à coragem, tendo em vista os conceitos de fuga ou ato heroico, respectivamente.

Consultando o dicionário Houaiss (2012) suicídio é o "1. ato ou efeito de suicidar-se. 2. fig. desgraça ou ruína causada por ação do próprio indivíduo, ou por falta de discernimento, de previdência etc.” . No Michaelis (2012), observa-se que suicídio significa: "1. Ação ou efeito de suicidar-se. 2. Ruína ou desgraça, procurada espontaneamente ou por falta de juízo.” Já o significado do termo suicidar: "1. Dar a morte a si mesmo; pôr termo à própria vida: ... 2. Arruinar-se, destruir a sua própria influência e prestígio, ser a causa da própria ruína”.

A conotação negativa da definição do suicídio nos dicionários consultados relaciona o ato à culpa, à covardia, à debilidade e à loucura, distante da concepção científica atual, mas representa a visão da sociedade, influenciando as crenças de famílias e indivíduos.

A condenação pelo ato suicida pode ser vista nas obras de Platão. A pessoa que consuma o ato suicida tem o seu enterro longe dos cemitérios, como forma de punição, sansão que ainda pode ser observada nos dias de hoje em algumas religiões. Partindo da influência dos filósofos, a igreja condena o suicídio, considerando-o como tríplice ofensa (a si mesmo, a cidade e a Deus), a partir dos entendimentos de Tomás de Aquino e de Agostinho (D'Oliveira, 2015). No século VI a igreja designa o suicídio como pecado mortal, situação que persiste na 
maioria das religiões cristãs (Bertolote, 2012).

Para Durkheim, filósofo precursor da visão sociológica do suicídio, "chama-se de suicídio todo o caso de morte que resulte direta ou indiretamente de um ato positivo (ex. enforcamento) ou negativo (ex. greve de fome), praticado pela própria vítima, sabedora que deveria produzir esse resultado" (2000, p. 14). Para Cassorla (2004, p. 21), o suicídio é "uma morte em que o indivíduo, voluntária e conscientemente, executou um ato ou adotou um comportamento que ele acreditava que o levaria à morte".

A depressão ou uma dor existencial profunda podem influenciar o raciocínio lógico de uma pessoa, fazendo que ela não tenha uma clareza de pensamentos suficiente para ter consciência do ato e de suas repercussões, bem como de quais outros caminhos teria para resolver seus problemas ou a sua dor, que não fossem pela morte. Assim, compreendemos que a intencionalidade de provocar a morte seja mais presente que ter a consciência plena desse ato.

Botega, Rapeli e Cais apontam que

podemos nos referir a um comportamento suicida como todo ato pelo qual o indivíduo causa lesão em si mesmo, qualquer que seja o grau de intenção letal e de conhecimento do verdadeiro motivo desse ato. Essa noção possibilita conceber o comportamento suicida ao longo de um continuum: a partir de pensamentos de autodestruição, passando por ameaças, gestos e tentativas de suicídio e finalmente o suicídio (2012, p. 335).

Qualquer pessoa, em algum momento da vida, pode imaginar como seria se morresse e o que aconteceria se acabasse com a própria vida, se tivesse um pensamento passageiro sobre o suicídio. Em nosso ponto de vista, é natural que pessoas tenham, pelo menos uma vez, um pensamento sobre sua morte, não obrigatoriamente o suicídio, no entanto, é preciso atenção específica em relação à frequência e a intensidade dessas ideias, considerando também o acesso a meios letais. Se estes pensamentos forem recorrentes, com grande intensidade, com planejamento ou ameaças, com acesso fácil à arma, comprimidos, lugares altos sem proteção, o risco fica muito aumentado.

Durkheim em 1897 publicou o livro Le suicide (2000) no qual apresentou a visão sociológica sobre o suicídio. Em sua pesquisa rejeitou todos os argumentos que não são sociais e que poderiam explicar esse fenômeno, apresentando a consciência coletiva como entidade moral superior ao indivíduo que determina, juntamente com a sociedade, o comportamento humano: o sentir, o pensar e o agir. Para o autor, as taxas de suicídio de um país são indicadores de sua situação social e as alterações nessas taxas associam-se a problemas que afetam essa sociedade. Afirma que o suicídio pode ser dividido em quatro classes, que serão explicadas 
adiante e que são relacionadas aos laços sociais do indivíduo, que se integra, envolve-se, sentese pertencente (considerando as relações sociais que ligam o indivíduo ao grupo) numa sociedade ou regula-se (envolvendo requisitos normativos ou morais exigidos) nessa sociedade para que pertença a um grupo.

a) O suicídio denominado como egoísta acontece com pessoas com baixa integração na sociedade, deprimidas, isoladas ou pertencentes a grupos não aceitos, pessoas que ficam acima ou à margem do grupo social;

b) O suicídio altruísta corresponde a pessoas, com alta integração na sociedade, que muitas vezes esquecem-se de si em prol de uma causa ou perdem a vida para defender/proteger indivíduos ou ideais, como os camicases, homens-bomba, religiosos, militares. Neste grupo estão incluídas pessoas que se matam por sentirem-se muito culpadas após cometerem uma infração ou efetuam o suicídio em prol de um grupo, como um ato de sacrifício;

c) O suicídio anômico tem relação com pessoas com baixa regulação na sociedade. Nesta classe estão incluídas as pessoas desempregadas, divorciadas, que não acompanham as pressões da escola/sociedade, que tiveram perdas na família, estão em situações de profunda desorientação e falta de perspectiva. Tem também uma relação forte com a desorganização social como, por exemplo, suicídios que ocorrem quando há grande instabilidade econômica;

d) O suicídio fatalista ocorre em pessoas com alta regulação com a sociedade, sendo indivíduos que estão submetidos ou submetem-se a regras ou a controles rígidos em que não há esperança de mudança ou que não conseguem modificar a situação em que são inseridas como, por exemplo, escravos, prisioneiros, pessoas que perderam a honra ou que lidam com desapontamentos constantes.

Muitas pesquisas foram feitas a partir da teoria de Durkheim. Há críticas à obra, referindo que o autor deixou "os fatores individuais em segundo plano e que não houve uma discussão do papel do sujeito, dos significados e da intencionalidade como parte integrante do fato e do ato social" (Minayo, 1998, p. 12). De qualquer forma, é inegável a importância dos estudos de Durkheim até os dias de hoje. Cabe salientar que esse estudo não relaciona o suicídio a um evento único e que os exemplos dados acima estão separados para fins didáticos.

Albert Camus (1989), em seu livro "O mito de Sisífo", traz uma visão filosófica sobre o suicídio após a grande influência sociológica, a partir da obra de Durkheim. O autor afirma que 
vida vale ou não vale a pena ser vivida é responder à questão fundamental da filosofia. O resto, se o mundo tem três dimensões, se o espírito tem nove ou doze categorias, aparece em seguida. São jogos. (Camus, 1989, p. 8).

Os estudos da psiquiatria em relação ao suicídio começaram no fim do século XVII com médicos, em especial os alienistas (aqueles que tratavam dos alienados - nome dado naquela época aos psiquiatras), que promoveram o debate sobre a etiologia do suicídio. Pinel e Esquirol deram continuidade aos estudos no início do século XIX, considerando as teorias apresentadas naquela época. O ponto comum e presente até os dias de hoje é que suicídio é resultado de doença. Apresentam uma visão individualista e médica do suicídio, propondo uma relação inegável entre os transtornos psiquiátricos e o suicídio (Correa \& Barrero, 2006b).

Estima-se que mais de $90 \%$ dos indivíduos que tentaram ou cometeram o suicídio têm transtornos mentais, $60 \%$ deles com transtorno afetivo, como transtorno bipolar ou transtorno depressivo maior, com sintomas confirmados ao passarem por consultas com clínicos gerais ou psiquiatras. A maioria das pessoas que tentaram o suicídio tem comorbidades, ou seja, com dois ou mais diagnósticos psiquiátricos simultâneos. Pessoas com distúrbios de humor têm de doze a vinte vezes mais risco de cometerem suicídio que a população geral (Wasserman, 2001). O risco de suicídio em pessoas com transtorno de humor, especialmente a depressão, é em torno de 6 a 15\%, com alcoolismo de 7 a 15\% e esquizofrenia de 4 a 10\% (OMS, 2000a). Invariavelmente as taxas de suicídio são indicadores dos índices de doença mental num país.

Barraclough e colaboradores (1974) afirmam que de cem pessoas que realizam o ato suicida, noventa são mentalmente enfermas, sendo setenta por depressão; vinte e sete por transtorno de personalidade; quinze por dependência de álcool; três por esquizofrenia; em treze delas ocorrerão comorbidades como, por exemplo, depressão e alcoolismo.

Werlang \& Botega (2004) encontraram em seu estudo sobre diagnósticos de transtornos mentais em casos de suicídio, que na população geral, 35,8\% apresentavam transtornos de humor, 22,4\% transtornos relacionados ao uso das substâncias, 11,6\% transtornos de personalidade, $10,6 \%$ esquizofrenia, $11,6 \%$ outros diagnósticos do eixo I (transtornos psiquiátricos clínicos, incluindo transtornos do desenvolvimento e aprendizado), $6,1 \%$ transtornos de ansiedade/somatoformes e o restante $1,9 \%$ correspondendo à soma dos transtornos mentais orgânicos, outros transtornos psicóticos e transtornos de adaptação, conforme demonstrado no gráfico a seguir: 
Figura 1: Diagnóstico de transtornos mentais em caso de suicídio

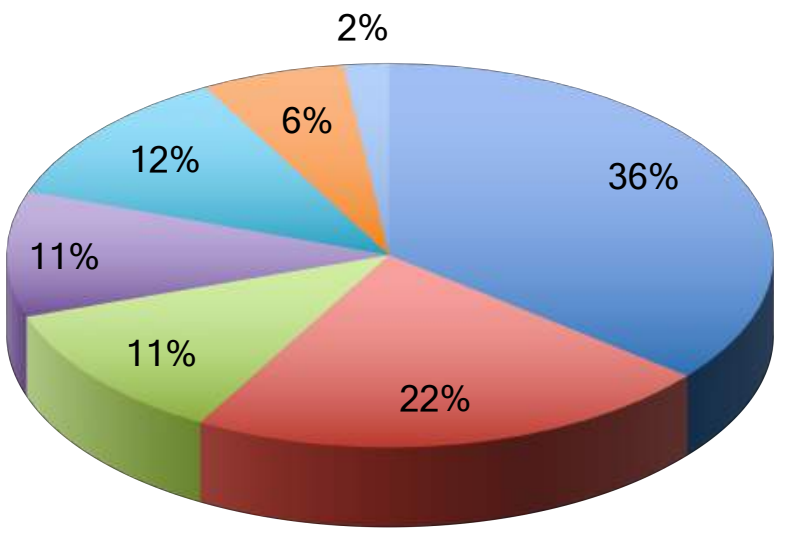

- Transtornos de humor

- Uso das substâncias

Transtornos de personalidade

Esquizofrenia

- Diagnósticos do Eixo I

Transtornos de ansiedade

Outros transtornos

Fonte: Werlang \& Botega (2004, p.41)

Do ponto de vista psicológico, Shneidman (1985), considerado o pai da suicidologia moderna, afirma que para haver um suicídio é fundamental a combinação dos seguintes elementos: sentimento de dor intolerável; atitude de autodesvalorização; constrição marcada da mente com prejuízo das tarefas do dia a dia; sensação de isolamento intenso e desesperança.

Cabe destacar que o autor denomina psychache (dor psíquica): a dor emocional insuportável, como fator fundamental para ocorrer um suicídio. Nessa situação matar-se seria a forma mais rápida de aliviar essa dor, que inclui uma sensação angustiante de estar preso em si mesmo e sem saída com um desespero irremediável e uma turbulência emocional interminável (Botega et al., 2012).

Para a Organização Pan-americana de Saúde (OPAS), o suicídio tem relação com os quatro Ds: a depressão, o desamparo, a desesperança e o desespero. Botega (2015) complementa os Ds com: dor psíquica (psychache), dependência química, delírio (percepção distorcida e falsa da realidade) e delirium (síndrome confusional aguda) - o que vale somente para a língua portuguesa. O suicídio, nesses casos, não é visto como um problema e sim como solução para um problema sentido, apresentando os três Is: intolerável, inescapável e interminável (Chiles \& Strosahl, 2005).

Os três principais aspectos psicológicos do estado em que se encontra a maioria das pessoas sob o risco de suicídio são a ambivalência, a impulsividade e a rigidez/constrição, como aponta o Manual de Prevenção do Suicídio do Ministério da Saúde (Brasil, 2006a). 
Estudos envolvendo genética e suicídio vem sendo desenvolvidos há décadas, iniciando-se com pesquisas no liquor e em estudos post-mortem envolvendo o ácido 5-HIAA, principal metabolito da serotonina (Correa \& Barrero, 2006a). Alguns marcadores relacionados à impulsividade e à agressividade foram encontrados, porém até hoje, não foi descoberto nenhum gene específico, que seja causador do suicídio.

Estudos recentes dedicam-se à epigenética do suicídio, nos quais eventos traumáticos ocorridos na infância, abuso de drogas, estresse e outros poderiam ocasionar mudanças fenotípicas, que não foram codificadas pelo DNA, alterando assim os níveis de expressão da depressão, por exemplo. Esses estudos referem-se ainda a processos herdados, porém mutáveis que regulam a forma como certos genes expressam-se em células ou em períodos de desenvolvimento específicos. Ainda não está claro como esses eventos podem ser o gatilho para modificações epigenéticas, que resultam em mudanças da expressão dos genes. Estudos como esses podem abrir um novo caminho terapêutico para a prevenção do suicídio com base em pesquisas das alterações nos marcadores epigenéticos de vítimas do suicídio (Autry \& Monteggia, 2009; Klempan, Ernst, Deleva, Labonte, \& Turecki, 2009; Lockwood, Su, \& Youssef, 2015).

O modelo diátese-estresse de Mann (2003) demonstra como uma predisposição genética, em conjunto com eventos estressores ocorridos na vida de uma pessoa, características pessoais, comorbidades, entre outros, elevam o risco de vulnerabilidade ao comportamento suicida em períodos de estresse.

Para a OMS, em seu mais recente documento Prevenção do suicídio: um imperativo global (tradução nossa), o suicídio é o ato deliberado de tirar a própria vida (WHO, 2014). No final de 1960, no Prevention of suicide guidelines for the formulation and implementation of national strategies (Diretrizes de prevenção do suicídio para a formulação e implementação de estratégias nacionais, tradução nossa), a OMS definiu que o comportamento suicida é um "fenômeno multifatorial, multideterminado e transacional, que se desenvolve por trajetórias complexas, porém identificáveis" (UN, 1996).

As primeiras compreensões acerca de suicídio iniciam a partir da filosofia, depois da religião e em 1621 passou a ser entendido pela psiquiatria, sociologia, mais adiante pela psicologia, saúde pública e atualmente utilizamos o conceito de multifatoriedade - fatores múltiplos, em que o suicídio é resultado multifacetado de vários fatores inter-relacionados incluindo fatores culturais, sociais, psicológicos psiquiátricos, biológicos, filosóficos, econômicos, religiosos, entre outros, que influenciam esse comportamento (SPRC, 2001). 
Shneidman aponta que "no Ocidente, o suicídio é um ato consciente de autoaniquilação, melhor compreendido como uma doença multidimensional num indivíduo carente que acredita ser o suicídio a melhor solução para resolver um problema" (Shneidman, 1987).

A relação entre fatores de risco e de proteção apontará pistas sobre o nível de risco de suicídio de uma pessoa. Bertolote, (2012) os fatores de risco dividem-se em:

Tabela 1: Fatores de risco do comportamento suicida

\begin{tabular}{|c|c|c|}
\hline $\begin{array}{c}\text { Fatores Predisponentes } \\
\text { (distais em relação ao } \\
\text { ato suicida) }\end{array}$ & \multicolumn{2}{|c|}{$\begin{array}{l}\text { Fatores Precipitantes } \\
\text { (proximais em relação } \\
\text { ao ato suicida) }\end{array}$} \\
\hline $\begin{array}{c}\text { Fatores sociodemográficos e } \\
\text { individuais }\end{array}$ & $\begin{array}{l}\text { Fatores } \\
\text { ambientais }\end{array}$ & $\begin{array}{c}\text { Fatores psicológicos e } \\
\text { estressores recentes }\end{array}$ \\
\hline $\begin{array}{l}\text { - Tentativa(s) prévia(s) de suicídio } \\
\text { - Transtornos psiquiátricos } \\
\text { - Condições clínicas incapacitantes } \\
\text { - História familiar de suicídio, } \\
\text { alcoolismo ou transtornos psiquiátricos } \\
\text { - Divorciado, viúvo ou solteiro } \\
\text { - Desempregado ou aposentado } \\
\text { - Luto ou abuso sexual na infância } \\
\text { - Alta recente de internação psiquiátrica }\end{array}$ & $\begin{array}{l}\text { - Fácil acesso } \\
\text { a métodos } \\
\text { de suicídio }\end{array}$ & $\begin{array}{l}\text { - Separação conjugal } \\
\text { - Luto } \\
\text { - Conflitos familiares } \\
\text { - Mudança de situação } \\
\text { empregatícia ou } \\
\text { financeira } \\
\text { - Rejeição por parte de } \\
\text { pessoa significativa } \\
\text { - Vergonha e temor de ser } \\
\text { considerado culpado }\end{array}$ \\
\hline
\end{tabular}

Outros fatores de risco, comumente encontrados na literatura, que podem ser acessados por meio do aumento da consciência pública, segundo apontamentos do Suicide Prevention Resource Center (SPRC, 2001) são:

- O estigma por procurar ajuda: esse fato ocorre porque as pessoas não sabem como e onde encontrar ajuda; por pensarem que não precisam de ajuda; por ficarem com medo de serem taxados como loucos ou pela dificuldade de manter a confidencialidade e sigilo nos centros de atendimento;

- Suicídio por "contágio": suicídios individuais ou ocorridos em um mesmo grupo (Clusters) podem ser contagiosos, principalmente se expostos pela mídia - a forma como um suicídio é tratado pela sociedade, empresa, escola, pode influenciar o comportamento de outros, principalmente se estiverem em condições 
econômicas, sociais e psicológicas parecidas, gerando uma maior identificação com a vítima, ocasionando um aumento no número de suicídios;

- Barreiras no acesso a cuidados de saúde, especialmente saúde mental e de tratamento do abuso de substâncias (álcool, drogas, medicamentos), pela pouca disponibilidade de locais de tratamento, pelo desconhecimento desses locais, pelas atitudes hostis de alguns profissionais da área da saúde diante do suicídio;

- Certas crenças culturais e religiosas, por exemplo, a crença de que o suicídio é uma nobre resolução de um dilema pessoal ou que pessoas que pensam em suicídio são fracas e pecadoras. Posições antagônicas e até certo ponto radicais.

Segundo Plutchik e Praag (1994), Wasserman (2001) e Botega (2015), os fatores de proteção do comportamento suicida englobam:

- Atendimento clínico eficaz para transtornos mentais, abusos físicos e abuso de substâncias;

- Fácil acesso a diversas intervenções clínicas e apoio para buscar ajuda;

- $\quad$ Acesso restrito a meios letais de suicídio;

- Relações significativas e comunicação aberta com a família, escola e comunidade;

- Habilidades para resolução de problemas e conflitos;

- $\quad$ Ter uma rede de apoio;

- Crenças culturais e religiosas que desestimulem o suicídio e promovam autopreservação;

- $\quad$ Ser resiliente;

- $\quad$ Ter acesso a medidas que melhorem os fatores de proteção.

O suicídio será o evento final da complexa relação entre uma série de fatores de risco e de proteção, observáveis ou não e da ajuda disponível oferecida e percebida (Wasserman \& Wasserman, 2009).

Nunca se deve apresentar versão simplista para um fenômeno complexo, tentar explicá-lo somente por um ângulo é uma visão reducionista. Nem todos os fatores têm o mesmo peso para as pessoas, porque o suicídio é um ato individual, que terá influências de múltiplos fatores em diferentes graus para cada pessoa. Não se pode culpar uma pessoa pela doença de outra, assim como não cabe uma única explicação causal para o suicídio, como se somente um fator (ou pessoa) fosse o responsável por essa morte. Há fatores biopsicossociais presentes na 
vida de cada um de nós. Olhar parte de uma história como o todo, leva à constrição, cristalização, não ampliando ou expandindo olhares, possibilidades e caminhos.

Conceitos e crenças ligadas ao suicídio terão relação com o comportamento suicida, que é carregado de vergonha, estigma e tabu, que muitas vezes impede que pessoas peçam e ofereçam ajuda. Promover a conscientização da população, dos sistemas de saúde e da sociedade é imperativo para a prevenção do suicídio, conforme a Organização Mundial de Saúde (WHO, 2014).

Tendo em vista o que apontamos, esse estudo traz um recorte da compreensão do suicídio, pesquisando o quanto a consciência pública influencia a concepção do sujeito, de sua família e da sociedade. É fundamental observar quanto essas questões reverberam no tabu do transtorno mental, no processo de luto pelo suicídio e nos serviços de prevenção e de posvenção, principalmente, como e o que se pode fazer para mudar essa situação.

\subsection{EPIDEMIOLOGIA}

Aproximadamente oitocentas mil pessoas cometem suicídio por ano, uma taxa de mortalidade mundial de 10.7 por 100 mil habitantes (WHO, 2017), sendo o suicídio a décima quinta causa de morte no mundo e a segunda mais frequente em indivíduos de 15 a 29 anos de idade, de ambos os sexos, o que corresponde a uma morte a cada quarenta segundos e uma tentativa a cada quatro segundos. É maior que a soma de todas as mortes ocorridas nas guerras, acidentes de trânsito e decorrentes de AIDS no mundo (WHO, 2010, 2014).

É um fenômeno global e responsável por 1,4\% das mortes no mundo. Apresentou um aumento de $60 \%$ nas taxas mundiais nos últimos quarenta e cinco anos, sendo que a projeção para o ano de 2020 é que aumentem 50\%, representando uma morte a cada vinte segundos e uma tentativa a cada dois segundos. Em 2012, 75\% dos suicídios ocorreram em países de baixa ou média renda, regiões em que houve o maior aumento de taxas. Nas regiões mais desenvolvidas e com maior renda, foi possível observar a diminuição das taxas, embora elas ainda sejam altas (WHO, 2014).

No Brasil, assim como em outros países do mundo, os atestados de óbito têm como referência a tabela CID (Classificação Estatística Internacional das Doenças) para determinar a causa da morte. No caso do CID 10 (versão atualizada e revisada), o suicídio é representado pelos códigos do X60 ao X84, que significa lesões autoprovocadas intencionalmente. Cada código refere-se a um tipo de lesão, meio e local como, por exemplo, o código x60.7 refere-se à “autointoxicação por exposição, intencional, a analgésicos, antipiréticos e antirreumáticos, 
não opiáceos - fazenda" e o código x 72.0, a "lesão autoprovocada intencionalmente por disparo de arma de fogo de mão - residência" (OMS, 2008).

Esses códigos abordam igualmente casos que não resultam em óbitos, como por exemplo, as tentativas de suicídio. Os levantamentos estatísticos de taxas de suicídio são baseados nos atestados de óbito com os códigos do CID-10 referentes a lesões autoprovocadas intencionalmente e que são enviados pelo Sistema Integrado de Mortalidade (SIM) ao Ministério da Saúde e conseguinte à OMS (Brasil, 2008).

Somente no ano de 2015, houve 11.736 mortes por suicídio no Brasil, o que corresponde a uma taxa de 5,7 por 100 mil habitantes (Brasil, 2017a), sendo que no período de 2002/2012 houve um aumento de $20,3 \%$ na taxa total de suicídios no país, um aumento maior que dos homicídios (2,1\%) e menor que acidentes de trânsito (26,5\%) (Waiselfisz, 2014).

O crescimento no período de 1980 a 2012 foi de 62,4\%, embora a taxa brasileira não seja tão alta se comparada às taxas mundiais, estamos em $63^{\circ}$ em números relativos e $8^{\circ}$ no ranking em números absolutos (OMS, 2014), que corresponde a uma média de trinta e dois suicídios completos por dia ou um, a cada quarenta e cinco minutos e de vinte tentativas no mesmo período. Estima-se que esses números sejam ainda aproximadamente 30\% maiores, devido à subnotificação no registro de óbitos (Botega, 2010).

No país temos um panorama complexo e heterogêneo, dadas as singularidades de cada região e do acesso a serviços de saúde mental. Apresentamos na tabela abaixo, os dez estados com as maiores taxas no Brasil. As últimas duas colunas correspondem à variação das taxas nos períodos de 2000 a 2012 e de 2011 a 2012 (Waiselfisz, 2014):

Tabela 2 - 10 Estados brasileiros com as maiores taxas de suicídio em 2012

\begin{tabular}{lllll}
\hline \multicolumn{1}{c}{ Estado } & Taxa em 2012 & \multicolumn{1}{c}{$\begin{array}{c}\text { Números em } \\
2012\end{array}$} & $\begin{array}{c}\text { Variação da taxa } \\
\text { de 2000 a 2012 }\end{array}$ & $\begin{array}{c}\text { Variação da taxa } \\
\text { de 2011 a 2012 }\end{array}$ \\
\hline Rio Grande do Sul & 10,9 & 1.178 & $10,2 \%$ & $12,8 \%$ \\
\hline Santa Catarina & 8,6 & 550 & $9,5 \%$ & $5,3 \%$ \\
\hline Mato Grosso do Sul & 8,4 & 210 & $6,2 \%$ & $-0,6 \%$ \\
\hline Roraima & 8,1 & 38 & $47,8 \%$ & $9,5 \%$ \\
\hline Piauí & 7,4 & 235 & $69,7 \%$ & $-0,6 \%$ \\
\hline Tocantins & 6,6 & 93 & $58,4 \%$ & $-1,2 \%$ \\
\hline Goiás & 6,5 & 397 & $-9,4 \%$ & $18,5 \%$ \\
\hline Minas Gerais & 6,4 & 1.262 & $46,3 \%$ & $0,2 \%$ \\
\hline Paraná & 6,0 & 633 & $0,7 \%$ & $5,7 \%$ \\
\hline Ceará & 5,9 & 508 & $-1,6 \%$ & $-8,9 \%$ \\
\hline
\end{tabular}

Fonte: Waiselfisz, 2014 
Há de se levar em consideração que o efeito da mídia aparece como um importante desencadeador do suicídio, ficando atrás do desemprego e da violência para todas as faixas etárias, tornando-se ainda maior para homens jovens com idades entre 15 e 29 anos (Loureiro, Moreira, \& Sachsida, 2013). Dessa forma, devemos ponderar que há diferenças significativas na forma como os jovens vivem nas regiões do país, há características semelhantes, relacionadas à adolescência, porém se o jovem vive numa região mais violenta, com maior índice de desemprego e com acesso a notícias irresponsáveis em relação ao comportamento suicida, as taxas dessa região tendem a crescer. Assim, relacionamos o suicídio de jovens não só, mas principalmente a componentes sociais e à influência da mídia nas suas várias formas de expressão.

No mundo, o suicídio correspondeu a $50 \%$ de todas as mortes violentas em homens e $71 \%$ em mulheres. Podemos ver que em países com baixa e média renda ocorrem 1,5 suicídios de homens para cada mulher e em países de alta renda, esse número dobra, três homens para cada mulher.

Segundo Botega, Mauro \& Cais (2004, p. 181), em um estudo realizado na Universidade Estadual de Campinas (UNICAMP), envolvendo 100 pessoas, 17\% tem ideação suicida, 5\% apresentam planejamento, $3 \%$ apresentam tentativa e $1 \%$ é atendida no pronto-socorro psiquiátrico por tentativa de suicídio.

Figura 2: Prevalência de comportamento suicida a cada 100 habitantes da cidade de Campinas

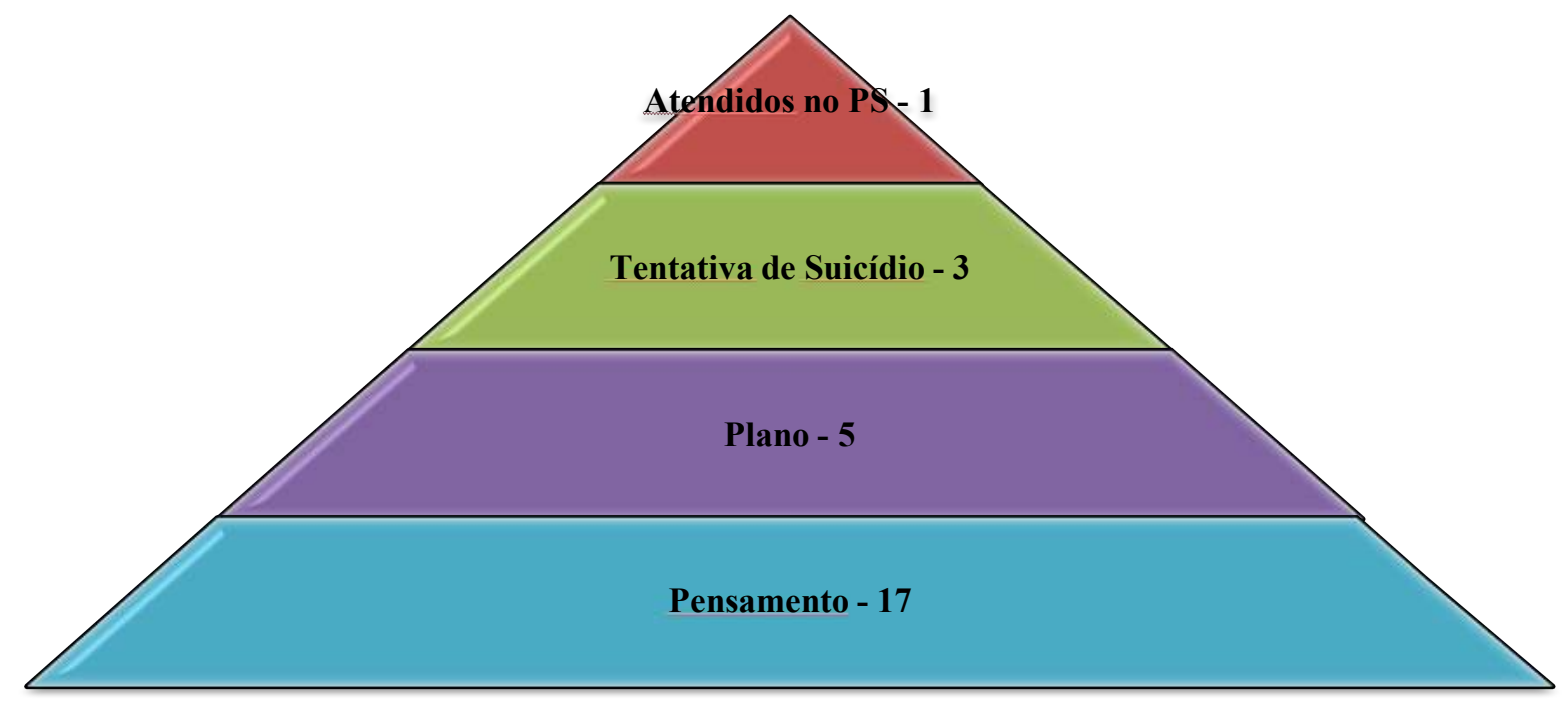

Fonte: Botega, Mauro \& Cais (2004, p. 81) 
Ao longo da existência $20 \%$ da população pode passar por um suicídio na família; $60 \%$ conhecerão uma pessoa que se matou e $50 \%$ dos psiquiatras e $20 \%$ dos psicólogos vão experienciar o suicídio de um paciente, segundo dados da American Foundation Suicide Prevention (AFSP, 2011).

A tentativa de suicídio ainda é o maior indicador de vulnerabilidade em relação ao suicídio e envolve seu maior risco. Após uma tentativa, 15\% daqueles que foram internados, fizeram outra tentativa no período de um ano (Meleiro, 2013), 1\% morreu por suicídio nesse período, outros $10 \%$ a 50\%, dependendo de suas características, vão tentar novamente, sendo que o período de maior risco é no primeiro ano após a tentativa, especialmente nos três primeiros meses (Retterstol \& Mehlum, 2001). Quanto mais tentativas, maior o risco. Tentativas de suicídio prévias, juntamente com a presença de transtorno mental, podem aumentar o risco de suicídio em até quarenta vezes (Tidemalm, Langstrom, Lichtenstein, \& Runeson, 2008).

Oferecer continuidade na ajuda e no apoio aos que tentaram suicídio, bem como diminuir o estigma relacionado a esse comportamento e ao fato de pedir ajuda destacam-se como fatores importantes para essa população de alto risco.

Vale lembrar que a suicidalidade tem diversas formas, uma forma não necessariamente leva à outra. Não há uma vítima típica, embora seja possível prevenir o suicídio em muitos casos, ainda não é possível prever quem, como e quando irá cometer suicídio. O comportamento suicida não fatal é comum, o suicídio completo é sua forma mais rara, que demonstra a importância da discussão e do tratamento para o comportamento suicida, que pode ser em muitos casos evitado.

A OMS (2015) define que podemos quantificar o impacto de uma doença em uma população por meio do Global Burden of Disease (GBD - Carga Global da Doença, tradução nossa). Fazem parte do GBD o Disability Ajusted Life Years (DALY'S - Anos de Vida Ajustados a Limitações, tradução nossa) e o Years os Life Lost (YLL - Anos de Vida Perdidos, tradução nossa).

De acordo com o Institute of Health Metrics and Evaluation (IHME, 2013), o suicídio representou $1,44 \%$ do gasto total com doenças em todo o mundo, em 2013, sendo 1,34\% no Brasil, estimado em DALY'S (IHME, 2013). Somente no ano de 2001, o prejuízo financeiro causado pela perda de produção devido a mortes por suicídio, ajustado pelas taxas de sobreviventes de tentativas foi de US\$0,6 bilhões de dólares ou US\$75 mil dólares por vítima (Carvalho, Cerqueira, Rodrigues, \& Lobão, 2007). 
O suicídio traz um custo de $\$ 44$ bilhões de dólares anualmente somente nos Estados Unidos (AFSP, 2016b). Para Gonçalves (2011), o suicídio e suas tentativas geram grande custo para a sociedade, não só financeiros, mas de perda de capital humano. Baseada em um estudo do Instituto de Pesquisa e Estudos Aplicados (IPEA, 2007), a autora (2011) afirma que aproximadamente $\mathrm{R} \$ 507,00$ foi o valor médio gasto com lesões autoprovocadas intencionalmente entre 1998-2004, com uma taxa de mortalidade de 3,70\% dos casos atendidos. Os anos de vida perdidos por causa das mortes prematuras por suicídio (Years of Life Lost, YLL) foi de 1,57 milhões de anos (Carvalho et al., 2007).

\subsection{PREVENÇÃO E POSVENÇÃO}

\subsubsection{Prevenção}

Prevenção (do latim Praeventio) no dicionário Michaelis (2018), significa: “Ato ou efeito de prevenir(se) ... 2. Precaução para evitar qualquer mal; evitação. ... 5. Medida tomada por antecipação, a fim de evitar um mal; cautela, precaução, previsão.”

O termo prevenção, na medicina e na saúde pública, está relacionado a precaução de doenças por meio de qualquer medida que seja tomada para que não atinja o indivíduo. Foi a partir da observação de John Snow, em 1854, durante uma epidemia de cólera em Londres, que o movimento sanitário iniciou, desenvolveu-se para a saúde pública e a epidemiologia foi criada (Pomerleau \& McKee, 2005).

Para Neiva, Vianna, e Moraes (2015),

Foi somente entre os anos 1920 e 1950, nos Estados Unidos da América e no Canadá, que surgiu a Medicina Preventiva, como reação à Medicina Curativa e ao modelo Contagionista. A Medicina Preventiva, segundo Sigerist (1945), definiu como funções da medicina: promoção da saúde, prevenção das doenças, a restauração e a reabilitação do doente (p. 1422)

Leavell and Clark (1958) desenvolveram a visão da história natural da doença (HND) e das causas múltiplas, na qual se observa que uma doença não é estática e não há necessidade de conhecer a etiologia de uma doença para que seja prevenida. Essa descoberta alterou o paradigma da saúde pública ao incluir, na prevenção, doenças que não eram infecciosas e comportamentos problemáticos, que não eram abarcados no conceito de prevenção até então. Eles conceberam a doença como um processo que chamaram de "horizonte da doença" e a separaram em quatro períodos: período pré-patológico, prodômico, patológico e convalescença, divididos em prevenção primária, secundária e terciária. Assim, a doença ou sua evolução 
natural poderiam ser prevenidas em qualquer etapa, mesmo que já tivessem se iniciado (Bertolote, 2012).

A Prevenção Primária corresponde à promoção de saúde geral, à prevenção de certos agentes ou a situações específicas, antes que o processo patológico estabeleça-se. Já a Secundária refere-se a intervenções direcionadas aos grupos "em risco" ou para fazer o diagnóstico e tratamento precoces, a fim de interromper ou reverter um processo que já tenha se iniciado. Por fim, a Terciária relaciona-se com intervenções de reabilitação, reintegração, gestão, estabilização de um processo, que pode deixar consequências funcionais ou levar à morte, para reduzir os custos sociais e econômicos resultantes dessa situação. Embora não seja utilizado nesse estudo, vale citar que atualmente falamos em prevenção quaternária, que tem relação com o excesso de intervencionismo médico, seja curativo ou preventivo, associados a atos médicos desnecessários, supertratamento (overmedicalization) ou prevenção da iatrogenia.

Por entender que o modelo proposto por Leavel e Clark apresentava problemas relacionados às variações quantitativas dos fenômenos, Gordon (1987 citado por Bertolote 2012) propôs um modelo baseado no risco que as pessoas apresentavam.

Tal modelo é dividido em:

a) prevenção universal, que é indicada a todos; o Dia Internacional dos Sobreviventes Enlutados pelo Suicídio, no qual toda a população teria, pelo menos em teoria, acesso às informações relacionadas ao luto por suicídio e ao suicídio, às campanhas de conscientização sobre o estigma ou diretrizes para a mídia, só para citar alguns exemplos.

b) prevenção seletiva é relacionada a pessoas com baixo ou médio risco de desenvolverem comportamentos suicidas, para impedir que desenvolvam, por meio da redução de fatores de risco, aumento dos fatores de proteção e também a busca ativa para identificar pessoas vulneráveis em certas populações. Considerando a prevenção do suicídio, podemos pensar em intervenções com adolescentes diagnosticados com depressão; no treinamento de equipes de saúde que lidarão com pessoas com comportamento suicida ou na educação socioemocional das crianças.

c) A prevenção indicada é relacionada a pessoas com alto-risco, que já tenham desenvolvido comportamentos suicidas. Esses programas geralmente são de longa duração e possuem vários componentes ou estruturas. Como exemplos temos: o protocolo de ligações de verificação de pessoas que tentaram o suicídio, apresentado no estudo de Botega, Silveira e Mauro (2010), desenvolvido na UNICAMP; protocolos de continuidade na ajuda para sobreviventes de tentativa; 
serviços especializados em luto por suicídio, que em nosso entendimento configura a posvenção.

\subsubsection{Prevenção do Suicídio}

Abordaremos a seguir o histórico da prevenção do suicídio no mundo e no Brasil.

Em 1960, foi fundada a "International Association for Suicide Prevention" (IASP), pelo suicidologista austríaco Erwil Ringel, em Viena. Atualmente a IASP tornou-se uma das instituições mais importantes na área, atua em colaboração com a OMS, conta com membros de sessenta países, promovendo congressos internacionais e diversas atividades na área. A revista científica CRISIS é publicada cinco vezes ao ano e produz boletins mensais enviados aos sócios. Grupos de interesse especiais (SIG) foram criados com o intuito de unir pessoas no campo da suicidologia, que tivessem o mesmo interesse, conforme podemos ver no SIG de posvenção, no qual a pesquisadora desse estudo faz parte, no SIG de suicídios por contágio, entre outros. Prêmios e bolsas de estudo sobre o tema são oferecidos, e todo dia 10 de setembro, o Dia Internacional do Suicídio, criado pelo IASP, ocorrem vários eventos e palestras de conscientização (Mehlum, 2009).

Em 1968, a "American Association of Suicidology" (AAS) foi criada por Edwin Shneidman, desde então desenvolveu, entre outras atividades, padrões e critérios para certificar centros de tratamento na crise pelos Estados Unidos e Canadá, certificando, desde 1976, mais de cento e sessenta centros nesses países por sua excelência no atendimento ou treinamento de profissionais, sendo que mais de quatrocentas pessoas já passaram por exame rigoroso a respeito de seu conhecimento e capacidade em lidar com pessoas em crise. Assim, como a IASP, a ASS organiza conferências, painéis e treinamentos, que atraem anualmente mais de setecentas pessoas. A cada dois meses, é lançada uma nova edição da revista científica "Suicide and Life-Threatening Behavior". Atualmente a AAS apresenta um diretório de referência para mais de seiscentos centros de crises e de prevenção do suicídio e trezentos grupos de apoio nos Estados Unidos. Prêmios, publicações, relatórios, fichas técnicas, livros e recursos são produzidos para o público e para profissionais (Berman, 2009).

Em 1987, especialistas na área se uniram com famílias que perderam pessoas por suicídio e fundaram "The American Foundation for Suicide Prevention" (AFSP), seguindo

\footnotetext{
1 www.iasp.org

${ }^{2}$ www.suicidology.org

${ }^{3}$ www.afsp.org
} 
uma abordagem já validada no tratamento e prevenção de outras doenças, como cardiopatias, diabetes e câncer. AFSP objetivava aprofundar pesquisas com o intuito de entender e prevenir o suicídio, tendo seu foco em cinco áreas: pesquisa, projetos de prevenção do suicídio; desenvolvimento de recursos educacionais; suporte aos sobreviventes; defensoria ${ }^{4}$ para desenvolver políticas estaduais e nacionais e legislar o aumento de recursos para pesquisas e intervenções na área (Haas, Gebbia, \& Clayton, 2009). O projeto Colcha da Memória Viva e o Dia Internacional dos Sobreviventes Enlutados pelo Suicídio, introduzidos no Brasil pelo Instituto Vita Alere, são eventos criados pela AFSP.

Em 1990, a "International Academy of Suicide Research"5 (IASR) estabeleceu-se em Bologna, Itália, na Universidade de Pádua, objetivando reduzir a mortalidade e a morbidade ao promover pesquisas de alto nível e comunicação entre pesquisadores da área da suicidologia. A IASR publica o jornal científico "Archives of Suicide Research" (ASR), além de livros e estudos de caso. Novos membros são nomeados por dois membros e precisam ser aceitos por um comitê e aprovados pela diretoria (Wasserman \& Mann, 2009).

Foi no início da década de 1990, que o secretário geral das Nações Unidas (UN) chamou a atenção para o crescente número de suicídios, especialmente em jovens. Em 1996, um relatório com diretrizes foi lançado pelas Nações Unidas, após encontro realizado em 1993 no Canadá, organizado em conjunto com a Organização Mundial da Saúde ${ }^{6}$ (OMS), com vários especialistas da área. Muitos países basearam-se nessas diretivas para lançarem seus programas nacionais. Em 1999, a OMS lançou a iniciativa internacional - SUPRE - com o objetivo de reduzir a mortalidade e a morbidade do comportamento suicida. Diversas parcerias foram estabelecidas com os objetivos de: aumentar a consciência da magnitude do problema; identificar estratégias economicamente viáveis para treinar profissionais para identificar e encontrar intervenções para o gerenciamento de pessoas em risco; propor estratégias para a diminuição do acesso aos meios $^{7}$ e identificar parceiros relevantes de setores diversos (Saraceno, 2009).

Em 2014, a OMS lançou seu primeiro relatório, "Preventing Suicide: A global Imperative”, do qual a pesquisadora foi uma das revisoras, para ressaltar a importância de prevenir o suicídio e para que seja elencado como grande problema de saúde pública. O relatório destacou que, embora as pesquisas a respeito do tema estejam aumentando, o tabu e o estigma

\footnotetext{
${ }^{4}$ Pessoa ou grupo que apoia publicamente uma causa.

${ }^{5} \mathrm{http}$ ://suicide-research.org

${ }^{6}$ www.who.org

${ }^{7}$ Como barreiras físicas em viadutos, restrição de venda à agrotóxicos, maior controle na venda de medicamentos.
} 
ainda persistem, fazendo que as pessoas fiquem isoladas e não peçam ajuda, ressaltando que quando buscam ajuda muitos sistemas de saúde falham em prover ajuda efetiva pelo tempo necessário. Atualmente, vinte e oito países têm planos nacionais de prevenção de suicídio implantados, o Brasil é um dos países que não possui plano nacional, embora tenha assinado o compromisso perante a OMS em reduzir até 2020, 10\% das taxas de suicídio no país (WHO, 2013).

Segundo Botega (2015), até o ano de 2000, por causa de doenças endêmicas e da violência urbana, o suicídio não era visto como problema de saúde pública no país. Dos marcos recentes da trajetória da prevenção do suicídio no Brasil, destacamos ${ }^{8}$ :

- 1962 - Início das atividades do Centro de Valorização da Vida;

- 1998 - Simpósio “Suicídio: Você já estudou sobre isso?”, na Universidade de São Paulo (USP);

- 2000 - Inclusão do Brasil no estudo SUPRE-MISS (estudo Multicêntrico de Intervenção no Comportamento Suicida) da OMS;

- Entre 2005 e 2006 foi desenvolvida a Estratégia Nacional de Prevenção do Suicídio (ENPS) com participação de diversas instituições e apoio do Ministério da Saúde, conforme será apresentado no Capítulo 7 - Discussão dos Resultados;

- 2009 - Início da campanha de prevenção do suicídio da Associação Brasileira de Psiquiatria (ABP);

- 2010 - Veiculação de chamada sobre prevenção do suicídio na Rede Globo de televisão;

- 2012 - Início da Rede Brasileira de Prevenção do Suicídio (REBRAPS) na internet ${ }^{9}$;

- 2010/2014 - Duzentos estudos brasileiros relacionados ao suicídio são publicados em revistas científicas internacionais.

Em 13 de junho de 2015 foi fundada a Associação Brasileira de Estudos e Prevenção do Suicídio ${ }^{10}$ (ABEPS), durante o I Simpósio Latino-americano de Prevenção do Suicídio. Devido à burocracia em nosso país, a ABEPS só conseguiu ser registrada oficialmente em 2017. Diversas atividades estão sendo desenvolvidas por seus membros em todas as regiões do país e o I Encontro de Sobreviventes do Suicídio ocorreu no I Congresso Brasileiro de Prevenção do Suicídio, em 2016 em Belo Horizonte/MG.

\footnotetext{
${ }^{8}$ A tabela completa encontra-se na página 251-252 de Botega (2015)

${ }^{9}$ www.rebraps.com.br, criada por Carlos Felipe D’Oliveira, psiquiatra e suicidologista.

${ }^{10}$ www.abeps.org.br
} 
Percebemos um aumento das atividades de prevenção e de posvenção no país, bem como de artigos e livros relacionados ao assunto.

Segundo a OMS (2015) em REBRAPS (2015), as estratégias em prevenção do suicídio podem ser resumidas na tabela de metas e objetivos abaixo:

Tabela 3: Metas e objetivos das Estratégias

\begin{tabular}{|c|c|}
\hline COMPONENTES & METAS E OBJETIVOS \\
\hline Vigilância & $\begin{array}{l}\text { Aumentar a qualidade dos dados nacionais de suicídio e tentativas. Apoiar } \\
\text { o estabelecimento de um sistema de dados integrados que serve para } \\
\text { identificar grupos vulneráveis, indivíduos e situações. }\end{array}$ \\
\hline Restrição aos meios & $\begin{array}{l}\text { Reduzir a disponibilidade, acessibilidade dos meios de suicídio (pesticidas, } \\
\text { armas de fogo, lugares altos). Reduzir a toxicidade/letalidade dos meios } \\
\text { disponíveis. }\end{array}$ \\
\hline Mídia & $\begin{array}{l}\text { Promover a implementação de manuais de mídia para apoiar reportagens } \\
\text { responsáveis na imprensa, televisão e mídia social. }\end{array}$ \\
\hline Acesso aos serviços & $\begin{array}{l}\text { Promover aumento do acesso aos serviços para aqueles vulneráveis ao } \\
\text { comportamento suicida. Remover barreiras aos cuidados. }\end{array}$ \\
\hline Treinamento e Educação & $\begin{array}{l}\text { Manter programas de treinamento para cuidadores identificados } \\
\text { (trabalhadores de saúde, educadores, policiais). Aumentar as competências } \\
\text { nos serviços de saúde mental e atenção primaria para reconhecerem e } \\
\text { tratarem pessoas vulneráveis. }\end{array}$ \\
\hline Tratamento & $\begin{array}{l}\text { Aumentar a qualidade das intervenções clínicas baseadas em evidencias, } \\
\text { especialmente após uma tentativa de suicídio. Aumentar as pesquisas e } \\
\text { avaliações das intervenções efetivas. }\end{array}$ \\
\hline Intervenção em crises & $\begin{array}{l}\text { Assegurar que as comunidades tenham a capacidade de responder a crises } \\
\text { com intervenções apropriadas e que indivíduos em situações de crise } \\
\text { tenham acesso aos cuidados de saúde mental emergencial, incluindo linhas } \\
\text { telefônicas ou internet. }\end{array}$ \\
\hline Posvenção & $\begin{array}{l}\text { Aumentar a resposta e o cuidado aqueles afetados por suicídio e tentativas } \\
\text { de suicídio. Prover serviços de apoio e de reabilitação para pessoas após } \\
\text { tentativas de suicídio. }\end{array}$ \\
\hline Consciência & $\begin{array}{l}\text { Estabelecer campanhas publicas de informação para apoiar a compreensão } \\
\text { de que o suicídio é previsível. }\end{array}$ \\
\hline Redução do estigma & $\begin{array}{l}\text { Promover o uso dos serviços de saúde mental, e serviços de prevenção de } \\
\text { abuso de substancias e suicídio. Reduzir a discriminação contra os usuários } \\
\text { destes serviços. }\end{array}$ \\
\hline Coordenação & $\begin{array}{l}\text { Estabelecer instituições ou agencias para promover e coordenar pesquisas, } \\
\text { treinamento e serviços em relação ao comportamento suicida. Fortalecer a } \\
\text { resposta do sistema de saúde e social em relação aos comportamentos } \\
\text { suicidas. }\end{array}$ \\
\hline
\end{tabular}

Para a OMS (2015), é preciso relacionar os fatores de risco do comportamento suicida com as intervenções relevantes para cada um deles. A espessura da linha no gráfico representa a importância da intervenção para aquele nível de cuidado. 
Figura 3: Principais fatores de risco para suicídio alinhados com intervenções relevantes

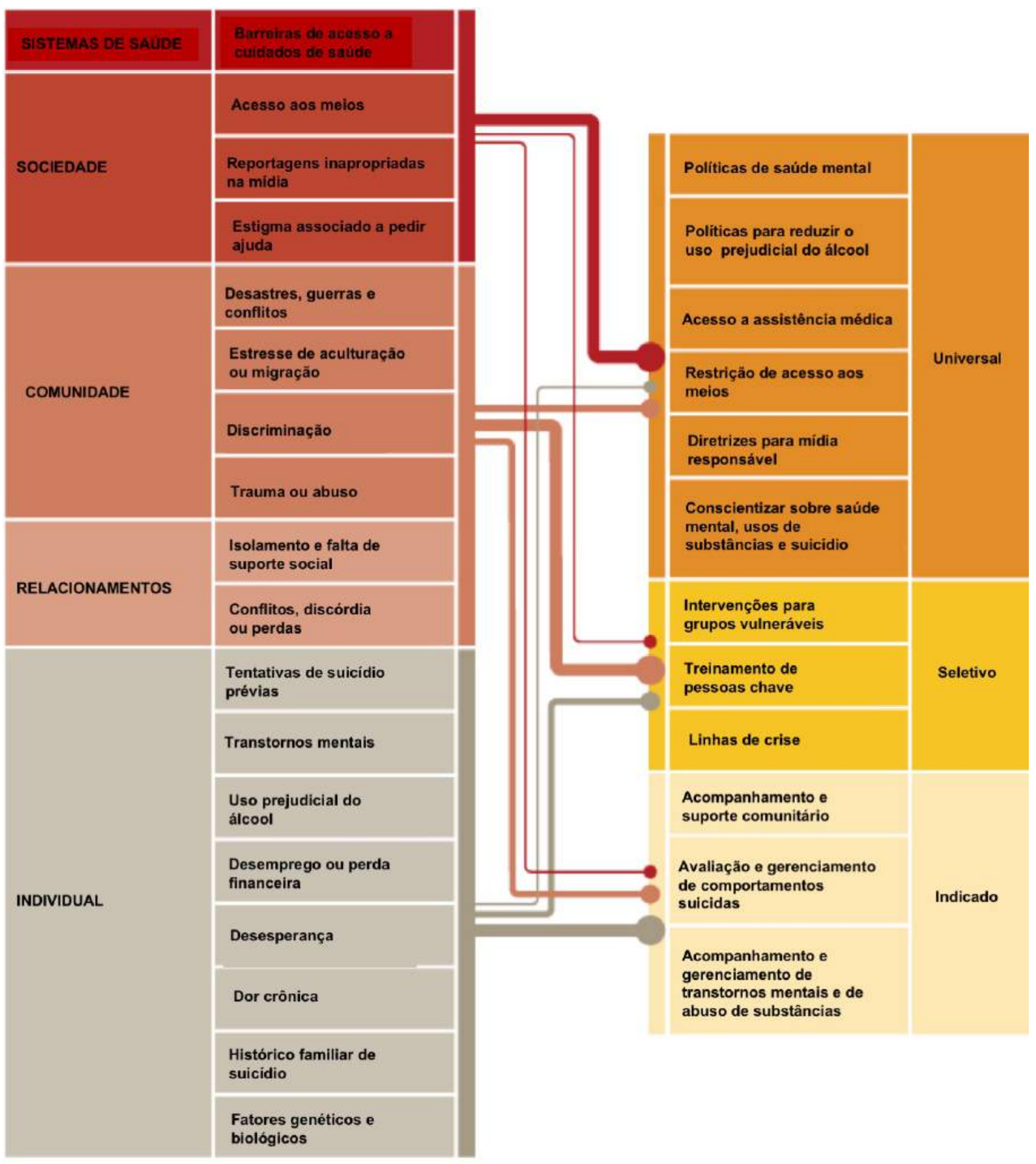

Fonte: OMS, 2015, p.31, tradução nossa 


\title{
3.3.3 Luto por suicídio
}

\author{
Quando o vento varre a casa, ele leva o que vê na frente. \\ É bem diferente de limpeza o que ele deixa ali. É devastação. \\ É tudo o que não queríamos que tivesse se movido de nós.
}

Há livros que constroem enquanto pensamos que construímos. Por longos anos tirava de manhã a pá para me dirigir a uma estranha construção para a qual eu estive vendada. Certa noite me foi tirada a venda. Algumas vezes ao procurar o castelo que eu imaginava erguer, encontrava apenas um fosso que costumava cavar. E só depois de um largo tempo foi que senti que a água estava por emergir. Puxei o balde e pude vislumbrar com inteireza as flores desse jardim já tão familiar. Eu enterrava meus mortos (Matos, 2018, p. 3).

O suicídio resulta em dor e luto para os sobreviventes, consequentemente, uma série de dificuldades podem ser observadas em vários âmbitos: sociais, econômicos, legais. Além disso, o sofrimento psicológico e acentuação do comportamento suicida podem ocorrer em sobreviventes, familiares, amigos ou qualquer pessoa que sofre o impacto do suicídio consumado (Andriessen \& Krysinska, 2012; Scavacini, 2011).

A OMS (WHO, 2014) estima que para cada morte por suicídio, há uma média de cinco a dez pessoas que serão severamente afetadas pelo evento, na maioria das vezes, com laços consanguíneos. Alguns autores sugerem que esse número é ainda maior, de vinte e oito a cinquenta pessoas, dependendo da idade do indivíduo e do tamanho da família. Isso significa que, por ano no Brasil temos em média 56.688 pessoas afetadas pelo suicídio, a quem nomeamos, nesse estudo, de sobreviventes enlutados. Sendo assim, os sobreviventes podem ser: familiares, amigos, colegas de trabalho/escola, pacientes, médicos e terapeutas, policiais que tenham encontrado o corpo e condutores de trens que atropelou alguém que se matou. Dessa maneira, considera-se que os sobreviventes são pessoas que perderam alguém significativo por suicídio ou qualquer pessoa que teve sua vida afetada ou mudada por causa dessa morte (Andriessen \& Krysinka, 2012), sendo a sobrevivência seu propósito fundamental, principalmente quando se trata de aprender a viver sem a pessoa querida que cometeu suicídio, pois salienta-se que existe uma vida antes e uma vida depois desse ato. (Grad, De Leo, Dyregrov, Andriessen \& Cimitam, 2014).

Apresentamos um gráfico com o crescimento estimado do número de pessoas afetadas pelo suicídio completo (sobreviventes) no Brasil nos últimos dez anos, conforme o número de suicídios no país pelo mapa da violência 2014 x número mínimo de cinco pessoas impactadas por um suicídio completo preconizado pela OMS. 
Figura 4: Crescimento estimado no número de sobreviventes enlutados pelo suicídio no Brasil de 2002 a 2012 em relação ao número de suicídios

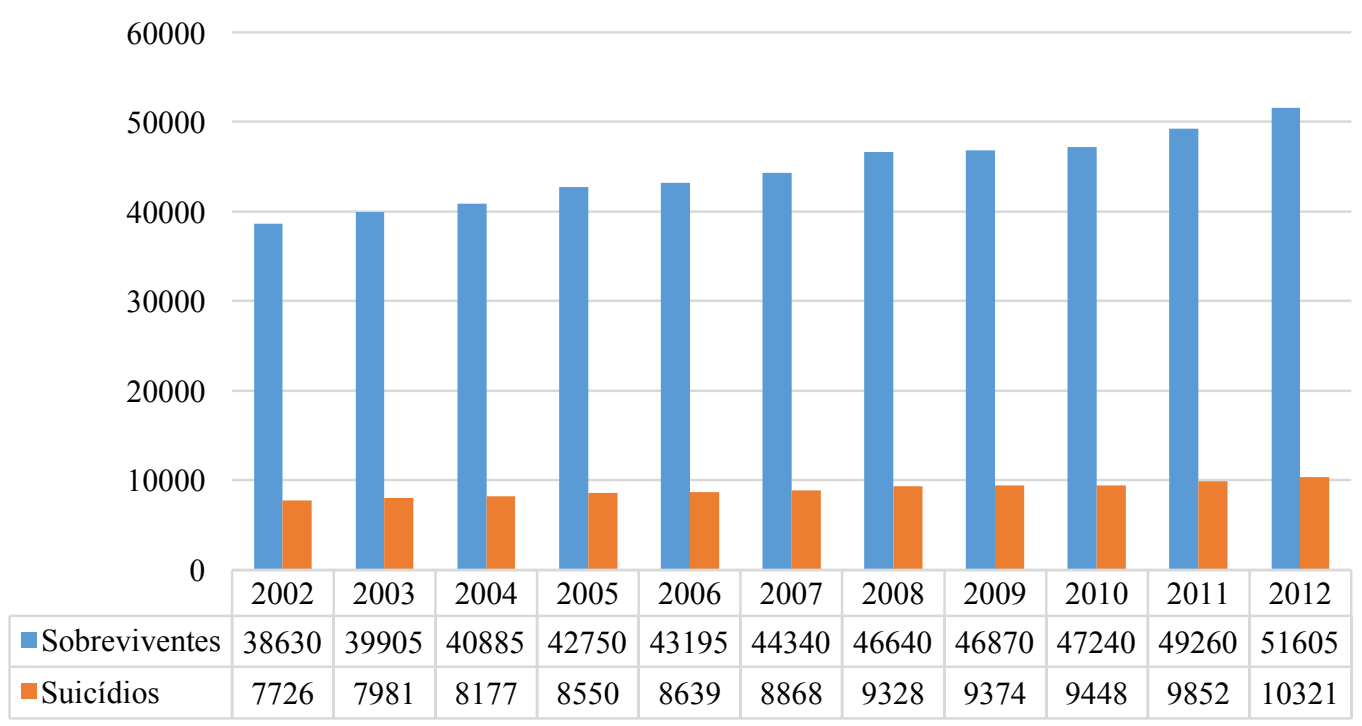

Fonte: produção do próprio autor (2018)

Existem diversos estudos sobre as diferenças entre o luto do suicídio e o de outras mortes. As ideias divergem a respeito do processo de luto por suicídio apresentar certas especificidades por ser morte violenta, estigmatizada e carregada de culpa (Jordan, 2001). Entendemos que no processo de luto devemos sempre considerar as singularidades do enlutado e da cultura que pertence. Segundo Franco (2010, p. 31), "embora continue sendo um processo, ele é vivido na sua singularidade, assim como foi singular a relação rompida que o precedeu". Com relação à cultura a autora aponta que

\footnotetext{
há enormes diferenças entre as culturas a respeito de como, quando, e até mesmo se o luto deve ser expresso, sentido, comunicado e entendido .... Portanto, para avaliar o que é normal para cada cultura, é necessário subjetivar a experiência do luto que é, por sua vez, multideterminada (Franco, 2010, p. $33)$.
}

Sobreviventes podem vivenciar uma série de emoções contraditórias e confusas após o suicídio o que altera suas vidas para sempre (Fine, 1997). Na maioria das vezes, o luto é enfrentado sem a necessidade de ajuda especializada, no entanto, o que se observa é que o luto por suicídio traz consigo algumas características peculiares que deixam marcas naqueles que vivem esse tipo de luto, por isso, seu enfrentamento é diferenciado de outras causas de morte, principalmente na intensidade, estigma, duração e aumento de sintomas depressivos. Além disso, salienta-se que as mortes por suicídio também têm grande impacto no sistema familiar. 
Diferenças no enfrentamento entre homens e mulheres também são evidenciadas no luto por suicídio, e em familiares e profissionais da área da saúde. Mulheres tendem a sentir-se mais culpadas, relatando mais sentimentos de frustração (Beautrais, 2004; Grad, Zavasnik, \& Groleger, 1997). Nos familiares da pessoa que consumou o suicídio, os relacionamentos podem ser afetados, principalmente pela forma como o luto é vivenciado, se é facilitado ou negado, gerando problemas no enfrentamento do luto, dificuldade em assumir papéis e tarefas, deterioração dos laços familiares, segredos do motivo da morte, transmissão psíquica transgeracional, entre outros.

De acordo com Shapiro (1994 citado por Silva, 2009, p. 52),

\footnotetext{
o luto é uma crise de apego e identidade, que interrompe a estabilidade da família nos domínios inter-relacionados de emoções, interações, papéis sociais e significados. É uma crise paradoxal que envolve o crescimento na família em um delicado processo de equilibrar as mudanças inerentes à perda.
}

Existem também os "efeitos adormecidos" que podem afetar o sistema familiar por muito tempo depois da morte, como mudanças nos padrões de comunicação e nos processos de desenvolvimento da família, levando a uma disseminação de visão de mundo e de família para futuras gerações, tendo um impacto negativo transgeracional de tais perdas (Jaques, 2000; Jordan, 2001). Irmãos tendem a ser "esquecidos" em seu luto e a proteger seus pais da sua dor, negando ou postergando a vivência do próprio processo de luto, assim como eles podem culpar ou apoiar uns aos outros (Jaques, 2000).

No caso dos prestadores de serviços, que trabalharam com a pessoa que cometeu o suicídio, fantasias de que eles poderiam ter sido melhores atreladas ao medo de enfrentar a família e/ou a justiça, além do luto pela morte de um paciente, podem acentuar sentimentos de culpa e de fracasso (Beautrais, 2004).

As características da perda, a morte em si, as dinâmicas familiares antes e depois da morte, a integração com a sociedade, as crenças em relação ao suicídio, os fatores demográficos (idade, sexo, raça, renda etc.), os recursos familiares, as dificuldades econômicas, a situação da pessoa, a presença de relações conflituosas e transtornos psiquiátricos graves anteriores à morte, entre outros, são situações que podem influenciar positiva ou negativamente o processo de luto (Beautrais, 2004; Jaques, 2000).

Um aumento de risco de transtornos psiquiátricos e de suicídios pode ser observado em descendentes da pessoa que se matou, pois geralmente a morte de um dos pais por suicídio está relacionada com a presença de doença mental grave em uma família (Runeson \& Asberg, 2003). No entanto, há de ponderar-se que a repetição pode acontecer na maneira dos filhos lidarem 
com o sofrimento, acreditando que suicídio seja uma saída para as dificuldades, porém, repetir maneiras de relacionar-se com outros ou com as adversidades da vida não significa que o ato suicida será repetido.

Apesar do levantamento de riscos ser imprescindível no trabalho da prevenção, pois, segundo Jamison (2010, p. 27), "muitos suicídios - embora de modo algum não todos - podem ser evitados. A brecha entre o que sabemos e o que fazemos é letal", podemos afirmar que a transmissão psíquica não é determinante, mas sim um dos inúmeros fatores de risco para que o filho ou o familiar repita o suicídio.

O risco de suicídio em sobreviventes pode ser de duas a três vezes maiores quando comparado a um grupo controle (Runeson \& Asberg, 2003) e que pode ser maior se o sobrevivente for diagnosticado com luto complicado. A explicação desse fenômeno pode vir da combinação entre genética e ambiente, mesmo que os resultados em relação à hereditariedade ainda sejam inconclusivos (Cerel, Jordan, \& Duberstein, 2008). Outra hipótese, que pode se chamar de "diátese suicida", descreve uma propensão para sobreviventes de responder a períodos de estresse com um comportamento suicida, o que traz outra preocupação, o medo de que os próprios sobreviventes ou pessoas próximas acabem cometendo suicídio (Jordan, 2001).

\subsubsection{Posvenção}

\footnotetext{
Por isso, convido-os a vir comigo para o tempo da delicadeza. A delicadeza que há no encontro, quando tudo parece sinalizar para a perda, o desencontro, a necessidade de preencher lacunas, mesmo que às custas de falácias que rapidamente precisam ser transformadas em verdades, quando a verdade se mostra borrada ou causadora de dor. Falo de transformações, portanto. As mudanças decorrentes das transições do luto podem se desdobrar diante de nós, portanto, como possibilidade de encontro (Franco, 2005, p. 14).
}

Mesmo que os sobreviventes lidem com o luto, com ou sem ajuda profissional, a posvenção, entendida como ações, atividades, intervenções, suporte e assistência para aqueles afetados por um suicídio consumado, é uma ferramenta reconhecida mundialmente como um componente importante no cuidado da saúde mental dessas pessoas. O objetivo da posvenção é auxiliar na lida dos sobreviventes em relação aos efeitos traumáticos da morte de seus entes queridos e é definido por E. Shneidman (1973) como qualquer ato apropriado e de ajuda que aconteça após o suicídio, com o objetivo de auxiliar os sobreviventes a viver mais, com mais produtividade e menos estresse que eles viveriam se não houvesse esse auxílio . Para o autor, a posvenção é prevenção para futuras gerações. 
O termo "postvention" foi criado por Edwin Shneidman quando citou o termo pela primeira vez no livro On the nature of suicide (1969), em várias obras, tais como, Definition of suicide (1985); The suicidal mind (1996); Suicide as Psychache: a clinical approach to selfdestructive behavior (1993). Shneidman não apenas criou o termo, mas também os relacionou com o trabalho de prevenção, manejo e intervenções do e para o suicídio.

Em nosso ponto de vista, "a história do movimento de apoio aos sobreviventes começou em 1970, com a fundação do primeiro grupo de apoio ao luto por suicídio nos Estados Unidos". (Scavacini, 2011, p.14)

Estudos apontam para o fato de que 15\% dos sobreviventes na Noruega, 50\% na Austrália e 76\% em Nova Iorque mencionaram que não receberam nenhuma ajuda, que provavelmente não desejam ajuda e/ou não encontraram o apoio que esperavam encontrar dos familiares e da sociedade. Esse número varia, pois é estimado que apenas um em quatro sobreviventes procura ajuda, e dentre eles, 75\% gostariam de ter acesso a serviços de posvenção mais formais (Provini, Everett, \& Pfeffer, 2000). Algumas pessoas afirmaram que não havia serviços disponíveis, outras não sabiam dessa disponibilidade e, em alguns casos, o suporte foi percebido como insuficiente e até prejudicial. Dessa forma,

\footnotetext{
sem ajuda apropriada, sobreviventes, especialmente crianças, podem experienciar um luto traumático e complicado. Esses serviços oferecem acesso aos cuidados especializados para o manejo do processo de luto, minimizando o risco de suicídios dentro desse grupo vulnerável (Scavacini, 2011, p. 6, tradução nossa).
}

Em 2008, a OMS organizou, juntamente com o IASP, o livro "Prevenindo o Suicídio: Como começar um grupo de sobreviventes", sendo que todo terceiro sábado do mês de novembro acontece o Dia Internacional de Sobreviventes do Suicídio, com diversas conferências nos Estados Unidos e no mundo (Scavacini, 2017a).

A atividade mais comum na posvenção são os grupos de autoajuda, os quais oferecem apoio, promovendo a sensação de pertencimento, local para compartilhar a dor e os sentimentos, além de aprender novas formas de lidar com o luto, renovando muitas vezes a esperança da travessia nesse processo (WHO, 2008).

Os serviços de posvenção podem ter uma perspectiva clínica ou de saúde pública, focando nas necessidades psicossociais dos sobreviventes e na prevenção de suicídios com atividades, tais como, aconselhamento, psicoterapia, atividades de suporte, intensificação da conscientização do tema, criação de campanhas socioeducativas, desenvolvimento das práticas e promoção da saúde mental em atividades de assistência prática, assessoria jurídica e 
financeira, limpeza do local do suicídio (se em casa), informações gerais, entre outras (Wilson \& Clark, 2005).

A posvenção pode ser ativa, quando o sobrevivente é procurado por uma equipe ou por outro sobrevivente, com o objetivo de oferecer ajuda; passiva, quando os serviços disponíveis esperam o sobrevivente ir até eles. Idealmente, estudos recentes sugerem que os serviços de posvenção devam ser oferecidos a sobreviventes, a partir da primeira semana depois do suicídio ocorrer (Beautrais, 2004; Wilson \& Clark, 2005).

Parkes (1998, p. 162) alerta que "os psiquiatras e outros profissionais de saúde estão geralmente por perto quando alguém comete suicídio, mas poucos usam a oportunidade para oferecer ajuda às famílias enlutadas por suicídio". Sendo assim, cuidar do estigma, da culpa e acolher por meio da escuta são alguns dos manejos destacados. É necessário que o profissional considere, por meio do aprimoramento da escuta, o estigma do suicídio, e a culpa que os sobreviventes sentem por ter tido uma pessoa da família que cometeu o suicídio; promovendo o acolhimento do sofrimento dessas pessoas.

O Círculo (The Circle) ${ }^{11}$ é um exemplo do quanto o processo de luto pode ser facilitado pelo fato das pessoas sentirem-se conectadas com outros sobreviventes. Scavacini (2017a) cita uma nova modalidade de apoio, a criação de grupos virtuais, que podem além de proteger a identidade de uma pessoa preocupada com esse fato, oferecer proximidade de pessoas que moram longe e/ou não tem acesso aos serviços físicos em sua cidade. Estudos apontam ser fundamental que os serviços propostos sejam acessíveis, mesmo que por telefone ou internet, conhecidos (divulgados), avaliados, tendo objetivos claros e mensuráveis, em equilíbrio com uma política governamental e com treinamento, local e equipe apropriados (Flexhaug \& Yazganoglu, 2008; Taylor, Kingdom, \& Jenkins, 1997).

Talvez porque não queiram, por não terem acesso, por não saberem o significado da palavra posvenção ou não conhecerem lugares que oferecem essas atividades, fica evidente a dificuldade dos sobreviventes de terem acesso aos serviços oferecidos, por esse motivo, poderão passar pelo processo de luto sem auxílio na sua elaboração (Scavacini, 2017a).

Programas existem em vários países prestando apoio aos enlutados. No Brasil estão em desenvolvimento atividades de posvenção. Nesse sentido, é necessário que as atividades após o suicídio possam desenvolver-se progressivamente a fim de englobarem cada vez mais serviços, promovendo a saúde mental, respeitando a singularidade e a complexidade do processo do luto.

\footnotetext{
${ }^{11} \mathrm{http}: / / \mathrm{www}$. survivorsofsuicide.com
} 


\subsection{TABU, ESTIGMA, PRECONCEITO E DISCRIMINAÇÃO.}

Tabu, segundo o dicionário Aurélio (Ferreira, 2010, p 724) significa:

\footnotetext{
1. Entre certos povos, imposição ritual e religiosa de que se evitem certos indivíduos, objetos, atos, etc. considerados sagrados, ou especialmente impuros ou perigosos. 2. Restrição costumeira ou tradicional a certos comportamentos que, se praticados, recebem forte reprovação moral e social. 3. Escrúpulo, zelo ou melindre. 4. Aquilo que está sujeito a esses tipos de imposições, restrições ou escrúpulos.
}

Em outras palavras, o tabu tem relação com a proibição de um ato que pode ser culturalmente reprovável, depende dos padrões morais de cada sociedade, evolui com a história e é criado a partir de convenções culturais, religiosas ou sociais. É uma restrição ao campo de ação das pessoas. Muitas vezes recorremos a eufemismos (termos agradáveis) ou disfemismos (termos depreciativos) ao nos referirmos a algum assunto tabu, dada a proibição de falar no tema. Câncer foi por muitos anos chamado de "aquela doença" e suicídio muitas vezes é descrito como "pensando em fazer besteira", são formas que uma sociedade encontra de falar sobre certo assunto sem quebrar a interdição velada sobre ele. Quebrar um tabu pode gerar culpa, vergonha, castigo social (por meio de discriminação ou condenação pública), constrangimento, castigo legal (por violar uma lei), dependendo do tamanho do tabu naquele ambiente.

Mishara and Weisstub (2016) realizaram uma pesquisa a partir dos códigos penais de cento e noventa e dois países e estados, encontraram que em vinte e cinco deles o suicídio é ilegal e em outros vinte países, especialmente aqueles que seguiam o Islamismo ou a Sharia, as pessoas que tentaram suicídio poderiam ser punidas e presas. Esse é um exemplo da consequência legal de quebrar um tabu em determinada sociedade.

O estigma, segundo o dicionário Aurélio (Ferreira, 2010, p. 319) significa "1. Cicatriz, sinal. 2. Ferrete.”. Esse termo tem origem a partir do hábito de marcar no corpo, por meio de cicatrizes de escravos ou criminosos a fim de que a sociedade conseguisse identificá-los com mais facilidade. No sentido figurado, estigma tem relação com uma situação ou pessoa que cometeu uma infração, indignidade ou desonra. Já o verbete "estigmatizar: 1. Marcar com estigma. 2. Censurar, condenar" (p. 319).

Para os sociólogos, o estigma social refere-se a indivíduos ou grupos que tenham características contrárias às normas ou aos padrões culturais aceitos por uma sociedade, por isso devem ser evitados por serem uma ameaça a essa sociedade.

Para Goffman (1963, p. 4), o estigma social é definido como "a situação do indivíduo que está inabilitado para aceitação social plena”, e compreende os conceitos de "identidade 
virtual" e "identidade real". Siqueira e Cardoso (2011, p. 94) ancorados em Goffman (1975) afirmam que

\footnotetext{
a identidade real é o conjunto de categorias e atributos que uma pessoa prova ter; e a identidade virtual é o conjunto de categoria e atributos que as pessoas tem para com um estranho que aparece a sua volta, portanto, são exigências e imputações de caráter, feitas pelos normais ${ }^{12}$, quanto ao que o estranho deveria ser.
}

O estigma aparece quando há uma discrepância negativa entre a identidade real e a virtual e pode levar ao uso de estereótipos, que é uma marca usada para representar ou caracterizar uma pessoa ou grupo social. Estereótipos relacionados ao comportamento suicida podem ser: fraco, louco, angustiado, manipulador, não tem Deus no coração, egoísta, entre outros.

O preconceito, segundo o dicionário Aurélio (Ferreira, 2010, p. 605) significa “1. Ideia preconcebida. 2. Suspeita, intolerância, aversão a outras raças, credos, religiões, etc.”; ou juízo de valor preconcebido e manifestado por meio da discriminação. Preconceitos do comportamento suicida podem incluir: medo, raiva, desgosto, insegurança, entre outros.

A discriminação refere-se a atitudes adversas perante características específicas, diferentes ou passíveis de preconceito. O preconceito está ligado à ideia e à forma de pensamento, já a discriminação à ação. Algumas atitudes discriminatórias do comportamento suicida são: coerção, distanciamento, descrença, falta de valor, afastamento, demissão, culpabilização, entre outros.

O tabu, o estigma, os estereótipos, o preconceito e a discriminação estão presentes nos transtornos mentais (Corrigan, Druss, \& Perlick, 2014; Rukavina et al., 2012), no comportamento suicida (Corrigan, Sheehan, Al-Khouja, \& Stigma of Suicide Research, 2017; Sudak, Maxim, \& Carpenter, 2008), com os sobreviventes de tentativas (Tzeng \& Lipson, 2004; Wiklander, Samuelsson, \& Asberg, 2003) e com os sobreviventes enlutados (Cvinar, 2005; Feigelman, Gorman, \& Jordan, 2009; Peters, Cunningham, Murphy, \& Jackson, 2016; Pitman, Osborn, Rantell, \& King, 2016; Scocco, Preti, Totaro, Ferrari, \& Toffol, 2017).

Esses elementos podem ser um fator de risco para o ato suicida (Pompili, Mancinelli, \& Tatarelli, 2003), interferindo nas estratégias de prevenção (Marquetti, Kawauchi, \& Pleffken, 2015), levando à autoestigma (self-stigma) (Rusch, Lieb, Bohus, \& Corrigan, 2006).

\footnotetext{
12 Termo usado por Goffman para definir aqueles que são considerados "normais" em uma sociedade que produzem ou reproduzem o estigma.
} 
Alguns programas de prevenção do suicídio são voltados ao aumento da consciência e diminuição do estigma (Corrigan \& Gelb, 2006; Henderson \& Thornicroft, 2009; Wasserman et al., 2009), algumas escalas já foram desenvolvidas para medirem o estigma relacionado às pessoas que tentaram o suicídio (Scocco, Castriotta, Toffol, \& Preti, 2012; Williams, Cero, Gauthier, \& Witte, 2018)

\subsection{CONSCIÊNCIA (awareness)}

Se, na verdade, não estou no mundo para simplesmente a ele me adaptar, mas para transformá-lo; se não é possível mudá-lo sem um certo sonho ou projeto de mundo, devo usar toda possibilidade que tenha para não apenas falar de minha utopia, mas participar de práticas com ela coerentes (Freire, 2000, p. $33)$.

Consciência no dicionário Aurélio (Ferreira, 2010) significa:

1. Atributo pelo qual o homem pode conhecer e julgar sua própria realidade. 2. Faculdade de estabelecer julgamentos morais dos atos realizados. 3 . Cuidado com que se executa um trabalho, se cumpre um dever; senso de responsabilidade. 4. Conhecimento. 5. Med. Percepção imediata dos acontecimentos e da própria atividade psíquica (p. 190).

No dicionário Merriam-Webster (2017), o verbete consciência (awareness) significa: "a qualidade ou o estado de consciência: o conhecimento e o entendimento de que algo está acontecendo ou existe. Promovendo uma maior conscientização do problema. Parecia ter apenas uma pequena consciência do que estava acontecendo".

No Brasil, podemos ver em vários estudos, principalmente na área da educação, o uso do termo "conscientização" a partir da visão de Paulo Freire (1980, p. 29), significando "o olhar mais crítico possível da realidade, que a 'des-vela' para conhecê-la e para conhecer os mitos que enganam e que ajudam a manter a realidade da estrutura dominante". Para Vieira e Ximenez (2008, p. 24), esse conceito "extrapola uma dimensão cognoscitiva (o conhecer melhor a realidade), pois traz consigo uma concepção política, qual seja, a da transformação dela". Acreditamos que a conscientização precisa ser acompanhada da ação e essa é uma das propostas desse estudo.

A consciência pública, chamada por Durkheim (2010) de consciência coletiva, corresponde ao conjunto cultural de ideias morais e normativas, constituído pelas crenças e sentimentos comuns aos membros de uma sociedade e que é adquirida através do processo de socialização. A consciência particular ou individual, está ligada aos sentimentos e crenças pessoais que tornam os indivíduos únicos e possibilita que exista a personalidade própria. 
Segundo Durkheim a consciência coletiva está formada antes do indivíduo nascer e influencia na formação de sua consciência individual. Essa consciência é externa ao indivíduo. Ela serve para orientar o comportamento das pessoas dentro da sociedade e os indivíduos têm que se adaptar a ela (Durkheim, 2010).

Dentre as formas para diminuir o tabu e o estigma que envolve o suicídio, campanhas e programas de aumento de consciência (awareness) têm sido propostas para profissionais, estudantes, público em geral, entre outros (De Silva, Bowerman, \& Zimitat, 2015; King, Strunk, \& Sorter, 2011; Silverman, Smith, \& Burns, 2013; Wasserman et al., 2012). Para Vincent (2013), aumentar a consciência é gerar esperança.

De acordo com Hoven (2004, p. 3), os objetivos de campanhas para aumento da consciência são

\footnotetext{
informar o público sobre a natureza e o tratamento dos transtornos mentais ..., o que facilitará a identificação precoce e o tratamento de tais problemas; reduzir o estigma associado aos problemas de saúde mental ... que podem causar maior sofrimento emocional e social ou impedir que um indivíduo busque tratamento e começar um diálogo entre diferentes grupos para que as pessoas comecem a trabalhar em conjunto para promover a saúde mental.
}

Para a autora (2004), ter consciência do estigma ajuda a superá-lo, podendo ser reduzido por meio de: 1. Conhecimento, especialmente com intervenções úteis e informações sobre a frequência desses problemas na população em geral; 2. Da identificação de pessoas em risco e tratamento precoce ao ensinar indivíduos a identificar quem está tendo problemas, depois informá-los sobre possíveis recursos comunitários e médicos, que podem aumentar suas chances de serem ajudados com antecedência e eficácia; 3. A promoção de mudanças no tratamento e na política de saúde mental ao fornecer informações às famílias, comunidades, escolas, governos e organizações sobre a necessidade de cuidados de saúde mental e prevenção do suicídio, assim esses grupos serão capazes de agir e implementar programas para apoiar, tratar e ajudar a prevenir o suicídio.

\subsection{COMPETÊNCIA (literacy)}

O termo "literacy", em inglês, pode ser definido como a habilidade da pessoa para ler, escrever e falar, bem como resolver problemas para conseguir trabalhar e viver em sociedade; alcançar os objetivos pessoais e desenvolver a capacidade e conhecimento individual (EUA, 2018). 
A partir desse termo foi criado o "health literacy", que está ligado à capacidade da pessoa em obter, processar e compreender as informações necessárias para tomar decisões de saúde apropriadas. Tem relação com fatores individuais e sistêmicos como: habilidades de comunicação; conhecimento a respeito de temas de saúde; cultura; demandas dos sistemas de saúde; situação ou contexto, afetando a localização, utilização dos serviços públicos e preenchimento de formulários de saúde; a explicação do estado de saúde e de medicamentos que utiliza; engajar-se no autocuidado e no tratamento de doenças crônicas; compreender conceitos relacionados a probabilidade e risco (EUA, 2018).

O Departamento de Saúde dos EUA sugere um Plano de Ação Nacional para implementar um programa abrangente de health literacy, incluindo sete objetivos (EUA, 2010, pp. 1-2)

1. Desenvolver e divulgar informações precisas, acessíveis de fácil acesso de saúde e segurança. 2. Promover mudanças no sistema de saúde para melhorar a informação de saúde, comunicação, tomada de decisão e acesso a serviços de saúde. 3. Incorporar informações e diretivas precisas, baseadas em evidências para o desenvolvimento em saúde e educação, da educação infantil até o nível universitário. 4. Apoiar e expandir os esforços locais para proporcionar educação para adultos, instrução de língua inglesa e serviços de informação de saúde cultural e linguisticamente adequados na comunidade. 5.Construir parcerias, desenvolver orientações e políticas. 6. Aumentar a pesquisa básica e o desenvolvimento, implementação e avaliação de práticas e intervenções para melhorar a alfabetização em saúde. 7. Aumentar a disseminação e o uso de práticas e intervenções de alfabetização em saúde baseadas em evidências.

Os conceitos apresentados sobre o suicídio; suas taxas; prevenção; prevenção do suicídio; luto por suicídio; posvenção; tabu, preconceito e discriminação; consciência e competência são as bases que sustentam teoricamente esse estudo. 


\section{MÉTODO}

Caminante, no hay caminho; se hace caminho al andar.

Al andar se hace caminho,

Y al volver la vista atrás,

Se v ela senda

Que nunca se ha de volver a pisar.

(Machado, 1946, p. 172)

Conforme o dicionário Michaelis (2018), método, do latim methodu significa:

\footnotetext{
1 Conjunto dos meios dispostos convenientemente para alcançar um fim e especialmente para chegar a um conhecimento científico ou comunicá-lo aos outros. 2 Ordem ou sistema que se segue no estudo ou no ensino de qualquer disciplina ... 4 Maneira de fazer as coisas; modo de proceder. 5 Circunspecção, prudência.
}

Dessa maneira, apresentaremos a seguir quais foram nossos caminhos, os rumos que utilizamos para dar vida ao projeto de pesquisa e transformá-lo nesse estudo. Caminho que foi conduzido somando-se prudência e processos reflexivos, que foram sendo amadurecidos e reconstruídos conforme nosso caminhar por esses percursos, ora retos e tranquilos, ora íngremes e espinhosos.

Trata-se de estudo qualitativo, exploratório, indutivo, aplicado, descritivo e exploratório, a partir da Teoria Fundamentada nos Dados (TFD) ou Grounded Theory (GT).

Segundo Dahlgren, Emmelin, e Winkvist (2007) e Lincoln e Guba (1985), a pesquisa qualitativa possui um pressuposto ontológico (ontological assumption), que diz que as realidades são múltiplas, subjetivas e construídas socialmente; buscam ter uma abordagem holística (holitic approach), assim todas as partes são analisadas dentro de um todo; tem um pressuposto epistemológico (epistemological assumption) a partir de como o conhecimento é gerado, uma suposição axiológica (axiological assumption), no qual a pesquisa tem valor e os preconceitos, expectativas e tendências do pesquisador devem ser debatidas abertamente.

Todo esse cenário influencia o processo de pesquisa (methodological assumption), que é indutivo, está dentro de um tempo e de um contexto que segue um design, tendo como objetivo principal conceituar o significado dos fenômenos e da ação humana.

Esse estudo também é aplicado ao buscar resolução dos problemas apresentados na pesquisa e no aproveitamento dos resultados encontrados (Barros \& Lehfeld, 2007) e descritivo ao abranger a "descoberta" de atitudes, opiniões, crenças e como estas influenciam as pessoas e a sociedade (Gil, 2010). 
Como afirma Minayo (2013) na pesquisa de natureza qualitativa, é possível aprofundarse em um universo de significados, motivos, crenças e valores ao compreender e explicar o objeto investigado. Assim, buscamos compreender os significados coletivos e singulares desse fenômeno na vida e história das pessoas e como podem influenciar na prevenção e posvenção.

Partindo do significado dado pelas pessoas é que acontece a estruturação, organização e entendimento do que ocorre em suas vidas, desse modo, levando a encontrar um sentido ou interpretação dos fenômenos chegando à sua constituição (Turato, 2003).

Segundo Creswell (1998, p. 15), “a pesquisa qualitativa é um processo de investigação e entendimento com base em tradições metodológicas distintas que exploram problemas humanos ou sociais. O pesquisador constrói um quadro complexo, holístico, analisa palavras e relata detalhadamente a visão dos participantes, e conduz o estudo em um ambiente natural"

Para Rey \& Luis (2011, p. 38):

\footnotetext{
As modalidades qualitativas produzem estruturas teóricas que vão muito além de qualquer critério atual de confirmação no plano empírico. Essas construções se convertem em recursos indispensáveis para entrar em zonas de sentido ocultas pela aparência. Esse princípio tem diferentes repercussões ao nível metodológico, entre os quais estão o lugar ativo do pesquisador e do sujeito pesquisado como produtores de pensamento.
}

"O qualitativo enfatiza a diferença, o individual, e a contextualização dos particulares leva a teorias gerais, mas que tem que ser adaptáveis a cada situação única" (Cassorla, 2003, p. 27). Por isso, a compreensão de experiências, do que é permitido ou proibido falar, dos valores individuais e culturais não reconhecidos, das influências presentes na vida cotidiana e na formação da pessoa são fundamentais na exploração da importância de uma consciência pública na prevenção do suicídio.

Ressaltamos que por se tratar de um processo de pesquisa emergente, o plano inicial de pesquisa não é rígido e pode ser alterado conforme o andamento do estudo e coleta de dados (Creswell, 2003). É também um estudo exploratório por propor um novo discurso interpretativo e pela possibilidade de gerar de hipóteses (Minayo, 2013).

\subsection{REFERENCIAL TEÓRICO: INTERACIONISMO SIMBÓLICO (IS)}

O Interacionismo Simbólico (IS) é a perspectiva teórica, que orientou o presente estudo e que pode ser visto em diversas pesquisas que adotam a TFD como metodologia de investigação (Charmaz, 2006). 
George Herbert Mead, professor de filosofia e psicólogo social da Universidade de Chicago foi um dos principais criadores do IS, sendo influenciado pelo behaviorismo, pragmatismo e darwinismo, juntamente com Herbert Blumer, que sistematizou e apresentou os pensamentos de Mead no desenvolvimento do IS (Charon, 2006).

Charon (2006) descreve as principais ideias do IS:

- O ser humano está em constante interação e muda seu comportamento a partir da interação que tem com outros. Assim, ele é ativo em seu desenvolvimento e a partir de sua interação com outros indivíduos que a sociedade é constituída. A partir dessa interação a pessoa age, percebe, interpreta e transforma a ação;

- A interação acontece no presente e influencia o indivíduo a agir a partir dele. O passado integra a ação dependendo da maneira como influencia o presente;

- A interação é interna e externa;

- O indivíduo é livre e faz escolhas conscientes, podendo direcionar suas ações a partir de suas avaliações ou da avaliação dos outros.

Para Charon (2006), o IS é uma perspectiva de compreensão da realidade, destacando à interação social; ao pensamento (representando a interação da pessoa consigo); à definição da realidade (resultante do pensamento com a interação social); ao presente (que tem importância maior do que o passado na forma como agimos) e à noção de liberdade (indicando que a pessoa tem papel ativo frente ao ambiente). Para o autor, os conceitos necessários para a compreensão do IS são:

O Símbolo, caracterizado por objetos sociais dinâmicos utilizados para transmitir ou representar uma situação, são usados interna e externamente. A comunicação apresenta-se pelos símbolos e a interação pela via de sua interpretação. Torna-se simbólico o ato acompanhado de significado ou intencionalidade, assim, compreender os símbolos é importante no entendimento da conduta humana. "Os humanos dão nome, lembram, categorizam, percebem, pensam, deliberam, resolvem problemas, transcendem o tempo e o espaço, transcendem a si mesmos, criam abstrações, criam novas ideias, e se direcionam - tudo isso através do símbolo" (Charon, 2006, p. 69).

O Self surge na infância e amplia-se à medida que a pessoa interage com outras e aprende as regras sociais, representa quem é o ser humano, em sua interação consigo e com os outros, assim, a capacidade do indivíduo colocar-se no lugar do outro possibilita que conheça outras perspectivas. É o self que possibilita a vida mental das pessoas (mind), usando os símbolos para atribuir significado, interpretar e dar sentido às experiências. 
A interação social faz surgir os símbolos, o self, a mente, a ação e desenvolve a cultura. Portanto, ao interagirmos, usamos os símbolos, direcionamos o self, nos colocamos no lugar do outro, interpretamos as situações por meio da mente (mind), tomamos as decisões, compartilhamos nossas perspectivas, por fim, definimos nossa realidade. As regras, entendimentos, linguagens, objetivos e valores emergem da cultura e criam a "comunidade do tempo", que está em constante mudança. Assumir o papel do outro ajuda no desenvolvimento do self, na aquisição e no uso de símbolos e na própria atividade mental, pois, ao fazer isso, a pessoa procura uma explicação à ação, alinhando-a a uma razão identificada, para que haja comunicação e interação simbólica.

A sociedade é dinâmica e as mudanças sociais são promovidas por indivíduos ativos. Os aspectos mais permanentes e estruturais de uma sociedade são reconhecidos, como os conceitos de estrutura, poder, papel social. Essa interação constante dos indivíduos define e altera a sociedade visto que todo grupo ou sociedade é formado por seres em interação comunicando-se por meio de símbolos, na qual, a ação de um afeta o outro, fazendo que pessoas ao engajarem-se em um processo de interação cooperativa, desenvolvam a cultura.

O significado torna-se fundamental para compreender o comportamento humano, suas interações e processos. Para Blumer (1969), os indivíduos agem conforme o significado que as coisas têm para eles, incluindo tudo o que os homens podem perceber no mundo; estes significados são derivados das interações sociais entre as pessoas, podendo ser alterados mediante o processo interpretativo que o indivíduo usa ao lidar com as coisas que encontra.

Dessa maneira, é importante apoderar-se do que um indivíduo experiência em um contexto particular afim de alcançar uma compreensão plena do processo social (Carvalho, Borges, \& Rego, 2010).

A TFD foi desenvolvida a partir de duas premissas do IS: a) A construção social da realidade, na qual a ciência juntamente com as experiências do cotidiano geram construções sociais da realidade, nessa perspectiva a sociedade é uma realidade objetiva que é percebida e criada subjetivamente, podendo gerar várias "verdades" existindo lado a lado; b) A habilidade de generalizar, baseada no processo de socialização, que contém três conceitos, interação, troca de papéis e generalização (Dahlgren et al., 2007).

Tal referencial teórico demostrou ser o mais adequado para esse estudo, na medida em que possibilita compreender como a interação da sociedade, com seus conceitos, normas, crenças, tabus com os indivíduos, pessoas com comportamento suicida ou sobreviventes enlutados pode aumentar ou prejudicar o aumento da consciência do suicídio e as ações decorrentes dela, tendo influência na sua prevenção e posvenção. 


\subsection{REFERENCIAL METODOLÓGICO: TEORIA FUNDAMENTADA NOS} DADOS (TFD) ou GROUNDED THEORY (GT)

Utilizamos como referencial metodológico a Teoria Fundamentada nos Dados (TFD) ou Grounded Theory (GT), que, segundo Strauss e Corbin (2008), significa que "a teoria foi derivada dos dados" ou conjunto de conceitos bem desenvolvidos, "sistematicamente reunidos e analisados por meio de processo de pesquisa" (p. 25), que predizem ou explicam um fenômeno. Segundo Health e Cowley (2004 citado por Gomes, 2015, p. 73), “o objetivo não é descobrir "a teoria", mas "uma teoria" que ajude a compreensão e a ação na área investigada".

Creswell (1998) aponta a TFD como um dos métodos possíveis de serem utilizados na análise qualitativa, objetivando gerar uma teoria com um esquema analítico e abstrato do fenômeno estudado, relacionado a uma determinada situação, "sendo essa situação em que os indivíduos interagem, agem e se envolvem em um processo contínuo de resposta ao fenômeno" (Creswell, 1998, p. 183)

A TFD foi criada pelos sociólogos Braney G. Glaser e Anselm L. Strauss em 1967 com o objetivo de construir explicações teóricas abstratas dos processos sociais (Glaser \& Strauss, 1967) durante seus estudos sobre o processo da morte em hospitais (Glaser \& Strauss, 1965). O Interacionismo Simbólico (IS) de Chicago (Chicago School of Socieology and Symbolic Interacionism) e a filosofia do pragmatismo de George Mead e John Dewey, constituem a epistemologia desse método (Strauss e Corbin, 2008). As contribuições da formação de Strauss na Escola de Chicago para o desenvolvimento dessa metodologia foram:

(a) A necessidade de sair a campo para descobrir o que está realmente acontecendo; (b) A relevância da teoria, baseada em dados, para o desenvolvimento de uma disciplina e como base para ação social; (c) A complexidade e a variabilidade dos fenômenos e das ações humanas; (d) A crença de que as pessoas são atores que assumem um papel ativo para responder a situações problemáticas; (e) A percepção de que as pessoas agem com base em significados; (f) $\mathrm{O}$ entendimento de que o significado é definido e redefinido através da interação; (g) Sensibilidade para a natureza evolutiva e reveladora dos fatos; (h) Consciência das inter-relações entre condições (estrutura), ação (processo) e consequências (Strauss e Corbin, p.22).

Glaser e Strauss (1965 citado por Charmaz, 2009, p. 19) acreditavam que os componentes determinantes da prática TFD eram constituídos de:

- O envolvimento simultâneo na coleta e na análise dos dados;

- A construção de códigos e categorias analíticas a partir dos dados, e não de hipóteses pré-concebidas e logicamente deduzidas; 


\begin{abstract}
- A utilização do método comparativo constante, que compreende a elaboração de comparações durante cada etapa da análise;

- O avanço no desenvolvimento da teoria em cada passo da coleta e da análise dos dados;

- A redação de memorandos para elaborar categorias, especificar as suas propriedades, determinar relações entre categorias e identificar lacunas;

- A amostragem dirigida à construção da teoria, e não visando à representatividade populacional;

- A realização da revisão bibliográfica após o desenvolvimento de uma análise independente.
\end{abstract}

Se tornar um pesquisador na TFD requer gerar construtos teóricos por meio de uma análise exaustivamente sistemática. Leite, da Silva, Oliveira e Stipp (2012, pp. 774-775) falam que as características e as aptidões necessárias para trabalhar com a TFD incluem: "atitude criativa, curiosidade e olhar estético; sensibilidade teórica e compromisso com os entrevistados e a sociedade e, por fim, determinação".

Para Strauss e Corbin (2008, p. 23), é importante que o pesquisador seja "flexível e ativo ... para que possa pensar nos dados e no mundo que vivem ... e aprendam a pensar comparativamente em termos de propriedades e dimensões ... garantindo um senso de visão no qual o analista segue junto com a pesquisa", ideal para pesquisadores que queiram "criar entendimentos novos e teoricamente expressos". Conceber ou intuir ideias e formulá-las em um esquema lógico faz parte da teorização.

\footnotetext{
No núcleo da teorização está à interação de fazer induções - derivando conceitos, suas propriedades e dimensões, a partir dos dados; e deduções criando hipóteses sobre as relações entre conceitos, às relações derivadas dos dados, que foram abstraídos pelo analista dos dados brutos (Strauss e Corbin, 2008, p. 35)
}

Tarozzi (2011) destaca que o termo "fundamentada", vem da tradução de grounded, que tem como significado firme à terra, encravado, enraizado, embasado; assim a teoria produzida origina-se da experiência vivida em conjunto com uma sólida base empírica, podendo ser caracterizada como original e com valor prático.

A aplicação do método não precisa ser rígida e apenas alguns dos procedimentos propostos podem ser utilizados, conforme os autores, possibilitando adaptações para contextos específicos (Strauss \& Corbin, 2008).

A TDF foi escolhida para essa pesquisa por proporcionar que fosse gerada uma teoria baseada nos dados da pesquisa, que o caminho fosse descoberto por meio da fala e da vivência dos colaboradores e não por pressupostos teóricos ou hipóteses. 


\subsection{PROCEDIMENTO METODOLÓGICO}

\subsubsection{Coleta de dados}

O suicídio é um fenômeno complexo, por essa razão não pode ser reduzido em apenas um ponto de vista. Com o objetivo de ampliar a compreensão e facilitar a discussão do fenômeno, moderamos um grupo focal, com pessoas que perderam alguém para o suicídio, os sobreviventes enlutados pelo suicídio.

Os grupos focais foram escolhidos por serem um meio pelo qual é possível criar linhas de comunicação que conectam o pesquisador e os colaboradores, nos quais o pesquisador assume o papel de moderador, trazendo discussões, permitindo ampliações de olhares e de ideias, promovendo reflexões e fazendo perguntas focadas no tema (Cacciacarro, 2016)

Conforme descrito por Aschidamini e Saupe (2004), as estratégias para a realização de um grupo focal compreendem um número de 8 a 10 participantes, de ambos os sexos, idades variadas e com algumas características em comum, no caso desse estudo, o que os participantes tinham em comum era ter perdido pessoas próximas por suicídio. Houve a participação de um observador que acompanhou os encontros em sua totalidade e com o qual foram discutidas questões surgidas durante o grupo.

Assim, procuramos abranger um número maior de experiências e de possibilitar uma ampla visão sobre o tema. Indivíduos enlutados pelo suicídio carregam consigo, na maioria das vezes, o estigma e o tabu de terem experienciado esse tipo de morte, podem colaborar com sua vivência acerca do tema, além de contar como gostariam de ter sido tratados e como gostariam que o suicídio fosse tratado pela sociedade de modo a colaborar com a diminuição do tabu e o aumento da consciência pública.

Foram realizados dois encontros do grupo focal, que tiveram em média duas horas de duração cada um, que foram gravados em áudio, posteriormente transcritos mediante autorização dos colaboradores. A pesquisadora ofereceu local apropriado para a realização dos grupos focais, atendendo aos princípios do anonimato, confidencialidade e privacidade.

Uma observadora acompanhou os encontros, conforme prevê o referencial teórico para Grupos Focais, ao final apresentou para a pesquisadora um relatório de observação, que se encontra no ANEXO H e foi produzido como forma de documentar suas percepções, sendo utilizado na discussão dos resultados.

Optamos por termos dois encontros, pois observamos que se fizéssemos uma nova reunião, o foco do grupo perder-se-ia e outras questões seriam discutidas, fugindo dos objetivos 
propostos para essa investigação. Perceber as convergências e as divergências no grupo pôde colaborar para uma visão mais extensa da situação, por conseguinte, uma compreensão maior do fenômeno e da necessidade de ações de conscientização.

Para Strauss e Corbin (2008), a pesquisa deve se iniciar com uma questão aberta e ampla, para permitir que os colaboradores trouxessem seu universo de possibilidades. Os encontros seguiram o modelo de funil reverso, que parte de questões mais amplas para as mais específicas e objetivas. O propósito de adotar essa estratégia é ir construindo com os colaboradores um caminho de compreensão e auxiliando-os a familiarizarem-se com os temas discutidos para que o foco seja mantido nas questões mais específicas (Berthoud, 2003). Considerando a perspectiva epistemológica do método, as experiências, o conhecimento prévio dos pesquisadores e a literatura não ficaram em primeiro plano e sim reconhecidas e consideradas, para que houvesse abertura às descobertas feitas no campo.

Assim, pesquisador e participante, em interação, direcionam a pesquisa, apresentando mais dados segundo os objetivos propostos (Turato, 2008). Ao iniciar o grupo com uma pergunta disparadora, que "introduz o tópico e guia a discussão para perguntar questões específicas" (Rubin e Rubin citado em Turato, 2008, p. 314) é possível elucidar dúvidas, obter detalhes, exemplos e o que experiências, que envolvam a falta de consciência, significam para o participante.

A partir do formato de entrevista adotado, todos os presentes puderam narrar suas experiências, expressando seus pontos de vista sobre todos os tópicos discutidos, se assim o quisessem. A pesquisadora buscou explorar os diálogos e as reflexões bem como permitir que conteúdos não programados anteriormente, fossem apresentados e discutidos pelo grupo.

Para Rey e Luis (2011, p. 4), “as construções do sujeito diante de situações pouco estruturadas produzem uma informação qualitativamente diferente da produzida pelas respostas a perguntas fechadas, cujo sentido para quem as responde está influenciado pela cosmovisão do investigador que as constrói”.

Um roteiro norteador, disponível no ANEXO A, foi construído com tópicos relacionados a: como eles gostariam que o suicídio fosse visto pela sociedade; tabu e consciência pública e as possibilidades de comunicação sobre o tema. As perguntas foram desenvolvidas levando em consideração o grau de vulnerabilidade do grupo.

Tendo essa base, as perguntas puderam ajudar a esclarecer e ampliar as respostas dadas sobre o tema a partir da questão disparadora: Como você acha que o suicídio é visto hoje no 
Brasil? A partir da resposta a esta pergunta, outras foram inseridas, como apresentamos a seguir:

- Vocês pensam que o suicídio é um tema tabu no Brasil? Por que vocês acham que isso acontece?

- Vocês acham que o tabu começa aonde?

- O que pensam a respeito conscientização da problemática do suicídio?

A sequência das questões pode ser alterada a depender do desenrolar do grupo focal. Uma entrevista piloto, com um especialista na área de prevenção do suicídio, foi realizada para fins de exame de qualificação, assim pudemos rever o roteiro de perguntas, verificar sua adequação e optarmos em basear a pesquisa na visão dos enlutados pelo suicídio, conforme sugestão da banca. Portanto, o roteiro elaborado para a realização da entrevista piloto foi adaptado para o primeiro encontro do grupo focal e revisto para o segundo encontro.

Para Rey e Luís (2011, p. 55), “o sujeito pesquisado é ativo no curso da pesquisa, não é simplesmente um reservatório de respostas ... na realidade, não responde linearmente às perguntas que lhe são feitas, mas realiza verdadeiras construções implicadas nos diálogos nos quais se expressa".

\footnotetext{
O pesquisador então recorre aos conhecimentos e experiências pessoais como auxiliares no processo de compreensão e interpretação do fenômeno estudado, considerando importantes, por conseguinte, a introspecção e a reflexão pessoal na pesquisa (Ludke e André, 1986, p.26).
}

\subsubsection{Participantes}

A escolha dos participantes foi intencional e por conveniência. Os colaboradores foram convidados por e-mail, por contato pessoal ou por anúncios nos grupos de apoio aos sobreviventes do suicídio.

A pesquisadora conhecia os colaboradores dos grupos de apoio aos enlutados pelo suicídio, o que contribuiu para o cuidado com os aspectos éticos e diminuição dos riscos. As diferenças entre Grupo Focal e Grupo de Apoio foram ressaltadas para que não houvesse confusão dos objetivos da participação dos colaboradores na pesquisa.

Participaram desse estudo onze colaboradores no primeiro encontro e nove no segundo, que preenchiam os critérios de inclusão. Dois participantes não puderam comparecer do segundo encontro por terem outros compromissos que foram agendados em cima da hora. 
Tabela 4 - Participantes do estudo

\begin{tabular}{|c|c|}
\hline Gênero & $\begin{array}{l}7 \text { mulheres }(63 \%) \\
4 \text { homens }(36 \%)\end{array}$ \\
\hline Estado civil & $\begin{array}{l}5 \text { casados }(45 \%) \\
4 \text { solteiros }(36 \%) \\
1 \text { divorciado }(9 \%) \\
1 \text { viúvo }(9 \%)\end{array}$ \\
\hline $\begin{array}{l}\text { Grau de parentesco com a pessoa que } \\
\text { morreu por suicídio }\end{array}$ & $\begin{array}{l}5(45 \%) \text { perderam filho(a) } \\
2(18 \%) \text { perderam irmão(ã) } \\
1(9 \%) \text { perdeu cônjuge } \\
1(9 \%) \text { perdeu paciente } \\
1(9 \%) \text { perdeu sobrinho } \\
1(9 \%) \text { perdeu amigo }\end{array}$ \\
\hline Tempo desde a perda & $\begin{array}{l}\text { de } 7 \text { meses a } 36 \text { anos, sendo que a maioria } 5 \\
(45 \%) \text { ocorreu entre } 2 \text { a } 4 \text { anos da data da } \\
\text { pesquisa }\end{array}$ \\
\hline Idade da pessoa que faleceu & $\begin{array}{l}13 \text { e } 71 \text { anos, sendo } 4(36 \%) \text { de } 13 \text { a } 18 \text { anos } \\
\text { e } 4(36 \%) \text { entre } 21 \text { e } 24 \text { anos }\end{array}$ \\
\hline Idade dos colaboradores na época da perda & $\begin{array}{l}\text { Entre } 16 \text { e } 70 \text { anos, sendo: } \\
2(18 \%) \text { entre } 15 \text { e } 16 \text { anos } \\
3(27 \%) \text { entre } 34 \text { e } 38 \text { anos } \\
2(18 \%) \text { entre } 44 \text { e } 48 \text { anos } \\
3(27 \%) \text { entre } 54 \text { e } 55 \text { anos } \\
1(9 \%) \text { acima de } 70 \text { anos }\end{array}$ \\
\hline Residência & $\begin{array}{l}\text { Somente } 1(9 \%) \text { colaborador residia fora do } \\
\text { estado de São Paulo }\end{array}$ \\
\hline Tempo de participação em grupos de apoio & $\begin{array}{l}\text { de } 4 \text { meses há } 3 \text { anos, sendo que maioria } \\
\text { deles } 5(45 \%) \text { já frequentava há mais de } 2 \\
\text { anos }\end{array}$ \\
\hline Em tratamento psicoterápico & $\begin{array}{l}7(63 \%) \text { colaboradores fazem ou fizeram } \\
\text { terapia }\end{array}$ \\
\hline Em decorrência da perda & $6(86 \%)$ o fazem em decorrência da perda \\
\hline Em tratamento psiquiátrico & $2(18 \%)$ dos colaboradores \\
\hline Em decorrência da perda & $1(50 \%)$ em decorrência da perda \\
\hline
\end{tabular}

Um quadro com todas as informações encontra-se disponível no ANEXO Q.

Podemos observar que o grupo era heterogêneo, com indivíduos de várias faixas etárias, grau de parentesco, idade que tinha na época da perda, tempo decorrente da perda e que faziam ou não psicoterapia e tratamento psiquiátrico, decorrentes ou não da perda. Assim, assumimos que, embora a TFD não estabeleça essa exigência, entendemos que os colaboradores representaram a diversidade das pessoas enlutadas pelo suicídio. 


\section{Critério de inclusão}

Foram convidadas pessoas que tenham perdido alguém para o suicídio, sem delimitação de parentesco. Eram maiores de idade, que desejassem participar do estudo e que tivessem assinado o Termo de Consentimento Livre e Esclarecido para a participação no estudo, após os objetivos do estudo serem explicados e as possíveis dúvidas sanadas, garantindo o anonimato e a confidencialidade do participante.

\section{Critério de exclusão}

Não participaram da pesquisa pessoas enlutadas pela morte por suicídio que tenha ocorrido há menos de seis meses cujo motivo foi a possível carga de sofrimento psicológico intenso nesse período. Também não foram incluídas pessoas em grande sofrimento psíquico, com limitações físicas ou cognitivas, com transtorno psiquiátrico e menores de idade. Não houve restrição quando ao nível socioeconômico, grau de instrução e escolaridade do grupo.

\subsubsection{Considerações éticas}

Essa pesquisa foi submetida e aprovada pelo Comitê de Ética em Pesquisa com Seres Humanos do Instituto de Psicologia da Universidade de São Paulo, no. do processo 54657616.3.0000.5561, disponível no ANEXO R.

As diretrizes regulamentadoras de pesquisas que envolvem seres humanos, do Ministério da Saúde (MS), como consta na resolução 466/12 no Código de Ética Profissional do Psicólogo, pautaram os aspectos éticos dessa pesquisa.

O caráter voluntário dos participantes, os objetivos e procedimentos da pesquisa foram frisados em todas as etapas, desde o convite, à entrevista, até à sua finalização. O Termo de Consentimento Livre e Esclarecido (TCLE), disponível no ANEXO B, foi lido em conjunto com os participantes e assinado antes do início do grupo focal.

Juntamente com o TCLE, outros pontos destacados foram:

- A entrevista será gravada, transcrita e analisada e ficará em posse da pesquisadora;

- Nomes e quaisquer dados que possam levar à identificação do participante serão alterados, conforme o princípio do anonimato e sigilo, durante a pesquisa ou qualquer trabalho resultante dela, sempre com fins acadêmicocientíficos;

- Não obrigatoriedade de responder a todas as perguntas e a possibilidade de 
interromper a participação no grupo, se assim o desejar;

- O acesso às informações da pesquisa, às transcrições, às análises e aos resultados estará à disposição do participante a qualquer momento;

- A explicação da diferença entre grupos de apoio e grupos focais para pesquisa foi feita antes do início da reunião para que não houvesse confusão na forma e nos objetivos do encontro;

- A pesquisadora poderia ser contatada a qualquer momento, para esclarecimentos, acolhimento ou encaminhamento para atendimento psicológico.

Foi acordado com os participantes que se houvesse sofrimento ou desconforto, haveria acolhimento pela pesquisadora e se necessário encaminhamento para atendimento psicológico.

Dois dias depois do primeiro encontro, a pesquisadora entrou em contato com os colaboradores via mensagem de celular (Whattsapp) para saber como estavam e se precisavam de algum apoio psicológico.

Um dos colaboradores pediu para agendar uma conversa com a pesquisadora, pois relatou sentir-se angustiado após o grupo. A conversa teve duração de uma hora, seguida de mais duas ligações telefônicas para saber se estava tudo bem. Esse contato aconteceu durante o período entre o primeiro e segundo encontro. Foi dada ao colaborador a opção de não comparecer no segundo encontro se não estivesse à vontade, sendo que ele preferiu participar e finalizou o segundo encontro dizendo que estava se sentindo bem.

Novo contato foi feito com os colaboradores da mesma maneira supracitada após o segundo encontro, para saber se alguém precisava de apoio psicológico. Nenhum dos participantes pediu esse apoio.

Houve um terceiro contato com os colaboradores para o envio da transcrição dos encontros e do roteiro norteador, para que eles(as) pudessem, se desejassem, alterarem, conferirem, incluírem ou retirarem conteúdos de sua participação no grupo ou complementarem as questões que foram feitas durante os encontros, assim poderiam participar mais ativamente do estudo e teriam a liberdade de rever o que falaram. Dois colaboradores responderam à pesquisadora com o roteiro norteador preenchido e o material foi codificado, analisado e utilizado no estudo.

O último contato se deu no envio do diagrama 11, para saber se os colaboradores achavam que ele representava o que havia sido discutido nos grupos focais e estava em concordância com o objetivo da pesquisa. 


\section{Riscos}

Essa pesquisa envolveu riscos, que se cuidou para que fossem mínimos ao participante. Não foi utilizada nenhuma técnica invasiva, porém desconfortos podem ser gerados por despertar lembranças, que podem causar sofrimento. Neste caso, o(a) participante foi acolhido(a) pela pesquisadora e referido a serviço de suporte psicológico, se necessário. $\mathrm{O}$ participante pôde deixar de responder às perguntas, conforme sua vontade.

\section{Benefícios}

Não há benefício direto para o participante, o potencial benefício para a sociedade é que esse estudo possa ajudar na compreensão da ampliação da consciência pública em relação ao suicídio e suas influências na sua prevenção e posvenção.

\subsection{PERCURSO METODOLÓGICO: CODIFICAÇÃO}

Após a realização dos grupos focais e transcrição dos encontros, iniciamos a análise baseada na TFD, por meio da microanálise ou codificação linha-por-linha, no qual pequenos trechos, frases ou linhas do texto foram codificados, com o objetivo de originar códigos, que posteriormente são transformados em conceitos, gerando grande quantidade de dados. Nesse estudo foram codificados 1681 trechos. Os códigos são trechos relevantes do discurso, identificados pelo pesquisador de maneira arbitrária (Charmaz, 2009)

Entrar em contato tão profundamente e detalhadamente com a narrativas dos colaboradores conscientiza o pesquisador do quanto está contido em uma pequena parte de dados e que cabe a ele explorá-los, sendo necessário "ouvir os dados", perceber como e o que estão dizendo, compará-los e questioná-los, assim exercitar sua capacidade analítica e desenvolver a sensibilidade teórica.

O processo de codificação acontece por meio da Codificação Aberta (Open Coding), Codificação Axial (Axial Coding) e Codificação Seletiva (Selective Coding), que serão descritas abaixo.

Um exemplo dessa codificação pode ser observada na sequência: 
Tabela 5 - Exemplo de codificação aberta

\begin{tabular}{l|l}
\hline \multicolumn{1}{c|}{ Trecho do Grupo Focal } & \multicolumn{1}{c}{ Códigos } \\
\hline Como tudo de ruim nessa vida, a gente acha que & A vida tem coisas ruins \\
com a gente não vai acontecer, sempre com os & Achando que coisas ruins só acontecem \\
outros. Eu por exemplo, eu tive um câncer e & com os outros \\
achava "imagine comigo não vai acontecer", ter & Sobrevivendo a um câncer \\
um suicídio na família jamais, minha família é tão & Jamais passarei por um suicídio \\
bem estruturada, tudo lindo maravilhoso, isso & Sentindo a família perfeita \\
nunca vai acontecer. Então você vê um filme você & Isso nunca vai acontecer \\
fala "é uma ficção, não existe na vida real, comigo & Suicídio como ficção \\
jamais vai acontecer" (Colaboradora P3). & \\
\hline
\end{tabular}

Fonte: produção do próprio autor (2018)

A tabela com os códigos, as transcrições codificadas, os memos ${ }^{13}$, os diários de bordo encontram-se no ANEXO. Optou-se por disponibilizar todos esses dados integralmente para que outros pesquisadores pudessem observar como é construído um estudo baseado na TFD. Pela quantidade de dados, esse material está em formato digital anexo ao estudo.

Uma reflexão e análise do significado dos códigos foi realizada, pelo processo de comparação de suas similaridades, diferenças, propriedades ${ }^{14}$ e dimensões ${ }^{15}$, para ampliá-los e agrupá-los em conceitos, que são os precursores das categorias. Esse movimento faz que os códigos, que são originalmente mais concretos agrupem-se em categorias sob termos explicativos mais abstratos, que se apresentam em várias dimensões.

Os conceitos podem ser "In Vivo" (Charmaz, 2009; Strauss e Corbin, 2008), quando são utilizadas expressões literais dos colaboradores, por sua força analítica e descritiva ou podem ser construídos pelo pesquisador que utiliza "de sua sensibilidade, experiência e referencial teórico para adotar termos que que traduzam o significado dos fatos, sentimentos e ações que estão sendo representados" (Berthoud, 2003, p. 84). O título desse estudo derivou-se de um código "In Vivo", retirado da fala de um colaborador durante a codificação.

A Codificação Axial ocorre simultaneamente à Codificação Aberta, pois durante a análise, novas comparações, ampliações e compreensões eram feitas baseadas no material. Durante a codificação axial são organizados os temas, categorias e as subcategorias em um processo constante de releitura e comparação dos dados (Strauss e Corbin, 2008).

\footnotetext{
${ }^{13}$ memos são registros feitos pelo pesquisador, sobre o processo de análise, contendo suas impressões, conexões entre os dados, hipóteses, significados, interpretações, insights etc.

${ }^{14}$ Características ou atributos gerais ou específicos de uma categoria (Strauss e Corbin, 2008, p. 17).

${ }^{15}$ Representam a localização de uma propriedade ao longo de uma linha ou faixa (Strauss e Corbin, 2008, p.117)
} 
As categorias são compostas por conceitos e subcategorias que derivam dos dados e formam ou representam os fenômenos ou temas, que são as ideias analíticas importantes, que emergem destes, como problemas, questões, assuntos e preocupações importantes. Contextualizamos esse fenômeno em relação à sua estrutura (circunstâncias ou condições em que um fenômeno existe, respondendo às questões por que, quando, como, de que forma); processo (interação ou ação dos indivíduos e da sociedade, suas respostas estratégicas ou rotineiras a certos problemas, acontecimentos, fatos ou questões,) e consequência (resultado do processo ou da falha a responder a ele) (Strauss e Corbin, 2008).

A Codificação seletiva (Selective Coding) representa o núcleo do fenômeno investigado e emerge a partir dos dados, precisa contemplar e relacionar-se com todas as categorias, sendo um processo de integração e refinamento da teoria (Strauss e Corbin, 2008), conforme explicaremos no Capítulo 6. A condição, interação e consequência do fenômeno foi destacada no modelo teórico apresentado na página 173.

O uso de memorandos (memos) foi fundamental para a organização das ideias e do processo criativo. A partir da escrita dos memos foi possível registrar o processo de raciocínio da análise, ideias, insights, hipóteses, dúvidas, que foi extremamente útil durante a escrita.

Exemplo de memorando - microanálise 104 - documento E1:

A dificuldade de ter atendimento digno e o medo do que pode encontrar dificulta achar tratamento. Precisamos falar mais, mas também das formas de tratamento, dos lugares, do que acontece num psiquiatra, do que acontece numa clínica de repouso? A pessoa não se mata, pede ajuda e a vida dela acaba? Acaba porque vai ser estigmatizada, julgada, talvez privada da liberdade. Vai gastar boa parte do que tem ou se endividar por causa de tratamento. Ela é vista como doente incapaz? Como é vista pela sociedade a pessoa que fala em cometer suicídio ou sobrevive a uma tentativa? Temos grande necessidade de empoderar essas pessoas ... Será que parte disso não é por lidar com o tabu, com o julgamento, com a falta de atendimento? Por que o atendimento não vem porque ela tentou? Muitas vezes são maltratados nos hospitais e colocados de volta na mesma situação, não foi lhe dada outra saída, o grito de socorro não foi ouvido, ele foi punido! Qual é o tratamento para ideação ou comportamento suicida? Existe um protocolo? Ou somente protocolo de segurança ambiental? A pessoa tem a esperança que se matar vai resolver, ela tenta, mas não mata aquela dor, aquele problema, muitas vezes ele piora. E às vezes ouve frases como 'nem para se matar tem capacidade'. Quem acredita naquela vida, quem vai dar crédito para ele melhorar ou ele vai ser sempre visto como 'o suicida'. Nisto talvez a aliança entre enlutados e pessoas que tentaram possa funcionar. Os enlutados entendem a dor (depois de algum tempo) e podem acolher e orientar quem pensa. Não com o objetivo da dor dos que ficam, mas com a esperança de que eles podem fazer diferença. Levando a consciência de que alguém se importa. Se o suicídio passa a EXISTIR a partir da morte de alguém para a maioria das pessoas, isso pode ser linkado [sic] com as tentativas. Penso em um slogan tipo 'ACONTECEU COMIGO, NÃO DEIXE ACONTECER COM VOCÊ'. TEMA POSSÍVEL? MUITO ALÉM DA CONSCIÊNCIA PÚBLICA (Produção do próprio autor, 2018). 
Um diário de bordo foi escrito para documentar os pensamentos da pesquisadora em relação ao estudo.

O uso de diagramas é indicado para representar graficamente as relações e criar modelos (representação diagramada, lógica, integrada e sistemática de um conjunto de ideias, que mostram as relações entre os conceitos).

Para trazer consistência ao estudo e validar a teoria gerada, enviamos o diagrama 11 para os colaboradores, via mensagem de celular (Whattsapp), para saber se identificavam-se com o modelo apresentado e se representava o que havíamos conversado nos encontros. Três colaboradores responderam afirmando que o diagrama representava a essência da pesquisa, uma legitimação da teoria construída a partir do que foi expresso nos grupos focais.

\subsubsection{Softwares de apoio}

Foram utilizados os programas MAXQDA12 e MAXQDA18 (Foxit, 2018) para a organização dos códigos, conceitos, agrupamento em subcategorias, categorias, escrita dos memorandos e diário de bordo. Embora o programa conte com vários recursos para analisar o conteúdo, foi utilizado somente como fonte de organização e para facilitar a visualização dos códigos, conceitos, subcategorias e categorias. Escolhemos esse programa por ser bem avaliado entre pesquisadores da TFD, ter uma versão em português e conter as ferramentas desejadas pela pesquisadora. Durante o processo, o desenvolvedor disponibilizou uma nova versão atualizada do software, por isso a utilização das duas versões do mesmo programa.

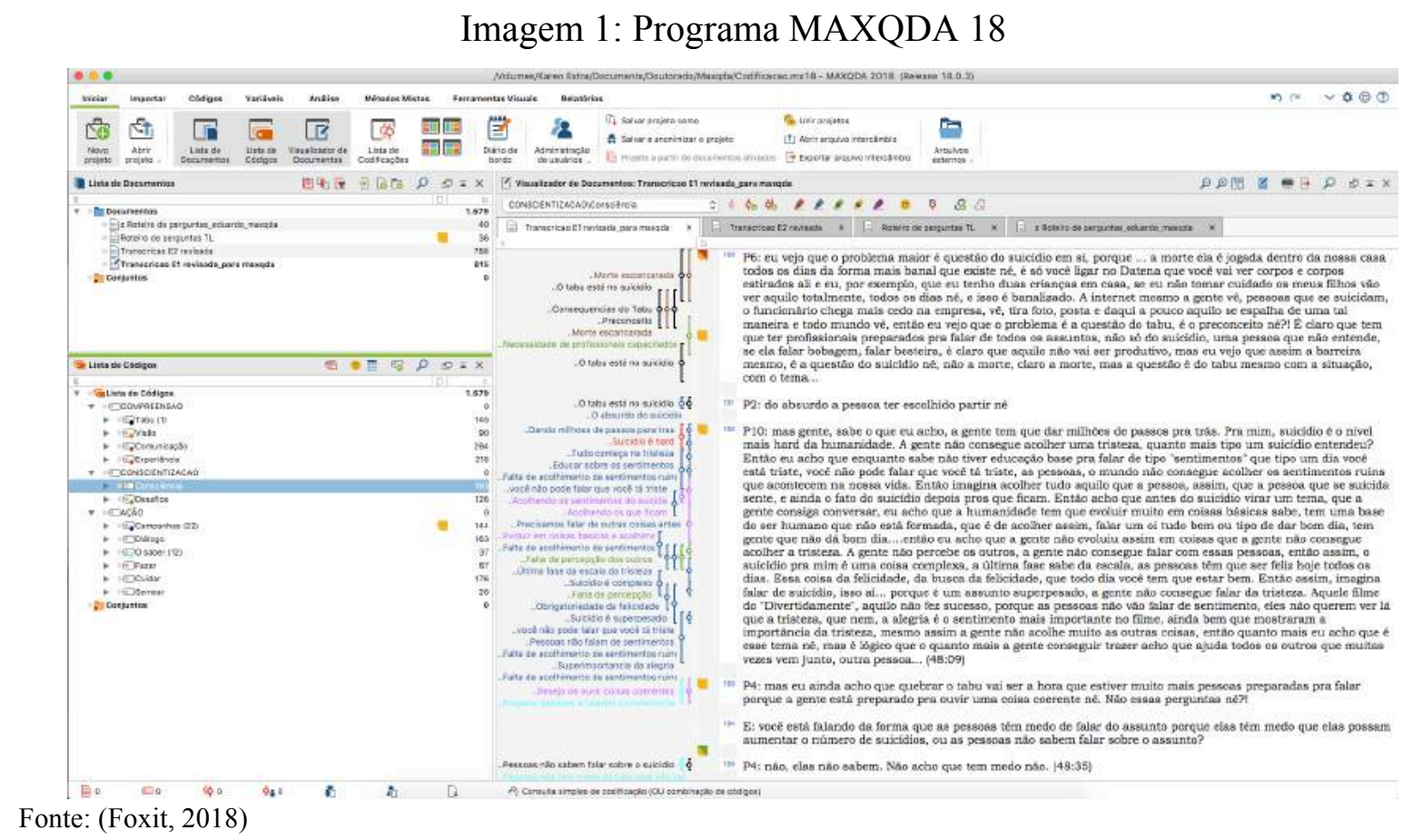


O programa iMindQ (I-Produkts, 2018) foi utilizado para a criação dos diagramas. Foi escolhido por ter uma interface simples e por proporcionar o desenho dos diagramas de várias maneiras.

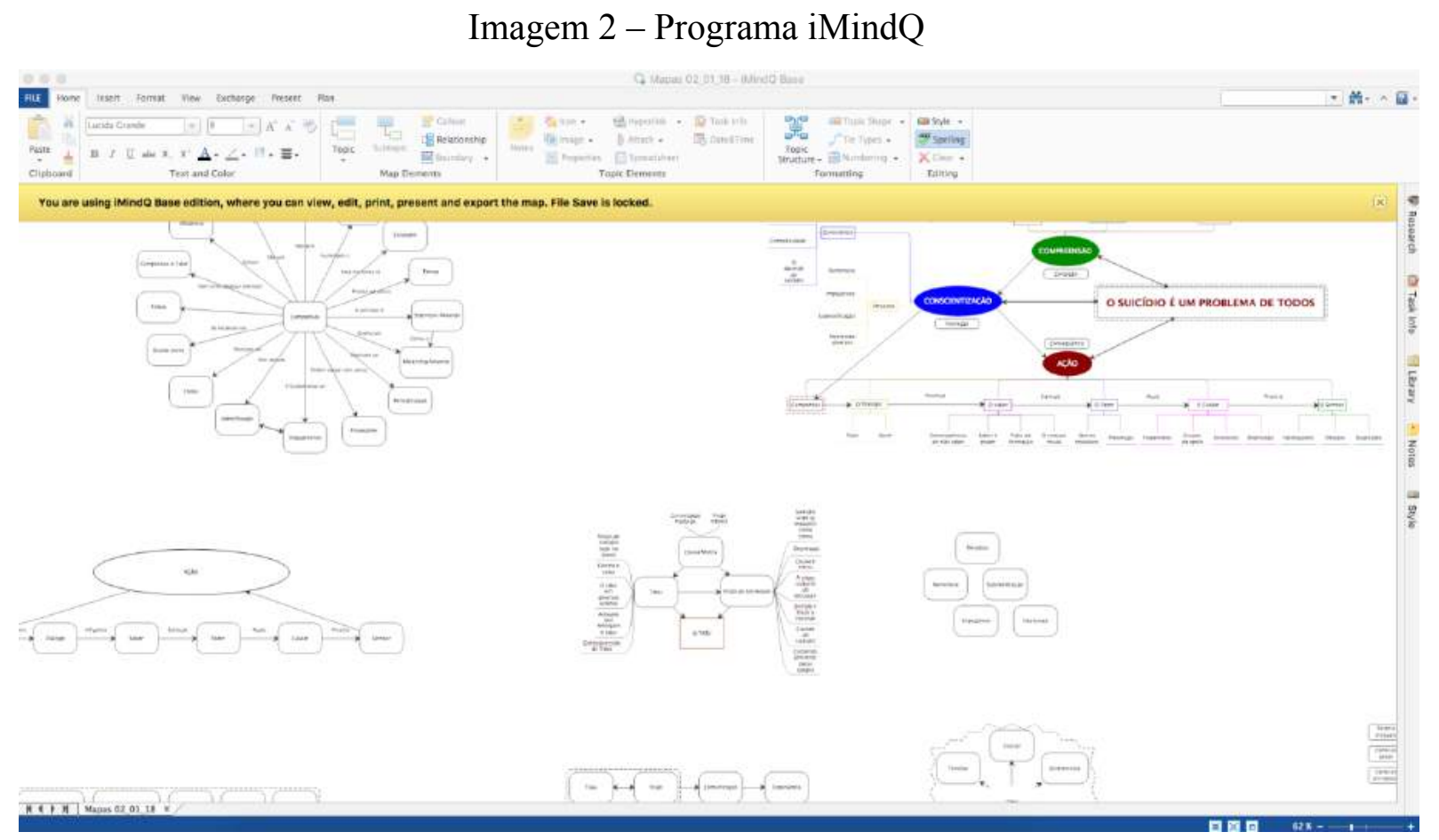

Fonte: (I-Produkts, 2018)

\subsection{PROCEDIMENTO DE ANÁLISE DOS DADOS}

a) A transcrição foi lida pela primeira vez e as observações foram feitas quanto às impressões e às questões geradas no pesquisador;

b) $\mathrm{Na}$ segunda leitura da transcrição, a codificação foi iniciada manualmente, sublinhando trechos da transcrição e escrevendo os códigos gerados na margem da folha;

c) Na terceira leitura, os códigos que estavam na margem da folha foram revistos e transcritos para o programa MAXQDA para auxílio no processo de compilação e organização desses códigos;

d) Memorandos foram utilizados durante todo o processo para registrarem o raciocínio analítico e o pensamento abstrato do pesquisador. Um diário de bordo começou a ser escrito, em forma de memorando, para registrar os pensamentos do pesquisador enquanto agente de realização da análise; 
Imagem 3 - Visão geral das anotações

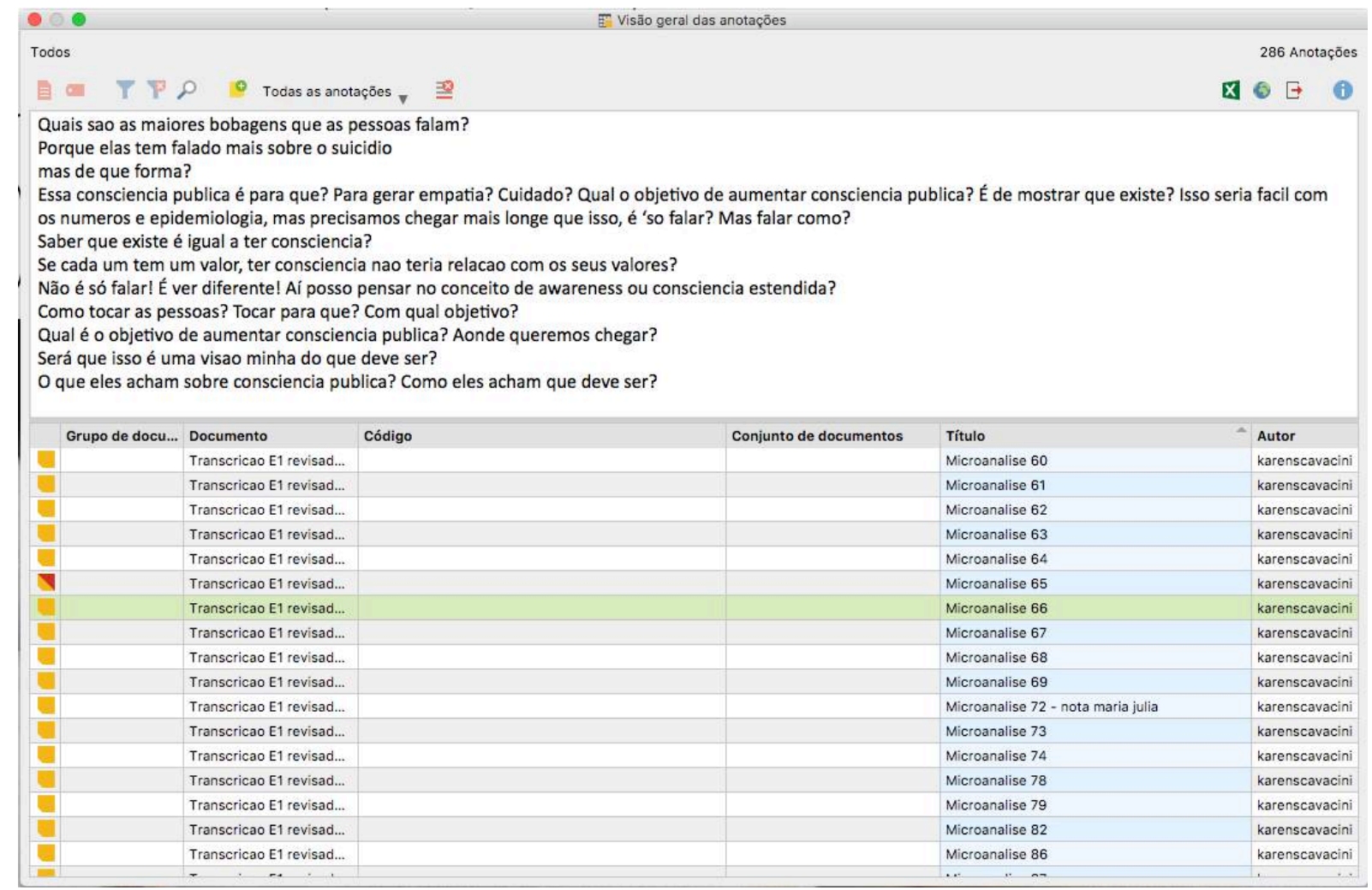

Fonte: produção do próprio autor (2018)

e) Alguns códigos foram agrupados e transformados em conceitos, conforme eram colocados pela pesquisadora no programa;

f) Uma tabela com os códigos e conceitos gerados foi impressa, cada linha de texto foi cortada para que fosse agrupada em categorias ou subcategorias. Nomes mais abstratos foram gerados para nomear as categorias que foram separadas e colocadas cada uma em um envelope diferente;

\section{Imagem 4 - Codificação Axial I}

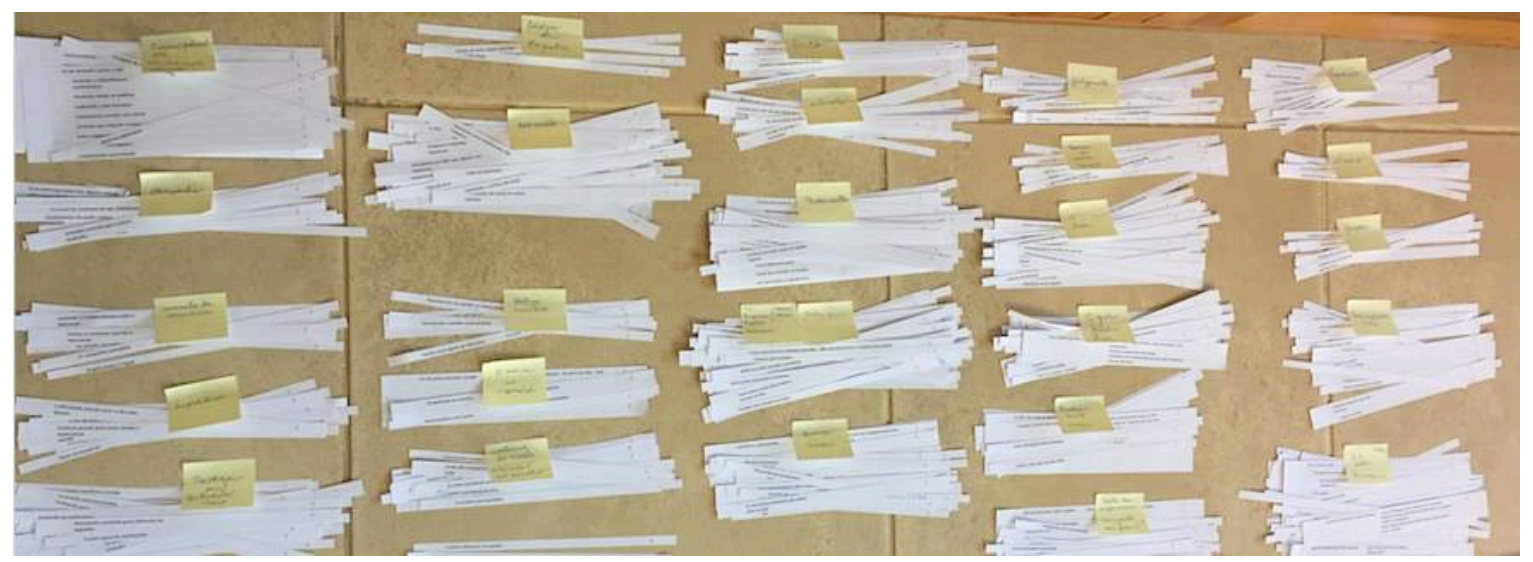

Fonte: produção do próprio autor (2018) 
Imagem 5 - Codificação Axial II

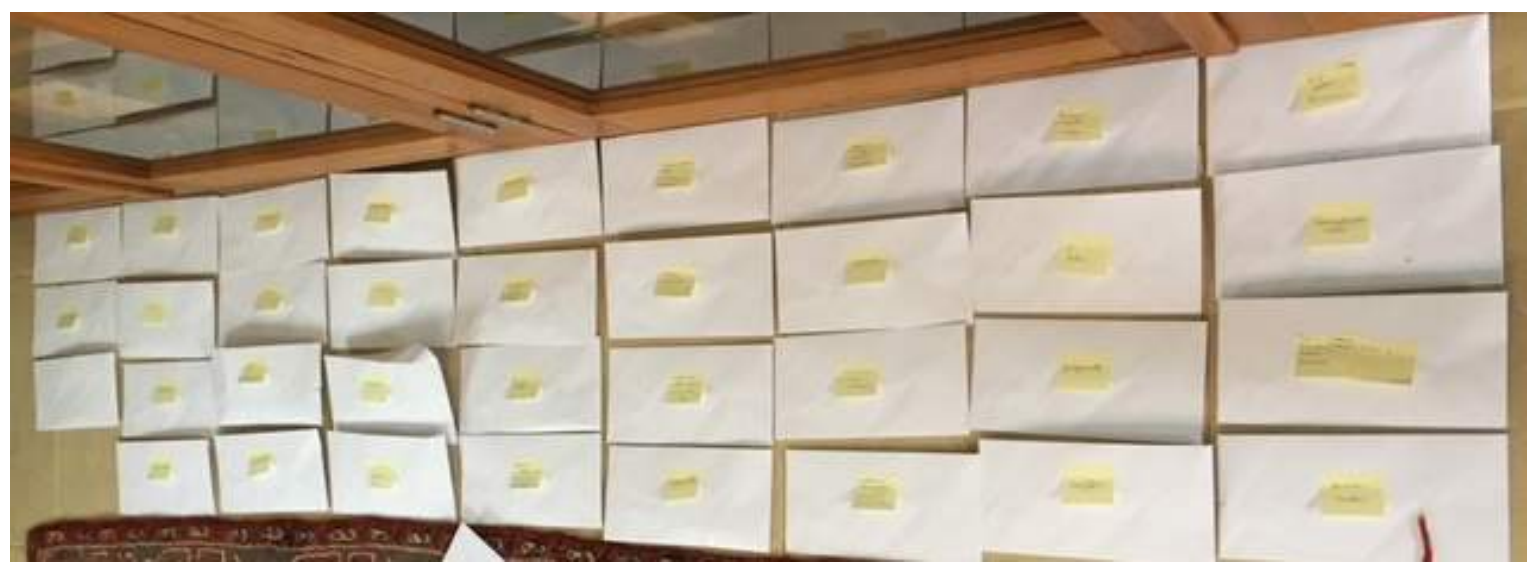

Fonte: produção do próprio autor (2018)

g) Após esse primeiro agrupamento, cada envelope foi analisado, todo o material foi revisto, com base em seus dimensões, significados e mudanças de categorias ou subcategorias foram efetuadas.

\section{Imagem 6 - Codificação Axial III}

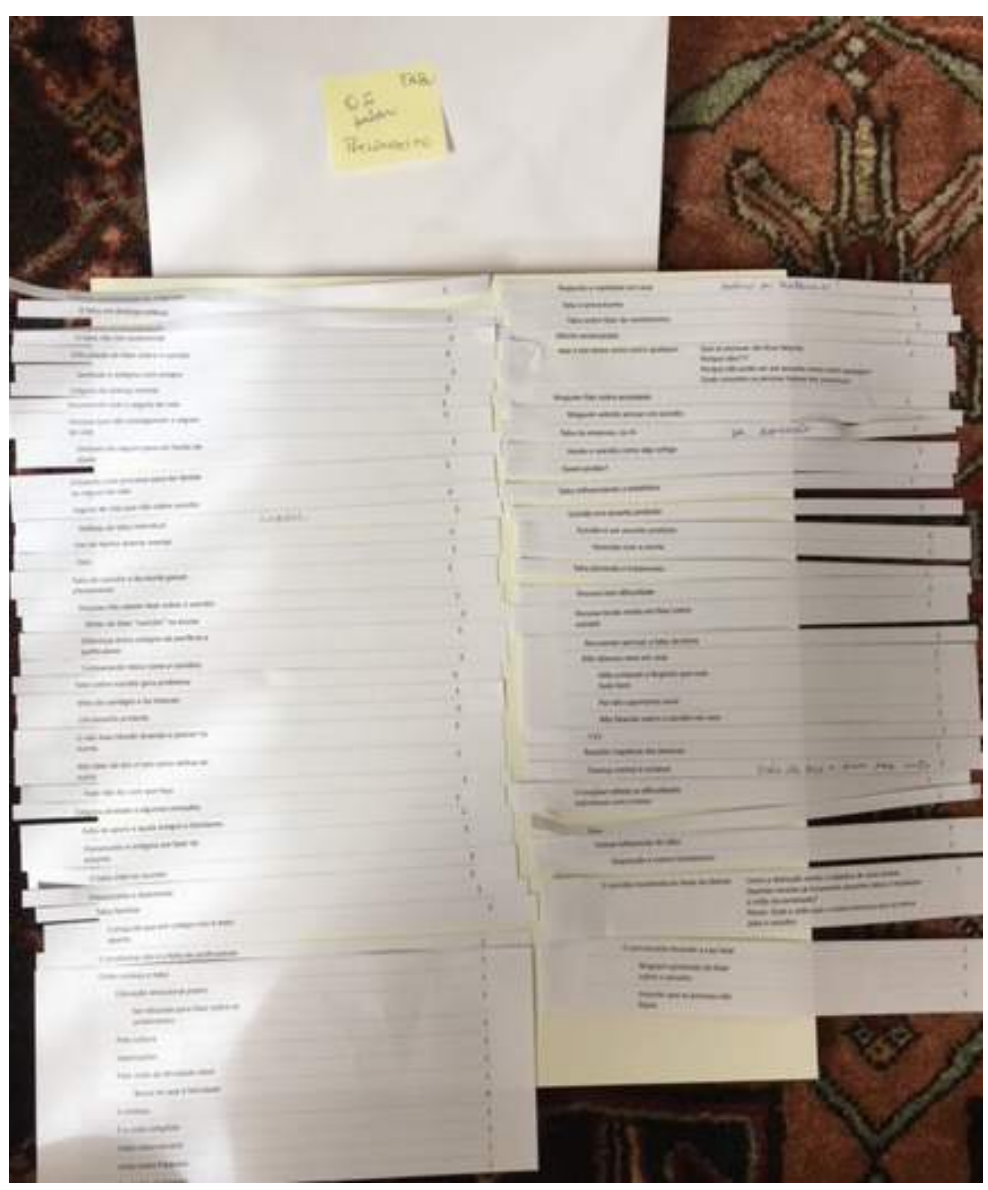


Imagem 7 - Codificação Axial IV

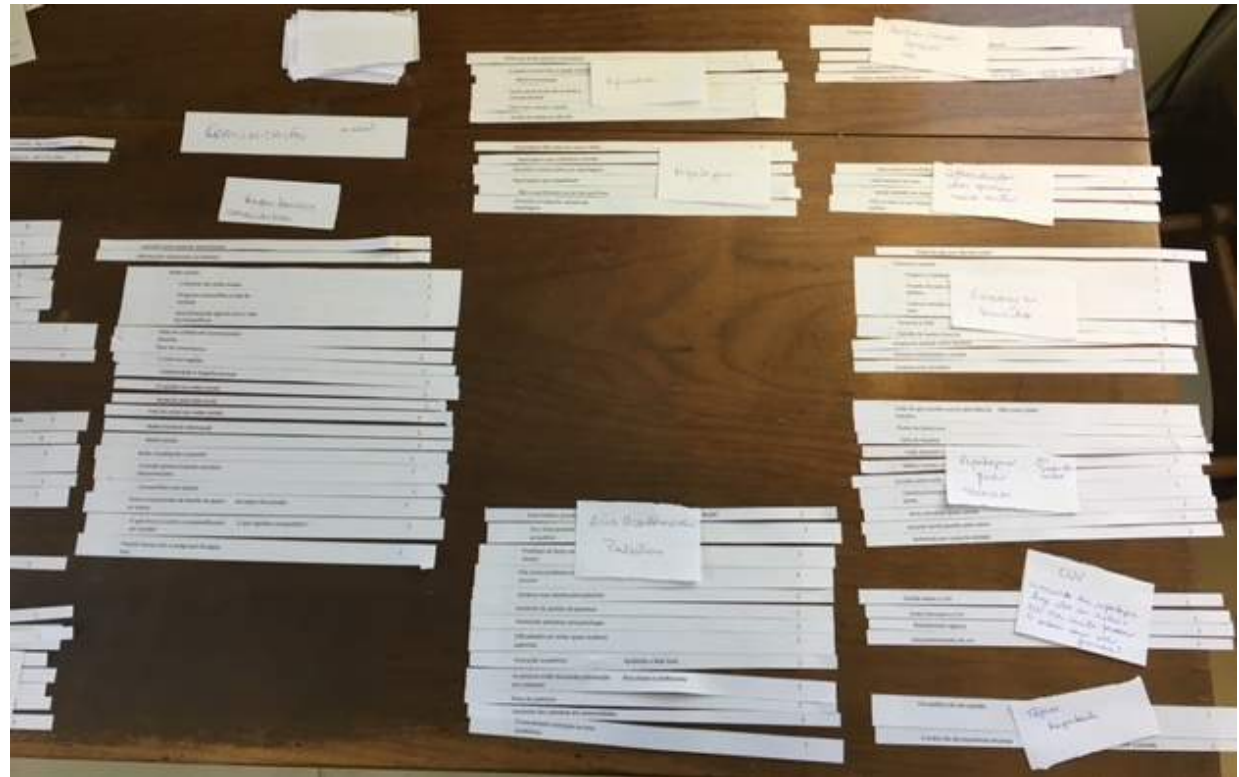

Fonte: produção do próprio autor (2018)

h) Repetiu-se o mesmo processo no programa MAXQDA, agrupando os códigos nas categorias ou subcategorias criadas;

i) Cores foram designadas para cada categoria criada para facilitar na visualização dos dados e uma tabela com as categorias e subcategorias foi impressa e analisada para reagrupamento;

j) Todos os papéis que continham os códigos foram retirados do envelope e organizados para mais uma análise e revisão de categorias;

Imagem 8 - Codificação Axial V

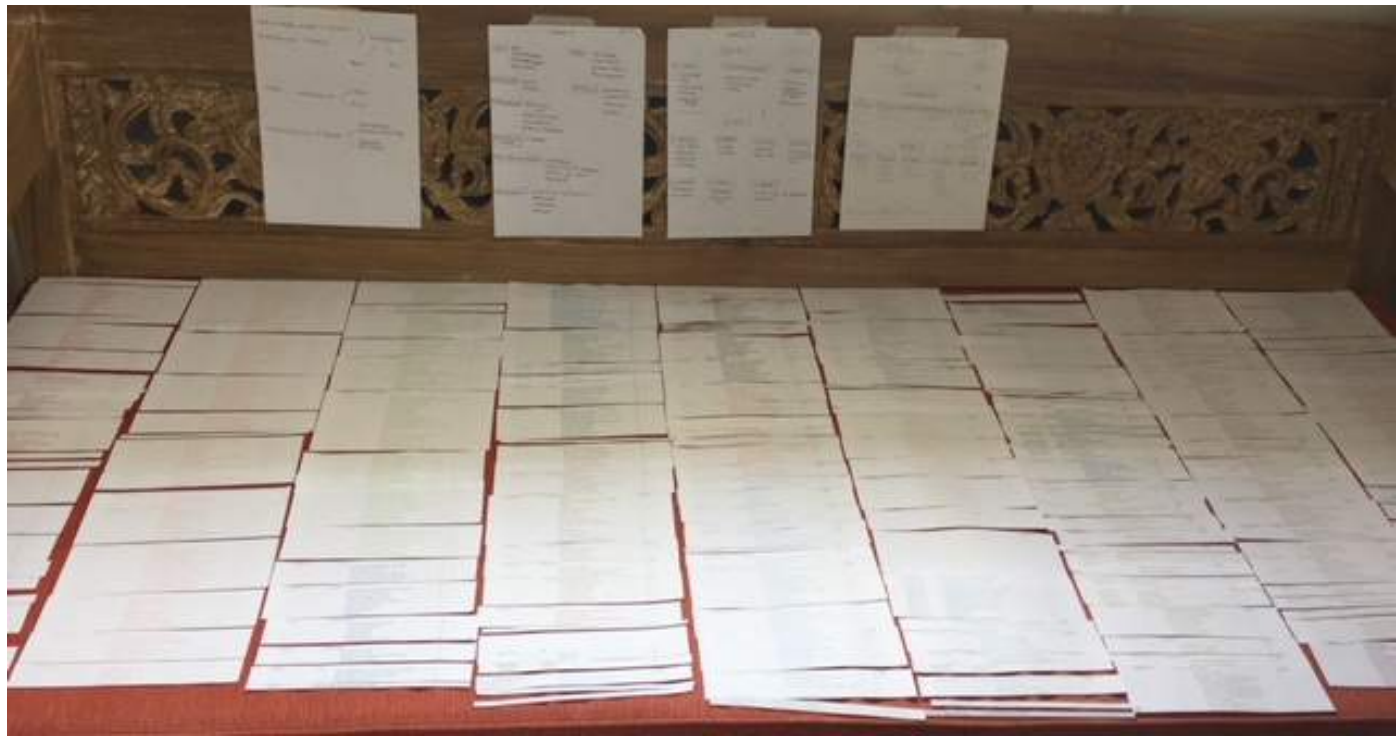

Fonte: produção do próprio autor (2018) 
k) Diagramas foram esboçados para conexão entre as categorias e subcategorias;

Imagem 9 - Codificação Axial VI

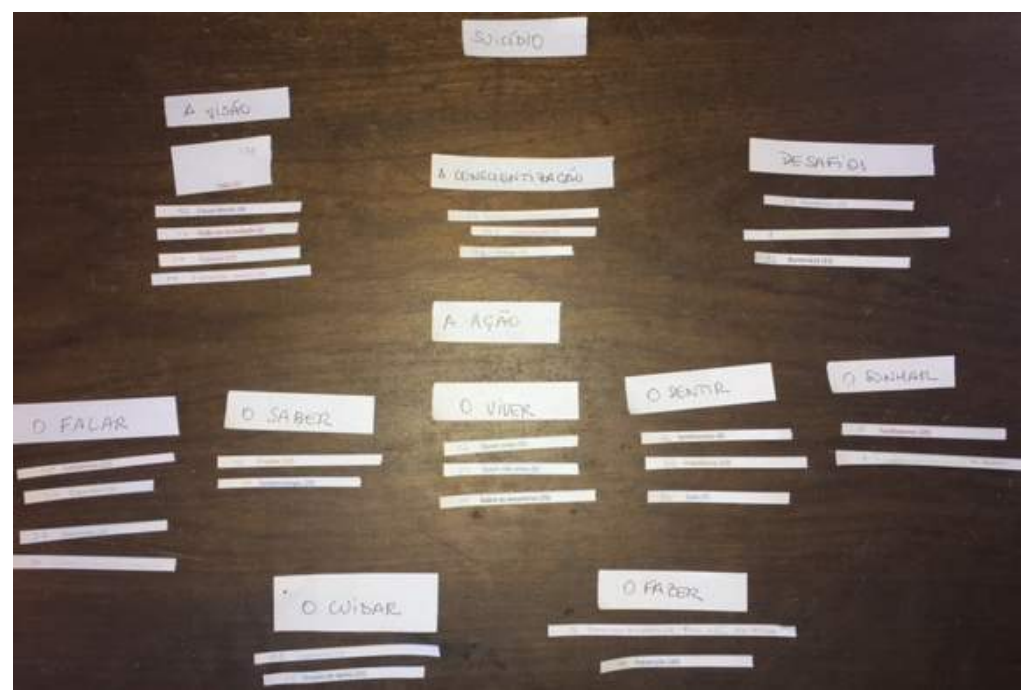

Fonte: produção do próprio autor (2018)

1) As categorias foram divididas em três temas centrais após vários diagramas e esboços de agrupamento serem desenvolvidos;

Imagem 10 - Codificação Axial VII

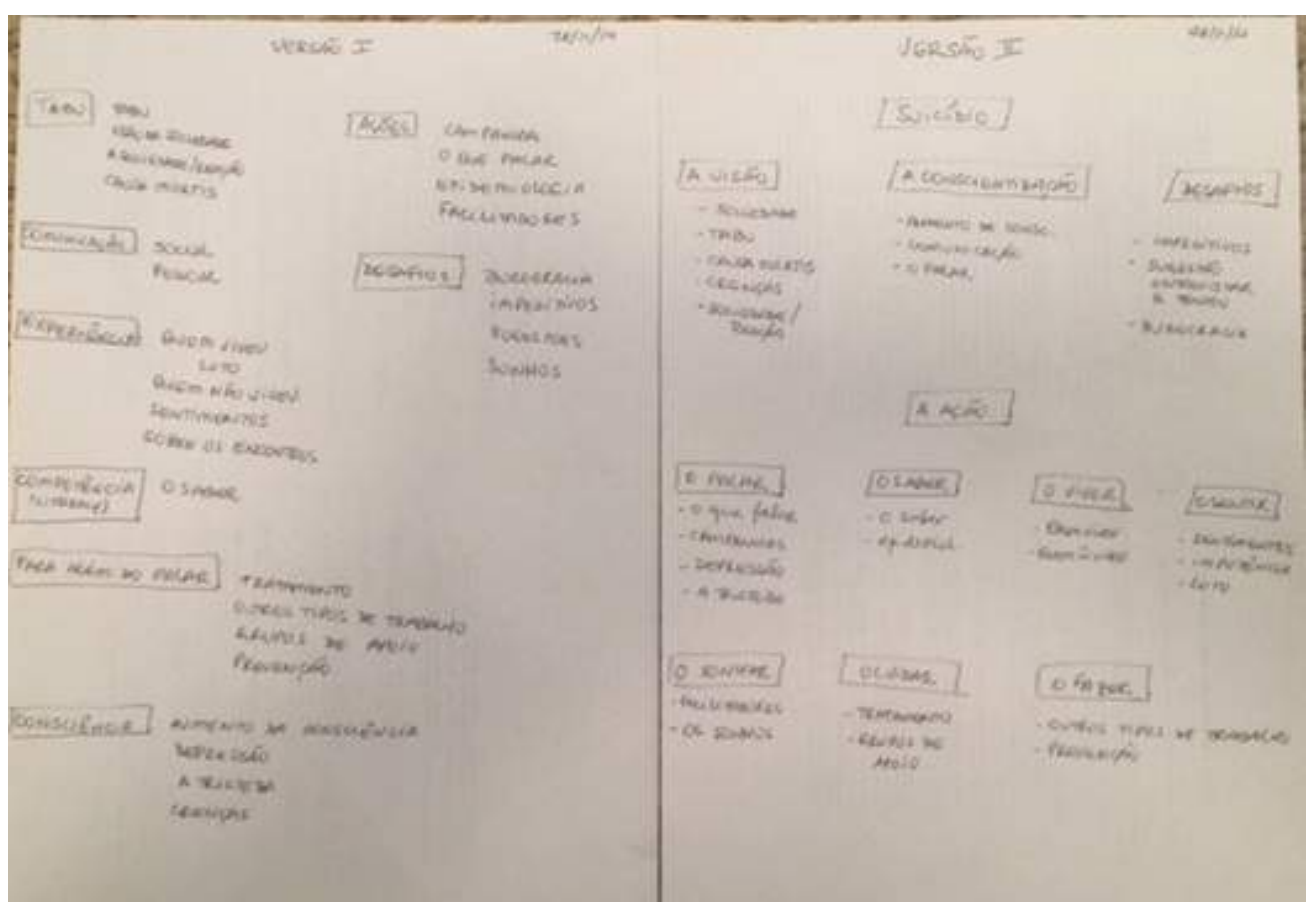

Fonte: produção do próprio autor (2018) 
Imagem 11 - Codificação Axial VIII

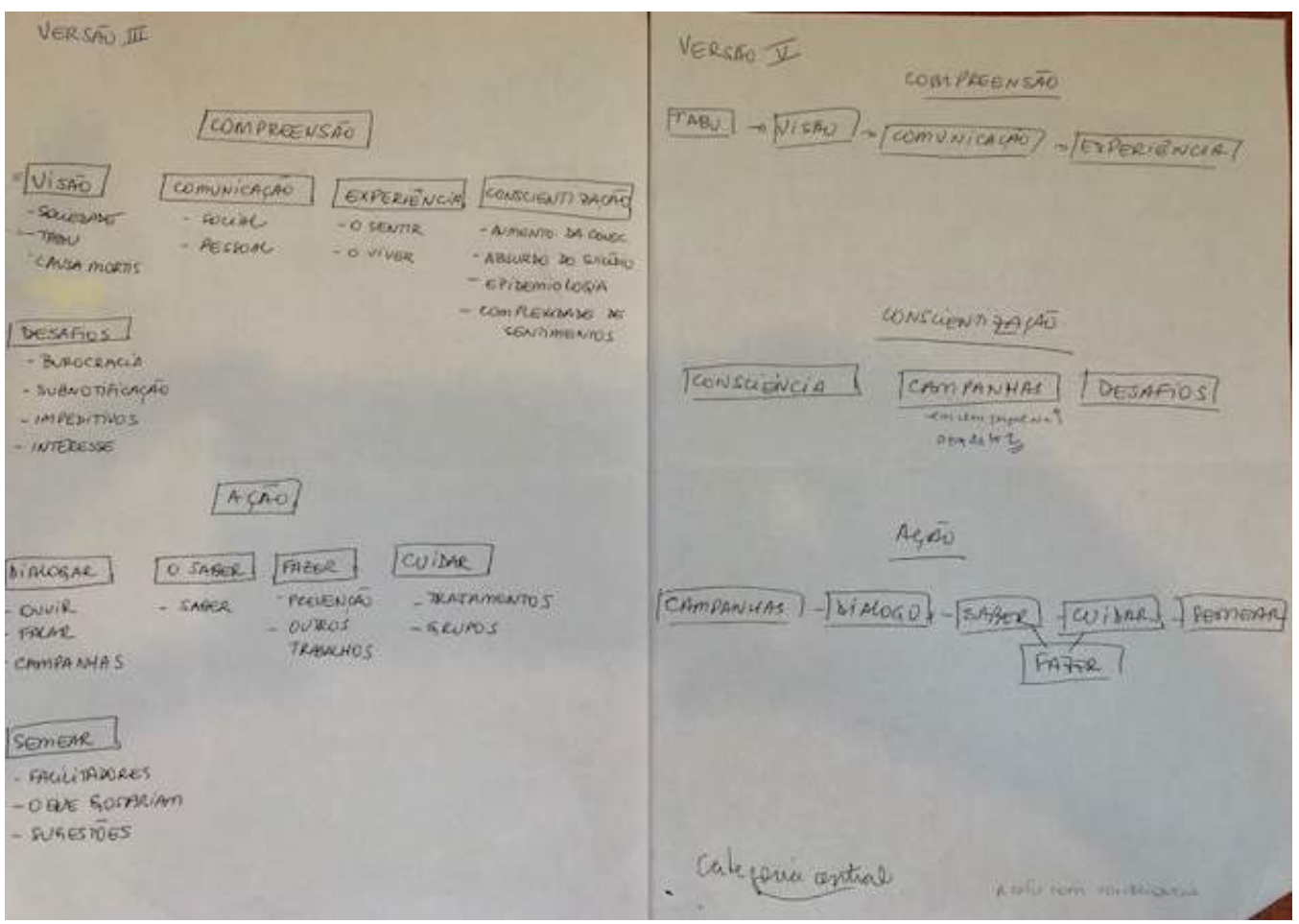

Fonte: produção do próprio autor (2018)

m) Memorandos sobre as categorias e temas gerados foram escritos;

n) Começou-se a escrita da análise, em que novamente o processo foi revisto e os memorandos foram lidos para a escrita do processo e da análise dos dados. Novos memorandos foram escritos com impressões ou questões sobre o processo. Diagramas foram feitos para explicarem visualmente a conexão e sentido das categorias e subcategorias;

o) O tema central foi gerado e o diagrama referente a ele foi desenvolvido.

A partir da análise dos dados, apresentada no Capítulo 5, da definição da categoria central, apresentada no Capítulo 6, faremos uma discussão dos resultados obtidos na análise em conjunto com a literatura e a experiência da pesquisadora, para apresentarmos nossas considerações finais no Capítulo 7.

\subsection{DIÁRIO DE BORDO METODOLÓGICO}

A escolha de uma metodologia traz consigo uma série de indagações que acompanham o pesquisador no decorrer do estudo. Compartilhamos algumas observações e sensações no que 
chamamos de diário de bordo, que trazem um resumo do percurso que tomamos e das escolhas que fizemos.

Por estarmos muito envolvidas na área de prevenção e posvenção, não queríamos fazer um estudo partindo de teorias já conhecidas ou das nossas crenças, foi preciso fazer o exercício do não saber, suspender os conceitos para que a "teoria" fosse revelada. Não almejávamos provar nenhuma hipótese, ambicionávamos trazer provocações, indagações, novas ideias e sugestões. Buscamos trabalhar com o que surgisse a partir da experiência de nossos colaboradores, pessoas enlutadas pelo suicídio. Buscamos dar-lhes a voz e a vez! A nossa proposta é que a teoria seria gerada, a partir dos colaboradores, vindo ao encontro com nossos objetivos.

Pudemos nos debruçar exaustivamente sobre transcrições do debate ocorrido nos dois grupos focais propostos, começando pela microanálise, que nos fez mergulhar nos dados, passar pelas etapas de codificação e a partir delas trazermos os dados desse estudo.

Por muitos momentos nos questionamos se havíamos feito à escolha do método adequado, temendo que não conseguíssemos trazer dados importantes sobre o tema, que não finalizaríamos o trabalho, gerando uma teoria consistente que contemplasse com profundidade o tema do suicídio. O desenrolar da pesquisa mostrou que estávamos no caminho certo visto que ao concluir o trabalho, compreendemos que todas as etapas foram necessárias, que o método escolhido foi fundamental para o resultado obtido e que foi a imersão nos dados, que proporcionaram a composição desse estudo.

Os momentos de escrita foram interessantes, pois ao iniciá-la a pesquisa tornou-se parte de nós e lembramos-nos dela em inúmeras ocasiões. Frases e parágrafos formaram-se no meio da madrugada, com ideias surgindo em situações inesperadas.

A costura atenta e cuidadosa das falas, dos sentimentos, dos códigos, dos dados, da literatura, daquela reportagem que foi encontrada sem esperar, da releitura de materiais que há muito havia sido guardados para serem usados no trabalho, das frases que escutamos de pessoas diversas, da nossa experiência, tudo foi inserido na gestação de uma tese. Estávamos em sintonia e conexão com o caminho que escolhemos percorrer.

O nosso conhecimento prévio e tudo o que vivenciamos nesses quatro longos anos também estiveram presentes na forma como codificamos e compreendemos os dados. O método nos orienta, mas somos nós que conduzimos a pesquisa.

Questionamos-nos se fazer grupos focais com pessoas que já frequentavam grupos de apoio, por isso, já estavam mais à vontade para falar sobre o tema, iriam representar aqueles que não têm essa vivência. Em nossa reflexão, percebemos que podem representar sim, pois o 
luto tem características singulares, mas as experiências apresentam coisas comuns. A experiência da pesquisadora com atendimentos a pessoas enlutadas pelo suicídio, e o que foi trazido pelo grupo focal representam a experiência dessa população. Acreditamos que o fato deles participarem de grupos e já conseguirem falar abertamente sobre o assunto nesses locais, foi uma proteção aos colaboradores. Assim, não cremos que a seleção dos participantes prejudicou os achados do estudo, dada a riqueza do material encontrado, entendemos que essa experiência nos grupos, facilitou entrar no assunto mais rapidamente e mais profundamente. Trata-se de uma população vulnerável, portanto toda cautela é necessária.

Depois da primeira reunião do grupo focal, saímos preocupadas, pois não conseguimos fazer todas as perguntas que haviam sido programadas no roteiro para o primeiro encontro, pois os colaboradores levantaram outras questões além das que havíamos pensado, era a luta da razão com o fenômeno. Se a teoria deveria emergir dos dados, tudo o que fosse levantado seria transformado em dado e analisado, portanto, nada era perdido. Falávamos de um tema tão complexo e significativo para eles que era difícil manter o foco na pergunta ou dentro de um só aspecto do tema, isso, ao nosso ver, trouxe riqueza ao estudo. Após o encontro, estudamos as perguntas que foram feitas e fizemos uma pré-análise dos dados, verificando quais questões surgiram do primeiro encontro e que precisariam ser incluídas para o segundo.

A segunda reunião aconteceu mais fluída, o grupo parecia estar mais “aquecido" para a conversa e com uma melhor interação, estavam mais focados e não queriam finalizar o encontro. Houve muita gratidão dos colaboradores em participarem do estudo.

Percebemos que eles precisavam compartilhar, que mesmo sendo colaboradores que frequentavam grupos de apoio, quando uma oportunidade de diálogo era oferecida, poderiam passar horas falando sobre as suas experiências e suas sugestões, com uma abertura amorosa e verdadeira ao trazerem suas histórias e suas dores. A sensação de poder ajudar o outro por meio da vivência que tiveram parecia ser benéfica para todos. Eles precisam e querem falar, basta a sociedade dar voz a eles.

Impactamos-nos, após a primeira reunião, ao sentirmos a mesma sensação de impotência que foi trazida pelos colaboradores, há muito que fazer. Precisávamos delimitar o objeto de estudo, permitindo o crescimento do que aparecia, mas não queríamos perder o foco.

Não achamos que todos precisam ou têm de falar sobre o suicídio de alguém amado, mas para aqueles que quisessem, isso deveria ser uma possibilidade e não um desafio. 
"Vilanela da mãe suicida"

Às vezes passo horas sem verter meu pranto. Mas depois sinto: sem chorar, vou à loucura. Sua vida não foi só morte e desencanto. Tentar, ela tentou, mas desistiu de tanto. Também cansei: buscar razões é vã procura. Às vezes passo horas sem verter meu pranto. O desespero, a raiva, a negação. No entanto, eu jamais a culpei por minha dor sem cura. Sua vida não foi só morte e desencanto, nem é minha somente a luta e o acalanto para salvá-la, pesquisando, ardendo com doçura. Às vezes passo horas sem verter meu pranto. Se eu dissesse: foi fácil, mentiria, e quanto. Entre ela e o mundo havia uma vidraça escura.

Mas a vida não foi só morte e desencanto.

Porém o fato, o fato ainda causa espanto.

Como grilhões, a ausência dela me tortura.

Às vezes passo horas sem verter meu pranto. Sua vida não foi só morte e desencanto." (Williams, 1997) 


\section{ANÁLISE DOS DADOS OU TEORIA EM CONSTRUÇÃO}

Traremos nesse capítulo a análise que foi gerada por meio da codificação dos dados, baseada somente no que foi conversado e debatido nos grupos focais, a partir das vivências, experiências dos colaboradores e nas duas respostas enviadas por e-mail, conforme apresentado no método. A discussão sobre esses dados e a construção da teoria fundamentada será apresentada no próximo capítulo.

A análise dos dados possibilitou compreender a importância do aumento da consciência pública do suicídio como um dos estágios fundamentais para a construção de ações de prevenção e posvenção. Ressaltamos que tal análise também considerou três grandes temas, são eles:

Compreensão - expressa as condições que entendemos, lidamos e relacionamos com o suicídio;

Conscientização - a interação necessária para que isso mude, sendo uma das ferramentas fundamentais para promover mudanças;

Ação - representa a consequência do processo, em suas formas, atitudes e caminhos necessários para que a conscientização influencie a forma de ver, sentir, lidar e cuidar dessa voz de sofrimento e de desespero humano que é o suicídio.

Os três temas apresentados englobam tudo o que foi falado e elaborado nos grupos focais, interligam-se, influenciam-se e integram-se em um processo dinâmico e inter-relacional, uma vez que estão profundamente conectados por meio dos seus sentidos e significados. Para pensarmos em conscientizar, precisamos saber as dimensões: o quê, em relação a que, quem, onde, como, para isso a compreensão do fenômeno é muito importante, tendo em vista que a conscientização por si só não traz mudanças, elas ocorrem se houver ação, a transformação da consciência em atos. A ação por sua vez influencia a compreensão, então entramos nesse círculo da tomada de consciência.

Para facilitar a visualização, os TEMAS serão grafados em maiúscula e em negrito, as CATEGORIAS em maiúscula, as subcategorias em negrito, os conceitos em sublinhado e os códigos em itálico. 


\subsection{COMPREENSÃO}

O tema COMPREENSÃO explicita a forma como as pessoas entendem, sentem e comunicam o suicídio, sendo dividida nas categorias: o TABU, a VISÃO, a COMUNICAÇÃO e a EXPERIÊNCIA.

Diagrama 1: Compreensão

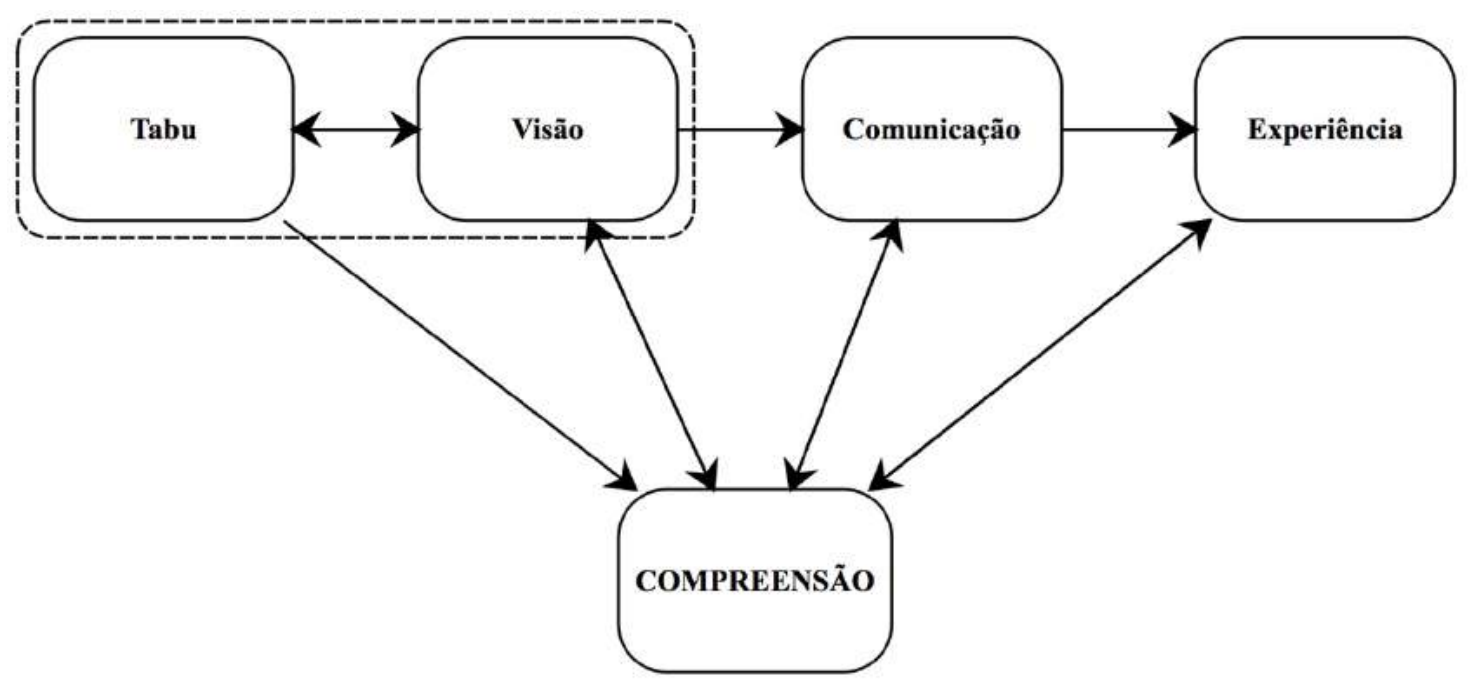

Fonte: produção do próprio autor (2018)

Percebemos, a partir do diagrama 1, que não é a COMPREENSÃO que influencia as categorias tabu, visão, comunicação e experiência, mas são elas que influenciam, facilitam ou prejudicam a COMPREENSÃO do fenômeno suicídio, gerando então reações e formas de relacionar-se que são contaminadas principalmente pela díade TABU e VISÃO.

Os diagramas, que serão apresentados, foram elaborados a partir da análise dos dados baseada na relação dos códigos, conceitos, subcategorias, categorias e temas. A tabela completa da origem desses dados está disponível no apêndice da pesquisa. Optamos por não colocar a tabela completa no corpo da tese por entendermos que poderia atrapalhar a compreensão da análise e por ser muito extensa.

A COMPREENSÃo é explicada por meio das categorias e subcategorias, como apresentamos na tabela a seguir: 
Tabela 6: Subcategorias, categorias e tema COMPREENSÃO

\begin{tabular}{|c|c|c|}
\hline TEMA & CATEGORIA & SUBCATEGORIA \\
\hline \multirow{11}{*}{ COMPREENSÃO } & \multirow{5}{*}{ Tabu } & O tabu está no suicídio \\
\hline & & Outros tabus \\
\hline & & O tabu em diversas esferas \\
\hline & & Atitudes que reforçam o tabu \\
\hline & & Consequências do tabu \\
\hline & \multirow{2}{*}{ Visão } & Visão da sociedade \\
\hline & & Causa mortis \\
\hline & \multirow{2}{*}{ Comunicação } & Social \\
\hline & & Pessoal \\
\hline & \multirow{2}{*}{ Experiência } & O sentir \\
\hline & & $\mathrm{O}$ viver \\
\hline
\end{tabular}

Fonte: produção do próprio autor (2018)

O TABU contamina a VISÃO, influencia e é influenciado por ela, ambos formam um círculo vicioso no modo de olhar o suicídio, que por sua vez facilitam ou prejudicam a COMUNICAÇÃO, que se relaciona diretamente com a EXPERIÊNCIA.

Dessa maneira, a interação social com o tema foi estabelecida por meio do TABU, que é influenciado pela cultura e pelos valores de uma sociedade. Esta sociedade, que enquanto não escancarar essas mortes, por meio de cada novo suicídio, do aumento dos casos e da divulgação da dor dos que ficam, dificilmente será levada a refletir e a mobilizar-se a fim de não aceitar que o suicídio seja um ponto cego e excluído da sociedade, da fala, da comunicação e da experiência. Durante muitos anos não se pôde falar sobre suicídio.

Portanto, antes de pensarmos em conscientizar o público sobre o suicídio, precisamos entender o que influencia a compreensão desse assunto, sua prevenção e posvenção para então analisarmos os fatores relacionados ao aumento de consciência.

Vale lembrar que o suicídio é um fenômeno multifatorial e complexo, assim, o aumento de consciência é parte de um processo multifacetado de cuidado, promoção de saúde e prevenção do suicídio.

\subsubsection{Tabu}

Tal categoria apresenta um assunto que foi julgado em um dado momento da história, sendo colocado à margem com a proibição velada de abordá-lo. Podemos pensar que hoje é a dor que traz à luz a esse tema, pois é a partir dessa dor que motiva muitas pessoas a falarem do assunto. No entanto, para outras, a dor sentida é motivo de mais vergonha, pois não se sentem 
validadas pela sociedade em sua dor, como se precisassem ter um motivo válido para cometerem o suicídio. Essa categoria é composta a partir de:

Tabela 7: Conceitos e Subcategorias do Tabu

\begin{tabular}{|c|c|c|c|}
\hline \multicolumn{2}{|c|}{ CONCEITOS } & SUBCATEGORIA & CATEGORIA \\
\hline \multicolumn{2}{|c|}{ O tabu está no suicídio } & $\begin{array}{l}\text { O tabu está no } \\
\text { suicídio }\end{array}$ & \multirow{5}{*}{ Tabu } \\
\hline $\begin{array}{l}\text { Comparando com } \\
\text { outros assuntos tabus }\end{array}$ & $\begin{array}{l}\text { Comparando tabus } \\
\text { (sexo e suicídio) }\end{array}$ & Outros Tabus & \\
\hline $\begin{array}{l}\text { Tabu Familiar } \\
\text { Tabu na empresa } \\
\text { Tabu Escolar } \\
\text { Tabu sobre falar de } \\
\text { sentimentos }\end{array}$ & $\begin{array}{c}\text { Tabu piorando o } \\
\text { tratamento } \\
\text { Transtornos } \\
\text { Mentais } \\
\text { Religião } \\
\text { Seguro de Vida } \\
\text { Estatística }\end{array}$ & $\begin{array}{c}\text { O tabu em diversas } \\
\text { esferas }\end{array}$ & \\
\hline $\begin{array}{c}\text { Utopias } \\
\text { A não validação das } \\
\text { doenças mentais } \\
\text { Não é um tema como } \\
\text { outro qualquer }\end{array}$ & $\begin{array}{l}\text { Aonde o tabu } \\
\text { começa } \\
\text { Problemas longe } \\
\text { dos meus não } \\
\text { interessam } \\
\text { Educação } \\
\text { emocional pobre }\end{array}$ & $\begin{array}{l}\text { Atitudes que } \\
\text { reforçam o tabu }\end{array}$ & \\
\hline $\begin{array}{c}\text { Julgamento } \\
\text { Preconceito } \\
\text { Estigma } \\
\text { Um assunto proibido }\end{array}$ & $\begin{array}{c}\text { O não falar } \\
\text { Afastamento } \\
\text { Exclusão } \\
\text { Mitos }\end{array}$ & $\begin{array}{l}\text { Consequências do } \\
\text { tabu }\end{array}$ & \\
\hline
\end{tabular}

Fonte: produção do próprio autor (2018)

A subcategoria o tabu está no suicídio representa a forma como os colaboradores expressaram-se, referindo que o suicídio é o maior dos tabus, mais que outras mortes. Da morte começamos a falar, mas de suicídio ainda não, por ser "uma das facetas mais difíceis do tema relacionado à morte, ao luto e à tristeza" (Colaborador 9).

eu vejo que o problema maior é questão do suicídio em si, porque [pausa] a morte, ela é jogada dentro da nossa casa todos os dias da forma mais banal que existe né? É só você ligar no Datena que você vai ver corpos e corpos estirados ali e eu, por exemplo, que eu tenho duas crianças em casa, se eu não tomar cuidado os meus filhos vão ver aquilo totalmente, todos os dias né? $\mathrm{E}$ isso é banalizado [pausa] mas eu vejo que assim a barreira mesmo, é a questão do suicídio né? Não a morte, claro a morte, mas a questão é do tabu mesmo com a situação, com o tema (Colaborador 6).

O tema suicídio ainda é assunto velado e carregado de preconceito. As discussões ainda geram temor e a maioria das pessoas prefere não olhar para um problema que afeta praticamente a todos (Colaborador 1). 
Já outros tabus refere-se à comparação com outros assuntos que foram enfrentados pela sociedade e que depois de muito trabalho hoje são tratados com mais naturalidade ou com menos preconceito. Compreendemos o fato de um assunto ser tratado como saúde pública representa que o tema passa a ser de preocupação médica, por isso pode ser falado. Para os colaboradores, um assunto carregado de proibições na fala, não pode ser escancarado, continua tabu, como no exemplo abaixo

Como outros problemas, quando começou a AIDS, há um tempo atrás, não sei, uns dezoito anos, então no começo também era um tabu se falar em AIDS né? Quando passou a ser considerado uma preocupação de saúde pública, então se abriu (Colaborador 1).

Podemos ver, por meio do grupo, os exemplos da AIDS, do sexo e do câncer. Existe uma crença que ao falar um assunto, há um estímulo para que ele aconteça. Um dos colaboradores traz essa experiência ao abordar o tema sexo, que foi falado no contexto escolar, sem desencadear um aumento da prática sexual entre os alunos.

Antigamente não se falava em sexo, na minha época em que eu fiz colégio, eu tive aula de educação sexual. A professora falava da camisinha tal e tal e isso não fazia com que a você saísse por aí [pausa] a torto e a direita (risos) (Colaborador 1).

Os risos no grupo, após essa declaração, representam uma sensação de cumplicidade e de aceitação na fala desse colaborador.

O tabu em diversas esferas traz uma visão multifacetada com exemplos onde ocorre. O tabu não é fechado somente em um ambiente, navega em diversas esferas, por isso tem influência muito maior, pois seu alcance é variado, portanto, mais espalhado e difícil de ser minimizado.

O tabu, ele vai estar em várias esferas. Ele está na esfera pública, de quando a gente fala do assunto na mídia, está na escola que não quer trabalhar o assunto, está na empresa que não entende e quer que a pessoa trabalhe (Entrevistadora).

Dessa maneira, é difícil perceber exatamente onde o tabu começa, em qual dessas esferas ele nasce. Os colaboradores citaram a religião como precursora do tabu, talvez ela seja uma das esferas mais poderosas, porém pretendemos, mais que perceber onde se inicia, identificar onde tem influência. Essa subcategoria é composta pelos códigos Tabu Familiar; 
$\underline{\text { Tabu na empresa; }} \underline{\text { Tabu sobre falar sobre sentimentos, }} \underline{\text { Tabu nos transtornos mentais; }}$ Religião; Seguro de Vida.

Em tabu familiar percebemos que, embora seja mais comum que se imagina e que se fala, muitas famílias têm em sua história mais de um suicídio, porém o assunto não é tratado abertamente por conta do tabu, dessa forma, deparamos-nos com uma das dimensões desse fenômeno, quando famílias escondem os casos, sem compartilhar socialmente e familiarmente o que aconteceu.

Depois que o [nome do filho] se foi eu lembrei que eu tive um primo que se suicidou há alguns anos atrás e que meu marido também teve um primo que se suicidou. Mas foi tão [pausa] as pessoas não falam. A família não falou (Colaborador 4).

Uma família, que passou por um suicídio recentemente, parece não conseguir lidar com a possibilidade de mais um suicídio, dessa forma, ela prefere calar, assim como a sociedade.

\footnotetext{
Mas agora em fevereiro e ela, eu realmente vi minha irmã morta assim na minha frente, porque ela tomou um remédio para a pressão, então quase que parou o coração dela, mas a gente não fala mais nada ... É como se ela não tivesse feito isso nem dentro da minha casa, que a gente perdeu já o nosso sobrinho, quer dizer, meu pai não suporta ouvir é, minha mãe evita, finge que está tudo bem, então a gente segue assim... é um assunto assim que as pessoas não falam (Colaborador 11).
}

O tabu na empresa reforça a influência e a força que ele tem, podemos perceber que esta cobrança ocorre tanto para o funcionário do hospital, que perdeu alguém para o suicídio, quanto ao profissional da área da saúde, às pessoas com transtorno mental e aos enlutados pelo suicídio.

A primeira oportunidade que a empresa tem o que ela faz? Manda embora. Isso é uma realidade né? É assim, eu vivo isso, no trabalho, em todos os lugares que eu já trabalhei, eu já convivi com pessoas assim, que na primeira oportunidade o RH mandava embora porque está dando muito atestado. Está com depressão (Colaborador 6).

O tabu do suicídio faz que pessoas percam o emprego, pois influencia a empresa com a visão de que depressão é frescura ou "corpo mole", não é vista como uma doença que precisa e que tem tratamento.

Uma colaboradora, que foi demitida no início do seu processo de luto, descreve que achou uma covardia o que aconteceu com ela, pois teve seu pedido de férias negado, porém foi autorizada pelo chefe a ficar em casa após a morte do sobrinho e foi surpreendida ao ser demitida com base em fotos retiradas de sua rede social. As empresas não entendem as especificidades do processo de luto decorrente de um suicídio, deixando a funcionária com um 
sentimento de traição, de quem não tem com quem contar, indignada pelo fato de que no lugar do diálogo houve julgamento baseado no que foi visto nas redes sociais.

Notamos que essa dificuldade também pode ser observada por meio de outra dimensão, quando uma funcionária da área da saúde perde um paciente por suicídio e a postura da empresa, que também era da área da saúde, é de insensibilidade, cobrança, responsabilização e não de acolhimento ou de permitir a funcionária viver seu luto.

\footnotetext{
Então assim, é cobrança de todos os lados. Já sei [pausa] e isso aconteceu de sexta para o sábado. Sábado de manhã eu fui lá, eu atendi a família e na segunda feira eu fui trabalhar. E assim, a empresa não me chamou, a empresa não perguntou se eu queria um ou dois dias, se eu precisava de ajuda, e eu estava péssima. Fiquei dois dias no quarto sem comer porque foi muito assim, foi terrível para eu passar por essa situação (Colaborador 6).
}

Outro local onde percebemos a influência do tabu é na escola, por meio da subcategoria tabu escolar, que afeta não somente os alunos que precisam de ajuda como também molda a visão dos futuros empregadores, pais e familiares com a mensagem de que suicídio não pode ser falado, causando o medo de tocar no assunto. A escola, pressionada pelos pais, normalmente decide não falar sobre o tema abertamente, e mesmo que a escola sinta essa necessidade, quando percebe ou lida com comportamento suicida nos alunos e procura palestras para oferecer a eles, tais palestras são "moldadas", ou seja, sofrem cortes ou alterações conforme a permissão ou não que os pais dão ao tema. Então, podemos pensar que o maior tabu em relação ao suicídio está com os pais e não com a escola.

A gente foi convidado para dar uma palestra sobre prevenção do suicídio e a valorização da vida e estava tudo certo aí no dia anterior liga a professora pedindo para não falar de suicídio na palestra. Porque os diretores não estavam concordando [pausa] porque tem os pais, que não vão querer, aí, porque aí eu vou tirar, e tal (Colaborador 1).

Pode ver que deve ser o maior problema dos colégios, os pais [pausa] não vamos falar sobre isso (Colaborador 4).

Outro fato constatado é que essa proibição é percebida mais em colégios de alta renda, nas quais os pais provavelmente exercem uma pressão maior. Os colégios de periferia são mais abertos para esse assunto, conforme a experiência dos colaboradores.

Outra esfera trazida foi o tabu de falar de sentimentos, que foi caracterizado pela sociedade não permitir uma pessoa expressar seus sentimentos, julgando-a como fraca, como possuidora de um comportamento inadequado, que exclui do convívio social se insistir em falar sobre suicídio ou se expressar seus sentimentos considerados ruins. 
Então, assim é a maneira de evitar esse impacto, né? Nós estamos falando de um tema que na nossa cultura é tabu, seria assim, falar sobre a emoção da tristeza e da importância de você poder conversar com o seu amigo, com a sua família quando você está triste (Colaborador 9).

A subcategoria o tabu piorando o tratamento refere-se a forma negativa que uma pessoa é tratada clinicamente quando tem o comportamento suicida ou sobrevive a uma tentativa, no tocante ao tratamento oferecido aos familiares enlutados. Pode ser entendido também como um reflexo do tabu individual sobre o tema.

Então, o sistema de saúde, hospital e plano de saúde ele vai de alguma maneira refletir a dificuldade que cada um individualmente tem com o tema. O tabu que tem, né? É um reflexo. Então, tanto o sistema de saúde quanto a policia vai ser um reflexo disso (Colaborador 9).

Em transtornos mentais, observamos que o tabu não envolve só a depressão, como também a ansiedade e outros transtornos, fazendo que não sejam validadas. $\mathrm{O}$ uso do termo doente mental ainda traz muito estigma visto que ao assumir ser portador de uma doença mental traz consigo um rótulo impregnado de conceitos e de características negativas, levando ao distanciamento da pessoa do diagnóstico e consequentemente do tratamento.

\footnotetext{
Aí a pessoa fala: 'Nossa, então eu sou doente mental' Não tem como mudar, suavizar esse conceito? Esse termo? Porque a pessoa aí não aceita esse termo porque [pausa] não sei. Mas assim [pausa] doença mental? Meu Deus, eu sou um doente mental? Não! É difícil a pessoa [pausa] para a pessoa assumir (Colaborador 2).
}

Outra questão é relacionada à depressão, que ainda não foi entendida pela sociedade como uma doença, como fala o colaborador 11: "eu acho que a grande maioria dos casos envolve depressão e a depressão não é respeitada como uma doença, não é tratada como uma doença, muitas das vezes ela é vista como uma frescura, como uma coisa assim".

A Religião foi identificada pelos colaboradores como a precursora do tabu ao serem questionados sobre onde achavam que esse começava. Há religiões que obrigam que a pessoa que consumou o suicídio seja enterrada separadamente dos outros mortos e que as famílias sejam punidas. Os colaboradores mencionaram a insensibilidade de alguns religiosos ao lidarem com o assunto. O colaborador 1 acredita que "esse tabu é decorrente de um processo social cultural atrelado a dogmas religiosos, a partir da condenação ao pecado mortal a pessoa que comete suicídio, estendendo as punições também à família”.

Outro problema identificado foi relacionado ao direito ou não do seguro de vida, que denuncia outros locais em que o tabu está enraizado, neste caso, usado a favor das seguradoras. 
Uma batalha jurídica longa e sem certeza de sucesso é vivida por quem decide receber o seguro de vida de quem morreu por suicídio, causando ainda mais dor naqueles que ficam e precisam provar que a pessoa que faleceu não estava com má-fé contra a seguradora e não fez isso só para receber o seguro, conforme a experiência do colaborador 4: "falando, eu lembrei que o preconceito já começa quando você tem um seguro de vida e não pode o suicídio".

A próxima esfera do tabu é tão grave que podemos pensar ser quase uma denúncia, ela refere-se aos dados estatísticos sobre o suicídio não serem fidedignos com a realidade por causa do tabu, da forma como são analisados e pelas subnotificações relacionadas à causa mortis. "Porque as outras, estatísticas [pausa] são colocadas estatísticas fiéis e não tem tabu em cima. E aqui não, é tudo escondido" (Colaborador 7). Embora a subcategoria Estatística seja citada nesta categoria por ter essa relação com o tabu, ela será analisada mais profundamente e sob outros prismas no tema CONSCIENTIZAÇÃO.

A subcategoria Atitudes que forçam o tabu foi pensada por abranger e representar diversos comportamentos que fazem que ele piore.

Em Utopias, três conceitos complementam-se: a crença na felicidade ideal, a exclusão da tristeza e as idealizações. Essas são características que vão reforçar o tabu e trazer consequências como uma sensação de inadequação, levando ao aumento da depressão e à dificuldade das pessoas acolherem aqueles que sofrem.

Segundo os colaboradores, existe uma visão equivocada de que felicidade seja ausência de tristeza, de perdas e de luto. Como consequência todas essas emoções são reprimidas, tornando-se um tabu. As pessoas não se sentem no direito de sentir tristeza e acham que devem sempre ser felizes, isso é uma utopia que afeta o tabu, pois ao não incluirmos tal sentimento, excluímos tudo que vem junto, não falamos de coisas ruins, como se fossem algo que não pertencesse ao humano, aumentando o tabu.

Mas isso é excluído, eu acho que isso, parte do tabu começa daí. Então se você vai procurar um amigo e você está feliz ok! Mas se você está triste, você é excluído (Colaborador 9).

Eu acho que tem um problema grande, que, na minha opinião, começa assim com a tristeza, tem um preconceito que é, falando um pouco do efeito facebook. Todo mundo quer aparecer feliz ou parecer feliz. (Colaborador $9-$ encontro 2).

É saber que felicidade não é tudo aquilo maravilhoso a toda hora, felicidade é você estar bem, fazer um pouco do que você gosta, se não é hoje, é ter sonhos para fazer depois, momentos, mas é tirar essa coisa de felicidade que tem que ser aquela coisa assim ... maravilhosa (Colaborador 4). 
A não validação das doenças mentais pelas pessoas, pelas empresas e pela sociedade é fruto do preconceito, do mito e do tabu, como se a pessoa pudesse ter a escolha de evitar a doença por meio de, por exemplo, ter ânimo ou ter coisas para fazer. Os sintomas dessas doenças são geralmente confundidos com falta de atitude ou reação.

A doença mental ela não é validada, mas é por causa do preconceito, é um mito, é o tabu. A pessoa pode ter qualquer doença que ela não escolheu, 'ah, mas a saúde emocional? Não, você pode evitar, né? É falta do que fazer né?! É falta do que se animar' (Colaborador 6).

Há uma crença que o suicídio não é um tema como outro qualquer, dos quais se pode falar livremente, mas como outros assuntos que já foram tabus e hoje é possível falar, também pode ocorrer com o suicídio, “é um assunto que você não vai ficar falando, não é um tema como outro qualquer" (Colaborador 1).

A dificuldade de falar sobre o assunto em diversos núcleos e a condenação da igreja, que coloca o suicídio como pecado, foram conceitos refletidos em relação onde o tabu começa. Os colaboradores consideraram que o tabu começa em todos os lugares, o que torna difícil o seu entendimento e demonstra a amplitude da proibição de falar sobre um assunto.

\footnotetext{
Na família, quando na tentativa de proteger o seu núcleo, os pais evitar [sic] comentar sobre o assunto. Geralmente, assuntos de suicídio e morte são proibidos nas discussões familiares. Nos nossos grupos sociais quando não se permite falar sobre suicídio, porque é assunto pesado e normalmente as pessoas consideram que naquele grupo não tem ninguém com ideação suicida. $\mathrm{Na}$ igreja, quando condena a pessoa com comportamento suicídio ao pecado mortal (Colaborador 1).
}

O mito de que não devemos falar sobre algo ou sobre um dado evento para não atraí-lo foi destacado como explicação para impedir essa fala, o que na verdade é um dos significados do tabu. A ideia de que não falar sobre algo seria de alguma forma não legitimar sua existência. Um dos colaboradores traz a visão de que "com a crença de que falar no assunto relacionado à morte, suicídio ou doenças, 'atraem' o fato. Evitar falar no assunto é como se fosse uma forma de evitar que isso exista ou aconteça" (Colaborador 9).

Quando a sociedade tem a postura de que problemas longe dos meus não me interessam, como no caso da legalização do aborto, quando não consegue colocar-se no lugar do outro e imaginar seu sofrimento, a partir disso, inferimos que há uma necessidade de conscientização das pessoas para depois alterar a visão delas sobre o tema e consequentemente influenciar nas decisões e ações de auxílio. 
O pessoal sempre tem essa mania né? Só porque é dos outros, dos outros não quer nem saber. Não sou favor do aborto, mas há muito tempo atrás teve uma pesquisa para liberar o aborto no Brasil, aí chegaram a seguinte conclusão da pesquisa, que jamais seria liberado no Brasil, por quê? Porque só a mulher quer fazer aborto, o homem não quer, então não é problema do homem. Se você pensar como o suicídio, aí o que acontece? Estava lá na faixa etária, quem tem menos de 15 anos não ia engravidar naquela época, é bem antiga a pesquisa, então ela é contra porque também não ia engravidar. E quem tinha mais de 40 e estava entrando na menopausa, das mulheres, também são contra porque elas não passariam pelo problema. Então, só quem votaria a favor seriam de 18 a 40 anos, portanto nunca foi aprovado. Eles pouco ligam para o problema dos outros (Colaborador 5).

Conforme os colaboradores, sendo um problema do outro e não me atingindo, não interajo com ele, essa situação pode ser observada em conversas, revisão e aprovação de leis e engajamento ou julgamento nas redes sociais.

\footnotetext{
É o caso do, quando você vai na $[s i c]$ página do seu amigo, que quer te dar algo da prevenção de mama, né? Aquele negócio de mamas ou então de drogas, não é só para quem está viciado, é também para quem [não tem esses problemas], então é para ser uma coisa no geral (Colaborador 1).
}

Outro fator citado que colabora para reforçar o tabu é a educação emocional pobre, referência à falta de educação emocional na sociedade, nas escolas e nas famílias, relacionando com a utopia de uma vida sem tristezas. Segundo os colaboradores, se as crianças não forem educadas para perceberem que existem diversos tipos de sentimentos, identificarem sentimentos alegres, tristes e saberem o que fazer com eles, elas podem crescer com a visão de que a tristeza é errada e a depressão é "frescura".

\footnotetext{
Isso que você falou de tem sentimentos que a gente não sabe nem nomear e acho que a gente tem uma educação emocional muito pobre de forma geral e acho que isso está na causa do tabu ... então a dificuldade, por exemplo, eu encontro amigos e às vezes a pessoa está passando uma angústia grande, mas ela não consegue falar, ela não foi educada, eu também não fui, então eu estou fazendo esse exercício. (Colaborador 9)
}

A última subcategoria é as consequências do tabu, que tem relação com os comportamentos que as pessoas têm influenciadas pelo tabu como o julgamento, o preconceito, o não falar, um assunto proibido, estigma, afastamento, exclusão e os mitos.

Julgamento foi citado em diversos momentos do grupo pelo fato das pessoas emitirem julgamentos sobre o suicídio e sobre todas as pessoas envolvidas nele, seja por meio do suicídio de alguém próximo, de alguém que não conhecem muito ou em casos com grande repercussão na mídia, como o voo 9525 da Germanwings, no qual o copiloto trancou-se na cabine, lançando o avião em direção a uma montanha, matando as cento e cinquenta pessoas que estavam a bordo. 


\begin{abstract}
Porque eu nem sei se eu não tivesse passado por isso, eu teria falado isso, mas eu ouvi muitas pessoas falarem assim: 'Se queria fazer isso, por que não fez sozinho em casa? Por que tinha que levar tantas pessoas inocentes e tal?' De repente você sabe que está errado, mas eu acho que é [pausa] A gente estava tão machucado que a gente começava até a entender, a dor deles é maior que a minha (Colaborador 4).
\end{abstract}

Alguns colaboradores também se sentiram julgados por psiquiatras, quando eles buscavam respostas simples ou faziam perguntas com tom de julgamento, como aquelas que buscam saber se a pessoa tinha ou não percebido a intenção suicida antes do ato, sentida pelos colaboradores como uma maneira de julgar os familiares ou a pessoa que morreu, "o psiquiatra perguntou para mim a primeira coisa 'a amante?"' (Colaborador 3 ).

O preconceito foi sentido por todos os colaboradores em algum momento de seu processo de luto, expressando desde a forma como as pessoas interagem, os comentários que fazem sobre o suicídio, a busca por um culpado, as dificuldades em falar e discutir o assunto, as brincadeiras com o tema e o distanciamento.

\footnotetext{
E quem passou também eu vejo que é muito dolorido falar então, por ter um preconceito também, por ser uma coisa que parece que as pessoas querem achar um culpado, querem achar um motivo, tem que ter uma razão né? Então quanto mais você fala, mais vão te cutucar, mais vão te machucar, mais vão né? Ás vezes sem querer mesmo né? Mas acabam te deixando mal (Colaborador 11).
}

Os comentários preconceituosos feitos quando uma foto de um suicídio é postada e rapidamente espalhada nas redes sociais também revelam o preconceito velado que o tema suscita.

A internet mesmo a gente vê, pessoas que se suicidam, o funcionário chega mais cedo na empresa, vê, tira foto, posta e daqui a pouco aquilo se espalha de uma tal maneira e todo mundo vê, então eu vejo que o problema é a questão do tabu, é o preconceito né?! (Colaborador 6).

O preconceito e o tabu estão carregados de mitos, fato que observamos entre os colaboradores, que tem medo de despertar a curiosidade ou incentivar um adolescente a matarse, se tocarem no assunto da forma "errada". O mito do "se falar pode fazer que alguém faça" apareceu em diversos momentos no grupo, o que demonstra que, mesmo entre os colaboradores, é o mito que gera mais receio e que tem como consequência não trazer o assunto à tona.

Outro mito citado é relacionado com a crença de "quem fala não faz". Isso foi demonstrado pelas reações dos colegas de trabalho de uma das colaboradoras. 


\begin{abstract}
'Nossa, você viu o formulário da semana da saúde que perguntaram se você tem vontade de se matar? Isso é pergunta? Se acha que alguém vai falar que tem vontade? Tipo, sabe?'. Eles ficaram surpresos de num formulário estar escrito fazendo essa pergunta. E então falaram: 'Duvido que alguém vai escrever que tipo, sim' (Colaborador 10).
\end{abstract}

O estigma, que é precursor do preconceito e se origina no tabu, influencia campanhas e impede que as pessoas abordem o assunto de maneira natural. A sociedade não está preparada para ouvir sobre o suicídio sem estigmatizar.

\footnotetext{
Eu acho que assim, muitas campanhas esbarram no estigma, porque falar sobre o assunto, eu acredito, isso eu percebi, assim né? que a pessoa que toca no assunto, ela sofre um preconceito de falar a respeito disso. É diferente, por exemplo, sei lá, falar de infarto, doença do coração. Se você estiver numa roda de amigos, como você falou, você pode trazer esse assunto e não vai ter preconceito. Ah! eu estou indo em numa academia, agora se você entra no tema do suicídio a pessoa: 'Não, mas você está pensando [pausa] e aí você [pausa] existe um estigma que atrapalha (Colaborador 9).
}

Uma das consequências do estigma é o afastamento das pessoas daquelas que falam sobre suicídio ou das que tem vontade de matar-se. Os colaboradores sentiram falta de apoio e da ajuda de amigos e de familiares por conta do afastamento, "toda vez que a gente fala de suicídio ou morte, existe na nossa cultura, em particular, um tabu grande. Então gera uma rejeição, gera um afastamento" (Colaborador 9). Esse estigma também é percebido em conversas, quando pessoas têm reações negativas ao ouvir falar sobre suicídio

O fato das pessoas não entenderem os diversos fatores que podem influenciar alguém a pensar em suicídio e a visão de que é necessário haver transtorno mental severo para que ocorra, é outro fator gerador de afastamento, pelo preconceito associado aos transtornos mentais, o que nos leva ao próximo conceito, a exclusão.

Destacamos a exclusão de individuos com depressão e outros transtornos mentais do convívio social, o que pode agravar uma situação que já é difícil e que gerou debate entre os colaboradores do quanto atualmente existe uma postura de utilitarismo em relação às outras pessoas. Para eles, o utilitarismo refere-se a: "se ela me serve, tudo bem, mas se tem problemas, não serve" (Colaborador 7). Outro fato citado foi que as pessoas precisam sorrir sempre para que sejam aceitas pelas outras, expressões de tristeza não são bem-vindas.

É utilitarismo. Na verdade, a pessoa está vendo um mundo à parte de si mesmo e as pessoas ao seu redor, elas apenas estão a serviço dos seus próprios interesses. Há aquelas que servem e aquelas que não servem. Isso é utilitarismo. Não existe amor. Não existe (Colaborador 7). 
Dessa maneira, percebemos que o suicídio, mesmo que já seja mais falado atualmente, em muitos momentos e em muitos locais ainda é assunto proibido na sociedade. Esta proibição teve sua origem antes da bíblia, sendo isso, conforme um dos colaboradores, que contribuiu para que o problema tornasse uma epidemia.

$\mathrm{O}$ ato suicida também era proibido e gerava grandes consequências para as famílias. "A família era excretada da sociedade. Toda a família daquele que suicidou-se [sic]. Não existia, era um disparate" (Colaborador 5).

\footnotetext{
Na nossa época o suicídio era um ... a família não comentava. Todo mundo escondia, todo mundo guardava aquilo, desaparecia e ninguém sabia nem o que aconteceu. Era proibido falar suicídio ... era terminantemente proibido ... não podia comentar em casa que o vizinho se suicidou, meu pai vinha e me dava uma surra (Colaborador 5).
}

Esta proibição levou a um não falar, sendo a forma como as pessoas reagiram e que se protegeram do preconceito, tabu e estigma. Quanto mais as pessoas calam e guardam essas vivências, mais pode colaborar para a perpetuação dessa condição de não falar.

\footnotetext{
Ainda é um assunto pouco discutido e muitas vezes evitado até por pessoas que passaram por situação de suicídio na família. Muitas pessoas têm vergonha de ter tentado ou mesmo de ter alguém na família que fez tentativa ou morreu por suicídio. Geralmente o assunto fica velado, por temer o estigma, o julgamento, enfim, o preconceito da sociedade (Colaborador 1).
}

Para os colaboradores, mesmo com os meios de comunicação falando mais sobre o suicídio atualmente, esse fato ainda não tem a repercussão necessária para que as pessoas debatam mais sobre o assunto. Se as pessoas comunicassem mais, provavelmente descobririam que o suicídio é mais comum que se imagina.

Eu acho que de fato é essa questão de você ter os meios de comunicação falando mais, eu acho que as pessoas se comunicando mais e de repente descobrindo que elas têm mais em comum porque aquela coisa acho que quase todo mundo tem de alguma forma é alguém no seu ciclo que já passou por isso. Mas não comunica, não fala (Colaborador 8).

Outra dimensão dessa falta de comunicação, inclui não falar sobre coisas difíceis do cotidiano: tristezas, angústias, etc. que podem ser fatores que influenciam alguém a pensar na morte. Dessa maneira, não nos referimos somente ao falar sobre o suicídio em si, mas de vários outros assuntos, dificultando a comunicação entre as pessoas próximas de tópicos que precisam ser ventilados. 
Mas quando a pessoa tem algo, que ela não sente à vontade de falar com alguém da família, com amigo, com marido, com esposa, com filhos, com os pais, isso é o que vai acumulando, aí chega num ponto que a pessoa chega a tirar a própria vida (Colaborador 9).

Assim, conforme mostra o diagrama abaixo, podemos ver que o tabu permeia e manifesta-se nas esferas: escolar, familiar, organizacional, estatística, religiosa, psiquiátrica e psicológica, suas consequências podem ser vistas na sociedade e individualmente, e influenciam como nos relacionamos com o suicídio atualmente.

Diagrama 2: Esferas do Tabu

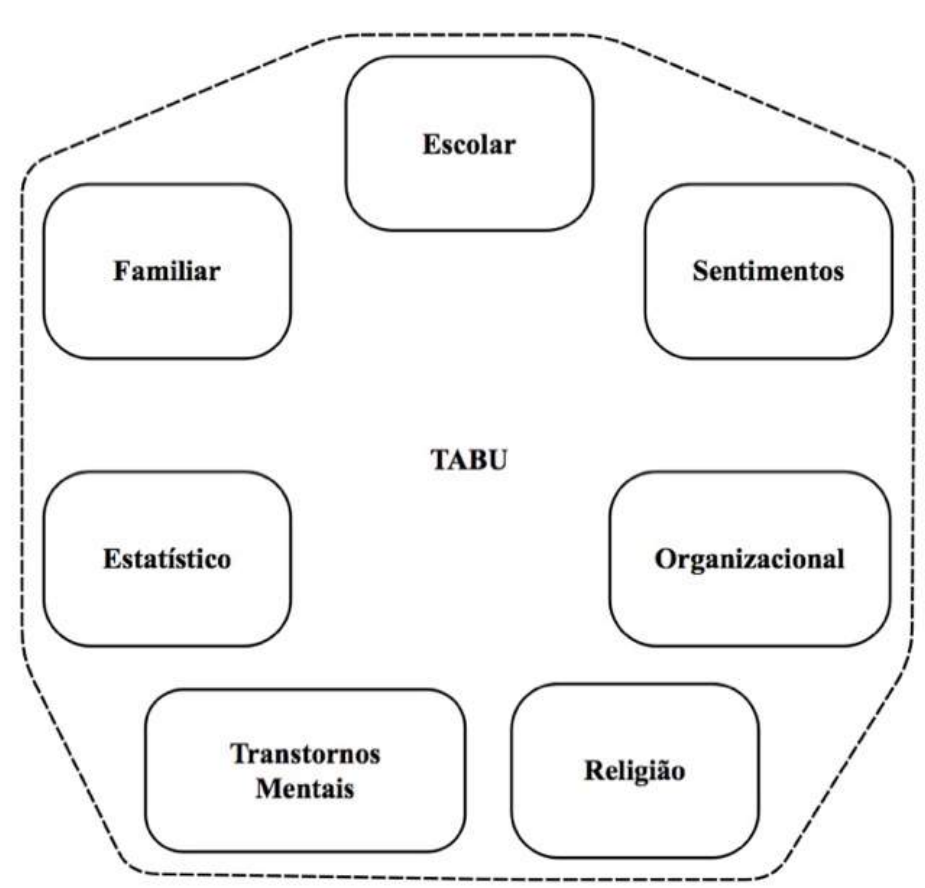

Fonte: produção do próprio autor (2018)

\subsection{2 - Visão}

Essa categoria tem relação em como as pessoas veem e compreendem o suicídio. Embora as duas categorias complementem-se, a VISÃO é diferente do TABU, pois traz outras perspectivas e contém as subcategorias sociedade e causa mortis. Conforme o diagrama abaixo, podemos observar que a sociedade julga a causa mortis, que define a visão, que influencia e é influenciada pela sociedade. 


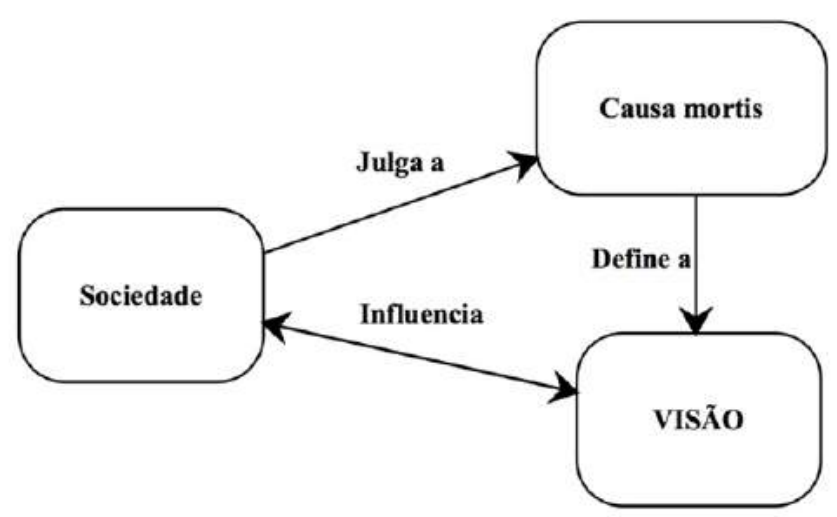

Fonte: produção do próprio autor (2018)

A categoria VISÃO é composta pelas categorias Sociedade e Causa Mortis, conforme vemos abaixo:

Tabela 8: Conceitos e subcategorias da Visão

\begin{tabular}{cc|c|c}
\hline \multicolumn{2}{c|}{ Conceitos } & Subcategoria & Categoria \\
\cline { 1 - 3 } $\begin{array}{c}\text { Visão do suicídio hoje } \\
\text { no Brasil }\end{array}$ & $\begin{array}{c}\text { Causas do suicídio } \\
\text { Depressão }\end{array}$ & Sociedade & \multirow{2}{*}{ Visão } \\
\cline { 1 - 2 } Visão infantil & Curiosidade mórbida & Causa Mortis & \\
\hline
\end{tabular}

Fonte: produção do próprio autor (2018)

A sociedade aponta como o suicídio é visto hoje no Brasil, e as causas que procura para explicar um suicídio e a sua visão da depressão.

Diagrama 4: Visão da sociedade

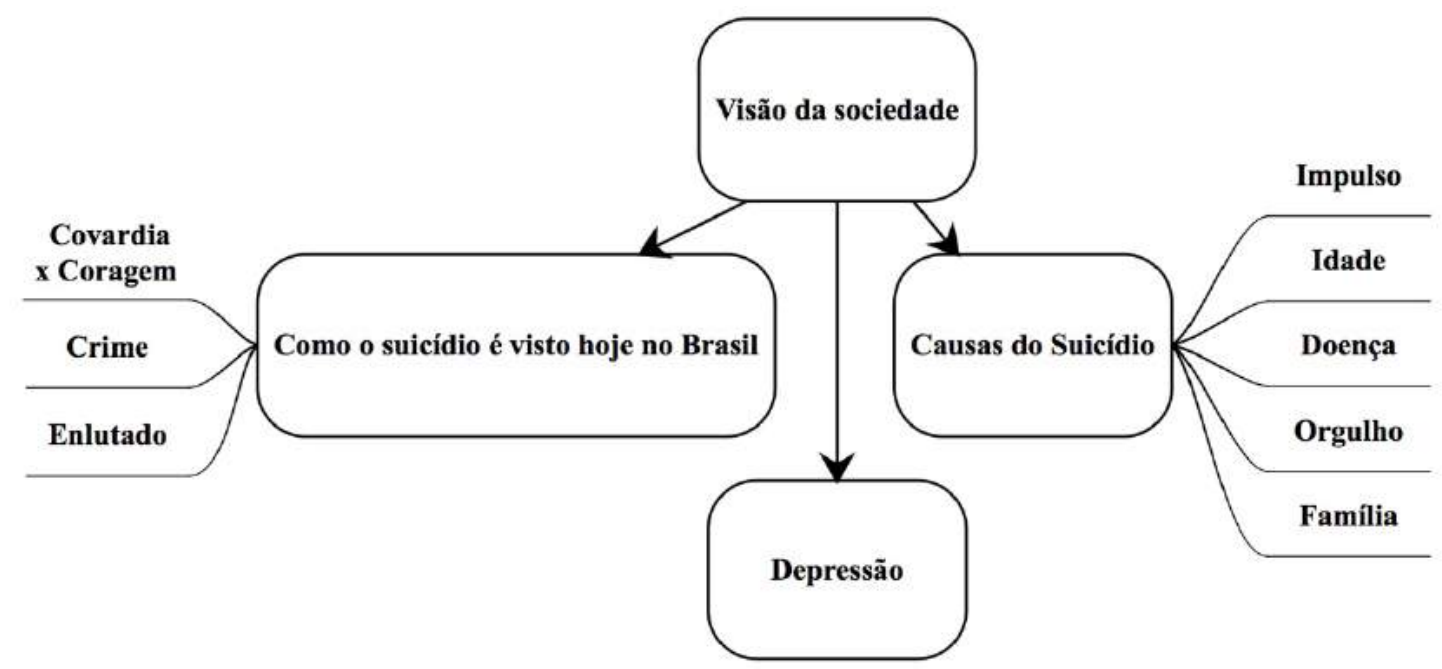

Fonte: produção do próprio autor (2018) 
A visão do suicídio hoje no Brasil foi discutida pelos colaboradores por meio dos conceitos de covardia x coragem, suicídio como crime e como deve se comportar um enlutado pelo suicídio.

Para os colaboradores, no Brasil o suicídio ainda é visto e tratado como crime, questão que coloca aquele que se mata como criminoso, os familiares e os amigos como cúmplices. Os desdobramentos dessa visão influenciam diretamente o tratamento para aqueles que tentam, que se mataram e aqueles que ficam. A análise da forma como o tratamento policial ocorre será abordada na categoria burocracia, mais adiante.

\footnotetext{
Mas acho que o grande problema disso que eu vejo é que a questão de que o suicídio é que ele ainda é uma de espécie de um crime ... E eu acho que todo esse problema também por ser um crime, é acaba tornando isso um tabu ainda maior. Piora o tratamento das pessoas que precisam de ajuda. (Colaborador 8)
}

A relação covardia e coragem revela uma das visões mais comuns relacionadas a quem se mata, aliando-se à questão do pecado em algumas religiões. Para os enlutados é comum ouvir pessoas falarem que o suicídio é coisa de pessoa fraca ou ficarem debatendo se o suicídio é ato de fraqueza ou de coragem. "Isso que você comentou, né? que quem se suicida é covarde, é o que eu ouvi” (Colaborador 9). A partir dessa visão simplista, a dor de quem morreu e de quem ficou é ignorada e a visão do todo no espectro do comportamento suicida fica distorcida.

Uma das colaboradoras, após ouvir muitas vezes esses comentários, diz que já está preparada para "rebater", ou seja, precisa proteger-se do que escuta. Se pensarmos em pessoas extremamente fragilizadas após o suicídio de alguém amado, ouvir que é um ato de fraqueza ou de coragem chega a ser cruel, porém reflete a visão da sociedade com relação a quem comete suicídio, a inabilidade de lidar com alguém em luto, e às necessidades de respostas, "matou-se porque era fraco".

Há uma expectativa da sociedade que em pouco tempo a pessoa "esteja bem e produtiva, sendo que não tem como" (Colaborador 11) e as consequências de expressar o luto, diferentemente do que é esperado pela sociedade, podem manifestar-se como insensibilidade ao seu sofrimento, cobrança de como deve se portar, podendo chegar até a demissão do trabalho.

Outro problema identificado pelos colaboradores foi a busca pelas causas do suicídio, por um culpado ou algo que possa explicar o ocorrido, geralmente de forma simplista.

A princípio, os colaboradores relacionaram essa busca pelas causas como um problema da sociedade, porém o próprio grupo, em alguns momentos caiu na tentação de explicar o que o houve com as pessoas que eles perderam pelo suicídio, a partir da visão de uma causa única. 
Eles mesmos buscam explicações para o que acontece, sendo quem muitos momentos tentam descobrir qual foi a razão, mesmo sabendo que talvez nunca encontrem a resposta correta.

As causas mais comuns para o suicídio vistas pela sociedade e pelo grupo focal foram: impulso, doença, família e orgulho.

Um ponto que chama nossa atenção é o fato do grupo focal rejeitar a visão baseada nas causas, porém um tempo depois questionar-se sobre o papel ou "culpa" da família em um dos casos comentados. Assim, às vezes, também colocam a família como causa, o que eles como familiares posicionam-se contrários em muitos momentos. Sobre o impulso, falam

\footnotetext{
Apesar [de] que tem suicídios que não é por depressão e sim, por exemplo, por impulso. Aquele rapaz de 23 anos que se atirou lá do Fórum da Barra Funda, tinha acabado de sair da audiência, a audiência não foi sido favorável para ele e em seguida ele se atirou. Foi impulso. Não planejado (Colaborador 9).
}

O grupo discute sobre o suicídio, que ocorreu no Fórum da Barra Funda, exemplificando como seus próprios filhos não deram indícios que poderiam cometer o ato ou não falaram sobre pensamentos suicidas que poderiam ter. Pensam que a depressão já estava presente nos seus entes queridos que, pelo fato de existirem planos em curto prazo, estavam seguros, não imaginavam o que estava por vir. À medida que tentam entender o que está ligado ao suicídio, também revisitam o suicídio que viveram.

Entre as causas mais comuns, a doença foi citada, porém entre as doenças mentais, a depressão que mais se destaca, pela maioria dos casos estarem relacionados com um transtorno mental, em especial a depressão. "Eu acho que a depressão como doença, que hoje é doença, está lá no CID e tudo mais, eu acho que, nunca escutei de ninguém que se suicidou sem depressão ... Talvez ninguém notou, ninguém viu, ninguém” (Colaborador 5).

Da mesma maneira que eles questionam o fato de talvez ninguém ter percebido os indícios do suicídio ou que não tomaram as medidas necessárias, "ter depressão não significa que as pessoas mostrem ou que ela tenha sido diagnosticada ou tratada" (Entrevistadora). Os colaboradores relataram que tomaram medidas, mas mesmo assim o suicídio ocorreu, ou seja, mesmo com providências nem sempre o suicídio é evitado.

A depressão pode ser uma doença silenciosa, de difícil diagnóstico e tratamento. Apresentaremos mais dados sobre depressão na próxima subcategoria, pois, neste estudo, a depressão é vista como um dos fatores do suicídio e também tem relação na forma como a sociedade a enxerga. 
O grupo tece uma teia de significados e de causas que os ajude a entender o que aconteceu. Percebem que existem fatores que influenciam o ato, querendo saber quais foram os fatores principais para aquela pessoa tomar a decisão de tirar sua própria vida. Buscar alguma explicação é importante para a família e um "alívio" para a sociedade, pois é mais fácil lidar com explicações, mesmo que simplistas, que com o não saber.

O orgulho foi citado pelo grupo focal e talvez seja uma das visões sobre o suicídio mais comuns no imaginário popular juntamente com covardia e coragem. Para eles, o suicídio por orgulho era comum antigamente, principalmente pelo peso que o julgamento da sociedade exercia nas pessoas. Portanto, conforme a visão dos colaboradores, o orgulho, pode ser um dos fatores principais quando pensamos em suicídio de idosos, que tinham o orgulho e a honra como valores mais fortes que da geração atual.

Há uma percepção do grupo de que hoje há uma banalização dos motivos, como se as pessoas matassem-se "por qualquer coisa", seja por honra, orgulho ou outras causas, denotando que atualmente há uma menor tolerância à frustração e um aumento da depressão.

A visão de que o suicídio ocorre por causa e efeito leva as pessoas a buscarem essas causas únicas e explica o comportamento de procurar um culpado, como a perda de um emprego ou uma família disfuncional. As buscas pelas causas são geralmente externas, "parece que as pessoas querem achar um culpado, querem achar um motivo, tem que ter uma razão né?" (Colaborador 11). O suicídio tem motivações múltiplas, entre as quais o sofrimento da pessoa, sendo que esses aspectos não são levados em conta, o ato suicida pode parecer absurdo, principalmente pela falta de respostas que gera. O suicídio sempre gera mais perguntas que respostas.

As causas apontadas pela sociedade diferem conforme a idade. Para idosos pode haver questionamentos se houve traição, se foi caso de amante, doença grave ou orgulho; para adultos, falência financeira; para jovens, uso de drogas, relacionamentos problemáticos ou culpa da família. Uma "forma pronta" de ver a situação, conforme a visão dos colaboradores.

Com relação a quem faz essas perguntas sobre as causas, percebemos que elas originamse das mais diversas fontes: familiares, amigos, conhecidos, mídia, colegas e até por psiquiatras, que a priori deveriam saber que os fatores envolvidos com o suicídio são múltiplos, além de tomar cuidados a não fazer perguntas que podem constranger ainda mais o familiar como, por exemplo, se havia amante.

Notamos que existe uma busca por parte dos sobreviventes enlutados em preservar a imagem daquele que faleceu para a sociedade, não querem que se mantenham estereótipos ou julgamentos. Uma das colaboradoras fez questão de provar para a família por meio do laudo 
toxicológico feito na autópsia, que o filho não era usuário de drogas, para que não tivessem uma imagem "errada" sobre ele.

A depressão foi colocada numa subcategoria separada de causas do suicídio, pois apresenta dimensões que vão além de ser uma das causas apontadas para o suicídio. O fato de ser incluída como subcategoria e não como uma categoria principal objetivou mostrar a depressão como uma das facetas relacionadas ao autoextermínio e não como a única ou mais importante delas. Esse é um ponto que esse estudo procura refletir, ao apontar a depressão como um fator e não como o único.

Mesmo que hoje a depressão seja vista como um dos fatores mais relacionados ao suicídio, a visão que a sociedade tem da depressão nos faz pensar em como isso afeta quem sofre da doença e consequentemente quem morre por suicídio.

De uma maneira limitante, a sociedade vê a pessoa com depressão como alguém que não teve capacidade de mudar a sua vida e seus pensamentos para um modo mais positivo, deixando a doença acontecer, isso quando a sociedade consegue ver a depressão como doença e não como escolha, "frescura" ou forma de enganar o outro para livrar-se de responsabilidades, como trabalhar, por exemplo. Uma das colaboradoras sente que quando fala para os outros que o filho se matou porque tinha depressão, os outros aceitam essa explicação por pena dela, pois eles acreditam que é melhor ela ser enganada pensando que foi depressão e não uso de drogas ou ter se metido em um relacionamento complicado, como pensam.

“O preconceito, o tabu é tão violento que para pessoa aceitar que ela tem a (sic) depressão, 'Ah, como é que eu vou me intitular de fraco, né? Vou ter que assumir que eu sou fraco, que eu sou preguiçoso, que eu sou covarde ... que eu sou"” (Colaborador 2). O tabu fica presente na forma de ver, de lidar e de entender a depressão e suas consequências, que pode ser desde a pessoa não procurar ajuda, não querer ter um diagnóstico de depressão, não fazer o tratamento, até ouvir piadas e lidar com desconfianças que quer enganar os outros.

\footnotetext{
As coisas têm que ter motivo, eu acho que é essa coisa de todo mundo tentar encaixar um pouco um conjunto de respostas, e disso ser visto assim, como as pessoas não entendem, elas têm que trabalhar com esse repertório que elas têm, que é limitado e fica encaixando dentro dessa, dessa lista de coisas o que elas acham ... É isso, então [pausa] se aconteceu com você, se aconteceu com a sua família é porque vocês têm problemas (Colaborador 8).
}

Segundo os colaboradores, as pessoas buscam justificativas, motivos e não conseguem entender a depressão. As pessoas com depressão também são influenciadas por essa visão, procuram motivos do por quê têm a doença. Muitas pessoas que cometem o suicídio não 
entendem a causa de sentirem-se tão mal, afinal tem uma família boa, não tem problemas financeiros, tem amigos, como se todos esses fatores fossem uma "vacina" que imunizasse à depressão. Ainda existem muitas dúvidas e incertezas em relação às causas, sintomas e tratamentos para a depressão.

Além da doença, algumas pessoas com depressão precisaram lidar também com um afastamento dos amigos, que por não entenderem o tema, a excluíam por acharem que ela tinha uma "energia" ruim. Isso nos levou a pensar em dois conceitos: o afastamento da sociedade de quem não está feliz e as dificuldades de lidar com alguém com depressão.

\footnotetext{
Mas eu não sei, porque eu lido com uma pessoa que tem depressão, a [nome de uma pessoa] e é muito difícil para gente tentar penetrar naquele mundo, é inabitável. Por mais que você queira ajudar, a pessoa se recusa, a pessoa não quer ajuda, a pessoa te dá pistas de que está bem, e de repente de que está mal. Aí você diz: 'Você não está bem?' aí ela fala: 'Mas agora eu estou bem, você é quem está querendo que eu fique mal'. É muito difícil. É um universo que eu desconheço gente, não dá para habitar. Por mais que você queira, você fala: ' $E$ agora, o que eu faço?'. Eu me sinto de mãos atadas. É [pausa] A energia dela é difícil? É, porque eu não consigo compreendê-la (Colaborador 2).
}

A dificuldade de lidar com alguém com depressão não é só da sociedade, é também das pessoas próximas, que não sabem como ajudar e ficam sem entender o que fazer, pois é difícil lidar com alguém com depressão. Portanto, a partir da visão dos colaboradores, podemos pensar que há dificuldades relacionadas a uma falta de entendimento da depressão como doença pela sociedade; como fazer o manejo por quem está próximo, ou seja, como ajudar alguém com depressão; da própria pessoa que não consegue entender os "motivos" que a levaram a ter depressão e não sabe onde e como receber ajuda.

A subcategoria causa mortis tem relação com a forma como a sociedade reage ao lidar com a morte por suicídio, o que é diferente da experiência pessoal de falar para alguém sobre a morte por suicídio, questão que será tratada na categoria comunicação pessoal.

Dois conceitos serão discutidos a seguir, a visão infantil e a curiosidade mórbida, por serem aspectos levantados nos grupos.

A visão infantil é decorrente da experiência de uma colaboradora, mostrando como crianças podem lidar naturalmente com o assunto e como a reação da sociedade pode moldar a forma como a criança entende, pensa e fala sobre suicídio com outras pessoas, mesmo que tenha liberdade para falar do assunto em casa. 
mas eu falei assim como se fosse a mesma coisa que ela tivesse morrido do coração e aí me arregalaram o olho assim e eu fiquei: 'Ué, mas [pausa] Porque era um assunto que em casa, assim, um lado da família falava o outro não [pausa] mas porque a minha mãe também tinha tido uma tia que tinha se suicidado. Então, era uma coisa que se falava de certa forma à mesa, né? Mas eu me lembro desse, desse choque das pessoas. E eu não falava para chocar. Eu falava porque sei lá, na minha cabeça era uma forma de morrer. Era uma forma de morrer. Era uma forma de morrer e a gente conversava sobre isso. Sempre se conversou sobre isso, em casa (Colaboradora 8).

Segundo a experiência dessa colaboradora, ela aprendeu que em casa poderia falar sobre suicídio, mas na rua não. Então mesmo que em parte da família haja abertura para falar o tema, o tabu está presente em outra parte da família e na sociedade, que ainda não sabe como lidar quando recebe uma comunicação de que houve morte por suicídio.

Em curiosidade mórbida podemos perceber que, além da busca de uma causa e de um culpado, como citamos anteriormente, há uma curiosidade sobre a forma da morte, detalhes sobre o corpo, velório, caixão. Essa curiosidade é percebida pelos enlutados, quando começam a contar que a morte foi por suicídio e começam a proteger-se de quem, como e onde falar, identificando quais são as pessoas, que realmente querem oferecer ajuda para eles e quais são as perguntas que aparecem como resultado de uma curiosidade a respeito do formato dessa morte.

\footnotetext{
Eu 'sinto muito' das pessoas, elas querem saber, quando você conta uma coisa, a curiosidade não é assim em: A) ter ajudado, como poderia ter ajudado, como ajudar o outro [pausa] eles querem saber como foi, como foi encontrado, o que aconteceu? Eu sinto muito! Ainda as pessoas querem [pausa] A abordagem era: 'Bom, mas como foi? Mas, como era? Como estava?' É horrível, assim. 'O caixão foi aberto ou fechado?' (Colaborador 4).
}

É, então, após experiências como estas que os sobreviventes enlutados aprendem, a partir da tentativa/erro, como falar ou não falar sobre esse suicídio. O grupo traz a vivência de que a maioria das pessoas pergunta do que aquela pessoa morreu e ao depararem-se com a resposta de que foi por suicídio, apresentam diversas reações, não se contém, realizam um interrogatório e depois emitem suas opiniões sobre o porquê acham que o suicídio ocorreu.

Outra dimensão da causa mortis, apontada pelo grupo focal, é o suicídio como espetáculo, quando se torna um entretenimento mórbido, das pessoas que ficam olhando alguém que ameaça matar-se e, às vezes, até gritam para que a pessoa faça logo, para postar fotos e vídeos na internet com os corpos de pessoas que morreram por suicídio. 


\subsubsection{Comunicação}

A categoria COMUNICAÇÃO refere-se à forma como o suicídio é informado, falado, dito ou não dito e suas implicações. Essa categoria foi dividida em social, quando a informação é recebida, muitas vezes por meio da mídia e em pessoal, que se refere às facetas individuais e ativas, envolvendo falar sobre o suicídio. A princípio a categoria pessoal era "o falar", mas foi alterada para pessoal por referir-se às ações e às interações decorrentes do ato de comunicação pessoal sobre aquela morte, seja para muitas ou poucas pessoas.

Foi uma das categorias com mais codificações (seiscentas e setenta e seis), isso mostra que uma das grandes formas de aumentar a consciência pública relaciona-se com a comunicação, sendo que a importância dada a esse tema pelos colaboradores demonstra esta relação.

No diagrama abaixo podemos ver como a categoria relaciona-se com as subcategorias e conceitos:

Diagrama 5: Comunicação

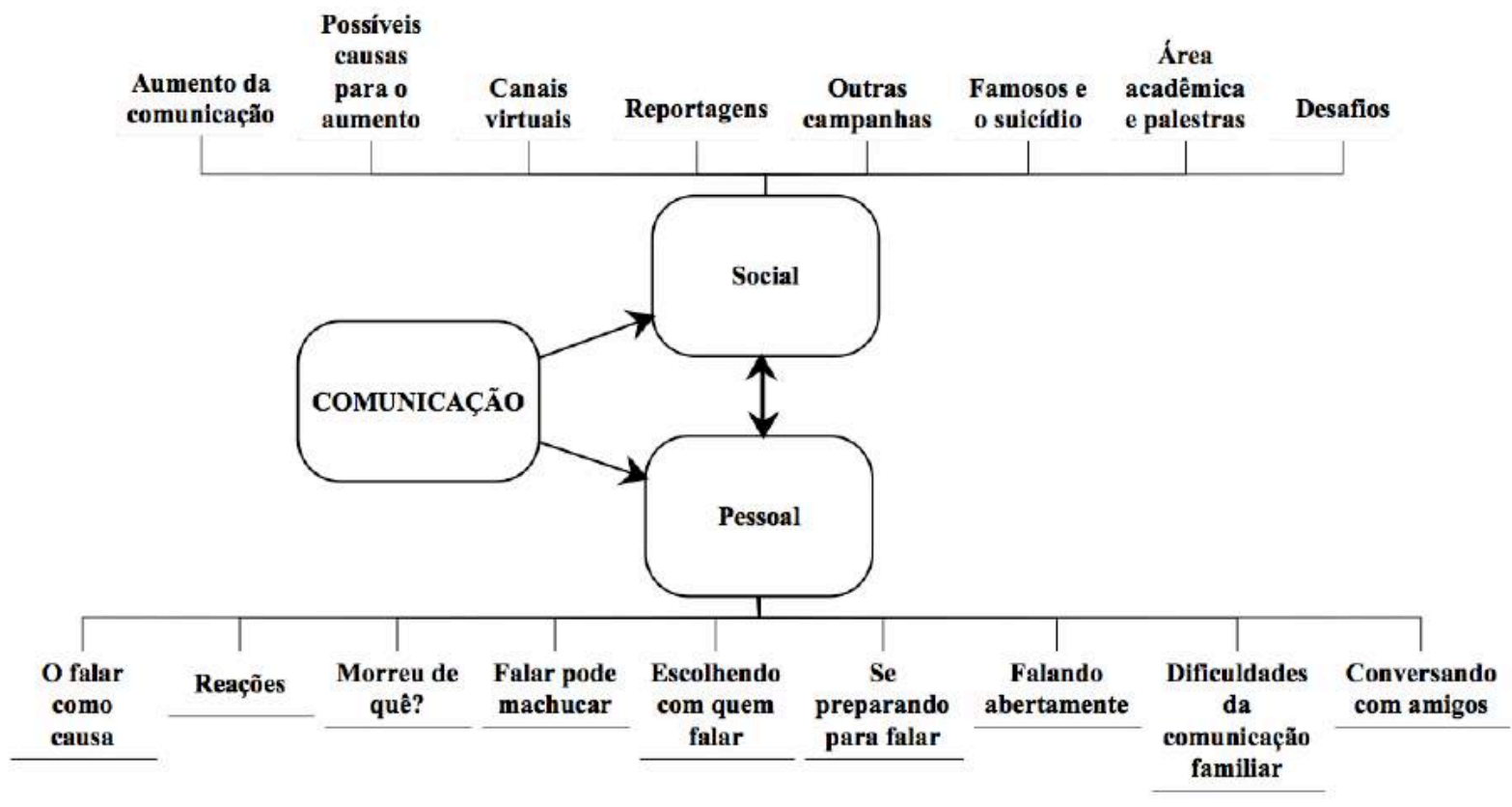

Fonte: produção do próprio autor (2018)

A subcategoria social trata do aumento da comunicação sobre o tema suicídio e quais são as possíveis causas para esse aumento. Ao pensarmos nessas causas, podemos ter orientações sobre como aumentar a consciência pública. Os canais virtuais, $\underline{\text { as reportagens, }}$ os famosos e o suicídio, a área acadêmica também foram apontados como fatores importantes para 
que ocorra essa comunicação. Trataremos também sobre o que se pode aprender com campanhas diversas, como as do câncer, além dos desafios que temos na área da comunicação.

Foi praticamente unanimidade entre os colaboradores que hoje se fala mais sobre o suicídio, comparado com tempos atrás, como se observa no conceito aumento da comunicação. Eles percebem esse aumento no volume de notícias e nas reportagens em canais de televisão, jornais e revistas. Embora, afirmem que ainda é preciso falar mais, já observaram mudanças.

Isso nos leva a refletir se foi a comunicação que realmente aumentou ou o interesse deles que fez que prestassem mais atenção ao tema, dando a sensação que atualmente falamos mais sobre suicídio. Talvez as duas possibilidades estejam presentes, pois atualmente podemos observar um aumento em séries, reportagens e campanhas sobre o assunto e como eles passaram por um suicídio, é um tema que os interessa.

Sentem como uma vitória o fato do suicídio poder ser falado na mídia, pela percepção que têm do quanto esse fato é importante para eles e para a sociedade.

“Sim, mas mesmo que você não vá procurar a informação chega até você através do jornal, imprensa, televisão. As informações estão chegando sem você procurar. Isso eu acho muito importante" (Colaborador 3). Eles percebem que hoje é possível ligar a televisão e ser surpreendido com reportagens sobre suicídio, significando que essa informação está sendo passada, o que antes não ocorria, segundo a experiência dos colaboradores. Relatam que perceberam esse aumento de comunicação na mídia, na sociedade, em palestras de suporte e em algumas empresas, em pequenos e grandes grupos.

Os participantes debateram se há horários em que os canais de televisão são proibidos de tocar no assunto suicídio, porém as experiências pessoais mostram que o tema tem sido abordado em diferentes grades e canais, em diversos horários. Um dos colaboradores conta que alguns programas chegaram a gravar matérias sobre suicídio com ele, mas essas não foram ao ar. Podemos perceber que há um interesse crescente sobre o tema, embora em alguns casos, mesmo com o programa pronto, ainda há um controle sobre o que falar, geralmente pela cúpula das emissoras, como foi o caso com esse colaborador. O repórter percebe a importância, faz a entrevista, mas depois a notícia é vetada. Não conhecemos os porquês de cada veto, mas podemos supor que é pelo fato do tema ser tabu para muitas pessoas.

Outros colaboradores consideram que não houve aumento de comunicação, houve sim aumento da informação, ou seja, podemos até ter mais reportagens hoje, mas não significa que pessoas consigam falar mais, ter diálogos abertos sobre o assunto.

Um colaborador sente a necessidade de que fossem propostos mais grupos focais como esse para o doutorado, pois tem a sensação de que são poucas pessoas debatendo o tema, 
incluindo os sobreviventes, vê nesse debate um potencial multiplicador, pois se cada um do grupo sair sensibilizado com a conversa e fizer alguma ação/divulgação, o efeito será de atingir cada vez mais pessoas.

Outra questão discutida foi a da mídia incluir os sobreviventes enlutados em suas reportagens, programas e séries, o que também não acontecia. Um dos colaboradores relata vários programas, matérias e reportagens nas quais participou. Acha importante que as pessoas saiam do anonimato como ele fez a fim de mostrar a sociedade o rosto e a dor dos que ficam, pois acredita que esse fato tem um potencial transformador.

Se houve um aumento, é necessário observar quais foram as possíveis causas para o aumento da comunicação.

Para os colaboradores 4 e 1, o suicídio e a depressão atualmente são assuntos que estão na "moda", o que faz que a comunicação seja maior, eles não apontaram o porquê exatamente acham isso. A repercussão das séries de televisão e das notícias frequentes sobre a Baleia Azul talvez sejam parte da explicação.

Há também uma sensação de que as pessoas tendem a falar mais sobre os variados "assuntos da moda" (Colaborador 10), que podem ser desde problemas na política como a série dos 13 Porquês sobre suicídio, passando uma sensação de falta de importância e de mobilização com o que é dito. Discute-se os assuntos do momento, mas com qual engajamento, eles se questionam.

Além dessa visão supracitada, os colaboradores refletem que a depressão também entra no mesmo contexto, essa pode ser outra causa para se falar mais sobre esses temas com profundidade, algo que não acontece pela volatilidade da informação. Assim, o fato de falarmos mais sobre depressão atualmente, automaticamente influencia o discurso sobre suicídio.

A série dos 13 Porquês trouxe muitas reações e reflexões manifestadas pelos participantes do grupo focal e na sociedade em geral, reações como choque e impacto nas pessoas, tendo como resultado que elas falassem e refletissem sobre a complexidade do comportamento suicida. "Até que esse seriado me levou a pensar isso, é que muitas vezes dentro da sua casa você não sabe o que está acontecendo com o seu filho, com seu sobrinho, na cabeça deles, né?” (Colaborador 4).

Outra explicação para o aumento da comunicação é que o suicídio está ficando mais frequente, os números têm aumentado, esse fato tem chamado mais atenção. Por essa razão pensamos na importância dos números, na importância de uma estatística correta e sua divulgação. 
Uma das colaboradoras afirma que esse aumento de informação não faz ainda que as pessoas tenham empatia com as atingidas por um suicídio. Ela questiona-se o quanto as pessoas compreendem o suicídio como um acontecimento próximo a ela e o quanto conseguem falar no assunto.

\begin{abstract}
E aí eu fico pensando, né? Se, assim, a gente está falando mais porque não sei se tem mais casos ou não e quem passa a entender que isso é uma realidade porque passou [e] consegue falar do assunto. Por que será que a gente tá falando mais ou tem mais casos? E as pessoas entendeu [sic] que vivem isso estão, sabe por que aquilo que eu falei na reunião passada: Pra mim o suicídio só se torna real na sua vida depois que você realmente [pausa] por que se não, acho que é uma coisa [pausa] O que está fazendo com [sic] que as pessoas falem mais? Será que é porque temos mais casos e elas passaram a enxergar isso como putz [sic] acontece ou [pausa] qualquer ser humano consegue falar mais sobre isso (Colaborador 10)."
\end{abstract}

O aumento da liberdade de expressão foi outro conceito trazido pelo grupo como uma das causas do aumento da comunicação. Hoje muitos assuntos foram escancarados pela sociedade, como o sexo, a homossexualidade e a AIDS, por exemplo, existe então uma maior facilidade de abordar questões que antes não eram abordadas. O suicídio é uma delas.

\footnotetext{
Então eu acho que esse é um assunto também que é difícil, que cada vez mais as pessoas assim não têm mais medo, não tem mais vergonha, assim como alguns outros assuntos difíceis que a gente tem hoje, que as pessoas, por exemplo, levantam bandeira e lutam por certas causas que antes não era uma coisa tão escancarada. Mas eu acho que cada vez mais a gente tem [pausa] te dão mais liberdade, enfim, e não tem mais vergonha, nem medo, nem se sente oprimido por falar de certos temas (Colaborador 10).
}

A globalização e a facilidade de conexão entre as pessoas e as notícias aceleraram a divulgação, promovendo o acesso a todos os tipos de assuntos e de opiniões em relação a eles. A liberdade de expressão facilitou o empoderamento das pessoas para tratar de assuntos, como se antes houvesse mais preconceito que hoje. Isso não é um privilégio de todos os países, conforme lembra uma das colaboradoras, o que pode causar sofrimento nas pessoas pela necessidade de disfarçar e não poder falar abertamente do tema em alguns lugares.

A última faceta das possíveis causas para o aumento da comunicação é o acesso à informação, que está relacionado com a facilidade de achar notícias sobre o tema atualmente e por receber informações mesmo sem procurar. O exemplo disso são algumas pessoas que se capacitaram sobre a prevenção do suicídio e oferecem excelentes palestras, mobilizando muita gente, que estão disponíveis nas redes sociais.

A existência e ampliação dos canais virtuais geraram grande impacto na forma e na quantidade de comunicação existente sobre o suicídio, tanto pessoal como social. O uso da 
internet possibilitou acesso às informações que antes eram muito mais difíceis de serem conseguidas. Sem dúvida, a prevenção do suicídio foi impactada positiva e negativamente pela chegada dos canais virtuais.

Canais virtuais entrou como uma subcategoria de comunicação por ser mais que uma das possíveis causas que ajudaram a aumentar a comunicação sobre o assunto e tem impactos em diversas dimensões. Os canais virtuais incluem sites de busca, acesso aos jornais, às revistas e às notícias, aos grupos de discussão, $b \log s$, apoio e uso de redes sociais.

Nos canais virtuais, as redes sociais destacaram-se pela influência que exercem atualmente na comunicação e na vida das pessoas. Percebemos que elas influenciam as pessoas de diversas maneiras, exemplificando:

- Trazem a ilusão de que as outras pessoas têm a vida perfeita, que ninguém tem problemas, mostra uma parte da história fantasiosa da vida das pessoas, mas é vista e encarada como o todo, como se só sentissem felicidade e prazer sempre, isso pode ter grande repercussão em pessoas com depressão e comportamento suicida. Uma das colaboradoras foi demitida quando o chefe julgou o luto dela pelas fotos postadas no facebook, como se representassem tudo o que estava vivendo;

\footnotetext{
É uma obrigação hoje em dia, por conta das redes sociais também isso que a P10 estava falando. Que todo mundo só compartilha momentos bons, comida boa, lugar bom, ninguém compartilha, né P10? A visão do metrô lotado, então eu acho que quem não tem, principalmente os jovens né? eles se sentem muito cobrados e muito 'poxa, mas todo mundo é feliz menos eu?', 'poxa, mas fulano está viajando, o outro está rico, o outro [pausa]' E ninguém está, a grande verdade, quando você pegar essas pessoas, é que ninguém está. Ninguém leva a vida que compartilha ali, são pouquíssimas pessoas que realmente têm uma vida maravilhosa todos os dias, aliás acho que, não sei quantas, mas não conheço, não conheço, então tem isso também de [que] você não pode falar que está triste, você não pode falar que não está legal, então, se você chorou você é fraco e se você não está bem ... (Colaborador 11).
}

- O compartilhamento de fotos do ato suicida e de casos de suicídio gera indignação nos colaboradores. Uma colaboradora brigou com a pessoa que postou uma dessas fotos, alegando que aquela pessoa tinha família, que não ela não poderia postar coisas assim;

- Os tipos de postagens que recebem mais curtidas são aquelas que expõem a tragédia pessoal e tem como resposta mensagens de solidariedade. Quando a postagem é sobre prevenção e posvenção do suicídio, com informações mais técnicas a quantidade de curtidas e comentários é menor; 
- As redes sociais são um canal de comunicação em grandes proporções, servindo para gerar impacto e divulgar informações, por espalharem a notícia rapidamente e serem utilizados por muitas pessoas;

\footnotetext{
Então, eu acho que o suicídio, como se torna cada vez mais comum dele acontecer e hoje com as redes [sociais] você consegue ter mais informação, eu acho que isso acaba se espalhando bem mais do que antigamente, então eu acho que acaba, assim como outros assuntos também vindo mais à tona ... e eu acho que isso ajuda bastante porque está tudo muito conectado, as pessoas ficam sabendo de tudo mais rápido, então desse assunto também, assim como outros assuntos que a gente vai descobrindo e vai vendo que existe e aí a sociedade começa a tentar a trabalhar em cima ou, por exemplo, uma doença, tenta achar a cura [pausa] teoricamente (Colaborador 10).
}

- É possível, por meio das redes sociais, colocar um rosto na tragédia, quando há a postagem de fotos e de fatos da vida da pessoa, que pode favorecer que a sociedade veja a pessoa com todo, com toda a sua história e não somente pelo suicídio. Pode também trazer a realidade e a dor dessa perda para mais pessoas, aproxima o mundo daquele que morreu e dos familiares que ficaram.

A internet é uma nova forma de relacionar-se e de comunicar-se, possibilita uma busca ativa e é uma ferramenta, que pode ser usada com objetivo positivo: acolhimento, busca de pares, divulgações, solidariedade; objetivo negativo: julgamentos, estigma, informações sobre meios de cometer o suicídio e compartilhamento de fotos e de vídeos do ato suicida.

Embora isso não tenha sido discutido em grupo, a internet chega a muitos lugares que não tem acesso físico a tratamentos e ajuda. Deixa as pessoas livres para contarem suas histórias e acharem apoio, mas pode dar liberdade aos comentários negativos sem consequências legais.

Com relação às reportagens a respeito de tema, percebe-se basicamente uma mudança na forma como são elaboradas essas matérias. Algumas críticas foram feitas pelo grupo focal, relacionadas ao fato das reportagens não se aprofundarem na dor dos que ficam visto que contêm informações sobre o luto, a morte e o suicídio, mas sem examinar a fundo a dor.

Informações que falam que o suicídio pode ser prevenido em mais de $90 \%$ dos casos ou que ele é resultado de falta de carinho e amor acabam produzindo culpa nas pessoas que estavam próximas de quem morreu, como os familiares, apontando que não foram capazes de prevenir o suicídio ou que viraram as costas para quem precisava, que se sentem incompetentes por não terem evitado o ato. Há um risco nesses comentários, embora bem-intencionados, tendo em vista que o suicídio pode ser prevenido em alguns casos, mas não em todos.

As reportagens podem capacitar sobreviventes para lidarem com o comportamento suicida de outros. Os colaboradores citam que buscam uma parte prática nas reportagens, que 
ensinam o que pode ser feito para a prevenção de um jeito claro e de fácil entendimento. No entanto, eles lembram de que a maioria das reportagens não proporciona essas explicações, limitando-se em descrever o que aconteceu em vez de incluir orientações práticas para a população.

Quando se trata de suicídios de grande repercussão, como o caso do piloto da Germanwings, todos comentaram que consideram a mídia irresponsável pela forma como tratou a questão. Questionaram se isso poderia ser explicado pelo fato do copiloto ter matado outras pessoas, além de ter causado a sua, demonstrando empatia ao pensarem na dor que ele estaria sentindo a fim de cometer tal ato. Obviamente não endossaram aquele comportamento, mas conseguem enxergar além, pelo prisma do sofrimento. Para eles, o copiloto já tinha "desligado", cortado os laços com as pessoas e com a vida antes de cometer o ato suicida.

Uma maneira de aumentarmos a comunicação sobre o suicídio hoje, pode englobar um olhar e análise detalhados para as grandes campanhas que já foram elaboradas para questões como o câncer e a AIDS, que tiveram mais abertura após serem consideradas questões de saúde pública. Assim estaremos aprendendo com quem veio antes, ressaltando a importância da prevenção do suicídio como questão de saúde pública.

Antigamente não se pronunciava a palavra câncer, era "aquela doença" e nem se podia apontar onde a pessoa tinha o tumor, pelo risco de contrair a doença, tamanho era o tabu relacionado ao assunto. Hoje as pessoas falam mais abertamente sobre o câncer, o que abre a esperança, como apontaram os colaboradores para que seja feito da mesma maneira com o suicídio.

Outro aspecto, levantado pelo grupo focal, foi a questão de que, após toda essa mudança que houve na visão das pessoas em relação ao câncer, hoje as pessoas oferecem acolhida a quem descobre a doença, têm compaixão, oferecem ajuda pessoal, profissional, com mais cuidados com aquela pessoa que teve o diagnóstico. Denominam as pessoas de lutadores e vencedores. Ao comparar essas diferenças de tratamento, de pessoas com câncer e no caso do suicídio, fica claro que ainda precisamos trabalhar muito para chegar ao mesmo ponto em relação à prevenção do suicídio. Um longo caminho, mas não impossível.

O grupo focal foi unânime ao afirmar que pessoas famosas podem causar grande repercussão, positiva ou negativa, na prevenção do suicídio.

Ressaltamos que há no imaginário popular uma visão de que as pessoas famosas têm a vida perfeita e são sempre felizes, pois "teoricamente não têm problema, têm fama" (Colaborador 2). Quando essas pessoas falam de seus problemas abertamente ou quando, por exemplo, o Cazuza, que assumiu ter AIDS e o Michael Jordan, que era portador do vírus HIV 
e falava abertamente sobre isso, trazem relatos que colaboram para que se tornem humanos, saindo do pedestal da fama e aproxima-os das pessoas.

Tomar conhecimento do suicídio de alguém famoso ou saber que eles lidaram com transtornos mentais ou passaram por tratamentos, pode ajudar a discutir o assunto e a perceber que o suicídio pode acontecer com qualquer um, até com aqueles que têm a vida "perfeita". Ao tornar o assunto público, por ter ocorrido com uma personalidade, fica difícil esconder da mídia e as pessoas fingirem que não estão sabendo de nada, facilitando o contato com o tema. "Quando é uma personalidade, eu acho que torna tão público que fica difícil a gente colocar um véu e fingir que não está sabendo de nada" (Colaborador 2).

Atualmente podemos encontrar alguns famosos que falam sobre o suicídio, como Selena Gomes e André Trigueiro. Pessoas que têm trazido o tema para discussão de forma aberta e acessível.

O grupo focal comentou sobre o suicídio de Santos Dumont ter sido escondido da sociedade, pelo fato da maioria das pessoas não saberem que essa foi a causa da sua morte, "só quem passou por isso sabe" (Colaborador 5). Entretanto, ao fazer uma busca no Google com o tema "do que morreu Santos Dumont" aparecem vários sites na primeira página de busca, falando que foi por enforcamento, trazendo detalhes do local, horário, entre outras questões. Este fato, mais uma vez, leva-nos à reflexão de que quem passou por um suicídio fica mais atento ao assunto e que a causa da morte de Santos Dumont não está escondida, a informação está disponível para quem procura.

O suicídio do Robin Willians foi o que mais chocou os colaboradores, pois viam nele uma referência de uma pessoa alegre e seus filmes eram "alto astral", apontando mais uma vez que suicídio não tem rosto certo. Há um sentimento de choque por ele ter feito um filme em que seu personagem ter ido buscar sua mulher que se suicida no inferno e ele como pessoa fazer a mesma coisa depois. Ele escancarou o fato de que a imagem que se passa, muitas vezes, é diferente da realidade da pessoa.

A área acadêmica e as palestras foram citadas por também serem locais onde a comunicação ocorre, de uma maneira diferente da comunicação na mídia. O grupo focal discutiu que atualmente há uma oferta e procura maior por palestras sobre suicídio, diferente do que havia antes. Escolas e universidades têm aberto suas portas para que ocorram comunicações sobre prevenção do suicídio e valorização da vida, principalmente se precisaram lidar com o suicídio de um aluno. Talvez em muitos locais só haja essa abertura quando a diretoria é obrigada a lidar com o assunto pelo aumento do comportamento suicida em alunos. 
A periferia tende a ter mais abertura para receber essas palestras, isso pode ser explicado pelo fato da escola ter mais dificuldade de ter ou levar um profissional de fora para falar. Quando há um profissional disponível nessas instituições a receptividade é maior. Se antes havia dificuldade de encontrar escolas que aceitassem receber essas palestras, hoje observamos Instituições que oferecem palestras em escolas duas a três vezes por semana.

A esposa de um dos colaboradores, que é estudante de psicologia, teve a oportunidade de ver duas palestras sobre prevenção do suicídio em apenas quatro meses e em entidades diferentes, o que demonstra o aumento da abertura e da oferta para falar sobre suicídio. Ambas as palestras aconteceram em semanas da psicologia, sendo uma delas em uma universidade federal e a outra em uma particular muito bem-conceituada na região. Isso demonstra que os estudantes já têm mais contato com o tema que tinham antes, quando se interessam, pois ainda não há nada obrigatório em termos de prevenção do suicídio nas grades universitárias da área de psicologia.

A prevenção do suicídio também tem sido trazida para o público por meio das especialidades da psicologia e da psiquiatria, provavelmente porque estas especialidades apresentam uma necessidade maior de falar sobre o assunto, pois percebem o aumento dos casos e lidam diretamente com as pessoas. Buscam que o suicídio e a depressão sejam uma preocupação de saúde pública, assim como o câncer e a AIDS, o que pode facilitar o aumento da comunicação sobre os temas e o desenvolvimento de campanhas periódicas.

Os desafios presentes na comunicação são claramente o tabu e o preconceito, que podem gerar um afastamento de notícias relativas ao suicídio, por se tratar de um evento que pertence à pessoa, que não atinge outros e se não atinge não há necessidade de inteirar-se sobre o assunto.

Piadas sobre o assunto, como aconteceu com a baleia azul e a comparação com a carteira azul (de trabalho) e as havaianas azuis (sandálias com tiras azuis usadas pelos pais para bater nos filhos quando eles não se comportam) acabam afastando mais as pessoas e dificultando que haja uma comunicação significativa nesse sentido.

Eu acho que tem uma distância também muito grande e assim, muito grande mesmo entre as pessoas que são os familiares, as pessoas próximas de alguém que se suicidou da pessoa que tem vontade, de que quer, que pensa no assunto, eu acho que essa distância ela ainda é muito grande, porque a gente está falando, eu acho que está se falando muito disso, mas eu acho que não a um ponto de que ainda dê segurança pra uma pessoa que pensa no assunto, se sentir à vontade, suficientemente à vontade de tratar esse assunto em qualquer situação. Eu acho que é essa a distância que ainda está muito grande. Então, eu acho que, fala-se mais, encontra mais respaldo aí de falar, diminuiu esse tabu, mas ao mesmo tempo isso não tem reflexos pra quem tá pensando. Isso é uma coisa que eu acho que ainda é um tema e a distância é grande (Colaborador 8). 
Outro desafio enfrentado é ajudar as pessoas que têm comportamento suicida a sentirem-se seguras e falarem sobre o assunto em várias situações. Uma colaboradora entende que há uma distância muito grande na compreensão sobre o suicídio, a partir da experiência de quem perdeu alguém dessa forma com relação a quem pensa em matar-se. Para ela, mesmo com a diminuição do tabu sobre o assunto, a sociedade ainda não entende e nem ajuda adequadamente quem pensa em cometer tal ato.

A categoria comunicação pessoal surgiu a partir da vivência dos colaboradores quando falam sobre a forma da morte do ente querido ou quando conversam com outras pessoas sobre o suicídio. Falar sobre o suicídio, após ter essa experiência, muda a forma de enxergar e de relacionar-se com o mundo, com o outro e com o tema em si. "Nas pessoas mais próximas, não consigo ainda hoje entrar no tema do suicídio sem notar um impacto de estranhamento e desconforto nas pessoas" (Colaborador 9).

Um ponto comum entre os colaboradores é a dificuldade de encontrar pessoas que consigam conversar com eles sobre o assunto, mesmo sendo pessoas próximas. "Na ocasião do setembro amarelo, passado em 2016, eu estava trabalhando como voluntário do CVV. É com tristeza que relato que não encontrei abertura para falar da campanha com ninguém da família e com a maioria dos amigos mais próximos" (Colaborador 9). Se um impeditivo é conseguir começar a falar sobre essa perda, outro maior ainda é achar alguém para ouvir, alguém que consiga escutar e conversar sobre essa morte, sobre o luto e sobre o suicídio.

Mesmo que atualmente tenhamos mais campanhas sobre a prevenção do suicídio e a mídia fale mais sobre o assunto, romper silêncios: íntimo, pessoal, familiar e social ainda pesam como um dos maiores desafios para a prevenção e posvenção.

Morreu de quê? é a pergunta que muitos sobreviventes mais temem e querem fugir, pois é a partir dela que eles precisam decidir se vão falar a verdade ou o que devem responder, então, começam as reações e o lidar com o fato em público e com tudo que vem depois. Ao falarem, o fato consuma-se, cruel, assim, percebemos que muitas pessoas precisam de um tempo e preparo para conversar sobre. O choque inicial é tão grande que, quando a forma da morte não é falada no momento, o segundo passo dessa trajetória consiste em definir para quem, quando e o que falar.

Por um lado, alguns colaboradores contaram a todos logo no início, sendo que hoje não mudaram o posicionamento perante o assunto, por outro, há famílias que precisaram lidar com o segredo e com a questão de quando falar, há famílias que tomam a postura de falar, como uma forma de enfrentamento da sociedade e do tabu. Ainda, há famílias que falam que foi 
acidente ou algum problema fulminante, deparando-se com mais uma infinidade de perguntas incessíveis sobre como foi, desde quando e os detalhes mórbidos, que já falamos previamente.

É interessante perceber que nenhum deles se questionaria se o assunto não fosse tabu, se essa forma de morte fosse aceita pela sociedade. As raízes dessa situação estão vinculadas ao tabu da sociedade e à proibição de enterrar os suicidas em "solos sagrados" em conjunto com punições para a família. Dessa forma, podemos dizer que eles ainda sentem as consequências dessas leis, mesmo que elas não existam mais.

No geral, os colaboradores relatam que as pessoas são muito insensíveis ao saberem da morte e "falam qualquer coisa ... as pessoas falam muita bobagem" (Colaborador 8)

Uma das reações comentadas foi que ao ouvirem a forma como a pessoa faleceu, as pessoas começam a contar sobre a morte de outras pessoas, incluindo o funcionário do cartório até pessoas mais próximas, que começam a comparar as situações e a contar mais casos. "Quando eu estou com a minha mãe no cartório pra registrar o óbito, o cara fala assim: ‘Ah, sabe quem morreu também essa semana?' (Colaborador 8).

Houve uma discussão no grupo se esta reação era igual ou diferente de outros tipos de morte que não eram por suicídio. Não foi uma unanimidade, mas a maioria dos colaboradores relatou que com o suicídio é diferente. A pessoa ao receber a notícia de uma morte como esta tem sim uma reação diferente do que teria com outras. "As pessoas recebem o impacto e começam a botar para fora qualquer coisa e né? não pensa no que está [sic] falando" (Colaborador 8). Parte disso pode ser pelo fato das pessoas não saberem o que fazer nessa situação, agregado à insensibilidade, ao julgamento e à curiosidade mórbida. "Eu já vi reações, às vezes a pessoa vai perguntando: 'ah e tal ... morreu' e você fala e a pessoa, bum. Fica todo mundo sem ação" (Colaborador 7).

Após saberem que a morte foi por suicídio, algumas pessoas citam o Umbral ${ }^{16}$, outras ficam dizendo que quem se mata não tem Deus no coração, estas são reações negativas que provocam impacto nos enlutados, quando ouvem isso.

Uma das colaboradoras ficou surpresa ao ouvir de amigos que o irmão havia falecido de ataque do coração, o que não era verdade, quem havia dito isso foi uma tia. "Eu tive essa

\footnotetext{
${ }^{16}$ O Umbral, na doutrina espírita, refere-se a uma "região destinada a esgotamento de resíduos mentais; uma espécie de zona purgatorial, onde se queima a prestações o material deteriorado das ilusões que a criatura adquiriu por atacado, menosprezando o sublime ensejo de uma existência terrena”. (Xavier, 1995, p. 58). Esta visão pode ser considerada como um sofrimento adicional para quem morreu por suicídio.
} 
situação de, por exemplo, a minha tia sair dizendo que o meu irmão morreu de um ataque fulminante. Um ataque cardíaco, mas ele não morreu de ataque cardíaco" (Colaborador 8).

Pelos motivos citados anteriormente que os colaboradores precisam preparar-se para falar sobre o suicídio em sociedade. Fazem um teste com a pessoa que estão conversando para perceber como ela reagiria ao saber do suicídio, isso por causa das experiências negativas que tiveram. "Aí eu tive experiências ruins, então, hoje o que eu percebo, assim, não falo sobre, primeiro que dou uma explorada para ver como é a visão dela em relação à morte pra $[\mathrm{sic}]$ saber se eu posso entrar no assunto" (Colaborador 9).

Uma das colaboradoras diz que não conta aos outros como o irmão faleceu, porém pensa em um dia poder falar sobre o assunto, "se eu quisesse falar que foi suicídio eu poderia falar e assumir, mas eu não contei, talvez um dia, enfim" (Colaborador 10).

Esses são exemplos práticos do tabu e da necessidade de aumentar a consciência pública. As pessoas têm o direito de falarem como alguém morreu sem serem julgadas por isso ou precisarem pensar para quem podem contar.

Os colaboradores procuraram identificar, entre eles, quem já falou; quem ainda não falou; quem abriu mão do anonimato. Conversaram o quanto à questão do falar impacta a todos, qualquer das escolhas trazem questões difíceis de serem lidadas.

"No primeiro momento eu acho que você fica muito sensível, que você não sabe nem que tem que [sic] falar, né?" (Colaborador 4). Todos concordam que no começo é muito mais difícil falar sobre tal assunto, sendo que esta questão vai melhorando com o tempo.

\footnotetext{
É uma discussão necessária [o falar ou não falar], entretanto, deve ser conduzida com muito cuidado em qualquer momento, porque depende muito dos fatores emocionais, dos conceitos de cada um a respeito do tema, dos laços de afetividades estabelecidos e do tempo decorrido [da morte] (Colaborador $1)$.
}

Todo esse cuidado precisa ser tomado, pois falar pode machucar a própria pessoa, o ato pode ser carregado com várias dores: de falar, de lembrar e de ser julgado. São as dores de compartilhar o tema.

\footnotetext{
Por ser uma coisa que parece que as pessoas querem achar um culpado, querem achar um motivo, tem que ter uma razão, então quanto mais você fala, mais vão te cutucar, mais vão te machucar, mais vão, às vezes sem querer mesmo, mas acabam te deixando mal (Colaborador 11).
}

A reação do outro pode estar influenciada pela sua história pessoal, experiência e os valores e as crenças em relação à morte, ao luto e ao suicídio. De qualquer maneira, esse fato 
não pode ser usado como desculpa para causar dor em quem perdeu alguém pelo suicídio. Então, muitos escolhem com quem falar e relatam a perda do ente querido e a dor da perda, mas não falam o motivo. Alguns colaboradores não falam sobre essa perda com a família por não querer ter de dar conta do "drama" do outro.

\footnotetext{
Porque a minha sogra, por exemplo, começa com as lamúrias dela e eu já tenho que dar uma cortada, 'porque ele não me leva também', então começa com drama. Porque sempre foi difícil, eu queria ficar com o meu neto. Aquilo começa a me dar um desgaste, então, eu falo 'Ai, por favor [pausa] não [pausa] para com isso'. Já vou logo para frente, mas é isso (Colaborador 2).
}

Isso nos leva para o nosso próximo conceito, as dificuldades na comunicação familiar. Muitas famílias que passaram por um suicídio, não conseguem falar no assunto. "Do lado do meu pai não. Do lado do meu pai ninguém fala a palavra" (Colaborador 8).

Precisamos levar em conta as diferenças no processo de luto de cada um, uns conseguem falar e outros não gostam, não há uma regra, o que tratamos aqui não é somente a forma do luto e sim a dificuldade de lidar com o assunto e transformá-lo em tabu familiar. "Tenho um filho que nunca tocou no assunto. Falou uma vez só, mas acho que porque eu perguntei. O outro toca no assunto quando eu quero falar, mas ele mais me escuta do que fala" (Colaborador 3 ).

Os filhos de um dos colaboradores afastam-se quando o pai começa a falar no assunto, segundo ele, os filhos ficam "constrangidos" (Colaborador 7). Este pai é o que mais concede entrevistas sobre o assunto na mídia, então podemos perceber uma diferença em lidar com o luto dentro da própria família e da necessidade de cada membro respeitar a escolha do outro.

Algumas vezes, os membros mais distantes conversam entre si, mas não incluem o núcleo familiar mais próximo da pessoa que morreu na conversa. "Não, essa é a outra que contou que o filhinho, mas contou para o filho depois de algum tempo, no começo ela não tocou no assunto, ela nunca conversou comigo sobre o assunto" (Colaborador 4). Essa atitude gera nos sobreviventes uma sensação de isolamento e de raiva.

A família de um dos colaboradores abriu um instituto após o suicídio da filha, então percebem que "na família, fora a família mais íntima né? quer dizer eu, a [nome da esposa] e a [nome da outra filha] não se fala [sic], fala muito do instituto, muitas coisas, mas assim fala mais de modo geral" (Colaborador 1).

Alguns colaboradores, por saberem que a família não quer conversar, não tocam mais no assunto. Então, encontram nos grupos de apoio locais nos quais podem falar abertamente sobre sua perda e seu sofrimento. "Na família nunca e em poucas tentativas não fui bem 
recebido. Muito raramente com uns poucos amigos muito próximos. Geralmente apenas dentro de grupos de sobreviventes ou ligando para o CVV" (Colaborador 9).

Falar abertamente sobre o suicídio na sociedade ainda necessita preparação. Colocar para fora o que aconteceu é como um grito de liberdade, mas que tem o seu preço.

\footnotetext{
Já foi muito difícil. Nos primeiros anos evitava falar a palavra suicídio [ou termos associados como se matou, tirou a própria vida]. Atualmente é um assunto que flui tranquilamente, sem preconceito. Todas às vezes que tenho a oportunidade, falo sobre as formas de prevenção, sobre como podem ser percebidos sinais, sobre como os preconceitos devem ser descontruídos (Colaborador 1).
}

Então aos poucos alguns conseguem falar abertamente com a família, após prepararemse e perceberem com quem podem ou não conversar sobre essa morte. Às vezes somente um dos lados da família consegue tocar no assunto.

Em algumas famílias fala-se sobre a morte em geral e até sobre o luto, mas não se fala sobre quem morreu. Algumas famílias só começam a falar entre si sobre o suicídio quando percebem que alguém da família íntima está seguindo adiante e já fala sobre o assunto com outros. É como se ela precisasse emitir um sinal de que está pronta para falar.

Talvez seja difícil para a família saber o que falar, quando e com quem, talvez eles mesmos não saibam como lidar com aqueles que perderam alguém e por medo de machucar o outro, distanciam-se do assunto.

Para uma das colaboradoras, a existência de "doenças críticas" na família e de outros suicídios facilitaram para que o assunto fosse tratado com mais abertura na família.

\footnotetext{
E sempre se falou sobre isso [suicídio da tia], sobre outras questões delicadas, assim, a gente sempre falou. Eu acho que em casa a gente sempre falou, mesmo antes. Sempre foi uma discussão, acho que do ponto de vista intelectual, sempre se conversou um pouco sobre isso. Até por questões de, por exemplo, de ter algumas doenças na família que são muito críticas, a gente sempre conversou: 'E se a gente for diagnosticada com isso, o que você faria?' A gente fazia esse exercício, um pouco porque é complicado também. Assim, como isso sempre foi um assunto dentro da minha casa, mas eu sei que se falasse fora arregalava-se o olho (Colaborador 8).
}

Em outros casos, a abertura do enlutado em falar na sociedade gerou interesse de outras pessoas da família em conversarem sobre o assunto e alguns outros já conseguem ajudar familiares que necessitam de ajuda e de conselhos. "Até por questão de ser uma situação presente para outras pessoas, eu tenho um primo que está passando por uma depressão profunda e minha irmã está tentando ajudar a minha tia" (Colaborador 8). 
A partir dessas experiências, começa a estabelecer uma rede de abertura, cuidado e diálogo.

\begin{abstract}
Mas assim eu ainda sinto, assim, receio de amigos quando falo no assunto, mas por outro lado, tem já alguns amigos que eles procuram, já é bastante casos de amigos deles, para gente ver se pode dar uma ajuda e tal, quer dizer, se ele vem é porque, é porque ele tem uma certa vontade que é de gente conversar (Colaborador 1).
\end{abstract}

Percebemos uma grande variedade de formas que as famílias lidam e comunicam-se a respeito dessa perda. No entanto, não se trata de uma comunicação fácil, como se bastasse descobrir com quem falar e isso resolvesse o assunto. Há o tempo necessário para que essa fala seja possível, pois existem muitas cicatrizes envolvidas.

\footnotetext{
É [pausa] depois com os amigos não, mas depois do que aconteceu com alguns amigos, eu converso sobre isso, falava às vezes alguma coisa, mas pouca coisa. Depois do acontecido eu acho que eu tive...eu tenho a sorte talvez de ter muitas pessoas que conseguem conversar isso bem, pessoas que se revelaram bons amigos, depois disso e hoje a gente fala, ainda fala, mas a gente não fala do meu irmão, mas a gente fala do assunto. Meu irmão ainda [pausa] acho que a cicatriz [pausa] a gente ainda não conversa sobre ele mas a gente fala sobre o assunto (Colaborador 8).
}

Alguns colaboradores percebem desconforto e estranhamento de outros ao falarem do tema, levando a mudança de assunto.

\footnotetext{
Nas pessoas mais próximas, não consigo ainda hoje entrar no tema do suicídio sem notar um impacto de estranhamento e desconforto nas pessoas. Falar no tema é encarado como mau agouro ou então percebo o preconceito na causa [do suicídio] e até um afastamento e perda de alguns vínculos de amizade. Alguns mais descontraídos brincam sobre ser um assunto negro e apesar de ser de forma mais educada, desviam-se do tema (Colaborador 9).
}

Quando se inicia esta fala em público com amigos e família, podemos observar diversas reações, tanto positivas quanto negativas. Entre as reações negativas encontradas percebemos que o julgamento é a mais comum. “'Ah, mas então ninguém percebeu', se tivesse percebido, não teria acontecido, né? se tivesse percebido a gente teria feito alguma coisa para evitar. Então, assim, é às vezes a gente não fala por conta disso também entendeu?" (Colaborador 11).

Outras reações citadas foram afastamento, agressividade verbal, ofensas, desconforto. A desinformação colabora para que ocorram essas reações, pois as pessoas, muitas vezes, não sabem o que fazer ou dizer para os enlutados. A reação negativa das pessoas causa impacto naqueles que começam a falar. Percebemos que as reações deles a essas situações foram bem singulares, cada um lidou de uma maneira. 
As reações positivas recebidas foram encontrar outras pessoas que são "militantes" na área, que ficaram sensibilizadas com o que aconteceu, conseguindo gerar interesse e procura por ajuda.

Uma das reações que impactou uma colaboradora foi a indiferença, não acreditava que as pessoas poderiam reagir dessa maneira. Durante uma viagem ouviu uma moça ao seu lado relatar o suicídio da irmã dela para todos, com muita naturalidade. Ficou esperando uma reação das pessoas ao redor, mas não houve, o que a surpreendeu.

\footnotetext{
Mas quando eu vi uma menina falando, as pessoas não fizeram nada com aquela informação, eu fiquei, falei [pausa] será que depois alguém vai vir falar pra mim: 'nossa, P10 viu a irmã dela se suicidou', ninguém fez nada com aquela informação (Colaborador 10).
}

Para uma das colaboradoras, as pessoas não falam porque sabem que pode ser doloroso para quem está ouvindo e lidando com o luto, ela vê nisso uma atitude de cuidado com sua dor.

\begin{abstract}
Elas sabem a gravidade do assunto [pausa] tem dificuldade em falar, que eles sabem que aquilo é tão doloroso para quem tá passando e ela não imagina que aquilo possa chegar até ela de tão doloroso que é, então, as pessoas evitam de [sic] falar, porque não tem o que falar e sabem o quanto é doloroso, eu já entendo diferente aqui de todo mundo, eu acho que não falam porque, por pena, e porque sabem o quanto aquilo é doloroso (Colaborador 3 ).
\end{abstract}

O falar pode ter diversos significados, também se transformar numa bandeira, numa forma de lidar com o luto e ajudar outras pessoas. O que percebemos no grupo a esse respeito foi uma visão e até uma pequena pressão para que as pessoas que viveram o suicídio precisassem falar sobre o assunto abertamente, pois são elas que devem abordar o assunto. Esse fato tem relação com a crença de um dos colaboradores de que todos precisam falar, porém deve-se respeitar a escolha de cada um, "mas eu converso mesmo com eles. Eu me imponho começar a falar, mesmo que dói [sic], eu me imponho, por causa dessa bandeira que eu abracei” (Colaborador 7).

Alguns se tornaram voluntários, outros abriram ONGs.

Atualmente falo com o intuito de informar, mas também procuro mostrar que não tem porque ter preconceito ou vergonha. Sempre esclareço que a causa foi morte por suicídio. Muitas vezes essa fala choca $[\mathrm{sic}]$ as pessoas e o assunto se encerra, até como certo pedido de desculpas de quem escuta. Entretanto, se a pessoa ou o grupo der uma abertura para continuidade do assunto, continuamos a conversa, sem constrangimentos. Falar é preciso. Falar é necessário (Colaborador 1). 


\subsubsection{Experiência}

A categoria EXPERIÊNCIA foi dividida entre as subcategorias o sentir e o viver, a primeira refere-se aos sentimentos mais comuns que encontramos no grupo a respeito do suicídio e a segunda tem relação com a experiência de perder alguém para o suicídio e seus impactos no entendimento, na reação e na vida das pessoas.

Tabela 9: Experiência

\begin{tabular}{|c|c|c|c|}
\hline \multicolumn{2}{|c|}{ CONCEITOS } & SUBCATEGORIA & CATEGORIA \\
\hline \multicolumn{2}{|c|}{ Sentimentos } & O sentir & \multirow{2}{*}{ Experiência } \\
\hline Quem viveu & Quem não viveu & $\mathrm{O}$ viver & \\
\hline
\end{tabular}

Fonte: produção do próprio autor (2018)

$\mathrm{Na}$ subcategoria o sentir, percebemos que os sentimentos mais presentes foram indignação pela maneira que foram tratados por outros; desamparo por achar que ninguém terá palavras para ajudar nessa dor, que não existe o que console a dor.

Um conceito encontrado foi a dor, de quem ficou e de quem partiu. Para quem fica, o suicídio foi denominado como uma tragédia, um processo doloroso, sem consolo, que pertence ao nível mais "hard da humanidade" (Colaboradora 10). Falam de uma dor que não tem tamanho, que não tem nome, de tão grande que é.

Os colaboradores demonstraram empatia e entendimento sobre a intensidade da dor que poderia estar presente nos que partiram, alguns conseguem ver o suicídio como um ato de dor (ato-dor), acham importante que as pessoas saibam dessa relação de suicídio-dor.

\footnotetext{
Então, ele deixou muito claro, então, que a dor era tamanha que ele não sabia o que fazer com ela. Essa grande [pausa] eu vejo pelo que eu passei né? de que eles não sentem entendidos, não se sentem pertencentes, quer dizer, 'poxa, eu estou aqui, a minha dor é tão grande, ninguém faz nada por mim, então eu vou embora' talvez (Colaborador 4).
}

No entanto, muito foi feito no caso acima, não podemos esquecer que a depressão diminui a capacidade da pessoa em perceber a ajuda que tem disponível e ter esperança, então mesmo que muitos tenham oferecido ajuda, ela pode não ter sido percebida ou sentida.

A dor existencial presente no ato suicida é tão grande que pode ultrapassar as crenças religiosas, a força, o sentimento e o amor que toda a família tinha por eles, ou seja, os fatores protetores do comportamento suicida. 
A dor é ele, ele porque senão todos aqui os nossos filhos amavam a gente. O meu deixou cartas, o que a maioria não deixou, o meu deixou muitas cartas, que a gente não tinha culpa, que ele amava, que o P5 era exemplo de pai, que ele queria ser igual a ele, então assim, ele deixou. Então, ele deixou muito claro [pausa] que a dor era tamanha, que ele não sabia o que fazer com ela. E meu filho tinha um fundamento religioso também, não ia falar que ele era um adolescente que nem pensava em nada. Não, ele tinha um medo, ele tinha [pausa] e falava 'vou pagar por isso, mas eu não estou conseguindo lidar com a minha tristeza', então, eu acho que no momento que eles estão passando a dor [pausa] não seria (Colaborador 4).

Os colaboradores entendem que a dor maior era a de quem se matou, uma dor que ficou insuportável, mas que depois do suicídio, acabou sendo transferida para eles. Houve no grupo focal uma comparação das dores, para alguns a dor maior é de quem se matou e para outros de quem ficou. Sabe-se, porém, que é impossível comparar dores, a dor maior é de quem a sente e essa que deve ser considerada quando se pensa em cuidados.

A subcategoria o viver foi separada: pelos que passaram pela experiência de perder pessoas por suicídio (quem viveu) e por quem não passou por ela (quem não viveu); pelas características singulares de cada grupo e por eles apresentarem importantes diferenças entre si no modo de ver e de lidar com o suicídio. Quem não viveu um suicídio próximo, tem difículdade de entender o suicídio, pois muitas vezes sentem que o evento é tão distante deles, que é como se não existisse. Não tomam contato com a questão, por isso é percebido como um assunto exclusivo de quem viveu a situação e não interessa para eles. "Acho que ainda as pessoas ... têm essa coisa de 'não vai acontecer comigo porque eu estou bem, minha vida é ótima' e então mais a vida pode ser ótima e pode acontecer, é isso!" (Colaborador 8).

Uma das razões para não se importar com o suicídio pode ser a crença de que não vai acontecer ou que coisas ruins só acontecem com os outros, "porque acham que é assim, uma coisa nada a ver que nem existe no mundo" (Colaborador 10).

Esta visão pode ter sérias implicações para a prevenção do suicídio, pois se não há interesse e existe um distanciamento, não há uma atenção nas campanhas preventivas, além de um descrédito em que pessoas possam suicidar-se. Assim, como todos os eventos negativos da vida como, por exemplo, o câncer, as pessoas acreditam que não possa acontecer com elas, mas acontece.

Vai falar o que [pausa] passa batido, porque todo mundo acha que a família dele é 'Doriana' é saudável e não vai passar por esse problema. Então, eles nem vão ler aquilo, tá? Quem não passou pelo problema, não lê (Colaborador $5)$. 
Algumas pessoas fazem piadas sobre o assunto, outras percebem o suicídio como espetáculo, que as entretém. Essas pessoas não têm conexão com o tema, o suicídio não os atinge.

\footnotetext{
E dá risada, acha engraçado, dão exemplo: 'porque tem gente que liga que fala que vai se suicidar' e tem gente que fala: 'pff, até parece', ou quando é falado talvez quem não viveu até acha assim 'ah, absurdo' ou dá risada (Colaborador 10).
}

Assim, percebemos o distanciamento das pessoas que não viveram o suicídio, ficando então distante e irreal. "Que eu acho que esse é o maior problema, porque senão, vamos supor, tem uma palestra, tem um artigo, quem nunca passou acha que não tem nada a ver com ela. Nem vai ler, nem vai se interessar" (Colaborador 9).

Alguns sobreviventes, ao lidarem com a dor absurda que se mantém após o suicídio, conseguem compreender as reações dos que não passaram pela sua experiência e desejam que eles nunca passem por isso. “Quem não passou não entende e nunca vai entender, graças a Deus por isso também, porque eu acho que é uma dor que ... só quem viveu mesmo que sabe o que significa, né?" (Colaborador 10).

Dessa maneira, podemos perceber as diferenças no entendimento, sentimento, respeito entre quem viveu e quem não viveu um suicídio próximo.

O conceito quem viveu inclui os códigos antes do suicídio, que aponta como as pessoas enlutadas eram parecidas com as do conceito quem não viveu, os colaboradores entendem que só mudaram a visão que tinham do suicídio após passarem por tal evento. Também, como a maioria das pessoas, emitiam julgamentos sobre a depressão, tinham a crença de que se não tivesse acontecido com elas, também não saberiam o que era o suicídio, não acreditavam na sua gravidade, achavam que nunca aconteceria com elas ou com alguém da família, não prestavam atenção em reportagens. Resumindo as palavras do grupo focal, o suicídio não era um evento que poderia transformar-se em realidade e mudar suas vidas para sempre, não entendiam o significado e o impacto que poderia ocasionar.

A não julgar mais. Quer dizer, isso para mim foi uma lição de vida, o que aconteceu comigo. De não julgar. Porque eu também achava que depressão era [pausa] a pessoa, não quer, sabe, vai [pausa] tem que acordar às cinco horas da manhã como eu acordava, então você não tinha tempo para estar deprimido (Colaborador 4). 
Os colaboradores acreditam que não há como haver uma preparação para o que aconteceu, ninguém, nunca, imagina ou espera a ocorrência de um suicídio. Assaltos e doenças podem acontecer, mas suicídio, nunca!

Relatam que quando viam reportagens sobre o suicídio as viam como qualquer outra notícia, que não chamava a atenção, à semelhança de reportagens sobre roubo, assalto e mortes. Para eles, essas reportagens não os atingiam, porque não aconteceu com eles, não tinham uma ligação pessoal ou interesse específico no assunto, gerando um distanciamento da possibilidade de algum dia o suicídio ocorrer na família deles. "A gente acaba sentindo que talvez se não tivesse acontecido com a gente, a gente nem saberia sobre isso" (Colaborador 4).

Passar pelo suicídio alterou de forma significativa como todos os colaboradores relacionam-se com o assunto e como mudou o dia a dia de cada um.

\footnotetext{
Sim, significativa. Antes eu não julgava, mas também não comentava. Entretanto, sempre que sabia que alguém tinha morrido por suicídio tinha uma angústia em imaginar como esta pessoa se sentia desamparada, desesperada ou vazia de si e do mundo naquele momento. Este sentimento eu ainda carrego. Atualmente, eu comento sobre o que já li e ouvi sobre o suicídio e procuro desmistificar o ato, minimizar os atos de tabus e preconceitos. Atualmente procuro conscientizar sobre o assunto (Colaborador 1).
}

Atualmente eles falam com maior apropriação sobre o que viveram e gostam de opinar no que veem e ouvem por terem passado por essa experiência, o que fez que analisassem de forma diferente as reportagens, pois agora sentem-se atingidos por elas, a partir do momento que seu olhar sobre o tema fica diferente.

Os colaboradores percebem que se tornaram mais cuidadosos com os outros, que aprenderam a não julgar as dores, as escolhas e as vidas das outras pessoas. "Eu aprendi depois a não julgar qual é a dor, qual o tamanho daquela dor, daquele problema que eu acho que não é nada, que daria para ser resolvido" (Colaborador 4).

Eles entenderam a gravidade do fenômeno do suicídio a partir da triste experiência que tiveram. Então, entraram no processo de luto por suicídio, que é rodeado de algumas características únicas como, por exemplo, lidar com duas dores, a dor da perda e o preconceito da sociedade.

Um dos colaboradores fala que ele luta em luto, fez da sua perda uma bandeira para ajudar outras pessoas e não se sente questionado ou julgado por isso, sente-se agradecido por, ao falar de sua perda, influenciar outras pessoas a não cometerem o suicídio. Ele acha que a sociedade assimila melhor quem desempenha esse papel. 
Alguns dos impactos relatados a respeito do processo de luto por suicídio foram a desestruturação individual e familiar; uma dificuldade em divertir-se, relaxar, dançar e lembrar-se de assuntos aleatórios ou de objetos.

Quando o luto é de um profissional que cuidava de um paciente que se matou, o que mais chama a atenção é a falta de acolhimento, a sensação de responsabilidade e de culpa que a empresa, sociedade e o próprio profissional atribuem-se.

Ao serem questionados sobre o que gostariam, os colaboradores relatam que gostariam de ter tido mais informação sobre prevenção do suicídio antes do fato de ter acontecido, trazendo a ideia de que se soubessem e percebessem os sinais de alerta do comportamento suicida, poderiam ter feito algo e mudado o desfecho. Esse fato é muito comum entre enlutados, pensar que poderiam ter evitado aquele suicídio.

Outra necessidade relatada pelos colaboradores é de ter um espaço para falar sobre o que aconteceu, sobre como estavam sentindo-se, sem serem julgadas, podendo conversar sobre como lidar com a culpa.

Para a família sobrevivente este lugar de fala, em uma sociedade que ainda é muito preconceituosa com a pessoa que morre por suicídio e com a família, é muito importante. Para a pessoa que faleceu, um lugar de fala por ela, poder falar sobre sua vida, suas memórias, suas histórias, seus projetos de vida, sobre seus sonhos (Colaborador 1).

Os colaboradores gostariam de ter tido educação emocional na infância para verem a perda como fenômeno natural da vida e mais espaços de encontro, compartilhamento e acolhimento.

\footnotetext{
Gostaria de que outros espaços como o do Vita Alere estivessem disponíveis para mais pessoas. Para a pessoa que faleceu, gostaria de que ela tivesse encontrado ao seu redor mais oportunidades de compartilhar sua dor, suas tristezas, de se abrir e ser bem recebido. Acredito que isso poderia ter evitado o suicídio (Colaborador 9).
}

Embora muitos colaboradores tragam lembranças de terem passado por situações conturbadas com a polícia, durante o processo policial e com alguns médicos, antes e depois do suicídio, eles tiveram experiências bem diferentes e marcantes, por essa razão houve mudança da visão deles em relação a esses profissionais e os impactou positivamente, levando-os à desconstrução da imagem negativa que tinham da polícia, por exemplo.

Eu estava em frangalhos, eu não conseguia nem se manter em pé e a delegada conversou muito comigo, me acalmou e eu perguntei para ela se ela 
poderia falar essas mesmas palavras para o meu marido. Ela saiu da delegacia, foi até ele e falou tudo aquilo com uma calma, uma mansidão (Colaborador 2).

Para mim foi também a mesma coisa. Foi uma delegada, era bem mocinha ela, uns trinta e poucos anos, me tratou assim, uma maravilha, nossa, foi uma das pessoas que mais me consolou. Foi assim maravilhoso (Colaborador 3).

Pensamos na importância de consolar, de acolher, que tais atitudes fazem diferença no momento do choque inicial e posteriormente no processo de luto dos colaboradores.

Então, o que eu ouvi de depoimentos é que eu também já passei em situações diferentes com uma notícia ou uma comunicação entre o profissional de saúde, não tive com a polícia, mas isso é uma dor a mais que se soma àquela que o enlutado já está passando (Colaborador 9).

Após perderem pessoas para o suicídio, os colaboradores relatam terem tido muitos aprendizados, como não julgar a dor do outro, não precisar provar nada para ninguém e desenvolver a consciência de que ao passar por essa perda e por outras experiências traumáticas modelam a sua forma de ser, mudando-as. Essa nova forma de ser torna-se parte da sua identidade, não conseguem separar o que viveram da sua vida atual. "Então, se eu ando de uma forma ou se eu me visto ou se eu falo, é por tudo que eu passei, pelo acidente que eu sofri, pelo estupro, pelo suicídio ... por tudo! Entendeu?” (Colaborador 11).

Quem viveu o suicídio desenvolve empatia pela dor do outro, sabe de muitas coisas sobre suicídio como, por exemplo, o fato de que Santos Dumont suicidou-se. Eles tornaram-se mais abertos e interessados no assunto.

As crenças religiosas dos colaboradores foram debatidas durante o grupo focal, e fazem parte das EXPERIÊNCIAS/o viver/quem viveu, por entendermos que elas são parte do processo de criação do tabu na sociedade e do acolhimento aos enlutados, como uma fonte de mudança e de conscientização pública.

Não está no escopo dessa pesquisa discutir o que propõe cada religião e sim pensar na religião como mais um veículo de aumento de consciência, de acolhimento e de cuidado. Após passarem por algumas experiências boas e ruins, os colaboradores aprenderam a ter cuidado sobre os locais frequentam para não se machucarem com religiões que emitem julgamentos sobre a pessoa que se matou e sobre a família. Percebemos que para a maioria deles a religiosidade tem um papel importante nesse processo do luto e do entendimento do comportamento suicida. Alguns tiveram experiências ruins, como procurar um padre em momentos de desespero, de angústia e não serem acolhidos e atendidos. Outros foram convidados a frequentarem centros espíritas para que pudessem ver se a pessoa estava no 
Umbral sofrendo, imagem que causa muita aflição em todos do grupo. "Ela chegou para um senhor e falou: 'Como o senhor acha que está meu filho?' Ele falou: 'Como você acha? Está no vale dos suicidas ${ }^{17}$. Vai ficar lá até o tempo que ele deveria estar aqui'. Ela entrou em desespero" (Colaborador 4).

Outros colaboradores tiveram experiências religiosas positivas marcantes, como receber cartas psicografadas daquele que faleceu, trazendo paz e conforto para a família.

\footnotetext{
Uma colega nossa chegou lá para a [nome da esposa] com um panfleto sobre uma palestra, do vale dos suicidas e disse, Dona [nome da esposa, a senhora não pode perder essa palestra, porque a [nome da filha] está lá, ela pegou o carro e ia, aí no meio do caminho ela disse: 'não vou, minha filha não está lá' aí voltou para casa. Quando foi a própria carta que ela recebeu, ela começa: 'Mãe, eu estou falando de um vale, não do vale suicidas' [risos] (Colaborador 1).
}

No geral, observamos que ter uma crença religiosa favorece o processo do luto, se for uma crença acolhedora. A liberdade de opinião entre as religiões foi um tema de grande discussão no grupo focal, da importância da liberdade e do respeito às crenças de cada um. Da possibilidade de acreditar em algumas partes daquela religião e em outras não, como também de incluir o que faz bem de várias crenças e não precisar pertencer a uma só.

$\mathrm{O}$ fato de alguns terem uma crença forte, mesmo assim terem consumado o suicídio, mostra para os que ficaram o tamanho daquela dor, que foi maior do que qualquer crença religiosa que a pessoa tinha. Cabe ressaltar que outros aceitam em paz o que a religião propõe.

\footnotetext{
A gente não fica com raiva. Eu, pelo menos, eu aceito, eu não dei a minha opinião, esse caso eu aceito. Eu entendo que isso é lógico, até porque o que eu falei aqui, a sua vida vai seguir adiante, a sua outra existência, continuarão sendo normais, como qualquer outra. Mas essa é uma coisa que não tem perdão. Não dá para negociar na existência seguinte, para ela não morrer na hora que ela mais quiser viver. Isso aí tem que acontecer para que ela fique tão impactada a ponto de nunca mais fazer isso na sequência das outras existências. Quer dizer, pela lógica que ela contém, ela não me agrediu. Eu continuo aceitando (Colaborador 7).
}

Notamos pela fala dos colaboradores uma mudança na forma de algumas religiões falarem sobre o suicídio, principalmente na doutrina espírita. Em muitos centros espíritas, não se fala mais em Vale dos suicidas e em punição em próximas reencarnações para aqueles que se mataram.

\footnotetext{
${ }^{17}$ Vale dos suicidas é outro nome dado ao Umbral.
} 
Finalizamos o tema, compreendendo melhor quais são as crenças e suas influências para a sociedade e para os indivíduos em relação ao comportamento suicida e a forma como os sobreviventes enlutados são tratados.

\subsection{CONSCIENTIZAÇÃO}

Cabe ressaltar que verificamos a ordem das categorias, subcategorias e conceitos a fim de reordená-los de uma forma que ficasse mais claro para o leitor seguir o raciocínio da análise.

A CONSCIENTIZACAO é a ligação necessária entre a COMPREENSÃO e a AÇÃO. É fundamental haver um aumento de consciência para que a compreensão do suicídio e a ação em relação a ele possam ser revisitadas e repensadas.

Diagrama 6: Conscientização

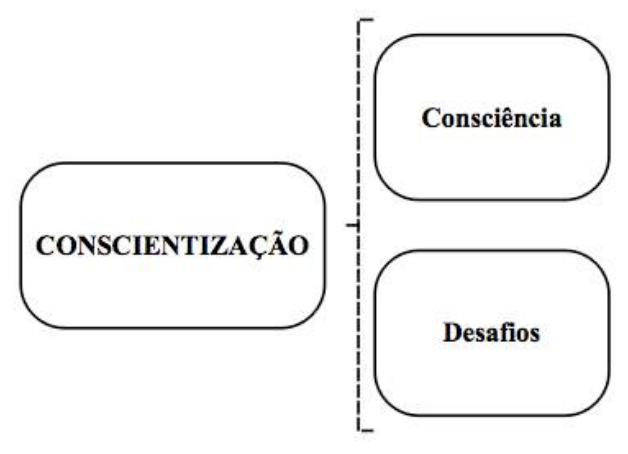

Fonte: produção do próprio autor (2018)

O tema CONSCIENTIZAÇÃO traz as categorias CONSCIÊNCIA e DESAFIOS, em que ampliamos as características e influências da conscientização, debatendo a sua importância em conjunto com os seus desafios, sejam eles sociais ou individuais.

Tabela 10: Conscientização

\begin{tabular}{c|l|l}
\hline TEMA & CATEGORIA & \multicolumn{1}{c}{ SUBCATEGORIA } \\
\hline \multirow{4}{*}{ Consciência } & Aumento da consciência \\
\cline { 3 - 3 } & & O absurdo do suicídio \\
\cline { 3 - 3 } CONSCIENTIZAÇÃO & Epidemiologia \\
\cline { 3 - 3 } & \multirow{4}{*}{ Desafios } & Complexidade \\
\cline { 3 - 3 } & & Interesses diversos \\
\cline { 3 - 3 } & & Impeditivos \\
\cline { 3 - 3 } & & Subnotificação \\
& & Burocracia \\
\hline
\end{tabular}

Fonte: produção do próprio autor (2018) 


\subsubsection{Consciência}

A categoria CONSCIÊNCIA é composta pelas subcategorias e conceitos abaixo:

Tabela 11: Consciência

\begin{tabular}{|c|c|c|c|}
\hline \multicolumn{2}{|c|}{ CONCEITOS } & SUBCATEGORIA & CATEGORIA \\
\hline $\begin{array}{l}\text { Condição } \\
\text { Prevenção }\end{array}$ & Consequência & $\begin{array}{l}\mathrm{O} \text { aumento da } \\
\text { consciência }\end{array}$ & \\
\hline $\begin{array}{l}\text { Prevenção x previsão } \\
\text { O não saber } \\
\text { Coisas ruins podem } \\
\text { acontecer na vida }\end{array}$ & $\begin{array}{c}\text { Limitações } \\
\text { É muita coisa para } \\
\text { fazer } \\
\text { Proximidade de } \\
\text { suicídios }\end{array}$ & $\begin{array}{l}\text { O absurdo do } \\
\text { suicídio }\end{array}$ & \\
\hline $\begin{array}{l}\text { Aumento pelo número } \\
\text { de casos } \\
\text { Epidemiologia dos } \\
\text { sobreviventes } \\
\text { Descobrindo o suicídio } \\
\text { como comum }\end{array}$ & $\begin{array}{c}\text { Causas não } \\
\text { divulgadas é } \\
\text { suicídio? } \\
\text { Importância da } \\
\text { percepção da } \\
\text { quantidade }\end{array}$ & Epidemiologia & Consciência \\
\hline $\begin{array}{c}\text { Complexidade de } \\
\text { sentimentos } \\
\text { Sofrimento mental não é } \\
\text { validado } \\
\text { Ditadura da alegria } \\
\text { Exclusão da Tristeza }\end{array}$ & $\begin{array}{l}\text { Assunto proibido } \\
\text { Onde tudo começa } \\
\text { A banalização da } \\
\text { depressão } \\
\text { Por onde começar }\end{array}$ & Complexidade & \\
\hline
\end{tabular}

Fonte: produção do próprio autor (2018)

Como podemos observar, a subcategoria aumento da consciência é composta por condição, prevenção e consequência.

Condição, pois para os colaboradores somos seres influenciáveis e por isso não conseguimos separar a consciência individual da pública, portanto, a consciência pública automaticamente torna-se condição para alcançar a consciência individual e consequentemente influenciar a prevenção do suicídio. "É que a consciência individual quase não existe, eu acho, na minha opinião. Acho que os seres, a gente não tem uma consciência, assim ... a gente nem se conhece para poder assim, não se deixar influenciar" (Colaborador 10).

Outra visão trazida pelo grupo focal foi que seguir tendências e moda é uma maneira de ser aceito pelos pares.

Quer dizer, a gente acha que é indivíduo, mas uma boa parte de nós é acomodação com outras coisas que outras pessoas também aceitam. Que é a tendência, a moda [pausa] então eu aceito que eu tenho que usar calça, camisa, 
enfim, essa coisa, então de repente, isso não é uma decisão minha, mas é a forma de como eu vou ser aceito (Colaborador 7).

A falta de conscientização é vista como uma cegueira que passa do individual para a cultura, afetando organizações e instituições, ou seja, há um efeito dominó em que há um desencadeamento na forma como estas tratam os indivíduos, voltando para organização, que reflete na cultura organizacional, por fim, retorna ao tabu individual.

\footnotetext{
Uma das coisas que eu percebo, assim, toda a cegueira que a gente tem individual vai para cultura. Isso também vai para cultura das organizações. Então, o sistema de saúde, hospital e plano de saúde ele vai de alguma maneira refletir a dificuldade que cada um individualmente tem com o tema. O tabu que tem, né? É um reflexo (Colaborador 9).
}

Assim, observamos que existe um continuum da conscientização: a consciência pública influencia a individual que reflete na cultural e assim por diante.

"A possibilidade de discutir o assunto abre espaço para que as pessoas possam se [sic] refletir sobre o tema. Possam mudar de postura. Possam se perceber e perceber o outro" (Colaborador 1). Os colaboradores relacionam o aumento de consciência com discutir mais o assunto, sendo difícil separar esse aumentar a consciência sem o agir, sem o falar. Não há mudança na passividade.

Um dos colaboradores relata que pensa que a falta de consciência pode ter influenciado o suicídio da pessoa que perdeu, a partir da exclusão social e do bullying, pois naquela época não se discutia publicamente estes assuntos, por isso acredita que se falássemos mais o suicídio poderia ter sido evitado.

O suicídio pode ser prevenido quando se compreender que falar abertamente passe a ser visto como prevenção, pois ao aumentarmos o conhecimento das pessoas a respeito do suicídio, pode-se diminuir o preconceito e o julgamento em relação àqueles que morrem por tal ato. "Mas eu acho que ... poder falar abertamente sobre isso [o suicídio], é mais importante para pessoa que pensa no assunto, do que propriamente para as pessoas que estão no entorno dela ..." (Colaborador 8). O falar mais pode ajudar a ambos os lados, quem pensa e quem convive.

Algumas sugestões dadas pelos colaboradores em relação à forma de promover prevenção e aumento de consciência pública serão apresentadas adiante:

A conscientização deve ser feita de forma que contemple toda a população. $\mathrm{O}$ que se percebe atualmente é que algumas pessoas já buscam informação, entretanto, há que se preparar a sociedade para a discussão sobre o assunto através de estratégias que mostrem a importância da divulgação das campanhas de prevenção e que o suicídio é um problema de saúde pública, é como tal, a 
população precisa se envolver de forma consciente, como tem se envolvido em outras campanhas de promoção de saúde e prevenção de doenças (Colaborador 1).

Para os colaboradores algumas dessas formas de prevenção podem ocorrer por meio da realização de campanhas periódicas, não só durante o Setembro Amarelo ${ }^{18}$, mas produzindo campanhas durante o ano todo. Outra proposta foi aumentar a conscientização da depressão e outros problemas psiquiátricos para que compreendêssemos melhor o que acontece com as pessoas à nossa volta, oferecendo ajuda.

Foi sugerido por alguns membros do grupo focal que não usássemos mais o termo suicídio, somente depressão, pois enxergam o suicídio como produto da depressão. Ainda, percebem que na atualidade a depressão é classificada como doença, o que pode facilitar o entendimento e explicação dos motivos de um suicídio.

Eu acho que a depressão como doença, que hoje é doença, está lá no CID e tudo mais, eu acho que, nunca escutei de ninguém que se suicidou sem depressão. Então se eu mudasse o termo suicídio para depressão, você poderia conversar sobre o assunto, resolver o problema e sem falar em suicídio. Porque a maioria do pessoal, eu nunca escutei falar de ninguém que estava bem alegre e contente e se matou (Colaborador 5).

Então eu concordo com você com esse negócio de depressão ... eu acho que se mudasse o termo de suicídio para prevenção a depressão já melhoraria. Seria bem mais fácil de lidar com o tema (Colaborador 7).

Percebemos que, embora o grupo ressalte a importância de falar abertamente sobre o tema, eles entendem que o uso da palavra suicídio pode ser impactante, por isso mudar de vocábulo, ou seja, em vez de suicídio falar depressão, poderia facilitar a comunicação em torno do assunto. Essa discussão foi gerada no grupo focal e mesmo que alguns colaboradores apoiem essa ideia, outros não concordam com ela, pois acham fundamental poder falar e usar a palavra suicídio livremente.

O projeto Semicolon ${ }^{19}$, projeto ponto e vírgula (tradução nossa), foi citado como uma forma de aumentar a consciência, podemos pensar que esse projeto, embora ajude a comunicação, demonstra a força daquele que sofre com um transtorno mental ou é sobrevivente do suicídio,

por exemplo, aquela moça jovem que o pai se suicidou lá na Europa e por causa disso ela criou aquele projeto, semicolon Project ou "Projeto ponto e vírgula", eu vou

\footnotetext{
${ }^{18}$ Mês da campanha e do Dia Internacional da Prevenção do Suicídio

${ }^{19}$ Projeto que consiste em tatuar um ponto e vírgula como um símbolo que representa uma superação pessoal ou que seja um lembrete de que a pessoa não precisa dar o ponto final em sua vida.
} 
tatuar o ponto e vírgula, até nessa matéria da [nome de revista] eu falei 'eu vou tatuar, eu vou incorporar isso' (Colaborador 7).

Podemos perceber que tal projeto tocou as pessoas, fez sentido para elas, possibilitando que muitas aderissem a ele e a partir dele transformassem uma forma comum numa marca de superação de um sofrimento ou conquista pessoal.

A consequência da falta de consciência para os colaboradores, além do tabu, que já foi discutido anteriormente, foi perder amizades, sentir-se machucado e achar que seria muito mais fácil para eles se a sociedade aceitasse melhor essa forma de morte, diminuindo o preconceito, julgamento e aumentando o acolhimento e entendimento.

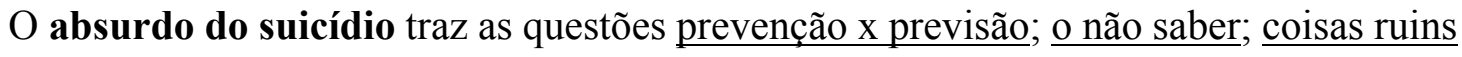
podem acontecer na vida; limitações; é é muita coisa para fazer e proximidade de suicídios.

Absurdo por trazer a sensação de impotência, de que algo fugiu do esperado e do controle, de algo que não tem explicação simples e que deixa mais perguntas que respostas.

$\mathrm{O}$ conceito prevenção x previsão trata da grande confusão existente entre prevenir o suicídio e conseguir prever quem, quando e como irá suicidar-se. Para o grupo focal, é difícil perceber ideação suicida, a pessoa precisa falar, pois muitos suicídios ocorrem sem sinais aparentes e em outros casos, mesmo a pessoa falando e em tratamento, o suicídio pode ocorrer. Em um dos casos, nem o psiquiatra notou a ideação e deu alta para a pessoa, que cometeu suicídio pouco tempo depois. Portanto, se a pessoa não falar ou não der sinais claros, nem especialistas nem leigos conseguem prever essa tragédia.

A correria do dia a dia também é um fator que dificulta a percepção dos sinais do suicídio e alguns fatores que seriam de proteção, como a religião e ter planos para o futuro próximo, na hora da crise não foram suficientes para impedir o suicídio.

O irmão de uma colaboradora tentou apagar os rastros e usou a Deep Web para pesquisar sobre como se matar, sobre depressão e bipolaridade, não permitindo que outras pessoas percebessem tais pesquisas. Esse fato demonstra que as pessoas, se quiserem, escondem suas intenções. Hoje existe fácil acesso às informações de onde buscar ajuda e também uma infinidade de sites relacionados aos métodos de provocar suicídio.

Com base nessas escolhas e nas informações colhidas, passamos para o conceito o não saber, no qual o grupo focal complementa o conceito anterior e traz a questão de não saberem de tudo, de não terem como ter todas as informações, de algumas pessoas camuflarem mais sinais que outras. O suicídio é o ato final em resposta a um conjunto de diversas razões e experiências de vida, abrangendo, em alguns casos, muito mais do que podemos saber e fazer. 
Nenhum dos colaboradores do grupo estava preparado ou imaginava que um suicídio poderia ocorrer:

\begin{abstract}
Então você vê um filme, você fala 'é uma ficção, não existe na vida real, comigo jamais vai acontecer'. Até que a hora que acontece, que você [pausa] eu me descobri mortal, eu me descobri a coisa mais absurda que poderia ter acontecido na minha vida seria um suicídio e, no entanto, aconteceu [pausa] e hoje em dia [pausa] não está preparada nunca para que uma coisa dessas aconteça, doença até a gente sabe que pode acontecer, mas suicídio, nunca! (Colaborador 3).
\end{abstract}

Conforme os colaboradores, coisas ruins podem acontecer na vida, algo que é visto como parte da vida humana, porém, para eles, não há preparação para vivenciar um suicídio, e ao acontecer, se sentem jogados na cruel realidade e na tragédia de perder alguém assim. Trazem à luz a limitação humana, que também está presente ao cuidar de alguém com transtorno mental ou com comportamento suicida. Todos têm limites e não conseguem ficar olhando para outra pessoa o tempo inteiro, é preciso reconhecer quando o limite é atingido e saber como agir a partir disso. "É a mesma coisa que eu sinto e é um conflito meu quando falam assim: 'Existe algo que eu posso fazer, mas eu tenho que conseguir saber reconhecer o meu limite até onde eu consigo ir. Isso é difícil" (Colaborador 2).

Essa sensação leva ao sentimento de que é preciso fazer muitas coisas para a prevenção, que ainda há muito trabalho a ser feito, que é necessária muita "gente do lado da gente" (colaborador 2), causando no grupo focal dúvidas se vão conseguir mudar a falta de recursos existentes na prevenção do suicídio, juntamente com cobranças de fazerem mais do que já se tem feito dentro desse tema.

Essa angústia levou o grupo perguntar à pesquisadora, por onde começar, pela mídia, ou por outro veículo de divulgação, pois, ao discutirem o que precisava ser feito, ficaram com a sensação de que a tarefa é grande demais, que tinha muita coisa a ser feita, uma sensação de impotência diante da quantidade de ações que ainda precisam ser desenvolvidas na área.

Aí a gente está falando de uma linha de proteção: mídia, polícia que tem que saber o que fazer na hora $\mathrm{H}$, os médicos, psicólogos, psiquiatras, a família, é tanta coisa, é a demanda que vai aumentar e a gente precisa de pessoas para onde? Mesmo que elas falem 'ok, aceito, preciso de ajuda'. A gente faz o quê? Está dando um nó na minha cabeça. É muita coisa ao mesmo tempo. A gente precisa de muita gente do lado da gente eu não estou conseguindo entender como é que a gente vai conseguir amarrar uma coisa à outra e aí (Colaborador 2).

Um dos colaboradores relata que saiu do primeiro encontro aflito, pensando em tudo que é necessário fazer para prevenir suicídios, que depois se acalmou e que juntamente com o 
grupo concordou que muita coisa ainda é necessária, mas que precisam começar de algum ponto. "Começando, pelo menos, tem que [sic] partir de algum ponto e se a gente achar que nada também vai surtir efeito, a gente vai parar e não vai fazer nada. Então, eu acho que tem que começar" (Colaborador 4).

Para o grupo focal, uma forma de aumentar a consciência, é perceber a proximidade de

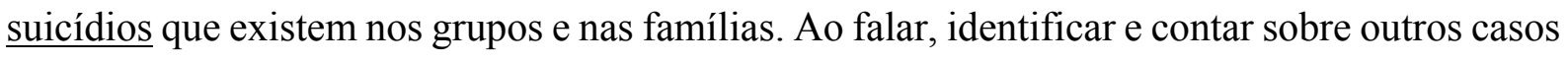
de suicídio que ocorreram dentro e fora da família, as pessoas perceberiam que o suicídio está mais próximo delas que se fala.

\footnotetext{
E eu acho que depois de um tempo que as pessoas foram [sic] começando a ver que se elas forem parar para pensar, elas têm mais pessoas próximas do que elas imaginam [que cometeram o suicídio], mas por alguma razão elas não falam e hoje eu acho que elas começaram a falar e ver: 'Olha, e não é que é verdade que tem alguém próximo e que isso já aconteceu, mas eu não quis enxergar' (Colaborador 8).
}

Uma das colaboradoras ainda convive com o fantasma da possibilidade de um novo suicídio, pois sua irmã já fez três tentativas desde que o sobrinho dela, filho dessa irmã, morreu por suicídio. Então, o fantasma do suicídio continua rondando algumas famílias, mesmo após um suicídio recente.

Ao pensarmos na quantidade de pessoas e na estatística, entramos na questão da epidemiologia.

A subcategoria epidemiologia é formada pelo aumento da consciência por meio do $\underline{\text { número de casos; }}$ epidemiologia dos sobreviventes; descobrindo o suicídio como comum e a importância da percepção da quantidade.

A epidemiologia, nesse estudo, refere-se ao uso de números e taxas relacionados a transtornos mentais, casos de suicídios completos, tentativas e do número de pessoas impactadas após uma morte (os sobreviventes). Tais números são usados como uma maneira de aumentar a consciência pública, por meio de uma forma palpável de provar a quantidade de pessoas impactadas pelo suicídio e a necessidade urgente de providências a esse respeito.

\footnotetext{
E se estatisticamente é uma média mínima de pelo menos seis pessoas para mais que é $[$ sic] afetada para cada suicídio. E nós temos suicídio a cada quarenta segundos. Nós temos um contingente da população expressivo e que certamente são de diversos perfis socioeconômicos e culturais [pausa] mas então, esse contingente, deve ter um percentual, não sei quanto, vamos chutar 10, 20\% de mil, duas mil pessoas, três mil pessoas, são milhares de pessoas que tem um status sociocultural e um perfil diferentes, inclusive alguns devem ser psicólogos, profissionais de saúde, aqui mesmo nós temos profissionais de saúde que são enlutados, né? (Colaborador 7).
} 
Assim, podemos pensar na quantidade de pessoas que são afetadas por um suicídio e se elas, além de representarem o número de pessoas impactadas, pudessem transformar-se em um canal de conscientização do suicídio, teríamos um grande contingente para facilitar esse processo.

Quando falamos em suicídio, precisamos levar em consideração a complexidade de sentimentos e de histórias humanas, a complexidade de fatores que levam alguém a matar-se, resultando na complexidade de ações que precisamos ter para prevenirmos o suicídio.

Essa subcategoria descreve essa complexidade. Para o grupo focal, existe uma

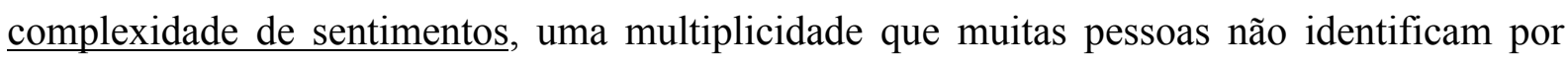
terem um repertório emocional pouco desenvolvido e isso diminui a percepção de si e do outro. Mesmo havendo um aumento do uso de palavras que descrevem uma variedade de sentimentos, muitos outros ainda não conseguem ser descritos em palavras.

Não se trata somente de renomear sentimentos, mas de conseguir reconhecer o que se sente e o que o outro sente. A singularidade do ser humano pode ser descrita como a impressão digital de cada um, é única, complexa e traz cicatrizes de machucados sofridos no decorrer da vida.

Assim, pelas pessoas não terem uma educação emocional adequada, portanto, com repertório emocional restrito, o sofrimento emocional não é validado, existindo uma ditadura da alegria e obrigatoriedade da felicidade, na qual a tristeza é excluída do convívio social e dos sentimentos que todos temos.

Essa exclusão da tristeza do cotidiano e da vida das pessoas gerou grande debate no grupo focal por perceberem que hoje não é permitido entristecer visto que ao falar que está triste para os outros e sentir-se mal traz culpa e a possibilidade de ser excluído do grupo. "Então, você já começa com as pessoas pondo de lado. Então, você já tem uma pessoa que está com um problema e aquilo agrava, porque ela é posta de lado porque ela não está ali sorrindo" (Colaborador 8).

A consequência é que uma série de sentimentos e assuntos ficam proibidos de se manifestarem.

Então, eu acho que tem essa questão do despertencimento [sic] de talvez você ter tanta dor e tantas coisas que as pessoas não passaram que você nem fala, né? Porque acha que não vão te entender. Aí você vai se fechando ... e é isso (Colaborador 11).

Dessa maneira, a exclusão da tristeza gera afastamento e pode aumentar o risco de suicídio. Para o grupo focal, este é um dos fatores que inicia o comportamento suicida, pois 
para eles, o suicídio também está relacionado às pequenas frustrações e tristezas que ocorrem no dia a dia, a alguns fatos do cotidiano como, por exemplo, não ter com quem conversar quando se está triste e sobre as coisas da vida diária, sobre sentir-se anormal por não estar feliz o tempo todo.

\begin{abstract}
Eu acho que falta um avanço nesse sentido, porque a pessoa fala 'putz, mas eu não estou com depressão' ou tipo 'não posso estar triste um dia', mas será que não existe uma variação? Você não precisa ser uma pessoa depressiva, mas tem um dia que você está sentindo algo que não tem nem nome ainda ... tudo evoluiu, agora, os sentimentos do ser humano não, continua tudo com o mesmo nome e aí é depressão (Colaborador 10).
\end{abstract}

Assim, a depressão está banalizada, pois todos os sentimentos ruins transformam-se em depressão e precisam ser medicados, não há espaço para as tristezas, angústias, medos, insatisfações, frustrações.

A maneira de começar a mudar essa realidade, segundo o grupo focal, é "dar milhões de passos para trás":

Sabe o que eu acho, a gente tem que [sic] dar milhões de passos para trás. Para mim, suicídio é o nível mais hard da humanidade. A gente não consegue acolher uma tristeza, quanto mais tipo um suicídio, entendeu? Então, eu acho que enquanto, sabe? não tiver educação base para falar de tipo 'sentimentos' que tipo um dia você está triste, você não pode falar que você está triste, as pessoas, o mundo não consegue acolher os sentimentos ruins que acontecem na nossa vida. Então, imagina acolher tudo aquilo que a pessoa, assim, que a pessoa que se suicida sente e ainda o fato do suicídio depois para os que ficam. Então acho que antes do suicídio virar um tema, que a gente consiga conversar, eu acho que a humanidade tem que [sic] evoluir muito em coisas básicas, sabe? Tem uma base do ser humano que não está formada, que é de acolher assim, falar um 'oi tudo bem?' ou tipo de dar 'bom dia', tem gente que não dá bom dia ... então, eu acho que a gente não evoluiu assim em coisas que a gente não consegue acolher a tristeza. A gente não percebe os outros, a gente não consegue falar com essas pessoas, então, assim, o suicídio para mim é uma coisa complexa, a última fase sabe da escala, as pessoas têm que [sic]ser felizes hoje todos os dias. Essa coisa da felicidade, da busca da felicidade, que todo dia você tem que [sic] estar bem. Então, assim, imagina falar de suicídio, isso aí ... porque é um assunto superpesado, a gente não consegue falar da tristeza. Aquele filme do 'Divertidamente', aquilo não fez sucesso, porque as pessoas não vão falar de sentimento, eles não querem ver lá que a tristeza que nem a alegria é o sentimento mais importante no filme, ainda bem que mostraram a importância da tristeza (Colaborador 10).

Acolher a tristeza, ensinar que sentir tristeza é normal e saudável, faz parte da vida, isso pode ser ensinado para crianças, para posteriormente ser dito, acolhido e prevenido o suicídio.

Então acho que a questão das campanhas do suicídio é essa: é primeiro eu tenho que trabalhar lá atrás, né? a questão do sentimento e talvez, se a gente trouxer isso através dessa base, as pessoas se conectem mais porque elas vão 
falar, nossa, isso que é um assunto que tem a ver comigo. Eu também sinto tristeza. Eu também às vezes estou triste (Colaborador 10).

Segundo os colaboradores, é necessário trazer para perto das pessoas a conexão com sentimentos comuns, incluindo a normalidade da tristeza e a complexidade dos sentimentos do ser humano como parte de um programa de conscientização pública que vise prevenir o suicídio.

\subsubsection{Desafios}

Os DESAFIOS dentro da CONSCIENTIZAÇÃO apontam questões que podem impedir e que precisam ser levadas em consideração para aumentar a consciência pública. Essa categoria é composta pela subnotificação, que aponta a importância e as falhas no processo de obtenção dos dados epidemiológicos; a burocracia, que atrapalha o processo tanto de notificação quanto dos cuidados com os enlutados e as pessoas que tiveram tentativas de suicídio, denunciando a burocracia envolvida nessas mortes; os impeditivos, que mostra dimensões que podem dificultar e até impedir que a consciência seja aumentada; interesses diversos, que discute a quem interessa prevenir ou não o suicídio.

Tabela 12: Desafios

\begin{tabular}{|c|c|c|c|}
\hline \multicolumn{2}{|c|}{ CONCEITOS } & \multirow{2}{*}{$\begin{array}{c}\text { SUBCATEGORIA } \\
\text { Subnotificação }\end{array}$} & \multirow{3}{*}{ CATEGORIA } \\
\hline Subnotificação de casos & $\begin{array}{c}\text { Subnotificação de } \\
\text { tentativas }\end{array}$ & & \\
\hline $\begin{array}{c}\text { Burocracia } \\
\text { Atestado de óbito }\end{array}$ & Processo policial & Burocracia & \\
\hline $\begin{array}{c}\text { Falta de percepção } \\
\text { Negação } \\
\text { Dificuldades } \\
\text { Medo do preconceito } \\
\text { Psicofobia } \\
\text { Difícil depoimento de } \\
\text { pessoas que tentaram } \\
\text { Acolhimento }\end{array}$ & $\begin{array}{c}\text { Incômodo } \\
\text { Distanciamento } \\
\text { Identificação } \\
\text { Dor e culpa } \\
\text { Capacitação } \\
\text { Falta de cuidado } \\
\text { Avaliação }\end{array}$ & Impeditivos & \multirow[t]{2}{*}{ Desafios } \\
\hline $\begin{array}{l}\text { Uso político de um } \\
\text { suicídio } \\
\text { A mídia não dá } \\
\text { importância de graça }\end{array}$ & $\begin{array}{l}\text { Aumento do } \\
\text { interesse em dar } \\
\text { visibilidade do } \\
\text { tema }\end{array}$ & Interesses diversos & \\
\hline
\end{tabular}

Fonte: produção do próprio autor (2018) 
Todas essas subcategorias conectam-se com o objetivo geral da pesquisa por trazerem mais elementos desse processo multifacetado e complexo que é o aumento da consciência pública na prevenção e posvenção do suicídio.

O primeiro desafio para a conscientização é a dificuldade de chegar-se a um número preciso de casos de suicídio, devido a grande incidência de subnotificação, que é dividido em $\underline{\text { subnotificação de casos e subnotificação de tentativas. }}$

O grupo focal propôs que uma das formas de aumentar a consciência seja por meio da epidemiologia, mas ela é diretamente influenciada pela subnotificação. Se houvesse uma fidedignidade nos números de suicídio, poderia ter um impacto ainda maior nas pessoas, redes de cuidado, projetos e leis, quando as pessoas conscientizassem-se da quantidade de pessoas que tiram sua vida, que pensam no assunto e que tem a sua vida afetada por um suicídio.

Portanto, conhecer os números com precisão influencia diretamente na forma como o suicídio é percebido e tratado, facilitando para que seja visto como problema de saúde pública, além de demonstrar para as pessoas que o suicídio está mais perto de todos.

Existe uma falta de padrão na notificação de casos de suicídio, não há clareza nos processos e nas responsabilidades de cada pessoa envolvida no assunto, o que leva a uma estatística incorreta. As causas dessa subnotificação são variadas.

Uma das colaboradoras trouxe o atestado de óbito do sobrinho no grupo, fala: "Aí tem um campo aqui que diz 'causas externas', aí está 'prováveis circunstâncias de morte não natural', aí tem o tipo 'acidente, Suicídio, homicídio, outros e ignorado', ele está como ignorado" (Colaborador 11).

Ela conta que todos da família sabem que foi suicídio, porém isso não consta em seu atestado de óbito. Este é um dos vários exemplos trazidos pelo grupo focal de suicídios que não foram atestados e consequentemente computados com outras causas de morte e não entraram nas estatísticas corretamente, levando a subnotificação.

Essa subnotificação ocorre também com as tentativas de suicídio, os motivos para que isso aconteça, segundo o grupo focal, é pelo suicídio ser visto como crime; pelas pessoas não quererem notificar; os hospitais não quererem ter problemas e o médico já ter muitas tarefas.

Mas, por exemplo, o meu outro irmão que não morreu, ele já tentou suicídio três vezes e nenhuma das vezes estava notificado como tentativa de suicídio, porque se não ele ia ter que passar por um processo e o médico falou 'ele vai ter que passar por um processo, por uma investigação, por um ... o hospital não dá' (Colaborador 8 ). 
Um dos colaboradores que é médico confirmou o que a colaboradora disse, que mesmo existindo a lei de atentado contra a vida, na prática, a notificação é bem diferente:

\footnotetext{
Eu sou médico, isso é uma lei, você tem que [sic] notificar polícia que é atentado contra a vida. Só que acontece o seguinte, agora olha só para o médico, que tem um milhão de pacientes para atender e o que acontece ele vai ter que ir em julgamento, no fórum, aquela baita encheção de saco, para não dar em nada e a família vai lá e acaba fazendo tudo, então para que ele vai? ... lei existe, mas ninguém cumpre a lei ... é igual aborto, aborto é proibido? É e se o médico notificar um aborto ele vai ter que passar dez anos da vida dele indo na delegacia ... justificando o porquê ... Eu só estou explicando o que acontece ... o médico, se você notificar dez casos desses eu estou perdido, eu vou passar o ano inteiro indo no fórum, eu não saio mais do fórum (Colaborador 5).
}

O médico não vê o sentido em notificar, não vê propósito nisso e não enxerga quem se beneficiaria com essa notificação, percebendo-a como mais uma burocracia que precisa passar e que não vai dar em nada, a notificação é vista como mais uma sobrecarga no cotidiano do médico. Talvez o processo que acontece após a notificação seja complicado demais para que os médicos aderirem a ele.

Fica claro que a subnotificação posa como um desafio na conscientização de todos os envolvidos, da sociedade, em saber a incidência de casos; dos políticos, para planejarem melhor a saúde pública; dos médicos, para sensibilizarem-se da necessidade e capacitarem-se para fazer a notificação; dos familiares, que gostariam de ter a causa verdadeira da morte no atestado; das pessoas que tentaram, para terem acesso aos tratamentos de saúde especializados.

A subnotificação está ligada à burocracia, que está dividida em processo policial e em atestado de óbito. O processo policial é aquele que a família de alguém que morreu por causas externas ou violentas precisa enfrentar para que haja uma investigação sobre aquela morte, assim verificar se foi realmente suicídio. Um dos colaboradores entendia bem o que acontece no Instituto Médico Legal (IML) e na delegacia, o que trouxe a discussão para o grupo focal, os participantes ficaram muito interessados em saber mais sobre esse processo, ao mesmo tempo em que manifestaram indignação com situações que viveram durante o inquérito.

Legalmente, conforme o colaborador presente, o médico legista não pode colocar no atestado de óbito que foi suicídio.

\footnotetext{
Não existe um médico que possa dar um atestado de óbito de um suicida legalmente. Eu posso ir lá, sou seu amigo, botar que ele morreu de outra causa, mas foi suicídio. Eu estou escondendo um crime da polícia. Bom, outra coisa é independente do que saia o laudo do IML, o teu problema está na delegacia, igual fizeram com você, com todos que passaram na delegacia [pausa] por favor, deixa eu te contar o que acontece no IML, eu .... no IML, deixa eu te
} 


\begin{abstract}
contar o que acontece [pausa] o corpo chega lá, como é que eu posso falar que ele estava amarrado em uma corda? Eu posso colocar que tem lesões no pescoço, indicando que parecia enforcamento por corda, o certo é ele colocar sufocamento e não suicídio, como é que a pessoa, qual é a técnica lá na sua casa vê uma pessoa lá e fotografa e tudo aquela coisa. Isso não vai para o médico, vai para a polícia científica na polícia, feito pelo policial. Para o médico chega o corpo lá e é só o que eu estou vendo no corpo, eu não posso supor nada. Não tenho que colocar lá 'está grávida' ou não está grávida, se é mulher você tem que fazer exame ginecológico, independente de qualquer coisa, se houve estupro ou não houve estupro, independente do que foi a causa da morte. Tudo isso você tem que [sic] averiguar no corpo, mas eu não posso colocar opinião minha 'ah, eu acho que foi por isso aquilo lá. Quem vai investigar essa outra parte é a equipe científica junto com a polícia (Colaborador 5).
\end{abstract}

Quando a morte é por causa externa ou causa suspeita, o corpo vai para o IML passar por autópsia para que o médico legista ateste o óbito, ele pode ou não colocar que a causa externa foi suicídio. Muitas vezes, essa informação vai ser acrescida no atestado de óbito após a conclusão do inquérito policial, que é feito em conjunto com a polícia científica. O laudo toxicológico que atesta se houve ou não ingestão de álcool, drogas ou remédios demora em torno de sessenta dias para ficar pronto, para então ser anexado ao inquérito policial.

Uma das colaboradoras relata que no atestado de óbito de seu irmão, que foi liberado junto com o corpo para o sepultamento, consta que a morte foi por suicídio, o nome e quantidade das medicações, o que contradiz o que o outro colaborador exemplificou.

$\mathrm{Na}$ experiência das famílias, em alguns atestados de óbito constam suicídios e em outros não. Portanto, vemos diferenças na forma como o suicídio foi atestado, denotando ausência de regras e processos claros.

Um dos colaboradores relata que após o perito saber a profissão dele "tudo ficou simplificado" e o corpo liberado no dia seguinte. No atestado de óbito consta "sufocamento" em vez de "suicídio", para ele o atestado ficou desta forma, pois, em sua concepção, o perito quis poupá-lo do descontentamento de ter escrito suicídio no atestado de óbito.

A maioria dos colaboradores afirma que o processo policial é horroroso, realizado sem acolhimento no momento em que os familiares ainda estão em choque com a notícia. Relatos de insensibilidade e grosserias foram feitos pelo grupo. Assim, percebermos que precisamos caminhar para melhorar a forma como os inquéritos são feitos e a burocracia que envolve todo o processo.

Outros impeditivos para a conscientização, relatados no grupo focal, foram a falta de percepção das pessoas e de suas necessidades em relações as outras; a dificuldade em prevenir o suicídio em pessoas mais idosas e também saber quais pessoas, dentro do círculo familiar, que realmente precisam ser incluídas no cuidado. 
A negação ou desinformação em relação ao comportamento suicida também foi citado por uma das colaboradoras, que se percebe na família que não "quer" acreditar na possibilidade de passar por mais um suicídio ou não consegue lidar com tanta dor e estresse ao mesmo tempo. O que se pode observar após os avós lidarem com o suicídio do neto e com as várias tentativas da filha, por essa razão, não conversam sobre o assunto e "fingem" que está tudo bem.

$\mathrm{O}$ medo do preconceito e a psicofobia também foram citados, pois as pessoas com comportamento suicida têm medo de sofrerem com o preconceito, sendo um impeditivo para buscar ajuda, elas e suas famílias não procuram psicólogos ou psiquiatras pelo preconceito que elas sentem em relação a esses profissionais.

A dificuldade de encontrar acolhimento, principalmente de profissionais, que sejam capacitados para este cuidado também fazem que a conscientização seja necessária.

Há um distanciamento entre quem perdeu um familiar ou amigo e quem pensa em matar-se, por isso uma das colaboradoras sugere que haja mais pesquisas que incluam quem tem o comportamento suicida, acreditando que são muito diferentes dos enlutados.

A dor do sobrevivente enlutado pode também gerar dor e culpa nas pessoas que pensam em tal ato e esse fato pode ajudar na prevenção, pela pessoa não querer fazer sofrer o familiar. No entanto, esse mesmo sentimento pode induzir o suicídio, porque ele pode aumentar a dor de quem pensa em suicidar-se, tornando outro fator de risco. Portanto, ao falar da dor dos sobreviventes como veículo de aumento de conscientização, há de considerar essas possibilidades.

O fato das notícias sobre suicídio gerar incômodo na sociedade, pode dificultar que seja abordado pelas grandes redes de televisão ou em novelas, pois uma das colaboradoras vê que as novelas devem distrair e não gerar incômodo, trazem junto o medo de incentivar o suicídio, caso apresentarem o assunto.

A falta de avaliação dos serviços propostos também é um impeditivo, pois mesmo que uma empresa ofereça cuidados de saúde mental e prevenção do suicídio, se não houver uma conscientização na maneira de encarar o problema e lidar com ele, as pessoas podem não usar o serviço quando precisarem, por exemplo, "tirar sarro" de quem procura esse serviço de apoio. Dessa maneira, há um preconceito em relação a quem procura ajuda, fazer piada nessa situação dificulta ainda mais a procura de quem precisa.

Em interesses diversos, podemos refletir que há um aumento do interesse em dar visibilidade ao tema, para alguns esse é um dever público em conjunto com um interesse pessoal de querer ajudar outras pessoas, observamos, porém, a fala do colaborador 1 que: 
a mídia não faz isso de graça ... ou é porque está tendo mais importância, porque é abcd morreram por suicídio e aí são pessoas que são famosas e tal e elas dão certa importância que tem a mídia vai fazer algo que não tem volta.

Refletimos qual é o interesse da mídia em tratar desse assunto e o que não se pode abordar ou falar.

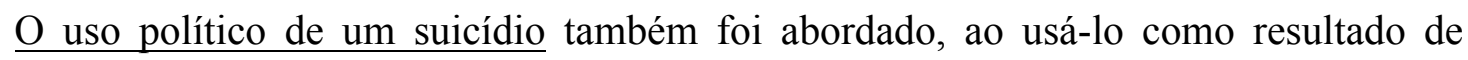
questões políticas da atualidade.

Embora o grupo não tenha trazido dessa maneira, podemos pensar a quem interessa prevenir o suicídio, quem mais se mobiliza e a quem interessa não tratar do assunto. Provavelmente políticos vêm uma chance de promoção pública; canais de TV, pela possibilidade do aumento da audiência; profissionais da área da saúde e da educação percebam a importância de falar do assunto pela sua experiência. No que concerne às universidades ainda há muito que fazer tanto na promoção de cursos e na capacitação quanto no atendimento e no cuidado aos estudantes desesperados e deprimidos, que cada vez mais se expressam por meio da ideação suicida e das tentativas de suicídio.

O tema CONSCIENTIZAÇÃO tratou de diversos fenômenos relacionados a necessidade de aumentar a consciência e aos impeditivos para que isso aconteça.

\subsection{AÇÃO}

O tema AÇÃO traz questões relacionadas tanto às ações necessárias na área da prevenção e posvenção do suicídio quanto às sugestões de ações, que precisam ser tomadas para ou a partir do aumento da consciência pública.

Diagrama 7: Ação

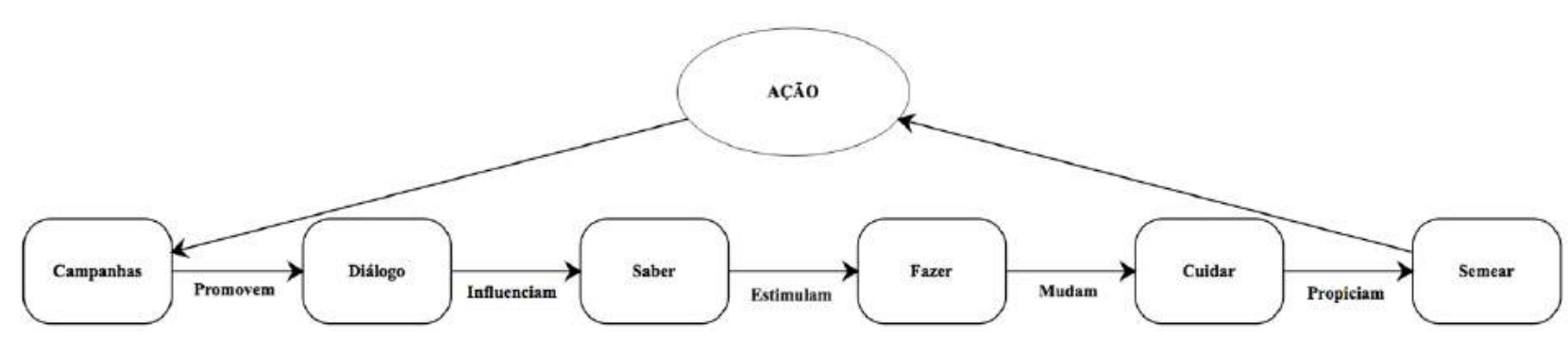

Fonte: produção do próprio autor (2018) 
O tema AÇÃO é composto pelas seguintes categorias e subcategorias:

Tabela 13: Ação

\begin{tabular}{|c|c|c|}
\hline TEMA & CATEGORIA & SUBCATEGORIA \\
\hline \multirow{32}{*}{ AÇÃO } & \multirow{16}{*}{ Campanhas } & Influência \\
\hline & & É um começo \\
\hline & & Alcance \\
\hline & & Capacitação \\
\hline & & Cuidados \\
\hline & & Temas \\
\hline & & Setembro Amarelo \\
\hline & & Marketing Amarelo \\
\hline & & Periodicidade \\
\hline & & Provedores \\
\hline & & Engajamento \\
\hline & & Identificação \\
\hline & & Efeito \\
\hline & & Outras cores \\
\hline & & Falhas \\
\hline & & Campanhas x falar \\
\hline & \multirow{2}{*}{ Diálogo } & O Falar \\
\hline & & Ouvir \\
\hline & \multirow{4}{*}{ Saber } & O contato muda \\
\hline & & Consequências do não saber \\
\hline & & Saber é poder \\
\hline & & Falta de formação \\
\hline & \multirow{2}{*}{ Fazer } & Prevenção \\
\hline & & Outros tipos de trabalho \\
\hline & \multirow{5}{*}{ Cuidar } & Depressão \\
\hline & & CVV \\
\hline & & Sobre os encontros \\
\hline & & Grupos de apoio \\
\hline & & Tratamento \\
\hline & \multirow{3}{*}{ Semear } & Facilitadores \\
\hline & & O que gostariam \\
\hline & & Sugestões \\
\hline
\end{tabular}

Fonte: produção do próprio autor (2018)

\subsection{1 - Campanhas}

Embora CAMPANHAS esteja no tema AÇÃO, elas podem ser consideradas uma ponte entre a conscientização e a ação, pois hoje as são formas mais comuns de promover a conscientização. 
A categoria CAMPANHAS traz as subcategorias: influência; é um começo; alcance; capacitação; cuidados; temas; setembro amarelo; marketing amarelo; periodicidade; provedores; engajamento; identificação; $\underline{\text { efeito; }}$ outras cores; falhas; campanha x falar.

Diagrama 8: Campanhas

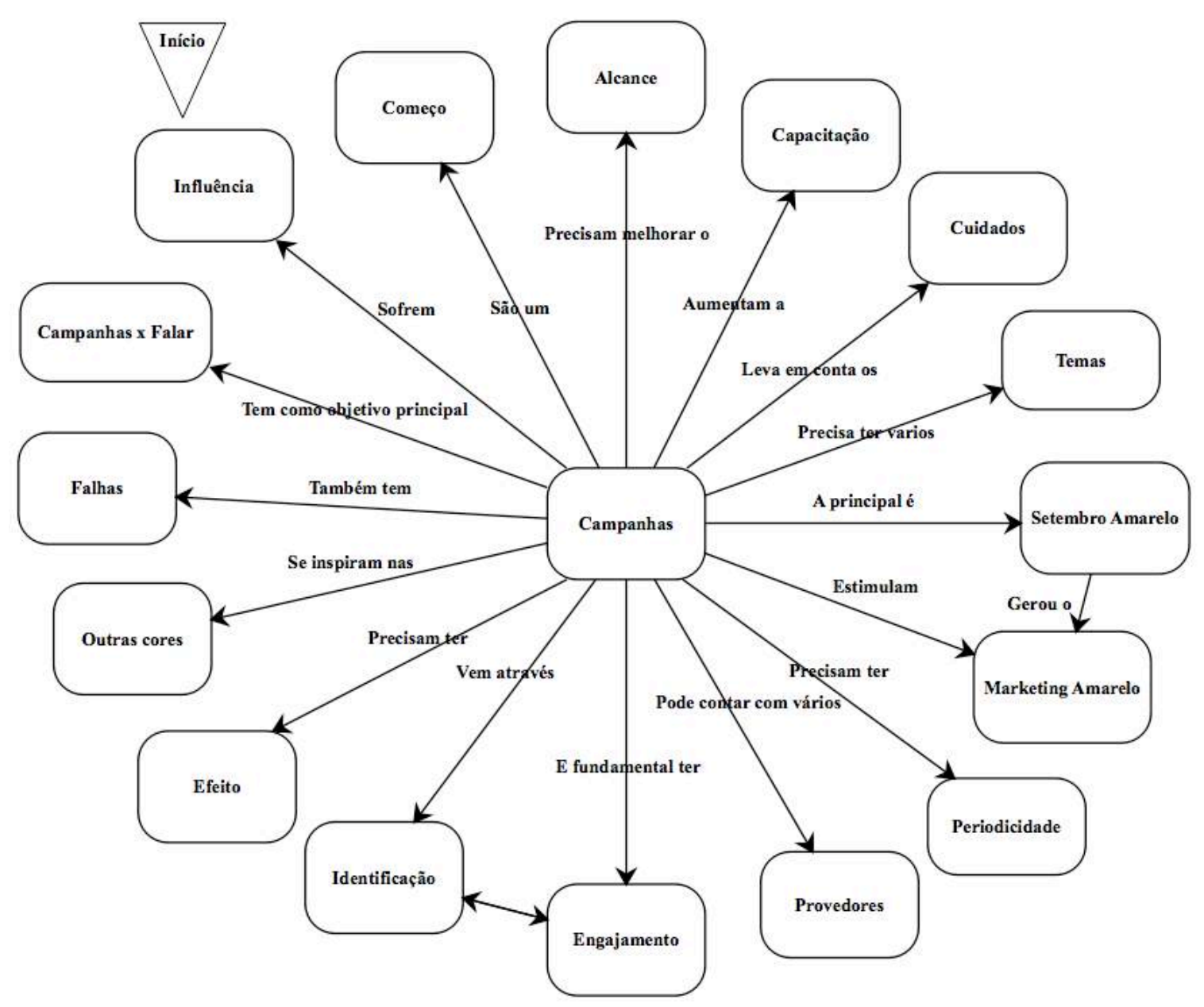

Fonte: produção do próprio autor (2018)

As campanhas sofrem influência da cultura e do tabu, porém influenciam a cultura ao mostrar que muitas pessoas podem sofrer do mesmo problema, mesmo com suas singularidades, impactando positivamente quem as vê, principalmente se forem bem-feitas. Um sinal disso, conforme os colaboradores, seria mexer, tocar as pessoas; para eles informação sem o apelo emocional não tem a mesma influência.

Para o grupo focal, ter as campanhas é um começo, é uma forma das pessoas iniciarem a falar do assunto e do tema estar presente na mídia, afirmam que não se deve parar nas campanhas e que mais precisa ser feito. As campanhas são precursoras de novas reportagens e de ações como um todo. 
O alcance das campanhas atuais foi descrito como muito bom, porém somente se a pessoa procurasse a informação, se ela tivesse um papel ativo de ir atrás de reportagens, por exemplo. Para o grupo focal, a informação era de boa qualidade, mas ela não chega a todas as pessoas, ainda está restrita a quem procura notícias sobre o assunto.

Capacitação refere-se à necessidade das pessoas estarem preparadas para falar sobre o assunto no âmbito público ou privado e "se a pessoa vai te perguntar pelo menos saber como ajudar, como te acolher”. Há uma percepção entre os colaboradores, de que falta capacitação, tanto de profissionais como da sociedade em geral para lidarem e falarem sobre o tema.

Os cuidados sugeridos pelo grupo focal foram inicialmente de tomar cuidado ao trazer a questão da religião, de ligar a religião ao tema, pois "Deus é uma coisa muito subjetiva" (Colaborador 10).

Outro colaborador questiona a "abordagem do impacto dos números do suicídio e falar de forma chocante sobre a morte para todos os grupos ... acho que pode reforçar uma postura de fechamento e retração" (Colaborador 9).

Para ele, é necessário ter cautela em ter campanhas que causem impacto pelo número de casos, pois dependendo da pessoa, elas podem gerar um fechamento em vez de abertura para o assunto.

Ao debaterem quais temas as campanhas deveriam abordar, foram apresentadas muitas ideias e debates entre os colaboradores. Para eles, é importante que as campanhas tragam histórias reais de pertencimento e superação e que inspirem para o bem, como a do Nick Vujicic $^{20}$. Para eles essa história é de um herói humano, pois não é de alguém famoso, o que aproxima mais a história da realidade das pessoas. "É fácil de se identificar por ser bonita, tocar e impressionar, mostra que é possível vencer e gera empatia pela história difícil" (Colaborador 10).

Nick Vujicic fala abertamente sobre os pensamentos suicidas que teve e como superar isso, ajuda as pessoas a terem exemplos para seguir, pois mesmo ao atravessar muitos desafios, mostra que é possivel ficar tudo bem.

Os colaboradores falam do desejo de que as campanhas tragam histórias verídicas e apresentam sugestões de filmes com pessoas que tentaram suicídio, assim as campanhas podem ser faladas por quem passou pela situação e atravessou-a. Assim, é mais fácil identificar-se com as histórias e mexer com a emoção de quem assiste, facilitando o contato e o interesse no assunto.

\footnotetext{
${ }^{20}$ Rapaz que nasceu com a síndrome Tetra-amelia, que acarreta na ausência dos quatro membros, atualmente faz palestras motivacionais de prevenção do suicídio pelo mundo.
} 
Outro tema discutido foi das campanhas oferecerem a informação de quem eles podem procurar se precisarem de ajuda, além de ensinar quando é a hora de procurar ajuda profissional, pois todos têm um limite do quanto podem ajudar e tem momentos que os profissionais e uma possível medicação precisa ser utilizada, porém eles ainda têm dúvidas em qual é o momento certo ou a partir de que sinais esse processo deve ser acionado. Assim, é possível passar a informação de que tem um limite, para ajudar a tirar a carga de uma pessoa só, pois eles falam que não dão conta de tudo.

Campanhas feitas pelo Conselho Federal de Psicologia (CFP) sobre psicofobia para diminuir o preconceito com relação aos psicólogos e aos psiquiatras a fim de ensinar que é possível fazer terapia como autoconhecimento, também para que as pessoas comecem a enxergar a terapia como aliada da saúde mental e não um procedimento pertence ao mundo dos "loucos", estas são algumas medidas trazidas pelos colaboradores, que poderiam ajudar a diminuir a resistência que as pessoas têm em procurar os psicólogos.

Outro tema discutido foi de ter campanhas que falassem das emoções e incluíssem $a$ tristeza, que produzissem uma capacitação para o diálogo para as pessoas aprenderem a conversar com alguém quando não estivessem bem. Essa campanha seria voltada para todos, não sendo específica para o suicídio, "eu acho que uma coisa que ajudaria, seria se as campanhas fossem voltadas para pessoas comuns, todo mundo, para capacitar a pessoa para melhorar o diálogo e falar de momentos de tristeza" (Colaborador 9).

Uma campanha para capacitar profissionais de diversas áreas é necessária, sobretudo policiais, psicólogos e médicos, pois pela experiência dos colaboradores, essas profissões precisam ser preparadas para atenderem melhor quem passa por um suicídio, pois "se nem aquelas pessoas que teriam o papel de acolher não estão preparadas, imagina outros seres que assim, né?". Dessa forma, a capacitação começaria com os profissionais das áreas mais afins estender-se-ia a sociedade como um todo.

Outra sugestão foi a de fazer campanhas com o foco em não julgar para que "as pessoas possam olhar com outro olhar a pessoa que está ali" (colaborador 4), oferecendo acolhimento e diálogo com o foco em promoção de saúde mental, pois uma coisa leva a outra, então, automaticamente se começa a prevenir o suicídio.

Lembro de uma campanha de TV muito antiga do CVV, aonde um homem pede dinheiro na rua e ao receber uma moeda entra num bar. Tudo dá a entender que ele vai comprar bebida alcoólica, mas ele compra uma ficha e vai a um telefone público dentro do bar e efetua uma ligação. Do outro lado da linha uma voz diz: 'CVV boa noite' e eles começam a conversar. Esta campanha antiga me marcou a respeito da imagem do CVV e que seria um 
lugar aonde $[\mathrm{sic}]$ se pode conversar. Acho uma campanha extremamente positiva e que nos aproxima. A ideia de que ao passar uma situação difícil, o CVV é um lugar aonde [sic] se pode conversar e ser ouvido. Acho que a campanha vai exatamente no ponto que é necessário a respeito do assunto. Abordando de forma prática um canal para o diálogo e a empatia e que estaria disponível para todos (Colaborador 9).

Divulgar o $C V V$ foi citado várias vezes no grupo focal, pois todos entendem a importância de as pessoas saberem sobre a existência e o trabalho deles, sugerindo que o CVV deveria usar os segundos gratuitos na TV em rede nacional, assim como acontece com outros temas, por se tratar de um órgão nacional. Outra sugestão foi a de mesmo em campanhas com um alcance menor ter sempre o número do CVV disponível, pois é visto pelo grupo como um local seguro e disponível para pedir ajuda.

Todos do grupo focal conhecem o setembro amarelo, campanha de conscientização do suicídio e percebem que ele tem crescido, sendo mais divulgado a cada ano, oferecendo aos sobreviventes à oportunidade de trabalho voluntário de conscientização e ajuda. Sentem que no setembro amarelo,

\footnotetext{
o impacto é positivo uma vez que consegue sensibilizar um grande número de pessoas ... foi divulgado nos meios de comunicação de massa e nas redes sociais. Muitas ações foram noticiadas nas principais emissoras de televisão e rádio do país (Colaborador 1).
}

O marketing amarelo foi sugerido pelos colaboradores como uma crítica ao engajamento verdadeiro das pessoas nas campanhas e no uso delas com o objetivo de cumprirem protocolo e promoverem-se nas redes sociais.

Tem muitas empresas que são assim, se engajam, mas não repassam para os seus funcionários, os seus colaboradores, aquela importância, dá um papelzinho, dá uma fitinha para colocar na camisa, mas agora vai ... volta a trabalhar então, mas coloca lá estampado que está dando o apoio, não sei o que lá ... mas não, não ... leva um profissional, nada (Colaborador 1).

Somente colocar uma fitinha amarela nos funcionários e não promover o debate, o aumento da consciência pública e a diminuição do tabu, cria uma campanha sem conscientização, trazendo dúvida se a campanha é de verdade ou se é uma ação de marketing com o nome de conscientização.

Eu vou citar um exemplo muito prático: Minha cunhada é assistente social numa unidade de saúde, o ano passado no Facebook apareceu ela com o lacinho amarelo com toda a turma fazendo pose, mas ela nunca conversou comigo sobre o assunto (Colaborador 2). 
Para eles não basta "cumprir o amarelo" (colaborador 2), tirar foto no facebook e acabou, o engajamento e a conscientização precisam ser verdadeiros.

Para o grupo, a peridiocidade das campanhas deve ocorrer com mais frequência, durante o ano todo, com campanhas menores e mais reportagens, pois as pessoas não assimilam tudo em setembro, pela quantidade de informação junta. $\mathrm{O}$ tema pode começar a ser abordado sutilmente em mais ocasiões, para que isso prepare as pessoas a habituarem-se a lidar com o tema no cotidiano.

Um dos colaboradores acredita que parcerias com empresas deveriam ser propostas, para que o tema seja divulgado massivamente, principalmente em conglomerados urbanos maiores, assim, possa atingir um número maior de pessoas. Para ele informação é poder, então esse deve ser o ponto de partida.

Entretanto, o grupo traz a reflexão que ser massivo pode fazer que pessoas, em um dado momento, não prestem mais atenção, ficando só o grupo das pessoas que se interessam pelo assunto, que estarão de camiseta participando de eventos, distribuindo folhetos, tentando, mas não conseguirão tanto sucesso em conscientização.

Para o grupo, os provedores, são relacionados as instituições que podem encabeçar as campanhas, para eles, essas campanhas devem ocorrer por meio do Conselho de Psicologia, assim como existem campanhas dos Conselhos Nacionais de Engenharia, Enfermagem, Fisioterapia, envolvendo a procura do profissional adequado, o CFP deveria fazer a mesma coisa.

Campanhas devem focar também a televisão, pois, para o grupo focal, ela atinge muita gente de todas as idades, incluindo a comunicação para os idosos, que assistem muita tevê e são um grupo de risco para o suicídio. Como os jovens não assistem muita tevê aberta, as campanhas devem se estender para as redes sociais que vão atingir esse público.

Um dos colaboradores fala que atualmente podemos ver audiências públicas na assembleia, convocadas por deputados estaduais, para debater o assunto, mas é fundamental haver o real envolvimento do poder público, do governo do Estado, da secretaria da saúde para a questão da prevenção do suicídio e que inclua diversas esferas, como institutos, universidades, conselhos regionais.

$\mathrm{O}$ engajamento foi trazido como um elemento fundamental para que ocorram as campanhas, para que não seja somente o marketing amarelo. Para os colaboradores, o que leva alguém a se engajar é ter um motivo pessoal para isso, mesmo que escondido. 
De ter que ter algo assim, pessoal, para você se engajar naquele tema, que é aquilo: suicídio só passa a ser realidade, você só presta atenção, quando você de alguma maneira tem a ver com aquilo, porque hoje em grandes campanhas, normalmente, que nem essa do trânsito, né? não sei, se as pessoas que perderam alguém, assim são as mais engajadas ... O que leva alguém a se engajar? Eu não sei (Colaborador 10).

Uma das colaboradoras cita sua experiência em eventos LGBT dentro da empresa que trabalha, dizendo que percebe o engajamento de pessoas que tem relação com o tema, que sente que os líderes são obrigados a se engajarem, para mostrar suporte, mesmo que eles particularmente não queriam fazer isso, pois as pessoas não querem se engajar em certos temas por haver o preconceito de se engajar em certos grupos. Para os outros, ela diz que ajuda o movimento LGBT, porque respeita a diversidade, mas esconde o motivo real, que é saber que eles são um grupo com altas taxas de suicídios sendo isso que a leva a ser engajada no LGBT. Para ela, engaja-se quem tem propósito:

\footnotetext{
Porque aquela coisa de talvez a pessoa pensar: 'Aí, vão achar, sei lá, alguma coisa de mim, porque eu estou engajada nesse grupo. Então, eu acho que essa campanha do GLBTA só atinge as pessoas que de alguma forma se sentem ligadas ao tema. Eles falando ali abertamente ou não ou lá na essência tem alguma coisinha que ele por, né? então, talvez essas campanhas do suicídio, elas só vão atingir quem, na sua essência, tem alguma ligação com o tema. Se não ela passa desapercebida. Tanto que a gente fica lá tentando engajar as pessoas para ir no GLBTA e assim, tipo as pessoas não vão. São raras. São raras. Aí lógico já tem vários líderes que vão porque, tipo, eles têm que [sic] ir, eles têm que liderar pelo exemplo, você tem que ir ... então eu não sei se não tivesse talvez um pouco disso de ser um exemplo, de ter que cumprir com isso, se aquelas pessoas iriam e aí eu não sei se, por exemplo, os jovens, por ser um grupo que tem um propósito, eles acabam se engajando também. Então é um fato interessante: eu não sei se eles se engajam porque eles têm a ver com algumas das letras ou porque na essência tem algo ali ou se é porque coisas com propósitos e eu vejo que é uma coisa que as novas gerações elas trazem isso (Colaborador 10).
}

Para haver o engajamento, o grupo focal percebe que precisa existir uma identificação com o tema e percebem que há campanhas, como a do trânsito que eles não prestam tanta atenção por não ter relação com eles, embora lembrem e tenham gostado da campanha da TV. Para eles, só se identifica com a campanha quem passou por isso ou tenham vivido alguma realidade próxima, sendo necessário que as pessoas percebam que aquilo também tem haver com elas, que não é algo tão distante de suas histórias.

Assim, para fazerem efeito, precisam gerar identificação, as pessoas precisam se preocupar com o tema, para que tenham alguma relação com o que é falado.

Outras cores foram citadas, ou seja, outras campanhas que se baseiam em cores, como o maio amarelo, que é da conscientização de acidentes no trânsito; novembro azul, que tem 
relação com o câncer de próstata; o outubro rosa, do câncer de mama, lembrado e citado por quase todos os colaboradores. Percebemos que é uma campanha que já está solidificada, as pessoas conhecem e sabem do que se trata. Fazer a comparação com as outras cores traz esperança para o grupo focal, de que falar sobre o suicídio, no futuro, seja tão comum como hoje falar da prevenção do câncer.

Para o grupo, as maiores falhas das campanhas é fazer que as pessoas sintam que aquilo não tem haver com elas, que quem não participa do assunto não sabe o que é o setembro amarelo, por causa do tabu envolvido no assunto, as campanhas não surtem efeito em pontos cegos da sociedade.

Dessa maneira, é fundamental aliar as campanhas $\mathrm{x}$ falar, pois mesmo que tenha aumentado a quantidade de informações e a campanha do setembro amarelo tenha crescido, muitos colaboradores não acharam ninguém para falar sobre o assunto, pois as relações pessoais ainda não começaram a dialogar sobre o suicídio, sendo mais fácil fazer campanha que falar abertamente sobre o assunto com quem passou diretamente por um suicídio.

\subsection{2 - Diálogo}

A categoria DIÁLOGO foi dividida em falar e ouvir, pois não adianta somente falar ou somente ouvir, reflete a importância de que a sociedade e as pessoas consigam estabelecer um DIÁLOGO sobre o suicídio. Conforme podemos ver no diagrama abaixo, o DIÁLOGO fica ENTRE o falar e o ouvir, ele nasce do encontro dessas duas ações.

Diagrama 9: Diálogo

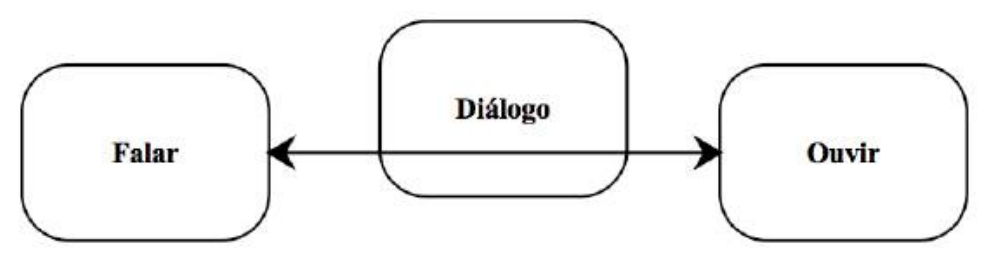

Fonte: produção do próprio autor (2018)

O falar representa o que os colaboradores gostariam que fosse falado, que mensagens deveriam ser passadas para que aumentássemos a consciência pública e preveníssemos o suicídio. Essa categoria foi dividida em: como (forma), o quê (mensagem), quem (para quem e por quem) e onde (locais). 
Tabela 14: Conceitos e Subcategorias do Diálogo

\begin{tabular}{|c|c|c|}
\hline CONCEITOS & SUBCATEGORIA & CATEGORIA \\
\hline $\begin{array}{ll}\text { O quê } & \text { Onde } \\
\text { Quem } & \text { Como } \\
\end{array}$ & Falar & \\
\hline $\begin{array}{l}\text { A dificuldade está em ouvir e não neles } \\
\text { falarem } \\
\text { Dificuldade dos outros ouvirem sobre o } \\
\text { suicídio } \\
\text { Pessoas não têm com quem conversar }\end{array}$ & Ouvir & Diálogo \\
\hline
\end{tabular}

Fonte: produção do próprio autor (2018)

$\underline{\mathrm{O} \text { quê }}$ deve ser falado ou as mensagens que precisam ser oferecidas, segundo os colaboradores, para aumentar consciência pública são:

Normatizar o suicídio, relacionando sentimentos que uma pessoa que pensa em matarse tem, com sentimentos comuns de várias outras pessoas, assim seria mais fácil das pessoas identificarem-se e reconhecerem o que é falado. Mostrar que muitas pessoas já passaram por essa situação e hoje estão bem para trazer esperança e a visão de que é possível superar o comportamento suicida.

Outra maneira é mostrar que existe uma visão estereotipada de uma pessoa suicida pela sociedade e que ela pode ser qualquer pessoa, não tem um rosto definido. Mostrar que pensar em suicídio é mais comum do que se imagina, pode trazer o tema mais para perto do contexto e do cotidiano das pessoas.

Assim desmistificar, tanto a medicação como o psiquiatra, como os termos depressão e suicídio. Para o grupo, muitas pessoas têm preconceito com remédios e não seguem o tratamento ou acham que vão ficar "viciadas". A percepção de que ir ao psiquiatra e tomar medicamento é "coisa de louco", impedindo muitas pessoas de receberem a ajuda necessária, portanto, existe a necessidade de desmistificar esse cuidado. Com relação aos termos depressão e suicídio, desmistificar faz-se necessário, pois além de todo o tabu, que já foi comentado anteriormente e o fato de que ambos virem carregados de significados negativos, pode fazer que uma pessoa com depressão não assuma seus sentimentos e sintomas decorrentes da doença por não querer receber esse rótulo.

Outra sugestão foi a de falar de estatística dos enlutados, como forma de aumentar a consciência de quantas pessoas são impactadas por essa dor. Um dos colaboradores acha que falar sobre impacto ou estatísticas pode causar rejeição ao tema, conforme falamos anteriormente. 
Outro tema a ser abordado tem relação com a depressão, para que ela fosse vista como outras doenças crônicas, como a diabetes e a pressão alta, dessa forma, não seria carregada de preconceitos. Falou-se da importância dessa mensagem ser voltada para pessoas de todas as classes. Os colaboradores acham que é mais fácil trazer a questão da depressão para a sociedade que do suicídio, pois falar de depressão já tem uma aceitação maior e pelo fato da depressão ser, na visão deles, a doença da moda, tornando mais fácil que o suicídio.

Mostrar que há ajuda disponível, que a pessoa não está sozinha e mesmo que ela sintase assim, existem pessoas que podem ajudar e locais onde ela pode encontrar ajuda. Mostrar que por meio da psicologia e psiquiatria há auxílio, por essa razão não precisam chegar ao suicídio.

Poder ensinar como agir por meio de reportagens com orientações práticas, pois o leigo não sabe o que fazer em muitas situações que envolvem o comportamento suicida. Uma colaboradora trouxe uma "visão utópica" que no futuro a sociedade ofereça acolhimento ao invés de espanto na comunicação suicida, a partir do momento que a sociedade for tão informada que saiba como agir e lidar diante dessa fala.

Muito colaboradores citaram que se ouvirem alguém falar que quer matar-se, ficam sem saber o que falar para ajudar, pois ficam sem saber como agir e ensinar o que fazer nessas situações poderia ajudar muitas pessoas. Ter à disposição as informações para saber até onde ir e o que está ao alcance de cada um foram sugestões trazidas por um colaborador, pois, segundo ele, atualmente muitas dessas informações estão disponíveis somente nos grupos de apoio, mas não na mídia.

Diferentemente dos temas das campanhas, citados anteriormente, aqui trazemos os temas que, conforme o grupo, devem ser abordados pela sociedade em geral, seja por meio de campanhas ou não. Para eles, o suicídio é um problema de todos, assim,

\footnotetext{
a sociedade tem que $[\mathrm{sic}]$ se conscientizar que o problema do suicídio é de todos. Não é classe financeira, não é cor, não é credo, não é nada. De que todos têm esse problema [pausa] o suicídio pode acontecer em qualquer lugar com qualquer pessoa e todo mundo pode ser tanto responsável por ajudar alguém com a prevenção como também pode acontecer em qualquer família (Colaborador 5).
}

A diferença entre prevenção do suicídio x previsão do ato suicida precisa estar clara para todos os envolvidos, para que não haja a confusão entre esses dois conceitos. É possível prevenirmos o suicídio, mas não podemos prever quando e como cometerá o ato. Outra questão levantada foi o fato de que existem diferenças no suicídio, que eles não ocorrem pelos mesmos 
fatores, que para cada pessoa um fator vai ser mais decisivo que outro e a sociedade precisa saber disso, assim, falamos em suicídios e não o suicídio.

Favorecer a empatia por meio de mensagens que ajudem as pessoas a envolverem-se mais e verem o suicídio mais próximo a elas foi outra sugestão. Para o grupo focal, essa atitude poderia "trazer um impacto positivo e uma aceitação maior" das pessoas afetadas pelo suicídio.

Poder falar das várias dores, dos que morreram e dos que ficaram, incluindo a visão de que é a dor que leva ao suicídio, mostrando o suicídio como um ato que é motivado pela dor e não, por exemplo, pela falta de amor. Uma das colaboradoras relata que se sente amada pelo filho, mas ele tinha uma dor maior que a minha, considera que se deve focar no amor e não na dor dos sobreviventes, pois, para ela, há muito amor e disponibilidade de ajudar e focar na dor pode criar "culpa" nas pessoas.

Um dos colaboradores disse que acha que é a forma mais eficaz de prevenir suicídios ao mostrar a dor dos que ficam, pois percebe que causa impacto com o seu relato, quando conta sua história para outras pessoas. "Eu acho também, existe um universo a ser explorado e esse contingente é que pode ser a chave para gente derrubar essa barreira" (Colaborador 7).

Outra sugestão foi a de ajudar as pessoas a lembrarem das dores da adolescência, assim elas entenderiam melhor as dores de seus filhos adolescentes e poderiam conectar-se melhor com eles. Outro ponto, foi que é a dor que leva a romper o laço com os outros e com a vida. Para eles, é importante que haja mensagens que mostrem o suicídio relacionado a uma dor que busca um fim.

Sugeriram falar sobre a ANSIEDADE como um dos fatores que levam ao suicídio, pois muito se fala da depressão, mas muitos suicídios têm relação estreita com a ansiedade, mas é um tópico que não é muito enfatizado ao falar de suicídio.

Os colaboradores sugerem que se fale de emoções e não somente do suicídio, pois para eles, as pessoas têm menor resistência se falar de emoções, mais próximas da realidade da maioria delas que o suicídio.

Quem traz os atores ou por quais pessoas essas mensagens poderiam ser passadas, que poderia falar ou ser porta-voz do tema suicídio para o público.

Diagrama 10: Quem

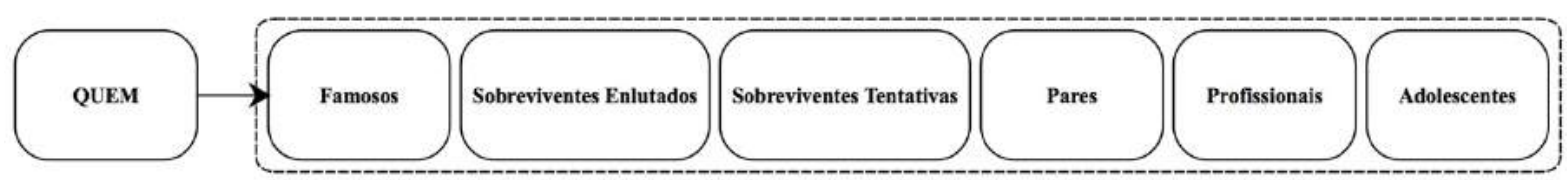

Fonte: produção do próprio autor (2018) 
Para o grupo, uma forma de chamar atenção para o assunto é ter famosos falando sobre o suicídio. Para eles, hoje tem mais figuras públicas que falam sobre o assunto, como o André Trigueiro. Os famosos que tiveram questões dificeis de lidar na sua vida fazem que as pessoas pensem no assunto, pois se famosos sofrem, pessoas comuns também podem sofrer e comunicar seu sofrimento.

Ter relatos de famosos, como o de Luiza Brunet, contando que foi agredida pelo marido, faz que as pessoas deixem de esconder o problema, o que poderia ocorrer também com o suicídio. Outro ponto é que de suicídios de famosos é falado, a mídia fala, o assunto não consegue ficar escondido, ele é "escancarado". O suicídio de famosos, como do ator americano Robin Willians, choca e não passa despercebido.

Outra maneira de aumentar a consciência e prevenir suicídio, conforme o grupo focal, seria pelos sobreviventes enlutados. O grupo focal não foi unanime quanto a essa questão, alguns acham que é uma forma de passar a mensagem, mas que não é a única ou a mais importante.

Para o grupo focal, quando as mensagens são passadas pelos sobreviventes enlutados, relatando suas experiências, falando da dor dos que ficam, do impacto e do desgaste nas famílias, há um apelo e abrangência maior. Um dos colaboradores pensa que é fundamental abrir mão do anonimato e a "sociedade começar a ver a cara dos que ficam, a dor dos que ficam" (Colaborador 7), isso pode impactar os que pensam em matar-se e a sociedade como um todo.

Segundo um dos colaboradores,

\begin{abstract}
se estatisticamente é uma média mínima de pelo menos seis pessoas para mais, que é afetada pra cada suicídio e nós temos um suicídio a cada quarenta segundos. Nós temos um contingente da população expressivo e que certamente são de diversos perfis socioeconômicos e culturais e que cada um atue e dialogue no seu meio e que poderia ser um grande formador de opinião e poderia ser um grande parceiro para desfrutar a consciência afetiva da sociedade como um todo (Colaborador 7).
\end{abstract}

Percebemos então que os sobreviventes enlutados formam um grande e expressivo contingente de pessoas com diversos perfis socioeconômicos e culturais que podem tornar-se formadores de opinião, que atuassem e dialogassem sobre o assunto em seu meio, convertendo pessoas em parceiros para transformarem a sociedade.

Sobreviventes de tentativas também são pessoas que poderiam oferecer seus relatos, para a sociedade ouvir de quem passou pela dor, pela escolha do suicídio e por sobreviver a isso ou ter depoimentos de quem já pensou, estas são maneiras propostas para trazer as pessoas mais próximas da realidade. 
Ouvir de um par, ou seja, ouvir uma pessoa como ele, isso pode gerar menos resistência,

\footnotetext{
porque a pessoa, ela, na fragilidade dela ela precisa, às vezes, de ver outra pessoa frágil, uma outra pessoa que chora, que dói, que fica com a palavra embargada pela dor que está sentindo ... então que é um igual, que é um par ... Assim, alguém que não é nada de mais e que é um como ele, que também está sofrendo e que até também pensou em suicídio e que de repente está ... na mesma faixa etária ou alguma coisa assim, né? (Colaborador 7).
}

Outros atores citados são os profissionais, porém em reportagens voltadas para leigos, com palavras apropriadas para esse público. Foi citado pelos colaboradores que dependendo da forma da comunicação pode haver resistência do público se for de profissional, pois eles podem afastar as pessoas. O profissional categorizado impõe autoridade, mas não pode ter o tom professoral, pois pessoas têm resistência a autoridades no assunto. Para eles, as autoridades no assunto devem falar para aqueles que buscam informação ou ajuda, ou seja, profissionais falando para seus pares ou para pessoas que procuram relatos de profissionais.

Mesmo que sendo frequentado por adultos, o grupo focal aponta para a importância de haver uma fala específica para adolescentes, para conscientizar alunos a perceberem suas situações de risco e de seus amigos. Logo, as pessoas estariam ensinando alunos a identificarem e a ouvirem seus amigos e os pais e professores poderiam aprender como abordar um adolescente.

Onde fala dos locais, trazidos pelo grupo focal, como possibilidades para que ocorra o diálogo sobre o suicídio.

Para os colaboradores devemos começar a conscientização nas faculdades com assuntos relacionados ao suicídio, por exemplo, na área da saúde. No entanto, ao serem questionados pela pesquisadora, dizem que não imaginam pessoas de outras áreas aprendendo sobre suicídio, pois, para eles, precisamos começar com os cursos que tem relação.

O grupo focal também evidencia que faz-se necessário ampliar o alcance das informações para todos os alunos, pois hoje, segundo eles, essas informações ocorrem em grupos fechados nestes lugares, e precisam abranger mais pessoas.

Aprender sobre o suicídio na escola da vida também foi falado pelo grupo focal, pois, para eles, na escola aprendem-se assuntos objetivos, mas na vida a pessoa tem de lidar com situações subjetivas, como transições, perdas, mudanças. Essas coisas subjetivas aprendem-se só na vida, o que torna esse aprendizado mais difícil.

Outro lugar para abordar o suicídio é a mídia, visto que, atinge muita gente. Foi proposta também a abordagem o suicídio em novelas, já que, segundo uma colaboradora, eles abordam 
tanto o transplante de coração, como na novela atual, mas eles não se lembram de nenhuma novela que abordasse a depressão. Ao mesmo tempo, ficam preocupados em tratar esses temas em novelas e incentivar pessoas para o suicídio, por isso acham que o assunto deve ser tratado de uma forma muito cuidadosa. Uma das colaboradoras trouxe a questão do suicídio ser tema incômodo para ser abordado por uma novela, mas os outros colaboradores complementam que várias novelas já trouxeram questões difíceis, por isso não há impeditivo para que sejam abordados nesse meio. Observamos que não há consenso entre os colaboradores sobre essa questão.

Como representa as diversas formas, sugeridas pelos colaboradores, que podemos passar mensagens e ser canais de aumento de consciência por meio do falar, se verbal ou visual.

As formas sugeridas foram por meio de multiplicadores de opinião, como universitários e professores que pudessem frequentar grupos de apoio, semanais e mesmo que não "abraçassem a causa e saíssem do anonimato" (Colaborador 7), poderiam multiplicar a informação que receberam.

As mensagens devem ser passadas por perfis variados, com diversidade para refletir a sociedade.

Usando depoimentos de pessoas, incluindo enlutados e pessoas que tentaram suicídio, pois é difícil ver depoimentos de pessoas que tentaram, mas quando vão aos grupos, é muito interessante de ouvir. A dificuldade de ouvir o relato de quem tentou suicídio pode provocar fortes emoções em quem, por exemplo, tem ideação suicida ou para pessoas enlutadas

Por meio de falar do cotidiano, pois muitas vezes não falar sobre os sentimentos pode ter um vínculo com chegar a um ponto de angústia que favoreça o suicídio, porém o desencadeador desse sentimento pode ser uma falta de espaço de expressão. Portanto, não falar do sofrimento é maior risco do que falar deles, mesmo que despertem fortes reações.

Outra forma seria começar a tratar como saúde pública. Eles não explicitaram exatamente como, mas usam esse fato para comparar com a quantidade de campanhas e a importância da prevenção do câncer e da AIDS hoje, que tem essa relevância após serem tratados como questões de saúde pública. Assim, o governo pode oferecer mais hospitais e tratamentos para quem não tem condições de pagar.

O ouvir foi gerado por abranger o outro lado do falar, segundo os colaboradores, se não ajudarmos as pessoas a começarem a ouvir, não adianta só falar.

Para os colaboradores a dificuldade está em ouvir e não neles falarem, muitas vezes as pessoas mudam de assunto quando os colaboradores conversam sobre o tema, dessa forma, eles 
percebem que há uma dificuldade dos outros ouvirem sobre o suicídio, pois "as outras pessoas que estão do outro lado tão com medo e não querem ouvir (Colaborador 1)."

Para uma das colaboradoras, as pessoas estão muito ocupadas atualmente e não tem tempo de ouvir. As pessoas não conseguem encontrar pessoas que as escutem, não acham quem vai escutá-las.

Um dos colaboradores, que já foi voluntário do CVV, exemplifica essa questão ao dizer que muitas pessoas ligam para o CVV por sentirem angústia de não terem com quem conversar e ele não está falando de pessoas em crise e sim sobre eventos cotidianos, "as pessoas não têm espaço para falar do que elas estão sentindo, perguntar o que aconteceu ou como foi o seu dia ou falam de coisas práticas (Colaborador 9)."

\subsubsection{O saber}

O SABER é relacionado com as informações e as capacitações que as pessoas, os profissionais e a sociedade precisam ter em relação ao suicídio. Fala também da consequência do não saber.

Essa categoria é composta por consequências do não saber; $\underline{\text { saber é poder; falta de }}$ formação e o contato muda.

Para o grupo focal, são várias as consequências do não saber como, por exemplo, pessoas tratando mal porque não entendem o que está acontecendo. Isso pode acontecer com médicos e enfermeiras, pois o suicídio foge da compreensão deles, assim, eles não querem cuidar, não querem ouvir. Preferem cuidar de pacientes "mais graves", mas que não estão pensando em suicídio, mas, para os colaboradores, isso tem como base a falta de informação no assunto.

Entretanto, para outros colaboradores, alguns médicos ficam angustiados com o jeito de falar dos colegas, mas entendem que isso é consequência de não saberem como fazê-lo, decorrente da falta de formação do assunto nas faculdades.

Outro colaborador sugere que as pessoas não têm medo de falar, elas não sabem, denotando novamente a importância do saber falar. Para ele, o que mais motiva o não falar sobre o assunto é o desconhecimento em vez do medo ou do receio.

Dessa maneira, saber é poder, pois ter informação normaliza o assunto, faz que ele torne-se um tema do cotidiano. Uma das colaboradoras compara com o câncer de mama, que por causa da conscientização que foi feita, se a pessoa sentir alguma coisa estranha, será normal ir ao médico e pedir exames, coisa que não era assim. Com relação ao câncer, os colaboradores 
também compararam que para o câncer há informação, pois o tema já foi mais estudado, as pessoas já foram mais atrás, já existem mais profissionais especializados no tema, então a sociedade como um todo já está mais preparada para lidar com essa doença.

A falta de informações sobre o suicídio foi citada diversas vezes no grupo focal. Uma das colaboradoras cita que mesmo que o "suicídio não é algo novo, a Bíblia já tem relatos" (colaboradora 6), porém sente que ainda falta muita informação sobre o tema, que mesmo sendo questão antiga, nunca se teve suficiente informação disponível sobre o suicídio. É importante lembrar que não é um suicídio como evento único e sim suicídios cada um com suas motivações e histórias, ou seja, um assunto inesgotável.

Geralmente, somente após os colaboradores passarem pelo suicídio é que perceberam que há uma grande falta de informação sobre o assunto. Muitos começaram a estudar o assunto após a sua perda, dizem que foram buscar conhecimento e hoje estão mais espertos com o suicídio como um todo.

Para eles, se o suicídio não é abordado nem em ambientes seguros para falar, como na medicina, "imagina no resto" (Colaboradora 10). Uma ilusão achar que a medicina é campo seguro visto que há uma sensação de que não há informações suficientes à disposição, que quem quer ter informação precisa buscar, quando encontra. Portanto, quanto mais informação, melhor o embasamento em relação ao suicídio.

Um dos colaboradores fala que informação é poder, que é o ponto de partida para que a situação do suicídio hoje possa mudar. Eles acreditam que o acesso à informação vai ajudar não só na prevenção suicídio, mas a todos os impactados pela questão ou porque perderam pessoas ou por já pensaram em matar-se.

Há uma necessidade de informação, que existe não só entre os colaboradores, mas também entre as pessoas em geral, nas empresas e para isso é fundamental preparar as pessoas para falarem corretamente. Para eles, o tabu só poderá ser quebrado, quando houver muito mais pessoas preparadas para falar, mas não comentaram quem seriam essas pessoas.

Uma das colaboradoras relata que se chocou com a sua falta de preparo e de conhecimento ao se deparar com um paciente com comportamento suicida. Para ela, esse fato reflete a falta de formação presente em relação ao assunto. Eles sugerem que existe uma falta de estudos e de preparo, que então deveria haver esforços para preparar profissionais nas diferentes áreas que entram no contexto do suicídio, na psicologia, na medicina, mas também para os policiais, que mesmo que tenham alguma informação teórica, muitas vezes vão atuar em ambientes nos quais precisam lidar com a violência de um suicídio. 
A falta de formação na faculdade de psicologia é vista com grande indignação pelos colaboradores e a esposa de um deles, que está no primeiro ano da faculdade de psicologia, ainda não tem aulas formais, no currículo sobre o tema.

Os colaboradores sentem que a forma como o assunto é tratado nas universidades é muito precária, só a pessoa que se interessa e vai atrás do conhecimento sobre prevenção é que consegue, sendo a maioria das vezes fora do currículo escolar.

Um dos colaboradores diz que quando procurou não achou cursos específicos sobre suicídio e diz que é quase impossível encontrar cursos voltados para o tema.

Para os colaboradores, o contato muda, inclusive se a pessoa trabalha com essa demanda e faz que busquem o conhecimento. Procuram o saber pela demanda que tiveram ou pelas situações que passaram.

\subsubsection{Fazer}

O FAZER está dividido em prevenção e outros tipos de trabalho. Esta categoria traz algumas visões e possibilidades de prevenção do suicídio.

Durante o grupo focal os colaboradores questionaram-se quem faz a prevenção, de quem é a responsabilidade, se é da sociedade ou se está nas mãos da pessoa que pensa em matarse, porém não chegam a um acordo sobre isso. Pensam que é importante que haja a conscientização das consequências do ato suicida, para que as pessoas entendam o resultado dos atos que estão pensando.

Para um dos colaboradores é preciso ter cuidado para não criar uma paranoia em detectar possíveis suicídios, para que as pessoas não achem que qualquer coisinha pode ser sinal de que a pessoa vai cometer suicídio.

No entanto, percebem a prevenção como multifatorial, mesmo que haja uma questão de saúde mental envolvida, eles têm certeza que o suicídio precisa ser trabalhado considerando diversos fatores e locais.

A prevenção em escolas foi citada como ponto importante e mesmo que não seja focada em suicídio, pode ensinar crianças a identificarem sentimentos. A prevenção pode ser realizada para levar a escola para além da teoria, das matérias teóricas do currículo escolar e ensinar como se cuidar e como cuidar do outro.

Um ponto interessante foi a grande discussão gerada sobre a profissão com o maior

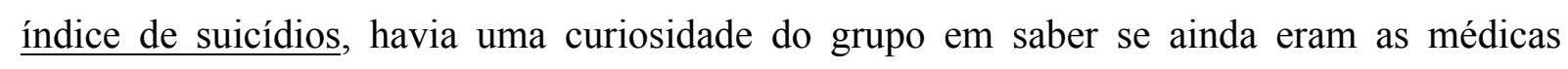
anestesistas e o porquê ocorria com elas. Um dos colaboradores presente confirmou que eram 
e levantou a hipótese de que era pelo fato delas vivenciarem muito a morte e terem fácil acesso às drogas.

Outros tipos de trabalho são compostos por sugestões de outros trabalhos que possam ser desenvolvidos em conjunto com a prevenção.

Para o grupo focal, os trabalhos podem começar com pequenos focos para assim, com o tempo, haver vários outros focos, o importante, segundo eles, é que esses focos encadeiemse como um processo, uma coisa de cada vez.

Outro fato citado é de haver pessoas buscando ajuda com eles, o que mostra que as pessoas começam a buscar auxílio com os sobreviventes, talvez por eles terem vivenciado um suicídio, tornando-se pessoas que podem ajudar por ter vivido mais de perto a situação.

Outra sugestão é a de cidadãos fazendo mudanças, pois, segundo o grupo, a partir de pessoas serem sensibilizadas pelos grupos de acolhimento, que na visão deles, deveriam ser semanais, seria possível fazer uma parceria entre os sobreviventes, a sociedade e os cidadãos para fomentar discussão e fazer mudanças.

Falar de suicídio com adolescentes e crianças é uma possibilidade de trabalho sugerida por uma colaboradora inspirada no trabalho do Nick Vujicic, pois ele palestra sobre bullying, além de sua experiência com crianças e adolescentes, sendo muito bem recebido por elas.

Para um colaborador, outro trabalho necessário é haver cuidado na informação e na comunicação com os enlutados, pois a forma como essa comunicação é feita, seja pela polícia, médicos, amigos e com a sociedade em geral, pode aumentar ou diminuir o risco de suicídio ou de sofrimento emocional nos enlutados.

Um dos colaboradores elabora seu luto sendo ativista como forma de passar pelo seu processo e aumentar a prevenção do suicídio na sociedade. Acredita que se os sobreviventes abrirem mão do anonimato e falarem abertamente sobre suicídio para ajudarem os prováveis suicidas "a se atinarem do mal que podem fazer ao destroçar famílias e as pessoas que eles amam" (colaborador 7,) poderiam prevenir suicídios.

Segundo o grupo, é possível usar a dor para ajudar aos outros, como um dos colaboradores, que abriu um Instituto de Prevenção do Suicídio após perder a filha e hoje ajuda muitas pessoas. Ele fala que nunca pensou em nada relacionado ao suicídio até o acontecimento com sua família. Outra colaboradora diz que se sente à vontade para ajudar aos outros, após ter tido a experiência de perder uma pessoa para o suicídio, percebendo que ao abrir-se os outros buscam ajuda, isso mostra como os sobreviventes podem ser fonte de cuidado e ajuda, a partir do momento em que se entendem prontos para isso. 
A questão da religião/espiritualidade também foi um tópico debatido e que sensibilizou alguns colaboradores. Essa sensibilização apareceu na forma de falar longamente sobre o assunto, como tema importante para alguns membros do grupo focal. Percebem que as religiões ajudam muitas pessoas em áreas diversas e que cada uma das religiões ajuda de alguma maneira. Para uma das colaboradoras a religião previne suicídios, pois acaba sendo um motivo mais forte que os familiares para a pessoa não se matar. Outra colabora acha que profissionais precisam estar à disposição de quem precisa, incluindo padres e líderes religiosos.

Outra colaboradora, que afirma ser muito católica, conta que se decepcionou com o padre, pois frequentava a igreja católica de modo "fervoroso", conta que um dia em que estava com uma tristeza muito grande, precisou falar com o padre e não foi bem atendida por ele, o que a deixou profundamente aborrecida por não ser acolhida pelo padre como esperava. Outro colaborador relata que teve grande influência positiva da espiritualidade, pois o instituto que tem hoje foi traçado para sua família por meio de cartas psicografadas. Assim podemos pensar na importância e abrangência da religião na vida das pessoas.

Uma das colaboradoras afirma, entretanto, que assim como na disciplina de religião obrigatória nas escolas católicas, se a pessoa não se identificar com o que está sendo falado vai tratar aquela informação de qualquer jeito. Da mesma maneira que aulas sobre prevenção do suicídio, se não fizerem sentido para quem assiste é só mais uma obrigação.

Várias sugestões sobre intervenções na era digital foram debatidas pelo grupo focal. Uma das sugestões foi aparecer um aviso de ajuda ao ser rastreado na internet se alguém digitar "como se matar" nas páginas de busca ou redes sociais. Segundo uma das colaboradoras, esse aviso poderia levar ao CVV, por exemplo. Dessa maneira, seria possível usar o mundo digital a favor da prevenção. Outra sugestão dada pelo grupo focal foi a de quando as pessoas procurassem "como se matar" ou "como tomar chumbinho", por exemplo, não aparecer a resposta para certas buscas na internet $\mathrm{e}$ as pessoas serem direcionadas para sites de ajuda. Se a pessoa procura formas de se matar nesse meio é porque tem alguma ligação com o tema, ninguém vai fazer essa busca sem motivo.

A sugestão de uma das colaboradoras foi a de usar o rastreamento que, em sua visão, é tão utilizada com propósitos de vendas e sugestões de produtos, que poderiam usar tal ferramenta para prevenir o suicídio. Ela citou o exemplo do Google e do Facebook, que usam o rastreamento para outros fins, para ela, pelo fato de estarmos em uma era digital e a maioria das pessoas terem acesso ao celular, esse meio poderia ser utilizado a partir de algumas palavras-chave ou da frequência dessas buscas, esta seria uma maneira de atingir pessoas que possam pesquisar como se matar. 
Outro ponto trazido pelos colaboradores foi que trabalhos científicos são um começo, assim como essa pesquisa, para ajudar a surgir ideias de como abordar o assunto da conscientização do suicídio.

Um dos colaboradores falou em relação aos planos de saúde, sugeriu a implantação de prevenção do suicídio em planos de saúde, assim como muitos planos que já tem programas de prevenção na área cardíaca, por exemplo, poderiam fazer o mesmo com o suicídio. Ele aponta que mesmo que os planos de saúde tenham como objetivo um interesse nos custos, essa proposta poderia ser implementada, ajudando muitas pessoas.

Talvez os planos de saúde possam ser um dos canais de entrada. Talvez, mostrando que atividades de prevenção podem ter uma influência direta na saúde dos segurados e por consequência na redução dos custos do plano. Indo por este caminho, acredito que é possível uma abertura para um fator multiplicador de ações, com recursos vindos dos próprios planos e com benefício para muitas pessoas (Colaborador 9).

\subsubsection{O cuidar}

A categoria CUIDAR foi pensada por tratar-se de um ponto fundamental na AÇão, que é relacionada ao cuidado e à forma de tratamento. Não adianta somente falar mais sobre o assunto se isso não se traduzir em ações conscientes. Essa categoria é composta pelas subcategorias: tratamento; depressão; grupos de apoio; sobre os encontros e CVV.

É uma compreensão das questões envolvidas no cuidar e de sugestões para que o cuidar seja mais completo.

Tratamento é composto pelos conceitos dificuldade de achar apoio adequado, acesso às formas de tratamento, Despreparo do psiquiatra, Tratamento não é garantia, mas deveria ser direito, Hospitalar e Clínicas sem condição.

Os colaboradores relatam as dificuldades de achar apoio adequado, para eles e para seus familiares, como da própria pessoa achar o que precisa.

Hoje eu encontrei, mas a gente sim ... o meu irmão passou por uma ... meu irmão estava desesperado procurando uma forma de sair daquilo e simplesmente não conseguia encontrar, não conseguia encontrar (Colaborador 8).

Para uma das colaboradoras, não existem clínicas para o tratamento de dependência química para adolescentes, em sua experiência é impossível achar clínicas em condições de atendimento. Sabemos que existem clínicas pelo Sistema Único de Saúde (SUS), mas essa não foi sua vivência. 
Para o grupo focal, há buracos que ninguém se responsabiliza, referindo-se à falta de preparação e de cuidado para os profissionais e para a sociedade lidarem com os enlutados.

Outra questão levantada foi haver uma existência maior de ajuda em cidades maiores, como São Paulo, porém para quem é de outras cidades, há dificuldade maior de encontrar serviços e informação.

O grupo citou a importância de ter locais com trabalhos especializados, como o do Vita Alere para o acolhimento de enlutados e pessoas com comportamento suicida.

$\mathrm{O}$ acesso a formas de tratamento foi criticado pelo grupo focal, mesmo que haja uma percepção de que há mais serviços disponíveis hoje, eles ocorrem em sua maioria nos grandes centros urbanos.

Para eles, é preciso mudar o sistema de saúde pela dificuldade em encontrar alguém que acolha e ouça os enlutados e as pessoas com comportamento suicida. Pensam que o acesso ao tratamento psicológico é mais fácil em termos de aceitação das pessoas que precisam ir ao psicólogo é mais "aceitável” para pessoas com comportamento suicida que ir ao psiquiatra.

Para o grupo focal, o sistema CAPS é deficiente, pois não dão conta da demanda. $\mathrm{O}$ colaborador que tem um Instituto de Prevenção do Suicídio diz que mesmo com quatro psicólogas trabalhando, a demanda só aumenta, pois têm recebido pessoas que os CAPS enviam para atendimento por não abarcarem tal demanda.

O grupo pensa que é fundamental haver um local onde as pessoas conseguissem ser atendidas, pois muitas pessoas têm dificuldade de pagar o tratamento, por ele ser caro e elas não conseguirem arcar com as despesas e não encontrarem atendimento gratuito disponível. Para eles, os tratamentos não são acessiveis financeiramente e as faculdades de psicologia e psiquiatria deveriam abrir mais vagas para atendimento do público, pois assim ajudariam bastante a mudar essa situação.

Um ponto polêmico e levantado pelos colaboradores foi que o aumento de conscientização poderia gerar aumento de demanda de atendimento, que não tem para onde encaminhar, tendo em vista que mesmo que as pessoas aceitem e/ou peçam ajuda não há para onde encaminhar essa demanda.

Colaboradores relatam situações sofridas pelo despreparo do psiquiatra, para eles há uma grande dificuldade de achar alguém preparado, que saiba lidar com a pessoa com ideação suicida e consiga orientar a família. Uma das colaboradoras conta que, por questões na família, o psiquiatra é considerado o médico da família e que demoraram muitos anos para achar um em quem confiassem. Relata que já ouviu alguns absurdos do psiquiatra. 
Mas a gente ouviu muitos absurdos ao longo da vida e uma das coisas é aquela coisa: 'eu estou aqui para tratar a vida e não para tratar a morte'. Então ele já fecha aí uma porta de que a minha educação e minha formação foi feita [pausa] se você está interessada em morrer, não fale isso comigo (Colaborador 8).

Esse despreparo também pode ser observado em residentes de psiquiatra, segundo o relato de uma das colaboradoras:

E eu infelizmente já vi. Eu presenciei muito. E isso acontece com muita frequência tá. Já trabalhei [pausa] esse hospital que eu trabalho hoje já é o quarto hospital que eu trabalho e por diversas vezes eu fui chamada para atender pacientes com tentativa de suicídio com uma fala assim, do profissional: 'A gente está aqui preocupada em salvar a vida e tem um querendo fazer graça'. Eu já escutei isso diversas vezes e eu participei de um grupo de estudos de prevenção de suicídio com um médico lá da minha cidade, um psiquiatra e ele falou: [nome da colaboradora] 'Infelizmente lá no PS a gente escuta isso todo dia dos meus residentes. Os meus residentes falam isso'. 'Agora eu vou te ensinar como se suicida, porque você fez tudo errado'. Ele falou: 'Eu tive que chamar o residente meu e falar: 'não, pode parar. Está tudo errado'. Porque o residente de psiquiatria tem essa fala e infelizmente acontece em alguns serviços sim (Colaborador 6).

O grupo focal entende que tratamento não é garantia, mas deveria ser direito, ou seja, ele não garante que a pessoa não vá morrer por suicídio, porém a pessoa deveria ter o direito de ter acesso aos tratamentos. Para uma das colaboradoras, mesmo que o filho escondesse os pensamentos suicidas da psicóloga, ela percebe como um fator positivo o fato de que eles conseguiram acesso ao tratamento psicológico, que ela havia sido orientada por uma psicóloga como proceder com ele.

O tratamento hospitalar a pessoas que tentaram o suicídio foi um assunto que gerou grande debate entre os colaboradores. A maioria aponta que há uma distinção no tratamento de tentativa de suicídio em hospital com relatos de situações em que isso ocorreu. Essa distinção foi citada pela experiência de alguns enlutados e pela funcionária de um hospital.

Ela tinha tomado uma caixa de remédios para a pressão do meu cunhado, então tinha que fazer uma lavagem com carvão, né? E as enfermeiras [pausa] eu nunca vi aquele tratamento lá no [nome de um hospital], mas assim, super grosseiras, ela passando mal, ela vomitando e elas lá, nem aí injetando [o medicamento] O médico saiu com cobertor para ir dormir, largou ela lá [pausa] porque entendeu [pausa]. Subiu muito, muito rápido e ela gritando que ia morrer e eles continuavam. Eu falava: 'Para, pelo amor de Deus'. Aí eles pararam e aí viram que a pressão tinha subido muito realmente, mas ela, assim, foi uma questão disso daqui. Eles parecem que não acreditavam nela, no que ela falou: 'Minha cabeça está explodindo, eu vou morrer', né? e continuaram. Então, com certeza, ela foi bem maltratada, assim, a gente foi no [nome de um hospital]. A minha mãe enfartando foi tratada de um jeito e a minha irmã totalmente de outro. E eu mesma já fiquei internada lá várias vezes também, outro tipo de tratamento e outra coisa que aconteceu foi que a pressão dela foi 
baixando, foi baixando, foi baixando muito, e estava acho que 4X2, assim, uma coisa que estava parando e eu toda hora ia falar: 'Olha, a pressão dela' e elas: 'Ah, não, a gente deu não sei o que lá e ela vai subir' (Colaborador 11).

Para um dos colaboradores, que é médico, não há distinção no hospital, pois quem está mais grave será atendido, não há preferência, seja qual for o motivo, o mais grave será atendido primeiro. Ele relata sobre a brutalidade da lavagem gástrica, pois, na sua visão, a equipe precisa ser rápida para salvar e o procedimento é violento. Ele finaliza falando que a lavagem gástrica não é um procedimento médico, que os responsáveis são da enfermagem, portanto, acha que não pode generalizar os atendimentos, pois podem haver enfermeiros que fazem essa distinção. Ele complementa que há diferenças no papel e nas sensações de cada um, pois talvez "tenha uma diferença, aí, entre a forma como o enfermeiro vê o que ele está fazendo, e a forma como a família sente que aquilo está sendo feito, a necessidade da família também” (Colaborador 5).

Um dos colaboradores relata ter sido bem atendido no hospital desde o momento que sua filha foi internada, que sente que eles fizeram tudo o que podiam para salvá-la.

Para o grupo a importância está no olhar, que há uma diferença entre o procedimento e o olhar, que a questão principal não é a forma do procedimento, mas a pessoa que tentou o suicídio ser tratada de forma empática e acolhedora.

Uma das colaboradoras chama a atenção para as clínicas sem condição, pois mesmo que a pessoa tenha acesso ao tratamento, tais clínicas não têm condições.

\footnotetext{
As pouquíssimas que a gente encontrou a gente não tinha condição de manter e ele passou por duas: uma teve um incêndio que morreram acho que sete pessoas, acho que eu te falei disso e na outra ele se matou né?... Então de três clínicas, uma a gente não tinha condição de pagar, uma ele disse que estava sendo agredido e a agente até [pausa] eu até duvidei, mas depois que teve um incêndio e as pessoas morreram e eu vi o depoimento de pessoas que estavam lá e que relataram tudo o que ele falava para a gente e na outra ele não era cuidado né? então não tem tratamento (Colaborador 11).
}

Para ela, seu sobrinho deu um grito que não foi ouvido e não foi levado em consideração pela clínica, pois, para ela, a clínica ignorou a comunicação suicida quando ele falou que pensava em matar-se, sendo deixado sozinho por horas no quarto.

Ter bons lugares pagáveis para tratamento faz-se necessário para essa colaboradora, para ela, o governo precisa começar a pensar nessa questão de saúde pública e ter hospitais e tratamentos para quem não tem condição de pagar. Além de locais decentes onde adolescentes possam ser tratados por depressão e dependência química, pois esta é uma opção que não existe hoje na experiência dela. 
A depressão pode ser vista em várias categorias ao longo da análise, porque apresenta diferentes dimensões sobre o tema. Em vez de falar sobre a depressão de uma vez só, consideramos mais didático que estivesse dividida pelas várias características que apresenta. Dessa maneira, a depressão no tema AÇÃO é dividida nos conceitos depressão é doença e as consequências da depressão.

O tema AÇ̃̃O traz a depressão voltada ao cuidar, as facetas relacionadas ao tratamento e consequências da depressão.

Para o grupo focal, depressão é doença e lidar com ela envolve compreender as dificuldades de lidar com alguém com depressão, pois muitas vezes por mais que queiram ajudar, a pessoa recusa, não quer ajuda, dá pistas que está bem e de repente fala que está mal, tal ambivalência torna o processo muito difícil, faz que os colaboradores sintam-se de "mãos atadas" em alguns momentos.

Uma das colaboradoras revela que às vezes sente a depressão como um mundo inabitável, onde é muito difícil de penetrar no universo daquela pessoa.

Isso os leva a se sentirem impotentes, pois percebem que é muito difícil olhar para a pessoa autodestruir-se e "você ficar de camarote porque ela não deixa você fazer nada" (colaboradora 2), depois ela pede ajuda e quando você vai ajudar, ela recua.

Outra colaboradora diz que hoje eles entendem que existe um limite, pois sentem que não havia mais nada que eles pudessem ter feito, que eles viram a depressão evoluir e tinham consciência do que poderia acontecer, mas que tudo que eles poderiam ter feito, eles fizeram.

Houve um debate no grupo, a partir da fala do colaborador que é médico, que insistiu que quem trata depressão é o profissional. O grupo concorda com o que ele fala, porém defendem a ideia de que querem levar para o profissional, pois não querem tratar sozinhos ou em casa, mas há uma dificuldade da pessoa aceitar esse tratamento. Mesmo que ajuda seja oferecida, eles não aceitam ajuda, não querem ir a psiquiatras ou a psicólogos.

Uma das colaboradoras relata que se sente abençoada por não ter depressão, pois hoje entende a profundidade dos sentimentos negativos que a pessoa com depressão apresenta.

Para o grupo focal, uma das consequências da depressão é que ela não deixa ver outras soluções, impede que as pessoas percebam outros caminhos, além do suicídio, por isso as pessoas que estão com depressão, não aceitam ajuda.

Os grupos de apoio foram uma forma de cuidado citada várias vezes pelo grupo focal. Os grupos são um local onde sou acolhido e acolho, onde há o encontro dos pares e pessoas vivendo histórias, sofrimentos, angústias e indagações parecidas. Eles sentem que entraram no 
$\underline{\text { mundo dos sobreviventes, }}$, isso torna o grupo um local de pertencimento e é o que os une nessa pesquisa. Sentem como um lugar para falar e honrar a memória:

\footnotetext{
Para mim, um local para falar sobre o que aconteceu, sobre como estava me sentindo, ver como outras pessoas foram sobrevivendo e principalmente falar sobre a minha filha, como ela vivia, sem julgamentos. Para a família sobrevivente este lugar de fala, em uma sociedade que ainda é muito preconceituosa com a pessoa que morre por suicídio e com a família, é muito importante. Para a pessoa que faleceu, um lugar de fala por ela, poder falar sobre sua vida, suas memórias, suas histórias, seus projetos de vida, sobre seus sonhos (Colaborador 1).
}

Os colaboradores concordam que os grupos deveriam ser mais frequentes, com a oferta de grupos semanais, pois para quem está com uma dor tão viva, ela não deveria esperar um mês para falar de sua dor.

Um dos colaboradores relata que é difícil participar de grupos, pois vive conflitos nos grupos, acaba comparando sua história com a dos outros e mesmo sabendo que iria encontrar opiniões diferentes, fica pensando se deveria ter realizado mais alguma para evitar o suicídio que ocorreu em sua história.

Falar que vai a grupos de suporte na sociedade, algumas vezes pode fazer que amigos falem para não se envolver com esses grupos, como se eles fossem "bobagem" ou não ajudassem em nada.

É comum nos colaboradores o sentimento de que se faz bem para mim fará bem para o outro, então sempre convidam novas pessoas para o grupo respeitando o seu livre arbítrio, porém percebem que as pessoas não querem participar mesmo sem terem experienciado se o grupo é bom ou não para elas.

Há uma comparação com outros grupos de apoio, como os Alcoólicos Anônimos, que tem o ANON, que é voltado para os parentes e familiares das pessoas com alcoolismo e ocorre com uma frequência maior e em mais locais.

O grupo focal discutiu que pessoas com comportamento suicída não conhecem os grupos de apoio, não sabem que existem grupos que possam frequentar e se soubessem e frequentassem, poderiam se sentir bem e acolhidos. Acham fundamental divulgar os grupos de apoio, pois é de extrema importância as pessoas saberem sobre os grupos. Sugerem que seja criado um protocolo de encaminhamento para grupos pelos profissionais de saúde para aqueles que precisam. Segundo um dos colaboradores, que soube por meio de um enlutado psicólogo sobre a existência dos grupos, disse que se não me falassem dos grupos ia ficar ao "Deus dará". 
Assim, os grupos facilitariam a identificação de um grupo de pertencimento formado por pessoas que entendem da dor que é ter ideação suicida ou perder alguém para o suicídio.

Sobre os encontros o grupo falou sobre as sensações e sobre os sentimentos dos colaboradores ao participarem dos grupos focais para a pesquisa. Eles relatam diversas sensações, um deles ficou impactado com as diferentes situações descritas e ficou mexido com a reunião anterior, porém conversou com a pesquisadora, sentindo-se bem depois. Há relatos de sentir-se bem ao desabafar e de gostar de falar sobre o assunto. Todos os colaboradores agradeceram por participarem do trabalho de pesquisa.

Um dos colaboradores fala que

\begin{abstract}
[se] coloc[a] à disposição para ajudar no que mais estiver ao meu alcance ... fico à disposição para conversar por celular ou pessoalmente. Agradeço muito todo o apoio e acolhimento que tenho recebido durante meu processo de elaboração do luto. Tem sido um processo transformador poder colocar um pouco de luz num tema que para mim foi tão difícil por tanto tempo. Fico feliz em poder retribuir uma fração de tudo o que recebi (Colaborador 9).
\end{abstract}

As citações sobre o $\mathbf{C V V}$ aparecem em algumas categorias distintas da pesquisa, isso acontece por que em cada lugar diferente que ela se encontra, o foco ser em uma dimensão diferente do mesmo tema.

Os participantes do grupo focal estavam com várias dúvidas sobre o papel do CVV e como ele funciona, que a sociedade em geral também deve ter essas questões. Comentam que há um desconhecimento do CVV pela sociedade em geral. Quando começam a debater para onde poderiam encaminhar as pessoas, lembram-se desse lugar, mas percebem que $C V V$ não é terapia, nem pronto-socorro que ofereça atendimento psiquiátrico. Pela explicação de um dos colaboradores, percebem que é para crises emocionais e conta com atendimento sigiloso, os voluntários só têm acesso às informações da pessoa se ela oferecer, mesmo que esteja falando que vai matar-se naquele momento, eles não podem enviar alguém para ajudar se ela não pedir.

\title{
5.3.6 O semear
}

O SEMEAR foi escolhido como última categoria de análise, pois representa os facilitadores, desejos e sugestões que os colaboradores têm para o aumento da consciência pública. 
Os facilitadores, segundo os colaboradores, têm relação com a humanidade passar por mudanças e hoje ser possível ver muitos cursos de autoajuda e pessoas mais humanas e preocupadas, buscando o resgate do eu.

\begin{abstract}
A humanidade está passando por isso. Eu acho que a gente se perdeu e a gente tá tentando resgatar o EU e talvez quando a gente voltar a ser mais humano, se importar um pouco mais em como a gente se relaciona, talvez ajude, né? porque, às vezes só um: 'Oi, tudo bem?', um 'Obrigada' ou um 'Como você está hoje?' Às vezes isso, pronto, já fez o seu dia, né? Ou alguém te manda uma mensagem você fala: 'Ah! É por isso que vale à pena viver', entendeu? São as diversas formas de amor. Então, eu acho que quando a gente voltar a resgatar o eu, talvez isso, né? ajude a gente acolher as pessoas porque acho que não vai ter profissional pra todo mundo todos os dias, mas se cada um fizer um pouquinho e ter boas relações e aí é assim, é difícil, a gente trabalha com isso todo dia isso vai ajudar também (Colaborador 10).
\end{abstract}

São formas de demonstração de cuidado e de sentir-se amada por outros e amar as pessoas no meio em que convive.

As redes sociais foram citadas como um salto para mudança, pela facilidade de se trabalhar com a informação e pelo impacto nos dias atuais, incluindo jovens a pessoas de meia idade.

A busca de propósito de alguns jovens e sua facilidade de engajamento são questões trazidas pelas novas gerações e que podem facilitar o aumento da conscientização.

Os desejos do grupo focal são relacionados ao desejo de ouvir coisas coerentes, na esperança de aumentar as falas sobre a prevenção do suicídio, tornando-se um evento comum, e no sonho de que se fale mais sobre o assunto.

\footnotetext{
Gostaria que fosse tratado como um problema de saúde que potencialmente afeta a população, independente da condição social. Gostaria que fosse tratado como causa decorrente de doença e não como um ato individual de coragem ou de covardia. Gostaria que fosse tratado com humanidade, compreensão e respeito, no sentido de que se troque o julgamento pela reflexão do que cada pessoa pode fazer a respeito, partindo do lugar comum para uma mudança de atitude (Colaborador 1).
}

$\underline{\text { Evoluir em coisas básicas e no acolhimento para que haja acolhimento dos que ficam } \mathrm{e}}$ dos sentimentos do suicida também foram citados.

Eles finalizam com a sugestão de entrevistar pessoas que tentaram o suicídio: "porque eu acho que ele tem respostas de uma perspectiva bem, talvez, assertiva, né? com relação a muitos dos pontos" (Colaborador 10).

Para então saber de quem tentou o suicídio, 
porque elas desistiram ou quem são referencias para elas ou, por exemplo, quem elas ouvem [pausa] O que te ajuda, aonde você vai, quais são as mídias que te atingem, o que você ouve, o que você acha do tipo 'ah, isso é uma porcaria, só tão falando porque tão cumprindo o protocolo’ (Colaborador 10).

O tema AÇ̃̃̃ trouxe muitas possibilidades de atuação frente ao aumento de consciência, à diminuição do tabu e do estigma e da necessidade de cuidado com pessoas com comportamento suicida. Demostra que existem muitas formas que vão além das campanhas e nos ajuda a refletir sobre a amplidão de intervenções que podem ser desenvolvidas. 


\section{A TEORIA FUNDAMENTADA NOS DADOS}

Um dos processos mais difíceis e provavelmente o mais determinante dentro da teoria fundamentada nos dados é a codificação seletiva (selective coding), que significa, segundo, Strauss and Corbin (2008) descobrir a essência ou núcleo do fenômeno investigado por meio do tema central, dando a ele um poder explanatório de reunir em si todas as categorias encontradas. Este tema central precisa relacionar-se com todos os outros temas e categorias que foram desenvolvidas previamente.

A descoberta da nossa categoria central surgiu no meio da escrita da análise dos dados, em que, para escrever, continuávamos revendo, questionando e comparando os dados por meio da cansativa reorganização dos códigos, conceitos, categorias e releitura dos memos. Numa tarde, ao relermos um dos códigos in-vivo, ou seja, um código que foi feito usando as palavras de um colaborador, compreendemos que havíamos achado o tema central, aquele que resume e explica conceitualmente o aumento da consciência pública na prevenção e posvenção. Ficamos um bom tempo refletindo, sentindo e raciocinando sobre a força desse código e percebemos que ele representava a categoria central.

Para ter certeza que havíamos realmente encontrado o fenômeno central, utilizamos os critérios propostos por Strauss citado em Strauss and Corbin (2008, p. 146) para escolher a categoria central, são eles:

1. Ela deve ser central, ou seja, todas as outras categorias importantes podem ser relacionadas a ela.

2. Deve aparecer frequentemente nos dados. Isso significa que em todos os casos, ou quase todos, há indicadores apontando para esse conceito.

3. A explicação que resulta da relação das categorias é lógica e consistente. Os dados não são forçados.

4. O nome ou a frase usada para descrever a categoria central deve ser suficientemente abstrata, de forma que possa ser usada para fazer pesquisa em outras áreas substanciais, levando ao desenvolvimento de uma teoria mais geral.

5. À medida que o conceito é refinado analiticamente por meio da integração com outros conceitos, a teoria ganha mais profundidade e mais poder explanatório.

6. O conceito consegue explicar variações e também o ponto principal nos dados; ou seja, quando as condições variam, a explicação ainda é válida, embora a forma na qual o fenômeno seja expresso possa parecer um pouco diferente. Devemos ser capazes de explicar casos contraditórios ou alternativos em termos dessa ideia central .

A partir desses critérios, construímos o modelo teórico (Diagrama 11) utilizando o conceito de paradigma (condições que influenciam o fenômeno, a interação necessária para que haja mudanças e as consequências advindas dessa interação) da TFD que contempla essa 
relação entre as categorias e os temas encontrados na pesquisa. Após a apresentação do tema central, que emergiu dos dados, faremos a discussão da análise, incluindo a literatura existente e apresentando nossas sugestões e questionamentos para o aumento da consciência pública.

\subsection{O TEMA CENTRAL}

Portanto, após coletar os dados, transcrever, codificar, categorizar, analisar, voltar a esses dados inúmeras vezes para "escutar", "sentir" e "compreender" o que eles mostravam, e em conexão com o profundo conhecimento trazido pelos colaboradores a respeito de sua experiência relacionada ao tabu e do aumento da consciência na prevenção e posvenção, chegamos à construção da teoria fundamentada nos dados por meio do tema central: $\mathbf{O}$ SUICÍDIO É UM PROBLEMA DE TODOS: A CONSCIÊNCIA, A COMPETÊNCIA E O DIÁlOGO NA PREVENÇÃo E POSVENÇÃo DO SUICÍDIO. 


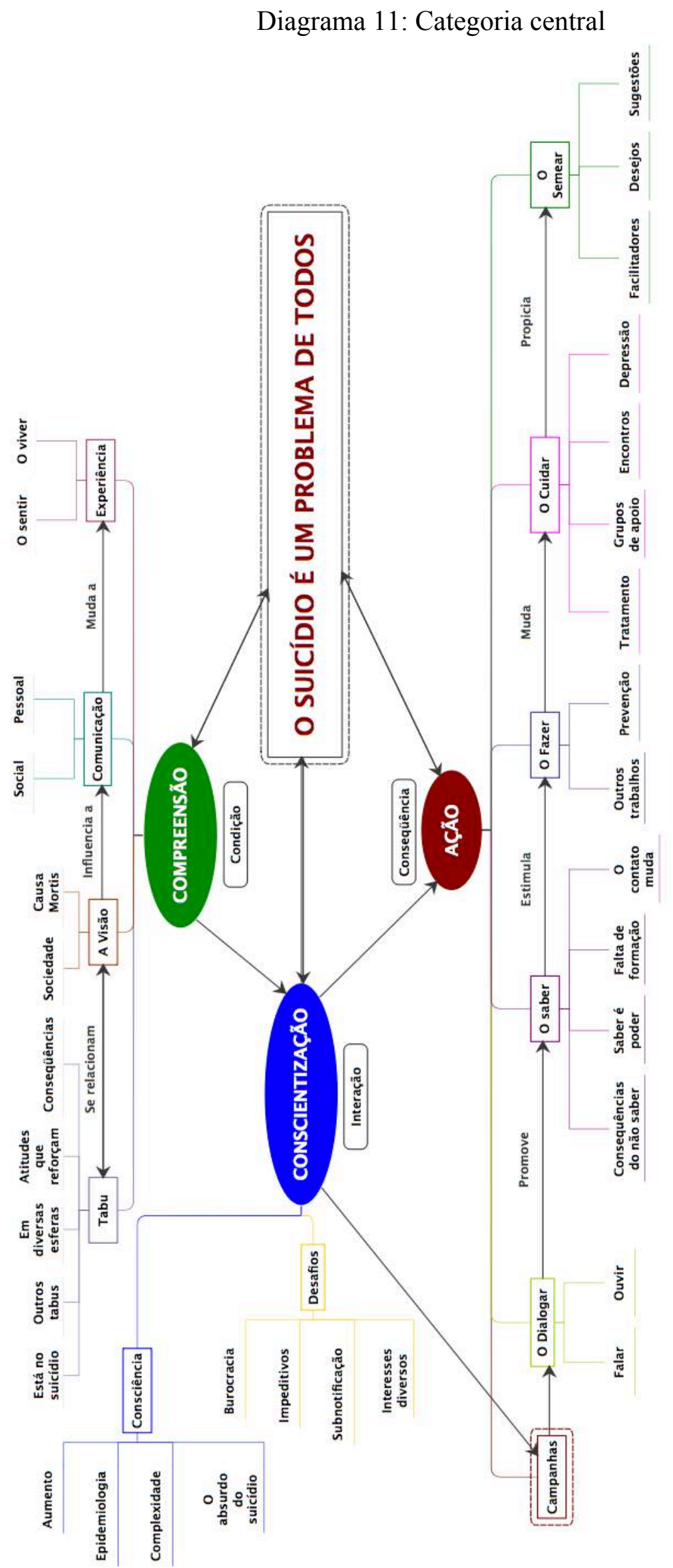

Fonte: produção do próprio autor (2018) 
Compreendemos que aumentar consciência pública não é só prevenir suicídio, é mudar a forma como as pessoas encaram o assunto e tratam umas às outras, é mostrar que precisamos cuidar em vez de julgar. É um processo que caminha para além da prevenção, trata-se de uma conscientização com informação, conhecimento e sentido. Conscientizar não é somente falar mais sobre o assunto, é ter a postura, transformar isso em atos, ter a consciência da problemática, o acolhimento, o diálogo e a ação conjunta. Assim, há uma conscientização, uma capacitação e um conversa sobre o assunto. Torna-se algo que tem envolvimento. Então, acontece uma tomada de consciência, é ativo, envolve receber e aceitar.

Por esse motivo que é conscientização, pois implica em ação, tendo em vista que consciência sem ação fica presa nas ideias. Já ação sem consciência e sentido é um fazer automático. A consciência precisa ser afetiva e efetiva. Cons-ciência e com sentido. Uma morte que não é sentida transforma-se numa dor que não mobiliza.

Por isso que as categorias fundem-se a partir da COMPREENSÃO, da CONSCIENTIZAÇÃO e da AÇÃO a fim de que a sociedade e as pessoas possam integrar que o suicídio é um problema de todos.

Portanto, a COMPREENSÃO é condição para que as pessoas entendam o que é suicídio, percebam o TABU que ainda está velado no tema e atinge diversas esferas, gerando consequências e atitudes que acabam reforçando o tabu. Dessa forma, o TABU e a VISÃO relacionam-se, pois ambos complementam-se a partir da visão que a SOCIEDADE tem sobre o suicídio e das reações à CAUSA MORTIS.

A VISÃO por sua vez, influencia a COMUNICAÇÃO, que, por meio da comunicação pessoal e social, pode-se mudar a experiência do sentir e do viver, seja pelas pessoas que passaram por suicídio ou não.

A COMPREENSÃO do fenômeno traz a necessidade de haver a CONSCIENTIZAÇÃO e esta torna-se a interação necessária para gerar mudança e é o que precisa acontecer para que a COMPREENSÃO e a AÇÃO possam desenvolver-se e aperfeiçoar-se. A CONSCIENTIZAÇÃO é afetada pela TOMADA DE CONSCIÊNCIA que pode ser gerada a partir do conhecimento do aumento dos casos, da epidemiologia, da complexidade envolvida e do absurdo do suicídio.

Atualmente, para muitas pessoas, o suicídio é ficção até que ele acontecer. Dar voz a essa realidade muda, transforma, previne e porque não, cura o preconceito e o tabu.

Os DESAFIOS encontrados para que a CONSCIENIZACAO ocorra são relacionados à burocracia, aos impeditivos, à subnotificação e aos interesses diversos que se relacionam com a vontade ou a falta dela, de haver um aumento nas falas sobre o suicídio. 
Assim, a AÇÃO transforma-se em consequência da CONSCIENTIZAÇÃO, para que a mudança seja tanto pessoal como da sociedade. As campanhas ajudam no aumento da CONSCIENTIZAÇÃO e compõem um dos passos para que haja a AÇÃO. As campanhas então levam ao diálogo, que acontece na interação, na relação entre o falar e o ouvir, promovendo um aumento do saber.

O DIÁLOGO, compreendido pelo movimento entre o falar e o ouvir, requer interação e deseja Presença (para ouvir), assim ele proporciona o OUVIR BENDITO e o FALAR BENDITO, bendito porque há o encontro e o compartilhamento de significados no espaço da PAUSA ATIVA, em que o ATO DIALÓGICO é a postura de ir aonde o outro está e facilita que essa comunicação, com liberdade e com sentido, ocorra.

O saber está relacionado com o conhecimento e a falta dele leva a consequências do não saber, assim sendo, saber é poder e não podemos mais aceitar que haja falta de formação, principalmente nas faculdades das áreas da saúde e educação. SABER que o suicídio existe é diferente de estar consciente de sua existência e de todas as esferas que ele atinge. Ter contato com o suicídio muda, transforma aquele que trabalham, que sentem e que perdem alguém para o suicídio.

O fazer é estimulado pelo saber. Ao ter o conhecimento necessário, os profissionais e a sociedade como um todo podem propor diversos outros trabalhos relacionados à prevenção e à posvenção, como o uso das redes sociais nessa tarefa.

Então, chegamos ao cuidar, a esfera do contato direto com aqueles que foram afetados pelo suicídio e aqueles que serão. O fazer muda o cuidar por proporcionar uma cadeia de ações, que são expressas por meio do cuidado, do tratamento e do acolhimento. O cuidar é expresso pelo tratamento, grupos de apoio e atenção à depressão. Participar dos encontros do grupo focal também faz parte do cuidar, cuidar de si e cuidar para que a situação atual possa mudar.

O cuidar propicia o semear. Semear esperança, cuidado, desejo de mudança, sugestões de pesquisas e aproveitar os facilitadores encontrados na geração atual para fazer tudo isso acontecer.

Diante disso, é necessário não só aumentar a consciência pública, mas sim criar uma consciência afetiva, que ligue as pessoas ao fenômeno do suicídio.

O SUICÍDIO PASSA A SER UM PROBLEMA DE TODOS, afeta a CONSCIENTIZAÇÃO e é gerado por ela. Ele pode ser expresso pela AÇÃO e a partir do momento que as pessoas conscientizarem-se sobre o tema, afetando a forma como a AÇÃO ocorre. A COMPREENSÃO pode levar as pessoas a perceberem a problemática da questão, o que pode transformar toda a COMPREENSÃO que se tem do suicídio atualmente. 
O aumento da CONSCIENTIZAÇÃO (awareness) juntamente com o desenvolvimento da COMPETÊNCIA (literacy) e a promoção do DIÁLOGO compõem as propostas necessárias para que haja a TOMADA DE CONSCIÊNCIA ativa, em que a pessoa toma, ela é o agente dessa ação, assim, entende, compreende, envolve-se e sente que o suicídio é um problema de todos.

Traremos nossas propostas de como trabalhar essas questões e atingir esses três objetivos: conscientização, competência e promoção de diálogo no capítulo a seguir. 


\section{DISCUSSÃO DOS RESULTADOS}

Durante o processo de análise, muitas ideias foram surgindo e junto com elas a vontade de fazer diferença no campo da psicologia, ou seja, dar voz àquelas pessoas, nesse caso os colaboradores, que viveram o suicídio por perderem entes queridos; àquele sofrimento, trazendo ideias de como falar sobre o suicídio para todos.

Os resultados dessa pesquisa refletem o processo vivido por pessoas enlutadas pelo suicídio com relação às suas experiências e às suas visões sobre o tabu, à conscientização e à ação necessárias para uma ampliação da consciência em relação à prevenção e à posvenção do suicídio.

Nesse trecho do trabalho discutimos as propostas e os caminhos que surgiram para que se possa aumentar a consciência pública sobre o suicídio. Esses caminhos nascem de alguns lugares, o principal deles vem por meio da análise dos dados em conjunto com a releitura das anotações (memos) realizadas após a codificação das falas nos grupos focais, complementandose com a literatura, com a experiência, vivência e esperança da pesquisadora.

O modelo elaborado pelo diagrama 11 (pág. 175) aponta que o maior desafio, relacionado ao aumento da consciência pública, é que o suicídio seja visto como um problema de todos.

O título da tese, que foi inspirado e criado a partir da teoria gerada pela análise dos dados, revela três preocupações: a conscientização, a competência e o diálogo. Acreditamos que estes são os pilares necessários para diminuir o tabu e aumentar a consciência - a tríade da mudança.

Figura 5: Tríade da mudança

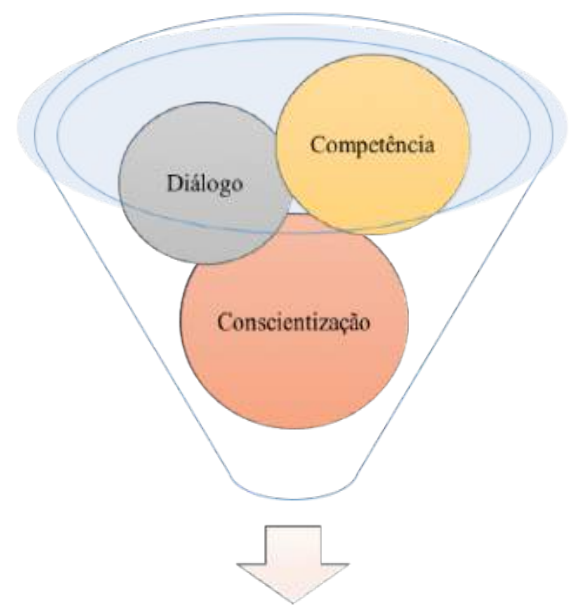

Tríade da mudança 
Aumentar a consciência não é somente falar mais sobre o assunto ou mostrar que o suicídio existe, isso seria fácil ao provar sua incidência com os números e taxas. Precisamos chegar mais longe que isso, pois não é só falar, fazer campanhas, é ver de forma diferente, é ser mobilizado pelo assunto e pelas pessoas. Tem relação com a postura e atitude, gerando comprometimento com tema e alcançar sentido. Assim, a conscientização apontada não é só relacionada a aumentar o conhecimento ou percepção de um fato, é ligada ao conceito de awareness, da gestaltterapia, que, segundo Yontef (1998), é ter consciência cognitiva, sensorial e afetiva e responder a isso. É ver, sentir e reagir estando presente e em contato com o fenômeno.

A competência em prevenção do suicídio (suicide literacy - SL) é um termo derivado da competência em saúde mental (mental health literacy - MHL). A competência em saúde mental foi definida por (Jorm, 2000) como crenças e conhecimento público sobre causas, fatores de risco, sintomas, sinais e tratamentos para os transtornos mentais e está ligada à diminuição do estigma e ao aumento de aptidões por "auxiliarem em seu reconhecimento, gestão e prevenção" (Oliveira, 2011, p. 6). MHL deriva da competência em saúde (health literacy - $H L$ ), que está ligada à competência em informação (information literacy - $I L$ ), que significa uso das informações de maneira correta para fins de tomadas de decisão e de resolução de problemas. Dessa forma, o desenvolvimento da SL está intimamente ligado ao aumento da capacitação sobre o assunto.

Embora, a maioria dos estudos esteja voltada para a competência em saúde mental (mental health literacy), ressaltamos a importância do desenvolvimento da competência em prevenção do suicídio (suicide literacy).

A promoção do diálogo está relacionada à comunicação efetiva diante do ato de falar e de ouvir, ressaltando que os sobreviventes relatam que o problema não é falar e sim a possibilidade das pessoas conseguirem ouvir sobre suicídio. O ouvir envolve tomar atitude, implicar-se, pois não é possível ignorar a comunicação sobre suicídio ou a fala sobre a perda por suicídio. Portanto, reiteramos que ouvir torna-se tão ou mais difícil que falar, como já dito, não adianta somente conscientizar, dar competência, se não houver abertura para o diálogo sobre o tema.

A tríade da mudança tem o formato de funil, como vemos na figura 5, os componentes sendo combinados para que a tríade seja formada, demonstrando as dificuldades enfrentadas para que seu conteúdo seja acessado por todos. A tríade precisa ser entendida como uma das peças de um complexo quebra-cabeça que é a prevenção e a posvenção do suicídio. Nenhuma 
intervenção pode ser pensada sozinha, precisa ser adaptada à cultura, às crenças e às necessidades de cada local. Precisa ser planejada e avaliada.

Toda ação de prevenção do suicídio precisa fazer parte de um plano integrado, compreensivo e abrangente e deve levar em consideração o modelo de saúde pública de quatro passos, conforme a OMS (WHO, 2014, p. 13) recomenda: Vigilância (definição do problema); Identificação dos fatores de risco e prevenção (quais são suas causas e quem ele afeta); Desenvolvimento e avaliação das intervenções (o que funciona para quem); Implementação (aumentar programas e políticas efetivas), conforme vemos na figura abaixo:

Figura 6: Modelo de saúde pública

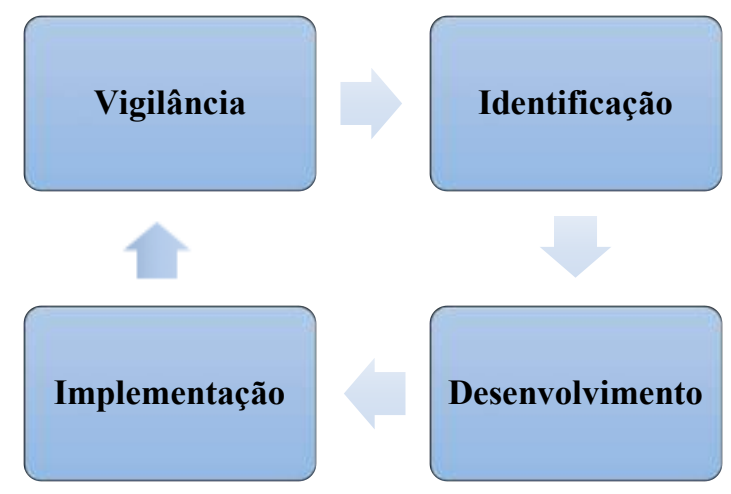

Fonte: WHO (2014, p.13)

Infelizmente, não temos uma cultura de prevenção em nosso país, “o modelo de atenção à saúde que temos hoje ainda está centrado na assistência curativa, individual, com foco no atendimento hospitalar” (Cestari \& Zago, 2005, p. 218). No Brasil, os esforços ainda são mais voltados para intervenção, o que reflete no planejamento e no financiamento das ações de prevenção. Para Chisholm et al. (2016), cada dólar investido no tratamento contra depressão e ansiedade gera um retorno de quatro dólares em saúde e a possibilidade para trabalhar. Essa afirmação demonstra que investimentos em prevenção de suicídio podem trazer retornos financeiros, além de outros ganhos na vida das pessoas.

O Suicide Prevention Resource Center (SPRC, 2017) aponta que para a prevenção do suicídio ser efetiva precisa ser baseada em três áreas: Planejamento estratégico, chaves para o sucesso e plano compreensivo. O desenvolvimento de um plano estratégico é realizado a partir de processo sistemático e baseado em dados para entender o problema, definir objetivos claros e priorizar as atividades que provavelmente promoverão a maior diferença. As chaves para o sucesso são compostas pelo envolvimento de pessoas que tenham vivência no assunto, parcerias e colaborações, mensagens e reportagens seguras e eficazes, abordagens culturais competentes 
e prevenção baseada em evidências. O plano compreensivo deve conter uma combinação de esforços para abranger diferentes aspectos do problema.

É interessante observar que muitas das orientações da SPRC foram encontradas nas falas dos colaboradores e sugeridas como formas de aumento de consciência nesse estudo, portanto, nossas sugestões estão alinhadas com as diretrizes da OMS e SPRC.

A OMS (WHO, 2014) destaca, que embora o suicídio seja uma das maiores causas de morte atualmente, essa questão tem pouca prioridade na saúde pública e não recebe o investimento financeiro e humano necessário.

Uma comparação feita pela American Foundation for Suicide Prevention (AFSP, 2016a) sobre os valores investidos em pesquisa e sua relação com o aumento ou diminuição das mortes no período de 2003-2013 pode ser vista na tabela abaixo:

Tabela 15: Valores investidos em pesquisa no ano de 2013 nos Estados Unidos

\begin{tabular}{l|l|l}
\hline \multicolumn{1}{c|}{ Causa da morte } & \multicolumn{1}{c}{ Investimento em 2013} & \multicolumn{1}{c}{ Índices } \\
\hline HIV/AIDS & 2.9 bilhões de dólares & Diminuição de $53.2 \%$ \\
\hline Doenças do coração & 1.2 bilhões de dólares & Diminuição de $29,1 \%$ \\
\hline Câncer de próstata & 266 milhões de dólares & Diminuição de $13,7 \%$ \\
\hline Suicídio & 37 milhões de dólares & Aumento de $20,4 \%$ \\
\hline
\end{tabular}

Fonte: AFSP (2016)

Fica clara a relação entre a quantidade de investimento em pesquisas e seu impacto nas taxas de mortalidade. Acreditamos que a variação das taxas de mortalidade não é a única forma de medir o sucesso de uma intervenção, porém a falta de investimentos na prevenção do suicídio pode fazer que suas taxas não parem de crescer. A conscientização pode influenciar o envolvimento das pessoas na sociedade, colaborando para que haja maior interesse no tema e objetivando gerar investimentos em pesquisa e no tratamento do comportamento suicida. A questão do envolvimento foi trazida pelos colaboradores ao falarem sobre a importância e a necessidade de engajamento como fatores que podem promover transformação.

A OMS (WHO, 2012) aponta que a mídia e a comunicação têm papéis fundamentais para o desenvolvimento de estratégias de prevenção do suicídio, aumentando o entendimento das questões e a participação da sociedade como um todo no processo. Engajamento social em conjunto com o aumento da comunicação e da conscientização podem influenciar políticos e a opinião pública, para mobilizarem e implementarem mais recursos. É vital que o público compreenda as questões e as necessidades envolvidas para que intervenções sejam bemsucedidas, para que haja a implicação da sociedade e a construção de comunidades, que 
reconheçam a importância da prevenção e da posvenção, fortalecendo esse ciclo de sensibilização e ação.

Diversos planos de prevenção salientam a importância do aumento da consciência na prevenção do suicídio como parte de um plano compreensivo. Para Hegerl, Dietrich, PfeifferGerschel, Wittenburg e Althaus (2008) as campanhas de conscientização produzem um efeito maior se forem aliadas a outras estratégias. Alguns programas que contemplam a conscientização como um dos níveis de intervenção são Choose Life, da Escócia, o The Nuremberg Alliance Against Depression, a National Estrategy for Suicide Prevention (NESP - EUA), a Defeat Depression Campaign do Reino Unido, o Beyondblue da Austrália e o United States Force Suicide Prevention Programme (USFSPP). Os autores sugerem que os programas de conscientização contemplem quatro níveis de intervenção:

Figura 7: Níveis de intervenção necessários em programas de conscientização

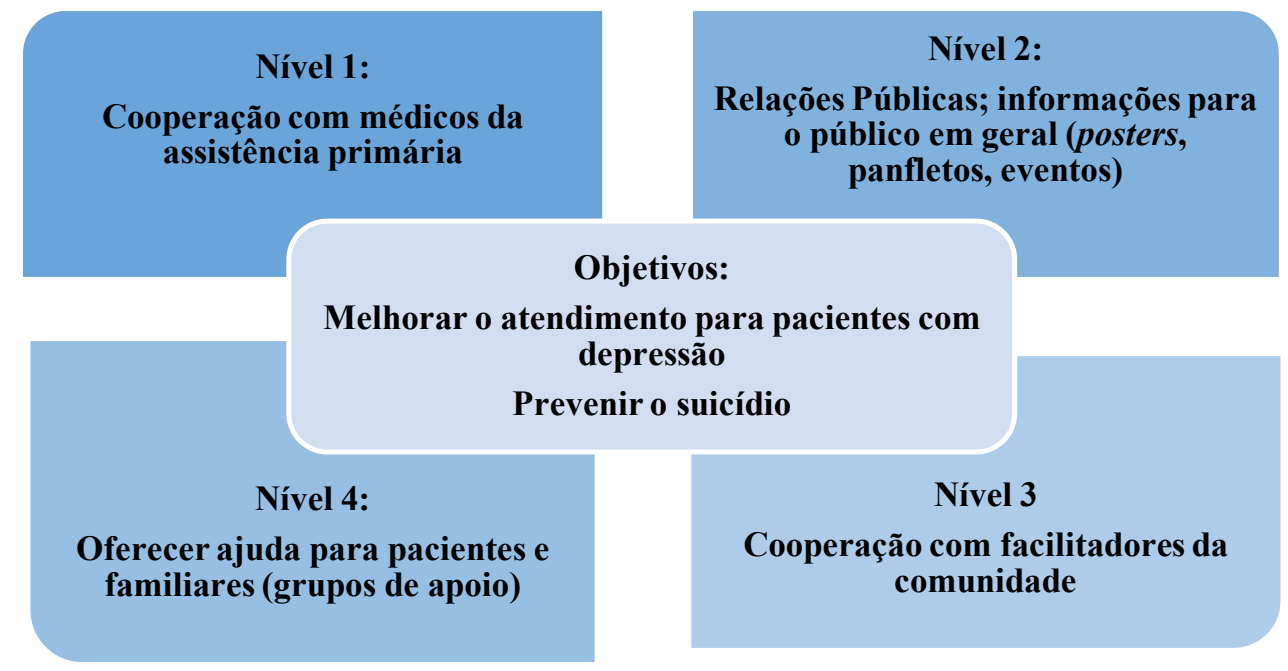

Fonte: Hegerl et al. (2008, pp. 498 - tradução nossa)

Um estudo sobre conscientização (awareness), desenvolvido em nove países, incluindo o Brasil, foi realizado entre 2002-2005, objetivando entender como poderiam aumentar o conhecimento e sensibilizar a sociedade para a promoção de saúde mental de crianças e adolescentes. $\mathrm{O}$ estudo demonstrou que aumentar a consciência não está relacionado somente a ensinar a perceber os sintomas e a responder adequadamente a uma crise suicida, mas que é possível mudar as atitudes das pessoas, influenciando o comportamento de pais, professores e estudantes, além de ajudar os participantes a notarem quando estavam estressados e a encorajar crianças em situação de estresse a falarem mais abertamente sobre seus problemas e preocupações. O estudo demonstrou que após ocorrerem ações de conscientização, pessoas 
mostravam-se mais interessadas em aprender sobre saúde mental que antes do projeto (Hoven, Wasserman, Wasserman, \& Mandell, 2009).

A partir dos projetos mencionados acima e dos achados da pesquisa, iniciamos a discussão, propondo algumas soluções para esse complexo quebra-cabeça, com o qual escolhemos trabalhar, a conscientização. Acreditamos que essa seja uma das peças fundamentais para o desenvolvimento de programas abrangentes e eficazes de prevenção do suicídio. Do nosso ponto de vista, não adianta oferecermos serviços, se as pessoas não se conscientizarem da necessidade de procurá-los e não perceberem a hora de pedir ou oferecer ajuda diante uma crise suicida. Não se trata somente de ensinar quais sinais podem ser percebidos, envolve perguntar e importar-se, que se agrega a uma ampliação da discussão social, moral, cultural, política, religiosa e ética sobre o tema. Poder falar abertamente, dialogar sobre o suicídio e sobre dores presentes também são fatores a serem considerados pelo aumento de consciência.

Antes de propor um plano de ação relacionado à conscientização, à competência e ao diálogo, percebemos a necessidade de abordar alguns pontos que foram trazidos por meio da análise das falas dos colaboradores nos grupos focais e discuti-los por perceber a importância de destacar algumas questões envolvendo a conscientização pública sobre o suicídio.

\subsection{COMPREENSÃO}

A sociedade e o tabu têm grande influência em tudo que se refere ao suicídio, seja nas conversas, nos tratamentos, nos apoios, nos diálogos e nos planejamentos de intervenções (Lester, 2013; Noyes, 1968). Ainda há um tabu sobre a comunicação em relação à morte, sendo o suicídio o espectro maior dentro dessa interdição (Kóvacs, 1992).

Podemos pensar o suicídio como uma ponte entre a morte interdita e a morte escancarada (Kovács, 2003), pois ele denuncia os pontos cegos da sociedade, principalmente quando ocorre em via pública, é publicado na mídia ou compartilhado nas redes sociais. Quanto mais mortes por suicídio ocorrerem, quanto mais jovens e expostas forem essas mortes, quanto mais pessoas famosas morrerem por suicídio, quanto mais séries televisivas forem baseadas no tema, mas difícil fica para a sociedade esconder a realidade do suicídio. Por essa razão, podemos pensar que o suicídio é um grito por socorro, das pessoas que morrem para a sociedade em que vivem.

Para as pessoas que ficam após um suicídio, diversas reações a essa perda podem ser observadas, uma delas esta relacionada à criação de campanhas, aos institutos e ao apoio a pesquisa, assim muitas questões tabus são levadas à reflexão e à ação a partir da dor dos que 
passaram por tais situações. Sabemos que muitos dos movimentos e campanhas de prevenção e posvenção do suicídio, que ocorrem atualmente nos Estados Unidos, foram iniciados a partir dos sobreviventes enlutados (Aguirre \& Slater, 2010; Cutcliffe \& Ball, 2009; Scavacini, 2011). Os colaboradores compartilham essa experiência em suas falas, portanto, podemos pensar que a dor "escancara" os problemas, fazendo que a sociedade se envolva com eles.

Um dos inúmeros exemplos dessas ações tem relação com o suicídio de Amanda $\operatorname{Todd}^{21}$, aos 14 anos de idade, que fez que houvesse uma grande mobilização das redes e das autoridades a respeito do cyberbullying, após sua morte. Leis contra o bullying foram criadas e sua mãe mantém um site com campanhas sobre bullying, segurança online, conscientização e saúde mental (Todd, 2017).

Essa maior exposição também acontece com outras problemáticas como, por exemplo, a enfermeira Pat Furlong, que criou o "Parent Project Muscular Distrophy" (Projeto de Pais para Distrofia Muscular) ${ }^{22}$, projeto criado depois que seus dois filhos foram diagnosticados com a doença ou o desafio do balde de gelo ${ }^{23}$ (ice bucket challenge), iniciado por Anthony Senerchia Jr. que com a ajuda de Pat Quinn e de Pete Frates popularizaram a campanha com o objetivo de conscientizar a população sobre a doença e de aumentar os recursos financeiros para pesquisa e para o tratamento da Esclerose Lateral Amiotrófica (ELA) (Sherman \& Wedge, 2017). Esse é um exemplo de uma campanha criada por alguém que vivenciou o problema e que arrecadou milhões de dólares, sendo o seu sucesso atribuído a uma ideia inovadora e inusitada com uma combinação do narcisismo online, facilidade de completar a tarefa, pressão das mídias sociais e competitividade (Guardian, 2014; Linden, 2017). A efetividade de campanhas como essa ficou evidente quando os cientistas, por meio do dinheiro arrecadado pelas doações, realizaram um estudo em que descobriram um novo gene ligado à doença (BBC, 2016).

No grupo de apoio para enlutados pelo suicídio, do qual a pesquisadora é facilitadora, fica cada vez mais claro o quanto se mobilizar em prol de uma causa, nesse caso, a prevenção do suicídio, faz que muitos pais prossigam na elaboração de seu processo de luto e ajudem outras pessoas. Essa proposta está também se desenvolvendo em outros países. No grupo focal, dois colaboradores abriram Organizações Não Governamentais (ONGs) após passarem por um

\footnotetext{
${ }^{21}$ Amanda Todd sofreu bullying e cyberbullying. Postou um vídeo no youtube falando sobre a sua história duas semanas antes de cometer o suicídio. Muitos vídeos parecidos foram feitos depois, com outras pessoas contando suas histórias da mesma maneira que ela.

$22 \mathrm{http} / / / \mathrm{www}$.parentprojectmd.org

${ }^{23}$ Desafio que constituía em filmar a ação de jogar um balde de água gelada na cabeça e desafiar amigos a fazerem da mesma forma nas próximas vinte e quatro horas. Quem não cumprisse a tarefa, precisaria fazer uma doação financeira para entidades ligadas ao estudo e tratamento da ELA (Esclerose lateral amiotrófica).
} 
suicídio próximo. Outra ONG, que foi fundada por sobreviventes, é o CDM (Centro Débora Mesquita), em Teresina/PI e a Nomoblidis em São Paulo. Ramos (2004) afirma que as ONGs tiveram importância fundamental na construção de políticas de saúde, ligadas à AIDS, à saúde da mulher (como no caso do câncer de mama) e à saúde mental durante a reforma psiquiátrica. A primeira $\mathrm{ONG}$ relacionada à prevenção do suicídio data de 1893, na Alemanha (Farberow e Schneidman (1961) citado em Andriessen, 2009).

As ONGs, criadas no Brasil na área da prevenção do suicídio, mostram que esse pode ser um caminho possível e de grande repercussão na prevenção e na conscientização da problemática do suicídio.

Embora a Associação Brasileira de Estudos e Prevenção do Suicídio (ABEPS) tenha sido fundada somente em 2015, sua criação demonstra o quanto à questão da prevenção tem evoluído. Em 2016, a ABEPS realizou o I Encontro de Sobreviventes do Suicídio, que aconteceu durante seu primeiro congresso, nesses encontros, nos quais participaram sobreviventes de tentativas, sobreviventes enlutados e profissionais, muito se debateu sobre o tabu sentido pelos enlutados pelo suicídio e pelas pessoas sobreviventes de tentativas, sobre a dificuldade de encontrar acolhimento para o luto e para o comportamento suicida, além da necessidade do preparo de profissionais para entenderem essas demandas (Scavacini, 2017a). Poder falar abertamente sobre o suicídio é fundamental para entender e acolher o processo.

A criação de uma Associação Brasileira de Sobreviventes do Suicídio pode ser a próxima etapa para que esse grupo se fortaleça ainda mais e possa, por meio de sua força e de sua dor, mudar leis e a forma como as pessoas veem e tratam o suicídio.

Se para uns a dor motiva, para outros é sentida e vista como vergonha ou fracasso, aumentando os riscos de suicídio. Há uma banalização da dor, conforme os colaboradores, visto que a sociedade em geral não está preparada e nem foi educada para lidar com essa dor e nem ver o suicídio como decorrência da dor e do sofrimento.

Ainda há um grande estigma, um medo da forma como a sociedade irá reagir se a pessoa disser que pensa em matar-se, sendo que esse fator influencia como as pessoas comportam-se, assim, em muitos momentos, a sociedade ainda oferece mais risco ao invés de um lugar para procurar proteção e ajuda.

É de extrema importância conhecer, por meio da perspectiva cultural, quais são as razões dadas por uma sociedade para a ocorrência de um suicídio, isso mostrará qual será a sua resposta para o ato e a ajuda que será ofertada para quem pensa em se matar, assim podemos desenvolver programas de prevenção, intervenção e posvenção que sejam culturalmente adaptados (Colucci, 2013b). Segundo Osafo (2012), o sentido do ato deve ser considerado no 
seu contexto cultural e moral, e que, em seu estudo, viola duas grandes regras: valores religiosos e a harmonia da sociedade. No levantamento bibliográfico não foi encontrado estudo que especificasse a visão da sociedade brasileira sobre suicídio.

Em muitas culturas, o suicídio ainda é ligado ao fracasso, à covardia, à fraqueza, à coragem e até à falta de Deus no coração (Colucci, 2013a; Sand, Gordon, \& Bresin, 2013). A sociedade busca causas únicas para explicar o que aconteceu, buscando culpados, por essa visão simplista transfere o julgamento da pessoa, que se acredita ser "fraca ou covarde", para a família, que é julgada como “insuficiente, irresponsável, culpada”. Essa sensação de ser julgado foi compartilhada pelos colaboradores em muitos momentos do grupo focal. Enquanto essa visão não for ampliada, a sociedade continuará replicando a mesma voz.

Essa visão de causa e efeito também pode ser observada em relação à depressão, na qual as pessoas buscam justificativas para a doença ter começado. Questionamos se essa forma de raciocínio vem da escola, se fomos restringidos de pensar, ensinados a pensar dualistamente ou se essa forma de pensar vem para aplacar o medo do desconhecido. Buscar uma causa única pode promover uma falsa calma ao tentar trazer uma resposta para o absurdo, que não tem explicação, como no caso do suicídio. A sociedade reduz o suicídio a causas para simplificar o assunto e tentar buscar sentido.

Pensamos também que ao encontrar um culpado as pessoas tiram a culpa de si ou minimizam o que aconteceu, assim não precisam conviver com essa falta de respostas, com esse não saber. Talvez essa seja a forma de manter distância do que houve, como se pudessem diferenciar-se de quem se matou, não se envolver ou pensar que o suicídio só acontece no "quintal do vizinho".

Percebemos, pela análise, que a sociedade busca essa culpa, muitas vezes, em fatores externos, na droga, na amante, no desemprego, na família. Há uma dificuldade em enxergar o suicídio como multifatorial, notando sua interação com diversos fatores externos e internos. Para Kovács (2013), "respostas simplistas e definitivas podem levar a um erro". Culpar uma doença pela morte de alguém pode facilitar o entendimento e a aceitação daquela morte, o que não acontece no suicídio, que traz inserido no ato a escolha pela morte, sendo a pessoa o personagem principal e não o coadjuvante como é no caso de doenças como o câncer.

Outra questão é ver o suicídio como ato consciente. Se pensarmos em uma pessoa com depressão ou com dor insuportável, física ou psíquica, sabemos que dificilmente essa pessoa estará consciente de suas escolhas, então a dor e a depressão são variáveis importantes neste contexto, portanto, precisamos mostrar que o suicídio pode ser um ato intencional, mas nem 
sempre consciente e livre. Shneidman (1993) afirma que para haver um suicídio é necessário que haja psychache ou uma dor psicológica insuportável, que

\footnotetext{
refere-se à dor, angústia, sofrimento, uma dor psicológica insuportável ... a dor de uma vergonha exaustivamente sentida, ou culpa, ou medo, ou humilhação, ou solidão, ou medo de envelhecer ou morrer mal ou o que quer que seja ... o suicídio ocorre quando a psychache é considerada por essa pessoa como insuportável (E. Shneidman, 1993, p. 51).
}

Campanhas e reportagens que focam na informação de que $90 \%$ dos casos de suicídio podem ser prevenidos, sem explicar o porquê dessa afirmação, podem aumentar na sociedade a visão/sentimento de que, se aconteceu o ato foi porque alguém não fez o que devia ou fez errado.

Reportagens, que tratam a prevenção dessa maneira, podem fazer que essa visão causal e de culpabilização prevaleça, pois trazem a sensação de que os sinais de um suicídio são fáceis e claramente vistos, se não foram percebidos é porque não se conseguiu ver ou nada foi feito em relação ao problema. É fundamental que as pessoas conheçam os sinais de alerta, mas isso não é o suficiente para que elas realmente os percebam ou consigam impedir um suicídio. Nesse caso, observa-se um conceito delicado abordado de forma simplista, sendo importante ressaltar que o suicídio pode ser prevenido, conforme recomenda a OMS (WHO, 2014), porém as explicações e informações sobre a prevenção precisam ser mais abrangentes. Dessa forma, a sociedade precisa entender que o suicídio pode ser prevenido, mas não é previsível, conforme já falamos anteriormente.

Com relação à visão da depressão, é essencial que ela seja vista e tratada como doença, porém precisamos mudar a forma de falar e ampliar o olhar da sociedade, ressaltando que a depressão não é o único fator responsável pelo suicídio e que há outros transtornos mentais associados, como a ansiedade e o abuso de substâncias, além de fatores sociais, culturais, ambientais e psicológicos envolvidos (Bertolote, 2012).

Explicar o suicídio somente a partir do modelo médico de transtornos mentais ou da irracionalidade do impulso impede que outras vozes, outros motivos, outros fatores sejam levados em consideração. De acordo com De Leo (2004), o suicídio é um problema que não está somente relacionado com a psiquiatria, onde, embora antidepressivos sejam efetivos nos tratamentos contra a depressão, não reduziram as taxas de suicídio. Para o autor, os antidepressivos não atuam sobre a variedade de fatores psicossociais, que estão relacionados com o suicídio, sendo que esses fatores são independentes e demoram mais para se modificar, se comparados com sintomas depressivos, por isso a combinação de tratamento psiquiátrico e 
psicoterapia é recomendada. Fatores como "preocupação" e "vergonha", que não são fatores psiquiátricos, podem, em muitas circunstancias e especialmente em homens, serem mais preocupantes do que a depressão. A cooperação com outras disciplinas vai permitir que a prevenção seja mais efetiva.

O suicídio entre religiosos mostra o quanto o processo é complexo, que o fato de ter uma crença e pertencer a uma comunidade religiosa não seja por si só certeza de proteção visto que a dor e o desespero ultrapassam essas crenças e o pensamento racional. Em dezembro de 2017, suicídios de pastores reabriram o debate sobre o poder da crença religiosa, a dificuldade de pedir ajuda, tomar medicação e a saúde mental dos líderes religiosos (JM Notícia, 2017). Algumas religiões podem contribuir para aumentar o estigma em relação ao suicídio e desencorajar a busca por uma assistência médica (Botega, 2015).

As causas para um suicídio são singulares e devem ser vistas a partir do conjunto de fatores, que mais se destacam para cada pessoa. Aparentemente, a sociedade acredita que o suicídio de jovens está mais ligado à depressão, ao impulso, à baixa tolerância a frustração; já para os idosos, às perdas, ao orgulho e à indignidade do fim da vida (Minayo, Figueiredo, \& Silva, 2016). Portanto, ao aumentar a consciência, essas especificidades precisam ser levadas em consideração para que as pessoas entendam que o suicídio é um ato complexo e mesmo que possua características mais associadas a cada idade, não devemos encarar o suicídio a partir de uma causa única.

Observamos que as questões de bullying e homossexualidade não foram citadas pelo grupo focal, quando falaram do suicídio de jovens, talvez porque as perguntas sobre homossexualidade não sejam feitas abertamente e também são tabus, assim como o suicídio. Ressaltamos que há um aumento de suicídios por conta de bullying e também entre a comunidade LGBT (Haas et al., 2011; McDermott, Roen, \& Scourfield, 2008).

É importante que haja questionamentos, a partir do aumento da consciência, como a sociedade pode ter colaborado para o aumento da depressão e consequentemente das taxas de suicídio. A depressão pode ser consequência de uma sociedade cada vez mais doente, por isso consideramos como raciocínio simplista colocar a depressão como o fator principal para que aconteça um suicídio, sem nos questionarmos o que tem levado a ela. Acreditamos que o suicídio é uma dor que não pode ser expressa de outra maneira, é um sintoma-dor ou ato-dor (Macedo \& Werlang, 2007) e não devemos olhar para o suicídio sempre relacionado à depressão, como muitas correntes acreditam (Hjelmeland, 2013).

Ainda que a maioria dos casos de câncer de pulmão não estejam ligados ao ato de fumar, pessoas que morreram por câncer de pulmão relatam ter sofrido estigma, mesmo que não 
tenham fumado a vida toda (Chapple, Ziebland, \& McPherson, 2004), porém não tem o mesmo julgamento em relação à morte se ela ocorrer por suicídio. Pacientes com câncer também passam por julgamentos no sentido de que provocaram seu câncer por ressentimento, mágoa ou por sentimentos não expressos (Else-Quest, LoConte, Schiller, \& Hyde, 2009). Essa forma de ver a doença ainda persiste, mas em menor grau porque o câncer também tem uma causalidade multifatorial, assim como o suicídio.

A AIDS talvez seja a doença que mais se aproxime do julgamento semelhante ao que ocorre com quem morra por suicídio, principalmente quando pensamos nos casos de jovens infectados por relação sexual consentida sem o uso do preservativo. Como se atualmente fosse inadmissível que alguém tenha relações sexuais sem proteção, sabendo dos riscos que corre, à semelhança de uma pessoa que provoque sua morte. No caso da AIDS houve muito preconceito a partir do que se considerava como "peste gay", por irresponsabilidade e desconhecimento. Muitas pessoas ainda escondem de cônjuges, empregadores, pacientes, manicures etc. o fato de serem HIV positivo, buscando serem tratados "normalmente" e fugindo do estigma que ainda acompanha o assunto (Zucchi, Paiva, \& Junior, 2013). No entanto, como hoje não se trata mais de uma doença mortal e por conta dos tratamentos, as pessoas não perdem mais massa magra e gordura, que davam a aparência de "AIDS”, uma boa parte desse impacto está diminuída, graças às campanhas de prevenção, ao investimento financeiro e à descoberta de novos medicamentos, que possibilitaram essa mudança.

O suicídio ainda não é um tema como outros, dos quais se pode falar livremente, assim como outros assuntos, que já foram tabus e que atualmente há uma possibilidade de falar sobre eles, da mesma forma pode ocorrer com o suicídio. A comparação de como o suicídio é visto hoje pela sociedade, como a AIDS, a sexualidade e o câncer eram vistos antigamente, que após muitas campanhas, pesquisas e investimentos, hoje têm uma possibilidade de comunicação mais aberta, traz aos colaboradores um sentimento de esperança, de que um dia será possível falar mais abertamente sobre o assunto.

Os colaboradores acreditam que as campanhas da AIDS e do câncer deram certo. Não podemos dizer que todas as expectativas foram atendidas, tendo em vista que ainda há problemas com a prevenção do câncer e os índices de AIDS terem aumentado, principalmente entre os jovens. Entretanto, podemos dizer que essas campanhas são mais abertas e frequentes, porém como todo problema complexo e de saúde pública, a conscientização é parte de um processo que envolve várias esferas e múltiplos esforços.

É difícil afirmarmos como o tabu começa, mas sabemos o porquê insiste em ficar. O grupo destacou as religiões como origem e multiplicadoras do tabu, levando-nos a refletir sobre 
a necessidade de preparar e capacitar religiosos para a prevenção e a posvenção do suicídio. Muitas religiões já têm mudado a forma de lidarem com o suicídio e com os transtornos mentais, porém ainda há um longo caminho pela frente.

O tabu pode estar presente em famílias por diversos motivos, um deles pode ser pela dificuldade para conversar sobre um suicídio, que ocorreu com um de seus membros e pelo medo de que aconteçam outros suicídios. Há também a vergonha e a atribuição de culpa. Como conviver com o medo de perder mais um familiar dessa forma? Como uma família pode reerguer-se, falando abertamente sobre essa ferida que continua aberta? Por isso precisamos respeitar quem não quer falar, mas trabalhar no sentido de não favorecer o tabu, possibilitar liberdade e espaço para aqueles que quiserem falar sobre o suicídio, encontrando um espaço seguro para isso (Jordan, 2001; Lifeline, 2009; McMenamy, Jordan, \& Mitchell, 2008).

Nas empresas podemos observar o tabu influenciando a forma como os gestores lidam com os transtornos mentais, com as pessoas com comportamento suicída e com os enlutados, situação relatada por alguns colaboradores. A visão do enlutado pela sociedade define a forma como esta espera que ele se comporte ou determine o tempo que deve levar para se recuperar, não levando em consideração as singularidades de cada processo (Andriessen, Krysinska, \& Grad, 2017; Fontanelle, 2008; Silva, 2015).

O tabu impede o tratamento pelo medo das pessoas serem taxadas de loucas e pelo estigma de ser doente mental ou suicida. Vem através da história da psiquiatria o medo das pessoas de serem internadas em manicômios, pois há a sensação de que insano é aquele que perde a liberdade e a si mesmo, que toma comprimidos em caixas de remédios com tarja preta, que contém o alerta para o vício. A psicofobia envolve vários tabus: o da depressão (ser fraco, covarde, falta de amor a Deus); o dos remédios psiquiátricos; o da psicologia (vou ter de pagar para alguém me ouvir?); o medo de perder a liberdade e ser internado; além da visão de que psicólogo é para ricos e que psiquiatra é para loucos.

É interessante pensar que pessoas internadas por outras causas também sofrem a privação da liberdade nos hospitais, quando estão doentes ficam internadas, sendo medicadas podem ter efeitos colaterais, mas se esse cenário for no setor ou no hospital psiquiátrico tudo isso parece assustador. O psiquiatra pode decidir sobre sedar ou não uma pessoa, propor procedimentos invasivos, internar e privar a pessoa do contato com a família, da mesma forma acontece com outras especialidades médicas, mas não são consideradas como um problema.

Não conseguimos encontrar nenhum artigo ou estudo que mostre quanto o tabu e a psicofobia influenciam ou não a busca por médicos psiquiatras e por psicólogos no Brasil. Baseada na experiência clínica da pesquisadora esse tabu e medo existem. 
A afirmação popular de que "problemas longe dos meus, não me interessa", ratifica a necessidade de as pessoas entenderem que "o suicídio é um problema de todos". Um dos colaboradores exemplificou sobre a descriminalização do aborto e do envolvimento das pessoas com o tema. Enquanto considerarmos que o suicídio é coisa de louco ou covarde, que só acontece com os outros, que está distante e que nunca vai acontecer com alguém próximo, é bem provável que a pessoa não se envolva, sendo que dificulta a empatia e a identificação com o tema.

O suicídio revela o preconceito, mostra o julgamento que o transforma em um assunto proibido, que leva a um não falar e pode gerar afastamento, exclusão e estigma (Batterham, Calear, \& Christensen, 2013a; Lester \& Walker, 2006).

Corrigan et al. (2017) apontam sobre “o sentido do estigma público do suicídio" (p. 351), mostrando quais são os componentes que existem no estigma. Para eles, o estigma está relacionado às pessoas que tentaram o suicídio, incluindo três tipos de estereótipos: "fraco, louco e angustiado"; dois de preconceito: "medo/desconfiança e raiva"; três de discriminação: “evitação, afastamento e coerção" (p. 351). Esse ponto pode desafiar sobreviventes de tentativas de suicídio no seu processo de recuperação e ser barreira para pedidos de ajuda (Chan, Batterham, Christensen, \& Galletly, 2014). Enlutados também podem sofrer com o courtesy stigma, que significa adquirir um estigma como resultado de ter relação com uma pessoa estigmatizada, levando os enlutados a serem vítimas do preconceito, de estereótipos e de discriminação (Goffman, 1963).

Algumas escalas foram desenvolvidas para medir o estigma em relação ao suicídio, como a Stigma of Suicide Scale (SOSS; Batterham, Calear, \& Christensen, 2013b) e a Suicide opinion questionaire (Domino \& Groth, 1997). Ambas as escalas são uma forma de mostrar esse estigma e sua intensidade numa determinada população, indicando qual seria o público alvo para uma campanha de conscientização, por exemplo. Existem dois tipos de estigma que influenciam o suicídio, o estigma público (Corrigan, Gause, Michaels, Buchholz, \& Larson, 2015) e o autoestigma, que é o estigma que as pessoas internalizam a partir dos estereótipos relacionados naquela sociedade (Boyd, Adler, Otilingam, \& Peters, 2014).

\subsection{COMUNICAÇÃO}

A conscientização pode ampliar a comunicação, tanto verbal quanto pessoal. Esse fato leva-nos a refletir se foi a comunicação que realmente aumentou nesses últimos anos ou se foi o interesse pessoal do grupo focal, que fez que tivessem essa sensação ao prestassem mais atenção ao tema, dando a impressão de que hoje falamos mais sobre suicídio. Talvez sejam as 
duas possibilidades, o grupo mais atento ao tema e atualmente podemos observar um aumento em séries televisivas, reportagens e campanhas sobre o assunto, tendência foi observada pelo grupo focal.

Refletimos se talvez não seja somente o aumento na quantidade de reportagens e sim a importância dada ao tema, a forma como é tratado. Notamos que antigamente o suicídio era noticiado geralmente no caderno policial dos jornais e com muitos detalhes. Atualmente, após a publicação do manual para imprensa, desenvolvido pela OMS (2000b), o suicídio é noticiado de outra maneira, em vários cadernos diferentes e com outros propósitos. É noticiado em sites e revistas variadas, desde aquelas voltadas para entretenimento, bem-estar como em revistas voltadas aos veterinários (Lara, 2017).

Foi realizada uma pesquisa informal nos sites dos jornais Folha de São Paulo (número de reportagens/reportagens de capa) e do Estadão (número de reportagens), na revista Veja (número de matérias), procurando a quantidade de notícias que apareceriam, utilizando a palavra-chave suicídio. Não analisamos o conteúdo das reportagens, apenas consideramos a quantidade.

Tabela 16: Número de artigos com a palavra-chave suicídio nos jornais Folha de São Paulo e O Estado de São Paulo; Revista Veja

\begin{tabular}{l|l|l|l|l|l|l|l}
\hline & 2010 & 2011 & 2012 & 2013 & 2014 & 2015 & 2016 \\
\hline Folha & $663 / 144$ & $862 / 197$ & $785 / 251$ & $887 / 277$ & $741 / 244$ & $655 / 195$ & $431 / 71$ \\
\hline Estado & 703 & 803 & 761 & 672 & 511 & 415 & 420 \\
\hline Veja & 02 & 00 & 14 & 24 & 23 & 21 & 21 \\
\hline
\end{tabular}

Fonte: produção do próprio autor (2018)

Uma pesquisa mais aprofundada nos conteúdos faz-se necessária, porém observamos que em 2016 houve menos reportagens que em anos anteriores não sabemos explicar o porquê dessa diminuição.

Pesquisando no acervo do Estadão, da mesma maneira que acima sobre o número de reportagens de algumas décadas, deparamos com a seguinte informação:

Tabela 17: Número de reportagens com a palavra-chave suicídio por década no Jornal "O Estado de São Paulo"

\begin{tabular}{l|c|c|c|c|c|c|c}
\hline Década & $\mathbf{1 8 7 0}$ & $\mathbf{1 8 8 0}$ & $\mathbf{1 8 9 0}$ & $\mathbf{1 9 0 0}$ & $\mathbf{1 9 1 0}$ & $\mathbf{1 9 2 0}$ & $\mathbf{1 9 3 0}$ \\
\hline N. de reportagens & 113 & 202 & 421 & 889 & 2679 & 1304 & 2061 \\
\hline Década & $\mathbf{1 9 4 0}$ & $\mathbf{1 9 5 0}$ & $\mathbf{1 9 6 0}$ & $\mathbf{1 9 7 0}$ & $\mathbf{1 9 8 0}$ & $\mathbf{1 9 9 0}$ & $\mathbf{2 0 0 0}$ \\
\hline N. de reportagens & 1106 & 1661 & 1466 & 1737 & 2311 & 3324 & 4942 \\
\hline
\end{tabular}

Fonte: produção do próprio autor (2018) 
Quando olhamos as décadas, é notório o aumento das reportagens que contém notícias relacionadas ao suicídio.

Da mesma maneira, foram pesquisados, nas bases de dados, artigos brasileiros, em português, que continham a palavra suicídio. Dos anos de 1998 a 2006 foram cento e dezesseis publicações; já de 2006 a 2016 foram seiscentos e noventa e seis, observando-se um aumento considerável. Podemos pensar que estamos falando e pesquisando mais sobre suicídio nos últimos anos.

Um dos colaboradores relata que vai participar de um filme sobre o assunto, que será passado num canal pago de grande repercussão, além dele como enlutado, jovens sobreviventes de tentativas de suicídio foram incluídos. Esse fato mostra como não só a quantidade, mas principalmente a forma como falamos sobre o suicídio hoje está mudando, em uma perspectiva mais abrangente e inclusiva. Notamos que os canais de TV estão investindo no tema, se isso acontece é devido aos resultados esperados como um aumento de audiência. Não foi discutido o porquê os canais estão investindo mais, sendo que não podemos pensar que é somente por uma questão de responsabilidade social, mesmo assim, o suicídio está sendo mais noticiado em diferentes mídias com propósitos variados.

Diversos estudos abordam a influência da mídia no suicídio (Meindl \& Ivy, 2017; Stack, 2003; Tousignant, Mishara, Caillaud, Fortin, \& St-Laurent, 2005), especialmente na cobertura de suicídio de famosos (Arendt \& Scherr, 2017a; Koburger et al., 2015; Park et al., 2016; Schafer \& Quiring, 2015) com sugestões e diretrizes de mídia responsável (John et al., 2014; OMS, 2000b; Pirkis, Blood, Beautrais, Burgess, \& Skehans, 2006), porém nenhum estudo aponta o porquê a mídia tem falado mais sobre o assunto e as causas desse aumento.

Um estudo sobre mudanças nas reportagens sobre suicídio na Austrália entre 2000/01 e 2006/07, seguindo as recomendações propostas pelo guia Reporting suicide and mental illness, demonstraram que as reportagens quase dobraram durante o período e com ênfase maior nas experiências individuais que em leis e intervenções (Pirkis et al., 2009).

Embora não tenha sido abordado pelo grupo, não há clareza o quanto a série "os 13 porquês" 24 influenciou o aumento do diálogo sobre o suicídio, o que percebemos foi um acréscimo de reportagens sobre o assunto. A personagem Hannah serviu de exemplo? De

\footnotetext{
${ }^{24}$ A série os 13 porquês, do Netflix (serviço de streaming de vídeo), apresenta a história do suicídio da Hannah e das treze fitas que ela deixou contando a sua história, cada fita representava uma pessoa. Acreditamos que a série trouxe o tema do suicídio para a mídia, mas falhou em não retratar quais outras formas a personagem poderia ter encontrado para não precisar morrer por suicídio. Ressaltamos que em uma das cenas, mostra o suicídio da personagem, de maneira gráfica, algo não recomendado pela OMS. A série também teve como um dos seus grandes focos atribuir à culpa pelo que aconteceu aos amigos da Hannah, dessa forma, notamos que trazer os porquês de forma simplista pode aumentar a culpa e o estigma dos sobreviventes enlutados pelo suicídio.
} 
caminho para quem não sabia aonde ir? Se essa pessoa está perdida, alguém que traz uma bússola, seja ela para onde for, pode tirar alguém da angústia de estar sofrendo e não saber que caminho tomar, mesmo que este seja o suicídio. Não basta somente divulgar o tema, é preciso abrir espaço para conversar a respeito. Penso quantos jovens tiveram acesso a algum adulto disponível para conversar abertamente sobre o tema? Por isso é imperativo unir a conscientização com o diálogo.

O grupo focal comentou que hoje temos mais liberdade de expressão e facilidade de acesso à informação por causa da internet e das mudanças sociais que ocorreram com os anos. A consciência trazida pela mídia, afeta a consciência individual e as pessoas comunicando-se mais tornam o assunto mais comum, no entanto, ainda não falam sobre o tema aqui destacado.

Sem dúvida muita coisa mudou na forma como nos comunicamos, sendo que a internet e as redes sociais abriram portas para conversamos com o mundo. Há um questionamento de que até que ponto essa liberdade de expressão existe em sociedades fechadas, famílias rígidas e religiosas. Temos ainda muito de trabalhar.

Um caso de grande comoção e impacto foi o suicídio do copiloto da Germanwings e consequente assassinato de todas as pessoas que estavam a bordo do avião. Uma pesquisa foi realizada na Alemanha um mês após o ocorrido para verificar se houve um aumento do estigma relacionado os transtornos mentais por causa do suicídio e da quantidade de reportagens relativas ao assunto, concluiu-se que um único evento, mesmo que devastador e grande cobertura da mídia teve um impacto limitado nas atitudes do público em relação ao estigma (von dem Knesebeck, Mnich, Angermeyer, Kofahl, \& Makowski, 2015). Podemos pensar que a mídia hipervaloriza casos de suicídio que chocam as pessoas e casos de grande repercussão, como o suicídio de celebridades, não pelo sofrimento associado a estes atos, mas pela abrangência e "importância" da notícia.

O aumento de posts, vídeos e fotos sobre suicídio na internet podem aumentar a curiosidade mórbida e esse conteúdo acaba sendo compartilhado sem reflexão. As pessoas não pensam na repercussão e na consequência de certos tipos de compartilhamento. Muitas vezes, ao fazerem tais compartilhamentos, colocam um motivo único para o evento do suicídio o que colabora para o aumento da visão que suicídios ocorrem por causas únicas. Ao lermos os comentários que são deixados nos compartilhamentos, observamos o tabu e o julgamento em ação que em sua maioria é carregada pela visão estereotipada de que o suicídio ocorre pela ausência de Deus no coração, falta do que fazer, como exemplos. Não foi discutido pelo grupo focal o que leva as pessoas a compartilharem essas postagens. 
Um dossiê elaborado pela agência Nova/SB (2017), em seu projeto "Comunica que muda" mostra que durante os meses de abril e de maio de 2017, durante o ápice de reportagens sobre o crime virtual Baleia Azul e a série do Netflix, "Os treze porquês", foram capturadas 1.230.197 menções sobre suicídio nas principais redes sociais (Facebook, Instagram, Twitter e YouTube). Durante esse período o tema suicídio alcançou o ápice de buscas no Google dos últimos cinco anos. Isso demonstra em números o quanto o assunto pode ser estimulado pela mídia.

\footnotetext{
As redes sociais surgiram há pouco tempo, mas entraram no cenário social com um forte chute na porta. Em poucos anos, tomaram conta de muitas horas gastas na web. Depois delas, mudamos muito a maneira com que nos relacionamos, e até como vemos a importância das nossas relações. Apesar de mais conectados, observamos que a abordagem sobre o suicídio ainda é muito superficial. Se de um lado, menos de $30 \%$ dos internautas que comentaram o assunto demonstraram alguma conscientização, por outro quase $20 \%$ do conteúdo das redes são de mensagens preconceituosas, que reforçam o tabu, incentivam o comportamento autodestrutivo ou impedem o socorro por quem passa esse problema, destacou a coordenadora-geral do Comunica Que Muda, Bia Pereira (Nova S/B, 2017).
}

Por ser um canal que oferece maior acessibilidade para captura dos comentários e de haver menor exposição aos familiares e aos amigos, se comparado com outras redes, o Twitter ficou com $94.2 \%$ e o Facebook com 5\% do total de comentários nas redes sociais durante esse período (Nova S/B, 2017).

Pelo uso das redes sociais para deixar mensagens de despedida e compartilhar o suicídio ao vivo, as grandes empresas da área, como o Google, o Twitter e o Facebook têm tomado providências, mesmo que insuficientes, para mudar essa situação. A internet tornou-se um importante espaço de prevenção e de posvenção, mas também de informação de meios de como matar-se, ou seja, há o bom e mau uso desses meios (Valle \& Kovács, 2014).

Um exemplo positivo foi a criação e a divulgação do jogo Baleia Rosa, que trouxe desafios relacionados à autoestima e a busca de cuidado, sendo desenvolvido em resposta ao crime virtual Baleia Azul (Baleia Rosa, 2017). Vale lembrar-se da existência de centenas de sites e de fóruns online sobre suicídio e depressão, principalmente aqueles que incentivam o ato.

Para Tam, Tang, and Fernando (2007), a internet possibilitou o acesso público a informações relacionadas ao suicídio e à automutilação, como nunca houve antes (Westerlund, Hadlaczky, \& Wasserman, 2012), além de romantizar o ato, ter impacto em assistir e promover o suicídio, facilitar o acesso aos remédios controlados e aos venenos que ultrapassam fronteiras 
e leis, o que quebra as dificuldades relacionadas à acessibilidade e à localização dos meios de cometer o suicídio.

A internet também pode trazer efeitos benéficos ao

\begin{abstract}
facilitar a identificação de pessoas em risco, prevenir suicídios e ajudar sobreviventes, com acesso a salas de bate papo e linhas de ajuda ... a internet também favorece o treinamento, provê acesso a sites de ajuda e serviços de prevenção baseados na internet, os quais infelizmente continuam sendo pouco utilizados ... questões que desafiam médicos para usar a internet de uma maneira benéfica (Tam et al., 2007, p. 453).
\end{abstract}

Uma pesquisa realizada por Gomes, Baptista, Carneiro, and Cardoso (2014) em sites de busca no Brasil, com palavras-chave como "suicídio indolor", "suicídio rápido", entre outras, observou-se que a maior frequência, nos sites da primeira página de busca, era de sites acadêmicos, seguido por de conteúdo religioso, concluindo que no Brasil não foram encontradas páginas com conteúdo pró-suicídio. Fizemos um teste utilizando a ferramenta de busca Google com a palavra chave "suicídio indolor", dos dez sites sugeridos sete traziam conteúdos que poderiam ensinar uma pessoa a matar-se, incluindo um fórum e um vídeo, portanto, na nossa experiência, a internet é um canal de busca que facilita o acesso à informação sobre formas de cometer suicídio.

Um exemplo do bom uso das redes sociais foi a criação de um grupo virtual de sobreviventes enlutados pelo suicídio, no Facebook, no qual pessoas de todo o país participam, ajudam-se, criando uma comunidade de cuidado e de pertencimento (Scavacini, 2017a). Para Robinson et al. (2016), as mídias sociais podem alcançar inúmeras pessoas e oferecer fóruns acessíveis sem julgamento para dividirem as suas experiências.

Já é possível, dependendo da pesquisa feita, receber mensagens nas páginas de busca, de onde procurar ajuda no Brasil, divulgando-se o número e o site do CVV. A escolha de quem recebe ou não essa mensagem de ajuda é feita automaticamente por meio de algoritmos, o que faz que não seja apresentada para todas as pessoas que façam buscas com palavras relacionadas ao suicídio, questão que precisa ser analisada e discutida com os provedores de busca (Haim, Arendt, \& Scherr, 2017).

Pudemos vivenciar como fazer a denúncia de um post com conteúdo suicida e ter resposta rápida da rede social. Recebemos na página do Facebook, do nosso grupo de apoio virtual aos sobreviventes enlutados, uma comunicação suicida de uma moça que estava falando que iria cometer o suicídio até a meia noite daquele dia. Houve uma movimentação no grupo com várias pessoas oferecendo ajuda, pedindo para que ela repensasse a decisão. Decidimos 
acionar o Facebook por meio de uma denúncia na qual esclarecemos o que estava acontecendo, a resposta da rede social foi rápida, em torno de três minutos, ainda, fomos avisados que se fosse necessário enviariam uma viatura da polícia para a residência da pessoa. Acabamos não precisando acionar a viatura, pois a moça, ao conversar com uma das colaboradoras do grupo, aceitou procurar ajuda no dia seguinte, desistindo de cometer o suicídio. Cada vez mais as pessoas usam as redes sociais como uma forma de comunicação, um pedido de ajuda, uma despedida ou cometem o suicídio ao vivo. Tivemos a experiência de ver como essas redes precisaram adaptar-se para prevenirem suicídios e tem conseguido responder à demanda em alguns casos.

Infelizmente, ter a resposta rápida à crise não é suficiente, pois sabemos que caso essa moça tivesse sido resgatada e levada para um serviço de emergência, poderia enfrentar maustratos no hospital, provavelmente seria liberada após pouco tempo, e teria muita dificuldade no processo de cuidado e ajuda, mas isso é tema para outro estudo.

Atualmente é comum ver relatos em redes sociais, de pessoas que sofreram abusos sexuais e de pessoas que tentaram o suicídio ou perderam alguém. É uma forma de denúncia e de aproximação com pessoas que passaram por situações parecidas, formando uma rede de apoio. Pode ser também a busca por empatia ou ajuda.

Infelizmente a internet também pode ser uma janela para o ódio e para o preconceito. Um exemplo dessa situação foi o vídeo do youtuber Logan Paul, que filmou o corpo de uma pessoa enforcada em uma floresta do Japão, depois fez piada sobre o evento, postando o vídeo em seu canal no Youtube (O Globo, 2018). A resposta do Youtube foi o bloqueio de seu canal, que contava com mais de quinze milhões de seguidores, além de moderar os vídeos no google prefeered $^{25}$ para evitar novos casos (Reuters, 2018). Portanto, mesmo que haja o discurso do preconceito, percebemos que as pessoas e as redes sociais já estão mais atentas e reagem de diferentes maneiras a essas postagens desrespeitosas.

Recentemente soubemos do caso da adolescente de 14 anos, Ammy "Dolly" Everett. Uma garota propaganda que sofria bullying e cyberbullying, que acabou matando-se na Austrália, causando choque e espanto pelo seu ato, pela sua idade e por ser uma pessoa conhecida. Seu pai deu algumas declarações, utilizando as redes sociais e convidou as pessoas que praticavam bullying em Ammy para comparecerem ao seu funeral e verem a dor que ajudaram a causar. Ele também agradeceu as palavras de apoio que recebeu, dizendo que o período "foi um exemplo de como mídias sociais devem ser usadas" (Ansa, 2018). Percebemos

\footnotetext{
${ }^{25}$ Serviço que oferece anunciantes de marcas aos principais produtores do YouTube.
} 
que os casos estão ganhando voz, muito a partir dos sobreviventes e da abrangência das redes sociais, que acabam conectando as pessoas às histórias, aumentando a consciência pública.

A internet é um veículo de informação rápido e prático, sendo utilizado por quem está em busca desesperada de encontrar uma saída para seus problemas e para a sua dor, procurando um caminho ou uma solução com urgência. Muitas pessoas buscam em ferramentas online, como o Google, porém, ao fazerem podem encontrar tanto conteúdos mostrando como cometer o ato, como onde procurar ajuda. A pergunta que nos fazemos é se a pessoa, ao procurar informações sobre suicídio encontre primeiro páginas sobre formas de matar-se ao invés de formas e de locais nos quais possa receber ajuda, o que é uma problemática muito grave. Perguntamo-nos se não é caso de ter censura como no caso da pedofilia. Devido ao aumento do uso dessas ferramentas com objetivos que oferecem proteção ou risco, estudos já estão sendo desenvolvidos para definirem quais são os fatores de risco; os dias e períodos com maior perigo (como em datas comemorativas) e as palavras-chave que devem ser "ensinadas" aos algoritmos (como "envenenamento") para que os resultados de busca dessas pesquisas mostrem ou direcionem a pessoa para sites de prevenção do suicídio (Arendt \& Scherr, 2017b).

Cabe ressaltar que a internet pode prover meios rápidos de acabar com a dor, tendo em vista o desespero associado ao ato, à facilidade de obter essas informações posa como um desafio de saúde pública e de tecnologia. Ressaltamos que pessoas nessa situação de dor existencial não conseguem esperar meses por uma consulta, um tempo longo para que a medicação faça efeito ou para psicoterapia por meses. Precisamos desenvolver formas acessíveis de tratar as pessoas em crise. Quanta dor as pessoas conseguem suportar? Será que o fato das pessoas estarem perdidas e sem saída, e possam encontrar uma saída para findar com o sofrimento, ou seja, para o suicídio? A internet tem meios para isso. Para muitos, os entraves de receber ajuda são maiores que os de tentar e cometer suicídio, no entanto, no desespero, pode se procurar a saída mais rápida.

Mesmo que existam linhas de ajuda para crise, como o CVV, elas não podem abranger o processo inteiro, muitas vezes, mesmo que ofereçam o atendimento telefônico na crise, não têm para onde encaminhar as pessoas, que necessitam de atendimento em longo prazo. Há um apoio do governo ao CVV, que recentemente alterou o número 141 (pago) para 188 (gratuito), ou seja, as pessoas não precisam mais pagar a ligação, porém o CVV ainda precisa conseguir ter acesso a locais onde pessoas em crise possam ser encaminhadas com a certeza de receberem atendimento. Ainda não há um protocolo que funcione nesses casos.

Em Londres, existe um local chamado de "Maytree - um santuário para suicidas" 
(tradução nossa), mantido e coordenado pela ONG Maytree em conjunto com o Samaritans ${ }^{26}$. É uma casa onde pessoas em crise suicida podem hospedar-se em uma "estadia gratuita de quatro noites, cinco dias, tendo a oportunidade de ser ajudado e ouvido com total confiança, sem julgamento, com compaixão e calor” (Maytree, 2013 - tradução nossa). Lá as pessoas recebem atenção de voluntários para repensarem suas vidas e a questão do suicídio. Não existem locais como este no Brasil, portanto, pessoas "conscientizadas" em crise que procurem ajuda, talvez só consigam a escuta urgente pelo CVV, o que pode ajudar em muitos casos, mas receber atendimento especializado ou ter locais para tratamento são demandas que provavelmente não serão supridas.

Não é fácil encontrar ajuda ou informações sobre ajuda. A partir da sugestão de um dos colaboradores, ressaltamos a necessidade de disponibilizar informações com instruções práticas de onde buscar ajuda, em que haja fácil acesso pelos meios virtuais e contenha instruções detalhadas do que fazer.

Quando pensamos no acesso a cuidados de saúde mental, precisamos lembrar-nos da reforma psiquiátrica, da diminuição dos manicômios e da descentralização do cuidado, que foram passos importantes tomados no país em relação à saúde mental (Borges \& Baptista, 2008; Medeiros \& Guimarães, 2002). No entanto, nos últimos vinte anos o número de leitos psiquiátricos diminuiu de 85000 para 45000 , sendo que $30 \%$ deles são ocupados por pacientes de longa permanência. Menos de 2\% dos hospitais gerais (apenas oitenta e quatro) têm unidades psiquiátricas (Larrobla \& Botega, 2001). No Brasil, a prevenção primária em saúde mental é quase inexistente, prevenção secundária e terciária são mal estruturadas, raras e lotadas (ABP, 2006). Encontrar atendimento em saúde mental infantil ou juvenil também são desafios enfrentados pela sociedade (Couto, Duarte, \& Delgado, 2008), realidade enfrentada por uma colaboradora ao tentar internação para seu sobrinho. $O$ fato da reforma psiquiátrica ter acontecido, não significa que haja um bom acesso ao tratamento em saúde mental atualmente.

Existem muitas dificuldades em conseguir ajuda e tratamento em saúde mental no país. Os Centros de Apoio Psicossociais (CAPS), pertencentes ao Sistema Único de Saúde (SUS) são escassos e frequentemente não abrangem a demanda, situações essas que foram relatadas pelos colaboradores. Muitos hospitais não possuem psiquiatras, devido à diminuição de leitos, tornou-se muito difícil conseguir internação para pessoas com comportamento suicida em risco. O primeiro atendimento das pessoas com comportamento suicida geralmente ocorre na Unidade de Pronto Atendimento (UPA) ou na Unidade Básica de Saúde (UBS), em que ambos não

\footnotetext{
${ }^{26}$ Os Samaritans oferecem escuta gratuita, feita por voluntários, para pessoas em crise (www.samaritans.org).
} 
trabalham psiquiatras (ABP, 2006).

A dificuldade de acesso a tratamentos e à internação psiquiátrica foi citada pelos colaboradores, que se sentem desamparados diante da falta de atendimento e de acesso à saúde mental de qualidade. Uma das colaboradoras, que perdeu o sobrinho para o suicídio em uma clínica de repouso, aponta a importância de haver fiscalização nesses estabelecimentos e um maior acesso ao tratamento de jovens.

Para Azevedo (2012), no nível de atenção primária os serviços seguem as orientações das Diretrizes Nacionais (Brasil, 2006b), nos níveis secundários e terciários, o despreparo, a negativa em cuidar e o desprezo prevalecem. Ações voltadas para uma formação, baseada na integralidade, humanização e no entendimento dos determinantes sociais do ato em conjunto com a ideia do sofrimento, são passos fundamentais para gerar mudança. Falaremos sobre os maus-tratos a pessoas com comportamento suicida mais adiante.

$\mathrm{Na}$ área acadêmica, precisamos aumentar substancialmente as falas e os eventos sobre o suicídio, trazendo a importância da prevenção e da posvenção na formação. Ressaltamos que diferentemente de outros países, não temos prêmios, patrocinadores ou incentivos para pesquisa em suicídio, além de não existir um comprometimento profícuo das universidades em colocar a prevenção do suicídio no currículo dos estudantes. Muitas universidades somente tomaram algum tipo de providência após acontecerem suicídios em suas dependências, sendo que muitas vezes os movimentos por mudança são encabeçados por alunos e diretórios acadêmicos. Em um dos encontros de sobreviventes, houve o relato de duas estudantes de psicologia que sobreviveram a tentativas de suicídio, sentiram preconceito dos professores e dos colegas do curso. Quando uma delas desabafou com o grupo sobre sua experiência, no entanto, a professora falou que ela se expôs demais. Não temos dúvidas que aumentar a consciência e a empatia nas universidades é um ponto fundamental para a melhora do tema.

Logo que a pesquisadora voltou de seu mestrado na Suécia, entrou em contato com o Conselho Regional de Psicologia (CRP), para tentar conversar com alguém sobre a necessidade de haver cursos de prevenção do suicídio na formação dos psicólogos. A resposta que recebeu foi que essa questão não era de competência do CRP, que deveria procurar o Ministério da Educação em Brasília. Finalizou o contato sentindo-se frustrada e com a sensação que ainda temos muito a caminhar.

Se falta um aumento de consciência nos alunos e nos docentes, além de existir uma cegueira acadêmica para o assunto, de um lado, mas podemos observar um aumento do interesse, de outro. Um evento na Universidade de São Paulo (USP), sobre prevenção do suicídio, realizado em 2013, contou com mais de quinhentos estudantes e profissionais 
interessados. Em 2017, foi realizado o I Simpósio Paulista de Prevenção e Posvenção do Suicídio na Universidade São Camilo, em São Paulo, com a presença de seiscentas pessoas, que demonstra que cada vez mais profissionais e estudantes estão interessados no assunto, procurando cursos e eventos relacionados ao tema.

Há um aumento de Trabalhos de Conclusão de Curso (TCC), mestrados e doutorados sobre o tema, o que mostra o interesse dos alunos e abertura dos orientadores para o assunto. Entretanto, ainda se nota uma dificuldade de aprovar nos comitês de ética trabalhos relacionados ao suicídio, talvez pelo tabu relacionado ao fato ou pelo medo de aprovar pesquisas com pessoas em situação de vulnerabilidade. Pela experiência da pesquisadora e pelo relato de colegas, tivemos dificuldades de aprovação de pesquisas sobre suicídio. Ressaltamos que apesar das dificuldades para aprovação devemos insistir, porque é muito importante realizar pesquisas sobre o assunto, com qualidade e respeito ético.

Embora um dos colaboradores relatasse ter tido muita dificuldade em encontrar cursos sobre o assunto, em 2018 serão realizados o primeiro curso de especialização de prevenção e de posvenção do suicídio em Teresina; o primeiro curso de aprimoramento em São Paulo; o primeiro curso avançado em suicidologia online. Esse fato levanta três questões, o aumento do interesse do público no assunto; a necessidade de haver formação especializada; a presença de profissionais e de professores capacitados no assunto.

A maioria dos alunos de psicologia não têm aulas sobre prevenção do suicídio e nem terão nos próximos anos, sendo essa uma meta importante: a criação de disciplinas sobre suicídio durante a formação da graduação e da pós-graduação. Disciplinas que abordem a tanatologia, ensinando ao aluno a respeito do luto e da morte também são necessárias para o cuidado com os enlutados pelo suicídio. Não podemos obrigar ninguém a aprender sobre o tema, a universidade que deveria ter a obrigação de oferecer disciplinas com esse conteúdo. Os ministérios da saúde e da educação deveriam se unir para enfrentar essa batalha juntos.

Os graduandos interessados pelo assunto do suicido ou da morte e luto têm de desdobrar-se atrás de cursos fora da universidade ou de palestras oferecidas em semanas da psicologia, por exemplo. Embora os colaboradores pensem que a formação deve ser voltada aos estudantes da área de saúde, o que é fundamental, a pesquisadora discorda parcialmente dessa opinião, tendo em vista que se tivéssemos aulas de prevenção do suicídio nas faculdades de arquitetura, ajudando os alunos a pensarem em construções seguras; nas faculdades de direito, para que percebam o suicídio também como produção social; nas faculdades de agronomia, ensinando sobre o uso e estocagem segura de pesticidas; nas faculdades de comunicação social, propaganda e marketing, jornalismo e cinema, para que pensassem em 
como discutir de forma responsável sobre o assunto e não se esconderem atrás do efeito Werther, pensando que falar sobre suicídio pode induzi-lo, isso teria impactos positivos para toda a sociedade em longo prazo.

O efeito "Werther" 27 , termo cunhado por Phillips (1974), refere-se ao aumento de casos de suicídio após reportagens sensacionalistas ou que mostrem com detalhes o suicídio de alguém. Esse efeito tem sido debatido por muitos autores, como indicam Pouliot, Mishara, and Labelle (2011) em seu estudo piloto sobre o efeito Werther à luz das vulnerabilidades psicológicas.

Um exemplo atual relacionado ao efeito Werther foi demonstrado no estudo de Fink, Santaella-Tenorio e Keys (2018) a respeito do aumento em 10\% dos casos de suicídio nos 5 meses posteriores à morte do ator Robin Willians. Os autores trazem a informação, que, dependendo da identificação das pessoas com aquele que se matou e a exposição da notícia na mídia, especialmente se for famoso, os suicídios podem aumentar. "No caso de celebridades, a possibilidade de alguém vulnerável fazer uma conexão afetiva e se identificar com a decisão (do suicídio) é maior. Em alguns casos, podem até interpretar a morte da celebridade como um sinal de que devem tirar a própria vida." (Fraser em BBC, 2018).

O efeito "Papageno" ${ }^{28}$, termo cunhado por Niederkrotenthaler et al. (2010), refere-se ao contrário, quando reportagens responsáveis podem diminuir o comportamento suicida no público, fornecendo exemplos de outras pessoas, que passaram com sucesso por crises suicidas, enfatizando alternativas ao ato, educando o público e gerando conscientização. (Pirkis, Mok, Robinson, \& Nordentoft, 2016).

O termo do efeito supracitado vem de um programa francês de prevenção do suicídio para estudantes com a finalidade de aumentar a consciência e melhorar a cobertura jornalística sobre o suicídio, no qual pessoas especializadas corrigem, guiam e provém informação; estagiários de psiquiatria desvendam os mitos e estudantes de jornalismo investigam o suicídio em suas dimensões sociais por meio de conversas abertas sobre o tema (Pauwels \& Notredame, 2015). Portanto, eles pretendem mudar a forma como ocorre a transmissão do conhecimento, para que todos sejam incluídos, objetivando promover uma sensibilização sustentável, assim "uma nova geração de jornalistas pode crescer estando mais consciente de sua

\footnotetext{
${ }^{27}$ Em referência ao livro de Goethe (2001) chamado “Os sofrimentos do jovem Werther”, que cometeu o suicídio após uma desilusão amorosa. Tal livro foi banido da Europa por ser relacionado a uma epidemia de suicídios, que ocorreram após o lançamento do livro (Thorson \& Öberg, 2003).

${ }^{28}$ Papageno é um personagem da ópera de Mozart (1791 citado em Schikaneder 1990) em "A Flauta Mágica", que ao temer perder seu grande amor, Papagena decide tirar sua própria vida, quando três garotos oferecem ajuda, sugerindo a ele melhores maneiras de lidar com o problema.
} 
responsabilidade" (Notredame, 2016, p. S29) ao optar espontaneamente em seguir as recomendações da OMS sobre a mídia, desenvolvendo novas formas de pensar. O programa visa também à descoberta de pontos de vista e de missões parecidas para encontrar as perspectivas em comum e criar redes de contato entre os estudantes. Assim, psiquiatras e jornalistas podem unir-se para que haja uma cobertura mais segura sobre o suicídio (Notredame, 2016), pois muitos jornalistas preferem ignorar o suicídio, não seguem as orientações da OMS e hesitam em fazer reportagens com esse tema (Beam, John, \& Yaqub, 2017).

Em 2017, por acreditar que falar sobre suicídio é fundamental e que escrever pode ser uma ferramenta de cura e de ressignificação, foi criado pela pesquisadora o I Concurso Literário para Sobreviventes do Suicídio, dividido em três categorias: sobreviventes de tentativas, enlutados e profissionais. A comissão julgadora do concurso ficou surpresa ao receber um maior número de obras de pessoas, que tentaram suicídio e praticamente nenhuma de profissionais. Esse fato leva-nos a refletir que os sobreviventes de tentativas podem estar mais abertos ou terem urgência maior para contar suas histórias, sendo que os profissionais têm mais dificuldades em escreverem ou falarem sobre o assunto. Os enlutados tiveram uma participação média, por isso refletimos que talvez, para eles, falar sobre o assunto pode ser mais dolorido e requer mais tempo para refletir e compartilhar suas histórias com os outros, como observamos nos colaboradores a necessidade de preparação para falar sobre o suicídio em sociedade.

Ao sensibilizarmos estudantes, poderíamos ter médicos e profissionais da área da saúde e da educação mais atentos, mais empáticos a essa dor, talvez pudéssemos, por exemplo, prevenir maus-tratos e julgamentos a pacientes que dão entrada nos prontos-socorros com tentativas de suicídio e com os enlutados pelo suicídio, situação discutida e apontada pelos colaboradores como um dos impedimentos do cuidado adequado no lugar citado.

\footnotetext{
A assistência ao paciente que tentou o suicídio no pronto-socorro é inadequada, marcada pela falta de preparo e fragmentação do cuidado. Evitase o contato com o sofrimento intenso relacionado com o ato suicida ... os fatores que influenciam na assistência precisam ser reconhecidos e reformulados para que haja melhoria na qualidade dos atendimentos, possibilitando um cuidado integral à pessoa com ideação e tentativa de suicídio (Toro, 2016, p. 8).
}

A reação dos profissionais às pessoas que tentaram suicídio, mais que um tabu, é uma situação que mexe profundamente na vocação deles visto que foram formados para salvar e para curar, sendo que o suicídio afronta de forma radical essa missão (Rigo, 2017). O estudo de Machin (2009) aponta que pessoas que chegam às emergências para atendimento das lesões autoprovocadas, não são tratadas nem como doentes (possuidoras de uma doença orgânica), 
nem como vítimas (por evento fortuito ou acidental), então, podemos imaginar como tais pessoas serão cuidadas. A autora (2009) vê a falta da formação médica para além do modelo biomédico, como um dos causadores dessa situação. Compreendemos que não podemos simplificar a questão somente na formação médica, esta é uma discussão complexa que envolve o estigma, o preconceito e o tabu.

Scavacini (2017b) atenta para a necessidade de adequação dos hospitais gerais e Unidades de Terapia Intensiva (UTI) para lidarem com o comportamento suicida, bem como a capacitação de psicólogos hospitalares para a detecção, manejo e sensibilização da equipe de saúde diante desse comportamento.

Durante o Setembro Amarelo, mês da prevenção do suicídio e do Dia Internacional da Prevenção do Suicídio (10 de setembro), muito se fala sobre o tema, em eventos que debatem sobre o suicídio. Muitas críticas e sugestões foram feitas pelo grupo referente a essa campanha, porém é inegável que houve aumento de reportagens, palestras, congressos, simpósios e atividades relacionadas à prevenção do suicídio. A cada ano, segundo experiência da própria pesquisadora, têm mais pessoas interessadas sobre o tema, buscando profissionais para falar sobre o assunto e pelo menos na área da saúde mental, a campanha tem crescido e tomado força, o que é um ótimo sinal, além de um aumento de eventos nacionais, estaduais, regionais e locais. Como toda campanha, precisa de ajustes, como planejar as ações, por exemplo, pois, pela análise aqui estabelecida, muitos eventos que compõem o Setembro Amarelo são realizados sem planejamento ou objetivo definido. É preciso saber aonde se quer chegar e as pessoas que se pretende alcançar para enfim traçar o melhor trajeto, pensando em campanhas como uma peça dentro de um plano de prevenção, para que todo o esforço não seja em vão.

Os colaboradores falaram sobre o Marketing Amarelo, sendo campanhas com propósito de promoção pessoal ou profissional, porém sem engajamento. Esse é um risco que ocorre com algumas, por isso é necessário que haja planejamento e avaliação dos objetivos.

Para Hoven, Tyano e Mandell (2009), acender uma vela não é suficiente, em alusão à campanha da International Association for Suicide Prevention (IASP) de acender uma vela no dia 10 de setembro para apoiar a causa. Para eles, campanhas como essa tem efeito breve, podendo trazer uma falsa esperança de alívio que não são acompanhadas pela disponibilidade de recursos para tratamento, para os autores, as campanhas precisam ter continuação e foco.

Muitas campanhas de aumento de consciência podem ser observadas, como o "Semicolon Project" 29 - projeto ponto e vírgula (tradução nossa), no qual pessoas tatuam um

\footnotetext{
${ }^{29}$ www.semicolonproject.com
} 
ponto e vírgula no corpo em alusão à luta contra um transtorno mental ou recuperação de um trauma; outra campanha a "People of color and mental illness photo project" ${ }^{30}$ (Pessoas de cor com transtorno mental - tradução nossa), que tenta diminuir o estigma e mostrar que os transtornos mentais e o suicídio ocorrem em todos os tipos de raças e de cores; na "Stop Suicide ${ }^{, 31}$ (Pare o suicídio - tradução nossa), pessoas são encorajadas a mandarem vídeos com suas histórias de superação a fim de ajudar outras pessoas a entenderem melhor o que é o comportamento suicida. Esses são alguns exemplos de diversas campanhas que podem ser vistas pela internet.

A “American Foundation for Suicide Prevention" (AFSP, 2017) tem uma página na internet, que ajuda as pessoas a criarem suas próprias campanhas com o intuito de arrecadarem dinheiro para essa instituição, dessa forma, ajudarem na pesquisa e na divulgação da prevenção do suicídio. Ainda, na página é possível escolher um tema e um objetivo para a campanha e divulgar para as pessoas. Esse é um exemplo de ação prática e fácil que colabora para que as pessoas criem campanhas, podendo personalizá-las.

A “Suicide Awareness Voices of Education" (SAVE, 2018) é uma instituição privada, especializada em ajudar pessoas nos Estados Unidos, a organizarem campanhas para a comunidade, além de eventos para a arrecadação de fundos para a prevenção e posvenção do suicídio.

Blogs como Taking about suicide ${ }^{32}$ entrevistam diferentes pessoas relacionadas ao tema, trazendo informações sobre o assunto; Sites como o Health Talk ${ }^{33}$ mostram depoimentos de pessoas enlutadas pelo suicídio; Campanhas como a da Associação Internacional para a Prevenção do Suicídio e a Organização Pan-Americana da Saúde/Organização Mundial da Saúde (OPAS/OMS), que em 2017 teve como lema da campanha "Doe um minuto. Mude uma vida $^{, 34}$, objetivando conscientizar a população de que o suicídio pode ser prevenido; Exposições interativas que falam sobre engajamento e problemas sociais, como a nova exposição do Museu do Amanhã ${ }^{35}$ no Rio de Janeiro, que traz informações sobre o suicídio, divulgando locais onde as pessoas podem engajar-se, mostram como dispomos de várias possibilidades de aumentar a consciência e como a sociedade já tem se mobilizado para que isso aconteça.

\footnotetext{
${ }^{30} \mathrm{http}: / /$ diorvargas.com/poc-mental-illness

31 www.stopsuicidepledge.org

$32 \mathrm{https} / / /$ talkingaboutsuicide.com

${ }^{33} \mathrm{http} / /$ www.healthtalk.org/peoples-experiences/dying-bereavement/bereavement-due-suicide/topics

${ }^{34} \mathrm{https}$ //nacoesunidas.org/campanha-da-onu-busca-conscientizar-populacao-sobre-prevencao-ao-suicidio/)

$35 \mathrm{https}$ ://museudoamanha.org.br/pt-br/irismais
} 
Essas são campanhas que visam dar voz, rosto, empoderamento àqueles que sofrem por causa do suicídio. No Dia Internacional dos Sobreviventes Enlutados pelo Suicídio, que é comemorado todo segundo sábado do mês de novembro, pessoas enlutadas saem às ruas, reunindo-se com o objetivo de falarem abertamente sobre o assunto. Essa campanha está na sua $3^{\mathrm{a}}$ edição no Brasil, sendo oferecida por meio da parceria do Instituto Vita Alere com a AFSP. Outra campanha é a Colcha da Memória Viva, projeto da AFSP e também iniciado no Brasil pelo Instituto Vita Alere, que consiste em uma colcha que é confeccionada com retângulos (quilts), que contém fotos de pessoas que se mataram e mensagens ou frases de seus pais. $\mathrm{O}$ objetivo desse projeto é aumentar a consciência pública ao mostrar que ninguém está sozinho e dar rosto aos números. É uma forma de humanizar as taxas e mostrar que não conseguimos saber se uma pessoa tem comportamento suicida somente pelo seu rosto, muitas pessoas conseguem esconder bem o que sentem; e que a vida de uma pessoa é muito mais do que a forma como ela morreu.

Devemos questionarmos, como sociedade e pesquisadores, sobre o que queremos conscientizar e para quem, com cada campanha e como fazer que essa conscientização continue em longo prazo. Campanhas podem focar na relação do bullying e do suicídio, podem ser direcionadas ao público LGBT, podem arrecadar fundos para pesquisas científicas na área da prevenção. São inúmeras as possibilidades, que vão além do "vamos falar mais sobre isso".

Para a qualificação do doutorado, a pesquisadora entrevistou um especialista sobre prevenção do suicídio, ressaltando que muito do que relatou também foi abordado pelos colaboradores, o que mostra que os pontos de vista, entre os afetados pelo suicídio e os especialistas não são tão diferentes assim. Uma das questões trazidas pelo profissional, também citada por um colaborador, foi o fato das campanhas gerarem demanda de atendimento e não termos locais de encaminhamento para pessoas que necessitam de ajuda.

A dificuldade de ter atendimento digno e o medo do que possam encontrar dificulta a busca de tratamento. Além de ampliar a comunicação sobre suicídio, é preciso expandir e melhorar as formas de tratamento em clínicas e em hospitais, que também devem ser devidamente monitorados para casos que precisam de internação. A pessoa pede ajuda e não se mata, mas a sua vida acaba, porque vai ser estigmatizada, julgada e talvez até privada da liberdade, também há uma grande probabilidade de muitos gastos com tratamento e endividamento por essa razão.

Para mudarmos esses contextos, precisamos saber como é vista pela sociedade a pessoa que fala em cometer suicídio ou sobrevive a uma tentativa. É muito importante que essas pessoas sejam compreendidas e acolhidas. Por que o manejo de pessoas com câncer difere das 
com tendências suicidas? Será a imprevisibilidade do ato? Será o medo da responsabilidade? Da culpa? As pessoas com câncer já foram e as com AIDS ainda são estigmatizadas pelas doenças, porém atualmente a aceitação dessas pessoas está melhor (Fife \& Wright, 2000).

Sabemos que uma tentativa aumenta o risco do suicídio. Será que parte desse risco não está relacionado ao tabu, ao julgamento e à falta de atendimento? Por que o atendimento que é rude não ajuda a quem tem ideação ou teve uma tentativa se suicídio. Essas pessoas, muitas vezes são maltratadas nos hospitais e colocadas de volta na mesma situação, que pode ter sido um dos fatores que levou a pessoa a pensar em matar-se. Não há acompanhamento e continuidade na ajuda, segundo Meleiro (2013), estudos mostram que 75\% das pessoas havia procurado os serviços primários de saúde e $45 \%$ fizeram essa procura um mês antes do suicídio; $15 \%$ dos pacientes com tentativa que são atendidos no hospital geral, fazem nova tentativa no período de um ano. Para Vidal and Gontijo (2013):

A baixa capacitação das equipes de atendimento e as deficiências estruturais dos serviços induzem os profissionais a se posicionarem de maneira impessoal e com difículdade de atuação de forma humanizada. A análise dos dados indica a necessidade de melhorar a formação dos profissionais da saúde, em especial os que trabalham nos serviços de pronto atendimento (Vidal \& Gontijo, 2013, p. 108).

Vidal e Gontijo (2013) dividiram as reações encontradas por essas pessoas em discriminação, negação do ato ou encaminhamento. A pessoa que tenta o suicídio acredita que ao matar-se resolverá seus problemas, mas após a tentativa que não resultou em morte percebe que a dor continua ou por vezes até piora, ouve frases como "nem para se matar tem capacidade". Provavelmente poucas pessoas vão acreditar na sua melhora, muitas vezes será sempre vista como "a suicida".

É nesse ponto que a aliança entre enlutados e pessoas que tentaram pode funcionar. Depois de algum tempo, em geral, os enlutados entendem a dor e podem acolher, orientar quem tem ideação suicida, não para tirar a dor ou a culpa pelo que aconteceu com alguém amado, mas com a esperança de que eles possam fazer diferença para alguém não chegar a cometer o ato.

Embora o foco desse trabalho não seja somente sobre as experiências de falar sobre o suicídio, a comunicação é influenciada pelo tabu, pela forma de falar ou pela necessidade de calar-se. A comunicação pode ser influenciada, se aumentarmos a consciência pública. Ninguém deve ser obrigado a falar sobre o suicídio, porém quando as pessoas encontram ressonância em sua comunicação, há abertura com possibilidade de acolhimento às suas 
necessidades de forma positiva. É importante abrir espaço para falar, respeitar os limites e haver espaço seguro sem proibição ou julgamento para que isso aconteça.

Percebemos no grupo de apoio a enlutados certa pressão para quem não relata em contexto social a morte por suicídio. Para alguns colaboradores, começar a falar sobre o assunto na sociedade é como se fosse uma vitória, para outros, deveria ser uma obrigação em prol da “causa". Não podemos esquecer que não há certo ou errado, o falar deve ser uma escolha consciente. Durante as reuniões dos grupos focais, uma colega psicóloga observou que quando a colaboradora falava sobre sua experiência ao perder um paciente por suicídio, o grupo pareceu atento, porém aparentemente não demonstrava a mesma identificação com ela como a que acontecia quando outro familiar falava, parecendo haver uma dificuldade de compreender o outro, mesmo nesse contexto, como se só o outro, que sentiu a perda no mesmo nível que eles, pode entender o que eles sentem. Então, quando falam na dificuldade de as pessoas terem empatia, eles parecem não perceber que ainda diferenciam experiências de acordo com sua própria história - quem perdeu um filho é diferente de quem perdeu um paciente ou um amigo? Claro que sim, pois cada perda é diferente, porém percebemos que no próprio grupo parece existir essa classificação de "graus" de sofrimento. Por vezes, nos parece que há certa dificuldade de cada um sair de sua própria vivência e olhar para o outro.

Quem não viveu a perda por suicídio não terá nunca a mesma visão de quem passou pelo processo, mas isso não significa que não possa ter uma postura empática e respeitosa diante dos que morreram e dos enlutados pelo suicídio. Então, fundamental é que haja a compreensão de que a dor é intensa e que as pessoas que tem essa dor precisam de cuidados.

\subsection{CONSCIENTIZAÇÃO}

Se analisarmos a série televisiva "Os treze porquês", observando sua abrangência e impacto, é preciso considerar que essa série foi produzida e comunicada por jovens para jovens, não teve tom professoral, utilizando um meio muito popular nessa faixa etária, a Netflix. Houve experiências e situações nas quais muitos se identificaram, pois reflete a realidade de problemas e pensamentos, que muitos deles experimentam atualmente. O cerne aqui é pertencimento e identificação, que pode ter uma influência ainda maior em adolescentes, que estão em uma fase de busca de aceitação do grupo.

Portanto, embora o grupo não tenha abordado o tema dessa maneira, se influenciarmos os grupos e gerarmos uma tendência de cuidado, preocupação e prevenção, essa perspectiva pode expandir e atingir cada vez mais pessoas. Seria uma forma mais adequada dessa tendência 
ser ditada que por uma série televisiva, que mostra o suicídio como "saída" para fugir do bullying e para outras situações da adolescência.

Cabe à pessoa expressar o que está sentindo, buscar ajuda ou formas de cometer o suicídio, só ela pode escolher. Podemos oferecer e desenvolver formas de prevenir o suicídio, mas, novamente, nunca poderemos prever quem fará a escolha pelo suicídio e em que momento e isso precisa estar muito claro para todos que se envolvem nessa área.

Embora um dos colaboradores tenha comentado que saiu aflito da reunião, percebemos que os grupos focais mobilizaram questões e acabaram tendo um caráter terapêutico para os participantes, mesmo não sendo esse o propósito. Isso reforça a ideia de que espaços de conversação são necessários, sendo que falar e ouvir fazem muita diferença para quem já passou pela experiência do suicídio.

Outra questão que surgiu está relacionada com a subnotificação e com o tabu, além de outras variáveis, influenciam a notificação do suicídio e as taxas. Rogers and Lester (2010) relatam como profissão, gênero, religião e outras características, tanto do legista, quanto do falecido podem influenciar se o óbito será classificado como suicídio ou por outras causas. Eles também relatam que existem diferenças nos números, se foram calculados baseados nos relatórios policiais ou nos relatórios do legista. Rockett (2010) aponta as diferenças de notificações entre os países e a importância de as taxas serem as mais fidedignas possíveis, apresentando as dificuldades a fim de que os países consigam ter dados precisos sobre o suicídio, para ele, as dificuldades na notificação deveriam ser vistas como um problema de saúde pública. Em 2014, uma portaria publicada pelo Ministério da Saúde tornou compulsória a notificação de tentativas de suicídio (Brasil, 2014). Mudanças na forma de notificação já mostram significantes alterações nas taxas brasileiras, como em Pelotas, que de janeiro ao final de outubro de 2017 teve um aumento nas taxas de tentativas de suicídio em 91\%, ou seja, de 19 casos em 2016 para 192 (Gaúcha ZH, 2017). Esses números demonstram a urgência e a importância da notificação correta, para tentativas de suicídio e suicídios completos.

Aparentemente não há uma regra clara sobre os atestados de óbito e suicídio, vide a experiência dos colaboradores, o que leva a uma grande margem para interpretações e subnotificações. Os dados de mortalidade enviados ao DATASUS, que geram as taxas de mortalidade, baseiam-se na causa de morte presente no atestado de óbito. Como só há a liberação do corpo com um atestado de óbito, muitos casos de suicídio vão a inquérito policial, é comum que apareça no atestado de óbito "causas indefinidas". Após o inquérito, o atestado pode ou não ser alterado para suicídio, porém o dado que gera as taxas de mortalidade mantém a causa original. Entre os colaboradores, houve o relato de apenas um caso em que o suicídio 
constava como causa de morte no atestado de óbito, o que nos apresenta o tamanho do problema.

A importância de apresentar números e taxas precisas auxilia na divulgação e no planejamento para onde os esforços de prevenção devem ser dirigidos. Precisamos conhecer as estatísticas para fazermos programas e conscientizações voltadas para o público alvo. Considerar os números pode demonstrar o quanto o suicídio é mais frequente que se imagina e o conhecimento desse fato pode promover a empatia pelas experiências de perda e de superação.

Enquanto houver uma condenação pela igreja ao suicídio, mesmo que velada, pessoas que pensam em matar-se e enlutados deixam de ter um importante local que deveria ser de acolhimento e compreensão, encontrando um lugar de julgamento e de exclusão. Essas questões podem fazer que a religião e a igreja tornem-se fatores de risco para pessoas que pensam em suicídio, e trazendo mais dor ao processo de luto dos sobreviventes.

Uma questão importante para nós é saber quem se interessaria que o suicídio fosse mais pesquisado e abordado na sociedade, com quem poderíamos contar. Chegamos a algumas reflexões que necessitariam de pesquisas para saber se procedem ou não. Em primeiro lugar, pensamos que é importante ter conhecimento de quem financia as campanhas do câncer e dos acidentes de trânsito. Percebemos que muitas pesquisas têm ligações com a indústria farmacêutica ou com seguradoras, portanto, tais empresas têm interesse financeiro para a implementação de programas de prevenção. Em segundo, precisaríamos identificar quem teria o interesse financeiro em financiar campanhas de prevenção do suicídio, para então transformálo em um parceiro para fundos de pesquisas e de desenvolvimento. Em terceiro lugar, poderíamos buscar parceiros nas esferas públicas, para desenvolvermos pesquisas e campanhas sobre o assunto, tendo em vista que nos Estados Unidos a maior parte das verbas de pesquisa vem de recursos federais, no entanto, o Brasil tem feitos movimentos contrários a essa iniciativa ao confirmar que congelará parte dos recursos aprovados na Lei do Orçamento da União para recursos destinados a instituições de pesquisa (Tuffani, 2018), acreditamos, entretanto, que isso não deve impedir que seja um recurso utilizado para financiar ações de prevenção do suicídio. Por fim, outros recursos poderiam vir por meio do terceiro setor; de pessoas com lived experience $^{36}$ ou de campanhas de financiamento coletivo.

Pensamos que em relação à depressão existe um interesse maior de patrocínio de pesquisas pela indústria farmacêutica, porém ainda precisamos desenvolver mais parcerias para pesquisa e tratamento da ideação e a tentativa de suicídio.

\footnotetext{
${ }^{36}$ Sobreviventes de tentativas e enlutados pelo suicídio, pessoas que tem a "experiência vivida"do assunto.
} 
Outra questão é o interesse das políticas públicas. Observamos esse interesse no Brasil? Do nosso ponto de vista pensamos que não. Aprovar um projeto de lei que institui o dia ou o mês de prevenção é um tipo de ação, ao nosso ver, mais voltada à autopromoção de algumas pessoas que o interesse da população. O suicídio denuncia muitas coisas, a falta de acesso a tratamentos e à saúde mental de uma população, além de ainda o tabu estar muito presente. Perguntamos, quais políticos realmente se interessariam em abordar o assunto?

Dessa forma, pensando nas políticas públicas brasileiras em relação ao suicídio, devemos destacar algumas questões. Segundo Machado, Leite, and Bando (2014), há uma "negligência histórica da prevenção do suicídio como objeto de políticas públicas no Brasil" (p. 334). O tabu, abordagem da mídia, o acesso aos métodos, a subnotificação e o atendimento são problemas que estão na "raiz do processo de negligência ao tema no sistema de saúde" (p. 335). Para Bertolote (2004), as políticas de prevenção do suicídio devem ser divididas da seguinte maneira: a) disponibilidade de centros para crises e linhas de ajuda; b) redução de acesso aos meios; c) progressos na divulgação do suicídio pela imprensa; d) tratamento de pessoas com transtornos mentais; e) treinamento de equipes de saúde; por fim, f) programas nas escolas.

Em 2000, foi lançado no Brasil uma série de manuais de prevenção do suicídio desenvolvidos pelo programa SUPRE (Suicide Prevention Program) da OMS (Brasil, 2006c), traduzidos por meio do SUPRE-MISS - Centro Brasileiro do Estudo Multicêntrico de Intervenção no Comportamento Suicida na UNICAMP.

Entre 2005 e 2006 foi desenvolvida a Estratégia Nacional de Prevenção do Suicídio (ENPS) com participação de diversas instituições e apoio do Ministério da Saúde. Foi criado o grupo de trabalho instituído pela Portaria no. 2.542 de 22 de dezembro de 2005 (Brasil, 2005) para elaborar as Diretrizes Nacionais para Prevenção do Suicídio (Brasil, 2006b), lançadas pela Portaria no. 1.876 de agosto de 2006, em que constam os principais objetivos para que seja desenvolvido um Plano Nacional de Prevenção do Suicídio.

\footnotetext{
A Estratégia é constituída de ações sistematizadas em diferentes eixos, de execução a curto, médio e longo prazo. Está apoiada num modelo compreensivo, baseado em evidências e sujeita à avaliação e monitoramento. Estes eixos são: 1. Sensibilização e mobilização da sociedade, em geral; 2. Qualificação dos profissionais de saúde na gestão e na atenção; 3 . Organização dos serviços de modo que ofereçam tratamentos mais efetivos; 4. Promoção de estudos e pesquisas; 5. Restrição e redução dos meios utilizados; 6. Melhora nos sistemas de informação e de vigilância em saúde e 7. Apoio à organização da sociedade nas suas iniciativas de promoção e atenção à saúde (D'Oliveira, 2014, p. 1).
} 
As Diretrizes colocaram o suicídio como problema de saúde pública (Botega, 2007), trazendo à luz a questão de sua problemática. No nosso entendimento, durante os onze anos desde o seu lançamento, muito foi proposto, porém pouco foi executado em termos práticos.

Podemos ver algumas mudanças na área da política, quando, em 2017, a Estratégia Nacional de Prevenção do Suicídio de 2006 foi retomada. O Ministério da Saúde divulgou o primeiro Boletim Epidemiológico de Tentativas e Óbitos por Suicídio no Brasil (Brasil, 2017b) e lançou uma Agenda de Ações Estratégicas Para a Vigilância e Prevenção do Suicídio e Promoção de Saúde no Brasil: 2017-2020 (Brasil, 2017a) a fim de atingir a meta proposta pela OMS (WHO, 2013) de diminuir em 10\% o número de casos do suicídio até o ano de 2020. É preciso observar como essa agenda está sendo cumprida e se o Plano Nacional de Prevenção do Suicídio será construído até 2020, conforme a Agenda Estratégica aponta.

Podemos ver essas iniciativas como avanços, mas ainda precisam repercutir no cuidado real daqueles que precisam. Não cabe nesse estudo a discussão das políticas públicas e sim a análise das consequências de haver políticas públicas que até certo ponto, estão afinadas com a necessidade das pessoas e da sociedade, mas que não estão sendo de fato implementadas.

Programas relacionados ao aumento de consciência estão presentes em diversos países, como Finlândia, Nova Zelândia, Noruega (Taylor et al., 1997), Austrália (2014), Estados Unidos (HHS, 2012), Suécia (2014), Irlanda (2015) em suas estratégias nacionais de prevenção do suicídio, conforme podemos observar na tabela abaixo:

Tabela 18: Componentes das Estratégias Nacionais de Prevenção do Suicídio

\begin{tabular}{l|c|c|c|c|c|c|c}
\hline \multicolumn{1}{c|}{ Países } & $\begin{array}{c}\text { Conscien- } \\
\text { tização } \\
\text { pública }\end{array}$ & $\begin{array}{c}\text { Educação } \\
\text { para a } \\
\text { mídia }\end{array}$ & $\begin{array}{c}\text { Acesso } \\
\text { aos } \\
\text { serviços }\end{array}$ & $\begin{array}{c}\text { Construção } \\
\text { capaciade } \\
\text { comunitária }\end{array}$ & $\begin{array}{c}\text { Restri- } \\
\text { ção aos } \\
\text { meios }\end{array}$ & $\begin{array}{c}\text { Treina- } \\
\text { mento }\end{array}$ & $\begin{array}{c}\text { Pesquisa e } \\
\text { avaliação }\end{array}$ \\
\hline Austrália & + & + & + & + & + & + & + \\
\hline Inglaterra & + & + & + & + & + & + & + \\
\hline Finlândia & + & + & + & + & + & + & + \\
\hline França & - & - & + & - & + & + & + \\
\hline Irlanda & + & + & + & + & + & + & + \\
\hline Noruega & + & - & + & + & - & + & + \\
\hline Escócia & + & + & + & + & + & + & + \\
\hline Suécia & + & + & + & + & + & + & + \\
\hline Nova Zelândia & + & + & + & + & + & + & + \\
\hline Estados Unidos & + & + & + & + & + & + & + \\
\hline
\end{tabular}

Fonte: (de Leo \& Evans, 2004; Escócia, 2006; Taylor et al., 1997)

$+=$ indica que a estratégia possui esse componente

- = indica que esse componente não foi incluído na estratégia 
Outro exemplo de programa desenvolvido em conjunto com as estratégias internacionais é o Youth Aware of Mental Health (YAM), um programa de conscientização desenvolvido pela Suécia e pelos Estados Unidos, para estudantes de 14 a 17 anos. São propostos quatro encontros direcionados para seis temas: sensibilização sobre saúde mental; autocuidado; lidando com o estresse e com crises; depressão e pensamentos suicidas, ajudando amigos com problemas e onde obter ajuda. O YAM faz parte do Saving and Empowering Young Lives in Europe (SEYLE), um programa de promoção de saúde mental para adolescentes em escolas da Europa, que objetiva ajudar adolescentes a melhorarem sua saúde mental por meio da diminuição de comportamentos de risco e do comportamento suicida (NASP, 2011). O SEYLE foi dividido em três estratégias de prevenção: treinamento de pessoas chave; aumento da conscientização e rastreamento de pessoas em risco por profissionais com posterior consulta clínica (Wasserman et al., 2010).

Segundo Fitzpatrick and Kerridge (2013), existem muitos desafios para haver uma discussão mais abrangente sobre o suicídio. Colocar a questão somente pela visão médica ou da saúde pública estreita a compreensão do fenômeno. Para os autores (2013), focar somente em interações individuais, discussões na comunidade ou campanhas de conscientização não abrangem a complexidade do problema, pois "trata-se de uma preocupação cultural e moral complexa que está profundamente inserida nas narrativas sociais e históricas e é improvável que seja alterada por qualquer forma de intervenção na saúde" (p. 470). Ainda, sugerem promover discussões sobre o fato, entendendo que não adianta medir o sucesso de intervenções de conscientização por meio de taxas ou do aumento da procura por tratamento, pois consideram que mudanças sociais profundas levam mais tempo para ocorrerem. Incluir na avaliação das propostas o aumento da tolerância do público aos temas de saúde mental, além da redução da descriminação e da estigmatização a fim de aumentar a consciência sobre os fatores de risco e a coesão comunitária como um todo são algumas das soluções encontradas por esse estudo.

A conscientização (awareness) também deve ser multifatorial, multissetorial e multidisciplinar. É necessária uma conscientização social, cultural, moral, política, religiosa, comunitária, individual, médica etc. que compreenda as diversas facetas do fenômeno e seja desenvolvida por e para diversos setores e profissionais. Falar somente na diminuição do tabu é simplificar uma discussão complexa. 
Sugerimos o desenvolvimento e a utilização do que chamamos de 6Cs:

Figura 8: 6Cs necessários para aumentar a conscientização, diminuir o estigma e prevenir o suicídio

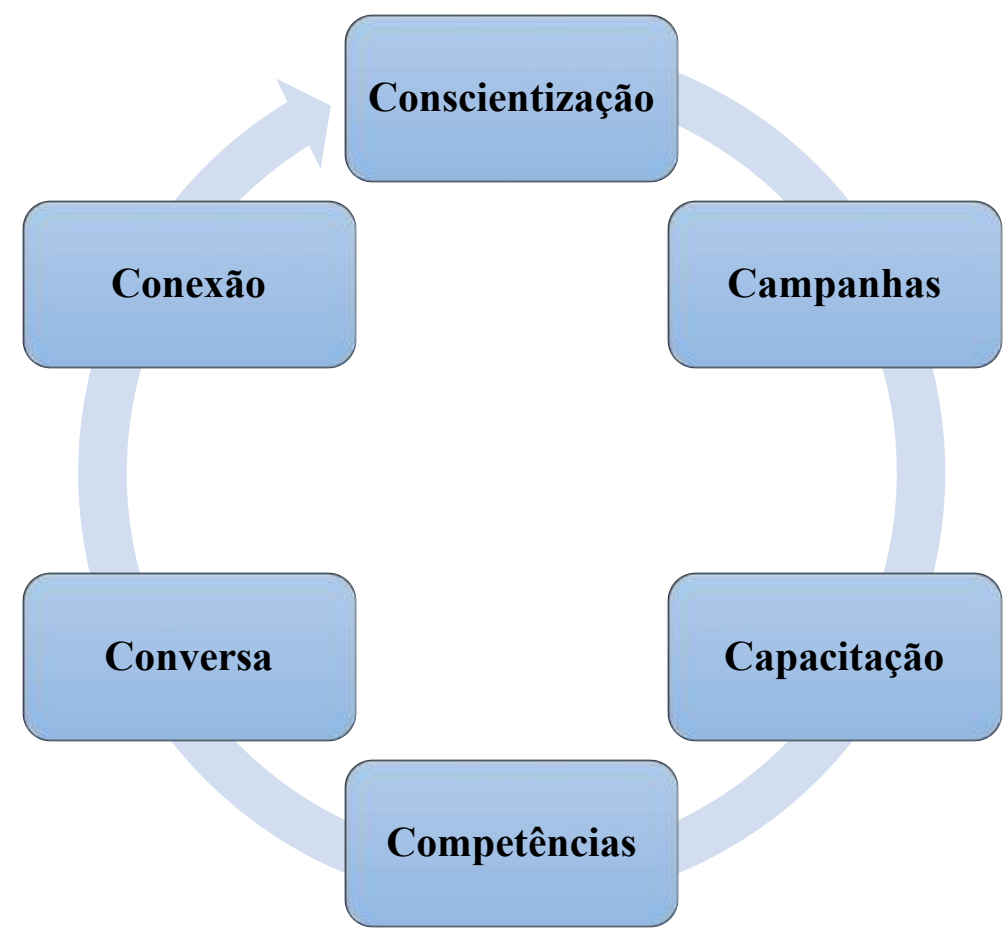

Fonte: produção do próprio autor (2018)

Conscientização (awareness) para as pessoas perceberem e saberem que o suicídio existe e que é um problema de todos; Campanhas para ajudar na conscientização e divulgação da problemática do suicídio; Capacitação para ensinar as pessoas e os profissionais como lidar e tratar do suicídio; Competência (literacy) para saber quando e como usar esse conhecimento para a pessoa com comportamento suicida e as pessoas próximas; Conversa para incentivar o diálogo e a possibilidade de falar abertamente sobre o suicídio e Conexão (connectedness) saudável entre pessoas, familiares, organizações, comunidades e grupos para perceber que há pessoas que se importam com a questão, assim, unindo forças na prevenção do suicídio

A Conexão (connectedness) é uma estratégia presente nos planos de prevenção do suicídio, recomendada pelo SPRC (2018a) e pelos Centros de Controle de doenças e prevenção dos Estados Unidos (CDC, 2011, p. 3), é definida pelo "grau em que uma pessoa ou grupo estão socialmente próximos, inter-relacionados ou compartilham recursos com outras pessoas ou grupos". 
Por acreditar na importância de transformar ideias, pesquisas e estudos em planos de ação, apresentamos sugestões para o aumento da conscientização, competência e promoção de diálogo, com base nos dados dessa pesquisa, complementando com a experiência profissional da pesquisadora e com a teoria sobre o assunto. Elas estão divididas em:
a) Conteúdo ou mensagens;
b) Em que lugar ou veículos para comunicação;
c) Como ou de que formas;
d) Quando ou periodicidade;
e) Por quem;
f) Para quem (esferas / áreas / público alvo);
g) Provedores ou interessados;
h) Desafios;
i) Facilitadores;
j) Outras ações.

Todas as intervenções envolvem conscientização, desenvolvimento de competências e promoção de diálogo, que devem ser culturalmente adaptadas, planejadas e integradas com o público alvo, os objetivos e a mensagem que se quer passar. Essas ações precisam ser compreensivas e fazer parte de um plano abrangente e integrado de prevenção e de posvenção do suicídio.

O assunto, os locais, as mensagens e as formas de intervenção sugeridas nesse estudo estão longe de serem definitivas, são propostas de atuação e de ação que podem ser complementadas, adaptadas ou transformadas, dependendo da necessidade e dos objetivos traçados.

a) Conteúdo ou mensagens

Os conteúdos e as mensagens tratam da essência do que precisa ser trabalhado na conscientização sobre prevenção e posvenção do suicídio, que sugerimos que sejam abordadas por meio dos veículos. 
Tabela 19: Conteúdos ou mensagens

\begin{tabular}{|c|c|c|}
\hline \multirow{10}{*}{$\begin{array}{l}\text { Conteúdos } \\
\quad \text { ou } \\
\text { Mensagens }\end{array}$} & Informações Práticas & $\begin{array}{l}\text { Locais de ajuda e tratamento } \\
\text { Para quem pedir ajuda ou quem pode } \\
\text { ajudar } \\
\text { Há ajuda disponível } \\
\text { Momento de procurar ajuda } \\
\text { Os limites do cuidador } \\
\text { O que observar (sinais e sintomas) } \\
\text { O que fazer }\end{array}$ \\
\hline & Desmistificar & $\begin{array}{l}\text { Psicofobia } \\
\text { Terapia como autoconhecimento } \\
\text { O papel do psiquiatra } \\
\text { Como funciona a medicação } \\
\text { O trabalho do psicólogo } \\
\text { Termos usados }\end{array}$ \\
\hline & Emoções & $\begin{array}{l}\text { Tristeza é uma emoção como as outras } \\
\text { Esperança } \\
\text { Raiva } \\
\text { Desespero }\end{array}$ \\
\hline & Epidemiologia & $\begin{array}{l}\text { Números e taxas } \\
\text { Presente em todas as classes sociais } \\
\text { Grupos de risco (LGBTA, estudantes, } \\
\text { idosos etc.) }\end{array}$ \\
\hline & Saúde Pública & $\begin{array}{l}\text { É um problema de saúde pública } \\
\text { Uso das UBS e CAPS } \\
\text { Direito ao remédio psiquiátrico } \\
\text { Protocolo de encaminhamento } \\
\text { Atendimento na emergência }\end{array}$ \\
\hline & Atitudes & $\begin{array}{l}\text { Não julgar } \\
\text { Acolher } \\
\text { Dialogar } \\
\text { Não manter segredo } \\
\text { Como abordar um alguém em risco } \\
\text { Empatia }\end{array}$ \\
\hline & Comunicação & $\begin{array}{l}\text { Fala responsável (p. 230) } \\
\text { Diretrizes para a mídia }\end{array}$ \\
\hline & Normatizar & $\begin{array}{l}\text { Pessoa com comportamento suicida } \\
\text { Não dá para ver no rosto } \\
\text { Sensibilizar profissionais } \\
\text { Visão estereotipada } \\
\text { Suicídio é mais comum que se pensa }\end{array}$ \\
\hline & Prevenção x Previsão & $\begin{array}{l}\text { O que é prevenção } \\
\text { Como funciona } \\
\text { Diferença entre prevenção e previsão }\end{array}$ \\
\hline & Transtornos mentais & $\begin{array}{l}\text { Sintomas } \\
\text { Causas }\end{array}$ \\
\hline
\end{tabular}




\begin{tabular}{|c|c|c|}
\hline \multirow{10}{*}{$\begin{array}{l}\text { Conteúdos } \\
\text { ou } \\
\text { Mensagens }\end{array}$} & Transtornos mentais & $\begin{array}{l}\text { Depressão } \\
\text { Ansiedade } \\
\text { Transtornos mentais como doença }\end{array}$ \\
\hline & Estigma & $\begin{array}{l}\text { De procurar ajuda } \\
\text { De precisar de ajuda } \\
\text { Manifestar tristeza } \\
\text { Comportamento suicida }\end{array}$ \\
\hline & Posvenção & $\begin{array}{l}\text { Tornar o conceito de posvenção } \\
\text { conhecido para os profissionais } \\
\text { Focar no amor ao invés da dor dos } \\
\text { sobreviventes } \\
\text { Epidemiologia dos sobreviventes } \\
\text { (números de pessoas impactadas) } \\
\text { Cuidado com os enlutados } \\
\text { A diferença do luto por suicídio } \\
\text { Grupos de apoio }\end{array}$ \\
\hline & Dor & $\begin{array}{l}\text { Dor de quem vai } \\
\text { Dor de quem fica }\end{array}$ \\
\hline & Multifatores & $\begin{array}{l}\text { O suicídio é multifatorial } \\
\text { Apresentação dos fatores } \\
\text { Suicídio ou suicídios }\end{array}$ \\
\hline & Mundo virtual & $\begin{array}{l}\text { O que fazer com as postagens sobre } \\
\text { suicídio } \\
\text { O perigo letal do Cyberbullying } \\
\text { Incitar suicídio é crime } \\
\text { Como ajudar pessoas a enfrentarem o } \\
\text { mundo virtual }\end{array}$ \\
\hline & Morte & $\begin{array}{l}\text { Como lidar com a morte } \\
\text { Como falar sobre a morte } \\
\text { Como ajudar alguém em luto } \\
\text { Como conversar sobre o suicídio }\end{array}$ \\
\hline & Cotidiano & $\begin{array}{l}\text { Como lidar com as frustrações do } \\
\text { cotidiano } \\
\text { Como aumentar resiliência } \\
\text { Promoção de saúde mental } \\
\text { Capacitação para o diálogo }\end{array}$ \\
\hline & Campanhas & $\begin{array}{l}\text { Como fazer campanhas } \\
\text { Como avaliar campanhas }\end{array}$ \\
\hline & Planos & $\begin{array}{l}\text { Como montar e avaliar planos de } \\
\text { prevenção e posvenção do suicídio }\end{array}$ \\
\hline
\end{tabular}

Fonte: produção do próprio autor (2018)

'conclusão'

A epidemiologia do suicídio pode ser usada para sensibilizar e não para assustar, afastar ou dar a impressão que o suicídio é uma epidemia ou um evento grande demais para que providências sejam tomadas. Segundo Carlos Etchichury em entrevista para Necchi (2017), é 
necessário "de tempos em tempos, mergulhar nas estatísticas, mostrar o descompromisso do Estado com políticas públicas" (p. 46).

Gostaríamos de enfatizar que não queremos normatizar o suicídio, considerar como um comportamento normal ou aceitável, e sim apontar que o suicídio é mais frequente do que se fala, que não há o "suicida" e sim uma pessoa com comportamento suicida; que não conseguimos ver no rosto das pessoas se elas pensam em matar-se, e é necessário diminuir a visão estereotipada de que quem morre por suicídio é louco, por exemplo.

As Campanhas e os Planos podem trazer mensagens, tanto para profissionais e para pessoas que queiram engajar-se na questão do suicídio e facilitar o acesso a informações que ajudem pessoas a desenvolver projetos e os transformem em ação, como podemos ver no site do SPRC (2018b), que orienta como criar planos estratégicos de prevenção do suicídio.

a) Em que lugar ou veículos para comunicação

Os veículos são os locais nos quais o conteúdo pode ser passado, que pode ser pela mídia; campanhas amplas ou específicas; reportagens; novelas; séries televisivas; programas na televisão aberta ou utilizando minutos gratuitos de propaganda; internet e redes sociais; arte, como exposições de fotos, vídeos, poesia, crônicas, festivais de música, letras de música; capacitação de profissionais e estudantes; grupos de apoio; programas de conscientização como a "Colcha da Memória Viva", conforme citado na página 205, e em caixas de remédio, conforme explicaremos mais adiante.

Tabela 20: Em que lugar ou veículos para comunicação

\begin{tabular}{c|l}
\hline & Mídia \\
& Campanhas \\
& Reportagens \\
& Novelas \\
& Séries televisivas \\
Onde & TV aberta \\
ou & Internet e redes sociais (Vídeos, postagens, podcasts, cursos, entre \\
Veículos & Catros) \\
& Gráficos de remédio imagens (pôsteres, cartazes, banners, entre outros) \\
& Arte \\
& Grupos de apoio \\
& Programas de conscientização \\
& Eventos diversos \\
& Capacitações \\
\hline
\end{tabular}

Fonte: produção do próprio autor (2018) 
Novelas têm grande apelo no Brasil, apresentaram questões difíceis e tabus como temas, por isso não há impeditivo para que a prevenção do suicídio seja abordada em novelas, desde

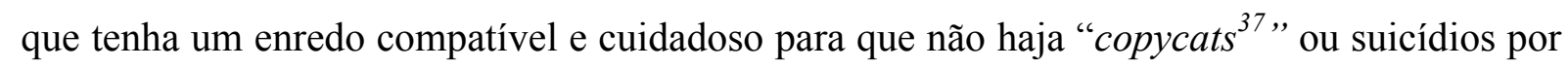
imitação. A novela "Força do querer" de 2017, da Rede Globo, abordou a questão do jogo da Baleia Azul, demonstrando que a novela pode ser mais um veículo de conscientização, dependendo de como o tema é abordado.

As novas tecnologias (internet, computadores e as redes sociais) têm hoje um papel fundamental na prevenção e posvenção do suicídio (Biddle, Donovan, Hawton, Kapur, \& Gunnell, 2008; Jacob, Scourfield, \& Evans, 2014; Luxton, June, \& Fairall, 2012; Tam et al., 2007). Diversas atividades podem ser oferecidas pela internet e as redes sociais tornaram-se um foco de atenção tanto para a disseminação de informação como para a identificação de pessoas em risco. Vídeos, postagens, grupos de ajuda, cursos e podcasts podem ser utilizados como meios de campanhas, capacitações, engajamento, entre outros.

Podcasts são uma forma de publicação de mídias, especialmente por áudio ou vídeo, que o acesso pode ser a qualquer momento via internet (Wikipedia, 2018). Alguns programas de prevenção do suicídio mantêm canais com podcasts relacionados a diversos assuntos na área, disponíveis e gratuitos, um exemplo é do Suicide Prevention Australia AudioBoom Channel (SPA, 2014) e o Postcasts at CDC: Suicide, do Centro de Controle e Prevenção de Doenças dos Estados Unidos (CDC, 2009).

Inspirada na campanha contra o tabaco, que traz mensagens e fotos nos maços de cigarro, poderíamos propor o mesmo processo nas caixas de antidepressivos, que trariam imagens que celebrem a vida ou o número da linha de ajuda (CVV). Seria uma forma da informação chegar naqueles que utilizam medicamentos psiquiátricos e que podem ter ideação suicida.

Tabela 21 - Sugestões de conteúdo para serem utilizados nas embalagens

O que poderia ser incluído nas embalagens de medicamentos psiquiátricos:

- os números das linhas de telefone de ajuda;

- fotos de sobreviventes com os dizeres "para cada suicídio, de 6 a 10 pessoas são extremamente impactadas por essa morte";

- foto de uma criança triste falando "crianças que perderam pais para o suicídio têm de 5 a 10 vezes mais chance de cometerem o suicídio que outras crianças;

- foto de um caminho escrito "o suicídio é uma solução permanente para um problema temporário", entre outros.

Fonte: produção do próprio autor (2018)

\footnotetext{
${ }^{37}$ Quando pessoas imitam o comportamento suicida de alguém.
} 
Essa proposta poderia também ser utilizada para medicamentos para tratar outros transtornos mentais, como a foto de uma mão aberta em sinal de pare, com os dizeres "não pare de tomar esse medicamento abruptamente, se estiver com dúvidas, fale com o seu médico".

Os gráficos ou imagens podem ser utilizados em uma variedade de produtos de comunicação visual, como pôsteres, cartazes e banners, podendo aumentar a compreensão de um determinado tema, conforme relacionam ideias a essas imagens. Segundo Houts, Doak, Doak, e Loscalzo (2006), esta é uma maneira de influenciar a aderência às instruções; produzir reações emocionais, que podem aumentar ou diminuir os comportamentos desejados e beneficiam especialmente pessoas com baixa instrução, portanto, devem ser incluídas como um veículo de comunicação de pontos-chave.

Silverman et al. (2013) descrevem um simpósio de artes, com a duração de dois dias, que reuniu diversas comunidades (LGBT, Cristãos, Judeus, entre outros) para discutirem e produzirem arte (teatro, música, escrita, pinturas) com o objetivo de estudarem se era possível criar e utilizar a arte para aumentar a consciência pública do suicídio. Os resultados indicaram que a arte facilitou o diálogo, a comunicação e o surgimento de temas culturais específicos, que poderiam ser desenvolvidos para atingir determinados público-alvo.

Cornejo, Cescon e Scavacini (2018) apontam que:

\footnotetext{
A arte também pode ser uma forma de elaboração do luto e de posvenção, já que esta inclui as estratégias para cuidar de si mesmo. Elena (2012), documentário de Petra Costa sobre sua irmã; o monólogo Processo do Conscerto do Desejo (2016), de Matheus Naschtergale, sobre a perda de sua mãe; e o livro Não estou sozinho (2016), de André Penteado, sobre a perda de seu pai e com fotos de outros sobreviventes, são expressões de um processo de elaboração do luto por suicídio. (p. 44)
}

Destacamos o trabalho de Matos (2018), com seu livro tridimensional "O vento que varre a casa", que une poesia, música e artes visuais para falar dos suicídios e lutos em quatro gerações da sua família (TUSP, 2015). Embora esse projeto tenha sido aprovado pela Lei Rouanet, não conseguiu patrocínio, o que demostra a dificuldade de encontrar parcerias e entidades dispostas a investirem em eventos relacionados ao tema.

Eventos diversos têm relação com a prevenção do suicídio incluindo as caminhadas, corridas, distribuição de pulseiras, laços, jantares beneficentes, atos ecumênicos, concertos, dentre outros.

Capacitações são fundamentais para que os profissionais e pessoas interessadas tenham acesso ao conhecimento e sejam educados para prevenção e posvenção do suicídio. 
b) Como ou de que forma

Os conteúdos podem ser passados pelos veículos por meio de histórias verídicas e de superação; depoimentos de quem já pensou, já tentou ou perdeu alguém para o suicídio; orientações técnicas; estatísticas sobre suicídio e sobre os enlutados; estudos científicos, que aumentassem o conhecimento sobre a prevenção e posvenção do suicídio. Algumas das formas foram citadas pelos colaboradores durante o grupo focal.

Tabela 22: Como ou de que forma

\begin{tabular}{c|l}
\hline & Histórias verídicas \\
Como & Histórias de superação \\
ou & Relato de famosos \\
Formas & Depoimentos de quem já pensou, já tentou ou perdeu alguém \\
& Estatística \\
& Estudos científicos \\
& Orientações técnicas \\
\hline
\end{tabular}

Fonte: produção do próprio autor (2018)

c) Por quem

As pessoas que poderiam ser os agentes do conteúdo, ou seja, por quem o conteúdo seria transmitido envolvem:

Tabela 23: Agentes ou pessoas que transmitem os conteúdos

\begin{tabular}{c|l}
\hline & Sobreviventes de tentativas de suicídio \\
& Sobreviventes enlutados por suicídio \\
& Pessoas famosas \\
& Profissionais \\
Por meio de & Formadores de opinião (youtubers, bloggers) \\
quem & Pessoas que superaram situações adversas \\
& Pares \\
& Religiosos \\
& Multiplicadores de opinião \\
& Líderes \\
& Familiares \\
& Cuidadores (gatekeepers \\
\hline
\end{tabular}

Fonte: produção do próprio autor (2018)

\footnotetext{
${ }^{38}$ São "pessoas-chave", ou, indivíduos que se encontram na linha de frente, tem contato pessoal com um grande número de indivíduos em sua comunidade ou trabalho. Eles podem ser treinados para identificarem pessoas em risco e agirem de acordo com protocolos estabelecidos, encaminhando a pessoa a cuidados específico, por exemplo, como socorristas, inspetores de escola, líderes comunitários, entre outros.(Burnette, Ramchand, \& Ayer, 2015)
} 
Sobreviventes de tentativas, como Kevin Hines (2013), que pulou da Golden Gate, hoje ministra palestras sobre a experiência que viveu, tendo como foco a prevenção do suicídio. Pode se pensar também em sobreviventes enlutados, como podemos ver no documentário da AFSP (2014) “A jornada”, no qual diversos sobreviventes contam sua jornada do luto por suicídio. Esse vídeo é utilizado nos eventos do Dia Internacional dos Sobreviventes Enlutados pelo Suicídio e está disponível na internet com legenda em diversos idiomas.

Pessoas famosas falando sobre o suicídio, merecem cuidado especial devido à sua capacidade de influenciar positiva ou negativamente. Pessoas famosas podem ajudar na prevenção, mas, dependendo do que falam ou como a morte de um famoso é divulgada, podem influenciar outros suicídios (Stack, 1987), conforme já falamos anteriormente Michael Phelps, famoso nadador e ganhador de vinte e oito medalhas olímpicas, fala abertamente sobre como contemplou a possibilidade de suicídio e hoje entende que "é OK não estar OK", falando sobre os transtornos mentais e o estigma que envolve o assunto (Scutti, 2018). A campanha "I am listening" (Entercom, 2017), produzida com a ajuda de várias celebridades é outro exemplo de como pessoas famosas podem engajar-se na prevenção do suicídio, utilizando a internet como veículo de comunicação.

Profissionais podem trazer a visão científica sobre o suicídio, contribuir com sua experiência clínica e profissional, avaliando as mensagens propostas. Formadores de opinião, como youtubers e bloggers têm grande influência atualmente, principalmente nos jovens. $\mathrm{O}$ fato deles serem pessoas que os jovens confiam e estão habituados a ver, são elementos facilitadores para que conteúdos sobre suicídio sejam passados.

Ainda, pessoas que superaram situações diversas, como Nicki Vujicic, que foi citado por um dos colaboradores, é um exemplo de pessoa que superou uma situação adversa e hoje consegue passar mensagens de aceitação, força e superação.

A mensagem também pode ser passada por pares, pessoas próximas à realidade do público alvo ou do próprio grupo alvo como, por exemplo, estudantes palestrando em escolas; médicos psiquiatras, que já perderam um paciente por suicídio, falando sobre essa experiência em congressos de psiquiatria; professores conversando com professores, só para citar algumas possibilidades.

Religiosos têm grande respeito e admiração em suas comunidades e frequentemente são procurados para ajudar em situações difíceis, mensagens deles podem ter grande impacto em tais grupos.

Multiplicadores de opinião são pessoas que foram conscientizadas e engajaram-se na prevenção do suicídio, podendo ser desde estudantes até voluntários de ONGs. Os 
colaboradores sugeriram que pessoas possam tornar-se facilitadores, multiplicadores de opinião, dessa maneira, o movimento de sensibilização pode partir dessas pessoas multiplicadoras e que contam suas histórias para outras, assim, atingem uma dimensão social maior. De tal modo que elas podem conversar entre si sobre o suicídio, pouco a pouco diminuindo o silêncio violento e intimidador que ronda o assunto.

Líderes podem ser chefes, gerentes, diretores, líderes comunitários, pessoas com postos de liderança que têm influência positiva em funcionários, colegas, colaboradores, e outras pessoas que podem beneficiar-se desse contato.

Familiares podem dar depoimentos sobre as dificuldades de lidar com o comportamento suicida e como se preocupam com sua família, podem trazer um apelo emocional para campanhas e a experiência vivida em outras situações.

d) Quando ou periodicidade

As campanhas devem acontecer o ano todo, tendo seu pico em setembro, em decorrência do "Setembro Amarelo", que, embora os colaboradores não considerem muito efetivo, tem estabelecido-se como campanha e com o tempo deve alcançar cada vez mais pessoas. Portanto, pode haver uma divulgação maciça em setembro, porém com campanhas menores, ações, reportagens e divulgações durante todo ano.

Tabela 24: Quando ou periodicidade

\begin{tabular}{c|l}
\hline Quando & $\begin{array}{l}\text { Pico em setembro para aproveitar o "Setembro amarelo" e o dia } \\
\text { internacional. }\end{array}$ \\
ou & $\begin{array}{l}\text { Durante o ano todo } \\
\text { Periodicidade } \\
\text { Divulgação maciça } \\
\text { Mais espaçado }\end{array}$ \\
\hline
\end{tabular}

Fonte: produção do próprio autor (2018)

e) Para quem

Para quem foi dividido em esferas, áreas e público alvo: 
Figura 9: Como é dividido o "para quem" os conteúdos devem ser passados

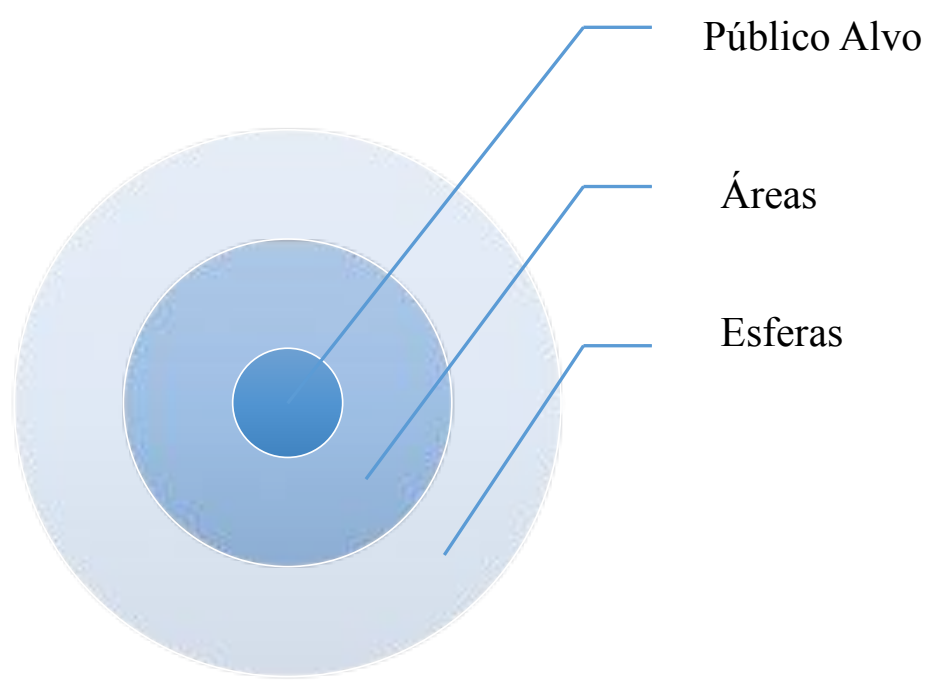

Fonte: produção do próprio autor (2018)

As esferas são mais amplas, tendo relação com os âmbitos que devem ser englobados pela tríade da mudança e os 6 C's.

Tabela 25: Esferas para conscientização

\begin{tabular}{l|l}
\hline \multirow{3}{*}{ Esferas } & Pública \\
& Política \\
& Comunitária \\
& Escolar \\
& Familiar \\
& Individual \\
\hline
\end{tabular}

Fonte: produção do próprio autor (2018)

As áreas de atuação compreendem os setores nos quais as ações podem ocorrer: incluindo a mídia; internet e as redes sociais; a comunidade científica; estudantes; universitários; policiais e socorristas (militares) e o poder público e privado.

Tabela 26: Áreas de atuação

\begin{tabular}{l|ll}
\hline \multirow{3}{*}{ Áreas } & Mídia & \\
& Internet e redes sociais & \\
Comunidade científica & 'continua' \\
& Estudantes & Universitários
\end{tabular}




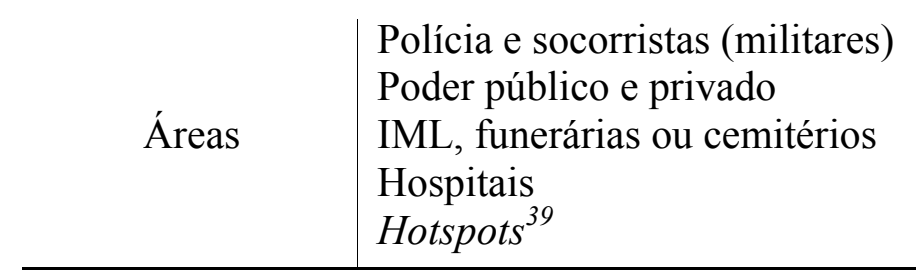

Fonte: produção do próprio autor (2018) ‘conclusão’

O Instituto Médico Legal (IML), as funerárias e cemitérios são locais que poderiam oferecer aos enlutados informações sobre onde procurar ajuda, sendo agentes de informação aos serviços de posvenção ativa ${ }^{40}$, quando estes forem criados no país.

Hotspots poderiam ser alvos de campanhas de conscientização para transformação desses locais em construções seguras através da responsabilização do Estado ou do setor privado, dependendo do local, para que providências sejam tomadas com o intuito de restringir o acesso com barreiras físicas ou prover contato com linhas de ajuda, como ocorre na Golden Gate, que tem em sua extensão diversos cartazes de apoio à vida e acesso a telefones, que conectam o indivíduo diretamente a especialistas em crise. A restrição de acesso aos meios, como barreiras físicas em locais utilizados para o suicídio ou restrição na compra de pesticidas, por exemplo, é considerada uma das mais eficazes em termos de prevenção do suicídio. Talvez, da mesma forma, que sobreviventes enlutados conseguiram, por meio de uma ação no Ministério Público, que o Shopping Pátio Brasil em Brasília, que havia se tornado um hotspot, que se colocasse barreiras de proteção nos parapeitos, os sobreviventes poderiam unir suas forças para exercer uma pressão pública para que as autoridades municipais e coordenações de locais privados tomem medidas que impeçam o acesso a locais que se configurem como hotspots. O prédio do Tribunal Regional do Trabalho e o Viaduto Santa Efigênia (um dos hotspots mais antigos da cidade), ambos em São Paulo, são exemplos de locais conhecidos escolhidos para o ato suicida, mas nenhuma providência foi tomada pela Prefeitura de São Paulo até o presente momento, para ampliar a proteção de pessoas com ideação suicida.

O público alvo das ações são: a sociedade; a comunidade (Rotarys, Lyons; igrejas; clubes; e outros); pessoas leigas; familiares; grupos de risco; crianças e adolescentes; profissionais; funcionários de hospitais, de UBS e CAPS; estudantes universitários; profissões

\footnotetext{
${ }^{39}$ Hotpots são locais com alto índice de suicídio e de conhecimento de todos, como pontes, antenas de TV etc. O hotspot mais conhecido do mundo é a ponte Golden Gate em São Francisco/EUA.

${ }^{40}$ A posvenção ativa ocorre quando a família em luto é procurada por um serviço ou instituição voluntária para receber ajuda no seu processo de luto ou quando informações sobre grupos de ajuda e luto por suicídio são enviadas para ela por correio ou e-mail. Ainda não temos nenhum serviço de posvenção ativa no Brasil.
} 
afins (polícia, bombeiros, agentes funerários, legistas, socorristas) e sobreviventes de tentativas e sobreviventes enlutados.

\section{Tabela 27: Público Alvo}

\begin{tabular}{l|l}
\hline & Sociedade \\
& Comunidade \\
& Leigos \\
& Familiares \\
& Grupos de risco \\
Público alvo & Crianças e adolescentes \\
& Profissionais \\
& Hospitais \\
& UBS/CAPS \\
& Estudantes universitários de diversas áreas \\
& Profissões afins \\
& Poder público \\
& Sobreviventes de tentativas \\
& Sobreviventes enlutados \\
\hline
\end{tabular}

Fonte: produção do próprio autor (2018)

Um curso de negociação com pessoas em crise suicida foi desenvolvido pelo corpo de bombeiros a partir de um manual de abordagem técnica a tentativas de suicídio (Munhoz, 2006). O curso acontece desde 2016 e já formou mais de cento e quarenta e oito bombeiros, policiais, socorristas em seis estados do Brasil (Munhoz, 2018). O curso foi desenvolvido por bombeiros com a supervisão de psiquiatras, um claro exemplo da união de saberes, desenvolvendo competências.

\section{f) Provedores ou interessados}

Os provadores ou interessados são pessoas que poderiam desenvolver e promover a tríade da mudança, como os Conselhos Regionais de várias profissões, mais especificamente os de Psicologia e Medicina; o poder público, o governo, as secretarias de saúde, as UBS, os CAPS; Hospitais; Institutos; Universidades; Empresas; Associações; Planos de saúde; as Organizações Não Governamentais (ONG's), muitas das quais fundadas por sobreviventes enlutados; Pessoas que tenham ligação com o suicídio por tentativa ou enlutamento (lived experience). Financiamentos coletivos poderiam ser feitos para a promoção de campanhas ou ações para favorecer a prevenção. 
Tabela 28: Provedores e/ou interessados em aumentar a consciência pública

\begin{tabular}{c|l}
\hline & Conselhos nacionais \\
& Conselho de psicologia e medicina \\
& Poder público - governo do estado, secretaria da saúde, CAPS \\
& Institutos \\
& Universidades \\
Empresas \\
interessados & Associações \\
& Planos de saúde \\
& ONGs \\
& Escolas \\
& Enlutados e sobreviventes de tentativas (lived experience) \\
& Hospitais \\
& Financiamento coletivo \\
\hline
\end{tabular}

Fonte: produção do próprio autor (2018)

g) Desafios

Os maiores desafios que as ações, campanhas, intervenções podem sofrer têm relação:

Tabela 29: Desafios para aumentar a consciência

\begin{tabular}{l|l}
\hline & Pessoas se identificarem com o tema \\
& Promover engajamento \\
& Criar conteúdos que aproximem e não gerem afastamento \\
& Pessoas falarem abertamente \\
Suscitar diálogo & Mudar atitudes \\
Desafios & Gerar demanda sem locais que absorvam essa demanda \\
& Locais especializados de tratamento \\
Atendimento no momento de crise \\
Acesso ao tratamento \\
Achar locais onde as pessoas possam engajar-se e desenvolver \\
atividades \\
Encontrar provedores e pessoas interessadas em patrocinar o \\
desenvolvimento e divulgação do tema
\end{tabular}

Fonte: produção do próprio autor (2018)

h) Facilitadores

Os facilitadores da conscientização pública são o aumento da liberdade de expressão em diversos temas; o alcance e a facilidade provida pela internet e pelas redes sociais; 
a facilidade de encontrar informações e a velocidade que podem ser divulgadas e pessoas mais abertas para falarem de sentimentos e para engajarem-se.

Tabela 30: Facilitadores da conscientização

\begin{tabular}{l|l}
\hline \multirow{5}{*}{ Facilitadores } & Liberdade de expressão \\
& Alcance e facilidade das redes \\
& Velocidade das informações \\
& Acesso às informações \\
& Pessoas mais abertas aos sentimentos \\
\hline
\end{tabular}

Fonte: produção do próprio autor (2018)

i) Outras ações

Tabela 31: Outras ações para o aumento da consciência pública do suicídio

\begin{tabular}{l|l}
\hline & Diretrizes para internet \\
& Uso das novas tecnologias \\
& Rastreamento virtual \\
& Educação socioemocional \\
Outras & Protocolos de ajuda \\
Ações & Currículo obrigatório nas universidades \\
& Posvenção \\
& Criação de grupos específicos (tentativas, enlutados, crianças, \\
& adolescentes) \\
& Prêmios para campanhas e reportagens \\
& Diretrizes da fala responsável \\
& Avaliação dos processos \\
\hline
\end{tabular}

Fonte: produção do próprio autor (2018)

Outras atividades e ações que possam ser relacionadas ao espectro da conscientização envolvem o desenvolvimento de diretrizes para a internet e redes sociais, gerando um guia de boas práticas, tanto para provedores como para usuários, uma discussão sobre o papel e a responsabilização das redes sobre a prevenção e posvenção do suicídio. Os serviços de busca poderiam fixar nas primeiras páginas dos resultados de busca de palavras-chave como "suicídio", "enforcamento", “como se matar", páginas e reportagens que falem de prevenção do suicídio e onde buscar ajuda. Assim, se evitaria que pessoas em desespero encontrassem com facilidade sites que ensinam o autoaniquilamento.

As novas tecnologias podem ser usadas para a capacitação, engajamento, prevenção do suicídio, entre outras coisas. 
O rastreamento virtual foi sugerido por uma colaboradora e envolve usar as técnicas de rastreamento, que hoje tem como principal objetivo o conhecimento do usuário para sugerir produtos para compra. A mesma técnica poderia promover o rastreamento de pessoas com possível comportamento suicida e assim oferecer ajuda.

O Twitter $^{41}$ tem sido usado por pessoas para divulgarem seus pensamentos e intenções de suicídio (Sueki, 2015). O'Dea, Larsen, Batterham, Calear, e Christensen (2017) demonstraram por meio da análise linguística que é possível diferenciar quem precisa ou não de ajuda nos posts do Twitter pelo "uso acentuado de pronomes em primeira pessoa, raiva extrema e um foco aumentado no presente" (p. 319). Estudos sobre as representações da depressão no Pinterest ${ }^{42}$ e suas repercussões na saúde mental foram realizados por Guidry, Zhang, Jin, e Parrish (2016); Burnap, Colombo, Amery, Hodorog, e Scourfield (2017) pesquisaram sobre o uso de máquinas para classificar postagens relacionadas ao suicídio no Twitter; Chhabra e Bryant (2016) apontam para o uso de postagens de despedida no Snapchat ${ }^{43}$ como forma de identificar, contextualizar e ajudar no tratamento por ingestão tóxica em tentativas de suicídio. Os estudos mencionados são apenas alguns exemplos que demonstram que o caminho do rastreamento para fins de prevenção em breve poderá ser um fato e que estudos já tem sido realizados com esse objetivo.

A educação socioemocional pode fazer parte dos programas desenvolvidos em escolas. O treinamento oferecido pelo Programa Amigos do Zippy, programa de educação emocional para crianças de seis e sete anos; e do Passaporte: Habilidades para a vida, programa de educação emocional que ensina jovens a partir de 11 anos a desenvolverem estratégias para lidarem com problemas de qualquer natureza. Ambos os programas são oferecidos pela Associação pela Saúde Emocional da Criança (ASEC), que é ligada ao CVV e ao Befrienders International (Inglaterra). Esses programas contaram com assessoria de Brian Mishara, do Canadá e outros profissionais, consistem no treinamento de habilidades socioemocionais para crianças e adolescentes (ASEC, 2014a, 2014b). Infelizmente muitas pessoas não conhecem ou não têm acesso aos programas.

Programas como o safeTALK, como apontam Bailey, Spittal, Pirkis, Gould, \& Robinson (2017), consistem em treinamento oferecido nas escolas para pessoas com mais de quinze anos sobre prevenção do suicídio e que poderiam ser desenvolvidos e oferecidos no Brasil.

\footnotetext{
${ }^{41}$ Mídia social que permite que os usuários troquem mensagens de até cento e quarenta caracteres.

${ }^{42}$ Rede social visual em que as pessoas publicam fotos e imagens.

${ }^{43}$ Rede social de mensagens instantâneas que desaparecem após alguns segundos ou no prazo máximo de 24 horas.
} 
Protocolos de ajuda poderiam ser estabelecidos para facilitarem e padronizarem o cuidado, atendimento, tratamento, detecção de risco, abordagem ao paciente e a família. $\mathrm{O}$ Manual para Profissionais da Saúde em Atenção Primária, desenvolvido como parte do programa SUPRE, da OMS (2000c), é um exemplo de informação e de capacitação para profissionais, que ficam na "linha de frente" do cuidado. Os encaminhamentos e acesso aos atendimentos deveriam ser garantidos e os profissionais deveriam ser capacitados nesses protocolos. Tratamento digno e acessível deve ser direito de todos.

As faculdades e as universidades deveriam ser obrigadas a oferecerem aos seus alunos disciplinas de prevenção e posvenção do suicídio ou cursos rápidos de conscientização e capacitação como o Question, Persuade and Refer (QPR, 2013), que consiste em treinamento de pessoas com 1h30m de duração. No Brasil o Instituto Vita Alere desenvolveu o Programa A.P.O.I.A.R., que consiste em um curso online, para leigos, de duas horas de duração sobre: Aprender sobre o suicídio, Perguntar, Ouvir, Incluir outros no cuidado, Agir e Reconectar a esperança. Neste curso é possível aprender sobre os principais fatores de risco, conceitos, sinais de alerta, como perguntar sobre o suicídio, a importância de ouvir, onde procurar ajuda, como agir e como se conectar com a pessoa para ajudá-la, tudo numa linguagem acessível a todos os públicos.

Um curso a distância sobre Crise e Urgência em Saúde Mental, que aborda o suicídio, feito em parceria com a Universidade Federal de Santa Catarina e o Ministério da Saúde certificou 1990 profissionais, que atuam no Sistema Único de Saúde (SUS) entre 2014 e 2015 (Brasil, 2017a). Podemos considerar este curso à distância como uma iniciativa na área, mas recomendamos que cursos específicos sobre prevenção do suicídio sejam oferecidos para profissionais e leigos como mais um passo em direção da capacitação e aumento de competência na prevenção do suicídio.

A posvenção é um termo relativamente novo no Brasil, conforme falado anteriormente no capítulo três e o cuidado com os enlutados está desenvolvendo-se lentamente no país, entretanto, ainda faltam serviços de apoio para crianças e adolescentes enlutados (Scavacini, 2017a). O termo posvenção tem tornado-se mais conhecido, observamos seu uso em congressos, palestras, artigos, livros, simpósios e algumas reportagens. Embora a OMS (WHO, 2014) tenha incluído a posvenção no seu relatório "Preventing suicide: a global imperative" como uma das atividades necessárias nos planos de prevenção do suicídio, o Brasil não incluiu a posvenção na Agenda de Ações Estratégicas para a Vigilância e Prevenção do Suicídio e Promoção de Saúde no Brasil, lançada em 2017 (Brasil, 2017a). Esse fato demonstra que ainda 
precisamos conscientizar as pessoas a respeito do luto por suicídio e da importância da posvenção.

A criação de grupos específicos de apoio a pessoas com ideação ou tentativas de suicídio, de familiares de pessoas com comportamento suicida, de enlutados, de crianças e adolescentes, de profissionais que perderam alguém para o suicídio ou lidam com pacientes com ideação e tentativas são ações que podem aumentar a consciência, ajudar no empoderamento dos participantes, proporcionar acolhimento e aceitação em locais seguros para abordar esses temas. Ressaltamos que os grupos podem ser parte do processo, mas não devem ser a única alternativa de tratamento ao alcance das pessoas.

É urgente a criação de grupos de apoio para pessoas com ideação ou que tentaram o suicídio, bem como grupos para crianças e adolescentes enlutados. A cultura de grupos de apoio relacionados à prevenção e à posvenção do suicídio tem aumentado nos últimos anos com a criação desses em diversos locais e também grupos virtuais (Scavacini, 2017a). Oferecer grupos exclusivos para crianças ainda é um desafio pelo tabu envolto na morte e no falar abertamente para elas. A criação de mais grupos de apoio foi uma das sugestões feitas pelos colaboradores, que percebem os grupos como locais seguros para falar sobre questões relativas ao suicídio, uma vez que promovem acolhimento, conhecimento e pertencimento, porém ainda são escassos, ocorrendo somente uma vez por mês, segundo a fala do colaborador 7 :

eu acho que esses grupos que nós estamos como esse e outros que a gente tem em vários lugares, é um lugar de pertencimento, porque toda vez que eu vou num grupo desses eu me sinto assim, não é que digamos estou à vontade, mas eu me sinto bem situado porque eu vejo que eu diante de pessoas que tão vivendo histórias parecidas e que estão tendo o sofrimento parecido, a angústia parecida, as dúvidas, as indagações parecidas, então eu de alguma forma eu me sinto acolhido. E eu também me sinto à vontade de ir acolher, eu vejo, por exemplo vocês, como os meus pares, são os meus iguais, então é um momento que nós estamos encontrando com os nossos iguais. Aqueles que entraram nesse mundo, no mundo dos sobreviventes. Nós temos até esse rótulo, né?! Então a gente consegue. Nossa! Existe um mundo que é o mundo dos sobreviventes e eu vejo a cara deles, eu vejo eles falarem, eles sentirem. Então, essas dinâmicas essa ... e outras e ocorrem no [local onde ocorrem grupos], no [local onde ocorrem grupos] eu acho que são muito boas e eu acho que esse é o caminho, é buscar esses lugares porque a gente vai se reconhecer.

Conforme os sobreviventes enlutados vão elaborando seu processo do luto, podem engajar-se e promover mudanças. Transformar os grupos de apoio em futuras associações de sobreviventes é outra sugestão desse estudo.

Prêmios são uma interessante estratégia para aumentar consciência, porém são praticamente inexistentes no Brasil. Andriessen (2005) propõe que prêmios para mídia 
responsável sejam incorporados nas estratégias de prevenção, que também poderiam ser utilizados na mídia responsável e incluírem pesquisas científicas, políticas públicas, blogs, campanhas, concursos literários (como o do Instituto Vita Alere, mencionado anteriormente), entre outros.

Foi citado pelo grupo focal, a necessidade de falar "corretamente" sobre o suicídio, encontramos na National Action Alliance for Suicide Prevention (Framework, 2014) um protocolo que foi desenvolvido após diversas pesquisas, relacionado à fala responsável, ou, mensagens de sucesso (sucessful message), direcionada para qualquer pessoa que esteja comunicando mensagens ao público sobre o suicídio e sua prevenção. Esse protocolo tem como prioridade mudar a forma como fala-se sobre o suicídio, considerando os quatro fatores-chave que descrevemos abaixo:

Figura 10: Protocolo para mensagens de sucesso (tradução nossa)

Fonte: (Framework, 2014)

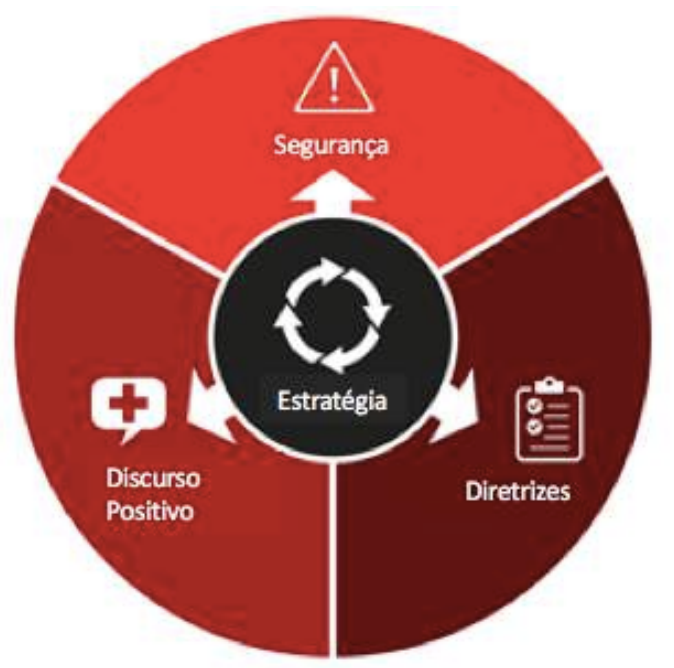

Sugerimos que o protocolo envolvendo mensagens de sucesso seja aplicado nos conteúdos e sugestões presentes nesse capítulo para que atinjam os objetivos de aumentar consciência, competência e prevenir o suicídio. De acordo com o Framework (2014), as mensagens/conteúdos beneficiariam a prevenção se aderissem às recomendações da literatura sobre comunicação ampla, que segue:

(a) Definir um propósito claro do quer ser comunicado antes de elaborar a mensagem; (b) incluir as mensagens como um dos componentes de um plano de prevenção mais amplo; (c) planejar a mensagem para promover comportamentos específicos em públicos definidos; (d) Usar informações sobre o público para projetar mensagens mais efetivas; (e) Escolher canais de comunicação que combinam o tipo de mensagem e a audiência e, por fim, (f) avaliar o sucesso da mensagem 
O primeiro passo é a estratégia, que se refere a pensar e a planejar de forma integral as mensagens para que tenham sucesso, isso significa que a mensagem conseguiu atingir o público alvo e o objetivo da comunicação. Nenhuma mensagem funcionará em todos os contextos, devendo ser usadas combinadas com outros programas, serviços ou recursos. Identificar o objetivo e o público são formas de desenvolver essa estratégia para criar mensagens que atinjam esses objetivos e usar pesquisas, estudos e teorias podem guiar as escolhas e direções que serão tomadas. Para eles, a comunicação deve focar na ação e não somente na conscientização, pois, as pessoas podem sensibilizar-se com tais mensagens, no entanto, podem não saber o que fazer com elas. É importante mostrar como podem agir ou conectar a sensibilização com uma chamada para ação (Framework, 2014).

A elaboração das mensagens deve levar em conta a segurança para evitar que sejam potencialmente prejudiciais, principalmente para pessoas em risco ou que já estejam vulneráveis ao comportamento suicida (Framework, 2014). O manual com instruções para profissionais da mídia da OMS (2000b) traz as seguintes recomendações: evitar cobertura sensacionalista e repetida; dar detalhes sobre o método utilizado para chegar à morte; onde ocorreu o evento; mostrar o suicídio como uma saída aceitável para as dificuldades vividas; não tornar o suicídio um espetáculo ou romantizá-lo; dar repostas simples ao que ocorreu; apresentar detalhes que facilitem a identificação com a pessoa que morreu. Segundo o Framework (2014), devemos ressaltar as soluções para o estigma em vez dos problemas gerados por ele, usando linguagem apropriada e evitar o uso de "suicídio bem-sucedido", "cometeu suicídio" ou "tentativa frustrada".

$\mathrm{O}$ discurso positivo (positive narrative) tem relação com enfatizar as ações que podem ser feitas pelas pessoas para prevenirem do suicídio; mostrar que a prevenção funciona e que a recuperação e a resiliência são possíveis; que serviços e programas efetivos existem e que há ajuda disponível. A ideia central do discurso positivo é de "mudar as narrativas nacionais a respeito do suicídio e da prevenção na direção de promover esperança, conectividade, suporte social, resiliência, tratamento e recuperação" (Framework, 2014, p. 4).

O uso de diretrizes (guidelines) ou recomendações é indicado para complementar o protocolo de mensagens de sucesso, utilizando conhecimento e sugestões para serem utilizadas em áreas específicas como o guia "Critérios da AAS (American Association Suicidology) para vídeos educacionais sobre suicídio juvenil” ou "Considerações especiais ao contar sua própria história: Melhores práticas para apresentações de sobreviventes de tentativas e sobreviventes enlutados" (Framework, 2014). Infelizmente não temos esse tipo de diretriz ou recomendação 
adaptada para a realidade brasileira e em português, nesse sentido, uma das recomendações da nossa pesquisa seriam o desenvolvimento de diretrizes e recomendações para mensagens e conteúdos seguros e positivos sobre a prevenção e posvenção do suicídio, que sejam de fácil acesso a todos, realizando-se as adaptações culturais necessárias.

A avaliação dos processos, propostas e campanhas é outra parte importante de qualquer programa de prevenção do suicídio, sendo uma das questões trazidas pelo especialista entrevistado, para que possamos aprender com o que já foi realizado e para o planejamento das próximas ações. Para Koch e Oliveira (2015, p. 164) ancorado em J. M. Bertolote (2004) "as avaliações dos resultados face aos objetivos propostos falham na eleição de indicadores, especialmente quando o produto final não corresponde ao que era esperado no início dos programas, deixando dúvidas inclusive sobre a legitimidade das pesquisas acadêmicas que os avaliam". Infelizmente a maioria das ações não é avaliada, novos marcadores e instrumentos de avaliação precisam ser desenvolvidos, para não nos basearmos somente nas taxas de mortalidade como formas de avaliar o sucesso das estratégias de prevenção do suicídio.

Segundo Acosta, Ramchand, e Becker (2017), uma lista de controle de itens (cheklist) pode ser utilizada na avaliação de campanhas em andamento e na preparação de futuras campanhas de prevenção do suicídio. A lista de controle "RAND Checklist of Best Practices for Suicide Prevention Communication Campaigns" contém quarenta e seis itens e foi desenvolvida pelos autores baseado no método RAND/UCLA ${ }^{44}$ de Fitch et al. (2001) em conjunto com uma revisão da literatura e com painéis com especialistas em prevenção do suicídio, em campanhas de prevenção do suicídio ou em campanhas promovidas pela mídia. Para os autores Acosta et al. (2017), uma campanha pode ser avaliada por meio dos seguintes itens:

Tabela 31: Lista de controle para a avaliação das campanhas

\begin{tabular}{|c|c|}
\hline Item & Área \\
\hline \multicolumn{2}{|r|}{ Itens aplicados a todas as campanhas sobre saúde em geral } \\
\hline Itens $1-5$ & Bases teóricas \\
\hline Itens $6-9$ & $\begin{array}{l}\text { Mensagens claras } \\
\text { Mensagens com objetivo }\end{array}$ \\
\hline Item 10 & Definição do público alvo \\
\hline Itens $11-15$ & $\begin{array}{l}\text { Testar as mensagens que serão utilizadas por meio de "mensagens } \\
\text { piloto" antes de desenvolver mais profundamente a ideia ou } \\
\text { disseminá-las em campanhas }\end{array}$ \\
\hline Itens 16 e 17 & Avaliação e monitoramento contínuos \\
\hline Itens 18 e 19 & Presença na mídia \\
\hline
\end{tabular}

\footnotetext{
${ }^{44}$ Um cheklist desenvolvido para avaliar campanhas relacionadas à comunicação em saúde
} 


\begin{tabular}{l|l}
\hline \multicolumn{1}{c|}{ Item } & \multicolumn{1}{c}{ Área } \\
\hline \multicolumn{2}{c}{ Itens aplicados especificamente para campanhas de prevenção do suicídio } \\
\hline Itens 20 e 21 & Considerações especiais de segurança durante o "teste piloto" \\
\hline Itens 21 - 31 & Conteúdos de prevenção do suicídio sugeridos \\
\hline Itens 32 - 35 & Sinais de risco, fatores de risco e fatores de proteção \\
\hline Itens 36-46 & Linguagem e elementos visuais \\
\hline Itens 44 e 45 & Moderação de fóruns públicos \\
\hline Item 46 & Divulgação \\
\hline
\end{tabular}

Fonte: (Fitch et al., 2001, p. 290)

Essa lista de controle pode ser um dos passos para avaliação das campanhas, consequentemente a melhora de sua qualidade ${ }^{45}$.

Não se trata somente de ensinar que sinais podem ser percebidos, mas é perguntar e importar-se, independente de qualquer sinal. Podemos ter muitos recursos disponíveis, o que ainda não é o caso do Brasil, porém se não sensibilizarmos a pessoa que está lutando contra o comportamento suicida, que ela precisa de ajuda, a estratégia não funciona bem. Mostrar que o suicídio é problema de todos, que as pessoas se importam e que soluções em vida poderão ser desenvolvidas, pode fazer toda a diferença.

As sugestões, ideias e processos propostos por esse estudo podem ser implementados ao unir o conhecimento, pesquisa, pessoas interessadas, os provedores, os agentes de comunicação, os veículos de comunicação, incluindo os $6 \mathrm{Cs}$, conforme mostramos no diagrama abaixo, na próxima página. Não há um caminho fácil de ser seguido, mas existe um caminho possível, sendo isso que esse estudo objetivou demonstrar.

45 Outras diretrizes sobre como a mídia deve falar sobre o suicídio podem ser encontradas no site www.reportingonsuicide.org. 
Diagrama 12: Resumo das soluções propostas por este estudo

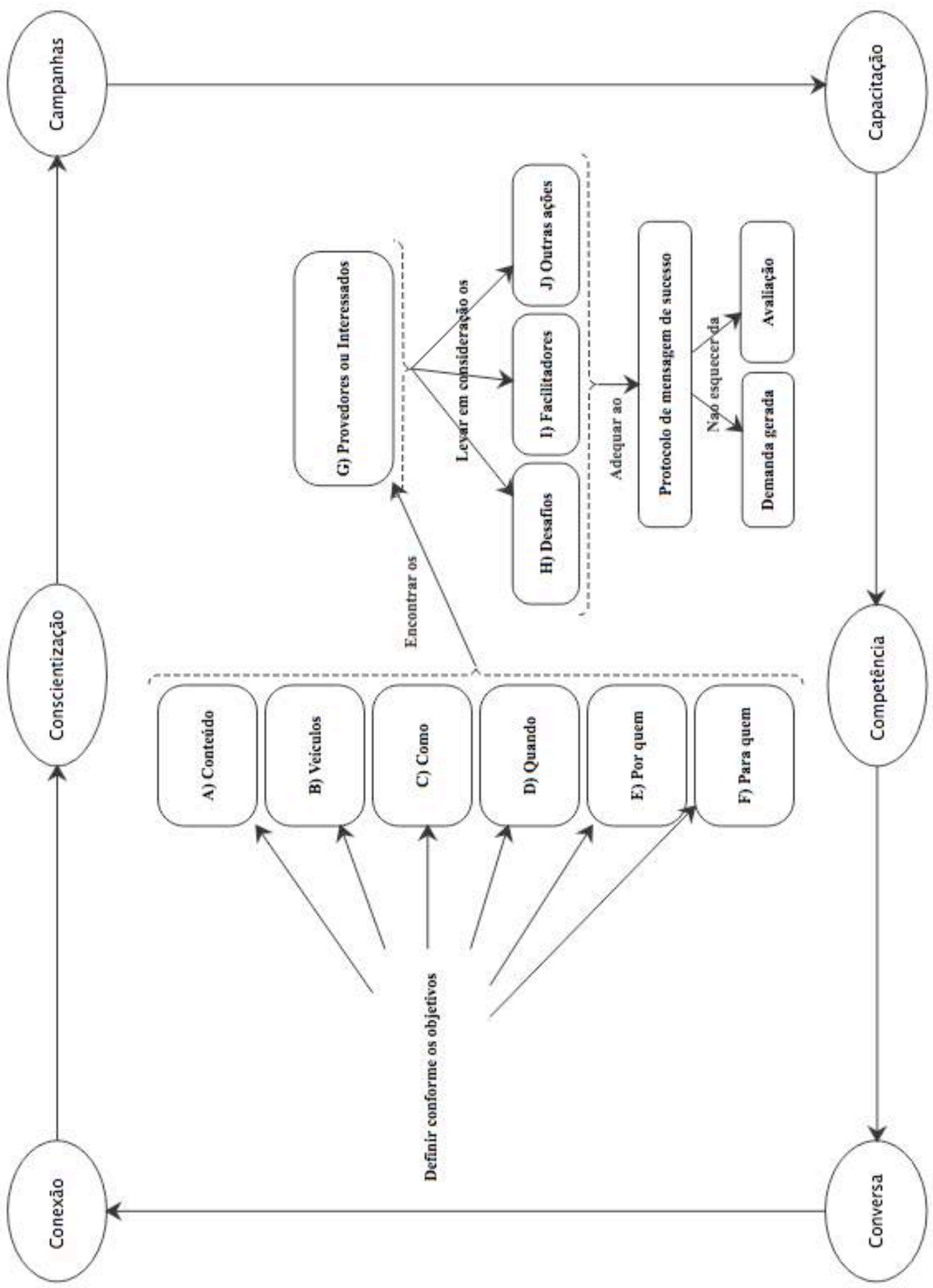

Fonte: produção do próprio autor (2018) 
Para finalizar esse capítulo, endossamos a fala da colaboradora 6:

Eu tenho uma visão assim acho que até um pouco utópica, mas eu sou muito sonhadora eu prefiro acreditar nela, mas quando eu era criança eu lembro que minha avó falava muito "aquela doença". Que é o câncer. Não podia falar câncer. É aquela doença. E não podia nem apontar aonde a pessoa tinha, porque senão você corria o risco de ter. E hoje as pessoas falam muito mais abertamente. Eu tenho uma visão utópica de que a pessoa chegue e fale: olha eu estou pensando em me suicidar, mas que a sociedade como um todo também não se espante ao ouvir isso. Que ela seja tão informada que ela consiga acolher esse sofrimento da pessoa. Então, por isso que eu sempre volto na informação, porque o sofrimento mental ele não é validado ... a doença mental ela não é validada, né? ... mas é por causa do preconceito, é um mito, é o tabu ... hoje as pessoas não sabem nomear o que elas sentem, elas não conseguem dar nome, elas não conseguem explicar, mas não conseguem pessoas que também as escutem, em sua grande [sic] maioria. As pessoas estão muito ocupadas, né? Elas não têm tempo para ouvir. 


\section{CONSIDERAÇÕES FINAIS}

A verdadeira viagem de descoberta não consiste na busca de novas
paisagens, mas de um novo olhar. (Proust)

Essa pesquisa objetivou verificar como a comunicação sobre o suicídio e a consciência pública podem colaborar com a prevenção e posvenção do suicídio, além de pesquisar como o tabu e o estigma influenciam o assunto; conhecer procedimentos que possam aumentar a consciência pública.

O método escolhido para atender os objetivos dessa pesquisa foi a Teoria Fundamentada nos Dados (Grounded Theory) ancorada em Glaser and Strauss (1967) e Strauss and Corbin (2008), essa escolha aconteceu pelo desafio de usarmos um método relativamente novo no país e pela vontade de vermos emergir dos dados a essência da análise, conforme explicamos no diário de bordo.

Desde o início do estudo a internet e as redes sociais tem sido canais cada vez mais utilizados para a divulgação de locais de ajuda, campanhas, e também, ameaças de suicídio, cartas de despedida e a transmissão de suicídios ao vivo, que posaram como um desafio para essas redes. O assunto foi trazido pela mídia por uma série de grande repercussão, "Os treze porquês", que teve como produtora executiva Selena Gomes, e pelo crime virtual "Baleia Azul”, que fizeram que a problemática do suicídio ganhasse espaço e fosse tratada até com exagero. A campanha do "Setembro Amarelo" desenvolveu-se, mas ainda precisa ganhar mais espaço e conquistar outros redutos não ligados à área da saúde. Observamos o aumento do número de campanhas, reportagens, pessoas engajadas na prevenção do suicídio, além disso, o termo posvenção vem sendo usado com mais frequência, fazendo que se estabeleça no campo.

Uma das nossas motivações para pesquisar o tema consciência pública sobre o suicídio surgiu ao ouvir, nos grupos de apoio, sobre a dificuldade de falar sobre o suicídio em público e entre pessoas próximas, como esse fato influenciava negativamente os sobreviventes. Finalizamos esse trabalho com a certeza de que conscientização sobre suicídio é uma das possibilidades de alterar essa realidade de estigma e de tabu em relação ao tema.

Pensamos que esse estudo conseguiu atingir seus objetivos ao identificarmos, a partir do discurso dos colaboradores, que aumentar a comunicação sobre o suicídio tem importância fundamental para a sociedade e para aqueles que foram tocados por essa tragédia. Percebemos que falar mais sobre o suicídio é o início do caminho, é necessário iniciar um processo para que se aumente a consciência pública. No momento que a sociedade compreender que "o suicídio é um problema de todos" e engajar-se em mudar esse fenômeno, muito mais pode ser feito. 
Os colaboradores evidenciaram que ainda há muito tabu relacionado ao assunto o que pode tornar-se um impeditivo de cuidado e um multiplicador de estigmas e de preconceito, dados em concordância com pesquisas internacionais sobre o tema.

Apontamos várias propostas para aumentar a consciência pública no capítulo sete, devido à sua importância, destacamos algumas delas.

Com relação a pessoas com comportamento suicida, propomos que:

- Orientações contendo passos fáceis de serem seguidos por pessoas em desespero sejam amplamente divulgadas, para que elas saibam onde encontrar ajuda sem gastar muito tempo para encontrá-las;

- Haja o tratamento adequado, por profisssionais de serviços de emergência e UTIs e em locais especializados na crise com o acompanhamento subsequente;

- Haja acesso à internação psiquiátrica e ao tratamento gratuito de qualidade, que seja avaliado e adaptado às necessidades dessa população específica;

- Criação de grupos de apoio;

- As pessoas com a experiência vivida (lived experience) possam ser "empoderadas", com foco em seus recursos e não em suas dificuldades, que haja o reconhecimento de sua história com a possibilidade de aproveitar esse percurso no aumento da conscientização e na ajuda de outras pessoas em situação de vulnerabilidade e para a sociedade em geral, sendo capacitados para tornarem-se porta-vozes dessa realidade e de seu sofrimento;

- Ultrapassar as barreiras invisíveis que a sociedade cria em relação aos transtornos mentais com conhecimento, diálogo, acolhimento e tratamentos necessários;

- Oferecer espaços de conversa segura e de pertencimento;

- Propor e desenvolver competências relacionadas ao autocuidado;

- Desenvolver estudos sobre como as pessoas com ideação e comportamento suicida gostariam de serem vistas e tratadas pela sociedade;

Ressaltamos que as pessoas têm diferentes necessidades, portanto, essas sugestões não devem ser tomadas como regras. 
Com relação aos sobreviventes enlutados pelo suicídio propomos:

- A fundação de uma Associação Brasileira de Sobreviventes e a consolidação de novas ONGs criadas e dirigidas por enlutados no país;

- Encontros de sobreviventes, que possam ocorrer com mais frequência. Possam ser criados espaços em congressos de diversas áreas, como educação, tecnologia, psicologia, psiquiatria etc. para a troca entre profissionais e enlutados, essa aliança pode trazer benefícios para todos os envolvidos;

- Criação de uma força-tarefa em posvenção, para unir os pesquisadores da área e desenvolver novas formas de ajuda aos sobreviventes;

- Oferecer espaços para falar do processo do luto por suicídio, evitando assim o tabu, que atinge as famílias. Esse cuidado às famílias pode ocorrer em grupos de apoio ou nos serviços de saúde mental;

- Ajudar a sociedade a reconhecer e a entender as especificidades do luto por suicídio;

- Alguns enlutados por suicídio podem ser multiplicadores, nesse caso, terem a possibilidade de receber capacitação para poder ajudar outras pessoas;

- A partir de um aumento de conscientização e dentro da singularidade de seu processo de luto, alguns enlutados poderão falar abertamente sobre o suicídio e sobre quem morreu, sendo facilitadores para àqueles que ainda estão no início do seu processo de luto com muito sofrimento, que pensam que irão sucumbir com a dor;

- Por meio do aumento da consciência e da competência, novos grupos de apoio podem ser criados e coordenados pelos próprios sobreviventes;

- Sejam criados serviços de posvenção ativa em parceria com o IML, funerárias, cemitérios e hospitais.

Com relação aos profissionais, acreditamos ser necessário:

- Sensibilizar e capacitar profissionais para o manejo do comportamento suicida e com os sobreviventes enlutados;

- Sensibilizar orientadores e comitês de ética sobre a necessidade de novas pesquisas;

- Desenvolver instrumentos consistentes e com indicadores diversos, para avaliação dos atendimentos públicos e do sucesso das intervenções e campanhas; 
- A união, sensibilização e conscientização de profissões diversas, além dos profissionais da área de saúde, que possam relacionar ou influenciar de alguma maneira a prevenção e a posvenção, como arquitetos, agrônomos, engenheiros civis, publicitários, só para citar alguns;

- A criação de leis que incentivem as universidades a iniciarem ou aumentarem a oferta de disciplinas sobre suicídio e comportamentos autodestrutivos, envolvendo: sensibilização, conhecimento, enfatizando a prevenção e a posvenção;

- Estimular as universidades a oferecerem serviços de apoio aos estudantes em risco;

- Capacitação de religiosos e pessoas-chave (gatekeepers) ou indivíduos da comunidade que têm contato pessoal com um grande número de pessoas em sua atividade diária, como enfermeiros, inspetores de escola, líderes comunitários, entre outros, podendo ser treinados para identificar pessoas em risco e encaminhá-las a serviços de suporte apropriados;

- A consolidação do termo posvenção e a capacitação para o desenvolvimento de atividades relacionadas ao luto por suicídio.

Com relação à sociedade:

- Compreensão da "psicofobia", o receio e o estigma dos transtornos mentais e dos tratamentos psicológicos e psiquiátricos;

- Reforçar a visão que "suicídio é um problema de todos", estimulando a empatia e a compaixão para os indivíduos com comportamentos suicidas e os enlutados pelo suicídio;

- Conscientização para que as pessoas falem abertamente sobre o tema, capacitação para que aprendam como lidar com essa comunicação e não precisem mudar de assunto ou tomarem atitudes negativas por não saberem lidar com ele, além de competência de terem as informações necessárias para pedirem ajuda, se necessário;

- O desenvolvimento da competência em suicídio (suicide literacy) a fím de, juntamente com a conscientização e o diálogo, promover as mudanças necessárias para que haja a diminuição do tabu, do estigma e do julgamento;

- O desenvolvimento de pesquisas e ações relacionadas à conexão (connectedness), por se tratar de um fator de proteção do comportamento suicida que pode ter grande impacto na prevenção e na promoção de saúde mental. 
Com relação às Políticas Públicas:

- Criar protocolos claros para o preenchimento correto das notificações compulsórias e do suicídio nos atestados de óbito;

- Conscientizar sobre a necessidade de preencher os protocolos e atestado de óbito corretamente;

- Planos compreensivos, integrados e abrangentes, que incluam a conscientização, a capacitação, o desenvolvimento de competências, o tratamento e a posvenção sejam desenvolvidos e implementados;

- Aproximação daqueles que fazem a política pública com aqueles que estão na linha de frente do cuidado - de quem comanda para a realidade de quem atende - unindo as estratégias com a experiência;

- Aumentar o investimento designado para a prevenção do suicídio.

Dez anos precisaram passar para que a Estratégia de 2006 (Brasil, 2006b) fosse retomada por meio da Agenda Estratégica no ano passado (Brasil, 2017a) e o primeiro Boletim Epidemiológico fosse divulgado. Embora observemos que diversos países já têm planos nacionais sobre o suicídio funcionando há muitos anos, no Brasil esses planos ainda são uma promessa. Esperamos que não sejam necessários mais dez para que as ações sejam implementadas, pois temos a expectativa de haver a continuidade das políticas públicas e sua implantação para prevenção e cuidados a pessoas com tentativa de suicídio e familiares enlutados.

Ao estimular a comunicação sobre o suicídio, se houver a união de forças entre a sociedade, os sobreviventes e familiares enlutados em ONGs e associações, é possível exercer pressão e mobilizar o governo para a criação e implementação de políticas públicas.

Por um lado, é fundamental que o Ministério da Saúde compreenda o suicídio como uma questão grave de saúde pública, assim, poder-se-ia aumentar a conscientização e a oferta de locais para tratamento. Por outro, é importante que haja a conscientização e o movimento da sociedade, questionando e propondo que governos tomem as providências necessárias para garantir a prevenção, a intervenção e a posvenção do suicídio. 
Com relação às campanhas, temos participado de grupos de discussão a respeito, trazendo algumas questões para reflexão:

- É fundamental haver campanhas que ressaltem que o suicídio pode ser prevenido e que há ajuda disponível, mas sugerimos não focar na questão dos $90 \%$ dos casos sem explicar o porquê dessa afirmação, conforme esclarecemos anteriormente, a afirmação que $90 \%$ dos suicídios podem ser prevenidos pode aumentar a sensação de culpa nos sobreviventes e a sensação que todos os suicídios são simples de serem prevenidos;

- Ressaltar o suicídio é multifatorial, ir contra uma tendência de atribuir uma causalidade única para o suicídio, explicando que uma pessoa matou-se porque perdeu o emprego, por exemplo, arrolar os múltiplos fatores que estão associados com o evento do suicídio;

- Desenvolver mensagens dirigidas a públicos específicos, adolescentes, idosos, LGBT, médicos, entre outros;

- Promover campanhas com a participação de famosos e influenciadores, para atingir mais pessoas e mostrar que o suicídio pode acontecer com qualquer um;

- Campanhas precisam ter foco, objetivo e serem avaliadas periodicamente para ver o quanto atingiram a população para quem foram dirigidas;

- Fazer campanhas integradas com um plano de ação coordenado, ou seja, além de ter um objetivo claro, entender as campanhas como parte de um processo, que deve incluir, por exemplo, o acesso aos serviços de saúde mental e a capacitação dos profissionais da área da saúde;

- Integrar as campanhas com protocolos de ajuda para que as pessoas sensibilizadas e necessitadas tenham onde receber a atenção que precisam;

- A sensibilização sobre a problemática para que não haja mais compartilhamentos de "suicídios espetaculares", que hoje são gravados por smartfones e postados nas redes sociais ou "campanhas espetaculares", nas quais as pessoas usam as campanhas como marketing pessoal ou marketing amarelo, como foi exposto nesse estudo, sem engajarem-se ou compreenderem a temática;

- Desenvolver protocolos de criação de campanhas a fim de ajudar pessoas que queiram engajar-se, mas não sabem exatamente como, quando, para quem e o que fazer. 
- Desenvolver diretrizes e recomendações para mensagens e conteúdos seguros e positivos sobre a prevenção e posvenção do suicídio, que possam ser adaptados culturalmente, que sejam de fácil acesso a todos.

Apresentamos a seguir alguns exemplos de campanhas: aumento do diálogo; foco na arrecadação de fundos para pesquisa; uso correto da medicação; "não jurar segredo", sobre comunicação suicida, principalmente entre adolescentes, que contam para o amigo que pensam em matar-se, mas pedem segredo sobre essa comunicação; “antidepressivo não é antitérmico", para a conscientização da necessidade da medicação e de como ela funciona; "depressão não é frescura", é doença; "não é só depressão", para a ampliação da percepção relacionada ao fato que o suicídio é multifatorial.

Com relação a outras ações:

- Desenvolver e utilizar novas tecnologias para aumentar a conscientização pública, capacitar os profissionais e detectar pessoas em risco;

- Não se basear somente na Inteligência Artificial (IA) ou em algoritmos para definir quem precisa ou não de ajuda ao fazer o rastreamento virtual em redes sociais; o algoritmo e as denúncias (como as do Facebook) devem ser analisadas por especialistas;

- Aumentar a oferta de fóruns e de grupos de apoio virtuais com o desafio de acolher, unir e ter o conhecimento para tomar providências, caso alguém esteja em risco;

- Avaliar as necessidades da população e, a partir delas, desenvolver instrumentos para medir a eficácia das intervenções e das campanhas. Utilizar apenas as taxas de mortalidade ou a busca por serviços pode simplificar uma equação complexa;

- Desenvolver planos de prevenção do suicídio e sensibilização de profíssionais em empresas. Um exemplo seria a cooperação assinada entre o Metrô de São Paulo, entre o Instituto Vita Alere e o Centro de Valorização da Vida (CVV), que atualmente oferece atendimentos voluntários do CVV em estações de metrô, desenvolve capacitações para funcionários e iluminou de amarelo algumas estações durante o mês de setembro, entre outras ações, a partir da preocupação do Metrô com seu papel e importância na sociedade.

- Pressionar o poder público para tomar providências relacionadas aos hotspots, fazendo alterações necessárias para impedir ou dificultar o acesso de pessoas 
vulneráveis ao ato suicida em locais conhecidos publicamente para esse fim como, por exemplo, vãos de shoppings, antenas de televisão, pontes e viadutos famosos pelo alto número de suicídios em cada cidade;

- Criar fundos de investimento, que poderiam ser providos por campanhas, para o desenvolvimento científico da prevenção, dessa forma, pesquisadores brasileiros poderiam fazer intercâmbio, estágios, doutorados no exterior para seu desenvolvimento e capacitação. Poderiam também receber financiamento para fazer pesquisas nacionais na área;

- A criação de uma revista científica especializada em prevenção do suicídio e posvenção, para possibilitar mais visibilidade, confiabilidade, credibilidade e estimular publicações específicas na área.

Com relação ao desenvolvimento da conscientização pública sobre suicídio propomos:

- Encontrar parceiros dispostos a investirem no desenvolvimento científico e em ações de conscientização, como campanhas e eventos sobre suicídio;

- Utilizar novas tecnologias e soluções alternativas para aumentar a consciência pública, como mensagens nas caixas de medicamentos, o uso da arte, eventos, novelas, podcasts, ações em hotspots, entre outros.

- A criação de prêmios para reportagens, que possam trazer verdadeira consciência e desenvolvimento sobre o tema; para campanhas e ações inovadoras na área;

- O ensino, desenvolvimento e divulgação de reportagens que produzam o efeito Papageno e a aliança entre diversos saberes para tornar isso possível;

- Promover o aumento da conscientização em várias frentes e não se limitar somente a campanhas. As ações devem ser pautadas em objetivos claros e serem avaliadas. A inclusão da competência e do diálogo, além da capacitação e da conexão são recomendadas. As maneiras de atingir esses objetivos estão resumidas abaixo: 
Figura 11: Sugestões para o desenvolvimento da conscientização

\begin{tabular}{|l|}
\hline \multicolumn{1}{|c|}{ OBJETIVOS } \\
\hline - Conteúdos ou mensagens \\
\hline - Em que lugar ou veículos de comunicação \\
\hline - Como ou de que formas \\
\hline - Quando ou periodicidade \\
\hline - Por quem \\
\hline - Para quem (esferas / áreas / público alvo) \\
\hline - Provedores ou interessados \\
\hline - Desafios \\
\hline - Facilitadores \\
\hline - Outras ações \\
\hline \\
\hline
\end{tabular}

Fonte: produção do próprio autor (2018)

Outras possibilidades de atuação que podem ser aprofundadas em futuras pesquisas estão descritas abaixo.

Pelo termo "competência" ser a tradução do termo "literacy", acreditamos que seja necessário compreender se essa é a palavra mais adequada para definir “literacy” em português. Optamos por utilizar o termo "competência" baseados em uma pesquisa realizada por Oliveira (2011), mas é importante o desenvolvimento de estudos para verificar se a melhor tradução é essa. Assim como, utilizava-se o termo "survivor" traduzido para "sobrevivente" no caso de enlutados por suicídio, atualmente, houve uma adaptação da tradução do termo, para "suicide loss survivor" ou "sobrevivente enlutado pelo suicídio" (tradução nossa), pois ao utilizar somente o termo "sobrevivente", gerava uma confusão se havia relação com ter sobrevivido a tentativas de suicídio ou a enlutados pelo suicídio, o que pode acontecer com "literacy". A tradução literal de "literacy" seria alfabetização, o que não explica o significado do termo em sua totalidade e no Brasil tem relação com aprender a ler e a escrever. "Habilidade" ou “aptidão", poderiam ser outras palavras utilizadas para traduzir "literacy".

Durante a realização desse trabalho, não encontramos pesquisas a respeito da visão que o brasileiro tem sobre o suicídio, por isso, é fundamental a exploração desse tema em novas 
pesquisas a fim de conhecermos em profundidade o grau do tabu, do estigma e do preconceito em relação ao suicídio no Brasil.

A tradução, adequação cultural e a consequente aplicação das escalas de estigma, como a SOSS (Stigma of Suicide Scale) e a Suicide opinion questionaire (SOQ) para identificar a proporção de tabu existente no Brasil e no que se baseia, pode identificar o melhor caminho e quais mensagens devem ser enfatizadas, ajudando a definição do público-alvo e do objetivo de campanhas de conscientização.

Outro estudo necessário tem relação com entender como as campanhas de arrecadação de fundos poderiam ser eficazes, o que fazer com o dinheiro arrecadado e sobre projetos a serem financiados.

O desenvolvimento de cartilhas para elaboração de campanhas e de comunicação sobre suicídio. Sabemos como não falar, mas ainda não sabemos como fomentar ativamente o aumento da conscientização, para gerar ações de prevenção e posvenção do suicídio.

Sabemos da urgente necessidade de capacitação dos profisssionais da linha de frente do cuidado, estudos são necessários para verificarmos os possíveis efeitos iatrogênicos do cuidado inadequado com pessoas com comportamento suicida.

Sugestões de pesquisas baseadas nesse trabalho incluem:

- Como transformar os dados desse estudo em ações possíveis de serem desenvolvidas no contexto brasileiro;

- Entrevistar pessoas que tentaram suicídios, os chamados sobreviventes de tentativas, pessoas com ideação suicida, além de pessoas que não tiveram experiência direta com suicídio, publicitários, especialistas e profissionais de áreas afins com relação ao aumento da consciência;

- Desenvolver a tríade da mudança (Consciência, Competência e Diálogo) e os 6Cs (Consciência, Campanhas, Capacitação, Competência, Conversa, Conexão) para o aumento da consciência.

Refletindo sobre pesquisa, os seus vários níveis de dados, nos perguntamos: Como conscientizar a sociedade sobre uma situação que não quer ser vista? Como mostrar uma realidade penosa e promover engajamento, sensibilização e cuidado? Acreditamos que as propostas desse estudo guardam possibilidades de respostas a essas inquietações. Para nós, a 
complexidade do suicídio reflete a complexidade da vida e das intervenções necessárias para sua prevenção.

A relevância do presente estudo trata de um tema atual, que atinge muitas pessoas e por trazer diversas reflexões e sugestões relacionadas a um assunto interdito de uma morte escancarada. Algumas das propostas originais do estudo foram a tríade da mudança, os 6Cs e a utilização das caixas de medicamento como veículo do aumento de consciência.

Acreditamos que muito pode ser feito a partir da conscientização, desde a sensibilização das pessoas, o empoderamento dos sobreviventes, a formação de comunidades de apoio e pertencimento, a mudança de atitudes e crenças de uma sociedade, o desenvolvimento de uma força de ação conjunta que tenha a capacidade de promover empatia, gerando engajamento e entendimento dos direitos dos cidadãos e das pessoas com transtornos mentais em relação ao acesso ao tratamento e aos deveres do Estado, em relação à proteção dos cidadãos vulneráveis e no acesso aos hotspots. Como diz Schopenhauer "A tarefa não é tanto ver aquilo que ninguém viu, mas pensar o que ninguém ainda pensou sobre aquilo que todo mundo vê".

Como finalização desse trabalho, lançamos um desafio para o leitor desse estudo, o convidamos para refletir a respeito do que fazer para lidar com o interdito, estigma, tabu e o silenciamento sobre o tema do suicídio. Como mudar essa realidade? Se o suicídio é um problema de todos, quais as soluções para o aumento da consciência, a prevenção e posvenção do suicídio? Como se pode unir a CONSCIENTIZA-AÇÃO? São perguntas complexas que demandam respostas aprofundadas, qualquer tentativa de simplificação poderá incorrer em erro.

\footnotetext{
Como tudo de ruim nessa vida, a gente acha que com a gente não vai acontecer, sempre com os outros. Eu, por exemplo, eu tive um câncer e achava ‘imagine comigo não vai acontecer' ... ter um suicídio na família jamais ... minha família é tão bem estruturada, tudo lindo maravilhoso, isso nunca vai acontecer. Então, você vê um filme você fala 'é uma ficção, não existe na vida real, comigo jamais vai acontecer'. Até que a hora que acontece, que você ... eu me descobri mortal, eu me descobri a coisa mais absurda que poderia ter acontecido na minha vida seria um suicídio e, no entanto, aconteceu ... e hoje em dia ... não está preparada nunca para que uma coisa dessas aconteça, doença até a gente sabe que pode acontecer, mas suicídio ... Nunca! (Colaboradora 3).
} 


\section{REFERÊNCIAS ${ }^{46}$}

ABP. (2006). Diretrizes para um modelo de assistência integral em saúde mental no Brasil. Recuperado de http://www.adpbrasil.org.br/diretrizes_final.pdf

Acosta, J., Ramchand, R., \& Becker, A. (2017). Best Practices for Suicide Prevention Messaging and Evaluating California's "Know the Signs" Media Campaign. Crisis, 38(5), 287-299. doi:10.1027/0227-5910/a000446

AFSP. (2011). After a Suicide: A Toolkit for Schools Newton, MA: Educational Development Center, Inc. Recuperado de http://www.afsp.org/files/Surviving/toolkit.pdf.

AFSP (Diretor). (2014). The Journey. [DVD]. New York, NY: American Foundation for Suicide Prevention

AFSP. (2016a). Issue Brief. In AFSP (Ed.), Federal advocacy. Washington: AFSP Public Policy Office. Recuperado de https://afsp.org/our-work/advocacy/

AFSP. (2016b). Suicide Statistics. About Suicide. Recuperado de https://afsp.org/aboutsuicide/suicide-statistics/

AFSP. (2017). Create a campaign. Recuperado de https://afsp.donordrive.com/index.cfm?fuseaction=cms.page\&id=1264\&eventID=1824

Aguirre, R. T., \& Slater, H. (2010). Suicide postvention as suicide prevention: improvement and expansion in the United States. Death Stud, 34(6), 529-540.

Andriessen, K. (2005). Media award for responsible portrayal of suicide and survivors. Pogled, III(1-2), 66-70. doi: 10.1186/1752-4458-5-15

Andriessen, K. (2009). The role of volunteer organizations in suicide prevention. In D. Wasserman \& A. Wasserman (Eds.), Oxford textbook of suicidology and suicide prevention: a global perspective (pp. 745-748). Oxford: Oxford University Press.

Andriessen, K., \& Krysinska, K. (2012). Essential questions on suicide bereavement and postvention. Int J Environ Res Public Health, 9(1), 24-32. doi:10.3390/ijerph9010024

Andriessen, K., Krysinska, K., \& Grad, O. T. (2017). Postvention in Action: The International Handbook of Bereavement Support. Boston, EUA: Hogrefe.

Ansa. (2018, 10/01/2018). Suicidio de garota-propaganda após bullying choca Austrália. Exame. Recuperado de https://exame.abril.com.br/mundo/suicidio-de-garota-propagandaapos-bullying-choca-australia/

Arendt, F., \& Scherr, S. (2017a). The Impact of a Highly Publicized Celebrity Suicide on Suicide-Related Online Information Seeking. Crisis, 38(3), 207-209. doi:10.1027/02275910/a000455

\footnotetext{
${ }^{46}$ De acordo com o estilo APA (American Psychological Association)
} 
Arendt, F. \& Scherr, S. (2017b). Optimizing Online Suicide Prevention: A Search EngineBased Tailored Approach. Health Commun, 32(11), 1403-1408. doi:10.1080/10410236.2016.1224451

Aschidamini, I. M., \& Saupe, R. (2004). Grupo Focal - Estratégia Metodológica Qualitativa: Um ensaio teórico. Cogitare Enfermagem, 9(1), 9-14. doi: http://dx.doi.org/10.5380/ce.v9i1.1700

ASEC. (2014a). Amigos do Zippy. Recuperado de http://www.amigosdozippy.org.br/

ASEC. (2014b). Passaporte: Habilidades para a vida. Recuperado de http://www.asecbrasil.org.br/passaporte-habilidades-para-a-vida.php

Austrália. (2014). National Suicide Prevention Strategy. Australian Government Recuperado de http://www.health.gov.au/internet/publications/publishing.nsf/Content/suicideprevention-activities-evaluation $\sim$ background national-suicide-prevention-strategy.

Autry, A. E., \& Monteggia, L. M. (2009). Epigenetics in Suicide and Depression. [Epigenética no Suicídio e na Depressão]. Biol Psychiary, 9(66), 812-813. doi: 10.1016/j.biopsych.2009.08.033

Azevedo, E. G. (2012). A Abordagem do Suicídio no SUS. (Especialista em Saúde Pública. Monografia), Universidade Federal de Santa Catarina, Santa Catarina.

Bailey, E., Spittal, M. J., Pirkis, J., Gould, M., \& Robinson, J. (2017). Universal Suicide Prevention in Young People. Crisis, 38(5), 300-308. doi:10.1027/0227-5910/a000465

Baleia Rosa (2017). Baleia Rosa. Recuperado de http://baleiarosa.com.br/

Barraclough, B., Bunch, J., Nelson, B., \& Sainsbury, P. (1974). A hundred cases of suicide: clinical aspects. Br J Psychiatry, 125(0), 355-373. doi: 10.1192/bjp.125.4.355

Barros, A. J. d. S., \& Lehfeld, N. A. d. S. (2007). Fundamentos de metodologia científica (3a. ed.). São Paulo: Pearson Prentice Hall.

Batterham, P. J., Calear, A. L., \& Christensen, H. (2013a). Correlates of suicide stigma and suicide literacy in the community. Suicide Life Threat Behav, 43(4), 406-417. doi:10.1111/sltb.12026

Batterham, P. J., Calear, A. L., \& Christensen, H. (2013b). The Stigma of Suicide Scale. Psychometric properties and correlates of the stigma of suicide. Crisis, 34(1), 13-21. doi:10.1027/0227-5910/a000156

BBC. (2016, 27 de julho de 2016). Gene Ligado a doença de Stephen Hawking é descoberto graças a desafio do balde de gelo. BBC Brasil. Recuperado de http://www.bbc.com/portuguese/geral-36907648

BBC. (2018, 8 de fevereiro de 2018). Suicídios aumentaram nos EUA logo após Robin Williams se matar, mostra levantamento. BBC Brasil. Retrieved from http://www.bbc.com/portuguese/geral-42988493?ocid=socialflow_twitter 
Beam, R. A., John, S. L., \& Yaqub, M. M. (2017). "We Don't Cover Suicide ... (Except When We Do Cover Suicide)". Journalism Studies, 1-19. doi:10.1080/1461670X.2017.1279563

Beautrais, A. L. (2004). Suicide Postvention: Support for families, Whanau and significant others after a suicide - A Literature review and synthesis of evidence. Wellington: Ministry of Youth Development. Recuperado de https://www.health.govt.nz/system/files/documents/publications/bereavedbysuicidelitreview.pdf

Berman, L. (2009). The American Association of Suicidology. In D. Wasserman \& C. Wasserman (Eds.), Oxford Textbook of Suicidology and Suicide Prevention - A Global Perspective (pp. 739 - 74). Washington: Oxford University Press.

Berthoud, C. M. E. (2003). "Re-significando a Parentalidade" Os desafios de ser pais na atualidade. Taubaté, SP: Cabral Editora e Livraria Universitária.

Bertolote, J. M. (2004). Suicide prevention: at what level does it work? World Psychiatry, 3(3), 147-151. Recuperado de https://www.ncbi.nlm.nih.gov/pmc/articles/PMC1414695/

Bertolote, J. M. (2012). O Suicídio e sua Prevenção. Sao Paulo: Editora Unesp.

Bertolote, J. M. (2013). Suicídio: território do livre-arbítrio ou da doença mental? Rev. SimbioLogias, 6(8), 122-128. Recuperado de http://www.ibb.unesp.br/Home/Departamentos/Educacao/Simbio-

Logias/suicidio_territorio_do_livre-arbitrio.pdf

Biddle, L., Donovan, J., Hawton, K., Kapur, N., \& Gunnell, D. (2008). Suicide and the internet. BMJ, 336(7648), 800-802. doi:10.1136/bmj.39525.442674.AD

Blumer, H. (1969). Symbolic Interacionism: perspective and method. Englewood Cliffs: Prentience-Hall.

Borges, C. F., \& Baptista, T. W. F. (2008). O modelo assistencial em saúde mental no Brasil: a trajetória da construção política de 1990 a 2004. Cadernos de Saúde Pública, 24(2), 456468.

Botega, N. J. (2007). Suicídio: saindo da sombra em direção a um Plano Nacional de Prevenção. Revista Brasileira de Psiquiatria, 29(1). Recuperado de http://repositorio.unicamp.br/bitstream/REPOSIP/34752/1/S151644462007000100004.pdf

Botega, N. J. (2010). Comportamento Suicida em Números Debates - Psiquiatria Hoje, 2, 11 15. Recuperado de http://www.abp.org.br/download/Debates_SetOut2010.pdf

Botega, N. J. (2015). Crise suicida - avaliação e manejo. Porto Alegre: Artmed.

Botega, N. J., Mauro, M. L. F., \& Cais, C. F. d. S. (2004). Estudo Multicêntrico de intervenção no comportamento suicída - Supre-Miss - Organização Mundial da Saúde. In B. G. Werlang \& N. J. Botega (Eds.), Comportamento Suicída (pp. 177-182). Porto Alegre: Artmed. 
Botega, N. J., Rapeli, C. B., \& Cais, C. F. d. S. (2012). Comportamento suicída. In N. J. Botega (Ed.), Pratica Psiquiátrica no Hospital Geral - interconsulta e emergência. Porto Alegre: Artmed.

Botega, N. J., Silveira, I. U., \& Mauro, M. L. F. (2010). Telefonemas na crise: percursos e desafios na prevenção do suicídio. Rio de Janeiro: ABP Editora.

Boyd, J. E., Adler, E. P., Otilingam, P. G., \& Peters, T. (2014). Internalized Stigma of Mental Illness (ISMI) scale: a multinational review. Compr Psychiatry, 55(1), 221-231. doi:10.1016/j.comppsych.2013.06.005

Brasil. (2005). Portaria n. 2.542, de 22 de dezembro de 2005 Brasília: Ministério da Saúde Recuperado de http://bvsms.saude.gov.br/bvs/saudelegis/gm/2006/prt1876_14_08_2006.html.

Brasil. (2006a). Manual de Prevenção do Suicídio. Brasilia: Ministério da Saúde.

Brasil. (2006b). Portaria n. 1.876/GM, de 14 de agosto de 2006. Brasília: Ministério da Saúde. Recuperado de http://bvsms.saude.gov.br/bvs/saudelegis/gm/2006/prt1876_14_08_2006.html.

Brasil. (2006c). Prevenção ao Suicídio - Manual Dirigido a Profissionais das Equipes de Saúde Mental. Brasília: Ministério da Saúde.

Brasil. (2008). CID 10. Brasília: Ministério da saúde. Recuperado de http://www.datasus.gov.br/cid10/V2008/WebHelp/x60_x84.htm.

Brasil. (2014). Portaria $n^{\circ}$ 1.271, de 6 de junho de 2014. Brasilia: Ministério da Saúde. Recuperado de http://bvsms.saude.gov.br/bvs/saudelegis/gm/2014/prt1271_06_06_2014.html.

Brasil. (2017a). Agenda de Ações Estratégicas para a Vigilância e Prevenção do Suicídio e Promoção da Saúde no Brasil: 2017-2020 Brasília: Ministério da Saúde Recuperado de http://portalarquivos.saude.gov.br/images/pdf/2017/setembro/21/Coletiva-suicidio-2109.pdf

Brasil. (2017b). Suicídio. Saber, agir e prevenir. Brasília: Ministério da Saúde.

Burnap, P., Colombo, G., Amery, R., Hodorog, A., \& Scourfield, J. (2017). Multi-class machine classification of suicide-related communication on Twitter. Online Soc Netw Media, 2, 32 44. doi:10.1016/j.osnem.2017.08.001

Burnette, C., Ramchand, R., \& Ayer, L. (2015). Gatekeeper Training for Suicide Prevention: A Theoretical Model and Review of the Empirical Literature. Rand Health Q, 5(1), 16. Recuperado de https://www.ncbi.nlm.nih.gov/pmc/articles/PMC5158249/

Cacciacarro, M. F. (2016). Educar para crescer: valores para a vida. O papel da família na transmissão de valores na primeira infância. (Dissertação de Mestrado), Pontífica Universidade Católica São Paulo (PUC), São Paulo, SP.

Camus, A. (1989). O mito de Sísifo (3a. edição ed.). Rio de Janeiro: Guanabara. 
Camus, A. (1991). Return to Tipasa (E. C. Kennedy, Trans.). In P. Thody (Ed.), Lyrical and Critical Essays. United Kingdom: Vintage.

Carvalho, A. X., Cerqueira, D. R. C., Rodrigues, R. I., \& Lobão, W. J. A. (2007). Custos das Mortes por Causas Externas no Brasil. Brasilia: IPEA - Instituto de Pesquisa Economica Aplicada Recuperado de http://www.ipea.gov.br/sites/000/2/publicacoes/tds/td_1268.pdf.

Carvalho, V. D., Borges, L. O., \& Rego, D. P. (2010). Interacionismo simbólico: origens, pressupostos e contribuições aos estudos em psicologia social. Psicologia Ciência e Profissão, 30(1), 146-161.

Cassorla, R. M. S. (2003). Prefácio. In E. R. Turato (Ed.), Tratado da Metodologia da Pesquisa Clínico-Qualiativa. Petrópolis, RJ: Vozes.

Cassorla, R. M. S. (2004). Suicídio e autodestruição humana. In B. G. Werlang \& N. J. Botega (Ed.), Comportamento Suicida. Porto Alegre: Artmed.

CDC (Produtor). (2009, 19 de janeiro de 2018). Podcasts at CDC: Suicide. Recuperado de https://www2c.cdc.gov/podcasts/

CDC. (2011). Strategic direction for the prevention of suicidal behavior: Promoting individual, family, and community connectedness to prevent suicidal behavior. Recuperado de https://www.cdc.gov/ViolencePrevention/pdf/Suicide_Strategic_Direction_Full_Versiona.pdf

Cerel, J., Jordan, J. R., \& Duberstein, P. R. (2008). The impact of suicide on the family. Crisis, 29(1), 38-44. doi: 10.1027/0227-5910.29.1.38

Cestari, M. E. W., \& Zago, M. M. F. (2005). A prevenção do câncer e a promoção de saúde: um desafio para o Século XXI. Revista Brasileira de Enfermagem, 58(2), 218-221. Recuperado de http://dx.doi.org/10.1590/S0034-71672005000200018.

Chan, W. I., Batterham, P., Christensen, H., \& Galletly, C. (2014). Suicide literacy, suicide stigma and help-seeking intentions in Australian medical students. Australas Psychiatry, 22(2), 132-139. doi:10.1177/1039856214522528

Chapple, A., Ziebland, S., \& McPherson, A. (2004). Stigma, shame, and blame experienced by patients with lung cancer: qualitative study. $B M J, \quad 328(7454), 1470$. doi:10.1136/bmj.38111.639734.7C

Charmaz, K. (2006). Constructing Grounded Theory: A pratical guide through qualitative analysis. Thousand Oaks: Sage Publications.

Charmaz, K. (2009). A construção da teoria fundamentada: Guia prático para a análise quantitativa (J. E. Costa, Trans.). Porto Alegre: Artmed.

Charon, J. M. (2006). Symbolic Interacionism: an introduction, an interpretation, an integration. Upper Saddle River, NJ: Prentice-Hall.

Chhabra, N., \& Bryant, S. M. (2016). Snapchat Toxicology: Social Media and Suicide. Ann Emerg Med, 68(4), 527. doi:10.1016/j.annemergmed.2016.05.031 
Chiles, J. A., \& Strosahl, K. D. (2005). Clinical Manual for Assessment and Treatment of Suicidal Patients: American Psychiatric Publishing.

Chisholm, D., Sweeny, K., Sheehan, P., Rasmussen, B., Smit, F., Cuijpers, P., \& Saxena, S. (2016). Scaling-up treatment of depression and anxiety: a global return on investment analysis. Lancet Psychiatry, 3(5), 415-424. doi:10.1016/S2215-0366(16)30024-4

Colucci, E. (2013a). Cultural Meaning(s) of Suicide: A Cross-Cultural Study. In E. Colucci \& D. Lester (Eds.), Suicide and culture: understanding the context (pp. 93-196). Massachusetts, EUA: Hogrefe.

Colucci, E. (2013b). Culture, cultural meaning(s) and suicide. In E. Colucci \& D. Lester (Eds.), Suicide and culture: understanding the context (pp. 25-46). Massachusetts, EUA: Hogrefe.

Cornejo, E. R. S. P. U., Cescon, L., \& Scavacini, K. (2018). A posvenção do suicídio e o cuidado com os enlutados. Em I. Gonçalves (Ed.), Suicídio: prevenção, posvenção e direito à vida (Vol. 3, pp. 37-48). João Pessoa/PB: CuideSi Espaço Integrado de Educação Emocional.

Correa, H., \& Barrero, S. P. (2006a). As pesquisas em biologia do suicídio: aspectos históricos. Em Correa, H. \& Barrero, S. P. (Eds.), Suicídio - uma morte evitável. São Paulo: Editora Atheneu.

Correa, H., \& Barrero, S. P. (2006b). As teorias do suicídio. In H. Correa, H. \& S. P. Barrero, (Eds.), Suicídio - Uma morte evitável (pp. 37-44). São Paulo, SP: Editora Atheneu.

Corrigan, P., \& Gelb, B. (2006). Three programs that use mass approaches to challenge the stigma of mental illness. Psychiatr Serv, 57(3), 393-398. doi:10.1176/appi.ps.57.3.393

Corrigan, P. W., Druss, B. G., \& Perlick, D. A. (2014). The Impact of Mental Illness Stigma on Seeking and Participating in Mental Health Care. Psychol Sci Public Interest, 15(2), 3770. doi:10.1177/1529100614531398

Corrigan, P. W., Gause, M., Michaels, P. J., Buchholz, B. A., \& Larson, J. E. (2015). The California Assessment of Stigma Change: A Short Battery to Measure Improvements in the Public Stigma of Mental Illness. Community Ment Health J, 51(6), 635-640. doi:10.1007/s10597-014-9797-5

Corrigan, P. W., Sheehan, L., Al-Khouja, M. A., \& Stigma of Suicide Research, T. (2017). Making Sense of the Public Stigma of Suicide. Crisis, 38(5), 351-359. doi:10.1027/02275910/a000456

Couto, M. C. V., Duarte, C. S., \& Delgado, P. G. G. (2008). A saúde mental infantil na Saúde Pública brasileira: situação atual e desafios. Revista Brasileira de Psiquiatria, 30(4), 390398. Recuperado de http://www.scielo.br/pdf/pc/v27n1/0103-5665-pc-27-01-00017.pdf

Creswell, J. W. (1998). Qualitative inquiry and research design. Choosing among five traditions. London: Sage Publications.

Creswell, J. W. (2003). Reseach design: Qualitative, quantitative and mixed methods approaches. Thousand Oaks: Sage Publications. 
Cutcliffe, J., \& Ball, P. B. (2009). Suicide survivors and the suicidology academe: reconciliation and reciprocity. Crisis, 30(4), 208-214. doi:C137671375W60554 [pii]

10.1027/0227-5910.30.4.208

Cvinar, J. G. (2005). Do suicide survivors suffer social stigma: a review of the literature. Perspect Psychiatr Care, 41(1), 14-21. doi: 10.1111/j.0031-5990.2005.00004.x

D'Oliveira, C. F. A. (2014). Estratégia nacional de prevenção do suicídio: suas diretrizes. Recuperado de http://www.rebraps.com.br/2014/09/estrategia-nacional-de-prevencaodo.html

D'Oliveira, C. F. A. (2015). A prevenção do suicídio e as diretrizes da estratégia brasileira. Palestra apresentada durante o III Seminário de Prevenção e Promoção da Saúde, Rio Branco. Recuperado de http://www.rebraps.com.br/2015/10/iii-seminario-de-prevencao-epromocao.html

Dahlgren, L., Emmelin, M., \& Winkvist, A. (2007). Qualitative Methodology for International Public Health. Umea: Print och Media, Umea University.

De Leo, D. (2004). Suicide prevention is far more than a psychiatric business. World Psychiatry, 3(3), 155-156. Recuperado de https://www.ncbi.nlm.nih.gov/pmc/articles/PMC1414698/

De Leo, D., \& Evans, R. (2004). International suicide rates and prevention strategies. Gottingen: Hogrefe e Huber.

De Silva, E., Bowerman, L., \& Zimitat, C. (2015). A suicide awareness and intervention program for health professional students. Educ Health (Abingdon), 28(3), 201-204. doi:10.4103/1357-6283.178597

Domino, G., \& Groth, M. (1997). Attitudes toward suicide: German and US Nationals. Omega, 35(3), 309-319. Recuperado de http://dx.doi.org/10.2190/H1CB-YFJD-W51B-P741

Durkheim, E. (2000). O suicídio: Estudo de sociologia (M. Stahel, Trans.). São Paulo: Martins Fontes.

Durkheim, E. (2010). Da divisão do trabalho social. São Paulo: WMF Martins Fontes.

Else-Quest, N. M., LoConte, N. K., Schiller, J. H., \& Hyde, J. S. (2009). Perceived stigma, selfblame, and adjustment among lung, breast and prostate cancer patients. Psychol Health, 24(8), 949-964. doi:10.1080/08870440802074664

Entercom. (2017). I'm Listening. Recuperado de http://www.imlistening.org/

Escócia. (2006). Evaluation of the first phase of Choose Life: The National Strategy and Action Plan to Prevent Suicide in Scotland. Scottish . Recuperado de http://www.gov.scot/Publications/2006/09/06094657/18.

EUA. (2010) National Action Plan to Improve Health Literacy. Washington: U. S. Department of Health and Human Services Recuperado de https://health.gov/communication/initiatives/health-literacy-action-plan.asp 
EUA. (2018). Quick guide to health literacy: Fact Sheet. Washington D.C.: U.S. Department of Health and Human Services Recuperado de https:/health.gov/communication/literacy/quickguide/factsbasic.htm - one.

Feigelman, W., Gorman, B. S., \& Jordan, J. R. (2009). Stigmatization and suicide bereavement. Death Stud, 33(7), 591-608. doi:10.1080/07481180902979973

Ferreira, A. B. H. (Ed.) (2010) Mini Aurélio: O dicionário da lingua portuguesa (8 ed.). Curitiba: Positivo.

Fife, B. L., \& Wright, E. R. (2000). The dimensionality of stigma: a comparison of its impact on the self of persons with HIV/AIDS and cancer. J Health Soc Behav, 41(1), 50-67. Recuperado de http://psycnet.apa.org/doi/10.2307/2676360

Fine, C. (1997). No time to say goodbye: surviving the suicide of a loved one. New York: Brodway Books.

Fink, D. S., Santaella-Tenorio, J., \& Keyes, K. M. (2018). Increase in suicide the months after the death of Robin Williams in the US. PLoS One, 13(2). https://doi.org/10.1371/journal.pone.0191405

Fitch, K., Bernstein, S. J., Aguilar, M. D., Burnand, B., LaCalle, J. R., Lazaro, P., \& Kahan, J. P. (2001). The RAND/UCLA appropriateness method user's manual. Recuperado de https://www.rand.org/pubs/monograph_reports/MR1269.html

Fitzpatrick, S. J., \& Kerridge, I. H. (2013). Challenges to a more open discussion of suicide. Med J Aust, 198(9), 470-471. doi: 10.5694/mja12.11540

Flexhaug, M., \& Yazganoglu, E. (2008). Alberta Takes Action on Suicide - Best and Promising Practices in Suicide Bereavement Support Services: A Review of the Literature. Canadá: Alberta Health Services Recuperado de http://www.albertahealthservices.ca/MentalHealthWellness/hi-mhw-b-and-p-practices-insuicide-bereavement-support-serv.pdf.

Fontanelle, P. (2008). Suicídio: O futuro interrompido: Guia para sobreviventes. São Paulo: Geração Editorial.

Foxit. (2018). MAXQDA Standard 2018 (Version 18.0.3). Berlin: VERBI GmbH Berlin. Recuperado de http://www.maxqda.com/

Framework. (2014). Action Alliance Framework for Successful Messaging. Recuperado de http://suicidepreventionmessaging.org/

Franco, M. H. P. (2005). Apresentação. In M. H. P. Franco (Ed.), Nada sobre mim sem mim: Estudos sobre Vida e Morte (pp. 13 - 17). Campinas: Livro Pleno.

Franco, M. H. P. (2010). Por que estudar o luto na atualidade? In M. H. P. Franco (Ed.), Formação e rompimento de vínculos: O dilema das perdas na atualidade (pp. 17 - 42). São Paulo: Summus.

Freire, P. (1980). Conscientização: Teoria e prática da libertação: uma introdução ao pensamento de Paulo Freire. São Paulo: Cortez e Moraes. 
Freire, P. (2000). Pedagogia da Indignação: cartas pedagógicas e outros escritos. São Paulo: UNESP.

Furlong, P. Parent Project Muscular Distrophy. Recuperado de http://www.parentprojectmd.org/

Gaúcha ZH. (2017). Com mudança no protocolo, registro de tentativas de suicídio aumenta $910 \%$ este ano em Pelotas. Gaúcha $Z H$. Recuperado de https://gauchazh.clicrbs.com.br/comportamento/noticia/2017/12/com-mudanca-noprotocolo-registro-de-tentativas-de-suicidio-aumenta-910-este-ano-em-pelotascjbidutmc02r101lszbimgkr3.html

Gil, A. C. (2010). Como elaborar projetos de pesquisa (5a. ed.). São Paulo, SP: Atlas.

Glaser, B. G., \& Strauss, A. L. (1965). Awareness of dying. Chicago: Aldine.

Glaser, B. G., \& Strauss, A. L. (1967). The discovery of grounded theory. Chicago: Aldine.

Goethe, J. W. (2001). Os sofrimentos do Joven Werther. Porto Alegre: L\&PM Editores.

Goffman, E. (1963). Stigma: Notes on the management of spoiled identity. Englewood Cliffs, NJ: Prentice-Hall.

Gomes, B. M. A. (2015). Políticas Públicas de Turismo: Interação Empresários-setor público em Curitiba sob a ótica institucional. (Tese de doutorado), Universidade Federal do Paraná, Curitiba.

Gomes, J. O., Baptista, M. N., Carneiro, A. M., \& Cardoso, H. F. (2014). Suicídio e internet: análise de resultados em ferramentas de busca. Psicologia \& Sociedade, 26(1), 63 - 73. Recuperado de http://dx.doi.org/10.1590/S0102-71822014000100008.

Gonçalves, L. R. C., Gonçalves, E., \& Oliveira Júnior, L. B. (2011). Determinantes espaciais e socioeconômicos do suicídio no Brasil: uma abordagem regional. Nova Economia, 21(2). Recuperado de http://dx.doi.org/10.1590/S0103-63512011000200005

Grad, O. T., Zavasnik, A., \& Groleger, U. (1997). Suicide of a patient: gender differences in bereavement reactions of therapists. Suicide Life Threat Behav, 27(4), 379-386. doi: 10.1111/j.1943-278X.1997.tb00517.x

Grad, O., de Leo, D., Dyregrov, K., Andriessen, K., \& Cimitan, A. (2014). Postvention: How to Organize it. In D. D. Leo, A. Cimitan, K. Dyregrov, O. Grad, \& K. Andriessen (Eds.), Bereavement after traumatic death (pp. 115-124). Boston, EUA: Hogrefe Publishing.

Guardian. (2014). Ice bucket challenge: what are the lessons for marketers? The Guardian. Recuperado de https://www.theguardian.com/media-network/media-networkblog/2014/aug/27/ice-bucket-challenge-lessons-marketing

Guidry, J., Zhang, Y., Jin, Y., \& Parrish, C. (2016). Portrayals of depression on pinterest and why public relations practioners should care. Public Relations Review(42), 232-236. Recuperado de http://dx.doi.org/10.1016/j.pubrev.2015.09.002 
Haas, A. P., Eliason, M., Mays, V. M., Mathy, R. M., Cochran, S. D., D'Augelli, A. R., ... Clayton, P. J. (2011). Suicide and suicide risk in lesbian, gay, bisexual, and transgender populations: review and recommendations. $J$ Homosex, 58(1), 10-51. doi:10.1080/00918369.2011.534038

Haas, A. P., Gebbia, R., \& Clayton, P. J. (2009). The American Foundation for Suicide Prevention. In D. Wasserman \& C. Wasserman (Eds.), Oxford Textbook of Suicidology and Suicide Prevention - A Global Perspective (pp. 741 - 742). Washington: Oxford University Press.

Haim, M., Arendt, F., \& Scherr, S. (2017). Abyss or Shelter? On the Relevance of Web Search Engines' Search Results When People Google for Suicide. Health Commun, 32(2), 253258. doi:10.1080/10410236.2015.1113484

Hegerl, U., Dietrich, S., Pfeiffer-Gerschel, T., Wittenburg, L., \& Althaus, D. (2008). Education and Awareness Programs for Adults: Selected and multilevel approaches in suicide prevention. In D. Wasserman \& C. Wasserman (Eds.), Oxford textbook of suicidology and suicide prevention: a global perspective (pp. 495-500). Oxford, NY: Oxford University Press.

Henderson, C., \& Thornicroft, G. (2009). Stigma and discrimination in mental illness: Time to Change. Lancet, 373(9679), 1928-1930. doi:10.1016/S0140-6736(09)61046-1

HHS. (2012). Office of the Surgeon General and National Action Alliance for Suicide Prevention. Washington, DC: ment of Health and Human Services. National Strategy for Suicide Prevention: Goals and Objectives for Action. Recuperado de https://www.ncbi.nlm.nih.gov/books/NBK109917/

Hines, K. (2013). Cracked not Broken: Surviving and Thriving After a Suicide Attempt. Maryland, USA: Rowman \& Littlefield Publisher.

Hjelmeland, H. (2013). Suicide Research and Prevention: The importance of culture in "Biological Times". In E. Colucci \& D. Lester (Eds.), Suicide and culture: understanding the context (pp. 3-24). Massachusetts, EUA: Hogrefe.

Houaiss, (Ed.) (2012) O Grande Dicionário Houaiss da Língua Portuguesa. UOL. Recuperado de https://houaiss.uol.com.br/pub/apps/www/v3-3/html/index.php\#0

Houts, P. S., Doak, C. C., Doak, L. G., \& Loscalzo, M. J. (2006). The role of pictures in improving health communication: a review of research on attention, comprehension, recall, and adherence. Patient Educ Couns, 61(2), 173-190. doi:10.1016/j.pec.2005.05.004

Hoven, C. W. (2004). Expanding Awareness of Mental Health in Childhood and Adolescence: The Awareness Program Manual. New York. Recuperado de https://www.icaf.org/pdfs/Expanding Awareness of Mental Health in Childhood and Adolescence.pdf.

Hoven, C. W., Tyano, S., \& Mandell, D. J. (2009). Suicide Awareness and Mental health among Youth in the Community. In D. Wasserman \& A. Wasserman (Eds.), The Oxford Textbook of Suicidology and Suicide Prevention: Oxford University Press. 
Hoven, C. W., Wasserman, D., Wasserman, C., \& Mandell, D. J. (2009). Awareness in nine countries: a public health approach to suicide prevention. Leg Med (Tokyo), 11 Suppl 1, S13-17. doi:10.1016/j.legalmed.2009.01.106

I-Produkts. (2018). iMindQ 8.0 (Version 8.1.1). Macedonia: Produkts Dooel. Recuperado de http://www.imindq.com/

IHME. (2013). GBD Compare, Global, All Ages, DALYs. Recuperado de http://vizhub.healthdata.org/gbd-compare/

IPEA. (2007). Custo da violência para o sistema público de saúde no Brasil. Texto para discussão no 1295. Brasilia: Instituto de Pesquisas e Estudos Aplicados. Recuperado de http://www.ipea.gov.br/portal/images/stories/PDFs/TDs/td_1295.pdf

Irlanda. (2015). Conecting for life: Ireland's National Strategy to Reduce Suicide 2015-2020. Dublin: Department of health. Recuperado de https://www.healthpromotion.ie/hpfiles/docs/HME00945.pdf.

Jacob, N., Scourfield, J., \& Evans, R. (2014). Suicide prevention via the Internet: a descriptive review. Crisis, 35(4), 261-267. doi:10.1027/0227-5910/a000254

Jamison, K. R. (2010). Quando a noite cai: entendendo a depressão e o suicídio (2 ed. ed.). Rio de Janeiro: Gryphus.

Jaques, J. D. (2000). Surviving Suicide: The Impact on the Family. The Family Journal, 8(4), 376-379. Recuperado de http://journals.sagepub.com/doi/abs/10.1177/1066480700084007

JM Notícia. (2017). Pastora tira a própria vida em SC; é o quarto caso entre líderes religiosos este mês. JM Notícia. Recuperado de http://www.jmnoticia.com.br/2017/12/29/pastoratira-a-propria-vida-em-sc-e-o-quarto-caso-entre-lideres-religiosos-este-mes/

John, A., Hawton, K., Lloyd, K., Luce, A., Platt, S., Scourfield, J., . . Dennis, M. S. (2014). PRINTQUAL - a measure for assessing the quality of newspaper reporting of suicide. Crisis, 35(6), 431-435. doi:10.1027/0227-5910/a000276

Jordan, J. R. (2001). Is Suicide Bereavement Different? A Reassessment of the Literature. Suicide and Life-Threatening Behavior, 31(1), 91-103.

Jorm, A. F. (2000). Mental health literacy. Public knowledge and beliefs about mental disorders. Br J Psychiatry, 177, 396-401. doi: 10.1192/bjp.177.5.396

King, K. A., Strunk, C. M., \& Sorter, M. T. (2011). Preliminary effectiveness of surviving the teens $(\mathrm{R})$ suicide prevention and depression awareness program on adolescents' suicidality and self-efficacy in performing help-seeking behaviors. $J$ Sch Health, 81(9), 581-590. doi:10.1111/j.1746-1561.2011.00630.x

Klempan, T. A., Ernst, C., Deleva, V., Labonte, B., \& Turecki, G. (2009). Characterization of QKI gene expression, genetics, and epigenetics in suicide victims with major depressive disorder. Biol Psychiatry, 66(9), 824-831. doi:10.1016/j.biopsych.2009.05.010 
Koburger, N., Mergl, R., Rummel-Kluge, C., Ibelshauser, A., Meise, U., Postuvan, V., . . . Hegerl, U. (2015). Celebrity suicide on the railway network: Can one case trigger international effects? J Affect Disord, 185, 38-46. doi:10.1016/j.jad.2015.06.037

Koch, D. B., \& Oliveira, P. R. M. (2015). As políticas públicas para prevenção de suicídios. Revista Brasileira de Tecnologias Sociais, 2(2), 161-172. doi: 10.14210/rbts.v2.n2.

Kovács, M. J. (1992). Morte e desenvolvimento humano. São Paulo: Casa do Psicólogo.

Kovács, M. J. (2003). Educação para a morte: Desafio na formação de profissionais de saúde e educação. São Paulo: Casa do Psicólogo.

Kovács, M. J. (2013). Revisão crítica sobre conflitos éticos envolvidos na situação de suicídio. Psicologia: teoria e Prática, 15(3). Recuperado de http://pepsic.bvsalud.org/scielo.php?script=sci_arttext\&pid=S1516-36872013000300005

Lara, S. (2017, Nov/2017). Quando o fardo pesa. Revista Cães e Gatos VET FOOD, Ano 33. Sorocaba, SP: Ciasulli Editores.

Larrobla, C., \& Botega, N. J. (2001). Restructuring mental health: a South American survey. Soc Psychiatry Psychiatr Epidemiol, 36(5), 256-259. Recuperado de https://doi.org/10.1007/s001270170057

Leavell, H. R., \& Clark, E. G. (1958). Preventive Medicine for the Doctor in his Comunity: An Epidemiologic Approach. London: McGraw-Hill Book Company.

Leite, J. L., da Silva, L. J., Oliveira, R. M. P., \& Stipp, M. A. C. (2012). Reflexões sobre o pesquisador nas trilhas da Teoria Fundamentada nos Dados. Revista da Escola de Enfermagem da USP, 46(3). doi:http://dx.doi.org/10.1590/S0080-62342012000300033

Lester, D. (2013). Culture and suicide. In E. Colucci \& D. Lester (Eds.), Suicide and Culture: Understanding the Context (pp. 59-90). Cambridge, MA: Hogrefe.

Lester, D., \& Walker, R. L. (2006). The stigma for attempting suicide and the loss to suicide prevention efforts. Crisis, 27(3), 147-148. doi:10.1027/0227-5910.27.3.147

Lifeline. (2009). Practice Handbook - Suicide Bereavement Support Group Facilitation Lifeline Australia (Ed.) Recuperado de http://www.lifeline.org.au/Find-Help/Preventingsuicide/Support-after-a-loss-by-suicide/Support-after-a-loss-by-suicide/default.aspx

Lincoln, Y. S., \& Guba, E. G. (1985). Naturalistic Inquiry. London: Sage Publications.

Linden, S. V. D. (2017). The nature of viral altruism and how to make it stick. Nature Human Behavior(0041). doi:10.1038/s41562-016-0041

Lockwood, L. E., Su, S., \& Youssef, N. A. (2015). The role of epigenetics in depression and suicide: A platform for gene-environment interactions. Psychiatry Res, 228(3), 235-242. doi:10.1016/j.psychres.2015.05.071

Loureiro, P. R. A., Moreira, T. B., \& Sachsida, A. (2013). Os efeitos da mídia sobre o suicídio: Uma análise empírica para os estados brasileiros. Rio de Janeiro: Instituto de Pesquisa 
Econômica Aplicada (IPEA). Recuperado de http://repositorio.ipea.gov.br/bitstream/11058/2264/1/TD_1851.pdf

Ludke, M., \& André, M. E. D. (1986). A pesquisa em educação: abordagens qualitativas. São Paulo, SP: EPU.

Luxton, D. D., June, J. D., \& Fairall, J. M. (2012). Social media and suicide: a public health perspective. Am J Public Health, 102 Suppl 2, S195-200. doi:10.2105/AJPH.2011.300608

Macedo, M. M. K., \& Werlang, B. S. G. (2007). Tentativa de suicídio: o traumático via atodor. Psicologia: Teoria e Pesquisa, 23(2), 185-194. Recuperado de http://www.scielo.br/pdf/ptp/v23n2/a09v23n2.pdf

Machado, A. (1946). Proverbios y cantares XXXIX. In A. Machado (Ed.), Poesias completas (pp. 172). Buenos Aires: Lozada.

Machado, M., Leite, C., \& Bando, D. (2014). Politicas Publicas de Prevenção do Suicídio no Brasil: uma revisão sistemática. Revista Gestão e Políticas Públicas, 4(2), 334-356. Recuperado de http://www.revistas.usp.br/rgpp/article/view/114406/112268

Machin, R. (2009). Nem doente, nem vítima: o atendimento às lesões autoprovocadas nas emergências. Ciencia e saúde coletiva, 14(5), 1741-1750. Recuperado de http://dx.doi.org/10.1590/S1413-81232009000500015.

Mann, J. J. (2003). Neurobiology of suicidal behavior. Neture reviews neuroscience, 4, 819828. doi: $10.1038 / \mathrm{nrn} 1220$

Marquetti, F. C., Kawauchi, K. T., \& Pleffken, C. (2015). O suicídio, interditos, tabus e consequencias nas estratégias de prevenção. Revista Brasileira de Psicologia, 2(1). Recuperado de http://revpsi.org/wp-content/uploads/2015/04/Marquetti-KawauchiPleffken-2015-O-suic\%C3\%ADdio-interditos-tabus-e-consequências-nas-estratégias-deprevenção.pdf

Matos, M. (2018). O vento que varre a casa. São Paulo, SP: Editora Patuá.

Maytree. (2013). Suicide Respite Centre. London: The Maytree Respite Centre. Recuperado de http://www.maytree.org.uk/

McDermott, E., Roen, K., \& Scourfield, J. (2008). Avoiding shame: young LGBT people, homophobia and self-destructive behaviours. Cult Health Sex, 10(8), 815-829. doi:10.1080/13691050802380974

McMenamy, J. M., Jordan, J. R., \& Mitchell, A. M. (2008). What do suicide survivors tell us they need? Results of a pilot study. Suicide Life Threat Behav, 38(4), 375-389. doi:10.1521/suli.2008.38.4.375 [pii]

Medeiros, S. M., \& Guimarães, J. (2002). Cidadania e saúde mental no Brasil: contribuição ao debate. Ciencia e saúde coletiva, 7(3), 571-579.

Mehlum, L. (2009). The International Association for Suicide Prevention. In D. Wasserman \& C. Wasserman (Eds.), Oxford Textbook of Suicidology and Suicide Prevention - A Global Perspective (pp. 729 - 731). Washington: Oxford University Press. 
Meindl, J. N., \& Ivy, J. W. (2017). Mass Shootings: The Role of the Media in Promoting Generalized Imitation. A $m$ J Public Health, 107(3), 368-370. doi:10.2105/AJPH.2016.303611

Meleiro, A. M. A. S. (2013). Atendimento de pacientes com comportamento suicida na prática médica. Neuropsiquiatria, 70(4), 22-27. Recuperado de http://www.moreirajr.com.br/revistas.asp?fase=r003\&id_materia $=5659$

Merriam-Webster. (Ed.) (2017) Merriam-Webster Dictionary. Recuperado de https://www.merriam-webster.com

Michaelis. (Ed.) (2018) Michaelis Dicionário Brasileiro da Lingua Portuguesa. Rio de Janeiro: Melhoramentos . Recuperado de http://michaelis.uol.com.br

Minayo, M. C. S. (1998). Violência auto inflingida: objeto da sociológica e problema para a saúde pública. Cad Saude Publica, 14(2), 421-428.

Minayo, M. C. S. (2013). O desafio da pesquisa social. In M. C. S. Minayo, S. F. Deslandes, \& M. R. Gomes (Eds.), Pesquisa social: teoria, método e criatividade (33a. ed.). Petrópolis, RJ: Editora Vozes.

Minayo, M. C. S., Figueiredo, A. E. B., \& Silva, R. M. (2016). Comportamento Suicida de Idosos. Fortaleza/CE: Edições UFC.

Mishara, B. L., \& Weisstub, D. N. (2016). The legal status of suicide: A global review. Int J Law Psychiatry, 44, 54-74. doi:10.1016/j.ijlp.2015.08.032

Munhoz, D. M. (2006). Manual de abordagem técnica a tentativas de suicídio. Matrícula Biblioteca Nacional N. 9779/17. Brasilia: Fundação Biblioteca Nacional. Ministério da Cultura

Munhoz, D. M. (2018). (comunicação pessoal, 16 de janeiro de 2018).

NASP. (2011). SEYLE - Saving and Empowering Young Lives in Europe. Sweden: National Centre for Suicide Research and Prevention of Mentall Ill-Health. Recuperado de $\mathrm{http} / / / \mathrm{ki}$.se/en/nasp/seyle-saving-and-empowering-young-lives-in-europe

Necchi, V. (2017). Imprensa deve tratar suicídio como fenômeno de saúde pública. Revista do Instituto Humanitas Unisinos - IHU ON-LINE, 515, 46-48.

Neiva, T. S., Vianna, L. G., \& Moraes, C. F. (2015). Prevenção em saúde na prática médica: da primária à quaternária. Revista Eletrônica Gestão \& Saúde, 6(2), 1418-1427. doi: http://dx.doi.org/10.18673/gs.v6i2.22477

Niederkrotenthaler, T., Voracek, M., Herberth, A., Till, B., Strauss, M., Etzersdorfer, E., .. . Sonneck, G. (2010). Media and suicide. Papageno v Werther effect. BMJ, 341, c5841. doi:10.1136/bmj.c5841

Notredame, C. E. (2016). Papageno program: When learners collaborate for a safer coverage $\begin{array}{llll}\text { of suicide. } \quad \text { European Psychiatry, } & \text { 33(Supplement), }\end{array}$ doi:http://dx.doi.org/10.1016/j.eurpsy.2016.01.851 
Nova S/B. (2017). Dossiê sobre suicídio. São Paulo: Agência Nova S/B. Recuperado de http://www.comunicaquemuda.com.br/dossie-sobre-suicidio/

Noyes, R., Jr. (1968). The taboo of suicide. Psychiatry, 31(2), 173-183. Recuperado de http://psycnet.apa.org/doi/10.1080/00332747.1968.11023545

O Globo. (2018, 11 de janeiro de 2018). Youtube corta laços com Logan Paul após polêmica com vídeo de suicídio. O Globo. Recuperado de https://oglobo.globo.com/cultura/youtubecorta-lacos-com-logan-paul-apos-polemica-com-video-de-suicidio-22276856

O'Dea, B., Larsen, M. E., Batterham, P. J., Calear, A. L., \& Christensen, H. (2017). A Linguistic Analysis of Suicide-Related Twitter Posts. Crisis, 38(5), 319-329. doi:10.1027/02275910/a000443

Oliveira, V. M. (2011). Competência em saúde mental (Mental Health Literacy): do conceito às estratégias na questão do suicídio no Brasil. (Dissertação de Mestrado), Fundação Oswaldo Cruz, Rio de Janeiro.

OMS. (2000a). Prevenção do suicídio: Um manual para médicos clínicos gerais. Genebra: Organização Mundial da Saúde. Recuperado de http://apps.who.int/iris/bitstream/10665/67165/7/WHO_MNH_MBD_00.1_por.pdf

OMS. (2000b). Prevenção do suicídio: Um manual para profissionais da mídia. Genebra: Organização Mundial da Saúde. Recuperado de http://www.who.int/mental_health/prevention/suicide/en/suicideprev_media_port.pdf

OMS. (2000c). Prevenção do suicídio: Um manual para profissionais da saúde em atenção primária. Genebra: Organização Mundial da Saúde. Recuperado de http://apps.who.int/iris/bitstream/10665/67603/8/WHO_MNH_MBD_00.4_por.pdf

OMS. (2008). CID 10 - Classificação Estatística Internacional de Doenças e Problemas Relacionados a Saude (7a. ed.). São Paulo, SP: EDUSP.

OMS. (2015). Global Burden of Disease. Genebra: Organização Mundial da Saúde. Recuperado de http://www.who.int/topics/global_burden_of_disease/en/

Orestano, F. (1913). Pensieri. Um libro per tutti. Italy: Edizioni Optima.

Osafo, J. (2012). Attitudes towards suicide: exploring the cultural meaning(s) of suicide in Guana. (Tese de doutorado). Noruega: Norwegian University of Science and Technology. Recuperado de https://brage.bibsys.no/xmlui/handle/11250/267883

Park, J., Choi, N., Kim, S. J., Kim, S., An, H., Lee, H. J., \& Lee, Y. J. (2016). The Impact of Celebrity Suicide on Subsequent Suicide Rates in the General Population of Korea from 1990 to 2010. J Korean Med Sci, 31(4), 598-603. doi:10.3346/jkms.2016.31.4.598

Parkes, C. M. (1998). Luto. São Paulo: Summus Editorial.

Pauwels, N., \& Notredame, C. E. (2015). From Weather to Papageno: a french student-based program of sensitization to the importance of responsible coverage of suicide. Recuperado de https://www.f2rsmpsy.fr/fichs/11645.pdf 
Peters, K., Cunningham, C., Murphy, G., \& Jackson, D. (2016). 'People look down on you when you tell them how he died': Qualitative insights into stigma as experienced by suicide survivors. Int J Ment Health Nurs, 25(3), 251-257. doi:10.1111/inm.12210

Phillips, D. P. (1974). The influence of suggestion on suicide: substantive and theoretical implications fo the Werther. American Sociological Review, 39, 340-354. Recuperado de http://psycnet.apa.org/doi/10.2307/2094294

Pirkis, J., Blood, R. W., Beautrais, A., Burgess, P., \& Skehans, J. (2006). Media guidelines on the reporting of suicide. Crisis, 27(2), 82-87. doi:10.1027/0227-5910.27.2.82

Pirkis, J., Dare, A., Blood, R. W., Rankin, B., Williamson, M., Burgess, P., \& Jolley, D. (2009). Changes in media reporting of suicide in Australia between 2000/01 and 2006/07. Crisis, 30(1), 25-33. doi:10.1027/0227-5910.30.1.25

Pirkis, J., Mok, K., Robinson, J., \& Nordentoft, M. (2016). Media influences on suicidal thoughts and behaviors. In R. C. O'Connor \& J. Pirkis (Eds.), The international handbook of suicide prevention (2a. ed., pp. 743-757). West Sussex, UK: Willey Blackwell.

Pitman, A. L., Osborn, D. P., Rantell, K., \& King, M. B. (2016). The stigma perceived by people bereaved by suicide and other sudden deaths: A cross-sectional UK study of 3432 bereaved adults. J Psychosom Res, 87, 22-29. doi:10.1016/j.jpsychores.2016.05.009

Plutchik, R., \& Van Praag, H. M. (1994). Suicide risk: amplifiers and attenuators. In H. N. J. Pollone (Ed.), The psychobiology of agression. Binghamtom, NY: Haworth Press.

Pomerleau, J., \& McKee, M. (2005). Issues in Public Health. Berkshire, EN: Open University Press.

Pompili, M., Mancinelli, I., \& Tatarelli, R. (2003). Stigma as a cause of suicide. Br J Psychiatry, 183, 173-174. doi: 10.1192/bjp.183.2.173-a

Pouliot, L., Mishara, B. L., \& Labelle, R. (2011). The Werther effect reconsidered in light of psychological vulnerabilities: results of a pilot study. J Affect Disord, 134(1-3), 488-496. doi:10.1016/j.jad.2011.04.050

Prado, A. (2011). A duração do dia. São Paulo: Editora Record. (2a. ed)

Provini, C., Everett, J. R., \& Pfeffer, C. R. (2000). Adults mourning suicide: self-reported concerns about bereavement, needs for assistance, and help-seeking behavior. Death Stud, 24(1), 1-19. doi: 10.1080/074811800200667

QPR. (2013). Question Persuade Refer. QPR Institute. Recuperado de https://qprinstitute.com

Ramos, S. (2004). O papel das ONGs na construção de políticas de saúde: a Aids, a saúde da mulher e a saúde mental. Ciencia e saúde coletiva, 9(4), 1067-1078. Recuperado de http://www.scielo.br/pdf/csc/v9n4/a27v9n4.pdf

REBRAPS. (2015). Artigos: A prevenção do suicídio e as diretrizes da estratégia brasileira. Rio de Janeiro: Rede Brasileira de Prevenção do Suicídio. Recuperado de http://www.rebraps.com.br/2015/10/artigos.html 
Retterstol, N., \& Mehlum, L. (2001). Attempted suicide as a risk factor for suicide: treatment and follow up. In D. Wasserman (Ed.), Suicide: an unnecessary death (pp. 125 - 131). London: Martin Dunitz.

Reuters. (2018). Youtube remove parceria com Logan Paul após vídeo de suicida. Exame. Recuperado de https://exame.abril.com.br/estilo-de-vida/youtube-remove-parceria-comlogan-paul-apos-video-de-suicida/

Rey, G., \& Luis, F. (2011). Pesquisa qualitativa em psicologia: caminhos e desafios (M. A. F. Silva, Trans.). São Paulo: Cengage Learning.

Rigo, S. C. (2017). O suicídio e a (des)ordem médica. Palestra apresentada durante o V Seminário de Prevenção do Suicídio no ES. Vitória. Recuperado de http://www.sauesp.org.br/sps005/soraya-carvalho-rigo-o-suic\%C3\%ADdio-e-a(des)ordem-medica.pdf

Robinson, J., Cox, G., Bailey, E., Hetrick, S., Rodrigues, M., Fisher, S., \& Herrman, H. (2016). Social media and suicide prevention: a systematic review. Early Interv Psychiatry, 10(2), 103-121. doi:10.1111/eip.12229

Rockett, I. R. (2010). Counting suicides and making suicide count as a public health problem. Crisis, 31(5), 227-230. doi:10.1027/0227-5910/a000071

Rogers, J. R., \& Lester, D. (2010). Understanding Suicide: Why we don't and how we might. Cambridge, MA: Hogrefe.

Rukavina, T. V., Nawka, A., Brborovic, O., Jovanovic, N., Kuzman, M. R., Nawkova, L., .. . Lattova, Z. (2012). Development of the PICMIN (picture of mental illness in newspapers): instrument to assess mental illness stigma in print media. Soc Psychiatry Psychiatr Epidemiol, 47(7), 1131-1144. doi:10.1007/s00127-011-0419-z

Runeson, B., \& Asberg, M. (2003). Family History of Suicide Among Suicide Victims. American Journal of Psychiatry, 160(8), 1525-1526.

Rusch, N., Lieb, K., Bohus, M., \& Corrigan, P. W. (2006). Self-stigma, empowerment, and perceived legitimacy of discrimination among women with mental illness. Psychiatr Serv, 57(3), 399-402. doi:10.1176/appi.ps.57.3.399

Sand, E., Gordon, K. H., \& Bresin, K. (2013). The impact of specifying suicide as the cause of death in an obituary. Crisis, 34(1), 63-66. doi:10.1027/0227-5910/a000154

Saraceno, B. (2009). The World health Organization's role in suicide prevention. In D. Wasserman \& C. Wasserman (Eds.), Oxford Textbook of Suicidology and Suicide Prevention - A Global Perspective (pp. 723-725). Washington: Oxford University Press.

SAVE. (2018). Suicide awareness voices of education. Recuperado de http://www.save.org/

Scavacini, K. (2011). Suicide Survivors Support Services and Postvention Activities - The availability of services and an interventions plan in Brazil. (Dissertação de Mestrado em Saúde Pública), Karolinska Institutet, Stockholm. 
Scavacini, K. (2017a). Brazil - The Development of Suicide Postvention. In K. Andriessen, K. Krysinska, \& O. T. Grad (Eds.), Postvention in action: The international handbook of suicide bereavement support (pp. 271-276). Boston, EUA: Hogrefe.

Scavacini, K. (2017b). Nas veredas da morte: o paciente com comportamento suicída. In F. S. R. Almendra (Ed.), Psicologia em unidade de terapia intensiva: intervenções em situações de urgência subjetiva (pp. 127-137). Rio de Janeiro, RJ: Atheneu.

Schafer, M., \& Quiring, O. (2015). The Press Coverage of Celebrity Suicide and the Development of Suicide Frequencies in Germany. Health Commun, 30(11), 1149-1158. doi:10.1080/10410236.2014.923273

Schikaneder, E. (1990). The Magic Flute: Libretto. Metropolitan Opera Guild.

Scocco, P., Castriotta, C., Toffol, E., \& Preti, A. (2012). Stigma of Suicide Attempt (STOSA) scale and Stigma of Suicide and Suicide Survivor (STOSASS) scale: two new assessment tools. Psychiatry Res, 200(2-3), 872-878. doi:10.1016/j.psychres.2012.06.033

Scocco, P., Preti, A., Totaro, S., Ferrari, A., \& Toffol, E. (2017). Stigma and psychological distress in suicide survivors. J Psychosom Res, 94, 39-46. doi:10.1016/j.jpsychores.2016.12.016

Scutti, S. (2018, 19 de Janeiro de 2018). Michael Phelps: "I am extremely thankful that I did not take my life". CNN. Recuperado de http://edition.cnn.com/2018/01/19/health/michaelphelps-depression/index.html

Sherman, C., \& Wedge, D. (2017). The ice bucket challenge: Pete Frates and the fight against $A L S$ (2a. ed.). New England: ForeEdge.

Shneidman, E. (1969). Fifty-eight years. In E. Shneidman (Ed.), On the nature of suicide (pp. 1-30). San Francisco: Jossey-Bass.

Shneidman, E. (1973). Deaths of a man. New York: Quadrangle.

Shneidman, E. (1985). Definition of Suicide. Oxford: Rowman \& Littlefield Publishers, INC.

Shneidman, E. (1987). A psychological approach to suicide. In G. Vandebos \& B. Bryant (Eds.), Cataclysms, crises and catastrophes: Pscyhology in action (pp. 147-182). Washington: American Psychological Association.

Shneidman, E. (1993). Suicide as Psychache: A clinical Approach to self-destructive behavior. New Jersey, London: Jason Aronson Inc.

Shneidman, E. (1996). The suicidal mind. Oxford: Oxford University Press.

Silva, D. R. (2009). E a vida continua... o processo de luto dos pais após o suicídio de um filho. (Mestrado em Psicologia Clínica), Pontífica Universidade de São Paulo, São Paulo.

Silva, D. R. (2015). Na trilha do silêncio: múltilos desafios do luto por suicídio. In G. Casellato (Ed.), O resgate da empatia: Suporte psicológico ao luto não reconhecido (pp. 111-128). São Paulo: Summus Editorial. 
Silverman, Y., Smith, F., \& Burns, M. (2013). Coming together in pain and joy: A multicultural and arts-based suicide awareness project. The arts in psychotherapy, 40(2), 216-223. doi:10.1016/j.aip.2013.02.003

Siqueira, R., \& Cardoso, H. (2011). O conceito de estigma como processo social: uma aproximação teórica a partir da literatura norte-americana. Imagonautas, 2(1). Recuperado de http://hdl.handle.net/11449/127032

SPA (Produtor). (2014, 19 de janeiro de 2018). The Official Suicide Prevention Australia AudioBoom Channel. Recuperado de https://itunes.apple.com/au/podcast/suicideprevention-australia/id1076488619?mt=2

SPRC. (2001). National Strategy for Suicide Prevention: Goals and Objectives for Action Risk and Protective Factors for Suicide. Newton, MA: Suicide Prevention Resource Center

SPRC. (2017). Effective Suicide Prevention. Suicide Prevention Resource Centre Recuperado de https://www.sprc.org/effective-suicide-prevention

SPRC. (2018a). Promote Social Connectedness and Support. Suicide Prevention Resource Centre Recuperado de http://www.sprc.org/comprehensive-approach/socialconnectedness

SPRC. (2018b). Strategic Planning. Suicide Prevention Resource Centre. Recuperado de http://www.sprc.org/effective-prevention/strategic-planning

Stack, S. (1987). Celebrities and suicide: a taxonomy and analysis, 1948-1983. Am Sociol Rev, 52(3), 401-412. Recuperado de https://www.ncbi.nlm.nih.gov/pubmed/11613886

Stack, S. (2003). Media coverage as a risk factor in suicide. J Epidemiol Community Health, 57(4), 238-240. Recuperado de http://jech.bmj.com/content/jech/57/4/238.full.pdf

Strauss, A., \& Corbin, J. (2008). Pesquisa Qualitativa: Técnicas e procedimentos para o desenvolvimento da teoria fundamentada (2a edição ed.). Porto Alegre: Artmed.

Sudak, H., Maxim, K., \& Carpenter, M. (2008). Suicide and stigma: a review of the literature and personal reflections. Acad Psychiatry, 32(2), 136-142. doi:10.1176/appi.ap.32.2.136

Suécia. (2014). Policies and programmes for suicide prevention. Stockholm: Karolinska Institutet. Recuperado de http://ki.se/en/nasp/policies-and-programmes-for-suicideprevention.

Sueki, H. (2015). The association of suicide-related Twitter use with suicidal behaviour: a cross-sectional study of young internet users in Japan. J Affect Disord, 170, 155-160. doi:10.1016/j.jad.2014.08.047

Tam, J., Tang, W. S., \& Fernando, D. J. (2007). The internet and suicide: A double-edged tool. Eur J Intern Med, 18(6), 453-455. doi:10.1016/j.ejim.2007.04.009

Tarozzi, M. (2011). O que é grounded theory: metodologia de pesquisa e de teoria fundamentada nos dados (C. Lussi, Trans.): Vozes. 
Taylor, S. J., Kingdom, D., \& Jenkins, R. (1997). How are nations trying to prevent suicide? An analysis of national suicide prevention strategies. Acta Psychiatr Scand, 95(6), 457463.

Thorson, J., \& Öberg, P.-A. (2003). Was there a suicide epidemic after Goethe's Werther? Archives of Suicide, 7(1), 69-72. Recuperado de http://psycnet.apa.org/doi/10.1080/13811110301568

Tidemalm, D., Langstrom, N., Lichtenstein, P., \& Runeson, B. (2008). Risk of suicide after suicide attempt according to coexisting psychiatric disorder: Swedish cohort study with long term follow-up. BMJ, 337, a2205. doi:10.1136/bmj.a2205

Todd, C. (2017). Amanda Todd Legacy. Recuperado de http://www.amandatoddlegacy.org/

Toro, G. V. R. (2016). Tentativa de suicídio: vivências dos profissionais de saúde no prontosocorro. (Dissertação de Mestrado em Psicologia), USP, São Paulo.

Tousignant, M., Mishara, B. L., Caillaud, A., Fortin, V., \& St-Laurent, D. (2005). The impact of media coverage of the suicide of a well-known Quebec reporter: the case of Gaetan Girouard. Soc Sci Med, 60(9), 1919-1926. doi:10.1016/j.socscimed.2004.08.054

Tuffani, M. (2018). De onde vem o dinheiro para pesquisas das universidades dos EUA? Direto da ciência. Recuperado de http://www.diretodaciencia.com/2018/01/27/de-onde-vem-odinheiro-para-pesquisa-das-universidades-dos-eua/

Turato, E. R. (2003). Psicologia da saúde: Estudos Clínico-Qualitativos. Taubaté, SP: Cabral Editora e Livraria Universitária.

Turato, E. R. (2008). Tratado da metodologia da pesquisa clínico-qualitativa: Construção teório-epistemológica, discussão comparada e aplicação nas áreas da saúde e humanas. (3a edição ed.). Rio de Janeiro: Vozes.

TUSP. (2015). Uma ciranda de nomes com estórias a se entrecruzar. Recuperado de http://www.usp.br/tusp/?portfolio=uma-ciranda-de-nomes-com-estorias-se-entrecruzar

Tzeng, W. C., \& Lipson, J. G. (2004). The cultural context of suicide stigma in Taiwan. Qual Health Res, 14(3), 345-358. doi:10.1177/1049732303262057

UN. (1996). Prevention of suicide guidelines for the formulation and implementation of national strategies. New York: United Nations.

Valle, T. G. R., \& Kovács, M. J. (2014). Análise do conteúdo de sites que abordam o suicídio. Boletim de Psicologia, 64(140). Recuperado de http://pepsic.bvsalud.org/scielo.php?script=sci_arttext\&pid=S000659432014000100004\&lng=pt\&tlng=pt.

Vidal, C. E. L., \& Gontijo, E. D. (2013). Tentativas de suicídio e o acolhimento nos serviços de urgência: a percepção de quem tenta. Cadernos de Saúde Coletiva, 21(2), 108-104. Recuperado de http://dx.doi.org/10.1590/S1414-462X2013000200002

Vieira, E. M., \& Ximenes, V. M. (2008). Conscientização: Em que interessa esse conceito à psicologia. Psicologia Argum., 26(52), 23 - 33. 
Vincent, T. (2013). Raising awareness, generating hope. Michigan Bar Journal(July). Recuperado de https://www.michbar.org/file/journal/pdf/pdf4article2236.pdf

Von Dem Knesebeck, O., Mnich, E., Angermeyer, M. C., Kofahl, C., \& Makowski, A. (2015). Changes in depression stigma after the Germanwings crash - Findings from German population surveys. J Affect Disord, 186, 261-265. doi:10.1016/j.jad.2015.07.029

Waiselfisz, J. J. (2014). Mapa da Violência: Os Jovens do Brasil. Brasilia: Flacso Brasil Recuperado de http://www.mapadaviolencia.org.br/pdf2014/Mapa2014_JovensBrasil.pdf.

Wasserman, C., Hoven, C. W., Wasserman, D., Carli, V., Sarchiapone, M., Al-Halabi, S., ... Postuvan, V. (2012). Suicide prevention for youth--a mental health awareness program: lessons learned from the Saving and Empowering Young Lives in Europe (SEYLE) intervention study. BMC Public Health, 12, 776. doi:10.1186/1471-2458-12-776

Wasserman, D. (2001). Suicide: An unnecessary death: Ed Martins Dunits.

Wasserman, D., Carli, V., Wasserman, C., Apter, A., Balazs, J., Bobes, J., . . Hoven, C. W. (2010). Saving and empowering young lives in Europe (SEYLE): a randomized controlled trial. BMC Public Health, 10, 192. doi:10.1186/1471-2458-10-192

Wasserman, D., \& Mann, J. J. (2009). The International Academy of Suicide Research. In D. Wasserman \& C. Wasserman (Eds.), Oxford Textbook of Suicidology and Suicide Prevention - A Global Perspective (pp. 733 - 734). Washington: Oxford University Press.

Wasserman, D., \& Wasserman, C. (2009). Oxford textbook of Suicidology and Suicide Prevention: a global perspective: Ed Oxford Press.

Werlang, B. G., \& Botega, N. J. (2004). Comportamento Suicida. Porto Alegre: Artmed.

Westerlund, M., Hadlaczky, G., \& Wasserman, D. (2012). The representation of suicide on the Internet: implications for clinicians. J Med Internet Res, 14(5), e122. doi:10.2196/jmir.1979

WHO. (2008). Preventing Suicide: How to start a survivors group. Geneva, Switzerland: World Health Organization.

WHO. (2010). Suicide Prevention (SUPRE). Geneva: World Health Organization. Recuperado de http://www.who.int/mental_health/prevention/suicide/suicideprevent/en/index.html

WHO. (2012). Public health action for the prevention of suicide: a framework. Geneva: World Health Organization. Recuperado de http://apps.who.int/iris/bitstream/10665/75166/1/9789241503570_eng.pdf

WHO. (2013). Mental Health Action Plan 2013-2020. Switzerland: WHO Press Recuperado de http://apps.who.int/iris/bitstream/10665/89966/1/9789241506021_eng.pdf?ua=1.

WHO. (2014). Preventing Suicide: A Global Imperative. Luxemburg: World Health Organization. Recuperado de http://apps.who.int/iris/bitstream/10665/131056/1/9789241564779_eng.pdf?ua=1\&ua=1 
WHO. (2017). Suicide rates (per 10000 population). Geneva: World Health Organization. Recuperado de http://www.who.int/gho/mental_health/suicide_rates/en/

Wikipedia. (2018). Podcasting Wikipedia. Recuperado de https://pt.wikipedia.org/wiki/Podcasting

Wiklander, M., Samuelsson, M., \& Asberg, M. (2003). Shame reactions after suicide attempt. Scand J Caring Sci, 17(3), 293-300. doi: 10.1046/j.1471-6712.2003.00227.x

Williams, C. K. (1997). Vilanela da mãe suicida. (C. Machado Trad.) Recuperado de http://www.elenafilme.com/livro/vilanela-da-mae-suicida/

Williams, C. L., Cero, I., Gauthier, J. M., \& Witte, T. (2018). An examination of the latent factor structure and construct validity of the stigma of suicide scale-short form. Death Stud. doi:10.1080/07481187.2017.1416431

Wilson, A., \& Clark, S. (2005). South Australian Suicide Postvention Project. Adelaide: Department of Health. Recuperado de https://hekyll.services.adelaide.edu.au/dspace/bitstream/2440/24871/1/South_Australian_ Suicide_Postvention_Report.pdf

Xavier, C. (1995). Nosso Lar. São Paulo, SP: Feb.

Yontef, G. (1998). Processo, diálogo e awareness: ensaios em Gestalt Terapia. São Paulo, SP: Summus Editorial.

Zucchi, E. M., Paiva, V. S. F., \& Junior, F. I. (2013). Intervenções para reduzir o estigma da Aids no Brasil: uma intevenção crítica. Temas em Psicologia, 21(3). Recuperado de http://dx.doi.org/10.9788/TP2013.3-EE15PT 


\author{
ANEXOS \\ divididos na seguinte ordem: \\ Anexo A - Roteiro Norteador do Grupo Focal \\ Anexo B - Termo de Consentimento Livre e Esclarecido (TCLE) \\ Anexo C - Transcrição do Grupo Focal encontro 1 \\ Anexo D - Transcrição do Grupo Focal encontro 2 \\ Anexo E - Roteiro de Perguntas C1 \\ Anexo F - Roteiro de Perguntas C9 \\ Anexo G - Transcrição da entrevista piloto para qualificação \\ Anexo H - Relato da Observadora \\ Anexo I - Codificação Grupo Focal 1 \\ Anexo J - Codificação Grupo Focal 2 \\ Anexo K - Codificação Roteiro de Perguntas C1 \\ Anexo L - Codificação Roteiro de Perguntas C9 \\ Anexo M - Visão Geral das Anotações (memos) \\ Anexo N - Tabela dos Códigos \\ Anexo O - Diário de Bordo \\ Anexo P - Segmentos Codificados \\ Anexo Q - Colaboradores \\ Anexo R - Parecer Consubstanciado do CEP
}

Os ANEXOS encontram-se em formato digital, no CD que acompanha o estudo, 


\section{Roteiro Prévio à Entrevista}

\section{Sobre o tabu e a consciência pública}

1) Como você acha que o suicídio é visto hoje no Brasil?

2) Você pensa que o suicídio é um tema tabu no Brasil? Por que você acha que isso acontece?

3) Vocês acham que o tabu começa aonde?

4) O que pensa a respeito conscientização da problemática do suicídio?

5) Você acha que falar mais sobre o assunto aumentaria a consciência pública do tema?

6) Você acha que isso teria algum impacto na prevenção e posvenção?

7) Como gostaria que o suicídio que fosse visto pela sociedade?

8) Qual o impacto de campanhas públicas, como o setembro amarelo, em cada um de vocês?

9) Alguém lembra de algum exemplo de campanha ou mensagem positiva/negativa sobre o suicídio na mídia?

\section{Sobre como aumentar a consciência pública}

10) Como poderia ocorrer essa conscientização no Brasil?

11) Como podemos começar a falar sobre o suicídio? O que nos impede de falar sobre o tema?

12) Que sugestões você teria para que o suicídio fosse mais falado no país?

13) Quando e onde você acha que esse tipo de informação deve ocorrer?

14) Como você pensa que deve ser abordada essa questão? (que mensagem deve ser passada?) Que ações seriam necessárias e como elas poderiam ser promovidas? 


\section{Sobre a consciência individual}

15) Vocês acham que a consciência pública influencia a consciência individual, de que forma?

16) Vocês acham que a falta de consciência pública pode ter influenciado o suicídio da pessoa que perderam?

\section{Experiências}

17) Como é para vocês falar sobre o suicídio?

18) A forma como a sociedade e as pessoas encaram o suicídio te toca?

19) Você já passou por alguma situação que envolvesse a falta ou não de consciência pública e individual em relação ao suicídio?

20) Como é falar sobre a causa de morte do ente querido e qual a causa de morte que é falada.

21) Vocês falam e/ou conversam sobre o suicídio com a família, amigos, conhecidos e/ou desconhecidos? Como?

22) Em que momentos essa comunicação é mais fácil e mais difícil.

23) Houve alguma mudança na sua forma de entender o suicídio depois da perda que você viveu? De que maneira?

24) Que informações você gostaria de ter tido ao se deparar com esse comportamento?

25) O que gostaria que tivesse disponível em termos de ajuda e/ou conhecimento para você no luto e para pessoa que faleceu?

\section{Finalização}

26) Quais são suas sugestões sobre o tema?

27) Deseja fazer algum comentário, esclarecimento ou consideração adicional? 
O Sr.(a) está sendo convidado (a) a participar da pesquisa ora intitulada "Vamos falar sobre suicídio? A consciência pública e o tabu na prevenção e posvenção do suicídio no Brasil" , de responsabilidade da psicóloga Karen Scavacini (CRP 06/64761), doutoranda em Psicologia Escolar e do Desenvolvimento Humano pela Universidade de São Paulo - USP e sob orientação da Professora Doutora MARIA JULIA KOVÁCS.

O objetivo desta pesquisa é compreender como a consciência pública e o tabu afetam a prevenção e posvenção do suicídio, à sua importância e de que forma é possível falar mais abertamente sobre esse tema de modo a colaborar com a prevenção e a posvenção do suicídio.

O Sr.(a) receberá todos os esclarecimentos necessários antes, durante e após a finalização da pesquisa. Os seus dados ou qualquer informação pessoal que possa identificá-lo (a) serão descaracterizados ou mesmo omitidos, em respeito à confidencialidade e privacidade, sendo mantido o sigilo diante de informações que permitam identificá-lo(a) em toda e qualquer situação, conforme os princípios éticos e as definições da Portaria do Ministério da Saúde 466/12 sobre Pesquisa com Seres Humanos.

A participação do Sr.(a) nesse estudo envolve em participar de duas entrevistas em grupo semi-estruturadas, com duração estimada de 2 horas cada uma. Informamos que o seu tempo de resposta será respeitado e que você pode se recusar a responder qualquer questão que provoque sofrimento. A entrevista será gravada e filmada e sua transcrição será enviada posteriormente por email, para que o Sr.(a) possa alterar, conferir, incluir ou retirar conteúdos.

O depoimento do Sr.(a) será gravado, transcrito e analisado, sem qualquer prejuízo para o sigilo e condição de informação anônima, sendo reservadas informações que possam identificar de alguma forma o participante. Os dados e materiais utilizados na pesquisa ficarão sob a guarda da pesquisadora responsável pela pesquisa. A imagem será utilizada somente para análise da pesquisadora e será destruída após o término da pesquisa. $O$ Sr. (a) pode optar em não ser filmado.

Os resultados da pesquisa serão devolvidso ao Sr.(a) por meio de de email e serão utilizados só para fins de publicação científica a que poderão ter acesso posteriormente.

Esta pesquisa possui riscos mínimos ao participante. Não será usada nenhuma técnica invasiva, porém algum desconforto pode ser gerado por despertar lembranças momentâneas que podem causar sofrimento. Neste caso o (a) Sr.(a) será acolhido pela pesquisadora e referido à serviço de suporte psicológico.

Não há benefício direto para o participante, o potencial benefício para a sociedade é que este estudo possa compreender como aumentar a consciência pública em relação ao suicídio e suas influências na prevenção e posvenção. 
A participação nesta pesquisa é de caráter voluntário, não havendo qualquer tipo de pagamento, despesa pessoal, ou de obrigatoriedade pela participação. O Sr.(a) tem inclusive o direito de retirar seu consentimento e sair da pesquisa sem que isso lhe traga qualquer tipo de prejuízo ou ônus, bastando para isso formalizar este desejo para a pesquisadora.

Ainda que se retire da pesquisa, o Sr.(a) mantém o direito de ter acesso às informações pertinentes a este estudo até o seu final.

Em qualquer etapa do estudo, o Sr.(a) terá acesso à responsável pela pesquisa para esclarecimento de eventuais dúvidas ou informações do andamento da pesquisa na Alameda Uananá, 200, Sala Orquídea, Planalto Paulista, São Paulo - SP, Telefones (11) 5084-3568, Email: karen.scavacini@usp.br.

Se você tiver alguma consideração ou dúvida sobre a ética da pesquisa, poderá entrar em contato com o Comitê de Ética em Pesquisa com Seres Humanos do Instituto de Psicologia da Universidade de São Paulo - CEPHIPUSP - Endereço: Av. Prof. Mello Moraes, 1.721 - Bloco G, $2^{\circ}$ andar, sala 27 - CEP 05508-030 - Cidade Universitária - São Paulo/SP. E-mail: ceph.ip@usp.br Tel. (11) 3091-4182

Dados relevantes da entrevista serão utilizados na pesquisa, e as citações sem identificação ficarão disponíveis ao público, bem como, para ensino, publicação em periódicos, livros e/ou apresentações em encontros científicos.

DADOS DE IDENTIFICAÇÃO DO PARTICIPANTE DA PESQUISA:

1. NOME:

2. DOCUMENTO DE IDENTIDADE No:

SEXO : .M $\square \square$ ESCOLARIDADE:

DATA NASCIMENTO: ..........................

EMAIL:

Este documento foi elaborado em duas vias, uma ficará com a pesquisadora responsável pela pesquisa e a outra com o participante da pesquisa.

$\mathrm{Eu}$, declaro estar devidamente esclarecido sobre os propósitos e procedimentos da pesquisa "Vamos falar sobre suicídio? A consciência pública e o tabu na prevenção e posvenção do suicídio no Brasil", ciente de todos os direitos, e em pleno acordo em participar e ter as entrevistas gravadas, transcritas e analisadas estando de posse de uma cópia deste Termo. 


\section{Anexo C - TRANSCRIÇÃO GRUPO FOCAL - ENCONTRO 1 - 01:55:12 H}

E: Sejam bem-vindos, agradeço a presença e a participação de todos. Primeiramente, vou passar para vocês o termo, são duas copias, uma eu vou já assinar e passar para vocês, e a outra vocês assinam e me entregam. Aqui está falando que vai ser filmado, mas não vai ser filmado, na verdade a ideia inicial era filmar, mas essa sala não ajuda na filmagem e a filmagem seria só para bater com o áudio, ver se estava certinho, mas só o áudio já funciona. Então vamos lá.

E: Termo de consentimento livre e esclarecido.

E: O Sr. (a) está sendo convidado (a) a participar da pesquisa ora intitulada "Vamos falar sobre suicídio? A consciência pública e o tabu na prevenção e posvenção do suicídio no Brasil", de responsabilidade da psicóloga Karen Scavacini (CRP 06/64761), doutoranda em Psicologia Escolar e do Desenvolvimento Humano pela Universidade de São Paulo - USP e sob orientação da Professora Doutora MARIA JULIA KOVÁCS.

E: O objetivo desta pesquisa é compreender como a consciência pública e o tabu afetam a prevenção e posvenção do suicídio, à sua importância e de que forma é possível falar mais abertamente sobre esse tema de modo a colaborar com a prevenção e a posvenção do suicídio.

E: O Sr. (a) receberá todos os esclarecimentos necessários antes, durante e após a finalização da pesquisa. Os seus dados ou qualquer informação pessoal que possa identificá-lo (a) serão descaracterizados ou mesmo omitidos, em respeito à confidencialidade e privacidade, sendo mantido o sigilo diante de informações que permitam identificá-lo (a) em toda e qualquer situação, conforme os princípios éticos e as definições da Portaria do Ministério da Saúde 466/12 sobre Pesquisa com Seres Humanos.

E: A participação do Sr. (a) nesse estudo envolve em participar de duas entrevistas em grupo semiestruturadas, com duração estimada de 2 horas cada uma. Informamos que o seu tempo de resposta será respeitado e que você pode se recusar a responder qualquer questão que provoque sofrimento. A entrevista será gravada e filmada e sua transcrição será enviada posteriormente por e-mail, para que o Sr. (a) possa alterar, conferir, incluir ou retirar conteúdos.

E: O depoimento do Sr. (a) será gravado, transcrito e analisado, sem qualquer prejuízo para o sigilo e condição de informação anônima, sendo reservadas informações que possam identificar de alguma forma o participante. Os dados e materiais utilizados na pesquisa ficarão sob a guarda da pesquisadora responsável pela pesquisa. A imagem será utilizada somente para análise da pesquisadora e será destruída após o término da pesquisa. O Sr. (a) pode optar em não ser filmado.

E: Os resultados da pesquisa serão devolvidos ao Sr. (a) por meio de e-mail e serão utilizados só para fins de publicação científica a que poderão ter acesso posteriormente.

E: Esta pesquisa possui riscos mínimos ao participante. Não será usada nenhuma técnica invasiva, porém algum desconforto pode ser gerado por despertar lembranças momentâneas que 
podem causar sofrimento. Neste caso o (a) Sr. (a) será acolhido pela pesquisadora e referido à serviço de suporte psicológico.

E: Não há benefício direto para o participante, o potencial benefício para a sociedade é que este estudo possa compreender como aumentar a consciência pública em relação ao suicídio e suas influências na prevenção e posvenção.

E: A participação nesta pesquisa é de caráter voluntário, não havendo qualquer tipo de pagamento, despesa pessoal, ou de obrigatoriedade pela participação. O Sr. (a) tem inclusive o direito de retirar seu consentimento e sair da pesquisa sem que isso lhe traga qualquer tipo de prejuízo ou ônus, bastando para isso formalizar este desejo para a pesquisadora.

E: Ainda que se retire da pesquisa, o Sr. (a) mantém o direito de ter acesso às informações pertinentes a este estudo até o seu final.

E: Em qualquer etapa do estudo, o Sr. (a) terá acesso à responsável pela pesquisa para esclarecimento de eventuais dúvidas ou informações do andamento da pesquisa na Alameda Uananá, 200, Sala Orquídea, Planalto Paulista, São Paulo - SP, Telefones (11) 5084-3568, Email: karen.scavacini@usp.br.

E: Se você tiver alguma consideração ou dúvida sobre a ética da pesquisa, poderá entrar em contato com o Comitê de Ética em Pesquisa com Seres Humanos do Instituto de Psicologia da Universidade de São Paulo - CEPH-IPUSP - Endereço: Av. Prof. Mello Moraes, 1.721 - Bloco G, $2^{\circ}$ andar, sala 27 - CEP 05508-030 - Cidade Universitária - São Paulo/SP. E-mail: ceph.ip@usp.br Tel.(11) 3091-4182

E: Dados relevantes da entrevista serão utilizados na pesquisa, e as citações sem identificação ficarão disponíveis ao público, bem como, para ensino, publicação em periódicos, livros e/ou apresentações em encontros científicos.

E: Dados de identificação do participante da pesquisa, nome, RG, sexo, escolaridade, data de nascimento e e-mail.

E: Este documento foi elaborado em duas vias, uma ficará com a pesquisadora responsável pela pesquisa e a outra com o participante da pesquisa.

E: Eu, então vocês colocam o seu nome, declaro estar devidamente esclarecido sobre os propósitos e procedimentos da pesquisa "Vamos falar sobre suicídio? A consciência pública e o tabu na prevenção e posvenção do suicídio no Brasil”, ciente de todos os direitos, e em pleno acordo em participar e ter as entrevistas gravadas, transcritas e analisadas estando de posse de uma cópia deste Termo.

E: Ou seja, se em qualquer momento vocês quiserem sair da pesquisa, é só me avisarem e tudo que vocês falarem vai ser apagado e não vai ser utilizado, todos os nomes de vocês não vão aparecer, vai aparecer provavelmente P1 para participante 1, P2 para participante 2, só para poder ter a distinção de quem que é e qualquer outro dado como nomes que vocês venham a falar, nada disso vai aparecer em qualquer parte da pesquisa, então eu vou assinar depois e vou entregar para vocês o meu assinado e eu gostaria que vocês lessem de novo se quiserem e 
assinassem, por favor, se vocês tiverem alguma dúvida é só entrar em contato comigo em qualquer momento que a gente conversa. E também tem um questionário para vocês preencherem que é para a gente não entrar nesses detalhes hoje para não ficarmos muito tempo conversando. Para preencher nome, idade, estado civil, nome de quem perdeu, o parentesco, a quanto tempo, idade que a pessoa tinha na época, idade que você tinha na época, há quanto tempo participa de grupos de apoio, se está ou esteve em tratamento psicológico, quanto tempo e se esse tratamento é em decorrência da perda ou luto, se está ou esteve em tratamento psiquiátrico, quanto tempo e se esse tratamento é em decorrência da perda. Isso é confidencial, só eu vou ter acesso. Se vocês não quiserem responder alguma das perguntas daqui também não tem problema nenhum. Essa parte de termo e questionário é só hoje, no próximo encontro não precisa. Vocês têm alguma dúvida?

P4: Esse aqui é qual nome?

E: É o nome de quem você perdeu.

P2: E esse?

E: É o seu nome. Essa cópia fica com vocês. Quando vocês terminarem de preencher eu entrego esse assinado, se não é muito papel.

P1: Depois você vai arrumar? Porque esse aqui eu troquei.

E: Não tem problema. Algum de vocês já participou de pesquisa científica antes?

P6: Tem essas burocracias.

P10: Eu já fiz, mas não era da psicologia.

P7: Eu já assinei uns de direito de imagem.

E: Sim, o termo de autorização de imagem.

P7: Era isso e outras coisas.

(barulho de papel)

E: Para quem chegou agora, fiquem à vontade para pegarem sanduíches, água, refrigerante. Pode pegar a qualquer momento, é só levantar e pegar. Fiquem à vontade.

E: Eu estava conversando, conforme eu lia o termo, sobre a diferença do grupo de acolhimento para o grupo de pesquisa, então não é um grupo de acolhimento, então só retomando um pouquinho para as pessoas que chegaram. Esse é um grupo de pesquisa onde vocês vão dar a opinião de vocês para os diversos temas que nós vamos discutir hoje. Não precisamos chegar em um acordo, mas o quanto mais a gente puder debater o assunto e vocês darem realmente a opinião de vocês, melhor. Se tiver qualquer pergunta que vocês não queiram responder, não 
precisa. Vamos lá.

(barulhos)

E: Alguma dúvida até agora? Imagino que a gente fique hoje no máximo 1 hora e meia.

P4: Demorou um pouquinho mais por causa dos papéis.

E: É, a leitura, e o que a gente não conseguir conversar hoje, conversamos no próximo encontro.

P10: Ou em outros, se precisar faz mais.

(risos)

E: Daqui a 15 dias. Bom, vamos lá. A (nome), que está aqui me auxiliando pode fazer algumas perguntas no meio do caminho. Se vocês também tiverem perguntas conforme as pessoas forem falando, tiverem alguma curiosidade, sobre aquilo que a pessoa esta falando, perguntem. Então para darmos continuidade eu queria que vocês se apresentassem falando o nome, a idade e quem perdeu. E depois começamos com as perguntas.

$\mathrm{P} 1: * * * * * * * * * *, 59$ anos, filha.

$\mathrm{P} 2: * * * * * * * * * *, 51$ anos, perdi um filho

P3:**********, 73 anos, perdi meu marido.

P4:**********, 48 anos, meu filho ****.

P5:**********, 59 anos, meu filho $* * * *$.

P6:**********, 39 anos, um paciente.

P7:**********, 58 anos, minha filha mais velha.

P8:**********, 40 anos, o meu irmão.

P9:**********, 51, um amigo

P10:**********, 28 anos, perdi meu irmão.

P11:**********, 35 anos, perdi meu sobrinho.

E: Obrigada. Bom, então para a gente continuar, como vocês acham que o suicídio é visto hoje no Brasil? 
P4: Ainda com bastante tabu, ainda. Mesmo falando bastante.

P2: E acho que reflete que a pessoa que se suicida é vista como fraca, um covarde, eu acho que é assim.

P10: Eu acho que as pessoas que não viveram isso talvez nem saibam que o suicídio existe, porque eu acho que não é uma coisa que as pessoas prestam atenção. Não sei, pelo menos no meu caso, mesmo quando eu via na TV eu acho que eu não... acho que é a mesma coisa de você ver reportagem de assalto, de roubo. Acho que assim, não sei se você não entende a gravidade do suicídio enquanto não acontece com você, né, com alguém próximo. Eu acho que acaba sendo um tema não muito, não sei, eu acho que só quem passou mesmo, dá a atenção. Eu acho que agora com a série lá dos "13" e da "baleia", talvez isso gerou né esse assunto em mais rodas, porque é uma série, é uma coisa que todo mundo ficou chocado. Mas senão eu não acho que, eu acho que é uma coisa que passa meio batida assim, se as pessoas não... ou quando é falado talvez quem não viveu até acha assim "ah, absurdo" ou dá risada. Eu já ouvi assim em empresa inclusive, quando fazem, por exemplo, palestra que dão suporte e dão exemplo: "porque tem gente que liga que fala que vai se suicidar" e tem gente que fala: "pff, até parece." E dá risada, acha engraçado. Que eu acho que talvez eles não entendam que isso é realidade, as pessoas que acho que não vivem talvez... não vejam como algo...

E: Vejam como algo distante...

P10: É, sabe quando te falam sobre algum assalto, sabe... não sei se as pessoas entendem o real significado do que é um suicídio. Eu mesmo antes de acontecer comigo, por exemplo, mesmo se eu visse em um filme ou na reportagem, ou em qualquer lugar assim "vulgar", eu achava que não... O real significado do suicídio...

P4: Não tocava dessa maneira...

P10: É, como se fosse algo "alguém morreu", sei lá.

P3: Como tudo de ruim nessa vida, a gente acha que com a gente não vai acontecer, sempre com os outros. Eu por exemplo, eu tive um câncer e achava "imagine comigo não vai acontecer" ... ter um suicídio na família jamais... minha família é tão bem estruturada, tudo lindo maravilhoso, isso nunca vai acontecer. Então você vê um filme você fala "é uma ficção, não existe na vida real, comigo jamais vai acontecer". Até que a hora que acontece, que você... eu me descobri mortal, eu me descobri a coisa mais absurda que poderia ter acontecido na minha vida seria um suicídio, e, no entanto, aconteceu ... e hoje em dia.... não está preparada nunca para que uma coisa dessas aconteça, doença até a gente sabe que pode acontecer, mas suicídio.... Nunca!

P9: a minha percepção de suicídio, que acho que eu tinha e que eu mudei depois é.... que eu passei ao conversar com as pessoas é que eu acho que a maioria enxerga como algo que não tem nada a ver com a própria realidade... é como se assim, por exemplo, um assalto até, a maioria das pessoas "um dia pode acontecer comigo", mas um suicídio... é assim... eu

P3: é que é tão absurdo que...

Material integrante da pesquisa de doutorado de Karen Scavacini Proibida a reprodução ou utilização sem autorização prévia do autor - 2018 
P9: é assim, é assunto que não tem nada a ver comigo, a maioria pensa assim, acho que em parte.... eu também pensava, né. Então a minha vivência depois até que eu fui conversar com as pessoas né, procurar ajuda para me abrir com os amigos, tal, é como se para eles isso é uma realidade que não tem nada a ver com eles. E aí o tratamento é com esse, um tabu, um preconceito de algo bem distante assim...

P11: não é distância né, eu acho que ninguém gosta de falar nem quem não passou por isso né, então acha que nunca vai acontecer, não precisa falar, e quem passou também eu vejo que é muito dolorido falar então, por ter um preconceito também, por ser uma coisa que parece que as pessoas querem achar um culpado, querem achar um motivo, tem que ter uma razão né, então quanto mais você fala, mais vão te cutucar, mais vão te machucar, mais vão né, as vezes sem querer mesmo né, mas acabam te deixando mal. "Ah, mas então ninguém percebeu..." Se tivesse percebido, não teria acontecido, né se tivesse percebido a gente teria feito alguma coisa para evitar. Então assim, é as vezes a gente não fala por conta disso também entendeu? Por....para evitar, porque parece que ninguém tem como ajudar né, só quem passou mesmo é que te entende. Quem não passou não entende, e nunca vai entender, graças a Deus por isso também, porque eu acho que é uma dor que ... só quem viveu mesmo que sabe o que significa né, e eu tenho assim mesmo na minha família o meu sobrinho que se matou, a minha irmã que já tinha tentado se matar várias vezes e depois que ele se matou ela tentou mais duas vezes né, uma agora em fevereiro e ela, eu realmente vi minha irmã morta assim na minha frente, porque ela tomou um remédio pra pressão, então quase que parou o coração dela, mas a gente não fala mais nada. É como se ela não tivesse feito isso nem dentro da minha casa, que a gente perdeu já o nosso sobrinho, quer dizer, meu pai não suporta ouvir é, minha mãe evita, finge que está tudo bem, então a gente segue assim... né é um assunto assim que as pessoas não falam.

P1: quando você tem a oportunidade de falar né, as pessoas já cortam logo o assunto para não ter que falar...

P11: sim, eu procurei a Karen, eu pedi, ela me indicou tratamento e tudo, quer dizer, aí minha mãe levou ela numa psiquiatra que mudou o remédio dela e ela foi fazer um curso, então está tudo bem porque então ela está bem, ela está fazendo um curso. Não, ela não está bem, né

P1: ela está falando assim, em termos, de um modo geral, quando se toca no assunto, que aconteceu com a sua filha, com o seu filho, o seu neto, seu familiar, para um amigo e você percebe que ele começa a mudar de assunto né, para não ter que mais falar sobre o assunto...

P3: é, porque as pessoas também não sabem o que falar. Não tem o que falar.

P4: Uns pedem desculpas eu já me peguei...quando falam assim, ainda mais por ser jovem acham... foi acidente? Aí se você fala que não, que agora eu ...

\section{P1: Exatamente}

P4: tomei a postura de já não, no começo eu tinha até de falar que era acidente, mas agora eu tomei a postura de falar... "aí desculpa", não, eu prefiro que fale... aí eu já entro porque agora 
também eu já estou mais preparada, porque teve uma época que eu também não queria falar né.

P5: as pessoas vinham falar por curiosidade, para saber um porque e achar um culpado... toda pessoa...

E: para achar um culpado...

P5: é, toda pergunta de qualquer pessoa é no fundo ela está querendo, quem não passou por isso...

P4: eu acho que têm idades né, então assim no meu caso, jovem, das questões ... drogas, acho que é uma das primeiras, que estava usando droga, ahh ... embora às vezes até se estivesse poderia já ser o fato da depressão mas isso eu vim aprender depois, então assim, primeiro é droga, segundo é que você, então se não era, como você não percebeu se era depressão, acho que quando a pessoa vai mais velha, questiona-se se tinha uma doença grave, se tinha uma amante, que foi um amor, uma amante, a mulher...

P3: o psiquiatra perguntou para mim a primeira coisa "a amante?".

P5: Ou perdeu o dinheiro,

P3: o psiquiatra

P4: Ou se é pessoa mais velha, se está sem dinheiro, então assim, eles já vêm com aquela forma pronta.

E: é visto de uma forma simplista

P4: é, para jovem eu acho que é a primeira pergunta "está usando droga?" "Se meteu com quem não devia?"

P1: com amigos, coisa assim...

P4: é então e aí quando passa de uma certa idade você ouve as outras perguntas, então acho que as pessoas têm... e aí não querem ouvir depressão ainda fica no sentido assim, eu já vi caras de pessoas assim tipo "nossa essa mãe está se enganando"

P8: quando é mesmo uma depressão as pessoas têm que achar uma justificativa.

P4: quem não tem nada né,

P8: porque ela a pessoa tem uma depressão, se ela tem uma condição tal e tal e depressão é uma coisa que você não explica necessariamente

P4: para o meu próprio filho eu fazia essa pergunta né, o que ele tinha? Que ele não tinha motivo, e então ele falava o que eu tenho? 
P8: as coisas têm que ter motivo, eu acho que é essa coisa de todo mundo tentar encaixar um pouco um conjunto de respostas... é e disso ser visto assim, como as pessoas não entendem elas têm que trabalhar com esse repertório que elas têm que é limitado e fica encaixando dentro dessa, dessa lista de coisas o que elas acham, então... acho que ainda as pessoas ficam têm essa coisa de "não vai acontecer comigo porque eu estou bem, minha vida é ótima", e então mais a vida pode ser ótima e pode acontecer, é isso! É isso, então... se aconteceu com você, se aconteceu com a sua família é porque vocês têm problemas...

P4: A pessoa pode estar pensando né, só que hoje o que eu entendo e até que esse seriado me levou a pensar isso, é que muitas vezes dentro da sua casa você não sabe o que está acontecendo com o seu filho, com seu sobrinho, na cabeça deles né, por que eu achei assim, do seriado tão, estava falando hoje para a P2, na hora eu e o P5 assistimos juntos, começamos a comentar "nossa, mas as coisas eram assim, de repente, a gente falou, não, não era insignificante... Nossa eu lembrei que eu já falsifiquei minha nota por que meu pai, porque aquilo era "TÃO", para mim dolorido mostrar que eu tirei uma nota ruim, então assim naquela época era aquilo, então de adolescência eu acho que a gente não sabe o que é... Eu aprendi depois a não julgar é.... qual é a dor, qual o tamanho daquela dor, daquele problema que eu acho que não é nada, que daria para ser resolvido. Então se eu vivendo ali na minha casa, só consegui, só conseguia mudar meu pensamento depois, então eu imagino quem ainda acha que não está vivendo né porque o que está acontecendo ali dentro, com os filhos e ninguém está percebendo, com essa correria do dia a dia né, acha que está tudo bem

P6: Eu penso, que... O tabu ele é muito grande, a dificuldade de falar, mas... assim..., pelo que eu passei eu vejo muito a questão da falta de informação, porque quando eu passei por uma situação, embora né alguns anos já dentro do hospital e atendendo assim essas pessoas, mas a fala delas assim é como se fosse uma notícia da TV, um homicídio, algo assim esporádico, mas quando eu passei aquela situação que eu comecei a pesquisar, ler, e eu comecei a ter um pouco mais de compreensão da realidade do Suicídio aquilo foi muito assustador pra mim, por que eu falei isso não é esporádico, isso acontece sim em número muito grande, todos os dias, então eu comecei a pensar o quanto eu tinha pouca informação, o quanto eu estava tanto tempo dentro de um hospital, atendendo essas pessoas, mas sem ter o conhecimento da realidade e da problemática mesmo né, porque assim, hoje a gente ouve falar muito da prevenção do câncer de mama, por exemplo, se de repente eu sentir alguma coisa pra mim vai ser normal ir ao ginecologista e pedir um exame e talvez se eu tivesse mais conhecimento também me ligaria muito mais, sei lá... nos sinais, nos fatores então hoje que eu estudei um pouco mais que eu tenho buscado cada vez mais, quando a pessoa tem alguma fala perto de mim né, ou da minha família ou não, eu já fico mais esperta, mas eu sei que a um tempo atrás não era assim, então eu ligo muito essa questão com a falta de informação, nós não temos informações, ninguém quer falar realmente sobre isso, não é comum né e assim, até por estar mais próxima disso hoje, de trabalhar com essa demanda hoje, é isso incomoda as pessoas, elas não querem falar sobre isso né , elas não, as pessoas elas me pedem palestras e falam assim "olha eu quero palestra, mas não é pra falar sobre Suicídio", né então, esses dias no hospital o cara me chamou e falou isso, e eu falei "olha, mas não dá, como vamos fazer prevenção do Suicídio sem falar do Suicídio", então é eu percebo essa dificuldade, embora estejam né falando muito mais sobre isso às séries tudo que a gente tem visto aí, os acontecimentos, as pessoas estão falando muito mais mas isso é uma 
coisa que acontece a muitos anos nessa proporção e só tem aumentado, não é nada novo, esses dias eu até falei para uma pessoa "olha o Suicídio não é algo novo, a Bíblia já tem relatos de Suicídio é algo que acontece a muito tempo" mas nós não temos informações e nunca tivemos né, eu creio que isso tá aumentando e eu tenho esperança que isso seja tão comum como hoje é falado da prevenção do câncer de mama, próstata, enfim...

P11: E é distorcido também porque eu vi é, no atestado de óbito do meu sobrinho não saiu né...

P7: No da minha filha também não

P11: Então assim, são quantos e quantos e quantos né, que não são né contabilizados.

P7: É subnotificado.

P8: Mas acho que o grande problema disso que eu vejo é que a questão de que o Suicídio é que ele ainda é uma de espécie de um crime, é você, é muita gente, você além do Suicídio, você tem que passar por polícia dentro da sua casa, existe um processo horroroso dentro de tudo isso, então eu acho que também tem muito subnotificação, por questão de às vezes um médico ou o que quer que seja tentando evitar, então por que é um processo também muito doloroso,

P11: Então, se não fosse tabu e se não tivesse toda essa questão...

P8: Claro, mas só que a polícia trata isso de uma forma que é uma coisa horrorosa, aí tivemos que dar depoimento e você vai numa delegacia e eles não te tratam bem, então isso tem também um questão meio complicada que eu acho que é uma tentativa complicada por conta desse tabu, mas por exemplo o meu outro irmão que não morreu, ele já tentou Suicídio 3 vezes, e nenhuma das vezes estava notificado como tentativa de suicídio, porque se não ele ia ter que passar por um processo e o médico falou "ele vai ter que passar por um processo, por uma investigação, por um... o hospital não dá...

P5: É isso.... Eu sou médico...

P8: Então...

P5: isso é uma lei, você tem que notificar polícia que é atentado contra a vida,

P8: Porque é atentado contra avida, e como é que você fica passando por isso né...

P5: Só que acontece o seguinte, agora olha só para o médico, que tem um milhão de pacientes para atender, e aí o que acontece ele vai ter que ir em julgamento, no fórum, aquela baita encheção de saco, para não dar em nada, E a família vai lá e acaba fazendo tudo, então para que ele vai?

P8: Isso só aumenta as complicações... E eu não estou nem justificando...

P5: lei existe, mas ninguém cumpre a lei... é igual aborto, aborto é proibido? É, e se o médico 
notificar um aborto ele vai ter que passar 10 anos da vida dele indo na delegacia... justificando o por que...

P8: eu não estou justificando também o caso...

P5: Eu só estou explicando o que acontece

E: Ele está só explicando o que acontece, eu não tinha essas informações

P5: o que acontece, o médico, se você notificar 10 casos desses eu estou perdido, eu vou passar o ano inteiro indo no fórum, eu não saio mais do fórum.

P8: E isso é super problemático

E: Sim, claro

P5: Agora, quanto a esse atestado de óbito que você está falando, é que é o seguinte, o atestado de óbito é do que morreu, não é a causa. A causa está na delegacia.

(barulhos)

P11: não é o atestado, é o laudo do IML mesmo, atestando que...

P5: o laudo do IML, o IML fala do que morreu...

P7: sufocamento e acabou.

P5: Sufocamento e acabou... agora...

(barulhos)

P11: Aquelas causas externas

P5: agora como foi o sufocamento, o porque do sufocamento é uma questão policial feita na delegacia igual ela falou.

P8: Mas do meu irmão está suicídio

E: no atestado de óbito

P5: Segundo lugar. É difícil sair dessa maneira, porque ele não pode colocar, o médico não pode colocar "Suicídio".

P7: mas devia!

P5: suicídio... mas espera um pouquinho, o Suicídio não é causa de morte. 
P11: Mas espera aí...

P5: legalmente

P7: mas para o bem social...

P5: sim, mas me escuta se ...

E: eu entendo é o órgão que...

P5: não existe um médico que possa dar um atestado de óbito de um suicida legalmente. Eu posso ir lá sou seu amigo, botar que ele morreu de outra causa, mas foi Suicídio. Eu estou escondendo um crime da polícia. Bom, outra coisa é independente do que saia o laudo do IML, o teu problema está na delegacia, igual fizeram com você, com todos que passaram na delegacia.

P8: eu tenho uma tia que foi e que não está dizendo Suicídio, mas o meu irmão está dizendo assim é exatamente nessas palavras, assim que o remédio que ele tomou e por Suicídio.

E: quer dizer a gente está falando que além de um problema de falar de um assunto...

P8: você não tem nem uma estatística

E: a gente está falando que não temos uma estatística correta porque não é notificado da forma como deveria.

P5: mas essa estatística é feita no IML junto com a polícia.

P11: então, mas olha aqui. Declaração de óbito, que é justamente do serviço funerário lá do município. Aí tem um campo aqui que diz "causas externas", aí está "prováveis circunstâncias de morte não natural", aí tem o tipo "acidente, Suicídio, homicídio, outros e ignorado", ele está como ignorado.

P5: porque

P8: mas está provado

P5: por favor, deixa eu te contar o que acontece no IML, eu trabalho no IML está, deixa eu te contar o que acontece...o corpo chega lá, como é que eu posso falar que ele estava amarrado em uma corda? Eu posso colocar que tem lesões no pescoço indicando que parecia enforcamento por corda.

P7: doutor, no meu caso antes do corpo da minha filha sair de casa veio a polícia científica, polícia técnica e eles fotografaram e tal e depois levaram pra aquele caixão de zinco que foi pro IML e foi liberado no dia seguinte só que eu sei que o perito ele quando ele soube que eu era um oficial de justiça eu sei que tudo ficou simplificado e a liberação do corpo, e saiu como 
sufocamento, e eu entendi que ele no intuito da mente dele de me poupar, do desgosto de estar a nomenclatura "Suicídio" ele colocou sufocamento. Agora eu estou entendendo...

P5: o certo é ele colocar sufocamento e não suicídio.

P7: agora eu estou entendendo.

P5: Eu não sei do que a pessoa, como é que a pessoa, qual é a técnica lá na sua casa vê uma pessoa lá... e fotografa... e tudo aquela coisa...

P7: mas eles sabiam que foi por suicídio... porque foi fotografado.

P5: mas isso não vai para o médico,

E: mas não tem uma falha de comunicação?

P5: não, isso não vai para o médico, vai para a polícia científica na polícia, feito pelo policial... para o médico chega o corpo lá,

E: ok

P1: só as evidências...

P5: é só o que eu estou vendo no corpo, eu não posso supor nada. Não tenho que colocar lá "está grávida" ou não está grávida, se é mulher você tem que fazer exame ginecológico, independente de qualquer coisa, se houve estupro ou não houve estupro, independente do que foi a causa da morte. Tudo isso você tem que averiguar no corpo, mas eu não posso colocar opinião minha "ah, eu acho que foi por isso aquilo lá..."

E: isso quem vai determinar é a polícia depois de uma investigação

P5: aí quem vai investigar essa outra parte é a equipe científica junto com a polícia.

P10: Até porque quem sufocou você não sabe se foi a pessoa mesmo ou outra pessoa, se foi...

P5: Sim, por isso que você toma parte da delegacia.

P8: No caso do meu irmão...

P5: Eu fui maltratado na delegacia

P8: Não, eu não, meus pais......

P5: Eu fui... porque eles acharam que eu era o culpado, talvez... então eles foram para cima de mim... me apertaram, fizeram um monte de pergunta, um monte de encheção de saco... quiseram ouvir ela sozinha, para saber se ele tinha problemas comigo, se eu brigava com ele..., mas escuta, eu tenho que entender, mas é óbvio, o cara não me conhece. O cara nunca me viu, não sabe quem 
eu sou,

P7: Ossos do ofício

P5: ele tem... o delegado tem que fazer a parte dele. Nós fomos ouvidos separadamente. E foram muito grossos comigo e com ela.

P8: é, no caso eu acho que foi, colocaram no atestado de óbito que o meu irmão ele deixou tudo muito explicado, ele colocou a dose, ele colocou tudo assim, bem explicadinho

E: para não dar dúvida,

P8: Para não dar dúvida tal, mas eu acho que é essa a questão, só meio para tentar estar dentro né, eu acho que o grande problema da subnotificação é isso, é não ter aonde isso,

E: não ter um padrão...

P8: não ter um padrão de como isso é registrado, se é no atestado de óbito, se é num lugar, se é no outro, os próprios... as próprias tentativas do suicídio que também não são notificadas, por causa de... e eu acho que todo esse problema também por ser um crime, é acaba tornando isso um tabu ainda maior. Piora o tratamento das pessoas que precisam de ajuda.

P5: só poderia colocar suicídio no atestado de óbito, botar assim como queira, pelo seguinte... pelos dados do atestado de óbito ele precisa colocar do ele morreu. Aí quando vem os outros 30, 40 dias depois vem a dosagem de sangue, se tinha álcool, se tinha droga... foi aí que comprovou se teu irmão tomou remédio ou não, ou que seja. Antes disso, o médico foi contratado só para enterrar, ele não tem, ele não sabe disso.

E: então olha a gente esta falando que o suicídio não é visto, quando ele é visto, ele é visto como algo alheio, longe da realidade de cada um. A gente está falando que o fato dos números não serem fidedignos também dificulta que ele seja visto por essa sociedade com a quantidade que ele ocorre. Então a gente também pode pensar se a gente tivesse esses números, passasse esses números talvez aumentasse uma consciência, quando as pessoas percebessem o número de casos, né.

P7: A burocracia

E: Tem a burocracia que atrapalha, tem uma falta de cuidado das pessoas ao lidar com o tema, e a gente está falando também que... tende-se a procurar um culpado. Ou a droga, ou é a falência financeira ou é a família ou

\section{P11: N motivos}

E: os profissionais... então tende-se a olhar o suicídio como um causa e efeito. É mais ou menos isso que a gente está conversando? 
P10: então, mas eu acho que tem também a questão dos estudos e do preparo dos profissionais, nas diferentes áreas que entram no contexto. Que por exemplo, pelo que eu saiba não fala sobre suicídio, por exemplo, num curso de psicologia, na medicina, etc... ou por exemplo, mesmo para os policiais, eu imagino assim nem eles têm a informação teoricamente de uma forma mais né científica, estruturada, com mais estudos, como que eles vão às vezes autuar nos seus ambientes aonde esse assunto surge mais, por exemplo a questão do câncer, cada vez mais foi estudado, as pessoas vão atrás entendeu... eles se especializam nesse tema, então eles estão mais preparados pra lidar com isso, mas por exemplo o suicídio se ele não é nem abordado nesses ambientes que são seguros, confiáveis, imagina no resto. E para mim continua essa questão, de que eu acho que, que nem, uma vez, é que eu não falo né que meu irmão se suicidou, então eu não vivi muitas situações, mas quando eu vi uma menina falando... tipo, as pessoas não fizeram nada com aquela informação eu fiquei: falei, putz, será que depois alguém vai vir falar pra mim "nossa, P10 viu a irmã dela se suicidou" Ninguém fez nada com aquela informação, então eu não sei se é porque, é que nem como se fosse qualquer outra coisa porque a pessoa não entende o quão grande é aquilo, e aí eles nem comentam nada. Por um lado, eu fiquei contente deles não terem comentado no sentido de tipo "aí credo então a família dela" que eles não julgaram, mas também não falaram nada então mostra talvez que a percepção é de algo distante né, algo que sei lá... tipo que não é faz parte da realidade. E aí eu não sei ... Ainda mais as pessoas que viveram isso, igual eu... não falam em menos lugares isso vai ser abordado e talvez é discutido ou não sei

P4: vai continuar a ficar no fechado

E: vocês acham que as pessoas percebem o suicídio como algo proibido de ser falado?

P4: Acho que igual a morte, não que a morte, não que a morte não...

P3: eu entendo que as pessoas têm muita dificuldade. Elas sabem a gravidade do assunto ... tem dificuldade em falar, que eles sabem que aquilo é tão doloroso para quem está passando, e ela não imagina que aquilo possa chegar até ela de tão doloroso que é, então as pessoas evitam de falar, porque não tem o que falar e sabem o quanto é doloroso, eu já entendo diferente aqui de todo mundo, eu acho que não falam porque, por pena, e porque sabem o quanto aquilo é doloroso. Não tem o que... nada que console.

P1: no caso que ela estava falando, no caso do meu... no colégio né... eu estava falando com a Karen estava falando no começo, a gente foi convidado para dar uma palestra sobre a valorização da vida, prevenção do suicídio e a valorização da vida e estava tudo certo aí no dia anterior liga a professora pedindo para não falar de suicídio na palestra. Porque os diretores não estavam concordando. Um colégio assim, de um nível bem elevado... e começa que como eu vou fazer uma palestra sobre suicídio sem falar de suicídio? Não... você pode falar assim de outro jeito e tal ..., mas você não pode falar... (risos), então fica difícil né, por causa disso, você fica...

P8: As pessoas acham que se você falar... que você está querendo estimular né. Que você está querendo induzir...

P1: antigamente não se falava em sexo né, na minha época em que eu fiz colégio eu tive aula né

Material integrante da pesquisa de doutorado de Karen Scavacini Proibida a reprodução ou utilização sem autorização prévia do autor - 2018 
de educação sexual. A professora falava da camisinha tal e tal e isso não fazia com que a você saísse por aí né... a torto e a direita... (risos) eles falam que se a gente falar de suicídio como se fosse... quem está com algum tipo de problema... como se fosse incentivar as pessoas que tem algum tipo de problema.

P4: então eu acho que deveria começar, quer dizer..., acho que a discussão toda é essa, dentro do trabalho da Karen... é começar a preparar pessoas para falar de uma maneira correta. Porque eu acho que alinha muito... entre o ... você falar e despertar a curiosidade do adolescente para aquilo, eu tenho muito medo. Assim, se eu tivesse que falar eu não sei aonde seria a linha de você falar com prevenção para que ele... chamar atenção para que a família ele peça ajuda né ou incentivar, acho que a linha... é ali aonde fica o pessoal não sabe a linha aonde começa, aonde você está incentivando e onde não está, então eu acho que deve ter profissionais muito mais capacitados para dar uma palestra... que disse que...

P1: mas tem profissionais capacitados, é o outro lado né que está...

P4: proíbe né...

P6: Acho que isso é mais uma questão do tabu em si... é o tabu mesmo...

P1: você tem professores que querem... mas tem diretor que acha que isso é prejudicial aos seus alunos.

P4: porque tem os pais, que não vão querer... aí... porque aí eu vou tirar... e tal...

P1: exatamente... os pais que não querem... e é colégio caro e tal... é isso aí

P4: pode ver que deve ser o maior problema dos colégios... os pais... não vamos falar sobre isso...

P1: De certa forma os colégios de periferia, de certa forma, a gente não tem problema de...

P6: eu vejo que o problema maior é questão do suicídio em si, porque ... a morte ela é jogada dentro da nossa casa todos os dias da forma mais banal que existe né, é só você ligar no Datena que você vai ver corpos e corpos estirados ali e eu, por exemplo, que eu tenho duas crianças em casa, se eu não tomar cuidado os meus filhos vão ver aquilo totalmente, todos os dias né, e isso é banalizado. A internet mesmo a gente vê, pessoas que se suicidam, o funcionário chega mais cedo na empresa, vê, tira foto, posta e daqui a pouco aquilo se espalha de uma tal maneira e todo mundo vê, então eu vejo que o problema é a questão do tabu, é o preconceito né?! É claro que tem que ter profissionais preparados para falar de todos os assuntos, não só do suicídio, uma pessoa que não entende, se ela falar bobagem, falar besteira, é claro que aquilo não vai ser produtivo, mas eu vejo que assim a barreira mesmo, é a questão do suicídio né, não a morte, claro a morte, mas a questão é do tabu mesmo com a situação, com o tema...

P2: do absurdo a pessoa ter escolhido partir né

P10: mas gente, sabe o que eu acho, a gente tem que dar milhões de passos para trás. Para mim, 
suicídio é o nível mais hard da humanidade. A gente não consegue acolher uma tristeza, quanto mais tipo um suicídio entendeu? Então eu acho que enquanto sabe não tiver educação base para falar de tipo "sentimentos" que tipo um dia você está triste, você não pode falar que você está triste, as pessoas, o mundo não consegue acolher os sentimentos ruins que acontecem na nossa vida. Então imagina acolher tudo aquilo que a pessoa, assim, que a pessoa que se suicida sente, e ainda o fato do suicídio depois para os que ficam. Então acho que antes do suicídio virar um tema, que a gente consiga conversar, eu acho que a humanidade tem que evoluir muito em coisas básicas sabe, tem uma base do ser humano que não está formada, que é de acolher assim, falar um oi tudo bem ou tipo de dar bom dia, tem gente que não dá bom dia....então eu acho que a gente não evoluiu assim em coisas que a gente não consegue acolher a tristeza. A gente não percebe os outros, a gente não consegue falar com essas pessoas, então assim, o suicídio para mim é uma coisa complexa, a última fase sabe da escala, as pessoas têm que ser felizes hoje todos os dias. Essa coisa da felicidade, da busca da felicidade, que todo dia você tem que estar bem. Então assim, imagina falar de suicídio, isso aí... porque é um assunto superpesado, a gente não consegue falar da tristeza. Aquele filme do "Divertidamente", aquilo não fez sucesso, porque as pessoas não vão falar de sentimento, eles não querem ver lá que a tristeza, que nem, a alegria é o sentimento mais importante no filme, ainda bem que mostraram a importância da tristeza, mesmo assim a gente não acolhe muito as outras coisas, então quanto mais eu acho que é esse tema né, mas é lógico que o quanto mais a gente conseguir trazer acho que ajuda todos os outros que muitas vezes vem junto, outra pessoa... (48:09)

P4: mas eu ainda acho que quebrar o tabu vai ser a hora que estiver muito mais pessoas preparadas para falar porque a gente está preparado para ouvir uma coisa coerente né. Não essas perguntas né?!

E: você está falando da forma que as pessoas têm medo de falar do assunto porque elas têm medo que elas possam aumentar o número de suicídios, ou as pessoas não sabem falar sobre o assunto?

P4: não, elas não sabem. Não acho que tem medo não. (48:35)

P7: é, uma coisa que eu percebo é que essa tragédia que é o suicídio ela dói. Mas para os outros que recebem a noticia, tomam conhecimento, pode até haver dor, mas o que há mais é o desconforto, e eu percebo, dou alguns exemplos: é.... fui eu que comuniquei a superiora da mãe da minha filha o que estava acontecendo, por que ela não podia atender... bom, o fato é que pela lei, são 3 dias de licença por causa da morte. Eles deram 2 semanas e depois prorrogaram mais 1, porque simplesmente aquilo... ela não pediu demissão... aquilo desestruturou todo mundo... aquilo né. Quando eu faço a postagem, eu sou ativista e abri mão do anonimato... então quando eu faço a postagem... quando é algo que está expondo, digamos a tragédia pessoal, a minha tragédia pessoal aí tem bastante curtida, tem bastante comentário, tem a solidariedade, aí quando eu faço uma postagem que é sobre prevenção e Posvenção ao suicídio... com bastante informação e tal, tem uma meia dúzia de curtidas e nenhum comentário. Quer dizer, a dor alheia, as pessoas têm um ímpeto de vim lá se solidarizar. A minha dor, no caso, então eles vem, eles se sentem até à vontade e fazem comentários, alguns cabíveis, alguns impertinentes é, mas a maioria é de boa vontade, ok? Mas assim, o ser humano tende a ser solidário. Então a solidariedade de uma dor e de uma tristeza? ok. Agora... a tragédia, lidar com a tragédia, o 
mecanismo, enfim a face, o rosto da tragédia isso gera um desconforto absurdo, até porque é uma inversão da lógica do instinto da autopreservação, então as pessoas ficam sem ação. (50:52)

P5: e ninguém quer discutir suicídio, igual ele falou aqui...

P7: não estou perplexo...

P5: vai falar o que... Passa batido, porque todo mundo acha que a família dele é "Doriana" é saudável e não vai passar por esse problema. Então, eles nem vão ler aquilo? Quem não passou pelo problema, não lê... (51:09)

P11: é uma obrigação hoje em dia, por conta das redes sociais também isso que a P10 estava falando. Que todo mundo só compartilha momentos bons, comida boa, lugar bom... ninguém compartilha, né P10, a visão do metrô lotado, então eu acho que quem não tem, principalmente os jovens né, eles se sentem muito cobrados, e muito... "poxa, mas todo mundo é feliz menos eu?", "poxa, mas fulano está viajando, o outro está rico...o outro...E ninguém está, a grande verdade, quando você pegar essas pessoas, é que ninguém está. Ninguém leva a vida que compartilha ali, são pouquíssimas pessoas que realmente têm uma vida maravilhosa todos os dias, aliás acho que né, não sei quantas, mas não conheço né, não conheço, então tem isso também de você não pode falar que está triste, você não pode falar que não está legal, né, então, se você chorou você é fraco, e se você não está bem... eu fui demitida em janeiro e uma das coisas que usaram foram as minhas fotos, depois da morte do meu sobrinho. Só que eu conversei com o meu chefe e ele me autorizou a ficar em casa e aí ele depois se juntou lá e me mandou embora. Eu achei uma covardia, uma coisa assim, que você acha que pode contar com as pessoas, mas você não pode. Você acha que estão te apoiando, quando na verdade estão criando, às vezes, alguma coisa para usar contra você. Então isso para mim foi terrível... foi... eu achei muito cruel, entendeu? Podiam me mandar embora por qualquer outro motivo, mas por aquelas fotos...eu pedi férias e não me deu. Ele me mandou ficar em casa né, então..., mas isso não é fato...

E: Então a gente pode falar que ...O tabu ele vai estar em várias esferas. Ele está na esfera pública, de quando a gente fala do assunto na mídia, está na escola que não quer trabalhar o assunto, está na empresa que não entende e quer que a pessoa trabalhe...

P11: esteja bem e produtiva... sendo que não tem como...

E: No hospital...

P6: nos hospitais e nos profissionais...

P4: Posso fazer uma pergunta para ela?

E: pode! $(53: 23)$

P4: Porque você passou agora com a sua irmã, não consumou então foi atendida no hospital, isso eu estava conversando com a P2 hoje, que era uma dúvida, que eu já ouvi de algumas pessoas. 
Perguntei e o P5 falou eu nunca vi distinção, mais aí eu não sei. Você notou que quem atendia a sua irmã fazia uma diferença, assim, se ela tivesse lá sendo atendida por câncer, uma dor?

P11: Com certeza, ela foi bem maltratada, assim, a gente foi no (nome de um hospital) ...

P4: Então, eu já ouvi muito isso.

P1: eu também já ouvi

P11: Ela tinha tomado uma caixa de remédios para a pressão do meu cunhado, então tinha que fazer uma lavagem com carvão, né, e as enfermeiras...eu nunca vi aquele tratamento lá no (nome de um hospital)..., mas assim... super grosseiras, ela passando mal, ela vomitando e elas lá, nem aí injetando... O médico saiu com cobertor para ir dormir, largou ela lá... porque entendeu

P4: tipo assim, tem tanta gente aqui que precisa...

P11: é tipo... é, "se você quer morrer o problema é seu". (54:22)

P4: Eu já ouvi muito isso. Eu não passei porque meu filho não chegou a ser atendido. Mas hoje eu falei porque eu já tinha perguntado para o P5. Eu falei: Olha, fala a verdade para mim, tem?

P11: Tem.

P4: Aí ele... ahhh...não, eu não tenho

P5: eu não tenho

P10: mas eu já ouvi também

P5: o que ela esta acabando de falar aí, é o tratamento normal...eles estavam tentando forçar ela, por essa sonda...a vomitar, ou botar para fora

(Todos falam ao mesmo tempo ????)

P11: É bom, cada um tem uma opinião

P4: mas eu já ouvi coisas...

P5: Estou falando sobre o que aconteceu no (nome de hospital)...

P10: A gente ouviu também... (54:55)

P5: É o seguinte, é que é um tratamento bruto mesmo. Você vai passar um cano dessa grossura pelo nariz da pessoa, pelo esôfago, vai colocar lá no estômago, quando vai passar na garganta a pessoa vai vomitar, vai ficar daquele jeito. Mas é o único meio de você lavar o estômago é colocar o carvão ativado. O carvão ativado lá dentro vai... o cartão ativado que você acabou de 
falar é para que? É para que o remédio não seja absorvido

Todos falam ao mesmo tempo. ?????

P2: mas não é procedimento, acho que é o olhar

P4: é o olhar, não é...

P5: e é um procedimento da enfermagem, não é do médico...

E: mas você acha que as enfermeiras têm com uma distinção?

P5: olha, eu nunca vi esse negocio. É o seguinte, quando você chega lá, quem está em prioridade é que vai ser atendido? Quem mais tiver grave

E: mas você acha que a forma de tratar, na sua visão, ela é a mesma para todos os casos?

P5: é a mesma para todos os casos, não é diferente. (55:55)

E: na tua já é diferente, na tua experiência.... É diferente

P11: a minha mãe enfartando foi tratada de um jeito, e a minha irmã totalmente de outro. E eu mesma já fiquei internada lá varias vezes também, outro tipo de tratamento e outra coisa que aconteceu foi que a pressão dela foi baixando, foi baixando, foi baixando muito, e estava acho que 4 por 2, assim, uma coisa que estava parando, e eu toda hora ia falar: "Olha... a pressão dela." E elas: "Ah, não, a gente deu não sei o que lá e ela vai subir". (56:19)

P5: Acho que o soro, algo do tipo.

P11: "Ah, daqui a pouco sobe. Daqui a pouco sobe". E eu que tinha que ir lá: "Olha, está baixando mais, está baixando mais." Aí eles pegaram uma veia no outro braço, acho que a adrenalina, sei lá o que é que dá, né dr? Eu sei que na hora que eles deram, ela subiu, ela ficou roxa, assim, o peito roxo, e ela: "Ai que eu vou morrer..." porque a pressão dela subiu de 4 por 2 para 14,15, sei lá. Subiu muito, muito rápido e ela gritando que ia morrer e eles continuavam. Eu falava: "Para, pelo amor de Deus". Aí eles pararam e aí viram que a pressão tinha subido muito realmente, mas ela, assim, foi uma questão disso daqui. Eles parecem que não acreditavam nela, no que ela falou: "Minha cabeça está explodindo, eu vou morrer", né, e continuaram. Então...

E: Talvez tenha uma diferença, aí, entre a forma como o enfermeiro vê o que ele está fazendo, e a forma como a família sente que aquilo está sendo feito, a necessidade da família também. $(57: 16)$

P5: É essa a diferença.

E: E também tem enfermeiros que não vão fazer distinção e enfermeiros que fazem distinção e 
vão tratar de formas diferentes.

P11: Com certeza a gente não pode generalizar nada (57:24)

P1: É, eu não participei, mas a minha filha de 15 anos, né, participou, porque eu não estava na cidade, estava em outra cidade, minha esposa estava vindo do trabalho, mas fui muito bem atendido, e fez todos aqueles processos embora um pouco assim...

P5: É bruto...

P1: ela colocou na hora o tubo, tudo, tudo e na cabeça da minha filha, né, quer dizer, que é uma criança né, se fosse um adulto pode até ser que seria mais até mais, mas não, pelo menos foi bem feito o serviço, é, tanto que com um dia e meio de manhã (vendendo coco ???) mas não deu...

P5: quanto antes você fizer, mais rápido você fizer, mais você vai salvar. Então tem que ver... Na verdade, eu vou te falar uma coisa,

E: Fala (nome de um participante)

P5: só um minutinho... é de suicídio que você está falando. Eu estou lá no pronto socorro e chega baleado um bandido e um policial. Não tem essa preferência. É o que estiver mais grave você vai atender.

P11: sim, acho que a questão não é essa, a gravidade e sim a forma como é tratado.

P5: na hora você não sabe o que é

E: Sim.

P5: É difícil você saber o que é na hora que entrou lá. (58:36)

P6: eu acho que a colocação dela é no sentido de não fazer distinção em quem atender, eu vejo que é no sentido de que você pode atender

P11: ... como atender.

P6: uma tentativa de suicídio de uma forma empática e acolhedora.

P11: ...sim, exatamente...

P6: E eu infelizmente já vi. Eu presenciei muito. (?) e isso acontece com muita frequência. Já trabalhei... esse hospital que eu trabalho hoje já é o 4o hospital que eu trabalho e por diversas vezes eu fui chamada para atender pacientes com tentativa de suicídio com uma fala assim, do profissional. "A gente está aqui preocupada em salvar a vida e tem um querendo fazer graça". Eu já escutei isso diversas vezes. E eu participei de um grupo de estudos de prevenção de suicídio com um médico lá da minha cidade, um psiquiatra e ele falou: (nome da participante) 
"Infelizmente lá no PS a gente escuta isso todo dia dos meus residentes. Os meus residentes falam isso" ."Agora eu vou te ensinar como se suicida, porque você fez tudo errado". Ele falou: "Eu tive que chamar o residente meu e falar: "não, pode parar. Está tudo errado". Porque o residente de psiquiatria tem essa fala e infelizmente acontece em alguns serviços sim

(burburinho)

P11: Parece até quando a criança... só rapidinho... quando a criança faz alguma coisa que a mãe fala: "Agora que você se machucou você vai apanhar mais?" Então parece que é um castigo mesmo. Foi o que eu percebi. (58:53)

P9: Uma experiência que eu pude ter.... no ano passado, por estar revivendo o processo, eu fui fazer alguns cursos de luto. Não tem nada específico de suicídio. Mas encontrei alguns cursos de luto e num deles, era... a maioria era médicos e enfermeiros e era sobre comunicação de pessoas, era na área de cuidados paliativos que tinha a ver com luto, e várias cenas eram recriadas, assim, os próprios médicos traziam situações onde eles tinham que comunicar uma notícia grave ou difícil para o paciente e eles relatavam que viam colegas falando de um jeito que não era legal. Então eles traziam isso como uma angustia, e aquilo era encenado junto com a pessoa que estava orientando. Olha... "Como poderia ser falado? " Muitas vezes passava-se por cima, tipo, a pessoa faleceu, a pessoa não tinha nenhum cuidado de falar. E era trazido isso. Aí a minha opinião né...eu acho que esbarra na própria dificuldade que o próprio médico ou as próprias pessoas têm de lidar com algumas questões. Acho que é uma limitação humana. Eu mesmo, assim, no relatar com amigos, eu tive reações, assim, desde pessoas que se afastaram, cortou o assunto e saiu fora mesmo e outras pessoas tinham reação agressiva. Depois eu pude entender, conversando né, que era uma coisa cultural da pessoa e da família inteira dela. Tudo que tinha haver com morte ou doença grave a pessoa não falava porque ela achava que atraia. Era uma coisa assim, muito recorrente: "se eu falar atrai" então na família inteira ninguém falava de nada de morte. Então o jeito que a pessoa reagia, nem era falando de uma maneira educada, era agredindo para cortar o assunto. Então por exemplo, uma postura... tanta pessoa (para ele?): "olha, eu prefiro não falar... Eu penso assim..." não. Aí eu entendi como era. Eu tenho amizade com a pessoa há muito tempo... eu entendi que é uma reação de defesa dela, um mecanismo dela... então eu acho que uma das coisas que eu acho que é mais grave, é um pouco o que a P9 falou, né, tudo que tem a ver com tristeza ou assuntos difíceis são tabu e as pessoas,

P7: causam desconforto.

P9: Não falam. Eu mesmo sofri... quando eu fui me abrir, com meus amigos, era assim meio tipo, levar uma bronca porque você está triste. "Para com isso."

P7: Eles estão desconfortáveis de ver você triste. Então às vezes eles estão fazendo isso não pelo preocupado com você, mas por eles mesmos...

P9: É uma forma de defesa. Então, dar espaço para os sentimentos de luto ou de tristeza, eu acho é, eu sinto como uma necessidade.

P10: E sabe o que é, eu acho que a gente aprende coisas na escola que são teóricas, e como lidar

Material integrante da pesquisa de doutorado de Karen Scavacini Proibida a reprodução ou utilização sem autorização prévia do autor - 2018 
com transições, perdas, mudanças, essas coisas subjetivas você não aprende em nenhum lugar, se aprende na vida mesmo, passando. Então eu acho que é por isso que é tão difícil, porque é a escola da vida né, que você acaba lidando com essas situações subjetivas.

P4: Mas nem na escola nem na família porque na família não falam e na escola também não...

E: Você queria falar alguma coisa?

P8: Não, só...

E: Então assim, que outras coisas vocês acham que podem influenciar esse tabu? Que a gente está falando que é um tabu, não se fala, que outras coisas além das que vocês? Já falaram várias, mas vocês acham que tem mais coisas que influenciam nesse tabu?

P2: Religião

Burburinho... religião com certeza...

P11: Eu acho que a grande maioria dos casos envolve depressão, e a depressão não é respeitada como uma doença, não é tratada como uma doença, muitas das vezes ela é vista como uma frescura, como uma coisa assim, então talvez se tivesse uma conscientização maior sobre a depressão e outros problemas psiquiátricos também as pessoas compreendessem mais e ajudassem mais quem está passando por isso.

E: E você acham que o tabu começa ... fala... (01:04:08)

P5: ...Só um minuto. Sobre o que ela falou. Eu acho que a depressão como doença, que hoje é doença, está lá no CID e tudo mais, eu acho que, nunca escutei de ninguém que se suicidou sem depressão. Então se eu mudasse o termo suicídio para a depressão, você poderia conversar sobre o assunto, resolver o problema e sem falar em suicídio. Porque a maioria do pessoal, eu nunca escutei falar de ninguém que estava bem alegre e contente e se matou.

P11: por isso que eu falei

P5: Então eu concordo com você com esse negócio de depressão... eu acho que se mudasse o termo de suicídio para prevenção à depressão já melhoraria.

E: Seria bem mais fácil de falar?

P5: Seria bem mais fácil de lidar com o tema.

P7: Apesar que tem suicídios que não é por depressão, e sim por exemplo, por impulso. Aquele rapaz de 23 anos que se atirou lá do Fórum da Barra Funda, tinha acabado de sair da audiência, a audiência não foi sido favorável para ele, ele atirou primeiro o celular que até acertou a barriga de uma grávida, mas não causou danos maiores, e em seguida ele se atirou. Foi impulso. Não planejado... 
P5: Mas se pesquisasse na família dele, antes de ir para lá...

P7: pode ser, pode ser, eu não tenho essas informações (falam junto)

P5: ... antes dele vir para lá... ele já estaria em depressão. Eu nunca vi nenhum caso de suicídio que a pessoa não tivesse com depressão antes. Talvez ninguém notou, ninguém viu, ninguém ...

P3: Talvez até tenha cometido algum crime por depressão

P5: ... percebeu entendeu? O maior problema então é o seguinte, a depressão não é nada... igual ela falou... depressão é "frescura"...

P11: É frescura...

P5: ...se você acha que a depressão é frescura então não se trata.

P7: $\mathrm{Eu}$ acho que tem pessoas que se suicidam que não demonstram em momento algum depressão. Minha filha foi um caso...

E: Ter depressão não significa que as pessoas mostrem ou que ela tenha sido diagnosticada ou tratada

P7: nunca mostraram... A conversa que tivemos na hora do almoço, estava perguntando do fim de semana... de tirar a carteira de motorista... (falando sobre a filha)

(burburinho - falatório)

P4: A não ser salvo alguns casos...

P5: Meu filho ia viajar para o Guarujá com a namorada... foi na casa dela e (???) e daí em meia hora ele fez isso

P3: Orgulho...

P4: E tem... acho que ainda mais antigamente, a pessoa tinha orgulho e tal e como que a sociedade vai me ver.... aí eu acho que...

P5: mas eu ainda acho que tem processos que (???) ninguém via

P7: ...a não a minha não...

P5: ninguém notava... ia no psiquiatra e o psiquiatra dava alta para ele....

P4: que eu não entra isso muito nos jovens hoje, mas as pessoas... acho que antigamente... era um alto índice (sobre o orgulho) 
P3: Olha, eles se suicidam por qualquer coisa assim... pela honra, orgulho...

E: E vocês acham que esse tabu, ele começa aonde? Ele começa na sociedade, na família, na escola? Onde que ele começa?

Falatório

P5: em todos os lugares.

P8: E é o que ela falou também, é visto como uma fraqueza, né quer dizer...

P7: Um pecado, em algumas religiões...

P11: ...é "poxa, mas você tem tudo, você tem uma família, você uma casa, você tem carro, você tem emprego, então porque você está triste?"

Falatório

P4: Eu acho que a chave é saber...

P8: a gente não sabe...

P7: Exato, tristeza né...

P4: ... é saber que felicidade não é tudo aquilo maravilhoso a toda hora, felicidade é você estar bem, fazer um pouco do que você gosta, se não é hoje é ter sonhos para fazer depois, momentos, mas é tirar essa coisa de felicidade que tem que ser aquela coisa assim (?)... maravilhosa...

E: Onde é aí que está a busca do que é felicidade também.

Vários: É

P11: Como uma visão errada

P11: Assim como existe sobre a beleza, quer dizer, então o que é uma mulher ideal... é um casamento ideal...

P4: eu acho que começa a quebrar daí... porque eu acho que daí a pessoa poderia começar a pensar assim, não, esses momentos de tristeza é normal, então... eu vou ter que trabalhar, ver o que está me deixando triste e me sentir melhor, e não se sentir tão culpados que eles estão tão tristes sem um motivo. Então eu acho assim, que tem que começar bem no que a P10 falou, muito lá de baixo, muito cultural... mas tem que começar... (01:08:00)

P8: é que as pessoas, a gente têm a tendência de falar "ah, aquela pessoa ela é depressiva, ela é negativa, ela tem uma energia ruim" As pessoas põem de lado as pessoas que não estão felizes por um momento, elas são postas de lado pelas pessoas 
P4: também... e também não são nem convidadas para os lugares pelas pessoas...

\section{Falatório}

P8: ... elas não são convidadas, elas não são... é, existe essa obrigação de ser feliz, acho que é mais que do que você colocar ou postar... é você as pessoas dizem: "Não chegue perto daquela pessoa porque ela é triste, ela é deprimida e ela...". Eu já ouvi falarem a pessoa é depressiva, ela tem uma energia ruim. Eu já ouvi isso. E então, você já começa com as pessoas pondo de lado.... Então você já tem uma pessoa que está com um problema, e aquilo agrava porque ela é posta de lado porque ela não está ali sorrindo...

P7: começa a falar junto: Porque não serve. É utilitarismo, isso é utilitarismo...

P8: é.... é exatamente... ela não serve para o que preciso...

P7: ...só as pessoas que servem para os meus próprios interesses, e as pessoas não me servem, que servem para o meu sucesso profissional, financeiro... e as que não me servem.

P8: fala junto - Eles maltratam

P7: É utilitarismo. Na verdade, a pessoa está vendo um mundo à parte de si mesmo e as pessoas ao seu redor elas apenas estão à serviço dos seus próprios interesses. Há aquelas que servem e aquelas que não servem. Isso é utilitarismo. Não existe amor. Não existe... (01:09:20)

P2: Mas eu não sei, porque eu lido com uma pessoa que tem depressão, a (nome de uma pessoa), e é muito difícil para a gente tentar penetrar naquele mundo... é inabitável. Por mais que você queira ajudar, a pessoa se recusa, a pessoa não quer ajuda, a pessoa te dá pistas de que está bem, e de repente de que está mal. Aí você diz:" Você não está bem? "aí ela fala: "Mas agora eu estou bem, você é quem está querendo que eu fique mal". É muito difícil. É um universo que eu desconheço gente, não dá para habitar. Por mais que você queira, você fala: "E agora, o que eu faço? Eu me sinto de mãos atadas. É... A energia dela é difícil? É.... porque eu não consigo compreendê-la.

P8: Mas ela tem o direito de estar ali.

(Falatório) ...

P2: Não, não, sim...

P8: Isso é que é a questão.

P2: Mas assim, é muito difícil você olhar para a pessoa e a pessoa se auto destruir e você ficar de camarote porque ela não deixa você fazer nada. Ao mesmo tempo te pede ajuda e aí você tenta ajudar e ela recua. Eu acho que esse preconceito... 
P8: É, mas a gente tem que entender também que... tem coisas que... porque o meu irmão a gente viu acontecer, a gente sabia que ia acontecer, (risos nervosos) e não tinha nada que pudesse ser feito. Tudo que a gente podia ter feito a gente fez.

(falatório)

P2:... vocês fizeram...

P4: Então, nós também...

(falatório)

P2: acho que o problema... é que eles não aceitam isso. Eles não querem que ajuda. $\mathrm{O}$ preconceito, o tabu é tão violento que para a pessoa aceitar que ela tem a depressão, "Ah, como é que eu vou me intitular de fraco, né? Vou ter que assumir que eu sou fraco, que eu sou preguiçoso, que eu sou covarde... que eu sou...

P8: É porque as pessoas dizem que depressão é isso, e não é...

P2: não é isso, então... então, o problema está nisso, no tabu, é depressão. Se a gente conseguisse de alguma forma, que eu não sei qual é....não sei qual é, gostaria muito que alguém descobrisse, é desmistificar mesmo para a gente poder olhar para a coisa como uma pressão alta né, como uma diabetes, né?

P8: Exato, quando eu paro para pensar...

(Falatório)

P5: deixa eu falar uma coisa aqui ... a depressão tem que ser tratada por um profissional, a gente querer tratar, é igual você querer tratar uma pressão alta... você consegue tratar uma pressão alta?

(Falatório)

P2: Mas eu não quero tratar... eu quero levar para um profissional

P5: então eu vou falar uma coisa para você... e as pessoas geralmente põe em casa e ficam tentando tratar em casa a depressão. Sem a ajuda de um profissional, sem a ajuda de nada. Bom, psiquiatra estuda lá não sei quantos anos para ser...

E: mas, sabe P5 as vezes o difícil é porque a pessoa nem quer ir para o psiquiatra

P2: é isso

P5: $\operatorname{sim}$

E: Você quer que ela vá no psicólogo, mas ela não vai no psicólogo. (01:11:50)

Material integrante da pesquisa de doutorado de Karen Scavacini Proibida a reprodução ou utilização sem autorização prévia do autor - 2018 
P10: Gente, de novo, assim ... eu acho nem que a gente sabe, tipo, tudo, a gente só fala de depressão agora, mas eu acho que existem variações de sentimentos que não tem nem nomes porque nem tudo é só tristeza, nem tudo é só fraqueza. Assim como a tecnologia evoluiu, as doenças, eu acho que os sentimentos, hoje os seres sentem diversas coisas, a gente não tem nome para as coisas. É tipo: tristeza, fraqueza e alegria. Só existe isso. Eu não posso sentir um meio termo? Primeiro eu acho esse ponto. Outro: eu acho que nem tudo é depressão nem tudo não é. Eu acho que existem variações de coisas na nossa vida que a gente ainda não consegue... não sei se é dar um nome, qual seria a palavra a respeito, entendeu? Porque não encaixa nem só aqui nem só ali. São outras coisas que a gente está vivendo, entende? Eu acho que falta um avanço nesse sentido, porque a pessoa fala "putz, mas eu não estou com depressão", ou tipo "não posso estar triste um dia". Mas será que não existe uma variação? Você não precisa ser uma pessoa depressiva mas tem um dia que você está sentindo algo que não tem nem nome ainda. Então, é por isso que eu falo, para mim a coisa assim que me gera, sabe, pensamentos milhões de...A gente tem que voltar muito ainda para dentro do ser humano, olhar outras questões porque não está dando para definir. A gente não tem hoje palavras, estudos e eu acho que..., não sei o que é, para conseguir...porque tem muito mais variação. Tudo evoluiu, agora, os sentimentos do ser humano não, continua tudo com o mesmo nome, e aí é depressão.

(Falatório)

P5: a depressão é coisa nova...,mas eu acho que você tem graus de depressão, você entendeu?

P10: Isso e outras coisas também, só que tipo ou a pessoa é classificada assim, ou ela é assim, e não é assim.

P9: Eu acho que tem outro sentimento de tristeza natural que é excluído. Ninguém pode ficar triste. E é normal, eu entendo hoje como algo normal. Quando acontece algo ruim, ou você tem alguma perda, é normal e é saudável você poder ficar triste e conversar com alguém. Mas isso é excluído, eu acho que isso, parte do tabu começa daí. Então se você vai procurar um amigo e você está feliz ok! Mas se você está triste, você é excluído.

P11: O despertencimento também, né? Quando você não se identifica com nenhum grupo, quando você acha que ninguém entende o que você sente, né? Um pouco disso que ela está falando que é...., mas isso eu acho que isso todo mundo sente, porque gente, cada um tem a sua história, cada um teve as suas dores, cada um passou pelos seus traumas, então você nunca vai encontrar alguém que saiba exatamente o que você sente, e é por isso que não tem o nome, porque não existe. Assim como cada um tem a sua impressão digital, eu acho que o jeito que a gente sente é muito pessoal e não existe nome, não existe... né? Então, se eu ando de uma forma, ou se eu me visto ou se eu falo, é por tudo que eu passei, pelo acidente que eu sofri, pelo estupro, pelo suicídio... por tudo! Entendeu? Porque às vezes as pessoas questionam, e aí nem a gente sabe porque a gente faz aquilo, mas quando você buscar... não, eu parei de andar sozinha, por causa disso ou daquilo, né... então eu acho que tem essa questão do despertencimento de talvez você ter tanta dor e tantas coisas que as pessoas não passaram que você nem fala, né? Porque acha que não vão te entender. Aí você vai se fechando ... e é isso 
P7: eu acho que esses grupos que nós estamos como esse e outros que a gente tem em vários lugares, é um lugar de pertencimento porque toda vez que eu vou num grupo desses eu me sinto assim, não é que digamos estou à vontade, mas eu me sinto bem situado porque eu vejo que eu diante de pessoas que tão vivendo histórias parecidas e que estão tendo o sofrimento parecido, a angústia parecida, as dúvidas, as indagações parecidas, então eu de alguma forma eu me sinto acolhido. E eu também me sinto à vontade de ir acolher, eu vejo por exemplo vocês como os meus pares, são os meus iguais, então é um momento que nós estamos encontrando com os nossos iguais. Aqueles que entraram nesse mundo, no mundo dos sobreviventes. Nós temos até esse rótulo né?! Então a gente consegue. Nossa! Existe um mundo que é o mundo dos sobreviventes, e eu vejo a cara deles, eu vejo eles falarem, eles sentirem. Então, essas dinâmicas essa... e outras e ocorrem no (local onde ocorrem grupos), no (local onde ocorrem grupos) eu acho que são muito boas, e eu acho que esse é o caminho, é buscar esses lugares porque a gente vai se reconhecer.

P11: Mas a gente está aqui é porque a gente passou por isso,

P7: Isso... só isso que nos une aqui...

P11: isso que eu acho que para quem chega a se matar, quer dizer, ele não sabe, ele não, ele não... porque não é falado. Então ele não sabe que existe um grupo desse que ele pode procurar, e que ele pode se sentir bem e acolhido e respeitado, e falar que...

\section{P7: Entendido}

P11: ...é exatamente, e eu acho que é aí que falta...

P4: eu vou tirar por mim... em reportagens, que eu acho que é meio o tema abordado aqui, que eu leio mais em reportagem que eu procuro ler, e eu acho que dão um pouquinho menos de valor, as reportagens normalmente dão um valor aos casos, né, como foi. Para mim eu vou para a última parte, quando se é falado o que a gente pode fazer, praticamente. Porque aí fica mais claro nos tópicos. Olha, te deixa a disposição, eu vou muito naquilo porque como eu não soube fazer antes, eu tento então saber como fazer agora. Então eu acho que teria que ter mais reportagens, a reportagem dar mais ênfase, até para um leigo num falando, tentando falar né com nenhum profissional, que as vezes quem vai estar lendo na sua casa você não vai ter um profissional . Como pelo menos de princípio como ajudar mais né, porque é isso que a P2 falou, que a gente não sabe o que fazer. Então eu gosto muito daquela parte da reportagem aonde está ali bem claro, ali...

E: quando tem né

P4: Então...,mas a maioria não tem. A maioria sempre, não estou criticando as reportagens, mas eles dão muito ênfase ao que está acontecendo. Agora está tendo muito por causa da baleia azul, do seriado, vai ter setembro, já começa no final de agosto já começa as reportagens..., mas eu leio mais assim é como agir. Então, uma mãe que está lendo ali, que percebe ali, ... que nossa, meu filho... 


\section{E: quer dizer orientações né?!}

P4: As orientações práticas para o leigo né eu acho que isso seria muito importante.

E: É, num próximo encontro a gente vai conversar muito sobre as sugestões que vocês têm de aumentar a consciência pública. Como que vocês acham que essa consciência pode ser aumentada. Vocês acham que falando mais sobre o assunto, aumenta a consciência pública? Se isso influenciaria na prevenção e posvenção do suicídio?

Vários: Sim, sim, sim....

P7: Eu acho que um dado muito importante é fazer as pessoas perceberem a quantidade de mortes que ocorrem a cada... a cada segundo ou a cada minuto né? Então isso é algo acho que eu considero importante porque quando eu falo para a pessoa: "Olha, enquanto a gente esteve conversando, agora, já morreram umas dez pessoas.

P4: estatisticamente é chocante então né.

E: a estatística é...

(Falatório)

P7: Para a pessoa perceber a grandeza, a dimensão, eu inclusive me permito, e aí eu sempre falo isso a título de conjectura pessoal que para mim, a minha convicção pessoal é que a maior causa de morte provocada da humanidade através da história é não só agora, é e sempre foi o suicídio. Mas é que sempre é ocultado, é uma das maiores, mas com certeza ela é a maior. Porque as outras, estatísticas... são colocadas estatísticas fiéis, e não tem tabu em cima. E aqui não, é tudo escondido. E eu falei... eu me permito acreditar que talvez a humanidade, a maior causa de morte da humanidade é o suicídio. O que é um grande paradoxo. E eu acho que se um dia as autoridades, os formadores de opinião, enfim, as elites pensantes, enfim, começarem a admitir uma possibilidade como essa... paradoxal, contraditória, assustadora, eu acho que a gente revoluciona, a gente muda, não sei.

\section{E: Você ia falar um pouquinho}

P8: Não, é que... eu não sei se... Eu acho que no falar, ele é tem alguma coisa que ainda eu ainda não consegui pensar muito bem, é a respeito sobre essa questão da prevenção. É.... e de que a prevenção ela está mais na mão da própria pessoa do que na dos outros. Então que também tem essa coisa, eu acho que falar é importante para que as pessoas que pensam nisso entendam também a consequência daquilo. E mais do que falar para que os outros em torno, porque possam detectar, porque senão também tem aquela paranoia. A pessoa então começa com alguma coisinha todo mundo já "ah, ah..." mas sabe, tipo... a gente tem que ficar atento com uma série de coisas. Na minha família isso é um assunto, de um dos lados, é um assunto que se fala abertamente. Do lado do meu pai não. Do lado do meu pai ninguém fala a palavra. Do lado da minha mãe não, então já tem aquela coisa... a gente está com um primo que está com uma depressão muito profunda, o pessoal está de olho. Mas também não pode ficar com uma paranoia 
em cima, de tipo qualquer coisa, mas eu acho que a prevenção ela passa mais o poder falar abertamente sobre isso, é mais importante para a pessoa que pensa no assunto, do que propriamente para as pessoas que estão no entorno dela, né, é mais isso... (01:22:24)

P9: Eu quero acrescentar uma coisa: no ano passado, eu fiquei alguns meses como voluntário do CVV. Então assim, eu não posso falar nenhum nome do CVV e nem nada dos casos que aconteceram, eu só posso falar da minha experiência. Eu fiquei um tempo atendendo ligações das pessoas que ligam, que procuram né, e a minha experiência assim foi de que a maioria do que é falado, e que as pessoas sentem angústia porque não tem com quem conversar..., porque são coisas cotidianas, então o que eu percebo e que eu acho que a grande dificuldade que a gente não relaciona esse cotidiano com digamos o fato em si é de que as pessoas não tem espaço pra falar do que elas estão sentindo: pergunta o que aconteceu, ou como foi o seu dia, ou falam de coisas práticas. Mas quando a pessoa tem algo, que ela não sente à vontade de falar com alguém da família, com amigo, com marido, com esposa, com filhos, com os pais, isso é o que vai acumulando aí chega num ponto que a pessoa chega a tirar a própria vida. Então, o que eu senti de grave, e aí eu estou tentando trazer isso na minha relação pessoal dos amigos, é que mesmo com os amigos quando eu vou conversar, eu percebo que eles não conseguem relacionar que não falar do sentimento, tem vínculo com chegar nesse ponto, que a angústia pode acrescentar até que chega a gota d'água de algo que acontece, mas que é, muitas vezes, só o desencadeador do fato, mas é falta de espaço de falar dos sentimentos. Isso que você falou de tem sentimentos que a gente não sabe nem nomear, e acho que a gente tem uma educação emocional muito pobre de forma geral, e acho que isso, está na causa do tabu. Então a dificuldade, por exemplo, eu encontro amigos e às vezes a pessoa está passando uma angustia grande, mas ela não consegue falar, ela não foi educada, eu também não fui, então eu estou fazendo esse exercício. Existe um tabu de falar o que está sentindo, que é visto como uma pessoa fraca, com defeito.... É excluído $\operatorname{sim} .$.

E: E como vocês gostariam que o suicídio fosse visto pela sociedade então? (1:24:40)

P5: Olha eu acho que já é bem visto hoje, porque eu sou um pouquinho mais antigo né, porque o que acontece? Na nossa época o suicídio era um... a família não comentava. Todo mundo escondia, todo mundo guardava aquilo, desaparecia e ninguém sabia nem o que aconteceu. Era proibido falar suicídio. A família era excretada da sociedade. Toda a família daquele que suicidou-se. Não existia, era um disparate.

P7: era um disparate

P5: principalmente o que eram mais idosos, que se suicidavam e geralmente amante ou financeiros o problema. Antigamente era esse o problema. O que acontece? E isso era proibido, era terminantemente proibido... não podia comentar em casa que o vizinho se suicidou, meu pai vinha e me dava uma surra.

P3: Tinha cemitérios que não se podia nem enterrar.

P5: Não podia enterrar, é verdade. Igual uma coisa que pouca gente sabe, Santos Dummont suicidou-se, né? 
P7:Sim.

P5: E ninguém divulga isso, né? .

P7: Ah, não. Mas isso....

P5: Ele suicidou-se no Guarujá. Só quem passou por isso sabe, se você fizer uma pesquisa aí de quem não passou por suicídio, você vai ver que $90 \%$ não sabe do que Santos Dummont morreu, de tanto que era escondida a coisa.

P7: Não, mas hoje já se fala muito mais...

P1: já se fala muito sim... eu...

P7:que Santos Dummont se suicidou.

P5: Sim, hoje se fala mais de suicídio... eu estou falando como era antigamente.

P7: há, no passado... entendi... entendi...

P1: não se fala assim como creio que se fosse mais como...a minha esposa está fazendo psicologia então, no mundo dela, na faculdade tudo... a quase toda semana tem temas que envolvem suicídio. Na faculdade se fala bastante, pode não ter uma disciplina sobre isso, mas, se fala bastante. É palestras e tal tal tal. Mas são grupos fechados né, dentro da universidade. Não leva pra fora né... a gente espera que... Mas mesmo assim a gente já vê que já tá que está mudando, você vê que se fala mais, já sai na televisão, é tem canais que vai... a Globo não pode falar...ou só a partir de tal horário, tem umas normas né.

P4: fala junto - os famosos, pelo menos ela falou... ??

P1:Então eu acho que isso, por exemplo a parte da manhã é hora que tem muito ?, você não pode falar isso no jornal nem nada.

P7: No mês de prevenção ao suicídio do ano retrasado, saiu uma matéria que inclusive um dos que foi entrevistados fui eu, foi no (nome do programa e do canal), que é o jornal (período do jornal).

P1: que dizer a Globo não faz...

P7:Saiu. Saiu também, na mesma (nome do canal e nome do programa) que eu também contribui...na do no passado...também no dia mundial da prevenção ao suicídio, no início da noite, as 7, 8 horas da noite, que é o (nome do programa)

E: Há duas semanas, naquele programa da Fátima Bernardes foi falado de suicídio. 
P7: de dia....

falatório

P7: Hoje no jornal da (nome de emissora de tv) eu vi a sua entrevista, eu vi... eu ate gravei... eu vi a sua entrevista, ela deu uma entrevista né, explicando a questão do suicídio, então isso já é uma vitória, né? Ah,(nome do programa) quis fazer um trabalho sobre a questão do suicídio em 4 semanas, eu ia participar de uma delas e depois a cúpula da (nome do canal) vetou. $\mathrm{O}$ (nome do repórter) comprou o negócio, veio a moça, lá, que me entrevistou tal e depois veio explicar lá no mês seguinte que a cúpula apagou ...

E: Então assim, vocês estão falando que hoje já se fala mais do que falava antes!

Falatório: - a sim, bem mais.... até na hora do....

E: Mas como que vocês gostariam que fosse falado? Como que vocês gostariam que a sociedade falasse sobre o suicídio? Como vocês gostariam que a sociedade visse o suicídio? (01:28:29)

P7: Então, eu acho que tá faltando só falar, eles pegam uma entrevista e eles me exploram na parte informativa e aquela coisa e vai retratar o episódio, e os depoimentos profissionais, agora saiu uma revista da (nome de revista) muito boa, tal. Agora... nenhuma abordagem tá sendo feita de mostrar a dor e o sofrimento dos que ficam. Porque fala só em estatística, que é em média 6 pessoas ficam impactadas por aquele suicídio... em média, 6 pessoas. Mas não falam como é que é o impacto, que essas as famílias ficam destroçadas, enfim todos desgastes que cabem em eventuais suicídios dessas pessoas. Por exemplo aquela moça jovem que o pai se suicidou lá na Europa e por causa disso ela criou aquele projeto, "semicolon Project" ou "Projeto ponto e vírgula", eu vou tatuar o ponto e vírgula, até nessa matéria da (nome de revista) eu falei "eu vou tatuar eu vou incorporar isso". Ela levou avante por anos e sucumbiu ela também se suicidou. Ela não aguentou, ela também se suicidou. Então eu mesmo uma vez numa reunião do (local de atendimento), eu vi o impacto que eu causei a uma moça da mesma idade da minha filha, só de começar a relatar né, que eu relatei que minha filha com 18 anos, até então ela tinha ouvido os outros relatos e quando ela ouviu o meu ela desabou. No final ela me abraçou e falou palavras agradecendo e tal... enfim, e eu sei que aí aquela moça diante do que ela viu do que o pai se tornou, ela jamais, ela não vai mais fazer isso porque ela sabe como é que o pai dela, a mãe dela vai sentir o sufoco todo.

E: como é que você gostaria que o suicídio fosse visto na sociedade?

P7: Então, tem que ver... tem que haver... onde eu quero chegar é que ao eles abrirem essa possibilidade de externar também o problema é o anonimato né, esse é o problema, mas tudo bem. É o direito. (Participando gaguejando muito) eu sei... Mas eu sinto como eu estou sendo aproveitado nessa parte, mas eu acho que se os prováveis suicidas conseguirem atinar no mal, em como destroçam a família e as pessoas que ela mais ama...

P5: (fala junto) ... e os amigos e todos que estão em volta...não são 6, são muito mais 
Homens: falam junto

P7: ...como ele vai acabar com a vida daquelas, a vida daquelas pessoas daquele jeito, nunca mais vai ser a mesma, né, o grau... E se elas tivessem noção como essa moça teve, é isso que eu quero mostrar, seria um ótimo elemento, um elemento de impacto, né. É como o cigarro que eles colocam o maço de cigarro mostrando como é que o cara fica e tal, ajuda. Tudo bem. Vai ter gente que vai pegar aquilo e vai pegar e vai fumar, mas com certeza tá ajudando. Então eu acho que mostrar né e, é claro que isso vai demandar eventualmente, e eu fíco feliz com que aconteceu nessa revista (nome da revista) apesar de eu ter sido entrevistado eu não fui aproveitado. Eles me disseram que como eu saí na outra entrevista..., porque outros abriram mão do anonimato, então estão havendo outras pessoas, além de mim, que estão abrindo mão do anonimato, e isso é legal, porque quando a sociedade começar a ver a cara dos que ficam, a dor dos que ficam...

E: então você tá falando assim, que, ao invés deles usarem somente informações sobre o fato, como eles costumam utilizar...

P7: (fala junto) - não invés, além...

E: ... isso, além, colocar da dor daqueles que ficam?

P7: Isso, a dor dos que ficam

Mulheres: falam junto

P4: Eu discordo um pouquinho, porque eu acho se a gente falou de todo esse processo que a pessoa está passando, isso aí não... eu acho que estatisticamente vai ser difícil...menos do que você acha que vai atingir. Eu acho que o processo interno da pessoa a dor é tanta que ele não vai prestar atenção naquele momento quem tá passando...

P1: (fala junto) - a dor maior é ele

P4: A dor é ele, ele porque senão todos aqui os nossos filhos amavam a gente. O meu deixou cartas, o que a maioria não deixou, o meu deixou muitas cartas... que a gente não tinha culpa, que ele amava, que o P5 era exemplo de pai, que ele queria ser igual a ele, então assim, ele deixou. Tanto que eu falei muito na revista talvez porque aproveitaram. Porque ela viu... assim, ela leu as cartas... a menina. Então, ele deixou muito claro... então que a dor era tamanha que ele não sabia o que fazer com ela. E meu filho tinha um fundamento religioso também, não ia falar que ele era um adolescente que nem pensava em nada . Não, ele tinha um medo, ele tinha... e falava "vou pagar por isso mas eu não estou conseguindo lidar com a minha tristeza", então eu acho que no momento que eles estão passando a dor... não seria...

E: então mostrar essa relação bem forte entre o suicídio e dor.

P4: É e eu acho que pra mim basicamente assim começar a tratar como saúde pública.

P7: Ah, sim... 
P4: Isso seria o ideal...pra começar... (01:33:46)

E: Então, a forma... a gente tá pensando: como a sociedade, como vocês gostariam que o suicídio fosse visto pela sociedade. A gente ainda não está na forma como a gente vai chegar lá, mas como que vocês, que ideia... então, de que é motivado por uma dor muito grande que ela ultrapassa o sentimento...

P4: (fala junto) - o amor... pelos familiares...

E: que se tem pelos outros, que causa muita dor também...

P7: mas eu acho que tem que ser falado viu...

P4: (fala junto): Não, também.

P7: mesmo que, mesmo que seja em vão...

P5: (fala junto) - acho que todos os temas... pra todos

Falatório:

P4: Se o ser humano esta passando a dor é tamanha ele não consegue enxergar, ele não consegue resolver a dor interna que ele tá tendo, ele não vai conseguir naquele momento lembrar que o pai e a mãe vão sofrer.

P5: só por isso que ele falou você não vai resolver o problema, ...

P7: (fala junto) - é, não, mas vai ajudar

P5:... mas vai ajudar, é, mas só por isso... não resolve

P7: (fala junto) - mas vai ter gente que vai pensar mais vezes...

Falatório:

P4: Acho que saúde pública... precisa começar... que os políticos tratar como saúde pública e a parte psiquiátrica, desmistificar que o psiquiatra é médico de louco, que o lugar...ter mais lugares pra quem não tem condições financeiras,

P5: (fala junto) - isso é legal...

(?) - ... principalmente...

P4: porque a gente está com esse problema, você sabe, lá do (nome de uma pessoa), então assim, uma pessoa, a gente está vendo, uma pessoa de classe média hoje... não é nem uma pessoa de 
classe muito baixa vamos dizer, de classe média não consegue as vezes manter em uma clínica ideal. Porque está tendo... está dopando o filho, o filho né, não está tendo assistência, está simplesmente jogando o ser humano lá e fala: "toma remédio aí, dorme, para ver se você se acalma". Então é isso que eu estou achando, que é uma questão de saúde pública. De ter mais... O governo começar a pensar que tem que ter hospitais... tratamento, para quem não tem condições de pagar uma clínica elite, né, desmistificar psiquiatra que é médico de louco, de que não, de que é uma pessoa que você pode tratar, psicólogos... os psicólogos eu acho ainda que o acesso é mais...eles gostam mais. Acho que quando está também né o psicólogo é mais leve (?) né do que o psiquiatra. Que às vezes medicação é necessária e o jovem acha que não, o mais velho: "Oh, eu estou ficando louco"...

E: quer dizer, as formas de tratamento.

P4: as formas de tratamento... tem que desmistificar... que nem, uma coisa que o P5 falava muito para o (nome do filho).

E: (fala junto) - aonde ele acha o tratamento...

P4: quando deram o medicamento para ele. O P5 falava muito: "(nome do filho) você tem que canalizar o seguinte: se eu não tenho problema de coração enfartei eu não tenho que tomar a vida inteira o meu remédio?

P5: É porque quando ele começou a tomar remédio psiquiátrico fica não... eu não vou tomar isso a vida inteira eu não posso tomar isso a vida inteira

(Falatório)

P4: Aí o P5 falou assim, se você tiver que tomar a vida inteira e se ajustar com o medicamento, você tem que tomar a vida inteira e não se preocupa com isso. Diabético não tem que tomar insulina? Então o (nome do marido) usava muito isso para ele... desmistificar também essa coisa do remédio.

E:... vamos lá...

P11: É um pouco do que eles estavam falando com relação à dor de quem fica eu acho que mais do que você colocar a dor como porque talvez a pessoa sinta o peso da responsabilidade, quer dizer, "poxa nem me matar eu posso né, eu estou sofrendo tanto e eu ainda tenho que ficar aqui aguentando tudo isso só para o outro ficar feliz?" Mas é de saber que ali tem tanto amor que aquelas pessoas estão dispostas a ajudar né, então que ele pode contar. Então assim, nós estamos aqui, nós vamos sofrer porque nós te amamos e nós queremos te ajudar né, então no sentido de envolver a família envolver...

E: ou seja, ele não está sozinho.

P11: Ele não está sozinho, porque eu acho que tem muito essa dor. Essa grande... eu vejo pelo que eu passei né, de que eles não sentem entendidos, não se sentem pertencentes, quer dizer, 
"poxa, eu estou aqui, a minha dor é tão grande, ninguém faz nada por mim, então eu vou embora" né, talvez. É um pouco do que eu vi né, então, meu sobrinho era dependente químico, é uma outra questão de saúde pública porque um adolescente não tem tratamento, simplesmente não tem está. Para você internar tem que ser maior de idade, é clínica para dependente químico tem um monte, mas para menor de idade não tem, entendeu? As pouquíssimas que a gente encontrou a gente não tinha condição de manter. E ele passou por duas: uma teve um incêndio que morreram acho que sete pessoas, acho que eu te falei disso e na outra ele se matou né. Então de três clínicas, uma a gente não tinha condição de pagar, uma ele disse que estava sendo agredido, e a agente até...eu até duvidei, mas depois que teve um incêndio e as pessoas morreram e eu vi o depoimento de pessoas que estavam lá e que relataram tudo o que ele falava para a gente, e na outra ele não era cuidado né, então não tem tratamento. Então, quer dizer, ele tem uma doença que tem a dependência química além da depressão, quer dizer, que se foi para droga tinha alguma coisa. E a gente não conseguia tratar porque simplesmente não tem opção.

E: ...então visto é trabalhado de uma forma multifatorial.

\section{P11: Com certeza.(01:39:02)}

P9: Sobre a pergunta "como eu gostaria que o suicídio fosse visto na sociedade?" Eu gostaria que fosse visto como algo que não é distante, que é um tema que envolve todas as pessoas. Mesmo as que não passaram por isso. Que eu acho que esse é o maior problema, porque senão, vamos supor, tem uma palestra, tem um artigo, quem nunca passou acha que não tem nada a ver com ela. Nem vai ler, nem vai se interessar. Então eu acho que esse vínculo que é o presente, sei lá, de novo, eu não sou especialista, estou aqui como voluntário, mas uma das coisas que eu aprendi lá no CVV, é de que é muito mais comum do que a gente imagina, passar pela cabeça da maioria das pessoas o suicídio. Só que ninguém fala, e aí ninguém vai admitir isso socialmente, então é esse tipo de coisa que fica guardado e a gente acha que não tem nada a ver com todas as pessoas, não só os envolvidos é que eu acho que é uma das causas para que culturalmente a gente não consiga fazer a prevenção. Que quando entra o trabalho de prevenção... não tem nada a ver comigo, não vou ler, não me interessa... se o amigo fala não quero nem saber.

P11: (fala junto) - ... eu não preciso...

P1: É o caso do, quando você vai na página do seu amigo, que que te dar algo da prevenção de mama né, aquele negócio de mamas ou então de drogas, não é só para quem está viciado né, é também para quem né...então é para ser uma coisa no geral. (01:40:31)

P5: posso falar uma coisa que não tem nada a ver, mas é rapidinho... só? (risos) O pessoal sempre tem essa mania né, só porque é dos outros, dos outros não quer nem saber. Não sou favor do aborto, mas há muito tempo atrás teve uma pesquisa para liberar o aborto no Brasil, aí chegaram a seguinte conclusão da pesquisa, que jamais seria liberado no Brasil, por que? Porque só a mulher quer fazer aborto, o homem não quer, então não é problema do homem. Se você pensar como o suicídio está.... Aí o que acontece...estava lá na faixa etária, quem tem menos de 15 anos não ia engravidar naquela época, é bem antiga a pesquisa... então ela é contra porque também não ia engravidar está. E quem tinha mais de 40 e tesava entrando na menopausa, das mulheres, também são contra porque elas não passariam pelo problema. Então, só quem votaria a 
favor seria de 18 a 40 anos, portanto nunca foi aprovado. Eles pouco ligam para o problema dos outros. A sociedade tem que se conscientizar que o problema do suicídio é de todos. Não é classe financeira, não é cor, não é credo, não é nada. De que todos tem esse problema. Só que o pessoal tem a mania de ver o problema como dos outros sabe, é bem típico né, é dos outros é dos outros. Não é nosso. Então tinha que ter uma conscientização para todos se envolverem no problema.

Burburinho

P10: Acho que o que ele falou realmente, acho que se a gente associasse o suicídio a coisas normais do dia a dia, talvez as pessoas conseguissem criar mais empatia com o tema. Assim... de... é que suicídio é uma coisa assim que é tão difícil né de identificar os sintomas, mas talvez se a gente conseguisse trazer o suicídio linkado a temas mais normais, sentimentos, ou assim, relatos de coisas que a pessoa pode ver e falar: "Putz, eu já senti, eu já ouvi de um amigo, tal, talvez ela tivesse mais interesse no tema. Porque, quando você fala de suicídio talvez ele pense: "Putz, uma pessoa que é louca está com muito problema" e a pessoa não, talvez não crie empatia, eu não sei. Abordar o tema de alguma forma que traga empatia, para a pessoa ter interesse em saber, ler...não sei, se envolver mais. Não achar que é uma coisa tão distante. Porque acham que é assim, uma coisa nada a ver que nem existe no mundo. Eu, é aquilo, eu não sabia que isso existia, eu não tinha...

P2: acho que todos nós fazíamos parte dessa fatia do bolo... eu acho que até bem pouco tempo nós fazíamos parte né dessa grande maioria aqui né, que não imaginava o suicídio como uma coisa real.

E: Quer dizer, talvez a sociedade veja o suicídio pode acontecer em qualquer lugar com qualquer pessoa e todo mundo pode ser tanto responsável por ajudar alguém com a prevenção, como também pode acontecer em qualquer família.

P2: sim

P1: sim

P11: Uma coisa que me ocorreu na fala dela é que talvez se a gente tivesse relatos de sobreviventes, mas não os familiares, por exemplo a minha irmã falando, quer dizer... o que que... como aquilo impactou a vida dela e porque ela desistiu de desistir? Entendeu? Talvez... Com certeza tem pessoas famosas que tentaram, que ninguém nunca fica sabendo, então assim, talvez levantasse o tema de uma maneira que as pessoas pensassem assim "não, isso acontece com todo mundo e eu posso buscar um tratamento, eu posso sair dessa."

P10: E com transparência sabe, acho que faz exatamente as coisas que você sentiu. Para não achar aquela coisa: "Nossa, aquela pessoa que se suicidou sentiu uma coisa... uau."

P11: Que nem a Luiza Brunet, que foi agredida pelo marido, quer dizer, as pessoas estão falando "oh, eu fui estuprada, oh, eu fui agredida, oh, ..." não estão mais escondendo. Eu vejo isso das mulheres agora né. E eu acho que a gente pode viver isso também com relação ao suicídio, ... 
E: (fala junto) - através de quem passou...

P11: ao suicídio... de quem passou.

E: desculpa P6... (01:44:17)

P6: ...eu tenho uma visão assim acho que até um pouco utópica. Mas eu sou muito sonhadora eu prefiro acreditar nela, mas quando eu era criança eu lembro que minha avó falava muito "Aquela doença". Que é o câncer. Não podia falar câncer. É aquela doença. E não podia nem apontar aonde a pessoa tinha, porque senão você corria o risco de ter. E hoje as pessoas falam muito mais abertamente. Eu tenho uma visão utópica de que a pessoa chegue e fale: olha eu estou pensando em me suicidar, mas que a sociedade como um todo também não se espante ao ouvir isso. Que ela seja tão informada que ela consiga colher esse sofrimento da pessoa. Então por isso que eu sempre volto na informação, porque o sofrimento mental ele não é validado. Se você chega na sua empresa e fala assim "eu descobri um câncer" todo mundo tem dó de você: "Você precisa de alguma coisa?" ... se você chega e leva um atestado de depressão, é vagabundo, não quer trabalhar. A primeira oportunidade que a empresa tem o que ela faz? Manda embora. Isso é uma realidade né? É assim, eu vivo isso, no trabalho, em todos os lugares que eu já trabalhei eu já convivi com pessoas assim, que na primeira oportunidade o $\mathrm{RH}$ mandava embora porque está dando muito atestado. Está com depressão. Ou com qualquer outra coisa, né? A doença mental ela não é validada, né..., mas é por causa do preconceito, é um mito, é o tabu. A pessoa pode ter qualquer doença que ela não escolheu, "ah, mas a saúde emocional?" Não, você pode evitar, né? "É falta do que fazer né?! É falta do que se animar". Então eu vejo que a questão da informação ela tem que ser trabalhada. Eu pego uma fala da P10, quando a gente vai dar palestra de prevenção, de informação em escola infantil. "Mas como vocês vai fazer prevenção de suicídio em escola infantil?" A gente ensina as crianças a nomearem os sentimentos, a gente trabalha aqueles bonequinhos do filme "Divertidamente" para que a criança saiba nomear o que está sentindo: "Ah, olha, hoje eu estou triste ok?" Tudo bem, é normal ficar triste de vez em quando né, mas hoje as pessoas não sabem nomear o que elas sentem, elas não conseguem dar nome, elas não conseguem explicar, mas não conseguem pessoas que também as escutem, em sua grande maioria. As pessoas estão muito ocupadas, né. Elas não têm tempo para ouvir...

P10: Elas não aceitam o que elas sentem, não é nem só renomear, mas é tipo reconhecer e falar "Nossa, eu estou sentindo isso" e é exatamente isso. E tudo bem!

P6: (fala junto) - exatamente, exatamente...

P6: E daí como o suicídio é algo que foge da nossa compreensão, muitas vezes o que acontece a pessoa ela sai de lá, ela não quer saber, ela não quer ouvir, eu tenho outro paciente mais grave para cuidar do que esse que está pensando em tirar sua própria vida, mas eu sempre volto na questão da informação. Eu tenho um sonho de que fale muito sobre isso. Que deem informações, não só prevenção. Porque assim também como ela falou e a gente sabe, tem situações que não vai prevenir, infelizmente tem suicídios que eles vão acontecer né. Só que é assim, a informação: as pessoas precisam ser informadas, todas elas. Quando eu passei por essa perda foi muito difícil, porque ligaram 5:30 da manhã em casa. "Você precisa vir aqui! ". Mais ou menos assim: "Oh, 
seu paciente se suicidou e agora você vem aqui atender a família" foi isso que fizeram comigo e eu estava destruída. Eu não tinha condições de ir para o hospital e atender aquela família. Mas eu fui, mas naquele momento eu precisava de ajuda. Meu marido falou "você não vai sair de casa, olha para você? Você vai fazer o que lá?" Aí eu falei: "não tem ninguém, eu preciso ir" e eu fui. Então assim, é cobrança de todos os lados. Já sei...e isso aconteceu de sexta para o sábado. Sábado de manhã eu fui lá, eu atendi a família e na segunda feira eu fui trabalhar. E assim, a empresa não me chamou, a empresa não perguntou se eu queria um ou dois dias, se eu precisava de ajuda, e eu estava péssima. Fiquei dois dias no quarto sem comer porque foi muito assim, foi terrível para eu passar por essa situação. Falta de informação. O RH da empresa não sabia o que fazer comigo, a equipe toda destruída, ninguém sabia fazer nada, ninguém sabia nada cara...

P7: (fala junto) - é um tsunami... é um tsunami... não tem jeito

P6:... Falta de informação... então assim, eu sempre volto na informação, então eu acho que a informação ela vai ajudar e muito, não só a prevenção, porque as vezes não vai prevenir, mas todos impactados...

E: Eu não sei você P6, mas eu não tive nenhuma aula de prevenção de suicídio na universidade toda.

P6: Nenhuma. Nunca tive.

P7: Hã!?

P11: Era isso que eu ia falar...

E: Não se tem aula de prevenção de suicídio nas universidades de psicologia. Ela (sobre a esposa do P1) ainda está tendo, é um currículo novo.

(Falatório)

P1: não é matéria...

E: a matéria não tem?

P1: não, matéria não tem, é palestra...

(Falatório)

P8: eu ia falar exatamente sobre isso, porque muito psiquiatra não está preparado para tratar disso. Eu já ouvi de um psiquiatra coisas, já ouvi absurdos, assim. Eu vou ao psiquiatra há muitos anos, a gente até lá em casa sempre brincou que é o médico da família sempre foi o psiquiatra, meus irmãos vão e tal, meu irmão ia, meu outro irmão a gente tem, hoje a gente conseguiu achar um que a gente confia muito. Mas a gente ouviu muitos absurdos ao longo da vida, e uma das coisas é aquela coisa, "eu estou aqui para tratar a vida, e não para tratar a morte". Então ele já fecha aí uma porta de que a minha educação e minha formação foi feita... se você 
está interessada em morrer, não fale isso comigo. Essa, essa é a parede também, se a pergunta é assim, que o que você acha que tem que mudar, então eu acho que o próprio sistema de saúde, ele... mesmo psicólogos, é muito difícil você achar alguém que acolha e que ouça. Hoje eu encontrei, mas a gente sim...o meu irmão passou por uma... meu irmão estava desesperado procurando uma forma de sair daquilo e simplesmente não conseguia encontrar, não conseguia encontrar...

P4: O meu filho ia e falava de outras coisas, e nenhuma psicóloga chegou, me chamou das que ele foi... chegou e me chamou lá para me falar: "olha, corre-se o risco." Porque não conseguia tirar dele,

P8: (fala junto) - e mesmo se conseguisse... se ela ia fazer algo que (?)

P4: ... e aí a única pessoa que me falou foi uma psicóloga que na verdade nem atendeu o meu filho. Ela me atendeu porque eu tinha marcado três sessões com ela e ele não foi. Ela foi indicada por uma amiga minha, e aí na terceira eu fiquei com muita dó, era fora do horário dela, e eu peguei o carro fui, eu falei "fica com ele que eu vou" e meu filho me ligou bem na hora: "Não traga ninguém. Eu não vou falar com ninguém". Ela ainda estava no... Isso foi uma semana antes, ela foi a única que se preocupou, assim escutando o meu relato, ela nem tinha visto, e ela me ligava outro dia e falava "olha, eu conversei com o psiquiatra assim, se você sentir necessidade vamos por ele numa clínica" Ainda ela me orientou que eu nunca vou esquecer: "Pega o seu colchão e dorme com ele, põe no quarto". Mas assim... eu não fiz isso. Porque eu também falei: "Mas ela nem viu, né, ... será que esse caso é tão grave?"

P5: (fala junto) - eu também acho que não ia dar certo você fazer isso...

P4: Não vem ao caso..., mas eu digo é difícil mesmo, é difícil achar alguém que está preparado.

P8: difícil achar alguém que esteja preparado para ouvir e dar a atenção que a pessoa esteja precisando assim...

P4: (fala junto) - ou chamar a família depois a parte, orientar a família.

P8: O quer que seja, eu acho que o que precisa mesmo também é isso ser mais falado dentro das universidades, das faculdades de medicina e de psicologia. É um assunto que ainda ...

P4: (fala junto) - acho que é a saúde pública né como um todo

P8: é exatamente... ele muito precário... a forma como é tratada dentro das faculdades mesmo. Ainda é uma coisa que só aquela pessoa que se interessou e foi atrás, e não é uma matéria.

P5: eu acho que quem passou pelo problema

E: a gente já está finalizando...

P11: outra coisa que vocês tão falando é de perceber ou não...é o depois que meu sobrinho 
morreu, lendo a ficha dele na penúltima clínica que ele passou, tinha que ele tinha acompanhamento lá e tinha coisas que ele escrevia e tinha coisas que a psicóloga escrevia. Tinha uma pergunta lá "pensa ou já pensou em suicídio?" E aí estava escrito assim: "sim, é o que mais penso ultimamente, mas não tenho coragem pois..." e aí não terminou de escrever a frase. Isso o psicólogo não finalizou ali, só que assim, isso não foi comunicado para nós e nem na outra clínica que eles tiveram acesso a isso, porque a ficha foi de uma para outra, não ficou com a gente né, a gente foi receber depois. Isso foi completamente ignorado pela psicóloga de lá também, entendeu, porque se tivesse sido dado atenção, quer dizer, você pega um adolescente que fala que o que ele mais pensa é em se matar, que tem problema de droga e ele está lá, você vai deixar ele horas sozinho dentro do quarto? Entendeu? Então assim, o que que faz com a informação? Também não adianta as vezes a pessoa pede, implora socorro e aí...

E: e aí essa informação é ignorada.

\section{P11: Ignorada completamente}

P5: Posso fazer uma pergunta para ti, qual é a profissão e o que é dos maiores índices, você tem aí dessas pesquisas aí de suicidas?

E: Qual é a profissão que mais se mata?

P5: É

P7: não são os médicos?

E: As médicas.

P5: Antigamente era está, por isso eu queria saber.

P1: não é militar não?

E: Não, não...

P5: Nos anos 80, eu li uma pesquisa, a maior quantia de pessoas que se suicidava era os médicos. Médicas, e sabe qual era a especialidade...anestesistas.

E: Isso, continua.

P5: Continua?

P7: Porque anestesia?

E: Porque eles têm acesso muito fácil as drogas.

P5: eu vi uma outra reportagem, desculpa, eu vi uma outra reportagem... aquela lá que vivenciam muito a morte...? 
P7: Como?

P5: Tem muitas pessoas que morrem com eles

E: vivenciam muito a morte...

P7: há sim, todo médico

E: Eu falei que a gente ia ficar aqui 1 hora e meia e já estamos aqui ha 2 horas, quer dizer, um assunto que a gente ... vai falando, falando...

(Falatório, tosse...)

E: Bom, então hoje a gente vai finalizar. Eu queria agradecer muito. Todos colaboraram de uma forma muito boa. Disso vai sair muita coisa. Tem muita coisa para a gente conversar, ainda, quer dizer, vamos ver o que a gente consegue conversar daqui ha 2 semanas, se não eu mando depois para vocês o que faltou se vocês quiserem completar, enfim

P10: faz um terceiro...

(Risos)

E: ...E eu queria realmente agradecer muito a presença de vocês. Qualquer incomodo, se precisar conversar, precisar falar, entrem em contato... vocês têm os meus contatos, aí, e eu vejo vocês, então, no dia (data), às 7:30 neste mesmo local. Está Bom? Obrigada, gente. 


\section{ANEXO D - TRANSCRIÇÃO - GRUPO FOCAL 2 - TOTAL: 02:15:19 HS}

E: Boa noite. Sejam bem-vindos. Bom, a ideia é de que a gente continue conversando sobre o mesmo tema, que é o aumento da consciência pública, eu trouxe algumas perguntas, mas antes de começar eu queria que vocês falassem só o nome de vocês de novo para poder registrar? Não precisa falar a idade, nada, só o nome e assim, rapidamente, se ficou tudo bem, como é que vocês ficaram depois do encontro, focado no que a gente conversou, enfim.

P1: *******-Tranquilo, normal

P2: *******. Fiquei bem.

P4: *******. E tudo bem, também.

P3: *******. Também foi, tranquilo.

P8: *******. Eu acho que foi tranquilo. Acho que as questões que foram apresentadas foram bem interessantes. Foi muito bom.

E2: *******, sou psicóloga e peço desculpas porque até muitas vezes eu fico calada, mas é porque a experiência de estar aqui ouvindo vocês é muito importante e agradeço por estar aqui de novo.

P9: *******. Eu fiquei um pouco mexido, e até a gente conversou depois, mas agora estou bem. É só comentando acho que (?) Como eu vi que são várias histórias diferentes, aquilo que muitas vezes a gente trás de ideia impacta outras pessoas e vice-versa. São situações diferentes. Isso me impactou.

P10: *******_ Eu fiquei bem. Inclusive eu achei bom que na mesma semana teve uma reunião a mais. Quer dizer... aqui né, mesmo assim, uma vez a mais...

(Risos)

E: Foi um bônus?... Está certo. A gente, na reunião passada uma das coisas que foram levantadas é que antes não se falava tanto e agora se fala mais do que antigamente. Por que vocês acham que isso aconteceu? Por que hoje já se fala mais do que se falava antes? Vocês acham que tem a ver com a imprensa? Com... O que vocês acham que motivou as pessoas começarem a falar mais?

P1: Bem, primeiro porque você não tinha ainda nada acontecendo com você ou com sua família então você não se preocupava. Você passou ser o centro, aí você tem uma maior preocupação, tanto de você vê como de repassar a notícia. No início você fica com aquele impacto de ficar aquilo reservado, mas pelo menos a gente, a gente pois para fora, entendeu, acho que foi uma das maneiras de se dar, é botar isso para fora e não ficar com aquilo dentro esconder, como se fazia antigamente. 


\section{E: Então você acha que as pessoas estão falando mais, então?}

P1: Eu acho que sim. Não só porque você passou por isso, mas.... éééééé porque já assim, ééééé como outros problemas aí, quando começou a AIDS aí a um tempo atrás, não sei, uns 18 anos, então no começo também era um tabu se falar em AIDS né, aí quando passou a ser considerado uma preocupação de saúde pública, então se abriu. Hoje eu sei, pelo menos quem trabalha na área, como da psicologia, da psiquiatria, ou seja, da área médica de um modo geral. Eles tão trabalhando no intuito de levar também a questão da depressão, para mim assim, vai juntando a depressão com o suicídio, com também algo de preocupação de saúde pública, para ter campanhas periódicas para poder, tipo o câncer, AIDS, né. Então isso tem movimento e esse movimento, queira ou não queira, embora seja na área acadêmica, mas chega de um modo geral. Então há essa preocupação hoje de fazer com que se procure dar uma atenção maior a essa problemática, então eu acho assim... está sendo bem mais comentado atualmente

P4: Eu acho que pela própria, pela depressão. Eu acho que começou a se falar muito em depressão, né? Os sentimentos da perda vão existir sempre, eu acho, mas não denominava esse nome e eu acho que de repente começou, de uns anos para cá, a todo mundo sentir, raramente você ouve as pessoas falarem em graus diferentes, mas as pessoas sentem e até tentam por para fora aquela angustia, aquela denominada vários nomes: angustia, tristeza, tal. Quando depressão alguns falam: "Ah, a doença da moda". Não é, mas eu acho que daí começou a falar nisso e isso começou... por que? Eu acho que está muito associado. Isso a gente até na saída daqui a gente foi conversando, aquele dia, porque a gente levantou que as diferenças... as vezes o suicídio dá aquele impacto ou por uma questão econômica, então vamos dizer, mas daí até o * levantou para a gente e, falou assim... mas naquele momento ele falou..., mas é que vocês estão falando em depressão, assim, de uma pessoa deprimida há muito tempo, fazendo um tratamento. Ele falou assim: "Mesmo que uma pessoa esteja com a questão financeira" Aí eu até achei bem colocada dele, ele falou: "Naquele momento ele estava deprimido para fazer aquilo porque se não você vai pensar outras soluções, bom enfim, aí pensar em outras soluções para ou começar de outro caminho. Eu acho que está muito associado por isso que eu acho que começou a falar mais.

P2: Eu acho que a mídia também, né? Como, quando o P1 falou da AIDS, a gente costuma tomar conhecimento da AIDS quando a gente ouve do Michael Jordon e o Cazuza, e ultimamente a gente tem ouvido também né, várias personalidades, né, que morreram por suicídio. E isso faz com que as pessoas parem e pensem: "Puxa, o famoso, teoricamente não tem problema, tem fama, né? Então eu acho que isso leva as pessoas a comentarem, pelo menos, um pouco mais assunto, e a gente sai da casa da gente, né? Que eu tive. Depois que o (nome do filho) se foi eu lembrei que eu tive um primo que se suicidou ha alguns anos atrás e que meu marido também teve um primo que se suicidou. Mas foi tão... as pessoas não falam. A família não falou. E quando é uma personalidade, eu acho que torna tão público que fica difícil a gente colocar um véu e fingir que não está sabendo de nada. Eu acho que acaba contribuindo de alguma forma também para que a gente perceba e olhe para o assunto né, para essa questão.

P10: Assim, a sociedade ela vem..., hoje a gente fala né da globalização é etc e eu acho que isso ajuda bastante porque tá tudo muito conectado, as pessoas ficam sabendo de tudo mais rápido, então desse assunto também, assim como outros assuntos que a gente vai descobrindo e vai vendo né que existe e aí a sociedade começa a tentar a trabalhar em cima, ou por exemplo, uma 
doença, tenta achar a cura... teoricamente... Então eu acho que o suicídio é um assunto também que vem aí nessa...como se torna cada vez mais comum, dele acontecer e hoje com as redes você consegue ter mais informação, eu acho que isso acaba se espalhando bem mais do que antigamente, então eu acho que acaba, assim como outros assuntos também vindo mais à tona. Eu acho que a questão de liberdade de expressão também, acho que os seres humanos eles tem se sentindo acho mais empoderados a falar de certos assuntos que antes eram difíceis. Então eu acho que esse é um assunto também que é difícil que cada vez mais as pessoas assim, não tem mais medo, não tem mais vergonha, assim como alguns outros assuntos difíceis que a gente tem hoje que as pessoas, por exemplo, levantam bandeira e lutam por certas causas que antes não era uma coisa tão escancarada. Você talvez ia sofrer muito mais preconceito ou sofrer muito mais por levantar uma certa bandeira ou tocar em determinado assunto. Acho que a gente, não todos, a gente é um pouco mais livre do que antes, acho que ainda existem países em que muita coisa ainda fica escondida, velada e as pessoas sofrem porque elas não poderem falar..., mas eu acho que cada vez mais a gente tem...te dão mais liberdade, enfim, e não tem mais vergonha, nem medo, nem se sente oprimido por falar de certos temas.

P9: Então como exemplo, particularmente, uns anos atrás, o Robin Williams, eu sempre gostei dos filmes dele e via ele como uma referencia de uma pessoa alegre e os filmes eram auto astral, assim, me chocou o suicídio dele. Então isso me marcou e ainda me fez parar para pensar, assim, que eu tinha uma imagem dele, do trabalho dele, e ele vivia uma outra coisa, assim. Foi algo que me marcou. E eu acho que aí foi falado muito. E foi um momento, assim. Particularmente que me marcou e tem a ver com essa mídia, assim. Se não fosse um ator que eu acompanhasse, gostasse dos filmes, talvez passasse batido mas chama a atenção.

P1: Só uma parte do que ele falou, que eu tenho uma coleção de DVDs originais daquilo que eu gosto, sabe? Eu vou lá e compro, né? Mesmo que tenha 10 anos o filme, sabe... aí um deles, acho que o nome é "Amor além da vida" eu assisti 10/15 vezes está certo? Então eu tinha aquilo assim... você associa no caso ao ator, né? À pessoa, né? Que são coisas distintas, mas você associa, se você ficou chocado e também fiquei, da mesma forma porque aquele filme para mim, eu assisti 10/12/15 vezes e eu fiquei pensando: mas ele vai buscar a mulher dele no inferno, como ele diz, foi buscar no inferno, e aí ele comete o suicídio, entendeu? Para mim, realmente foi um choque.

P3: Eu acho que a própria psicologia, psiquiatria está percebendo que há necessidade de se colocar isso público e que como está aumentando o número, então, se tem essa necessidade de dar mais informação ao público em geral, as pessoas deprimidas e que podem ser ajudadas e que não precisam chegar a esse extremo que, através da psicologia e da psiquiatria ha uma grande ajuda. Eu acho que isso é muito importante. Chegar a público e a imprensa em geral para dar essa informação que as pessoas podem ser ajudadas.

P1: O trabalho, né, do (nome de uma instituição), né, porque eu acho assim... importante... em São Paulo é comum e em (nome de uma capital) é bem menor do que São Paulo, né? É que aqui é a capital do país, viu! Então, São Paulo é... (nome de uma capital) até um pouco tempo atrás você não tinha o que tem hoje, só o CVV né, não tinha entendeu, aí hoje, já tem...

P3: Mas eu digo assim, a imprensa em geral. Você liga a televisão as pessoas estão dando 
informação...

P1: Exato, exato, assim, esse de boca a boca assim, também é muito pequeno, pequeno né, assim aqui, pequeno né, tem 10, 12 pessoas né, mas cada pessoa ela multiplica né e faz alguma ação, faz alguma coisa que divulga né, quer dizer, antes você não tinha isso também não.

P3: Sim, mas mesmo que você não vá procurar a informação chega até você, através do jornal, imprensa, televisão. As informações estão chegando sem você procurar. Isso eu acho muito importante.

E: Que era uma informação que não tinha muito antes né...

P1: Exato...

E: Não saia, não tinha algo na imprensa.... Hoje se vê mais na imprensa.

P3: Eu acho que isso está ajudando bastante...

P8: E aquelas causas não divulgadas. Eu não sei se aumentou tanto o número. Se aumentou, se diminuiu, acho que esse receio de se divulgar que uma causa de uma morte é por suicídio ou não. Acho que não sei dizer. Eu acho que de fato é essa questão de você ter os meios de comunicação falando mais, eu acho que as pessoas se comunicando mais e de repente descobrindo que elas tem mais em comum porque aquela coisa acho que...quase todo mundo tem de alguma forma é... alguém no seu ciclo que já passou por isso. Mas não comunica, não fala. É como se fosse uma... eu acho que ... me lembro a primeira vez que eu falei alguma coisa sobre isso com alguém, eu devia ter uns 13/14 anos porque a esposa do meu tio tinha acabado de se suicidar... eu tinha é uns 12 anos quando ela fez isso, a esposa do meu tio. Ela era nova tal, mas eu falei assim como se fosse a mesma coisa que ela tivesse morrido do coração e aí me arregalaram o olho, assim, e eu fiquei: "Ué, mas..." Porque era um assunto que em casa, assim, um lado da família falava o outro não..., mas porque a minha mãe também tinha tido uma tia que tinha se suicidado. Então era uma coisa que se falava de certa forma, à mesa, né? Mas eu me lembro desse, desse choque das pessoas. E eu não falava para chocar. Eu falava porque sei lá, na minha cabeça era uma forma de morrer.

E: Não tinha preconceito, né, era uma forma de morrer...

P8:Não tinha. Era uma forma de morrer. Era uma forma de morrer e a gente conversava sobre isso... Sempre se conversou sobre isso, em casa. E sempre se falou sobre isso, sobre outras questões delicadas, assim, a gente sempre falou. E eu acho que, depois de um tempo que as pessoas foram começando a ver que se elas forem parar para pensar elas tem mais pessoas próximas do que ela imaginam, mas por alguma razão elas não falam e hoje eu acho que elas começaram a falar e ver: "Olha, e não é que é verdade que tem alguém próximo e que isso já aconteceu, mas eu não quis enxergar". Eu acho que tem isso. Acho que as pessoas estão se comunicando mais. Falando mais sobre assuntos... 
E: Quer dizer, mesmo dentro da própria família.

P8: É....eu acho que sim...

E: Família, amigos, círculo social...

P8: É....exatamente...

E: As pessoas estão falando mais no assunto, no geral.

P8: Eu acho que sim...não sei...dá uma impressão. Assim, como isso sempre foi um assunto dentro da minha casa..., mas eu sei que se falasse fora arregalava-se o olho, hoje eu já não sinto mais tanto desconforto de falar isso, sobre o assunto, como eu sentia, ééé, assim....

P10: E aí eu fico pensando, né, se, assim, a gente está falando mais porque não sei se tem mais casos ou não e quem passa a entender que isso é uma realidade por que passou consegue falar do assunto. Porque, será que a gente está falando mais ou tem mais casos e as pessoas entendeu, que vivem isso estão, sabe porque aquilo que eu falei na sessão passada: Para mim o suicídio só se torna real na sua vida depois que você realmente... porque se não, acho que é uma coisa.... Até você estava falando, eu lembrei que a minha melhor amiga, a tia dela tinha tentado e quando eu era menor eu acho que fiquei sabendo dessa história, mas eu nem achei nada a respeito. Sabe quando você nem... acha que é grave, nem que não acha nada. Mas hoje, quando ela me conta eu falo: "Nossa!" eu entendo, mas porque agora eu passei. Então eu não sei se...., sabe, quem vem primeiro. O que está fazendo com que as pessoas falem mais. Será que é porque temos mais casos e elas passaram a enxergar isso como putz acontece, ou...qualquer ser humano consegue falar mais sobre isso. Porque eu não sei se as pessoas têm empatia e elas estão falando: "Noooossa, realmente, assim, uau!" Mas se não é algo.... Porque não é um assunto assim tão... por exemplo, você esta na roda de amigos, ninguém fica falando sobre isso. Ou tem gente que ainda faz brincadeira, sabe?

P4: Eu acho que nem nas nossas experiências, nem eles mesmos nos falaram, nem a pessoa que está sentindo.... Eu ainda acho.... Eu não vejo esse falar muito também, não.

P1: É porque assim, como eu estava falando, e assim, o que a gente, a gente que passou, de alguma forma para a gente, a gente acha que ainda está assim, vai ser uma bomba, mas não tão mais como era antigamente, para a gente, porque a gente já passou por essa dor, estava passando e vai, cada um acaba sentindo...

P4: E a gente sente, é o que ela falou, a gente acaba sentindo que talvez se não tivesse acontecido com a gente a gente nem saberia sobre isso.

P1: a gente fala assim, as vezes é normal, mas a gente não esconde, a gente conversa tal, quem quiser ouvir... aí eles decidem se tem que mudar de assunto, porque... as outras pessoas que estão do outro lado tão com medo e não querem ouvir... porque acha que né, mas assim, eu também assim, eu acho que... difícil falar não, mas ... 
P8: Eu acho que tem uma distância também muito grande, e assim, muito grande mesmo entre as pessoas que são os familiares, as pessoas próximas de alguém que se suicidou da pessoa que tem vontade, de que quer, que pensa no assunto, eu acho que essa distância ela ainda é muito grande porque a gente está falando, eu acho que está se falando muito disso mas eu acho que não...a um ponto de que ainda dê segurança pra uma pessoa que pensa no assunto, se sentir à vontade, suficientemente à vontade de tratar esse assunto em qualquer situação. Eu acho que é essa a distância que ainda está muito grande. Então, eu acho que, fala-se mais, encontra mais respaldo aí de falar né ninguém, assim... diminuiu esse tabu, mas ao mesmo tempo isso não tem reflexos para quem está passando por esses pensamentos. Isso é uma coisa que eu acho que ainda é um tema e a distância é grande.

P10: É que é a mesma coisa, por exemplo, talvez, a gente, que eu estou pensando, assim, quando sabe, almoço corporativo, que você sai para almoçar com as pessoas, elas falam que está na moda naquele momento. Então se o problema está agora na política, eles vão falar no almoço da política, se são os 13 porquês da série, eles vão falar da série. Se é a baleia azul, entendeu, as mães vão se preocupar: "Meu Deus e esse negócio da baleia azul...," mas porque ela tem filhos. Talvez se elas nem filhos tivessem, eu não sei se elas falariam desse tema aí. Entendeu? Então a coisa assim que...não sei se falava porque estava na moda, enfim, as pessoas realmente... ou porque pode ser porque quando é com adolescentes..."Putz, eu tenho um filho", né? Estou criando então pode ser que chegue em mim né, então acho que ela né... vê um pouco, né? Então não sei se, não dá para...

P1: Assim, são duas, assim, uma é esse dia a dia e a outra é a questão da divulgação, eu não sou da área mas a minha esposa faz psicologia e eu fico acompanhando a * em algumas coisas, palestras e tal e então ela já comentou que nesse último ano, do ano passado para esse ano, o que tem de palestra em que a moda do tema é falar sobre o suicídio porque antes não se falava né, eu acho que nem disciplina tem que se fale sobre isso, então, só esse ano já foi 2, e nós estamos perto do meio do ano né, ou seja 4meses só de aula, veja bem, uma foi em uma universidade federal, e a outra na (nome de universidade), que é particular também e assim, muito conceituada, dois cursos bons de psicologia, os dois na semana de psicologia, esses encontros e os temas eles falavam sobre a questão do suicídio, Então, assim, ela está só no primeiro semestre, então esse ano ela sentiu...

E: Quer dizer, os estudantes já tem mais contato que também não tinham antes...

P1: Uma é a questão da formação acadêmica. E a outra é essa questão que eu acho que ia estar, como você falou, é um assunto que você não vai ficar falando, não é um tema como outro qualquer, assim, que as pessoas vão ficar falando...

P3: Mas você pega o programa da Fátima Bernardes, falaram sobre suicídio, e é uma coisa assim que estão instruindo as pessoas...

P8: E que atinge muita gente...

P1: Sim, Sim, perfeito... 
P3: Então, o que eu te disse é isso, você liga a televisão, você vê um jornal, qualquer coisa, existe esse tema que antes não existia...

P10: Talvez não seja a quantidade, mas a importância que estão dando para o tema, não sei se é porque aumentou ou não aumentou, mas talvez a relevância do tema tenha aumentado. $(23: 27: 71)$

P1: E você só dá essa importância, principalmente a mídia, não faz isso de graça... ou é porque está tendo mais importância porque é abcd morreram por suicídio e aí são pessoas que são famosas e tal, e elas dão certa importância que tem a mídia vai fazer algo que não tem volta.

P4:Deviam abordar em novela esse tema, porque eles abordam tanto transplante de coração, não sei o que... não estou acompanhando mas parece que essa novela está rodando no estrangeiro. Nunca que eu me lembre, nunca teve nenhuma novela que abordasse, assim, depressão as vezes, (falatório)....

P3: Ë que incomoda as pessoas, ao invés de ser uma distração, vai incomodar as pessoas...

P4: Ou não sei se não pode... antigamente achava que seria incentivo, então, também não sei para que lado... teria que ser uma coisa muito cuidadosa, muito...

P10: Mas tem outros temas que super incomodam também, entendeu? Acho que tem vários temas que eles abordam as vezes nas novelas que também incomodam, eu não sei também o quanto de um quanto do outro, mas...

E: E qual é o impacto das campanhas públicas como setembro amarelo em vocês? Agora os setembros tem sido mais cheios de informações, mais publicações...

\section{FALATÓRIO}

P4: Foi mais o ano passado que eu senti que estava falando mais, o retrasado...

E: ainda não... o retrasado ele foi bem mais fraquinho...

P3: só fiquei sabendo através do nosso amigo aqui... (referindo-se ao P7)

\section{FALATÓRIO}

P8: Mas mesmo assim o outubro rosa todo mundo sabe o que é, o maio amarelo...

P1: O novembro azul...

P8: ...uma pessoa que não está, assim, participando do assunto, as pessoas sabem o que é o setembro amarelo, mas se você perguntar para alguém ninguém sabe o que é. 
P10: Eu também acho que não. Acho que é ainda é muito pouco...

P1: É, mas já foi mais divulgado, esse do ano passado...

P8: Para quem procurava estava divulgado e estava uma divulgação boa, mas você procurando....

P1: Porque lá em (nome de capital) teve um deputado estadual, que provocou uma audiência pública na Assembleia e levou o pessoal do CVV, do (nome de Instituto), levou o pessoal do núcleo da (nome de universidade), da psicologia e tal, já no intuito de buscar maior ferramenta do poder público, do governo do Estado, né? Da secretaria de Saúde para essa problemática. Então ele já começou a fazer isso, e assim, começam os movimentos né, é, estão começando e foi muito assim, difícil, porque a gente participou muito então a gente acaba, nosso dever público é tão bom que você acaba engajado né, mas eu acho que esse também vai ser, assim, já começou né...

E: Você acha que por enquanto quem recebe a informação é aquele que procura, ela não é uma informação ainda que ela chega para todas as pessoas...

P8: Isso, se a gente procura a gente acha coisa e acha coisa muito interessante, agora, não é uma coisa que chega em você. Você está tipo, andando na rua isso chega em você e você fala: "Nossa! existia esse assunto!" ..., mas por exemplo, o maio amarelo, que é do trânsito. Todo mundo...é uma coisa que você percebe...

E: mas aí você vê eles indo nas escolas...

P4: assim, aquele repórter da Globo, o André Trigueiro... ele tem uma palestra desde 2012, que eu vi, outro dia eu fui numa palestra dele, que ele veio em São Paulo, foi ótimo, mas ele tem, desde 2012 que ele fala sobre o tema e eu não sabia, quer dizer, foi pesquisando na internet, você vê, uma pessoa da globo e ninguém comenta nada, e ninguém faz isso fora o André Trigueiro. Uma palestra excelente dele.

P1: Ele sempre faz Andre, sem ser o André da Globo, que ele quer ser livre...

P4: Peguei na internet também. Me surpreendi porque eu já gostava dele como repórter, tal, mas eu nunca imaginei que ele falasse sobre o tema...

P2: Aí eu fico me questionando, será que muitas vezes a campanha não é apenas para cumprir o protocolo? Será que ela acontece de verdade? Eu vou citar um exemplo muito prático: Minha cunhada é assistente social numa unidade de saúde, o ano passado no Facebook apareceu ela com o lacinho amarelo com toda a turma fazendo pose, está, ela nunca conversou comigo sobre o assunto. Então....

P4: ... essa é aquela que não deixava falar para os filhos...

P2... não, essa é a outra que contou que o filhinho né, mas contou para o filho depois de algum tempo, no começo ela não tocou no assunto, ela nunca conversou comigo sobre o assunto. Nunca, e assim, ela sabe que eu tenho, que eu sou aberta para qualquer tipo de assunto. Não sei 
se a dor dela está tão violenta, não sei o que se passa na cabeça dela. Mas eu acho que... poxa P2 me fala: "E aí, o que você acha? O que eu posso fazer para ajudar? Você conhece algum órgão?". Não. É como se fosse um assunto que não me diz respeito...

P4: Por que se as pessoas vem aqui? Eles estão precisando falar? Ou o que elas querem é ver se você está...

P2:... deveria ter algum conhecimento...

P4: de alguma maneira participando, engajado em alguma coisa é de pelo menos ter um.... Se a pessoa vai te perguntar pelo menos saber como ajudar, como te acolher.

P2: Acolhimento né... e ela sabe que eu sou engajada, ela sabe que eu participo de muita coisa

E: Mas P2 qual é a leitura que você se faz disso?

P2: Cumpre o protocolo, sei lá. Cumpre o amarelo.

E: Tira foto, posta no facebook e acabou...

P2: Estamos cumprindo o programa de setembro...

P1: Tem muitas empresas que são assim, se engajam, mas não repassam para os seus funcionários, os seus colaboradores, aquela importância, dá um papelzinho, dá uma fitinha para colocar na camisa, mas agora vai... volta a trabalhar então, mas coloca lá estampado que está dando o apoio, não sei o que lá..., mas não, não... leva um profissional, nada...

E: Quer dizer, é marketing

P1: Marketing...

E: Uma ação de marketing com o nome de conscientização

P2: Marketing que ele vende como conscientização.... uma coisa muito vazia né

P9: No ano passado no setembro amarelo eu estava trabalhando no CVV, então houveram várias ações que foram em metrô, escolas e a gente podia trabalhar como voluntário. Só que é assim, a percepção que eu tive, foi um pouco do que ela falou. Acho que foi você que falou, assim, que, quando a gente passa, o nosso olhar fica diferente. Eu sou muito atento em relação a isso. Por exemplo: Quando a gente está envolvido no assunto, a gente tende a enxergar mais. Quando a gente não está e aquele assunto é um tabu, no caso, não só a gente não repara como é um ponto cego. A minha percepção é que é assim... A referência que eu uso é que tem coisa que está na mídia, está sendo falada. Mas a minha vivência nas relações pessoais não é de mais abertura de falar. Eu tive muita dificuldade, assim, eu não, eu tive momentos que eu não tinha nem uma pessoa para falar sobre o assunto. Nem uma. Então, eu mesmo ligava no CVV. Foi assim que eu acabei virando voluntário. Eu acho que assim, muitas campanhas esbarram no estigma, porque 
falar sobre o assunto, eu acredito, isso eu percebi, assim né, que a pessoa que toca no assunto, ela sofre um preconceito de falar a respeito disso. É diferente, por exemplo, sei lá, falar de infarto, doença do coração. Se você estiver numa roda de amigos, como você falou, você pode trazer esse assunto e não vai ter preconceito. Ah eu estou indo em numa academia... agora se você entra no tema do suicídio a pessoa: "Não, mas você está pensando..."e aí você... existe um estigma que atrapalha.

E: Como é que você acha que as pessoas podem começar a falar mais, então, entre elas?

P9: É... Que nem...na reunião passada foi falado... eu acho que tem um problema grande, que na minha opinião né, começa assim, com a tristeza, tem um preconceito que é, falando um pouco do efeito facebook. Todo mundo quer aparecer feliz ou parecer feliz. Daí, desse, a tristeza ser preconceito vem a morte, o luto, suicídio... vem tudo atrelado. Então, qualquer pessoa que começa a trazer o assunto que é considerado triste..., mas isso já é uma coisa interna, acho que da nossa cultura.

P4: Você acha que começar a abordar, que todo mundo sente tristeza em algum momento? Tem como alguém...

P9: Sim, como algo natural, como algo natural.

P4: Não já como depressão, mas como: tristeza é uma coisa normal que todos nós sentimos

P9: Isso! Como algo saudável. Enquanto não tiver isso... então qualquer assunto... vamos supor: se eu chegar num churrasco, está todo mundo tomando cerveja, e eu falar "Ah, estou indo numa academia. Poxa, me matriculei eu vou." todo mundo fala numa boa. Mas, se falar: "Putz, eu ando meio triste, eu ando meio deprimido"... Ihhh, existe o isolamento...

P8: É visto como uma coisa negativa, né? Aquela coisa do... aquela pessoa ela é negativa.

P9: Eu acho que existe um estigma atrelado a algumas emoções. Enquanto a gente não resolver isso, o assunto em si ficou um ponto cego da sociedade. Aí as campanhas, também, é o que eu percebi...

P4: não surtem efeito... (fala junto)

P9: ... eu estava trabalhando no CVV, e eu falei com duas pessoas que tiveram, pessoas que próximas do suicídio... para participarem do (nome de instituição)...

P7: (fala junto)... não conseguiu levar nenhuma...

P9: ... eu não consegui levar nenhum. Um eu não consegui nem terminar a conversa e outra pessoa parou de falar comigo. Porque é uma dificuldade do assunto. Então, a pessoa não quer falar que tem esse problema porque ela vai sofrer o preconceito e ela não quer falar com você também... 
E: Quer dizer então as campanhas elas vão ter que efeito? Até onde vocês acham que chega a campanha?

P9: Na minha opinião ela funciona, por exemplo, a pessoa que tem, ela ou alguém próximo que tem depressão que aí é socialmente aceito, falar que a pessoa tem depressão eu acho que aí funciona...

P4: Para os familiares, quando você está percebendo alguém ou algum amigo, não só um familiar né, alguém próximo, como agir. Eu acho que deveria ter um pouco mais, porque muitas vezes, as vezes alguém que quero ajudar, mas eu não sabia como agir. Nem sei se eu sei hoje se alguém chegar para mim e falar que: "Ai eu não, eu não quero mais viver"... Eu não sei, eu ainda nem sei se eu sei o que falar. Eu sei que eu vou querer ajudar. Vou procurar ajuda, vou tentar levar em algum lugar, mas agora eu não sei se eu mesma sei o que falar... eu acho que para a gente conseguir tocar quem está vendo....

P3: (fala junto) E precisa a pessoa falar, né? Porque a gente perceber é muito difícil...

P4: ... é, ou antes da pessoa, ou se está percebendo... é, eu sei lá, alertar ali, mais pais, cuidadores, quem cuida, que hoje em dia nem as vezes é mais os pais... é avós, tios.... mas alertar se tiver alguma coisa como abordar um adolescente, principalmente acho que adolescente, assim que fica lá mais fechado no quarto, e tal, mais...porque o adulto as vezes vai camuflar muito mais, que a gente não precisa nem... eu acho que quanto mais a idade vai passando, acho que isso aí você não consegue tirar nada.

P10: Eu acho que a gente comentou um pouco isso na sessão passada né, que a gente tem ainda uma base, um $b$ a bá que a gente tem que dar milhões de passos para trás porque assim, para mim, suicídio é o nível hard, entendeu? E aí, que nem ele estava falando né, da tristeza e tudo. E eu acho que vir muito ainda, acho que trabalhar muito mais esse tema de tristeza, tal, para depois chegar no suicídio. E aí eu acho também, que a pessoa, ela só vai passar a se interessar, a campanha só tem efeito naqueles que na essência tem, acho, alguma coisa a ver com o tema. Por exemplo: eu sou envolvida no GLBTA (Gays, lésbicas, Bi, Trans e aliados) e aí assim, quando eu olho esse grupo, as pessoas que lideram os grupos, normalmente são pessoas que são ou gays ou lésbicas... no meu caso eu não sou, mas eu estou ainda mais engajada porque que eu sei que esse é grupo que se suicida. Então se alguém, assim, eu não falo, né? Porque se alguém me perguntar: "Por que você é engajada no (GLBTA)"! Eu falo que eu quero que cada um possa ser o que ele quer, quero que as pessoas venham verdadeiramente para a empresa... porque o fato de você não poder ser você, você deixa o seu você em casa e vem trabalhar. E como eu sei que assim, são várias pessoas sofrem e cometem suicídio, a verdadeira razão, né, vem um pouco que eu sei a importância da diversidade, mas para mim, lá no fim tem a ponta do suicídio. É que eu acho que cada um, a gente fez um evento na semana passada no trabalho, e quando eu olho as pessoas que vão, normalmente são pessoas que são alguma das letras, e o A, que é do aliado, que sou eu, você não vê tantos. Porque aquela coisa de talvez a pessoa pensar: "Aí, vão achar, sei lá, alguma coisa de mim porque eu estou engajada nesse grupo. Então eu acho que essa campanha do GLBTA só atinge as pessoas que de alguma forma se sentem ligadas ao tema. Eles falando ali abertamente ou não ou lá na essência tem alguma coisinha que ele por, né... então, talvez essas campanhas do suicídio, elas só vão atingir quem, na sua essência, tem alguma ligação com o tema. Se não ela passa desapercebida. Tanto que a gente fica lá tentando engajar as pessoas para 
ir no GLBTA, e assim, tipo as pessoas não vão. São raras. São raras. Aí lógico já tem vários líderes que vão porque, tipo, eles tem que ir, eles tem que liderar pelo exemplo, você tem que ir... então eu não sei se não tivesse talvez um pouco disso de ser um exemplo, de ter que cumprir com isso, se aquelas pessoas iriam, e aí eu não sei se por exemplo os jovens, por ser um grupo que tem um propósito, eles acabam se engajando também. Então é um fato interessante: eu não sei se eles se engajam porque eles tem a ver com algumas das letras ou porque na essência tem algo, ali, ou se é porque coisas com propósitos, e eu vejo que é uma coisa que as novas gerações elas trazem isso. Que nem, por exemplo, a busca por um emprego que tenha um propósito maior. Então acho que a questão das campanhas do suicídio é essa: é primeiro eu tenho que trabalhar lá atrás, né, a questão do sentimento. E talvez, se a gente trouxer isso através dessa base, as pessoas se conectem mais porque elas vão falar, nossa, isso que é um assunto que tem a ver comigo. Eu também sinto tristeza. Eu também às vezes estou triste. Talvez elas surtiriam mais efeito quando você sente a empatia porque hoje em grandes campanhas, normalmente, que nem essa do transito, né, não sei, se as pessoas que perderam alguém, assim são as mais engajadas... O que leva alguém a se engajar? Eu não sei. Essa do Trânsito para mim é uma que eu não presto muita a atenção. Sei que ela existe, mas assim, para mim é X. Também passa desapercebida. Eu não sei se tem isso, entendeu? De ter que ter algo, assim, pessoal para você se engajar naquele tema... que é aquilo: suicídio só passa a ser realidade, você só presta atenção, quando você de alguma maneira tem a ver com aquilo. Não sei.

P3: Essa campanha do trânsito mexe muito comigo apesar de eu não ter ninguém, mas está muito bem-feita. É uma moça que ficou paralítica e ela ficou falando do quanto mudou a vida dela depois desse acidente. É uma coisa muito... presta a atenção é linda a campanha, emocionante. Aquilo mexe comigo apesar de eu não ter nada a ver, mas é uma coisa muito bonita e mexe com as pessoas... E tem uma coisa que eu acho que poderia ser chamada a atenção para a ansiedade. Não só a depressão, mas a ansiedade, eu acho que é uma coisa muito pesada, pelo menos deve ter sido o meu caso. A pessoa não sabe lidar com essa ansiedade. Eu acho que nem foi depressão, foi ansiedade. É uma coisa que ninguém fala. Eu acho que nas campanhas deve ser falado para as pessoas se tocarem... o quanto isso também incomoda. Não só depressão.

P9: Assim, a minha experiência, então, eu não sou da área, mas assim, a minha vivência é que eu percebi que as campanhas, elas funcionam bem para quem não tem a informação e tenha uma realidade próxima de depressão. Porque aí a pessoa fala: "Puxa, eu não sei como lidar, isso pode levar ao suicídio e aí não sabia nem que encaminhamento fazer. Não sabia que existia o CVV, não sabia que as vezes é necessário a medicação, a busca de um profissional. Nisso eu acho que as campanhas funcionam. Porque a pessoa se identifica. Aonde eu acho que elas falham, aí é uma visão minha também de leigo: Eu tenho a impressão que existem alguns casos, assim, de suicídio, que não tem a ver com uma depressão caracterizada, que é assim, a soma de um monte de pequenas coisas: Poxa, assim, ahh, está com dificuldade no relacionamento na família, aí problema no trabalho... São essas pequenas coisas somadas que podem levar ao suicídio. Aí, esse caso, eu acho que poderia fazer com que qualquer pessoa se identificasse e dizer assim: "Poxa, se você tem algum problema que você não consegue lidar ou tem dificuldade em falar. Eu tenho dificuldade de encaminhar e isso pode chegar nesse ponto, de suicídio. Eu acho que nesse ponto as campanhas falham porque a impressão que eu tive, como leigo, é de que assim, isso não tem a ver comigo. É o que eu sentia com os amigos. Assim, por exemplo, se eu ia falar com eles... não, 
na minha família ninguém tem depressão então não tem nada a ver comigo e aí o assunto morria.

P10: E sabe porque eu dou esse exemplo, teve uma vez uma moça que foi fazer uma palestra, lá que é daquele tipo 0800 para auxiliar os empregados, tal, que tem vários serviços e aí eles tem serviço jurídico, psicológico, sei lá, e mais outros dois. E aí, quando ela estava dando exemplos, aí ela falou assim: Há, porque tem algumas pessoas...que ela falou assim: o único momento que a gente quebra o sigilo para a empresa desse serviço, é quando alguém fala que vai se matar. As pessoas começaram a dar risada na sala... "ah é, tipo, até parece que a pessoa vai"... entendeu? Então assim acho que tem pessoas..., eu também uma vez estava num almoço com outras pessoas da empresa e falaram que acho que alguém do prédio do lado tentou, sabe uma coisa assim? " E tipo eles falaram "Ah! Nossa, que coisa engraçada, tipo, por que não se joga, mesmo". Então assim, o nível de entendimento das pessoas, a gravidade de que aquilo é real, não é o suficiente para realmente a pessoa ir lá ouvir uma campanha...ou teve uns que eu já ouvi: "Nossa, se viu o formulário da semana da saúde que perguntaram se você tem vontade de se matar? Isso é pergunta? Se acha que alguém vai falar que tem vontade? Tipo, sabe? Eles ficaram surpresos de num formulário estar escrito fazendo essa pergunta. E então falaram: "Duvido que alguém vai escrever que tipo, sim." Ou o que a empresa vai fazer? Entendeu? Então assim, existem pequenas ações que às vezes a gente faz, só que a reação nem sempre é aquela esperada. Ou essa moça fazendo a palestra falando que era um serviço que eles né, prestavam, e eles assim, dando risada, achando tipo, aí, quem é que vai fazer isso...

E: E quando vocês viram as campanhas, por exemplo do setembro amarelo, qual foi o impacto em vocês? Impactou negativamente ou positivamente de alguma forma?

P4: Para mim positivamente, porque eu achei que pelo menos está se fazendo alguma coisa. As pessoas estão pensando nisso, no assunto. Começando, pelo menos, tem que partir de algum ponto. E se a gente achar que nada também vai surtir efeito, a gente vai parar e não vai fazer nada. Então eu acho que tem que começar, fiquei feliz de os programas estarem falando, pelo menos naquele mês, massivamente abordando, saindo em jornal, matéria que... tem que começar! E daí está vendo, né, um trabalho assim, como o seu, e as pessoas se dedicando a isso para estar surgindo ideias da gente como abordar.

E: Vocês lembram de algum exemplo de campanha ou mensagem positiva ou negativa sobre suicídio na mídia?

P4: De campanha, não...

E: Campanha, ou mensagem, ou reportagem...

P4: eu me lembro, que, acho que foi agora, no ano passado, colocaram no facebook, e eu até discuti com uma amiga minha porque ela que passou adiante, quando eu vi aquilo...até o (nome do marido) mandou para ela tirar na hora... aquele empresário... aí "Olha o que a Dilma está fazendo com as pessoas. Aí tem uma foto do empresário que filmaram de manhã, que os empregados chegaram, e ele tinha...

$\mathrm{E}:$... aquele da fábrica de colchão... 
P4: ... eu nem vi direito. Eu sei que na hora eu fiquei brava com ela assim, aí ela: "Não, mas eu quis dizer... e aí eu disse... "Não, você pode até falar o texto: "Olha o que está acontecendo com as pessoas que estão, né...," Mas não divulgar a foto. Jamais! Você esqueceu que essa pessoa, pode não estar aqui mas tem família? E aí, eu lembro que eu briguei muito com ela, né, porque ela queria me mostrar que ela só fez para que outras pessoas.... Eu falei: "Não, mas as pessoas tem família. Você gostaria de ver alguém da sua família nisso, exposto no facebook. Porque alguém fotografou? A gente sabe.... Eu "sinto muito" das pessoas, elas querem saber, quando você conta uma coisa, a curiosidade não é assim em: A) ter ajudado, como poderia ter ajudado, como ajudar o outro... eles querem saber como foi, como foi encontrado, o que aconteceu? Eu sinto muito! Ainda as pessoas querem...

P3: (fala junto) ... detalhes mórbidos.

P4: Detalhes mórbidos, um filme. Elas querem saber... sabe... você viu?

P8: para depois disso darem opinião, né?

P4: Hã?

P8: Para depois que souber os detalhes darem opinião... (falatório)

P4: É! A curiosidade é tanta de saber, e não é de saber o que a pessoa estava sentindo, ou tipo, nossa, como eu posso... eu nunca, nunca ninguém me perguntou assim: Como eu posso te ajudar? Você está pensando nisso? Nunca ninguém me perguntou de amigos ou familiares. $\mathrm{O}$ que você está sentindo com isso? Eu posso te ajudar de que maneira? Isso eu senti. Nunca ninguém me abordou assim. A abordagem era: Bom, mas como foi? Mas, como era? Como estava? É horrível, assim. O caixão foi aberto ou fechado? Sabe, assim, aquilo...

P2: Falta de sensibilidade né...

P4: É.... então eu percebo na internet, casos, as pessoas vão ler pra...saber...como... esse caso eu fiquei chocada, assim, de publicarem e muita gente compartilhar.

P2: Da baleia azul também, recentemente. Quando as pessoas postavam assim: "Há... dá uma carteira azul para ele. Carteira de trabalho... para esse jovem que de repente isso não vai mais acontecer" Eu acho que é uma falta de respeito porque o jovem que entra nessa, está deprimido, né, uma carteira de trabalho não vai resolver o problema dele. Então isso...

P8: Bom, eu acho que eu lembro mais um conjunto de reportagens que saiu acho que quando... teve aquele suicídio do piloto do avião, né? Que ele jogou... eu me lembro porque foi assim pouquíssimo tempo, foi quase junto com a morte do meu irmão. E eu acho, o que eu me lembro muito, o que eu acho que também me deixa um pouco cismada, é que eram reportagens até de colunistas da Folha dizendo que aí, que isso aí, que essas coisas, que esse suicídio é plenamente evitável, isso é falta de carinho, falta de amor, falta de não sei o que.... e tipo, eram muitas as reportagens e a gente vê, que culpabiliza todas as pessoas em volta. Como se as pessoas em volta tivessem negado ou virado as costas, ou não tivessem enxergado... 
P4: (fala junto) ou não tivesse percebido...

P8: É, mas a gente não consegue ficar olhando para os outros também o tempo inteiro....

P4: Mas eu lembro também dessa reportagem, também lembro que eu senti...aí quando você passa aí que você começa a analisar de outro jeito. Porque eu nem sei se eu não tivesse passado por isso, eu teria falado isso, mas eu ouvi muitas pessoas falarem assim: "Se queria fazer isso, porque não fez sozinho em casa? Porque tinha que levar tantas pessoas inocentes e tal?" De repente você sabe que está errado, mas eu acho que é...

P8: (fala junto) Mas vai saber o que estava passando na cabeça da pessoa, a gente não sabe o que estava passando na cabeça...

P4: A gente estava tão machucado que a gente começava até a entender.... Sei lá. É exatamente o que a gente falou, que eu penso e falei aquele dia, para mim, a dor deles é maior que a minha.

P8: (fala junto) a pessoa está em outra realidade...

P4: A dor do (nome do filho) para mim é maior que a minha, a gente chegou a falar. Porque se a minha fosse tão a que ele tivesse sentindo, teu também teria então falado que não quero mais viver. E em nenhum momento eu pensei em fazer isso comigo. Então, para mim, eu não consigo passar assim, o que eles fazem que... no momento, eu tenho certeza que eles só não pensam na gente porque a dor é tamanha de algo que nem eu posso imaginar... então, aí que nesse dia que eu comecei também, desse rapaz com as pessoas julgando

P8: (fala junto)... a pessoa já rompeu o laço...

P4:... a não julgar mais. Quer dizer, isso para mim foi uma lição de vida, o que aconteceu comigo. De não julgar. Porque eu também achava que depressão era...a pessoa ah, não quer, sabe, vai... tem que acordar as 5 horas da manhã como eu acordava, então você não tinha tempo para estar deprimido. Hoje eu sinto que eu sou abençoada por eu não sentir nada disso, nem com tudo que eu passei eu não sinto, é lógico, tristeza é uma coisa, a gente sente em todos os momentos, mas não sinto, aí, fico com dó de mim, tinha que, nada... eu não sinto isso, então não julgar eu acho que essas campanhas....

P8: é porque eu acho que olhar a outra situação...

P4: (fala junto) tem que olhar com outro olhar que a pessoa está num momento alí...

P8: É, eu acho que a mídia, ela trata toda aquela situação dessa forma porque eu acho que ele tinha levado outras pessoas junto. Mas a forma como toda a cobertura foi feita, eu achei muito irresponsável. Que não foi em outras, mas eu acho que naquele momento a cobertura, toda cobertura...eu acho que gente que começou a falar aleatoriamente sobre o assunto e eu acho que por ter esse negócio de ter matado outras pessoas, foi totalmente irresponsável. Eu achei assim. Esse foi o momento que eu achei que os canais de comunicação foram irresponsáveis no tratamento do assunto, assim de em nenhum momento mostrar que, meu, o cara já tinha 
desligado, ele já não estava...que é quando a pessoa faz isso ela já não está neste plano, ela já não tem mais, ela já perdeu, cortou os laços com as pessoas. Eu acho que isso que...eu acho que esse foi o momento que foi irresponsável, né, da cobertura.

E: Vocês lembram de mais algum?

E: Como vocês acham que a gente pode começar a falar mais sobre suicídio? Que sugestões vocês teriam para que o suicídio fosse o mais falado do País?

P4: Não só do setembro, acho que ter mais campanhas durante o ano. Como teve o aviso do cigarro, enfim... entendeu, ter mais. Não ficar esperando tudo, concentrar tudo, porque eu acho que a pessoa nem assimila. Porque daí ela começa... "Ah, setembro tão falando isso." Ter mais coisas menores, campanhas, coisinhas menores, mas, mais reportagens. Eu acho que a mídia começar a abordar, de uma maneira mais sutil e ir chegando...

E: Com mais frequência...

P4: Com mais frequência. Não precisa ser tão massivo porque aí as pessoas não prestam mais atenção, só aquele grupo que vai prestar atenção, que vai se engajar, vai está ali de camiseta participando, dando folheto, tentando, mas assim, acho que ter um horário para divulgar que o CVV está disponível que aí é um órgão nacional. É uma coisa nacional. Então, ter uns segundos ali na TV... a gente tem tanto segundos ali gratuitos para falar de tanta coisa, porque não alertar que o CVV está aí. Acho que pelo menos a pessoa teria um lugar seguro para pedir ajuda. Colocar que é ali que você vai ficar. Eu acho que fica.

\section{E: Fica 24 horas...}

P4: 24 horas eu sei, mas que fica o sigilo.

E: Sigilo, sim.

P4: E se a pessoa liga e fala que vai cometer? Pode? É aberto um chamado para policia, não?

P5: A não ser que ela peça ajuda. Se ela falar... eu já fiz o ato e estou precisando de ajuda. E ela passar o endereço... aí você pode. Se ela falar... pois não tem identificador de chamada.

P4: Então, mas eu acho que uma coisa interessante seria isso, ter espaço, na mídia, principalmente TV que atinge muita gente, de todas as idades, porque a gente está aqui falando se jovens..., mas que as vezes não vai ver tv aberta tanto, mas a gente está falando de pessoas de mais idade também que está aí sozinha em casa, pensando, e aparecer, porque eu não sei, mas eu acho que se eu perguntasse para a minha avó ela não sabe do CVV. Se ela... então eu acho que devia ter mais campanhazinhas... mini coisinhas assim, com esse número disponível. (54:45)

P3: O que eu acho que também poderia ter, faculdades de psicologia que abrisse ao público porque é muito caro um tratamento, hoje. Um psicólogo, psiquiatra, acho que poderia ter mais 
faculdades, aí, atendendo o povo em geral e... Acho que ajudaria bastante.

E: Se você conseguir pegar essa demanda, porque você começa a falar, você gera demanda, né? E daí, para onde vai essa demanda? Não é? Se você falar... observe, converse e encaminhe para o tratamento, mas para onde?

P4: Procure ajuda.... Tem o CVV se a pessoa quer...

P3: Mas o CVV é atendimento só telefônico

P4: Mas pega o urgente, mas ele poderia também... se tivesse mais locais, se a pessoa pedir ajuda, falando assim: "“Ah, mas eu não tenho dinheiro, eu não tenho como ir ao psiquiatra, eu estou me sentindo mal" Aí ter publicamente um lugar para encaminhar.

E: Mas eles tem, o CVV, eles tem atendimento pessoal. Só que ele é para aquela crise emocional. Você não pode fazer dele uma terapia. Não tem um acompanhamento para você ir sempre com a mesma pessoa... a formação é outra, né.

P3: Eu acho que isso seria muito interessante: um lugar onde as pessoas pudessem ser atendidas porque é muito caro e quantas pessoas podem arcar com isso?

P1: Aqueles, é... CAPS, são deficientes né...

E: São...

P1: Não dá conta da demanda...

P9: Eu endosso tudo o que foi falado, assim, em relação a esse trabalho como aqueles casos quando a pessoa já está na iminência de. A divulgação do CVV e outros lugares que as pessoas podem buscar ajuda, facilitar o acesso né, porque muitas soluções são caras, não são acessíveis, mas, a minha experiência pessoal é que é assim: toda vez que a gente fala de suicídio, ou morte, existe na nossa cultura, em particular, um tabu grande. Então gera uma rejeição, gera um afastamento. Então assim, eu, não sei. Eu tenho tentado...eu imagino, assim: um caminho que pode ajudar, é a gente falar das emoções, e que a falta de diálogo, não só assim como você está na crise aí você ligar para o CVV, mas a falta de você, por exemplo, de poder chegar para um amigo, ou um parente e conversar sobre um assunto difícil é que lá na ponta..., vai... é um dos casos de... não é?

\section{E: $\operatorname{Sim}$}

P9: É, mas um dos casos é esse, assim, que a pessoa não tem com quem falar e isso acho que é cultural, eu acho que isso eu acho que tem a ver com prevenção de suicídio e eu acho que aproxima as pessoas, porque tem a ver com todo mundo, não é só aquele caso...

E: Quer dizer, você tem uma campanha, por exemplo, focada em acolhimento, em diálogo, que a gente estava falando em prevenção em saúde mental, não está falando exatamente de prevenção do suicídio, mas que automaticamente uma coisa que vai levar a outra. Você promove saúde 
mental você diminui o número de suicídios...

P10: E você capacita os profissionais, né? Que nem a gente vê...a gente já ouviu relato as pessoas que tentaram que eles não tiveram o atendimento adequado, né? Então, acho que assim, nem aquelas pessoas que teriam o papel de acolher não estão preparadas, imagina outros seres que assim, né? Na profissão, isso não vai saber mesmo. No seu meio, você talvez tente por amar as outras pessoas com quem você convive, mas acho que a questão de capacitação, que nem, de universitários, mas a questão, tipo, a policia, os médicos, entendeu? Acho que em vários, assim. Vários profissionais que precisam estar um pouco mais capacitados para lidar com isso né, então como que a gente consegue?

E: Mas será que por exemplo, na universidade, seja ela de qualquer assunto que for, se tivesse um programa de conscientização, de saúde mental, isso poderia funcionar? Por exemplo?

P7: Também...

E: Por exemplo, numa faculdade de engenharia?

P10: Não, não. Eu acho que tem que ir primeiro naqueles que tem o assunto mais relacionado. Por exemplo, a disciplina religião, sério, no colégio. Todo mundo... tipo, não vai na aula, trata de qualquer jeito, joga papel no ar, entendeu? Porque nem todo mundo que está ali se identifica com o tema. Então, por exemplo: talvez se começar com os cursos que tem uma relação, um pouco mais, né? Talvez os médicos, os psicólogos,

P4: (fala junto) Os recursos humanos... acho que eles tinha que ter mais...

P10: (Continua falando junto) na área de recursos humanos......enfermagem... assim, você tem uns que teoricamente são os mais... não tem, imagina uma pessoa de direito, engenharia....

P4: Uma pessoa chega lá para você... estou com depressão, estou mal ou estou me sentindo triste.... Se você não tivesse passado por isso ia passar...

P7: Sobre essa questão, eu acho também, existe um universo a ser explorado e esse contingente é que pode ser a chave para a gente derrubar essa barreira. Eu percebo, até nas recentes reportagens que eles não aprofundam sobre a dor dos que ficam. Fala do luto, fala da morte, fala do suicídio, mas não aprofunda a dor dos que ficam. E se estatisticamente é uma média mínima de pelo menos 6 pessoas para mais, que é afetada para cada suicídio. E nós temos suicídio a cada 40 segundos. Nós temos um contingente da população expressivo e que certamente são de diversos perfis socioeconômicos e culturais e que cada um atue e dialogue no seu meio e que poderia ser um grande formador de opinião e poderia ser um grande parceiro para desfrutar a consciência afetiva da sociedade como um todo. Então nós somos poucos, nós somos é episódios... episódios. Se a cada 40 segundos tiver uma média de 6 , no mínimo... então nós somos apenas $1 \%, 2 \%, 3 \%$, acho até que eu estou sendo muito

E: O P7, deixa eu te perguntar uma coisa. Você acha que a mensagem ela deve ser, por exemplo: Mostrando a dor dos que ficam ou, a união da dor dos que ficam pode ajudar a fazer coisas 
diferentes?

P7: Vou tentar. É que eu tenho uma dificuldade...

E: Mas você entendeu o que eu te perguntei?

P7: Entendi. É que eu...veja bem, você me desculpe, com o maior respeito, mas eu tenho uma dificuldade... eu... eu fiquei ouvindo pacientemente, mas não entendi nada do que você falou, que eu estou tentando sustentar a ideia...é uma dificuldade. É uma limitação minha. Eu adquiri isso desde a primeira separação, se agravou na segunda e agora com esse baque... então, eu não consigo... eu fiquei "mono". Então, depois eu quero ouvir o que você falou para tentar contribuir. Mas então, esse contingente, deve ter um percentual, não sei quanto, vamos chutar $10,20 \%$ de mil, 2 mil pessoas, 3 mil pessoas, são milhares de pessoas que tem um status sociocultural e um perfil, inclusive alguns devem ser psicólogos, profissionais de saúde, aqui mesmo nós temos profissionais de saúde que são enlutados, né? Enfim, e que somem a esses dados, diferentes faixas etárias em que, se a gente divulgar, grupos de enlutados de instituições como o CVV, o Vita Alere, etc, parece que tem outras também. Que fazem esse trabalho nas diversas cidades, nos conglomerados urbanos maiores, pelo menos, e procurar fazer parceria com empresa, para atacar massivamente divulgando. Porque, o que ocorre? Por ser massivo, todo mundo, o familiar, "Não, olha tem isso aqui." "Tem esse aqui, não sei aonde tem um grupo". Fim de semana, durante a semana, vai lá, alguém vai lá, vai procurar saber. Então, se a gente conseguir manter, não de forma episódica, mas, assim, constante, que existem esses centros, esses grupos que trabalham com a dor dos que ficam. E não só dos que ficam, tá? Daqueles que estão lidando com alguém que está tentando e ainda não consumou e a pessoa está sofrendo... ou até mesmo alguém que tentou e não conseguiu ele mesmo..., mas assim, eu acho que se isso for feito, o que vai ocorrer? Informação é poder. Então, as pessoas sabendo que isso existe... eu mesmo só soube porque alguém que era enlutado e era psicólogo que soube, tal. Porque eu sou mais ou menos conhecido, que é era a irmã de uma colega de dança que me avisou e eu fui conhecer você e a $\operatorname{Dr}^{\mathrm{a}}$ (nome). Mas assim, eu ia ficar ao Deus dará por que... por exemplo, os alcoólicos anônimos tem o Anon para os parentes, o AA. Então eu acho que essa massividade de divulgação, informação é poder, eu repito, eu acho o ponto de partida. Porque a via desse porto seguro para acolhimento é.... e sendo massivamente divulgado, até mesmo os profissionais de saúde colocar até como um protocolo, protocolo, encaminhar, ou pelo menos dar as indicações das opções disponíveis para procurar. Porque, o que que vai, quando a pessoa chega, ela pode até não continuar, mas ela já foi e sabe como é, e tal. E aí vai ter um contingente que vai abraçar, de alguma forma. Não digo que vá abrir mão do anonimato, que vai fazer... mas vai fazer pelo menos isso que ele está fazendo e muito mais. Se o cara é um universitário, ele vai começar a conversar com pessoas do meio universitário. Se ele é um professor, professor é um grande formador de opinião, se ele é um profissional de saúde, ou é estudante da área de saúde, enfim... eu acho que isso seria um grande salto. Um salto para a mudança. Trabalhando com a informação. Eu acho que aí, as pessoas, cada uma hoje em dia, ainda mais se for mais jovem ou de meia idade, usa muito a rede social. Então vai impactar. A pessoa, muitos deles vão fazer disso um habito, um habito mensal, semanal, que seja e aí de está indo lá. E eu acho até que deveria ter, além das reuniões mensais, alguma coisa semanal. Algum mecanismo de acolhimento, semanal.... Porque a pessoa esperar um mês, as vezes a pessoa já esqueceu. Então, semanal deveria ter. Enfim, eu acho que essa lógica, ela vai nos trazer uma grande parceria. Uma 
grande parceria de cidadãos que vão cumprir esse papel de reproduzir as suas realidades, fomentar discussão e assim fazer a mudança, creio eu. Mas desculpa, agora o que você falou, por favor.

E: Você me respondeu, respondeu...

P7: Desculpa, viu?

E: Imagina... eu que peço desculpas de interromper sua linha de raciocínio.

P2: Aí a gente esta falando de uma linha de proteção: mídia, polícia que tem que saber o que fazer na hora $\mathrm{H}$, os médicos, psicólogos, psiquiatras, a família... é tanta coisa... é a demanda que vai aumentar e a gente precisa de pessoas para onde? Mesmo que elas falem "ok, aceito, preciso de ajuda". A gente faz o que? Está dando um nó na minha cabeça. É muita coisa ao mesmo tempo. A gente precisa de muita gente do lado da gente eu não estou conseguindo entender como é que a gente vai conseguir amarrar uma coisa à outra e aí...

E: É P2, é assim, como toda a questão complexa, não tem uma resposta simples que a gente possa...eu acho que se aumentar a consciência, você falar mais sobre o assunto, as pessoas entenderem que precisam de ajuda, é um passinho.

\section{P2: Através da mídia? Através do que?}

E: Então, é justamente é isso que a gente quer descobrir com esse estudo. Através do que, como que a gente pode aumentar essa consciência a ponto de ajudar as pessoas a prevenirem o suicídio.

P10: e tem as redes sociais...

P1: Quando a gente abriu o (nome de instituto), eu não sou a pessoa mais apropriada para falar, mas, porque a (nome da esposa) fala muito melhor que eu, mas assim, até a bem pouco tempo a gente não tinha nem ideia sobre o suicídio, com o que aconteceu com a (nome da filha) a e depois por outros motivos, a gente criou o instituto, está certo? Esse instituto ele já foi traçado através de mensagens para a gente, ele foi traçado como ele devia trabalhar, inclusive para aquelas pessoas, tanto faz ser da periferia ou não... que sofrem de depressão. Então a gente montou palestras, a (nome da esposa) montou palestras com as psicólogas. E a gente tinha dificuldade em achar uma escola para dar palestras no começo. Hoje a gente está dando 2 as vezes até 3 por semana nas escolas. Principalmente na periferia, as escolas que tem mais dificuldade de ter, de levar o profissional né. Essa palestra ela foi passada e mostrada para vários profissionais e tal, é uma palestra que você fala sobre prevenção do suicídio e a valorização da vida. E tenta criar, conscientizar os alunos para perceberem outro amigo seu, varias situações de risco. Que você possa conversar entre eles, então essa é a filosofia dessas palestras. É apresentar e tudo, falar da família que necessita e tal, mas principalmente para que ela possa sentir nesse amigo alguma coisa. Que ninguém vai falar, mas sempre tem alguém que chega para uma pessoa e fala "hoje eu estou triste, estou isso, aquilo...". Então a pessoa começa a despertar e saber, pelo menos, ouvir. Está certo. Essa é assim, o ponto chave. E o outro foi o atendimento, hoje está com 
4 psicólogas porque a demanda é muito grande, estavam falando que é CAPS, é isso, e você não consegue é efetivamente, e até o CAPS estaria mandando para lá, porque eles não tem como atender todos, tal... então assim, a gente faz aquilo que pode né, sabemos que precisamos fazer além disso, mas é um começo, é um focozinho aqui, outro acolá, como ele falou, então se você tem vários focos desses, percebe, e começa a se expandir, mas tem que começar né, uma coisa de cada vez.

P10: Eu penso, por exemplo...a gente está indo cada vez mais para uma era mais digital, né, e eu lembro que quando eu pegaram o Laptop do meu irmão, estava lá no google pesquisas, né, de como se matar, depressão, bipolaridade. Então acho que é assim, só que naquela internet, black internet, underweb, que ninguém consegue rastrear. É uma internet que, né? Acontecem várias coisas ali que eu nem sei, com certeza tráfico, diversas mil coisas... eu acho que pessoas que acham que às vezes pensam isso, talvez elas façam algumas pesquisas, acho que todos nós. A gente abre uma vez por dia o Google, né, é assim como acho que o Google usa a rastreabilidade de dados para certas coisas e a gente usa, né, eu acho que a gente poderia usar talvez para isso também. Por exemplo, quando você vê que tem uma pessoa, um computador, um aplicativo ou algum celular que está procurando... por exemplo, se alguém escreve "como se matar", não é possível que a pessoa não está pensando. Talvez não para ela, mas assim...alguma coisa de "como se matar". Então assim, eu não sei se tem como a gente atuar porque as vezes... que nem, eu fui pesquisar, porque como o meu irmão tinha pesquisado, mas eu pesquisei numa internet normal, então se fizesse uma intervenção comigo, que eu estava fazendo uma pesquisa. Então eu acho que essa questão de rastrear o que as pessoas procuram.... a gente vai rastrear um bando de idiotice? Que a gente use talvez pra causas assim, graves mesmo, porque tudo nosso é rastreado, entendeu? Todo mundo sabe tudo da nossa vida, hoje. Então, será que não tem como a gente usar as redes para a gente entender e aí pegar algumas palavras chaves de tipo há... ou se aquele computador, aquele celular vive procurando aquilo. Ou eu até acho que nem deveria aparecer na internet com a resposta da pergunta "como se matar", porque existe. Se vocês procurarem... não sei se vocês já procuraram...entendeu? Tudo bem, nessa internet que não é rastreada, e assim, eu nem sei quem faz a gestão disso. Acho que é uma coisa que sempre vão burlar e talvez sempre exista. Mas a internet normal, talvez eu não sei se deveria ter a resposta para isso. Ou tipo tomar chumbinho, sabe, acho que tem algumas ideias, que tem na internet hoje, que eu não vejo necessidade de existir porque não vai gerar nada bom. Então acho que a questão disso talvez porque todo mundo vai sempre no Google e talvez através do Google você é rastreado, eu sei que o facebook ele começa a monitorar também o seu comportamento à respeito dos seus posts e tal, e o face tem algumas coisas que eles começam a monitorar o que a pessoa está fazendo... então, como hoje a gente está na era bem digital, e todos nós, teoricamente, temos um celular, que não é todo mundo mas que, enfim, talvez também tenha que ver por aí né... não sei se o mundo digital consegue ajudar a gente, já que também atrapalha, né? Que a gente use ele de uma forma inteligente para entender o comportamento humano, ou conseguir...ou por exemplo, digitou lá "como se matar", que apareça um negócio por exemplo: O CVV, você está triste, não tente...eu sei lá.... não sei...

E: Agora aparece. Quando você põe no Google "Suicídio", aparece o resultado de busca e aparece o número do CVV em cima... 
P7: Aí, que interessante...

P10: E outras coisas, que eu acho que ajudam, são também depoimentos de pessoas que passaram por isso, por exemplo, tem aquele Nicki... e eu não sei falar o sobrenome dele... é um cara que não tem braço e pernas, ele para mim assim, eu assisto os vídeos dele, acho que semanalmente, o mesmo, sempre faço isso, porque eu olho a história dele e eu já li vários livros dele e ele fala que ele já tentou, que ele tinha pensamento suicidas, etc., etc. Eu acho que histórias que nos inspiram pro bem, talvez ajudariam as pessoas porque as palestras que ele faz, por exemplo, em colégio, você vê vários adolescentes chorando porque com certeza eles se identificam com a história em algum momento do depoimento, né, que ele faz dos sentimentos, as coisas que ele viveu, então, assim, a história dele é impressionante. Eu acho que o trabalho que ele faz é muito incrível porque ele fala de suicídio e eu acho que as pessoas acabam tendo um pouco de empatia, pela história difícil que ele tem. Então, e se a gente tivesse histórias herói? Heróis, assim, pessoas referencia, sabe, de superação...e assim, histórias reais e não para o cara ficar famoso e tipo aí, sabe...eu acho que tem que ser uma coisa humana. Para mim ele é maravilhoso e ele fala muito de suicídio, de bullying e eu tenho certeza que os adolescentes e as crianças, eu também assim me identifico e é muito bonita, a história dele. E aí ele trás a mensagem de Deus. E aí é que Deus é uma coisa muito subjetiva, né, que cada um..., mas eu acho que tem histórias, como a dele, que eu acho que inspiram. Tipo é possível vencer, que realmente a história dele é bem... quando ele fala, tem uma hora que ele fala assim, que ele queria que alguém falasse que ia ficar tudo bem, mas como, se todo, ele não conhece ninguém que não tenha braços e pernas na verdade tem mais uma criança que chama Daniel que nasceu depois, né, quando você se coloca no lugar dele, realmente, não tem um ser humano na face da terra que passou pelo o que o cara passou para poder falar "Olha vai ficar tudo bem" eu sou um exemplo. Então eu acho que essa questão, ele também procurava um exemplo, entende? Então eu acho que a questão do exemplo, do tipo as pessoas falarem: "Olha, passei por isso, mas hoje eu estou bem". Ter depoimentos, tanto de pessoas que ficaram da família e que são os enlutados para criar empatia de outras famílias, como pessoas que tentaram. Porque você não vê muito depoimento de pessoas que tentaram. Até no nosso grupo quando alguém vai, é interessante você ouvir...

P4: Mas a pessoa não sente à vontade...

P10: Exato porque falar, é só...

P7: Vai ter. Por causa da (nome de canal de televisão). Vai ter 3 jovens que tentaram o suicídio que vão participar agora do filme que eu vou estar participando. Porque os produtores me falaram. Eu sou o enlutado mas tem 3 jovens, acho que de 20 e poucos anos que abriram mão do anonimato, na condição de terem tentado o suicídio e vão relatar suas histórias. Eu acho que são 2 rapazes e 1 moça ou vice-versa. Eu não sei mais detalhes, mas vai ter. Vai ter.

E: Quer dizer, histórias verídicas...

P7: Verídicas. Reais. (01:17:58)

Material integrante da pesquisa de doutorado de Karen Scavacini Proibida a reprodução ou utilização sem autorização prévia do autor - 2018 
P9: Sim, eu acho que uma coisa que ajudaria, seria se as campanhas fossem voltadas para pessoas comuns, todo mundo, para capacitar a pessoa para melhorar o diálogo e falar de momentos de tristeza. Ao mesmo tempo, passar informação de que tem um certo ponto de que aí eu? e vou amigo. Já foge da minha alçada, puxa será que já não é hora de... podia procurar o CVV, um psicólogo, será que não é hora de tomar medicação... se isso fosse parte do diálogo comum, eu acho que assim, é, elas teriam um alcance maior. Que a campanha não fosse voltada pra.... o que eu sinto de grande dificuldade é que as pessoas não se identificam com as outras quando falam... a não ser quem passou. Então assim, é, a maneira de evitar esse impacto, né, nós estamos falando de um tema que na nossa cultura é tabu, seria assim, falar sobre a emoção da tristeza e da importância de você poder conversar com o seu amigo, com a sua família quando você está triste. E aí eu acho que uma boa parte, isso é a minha referência, quando eu estava no CVV, uma boa parte das ligações que eu recebi, era isso. Só que elas vão se somando ate chegar naquela gota d'água. A pessoa nunca tem com quem falar sobre nada, quando ela está triste, e um dos casos é isso da gota d'água. Outros não. Existe um problema de saúde mental. Mas eu acho que se todo mundo fosse mais preparado para conversar, no cotidiano, sobre assuntos de tristeza, e as pessoas soubessem: "Bom, até aqui, eu posso ir como amigo. A partir daqui seria legal, talvez, você procurar um profissional, ligar para o CVV..." Eu acho que a gente iria para um lado que aproxima mais e cria menos resistência.

E: Então olha, a gente está falando dos locais onde poderiam ter essas informações. A gente estava falando de rede social, de televisão, de escola, de universidade, de grupos de ajuda. A gente está falando em mensagens: de superação, de quem perdeu, de pessoas que tentaram e superaram e tem uma mensagem positiva para passar, de tristeza, né, falar sobre a tristeza, onde de procurar ajuda, o que identificar... O que mais? Que outras mensagens que vocês pensam que podem ser faladas.

P3: Eu a muito tempo estava com uma tristeza muito grande e fui procurar um padre. Por incrível que pareça, não fui acolhida: "Olha você vai me desculpar, mas eu não tenho tempo. Eu só posso confessar tal hora, se você quiser." Você vai ter 5 minutos para se confessar, né? Isso é igreja católica.

P7: Não tem vocação esse padre... deus me livre...

P3: Mas olha, é a maioria.... Na igreja evangélica eu não sei como é que está, pelo jeito eles acolhem muito bem, mas a igreja católica, eu tive essa experiência e era uma pessoa fervorosa, frequentava.... Aquilo me decepcionou tanto, que eu continuei praticando, mas essa decepção é quanto aos padres. Acredito que não sejam todos, mas me decepcionei muito. Então eu acho que isso seria uma grande ajuda você encontrar uma psicóloga, psiquiatra, um padre eu acho que a grande ajuda é essa. São profissionais que estariam ali à disposição para isso.

P2: Os líderes religiosos, de repente...

P3: Os líderes religiosos, porque eu acho que a única coisa que prende para você não cometer o suicídio é a religião. Você fala: "Não... não é nem pensando na família, é pensando na religião. 
P1: O conselho de psicologia devia fazer uma divulgação na, assim, acho que a gente falou isso na vez passada, que se você vai procurar um psicólogo já pensa que é, está doente, que a pessoa é louca...

P8: Que é louca

P1: então é tirar esse né, acho que o conselho de psicologia devia fazer campanha...

P3: psicofobia...

P8: É, tem duas coisas né, para mim, tem o pessoal da psicologia e as pessoas que acham que todo mundo é psicólogo. Também tem essa também. Eu acho que aí tem, eu ouço tantas coisas, assim, das pessoas. A pessoa leu algum folheto, alguma coisa... tem isso também. Que parece, que, das pessoas até entenderem também, como ele falou. Tem aquilo que pode ser acolhido por amigos e tem a gente saber detectar o momento que... olha... que a gente precisa... aqui a gente já não dá conta e precisa ajudar aquela pessoa a saber a quem procurar... acho que isso é importante...

P9: Principalmente a pessoa próxima... que pode ajudar essa família...

P8: Porque a gente também não dá conta de tudo... as vezes a gente nem dá conta da gente...

P1: Por exemplo. Igual o conselho de engenharia faz campanha, de arquitetura, e assim vai, né... de enfermagem, de... eu vi até a pouco tempo, de terapia ocupacional, tudo... fisioterapia, e o conselho de psicologia poderia também entrar nessa né, está sempre, agora... acho que foi no Fantástico, no domingo, no Fantástico, é... aquele que... não se faz uma obra sem consultar um profissional, né, o que que acontece... não tem um quadro assim... a porta que não abre, sei lá... então fazer uma campanha numa área que fale sobre procurar o profissional adequado né.. e acho que a psicologia poderia também entrar nessa de...

P9: Eu concordo com o P1, assim, disso, existe um estigma de quem procura um psicólogo tem algum problema, mas eu acho que tem um lado que podia ser explorado porque eu já vejo também, em algumas situações que a pessoa entende, assim, procurar uma terapia como autoconhecimento. Também está crescendo... é pequeno mas acho que... existe esse outro lado que é um lado positivo, saudável. Acho que poderia ser mais divulgado, isso.

P10: Mas tem isso pode haver uma autoajuda, curso de psicólogos, palestra motivacional, cursos onde as pessoas vão para não sei aonde, passar o final de semana para ficar sozinho e encontrar o seu eu, meditação, Yoga... A humanidade está passando por isso. Eu acho que a gente se perdeu e a gente está tentando resgatar o EU, e talvez quando a gente voltar a ser mais humano, se importar um pouco mais em como a gente se relaciona, talvez ajude, né, porque, as vezes só um: "Oi, tudo bem?", um "Obrigada", ou um "Como você está hoje?" Às vezes isso, pronto, já fez o seu dia, né? Ou alguém te manda uma mensagem você fala: "Ah! É por isso que vale à pena viver", entendeu. São as diversas formas de amor. Então, eu acho que quando a gente voltar a resgatar o eu, talvez isso, né, ajude a gente acolher as pessoas porque acho que não vai ter profissional para todo mundo todos os dias, mas, se cada um fizer um pouquinho e ter boas 
relações e aí é assim, é difícil, a gente trabalha com isso todo dia isso vai ajudar, também...

P2: E o estigma de "Doença mental". Que quando a gente fala em doença mental entra depressão, ansiedade, entra tudo isso. Aí a pessoa fala: "Nossa, então eu sou doente mental" Não como mudar, suavizar esse conceito? Esse termo? Porque a pessoa aí não aceita esse termo porque...

P7: Transtorno? Chamar de transtorno...

P2: Não sei. Mas assim... Doença mental? Meu Deus, eu sou um doente mental? Não! É difícil a pessoa... para a pessoa assumir...

P7: Transtorno, talvez. A palavra mais suave...

P2: É.....

E: A gente está falando das mensagens, da forma, dos locais. Aí fiquei pensando: Por quem que essas mensagens poderiam ser passadas? Vamos imaginar que tem lá alguma coisa na TV, tem alguma coisa, é por um jovem falando...ou será que vai me tocar mais se for uma pessoa mais ou menos da minha idade ou se for...

P4: Variado...

P7: Vários perfis...

P10: Diversidade... tem que refletir a sociedade...

P7: E não pode ser professoral, não pode... porque por exemplo, se for um profissional de saúde categorizado vai ficar professoral... você, por exemplo, impõe, impõe autoridade. E aí sim... para o segmento, (risos). Autoridade... sim, porque você tem um título...tem um reconhecimento e tal. Então, quando vai falar, aí, é para aquele contingente que busca uma informação e quer ouvir uma autoridade no assunto. Então ele vai, então serve a esse fim, então agora, existe um outro contingente que não quer ouvir, é, quer ouvir, às vezes, uma pessoa como ele, esse...eu também já vi alguns dele, esse que não tem os braços e pernas, esse camarada, ele até pode ter o tom profissional também mas acontece que ele vive a realidade, então aquela resistência que muita gente vai ter à pessoa que é autoridade do assunto. Porque a pessoa, ela, na fragilidade dela ela precisa, às vezes, de ver outra pessoa frágil, uma outra pessoa que chora, que dói, que fica com a palavra embargada pela dor que está sentindo...então que é um igual, que é um par...

E: Alguém que ela se identifica...

P7: Parecido com ela, um par....

P10: E essa eu acho que é uma pergunta para se fazer para pessoas que já tentaram, porque assim: porque elas desistiram ou quem são referencias para elas, ou por exemplo, quem elas 
ouvem.

P4: Muito bom isso

P10: Entendeu? Acho que pessoas que já tentaram são excelentes pessoas para responder, assim: O que te ajuda, aonde você vai, quais são as mídias que te atingem, o que você ouve, o que você acha do tipo “ah, isso é uma porcaria, só tão falando porque tão cumprindo o protocolo"... então acho que eles podem responder essa pergunta, melhor ainda...

P7: E uma pessoa dessas, por exemplo, talvez não tenha um coração aberto para ouvir alguma autoridade sobre o assunto, um psicólogo, alguém institucional, mas, não vai ter a resistência se vier um de nós, assim, alguém que não é nada de mais, e que é o um como ele, que também está sofrendo e que até também pensou em suicídio, e que de repente está... na mesma faixa etária, ou alguma coisa assim, né, então aí, é isso.

E: E vocês acham que essa consciência pública influencia a consciência individual?

P10: Não tem como

Vários: Sim

E: Não, só estou checando...

P7: Mundial, você falou?

E: Individual

P7: Ah! Individual

E: Se essa visão que o público tem, se essa visão que a sociedade tem do suicídio, da prevenção do suicídio, se ela influencia a pessoa tanto a buscar ajuda, a não buscar ajuda, a falar, a não falar, ir num psicólogo, ir num psiquiatra...quer dizer, essa sociedade ela tem essa influencia dentro do comportamento do indivíduo.

P10: É que a consciência individual, quase não existe, eu acho na minha opinião. Acho que os seres, a gente não tem uma consciência, assim...a gente nem se conhece para poder assim, não se deixar influenciar.

E: Ainda mais separar...

P10: Eu acho que é uma coisa assim, uhu, tudo junto...

P8: Mas é que não é uma coisa que vai ser $100 \% \ldots$

P4: Não, nada vai ser $100 \%$, mas eu acho que... 
P7: Tendências né, nós somos influenciados por tendências, modas e etc... Quer dizer, a gente acha que é indivíduo, mas uma boa parte de nós é acomodação com outras coisas que outras pessoas também aceitam. Que é a tendência, a moda...então eu aceito que eu tenho que usar calça, camisa, enfim, essa coisa, então de repente, isso não é uma decisão minha, mas é a forma de como eu vou ser aceito.

E: E a forma como a sociedade, as pessoas encaram o suicídio. Toca vocês? Vocês se sentem tocados pela forma como a sociedade encara o suicídio. Influencia vocês nos seus nos atos? Por exemplo: Quando alguém vem e pergunta do que a pessoa morreu.

P7: Eu pego e falo...

P1: A gente também já não esconde mais...

E: Sim, hoje em dia vocês falam?

P1: Mas eu acho que para quem está ainda no início...

P7: Você fala no início, no primeiro instante?

P8: Eu falo para algumas pessoas para outras não, assim como eu falo que uma pessoa querida que morreu de câncer, eu falo para uns e não falo para outros... quer dizer, eu falo para quem...

E: Por exemplo, como que seria isso, né? Está uma roda de pessoas falando que quem se mata é fraco. Isso é uma visão da sociedade...

P7: Tem uns que falam isso para mim...

P4: Eu se hoje em dia estiver em uma eu falo... porque, você já passou por isso? Como é? Qual é a experiência que você tem? Como você sabe? Aí eu vou partir já até pra...

P2: Para a defesa né...

P4: É...., mas em outras épocas não. No primeiro momento eu acho que você fica muito sensível, que você não sabe nem que tem que falar, né? Mas depois... você começa né...

E: Vocês já passaram por situações onde essa falta de consciência publica e individual machucou vocês?

P7: Machuca!

P4: Nossa! Eu passei muito. De perder amizades...

P7: O fotógrafo que foi lá apresentar os trabalhos de formatura da minha filha, a que está viva né..., mas aí no final ele disse, "Mas e então, a formatura da outra, tem aqui..., mas cadê ela?" Aí eu olhei.... Minha filha? Morreu. E ele: "ah! morreu, é? Do que ela morreu?" Minha filha se 
suicidou. E ele, ele é tipo japonês, eu não sei, talvez pela formação e tudo, "Ah, mas suicídio, a pessoa, ela... tem religião até que ela não é nem enterrado junto." Aí começou então a falar... meu deus que inconveniente, e eu olhava para a minha filha, e eu fiquei olhando para ele, e olhava para a minha filha. Até uma hora ele viu que não estava fazendo "feedback" né. Aí... vou voltar...quer dizer então as pessoas recebem o impacto e começam a botar para fora qualquer coisa e né, não pensa no que está falando...

P8: Mas isso eu acho que é para qualquer tipo de morte. Não sei...

P3: Acho que não.... Eles acolhem tanto todos tipos de morte, sabe? Na outra vez...

P8: Eu tive essa situação de por exemplo a minha tia sair dizendo que o meu irmão morreu de um ataque fulminante. Um ataque cardíaco. E eu sentei numa mesa de uma pessoa que eu não via ha tempo e ela virou assim: "AH! É o seu irmão morreu de um ataque cardíaco fulminante, né?" Eu olhei para ela e falei assim: "Ah sei lá, né. Se te falaram isso deve ser, né?" Aí ela começou a rir e me contou de umas 5 pessoas que tinham morrido de ataque cardíaco fulminante com 10 anos, com 20 anos, com 60 anos... e as pessoas fazem isso....

P3: Mas não julgaram o seu irmão...

P8: Então...

P3: Há, se ele teve um ataque cardíaco... e por causa de...

P8: Mas ele não morreu de ataque cardíaco...

P3: Sim, mas não foi isso...

P8: Sim, mas as pessoas falam coisas. Elas falam qualquer coisa. De quando eu estou com a minha mãe no cartório para registrar o óbito o cara fala assim: "Ah, sabe que morreu também essa semana?" Um dia depois que o meu irmão morreu falaram isso para minha mãe. As pessoas são completamente sem noção. Eu acho que no suicídio talvez as pessoas ficam, eu não sei se julgam ou ficam mais sem saber o que fazer e fica falando...

P7: Sem saber o que fazer é uma reação normal... eu já vi reações, as vezes a pessoa vai perguntando, ah e tal... morreu, e você fala e a pessoa, bum. Fica todo mundo sem ação.

P8: É que com outros tipos de morte a pessoa sabe o que fazer porque conhece alguém, porque não sei o que...aí eles começam a falar essas coisas, de... uma coisa que leu, lá, e começam a falar essas coisas como falaram para você. As pessoas falam muita bobagem...

P9: Isso que você comentou, né, que quem se suicida é covarde, é o que eu ouvi, assim. De uma pessoa próxima, então eu tive essa experiência e aí eu tive assim, primeiro eu fiquei sem entender porque, a reação, uma reação agressiva da pessoa, de ofender mesmo. 
P7: Ela teve a intenção de ofender?

P9: Começou a levantar a voz, falou que eu acho você um indivíduo... e eu falei, não, eu estou indo em um grupo de suporte... você não devia se envolver com essas coisas... uma pessoa próxima, assim, que eu conheço ha muitos anos. Eu acabei me afastando, eu levei um tempo para processar isso. E aí, depois é que eu fui entender que é um mecanismo, nesse caso em particular, de defesa dela e da família inteira dela. É a esposa de um amigo meu que tem dificuldade de lidar com qualquer tema que é morte ou doença grave, o jeito da pessoa cortar o assunto é agredindo.

P7: Eu acho que você falou isso um pouco né...

P9: É então, eu, é lógico que é doído, assim. Naquele momento que você vai procurar suporte de um amigo... E assim, o curioso é que é o mesmo amigo que falou do "divertidamente", o filme, e que ele comprou para as filhas e falou que todas as emoções, mas na mesma família tem isso. Então, dessa experiência que eu trouxe, assim, que as vezes chegar nesse tema, assim, meio tipo, as vezes eu vejo algumas informações serem passadas com impacto, né, de estatísticas, eu percebo que para a pessoa que já tem dificuldade, cria, talvez uma rejeição, talvez uma maneira de falar das emoções... que a tristeza faz parte, que o luto faz parte... talvez tenha uma resistência menor.

E: Você acha que talvez se as pessoas tivessem reações diferentes, ou mais positivas, vamos dizer assim. Se a sociedade aceitasse melhor essa morte e falasse mais abertamente de suicídio, diminuísse o tabu em relação ao assunto, quer dizer, a reação das pessoas ao lidar com esse comportamento ou ao lidar com alguém que perdeu seria diferente?

P4: Sim, mais fácil. Porque a gente lida com duas coisas, a gente falava muito isso no grupo, são duas, e eu passei muito por isso... são dois, é lida com a perda, com o luto e da maneira que foi... muitas cobranças, muitos "por ques", muitas pessoas querendo saber por que. Eu tinha que dar uma resposta, né! Em um caso do meu filho que era jovem era, a pergunta era, ou droga, de namorar, assim, a opção sexual eles não tinham dúvidas, porque eles tinham até namorada, mas se não tivesse, seria uma outra pergunta..., mas meu filho era drogas, por causa da idade, nunca, assim, pessoas que viram ele, que ele estava deprimido, que ele estava ruim e vinham perguntar, "há, mas ele estava envolvido com alguma coisa, mas ele estava envolvido com drogas?"

P2: (fala junto) É aí que eu falo...

P4: Eu tive, eu tive, eu tive a sensação de raiva no dia em que eu peguei o atestado de óbito, eu tirei uma cópia e pedi para minha tia entregar para um primo meu que tinha falado... porque lá constava que não constava nada de álcool e nem de nenhum medicamento, que ele estava, na verdade, que na verdade a primeira reação eu achei que ele tinha tomado todo o medicamento. E aí dava negativo dos dois. Eu naquele momento, dois meses depois, que veio o laudo, eu fiz questão de mostrar... hoje eu não faria mais isso, entendeu? Já passou. Mas naquele momento a pressão era tanto, deles falarem, que eu queria, assim, ser mal-educada mesmo, eu queria calar boca deles, então eu queria assim, eu falei para minha tia, pega esse papel, mas você faz assim, você esfrega na cara do seu filho, como a minha tia amava o meu filho com se fosse o filho dela, essa minha tia, e esse meu primo é, trabalha com ela, é afilhado dela... trabalha dentro da 
empresa dela, ela entregou para ele.

P10: Acho que quanto mais a gente tiver esse assunto, talvez, mais presente, mais comum, mais falado, talvez até as pessoas parem de ter pré-julgamentos porque elas vão aumentar o conhecimento a respeito do tema.

P7: Formação é importante...

P10: Então elas vão talvez julgar menos. E sinceramente, por exemplo, no centro espírita fala que tem o vale, esqueci o nome,

P3: Não tem mais...

P1: Não existe mais isso...

P10: O vale dos suicidas, então, em alguns lugares, né, no centro que eu vou, eles dão a palestra e fala sobre isso. Mas eu não levanto e saio correndo, porque para mim aquilo é uma opinião, e eu respeito. Se ele acha que é aquilo, se ele acredita naquilo, ele tem o direito de acreditar que existe um vale, etc., etc. Eu tenho outra opinião. Assim como acho que cada um de nós, a gente também quer que esse assunto seja respeitado, a gente também tem que respeitar se alguém acha..., né? Então, e talvez tenha alguém que tenha se suicidado porque foi covarde naquele momento, talvez sim, mas gente nunca vai saber, quais foram os casos que foram por covardia, outros porque são valentes, outros... então assim, muitas coisas são opiniões e cada um tem a sua. Eu, quando ouço essas coisas, eu respeito. Eu falo: essa é a opinião da pessoa, embasada no que ela sabe, no que ela viveu. Muita gente nem viveu o suicídio e vai ter uma opinião e ela vai se dar opinião sobre diversos outros temas sem saber. Eu tento dar opinião daquilo que eu vivo. Né, então, por exemplo, hoje tem algumas situações que quando eu vejo eu falo: olha, eu não sei te falar porque eu não sei como, assim, fazer com isso. Então eu acho que as pessoas, elas vão dar opinião sim, vão continuar dando e a gente tem que respeitar, se tem pessoas que acham, sei lá o quê elas acham, como eu não quero ser agredida quando eu por dar a minha opinião a respeito do assunto do suicídio né, e outra, eu conheço meu irmão, né, e eu... então assim, os motivos que levaram a ele, a se suicidar, só cabe a ele e eu tenho uma opinião a respeito. Eu sei os porquês, mas é uma opinião íntima minha. Não sei explicar, olha, foi por A né? Assim como meu pai deve ter uma opinião, minha mãe, cada um tem uma opinião, então... eu acho que mesmo que...é, eu acho que machuca e por saber que machuca, acho que a gente tem que saber onde a gente vai... eu posso não ir mais no centro espírita porque eles tem essa opinião, mas cabe a mim decidir se eu quero continuar a ir, mas sabendo que pode ser que eu chegue um dia lá e que a palestra vai ser falando que tem o vale que as pessoas ficam lá sofrendo...

P4: Então para eles, ninguém mais fala desse vale...

P10: É talvez tenham algumas linhas que sim, talvez seja pelo nível de informação, olha só, talvez não seja geral, talvez os centros espíritas, hoje, olha que legal, depois de um tempo a mais lidando com o assunto, tenha outras opiniões, que foram outros, não sei, onde que eles se basearam. Então acho que é muito isso. Acho que quanto mais informação tiver aí, as pessoas 
vão se embasar um pouco melhor. E tem outras que vão se embasar mesmo sem saber e vão achar que é aquilo e cada um acredita no que quer...

P7: No meu meio que eu frequento religioso que é a Gnose, a questão é digamos, mais ou menos, dogmática que parte do princípio da sabedoria do mestre. E o que ele fala, que está registrado nos livros e é o que a gente aceita como doutrina, é que quando a pessoa, quando ela se mata, comete o suicídio, ela volta, vive a vida normalmente conforme o seu carma e darma, conforme o que já tinha, né, mas toda a vida dela vai ser estruturada, e ele vai viver, e na hora em que ele estiver mais feliz e querendo viver, ele vai morrer. Então, por exemplo: aquela pessoa que está prestes a casar, então está na festa de casamento morre aí. Que conseguiu conquistar tudo e vai gozar e morre ali, na hora. Quer dizer, na hora em que ela mais esta querendo viver a vida lhe é tirada.

E: E essa visão que a tua religião dá...

P7: Daí a gente aceita. A gente não fica com raiva. Eu, pelo menos, eu aceito, eu não dei a minha opinião...esse caso eu aceito. Eu entendo que isso é lógico, até porque o que eu falei aqui, a sua vida vai seguir adiante, a sua outra existência, continuarão sendo normal, como qualquer outra. Mas essa é uma coisa que não tem perdão. Não dá para negociar na existência seguinte, para ela não morrer na hora que ela mais quiser viver. Isso aí tem que acontecer para que ela fique tão impactada a ponto de nunca mais fazer isso na sequencia das outras existências. Quer dizer, pela lógica que ela contem, ela não me agrediu. Eu continuo aceitando e eu acho, eu sei que a minha filha já nasceu ou vai nascer ou já nasceu, não sei, não tenho esse grau de consciência para saber e que vai na hora em que ela mais quiser viver a vida lhe vai lhe ser tirada. Por exemplo, os Mamonas Assassinas, aquele grupo, estava no auge do seu sucesso. Bum, morreram todos. Quando mais queriam viver. Quando a vida lhe sorria e tem outros exemplos, né? Quer dizer, exemplos famosos, né? E para mim, na minha religião, eu aceito isso em paz...

P4: E que religião que é...

P7: é cristianismo gnóstico.

P10: Assim como tiveram pessoas, que sei lá, faleceram, que caíram do avião, por exemplo, que eu não sei se estava no auge. Acho que é aquilo, acho que cada um aceita, né, ou você pode aceitar tudo de uma religião e aquele ponto não. Acho que é nosso direito. A gente fala: Ah, eu sigo $50 \%$ dessa, $1 \%$ daquela....

P7: Pode ser. É que no meu caso, esse ponto que fala do suicídio, para mim foi pacífico. Para mim e para minha família. Porque é tão lógico, porque eu acho que a razão de ser da vida é o aprendizado. O ser feliz ou o ser triste é uma variável...

P4: Nós fizemos uma discussão sobre isso e hoje é considerado, assim, primeiro que na verdade eles estudam que já não é mais aquilo, há, então você morreu de suicídio com um tiro na cabeça você vai vir com problemas mentais. Não é mais essa ligação. Eles foram estudando e vendo que as coisas não são assim. Pode ser, pode não ser. E assim, uma vez deram um exemplo, eles nem sabiam que eu tinha no....e eu achei muito legal. Muitas vezes pode vir um médico, um 
psiquiatra, alguém que vai ligar, que vai trabalhar com isso. Porque ele já vai vir com algo dentro dele sabendo, entendeu, como lidar com a situação. Então vai ser aproveitado de uma maneira benéfica, não necessariamente vai vir debilitado, então, tem enes maneiras de voltar. Se não a gente ia ficar maluco se ficar pensando como vai.

E: Quer dizer, a religião, ela também vai trazer uma consciência. Ela tem um poder de influenciar muitas pessoas e a forma como ela vai lidar com o suicídio, vai influenciar muito a forma que as pessoas veem. Então, talvez um outro local também, de você aumentar a consciência é dentro da igreja. E das religiões.

P4: Exatamente, talvez a religião que a pessoa, que não é o caso da minha, mas vamos dizer que uma pessoa, daquela religião, a gente aprende muito isso: cada um está, às vezes, na religião certa e quando não está, não é o momento mais, vai procurar uma outra. Porque muitas vezes a pessoa que estava na igreja evangélica, e aprende, porque é necessário, porque eles tem tantas... de acreditar, é necessário as vezes ainda, porque as vezes lá seguram, um pai de família que está bebendo e as vezes vai lá e por temor a Deus, que na nossa já não é o temor, mas por temor a Deus, para de beber, não bate na mulher, entendeu? Se modifica. Então, são necessárias, depende do grau que você vá buscando. Você vai buscando mais, mais, vai questionando...

P3:Eles conseguem, inclusive nas cadeias, recuperam tanta gente...

P4: Tem, tem seu mérito, todas elas tem, na essência um mérito bom... O que as vezes prejudica uma religião ou outra somos nós mesmos, seres humanos que estamos administrando.

P9: Acho que religião, eu acho que é importante, mas é importante frisar a liberdade de cada um ter opinião diferente.

\section{P7: Até de não ter religião}

P9: Porque nunca se crê em coisas conflitantes, não é? E aí poder, assim, ter a liberdade de conversar e se abrir, e falar, não, eu penso diferente na minha religião....

P4: Meu filho escreveu muitas cartas, e nas cartas pela religião dele, que ele frequentava ele falava o que ele sabia, que simplesmente ele não sabia qual era o local dele neste mundo. Mas... que ele sabia que ele teria que voltar algum dia e, ele não usa pagar por isso, mas ele fala, resgatar o que ele fez..., mas que aqui neste momento ele não estava pronto, que o mundo era um lugar muito escuro para ele, que ele não sabia qual era a posição que ele tinha que tomar. Então assim, na verdade é dele, não são cartas psicografadas, é dele né? A sensação era maior do que a educação que ele teve de desde os 5 anos de evangelização espírita. Então ele sabia que tinha outra coisa? Eu questionei muito isso, na época. Como então? Mas como? Se a pessoa comete o ato achando que lá não tem mais nada, então eu vou tirar a minha dor, como que meu filho fez isso sabendo que tinha alguma coisa? Eu fui pesquisar muito isso na doutrina, conversar com muita gente... ler muito... por isso que eu sei que assim, só os livros muito antigos, os mais antigos que não vão lá continuar estudando, lendo, que ainda revê esse vale dos suicidas, porque falaram isso pra (nome de uma amiga), e ela ligou para mim em desespero, ela chegou para um senhor e falou: "Como o senhor acha que está meu filho?" Ele falou: " Como você acha? Está no 
vale dos suicidas. Vai ficar lá até o tempo que ele deveria estar aqui". Ela entrou em desespero então, é um ser humano, a pessoa, você não dá para falar que aquilo, você falar em nome, né?

P1: Uma colega nossa chegou lá para a (nome da esposa), com um panfleto sobre uma palestra, do vale dos suicidas e disse, Dona (nome da esposa), a senhora não pode perder essa palestra, porque a (nome da filha) está lá, ela ficou assim no desespero né, ficou tal, e foi sair e disse, não deixa de ir não... e a (nome da esposa) fícou, aí, ela pegou o carro e ia, aí no meio do caminho ela disse: " não vou, minha filha não está lá" aí voltou para a casa. Quando foi a própria carta que ela recebeu, ela começa: "Mãe, eu estou falando de um vale, não do vale suicidas." (Risos)

P7: Eu estou falando...

P1: De um vale, mas não é o vale dos suicidas...

P7: (fala junto) Nossa, essa menina...

P1: Entendeu, assim, as coisas, aí ela ficou...

P4: (fala junto) A gente ouve cada coisa que as pessoas acham que a gente é maluco...

P1: Aí ela ficou assim, ela não falou isso para ninguém né... pois é.... nem eu sabia, fiquei sabendo depois, que a menina tinha dado para ela, que ia ter uma palestra sobre o vale dos suicidas.

P4: Eu fiz uma boa pergunta, é, muito, assim, mentalmente também, assistindo a um filme, na outra carta o meu filho respondeu.... Não, aqui nós temos obrigações diárias de afinidades, não de namorados. Eu tinha feito uma pergunta, em casa né...

E: A gente está chegando no final e eu tenho mais uma última pergunta. Depois eu vou mandar para vocês um roteiro porque a gente fala de muitas coisas, não na ordem, enfim, aí se vocês quiserem complementar...,mas, se vocês falam, porque a gente esta falando até agora de: como que a sociedade pode falar ou como que a gente pode trazer...agora vocês, vocês conversam sobre suicídio em casa, na família, com os amigos? É uma conversa aberta? Como é que é?

P4: Agora só... de 2 anos para cá...

P7: Com a família sim, mas com a família não, com os amigos sim.

P4: Eu agora na família eu falo, de 2 anos para cá, aliás as pessoas agora, sentindo que eu estou melhor, me procuram para quando sabe, por exemplo, uma amiga minha, que era uma das que me pressionaram muito, mas por que?... a sobrinha dela está com problemas e se está falando para a mãe, ela toma medicamentos, sérios problemas e ela agora começou a falar para a mãe que não quer mais viver. Já deu muitos problemas. Ela foi convidada a se retirar da escola, uma escola muito boa, aqui em São Paulo. Ia com saia muito curta, você entendeu... só que agora está... e essa minha amiga, outro dia, veio me procurar. Inclusive pensei em indica-la para a mãe, mas a mãe está restrições de mandar ela para uma terapia. O psiquiatra está falando que ela tem 
que ir. Então ela veio me procurar: "Ah, preciso te contar uma coisa..." Porque ela se sentiu à vontade de me contar e que eu... "Não porque...sei que você né? Tem vários lugares... o que eu posso indicar para a minha cunhada, eu falei, eu acho que terapia, acho que dá para ficar em cima com ela para ela tomar o medicamento, vê o resultado do medicamento... então assim, agora as pessoas estão perguntando.

\section{E: Por causa da sua experiência...}

P4: Porque estão vendo que eu estou levando adiante, eu estou falando sobre o assunto. Então eu falo abertamente com o (nome do filho do marido) que mora comigo, que é filho do P5, né, o mais novo que era como irmão do (nome do filho), então a gente fala, quando a gente ficou preocupado com o meio irmão dele a gente conversa sobre isso. Então, a gente conversa.

P3: Tenho um filho que nunca tocou no assunto. Falou uma vez só mas acho que porque eu perguntei. O outro toca no assunto quando eu quero falar. Mas ele mais me escuta do que ele mesmo fala. Então eu sinto que aquilo machuca...eu procuro evitar.

E: Mas isso com a família próxima. Amigos tocam no assunto?

P3: Não, não. As pessoas tem esse receio. Não sabem como tocar... como eu também não falo. Eu tenho uma prima que é psicóloga. Com essa eu converso muito, mas fora isso não.

P2: Com amigos, muito. Com colegas, pouco. Com uma parte da família, muito e outra parte quase nada. Porque a minha sogra, por exemplo, começa com as lamúrias dela e aí eu já tenho que dar uma cortada, "aí, porque ele não me leva também...", aí começa com drama. Aí, porque sempre foi difícil, eu queria ficar com o meu neto. Aí aquilo começa a me dar um desgaste né, aí eu falo "Ai, por favor... não... para com isso". Aí já vou logo para frente. Mas é isso. Agora em casa com o marido falo bastante.

P8: Eu acho que em casa a gente sempre falou, mesmo antes. Sempre foi uma discussão, acho que do ponto de vista intelectual, sempre se conversou um pouco sobre isso. Até por questões de...por exemplo, de ter algumas doenças na família que são muito críticas, a gente sempre conversou: "E se a gente for diagnosticado com isso, o que você faria?" A gente fazia esse exercício, um pouco, porque é complicado também. É.... depois com os amigos não. Mas depois do que aconteceu com alguns amigos eu converso sobre isso, falava as vezes alguma coisa, mas pouca coisa. Depois do acontecido eu acho que eu tive...eu tenho a sorte talvez de ter muitas pessoas que conseguem conversar com isso bem, pessoas que se revelaram bons amigos, depois disso e hoje a gente fala, ainda fala, mas a gente não fala do meu irmão, mas a gente fala do assunto. Meu irmão ainda...acho que a cicatriz...a gente ainda não conversa sobre ele, mas a gente fala sobre o assunto. Até por questão de ser uma situação presente para outras pessoas, eu tenho um primo que esta passando por uma depressão profunda e minha irmã está tentando ajudar a minha tia.... Então fala-se, mas a gente não fala do meu irmão, ainda.

P1: A gente fala o tempo todinho né, porque a gente trabalha com isso né..., mas assim eu ainda sinto, assim, receio de amigos quando falo no assunto. Mas por outro lado, tem já alguns amigos que eles procuram...já é bastante casos de amigos deles, para a gente ver se pode dar uma ajuda e 
tal, quer dizer, se ele vem é porque, é porque ele tem uma certa vontade que é de gente conversar. Na família, fora a família mais íntima né, quer dizer eu, a (nome da esposa) e a (nome da outra filha), não se fala né, fala muito do instituto né, muitas coisas, mas assim fala mais de modo geral...

E: Do suicídio da (nome da filha) não?

P1: É, do suicídio da (nome da filha) não. Mas não é assim tão, assim, para a gente, é transparente...

P4: (fala junto) Isso é lindo, que vocês fazem, de usar essa dor, para ajudar os outros.

P1: Exato, entendem. É isso!

P10: Eu falo com minha mãe e meu pai, minha avó, com uma tia e com duas amigas, mas é porque as pessoas não sabem. A gente não falou que foi suicídio, só dentro da família. Meus amigos, teoricamente se eles sabem não foi porque eu contei, não sei se ficaram sabendo e não falaram.... Então...nem na empresa, em nenhum lugar as pessoas, eu não falo com ninguém porque eu não falei que foi suicídio. Eu falo da perda do meu irmão. Isso eu falo. Mas não falo do motivo. E na minha família só com as pessoas que são realmente mais próximas, né? Meus pais, a minha avó, essa minha tia... A minha melhor amiga sabe, inclusive na família dela também tiveram alguns casos. Então mais assim. Mas na sociedade, ninguém, né, assim é coisa que eu não falo então eu não tenho assim muito... eu não falo com ninguém mas é por escolha. Se eu quisesse falar que foi suicídio eu poderia falar e assumir, mas eu não contei, talvez um dia, enfim...

\section{E: Importante assim você se respeitar.}

P7: Com a família, a gente não fala porque já sabe que não quer falar sobre o assunto. A única exceção que eles participaram de alguma coisa foi na (nome de um canal de televisão) que deram um breve depoimento, a mãe, e a (nome da filha do meio), o meu filho menor não. Mas eles não gostam e quando eu estou conversando com alguém eles se afastam se o tema entra nesse assunto, né? Então, eles ficam constrangidos, não querem conversar sobre o assunto, é uma forma de eles lidarem... agora, os amigos não. Com os amigos eu converso..., mas é porque está embutido na conversa com os amigos, e uma parte deles é militante, batalhador que nem eu, então eles até se identificaram, ficaram meio tocados. Você está sempre lutando e abraçou mais essa luta, é isso aí, tal. Essa feição de luta, de coisa, como é algo que a sociedade assimila legal, no caso, o cara está fazendo uma luta por as outras pessoas, então permite as pessoas, acho que, por causa desse viés, elas conseguem conversar. Porque elas não ficam aprofundando a questão do suicídio, mas a luta que está fazendo. Agora, o impacto que está causando, principalmente entre os profissionais da área, que me conhecem de longa data e alguns são da dança, os profisssionais de dança, é que eles não se conformam com essa impossibilidade que eu adquiri de dançar, né? Então eles... eu sinto que alguns até ficam compungidos. Profissionais principalmente, muito compungidos. É como se tivessem perdido com que o dançarino morreu, né? É onde eu sinto assim mais uma carga emocional, por mim. Quer dizer, não se conformam com fato de eu não dançar e como eu já eu ouvi em alguns casos, alguns apelos de algumas 
parceiras do passado, de que um dia eu gostaria de voltar a dançar comigo... eu acho que as pessoas, elas falam P7, você, tem direito a ser feliz, você tem que voltar a dançar porque quem dança é mais feliz...Ainda mais eu que defendia, eu abracei essa bandeira da dança, sabe, é uma bandeira que eu abracei. Imagina eu amanhã eu abandonar a luta pelo suicídio, a luta pela prevenção ao suicídio.; Como vocês vão se sentir? Se eu abandonar essa luta? E não participar? É o que eles estão sentindo porque eu era um grande divulgador, os profissionais de dança ficaram muito agradecidos porque eu ajudava e tal... e onde eu vivo hoje em dia quase não tem mais jantar dançante... eu fiquei espantado, P7, a dança morreu aqui em (nome de uma cidade), quer dizer então que eu era a chama...então nesse ambiente o impacto é maior. Mas eu falo: "Gente, eu não danço porque eu não quero. Eu não consigo." Aí hoje eu encontrei uma..., hoje não, ha pouco tempo, eu encontrei uma figura, um exemplo, para poder as pessoas entender o que é. Não é exatamente isso, mas eu acho que é o que chega mais perto. Imagina você ter que fazer sexo com alguém, sem vontade, apenas para agradar essa pessoa. Não dá. Não vou conseguir. Então, eu não consigo dançar porque tem que ter emoção, assim como no sexo tem que ter o desejo, a vontade, o impulso, é o sagrado, é o que gera a vida, é o que desenvolve o amor enfim, né? E você vai fazer uma coisa mecânica. Então, é a mesma coisa a dança. Então, esse contingente está seriamente impactado. Mas eu converso, mesmo, com eles. Eu me imponho começar a falar, mesmo que dói, eu me imponho, por causa dessa bandeira que eu abracei...

P9: Eu converso com poucas pessoas. Acho que teve uma pessoa que eu falei sobre o tema e ela e a pessoa falou: "Nossa que interessante!" Perguntou mais coisas. Aí eu tive experiências ruins, então hoje o que eu percebo, assim, não falo sobre, primeiro que dou uma explorada para ver como é a visão dela em relação a morte, para saber se eu posso entrar no assunto.

\section{P10: Você faz um teste.}

P9: É, é, por experiência prática. Então, até desses amigos, tinha essa, que eu recebi uma reação bem negativa, eles têm duas filhas. Então, tinha um certo conflito, uma angustia, de eu ter muita informação e querer compartilhar e sofrer essa resistência. Então hoje eu consegui assim, ligar e falar assim: "Posso te falar sobre tal, tal, coisa? "E aí, o meu amigo disse, ok... aí de vez enquanto eu passo a informação. Mas criou um afastamento. $\mathrm{O}$ tema criou um afastamento. Então, eu encontrei...Apesar de ter tido esse tempo no CVV, eu tive poucas pessoas com quem eu pude compartilhar a experiência. Isso é uma coisa que para mim entristece bastante.

\section{E: Alguém tem alguma outra observação, quer falar mais alguma coisa?}

P9: Eu tenho. Da reunião passada, por exemplo, uma coisa que me tocou e foi o que eu fiquei refletindo né. Quando a P2 falou: "Poxa, eu tenho uma pessoa com depressão, mas eu não consigo..." E falou com esse sofrimento. Então, é a mesma coisa que eu sinto, e é um conflito meu, quando falam assim: "Existe algo que eu posso fazer, mas eu tenho que conseguir saber reconhecer o meu limite até onde eu consigo ir. Isso é difícil. Para mim participar do grupo foi difícil, assim, porque eu sabia que teriam opiniões diferentes né? $\mathrm{E}$ algumas coisas que a gente fala como a história do outro é diferente, às vezes chega, né, de uma maneira dolorosa. Puxa, mas então, eu devia fazer algo e será que eu não fiz? É o meu conflito que eu fiquei. Então, tenho algo para acrescentar? Por exemplo: uma experiência que eu particularmente vivi, que foi a perda de um amigo, foi o que muita gente relatou do processo, né, é do atestado de óbito, da polícia e tal. Assim, a minha área administração, então, eu fiquei pensando o que poderia ser 
feito. Uma das coisas que eu percebo, assim, toda a cegueira que a gente tem individual vai para a cultura. Isso também vai para a cultura das organizações. Então, o sistema de saúde, hospital e plano de saúde ele vai de alguma maneira refletir a dificuldade que cada um individualmente tem com o tema. O tabu que tem, né? É um reflexo. Então, tanto o sistema de saúde quanto a policia vai ser um reflexo disso. Aí me tocou bastante, assim, alguns depoimentos do como é doloroso esse processo... então, eu queria trazer assim: Um relato bonito que eu ouvi de uma médica é o cuidado que ela tem. Quando vai tratar alguns assuntos com a família, ela falava, ela falava assim: "Eu sei que vai ser um momento que aquela família, aquelas pessoas vão levar para o resto da vida. Então, o que eu ouvi de depoimentos é que eu também já passei em situações diferentes com uma notícia, ou uma comunicação entre o profissional de saúde, não tive com a policia, mas isso é uma dor a mais que se soma à aquela que o enlutado já está passando. Então, uma sugestão, né, que eu acho que seria importante para vários profissionais. Eu não sou da administração da área de saúde, mas, essa discussão, esse cuidado na informação, na comunicação dessas organizações com os enlutados, eu acho que poderia diminuir o risco. Porque assim, é uma dor a mais, na ferida. Então, eu acho que tem alguns meandros que talvez, assim, vamos supor, o profissional de saúde atua...esse é o trabalho deles. O policial tem, esse é o trabalho dele. Mas talvez tenham buracos que ninguém, não tem ninguém, digamos, responsável, né? E que a pessoa enlutada, as vezes ela passa e não tem ninguém... fica um buraco...

P4: Falando eu lembrei que o preconceito já começa quando você tem um seguro de vida e não pode o suicídio. Porque o (nome do filho), tinha comprado um carro fazia pouco tempo e estava financiado uma parte e a gente fez automaticamente um seguro de vida e ela falou no dia para o P5, que ninguém achava o documento dele, o P5 não achava, eu não quis ir para a casa, e o P5 telefonou para gerente do banco que eu tinha acabado de sair e me despedi dela porque eu ia viajar. Aí eu lembrei, liga que ela tem a documentação dele. Aí ela falou: "Olha, no fim de semana retrasado, eu nem falei para a P4, no seguro de vida, não cobriu, deu negativo. Depois por o (nome do filho) estar trabalhando com uma grande amiga que era que nem mãe dele né, ela pegou e falou, me dá aqui, meu filho acabou de se formar, que era irmão do grande amigo do (nome do filho), vai ser a primeira causa dele, ela conseguiu no (seguradora) com alguns casos que já tinham acontecido de depressão, ela levou todo o histórico dele dos médicos, ela levou os remédios que ele estava tomando, tudo, fez um processo. Demorou 2 anos e ela sabia que eu não ia usar esse dinheiro... eu queria esse dinheiro não para mim, eu queria deixar esse dinheiro num fundo para ajudar as coisas. Ela conseguiu no * mas foi assim, uma briga, o da (nome de amiga) tinha e o advogado não conseguiu. E também não quis brigar. Eu também não queria brigar por isso. Eu tinha deixado. Faltavam 5 dias para expirar o prazo, porque tem um ano só para entrar. Já tinha vindo uma negativa. Eu só comentei com ela que eu ia entrar aí ela falou assim: "Me da aqui que eu entrego..."

\section{P7: Ah que bom! Gostei muito de saber disso.}

P2: Eu queria só acrescentar que eu fiquei muito surpresa com o tratamento que eu tive pela policia. Eu não esperava né. Esperava realmente um tratamento meio hostil e eles não foram em nenhum momento. Desde a delegada, todos que foram... os peritos, todos eles foram tão acolhedores que eu precisei voltar depois para agradecer, sabe? Eu estava em frangalhos, eu não conseguia nem se manter em pé e a delegada conversou muito comigo, me acalmou e eu perguntei para ela se ela poderia falar essas mesmas palavras para o meu marido. Ela saiu da 
delegacia, foi até ele e falou tudo aquilo com uma calma, uma mansidão, e todos eles de um respeito que eu fiquei muito surpresa e aí eu tive que desconstruir toda a imagem negativa que eu tinha da polícia naquele momento....

P7: Que bom...

P3: Para mim foi também a mesma coisa. Foi uma delegada, era bem mocinha ela, uns 30 e poucos anos, me tratou assim, uma maravilha, nossa, foi uma das pessoas que mais me consolou. Foi assim maravilhoso.

P2: Quer dizer, são raros, mas existem né enfim,

E: Então, eu acho que isso que vocês estão falando é que essa forma como essa comunicação chega, principalmente nesse início faz um impacto grande, seja da polícia, da saúde, enfim, isso tem realmente um impacto dentro desse processo todo.... Gente, a gente vai precisar parar...

P10: Eu acho que esse estudo teria que perguntar também para as pessoas que tentaram, tudo isso porque eu acho que ele tem respostas de uma perspectiva bem, talvez, assertiva, né, com relação a muitos dos pontos.

P7: Eu tenho um informe a dar, um informe a dar. É....eu... fui entrevistado pela (nome de canal de televisão) essa semana, eles foram lá em casa né. Eles fizeram vários registros, tal e disseram que é o programa (nome do programa) de toda (data e horário do programa). Dura $50 \mathrm{~min}$. (nome de canal de televisão e nome do programa). Vai ser provavelmente na (dia da semana) feira dia * sem ser a próxima, a outra.

P9: Só uma observação, você falou de locais para atuar, eu tive uma ideia, assim, pensando no lado de administração, assim por exemplo, os planos de saúde eu já participei, tem programas de prevenção, cardíaco, tal, e sim, muitas vezes infelizmente não é por uma consciência, uma conscientização, mas é por causa dos custos, mas até por isso, talvez, a partir de alguns dados possa se implantar dentro do programa de saúde, um programa de prevenção nessa linha, né?

P3: Eu acho isso bem interessante...

E: Gente, eu agradeço imensamente a disponibilidade de vocês terem vindo 2 vezes, de estarem aqui na segunda noite, frio chovendo, São Paulo...

P4: Karen acho que nós todos aqui estamos agradecidos com esse trabalho

P7: É o mínimo, imagina, você também nos acolhe.

P4: Nós estamos aqui porque temos uma causa, você está... tudo bem, você é profissional, mas é para ajudar, então, para evitar, então nós que agradecemos.

P3: Desabafar é uma coisa que ajuda muito. 
E: Eu não tenho como agradecer. Continuo à disposição qualquer coisa vocês entrem em contato comigo. Assim que tiver transcrito eu vou enviar para vocês o texto e vou enviar as perguntas. Se vocês quiserem complementar alguma coisa nas perguntas complementem, se não, não precisa. Se quiserem alterar alguma coisa no texto, alterem. Eu vou tentar colocar...no texto que eu vou passar para vocês vai estar o nome de quem está falando. Depois, quando isso for para a análise, porque eu vou fazer a analise, quando isso for ser publicado, aí vai ser P1, P2 para que não tenha identificação. Mas para vocês vai o nome até para vocês verem se vocês querem alterar ou não alguma coisa que vocês falaram ou complementar. Está bom? Muito obrigada bom descanso e estou à disposição.

TOTAL: 02:15:19 HS 


\section{Anexo E - Roteiro de perguntas C1}

\section{Sobre o tabu e a consciência pública}

1) Como você acha que o suicídio é visto hoje no Brasil?

R. O tema suicídio ainda é assunto velado e carregado de preconceito. As discussões ainda geram temor e a maioria das pessoas prefere não olhar para um problema que afeta praticamente a todos.

2) Você pensa que o suicídio é um tema tabu no Brasil? Por que você acha que isso acontece?

R. Sim. Ainda é um assunto pouco discutido e muitas vezes evitado até por pessoas que passaram por situação de suicídio na família. Muitas pessoas têm vergonha de ter tentado ou mesmo de ter alguém na família que fez tentativa ou morreu por suicídio. Geralmente o assunto fica velado, por temer o estigma, o julgamento, enfim, o preconceito da sociedade.

Acredito que esse tabu é decorrente de um processo social cultural atrelado a dogmas religiosos, a partir da condenação ao pecado mortal a pessoa que comete suicídio, estendendo as punições também à família.

Assim como tudo que nos causa sofrimento e medo, o suicídio foi ao longo do tempo se tornando assunto proibido na sociedade. Tudo isso, contribuiu de forma significativa para que o problema tomasse dimensão de uma epidemia.

3) Vocês acham que o tabu começa aonde?

R. Na família, quando na tentativa de proteger o seu núcleo, os pais evitar comentar sobre o assunto. Geralmente, assuntos de suicídio e morte são proibidos nas discussões familiares. Nos nossos grupos sociais quando não se permite falar sobre suicídio, porque é assunto pesado e normalmente as pessoas consideram que naquele grupo não tem ninguém com ideação suicida. Na igreja, quando condena a pessoa com comportamento suicídio ao pecado mortal.

4) O que pensa a respeito conscientização da problemática do suicídio?

R. É importante e necessária. A falta de informação pode ser considerada como um fator que contribui para o crescimento dos índices de tentativas e de mortes por suicídio. Por 
falta de informação as pessoas deixam de tomar conhecimento sofre os fatores de risco, sobre os sinais que uma pessoa com ideação suicida apresenta e ainda sobre o que fazer quando alguém faz uma tentativa de suicídio, quais as posturas corretas, como a família deve cuidar desta pessoa e principalmente onde e como a família a deve buscar orientação.

A conscientização deve ser feita de forma que contemple toda a população. O que se percebe atualmente é que algumas pessoas já buscam informação, entretanto, há que se preparar a sociedade para a discussão sobre o assunto, através de estratégias que mostrem a importância da divulgação das campanhas de prevenção e que o suicídio é um problema de saúde pública, é como tal, a população precisa se envolver de forma consciente, como tem se envolvido em outras campanhas de promoção de saúde e prevenção de doenças.

5) Você acha que falar mais sobre o assunto aumentaria a consciência pública do tema?

R. Sim. Desde que de forma respeitosa e consciente, evitando o senso comum, desmistificando os tabus e desconstruindo o preconceito em torno do tema. É importante informar sobre as formas de prevenção, sobre os fatores de riscos, sobre os fatores protetivos e sobre a importância de buscar ajuda.

6) Você acha que isso teria algum impacto na prevenção e posvenção?

R. Sim. A possibilidade de discutir o assunto abre espaço para que as pessoas possam se refletir sobre o tema. Posam mudar de postura. Possam se perceber e perceber o outro.

7) Como gostaria que o suicídio que fosse visto pela sociedade?

R. Gostaria que fosse tratado como um problema de saúde que potencialmente afeta a população, independente da condição social. Gostaria que fosse tratado como causa decorrente de doença, e não como um ato individual de coragem ou de covardia. Gostaria que fosse tratado com humanidade, compreensão e respeito, no sentido de que, se troque o julgamento pela reflexão do que cada pessoas pode fazer a respeito, partindo do lugar comum para uma mudança de atitude.

8) Qual o impacto de campanhas públicas, como o setembro amarelo, em cada um de vocês?

R. Eu tomei conhecimento da Campanha Setembro Amarelo em 2015. Foi a primeira vez que participei de um evento público. O impacto é positivo uma vez que consegue sensibilizar um grande número de pessoas. 
9) Alguém lembra de algum exemplo de campanha ou mensagem positiva/negativa sobre o suicídio na mídia?

R. A Campanha Setembro Amarelo, em 2016, foi divulgada nos meios de comunicação de massa e nas redes sociais. Muitas ações foram noticiadas nas principais emissoras de televisão e rádio do país.

\section{Sobre como aumentar a consciência pública}

10) Como poderia ocorrer essa conscientização no Brasil?

R. Através de um programa regular de palestras, fóruns e seminários nas escolhas de ensino fundamental, médio e nas universidades. Através da divulgação de informações nos meios de comunicação. Através de peças e filmes que abordem o assunto.

11) Como podemos começar a falar sobre o suicídio? O que nos impede de falar sobre o tema?

R. Podemos começar falando sobre prevenção do suicídio, sobre a relação do suicídio com a saúde mental, sobre a importância de discutir o tema para que as pessoas possam buscar ajuda, nos nossos grupos sociais mais próximos, na família, na igreja, no trabalho.

Podemos falar quando alguém abordar o assunto de forma preconceituosa, ou quando julga a pessoa que comete suicídio como um a pessoa "corajosa" ou "covarde" ou mesmo uma pessoa que não tem amor pela vida e não pensa nos familiares. Essas, são oportunidades particulares que podem ser aproveitadas para conscientização.

12) Que sugestões você teria para que o suicídio fosse mais falado no país?

R. Seriam importantes campanhas de prevenção do suicídio veiculadas nos meios de comunicação, promovida pelo Ministério da Saúde e pelas Secretarias de Saúde dos estados, a exemplo de outras campanhas que são promovidas quando identificas epidemias ou o avanço de certas doenças.

13) Quando e onde você acha que esse tipo de informação deve ocorrer?

R. Geralmente estes temas tem uma discussão mais ampla através de fóruns, simpósios e congressos, entretanto as discussões ficam mais no meio acadêmico e técnico, o que é importante, mas não abrange um grande contingente. As informações devem chegar a sociedade em geral através de palestras nas escolas e nas universidades, organização de 
grupos de estudos sobre o tema, formação de rodas de conversas mediadas por alguém que já estude o tema

14) Como você pensa que deve ser abordada essa questão? (que mensagem deve ser passada?) Que ações seriam necessárias e como elas poderiam ser promovidas?

R. Acredito que o tema deve ser abordado da mesma forma que são abordados os problemas de saúde pública, as epidemias, as questões que afetam a sociedade; com de forma esclarecedora, informativa, com uma linguagem simples e acessível a todas as pessoas.

Devem ser promovidas palestras e oficinas para adolescentes através das escolas, com o objetivo não só de falar sobre o suicídio, mas também de como lidar com os sentimentos, se perceber e perceber o outro, e ainda como e onde buscar ajuda.

Acredito que deverão ser oferecidos programas de conscientização para professores, pais, e cuidadores, com o fim de levar a informação sobre a prevenção do suicídio e como tomar uma atitude ou como buscar ajuda.

Devem ser passadas mensagens de que o suicídio pode ser prevenido, que o suicídio na maioria das vezes está relacionado a uma doença mental, que as pessoas que estão com ideação suicida devem buscar ajuda.

\section{Sobre a consciência individual}

15) Vocês acham que a consciência pública influencia a consciência individual, de que forma?

$\mathrm{R}$.

16) Vocês acham que a falta de consciência pública pode ter influenciado o suicídio da pessoa que perderam?

R.

\section{Experiências}

17) Como é para vocês falar sobre o suicídio?

R. Já foi muito difícil. Nos primeiros anos evitava falar a palavra suicídio (ou termos associados como se matou, tirou a própria vida). Atualmente é um assunto que flui tranquilamente, sem preconceito. Todas as vezes que tenho a oportunidade falo sobre as formas de prevenção, sobre como podem ser percebidos sinais, sobre como os 
preconceitos devem ser descontruídos.

18) A forma como a sociedade e as pessoas encaram o suicídio te toca?

R. Ah, sim. Principalmente pela falta de informação. Pela falta de humanidade e de empatia de entender o sofrimento do outros. O julgamento que grande parte da sociedade faz, ainda é baseado em dogmas religiosos; na questão do pecado. Por outro lado, percebe-se claramente como a sociedade fica perplexa diante de um suicídio e como esta mesma sociedade silencia a morte por suicídio.

19) Você já passou por alguma situação que envolvesse a falta ou não de consciência pública e individual em relação ao suicídio?

R. Sim, já passei por várias situações, que envolveram falta de consciência individual e pública. Primeiro, a busca de um porque, é uma necessidade que angustia a sociedade. Se a família, ainda em choque com o suicídio não consegue encontrar um motivo, a sociedade se encarrega de encontrar um porque, e surge uma lista de porquês, desde coisas mais simples até motivos absurdos. A sociedade faz um julgamento. Os amigos e familiares também fazem seus julgamentos: julgamento de que a família não foi presente; julgamento de que suicídio entre adolescentes ocorrem em famílias desestruturadas; julgamento de que quem comete suicídio é um egoísta, entre outros.

20) Como é falar sobre a causa de morte do ente querido e qual a causa de morte que é falada.

R. Ainda é difícil, mas necessário falar; não pelo fato da morte por suicídio, mas pela questão afetiva, pela saudade, pelos planos interrompidos, pelo que ficou no meio do caminho...

Atualmente falo com o intuito de informar, mas também procuro mostrar que não tem porque ter preconceito ou vergonha. Sempre esclareço que a causa foi morte por suicídio. Muitas vezes essa fala choca as pessoas e o assunto se encerra, até como certo pedido de desculpas de quem escuta. Entretanto, se a pessoa ou o grupo der uma abertura para continuidade do assunto, continuamos a conversa, sem constrangimentos. Falar é preciso. Falar é necessário.

21) Vocês falam e/ou conversam sobre o suicídio com a família, amigos, conhecidos e/ou desconhecidos? Como?

R. Antes do suicídio, nunca se falou sobre o tema suicídio como algo que pusesse fazer parte da nossa vida. $\mathrm{O}$ assunto morte também não se discutia em família. Após o fato, 
passamos a falar no tema morte, vida após a morte em família e inevitavelmente sobre o "morrer por suicídio", mas numa visão muito particular, sobre o que nos afetava, sobre como e como a sociedade julgava o suicídio. Nos primeiros anos este assunto ficou muito restrito a família e amigos próximos. Posteriormente, quando decidimos buscar informações, livros, vídeos, documentários a respeitos do assunto, passamos a discutir o assunto de forma mais aberta e consciente. Atualmente falamos sobre o tema com conhecidos e desconhecidos, através de palestras, rodas de conversas, em pequenos grupos.

22) Em que momentos essa comunicação é mais fácil e mais difícil.

R. É uma discussão necessária, entretanto, deve ser conduzida com muito cuidado em qualquer momento, porque depende muito dos fatores emocionais, dos conceitos de cada um a respeito do tema, dos laços de afetividades estabelecidos do tempo decorrido.

23) Houve alguma mudança na sua forma de entender o suicídio depois da perda que você viveu? De que maneira?

R. Sim, significativa. Antes eu não julgava, mas também não comentava. Entretanto, sempre que sabia que algum tinha morrido por suicídio tinha uma angústia em imaginar como esta pessoa se sentia desamparada, desesperada ou vazia de si e do mundo naquele momento. Este sentimento eu ainda carrego. Atualmente, eu comento sobre o que já li e ouvi sobre o suicídio e procuro desmistificar o ato, minimizar os atos de tabus e preconceitos. Atualmente procuro conscientizar sobre o assunto.

24) Que informações você gostaria de ter tido ao se deparar com esse comportamento?

R. O tema suicídio para que não vivenciou uma situação, é um tema que dá medo, e, tudo que nos apavora, queremos distância; assim era com o tema suicídio. Gostaria de ter sido mais aberto para falar sobre o assunto e saber que a pessoa que está com pensamento suicida dá sinais, pede socorro de uma forma implícita, que somente quem está atento percebe. Gostaria de saber tudo que sei hoje, antes. Certamente eu teria tido uma atitude diferente. Talvez eu pudesse ter mudado a história...

25) O que gostaria que tivesse disponível em termos de ajuda e/ou conhecimento para você no luto e para pessoa que faleceu?

R. Para mim, um local para falar sobre o que aconteceu, sobre como estava me sentindo, ver como outras pessoas foram sobrevivendo, e, principalmente falar sobre a minha filha, como ela vivia, sem julgamentos. Para a família sobrevivente este lugar de fala, em uma 
sociedade que ainda é muito preconceituosa com a pessoa que morre por suicídio e com a família, é muito importante. Para a pessoa que faleceu, um lugar de fala por ela, poder falar sobre sua vida, suas memórias, suas histórias, seus projetos de vida, sobre seus sonhos.

\section{Finalização}

26) Quais são suas sugestões sobre o tema?

R. As sugestões são que o tema seja cada vez mais estudado e discutido, no intuído de desconstruir tabus e estigma e que seja focando no esclarecimento, na informação sobre as formas de prevenção e conscientização.

27) Deseja fazer algum comentário, esclarecimento ou consideração adicional?

R. Somente agradece pela oportunidade de falar sobre a temática suicídio e torcer por você para que tenha uma excelente Tese de Doutorado, e que venha a ajudar para desmitificar essa temática. 


\section{Anexo F - Roteiro de perguntas C9}

\section{Sobre o tabu e a consciência pública}

P: Como você acha que o suicídio é visto hoje no Brasil?

R: De forma geral acho que o suicidio é visto com muito preconceito, e como casos isolados e não na proporção que realmente acontecem.

P: Você pensa que o suicídio é um tema tabu no Brasil?

R: Sim, acredito que é uma das facetas mais dificeis do tema relacionado ao morte, luto e tristeza

P: Por que você acha que isso acontece?

R: Acredito que a origem disso vem da visão equivocada de que felicidade é ausência de tristeza, perdas e luto. Como consequência todos essas emoções são reprimidas e se tornam um tabu.

P: Vocês acham que o tabu começa aonde?

$\mathrm{R}$ : Com a crença de que falar no assunto relacionado a morte, suicidio ou doenças, "atraem" o fato. Evitar falar no assunto é como se fosse uma forma de evitar que isso exista ou aconteça. E não de que para vivenciarmos plenamente as emoções como alegria, é necessário também estar aberto para sentir a tristeza. Que não é possível anestesiar apenas uma das emoções sem se anestesiar para as outras.

P: O que pensa a respeito conscientização da problemática do suicídio?

R: Acho muito importante, pois a minha impressão sobre o tema é de que a grande maioria das pessoas só entra em contato com o assunto depois de ter passado por uma perda de alguém próximo. Através da conscientização percebo que a prevenção seria possível, já que é nas relações e nos vínculos entre as pessoas que temos a possibilidade de prevenir.

P: Você acha que falar mais sobre o assunto aumentaria a consciência pública do tema?

R: Depende do publico direcionado e da forma como o assunto é abordado. Para grupos diferentes é acredito que é necessária uma abordagem especifica. Para profissionais da área de saúde, de psicologia e psiquiatria, uma abordagem mais direta com todas as informações disponíveis e um diálogo aberto e franco. Para o publico leigo em geral é necessária uma abordagem diferente e que leve em conta o tabu e que cria resistência, e pode criar até em alguns casos aversão ao tema. Pude observar isso, através de experiências pessoais, e pelos depoimentos que tenho ouvido de pessoas enlutadas por suicídio.

P: Você acha que isso teria algum impacto na prevenção e posvenção? 


\section{R: Certamente. \\ P: Como gostaria que o suicídio que fosse visto pela sociedade?}

R: Primeiro como algo que não é distante. A minha própria experiência e pelo compartilhar de outras pessoas que também passaram por suicídio de alguém próximo, é de que até aquele momento, o suicídio era um assunto distante. Que nunca aconteceria com alguém próximo. Acho que estamos despreparados de forma geral para reconhecer os elementos que podem levar ao suicídio nos aspectos que fazem parte da vida de qualquer pessoa. Sim, existem os casos em que ele é decorrência de um transtorno mental mais severo. Mas de forma geral acho que esta ideia afasta o tema das pessoas. A associação apenas com estes casos, faz com que em primeiro momento nem se queira falar no assunto pois significaria que a pessoa tem nela ou em alguém próximo um transtorno mais grave.

Mas pelo que vi, todas as pessoas podem ter num certo grau, elementos que a colocam num grupo de risco e que a coincidência de fatores e eventos da vida podem se somar para que a pessoa chegue ao ato do suicídio. Esta percepção de que isto pode acontecer com qualquer pessoa, e dentro de qualquer família, aproxima o tema. Pode trazer o interesse para a prevenção e para o diálogo sobre o assunto.

Ainda assim, vejo a barreira do preconceito sobre o que comumente são chamados de assuntos "negativos", como suicídio, morte, doenças. Isto também cria uma repulsa da discussão e do diálogo sobre o tema.

P: Qual o impacto de campanhas públicas, como o setembro amarelo, em cada um de vocês?

$\mathrm{R}$ : Na ocasião do Setembro amarelo passado em 2016, eu estava trabalhando como voluntário do CVV. É com tristeza que relato que não encontrei abertura para falar da campanha com ninguém da família e com a maioria dos amigos mais próximos. Os motivos são os comentados acima. Nas pessoas mais próximas, não consigo ainda hoje entrar no tema do suicídio sem notar um impacto de estranhamento e desconforto nas pessoas. Falar no tema é encarado como mau agouro, ou então percebo o preconceito na causa e até um afastamento e perda de alguns vínculos de amizade. Alguns mais descontraídos brincam sobre ser um assunto negro, e apesar de ser de forma mais educada, desviam-se do tema. Tive apenas uma pessoa da família que achou interessante e quis saber um pouco mais sobre o tema. Mas de forma geral, o fato de eu tocar no assunto sendo apenas leigo, faz com que algumas pessoas me olhem como se eu fosse um problema. Muitas acabam reagindo ou se afastando.

P: Alguém lembra de algum exemplo de campanha ou mensagem positiva/negativa sobre o suicídio na mídia?

R: Lembro de uma campanha de tevê muito antiga do CVV, aonde um homem pede dinheiro na rua, e ao receber uma moeda entra num bar. Tudo dá a entender que ele vai comprar bebida alcoólica. Mas ele compra uma ficha e vai a um telefone publico dentro 
do bar e efetua uma ligação. Do outro lado da linha uma voz diz: "CVV boa noite", e eles começam a conversar. Esta campanha antiga, me marcou a respeito da imagem do CVV e que seria um lugar aonde se pode conversar. Acho uma campanha extremamente positiva e que nos aproxima. A ideia de que ao passar uma situação difícil, o CVV é um lugar aonde se pode conversar e ser ouvido. Acho que a campanha vai exatamente no ponto que é necessário a respeito do assunto. Abordando de forma prática um canal para o diálogo e a empatia, e que estaria disponível para todos. Hoje questiono a abordagem do impacto dos números do suicídio, e falar de forma chocante sobre a morte para todos os grupos. Para o público em geral no Brasil, que tem um grande preconceito com o tabu e o preconceito com a morte, acho que pode reforçar uma postura de fechamento e retração.

\section{Sobre como aumentar a consciência pública}

\section{P: Como poderia ocorrer essa conscientização no Brasil?}

R: Refletindo bastante, acredito que a conscientização no Brasil, ainda requer uma abordagem totalmente diferente para o público. A abordagem que hoje tenho visto sobre o tema do suicídio, acho extremamente adequada para profissionais da área ou para pessoas que já tem uma abertura e interesse no tema. Seja por motivos profissionais ou pessoais (quando viveram algum caso próximo). Para este grupo, informações mais detalhadas que incluem estatísticas e dados mais específicos considero extremamente úteis. Mas para o público em geral, acho que é necessária uma abordagem diferente, elaborada em conjunto com profissionais da área, levando em conta que nossa cultura tem hoje uma aversão aos temas ligados a morte, e a depressão. Acho que uma campanha que foca na empatia em momentos de tristeza, que são comuns a qualquer pessoa, teria um impacto positivo e uma aceitação maior.

P: Como podemos começar a falar sobre o suicídio? O que nos impede de falar sobre o tema?

R: Dividiria num primeiro momento a abordagem em três grupos: 1 - Com profissionais da área, uma abordagem direta com estatísticas e com pesquisas sobre o tema. 2 - Para enlutados e sobreviventes do suicidio, uma abordagem de acolhimento como o que tenho observado no Vita Alere. Friso por exemplo que observo, o como a informação de que 9 entre 10 suicídios podem ser prevenidos, acentua para algumas pessoas enlutadas, um sentimento de culpa. 3 - Para o publico em geral, acho que o tema do diálogo e da empatia nos momentos difíceis que todos nós passamos, teria uma eficácia muito grande na prevenção. Dentro da família, no trabalho, nas amizades e nos relacionamentos de casal. O que acho que nos impede de falar sobre o tema é de forma geral, algo que está na cultura brasileira, que tem muito forte a ideia de ser um país da alegria, da festa. Acho que isto cria uma sombra, e reprime aspectos naturais da tristeza e das perdas que todos nós passamos. Observo que parte da nossa etnia, vem dos portugueses e curiosamente soube que Portugal é a terra aonde se tem uma certa apreciação pela tristeza ou melancolia (joy in sadness). O fado, uma musica tradicional portuguesa, é uma música que traduz isso. Talvez sejamos o outro lado da mesma moeda. 
P: Que sugestões você teria para que o suicídio fosse mais falado no país?

R: Acho que seria interessante ter como foco num primeiro momento nos suicídios que ocorrem da somatória de pequenos fatores, e que todos estamos expostos. Trazer o tema de que as tristezas e perdas cotidianas, quando não elaboradas e quando não encontramos espaço para poder dialogar sobre elas com as pessoas próximas, podem se somar e levar até ao suicídio. Mas focar mais nas atitudes preventivas, que seriam empatia, diálogo, aprender a lidar com as perdas. Evitar uma abordagem muito direta dos temas mais tabus.

P: Quando e onde você acha que esse tipo de informação deve ocorrer?

R: Falar sobre a empatia e o diálogo, a aceitação da tristeza e seu papel pode ocorrer dentro de vários locais. Dentro da escola, na família, no trabalho, dentro de grupos religiosos. Informações mais diretas sobre o tema suicídio e o que está diretamente relacionado (morte, luto, doenças terminais, depressão), dentro de grupos específicos de profissionais de saúde (Psicologia, psiquiatria, medicina, enfermagem).

P: Como você pensa que deve ser abordada essa questão? (que mensagem deve ser passada?) Que ações seriam necessárias e como elas poderiam ser promovidas? Como comentei, dividiria em três grupos, profissionais de saúde, enlutados e sobreviventes e público em geral.

R: Iniciaria a discussão com profissionais de saúde, enlutados e sobreviventes. A partir desta visão geral elegeria as principais causas e quais os fatores que podem ajudar na prevenção. Nesta discussão também incluiria profissionais da área de comunicação. Para a elaboração das ações necessárias, vejo que além da área de saúde, estamos falando de comunicação. Para profissionais da área, uma abordagem mais profunda e técnica sobre o assunto. Para enlutados, informações sobre como elaborar o luto e trabalhar a culpa. Bem como dar alternativas e informações de suporte (CVV, grupos de sobreviventes, terapeutas), além de como uma pessoa que não tem acesso a estas formas de suporte (seja pela localidade, ou por condições financeiras), pode criar seu próprio grupo de apoio através da família, amigos, religião.

Para o público em geral, teria uma abordagem a partir da empatia nos momentos difíceis. Talvez o espírito mais acolhedor e fraterno brasileiro seja receptivo a temas como solidariedade e empatia, e que pode ser uma forma prática de agir na prevenção. Campanhas que promovam o diálogo e a solidariedade em momentos difíceis, acredito que teriam uma aceitação melhor do que campanhas que falem diretamente do suicídio, morte e luto. Abordar algumas causas como bullying, rompimentos afetivos, perda de trabalho, dificuldades financeiras, problemas de saúde, sob a ótica de que a empatia e o diálogo nestes momentos, pode ter uma eficácia maior. Os profissionais da área saberiam que estão atuando dentro do tema do suicídio, mas o público em geral creio que seja mais receptivo a uma abordagem indireta. Acho que os efeitos a longo prazo seriam mais duradouros. 


\section{Sobre a consciência individual}

P: Vocês acham que a consciência publica influencia a consciência individual, de que forma?

R: Acho que elas se influenciam mutuamente. Estão interligadas.

P: Vocês acham que a falta de consciência pública pode ter influenciado o suicídio da pessoa que perderam?

R: Sim, alguns no caso da pessoa que perdi, a exclusão social, bullying, acredito que teve uma influência direta. Naquele momento, não havia uma discussão sobre estes assuntos publicamente como há hoje.

\section{Experiências}

P: Como é para vocês falar sobre o suicídio?

R: Para mim, é um tema importante e que requer uma ação imediata, mas que apesar da gravidade e da urgência, não encontro muitas oportunidades e pessoas com quem conversar a respeito.

P: A forma como a sociedade e as pessoas encaram o suicídio te toca?

R: Bastante, pois sinto que há um preconceito muito grande. Pois a visão atual só tende a colaborar que isso continue ocorrendo.

P: Você já passou por alguma situação que envolvesse a falta ou não de consciência pública e individual em relação ao suicídio?

R: Sim, passei por várias situações de falta de consciência sobre o suicídio. Desde a pessoa que disse que "quem se suicida é um covarde", que soube depois que era uma forma dela cortar o assunto, pois dentro de toda a família dela, falar em morte e doenças graves, "atrai"... Palavras fortes e com muito julgamento, que hoje entendo que foram uma forma de defesa da pessoa que disse. Uma dificuldade da própria pessoa em lidar com o tema.

Também ao me abrir com um amigo, sobre meu processo de luto, sofri preconceito e afastamento, como se eu a tristeza não fosse parte de um processo natural. Pois para ele, o estado de uma pessoa saudável é de apenas alegria.

P: Como é falar sobre a causa de morte do ente querido e qual a causa de morte que é falada. 
R: Meu amigo se suicidou com um tiro na cabeça com um revolver do tio. Para mim, hoje é mais natural, mas como não tive muitas oportunidades de falar no assunto com quase ninguém, ainda sinto um certo estranhamento e uma certa dificuldade.

P: Vocês falam e/ou conversam sobre o suicídio com a família, amigos, conhecidos e/ou desconhecidos? Como?

$\mathrm{R}$ : Na família nunca, e em poucas tentativas não fui bem recebido. Muito raramente com uns poucos amigos muito próximos. Geralmente apenas dentro de grupos de sobreviventes ou ligando para o CVV.

P: Em que momentos essa comunicação é mais fácil e mais difícil.

R: A comunicação é mais fácil apenas quando a outra pessoa já passou por isso e também está aberta a conversar sobre o tema. Com pessoas que não tiveram um caso próximo, acho de forma geral muito difícil essa comunicação.

P: Houve alguma mudança na sua forma de entender o suicídio depois da perda que você viveu? De que maneira?

R: Sim, houve uma mudança muito grande após elaborar melhor o luto e conhecer um pouco mais do assunto. Percebi que a falta de espaço para as pessoas dialogarem sobre suas dificuldades cotidianas, suas tristezas e perdas e também em muitos casos o fato da pessoa saber que não pode falar de algum assunto ou problema que a aflige com as pessoas próximas, agrava seu sofrimento. Participando do Vita Alere, a partir do compartilhamento e da possibilidade de me abrir e acessar emoções guardadas, pude enfim, realizar meu processo de luto. Dentro do grupo também percebi que alguns sentimentos como a culpa, e a dificuldade de encontrar pessoas para dialogar, eram comuns a outros enlutados. Ao trabalhar no CVV como voluntário, um outro tema que não citei e que era muito recorrente na busca de apoio, era a solidão em diversas formas. As vezes para uma pessoa idosa, ou aposentada porque a família se distanciou e porque a pessoas não se sente mais inserida na sociedade através do trabalho, as vezes porque uma doença mais séria a debilita e a impede de ter a liberdade em atividades cotidianas. Outras vezes porque dentro de uma família há muitos conflitos e discussões. Outras vezes porque dentro de um casal, um deles passa por um problema que não pode compartilhar com o cônjuge e sofre porque não consegue resolver sozinho, mas não pode pedir ajuda. Todos estes elementos cotidianos podem gerar um sofrimento tão grande que podem levar uma pessoa ao suicídio, num dia aonde muitos fatores se somam.

P: Que informações você gostaria de ter tido ao se deparar com esse comportamento?

$\mathrm{R}$ : Eu gostaria de ter tido mais informações sobre como lidar com a culpa, algo que apenas recentemente através do Vita Alere, estou tendo. Gostaria de saber que o suicídio é também em muitos casos uma somatória de fatores que todos nós estamos expostos. Gostaria de ter tido uma educação emocional que incluísse a tristeza, o luto e a perda como algo natural e saudável da vida.

P: O que gostaria que tivesse disponível em termos de ajuda e/ou conhecimento para você no luto e para pessoa que faleceu? 
R: Gostaria de poder ter uma forma de que fosse possível encontrar pessoas que tem abertura e disponibilidade para conversar sobre o assunto.

Com relação ao grupo de suporte, tem sido um lugar de acolhimento importante em momentos mais difíceis do processo. Sei que a viabilização é fruto da doação do trabalho e do tempo de muitas pessoas, bem como a infra-estrutura de espaço para os eventos acontecerem. Gostaria de que outros espaços como o do Vita Alere estivessem disponíveis para mais pessoas. Para a pessoa que faleceu, gostaria de que ela tivesse encontrado ao seu redor mais oportunidades de compartilhar sua dor, suas tristezas, de se abrir e ser bem recebido. Acredito que isso poderia ter evitado o suicídio.

\section{Finalização}

P: Quais são suas sugestões sobre o tema?

R: Talvez os planos de saúde possam ser um dos canais de entrada. Talvez, mostrando que atividades de prevenção podem uma influência direta na saúde dos segurados e por consequência na redução dos custos do plano. Indo por este caminho, acredito que é possível uma abertura para um fator multiplicador de ações, com recursos vindos dos próprios planos e com benefício para muitas pessoas. Uma abordagem mais indireta para o público em geral, e mais direta para os profissionais de saúde. Focar na comunicação e ações de prevenção diretamente nas causas cotidianas, abordando assuntos que tem mais aceitação e menos resistência por tabus. Abordar de que o sentimento de tristeza é natural e parte de uma vida emocional saudável, e de que para vivenciar plenamente a alegria é preciso estar aberto a todas as outras emoções. Enfim, uma educação emocional direcionada ao público em geral, mas com o foco no diálogo e empatia entre as pessoas para acolhimento nos momentos de adversidade. Tudo isso tendo como objetivo ações concretas para a prevenção do suicídio, levando em conta as resistências e tabus que existem no Brasil. A partir do momento que há uma abertura de alguém para falar sobre o tema, percebo que a pergunta que surge a seguir é: "o que eu posso fazer por alguém?". Ao me fazer esta pergunta muitas vezes, percebi que é num primeiro momento estar aberto para ouvir o outro e acolher diante de uma dor que a pessoa passa. E saber até aonde posso ir, e quando está além do meu alcance. Esta informação não está disponível para a maioria das pessoas e só consegui elaborar através da participação dos grupos e do auxílio de profissionais. Gostaria que este conhecimento em essência, pudesse ser traduzida numa forma de informação que estivesse disponível para as pessoas em geral.

P: Deseja fazer algum comentário, esclarecimento ou consideração adicional?

$\mathrm{R}$ : Me coloco a disposição para ajudar no que mais estiver ao meu alcance. Sobre as respostas do questionário, fico a disposição para conversar por celular ou pessoalmente. Agradeço muito todo o apoio e acolhimento que tenho recebido através do trabalho do Vita Alere durante meu processo de elaboração do luto. Tem sido um processo transformador poder colocar um pouco de luz num tema que para mim foi tão difícil por tanto tempo. Fico feliz em poder retribuir uma fração de tudo o que recebi. 


\section{Anexo G - Transcrição da entrevista piloto}

P: Bom, vamos lá. Eu queria que você começasse me contando um pouquinho a quanto tempo você trabalha nessa área, qual sua formação e há quanto tempo você trabalha nessa área.

E: Eu trabalho exatamente...Acho que mais ou menos uns (...) anos. Exatamente. $\mathrm{Na}$ realidade, eu comecei a me interessar pelo tema do suicídio quando eu estava terminando minha tese de mestrado em (...) e quando comecei a encontrar trabalhos que mostravam quadros depressão após o uso da (...). O que me chamou a atenção e casos de depressão com quadros de suicídio em jovens. E essa era uma questão importante que estava acontecendo nos Estados Unidos, porque o Conselho Nacional de Educação dos Estados Unidos viu alguns milhares de estudantes usando (....) nos Estados Unidos, então, começou... A partir daquele momento, eu comecei a me interessar pelo tema. Terminei minha tese e logo em seguida fui procurar o que existia no tema. Então, no Brasil, eu não tinha no primeiro momento encontrado. Utilizei as redes, a internet para fazer buscas, não havia encontrado muita coisa sobre o tema. A página da OMS, naquela época, não havia absolutamente nada, a página de saúde mental não tinha nada. Aí eu fiz contato com a (...) e me inscrevi na associação e passei a ir em vários encontros. Fui naqueles congressos e aí foi que eu vi. Tive um contato assim, tanto com o pessoal acadêmico que estava produzindo, quando com as redes sociais e as organizações que vinham dando suporte aos casos de sobreviventes. Naquele momento, foi que eu tive o primeiro contato, inclusive, com essa palavra sobreviventes e o significado disso e tal. Foi a partir daí. Esse foi o início.

P: Você é formado em (...)?

E: Sou formado em (...), sou (...) de formação e depois fiz formação em (...). Quando eu comecei a me interessar pelo tema, voltei desses congressos, fiz contato com (...) E aí assim consegui trazer para trabalhar comigo uma (...) da área de (...) que tinha feito uma pós-graduação na uma universidade do exterior e a gente... Eu e a (...), que era médica também, minha colega de turma, e a gente elaborou uma ficha de (...). Isso em (....) exatamente. E quando, aí essa ficha foi instituída no (...). Foi assim, o primeiro momento que conseguimos fazer alguma coisa, vencer algumas barreiras, porque eu tinha feito uma proposta de criar um núcleo de atenção ao suicídio, um lugar para receber de portas abertas, para receber pessoas que tinham feito tentativas e havia muito...Tiveram resistências de vários lados, assim... Mesmo psiquiatras, que eu estava criando uma especialidade, era esse o discurso. Em um determinado momento eu consegui montar esse núcleo dentro do (...). Houve uma receptividade para isso do diretor e quando... E eu era funcionário (...), estava à disposição da (...) e eu fui para o (...) e assumi a chefia do (...), eu tive minha... Bastante possibilidade de apoiar esse núcleo e esse núcleo a gente começou a trabalhar com... Era um núcleo que recebia de portas abertas...

P: Qualquer pessoa...

E: Após tentativas e tínhamos em (...) , já tínhamos instituído a ficha de (...) e tínhamos proposto que a ficha fosse enviada... uma vez preenchida, elas fossem (...) . Então, nós temos cerca de (...) .

P: Daquela época? 
E: Daquela época, de um determinado período.

P: E você lembra... Você teve alguma aula na faculdade sobre prevenção do suicídio?

E: Não, nem suicídio.

P: Nem suicídio? Nem prevenção, nem nada...

E: Nem suicídio. Nem sobre a morte. A morte, o êxito letal? Eu sempre fico... Eu me lembro assim quando eu comecei a estudar o tema como que as... Nos tratados de (...), a doença tem toda uma descrição enorme e aí quando... Vai chegando ao final o tratamento já vai diminuindo, aí vai chegando no prognóstico já não chega praticamente mais nada e pronto morre. Então, assim... não é um tema. Não é um... Mesmo, mesmo dentro da cadeira de (...), não havia... uma atenção.

P: Não se falava.

E: Não, não se falava.

P: E como que você vê e entende o suicídio?

E: O suicídio é... eu vejo o suicídio assim... é algo que acontece... um evento que acontece no âmbito do indivíduo seja no corpo do indivíduo, mas ele acontece dentro de um espaço coletivo. Quer dizer, eu acho que essa visão dessas duas dimensões, elas tem que estar sempre presentes. Eu acho que... o fato, quer dizer, assim, grande parte dos argumentos de que é uma questão nosológica, individual... tem sempre a ver com o fato de que acontece no corpo do indivíduo, essa tem sido a grande... a grande defesa quando não quer ser observado de que existe, que aquilo acontece no indivíduo, mas dentro de um... sistema social qualquer que seja, seja a família, seja a comunidade e... E isso tem implicações como todo e qualquer evento. Por exemplo, quando a gente começa a ver como que a medicina, principalmente a medicina, trata das questões... de doenças e transmissões, eu acho que isso é importante. Quando a gente começa a falar de... e o suicídio pode ser contagioso e isso é uma visão muito... Ninguém falaria isso se não tivesse a visão da medicina, de Pasteur, de que as doenças são transmissíveis, ou seja, a doença, uma doença como, por exemplo, uma tuberculose. Não se tinha nenhum conhecimento a respeito da tuberculose, os conhecimentos eram nada empíricos, várias crenças a respeito até o momento que conseguiu descobrir que existia um bacilo, fazendo esse tipo de transmissão. Isso era um fato que poderia fazer com que aquele indivíduo tivesse ou não um quadro, de tuberculose, porque não era só ele estar em contato. Tinha um conjunto de condições. Ou seja, o risco desse indivíduo ter alguma coisa estava relacionado também a uma série de outras variáveis relacionadas tanto ao meio em que ele estava, não era apenas a ele... alguém cuspiu nele e passou um bacilo, porque isso não transmite tuberculose. É preciso uma persistência daquele... do evento, da possibilidade, da possibilidade do evento e, também, de como que... ou seja, das condições que aquele indivíduo está no meio e, também, de que forma ele é assistido... isso, quer dizer, isso nos leva a questão do risco... Porque é preciso entender a questão do suicídio por todo o conjunto de variáveis que podem estar ligadas ao evento em si, a partir desse... de maior ou menor importância, de maior ou menor significância dos riscos, porque isso vai implicar nas... Isso te diz como é que você vê, qual é a sua concepção e não dá para a gente não pensar numa determinada forma, quer dizer, não dá para se pensar nenhuma politica pública, nenhum tipo de intervenção se ele não estiver bases empíricas e se não tiver uma maior aproximação com esse conjunto de variáveis, ou seja, é um fato extremamente... então, o suicídio é um evento extremamente 
complexo, agora, e complexo do ponto de vista dessa... da visão de complexidade que alguns filósofos trouxeram de que nós vivemos diante de situações, vivemos sempre diante de situações de risco. Nós somos uma sociedade de risco e aí tem todos os estudos de Beck que aprofundam nesse campo e que existem fatos. É, então, um evento pode ocorrer e pode ter fatores previsíveis, previníveis e, também, fatores ao acaso. Fatores ao acaso podem ser fatores ou informações ou falta de conhecimentos hoje, porque a ciência se faz a partir de... cada vez vai adquirindo mais conhecimento e com isso você tem maior controle do que está se passando. Bem, então, o suicídio é extremamente complexo, é um fenômeno complexo e essa visão, ela tem que ser entendida desse ponto de vista, não estou falando de que é algo complicado. Estou usando complexidade do ponto de vista, um conceito teórico. É importante nós entendermos isso, porque senão nós não vamos conseguir entender os diversos fatores de risco individuais e coletivos.

P: Sim.

E: E pode ser que... e eu acredito que dependendo de determinadas, determinado perfil da população, determinada faixa etária da população, você pode ter fatores mais ou menos individuais ou mais ou menos coletivos. Ou seja, se a gente imaginar que temos duas dimensões uma individual e uma coletiva e eu não estou definindo como categoria, mas como dimensão, algo que tem uma continuidade. Nós teríamos esses eventos acontecendo em determinadas populações ou em determinados clusters que podem ser predominantemente influenciados pelo coletivo ou predominante pelo individuo e mistos... É... Isso tem importância... Por exemplo, quando nós falamos das populações indígenas, eu não tenho a menor dúvida de que a dimensão predominantemente coletiva é essa que está provocando o suicídio. Quando nós falamos na população idosa, que tem uma taxa bastante elevada, eu acho que a gente pode pensar numa forma mista, predominante... Assim, com predomínio individual e coletivo, mas mista. Porque eu acho que as diversas variáveis do ponto de vista do individuo, quando ele atinge uma determinada idade... doenças crônicas que imobilizam, a perda de relações naturalmente porque as pessoas morrem e porque as pessoas se aposentam e deixam de trabalhar. Tem essas características... Quer dizer, então, tem algumas características do ponto de vista individuais e outras do coletivo e elas estão misturadas. E eu acho que do ponto de vista de uma intervenção, isso é importante, porque você teria que trabalhar em ambos os aspectos. Se nós falamos da população indígena e que nós estamos vendo... o que eles têm falado, o que eles têm sentido é uma grande anomia, uma grande perda das suas identidades, perdas das suas terras que para eles corresponde a uma identidade... Isso tem um valor enorme para eles. Você não... Você quando vai transferir... Você chega e tem uma população indígena. Você chega e diz para ela: 'Vamos transferir.' 'Ok.' 'Nós vamos construir aqui uma represa, então, vamos tirar vocês daqui e vamos colocar vocês ali.'. Isso acontece aqui e aconteceu nos Estados Unidos. Eles até dizem assim: 'Mas nós enterramos nossos mortos aqui', 'E aí como que vamos fazer isso?'. Não adianta dizer assim, nós não vamos carregar os raios dos corpos. Não é assim que funciona. Então, eles têm um rompimento muito sério, muito grande... então, predominantemente no coletivo, eles são afetados. Então, eu acho assim... Essa é a visão... de um fenômeno complexo, que é um fenômeno... Que tem um conjunto de variáveis enormes. É... E que podem, e que estão submetidas ou não a situações de alguma previsibilidade ou acaso. Isso tem ligações também importantes do ponto de vista... Sempre imaginei, assim, do ponto de vista das equipes... Quando as equipes começavam a trabalhar e eu 
sentia dificuldade das equipes de trabalharem com pessoas... 'Ah, eu não gosto de trabalhar com esse tema.' Isso escolas, (...) pessoas que deveriam... Que são aquelas pessoas que estão ali para trabalhar com essa equipe. E eu ouvia nos cursos. Eram grupos de reflexão que a gente fazia em alguns (...) e aí os (...) e os (...) começavam a falar que atendeu o suicídio, o (...) daqui se suicidou... e começam a falar dessa grande dificuldade em lidar com o tema. Eu também entendia que eles tinham... Eu também entendia que eles tinham dificuldade de lidar com sua própria impotência diante da situação e... isso depois eu fui vendo em alguns casos de alguns (...) que perderam pacientes. E isso tem a ver com a questão de... Se você consegue ver o fenômeno como é que pode ocorrer, que tem um acaso nessa complexidade e que você não tem controle. Você precisa ter isso para você poder trabalhar com esse paciente, senão você não vai conseguir trabalhar, porque você acha que vai dar conta de todos os casos e se alguém tiver do seu lado e sair correndo e pular uma janela, que tem vários relatos desse tipo. Você vai se sentir culpado pelo resto da vida. Então, quando a gente define bem a concepção do suicídio e não fica única e exclusivamente... Quando não tem uma visão estreita ou limitada ou quando não consegue considerar os diversos fatores, a gente também está criando menos possibilidades de intervenção ou de intervenções que eu diria não qualificadas... Até aí, deu para explicar sobre a concepção?

P: Excelente. Excelente. Como que você pensa que as pessoas vêem ou entendem o suicídio hoje no Brasil?

E: Então, eu acho, Karen, que assim... Quando... Eu tenho bem... pode ser... Como eu vim trabalhando desde esse tempo, vi todas as dificuldades, vi as dificuldades com meus colegas, com os (..._, com aquelas pessoas... Com os (...). A dificuldade não era só no âmbito, não era só entre os (..._, era também entre os (...), porque eu encontrava (...) que me diziam assim: 'Não, não adianta você fazer... Desenvolver um plano de prevenção, porque as pessoas vão se suicidar em algum momento' e eu dizia: 'Mas eu não entendo como você é um (...) e não está levando em consideração os riscos e a possibilidade de intervenção.' Então, era assim. Havia um distanciamento sobre tema muito grande, questões que eu não sei. Cada um tinha suas questões. Ou seja, então naquele momento, eu tive que... Eu entendi assim, o que que é fazer... Respondendo sua pergunta. O que é fazer, permitir que o tema entre. O que a gente precisava que o tema... Pudesse se falar do tema. Eu me lembro em alguns momentos quando de alguma forma eu tive apoio de jornalistas que queriam lidar com o tema, como o (...) e alguns outros. Eles abriram o canal, assim, para que eu pudesse ir para um programa. Então, eu me lembro. Eu me lembro de ter ido para um programa (...), que era um programa que tinha na TV (...), que era um programa de jovens para jovens e que aquilo... E que eu ia falar sobre o tema e eu estava lá pronto para falar sobre o tema e aí veio na época. A TV era (numa capital do país), no centro. Aí veio uma ordem, do Ministério da Educação, Brasília, que não, esse tema não, não sei que... E na hora o produtor resolveu bancar e disse... Até aquele momento, eu estava até muito tranquilo. Quando começaram a criar, eu fiquei pensando: 'Vai que alguém usa a mídia para um determinado momento resolver atuar e fazer ali'. Ligar e dizer: 'Estou fazendo uma tentativa'. Eu consegui falar, na realidade, uma das pessoas que (...). Tinha um (...), as pessoas (...). E aí diziam... Aí foram... Me lembro de uma jovem que (...) e disse: 'Olha, eu quero falar que eu tentei o suicídio aos 14 anos e graças a Deus me acolheram, eu fui tratada e eu estou aqui viva e muito feliz de não ter morrido naquela época.' Eu disse assim: 'Poxa, essa fala, esse depoimento, ele é super 
importante.'. Então, na realidade, é... Eu acho que continua sendo um tabu. Da mesma forma que foi a AIDS e por vários motivos. Um dos motivos que eu acho que é importante a gente dizer quando... Quando elaboramos a (...) e eu... E eu defendia que a justificativa era que o suicídio era um problema de saúde pública e podia ser prevenido. Na realidade, estava dizendo o seguinte se é de saúde pública, ele acontece no âmbito do coletivo e o coletivo tem uma responsabilidade e pode ser prevenido... como uma família que... E eu conheço várias, você também deve conhecer várias... Que vivem com aquele drama e se sente culpada, ela ia ouvir aquilo e dizer: 'Puxa, aquilo é... Isso é do âmbito do coletivo' 'Isso é do âmbito da sociedade'. De que forma isso poderia diminuir a sensação de culpa e permitir que a pessoa saísse daquela, de alguma situação e procurasse falar sobre isso. Então, quando nós montamos o (..), as pessoas diziam assim: 'Que bom que eu venho aqui, porque aqui eu estou falando de uma coisa que eu estava falando só para mim mesma e estou encontrando outros que estão passando por isso'. Então, isso foi muito importante. Quando nós (...), os grupos que estavam indo eram às (...), a gente fazia um debate. Os grupos eram os mesmos grupos. Tinham grupos que iam todas as (...) e iam fazendo... E cada vez um ou outro começou a hora do debate, a fazer depoimentos que estavam sentindo no ambiente, que tinha um acolhimento para o tema que estavam encontrando, não tinha ninguém apontando, mostrando...

P: Era um lugar seguro para falar.

E: Era um lugar seguro para falar. Então, daquele tempo para trás para hoje, eu acho que a gente conseguiu bem. Tentando responder a sua pergunta. A gente conseguiu colocar mais na mídia o tema. A gente conseguiu da forma que eu dizia que assim: 'Temos que colocar, o que nós temos que colocar?'. Temos que debater, falar, não queremos ficar descrevendo casos de suicídio, não é essa a nossa intenção... Queremos falar do suicídio como um problema, dar visibilidade, da mesma forma que se falou da AIDS, porque? Porque a AIDS no inicio também teve todo um tabu, porque estava relacionada a várias questões, questões que envolviam a sexualidade, questões que eram tabus dentro da sociedade... então, da mesma forma o suicídio, vai aparecer assim como aparece bem... Hoje, a gente fala de câncer. O câncer era uma coisa inominável, não se falava... Tem pessoas que não querem nem falar, como se...

\section{P: A palavra.}

E: É como se isso pudesse provocar um contagio, né? Eu acho que é... Essa é a visão. Ou seja, mas de que forma a gente pode entender num país dessa dimensão o que está se passando, entendeu? Porque se a gente abrir os grandes jornais: 'Ah tem uma matéria interessante e tal.'. A gente pode estar achando 'Ok, tem essa matéria. Vai atingir aqueles que vão ler.'. Mas... Em ambientes extremamente fechados, em localidades fechadas... Em localidades que a transmissão é feita por... Por... Oralmente, como em (...), que eu fui. (...) Mas tem ali aqueles número de suicídios que vinham acontecendo, ele era retrato de... Poderiam ser de um contágio não midiático. Era um contágio que acontecia oralmente e que fazia e que isso, eu acho que era. Me chamou muita atenção. Eu achei muito crítico, porque ele estava derrubando o que para os jovens era uma barreira que era... quando os jovens começavam a dizer: 'Ah, a minha amiga tentou o suicídio e eu vi que isso é possível.'... Até então, elas estavam de alguma forma se sentindo protegidos em relação a um ato desse tipo.. bem, então, eu acho que essa é uma... Debater sobre isso, falar sobre isso, vai ser tão... Vai ser um trabalho constante. Entendeu? Podemos ter 
momentos de avanço e de retrocessos. A sociedade se movimenta assim. A gente assiste isso hoje. Então, tem uma culpabilização que eu acho que essa é crítica em relação as famílias. Eu sempre fico com muito cuidado quando eu digo que ele ocorre no meio, ele ocorre no meio da família. É porque eu tenho que pensar que eu posso estar dizendo... Eu posso ser entendido que eu estou culpabilizando a família por uma determinada situação. Não vai ter a menor utilidade, só vai ser mais crítico aí. Mas é importante nós entendermos que ocorre dentro de um ambiente, porque senão nós vamos lavar as mãos e dizer: 'Bem, não vamos intervir, porque isso é do âmbito da família.'. Mesma coisa assim, a mulher está apanhando do marido, mas ninguém mete a mão, porque isso é do âmbito da família e do indivíduo. Então, eu acho que quando a gente... É... Tem uma concepção de que vivemos na sociedade e somos influenciados por ela e essas ações tem uma influência muito grande. Eu acho que a gente tem que estar sempre de alguma forma colocando. Eu fico impressionado, estou aqui pensando, porque quando eu li Durkheim, e que tem mais de cem anos. Quer dizer, não faz mais de cem anos que eu li, mas ele tem mais de cem anos (risada). E eu reli, relia... Agora, eu estou relendo novamente por conta da questão da comunicação, quando ele fala... Porque essa questão da comunicação que eu estava falando: 'Ah, o suicídio é contagioso'. E eu fico às vezes... Aí eu vejo que alguém repete aí ele diz assim... que quando veio essa história do suicídio contagioso: 'Puxa, é a polícia médica.', é o termo vem. O termo é médico, o termo é estritamente médico. Então, quando eu digo 'É contagioso', o outro pode entender assim: 'É igual a AIDS. É igual assim... Se eu chegar perto, pega.'. E é muito interessante, porque o Durkheim, cem anos atrás, ele já colocava isso. Você vê um capítulo sobre comunicação que é impressionante. Ele conseguiu, eu acho assim impressionante, que naquele época... $\mathrm{Na}$ realidade, fazer um grande estudo epidemiológico e depois sociológico. Um estudo epidemiológico a partir de informações que eram, que na realidade, eu acredito que ele tenha feito, porque naquele século o que existia de maior é... Tanto na França, como na Alemanha, o que havia de maior é... É... Confiabilidade... De maior confiabilidade, estava tentando... Era a informação sobre nascimentos e mortos, porque isso interessava, interessava ao Estado. Os Estados quando eles se organizaram, eles tiveram que pensar, quem nasce e quem morre. Até porque eram Estados, impérios que iam para guerra, então eles precisam saber um número, 'Quantos homens eu vou ter no exército?'. Então, ele consegue utilizar uma informação disponível mesmo naquela época, outras não teriam. Eu acho que, então, ... Aí porque nós vamos dar um pulo para uma outra questão que é o seguinte... As nossas informações, elas estão boas, elas estão qualificadas? A gente conseguiu melhorar, não tenho a menor dúvida de conseguimos melhorar, porque também quando se avança em relação ao tabu, a gente consegue que alguém faça uma descrição, mas a captação daquela informação. Faça uma descrição melhor do que aconteceu na hora que uma pessoa entrou em uma unidade de saúde por uma tentativa de suicídio ou por um suicídio. Agora a captação daquela informação que as vezes pode estar ali dentro daquele prontuário. Ela é... Um trabalho investigativo. Um trabalho que você tem que ter uma grande dedicação. Essas mil e poucas fichas que nós temos, nós fomos observando de que forma cada uma das pessoas ia descrevendo. Porque nós também dissemos assim: 'Qualquer um pode preencher isso.'. Nós estamos querendo ampliar o número de comunicador... a assistente social, enfermeira, auxiliar ou o segurança que estivesse ali. Era um questionário, autoexplicativo e então, assim, nós precisaríamos... Ou seja, tem muita informação, provavelmente, nos hospitais e tal... que não estão sendo captadas. De qualquer 
forma, eu acho que melhorou o nível de informação. Isso é importante, porque isso ajuda a dar mais visibilidade, por outro lado, isso tem uma implicação e eu acho muito interessante o livro do (...)t, esse de avaliação de problemas e prevenção do suicídio, porque isso tem uma... Ele traz, ele não está falando especificamente é...de uma, do que ocorreu em relação à decisão da Organização Mundial de Saúde de definir uma redução em $10 \%$ dos casos até 2020 e tal, mas quando eu vi que isso saiu, eu me perguntei: ' $10 \%$, por quê? Da onde tiraram esses $10 \%$ ?'. Isso é uma medida empírica, você tem que imaginar o porquê dos $10 \% \ldots$ é a vontade que a gente tem, $10 \%, 10 \% \ldots$ É uma decisão politica, porque tecnicamente não existe, tá? Então, e ele faz uma crítica e o livro é anterior a essa decisão da OMS, mas ele faz uma crítica muito interessante sobre os indicadores para avaliar os programas de prevenção e as taxas de mortalidade não são os melhores indicadores. Isso é muito importante, porque isso diz respeito a... se você estiver desenvolvendo um determinado trabalho numa determinada região, você acredita no que você está fazendo, mas não ocorre uma melhora na taxa. Primeiro, você como coordenador do projeto, gestor do projeto, vai ser criticado, porque 'Olha, isso daqui... Você não está atingindo.'. O problema é quando você coloca um determinado indicador para ser forma de avaliação de um programa e quando você tem falha na escolha do indicador. Então, é... Isso é crítico. Crítico do ponto de vista de políticas públicas, porque está na cara (risos)... É óbvio. Exatamente. Então, quando... É muito mais importante, a gente poder falar dos processos e ele fala disso, quais são os determinados processos e quais são, quais são as intervenções eu nós vamos fazer com cada uma da clientela que nós estamos definindo. É... Isso é importante, né? Faixa etária, né? Questões de gênero, todas essas questões, elas vão ser bastante importantes.

P: Até a forma de você falar ou passar alguma mensagem vai depender muito de qual população você vai atingir, né?

E: Claro, claro. Por exemplo, os jovens... Eu... Assim, fiquei... Os jovens escutam os jovens. Ou então, um velho que tenha espírito de jovem, porque senão não vão escutar. Eles não querem ouvir regras, sermões, não querem. Então, mesmo quando... E isso eu vi num, num desses... Num, como é que era... Num hotline lá em (....) que era para jovens, coordenado por jovens. Os jovens estavam com supervisão, mas eram jovens falando com jovens. Claro que você tinha que ter mais cuidado, porque tocava e isso eu vi essa experiência em (...), que eram jovens, eram estagiários universitários que estavam atendendo e eles ficavam num espaço, era um... Era um... Era como se fosse um telemarketing, um espaço e ali eles estavam recebendo as ligações, recebiam as ligações e (...) várias ligações em que o abuso estava ocorrendo...

P: Naquele momento.

E: Naquele momento lá em (...), como fazer e como lidar com aquilo. Os jovens tinham que ter então... Uma supervisão, é... Um período de descanso, eles saiam para uma sala que ficavam tocando violão, depois de ficar uma hora, voltavam... Ou seja, mas era interessante assim... Quer dizer, o que eles estavam ouvindo não era relacionado especificamente a jovens, mas eram jovens atuando. Os jovens atuando, eu acho interessante do ponto de vista que eles têm uma linguagem, quebram uma barreira de... Vou chamar de desconfiança ou de mais confiança, de confiar naquele que tem uma idade parecida. É... Então, eu não me lembro do porque apareceu essa história...

P: Porque a forma de falar depende do público e... 
E: É, é.

P: Então, essa seria uma das ações a serem feitas. Por exemplo, o jovem falando para o jovem. Que outras ações poderiam ser, você acha que podem ser feitas para as pessoas falarem mais? Que mensagem a gente pode passar e que deveria ser passada?

E: Eu sempre... É... Quando você lida com determinado tabu... E mesmo, acho... As doenças mentais são todas elas grandes tabus... Entre as pessoas também, entre os profissionais, é... Então, assim, é como...

P: O tabu começa daí.

E: É, o tabu começa daí. Eu acho que tem esse tabu. Tem esse... Tem essa visão... que agora vendo o filme da Nise da Silveira como ela teve... Na verdade, foi a única mulher da faculdade de medicina naquele ano, como que ela teve que lutar com aquele, contra... Aquelas posições e antes dela... A Frida Fromm Reichman também e foi conviver, foi trabalhar, viver praticamente com os doentes, com os doentes com transtornos mentais e que quando ela falava e conversava com os pacientes e os psiquiatras diziam: 'Mas você está tendo uma conversa lógica com esse pacientes? Como que você está tendo uma conversa lógica com eles? Eles não estão aí.' E ela... E ela usava aquilo como técnica... Porque ela em vários casos,... Que os pacientes tinham seus delírios e conversavam a noite com... E ela dizia, num caso especifico, ela dizia para a enfermeira: 'Quando ele acordar e começar a conversar, você me chama e tal'. E ela foi com o paciente. Isso quando ela já estava em crise nos Estados Unidos. Ela foi conversar e ela passava toda noite, indo conversar com os fantasmas, com os personagens desse paciente e tal e ela... Depois, tem uns relatos de como ela tinha... Ah que o paciente nem se lembrava, o paciente não lembrava daquela conversa e tal. Depois, o paciente... Foi diminuindo essas crises e... Agora, né?

P: Até para conversar dentro da própria área médica...

E: Exatamente, porque? Porque também como que ela e essa foi uma questão. Quando ela e Bateson e vários... O Instituto de Esalem na Califórnia, chegou e disse assim: 'Vamos...'. Convidou uns vinte talentos que eram o Bateson, a Frida Fromm Reichman e vários outros. 'Vocês vão ficar aqui um ano' e deram uma bolsa. 'Vocês podem ficar aqui pensando, escrevendo, pá, pá e trocando entre vocês' e aí ela dizia assim... O tema principal que eles tinham que trabalhar era intuição. Como trabalhar intuição do ponto de vista empírico, cientifico, médico? Como fazer? Como transformar a intuição como método? Transformar intuição como método? Esse era o debate. Estavam lá, tinha uma instituição poderosa financiando esse trabalho. Então, eu acho... Assim... Isso diz respeito a comunicação... Para um jovem, isso vai dizer respeito à comunicação. Não quer dizer, não é... Não vão ser clichês que vão permitir que eles entendam esse debate. Eu acho que assim... Se os jovens tivesse mais organizados em grupos com mais... Com mais possibilidade. Isso do ponto de vista de dentro da sociedade, em um microcosmo... Eu acho que isso seria uma coisa importante. Isso permite uma transformação. Quer ver, eu estava vendo o vídeo dessa... No (...), está acontecendo... Já tem 70 escolas ocupadas, né? E eu estava assistindo os vídeos de uma escola que foi uma escola (...), o colégio (...) e estava tendo o show da Marisa Monte e o Evandro Mesquita foi lá. E eu estava vendo aqueles jovens ali e depois fiquei ouvindo aqueles jovens. Tem um... Tem um youtube de uma... Acho que o twitter do Ninja, eles estão lá. E eles falando e vários professores dizendo: 'Eles estão fazendo uma coisa que nós estávamos há muito tempo reclamando, querendo por melhores condições, querendo...'. E eles estavam 
reclamando que eles queriam algumas coisas, por exemplo, que eles queriam introdução de filosofia e sociologia no currículo. E eles estavam felizes da vida que pela primeira vez, eles estavam tendo filosofia e sociologia no currículo, começaram a ter aulas e acharam ótimo isso. $\mathrm{E}$ assim, eles estavam muitos animados com a possibilidade, exatamente com a possibilidade que eles estavam tendo de transformar alguma coisa. E eles mesmo dizendo: 'Os professores, a gente vê que eles reclamando e eles não estão conseguindo nada e nós estamos também sendo porta-vozes deles.' . Então, eu disse assim: 'Gente' e vendo alguns analistas falando que isso que está acontecendo é muito interessante, isso tem uma potência. Então... Aí eu acredito nisso. Eu acho que essas mudanças, elas podem permitir que abram-se canais de comunicação de maior transparência, de maior confiança, porque isso... Isso, eu acho que é importante. Hoje, a grande mídia está muito desacreditada de um modo geral, né? Então, é...

P: Tem que ter outros canais.

E: Tem que ter outros canais. Hoje, tudo é muito BBB.

P: Mas se você fosse... Fosse fazer um programa, uma campanha de prevenção. Qual iria ser a tua, a tua mensagem?

E: Uhum. Olha, é... (risos) Complicado. Eu acho que seria através dos jovens, seria através dos jovens, através dessas ideias de organizações locais, de conversas locais em que eles possam estar falando o que eles estão falando entre eles sem que sejam é... Criticados. Achar que aquilo dali tem uma potência, tem uma capacidade de mudança.

P: Um empoderamento.

E: Dar um empoderamento. Exato. Um empoderamento, que eles têm isso e que eles estão podendo... Eu acho que esso é um canal.

P: Começaria dos pequenos encontros, dos...

E: É, é.

P: Das pequenas reuniões para a partir daí mudar alguma consciência, alguma coisa...

E: É, é, é. A capacidade, assim... Que eles teriam de... Eu percebi isso no grupo, lá em (...), como que eles vão, esses jovens, aqui, conseguir juntar uns quarenta jovens, eu disse assim: 'O que vocês acham de vocês?' Todos reclamavam, porque esse lugar aqui é horrível. A gente está distante. Leva (...) para chegar em uma cidadezinha maiorzinha que pode ter uma balada. E nós não queremos ir mais para a feira, para a feira da praça principal', da cidade de (...) habitantes 'para as barraquinhas. Isso já não dá.'. Eles já sabem que o mundo é maior que esse negócio. 'Pois é, qual poderia ser um projeto que vocês poderiam estar contactados com esses outros que estão há (...) de uma outra cidade mais próxima?', que tem, que é uma cidade de (...) mil habitantes e tem outros tipos de atividades, tem grupo de teatro e tal, porque... Construir alguma coisa. E aí eles disseram: 'Bem, mas aí a gente precisa de internet, porque sem internet a gente não consegue. Precisamos de uma internet que funcione aqui para a gente montar alguma coisa.' Eu vi que tinha algumas lideranças naquele grupo que poderiam fazer esse tipo de coisa, eram coisas que eles estavam querendo. Eles queriam se encontrar com os outros, eles queriam participar de um mundo que eles sabiam que existia. 
P: Quer dizer, precisa também ter uma comunicação com sentido. Significativa para eles...

E: Claro, claro...

P: ... e dentro do contexto que eles estão inseridos, porque senão a mensagem não chega. Não chega e não entra, vai embora.

E: É. Não, não chega. Vai embora. É. Vai embora. E, hoje, quando a gente olha que eles estão todos. Todos eles... Que a internet é fundamental. Tem que funcionar. Tem que ter um satélite aqui em cima que transmita essa mensagem para a gente poder estar fazendo essas coisas, criando alguma possibilidade. Então, eu acho que é isso, que isso pode ter realmente uma potência. Estou vendo, assim... Estou prestando atenção nessa história das escolas, o que eles estão fazendo ali... É... E eles estão dizendo... Uma coisa que eu achei muito interessante. 'Nós não queremos escolas modelo.' Porque existem dentro de escolas públicas do estado, aquelas que viram escola modelo. 'Não, nós queremos que todas as escolas funcionem, não queremos as escolas modelo. Tudo bem o que elas tiverem a gente pode até aprender, trocar e tal.' , mas queremos é... Não tem que existir essa escola modelo. Todas as escolas tem que ser assim, do jeito...

P: Algo mais igualitário.

E: Exatamente. Essa era a palavra que eles estavam colocando. Tem que ser igualitário. Todo mundo ficar em escolas. Não precisa ser modelo.

P: Igualitário, um sistema igualitário onde eles pertençam.

E: Sim.

P: Sensação de pertencimento também.

E: Isso é fundamental. Eu acho que essas coisas assim... É... Assim... Porque uma das coisas assim... Eu também fico pensando assim... Quando eu encontrei (...), eu também ficava pensando e conversando com as pessoas. Ia ao lugar que os jovens estavam e é... Nos bares que eles estavam, conversava com os jovens e ficava assim... Eu dizia assim... Perguntava para as pessoas... Primeiro, eu percebia que eles bebiam muito. Tinha assim... Aí alguns pais, fizeram uns ônibus que circulavam e que carregavam as pessoas. Ninguém ia de carro para não ter mais acidente. Os ônibus para poder transportar. Bem, tinha isso... Bem, o uso de droga era uma coisa profunda e sem limite. Agora, algumas pessoas diziam: 'Essa é uma cidade do rock' in roll', eu dizia assim: 'O que significa isso?' (risos). O que significa? Por que que essa população tem uma taxa tão alta? Quase (...) na população de jovem, é uma taxa muito alta. O que que é isso? Quem são essas pessoas? Agora, com essas taxas... Porque... Estou fazendo uma comparação. Esses... (...) é uma cidade, ainda que uma cidade de interior do (...) possa ter aquelas estruturas conservadoras e tal... (...) é uma cidade assim, que não é conservadora, não é uma cidade que tenha traços fechados, não. Não é.

\section{P: Careta.}

E: Não, não é. Então, esses jovens ali, eles 'tão' encontrando espaço. Fazendo uma comparação assim... Encontrando espaço e se identificando. Agora, quando eu vejo a questão dos jovens que estão se suicidando em (...), que é... Tem um perfil diferente. Eles são jovens que estão vindo de outros locais, não são de (...) exclusivamente, vem 
com aquela história daquelas (...) que competem entre... Entre elas e entre as melhores do Brasil, pá, pá, pá. Ou seja, então, criou-se o que eu fico imaginando... Poxa, imagina o significado disso para um estado que todo mundo sabe que é um estado que... Isso deve ter um significado importante para essas famílias terem seus filhos nessas escolas e essas escolas estarem no ranking, nesse ranking, bem situadas no ranking nacional. E agora, é... eu fico imaginando que esses jovens estão sozinhos no ambiente de muita competição e que sem sustentação. Ali, eu tenho que ser o primeiro. Mas como você vai ser o primeiro... Qual o custo disso, né? É a mesma coisa que acontece com o jovem lá no Japão, uma sociedade altamente competitiva e que eles têm que dar conta disso. Então, é... Isso só ocorre aqui? Não. Porque quando você vê as universidades americanas que estão se queixando de que faltam serviços de apoio aos estudantes, porque ocorrem da mesma forma... Esses estudantes... $\mathrm{Na}$ realidade, nos Estados Unidos, quanto mais longe você for da casa da sua família estudar melhor. Então, é mandado sempre para bastante longe. E tem uma taxa de suicídio que estão aumentando e eles veem que as universidades não estão dando um suporte, não tem serviço de assistência psicológica e tal. Então, isso ocorre... Como dar conta disso diante de um processo, de uma sociedade, de sociedades altamente competitivas e altamente consumidores, que consomem tudo. Tudo. Não é apenas o bem físico, é...

P: Quer dizer, a gente está falando de jovens muito assim... Similares em algumas coisas, mas muitos diferentes. Você pega o jovem de (...), você pega esse jovem de (...), você pega o jovem de uma universidade dos Estados Unidos. A mensagem tem que ser diferente.

E: Exatamente. A mensagem tem que ser diferente. A mensagem tem que ser diferente.

P: A forma de trabalho precisa ser diferente. Bem, mais específica.

E: É, verdade... tem que ser especifica. Só que eu acho que tem que ter como linha estratégia um suporte social e uma assistência. Uma assistência qualificada, uma assistência qualificada não é apenas um profissional que vai fazer um bom diagnóstico, um bom. Tem que fazer um, né? Ele tem que pensar qual é... Tem que ter uma boa escuta, ele tem que ter uma... Uma experiência em lidar também... Tem que ter uma experiência em lidar, inclusive, com o jovem, que é bem diferente,

P: E ele não pode ter medo em falar de morte.

E: Não, não pode. Não, isso ele não pode (risos). Não pode... Agora, então, eu acho que se a gente quiser caminhar, assim, não são... É... As informações... Sempre que nós pensarmos uma informação que a gente... Acho que tem a ver um pouco a ver com a coisa da campanha e botar numa campanha. A gente tem que pensar o seguinte: 'Ok, eu coloco isso aí e onde está a minha retaguarda?'. Eu dizia assim quando eu estava no (...) 'Gente, vocês estão mandando as pessoas procurarem um serviço que não existe.' Isso é uma hipocrisia.

P: Você cria uma demanda que não tem para onde ir.

E: Pois é, não tem para onde ir. Hoje, esses espaços, eles não tem ou não tem uma identidade. Eu me lembro quando nos programas, programas para controle de doenças sexualmente transmissíveis nas unidades de saúde. Chegavam e me diziam assim: 'Ah, as meninas vem, os rapazes nunca vem. As meninas vem e os rapazes...' e eu disse assim: 'Quem chama?', 'Ah, já nós fomos. A fulana...'.Eu disse assim: 
'Primeiro que eu só estou vendo mulheres chamando os rapazes... É mais difícil de vir. Depois, qual a visão que eles têm, que eles têm dessas unidades. Vocês sabem o que que eles... Vocês já ouviram? Vocês já perguntaram para eles?' 'Pois é, eu já perguntei e sabe o que eles me dizem? Ah é aquele lugar onde as mulheres vão tudo com o peito para fora.'. E eu disse: 'Por que? Por causa dos programas de amamentação.' Eles não têm nada a ver com isso. Não se identificam. Então, eu disse: 'Eles não vão vir para cá. Que tal vocês irem onde eles estão. Onde eles estão? Eles estão jogando bola, gente. Eles estão jogando bola lá. Então, se desloca... O objetivo é esse. É claro que eles tem todo o interesse no tema das doenças sexualmente transmissíveis, vai ser aquela coisa (faz som de risada e de nojo). Vai ser aquela brincadeirada toda, mas vocês vão ter que ir para o campo. E não tem homem também. Alguém para falar.' E ok.

P: Tem que ser ativo.

E: Porque senão não adianta. Eu me lembro... É uma coisa assim. Uma vez eu observei na escola. Isso tem a ver com como lidar com questões, que é uma coisa que... Você acaba escutando muito através da clínica, com questões masculinas e ouvir que vão ser colocadas por um profissional, por um técnico homem. Não colocam para as mulheres. Então, isso vai se dar em todo o ambiente. Nós temos uma... E no ambiente. Tanto o ambiente escolar tanto esse ambiente do serviço de saúde ele é... Se não é a escola... Uma escola só masculina, só feminina. É um ambiente extremamente feminino... Você tem muito mais professoras, que não é uma coisa assim... É uma coisa muito diferente de outros países, porque quando outros países em que os professores... Ou mesmo escolas de melhor padrão em que os professores são mais bem pagos, você vai encontra professores e professoras... É... E nas escolas... Nas escolas na Suíça, nos Estados Unidos, no Canadá, você vê professores e professoras. Os jovens conseguem lidar com questões de gênero com seus parceiros de gênero. Isso tem uma importância, isso cria canais de comunicação. Infelizmente, isso é uma questão estrutural. Isso é uma questão estrutural. É... E mesmo nas escolas, quer dizer, mesmo nas escolas particulares... Isso, você consegue ter quando entra no segundo grau. Para os pequenos, você não consegue. Só mulher... Aí os garotos... Eu me lembro quando eu ainda ia na escola: 'Cadê a bola?' 'Ah, está lá dentro do armário'. Os garotos querem jogar bola e a bola está lá dentro do armário. Eu discutia com a diretora e tal. Aí a professora chega e diz: '(...). E aí eu dizia assim: 'Meu Deus, eu tenho a certeza absoluta', dizia para minha esposa, 'tenho certeza absoluta que eu nunca ouviria isso de um professor', porque ele não está nem aí se o garoto (...). Aí eu tenho que ouvir uma professora que fazia assim (faz algum gesto). E eu já estava assim... Eu acho que isso é uma questão... Não sei... Isso é uma questão... Isso acontece com os pequenos, vai acontecer com os pequenos. Se a gente imaginar, é... No âmbito das famílias, estruturas familiares, em todos os níveis, mas aquelas em que você só tem, você tem mais uma mulher cuidando dos filhos. Ou sejam porque tem mais estrutura de separação ou... É... Isso tem... Isso tem... Quer dizer, não encontra um...

\section{P: Tem impacto?}

E: Tem impacto. Eu tenho certeza que isso tem um impacto. Tem um impacto de comunicação. Aí de repente a gente quer se fazer... Se comunicar e fazer com que eles se comuniquem, mas eles... Mas...

P: É diferente. 
E: É. Tem que... Como que eu vou encontrar esse canal. Então, eu... Na realidade, eu não estou sendo pessimista não (risos). Eu fiquei até bastante... Achei bastante interessante essa questão desses jovens nas escolas no Rio, ouvindo os discursos deles, ouvindo que eles estavam se empoderando, que eles estavam se sentindo capazes, estavam se considerando. E muito interessante porque eu disse assim 'Gente, eles estão pedindo uma coisa que eles... Que é super natural que as escolas tenham. Eles querem melhores condições. Você vai ver na escola, eles estão lá varrendo, limpando. Eles querem condições.

P: E eles querem ser ouvidos.

E: Querem ser ouvidos. É, com certeza. Então, eu acho que isso tem uma... Assim, tenho certeza que eles ali naquele ambiente, que eles se encontraram, que eles estão ali juntos, porque eles estão ali o dia inteiro, ali nessa escola, que é a mais próxima que eu tenho contato, eu vi que as pessoas foram lá dar aula, foram participar. Pessoas resolveram ir lá...

P: A comunidade se mobilizou...

E: Todo mundo se mobilizou... Está indo lá falar 'Vamos falar sobre isso, vamos falar sobre aquilo'. Cada um resolveu ir falar sobre alguma coisa. Isso é diferente. Isso é diferente.

P: Se deixar eu fico aqui conversando com você umas três horas, mas enfim...

E: 'Tá' bom, mas a gente vai embora (risos).

P: Eu vou fazer algumas perguntas. Você já respondeu muito do que eu queria saber.

E: Que aí você vai podendo encaixar aí.

P: Eu vou encaixar em tudo aqui. Eu só vou fazer a pergunta para saber se você quer complementar algo dentro dela. Você já englobou... Nossa, excelente. Vamos lá, você pensa que o suicídio é um tema tabu no Brasil? Por que você pensa que esse fato acontece? Você já me falou do tabu...

E: É, eu acho que eu já falei da questão, né? Como ele ocorre no âmbito, como ele ocorre no âmbito da família e as famílias se sentem culpabilizadas e impotentes diante de uma situação desta e tem dificuldade. Naturalmente dificuldade de falar sobre um tema.

P: O que você pensa da conscientização do problema do suicídio no país?

E: É, eu acho assim... Eu acho que... Conscientizar em relação ao suicídio, ao tema, é a gente poder falar dos temas tabus. É a gente poder falar do que a sociedade tem dificuldade pra falar, mesmo que querendo falar. Acho que a gente conseguiu isso com a AIDs, conseguiu... Não sei o que mais adiante vai surgir. Então, eu acho que... É... Eu acho que é fundamental, mas é um trabalho de quão, como a sociedade se permite falar dos seus... Dos seus desafios... Das suas... Eu acho que, nesse momento, eu vejo a sociedade todo mundo falando de tudo... Falando assim para o bem, para o mal, não importa... 'Tá' todo mundo falando de tudo que é jeito...

P: Mas fala (risos).

E: Eu acho assim que... É pode ser assim... Se é uma crise e aí eu estou generalizando. Se estamos diante de situações de crise, em situações críticas que afetam a sociedade, eu acho que se as pessoas perceberem que elas podem falar, elas 
perceberem que não há uma... Que há uma transparência, há uma receptividade, que não existe...

P: Censura...

E: Censura e mais... E que não... E que o seu discurso não vai ser interpretado de uma forma hipócrita, sabe? Eu acho assim... É porque... Esse tema, a questão da hipocrisia, eu acho que é um tema profundo na sociedade. Quando se trabalhou a questão da AIDS, trabalhou a questão da hipocrisia. Chegou e se tocou em temas que eram bastante difíceis para a sociedade. Profundamente difíceis, porque concepções antigas, concepções filosóficas, religiosas e morais e culturais, então, assim... Mas se lidou, se enfrentou essa realidade. E aí quando se enfrenta isso de alguma forma... diminui... A sociedade começa a aceitar mais o outro e não se coloca no papel de julgadora... Eu acho que essa é uma questão importante, assim... Essa questão do julgamento, porque eu acho que ele acaba reforçando os tabus.

P: Você já me falou como você pensa que deve ser abordada a questão, A gente já conversou bastante. Quando e onde você acha que esse tipo de informação deve correr, também já falamos bastante. A não ser que você queira...

\section{E: Não.}

P: Que ações seriam necessárias e como elas poderiam ser promovidas?

E: Pois é, o conjunto das ações é assim... Do ponto de vista... Eu acho que teriam coisas que poderiam, nesse momento, do ponto de vista do poder público, poderia estar sendo feito de uma forma mais, mais afirmativa, que é melhorar todo... Não estou falando de campanha, mas estou falando de melhorar todos os sistemas de informação, porque uma das... Quando eu comecei a trabalhar (...).' Então, sempre que for dar visibilidade ao tema, vai ser bom, porque primeiro que a gente sempre vai trazer, vai estar sempre trazendo aqueles que estão com o tema dentro de si e não estão podendo encontrar um espaço e eles estão ali. Tão ali esperando para serem chamados, porque eles estão vivendo profundamente essa situação. Seja porque foram... 'Tão' vivendo porque tem casos de tentativas ou tiveram perdas na família. Então, eu acho que isso... Que essa é uma ação bastante importante e eu acho... Um investimento... Outro dia, eu estava vendo o investimento na formação de CAPs no (...) Um trabalho feito pontualmente em três ou quatro cidades. Ótimo, porque eles estavam levando o tema para dentro desses centros e estavam fazendo que os profissionais lidassem com o tema. Os profissionais também ficam... Aqueles que ficam totalmente isolados não... Não... Sem poder conversar, sem poder saber, ficam com um problema para si só... Então, investir nesse... Nesse treinamento que é mais que um treinamento, é dar um espaço para eles poderem falar e eles perceberem o que você pode fazer no lugar que você está que pode contribuir para melhorar a clínica do teu ambiente. Assim não falo da burocracia, estou falando da clínica do ambiente. Até porque eu acho que grande parte da dificuldade das estruturas burocráticas de saúde, é porque elas tentam fazer com que a clínica se adeque à burocracia e não a burocracia a clínica. Ou seja, quando alguém faz uma tentativa de suicídio e não encontra uma porta aberta e diz assim... A burocracia diz: "Você vai ser atendido por um profissional daqui 30 dias'. Esta tentando adequar a clínica à burocracia. Quando nós sabemos se ele fez uma tentativa, ele pode... Ele não vai esperar um mês. Ele pode fazer uma outra daqui a dois dias. Então, não pode. A clínica... Aí eu acho que é uma hipocrisia, quando o estado burocrático tenta adequar a estrutura do espaço de assistência aos seus interesses e não aos interesses da clínica, que são os interesses do 
indivíduo. Então, isso é uma revolução. E aí, isso daí é o tipo da coisa: 'Ah, a gente pode montar umas estruturas que sirvam de modelo', e aí os estudantes: 'Mas a gente não quer mais modelo. A gente quer que tudo funcione bem'. (risada) Que bom, né?

P: Mais algum comentário.

E: Não.

P: Alguma coisa que você gostaria de adicionar.

E: Não, tá bom.

P: Agradeço muito, muito. Igual eu falei, se deixasse eu fico aqui conversando com você horas. Porque muito legal te ouvir falar. (barulho de toque de celular). Olha, na hora. Deixa eu desligar. É isso, aí eu vou fazer o seguinte, vou fazer a transcrição... 


\section{Anexo H - Relato da Observadora}

\section{OBSERVAC̄̃̃O - GRUPO 1 DE PESQUISA DO DOUTORADO}

O encontro contou com 11 participantes (4 homens e 7 mulheres).

O grupo demonstrava um clima de expectativa. Depois das orientações e da assinatura do termo de consentimento, iniciou-se a discussão. Diante da primeira questão "Como o suicídio é visto no Brasil?", inicialmente houve uma pequena pausa, mas então todos começaram a se colocar. Diante das falas "Tabu ... a pessoa é vista como fraca, covarde ... não prestam atenção até passarem por isso", observo que muitos acenam com a cabeça, concordando.

A ideia de que "só quem passou por isso entende" pode ser uma das explicações da importância da participação em grupos de enlutados para os participantes. Pertencimento. "E se meu ente querido soubesse que havia um lugar onde ele poderia falar sobre seus pensamentos e sentimentos sem ter medo de ser julgado, para ser acolhido e compreendido?" Parecem se sentir fortalecidos com o grupo, e imaginam se esse recurso teria feito diferença na história de seus entes queridos.

Observei que quando a psicóloga que também é uma sobrevivente falava sobre sua experiência ao perder um paciente por suicídio, o grupo pareceu atento, porém aparentemente não sinalizava a mesma identificação que acontecia quando outro familiar se colocava. De fato, parece haver uma dificuldade de compreender o outro, mesmo dentro deste universo. "Só o outro, que sentiu a perda no mesmo nível que eu, pode entender o que eu estou sentindo" ... Então, quando falam na dificuldade das pessoas terem empatia, parecem não perceber que eles mesmos ainda diferenciam experiências de acordo com sua própria história - quem perdeu um filho é diferente de quem perdeu um paciente ou um amigo ... Claro que sim, mas quero dizer que no próprio grupo parece existir essa classificação de "graus" de sofrimento. Por vezes, me parece que há uma certa dificuldade de cada um sair de sua própria vivência e olhar para o outro ...

A questão da subnotificação e dos processos burocráticos pelos quais os familiares passam também mobilizou o grupo ... "O médico só pode atestar o que está no corpo", diz um dos sobreviventes que também é médico. Uns afirmam que o suicídio deveria aparecer no atestado de óbito, para que as estatísticas fossem mais fidedignas; outros, admitem que mesmo entre pessoas próximas, existem alguns que não sabem a causa de morte real do seu familiar.

Críticas do grupo: a informação sobre como lidar com o suicídio e seus familiares não faz parte da formação dos profissionais desse contexto: policiais, da área 
da saúde ... Maus tratos no hospital... não há capacitação para comunicação de más notícias ... Uma dor a mais para quem fica.

Ampliação: nossa sociedade não acolhe nem a tristeza, quanto mais o suicídio ... de maneira geral, parece haver dor para os sobreviventes e desconforto para os demais ao falar sobre o tema em nosso meio ...

Todos os participantes querem falar muito ... uma única pergunta gera desdobramentos, e todos parecem querer dar sua opinião.

“A depressão é um tabu ... Educação emocional muito pobre em nossa sociedade. As pessoas não têm espaço para dizer o que estão sentindo, mesmo entre familiares e amigos".

“O sofrimento mental não é validado”.

"Quem tem câncer é acolhido, quem tem depressão é visto como folgado".

Seria importante (Sugestões do grupo):

- Falar da dor e do sofrimento dos que ficam

- Suicídio como problema de saúde pública

- Desmistificar psiquiatria e medicação

- Envolver a família

- Suicídio como algo que não é distante das pessoas, que pode acontecer com qualquer um ...

- Relatos de pessoas que tentaram suicídio - como Luiza Brunet quando denunciou a violência doméstica que sofreu - podem ajudar.

O grupo parece aproveitar o encontro para compartilhar experiências e se despede de forma afetuosa. 


\section{OBSERVAC̄ÃO - GRUPO 2 DE PESQUISA DO DOUTORADO}

Menos pessoas do que no encontro anterior.

Antes do começo do grupo, enlutados trocam experiências sobre cartas psicografadas - parece fazer diferença ter a certeza de que seus entes queridos continuam a existir em algum lugar e se comunicam com eles. (Há alguma pesquisa nesse sentido? De quantas pessoas aderem ao Espiritismo após uma perda como essa?).

A maioria diz que ficou bem depois da última reunião; um dos participantes diz que ficou impactado pela experiência dos demais. Penso que alguns participantes dos grupos de enlutados, mesmo após diversos encontros compartilhando experiências, parecem "guardar" mais as falas dos outros com as quais se identificam ...

Questionamento sobre o alcance de campanhas como "Setembro Amarelo" - pessoas que não passaram pela experiência podem sentir que não tem nada a ver com o tema e não receber a informação.

Importante divulgar como a pessoa que está em sofrimento ou tem alguém próximo passando por isso saiba onde pode procurar ajuda.

"Ninguém me perguntou como poderia ajudar, mas queriam saber sobre detalhes mórbidos" - a maioria refere que as pessoas de fora não sabem como ajudar, julgam ou se afastam ...

Divulgação de sinais de alerta podem ser vistos por outras pessoas como negligência dos familiares: "falta de amor", "Você não percebeu que ele não estava bem?".

Sugestões do grupo:

- Não falar sobre prevenção do suicídio só em setembro

- Divulgação do CVV na televisão

- Faculdades de Psicologia atendendo a esta demanda

- Capacitar profissionais

- Mais grupos de apoio (e seus participantes tornando-se multiplicadores em seus espaços - trabalho, faculdade, mídias sociais).

- Rede de proteção (mídia, família, profissionais)

- Bloquear acesso a conteúdos negativos na Internet 
- Divulgar mais a importância da terapia como forma de autoconhecimento e não "coisa de louco"

- Ser mais humano no dia a dia "É por isso que vale a pena viver".

- Mais conhecimento e menos pré-julgamento.

No final do encontro, agradecem à pesquisadora por falar sobre o tema e por seu trabalho, na pesquisa e na prática.

Me parece que os participantes saem aliviados, sentem que participar do estudo traz mais um sentido para o que aconteceu e pode gerar benefícios para outras pessoas. Confiam na pesquisadora, por já a conhecerem há algum tempo, o que faz com que possam falar sem receio. Dão a impressão de que voltariam para outros encontros, se fosse necessário. 


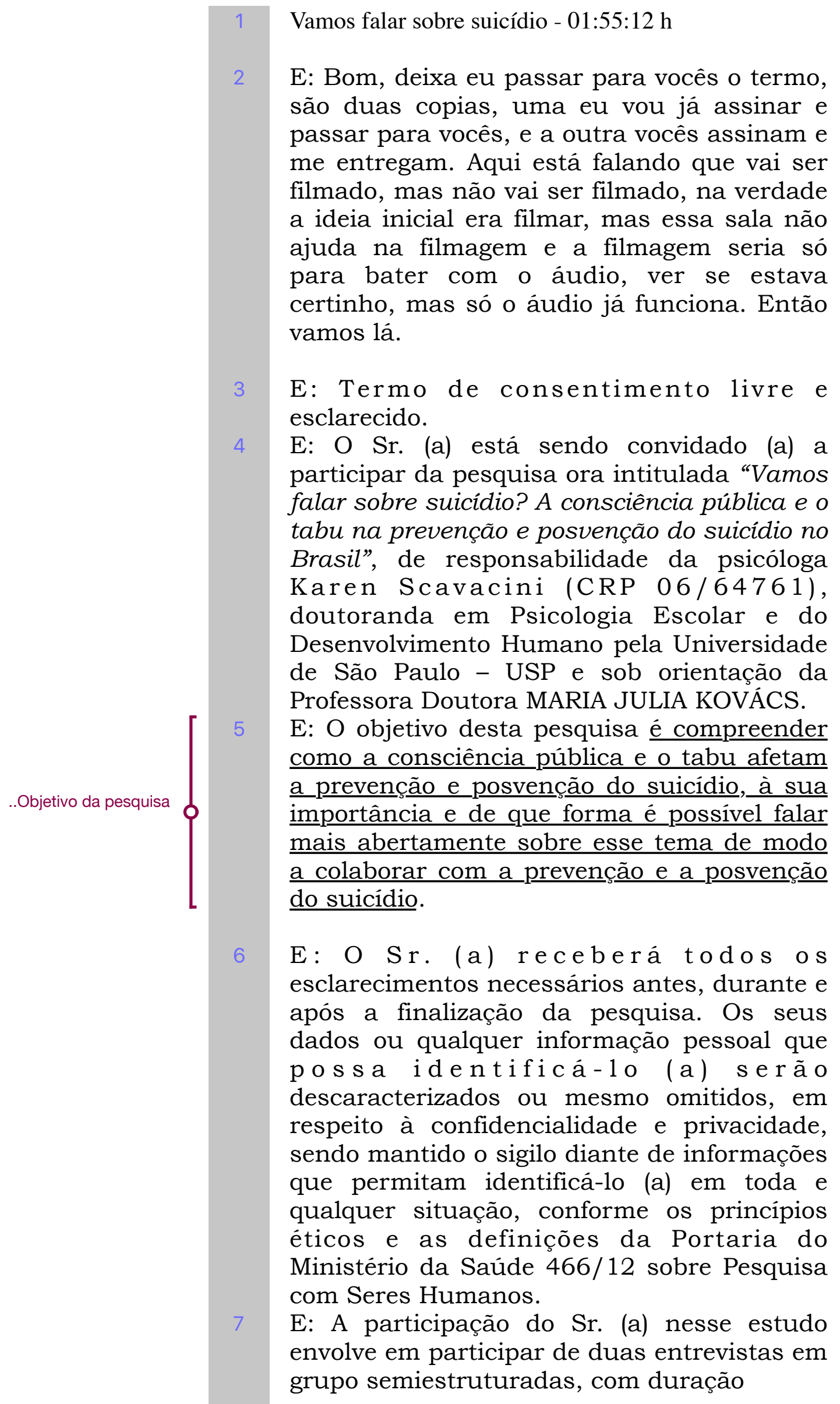


estimada de 2 horas cada uma. Informamos que o seu tempo de resposta será respeitado e que você pode se recusar a responder qualquer questão que provoque sofrimento. A entrevista será gravada e filmada e sua transcrição será enviada posteriormente por e-mail, para que o Sr. (a) possa alterar, conferir, incluir ou retirar conteúdos.

E: O depoimento do Sr. (a) será gravado, transcrito e analisado, sem qualquer prejuizo para o sigilo e condição de informação anônima, sendo reservadas informações que possam identificar de alguma forma o participante. Os dados e materiais utilizados na pesquisa ficarão sob a guarda da pesquisadora responsável pela pesquisa. A imagem será utilizada somente para análise da pesquisadora e será destruída após o término da pesquisa. O Sr. (a) pode optar em não ser filmado.

E: Os resultados da pesquisa serão devolvidos ao Sr. (a) por meio de e-mail e serão utilizados só para fins de publicação científica a que poderão ter acesso posteriormente.

E: Esta pesquisa possui riscos mínimos ao participante. Não será usada nenhuma técnica invasiva, porém algum desconforto pode ser gerado por despertar lembranças momentâneas que podem causar sofrimento. Neste caso o (a) Sr. (a) será acolhido pela pesquisadora e referido à serviço de suporte psicológico.

E: Não há benefício direto para o participante, o potencial beneficio para a sociedade é que este estudo possa compreender como aumentar a consciência pública em relação ao suicídio e suas influências na prevenção e posvenção. E: A participação nesta pesquisa é de caráter voluntário, não havendo qualquer tipo de pagamento, despesa pessoal, ou de obrigatoriedade pela participação. O Sr. (a) tem inclusive o direito de retirar seu consentimento e sair da pesquisa sem que isso lhe traga qualquer tipo de prejuízo ou ônus, bastando para isso formalizar este desejo para a pesquisadora.

E: Ainda que se retire da pesquisa, o Sr. (a) 
mantém o direito de ter acesso às informações pertinentes a este estudo até o seu final.

E: Em qualquer etapa do estudo, o Sr. (a) terá acesso à responsável pela pesquisa para esclarecimento de eventuais dúvidas ou informações do andamento da pesquisa na Alameda Uananá, 200, Sala Orquídea, Planalto Paulista, São Paulo - SP, Telefones (11) 5084-3568, E-mail:

karen.scavacini@usp.br.

E: Se você tiver alguma consideração ou dúvida sobre a ética da pesquisa, poderá entrar em contato com o Comitê de Ética em Pesquisa com Seres Humanos do Instituto de Psicologia da Universidade de São Paulo CEPH-IPUSP - Endereço: Av. Prof. Mello Moraes, 1.721 - Bloco G, $2^{\circ}$ andar, sala 27 CEP 05508-030 - Cidade Universitária - São Paulo/SP. E-mail: ceph.ip@usp.br Tel. (11) 3091-4182

E: Dados relevantes da entrevista serão utilizados na pesquisa, e as citações sem identificação ficarão disponíveis ao público, bem como, para ensino, publicação em periódicos, livros e/ou apresentações em encontros científicos.

E: Dados de identificação do participante da pesquisa, nome, RG, sexo, escolaridade, data de nascimento e e-mail.

E: Este documento foi elaborado em duas vias, uma ficará com a pesquisadora responsável pela pesquisa e a outra com o participante da pesquisa.

E: Eu, então vocês colocam o seu nome, declaro estar devidamente esclarecido sobre os propósitos e procedimentos da pesquisa

"Vamos falar sobre suicidio? $A$ consciência pública e o tabu na prevenção e posvenção do suicidio no Brasil", ciente de todos os direitos, e em pleno acordo em participar e ter as entrevistas gravadas, transcritas e analisadas estando de posse de uma cópia deste Termo.

E: Ou seja, se em qualquer momento vocês quiserem sair da pesquisa, é só me avisarem e tudo que vocês falarem vai ser apagado e 
não vai ser utilizado, todos os nomes de vocês não vão aparecer, vai aparecer provavelmente P1 para participante 1, P2 para participante 2 , só para poder ter a distinção de quem que é e qualquer outro dado como nomes que vocês venham a falar, nada disso vai aparecer em qualquer parte da pesquisa, então eu vou assinar depois e vou entregar para vocês o meu assinado e eu gostaria que vocês lessem de novo se quiserem e assinassem, por favor, se vocês tiverem alguma dúvida é só entrar em contato comigo em qualquer momento que a gente conversa. $\mathrm{E}$ também tem um questionário para vocês preencherem que é para a gente não entrar nesses detalhes hoje para não ficarmos muito tempo conversando. Para preencher nome, idade, estado civil, nome de quem perdeu, o parentesco, a quanto tempo, idade que a pessoa tinha na época, idade que você tinha na época, há quanto tempo participa de grupos de apoio, se está ou esteve em tratamento psicológico, quanto tempo e se esse tratamento é em decorrência da perda ou luto, se está ou esteve em tratamento psiquiátrico, quanto tempo e se esse tratamento é em decorrência da perda. Isso é confidencial, só eu vou ter acesso. Se vocês não quiserem responder alguma das perguntas daqui também não tem problema nenhum. Essa parte de termo e questionário é só hoje, no próximo encontro não precisa. Vocês têm alguma dúvida?

P4: Esse aqui é qual nome?

E: É o nome de quem você perdeu.

P2: E esse?

E: É o seu nome. Essa cópia fica com vocês. Quando vocês terminarem de preencher eu entrego esse assinado, se não é muito papel.

P1: Depois você vai arrumar? Porque esse aqui eu troquei.

E: Não tem problema. Algum de vocês já 


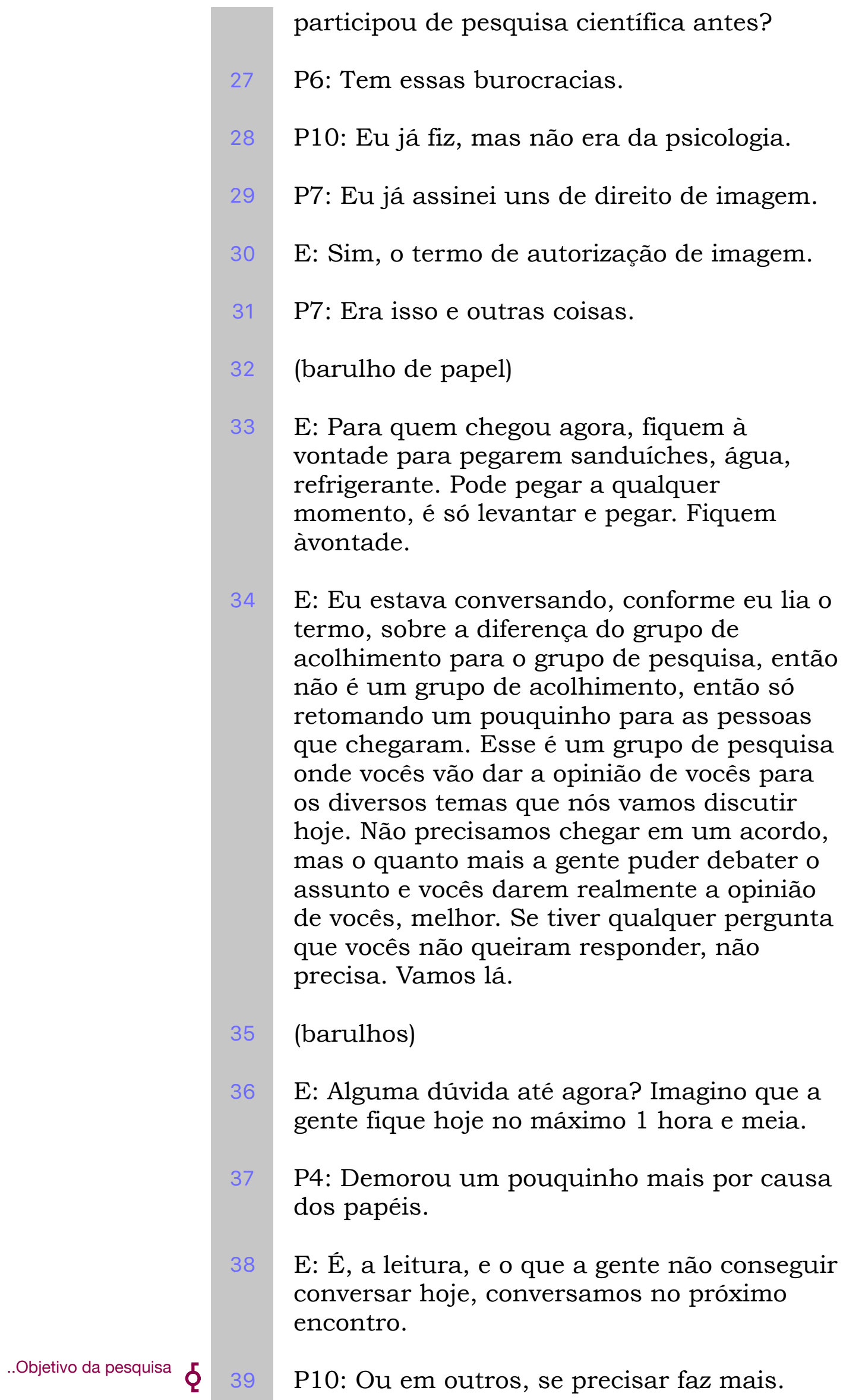


(risos)

E: Daqui a 15 dias. Bom, vamos lá. A *, que está aqui me auxiliando pode fazer algumas perguntas no meio do caminho. Se vocês também tiverem perguntas conforme as pessoas forem falando, tiverem alguma curiosidade, sobre aquilo que a pessoa esta falando, perguntem. Então para darmos continuidade eu queria que vocês se apresentassem falando o nome, a idade e quem perdeu. E depois começamos com as perguntas.

$\mathrm{P} 1:^{* * * * * * * * * *}, 59$ anos, filha.

P2:**********, 51 anos, perdi um filho

P3:*********, 73 anos, perdi meu marido.

P4:*********, 48 anos, meu filho ${ }^{* * * *}$.

P5:**********, 59 anos, meu filho $* * * *$.

P6: ${ }^{* * * * * * * * * *}, 39$ anos, um paciente.

P7:*********, 58 anos, minha filha mais velha.

P8:**********, 40 anos, o meu irmão.

P9:**********, 51 , um amigo

P10:*********, 28 anos, perdi meu irmão.

P11:**********, 35 anos, perdi meu sobrinho.

E: Obrigada. Bom, então para a gente continuar, como vocês acham que o suicídio é visto hoje no Brasil?

P4: Ainda com bastante tabu, ainda. Mesmo falando bastante.

P2: $\mathrm{E}$ acho que reflete que a pessoa que se suicida é vista como fraca, um covarde, eu acho que é assim. 


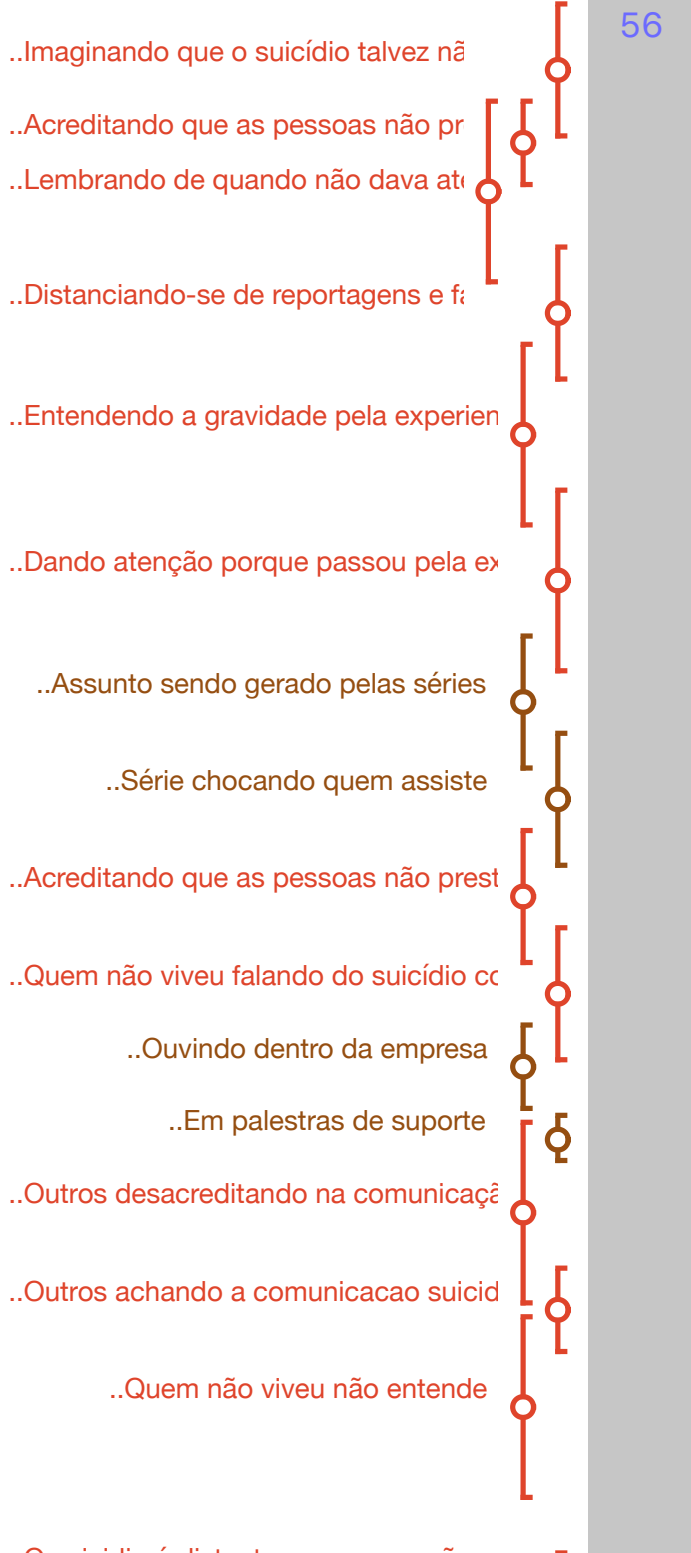

..O suicidio é distante para quem não pas` $\mathbf{\Phi} 57$

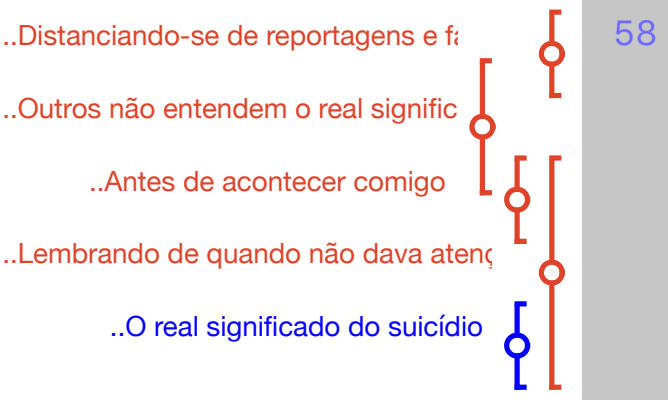

..Lembrando de quando não dava atenç $\mathbf{\Phi} \mathbf{\Phi}$

..Dando atenção porque passou pela ex

..Sentindo a morte como longe

..A vida tem coisas ruins
P10: Eu acho que as pessoas que não viveram isso talvez nem saibam que o suicídio existe, porque eu acho que não é uma coisa que as pessoas prestam atenção. Não sei, pelo menos no meu caso, mesmo quando eu via na TV eu acho que eu não... acho que é a mesma coisa de você ver reportagem de assalto, de roubo. Acho que assim, não sei se você não entende a gravidade do suicídio enquanto não acontece com você, né, com alguém próximo. Eu acho que acaba sendo um tema não muito, não sei, eu acho que só quem passou mesmo, dá a atenção. Eu acho que agora com a série lá dos "13" e da "baleia", talvez isso gerou né esse assunto em mais rodas, porque é uma série, é uma coisa que todo mundo ficou chocado. Mas senão eu não acho que, eu acho que é uma coisa que passa meio batida assim, se as pessoas não... ou quando é falado talvez quem não viveu até acha assim "ah, absurdo" ou dá risada. Eu já ouvi assim em empresa inclusive, quando fazem, por exemplo, palestra que dão suporte e dão exemplo: "porque tem gente que liga que fala que vai se suicidar" e tem gente que fala: "pff, até parece." E dá risada, acha engraçado. Que eu acho que talvez eles não entendam que isso é realidade, as pessoas que acho que não vivem talvez... não vejam como algo...

E: Vejam como algo distante...

P10: É, sabe quando te falam sobre algum assalto, sabe... não sei se as pessoas entendem o real significado do que é um suicídio. Eu mesmo antes de acontecer comigo, por exemplo, mesmo se eu visse em um filme ou na reportagem, ou em qualquer lugar assim "vulgar", eu achava que não... O real significado do suicídio...

P4: Não tocava dessa maneira...

P10: É, como se fosse algo "alguém morreu", sei lá.

P3: Como tudo de ruim nessa vida, a gente 


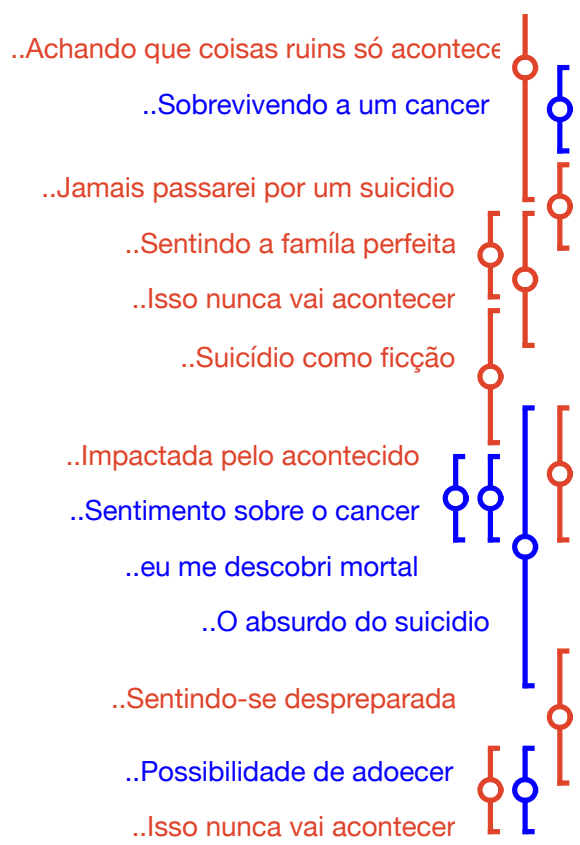

..Tendo uma percepcao sobre o sı
...Mudando a percepção sobre o s
... Imaginando que o suicídio talvez pode acontecer comigo
..Isso nunca vai acontecer

.. absurdo do suicidio

\$ 63

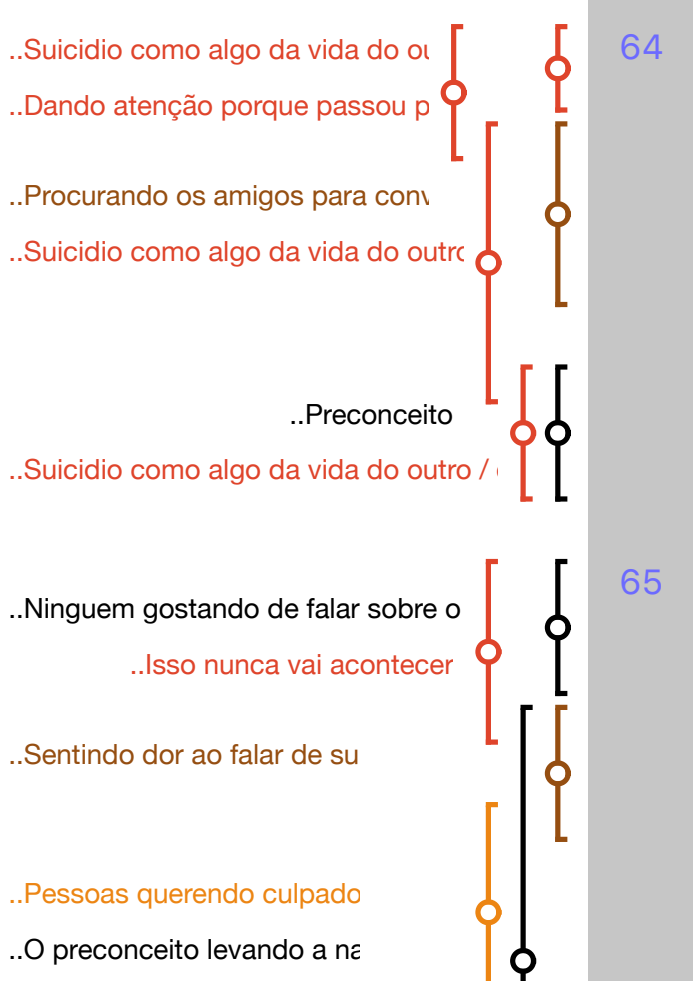

acha que com a gente não vai acontecer, sempre com os outros. Eu por exemplo, eu tive um câncer e achava "imagine comigo não vai acontecer" ... ter um suicídio na família jamais... minha família é tão bem estruturada, tudo lindo maravilhoso, isso nunca vai acontecer. Então você vê um filme você fala "é uma ficção, não existe na vida real, comigo jamais vai acontecer". Até que a hora que acontece, que você... eu me descobri mortal, eu me descobri a coisa mais absurda que poderia ter acontecido na minha vida seria um suicídio, e, no entanto, aconteceu ... e hoje em dia.... não está preparada nunca pra que uma coisa dessas aconteça, doença até a gente sabe que pode acontecer, mas suicídio... Nunca!

P9: a minha percepção de suicídio, que acho que eu tinha e que eu mudei depois é.... que eu passei ao conversar com as pessoas é que eu acho que a maioria enxerga como algo que não tem nada a ver com a própria realidade... é como se assim, por exemplo, um assalto até, a maioria das pessoas "um dia pode acontecer comigo", mas um suicídio... é assim... eu

P3: é que é tão absurdo que...

P9: é assim, é assunto que não tem nada a ver comigo, a maioria pensa assim, acho que em parte.... eu também pensava, né. Então a minha vivência depois até que eu fui conversar com as pessoas né, procurar ajuda pra me abrir com os amigos, tal, é como se pra eles isso é uma realidade que não tem nada a ver com eles. E aí o tratamento é com esse, um tabu, um preconceito de algo bem distante assim...

P11: não é distância né, eu acho que ninguém gosta de falar nem quem não passou por isso né, então acha que nunca vai acontecer, não precisa falar, e quem passou também eu vejo que é muito dolorido falar então, por ter um preconceito também, por ser uma coisa que parece que as pessoas querem achar um culpado, querem achar 


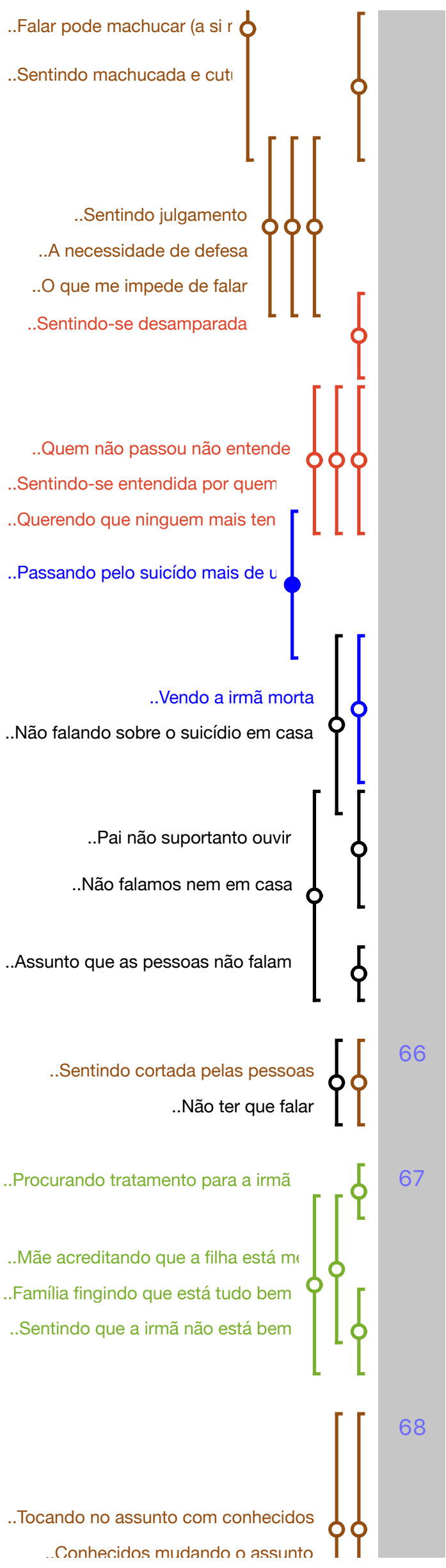

um motivo, tem que ter uma razão né, então quanto mais você fala, mais vão te cutucar, mais vão te machucar, mais vão né, as vezes sem querer mesmo né, mas acabam te deixando mal. "Ah, mas então ninguém percebeu..." Se tivesse percebido, não teria acontecido, né se tivesse percebido a gente teria feito alguma coisa pra evitar. Então assim, é as vezes a gente não fala por conta disso também entendeu? Por....pra evitar, porque parece que ninguém tem como ajudar né, só quem passou mesmo é que te entende. Quem não passou não entende, e nunca vai entender, graças a Deus por isso também, porque eu acho que é uma dor que ... só quem viveu mesmo que sabe o que significa né, e eu tenho assim mesmo na minha família o meu sobrinho que se matou, a minha irmã que já tinha tentado se matar várias vezes e depois que ele se matou ela tentou mais duas vezes né, uma agora em fevereiro e ela, eu realmente vi minha irmã morta assim na minha frente, porque ela tomou um remédio pra pressão, então quase que parou o coração dela, mas a gente não fala mais nada. É como se ela não tivesse feito isso nem dentro da minha casa, que a gente perdeu já o nosso sobrinho, quer dizer, meu pai não suporta ouvir é, minha mãe evita, finge que tá tudo bem, então a gente segue assim... né é um assunto assim que as pessoas não falam.

P1: quando você tem a oportunidade de falar né, as pessoas já cortam logo o assunto pra não ter que falar...

P11: sim, eu procurei a Karen, eu pedi, ela me indicou tratamento e tudo, quer dizer, aí minha mãe levou ela numa psiquiatra que mudou o remédio dela e ela foi fazer um curso, então tá tudo bem porque então ela tá bem, ela tá fazendo um curso. Não, ela não tá bem, né

P1:ela está falando assim, em termos, de um modo geral, quando se toca no assunto, que aconteceu com a sua filha, com o seu filho, o seu neto, seu familiar, para um amigo e você 


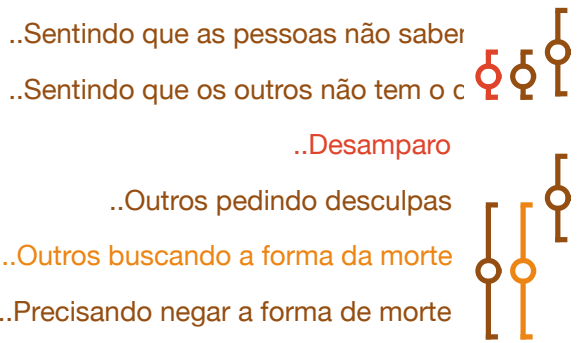

..Tomando a postura de não negar a for ..Falando que foi por acidente

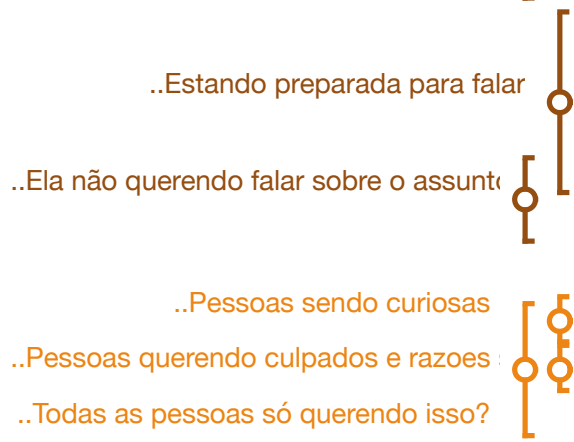

74
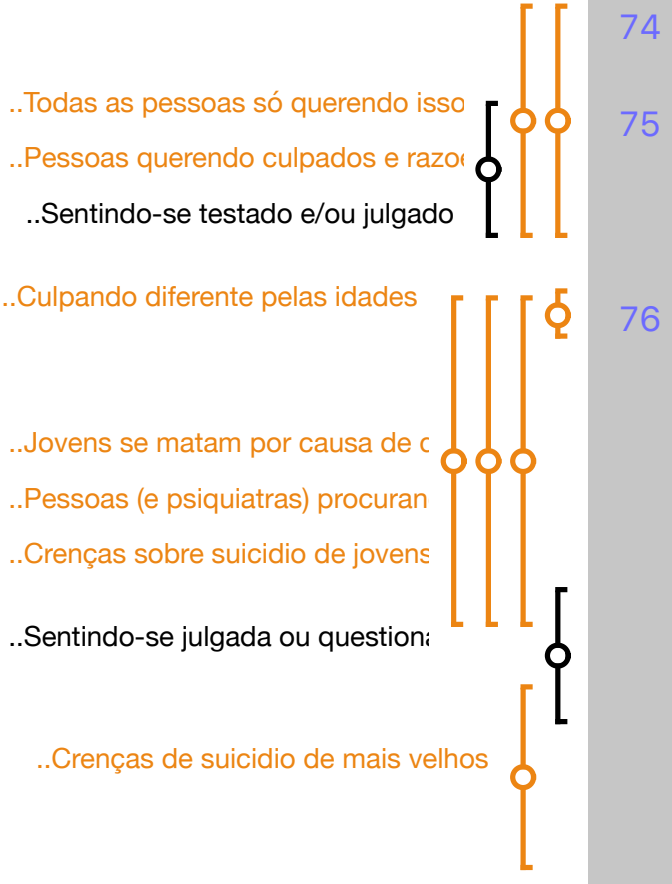

.Psiquiatras tendo o mesmo julgamentc

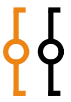

77

Psiquiatras buscando causa unica?

..Psiquiatras tendo o mesmo julgament،

Psiquiatras buscando causa unica? percebe que ele começa a mudar de assunto né, pra não ter que mais falar sobre o assunto...

P3: é, porque as pessoas também não sabem o que falar. Não tem o que falar.

P4: Uns pedem desculpas eu já me peguei....quando falam assim, ainda mais por ser jovem acham... foi acidente? Aí se você fala que não, que agora eu ...

\section{P1: Exatamente}

P4: tomei a postura de já não, no começo eu tinha até de falar que era acidente, mas agora eu tomei a postura de falar... "aí desculpa", não, eu prefiro que fale... aí eu já entro porque agora também eu já estou mais preparada, porque teve uma época que eu também não queria falar né.

P5: as pessoas vinham falar por curiosidade, prasaber um porque e achar um culpado... toda pessoa...

E: pra achar um culpado...

P5: é, toda pergunta de qualquer pessoa é no fundo ela está querendo, quem não passou por isso tá...

P4: eu acho que têm idades né, então assim no meu caso, jovem, das questões ... drogas, acho que é uma das primeiras, que estava usando droga, ahh ... embora às vezes até se estivesse poderia já ser o fato da depressão mas isso eu vim aprender depois, então assim, primeiro é droga, segundo é que você, então se não era, como você não percebeu se era depressão, acho que quando a pessoa vai mais velha, questiona-se se tinha uma doença grave, se tinha uma amante, que foi um amor, uma amante, a mulher...

P3: o psiquiatra perguntou pra mim a primeira coisa "a amante?".

P5: Ou perdeu o dinheiro, 


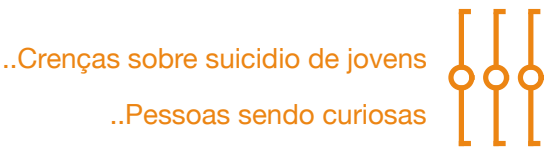

..Pessoas (e psiquiatras) procurando

Crenças sobre suicidio de jovens

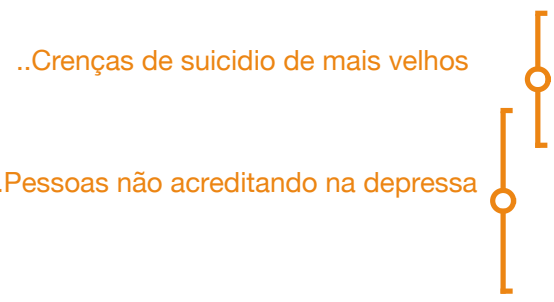

..Pessoas buscando justificativa para dep

..Pessoas buscando justificativa para depr

Pessoas buscando justificativa para $d \mathfrak{d}$

Sentindo que depressao nao se explic

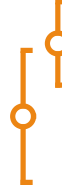

87

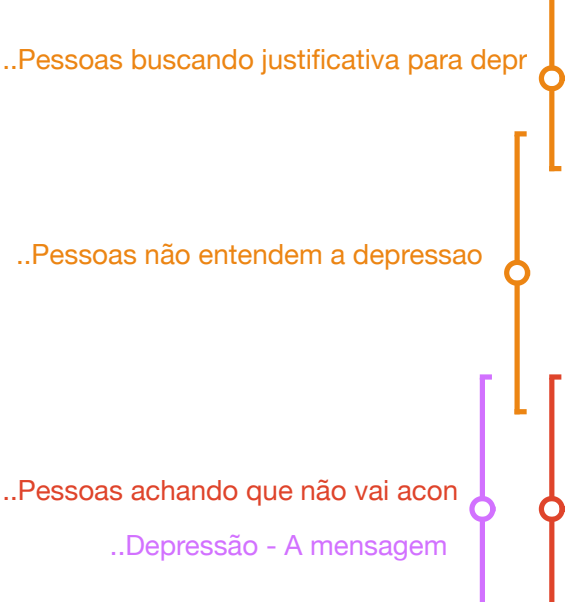

P3: o psiquiatra

P4: Ou se é pessoa mais velha, se está sem dinheiro, então assim, eles já vêm com aquela forma pronta.

E: é visto de uma forma simplista

P4: é, pra jovem eu acho que é a primeira pergunta "está usando droga?" "Se meteu com quem não devia?"

P1: com amigos, coisa assim...

P4: é então e aí quando passa de uma certa idade você ouve as outras perguntas, então acho que as pessoas têm... e aí não querem ouvir depressão ainda fica no sentido assim, eu já vi caras de pessoas assim tipo "nossa essa mãe está se enganando"

P8: quando é mesmo uma depressão as pessoas têm que achar uma justificativa.

P4: quem não tem nada né,

P8: porque ela a pessoa tem uma depressão, se ela tem uma condição tal e tal e depressão é uma coisa que você não explica necessariamente

P4: pro meu próprio filho eu fazia essa pergunta né, o que ele tinha? que ele não tinha motivo, e então ele falava o que eu tenho?

P8: as coisas têm que ter motivo, eu acho que é essa coisa de todo mundo tentar encaixar um pouco um conjunto de respostas... é e disso ser visto assim, como as pessoas não entendem elas têm que trabalhar com esse repertório que elas têm que é limitado e fica encaixando dentro dessa, dessa lista de coisas o que elas acham, então... acho queainda as pessoas ficam têm essa coisa de "não vai acontecer comigo porque eu estou bem, minha vida é ótima", e então mais a vida pode ser ótima e 


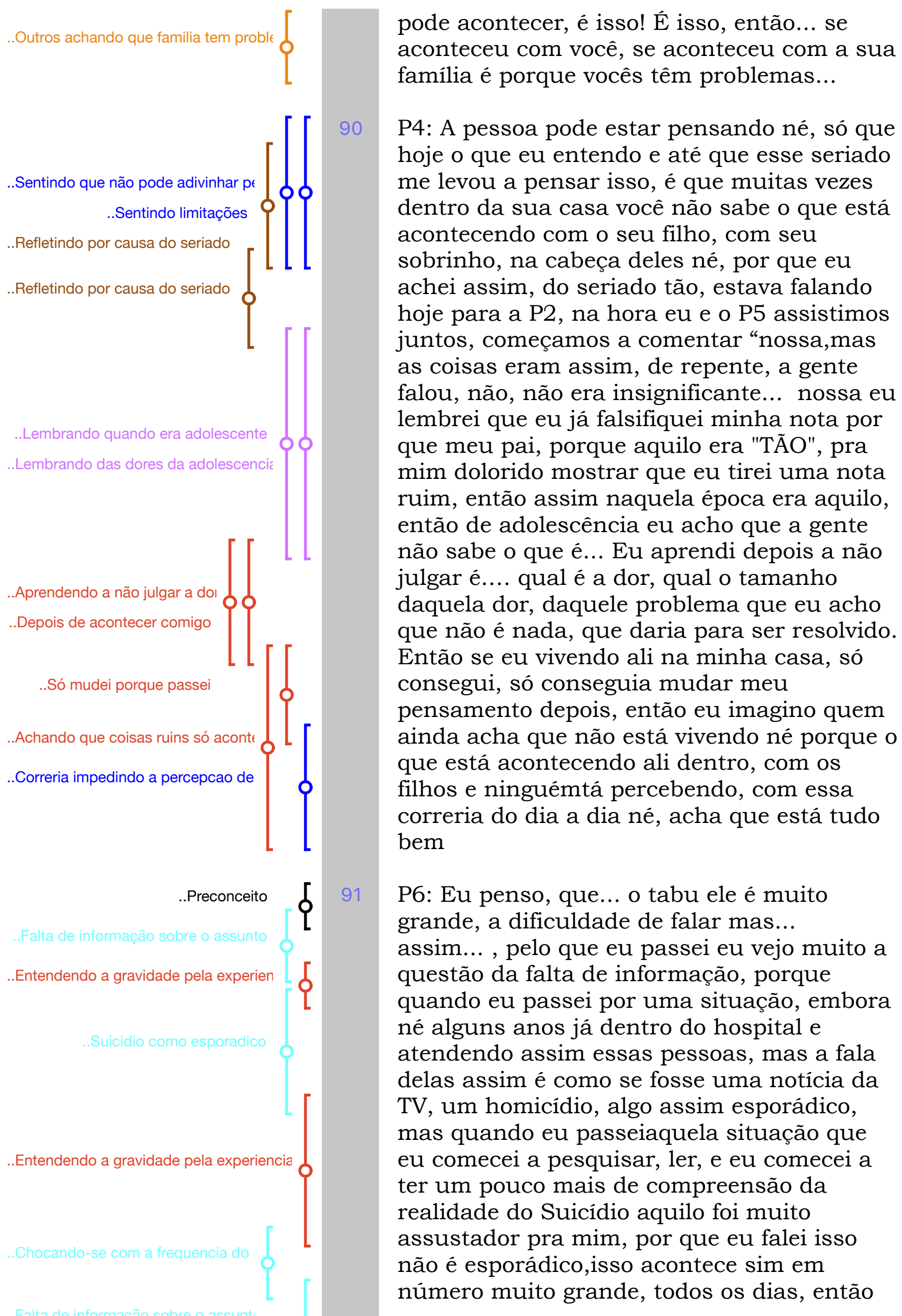




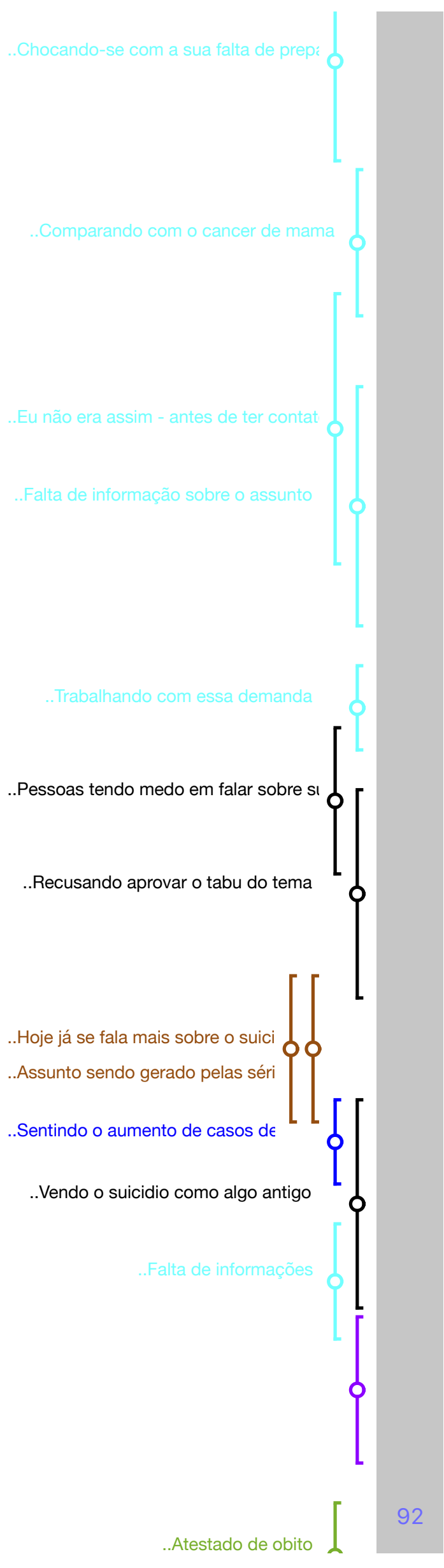

éaí eu comecei a pensar o quanto eu tinha pouca informação, o quanto eu estava tanto tempo dentro de um hospital, atendendo essas pessoas, mas sem ter o conhecimento da realidade e da problemática mesmo né, porque assim, hoje a gente ouve falar muito da prevenção do câncer de mama, por exemplo, se de repente eu sentir alguma coisa pra mim vai ser normal ir ao ginecologista e pedir um exame e talvez se eu tivesse mais conhecimento também me ligaria muito mais, sei lá... nos sinais, nos fatores então hoje que eu estudei um pouco mais que eu tenho buscado cada vez mais, quando a pessoa tem alguma fala perto de mim né, ou da minha família ou não, eu já fico mais esperta, mas eu sei que a um tempo atrás não era assim, então eu ligo muito essa questão com a falta de informação, nós não temos informações, ninguém quer falar realmente sobre isso, não é comum né e assim, até por estar mais próxima disso hoje, de trabalhar com essa demanda hoje, é isso incomoda as pessoas, elas não querem falar sobre isso né, elas não, as pessoas elas me pedem palestras e falam assim "olha eu quero palestra, mas não é pra falar sobre Suicídio", né então, esses dias no hospital o cara me chamou e falou isso, e eu falei "olha, mas não dá, como vamos fazer prevenção do Suicídio sem falar do Suicídio", então é eu percebo essa dificuldade, embora estejam né falando muito mais sobre isso às séries tudo que a gente tem visto aí, os acontecimentos, as pessoas estão falando muito maismas isso é uma coisa que acontece a muitos anos nessa proporção e só tem aumentado, não é nada novo, esses dias eu até falei para uma pessoa "olha o Suicídio não é algo novo, a Bíblia já tem relatos de Suicídio é algo que acontece a muito tempo" mas nós não temos informações e nunca tivemos né, eu creio que isso tá aumentando e eu tenho esperança que isso seja tão comum como hoje é falado da prevenção do câncer de mama, próstata, enfim...

P11: E é distorcido também porque eu vi é, 


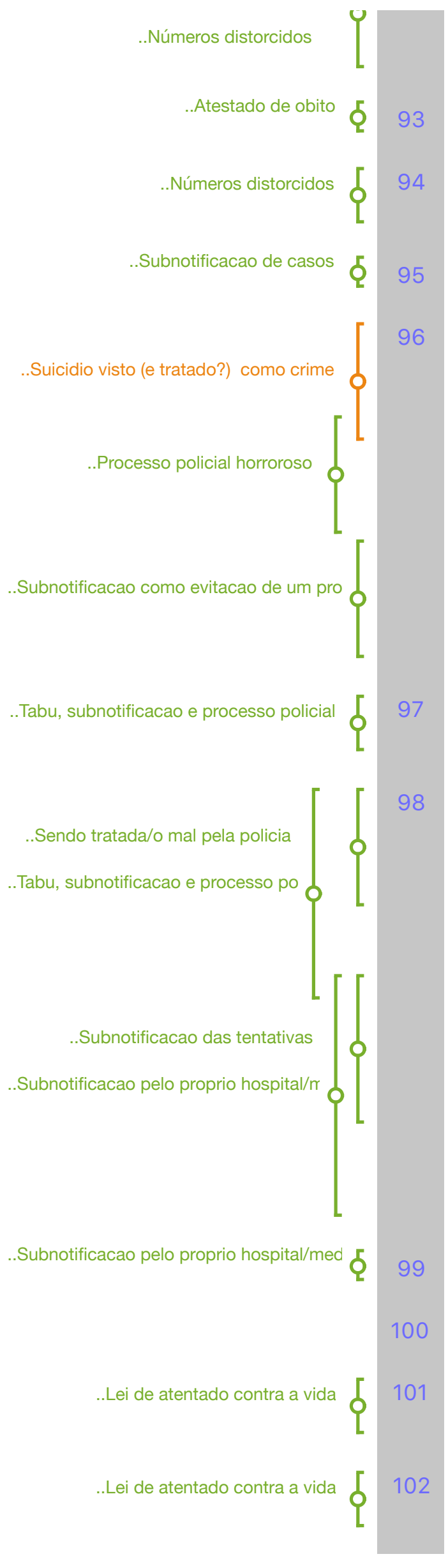

no atestado de óbito do meu sobrinho não saiu né...

P7: No da minha filha também não

P11: Então assim, são quantos e quantos e quantos né, que não são né contabilizados.

P7: É subnotificado.

P8: Mas acho que o grande problema disso que eu vejo é que a questão de que o Suicídio é que ele ainda é uma de espécie de um crime, é você, é muita gente, você além do Suicídio, você tem que passar por polícia dentro da sua casa, existe um processo horroroso dentro de tudo isso, então eu acho que também tem muito subnotificação, por questão de às vezes um médico ou o que quer que seja tentando evitar, então por que é um processo também muito doloroso,

P11: Então, se não fosse tabu e se não tivesse toda essa questão...

P8: Claro, mas só que a polícia trata isso de uma forma que é uma coisahorrorosa, aí tivemos que dar depoimento e você vai numa delegacia e eles não te tratam bem, então isso tem também um questão meio complicada que eu acho que é uma tentativa complicada por conta desse tabu, mas por exemplo o meu outro irmão que não morreu, ele já tentou Suicídio 3 vezes, e nenhuma das vezes estava notificado como tentativa de suicídio, porque se não ele ia ter que passar por um processo e o médico falou "ele vai ter que passar por um processo, por uma investigação, por um... o hospital não dá...

P5: É isso.... Eu sou médico tá,

P8: Então...

P5: isso é uma lei, você tem que notificar polícia que é atentado contra a vida,

P8: Porque é atentado contra avida, e como é que você fica passando por isso né... 


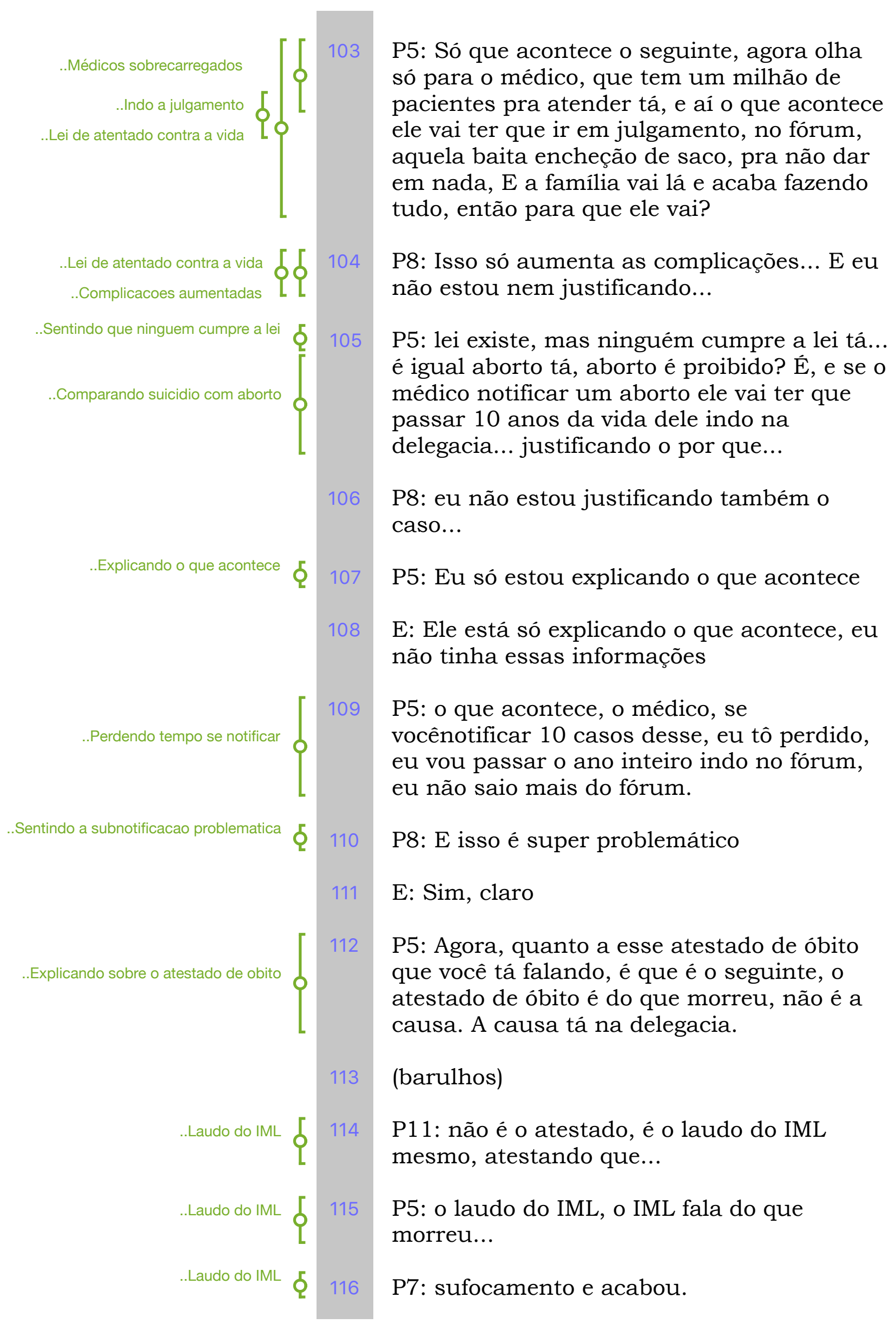




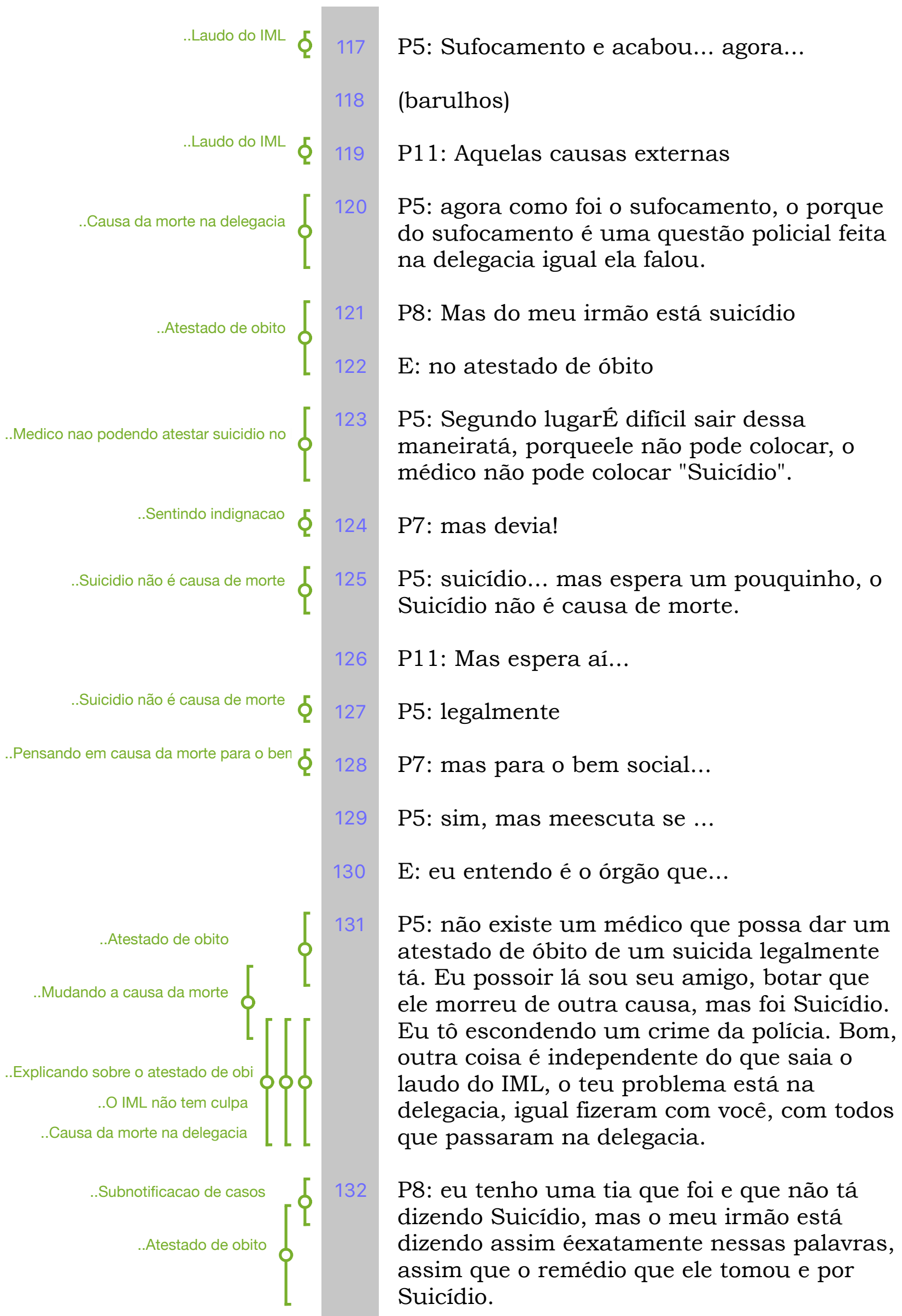




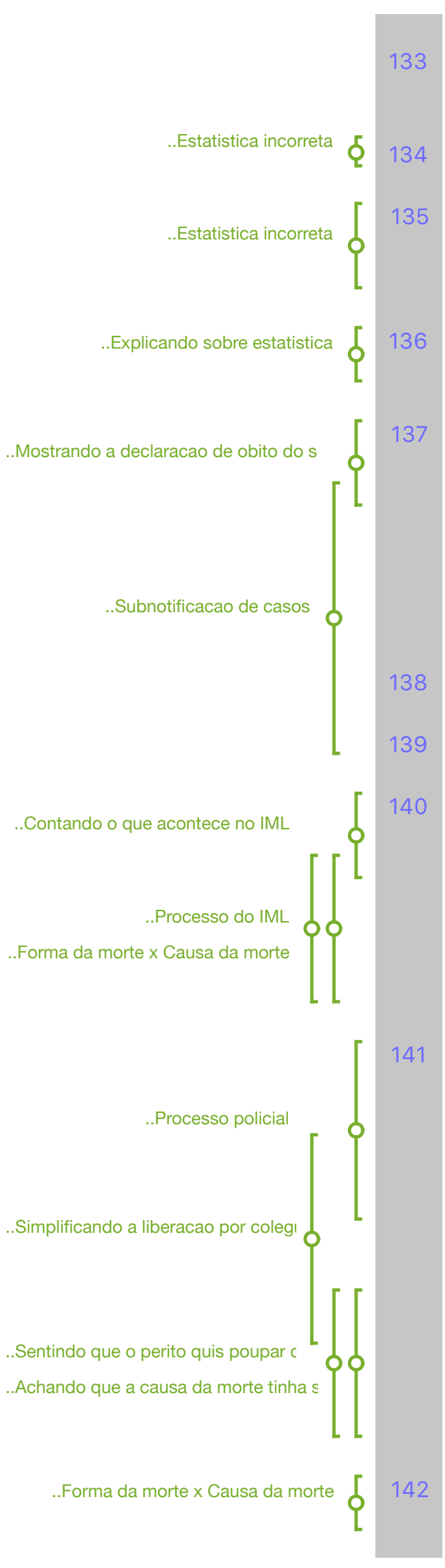

E: quer dizer a gente está falando que além de um problema de falar de um assunto...

P8: você não tem nem uma estatística

E: a gente está falando que não temos uma estatística correta porque não é notificado da forma como deveria.

P5: mas essa estatística é feita no IML junto com a polícia tá.

P11: então, mas olha aqui. Declaração de óbito, que é justamente do serviço funerário lá do município. Aí tem um campo aqui que diz "causas externas", aí tá "prováveis circunstâncias de morte não natural", aí tem o tipo "acidente, Suicídio, homicídio, outros e ignorado", ele está como ignorado.

P5: porque

P8: mas tá provado

P5: por favor, deixa eu te contar o que acontece no IML, eu trabalho no IML tá, deixa eu te contar o que acontece...o corpo chega lá, como é que eu posso falar que ele estava amarrado em uma corda? Eu posso colocar que tem lesões no pescoço indicando que parecia enforcamento por corda.

P7: doutor, no meu caso antes do corpo da minha filha sair de casa veio a polícia científica, polícia técnica e eles fotografaram e tal e depois levaram pra aquele caixão de zinco que foi pro IML e foi liberado no dia seguinte só que eu sei que operito ele quando ele soube que eu era um oficial de justiça eu sei que tudo ficou simplificado e a liberação do corpo, e saiu como sufocamento, e eu entendi que ele no intuito da mente dele de me poupar, do desgosto de estar a nomenclatura "Suicídio" ele colocou sufocamento. Agora eu estou entendendo...

P5: o certo é ele colocar sufocamento e não suicídio. 


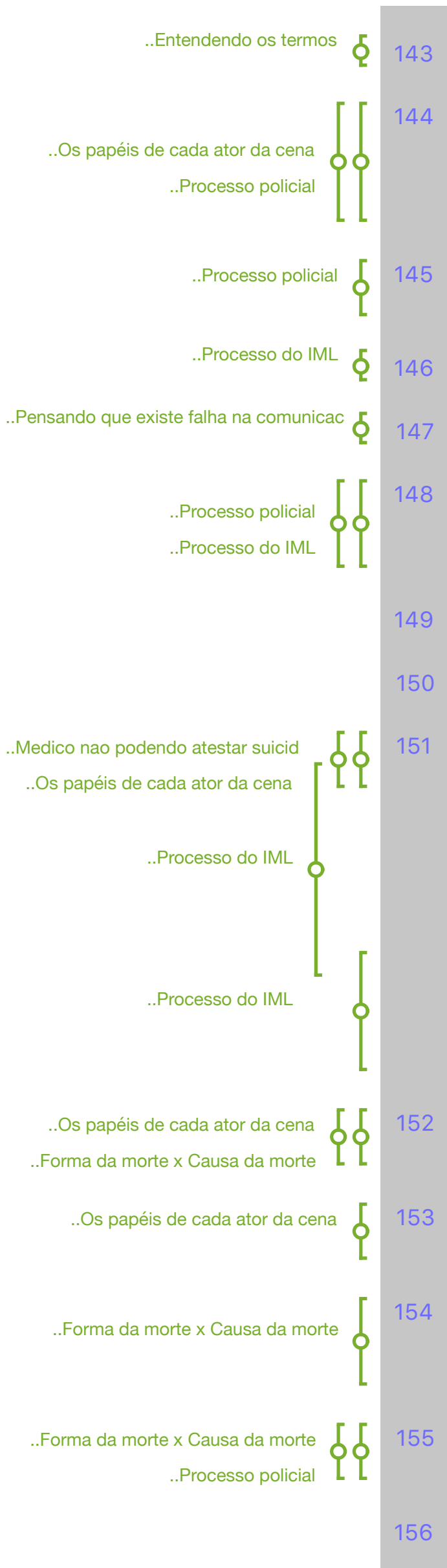

P7: agora eu estou entendendo.

P5: Eu não sei do que a pessoa, como é que a pessoa, qual é a técnica lá na sua casa vê uma pessoalá... e fotografa... e tudo aquela coisa...

P7: mas eles sabiam que foi por suicídio... porque foi fotografado.

P5: mas isso não vai pro médico,

E: mas não tem uma falha de comunicação?

P5: não, isso não vai para o médico, vai para a polícia científica na polícia, feito pelo policial... pro médico chega o corpo lá,

E: tá

P1: só as evidências...

P5: é só o que eu estou vendo no corpo, eu não posso supor nada. Não tenho que colocar lá "tá grávida" ou não tá grávida, se é mulher você tem que fazer exame ginecológico, independente de qualquer coisa, se houve estupro ou não houve estupro, independente do que foi a causa da morte. Tudo isso você tem que averiguar no corpo, mas eu não posso colocar opinião minha "ah, eu acho que foi por isso aquilo lá..."

E: isso quem vai determinar é a polícia depois de uma investigação

P5: aí quem vai investigar essa outra parte é a equipe científica junto com a polícia.

P10: Até porque quem sufocou você não sabe se foi a pessoa mesmo ou outra pessoa, se foi...

P5: Sim, por isso que você toma parte da delegacia.

P8: No caso do meu irmão... 


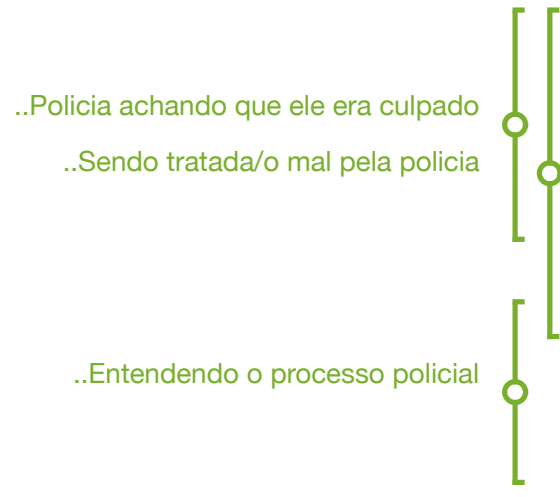

Entendendo o processo policial

Entendendo o processo policial Sendo tratada/o mal pela policia
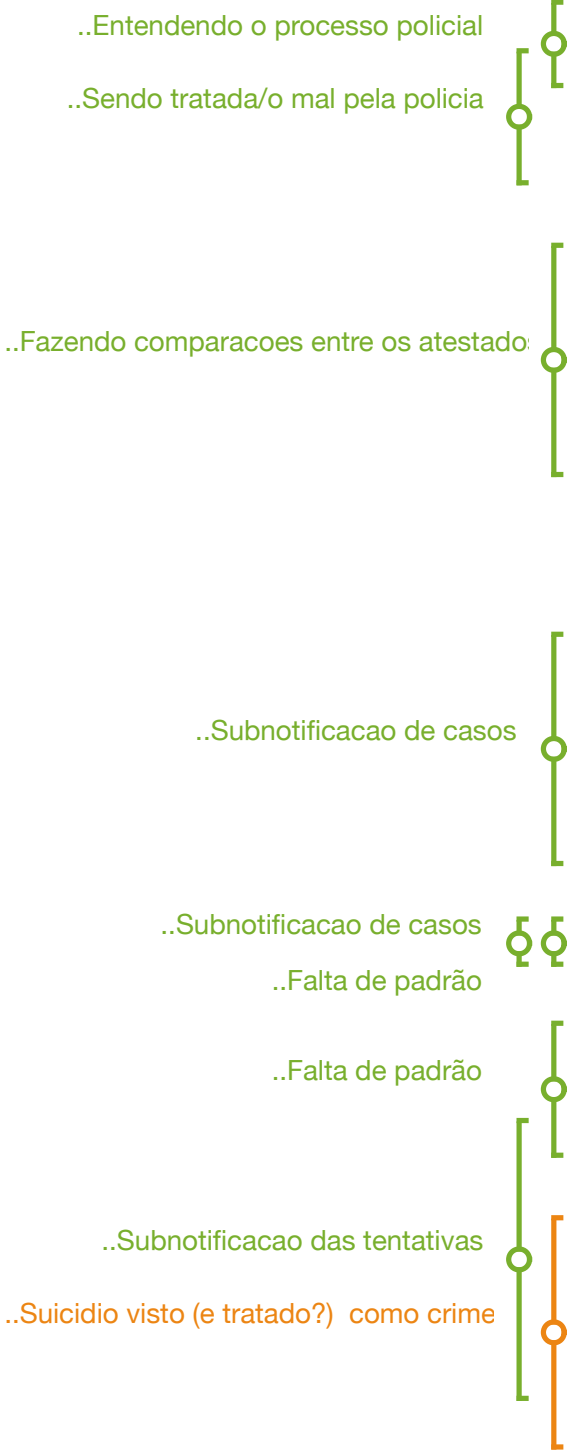

P5: Eu fui maltratado na delegacia

P8: Não, eu não, meus pais......

P5: Eu fui... porque eles acharam que eu era o culpado, talvez... então eles foram para cima de mim... me apertaram, fizeram um monte de pergunta, um monte de encheção de saco... quiseram ouvir ela sozinha, pra saber se ele tinha problemas comigo, se eu brigava com ele..., mas escuta, eu tenho que entender, mas é óbvio, o cara não me conhece. O cara nunca me viu, não sabe quem eu sou,

\section{P7: Ossos do ofício}

P5: ele tem... o delegado tem que fazer a parte dele. Nós fomos ouvidos separadamente. E foram muito grossos comigo e com ela.

P8: é, no caso eu acho que f colocaram no atestado de óbito que o meu irmão ele deixou tudo muito explicado, ele colocou a dose, ele colocou tudo assim, bem explicadinho

E: pra não dar dúvida,

P8: Pra não dar dúvida tal, mas eu acho que é essa a questão, só meio pra tentar estar dentro né, eu acho que o grande problema da subnotificação é isso, é não ter aonde isso tá,

E: não ter um padrão...

P8: não ter um padrão de como isso é registrado, se é no atestado de óbito, se é num lugar, se éno outro, os próprios... as próprias tentativas do suicídio que também não são notificadas, por causa de... e eu acho que todo esse problema também por ser um crime, é acaba tornando isso um tabu ainda maior. Piora o tratamento das pessoas que precisam de ajuda. 


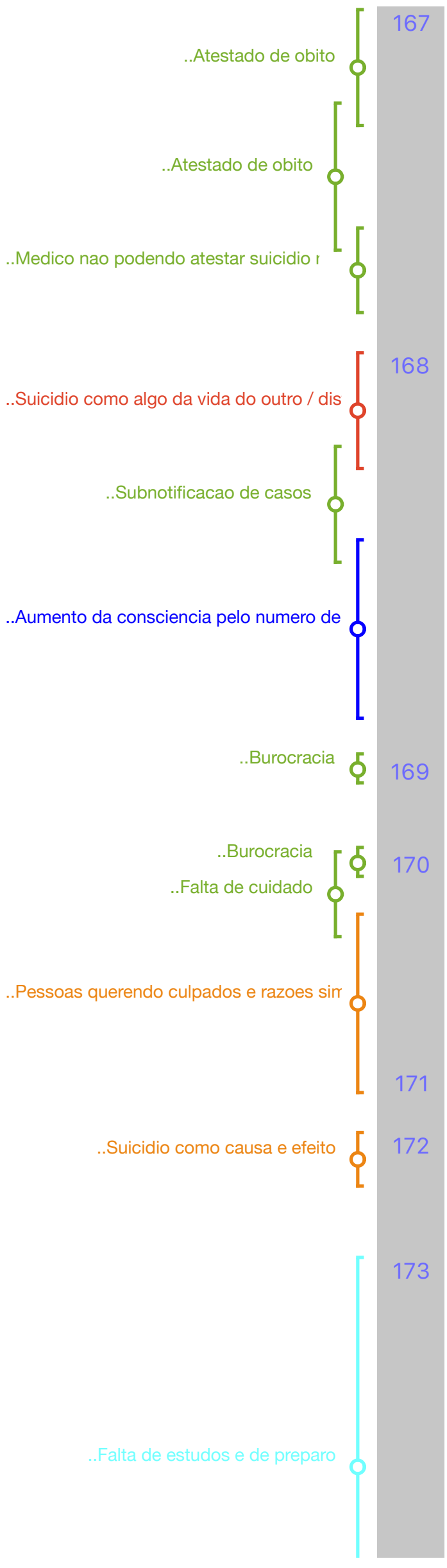

P5: só poderia colocar suicídio no atestado de óbito, botar assim como queira, pelo seguinte... pelos dados do atestado de óbito ele precisa colocar do ele morreu. Aí quando vem os outros 30, 40 dias depois vem a dosagem de sangue, se tinha álcool, se tinha droga... foi aí que comprovou se teu irmão tomou remédio ou não, ou que seja. Antes disso, o médico foi contratado só praenterrar, ele não tem, ele não sabe disso.

E: então olha a gente esta falando que o suicídio não é visto, quando ele é visto, ele é visto como algo alheio, longe da realidade de cada um. A gente está falando que o fato dos números não serem fidedignos também dificulta que ele seja visto por essa sociedade com a quantidade que ele ocorre. Então a gente também pode pensar se a gente tivesse esses números, passasse esses números talvez aumentasse uma consciência, quando as pessoas percebessem o número de casos, né.

\section{P7: A burocracia}

E: Tem a burocracia que atrapalha, tem uma falta de cuidado das pessoas ao lidar com o tema, e a gente está falando também que... tende-se a procurar um culpado. Ou a droga, ou é a falência financeira ou é a família ou

\section{P11: N motivos}

E: os profissionais... então tende-se a olhar o suicídio como um causa e efeito. É mais ou menos isso que a gente tá conversando?

P10: então, mas eu acho que tem também a questão dos estudos e do preparo dos profissionais, nas diferentes áreas que entram no contexto. Que por exemplo, pelo que eu saiba não fala sobre suicídio, por exemplo, num curso de psicologia, na medicina, etc, etc... ou por exemplo, mesmoprospoliciais, eu imagino assim nem eles têm a informação teoricamente de uma 


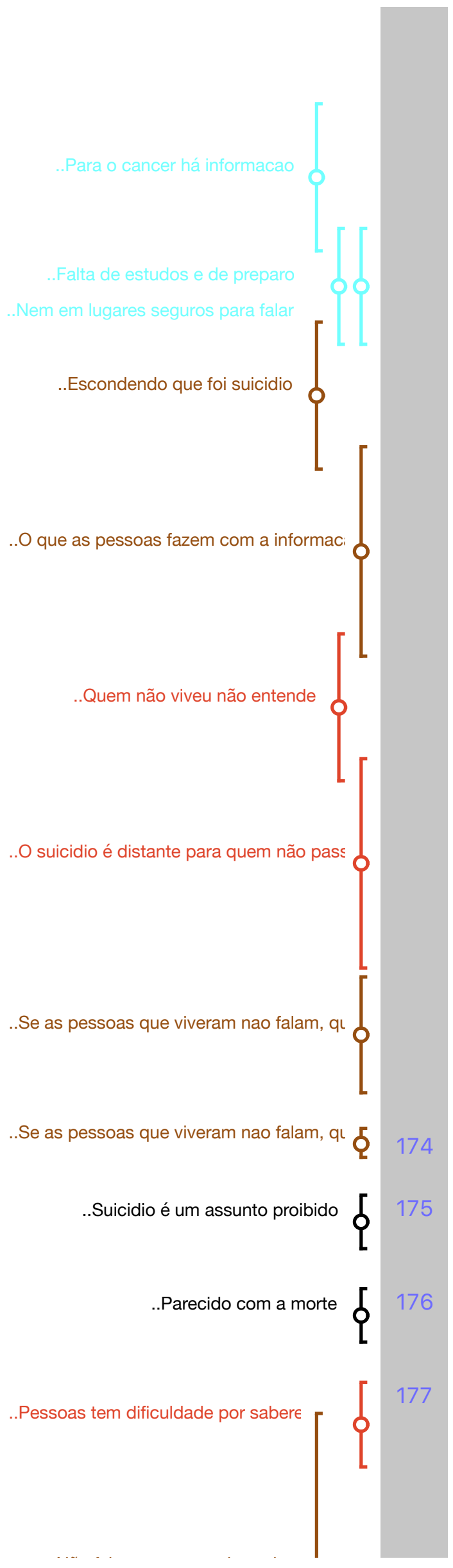

forma mais né científica, estruturada, com mais estudos, como que eles vão às vezes autuar nos seus ambientes aonde esse assunto surge mais, por exemplo a questão do câncer, cada vez mais foi estudado, as pessoas vão atrás entendeu... eles se especializam nesse tema, então eles estão mais preparados pra lidar com isso, mas por exemplo o suicídio se ele não é nem abordado nesses ambientes que são seguros, confiáveis, imagina no resto. E para mim continua essa questão, de que eu acho que, que nem, uma vez, é que eu não falo né que meu irmão se suicidou, então eu não vivi muitas situações, mas quando eu vi uma menina falando... tipo, as pessoas não fizeram nada com aquela informação eu fiquei: falei, putz, será que depois alguém vai vir falar pra mim "nossa, P10 viu a Irma Dela se suicidou" Ninguém fez nada com aquela informação, então eu não sei se é porque, é que nem como se fosse qualquer outra coisa porque a pessoa não entende $o$ quão grande é aquilo, e aí eles nem comentam nada. Por um lado eu fiquei contente deles não terem comentado no sentido de tipo "aí credo então a família Dela" que eles não julgaram, mas também não falaram nada então mostra talvez que a percepção é de algo distante né, algo que sei lá... tipo que não é faz parte da realidade. $\mathrm{E}$ aí eu não sei ... Ainda mais as pessoas que viveram isso, igual eu... não falam em menos lugares isso vai ser abordado e talvez é discutido ou não sei

\section{P4: vai continuar a ficar no fechado}

E: vocês acham que as pessoas percebem o suicídio como algo proibido de ser falado?

P4: Acho que igual a morte, não que a morte, não que a morte não...

P3: eu entendo que as pessoas têm muita dificuldade. Elas sabem a gravidade do assunto ... tem dificuldade em falar, que eles sabem que aquilo é tão doloroso pra quem tá passando, e ela não imagina que aquilo 


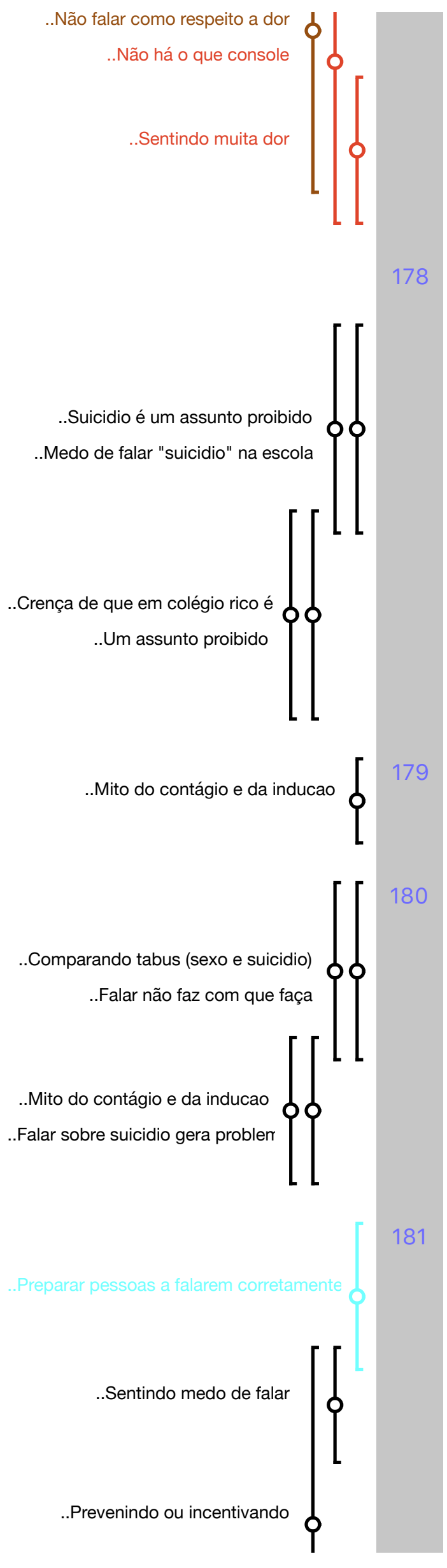

possa chegar até ela de tão doloroso que é, então as pessoas evitam de falar, porque não tem o que falar e sabem o quanto é doloroso, eu já entendo diferente aqui de todo mundo, eu acho que não falam porque, por pena, e porque sabem o quanto aquilo é doloroso. Não tem o que... nada que console.

P1: no caso que ela tava falando, no caso do meu... no colégio né... eu estava falando com a Karen tava falando no começo, a gente foi convidado pra dar uma palestra sobre a valorização da vida, prevenção do suicídio e a valorização da vida e tava tudo certo aí no dia anterior liga a professora pedindo pra não falar de suicídio na palestra. Porque os diretores não estavam concordando. Um colégio assim, de um nivel bem elevado... e começa que como eu vou fazer uma palestra sobre suicídio sem falar de suicídio? Não... você pode falar assim de outro jeito e tal ... mas você não pode falar... (risos), então fica difícil né, por causa disso, você fica...

P8: As pessoas acham que se você falar... que você está querendo estimular né. Que você está querendo induzir...

P1: antigamente não se falava em sexo né, na minha época em que eu fiz colégio eu tive aula né de educação sexual. A professora falava da camisinha tal e tal e isso não fazia com que a você saísse por aí né... a torto e a direita... (risos) eles falam que se a gente falar de suicídio como se fosse... quem está com algum tipo de problema... como se fosse incentivar as pessoas que tem algum tipo de problema.

P4: então eu acho que deveria começar, quer dizer..., acho que a discussão toda é essa, dentro do trabalho da Karen... é começar a preparar pessoas para falar de uma maneira correta. Porque eu acho que alinha muito... entre o ... você falar e despertar a curiosidade do adolescente para aquilo, eu tenho muito medo. Assim, se eu tivesse que falar eu não sei aonde seria a linha de você falar com prevenção pra que ele... chamar 


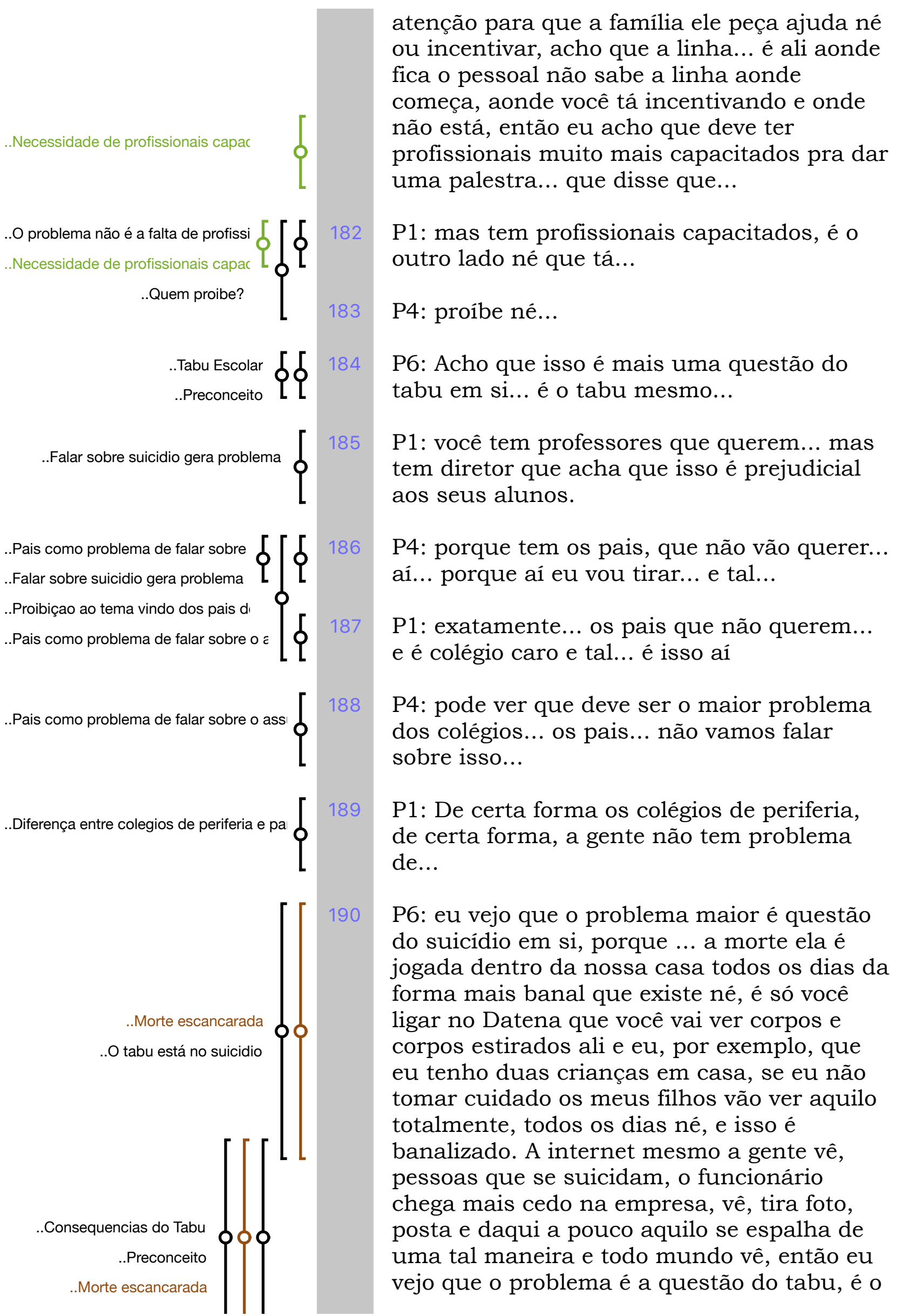


preconceito né?! É claro que tem que ter profissionais preparados pra falar de todos os assuntos, não só do suicídio, uma pessoa que não entende, se ela falar bobagem, falar besteira, é claro que aquilo não vai ser produtivo, mas eu vejo que assim a barreira mesmo, é a questão do suicídio né, não a morte, claro a morte, mas a questão é do tabu mesmo com a situação, com o tema...

P2: do absurdo a pessoa ter escolhido partir né

P10: mas gente, sabe o que eu acho, a gente tem que dar milhões de passos pra trás. Pra mim, suicídio é o nivel mais hard da humanidade. A gente não consegue acolher uma tristeza, quanto mais tipo um suicídio entendeu? Então eu acho que enquanto sabe não tiver educação base pra falar de tipo "sentimentos" que tipo um dia você está triste, você não pode falar que você tá triste, as pessoas, o mundo não consegue acolher os sentimentos ruins que acontecem na nossa vida. Então imagina acolher tudo aquilo que a pessoa, assim, que a pessoa que se suicida sente, e ainda o fato do suicídio depois pros que ficam. Então acho que antes do suicídio virar um tema, que a gente consiga conversar, eu acho que a humanidade tem que evoluir muito em coisas básicas sabe, tem uma base do ser humano que não está formada, que é de acolher assim, falar um oi tudo bem ou tipo de dar bom dia, tem gente que não dá bom dia....então eu acho que a gente não evoluiu assim em coisas que a gente não consegue acolher a tristeza. A gente não percebe os outros, a gente não consegue falar com essas pessoas, então assim, o suicídio pra mim é uma coisa complexa, a última fase sabe da escala, as pessoas têm que ser feliz hoje todos os dias. Essa coisa da felicidade, da busca da felicidade, que todo dia você tem que estar bem. Então assim, imagina falar de suicídio, isso aí... porque é um assunto superpesado, a gente não consegue falar da tristeza. Aquele filme do "Divertidamente", aquilo não fez sucesso, 


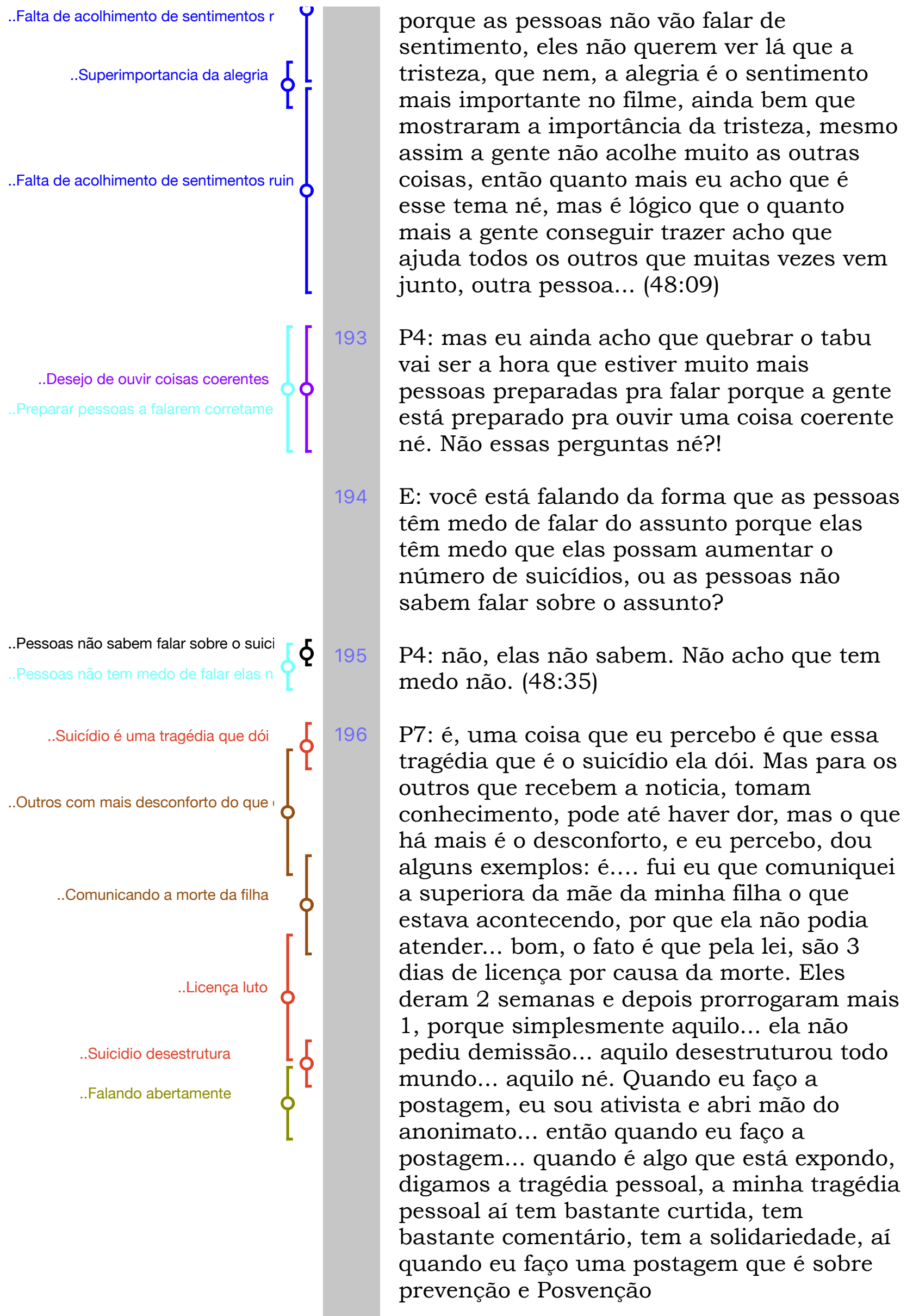




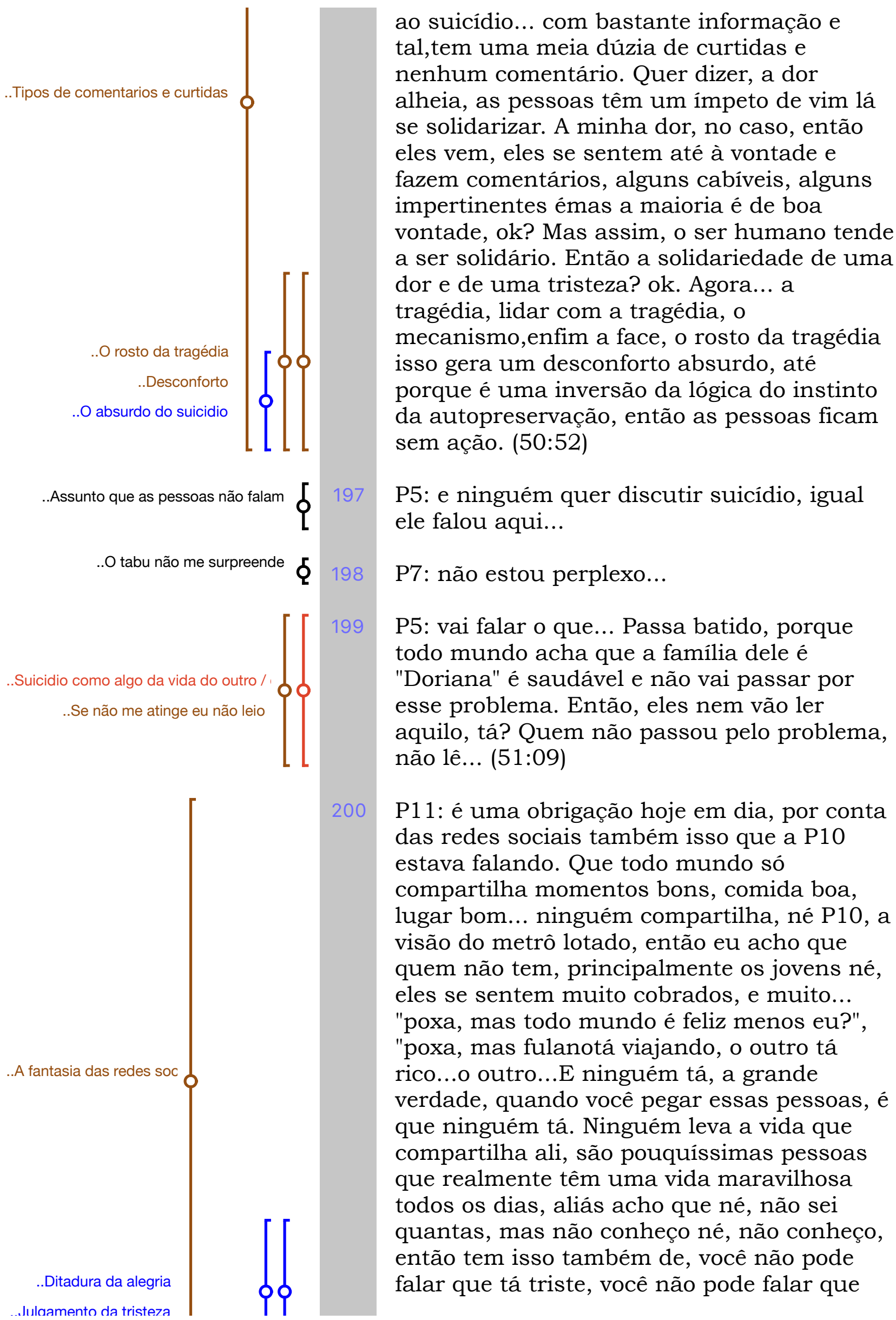




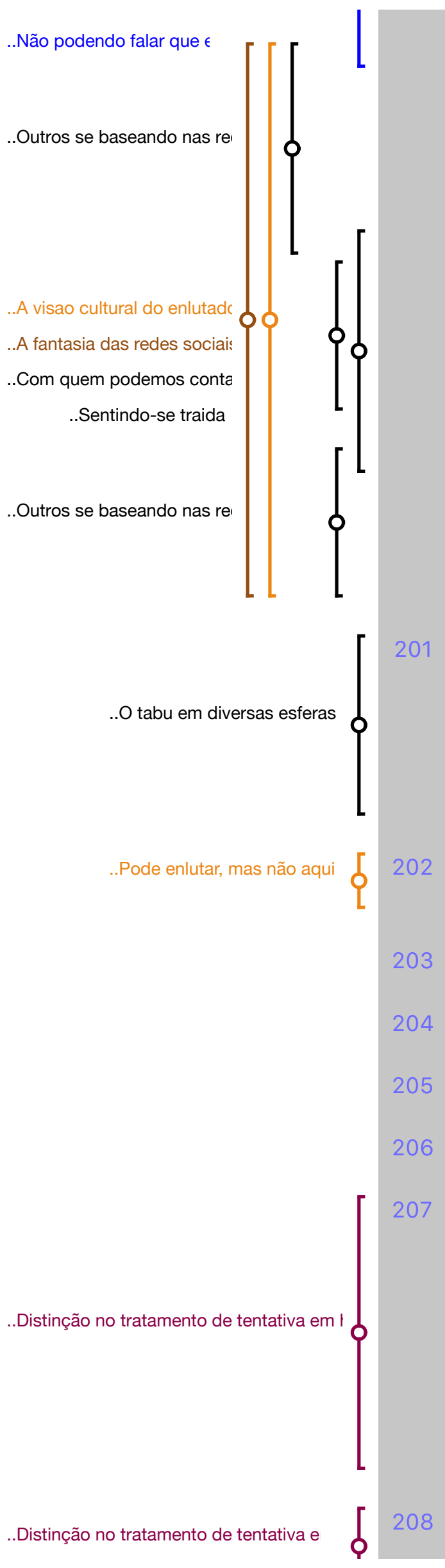

não tá legal, né, então, se você chorou você é fraco, e se você não está bem... eu fui demitida em janeiro e uma das coisas que usaram foram as minhas fotos, depois da morte do meu sobrinho. Só que eu conversei com o meu chefe e ele me autorizou a ficar em casa e aí ele depois se juntou lá e me mandou embora. Eu achei uma covardia, uma coisa assim, que você acha que pode contar com as pessoas mas você não pode. Você acha que estão te apoiando, quando na verdade estão criando, às vezes, alguma coisa pra usar contra você. Então isso pra mim foi terrivel... foi... eu achei muito cruel, entendeu? Podiam me mandar embora por qualquer outro motivo, mas por aquelas fotos...eu pedi férias e não me deu. Ele me mandou ficar em casa né, então... mas isso não é fato...

E: Então a gente pode falar que ...O tabu ele vai estar em várias esferas. Ele está na esfera pública, de quando a gente fala do assunto na mídia, tá na escola que não quer trabalhar o assunto, tá na empresa que não entende e quer que a pessoa trabalhe...

P11: esteja bem e produtiva... sendo que não tem como...

E: No hospital...

P6: nos hospitais e nos profissionais...

P4: Posso fazer uma pergunta pra ela?

E: pode! (53:23)

P4: Porque você passou agora com a sua irmã, não consumou então foi atendida no hospital, isso eu tava conversando com a P2 hoje, que era uma dúvida, que eu já ouvi de algumas pessoas. Perguntei e o P5 falou eu nunca vi distinção, mais aí eu não sei. Você notou que quem atendia a sua irmã fazia uma diferença, assim, se ela tivesse lá sendo atendida por câncer, uma dor?

P11: Com certeza, ela foi bem maltratada, 


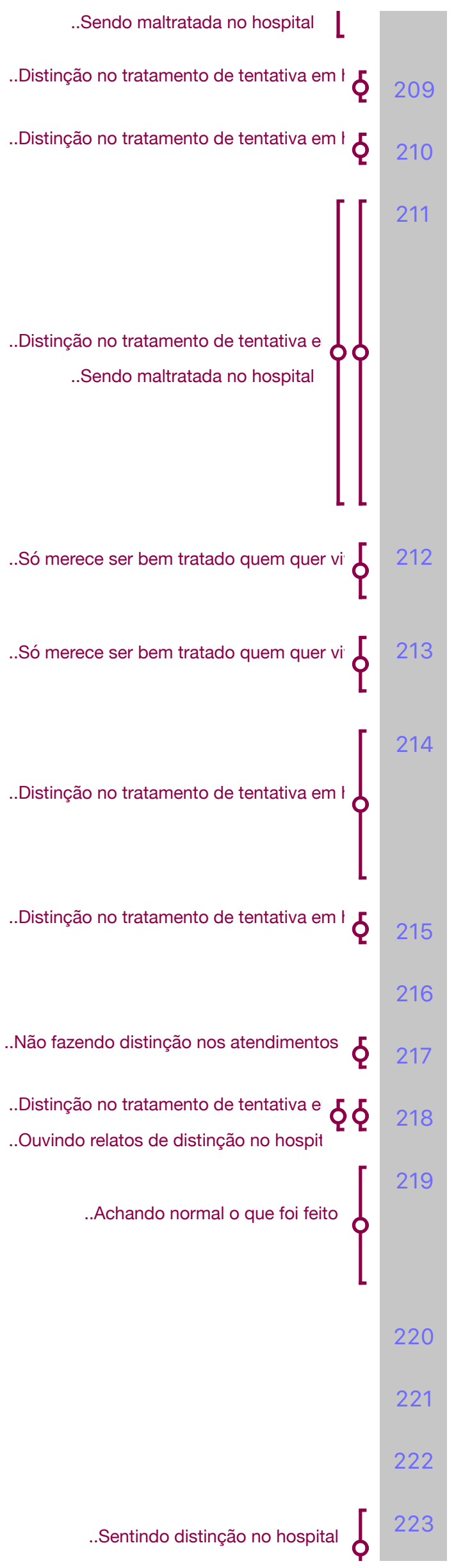

assim, a gente foi no (nome de um hospital)..

P4: Então, eu já ouvi muito isso.

P1: eu também já ouvi

P11: Ela tinha tomado uma caixa de remédios pra pressão do meu cunhado, então tinha que fazer uma lavagem com carvão, né, e as enfermeiras...eu nunca vi aquele tratamento lá no (nome de um hospital)... mas assim....Super grosseiras, ela passando mal, ela vomitando e elas lá, nem aí injetando... O médico saiu com cobertor pra ir dormir, largou ela lá... porque entendeu

P4: tipo assim, tem tanta gente aqui que precisa...

P11: é tipo... é, "se você quer morrer o problema é seu". (54:22)

P4:Eu já ouvi muito isso. Eu não passei porque meu filho não chegou a ser atendido. Mas hoje eu falei porque eu já tinha perguntado para o P5. Eu falei: Olha, fala a verdade pra mim, tem?

P11:Tem.

P4: Aỉ ele... ahhh...não, eu não tenho

P5: eu não tenho

P10: mas eu há ouvi também

P5: o que ela ta acabando de falar aí, é o tratamento normal...eles estavam tentando forçar ela, por essa sonda...a vomitar, ou botar para fora

(Todos falam ao mesmo tempo ????)

P11: É bom, cada um tem uma opinião

P4: mas eu já ouvi coisas...

P5: Estou falando sobre o que aconteceu no 
(nome de hospital) tá...

P10: A gente ouviu também... (54:55)

P5: É o seguinte, é que é um tratamento bruto mesmo. Você vai passar um cano dessa grossura pelo nariz da pessoa, pelo esôfago, vai colocar lá no estômago, quando vai passar na garganta a pessoa vai vomitar, vai ficar daquele jeito. Mas é o único meio de você lavar o estômago é colocar o carvão ativado. O carvão ativado lá dentro vai... o cartão ativado que você acabou de falar é pra que? É pra que o remédio não seja absorvido

Todos falam ao mesmo tempo. ?????

P2: mas não é procedimento, acho que é o olhar

P4: é o olhar, não é...

P5: e é um procedimento da enfermagem, não é do médico...

E: mas você acha que as enfermeiras tem com uma distinção?

P5: olha, eu nunca vi esse negocio. É o seguinte, quando você chega lá, quem tá em prioridade é que vai ser atendido? Quem mais tiver grave tá

E: mas você acha que a forma de tratar, na sua visão, ela é a mesma pra todos os casos?

P5: é a mesma pra todos os casos, não é diferente. (55:55)

E: na tua já é diferente, na tua experiência.... é diferente

P11: a minha mãe enfartando foi tratada de um jeito, e a minha irmã totalmente de outro. E eu mesma já fiquei internada lá varias vezes também, outro tipo de tratamento e outra coisa que aconteceu foi que a pressão dela foi baixando, foi 


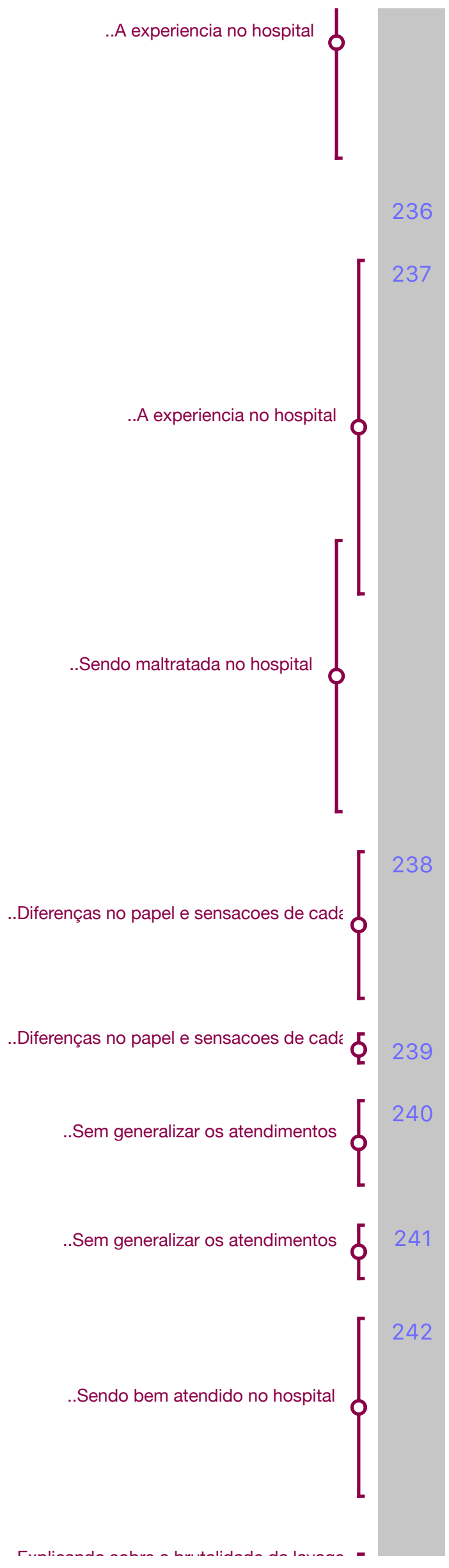

baixando, foi baixando muito, e tavaacho que 4 por 2, assim, uma coisa que tava parando, e eu toda hora ia falar: "Olha... a pressão dela." E elas: "Ah, não, a gente deu não sei o que lá e ela vai subir". (56:19)

P5: Acho que o soro, algo do tipo.

P11: "Ah, daqui a pouco sobe.Daqui a pouco sobe".E eu que tinha que ir lá: "Olha, ta baixando mais, tá baixando mais." Aí eles pegaram uma veia no outro braço, acho que a adrenalina, sei lá o que é que dá, né dr? Eu sei que na hora que eles deram, ela subiu, ela ficou roxa, assim, o peito roxo, e ela: "Ai que eu vou morrer..." porque a pressão dela subiu de 4 por 2 pra 14, 15, sei lá. Subiu muito, muito rápido e ela gritando que ia morrer e eles continuavam. Eu falava: "Para, pelo amor de Deus". Aí eles pararam e aí viram que a pressão tinha subido muito realmente, mas ela, assim, foi uma questão disso daqui. Eles parecem que não acreditavam nela, no que ela falou: "Minha cabeça está explodindo, eu vou morrer", né, e continuaram. Então...

E: Talvez tenha uma diferença, aí, entre a forma como o enfermeiro vê o que ele tá fazendo, e a forma como a família sente que aquilo está sendo feito, a necessidade da família também. (57:16)

P5: É essa a diferença.

$\mathrm{E}$ : $\mathrm{E}$ também tem enfermeiros que não vão fazer distinção e enfermeiros que fazem distinção e vão tratar de formas diferentes.

P11: Com certeza a gente não pode generalizar nada $(57: 24)$

P1: É, eu não participei mas a minha filha de 15 anos, né, participou, porque eu não estava na cidade, estava em outra cidade, minha esposa estava vindo do trabalho, mas fui muito bem atendido, e fez todos aqueles processos embora um pouco assim... 
P5: É bruto...

P1: ela colocou na hora o tubo, tudo, tudo e na cabeça da minha filha, né, quer dizer, que é uma criança né, se fosse um adulto pode até ser que seria mais até mais, mas não, pelo menos foi bem feito o serviço, é, tanto que com um dia e meio de manhã (vendendo coco ???) mas não deu...

P5: quanto antes você fizer, mais rápido você fizer, mais você vai salvar. Então tem que ver... Na verdade eu vou te falar uma coisa,

E: Fala $* * * * *$

P5: só um minutinho... é de suicídio que você tá falando. Eu tô lá no pronto socorro e chega baleado um bandido e um policial. Não tem essa preferência. É o que estiver mais grave você vai atender.

P11: sim, acho que a questão não é essa, a gravidade e sim a forma como é tratado.

P5: na hora você não sabe o que é

E: Sim.

P5: É difícil você saber o que é na hora que entrou lá. (58:36)

P6: eu acho que a colocação dela é no sentido de não fazer distinção em quem atender, eu vejo que é no sentido de que você pode atender

P11: ... como atender.

P6: uma tentativa de suicídio de uma forma empática e acolhedora.

P11: ...sim, exatamente...

P6: E eu infelizmente já vi. Eu presenciei muito. (?) e isso acontece com muita frequência tá. Já trabalhei... esse hospital que eu trabalho hoje já é o 4o hospital que eu trabalho e por diversas vezes eu fui 


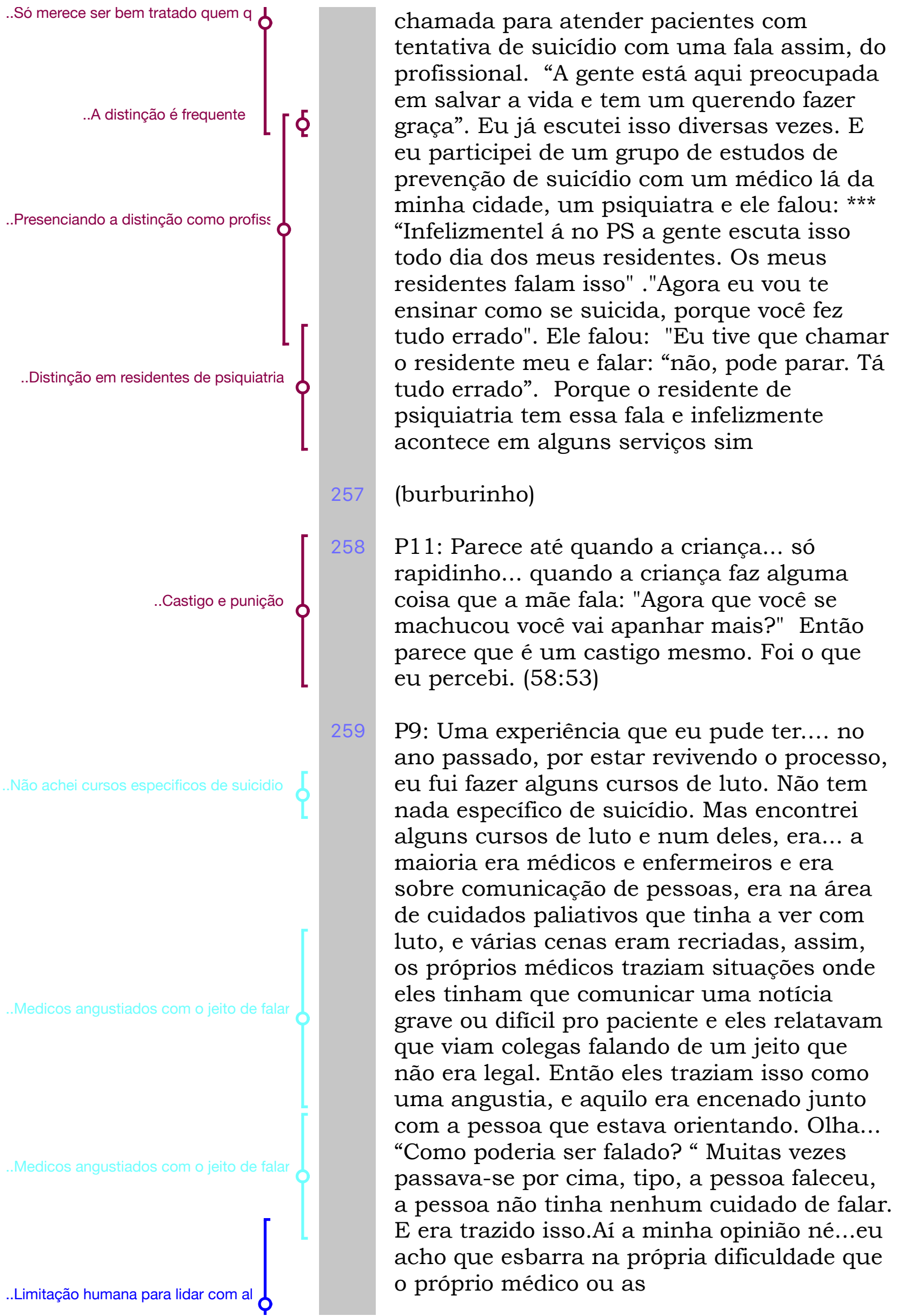




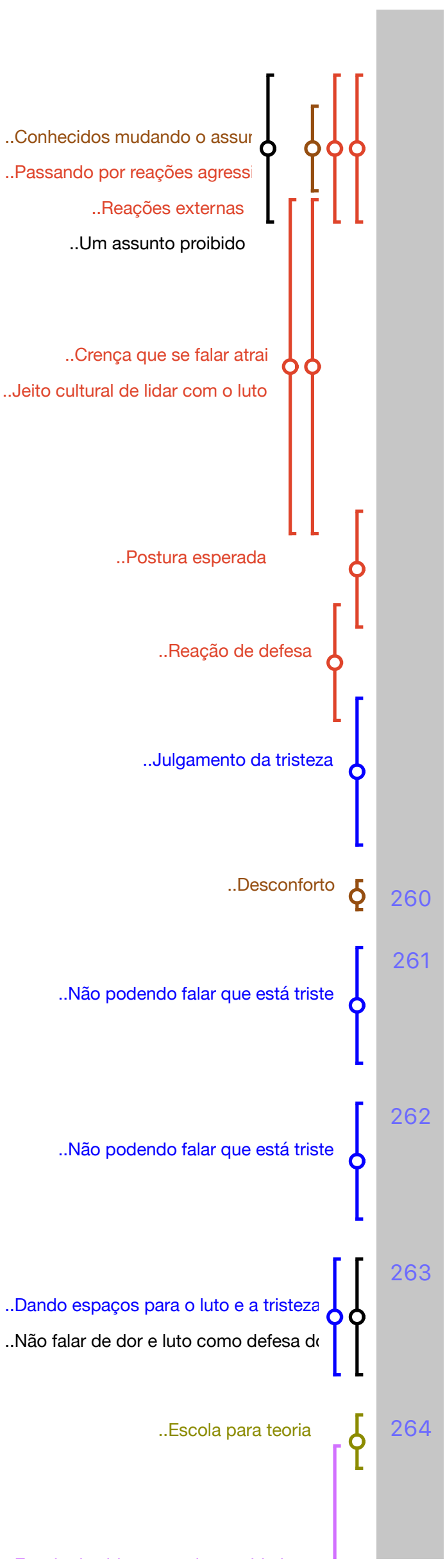

próprias pessoas têm de lidar com algumas questões. Acho que é uma limitação humana. Eu mesmo, assim, no relatar com amigos, eu tive reações, assim, desde pessoas que se afastaram, cortou o assunto e saiu fora mesmo e outras pessoas tinham reação agressiva. Depois eu pude entender, conversando né, que era uma coisa cultural da pessoa e da família inteira dela. Tudo que tinha haver com morte ou doença grave a pessoa não falava porque ela achava que atraia. Era uma coisa assim, muito recorrente: "se eu falar atrai" então na família inteira ninguém falava de nada de morte. Então o jeito que a pessoa reagia, nem era falando de uma maneira educada, era agredindo pra cortar o assunto. Então por exemplo, uma postura... tanta pessoa (pra ele?): "olha, eu prefiro não falar... Eu penso assim..." não. Aí eu entendi como era. Eu tenho amizade com a pessoa há muito tempo... eu entendi que é uma reação de defesa dela, um mecanismo dela... então eu acho que uma das coisas que eu acho que é mais grave, é um pouco o que a P9 falou, né, tudo que tem a ver com tristeza ou assuntos dificeis são tabu e as pessoas,

P7: causam desconforto.

P9: Não falam. Eu mesmo sofri... quando eu fui me abrir, com meus amigos, era assim meio tipo, levar uma bronca porque você está triste. "Para com isso."

P7: Eles estão desconfortáveis de ver você triste. Então às vezes eles estão fazendo isso não pelo preocupado com você, mas por eles mesmos...

P9: É uma forma de defesa. Então, dar espaço pros sentimentos de luto ou de tristeza, eu acho é, eu sinto como uma necessidade.

P10: E sabe o que é, eu acho que a gente aprende coisas na escola que são teóricas, e como lidar com transições, perdas,mudanças, essas coisas subjetivas 


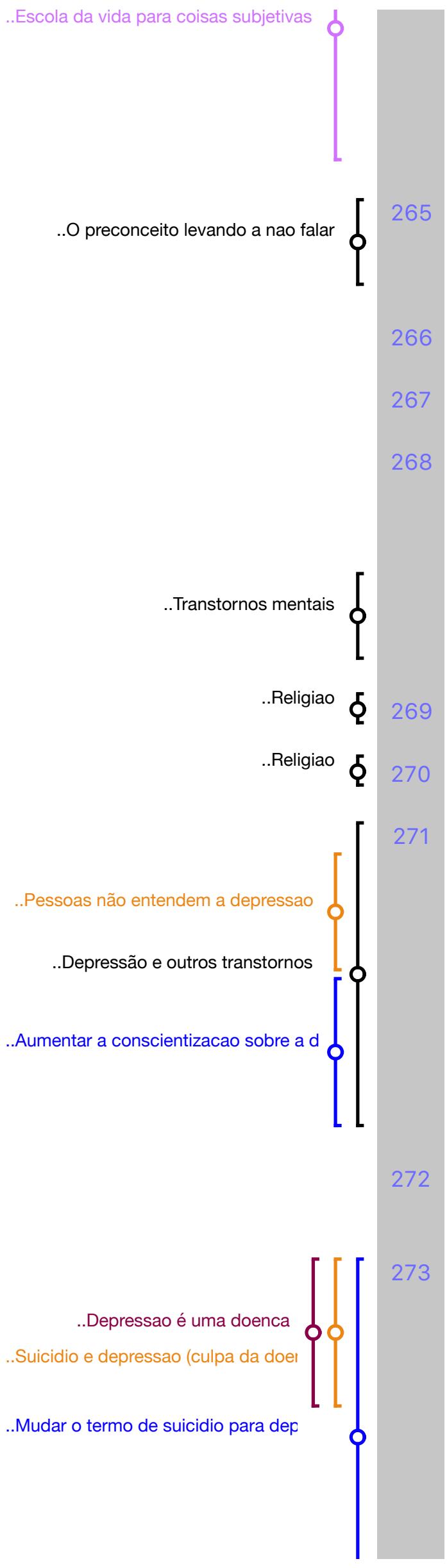

você não aprende em nenhum lugar, se aprende na vida mesmo, passando. Então eu acho que é por isso que é tão dificil, porque é a escola da vida né, que você acaba lidando com essas situações subjetivas.

P4: Mas nem na escola nem na família porque na família não falam e na escola também não...

E: Você queria falar alguma coisa?

P8: Não, só...

E: Então assim, que outras coisas vocês acham que podem influenciar esse tabu? Que a gente tá falando que é um tabu, não se fala, que outras coisas além das que vocês? Já falaram várias, mas vocês acham que tem mais coisas que influenciam nesse tabu?

P2: Religião

Burburinho... religião com certeza...

P11: Eu acho que a grande maioria dos casos envolve depressão, e a depressão não é respeitada como uma doença, não é tratada como uma doença, muitas das vezes ela é vista como uma frescura, como uma coisa assim, então talvez se tivesse uma conscientização maior sobre a depressão e outros problemas psiquiátricos também as pessoas compreendessem mais e ajudassem mais quem está passando por isso.

$\mathrm{E}$ : E você acham que o tabu começa ... fala... (01:04:08)

P5: ...Só um minuto. Sobre o que ela falou. Eu acho que a depressão como doença, que hoje é doença, tá lá no CID e tudo mais, eu acho que, nunca escutei de ninguém que se suicidou sem depressão. Então se eu mudasse o termo suicídio pra depressão,você poderia conversar sobre o assunto, resolver o problema e sem falar em suicídio. Porque a maioria do pessoal, eu 


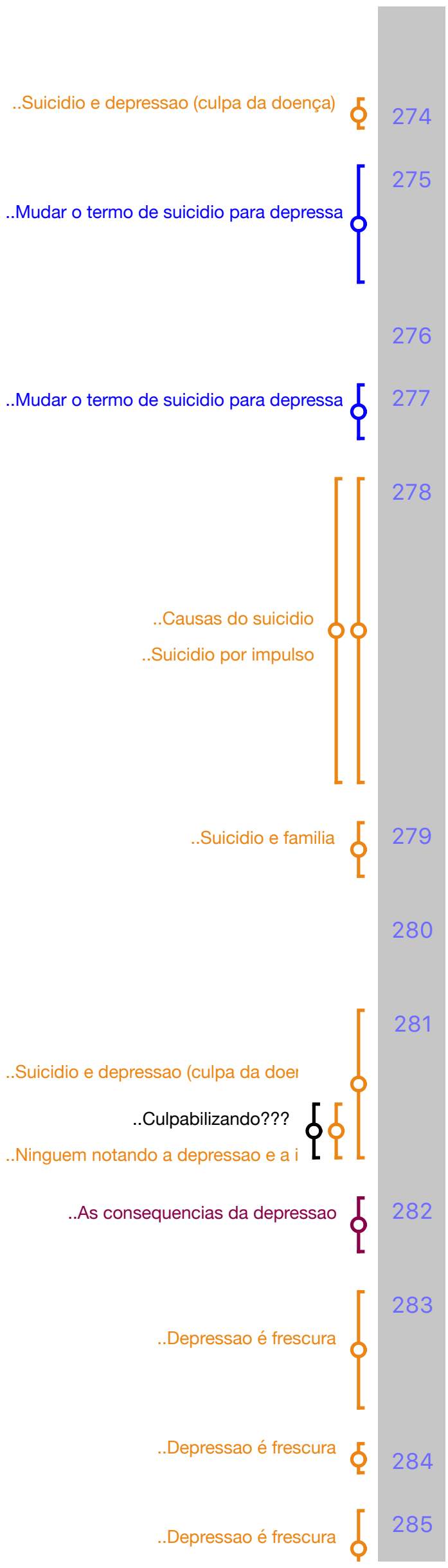

nunca escutei falar de ninguém que estava bem alegre e contente e se matou.

P11: por isso que eu falei

P5: Então eu concordo com você com esse negócio de depressão... eu acho que se mudasse o termo de suicídio para prevenção à depressão já melhoraria.

E: Seria bem mais fácil de falar?

P5: Seria bem mais fácil de lidar com o tema. Tá?

P7: Apesar que tem suicídios que não é por depressão, e sim por exemplo, por impulso. Aquele rapaz de 23 anos que se atirou lá do Fórum da Barra Funda, tinha acabado de sair da audiência, a audiência não foi sido favorável pra ele, ele atirou primeiro o celular que até acertou a barriga de uma grávida mas não causou danos maiores, e em seguida ele se atirou. Foi impulso. Não planejado...

P5: Mas se pesquisasse na família dele, antes de ir pra lá...

P7: pode ser, pode ser, eu não tenho essas informações (falam junto)

P5: ... antes dele vir para lá... ele já estaria em depressão tá. Eu nunca vi nenhum caso de suicídio que a pessoa não tivesse com depressão antes. Talvez ninguém notou, ninguém viu, ninguém ...

P3: Talvez até tenha cometido algum crime por depressão

P5: ... percebeu entendeu? O maior problema então é o seguinte, a depressão não é nada... igual ela falou... depressão é "frescura"...

P11: É frescura...

P5: ...se você acha que a depressão é 


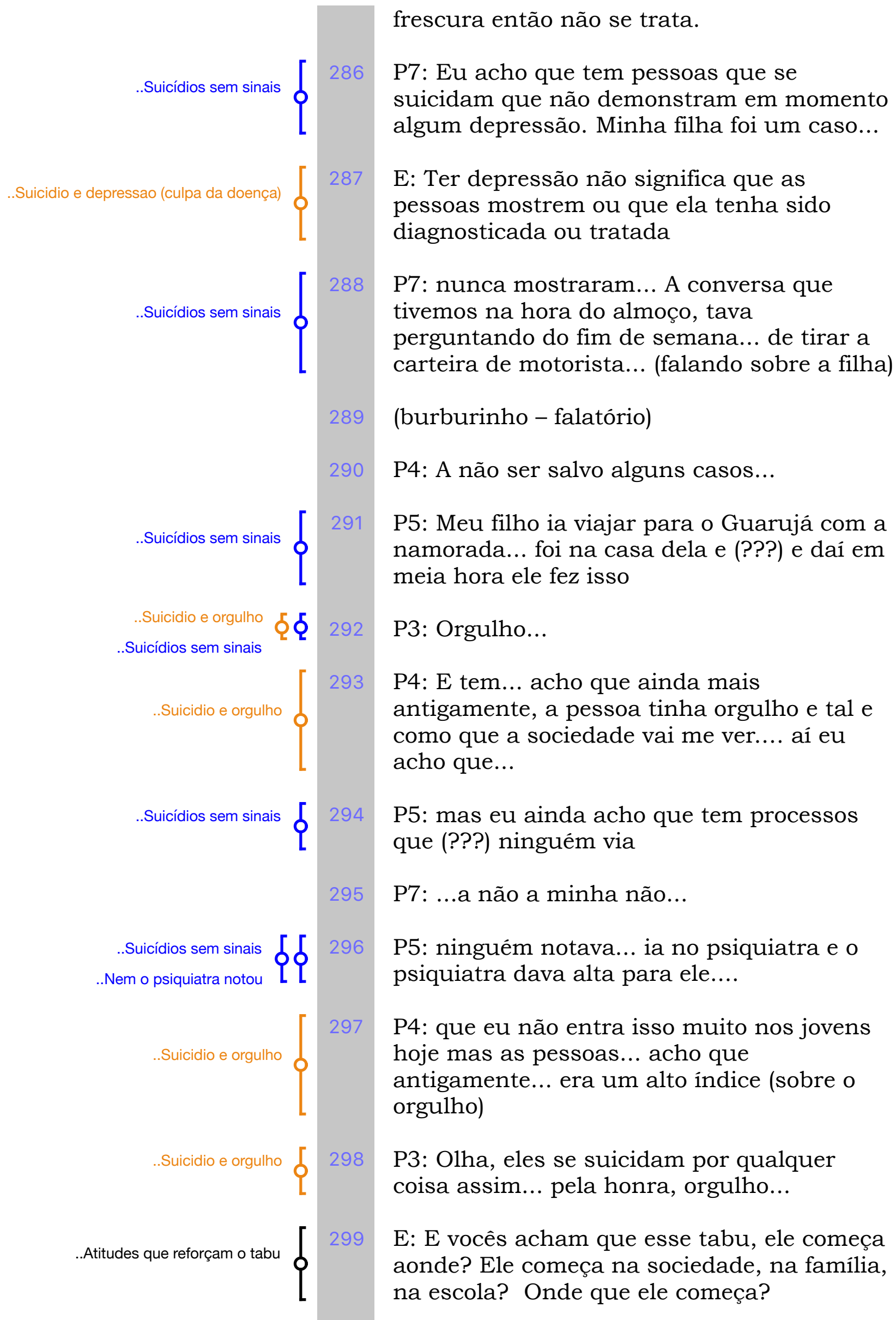




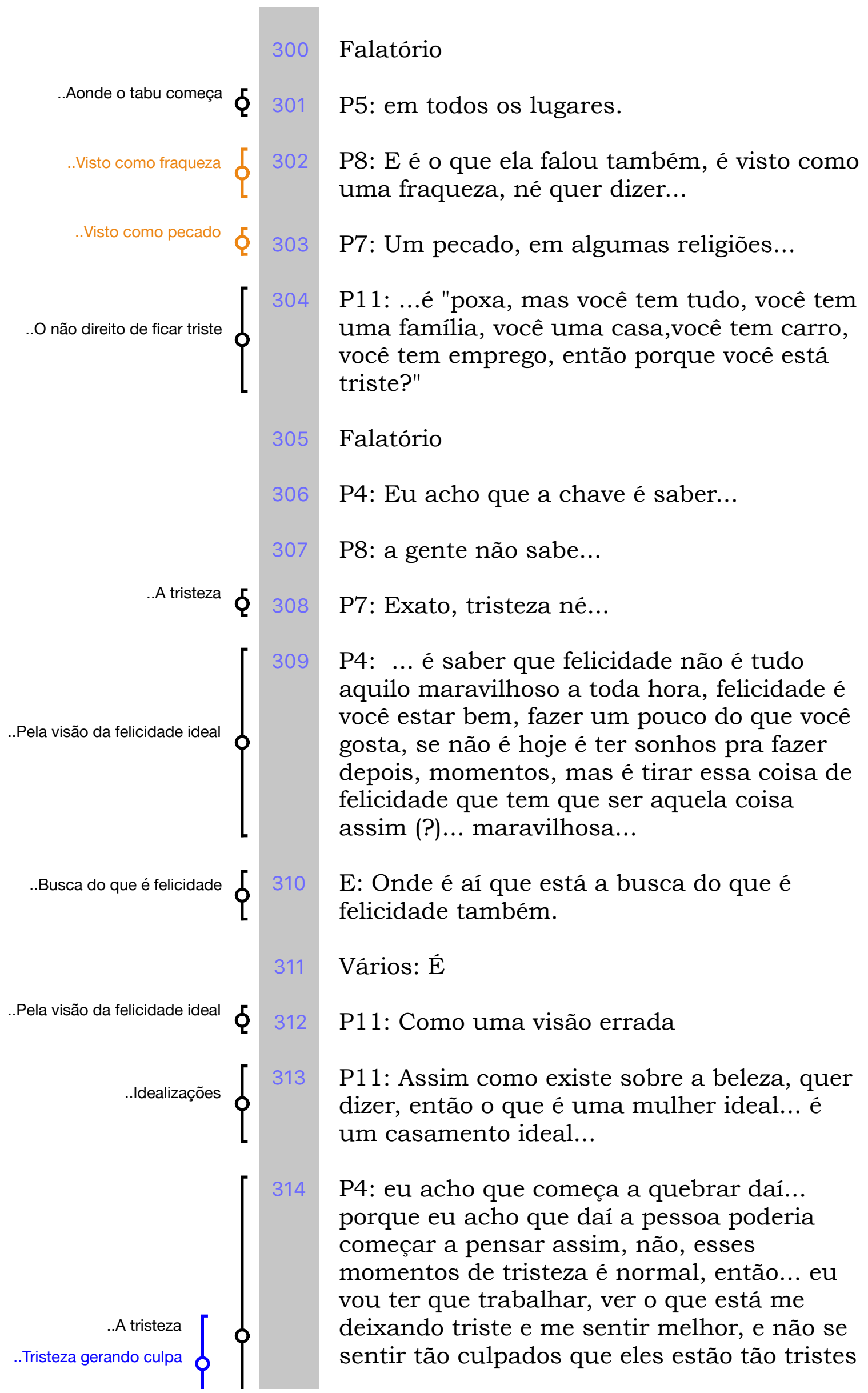




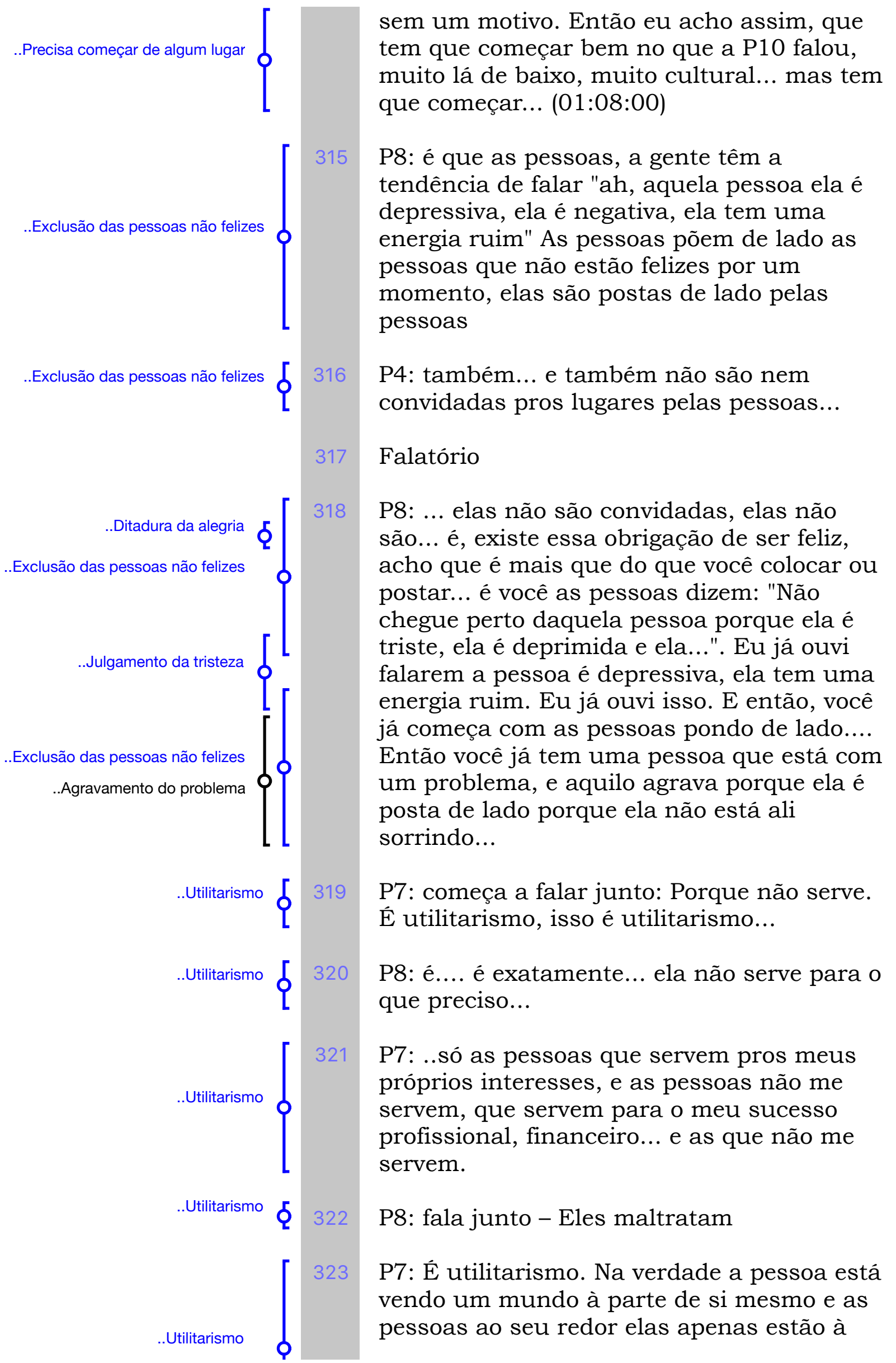




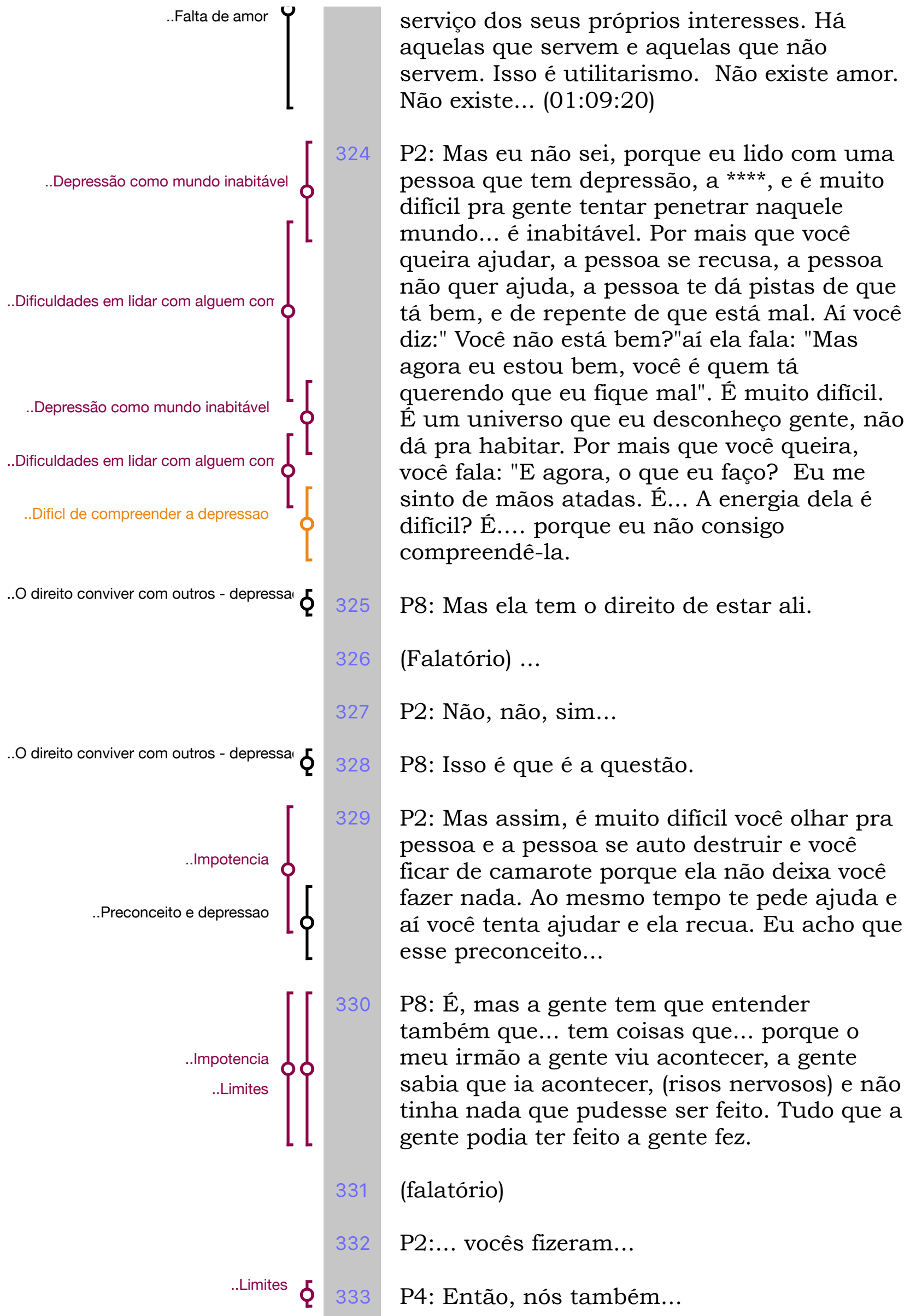




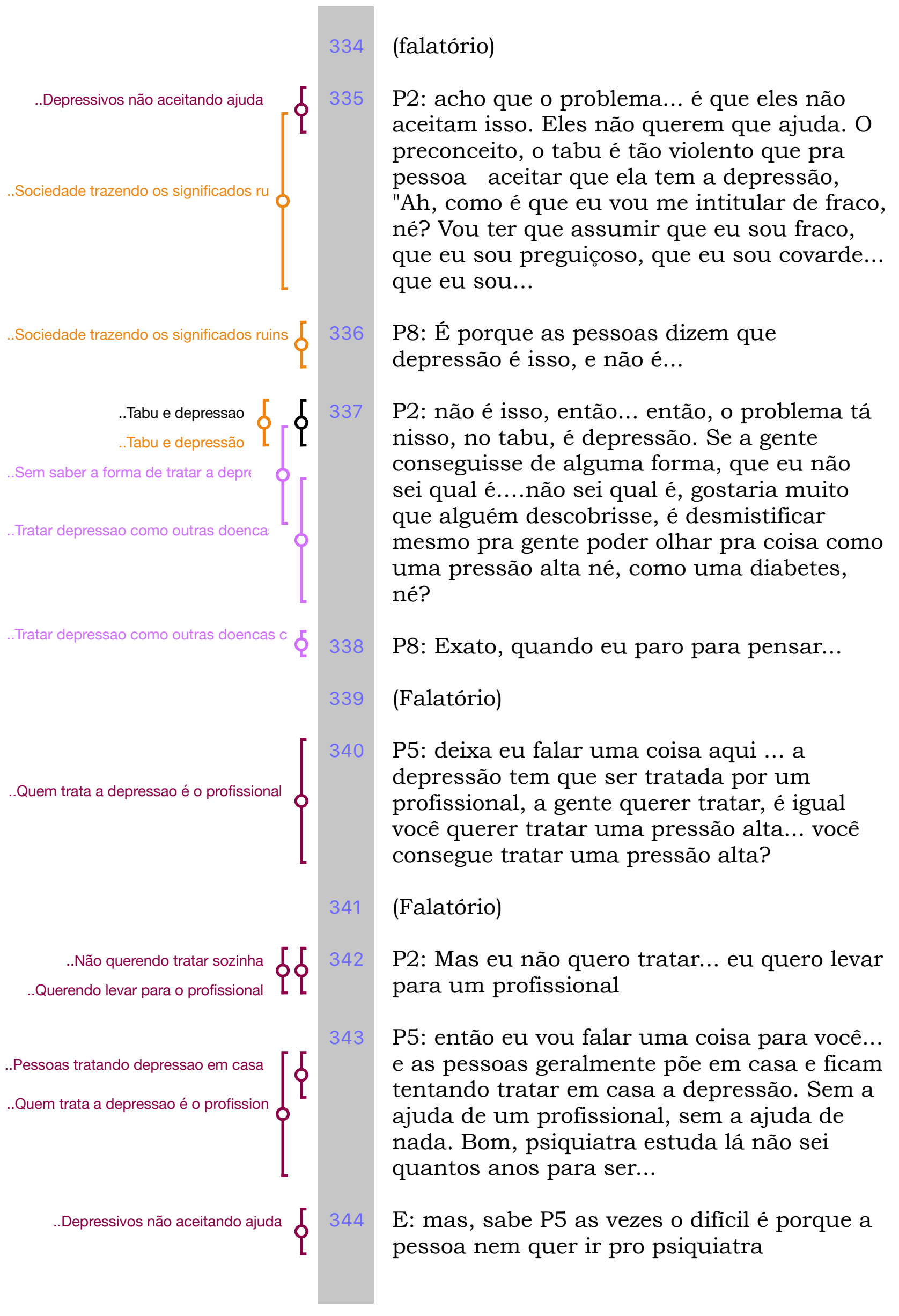


..Não sabendo tudo sobre depressac

..Complexidade dos sentimentc

..Complexidade dos sentimentos

.Desconhecimento emocional?
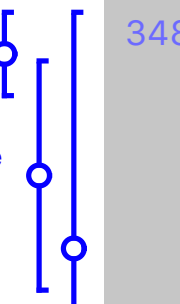

Gente, de novo, assim ... eu acho nem que a gente sabe, tipo, tudo, a gente só fala de depressão agora, mas eu acho que existem variações de sentimentos que não tem nem nomes porque nem tudo é só tristeza, nem tudo é só fraqueza. Assim como a tecnologia evoluiu, as doenças, eu acho que os sentimentos, hoje os seres sentem diversas coisas, a gente não tem nome pras coisas. É tipo: tristeza, fraqueza e alegria. Só existe isso. Eu não posso sentir um meio termo? Primeiro eu acho esse ponto. Outro: eu acho que nem tudo é depressão nem tudo não é. Eu acho que existem variações de coisas na nossa vida que a gente ainda não consegue... não sei se é dar um nome, qual seria a palavra a respeito, entendeu? Porque não encaixa nem só aqui nem só ali. São outras coisas que a gente está vivendo, entende? Eu acho que falta um avanço nesse sentido, porque a pessoa fala "putz, mas eu não tô com depressão", ou tipo "não posso estar triste um dia". Mas será que não existe uma variação? Você não precisa ser uma pessoa depressiva mas tem um dia que você está sentindo algo que não tem nem nome ainda.Então, é por isso que eu falo, pra mim a coisa assim que me gera, sabe, pensamentos milhões de...A gente tem que voltar muito ainda pra dentro do ser humano, olhar outras questões porque não está dando para definir. A gente não tem hoje palavras, estudos e eu acho que..., não sei o que é, pra conseguir...porque tem muito mais variação. Tudo evoluiu, agora, os sentimentos do ser humano não, continua tudo com o mesmo nome, e aí é depressão.

(Falatório)

P5: a depressão é coisa nova...mas eu acho 


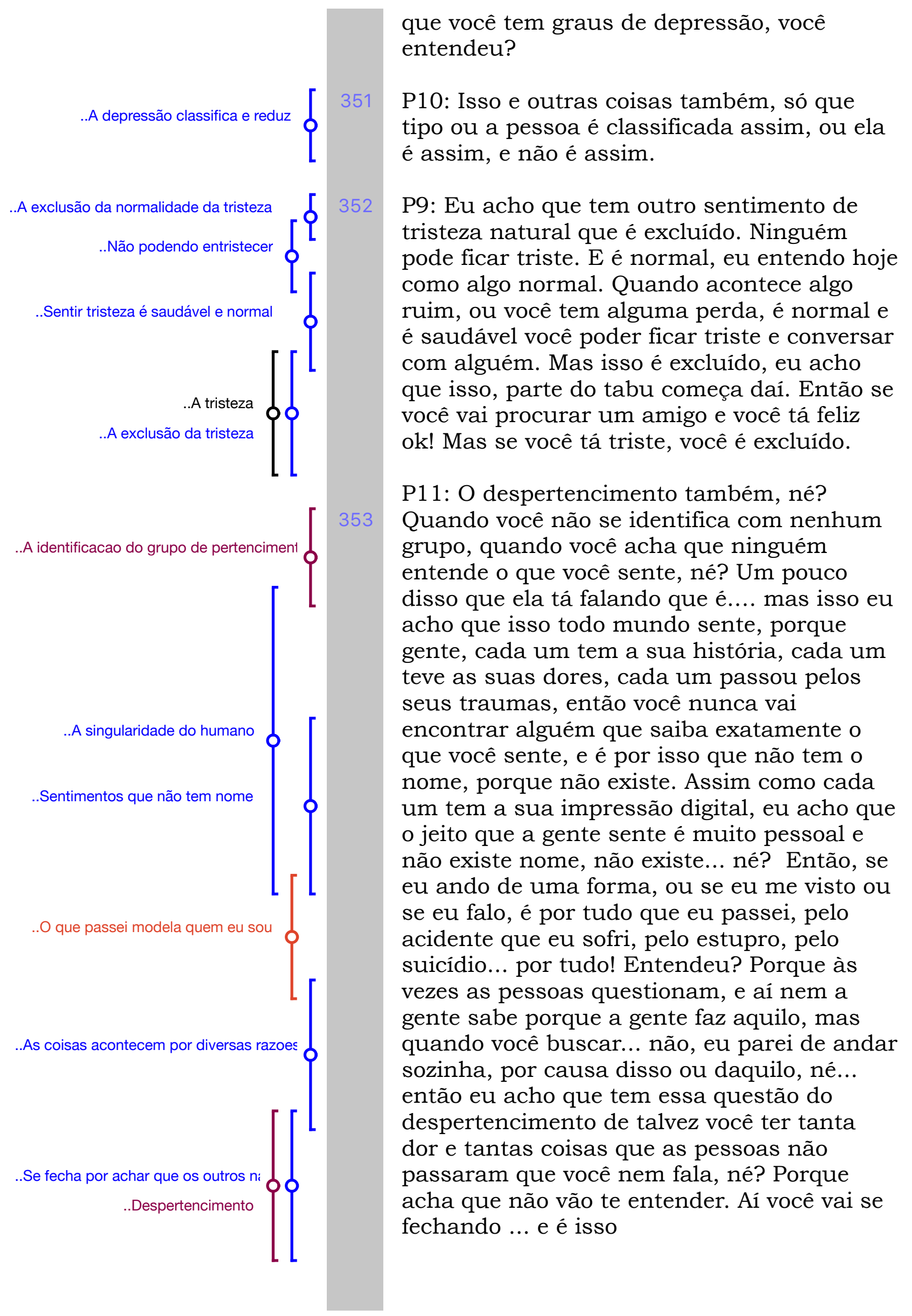




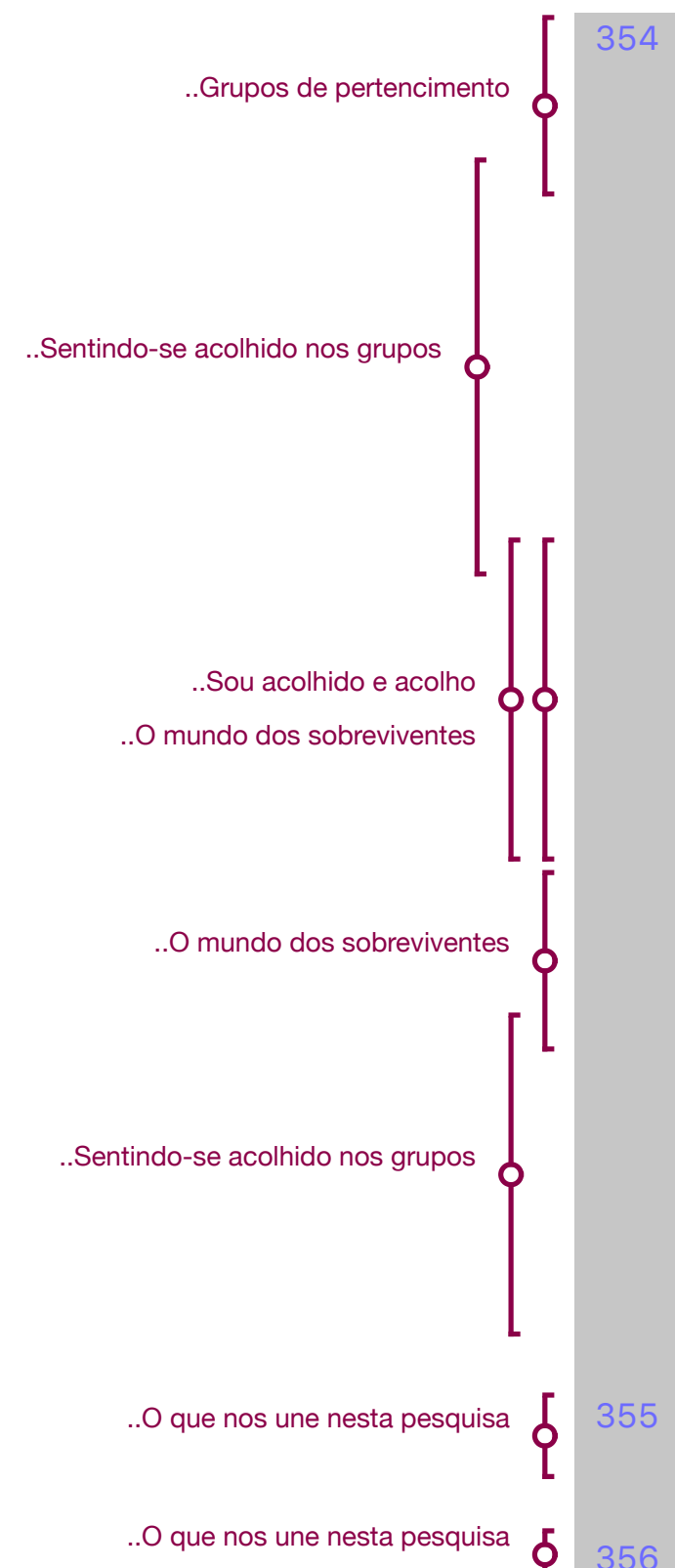

..Suicidas não conhecem os grupos

358

..Suicidas saberem e frequentarem os grur

.Reportagens dão valor aos casos e fatos

359
P7: eu acho que esses grupos que nós estamos como esse e outros que a gente tem em vários lugares, é um lugar de pertencimento porque toda vez que eu vou num grupo desses eu me sinto assim, não é que digamos estou à vontade, mas eu me sinto bem situado porque eu vejo que eu diante de pessoas que tão vivendo histórias parecidas e que estão tendo o sofrimento parecido, a angústia parecida, as dúvidas, as indagações parecidas, então eu de alguma forma eu me sinto acolhido. E eu também me sinto à vontade de ir acolher, eu vejo por exemplo vocês como os meus pares, são os meus iguais, então é um momento que nós estamos encontrando com os nossos iguais. Aqueles que entraram nesse mundo, no mundo dos sobreviventes. Nós temos até esse rótulo né?! Então a gente consegue. Nossa! Existe um mundo que é o mundo dos sobreviventes, e eu vejo a cara deles, eu vejo eles falarem, eles sentirem. Então, essas dinâmicas essa... e outras e ocorrem no (local onde ocorrem grupos), no (local onde ocorrem grupos) eu acho que são muito boas, e eu acho que esse é o caminho, é buscar esses lugares porque a gente vai se reconhecer.

P11: Mas a gente tá aqui é porque a gente passou por isso,

P7: Isso... só isso que nos une aqui...

357 P11: isso que eu acho que pra quem chega a se matar, quer dizer, ele não sabe, ele não, ele não... porque não é falado. Então ele não sabe que existe um grupo desse que ele pode procurar, e que ele pode se sentir bem e acolhido e respeitado, e falar que...

P7: Entendido

P11: ...é exatamente, e eu acho que é aí que falta...

P4: eu vou tirar por mim... em reportagens, que eu acho que é meio o tema abordado aqui, que eu leio mais em reportagem que eu 


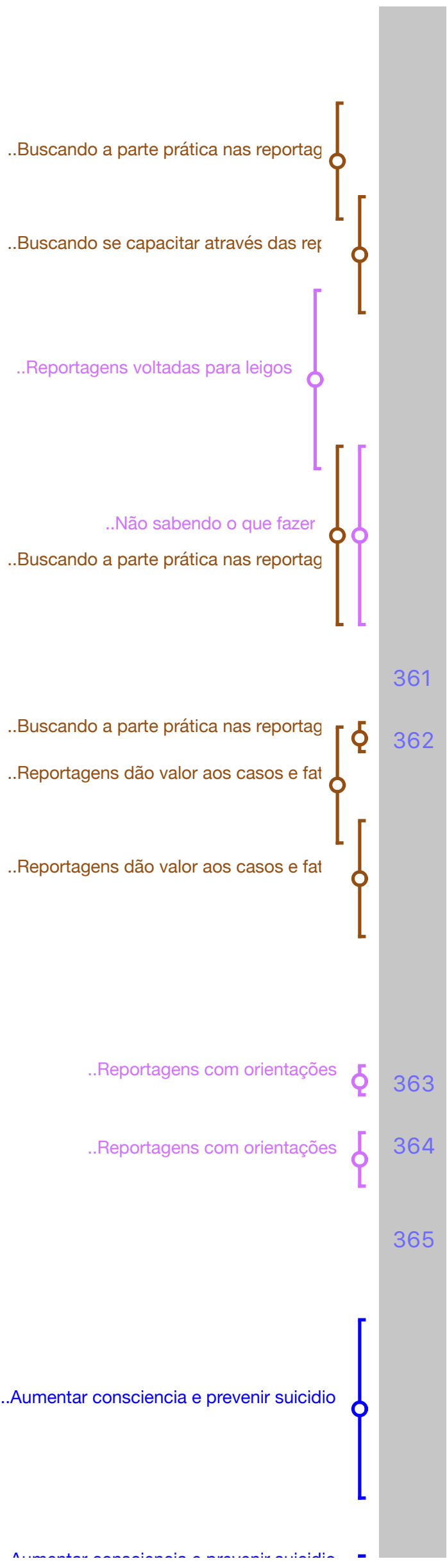

procuro ler, e eu acho que dão um pouquinho menos de valor, as reportagens normalmente dão um valor aos casos, né, como foi. Para mim eu vou para a última parte, quando se é falado o que a gente pode fazer, praticamente. Porque aí fica mais claro nos tópicos. Olha, te deixa a disposição, eu vou muito naquilo porque como eu não soube fazer antes, eu tento então saber como fazer agora. Então eu acho que teria que ter mais reportagens, a reportagem dar mais ênfase, até pra um leigo num falando, tentando falar né com nenhum profissional, que as vezes quem vai estar lendo na sua casa você não vai ter um profissional . Como pelo menos de princípio como ajudar mais né, porque é isso que a P2 falou, que a gente não sabe o que fazer. Então eu gosto muito daquela parte da reportagem aonde táali bem claro, ali...

E: quando tem né

P4: Então...mas a maioria não tem. A maioria sempre, não tô criticando as reportagens, mas eles dão muito ênfase ao que tá acontecendo. Agora tá tendo muito por causa da baleia azul, do seriado, vai ter setembro, já começa no final de agosto já começa as reportagens... mas eu leio mais assim é como agir. Então, uma mãe que está lendo ali, que percebe ali, ... que nossa, meu filho...

E: quer dizer orientações né?!

P4: As orientações práticas pro leigo né eu acho que isso seria muito importante.

$\mathrm{E}$ : É, num próximo encontro a gente vai conversar muito sobre as sugestões que vocês têm de aumentar a consciência pública. Como que vocês acham que essa consciência pode ser aumentada. Vocês acham que falando mais sobre o assunto, aumenta a consciência pública? Se isso influenciaria na prevenção e posvenção do suicídio? 
Vários: Sim, sim, sim....

P7: Eu acho que um dado muito importante é fazer as pessoas perceberem a quantidade de mortes que ocorrem a cada... a cada segundo ou a cada minuto né? Então isso é algo acho que eu considero importante porque quando eu falo pra pessoa: "Olha, enquanto a gente esteve conversando, agora, já morreram umas dez pessoas.

P4: estatisticamente é chocante então né.

E: a estatística é...

(Falatório)

P7: Pra pessoa perceber a grandeza, a dimensão, eu inclusive me permito, e aí eu sempre falo isso a título de conjectura pessoal que para mim, a minha convicção pessoal é que a maior causa de morte provocada da humanidade através da história é não só agora, é e sempre foi o suicídio. Mas é que sempre é ocultado, é uma das maiores, mas com certeza ela é a maior. Porque as outras, estatísticas... são colocadas estatísticas fiéis, e não tem tabu em cima. E aqui não, é tudo escondido. E eu falei... eu me permito acreditar que talvez a humanidade, a maior causa de morte da humanidade é o suicídio. O que é um grande paradoxo. E eu acho que se um dia as autoridades, os formadores de opinião, ..Ao admitir isso podemos mudar enfim, as elites pensantes, enfim, começarem a admitir uma possibilidade como essa... paradoxal, contraditória, assustadora, eu acho que a gente revoluciona, a gente muda, não sei.

E: Você ia falar um pouquinho

P8: Não, é que... eu não sei se... Eu acho que no falar, ele é tem alguma coisa que ainda eu ainda não consegui pensar muito bem, é a respeito sobre essa questão da prevenção. É. ... e de que a prevenção ela tá mais na mão da própria pessoa do que na dos outros. Então que também tem essa coisa, 


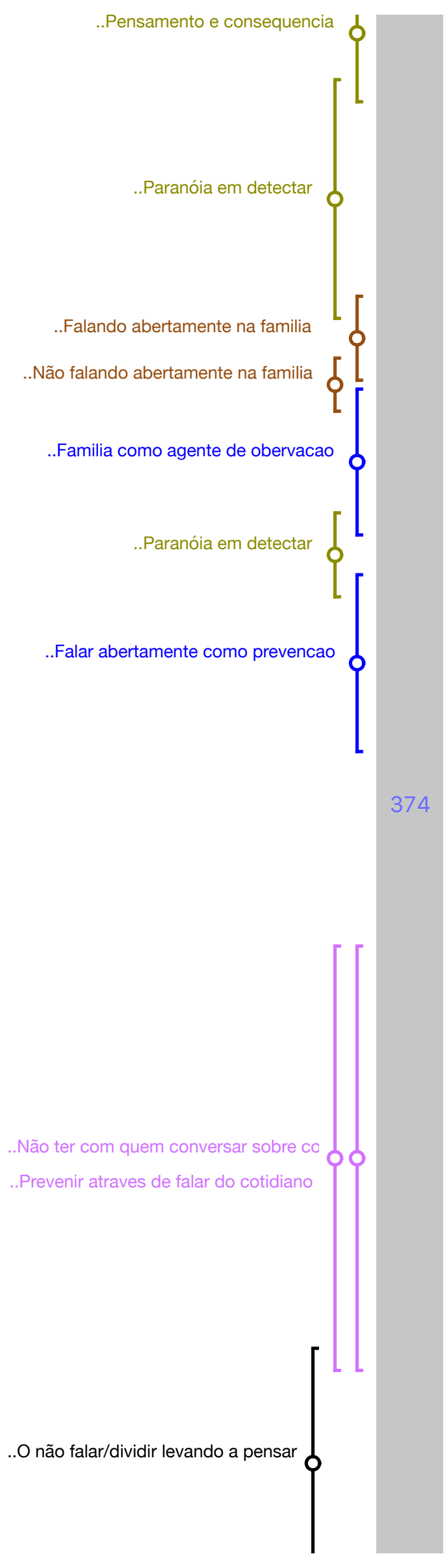

eu acho que falar é importante para que as pessoas que pensam nisso entendam também a consequência daquilo. $\mathrm{E}$ mais do que falar para que os outros em torno, porque possam detectar, porque senão também tem aquela paranoia. A pessoa então começa com alguma coisinha todo mundo já "ah, ah..." mas sabe, tipo... a gente tem que ficar atento com uma série de coisas. Na minha família isso é um assunto, de um dos lados, é um assunto que se fala abertamente. Do lado do meu pai não. Do lado do meu pai ninguém fala a palavra. Do lado da minha mãe não, então já tem aquela coisa... a gentetá com um primo que tá com uma depressão muito profunda, o pessoal tá de olho. Mas também não pode ficar com uma paranoia em cima, de de tipo qualquer coisa, mas eu acho que a prevenção ela passa mais o poder falar abertamente sobre isso, é mais importante pra pessoa que pensa no assunto, do que propriamente para as pessoas que estão no entorno dela, né, é mais isso... (01:22:24)

P9: Eu quero acrescentar uma coisa: no ano passado, eu fiquei alguns meses como voluntário do CVV. Então assim, eu não posso falar nenhum nome do CVV e nem nada dos casos que aconteceram, eu só posso falar da minha experiência. Eu fiquei um tempo atendendo ligações das pessoas que ligam, que procuram né, e a minha experiência assim foi de que a maioria do que é falado,e que as pessoas sentem angústia porque não tem com quem conversar..., porque são coisas cotidianas, então o que eu percebo e que eu acho que a grande dificuldade que a gente não relaciona esse cotidiano com digamos o fato em si é de que as pessoas não tem espaço pra falar do que elas estão sentindo: pergunta o que aconteceu, ou como foi o seu dia, ou falam de coisas práticas. Mas quando a pessoa tem algo, que ela não sente à vontade de falar com alguém da família, com amigo, com marido, com esposa, com filhos,com ospais, isso é o que vai acumulando aí chega num ponto que a pessoa chega a tirar a própria 


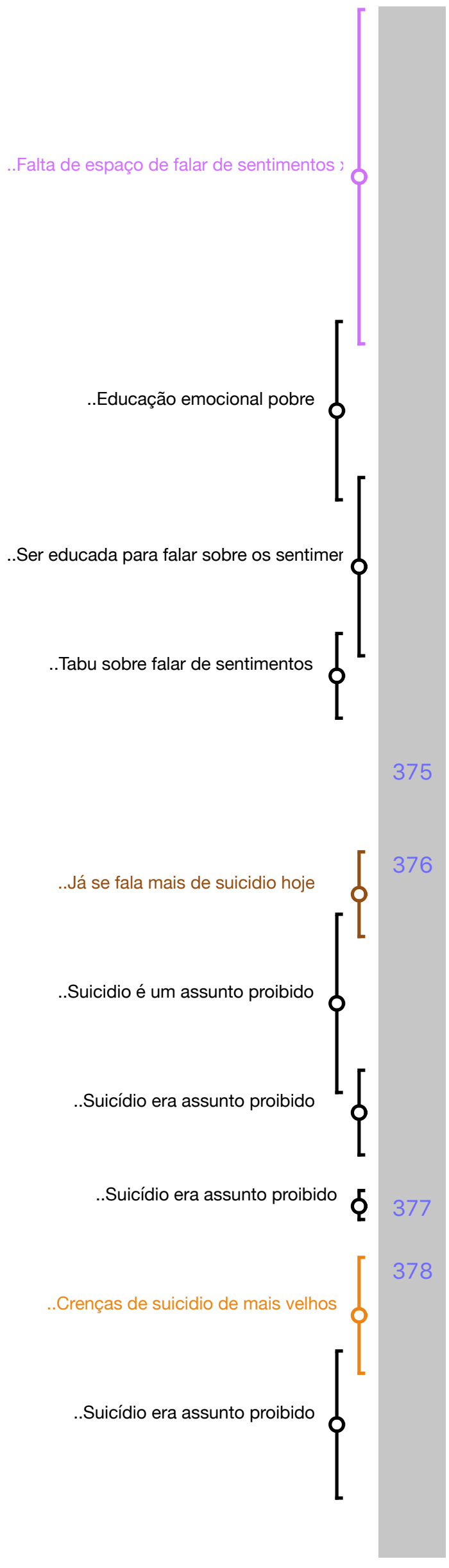

vida. Então, o que eu senti de grave, e aí eu tô tentando trazer isso na minha relação pessoal dos amigos, é que mesmo com os amigos quando eu vou conversar, eu percebo que eles não conseguem relacionar que não falar do sentimento, tem vínculo com chegar nesse ponto, que a angústia pode acrescentar até que chega a gota d'água de algo que acontece, mas que é, muitas vezes, só o desencadeador do fato, mas é falta de espaço de falar dos sentimentos. Isso que você falou de tem sentimentos que a gente não sabe nem nomear, e acho que a gente tem uma educação emocional muito pobre de forma geral, e acho que isso,tá na causa do tabu. Então a dificuldade, por exemplo, eu encontro amigos e às vezes a pessoa tá passando uma angustia grande mas ela não consegue falar, ela não foi educada, eu também não fui, então eu tô fazendo esse exercício. Existe um tabu de falar o que tá sentindo, que é visto como uma pessoa fraca, com defeito.... É excluído sim...

E: E como vocês gostariam que o suicídio fosse visto pela sociedade então? (1:24:40)

P5: Olha eu acho que já é bem visto hoje, porque eu sou um pouquinho mais antigo né, porque o que acontece? Na nossa época o suicídio era um... a família não comentava. Todo mundo escondia, todo mundo guardava aquilo, desaparecia e ninguém sabia nem o que aconteceu. Era proibido falar suicídio. A família era excretada da sociedade. Toda a família daquele que suicidou-se. Não existia, era um disparate.

P7: era um disparate

P5: principalmente o que eram mais idosos, que se suicidavam e geralmente amante ou financeiros o problema. Antigamente era esse o problema. O que acontece? E isso era proibido, era terminantemente proibido... não podia comentar em casa que o vizinho se suicidou, meu pai vinha e me dava uma surra. 


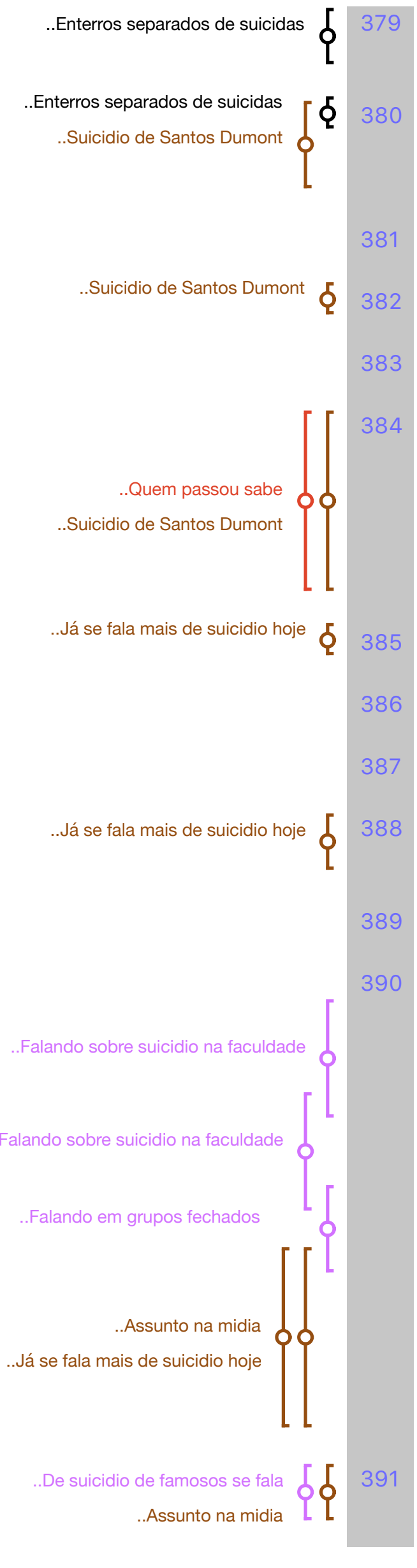

P3: Tinha cemitérios que não se podia nem enterrar.

P5: Não podia enterrar, é verdade. Igual uma coisa que pouca gente sabe, Santos Dummont suicidou-se, né?

P7:Sim.

P5: E ninguém divulga isso, né? .

P7: Ah, não. Mas isso....

P5: Ele suicidou-se no Guarujá. Só quem passou por isso sabe, se você fizer uma pesquisa aí de quem não passou por suicídio, você vai ver que $90 \%$ não sabe do que Santos Dummont morreu, de tanto que era escondida a coisa.

P7: Não, mas hoje já se fala muito mais...

P1: já se fala muito sim... eu eu

P7:que Santos Dummont se suicidou.

P5: Sim, hoje se fala mais de suicídio... eu tô falando como era antigamente.

P7: há, no passado... entendi... entendi...

P1: não se fala assim como creio que se fosse mais como.... minha esposa tá fazendo psicologia então, no mundo dela, fa faculdade tudo... a quase toda semana tem temas que envolvem suicídio. Na faculdade se fala bastante, pode não ter uma disciplina sobre isso mas, se fala bastante. É palestras e tal tal tal. Mas são grupos fechados né, dentro da universidade.Não leva pra fora né... a gente espera que... Mas mesmo assim a gente já vê que já tá que está mudando, você vê que se fala mais, já sai na televisão, é tem canais que vai... a Globo não pode falar...ou só a partir de tal horário, tem umas normas né.

P4: fala junto - os famosos, pelo menos ela falou... ?? 


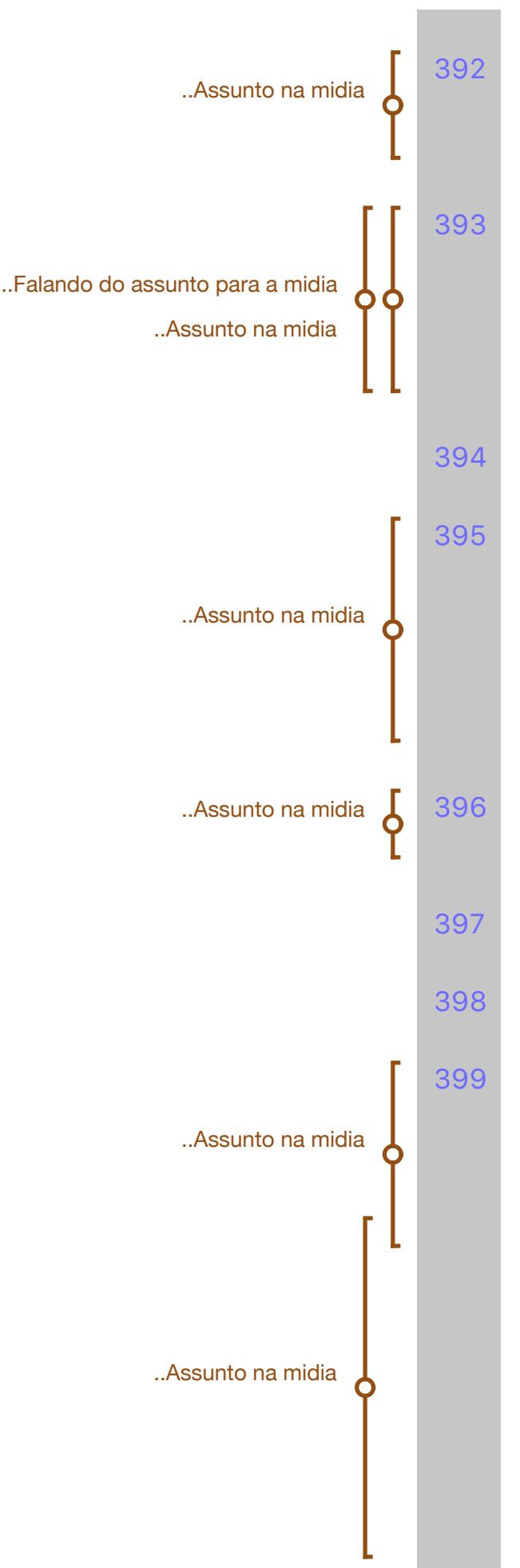

..Já se fala mais de suicidio hoje ..Aumento da comunicação ..Já se fala mais de suicidio hoje †
$\mathrm{P} 1$ :Então eu acho que isso, por exemplo a parte da manhã é hora que tem muito ?, você não pode falar isso no jornal nem nada.

P7: No mês de prevenção ao suicídio do ano retrasado, saiu uma matéria que inclusive um dos que foi entrevistados fui eu, foi no(nome do programa e do canal), que é o jornal da manhã.

P1: que dizer a Globo não faz...

P7:Saiu. Saiu também, na mesma (nome do canal e nome do programa) que eu também contribui...na do no passado...também no dia mundial da prevenção ao suicídio, no início da noite, as 7,8 horas da noite, que é o (nome do programa)

E: Há duas semanas, naquele programa da Fátima Bernardes foi falado de suicídio.

P7: de dia....

falatório

P7: Hoje no jornal da (nome de emissora de tv) eu vi a sua entrevista, eu vi... eu ate gravei... eu vi a sua entrevista, ela deu uma entrevista né, explicando a questão do suicídio, então isso já é uma vitória, né? Ah, (nome do programa) quis fazer um trabalho sobre a questão do suicídio em 4 semanas, eu ia participar de uma delas e depois a cúpula da (nome do canal) vetou. O (nome do repórter) comprou o negócio, veio a moça, lá, que me entrevistou tal e depois veio explicar lá no mês seguinte que a cúpulaapagou ...

E: Então assim, vocês estão falando que hoje já se fala mais do que falava antes!

Falatório: - a sim, bem mais.... até na hora do....

402 E: Mas como que vocês gostariam que fosse falado? Como que vocês gostariam que a 


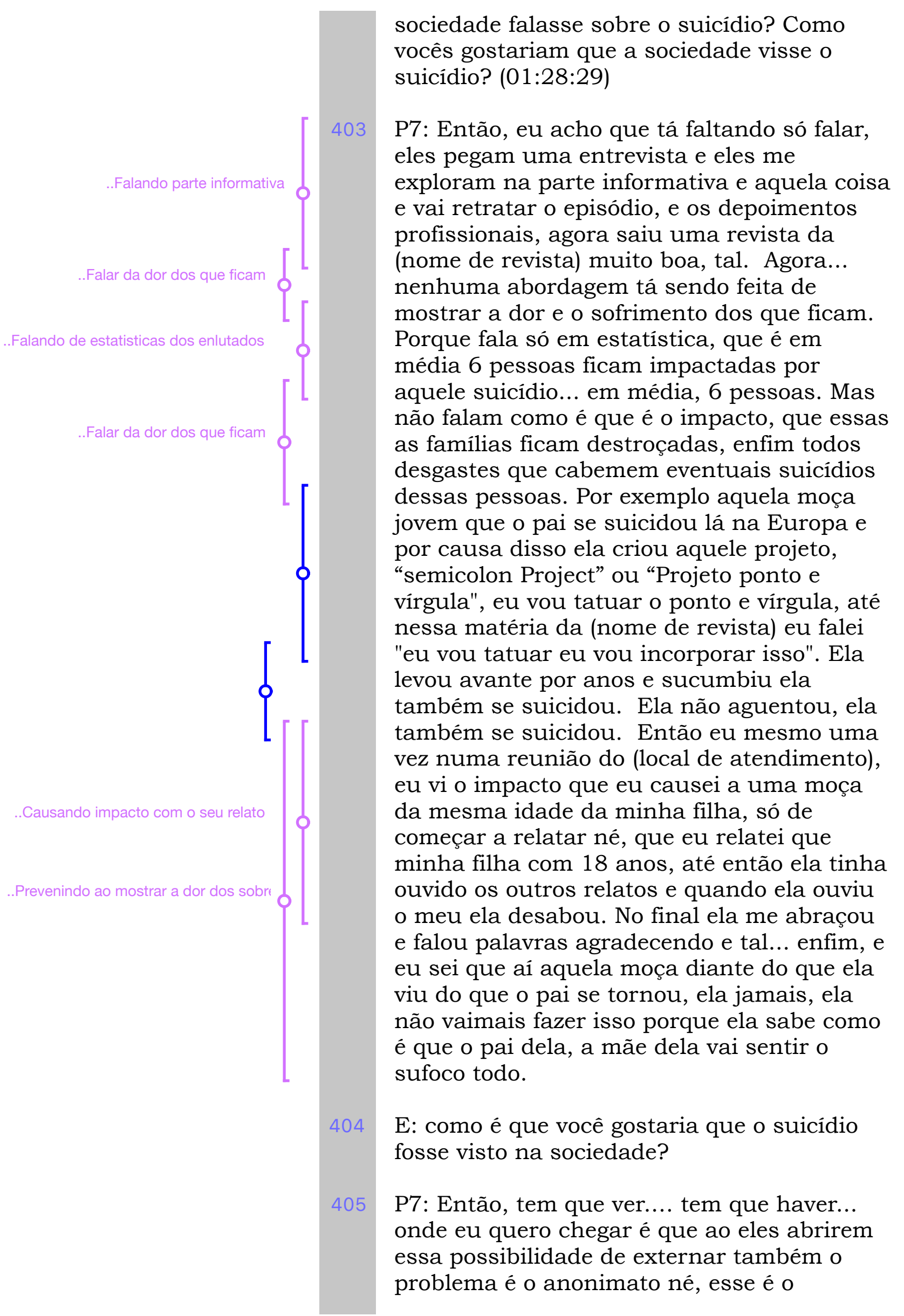




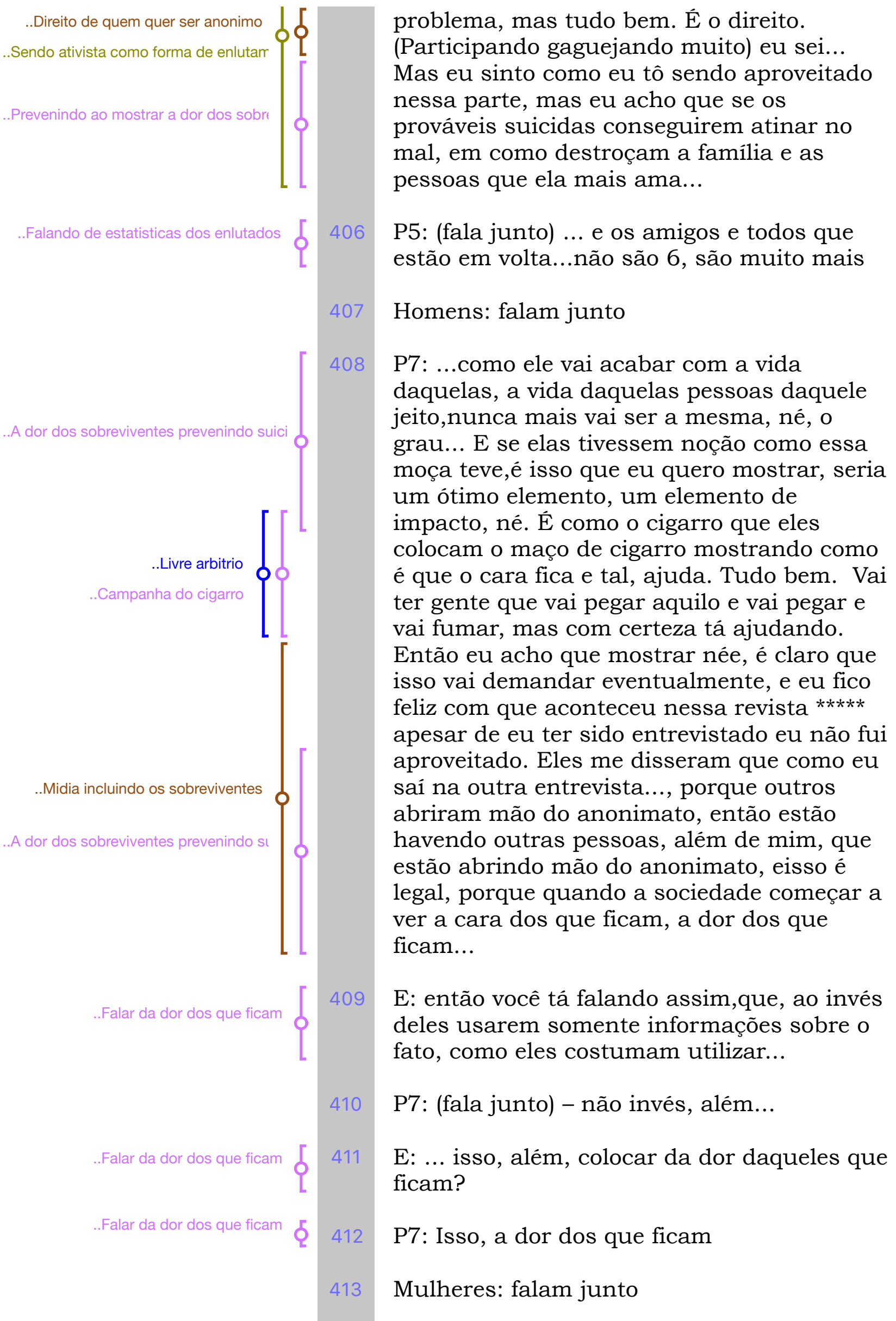


P4: Eu discordo um pouquinho, porque eu acho se a gente falou de todo esse processo que a pessoa está passando, isso aí não... eu acho que estatisticamente vai ser dificil...menos do que você acha que vai atingir. Eu acho que o processo interno da pessoa a dor é tanta que ele não vai prestar atenção naquele momento quem tá passando...

P1: (fala junto) - a dor maior é ele

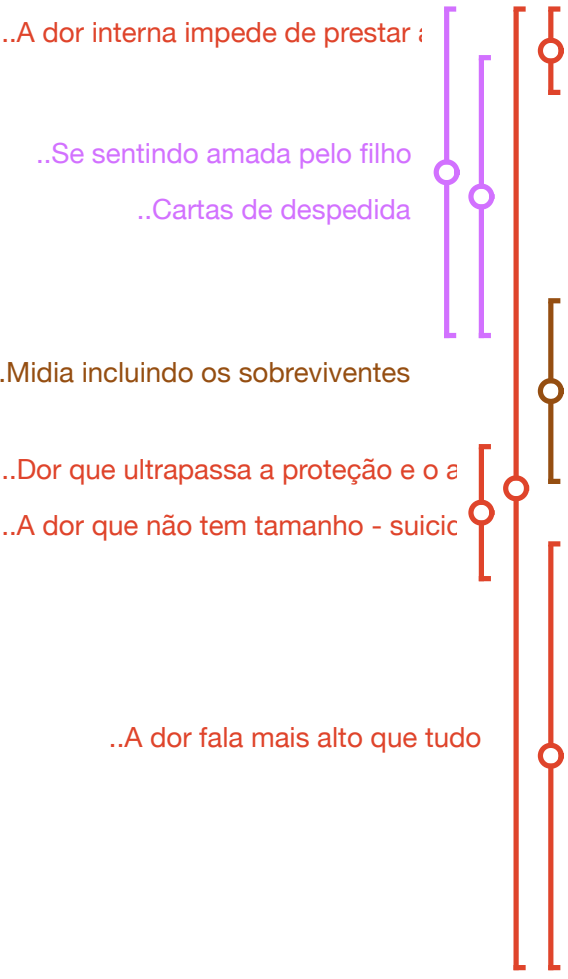

..A dor que não tem tamanho - suicidio
P4: A dor é ele, ele porque senão todos aqui os nossos filhos amavam a gente. $\mathrm{O}$ meu deixou cartas, o que a maioria não deixou, o meu deixou muitas cartas... que a gente não tinha culpa, que ele amava, que o P5 era exemplo de pai, que ele queria ser igual a ele, então assim, ele deixou. Tanto que eu falei muito na revista talvez porque aproveitaram. Porque ela viu... assim, ela leu as cartas... a menina. Então, ele deixou muito claro... então que a dor era tamanha que ele não sabia o que fazer com ela. E meu filho tinha um fundamento religioso também, não ia falar que ele era um adolescente que nem pensava em nada . Não, ele tinha um medo, ele tinha... e falava "vou pagar por isso mas eu não tô conseguindo lidar com a minha tristeza", então eu acho que no momento que eles estão passando a dor... não seria...

E: então mostrar essa relação bem forte entre o suicídio e dor.

P4: É e eu acho que pra mim basicamente assim começar a tratar como saúde pública.

P7: Ah, sim...

P4: Isso seria o ideal...pra começar... (01:33:46)

E: Então, a forma... a gente tá pensando: como a sociedade, como vocês gostariam que o suicídio fosse visto pela sociedade. A gente ainda não está na forma como a gente vai 


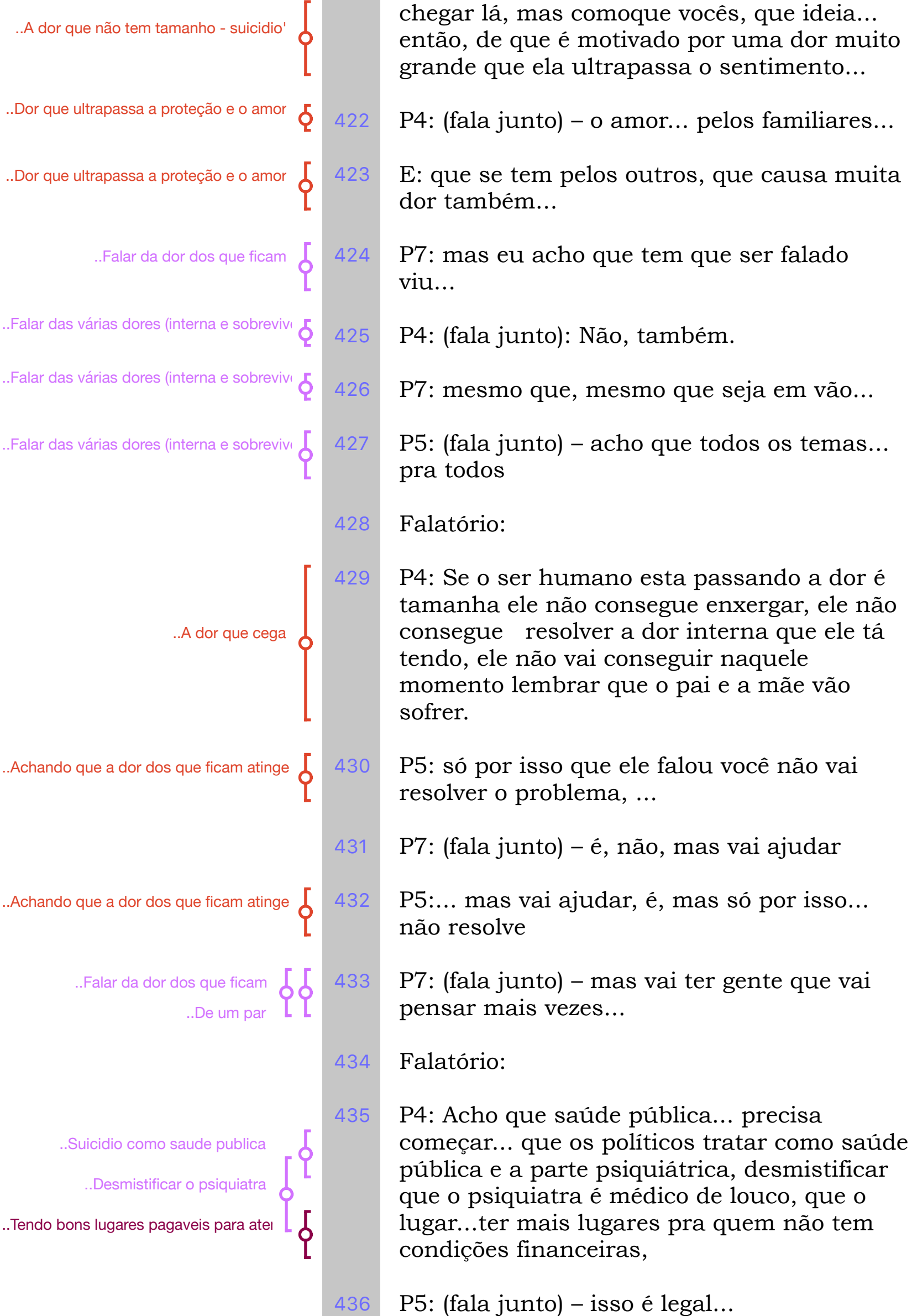

..A dor que não tem tamanho - suicidio'

.Dor que ultrapassa a proteção e o amor

Dor que ultrapassa a proteção e o amor

Falar da dor dos que ficam

Falar das várias dores (interna e sobrevivı $\mathbf{\Phi}$

..Falar das várias dores (interna e sobrevivı $\mathbf{\Phi}$

..Falar das várias dores (interna e sobrevivı

Achando que a dor dos que ficam atinge

chegar lá, mas comoque vocês, que ideia... então, de que é motivado por uma dor muito grande que ela ultrapassa o sentimento...

P4: (fala junto) - o amor... pelos familiares...

$\mathrm{E}$ : que se tem pelos outros, que causa muita dor também...

P7: mas eu acho que tem que ser falado viu...

P4: (fala junto): Não, também.

P7: mesmo que, mesmo que seja em vão...

P5: (fala junto) - acho que todos os temas... pra todos

Falatório:

P4: Se o ser humano esta passando a dor é tamanha ele não consegue enxergar, ele não consegue resolver a dor interna que ele tá tendo, ele não vai conseguir naquele momento lembrar que o pai e a mãe vão sofrer.

P5: só por isso que ele falou você não vai resolver o problema, ...

P7: (fala junto) - é, não, mas vai ajudar

P5:... mas vai ajudar, é, mas só por isso... não resolve

P7: (fala junto) - mas vai ter gente que vai pensar mais vezes...

Falatório:

P4: Acho que saúde pública... precisa começar... que os políticos tratar como saúde pública e a parte psiquiátrica, desmistificar que o psiquiatra é médico de louco, que o lugar...ter mais lugares pra quem não tem condições financeiras, 


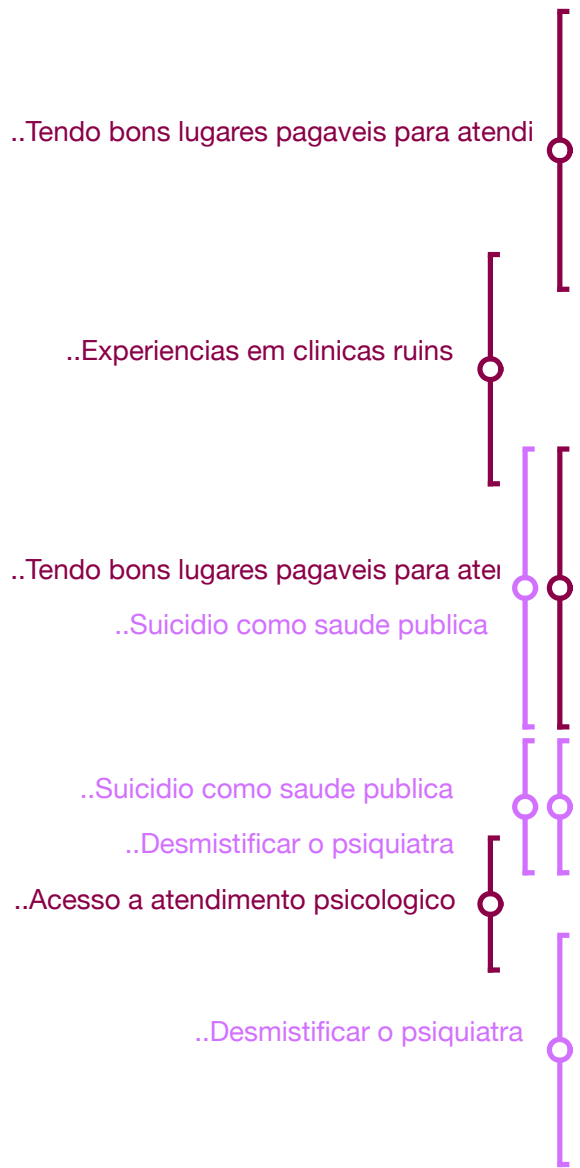

..Acesso a formas de tratamento

.Acesso a formas de tratamento

.Desmistificar o psiquiatra
(?) - ... principalmente...

P4: porque a gente tá com esse problema, você sabe, lá do ***, então assim, uma pessoa, a gente tá vendo, uma pessoa de classe média hoje... não é nem uma pessoa de classe muito baixa vamos dizer, de classe média não consegue as vezes manter em uma clínica ideal. Porque tá tendo... tá dopando o filho,o filho né, não tá tendo assistência, tá simplesmente jogando o ser humano lá e fala: "toma remédio aí, dorme, para ver se você se acalma". Então é isso que eu tô achando,que é uma questão de saúde pública. De ter mais... O governo começar a pensar que tem que ter hospitais... tratamento, pra quem não tem condições de pagar uma clínica elite, né, desmistificar psiquiatra que é médico de louco, de que não, de que é uma pessoa que você pode tratar, psicólogos... os psicólogoseu acho ainda que o acesso é mais...eles gostam mais. Acho que quando tá também né o psicólogo é mais leve (?) né do que o psiquiatra. Que às vezes medicação é necessária e o jovem acha que não, o mais velho: "Oh, eu tô ficando louco"...

E: quer dizer, as formas de tratamento.

P4: as formas de tratamento... tem que desmistificar... que nem, uma coisa que o P5 falava muito pro ${ }^{* * * *}$.

E: (fala junto) - aonde ele acha o tratamento...

P4: quando deram o medicamento pra ele. O P5 falava muito: "***** você tem que canalizar o seguinte: se eu não tenho problema de coração enfartei eu não tenho que tomar a vida inteira o meu remédio?

P5: É porque quando ele começou a tomar remédio psiquiátrico fica não... eu não vou tomar isso a vida inteira eu não posso tomar isso a vida inteira 


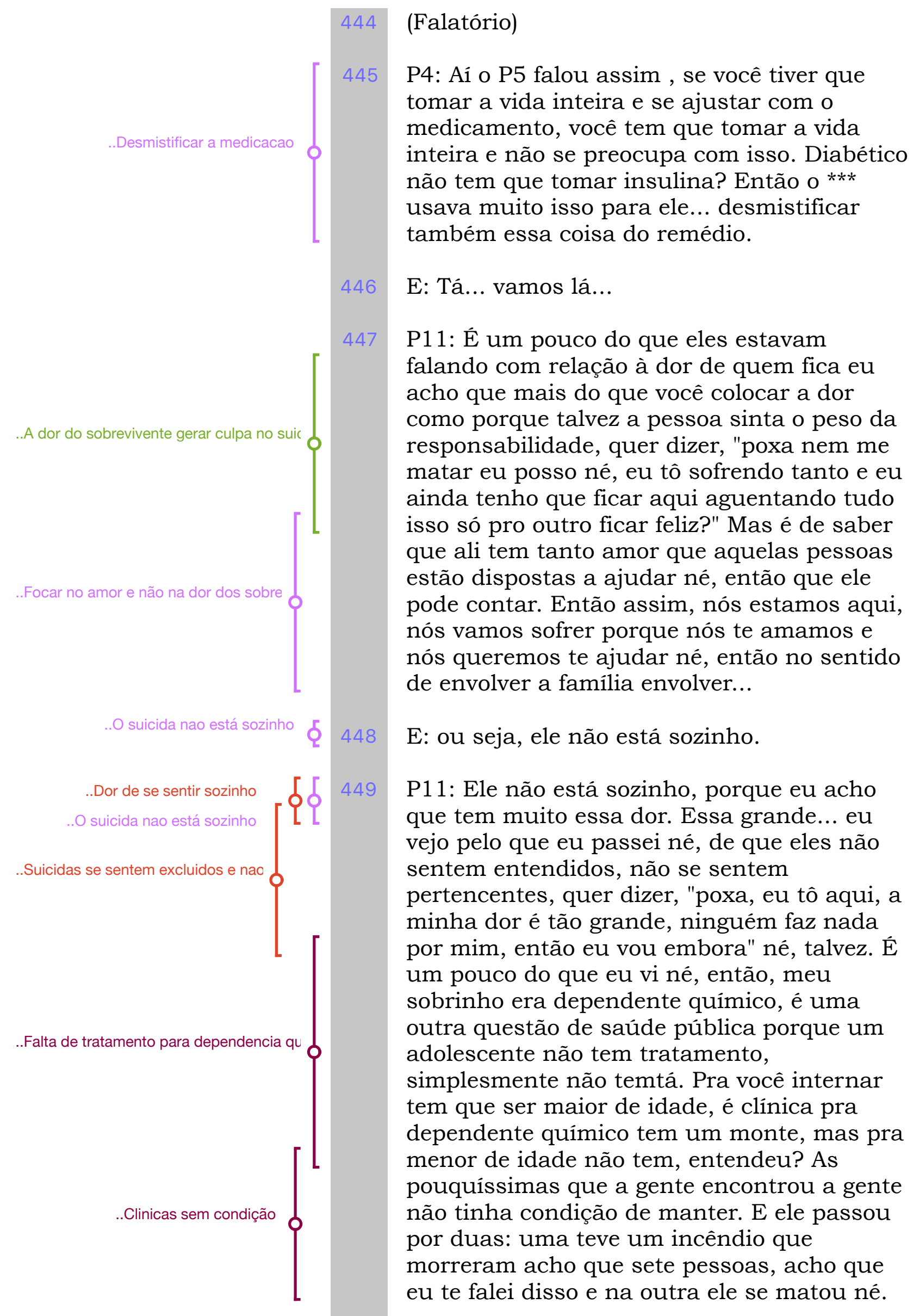




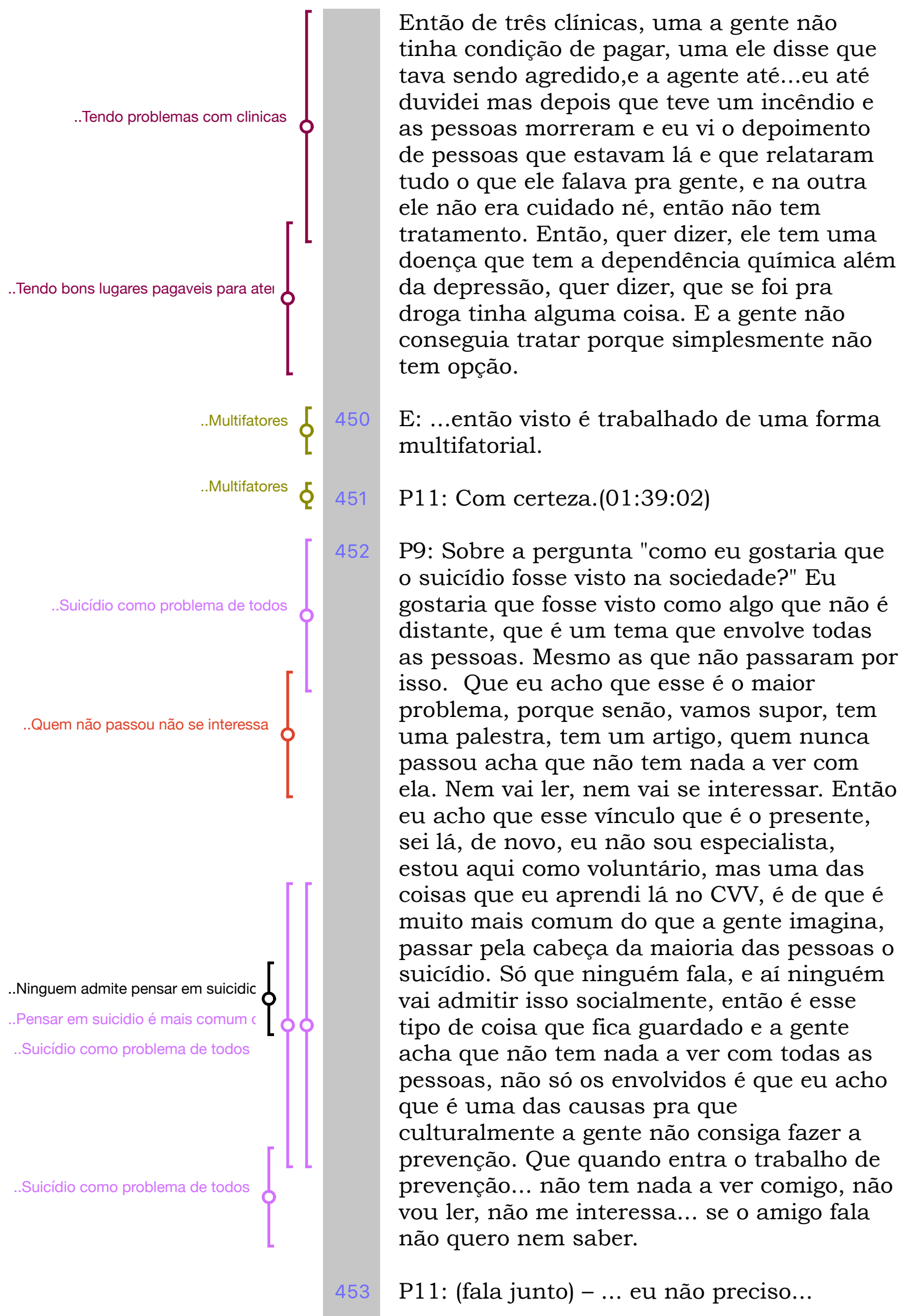


P1: É o caso do, quando você vai na página do seu amigo, que que te dar algo da prevenção de mama né, aquele negócio de mamas ou então de drogas, não é só pra quem tá viciado né, é também para quem né...então é pra ser uma coisa no geral. (01:40:31)

P5: posso falar uma coisa que não tem nada a ver, mas é rapidinho... só? (risos) O pessoal sempre tem essa mania né, só porque é dos outros, dos outros não quer nem saber. Não sou favor do aborto, mas há muito tempo atrás teve uma pesquisa pra liberar o aborto no Brasil, aí chegaram a seguinte conclusão da pesquisa, que jamais seria liberado no Brasil, por que ? Porque só a mulher quer fazer aborto, o homem não quer, então não é problema do homem. Se você pensar como o suicídio tá... Aí o que acontece...tava lá na faixa etária, quem tem menos de 15 anos não ia engravidar naquela época, é bem antiga a pesquisa tá... então ela é contra porque também não ia engravidar tá. $\mathrm{E}$ quem tinha mais de 40 e tava entrando na menopausa, das mulheres, também são contra porque elas não passariam pelo problema. Então, só quem votaria a favor seria de 18 a 40 anos, portanto nunca foi aprovado. Eles pouco ligam pro problema dos outros. A sociedade tem que se conscientizar que o problema do suicídio é de todos. Não é classe financeira, não é cor, não é credo, não é nada.De que todos tem esse problema. Só que o pessoal tem a mania de ver o problema como dos outros tásabe, é bem típico né, é dos outros é dos outros. Não é nosso. Então tinha que ter uma conscientização para todos se envolverem no problema.

Burburinho

P10: Acho que o que ele falou realmente, acho que se a gente associasse o suicídio a coisas normais do dia a dia, talvez as pessoas conseguissem criar mais empatia com o tema. Assim... de... é que suicídio é 


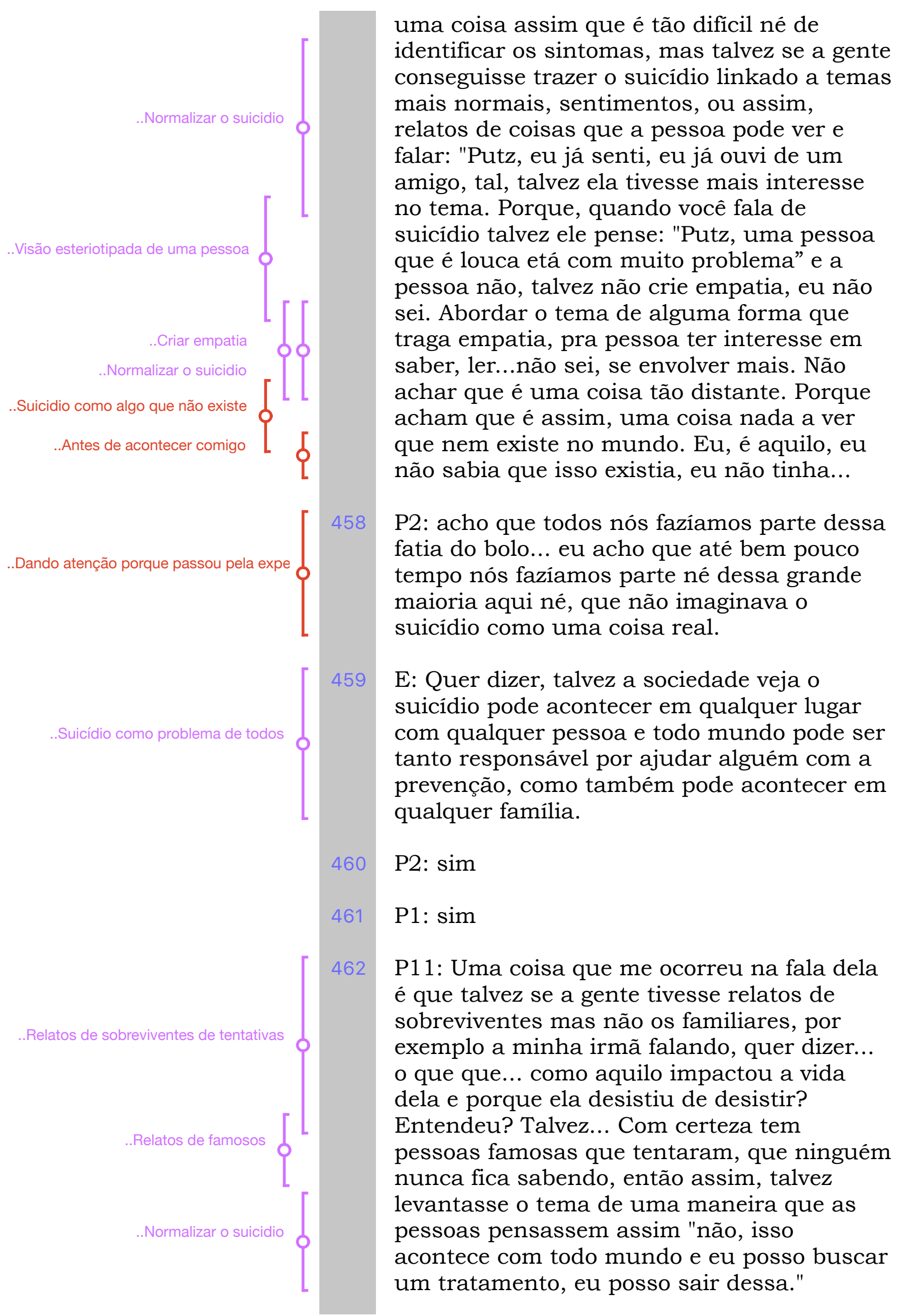




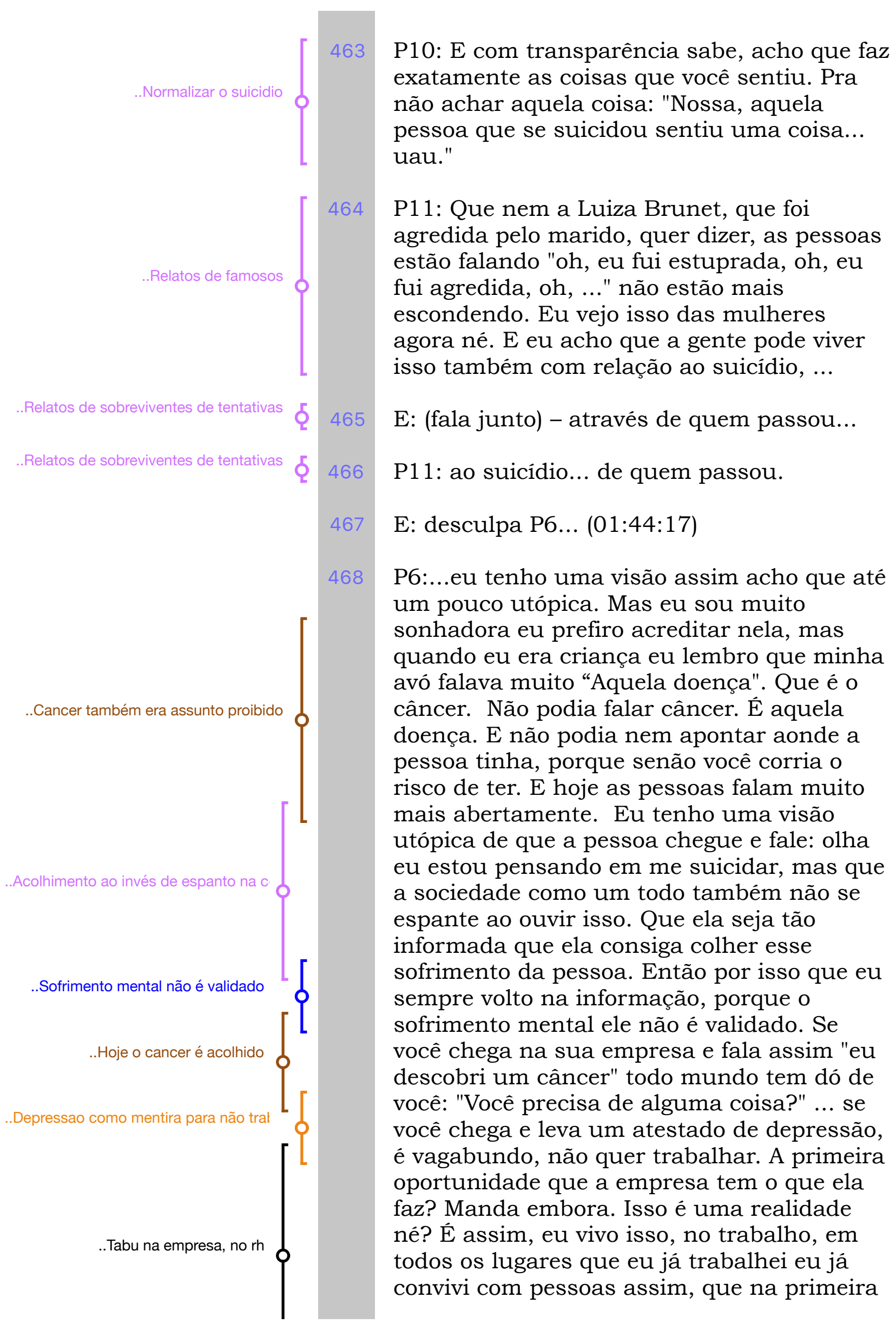




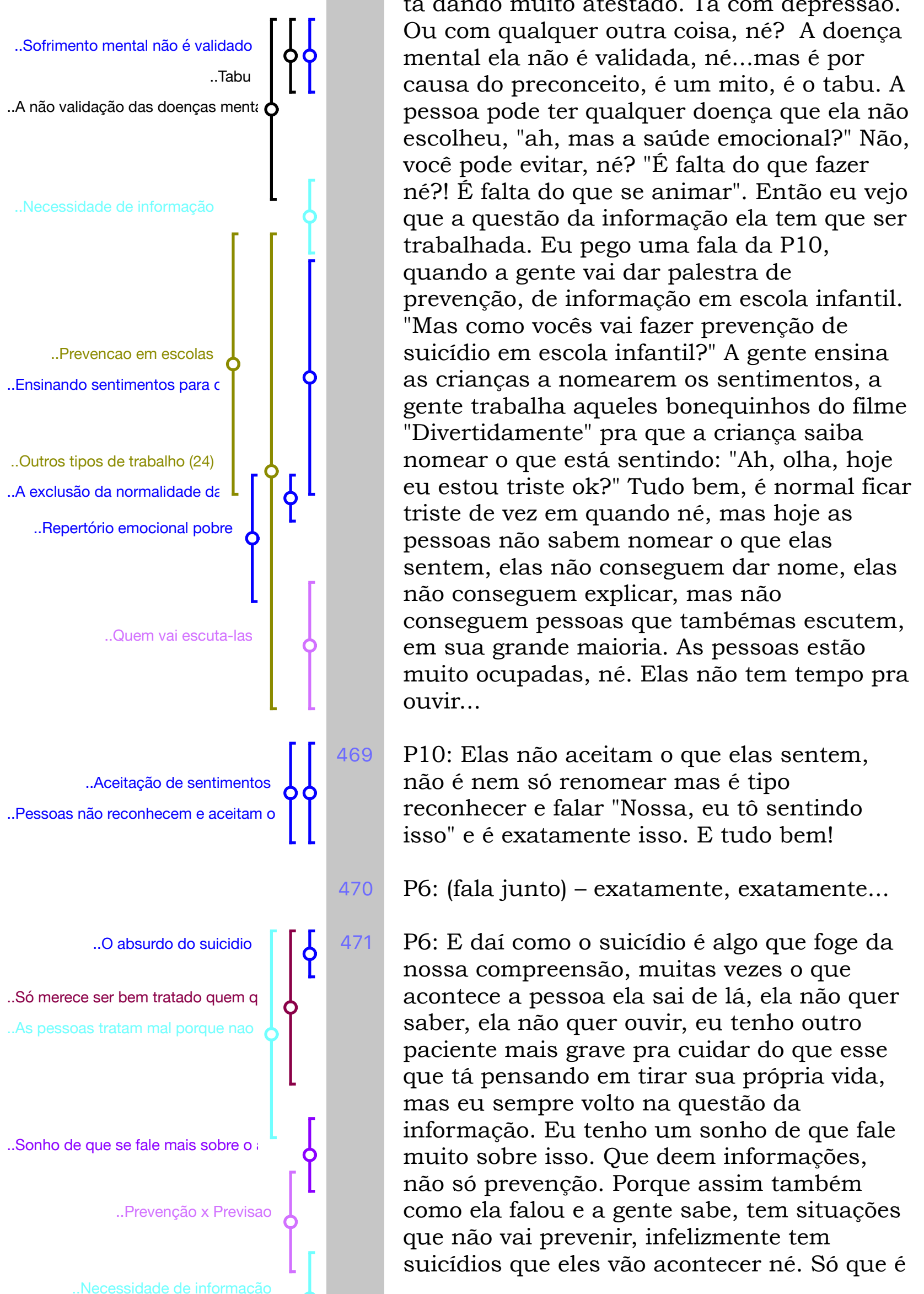

oportunidade o RH mandava embora porque tá dando muito atestado. Tá com depressão. Ou com qualquer outra coisa, né? A doença mental ela não é validada, né...mas é por causa do preconceito, é um mito, é o tabu. A pessoa pode ter qualquer doença que ela não escolheu, "ah, mas a saúde emocional?" Não, você pode evitar, né? "É falta do que fazer né?! E falta do que se animar". Então eu vejo que a questão da informação ela tem que ser trabalhada. Eu pego uma fala da P10, quando a gente vai dar palestra de prevenção, de informação em escola infantil. "Mas como vocês vai fazer prevenção de suicídio em escola infantil?" A gente ensina as crianças a nomearem os sentimentos, a gente trabalha aqueles bonequinhos do filme "Divertidamente" pra que a criança saiba nomear o que está sentindo: "Ah, olha, hoje eu estou triste ok?" Tudo bem, é normal ficar triste de vez em quando né, mas hoje as pessoas não sabem nomear o que elas sentem, elas não conseguem dar nome, elas não conseguem explicar, mas não conseguem pessoas que tambémas escutem, em sua grande maioria. As pessoas estão muito ocupadas, né. Elas não tem tempo pra ouvir...

P10: Elas não aceitam o que elas sentem, tipo reconhecer e falar "Nossa, eu tô sentindo isso" e é exatamente isso. E tudo bem!

P6: (fala junto) - exatamente, exatamente...

P6: E daí como o suicídio é algo que foge da nossa compreensão, muitas vezes o que acontece a pessoa ela sai de lá, ela não quer saber, ela não quer ouvir, eu tenho outro paciente mais grave pra cuidar do que esse que tá pensando em tirar sua própria vida, mas eu sempre volto na questão da informação. Eu tenho um sonho de que fale muito sobre isso. Que deem informações, não só prevenção. Porque assim também como ela falou e a gente sabe, tem situações suicídios que eles vão acontecer né. Só que é 


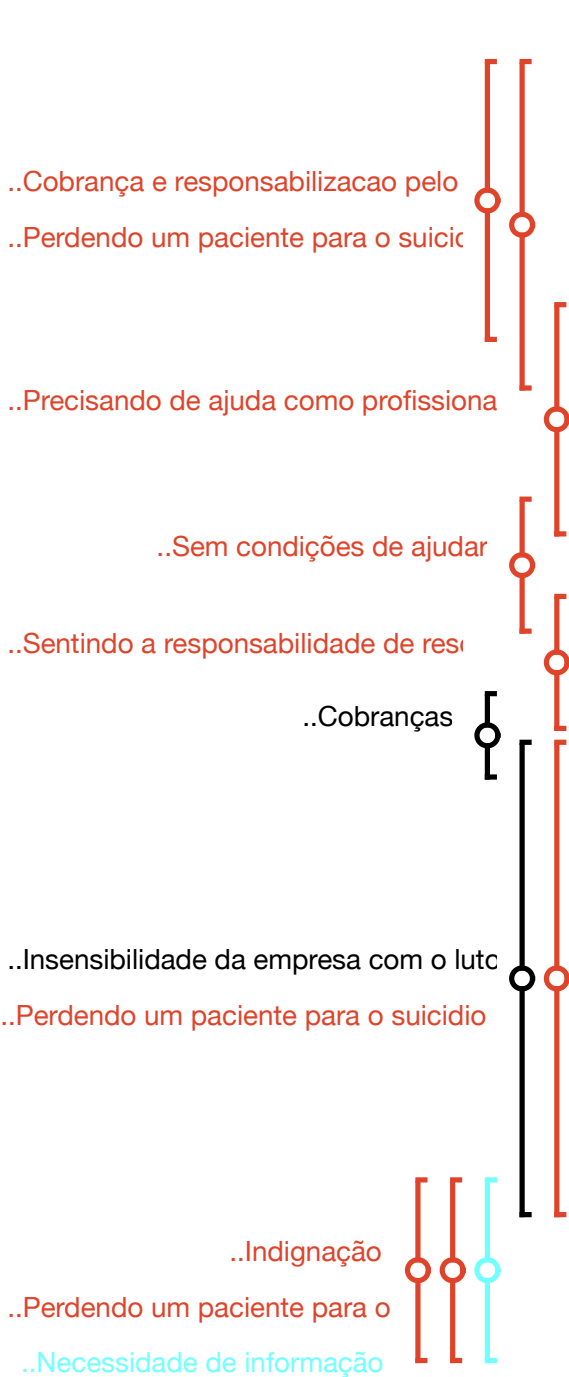

472
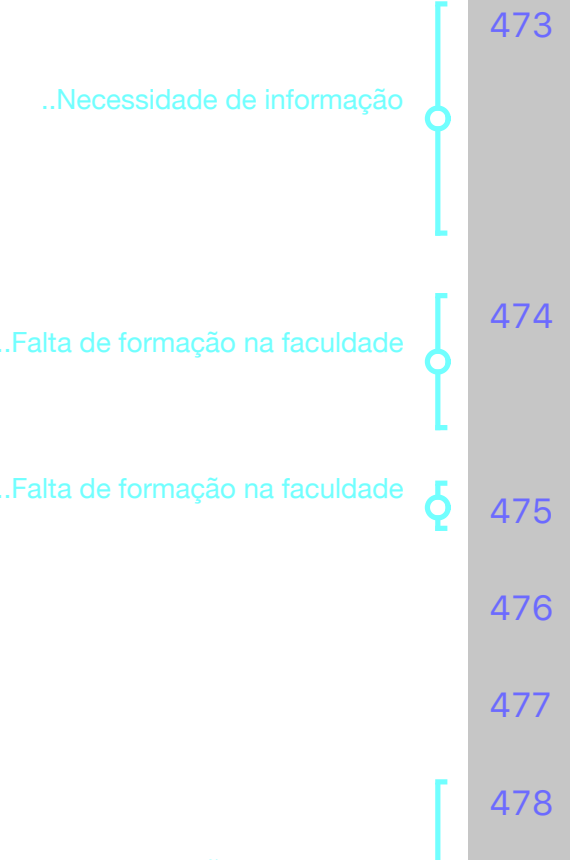

assim, a informação: as pessoas precisam ser informadas, todas elas. Quando eu passei por essa perda foi muito dificil, porque ligaram 5:30 da manhã em casa. "Você precisa vir aqui! ". Mais ou menos assim: "Oh, seu paciente se suicidou e agora você vem aqui atender a família" foi isso que fizeram comigo e eu estava destruida. Eu não tinha condições de ir pro hospital e atender aquela familia. Mas eu fui, mas naquele momento eu precisava de ajuda. Meu marido falou "você não vai sair de casa, olha pra você? Você vai fazer o que lá?" Aí eu falei: "não tem ninguém, eu preciso ir" e eu fui. Então assim, é cobrança de todos os lados. Já sei...e isso aconteceu de sexta pro sábado. Sábado de manhã eu fui lá, euatendi a família e na segunda feira eu fui trabalhar. E assim, a empresa não me chamou, a empresa não perguntou se eu queria um ou dois dias, se eu precisava de ajuda, e eu estava péssima. Fiquei dois dias no quarto sem comer porque foi muito assim, foi terrivel pra eu passar por essa situação. Falta de informação. O RH da empresa não sabia o que fazer comigo, a equipe toda destruída, ninguém sabia fazer nada, ninguém sabia nada cara...

P7: (fala junto) - é um tsunami... é um tsunami... não tem jeito

P6:... Falta de informação... então assim, eu sempre volto na informação, então eu acho que a informação ela vai ajudar e muito, não só a prevenção, porque as vezes não vai prevenir, mas todos impactados...

E: Eu não sei você P6, mas eu não tive nenhuma aula de prevenção de suicídio na universidade toda.

P6:Nenhuma. Nunca tive.

P7: Hã!?

P11: Era isso que eu ia falar...

E: Não se tem aula de prevenção de suicídio 


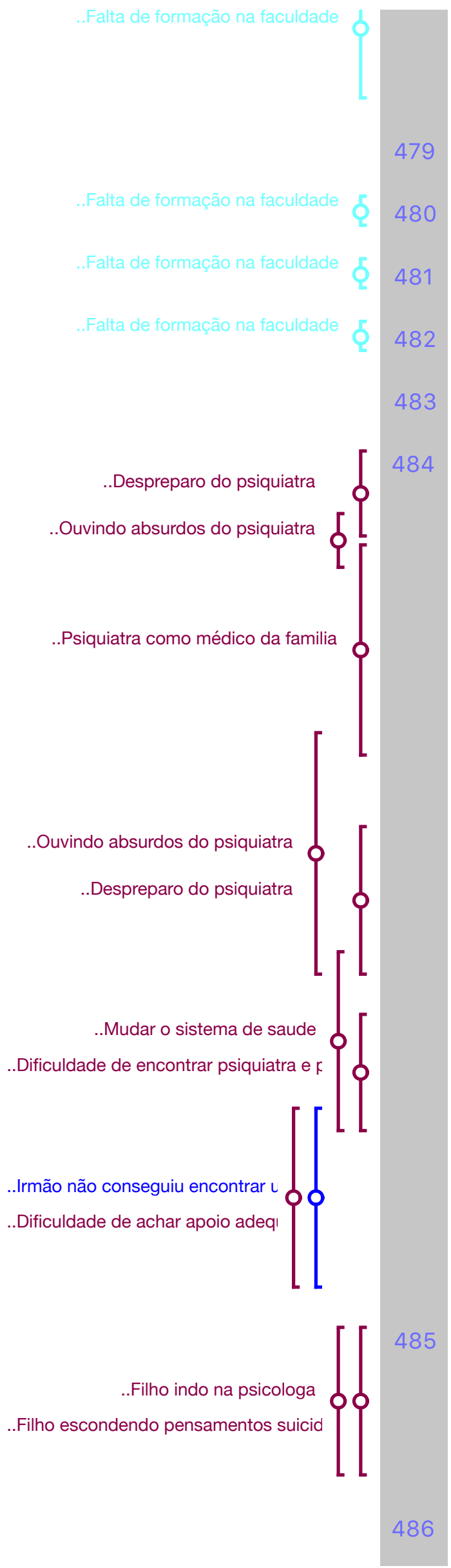

nas universidades de psicologia. Ela (sobre a esposa do P1) ainda está tendo, é um currículo novo.

(Falatório)

P1: não é matéria...

E: a matéria não tem?

P1: não, matéria não tem, é palestra...

(Falatório)

P8: eu ia falar exatamente sobre isso, porque muito psiquiatra não tá preparado pra tratar disso. Eu já ouvi de um psiquiatra coisas, já ouvi absurdos, assim. Eu vou ao psiquiatra há muitos anos, a gente até lá em casa sempre brincou que é o médico da família sempre foi o psiquiatra, meus irmãos vão e tal, meu irmão ia, meu outro irmão a gente tem, hoje a gente conseguiu achar um que a gente confia muito. Mas a gente ouviu muitos absurdos ao longo da vida, e uma das coisas é aquela coisa, "eu estou aqui pra tratar a vida, e não pra tratar a morte". Então ele já fecha aí uma porta de que a minha educação e minha formação foi feita... se você está interessada em morrer, não fale isso comigo. Essa, essa é a parede também, se a pergunta é assim, que o que você acha que tem que mudar, então eu acho que o próprio sistema de saúde, ele... mesmo psicólogos, é muito dificil você achar alguém que acolha e que ouça. Hoje eu encontrei, mas a gente sim...o meu irmão passou por uma... meu irmão estava desesperado procurando uma forma de sair daquilo e simplesmente não conseguia encontrar, não conseguia encontrar...

P4: O meu filho ia e falava de outras coisas, e nenhuma psicóloga chegou, me chamou das que ele foi... chegou e me chamou lá pra me falar: "olha, corre-se o risco." Porque não conseguia tirar dele,

P8: (fala junto) - e mesmo se conseguisse... 


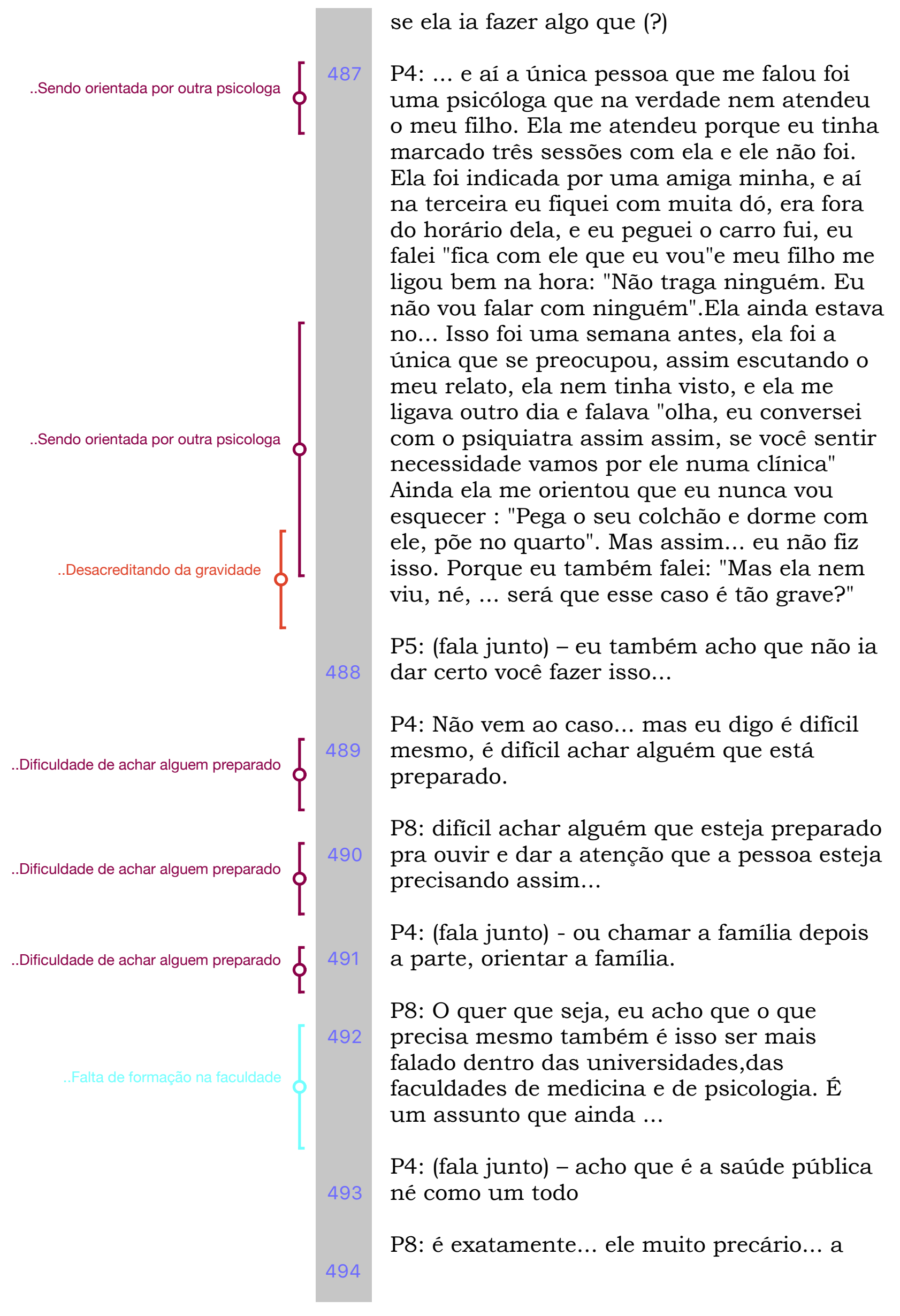




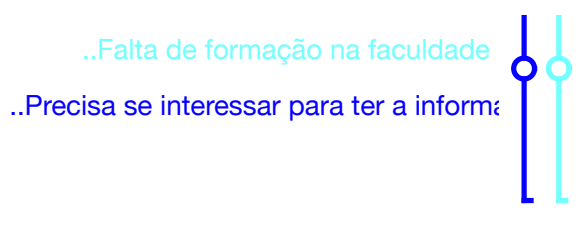

..Precisa se interessar para ter a informaca $\mathbf{Q}$ forma como é tratada dentro das faculdades mesmo. Ainda é uma coisa que só aquela pessoa que se interessou e foi atrás, e não é umamatéria.

P5: eu acho que quem passou pelo problema

E: a gente já está finalizando...

P11: outra coisa que vocês tão falando é de perceber ou não...é o depois que meu sobrinho morreu, lendo a ficha dele na penúltima clínica que ele passou, tinha que ele tinha acompanhamento lá e tinha coisas que ele escrevia e tinha coisas que a psicóloga escrevia. Tinha uma pergunta lá "pensa ou já pensou em suicídio?" E aí tava escrito assim: "sim, é o que mais penso ultimamente, mas não tenho coragem pois..." e aí não terminou de escrever a frase. Isso o psicólogo não finalizou ali, só que assim, isso não foi comunicado pra nós e nem na outra clínica que eles tiveram acesso a isso, porque a ficha foi de uma pra outra, não ficou com a gente né, a gente foi receber depois. Isso foi completamente ignorado pela psicóloga de lá também, entendeu, porque se tivesse sido dado atenção, quer dizer, você pega um adolescente que fala que o que ele mais pensa é em se matar, que tem problema de droga e ele tá lá, você vai deixar ele horas sozinho dentro do quarto?

Entendeu? Então assim, o que que faz com a informação? Também não adianta as vezes a pessoa pede, implora socorro e aí...

E: e aí essa informação é ignorada.

P11: Ignorada completamente

500 P5: Posso fazer uma pergunta para ti, qual é a profissão e o que é dos maiores índices, você tem aí dessas pesquisas aí de suicidas?

E: Qual é a profissão que mais se mata?

P5: É

P7: não são os médicos? 


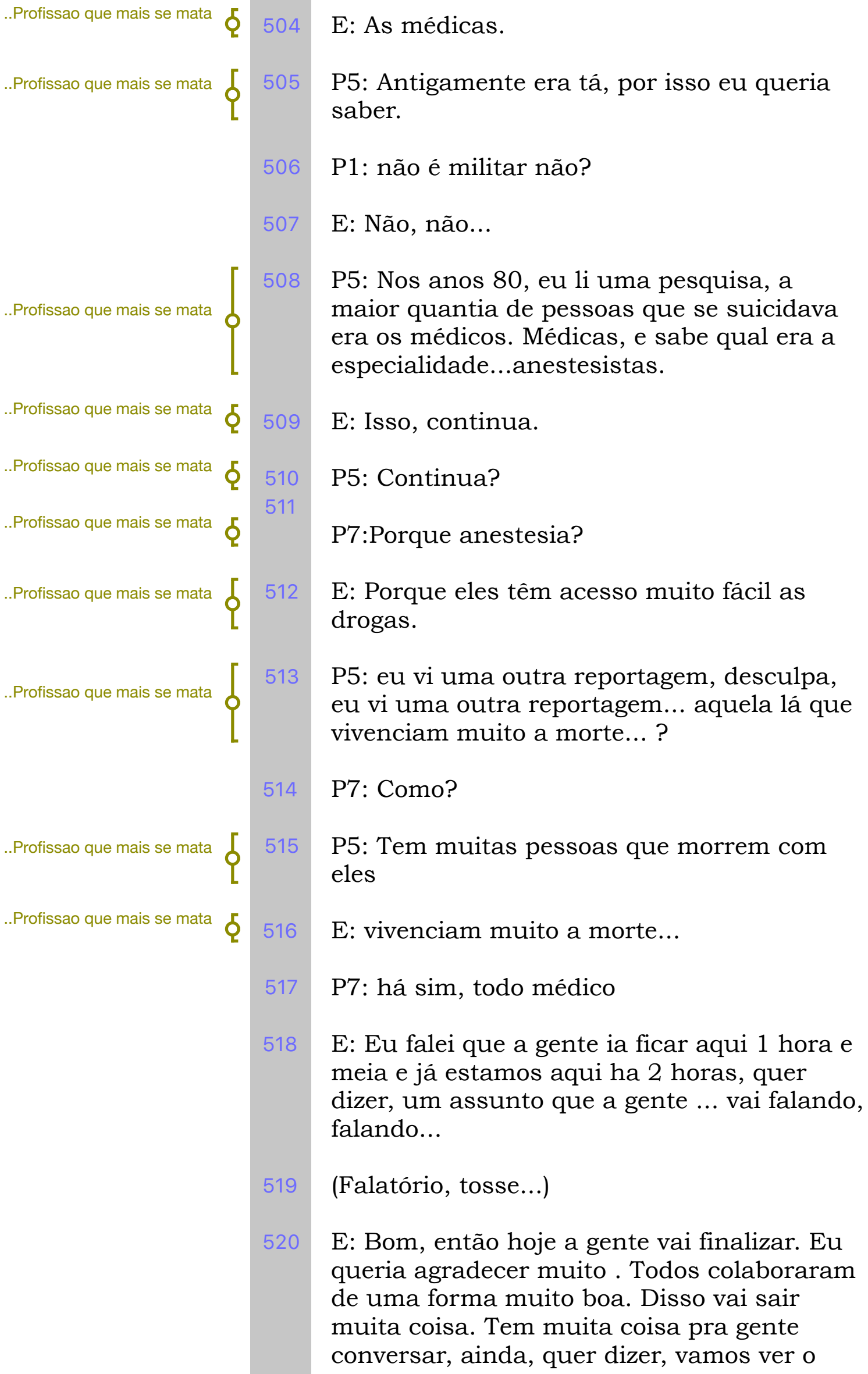

..Profissao que mais se mata

508

Profs

Profissao que mais se mata

Profissao que mais se mata

..Profissao que mais se mata

.Profissao que mais se mata

.Profissao que mais se mata

Profissao que mais se mata

Profissao que mais se mata

E: As médicas.

P5: Antigamente era tá, por isso eu queria saber.

P1: não é militar não?

E: Não, não...

P5: Nos anos 80, eu li uma pesquisa, a maior quantia de pessoas que se suicidava era os médicos. Médicas, e sabe qual era a especialidade...anestesistas.

509 E: Isso, continua.

510

511

P5: Continua?

P7:Porque anestesia?

512 E: Porque eles têm acesso muito fácil as drogas.

513 P5: eu vi uma outra reportagem, desculpa, eu vi uma outra reportagem... aquela lá que vivenciam muito a morte... ?

514

P7: Como?

515

P5: Tem muitas pessoas que morrem com eles

E: vivenciam muito a morte...

P7: há sim, todo médico

E: Eu falei que a gente ia ficar aqui 1 hora e meia e já estamos aqui ha 2 horas, quer dizer, um assunto que a gente ... vai falando, falando...

(Falatório, tosse...)

E: Bom, então hoje a gente vai finalizar. Eu queria agradecer muito . Todos colaboraram de uma forma muito boa. Disso vai sair muita coisa. Tem muita coisa pra gente conversar, ainda, quer dizer, vamos ver o 
que a gente consegue conversar daqui ha 2 semanas, se não eu mando depois pra vocês o que faltou se vocês quiserem completar, enfim

521 P10: faz um terceiro...

522 (risos)

523 E:...E eu queria realmente agradecer muito a presença de vocês. Qualquer incomodo, se precisar conversar, precisar falar, entrem em contato... vocês tem os meus contatos, aí, e eu vejo vocês, então, no dia ****, às 7:30 neste mesmo local. Tá Bom? Obrigada, gente. 


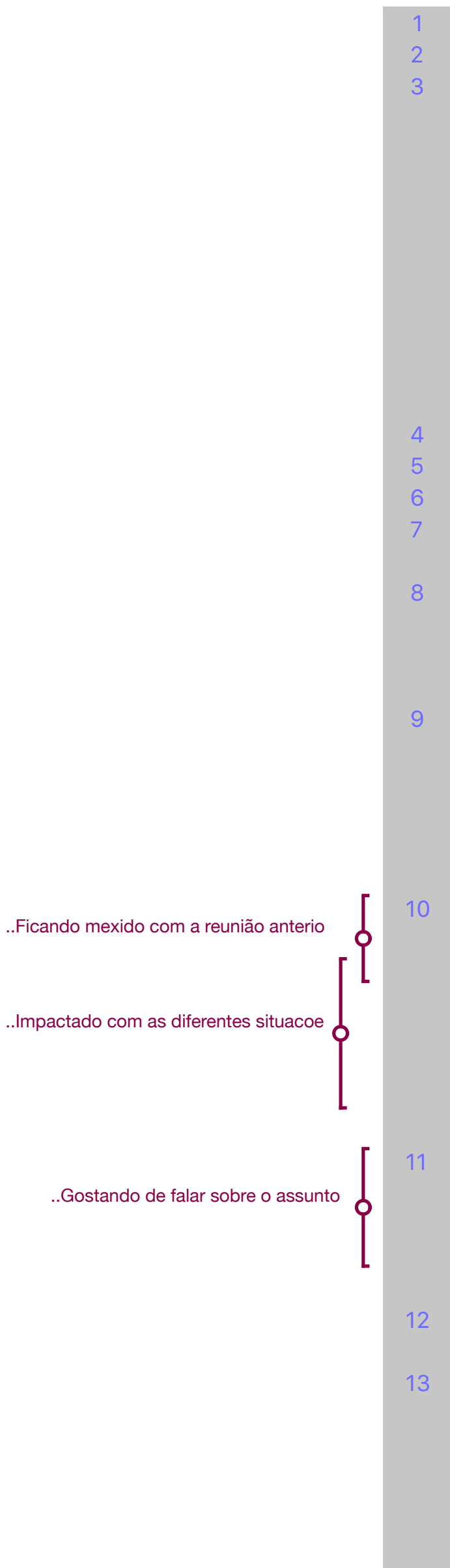

TRANSCRIÇÃO 2 -

Primeira Parte: 01:36:55 h

E: Boa noite. Sejam bem vindos. Bom, a ideia é de que a gente continue conversando sobre o mesmo tema, que é o aumento da consciência pública, eu trouxe algumas perguntas, mas antes de começar eu queria que vocês falassem só o nome de vocês de novo pra poder registrar, tá? Não precisa falar a idade, nada, só o nome e assim, rapidamente, se ficou tudo bem, como é que vocês ficaram depois do encontro, focado no que a gente conversou, enfim.

P1: $* * * * * * *$ Tranquilo, normal

P2: *******. Fiquei bem.

P4: *******. E tudo bem, também.

P3: *******. Também foi, tranquilo.

P8: *******. Eu acho que foi tranquilo. Acho que as questões que foram apresentadas foram bem interessantes. Foi muito bom.

E2: $* * * * * * *$, sou psicóloga e peço desculpas porque até muitas vezes eu fico calada mas é porque a experiência de estar aqui ouvindo vocês é muito importante e agradeço por estar aqui de novo.

P9: *******. Eu fiquei um pouco mexido, e até a gente conversou depois, mas agora estou bem. É só comentando acho que (?) Como eu vi que são várias histórias diferentes, aquilo que muitas vezes a gente trás de ideia impacta outras pessoas e vice-versa. São situações diferentes. Isso me impactou.

P10: *******- Eu fiquei bem. Inclusive eu achei bom que na mesma semana teve uma reunião a mais. Quer dizer... aqui né, mesmo assim, uma vez a mais...

(Risos)

E: Foi um bônus?.... Tá certo. A gente, na reunião passada uma das coisas que foram levantadas é que antes não se falava tanto e agora se fala mais do que antigamente. Por que vocês acham que isso aconteceu? Por que hoje já se fala mais do que se falava 


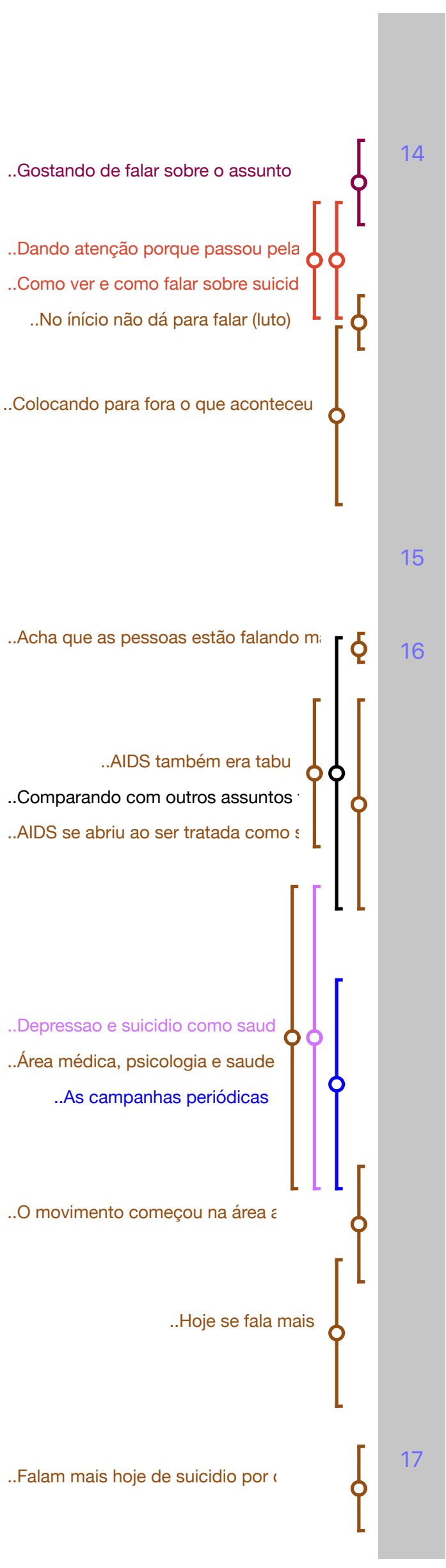

antes? Vocês acham que tem a ver com a imprensa? Com... O que vocês acham que motivou as pessoas começarem a falar mais?

P1: Bem, primeiro porque você não tinha ainda nada acontecendo com você ou com sua família então você não se preocupava. Você passou ser o centro, aí você tem uma maior preocupação, tanto de você vê como de repassar a notícia. No início você fica com aquele impacto de ficar aquilo reservado, mas pelo menos a gente, a gente pois para fora, entendeu, acho que foi uma das maneiras de se dar, é botar isso para fora e não ficar com aquilo dentro esconder, como se fazia antigamente.

E: Então você acha que as pessoas estão falando mais, então?

P1: Eu acho que sim. Não só porque você passou por isso mas.... éééééé porque já assim, ééééé como outros problemas aí, quando começou a AIDS aí a um tempo atrás, não sei, uns 18 anos, então no começo também era um tabu se falar em AIDS né, ai quando passou a ser considerado uma preocupação de saúde pública, então se abriu. Hoje eu sei, pelo menos quem trabalha na área, como da psicologia, da psiquiatria, ou seja, da área médica de um modo geral. Eles tão trabalhando no intuito de levar também a questão da depressão, pra mim assim, vai juntando a depressão com o suicídio, com também algo de preocupação de saúde pública, pra ter campanhas periódicas para poder, tipo o câncer, AIDS, né. Então isso tem movimento e esse movimento, queira ou não queira, embora seja na área acadêmica, mas chega de um modo geral. Então há essa preocupação hoje de fazer com que se procure dar uma atenção maior a essa problemática, então eu acho assim... tá sendo bem mais comentado atualmente

P4: Eu acho que pela própria, pela depressão. Eu acho que começou a se falar muito em depressão, né? Os sentimentos da 


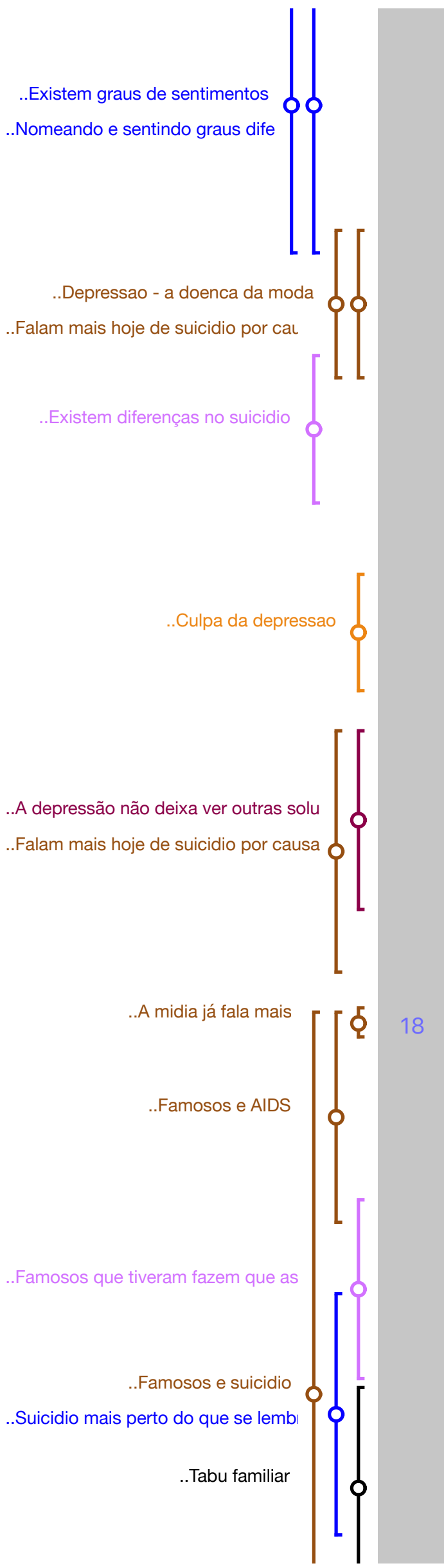

perda vão existir sempre, eu acho mas não denominava esse nome e eu acho que de repente começou, de uns anos pra cá, a todo mundo sentir, raramente você ouve as pessoas falarem em graus diferentes mas as pessoas sentem e até tentam por pra fora aquela angustia, aquela denominada vários nomes: angustia, tristeza, tal. Quando depressão alguns falam: "Ah, a doença da moda". Não é, mas eu acho que daí começou a falar nisso e isso começou... por que? Eu acho que tá muito associado. Isso a gente até na saída daqui a gente foi conversando, aquele dia, porque a gente levantou que as diferenças... as vezes o suicídio dá aquele impacto ou por uma questão econômica, então vamos dizer, mas daí até o * levantou para a gente e, falou assim... mas naquele momento ele falou.. mas é que vocês estão falando em depressão, assim, de uma pessoa deprimida há muito tempo, fazendo um tratamento. Ele falou assim: "Mesmo que uma pessoa esteja com a questão financeira" Aí eu até achei bem colocada dele, ele falou: "Naquele momento ele estava deprimido pra fazer aquilo porque se não você vai pensar outras soluções, bom enfim, aí pensar em outras soluções pra ou começar de outro caminho. Eu acho que está muito associado por isso que eu acho que começou a falar mais.

P2: Eu acho que a mídia também, né? Como, quando o P1 falou da AIDS, a gente costuma tomar conhecimento da AIDS quando a gente ouve do Michael Jordon e o Cazuza, e ultimamente a gente tem ouvido também né, várias personalidades, né, que morreram por suicídio. E isso faz com que as pessoas parem e pensem: "Puxa, o famoso, teoricamente não tem problema, tem fama, né? Então eu acho que isso leva as pessoas a comentarem, pelo menos, um pouco mais assunto, e a gente sai da casa da gente, né? Que eu tive. Depois que o (nome do filho) se foi eu lembrei que eu tive um primo que se suicidou ha alguns anos atrás e que meu marido também teve um primo que se suicidou. Mas foi tão... as pessoas não 


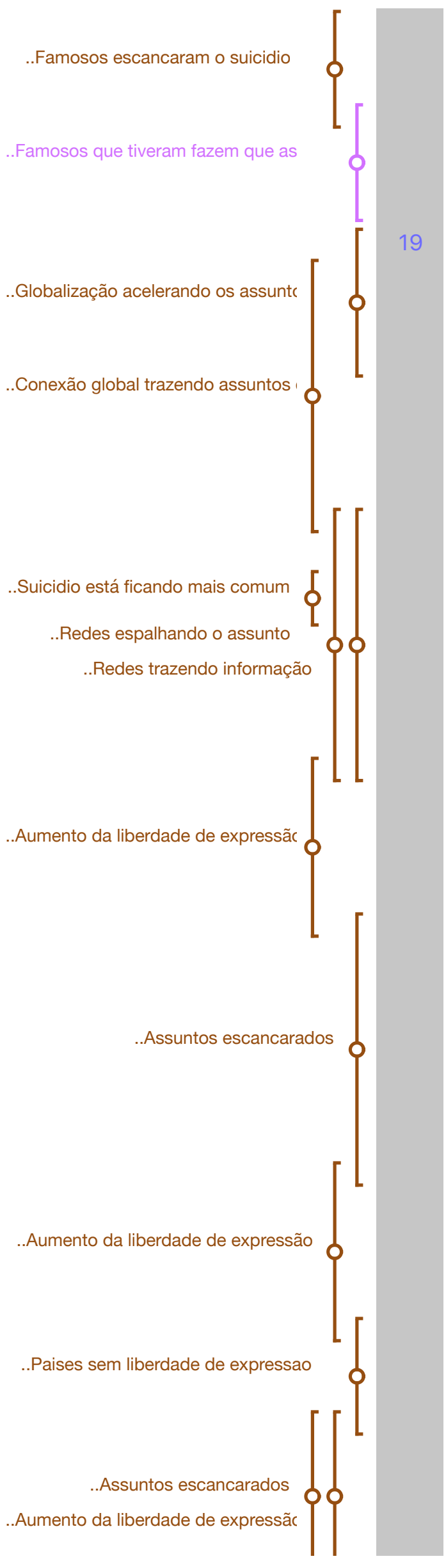

falam. A família não falou. E quando é uma personalidade, eu acho que torna tão público que fica dificil a gente colocar um véu e fingir que não está sabendo de nada. Eu acho que acaba contribuindo de alguma forma também para que a gente perceba e olhe para o assunto né, para essa questão.

P10: Assim, a sociedade ela vem..., hoje a gente fala né da globalização é etc e eu acho que isso ajuda bastante porque tá tudo muito conectado, as pessoas ficam sabendo de tudo mais rápido, então desse assunto também, assim como outros assuntos que a gente vai descobrindo e vai vendo né que existe e aí a sociedade começa a tentar a trabalhar em cima, ou por exemplo, uma doença, tenta achar a cura... teoricamente... Então eu acho que o suicídio é um assunto também que vem aí nessa...como se torna cada vez mais comum, dele acontecer e hoje com as redes você consegue ter mais informação, eu acho que isso acaba se espalhando bem mais do que antigamente, então eu acho que acaba,assim como outros assuntos também vindo mais à tona. Eu acho que a questão de liberdade de expressão também, acho que os seres humanos eles tem tem se sentindo acho mais empoderados a falar de certos assuntos que antes eram dificeis. Então eu acho que esse é um assunto também que é difícil que cada vez mais as pessoas assim, não tem mais medo, não tem mais vergonha, assim como alguns outros assuntos dificeis que a gente tem hoje que as pessoas, por exemplo, levantam bandeira e lutam por certas causas que antes não era uma coisa tão escancarada. Você talvez ia sofrer muito mais preconceito ou sofrer muito mais por levantar uma certa bandeira ou tocar em determinado assunto. Acho que a gente, não todos, a gente é um pouco mais livre do que antes, acho que ainda existem países em que muita coisa ainda fica escondida, velada e as pessoas sofrem porque elas não poderem falar...Mas eu acho que cada vez mais a gente tem...te dão mais liberdade, enfim, e não tem mais vergonha, nem medo, nem se sente oprimido por falar de certos 


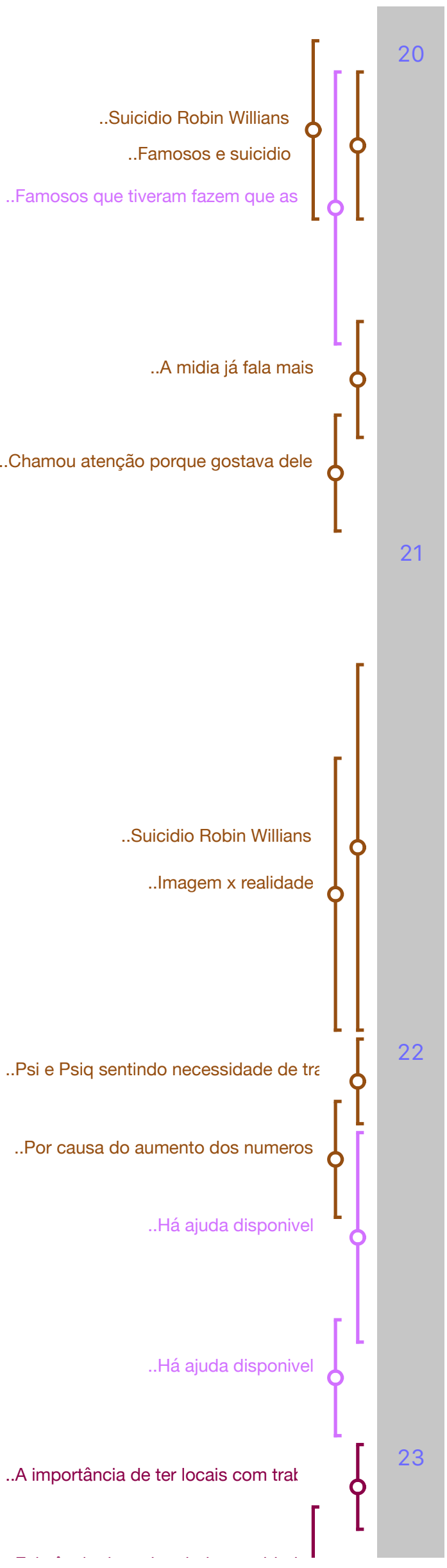

temas.

P9: Então como exemplo, particularmente, uns anos atrás, o Robin Williams, eu sempre gostei dos filmes dele e via ele como uma referencia de uma pessoa alegre e os filmes eram auto astral, assim, me chocou o suicídio dele. Então isso me marcou e ainda me fez parar pra pensar, assim, que eu tinha uma imagem dele, do trabalho dele, e ele vivia uma outra coisa, assim. Foi algo que me marcou. E eu acho que aí foi falado muito. E foi um momento, assim. Particularmente que me marcou e tem a ver com essa mídia, assim. Se não fosse um ator que eu acompanhasse, gostasse dos filmes,talvez passasse batido mas chama a atenção.

P1: Só uma parte do que ele falou, que eu tenho uma coleção de DVDs originais daquilo que eu gosto, sabe? Eu vou lá e compro, né? Mesmo que tenha 10 anos o filme, sabe... aí um deles, acho que o nome é "Amor além da vida" eu assisti 10/15 vezes tá certo? Então eu tinha aquilo assim... você associa no caso ao ator, né? À pessoa, né? Que são coisas distintas mas você associa, se você ficou chocado e também fiquei,da mesma forma porque aquele filme pra mim, eu assisti 10/12/15 vezes e eu fiquei pensando: mas ele vai buscar a mulher dele no inferno, como ele diz, foi buscar no inferno, e aiele comete o suicídio, entendeu? Pra mim, realmente foi um choque.

P3: Eu acho que a própria psicologia, psiquiatria está percebendo que há necessidade de se colocar isso público e que como está aumentando o número, então, se tem essa necessidade de dar mais informação ao público em geral, as pessoas deprimidas e que podem ser ajudadas e que não precisam chegar a esse extremo que, através da psicologia e da psiquiatria ha uma grande ajuda. Eu acho que isso é muito importante. Chegar a público e a imprensa em geral pra dar essa informação que as pessoas podem ser ajudadas.

P1: O trabalho, né, do (nome de uma instituição), né, porque eu acho assim... importante... em São Paulo é comum e em 


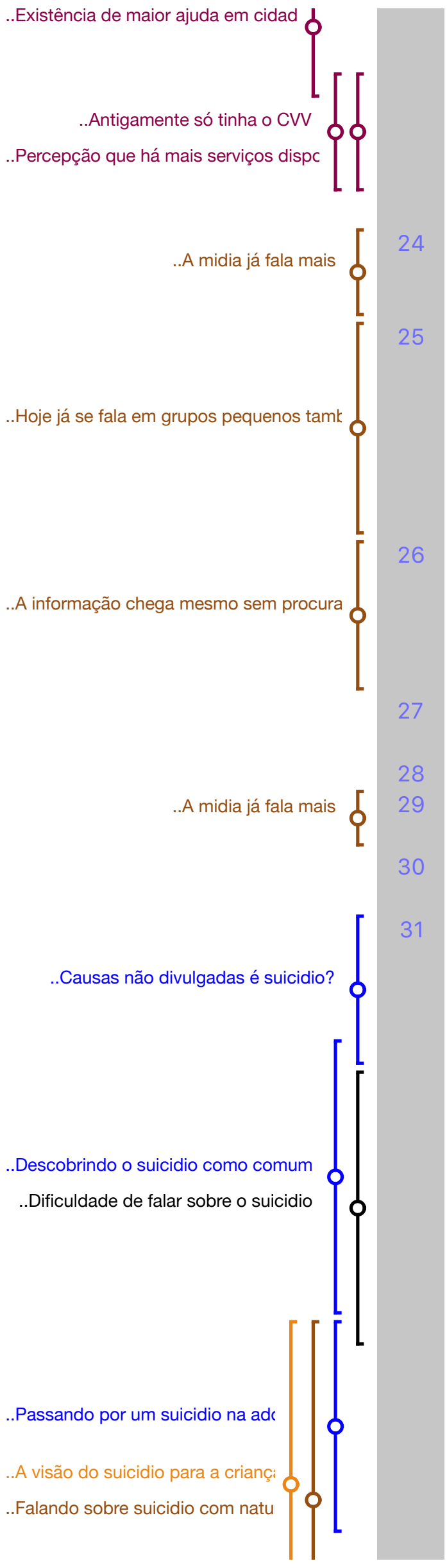

(nome de uma capital) é bem menor do que São Paulo, né? É que aqui é a capital do país, viu! Então, São Paulo é... (nome de uma capital) até um pouco tempo atrás você não tinha o que tem hoje, só o CVV né, não tinha entendeu, aí hoje, já tem...

P3: Mas eu digo assim, a imprensa em geral. Você liga a televisão as pessoas estão dando informação...

P1: Exato, exato, assim, esse de boca a boca assim, também é muito pequeno, pequeno né, assim aqui, pequeno né, tem 10, 12 pessoas né, mas cada pessoa ela multiplica née faz alguma ação, faz alguma coisa que divulga né, quer dizer, antes você não tinha isso também não.

P3: Sim, mas mesmo que você não vá procurar a informação chega até você, através do jornal, imprensa, televisão. As informações estão chegando sem você procurar. Isso eu acho muito importante.

E: Que era uma informação que não tinha muito antes né...

P1: Exato...

E: Não saia, não tinha algo na imprensa... Hoje se vê mais na imprensa.

P3: Eu acho que isso está ajudando bastante...

P8: E aquelas causas não divulgadas. Eu não sei se aumentou tanto o número. Se aumentou, se diminuiu, acho que esse receio de se divulgar que uma causa de uma morte é por suicídio ou não. Acho que não sei dizer. Eu acho que de fato è essa questão de você ter os meios de comunicação falando mais, eu acho que as pessoas se comunicando mais e de repente descobrindo que elas tem mais em comum porque aquela coisa acho que...quase todo mundo tem de alguma forma é... alguém no seu ciclo que já passou por isso. Mas não comunica, não fala. É como se fosse uma... eu acho que ... me lembro a primeira vez que eu falei alguma coisa sobre isso com alguém, eu devia ter uns 13/14 anos porque a esposa do meu tio tinha acabado de se suicidar... eu tinha é uns 12 anos quando ela fez isso, a esposa do meu tio. Ela era nova tal mas eu 


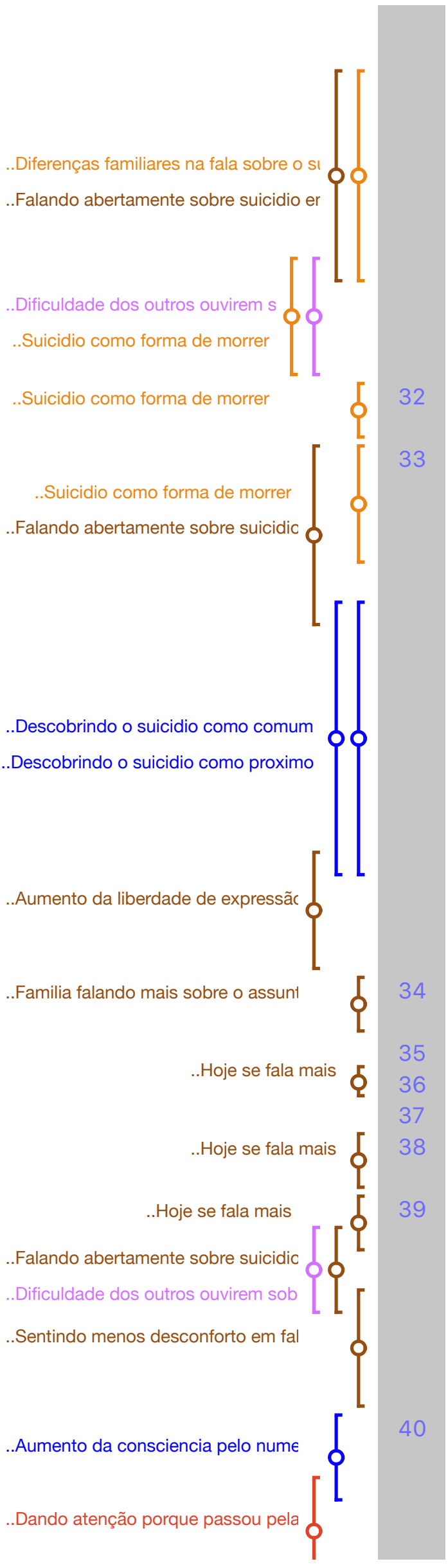

falei assim como se fosse a mesma coisa que ela tivesse morrido do coração e aí me arregalaram o olho, assim, e eu fiquei: "Ué, mas..." Porque era um assunto que em casa, assim, um lado da família falava o outro não... mas porque a minha mãe também tinha tido uma tia que tinha se suicidado. Então era uma coisa que se falava de certa forma, à mesa, né? Mas eu me lembro desse, desse choque das pessoas. E eu não falava pra chocar. Eu falava porque sei lá, na minha cabeça era uma forma de morrer.

E: Não tinha preconceito, né, era uma forma de morrer...

P8:Não tinha. Era uma forma de morrer. Era uma forma de morrer e a gente conversava sobre isso... Sempre se conversou sobre isso, em casa. E sempre se falou sobre isso, sobre outras questões delicadas, assim, a gente sempre falou. E eu acho que, depois de um tempo que as pessoas foram começando a ver que se elas forem parar pra pensar elas tem mais pessoas próximas do que ela imaginam mas por alguma razão elas não falam e hoje eu acho que elas começaram a falar e ver: "Olha, e não é que é verdade que tem alguém próximo e que isso já aconteceu mas eu não quis enxergar". Eu acho que tem isso. Acho que as pessoas estão se comunicando mais. Falando mais sobre assuntos...

E: Quer dizer, mesmo dentro da própria família.

P8: É...eu acho que sim...

E: Família, amigos, círculo social...

P8: É...exatamente...

E: As pessoas estão falando mais no assunto, no geral.

P8: Eu acho que sim...não sei...dá uma impressão.Assim, como isso sempre foi um assunto dentro da minha casa... mas eu sei que se falasse fora arregalava-se o olho, hoje eu já não sinto mais tanto desconforto de falar isso, sobre o assunto, como eu sentia, éééé, assim....

P10: E aí eu fico pensando, né, se, assim, a gente está falando mais porque não sei se tem mais casos ou não e quem passa a entender que isso é uma realidade por que 


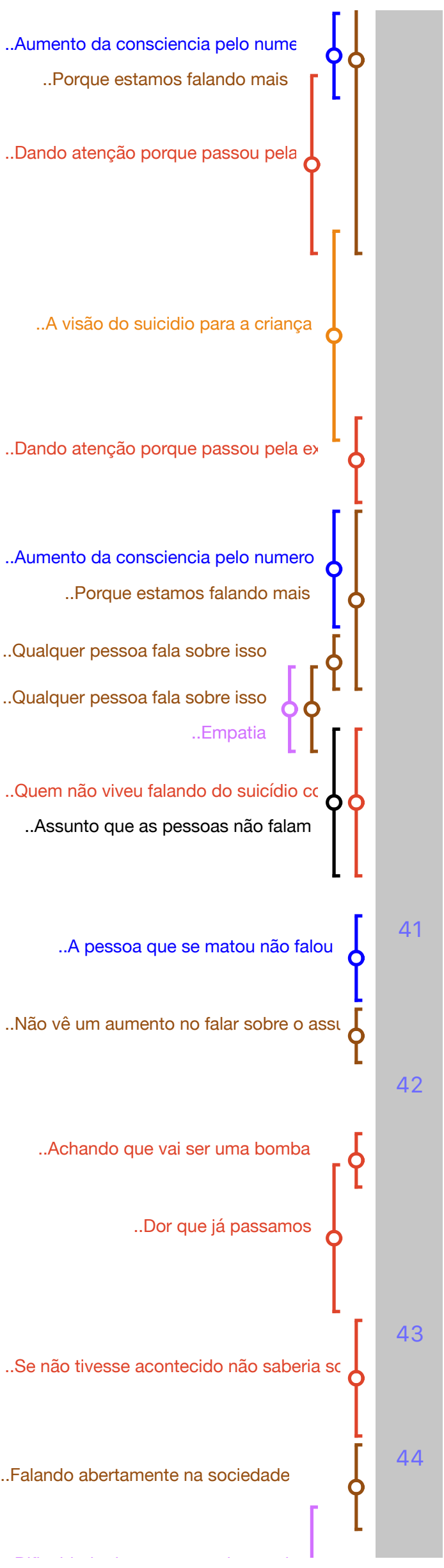

passou consegue falar do assunto. Porque, será que a gente tá falando mais ou tem mais casos e as pessoas entendeu, que vivem isso estão, sabe porque aquilo que eu falei na sessão passada: Pra mim o suicídio só se torna real na sua vida depois que você realmente... porque se não, acho que é uma coisa.. Até você estava falando, eu lembrei que a minha melhor amiga, a tia dela tinha tentado e quando eu era menor eu acho que fiquei sabendo dessa história, mas eu nem achei nada a respeito. Sabe quando você nem... acha que é grave, nem que não acha nada. Mas hoje, quando ela me conta eu falo:"Nossa!" eu entendo mas porque agora eu passei. Então eu não sei se..., sabe, quem vem primeiro. O que está fazendo com que as pessoas falem mais. Será que é porque temos mais casos e elas passaram a enxergar isso como putz acontece, ou...qualquer ser humano consegue falar mais sobre isso. Porque eu não sei se as pessoas têm empatia e elas estão falando: "Noooossa, realmente, assim, uau!" Mas se não é algo...Porque não é um assunto assim tão... Por exemplo, você esta na roda de amigos, ninguém fica falando sobre isso. Ou tem gente que ainda faz brincadeira, sabe?

P4: Eu acho que nem nas nossas experiências, nem eles mesmos nos falaram, nem a pessoa que está sentindo... Eu ainda acho...Eu não vejo esse falar muito também, não.

P1: É porque assim, como eu estava falando, e assim, o que a gente, a gente que passou, de alguma forma para a gente, a gente acha que ainda está assim, vai ser uma bomba, mas não tão mais como era antigamente, para a gente, porque a gente já passou por essa dor, estava passando e vai, cada um acaba sentindo...

P4: E a gente sente, é o que ela falou, a gente acaba sentindo que talvez se não tivesse acontecido com a gente a gente nem saberia sobre isso.

P1: a gente fala assim, as vezes é normal, mas a gente não esconde, a gente conversa tal, quem quiser ouvir... aí eles decidem se 


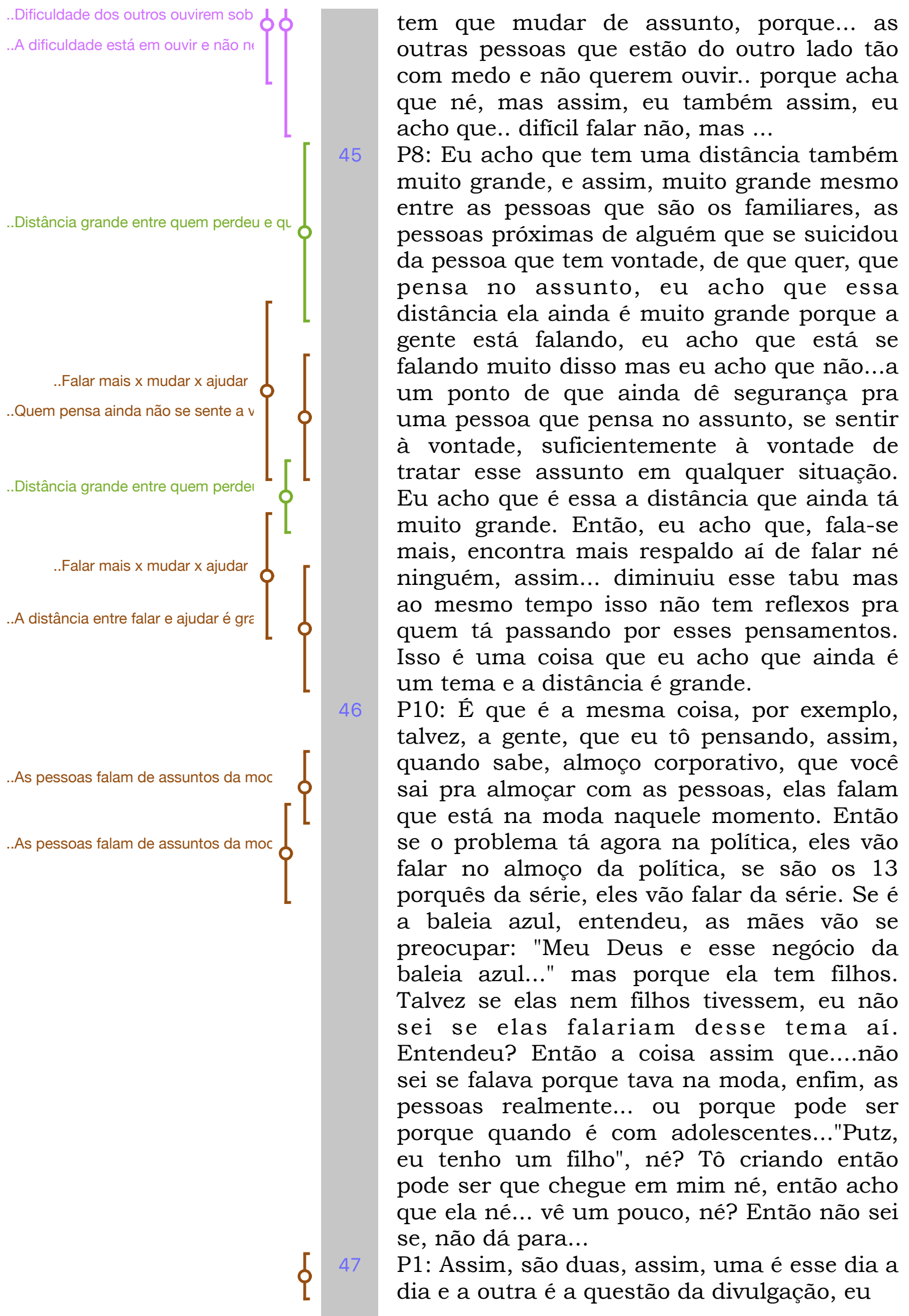




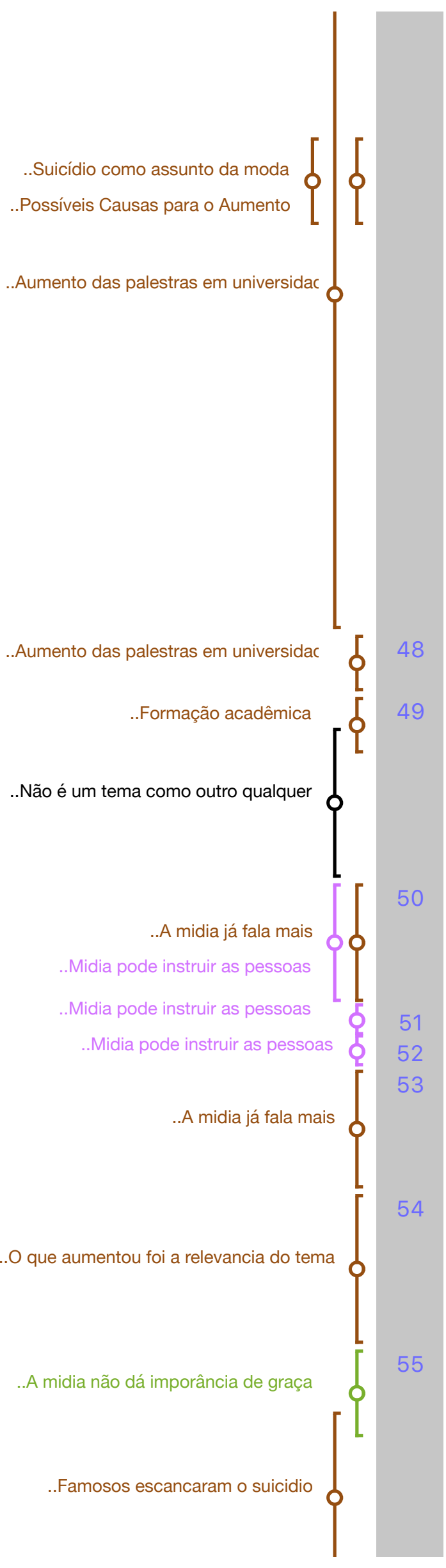

não sou da área mas a minha esposa faz psicologia e eu fico acompanhando a * em algumas coisas, palestras e tal e então ela já comentou que nesse último ano, do ano passado para esse ano, o que tem de palestra em que a moda do tema é falar sobre o suicídio porque antes não se falava né, eu acho que nem disciplina tem que se fale sobre isso, então, só esse ano já foi 2 , e nós estamos perto do meio do ano né, ou seja 4meses só de aula, veja bem, uma foi em uma universidade federal, e a outra na (nome de universidade), que é particular também e assim, muito conceituada, dois cursos bons de psicologia, os dois na semana de psicologia, esses encontros e os temas eles falavam sobre a questão do suicídio, Então, assim, ela está só no primeiro semestre, então esse ano ela sentiu...

E: Quer dizer, os estudantes já tem mais contato que também não tinham antes...

P1: Uma é a questão da formação acadêmica. E a outra é essa questão que eu acho que ia estar, como você falou, é um assunto que você não vai ficar falando, não é um tema como outro qualquer, assim, que as pessoas vão ficar falando...

P3: Mas você pega o programa da Fátima Bernardes, falaram sobre suicídio, e é uma coisa assim que estão instruindo as pessoas...

P8: E que atinge muita gente...

P1: Sim, Sim, perfeito...

P3: Então, o que eu te disse é isso, você liga a televisão, você vê um jornal, qualquer coisa, existe esse tema que antes não existia...

P10: Talvez não seja a quantidade, mas a importância que estão dando pro tema, não sei se é porque aumentou ou não aumentou, mas talvez a relevância do tema tenha aumentado. (23:27:71)

P1: E você só dá essa importância, principalmente a mídia, não faz isso de graça... ou é porque está tendo mais importância porque é abcd morreram por suicídio e aí são pessoas que são famosas e tal, e elas dão certa importância que tem a 


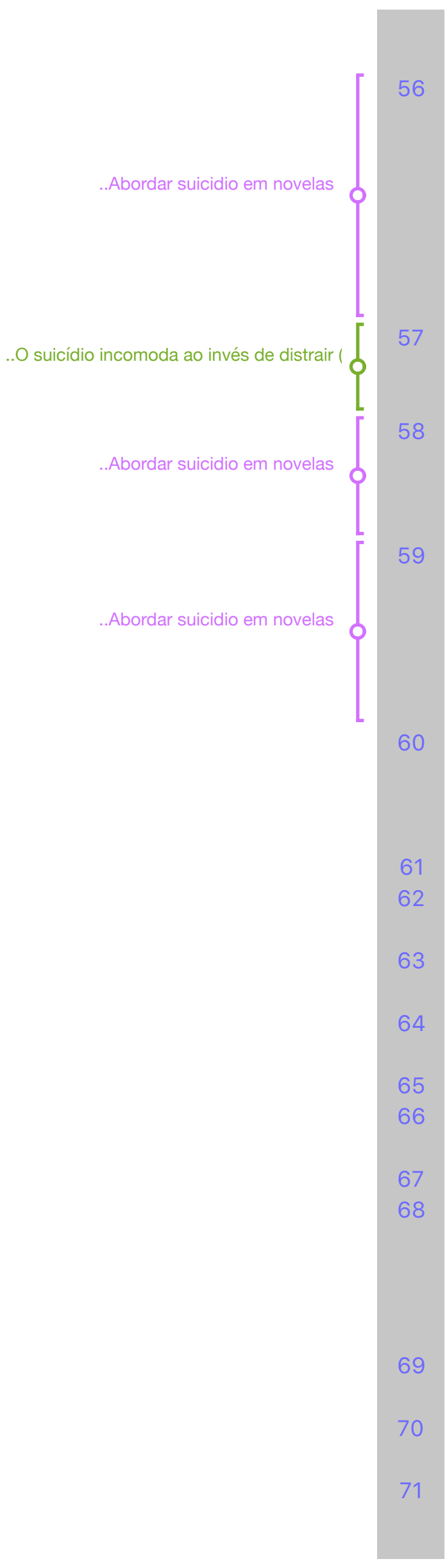

mídia vai fazer algo que não tem volta.

P4:Deviam abordar em novela esse tema, porque eles abordam tanto transplante de coração, não sei o que... não estou acompanhando mas parece que essa novela está rodando no estrangeiro. Nunca que eu me lembre, nunca teve nenhuma novela que abordasse, assim, depressão as vezes, (falatório)....

P3: Ё que incomoda as pessoas, ao invés de ser uma distração, vai incomodar as pessoas...

P4: Ou não sei se não pode... antigamente achava que seria incentivo, então, também não sei pra que lado... teria que ser uma coisa muito cuidadosa, muito...

P10: Mas tem outros temas que super incomodam também, entendeu? Acho que tem vários temas que eles abordam as vezes nas novelas que também incomodam, eu não sei também o quanto de um quanto do outro, mas...

E: E qual é o impacto das campanhas públicas como setembro amarelo em vocês? Agora os setembros tem sido mais cheios de informações, mais publicações...

FALATÓRIO

P4: Foi mais o ano passado que eu senti que estava falando mais, o retrasado...

E: ainda não... o retrasado ele foi bem mais fraquinho...

P3: só fiquei sabendo através do nosso amigo aqui... (referindo-se ao P7)

FALATÓRIO

P8: Mas mesmo assim o outubro rosa todo mundo sabe o que é, o maio amarelo...

P1: O novembro azul...

P8: ...uma pessoa que não está, assim, participando do assunto, as pessoas sabem o que é o setembro amarelo, mas se você perguntar para alguém ninguém sabe o que é.

P10: Eu também acho que não. Acho que é ainda é muito pouco...

P1: É, mas já foi mais divulgado, esse do ano passado...

P8: Pra quem procurava tava divulgado e tava uma divulgação boa mas você 


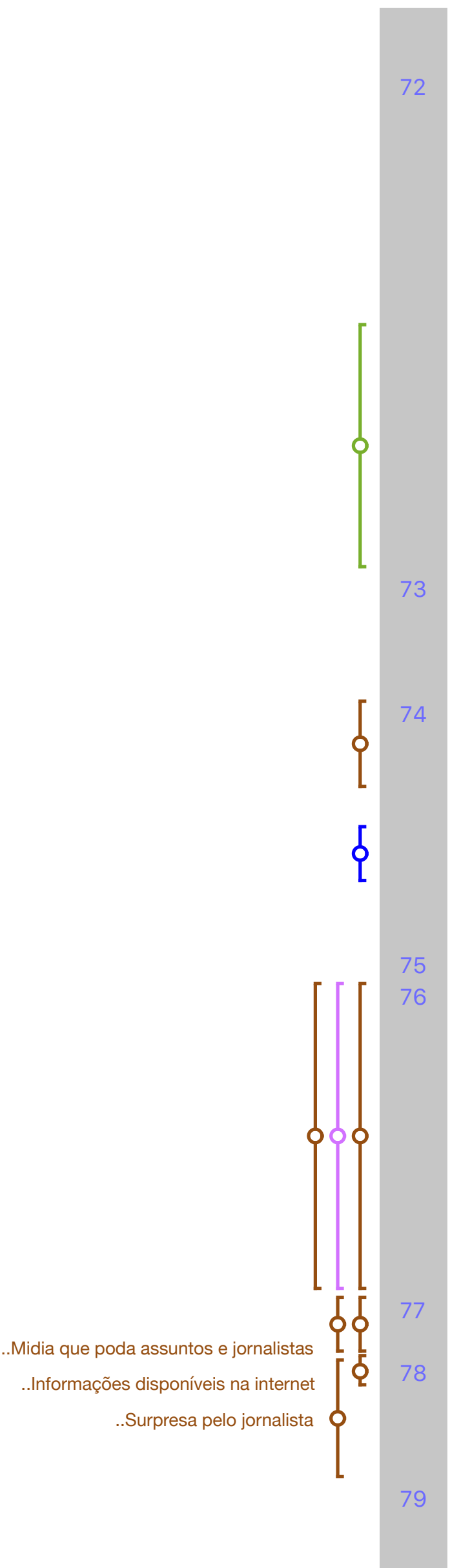

procurando....

P1: Porque lá em (nome de capital) teve um deputado estadual, que provocou uma audiência pública na Assembleia e levou o pessoal do CVV, do (nome de Instituto), levou o pessoal do núcleo da (nome de universidade), da psicologia e tal, já no intuito de buscar maior ferramenta do poder público, do governo do Estado, né? Da secretaria de Saúde pra essa problemática. Então ele já começou a fazer isso, e assim, começam os movimentos né, é, estão começando e foi muito assim, difícil, porque a gente participou muito então a gente acaba, nosso dever público é tão bom que você acaba engajado né, mas eu acho que esse também vai ser, assim, já começou né..

$\mathrm{E}$ : Você acha que por enquanto quem recebe a informação é aquele que procura, ela não é uma informação ainda que ela chega para todas as pessoas...

P8: Isso, se a gente procura a gente acha coisa e acha coisa muito interessante, agora, não é uma coisa que chega em você. Você está tipo, andando na rua isso chega em você e você fala: "Nossa! existia esse assunto!" ... Mas por exemplo, o maio amarelo, que é do trânsito. Todo mundo...é uma coisa que você percebe...

$E$ : mas aí você vê eles indo nas escolas...

P4: assim, aquele repórter da Globo, o André Trigueiro... ele tem uma palestra desde 2012, que eu vi, outro dia eu fui numa palestra dele, que ele veio em São Paulo, foi ótimo, mas ele tem, desde 2012 que ele fala sobre o tema e eu não sabia, quer dizer, foi pesquisando na internet, você vê, uma pessoa da globo e ninguém comenta nada, e ninguém faz isso fora o André Trigueiro. Uma palestra excelente dele.

P1: Ele sempre faz Andre, sem ser o André da Globo, que ele quer ser livre..

P4: Peguei na internet também. Me surpreendi porque eu já gostava dele como repórter, tal, mas eu nunca imaginei que ele falasse sobre o tema..

P2: Aí eu fico me questionando, será que muitas vezes a campanha não é apenas pra 


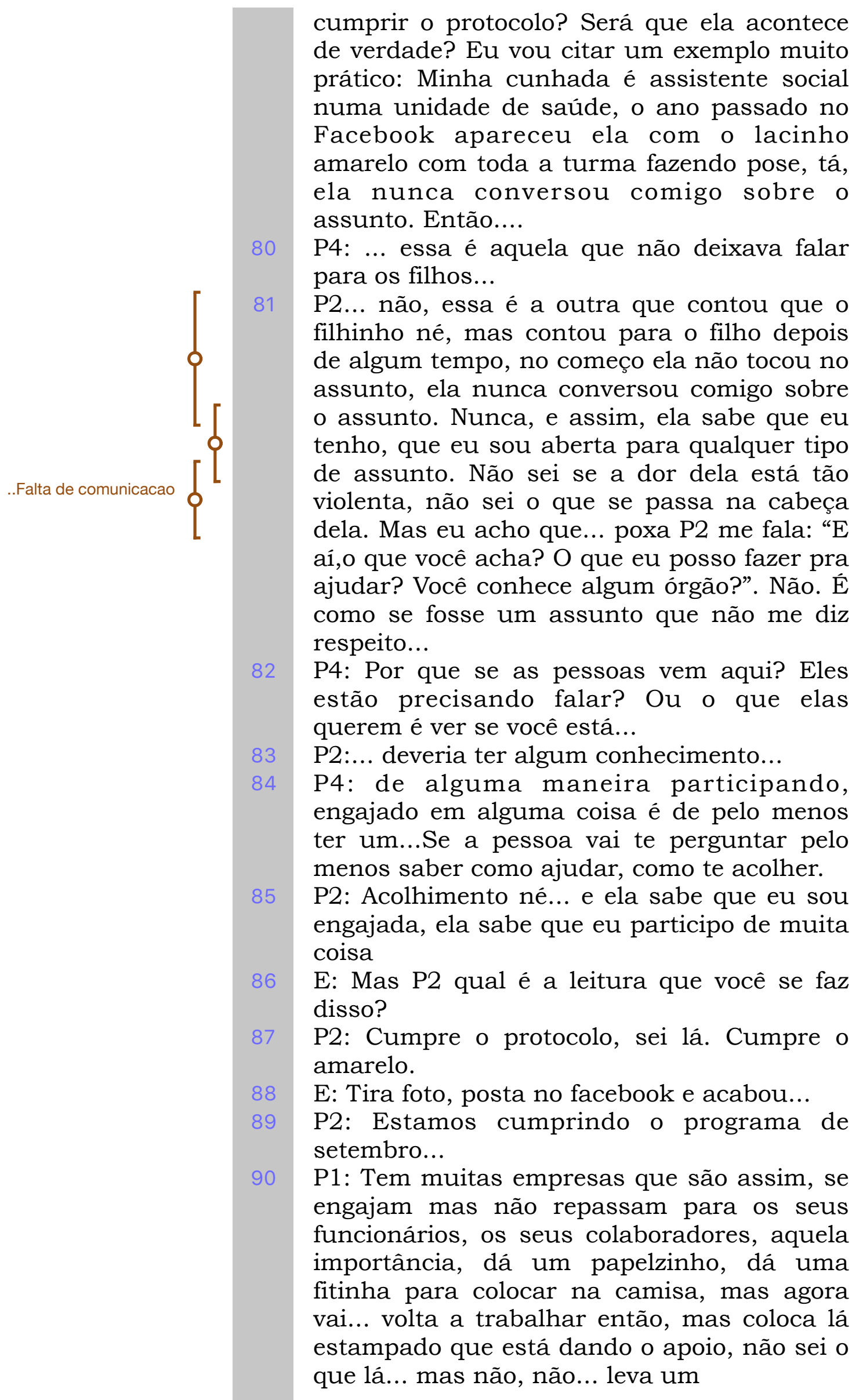




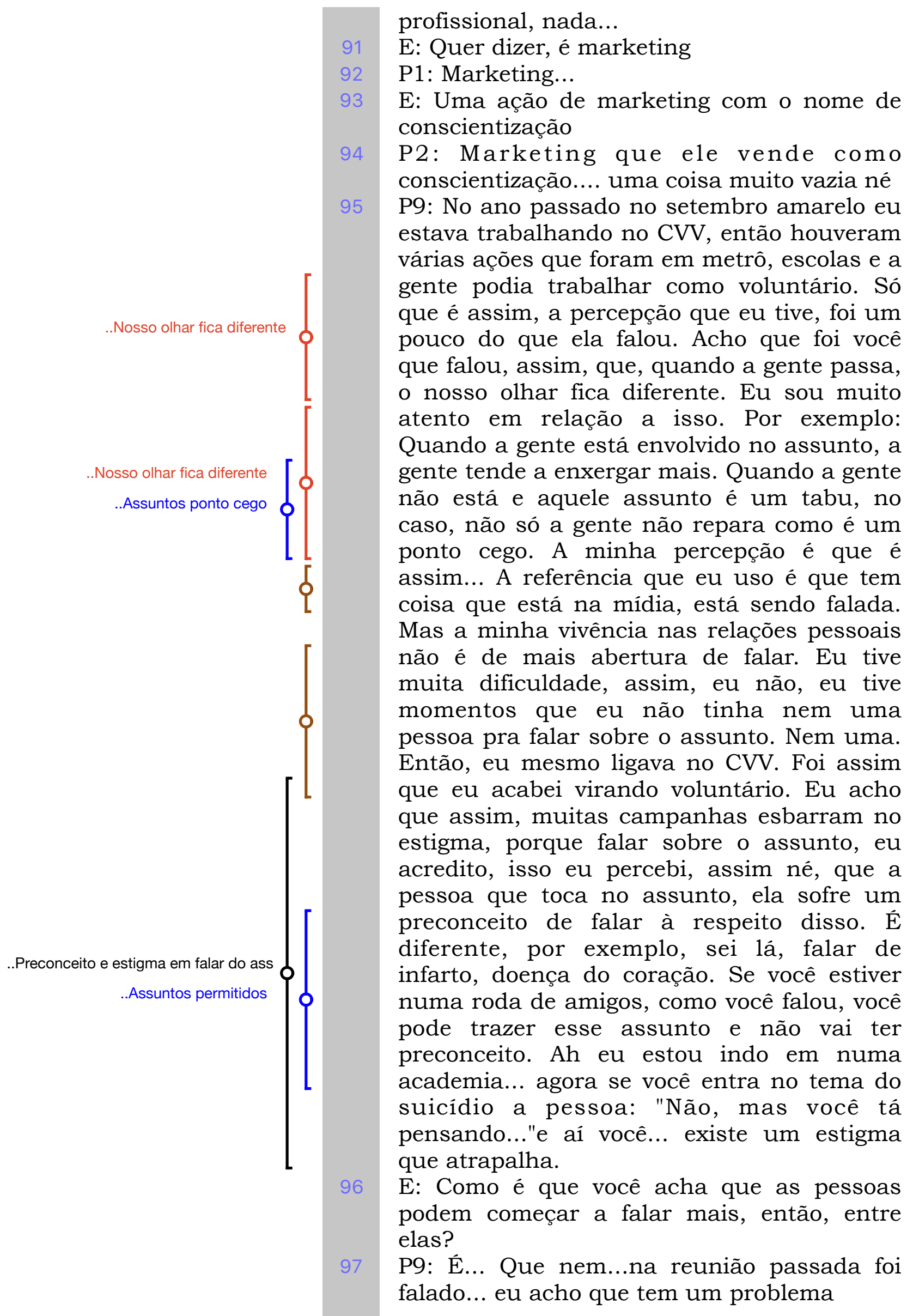




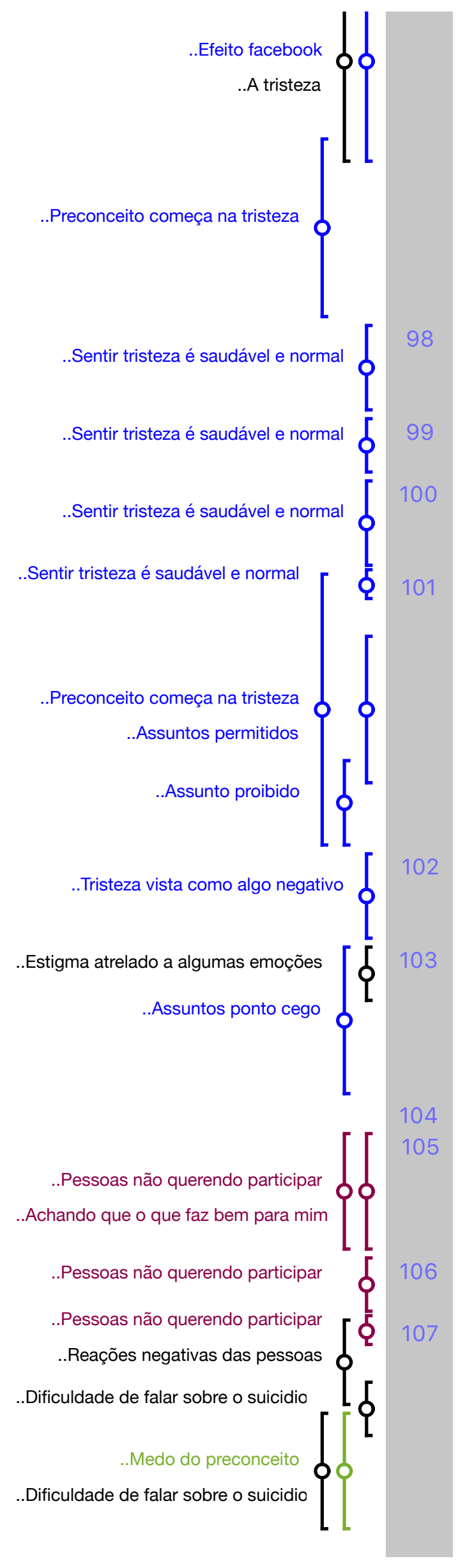

grande, que na minha opinião né, começa assim, com a tristeza, tem um preconceito que é, falando um pouco do efeito facebook. Todo mundo quer aparecer feliz ou parecer feliz. Daí, desse, a tristeza ser preconceito vem a morte, o luto, suicídio... vem tudo atrelado. Então, qualquer pessoa que começa a trazer o assunto que é considerado triste... mas isso já é uma coisa interna, acho que da nossa cultura.

P4: Você acha que começar a abordar, que todo mundo sente tristeza em algum momento? Tem como alguém...

P9: Sim, como algo natural, como algo natural.

P4: Não já como depressão, mas como: tristeza é uma coisa normal que todos nós sentimos

P9: Isso!Como algo saudável. Enquanto não tiver isso... então qualquer assunto... vamos supor: se eu chegar num churrasco, está todo mundo tomando cerveja, e eu falar "Ah, estou indo numa academia. Poxa, me matriculei eu vou." todo mundo fala numa boa. Mas, se falar: "Putz, eu ando meio triste, eu ando meio deprimido"... Ihhh, existe o isolamento...

P8: É visto como uma coisa negativa, né? Aquela coisa do... aquela pessoa ela é negativa.

P9: Eu acho que existe um estigma atrelado a algumas emoções. Enquanto a gente não resolver isso, o assunto em si ficou um ponto cego da sociedade. Aí as campanhas, também, é o que eu percebi...

P4: não surtem efeito... (fala junto)

P9: ... eu estava trabalhando no CVV, e eu falei com duas pessoas que tiveram, pessoas que próximas do suicídio... para participarem do (nome de instituição)...

P7: (fala junto)... não conseguiu levar nenhuma...

P9: ... eu não consegui levar nenhum. Um eu não consegui nem terminar a conversa e outra pessoa parou de falar comigo. Porque é uma dificuldade do assunto. Então, a pessoa não quer falar que tem esse problema porque ela vai sofrer o preconceito e ela não quer falar com você também... 
E: Quer dizer então as campanhas elas vão ter que efeito? Até onde vocês acham que chega a campanha?

P9: Na minha opinião ela funciona, por exemplo, a pessoa que tem, ela ou alguém próximo que tem depressão que aí é socialmente aceito, falar que a pessoa tem depressão eu acho que aí funciona...

110 P4: Pros familiares, quando você está percebendo alguém ou algum amigo, não só um familiar né, alguém próximo, como agir. $\mathrm{Eu}$ acho que deveria ter um pouco mais, porque muitas vezes, as vezes alguém que quero ajudar mas eu não sabia como agir. Nem sei se eu sei hoje se alguém chegar pra mim e falar que: "Ai eu não, eu não quero mais viver"... Eu não sei, eu ainda nem sei se eu sei o que falar. Eu sei que eu vou querer ajudar. Vou procurar ajuda, vou tentar levar em algum lugar, mas agora eu não sei se eu mesma sei o que falar... eu acho que pra gente conseguir tocar quem tá vendo....

P3: (fala junto) E precisa a pessoa falar, né? Porque a gente perceber é muito dificil...

P4: ... é, ou antes da pessoa, ou se está percebendo... é, eu sei lá, alertar ali, mais pais, cuidadores, quem cuida, que hoje em dia nem as vezes é mais os pais... é avós, tios.... mas alertar se tiver alguma coisa como abordar um adolescente, principalmente acho que adolescente, assim que fica lá mais fechado no quarto, e tal, mais...porque o adulto as vezes vai camuflar muito mais, que a gente não precisa nem... eu acho que quanto mais a idade vai passando, acho que isso aí você não consegue tirar nada.

P10: Eu acho que a gente comentou um pouco isso na sessão passada né, que a gente tem ainda uma base, um b a bá que a gente tem que dar milhões de passos pra trás porque assim, pra mim, suicídio é o nivel hard, entendeu? $\mathrm{E}$ aí, que nem ele tava falando né, da tristeza e tudo. E eu acho que vir muito ainda, acho que trabalhar muito mais esse tema de tristeza, tal, pra depois chegar no suicídio. E aí eu acho também, que a pessoa, ela só vai passar a se 
interessar, a campanha só tem efeito naqueles que na essência tem, acho, alguma coisa a ver com o tema. Por exemplo: eu sou envolvida no GLBTA (Gays, lésbicas, $\mathrm{Bi}$, Trans e aliados) e aí assim, quando eu olho esse grupo, as pessoas que lideram os grupos, normalmente são pessoas que são ou gays ou lésbicas... no meu caso eu não sou, mas eu tô ainda mais engajada porque que eu sei que esse é grupo que se suicida. Então se alguém, assim, eu não falo, né? Porque se alguém me perguntar: "Por que você é engajada no (GLBTA)"! Eu falo que eu quero que cada um possa ser o que ele quer, quero que as pessoas venham verdadeiramente pra empresa... porque o fato de você não poder ser você, você deixa o seu você em casa e vem trabalhar. E como eu sei que assim, são várias pessoas sofrem e cometem suicídio, a verdadeira razão, né, vem um pouco que eu sei a importância da diversidade, mas pra mim, lá no fim tem a ponta do suicídio. É que eu acho que cada um, a gente fez um evento na semana passada no trabalho, e quando eu olho as pessoas que vão, normalmente são pessoas que são alguma das letras, e o A, que é do aliado, que sou eu, você não vê tantos. Porque aquela coisa de talvez a pessoa pensar: "Ai, vão achar, sei lá, alguma coisa de mim porque eu estou engajada nesse grupo. Então eu acho que essa campanha do GLBTA só atinge as pessoas que de alguma forma se sentem ligadas ao tema. Eles falando ali abertamente ou não ou lá na essência tem alguma coisinha que ele por, né... então, talvez essas campanhas do suicídio, elas só vão atingir quem, na sua essência, tem alguma ligação com o tema. Se não ela passa desapercebida. Tanto que a gente fica lá tentando engajar as pessoas pra ir no GLBTA, e assim, tipo as pessoas não vão. São raras. São raras. Aí lógico já tem vários líderes que vão porque, tipo, eles tem que ir, eles tem que liderar pelo exemplo, você tem que ir... então eu não sei se não tivesse talvez um pouco disso de ser um exemplo, de ter que cumprir com isso, se aquelas pessoas iriam, e aí eu não sei se por 


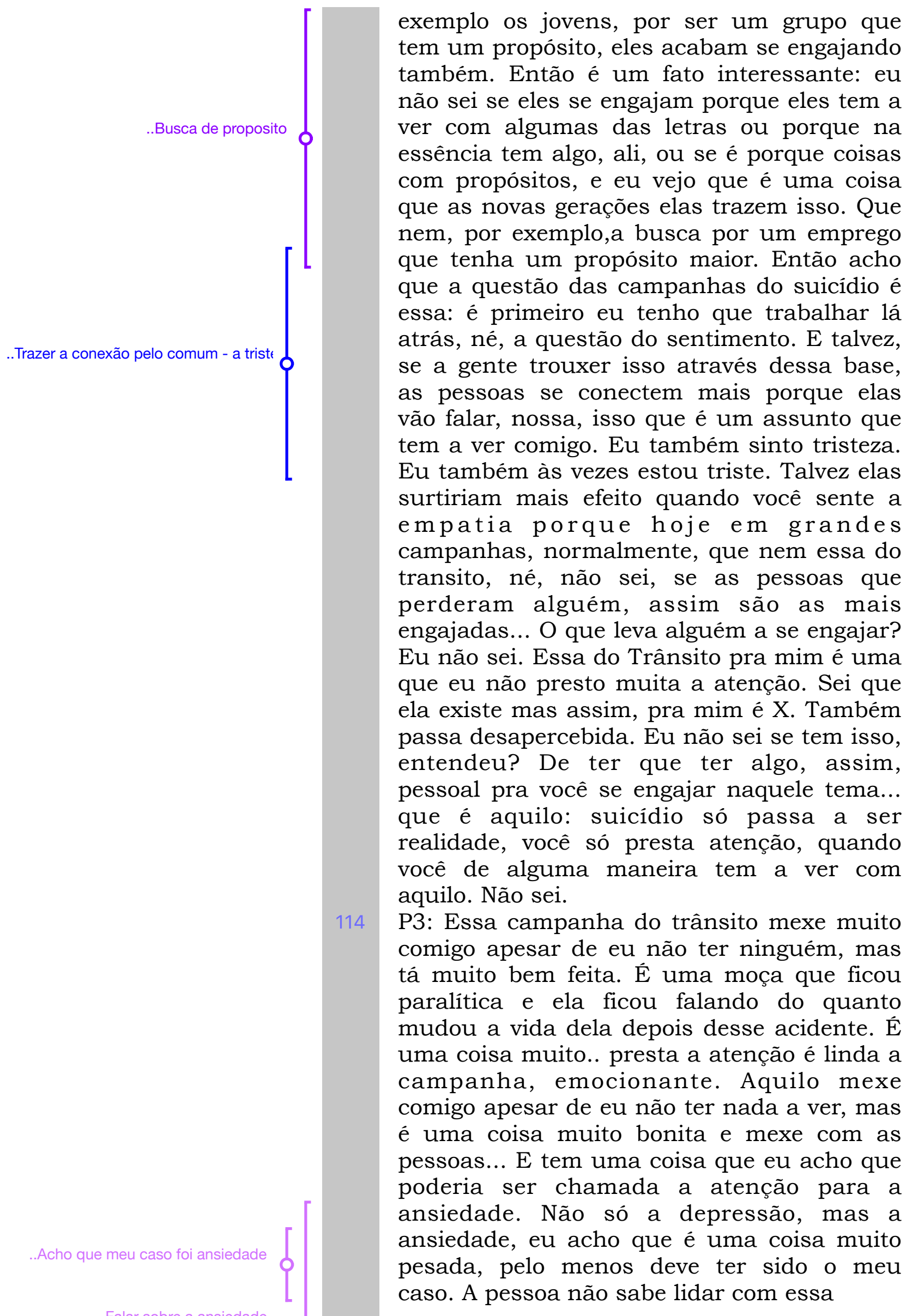


ansiedade. Eu acho que nem foi depressão, foi ansiedade. É uma coisa que ninguém fala. Eu acho que nas campanhas deve ser falado pras pessoas se tocarem... o quanto isso também incomoda. Não só depressão.

P9: Assim, a minha experiência, então, eu não sou da área mas assim, a minha vivência é que eu percebi que as campanhas, elas funcionam bem pra quem não tem a informação e tenha uma realidade próxima de depressão. Porque aí a pessoa fala: "Puxa, eu não sei como lidar, isso pode levar ao suicídio e aí não sabia nem que encaminhamento fazer. Não sabia que existia o CVV, não sabia que as vezes é necessário a medicação, a busca de um profissional. Nisso eu acho que as campanhas funcionam. Porque a pessoa se identifica. Aonde eu acho que elas falham, aí é uma visão minha também de leigo: Eu tenho a impressão que existem alguns casos, assim, de suicídio, que não tem a ver com uma depressão caracterizada, que é assim, a soma de um monte de pequenas coisas: Poxa, assim, ahh, tá com dificuldade no relacionamento na família, aí problema no trabalho... São essas pequenas coisas somadas que podem levar ao suicídio. Aí, esse caso, eu acho que poderia fazer com que qualquer pessoa se identificasse e dizer assim: "Poxa, se você tem algum problema que você não consegue lidar ou tem dificuldade em falar. Eu tenho dificuldade de encaminhar e isso pode chegar nesse ponto, de suicídio. Eu acho que nesse ponto as campanhas falham porque a impressão que eu tive, como leigo, é de que assim, isso não tem a ver comigo. É o que eu ..Amigos achando que depressão não tı sentia com os amigos. Assim, por exemplo, se eu ia falar com eles... não,na minha família ninguém tem depressão então não tem nada a ver comigo e aí o assunto morria. P10: E sabe porque eu dou esse exemplo, teve uma vez uma moça que foi fazer uma palestra, lá que é daquele, tipo 0800 para auxiliar os empregados, tal, que tem vários serviços e aí eles tem serviço jurídico, psicológico, sei lá, e mais outros dois. E aí, quando ela tava dando exemplos, aí ela falou 


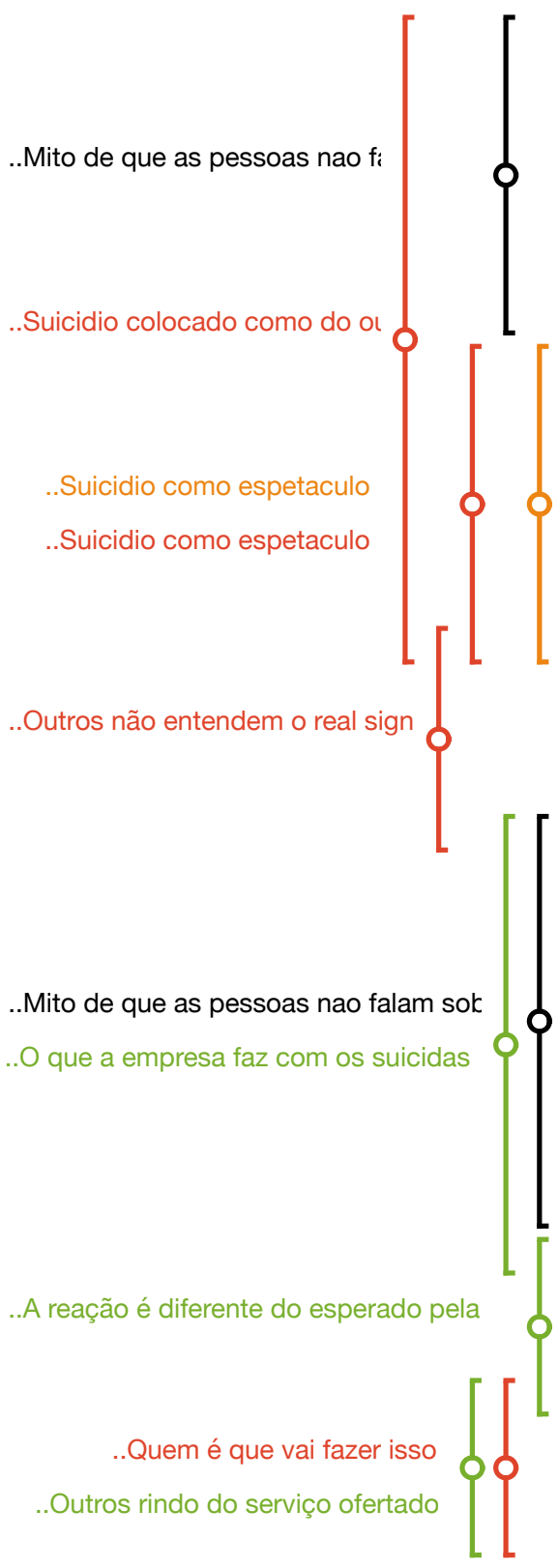

117

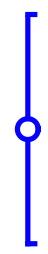

assim: Há, porque tem algumas pessoas...que ela falou assim: o único momento que a gente quebra o sigilo para a empresa desse serviço, é quando alguém fala que vai se matar. As pessoas começaram a dar risada na sala.. "ah é, tipo, até parece que a pessoa vai"... entendeu? Então assim acho que tem pessoas..., eu também uma vez estava num almoço com outras pessoas da empresa e falaram que acho que alguém do prédio do lado tentou, sabe uma coisa assim? " E tipo eles falaram "Ah! Nossa, que coisa engraçada, tipo, por que não se joga, mesmo". Então assim, o nível de entendimento das pessoas, a gravidade de que aquilo é real, não é o suficiente pra realmente a pessoa ir lá ouvir uma campanha...ou teve uns que eu já ouvi: "Nossa, se viu o formulário da semana da saúde que perguntaram se você tem vontade de se matar? Isso é pergunta? Se acha que alguém vai falar que tem vontade? Tipo, sabe? Eles ficaram surpresos de num formulário estar escrito fazendo essa pergunta. E então falaram: "Duvido que alguém vai escrever que tipo, sim." Ou o que a empresa vai fazer? Entendeu? Então assim, existem pequenas ações que às vezes a gente faz, só que a reação nem sempre é aquela esperada. Ou essa moça fazendo a palestra falando que era um serviço que eles né, prestavam, e eles assim, dando risada, achando tipo, ai, quem é que vai fazer isso...

E: E quando vocês viram as campanhas, por exemplo do setembro amarelo, qual foi o impacto em vocês? Impactou negativamente ou positivamente de alguma forma?

P4: Pra mim positivamente, porque eu achei que pelo menos está se fazendo alguma coisa. As pessoas estão pensando nisso, no assunto. Começando, pelo menos, tem que partir de algum ponto. $\mathrm{E}$ se a gente achar que nada também vai surtir efeito, a gente vai parar e não vai fazer nada. Então eu acho que tem que começar, fiquei feliz de os programas estarem falando, pelo menos naquele mês, massivamente abordando, saindo em jornal, matéria que... tem que 


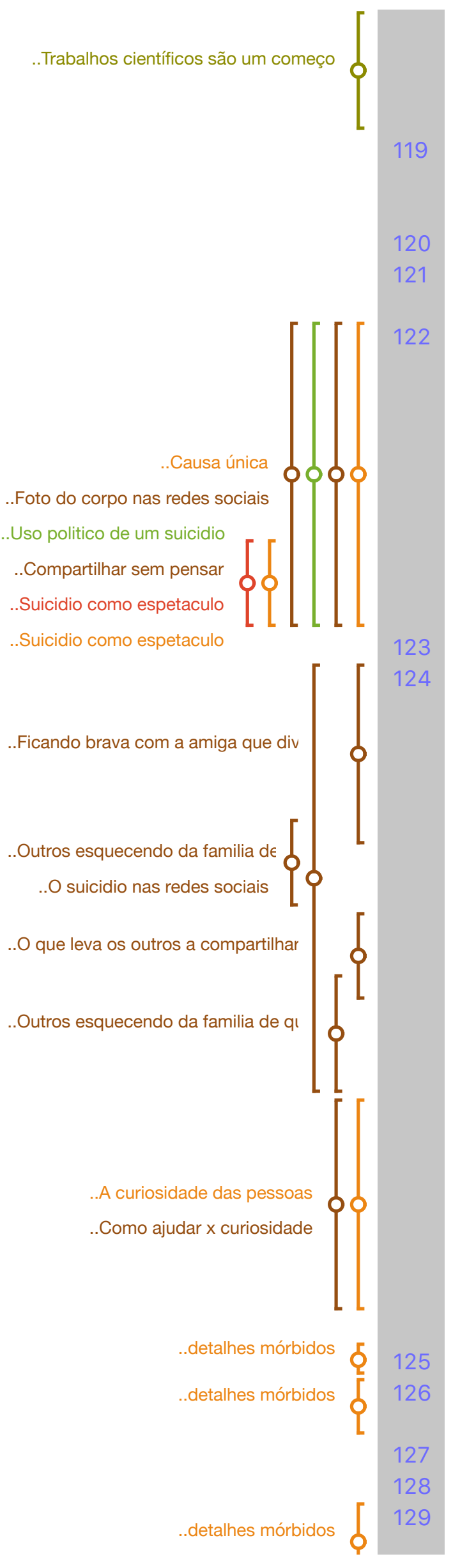

começar! E daí tá vendo, né, um trabalho assim, como o seu, e as pessoas se dedicando a isso pra estar surgindo ideias da gente como abordar.

E: Vocês lembram de algum exemplo de campanha ou mensagem positiva ou negativa sobre suicídio na mídia?

P4: De campanha, não...

E: Campanha, ou mensagem, ou reportagem...

P4: eu me lembro, que, acho que foi agora, no ano passado, colocaram no facebook, e eu até discuti com uma amiga minha porque ela que passou adiante, quando eu vi aquilo...até o (nome do marido) mandou pra ela tirar na hora... aquele empresário... aí "Olha o que a Dilma está fazendo com as pessoas. Aí tem uma foto do empresário que filmaram de manhã, que os empregados chegaram, e ele tinha...

E: ... aquele da fábrica de colchão...

P4: ... eu nem vi direito. Eu sei que na hora eu fiquei brava com ela assim, Aí ela: "Não, mas eu quis dizer... e aí eu disse... "Não,você pode até falar o texto: "Olha o que está acontecendo com as pessoas que estão, né..." Mas não divulgar a foto. Jamais! Você esqueceu que essa pessoa, pode não estar aqui mas tem família? $\mathrm{E}$ aî, eu lembro que eu briguei muito com ela, né, porque ela queria me mostrar que ela só fez pra que outras pessoas... Eu falei: "Não, mas as pessoas tem família. Você gostaria de ver alguém da sua família nisso, exposto no facebook. Porque alguém fotografou? A gente sabe... Eu "sinto muito" das pessoas, elas querem saber, quando você conta uma coisa, a curiosidade não é assim em: A) ter ajudado, como poderia ter ajudado, como ajudar o outro... eles querem saber como foi, como foi encontrado, o que aconteceu? Eu sinto muito! Ainda as pessoas querem...

P3: (fala junto) ... detalhes mórbidos.

P4: Detalhes mórbidos, um filme. Elas querem saber... sabe... você viu?

P8: pra depois disso darem opinião, né?

P4: Hã?

P8: Pra depois que souber os detalhes darem 


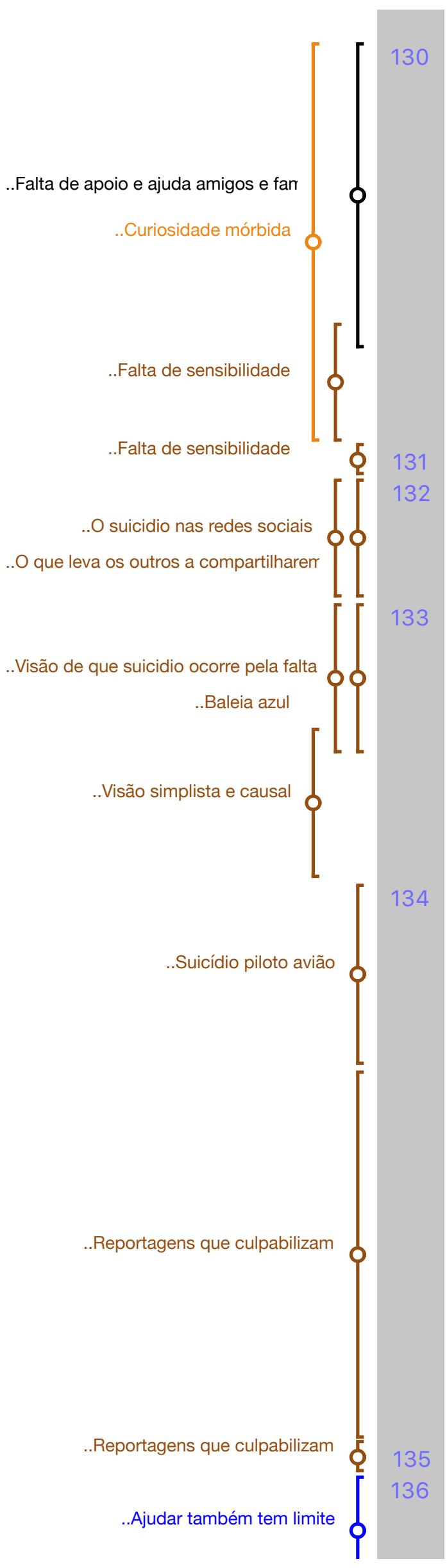

opinião... (falatório)

P4: É! A curiosidade é tanta de saber, e não é de saber o que a pessoa tava sentindo, ou tipo, nossa, como eu posso... eu nunca, nunca ninguém me perguntou assim: Como eu posso te ajudar? Você está pensando nisso? Nunca ninguém me perguntou de amigos ou familiares. O que você está sentindo com isso? Eu posso te ajudar de que maneira? Isso eu senti. Nunca ninguém me abordou assim. A abordagem era: Bom, mas como foi? Mas, como era? Como estava? É horrivel, assim. O caixão foi aberto ou fechado? Sabe, assim, aquilo...

P2: Falta de sensibilidade né...

P4: É... então eu percebo na internet, casos, as pessoas vão ler pra...saber...como... esse caso eu fiquei chocada, assim, de publicarem e muita gente compartilhar.

P2: Da baleia azul também, recentemente. Quando as pessoas postavam assim: "Há... dá uma carteira azul pra ele. Carteira de trabalho... para esse jovem que de repente isso não vai mais acontecer" Eu acho que é uma falta de respeito porque o jovem que entra nessa, está deprimido, né, uma carteira de trabalho não vai resolver o problema dele. Então isso...

P8: Bom, eu acho que eu lembro mais um conjunto de reportagens que saiu acho que quando... teve aquele suicídio do piloto do avião, né? Que ele jogou... eu me lembro porque foi assim pouquíssimo tempo, foi quase junto com a morte do meu irmão. E eu acho, o que eu me lembro muito, o que eu acho que também me deixa um pouco cismada, é que eram reportagens até de colunistas da Folha dizendo que aí, que isso aí, que essas coisas, que esse suicídio é plenamente evitável, isso é falta de carinho, falta de amor, falta de não sei o que.... e tipo, eram muitas as reportagens e a gente vê, que culpabiliza todas as pessoas em volta. Como se as pessoas em volta tivessem negado ou virado as costas, ou não tivessem enxergado...

P4: (fala junto) ou não tivesse percebido...

P8: É, mas a gente não consegue ficar olhando pros outros também o tempo 


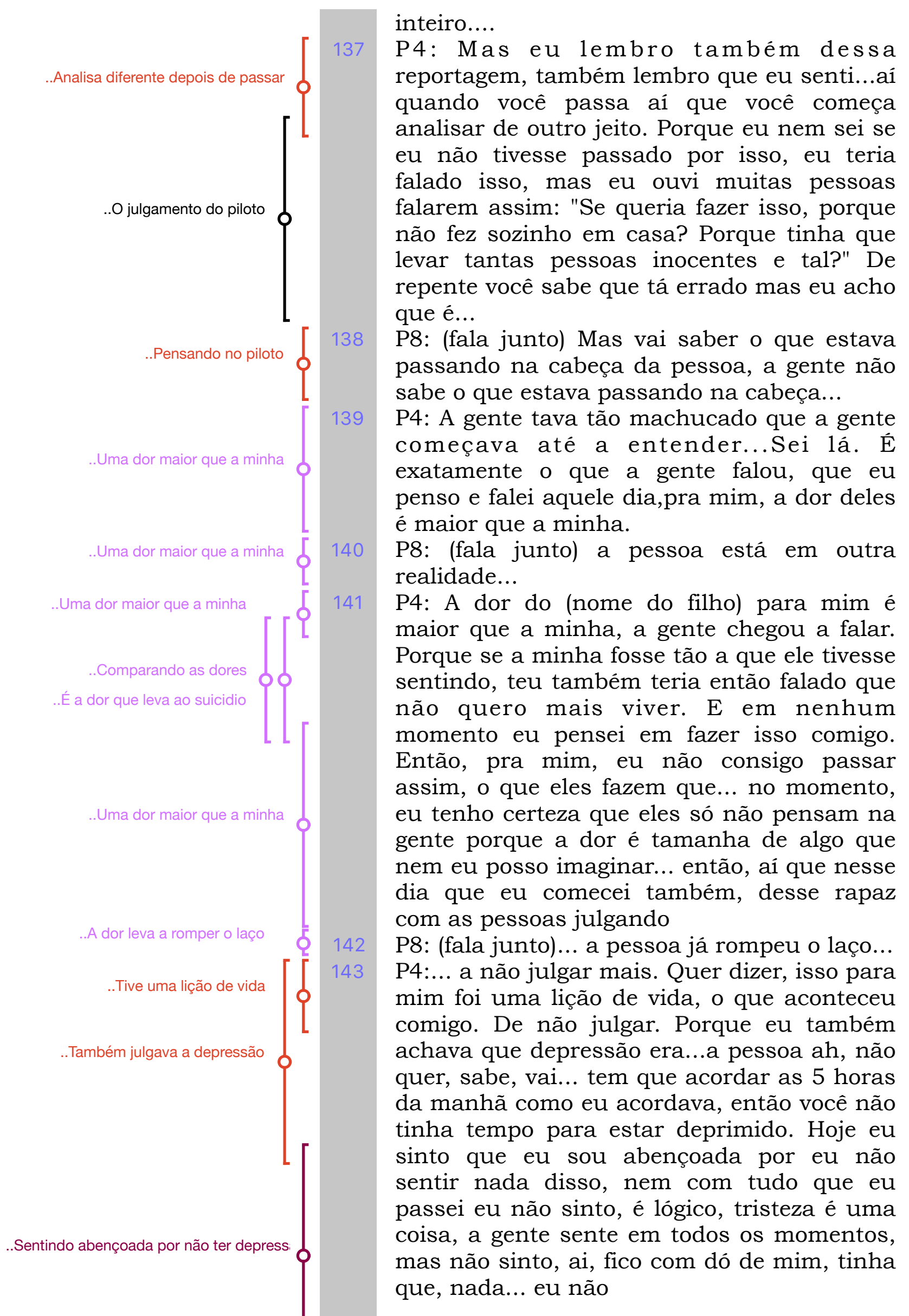




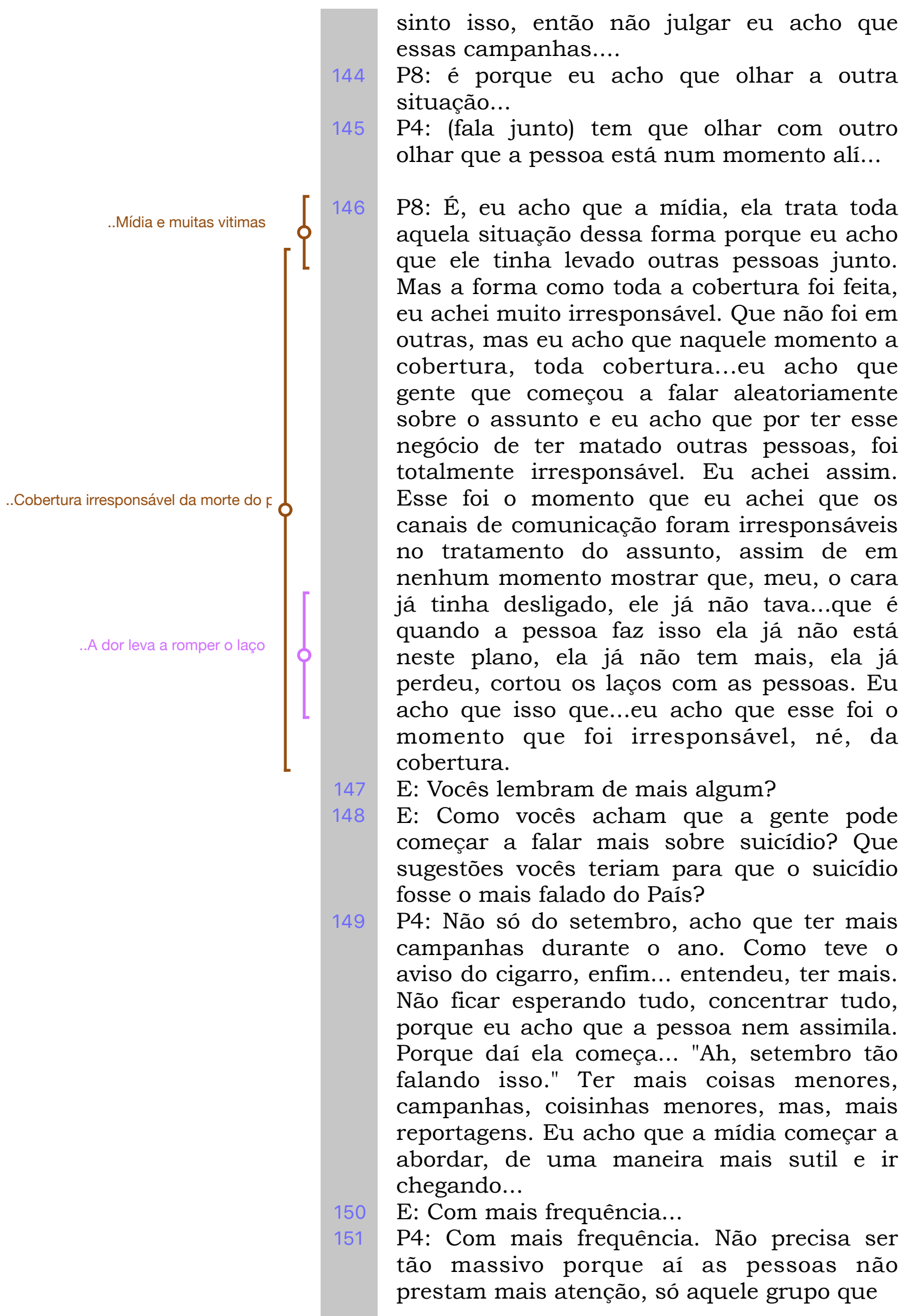




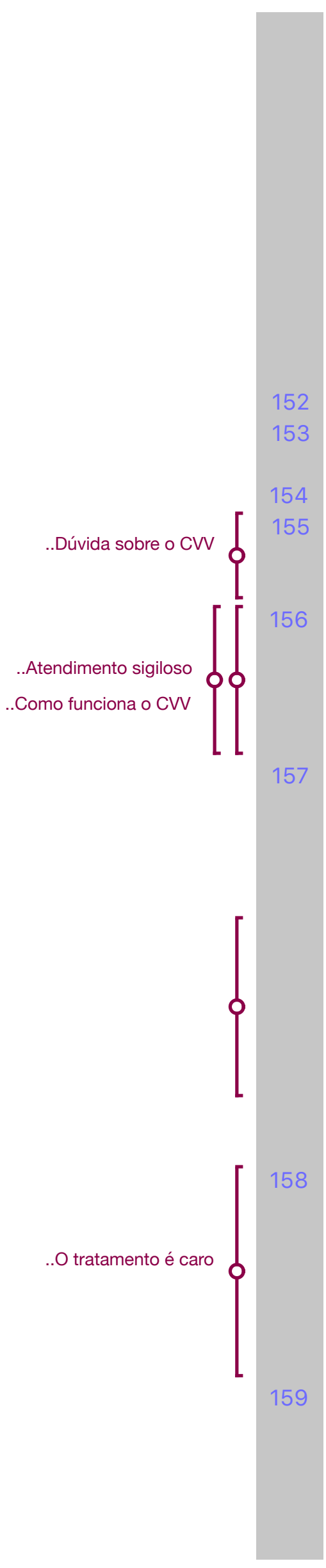

vai prestar atenção, que vai se engajar, vai tá ali de camiseta participando, dando folheto, tentando, mas assim, acho que ter um horário pra divulgar que o CVV está disponível que aí é um órgão nacional. É uma coisa nacional. Então, ter uns segundos ali na TV... a gente tem tanto segundos ali gratuitos pra falar de tanta coisa, porque não alertar que o CVV está aí. Acho que pelo menos a pessoa teria um lugar seguro pra pedir ajuda. Colocar que é ali que você vai ficar. Eu acho que fica.

E: Fica 24 horas...

P4: 24 horas eu sei, mas que fica o sigilo.

E: Sigilo, sim.

P4: E se a pessoa liga e fala que vai cometer? Pode? É aberto um chamado pra policia, não?

P5: A não ser que ela peça ajuda. Se ela falar... eu já fiz o ato e estou precisando de ajuda. E ela passar o endereço... aí você pode. Se ela falar... pois não tem identificador de chamada.

P4: Então mas eu acho que uma coisa interessante seria isso, ter espaço, na mídia, principalmente TV que atinge muita gente, de todas as idades, porque a gente está aqui falando se jovens... mas que as vezes não vai ver tv aberta tanto, mas a gente está falando de pessoas de mais idade também que está aí sozinha em casa, pensando, e aparecer, porque eu não sei, mas eu acho que se eu perguntasse para a minha avó ela não sabe do CVV. Se ela.. então eu acho que devia ter mais campanhazinhas.. mini coisinhas assim, com esse número disponível. (54:45) P3: O que eu acho que também poderia ter, faculdades de psicologia que abrisse ao público porque é muito caro um tratamento, hoje. Um psicólogo, psiquiatra, acho que poderia ter mais faculdades, aí, atendendo o povo em geral e... Acho que ajudaria bastante.

E: Se você conseguir pegar essa demanda, porque você começa a falar, você gera demanda, né? $\mathrm{E}$ daí, pra onde vai essa demanda? Não é? Se você falar... observe, converse e encaminhe para o tratamento, 


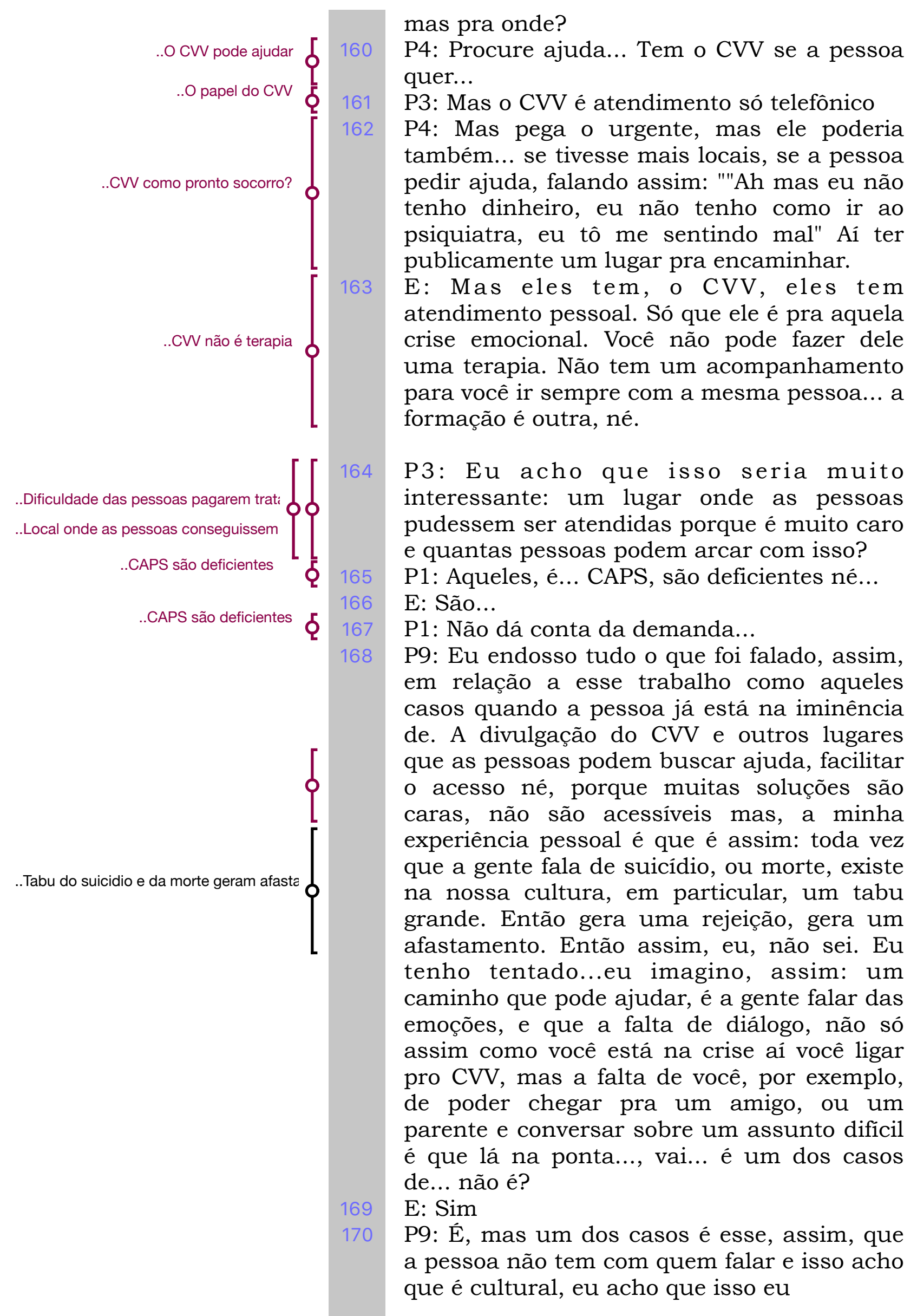


acho que tem a ver com prevenção de suicídio e eu acho que aproxima as pessoas, porque tem a ver com todo mundo, não é só aquele caso...

E: Quer dizer, você tem uma campanha, por exemplo, focada em acolhimento, em diálogo, que a gente estava falando em prevenção em saúde mental, não está falando exatamente de prevenção do suicídio, mas que automaticamente uma coisa que vai levar a outra. Você promove saúde mental você diminui o número de suicídios...

P10: E você capacita os profissionais, né? Que nem a gente vê...a gente já ouviu relato as pessoas que tentaram que eles não tiveram o atendimento adequado, né? Então, acho que assim, nem aquelas pessoas que teriam o papel de acolher não estão preparadas, imagina outros seres que assim, né? $\mathrm{Na}$ profissão, isso não vai saber mesmo. No seu meio, você talvez tente por amar as outras pessoas com quem você convive, mas acho que a questão de capacitação, que nem, de universitários, mas a questão, tipo, a policia, os médicos, entendeu? Acho que em vários, assim. Vários profissionais que precisam estar um pouco mais capacitados para lidar com isso né, então como que a gente consegue?

E: Mas será que por exemplo, na universidade, seja ela de qualquer assunto que for, se tivesse um programa de conscientização, de saúde mental, isso poderia funcionar? Por exemplo?

P7: Também..

E: Por exemplo, numa faculdade de engenharia?

P10: Não, não. Eu acho que tem que ir primeiro naqueles que tem o assunto mais relacionado. Por exemplo, a disciplina religião, sério, no colégio. Todo mundo... tipo, não vai na aula, trata de qualquer jeito, joga papel no ar, entendeu? Porque nem todo mundo que tá ali se identifica com o tema. Então, por exemplo: talvez se começar com os cursos que tem uma relação, um pouco mais, né? Talvez os médicos, os psicólogos, 


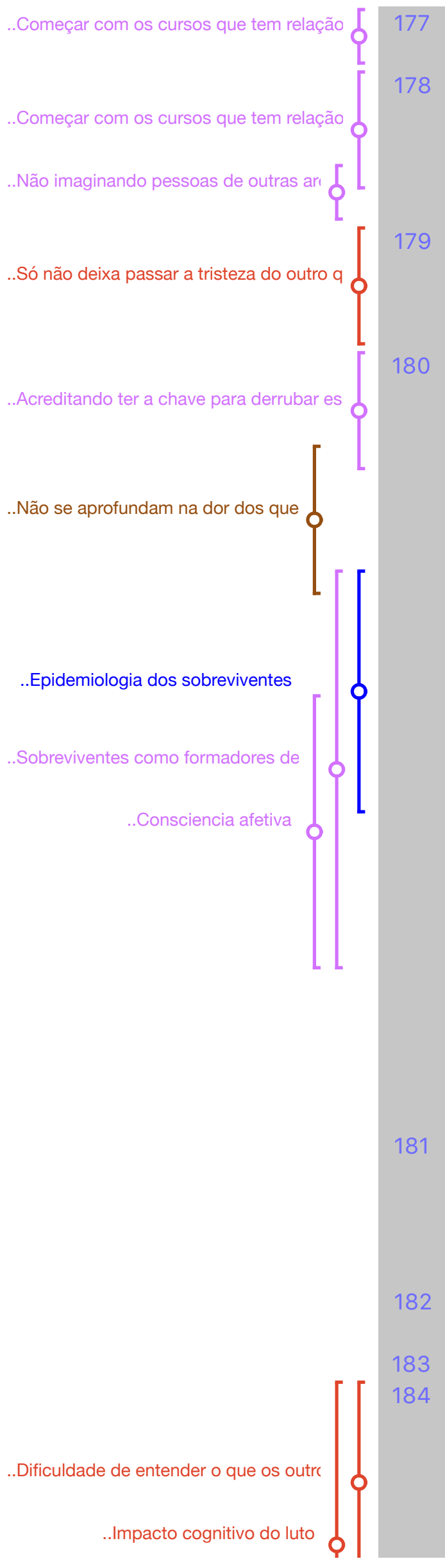

P4: (fala junto) Os recursos humanos... acho que eles tinha que ter mais...

P10: (Continua falando junto) na área de recursos humanos.....enfermagem... assim, você tem uns que teoricamente são os mais... não tem, imagina uma pessoa de direito, engenharia....

P4: Uma pessoa chega lá para você... tô com depressão, tô mal ou tô me sentindo triste... Se você não tivesse passado por isso ia passar...

P7: Sobre essa questão, eu acho também, existe um universo a ser explorado e esse contingente é que pode ser a chave pra gente derrubar essa barreira. Eu percebo, até nas recentes reportagens que eles não aprofundam sobre a dor dos que ficam. Fala do luto, fala da morte, fala do suicídio mas não aprofunda a dor dos que ficam. E se estatisticamente é uma média mínima de pelo menos 6 pessoas pra mais, que é afetada pra cada suicídio. E nós temos suicídio a cada 40 segundos. Nós temos um contingente da população expressivo e que certamente são de diversos perfis socioeconômicos e culturais e que cada um atue e dialogue no seu meio e que poderia ser um grande formador de opinião e poderia ser um grande parceiro pra desfrutar a consciência afetiva da sociedade como um todo. Então nós somos poucos, nós somos é episódios....episódios. Se a cada 40 segundos tiver uma média de 6 , no mínimo... então nós somos apenas $1 \%, 2 \%, 3 \%$, acho até que eu estou sendo muito

E: O P7, deixa eu te perguntar uma coisa. Você acha que a mensagem ela deve ser, por exemplo: Mostrando a dor dos que ficam ou, a união da dor dos que ficam pode ajudar a fazer coisas diferentes?

P7: Vou tentar. É que eu tenho uma dificuldade...

E: Mas você entendeu o que eu te perguntei? P7: Entendi.É que eu...veja bem, Você me desculpe, com o maior respeito mas eu tenho uma dificuldade... eu... eu fiquei ouvindo pacientemente mas não entendi nada do que você falou, que eu tô tentando 


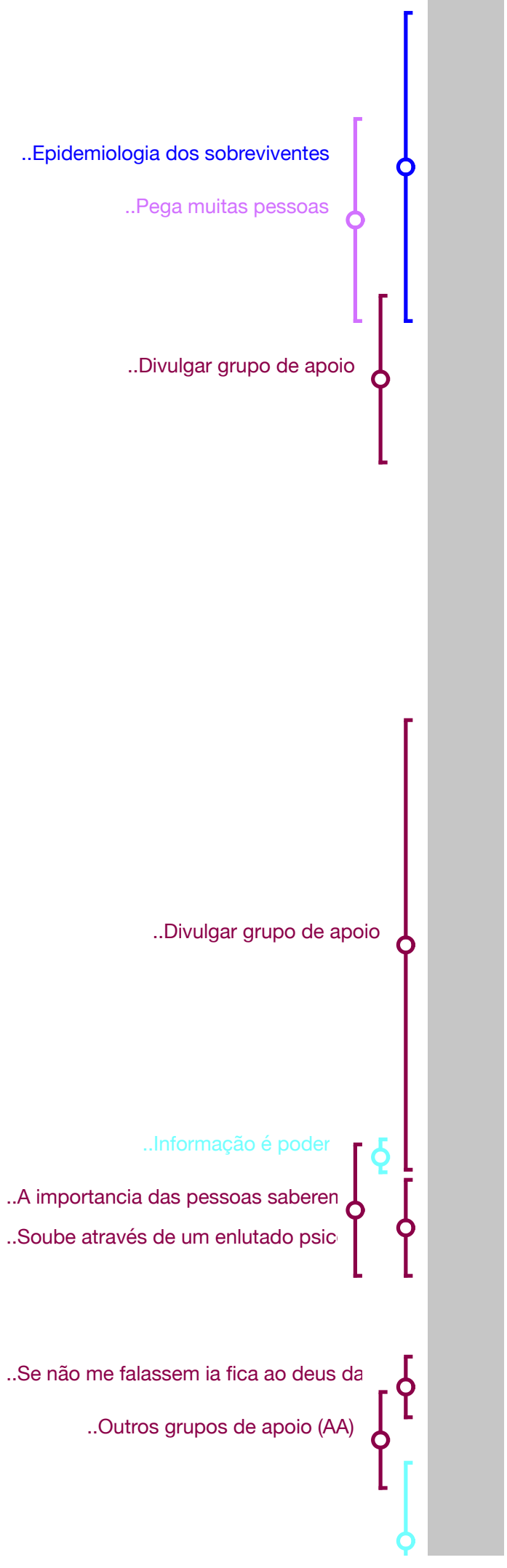

sustentar a ideia...é uma dificuldade. É uma limitação minha. Eu adquiri isso desde a primeira separação, se agravou na segunda e agora com esse baque... então, eu não consigo... eu fiquei "mono". Então, depois eu quero ouvir o que você falou pra tentar contribuir. Mas então, esse contingente, deve ter um percentual, não sei quanto, vamos chutar 10,20\% de mil, 2 mil pessoas, 3 mil pessoas, são milhares de pessoas que tem um status sociocultural e um perfil, inclusive alguns devem ser psicólogos, profissionais de saúde, aqui mesmo nós temos profissionais de saúde que são enlutados, né? Enfim, e que somem a esses dados, diferentes faixas etárias em que, se a gente divulgar, grupos de enlutados de instituições como o CVV, o Vita Alere, etc, parece que tem outras também. Que fazem esse trabalho nas diversas cidades, nos conglomerados urbanos maiores, pelo menos, e procurar fazer parceria com empresa, para atacar massivamente divulgando. Porque, o que ocorre? Por ser massivo, todo mundo, o familiar, "Não, olha tem isso aqui." "Tem esse aqui, não sei aonde tem um grupo". Fim de semana, durante asemana, vai lá, alguém vai lá, vai procurar saber. Então, se a gente conseguir manter, não de forma episódica mas, assim, constante, que existem esses centros, esses grupos que trabalham com a dor dos que ficam. E não só dos que ficam, tá? Daqueles que estão lidando com alguém que tá tentando e ainda não consumou e a pessoa tá sofrendo... ou até mesmo alguém que tentou e não conseguiu ele mesmo... mas assim, eu acho que se isso for feito, o que vai ocorrer? Informação é poder. Então, as pessoas sabendo que isso existe... eu mesmo só soube porque alguém que era enlutado e era psicólogo que soube, tal. Porque eu sou mais ou menos conhecido, que é era a irmã de uma colega de dança que me avisou e eu fui conhecer você e a $\operatorname{Dr}^{\mathrm{a}}$ (nome). Mas assim, eu ia ficar ao Deus dará por que... por exemplo, os alcoólicos anônimos tem o Anon para os parentes, o AA. Então eu acho que essa massividade de divulgação, informação 


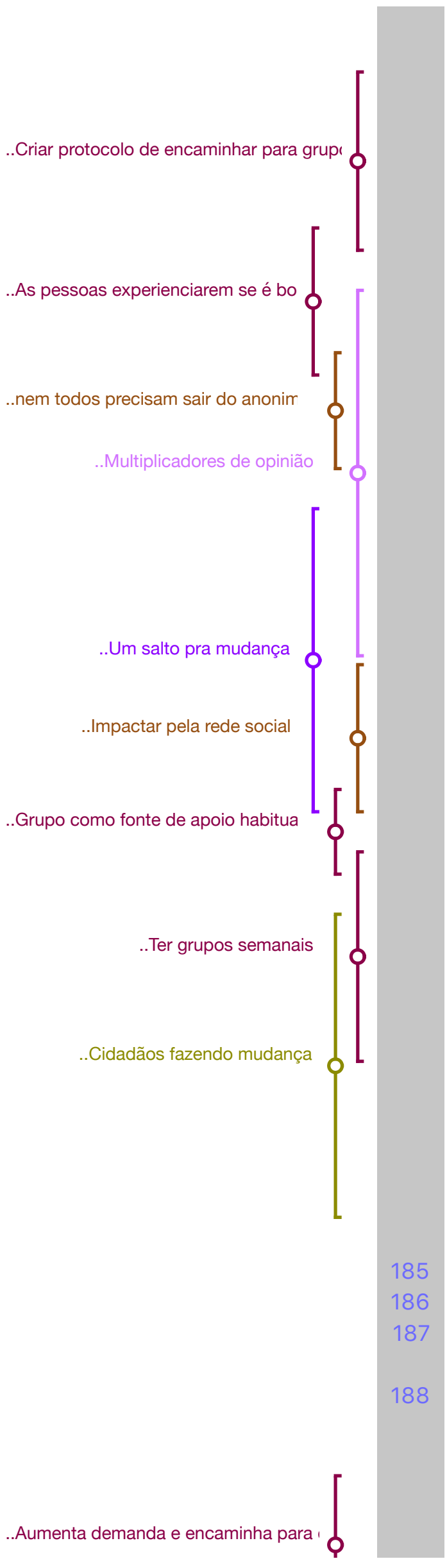

é poder, eu repito, eu acho o ponto de partida. Porque a via desse porto seguro pra acolhiment é... e sendo massivamente divulgado, até mesmo os profissionais de saúde colocar até como um protocolo, protocolo, encaminhar, ou pelo menos dar as indicações das opções disponíveis para procurar. Porque, o que que vai, quando a pessoa chega, ela pode até não continuar, mas ela já foi e sabe como é, e tal. E aí vaiter um contingente que vai abraçar, de alguma forma. Não digo que vá abrir mão do anonimato, que vai fazer... mas vai fazer pelo menos isso que ele está fazendo e muito mais. Se o cara é um universitário, ele vai começar a conversar com pessoas do meio universitário. Se ele é um professor, professor é um grande formador de opinião, se ele é um profissional de saúde, ou é estudante da área de saúde, enfim... eu acho que isso seria um grande salto. Um salto pra mudança. Trabalhando com a informação. Eu acho que aí, as pessoas, cada uma hoje em dia, ainda mais se for mais jovem ou de meia idade, usa muito a rede social. Então vai impactar. A pessoa, muitos deles vão fazer disso um habito, um habito mensal, semanal, que seja e aí de tá indo lá. E eu acho até que deveria ter, além das reuniões mensais, alguma coisa semanal. Algum mecanismo de acolhimento, semanal... Porque a pessoa esperar um mês, as vezes a pessoa já esqueceu. Então, semanal deveria ter. Enfim, eu acho que essa lógica, ela vai nos trazer uma grande parceria.Uma grande parceria de cidadãos que vão cumprir esse papel de reproduzir as suas realidades, fomentar discussão e assim fazer a mudança, creio eu. Mas desculpa, agora o que você falou, por favor.

E: Você me respondeu, respondeu...

P7: Desculpa, viu?

E: Imagina... eu que peço desculpas de interromper sua linha de raciocínio.

P2: Aí a gente esta falando de uma linha de proteção: mídia, polícia que tem que saber o que fazer na hora $\mathrm{H}$, os médicos, psicólogos, psiquiatras, a familia... é tanta coisa... é a demanda que vai aumentar e a gente precisa 


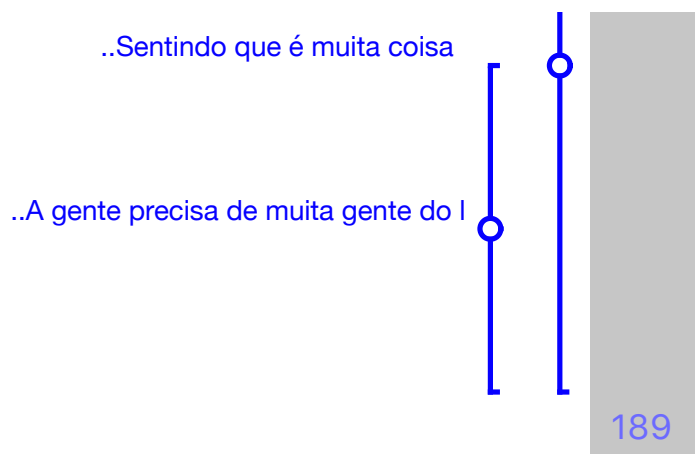

..Por onde começamos?

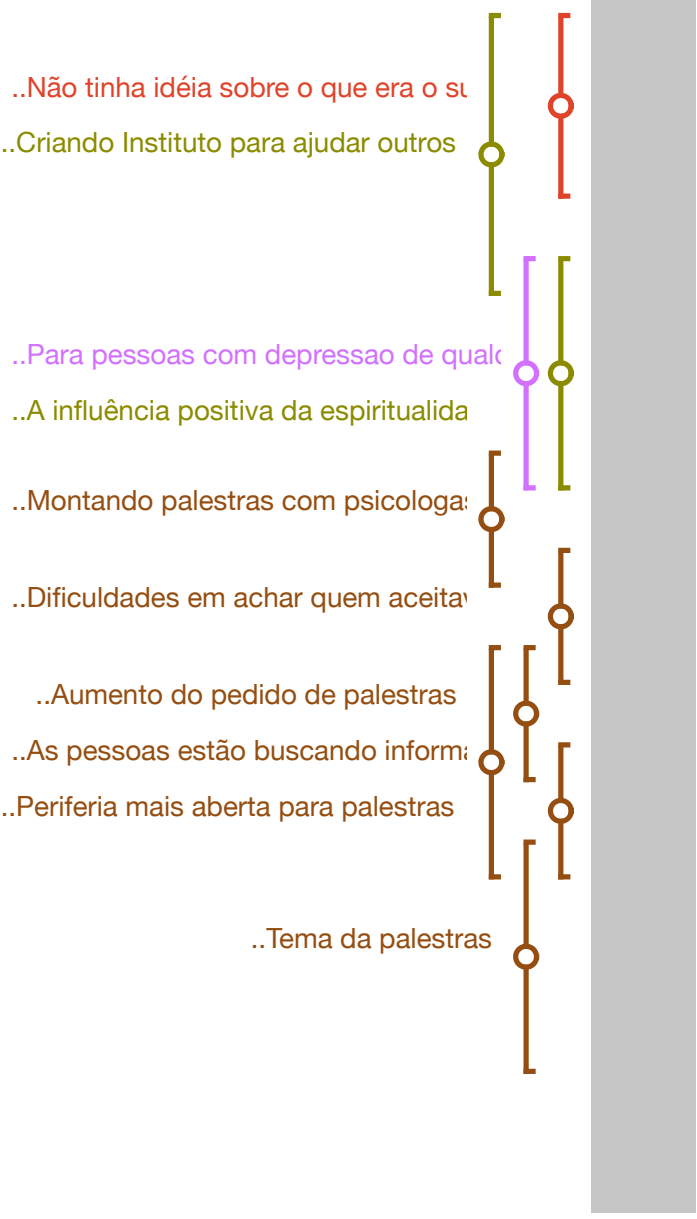

de pessoas para onde? Mesmo que elas falem "ok, aceito, preciso de ajuda". A gente faz o que? Tá dando um nó na minha cabeça. É muita coisa ao mesmo tempo. A gente precisa de muita gente do lado da gente eu não estou conseguindo entender como é que a gente vai conseguir amarrar uma coisa à outra e aí...

E: É P2, é assim, como toda a questão complexa, não tem uma resposta simples que a gente possa...eu acho que se aumentar a consciência, você falar mais sobre o assunto, as pessoas entenderem que precisam de ajuda, é um passinho.

P2: Através da mídia? Através do que?

E: Então, é justamente é isso que a gente quer descobrir com esse estudo. Através do que, como que a gente pode aumentar essa consciência a ponto de ajudar as pessoas a prevenirem o suicídio.

P10: e tem as redes sociais...

P1: Quando a gente abriu o (nome de instituto), eu não sou a pessoa mais apropriada para falar, mas, porque a (nome da esposa) fala muito melhor que eu, mas assim, até a bem pouco tempo a gente não tinha nem ideia sobre o suicídio, com o que aconteceu com a (nome da filha) a e depois por outros motivos, a gente criou o instituto, está certo? Esse instituto ele já foi traçado através de mensagens para a gente, ele foi traçado como ele devia trabalhar, inclusive para aquelas pessoas, tanto faz ser da periferia ou não... que sofrem de depressão. Então a gente montou palestras, a (nome da esposa) montou palestras com as psicólogas. $\mathrm{E}$ a gente tinha dificuldade em achar uma escola para dar palestras no começo. Hoje a gente tá dando 2 as vezes até 3 por semana nas escolas. Principalmente na periferia, as escolas que tem mais dificuldade de ter, de levar o profissional né. Essa palestra ela foi passada e mostrada para vários profissionais e tal, é uma palestra que você fala sobre prevenção do suicídio e a valorização da vida. E tenta criar, conscientizar os alunos para perceberem outro amigo seu, varias situações de risco. 


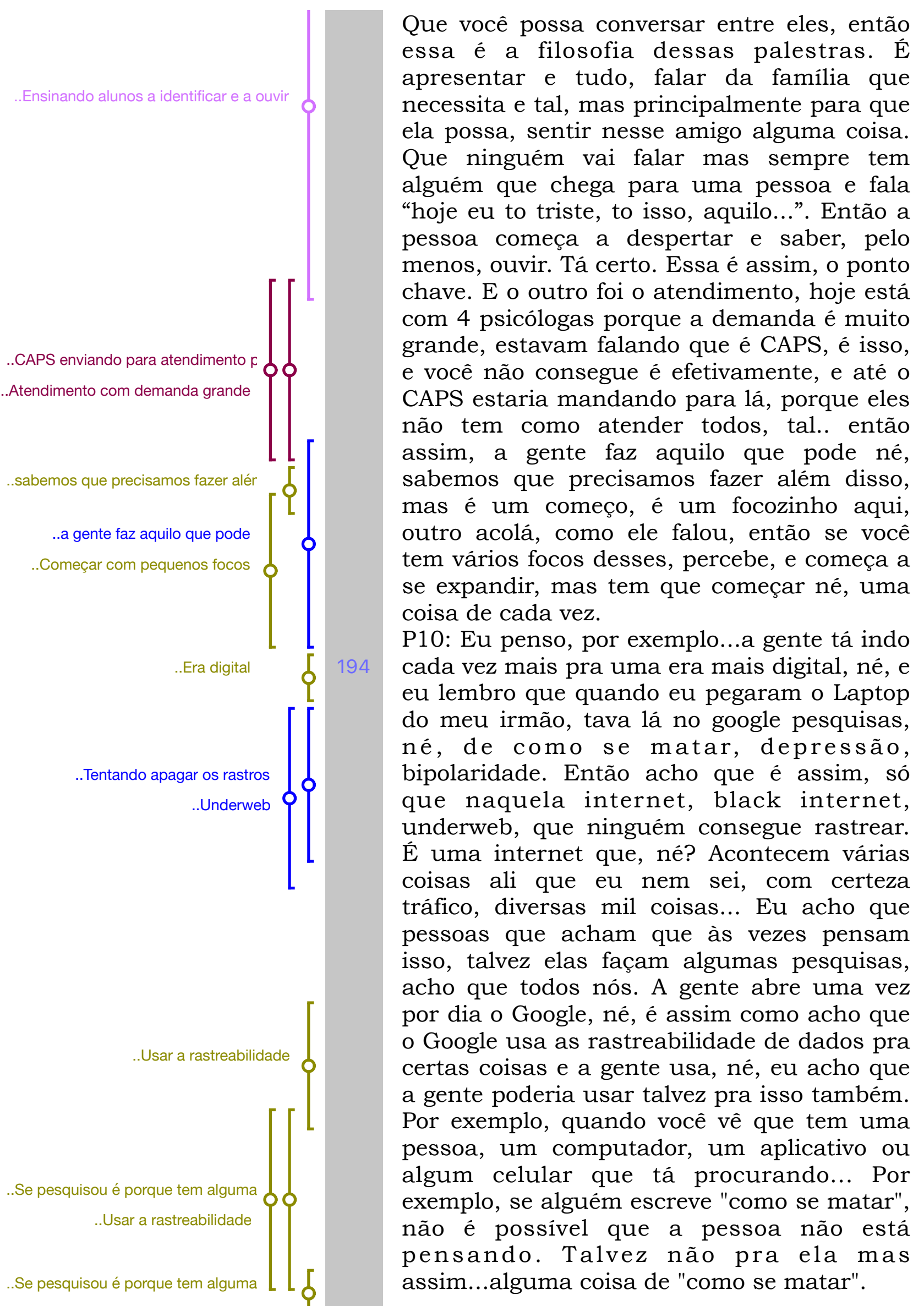




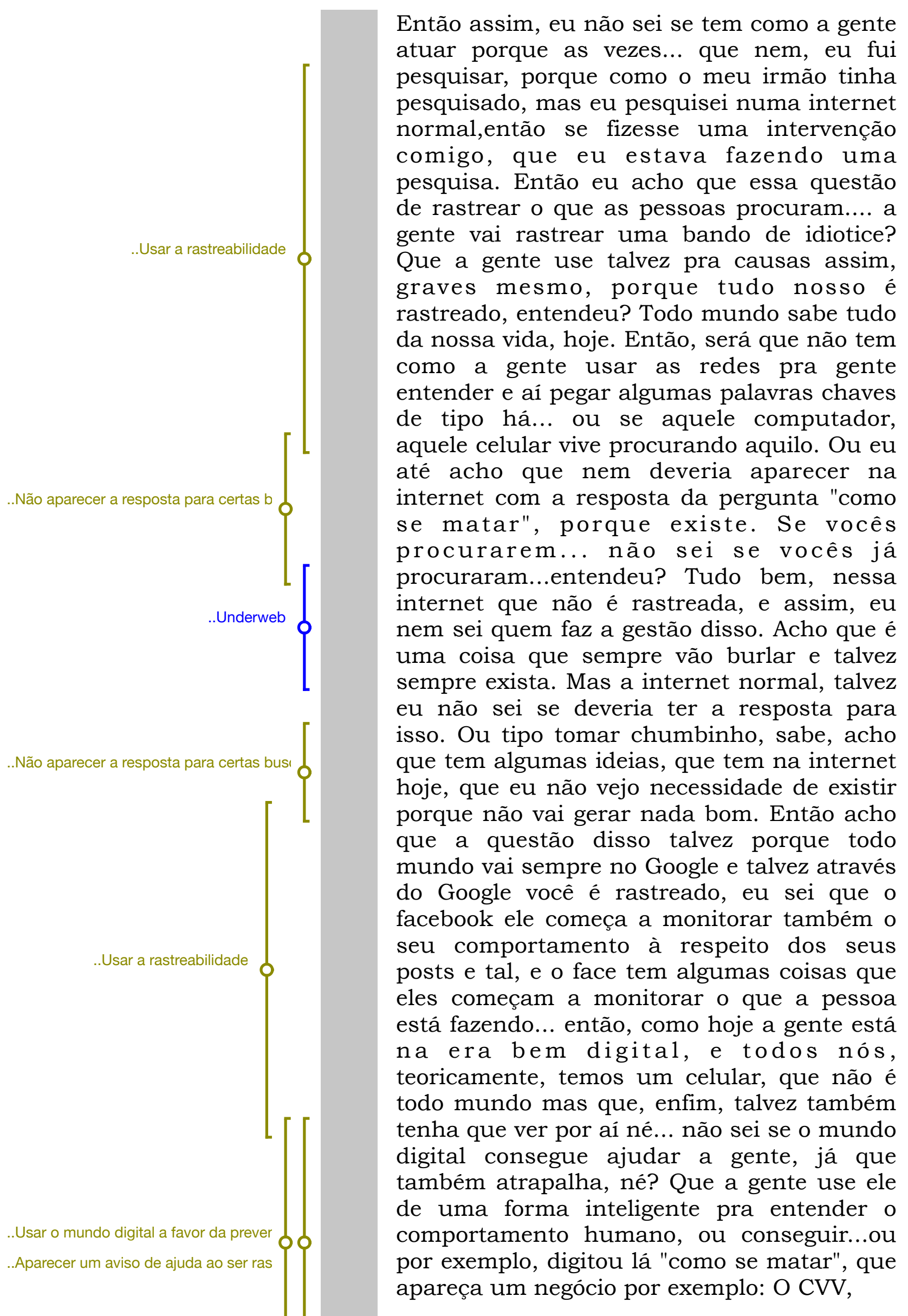




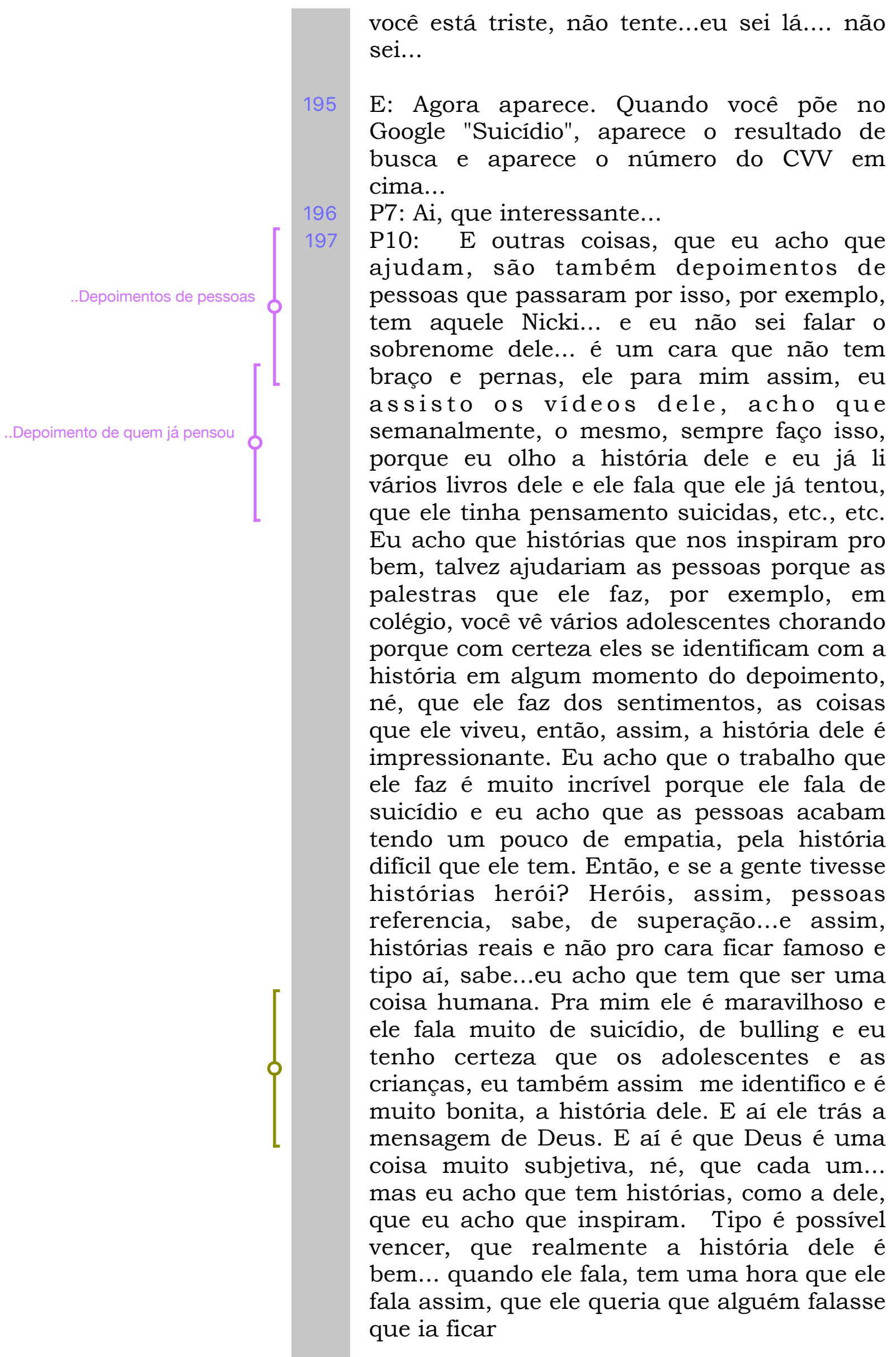




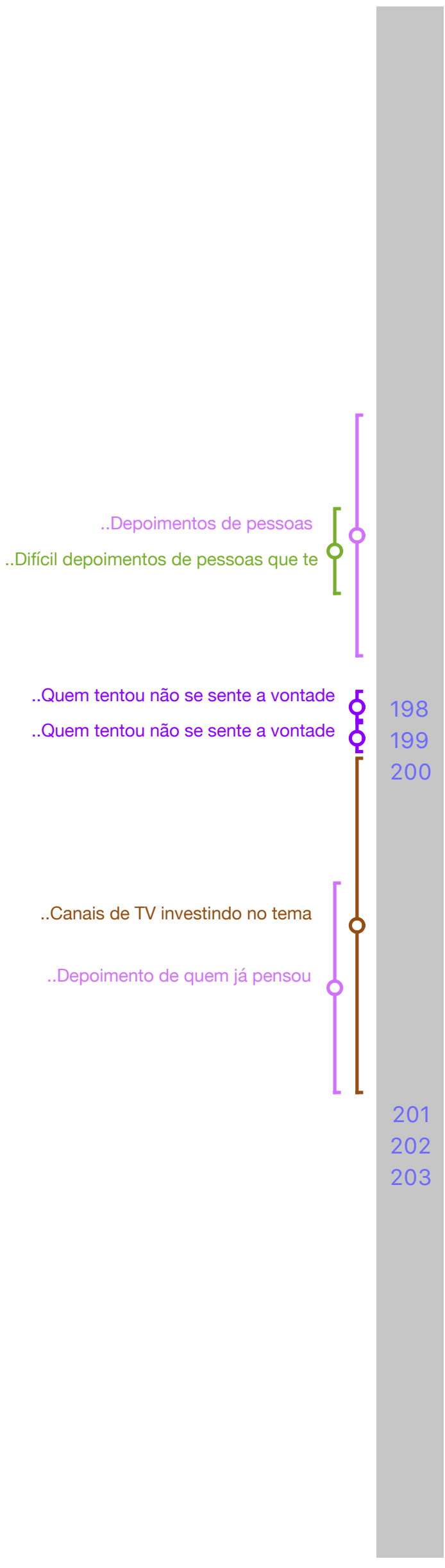

tudo bem, mas como, se todo, ele não conhece ninguém que não tenha braços $\mathrm{e}$ pernas na verdade tem mais uma criança que chama Daniel que nasceu depois, né, quando você se coloca no lugar dele, realmente, não tem um ser humano na face da terra que passou pelo o que o cara passou pra poder falar "Olha vai ficar tudo bem" eu sou um exemplo. Então eu acho que essa questão, ele também procurava um exemplo, entende? Então eu acho que a questão do exemplo, do tipo as pessoas falarem: "Olha, passei por isso mas hoje eu estou bem". Ter depoimentos, tanto de pessoas que ficaram da família e que são os enlutados pra criar empatia de outras famílias, como pessoas que tentaram. Porque você não vê muito depoimento de pessoas que tentaram. Até no nosso grupo quando alguém vai, é interessante você ouvir...

P4: Mas a pessoa não sente à vontade...

P10: Exato porque falar, é só...

P7: Vai ter. Por causa da (nome de canal de televisão). Vai ter 3 jovens que tentaram o suicídio que vão participar agora do filme que eu vou estar participando. Porque os produtores me falaram. Eu sou o enlutado mas tem 3 jovens, acho que de 20 e poucos anos que abriram mão do anonimato, na condição de terem tentado o suicídio e vão relatar suas histórias. Eu acho que são 2 rapazes e 1 moça ou vice-versa. Eu não sei mais detalhes, mas vai ter. Vai ter.

E: Quer dizer, histórias verídicas...

P7: Verídicas. Reais. (01:17:58)

P9: Sim, eu acho que uma coisa que ajudaria, seria se as campanhas fossem voltadas para pessoas comuns, todo mundo, para capacitar a pessoa pra melhorar o diálogo e falar de momentos de tristeza. Ao mesmo tempo, passar informação de que tem um certo ponto de que aí eu ? e vou amigo. Já foge da minha alçada, puxa será que já não é hora de... podia procurar o CVV, um psicólogo, será que não é hora de tomar medicação... se isso fosse parte do diálogo comum, eu acho que assim, é, elas 


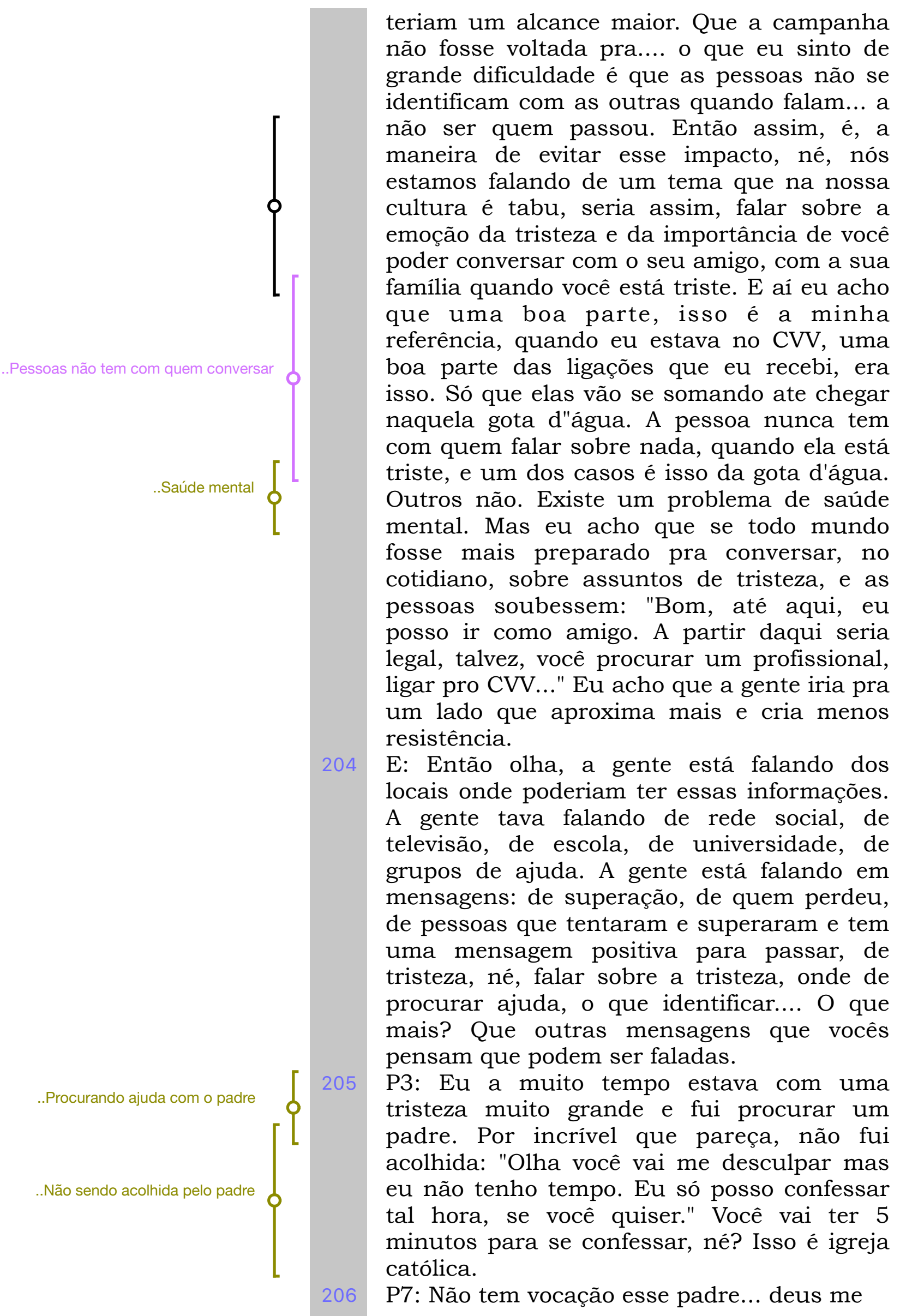




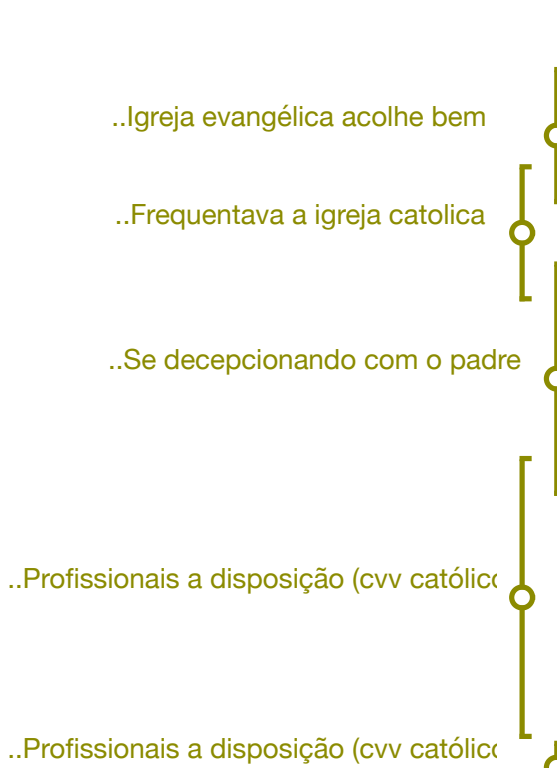

..Profissionais a disposição (cvv católice

.Acreditando que a religião previne suicidi
P3: Mas olha, É a maioria...Na igreja evangélica eu não sei como é que está, pelo jeito eles acolhem muito bem, mas a igreja católica, eu tive essa experiência e era uma pessoa fervorosa, frequentava.... Aquilo me decepcionou tanto, que eu continuei praticando, mas essa decepção é quanto aos padres. Acredito que não sejam todos mas me decepcionei muito. Então eu acho que isso seria uma grande ajuda você encontrar uma psicóloga, psiquiatra, um padre eu acho que a grande ajuda é essa. São profissionais que estariam ali à disposição pra isso.

P2: Os líderes religiosos, de repente...

P3: Os lideres religiosos, porque eu acho que a única coisa que prende pra você não cometer o suicídio é a religião. Você fala: "Não... não é nem pensando na família, é pensando na religião.

P1: O conselho de psicologia devia fazer uma divulgação na, assim, acho que a gente falou isso na vez passada, que se você vai procurar um psicólogo já pensa que é, tá doente, que a pessoa é louca...

P8: Que é louca

211

P1: então é tirar esse né, acho que o conselho de psicologia devia fazer campanha...

P3: psicofobia...

P8: É, tem duas coisas né, para mim, tem o pessoal da psicologia e as pessoas que acham que todo mundo é psicólogo. Também tem essa também. Eu acho que ai tem, eu ouço tantas coisas, assim, das pessoas. A pessoa leu algum folheto, alguma coisa... tem isso também. Que parece, que, das pessoas até entenderem também, como ele falou. Tem aquilo que pode ser acolhido por amigos $\mathrm{e}$ tem a gente saber detectar o momento que.. olha... que a gente precisa... aqui a gente já não dá conta e precisa ajudar aquela pessoa a saber a quem procurar... acho que isso é importante...

P9: Principalmente a pessoa próxima... que pode ajudar essa família...

P8: Porque a gente também não dá conta de 
gente...

P1: Por exemplo. Igual o conselho de engenharia faz campanha, de arquitetura, e assim vai, né... de enfermagem, de... eu vi até a pouco tempo, de terapia ocupacional, tudo... fisioterapia, e o conselho de psicologia poderia também entrar nessa né, está sempre, agora... acho que foi no Fantástico, no domingo, no Fantástico, é... aquele que... não se faz uma obra sem consultar um profissional, né, o que que acontece... não tem um quadro assim... a porta que não abre, sei lá... então fazer uma campanha numa área que fale sobre procurar o profissional adequado né.. e acho que a psicologia poderia também entrar nessa de...

P9: Eu concordo com o P1, assim, disso, existe um estigma de quem procura um psicólogo tem algum problema, mas eu acho que tem um lado que podia ser explorado porque eu já vejo também, em algumas situações que a pessoa entende, assim, procurar uma terapia como autoconhecimento. Também tá crescendo... é pequeno mas acho que... existe esse outro lado que é um lado positivo, saudável. Acho que poderia ser mais divulgado, isso.

P10: Mas tem isso pode haver uma autoajuda, curso de psicólogos, palestra motivacional, cursos onde as pessoas vão para não sei aonde, passar o final de semana pra ficar sozinho e encontrar o seu eu, meditação, Yoga... A humanidade está

..Achando que as pessoas se perderi

..Pessoas mais humanas e preocupa

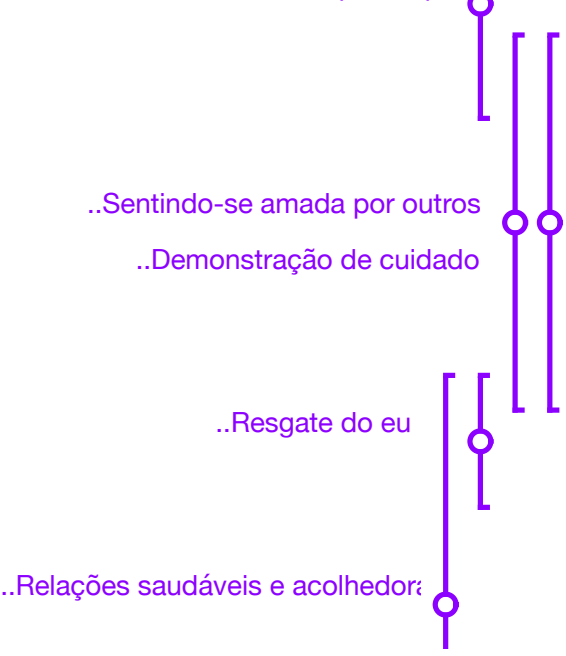
passando por isso. Eu acho que a gente se perdeu e a gente tá tentando resgatar o EU, e talvez quando a gente voltar a ser mais humano, se importar um pouco mais em como a gente se relaciona, talvez ajude, né, porque, as vezes só um: "Oi, tudo bem?", um "Obrigada", ou um "Como você está hoje?" Às vezes isso, pronto, já fez o seu dia, né? Ou alguém te manda uma mensagem você fala: "Ah! É por isso que vale à pena viver", entendeu. São as diversas formas de amor. Então, eu acho que quando a gente voltar a resgatar o eu, talvez isso, né, ajude a gente acolher as pessoas porque acho que não vai ter profissional pra todo mundo todos os 


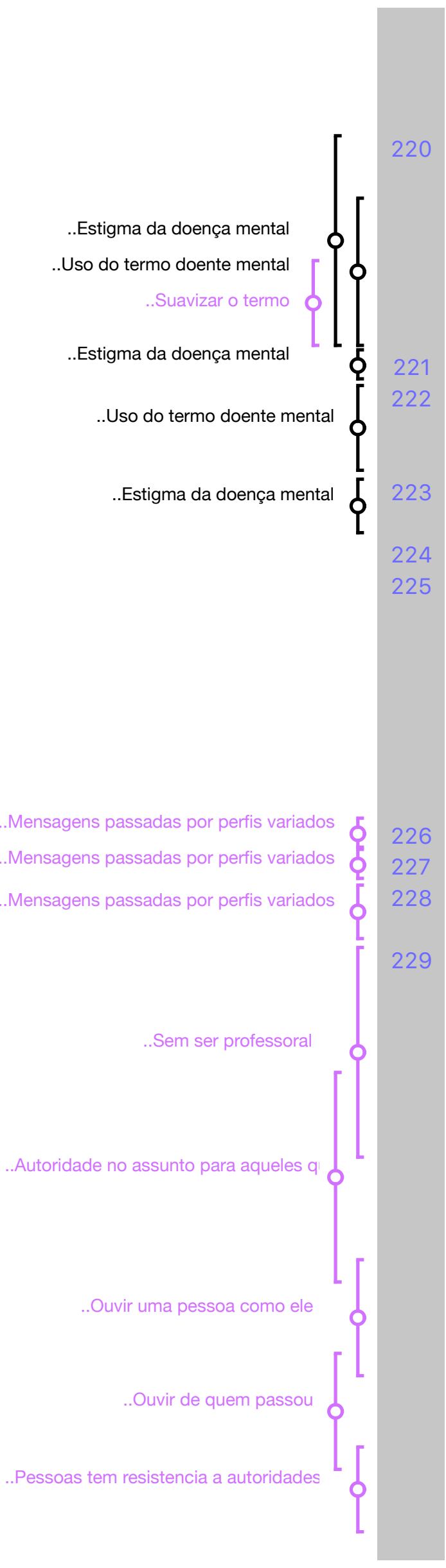

dias mas, se cada um fizer um pouquinho e ter boas relações e aí é assim, é dificil, a gente trabalha com isso todo dia isso vai ajudar, também...

P2: E o estigma de "Doença mental". Que quando a gente fala em doença mental entra depressão, ansiedade, entra tudo isso. Ai a pessoa fala: "Nossa, então eu sou doente mental" Não como mudar, suavizar esse conceito? Esse termo? Porque a pessoa ai não aceita esse termo porque...

P7: Transtorno? Chamar de transtorno...

P2: Não sei. Mas assim... Doença mental? Meu Deus, eu sou um doente mental? Não! É dificil a pessoa... para a pessoa assumir...

P7: Transtorno, talvez. A palavra mais suave...

P2: É.....

E: A gente está falando das mensagens, da forma, dos locais. Ai fiquei pensando: Por quem que essas mensagens poderiam ser passadas? Vamos imaginar que tem lá alguma coisa na TV, tem alguma coisa, é por um jovem falando...ou será que vai me tocar mais se for uma pessoa mais ou menos da minha idade ou se for...

P4: Variado...

P7: Vários perfis...

P10: Diversidade... tem que refletir a sociedade...

P7: E não pode ser professoral, não pode... porque por exemplo, se for um profissional de saúde categorizado vai ficar professoral... Você, por exemplo, impõe, impõe autoridade. E aí sim... para o segmento, (risos). Autoridade... sim, porque você tem um título...tem um reconhecimento e tal. Então, quando vai falar, aí, é pra aquele contingente que busca uma informação e quer ouvir uma autoridade no assunto. Então ele vai, então serve a esse fim, entãoagora, existe um outro contingente que não quer ouvir, é, quer ouvir, as vezes, uma pessoa como ele, esse...eu também já vi alguns dele, esse que não tem os braços e pernas, esse camarada, ele até pode ter o tom profissional também mas acontece que ele vive a realidade, então aquela resistência que muita gente vai ter à pessoa que é autoridade do assunto. Porque 


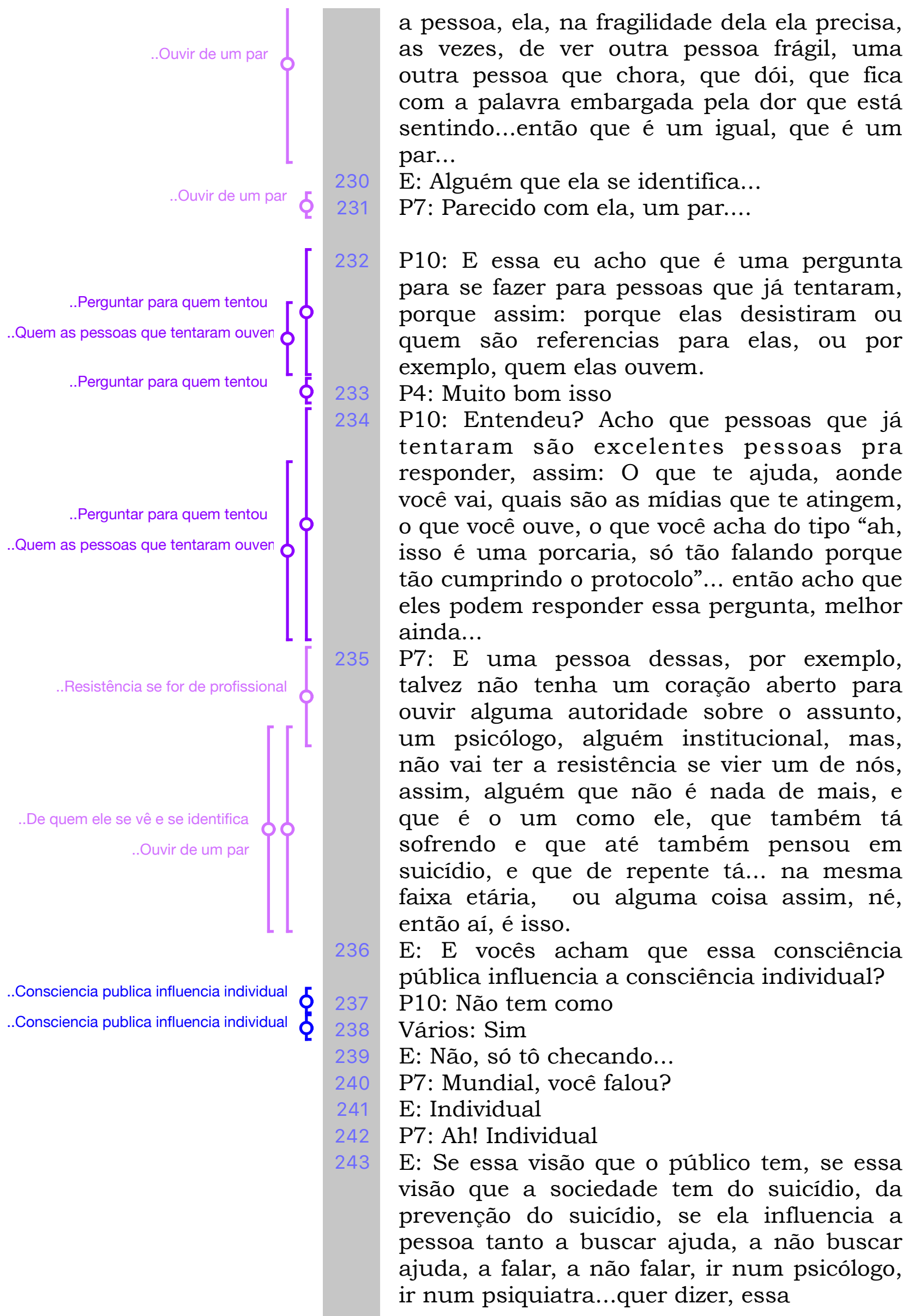


sociedade ela tem essa influencia dentro do comportamento do individuo.

P10: É que a consciência individual, quase

..Quase não existe consciencia individual

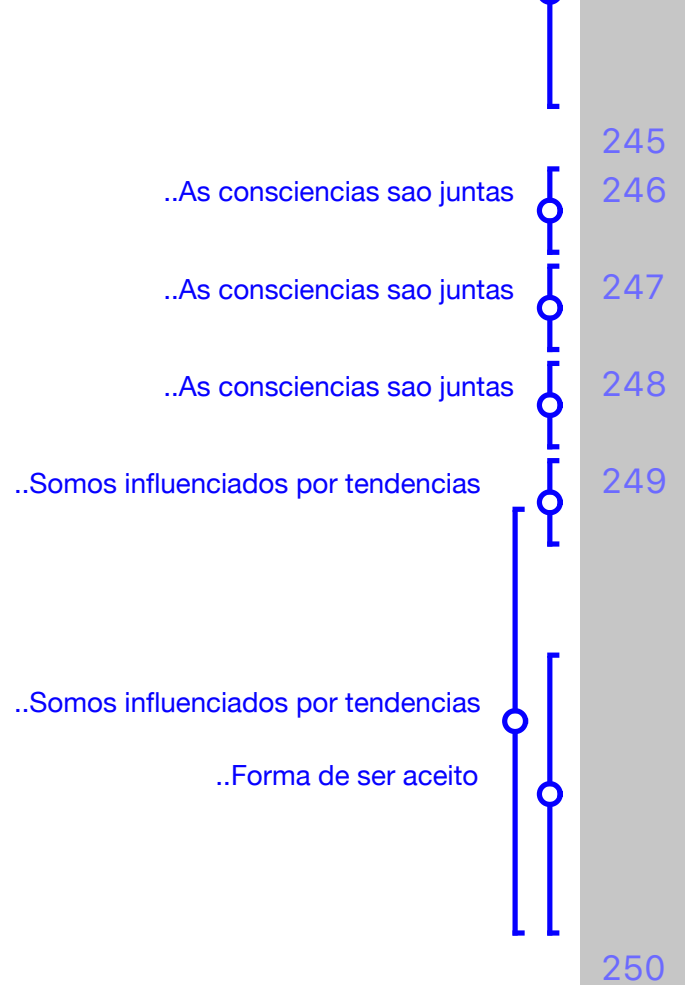

..Falando sobre o suicidio para outros

.Falando sobre o suicidio para outros

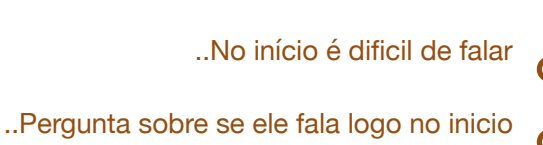

..Já ouvi falarem que quem se mata é frace

Reações ao quem se mata é fraco não existe, eu acho na minha opinião. Acho que os seres, a gente não tem uma consciência, assim...a gente nem se conhece pra poder assim, não se deixar influenciar.

E: Ainda mais separar...

P10: Eu acho que é uma coisa assim, uhu, tudo junto...

P8: Mas é que não é uma coisa que vai ser $100 \% \ldots$

P4: Não, nada vai ser $100 \%$ mas eu acho que...

P7: Tendências né, nós somos influenciados por tendências, modas e etc. Quer dizer, a gente acha que é individuo mas uma boa parte de nós é acomodação com outras coisas que outras pessoas também aceitam. Que é a tendência, a moda...então eu aceito que eu tenho que usar calça, camisa, enfim, essa coisa, então de repente, isso não é uma decisão minha mas é a forma de como eu vou ser aceito.

E: E a forma como a sociedade, as pessoas encaram o suicídio. Toca vocês? Vocês se sentem tocados pela forma como a sociedade encara o suicídio. Influencia vocês nos seus nos atos? Por exemplo: Quando alguém vem e pergunta do que a pessoa morreu.

P7: Eu pego e falo...

P1: A gente também já não esconde mais...

E: Sim, hoje em dia vocês falam?

P1: Mas eu acho que pra quem tá ainda no início...

P7: Você fala no início, no primeiro instante?

P8: Eu falo pra algumas pessoas pra outras não, assim como eu falo que uma pessoa querida que morreu de câncer, eu falo pra uns e não falo pra outros... quer dizer, eu falo para quem...

257 E: Por exemplo, como que seria isso, né? Está uma roda de pessoas falando que quem se mata é fraco. Isso é uma visão da sociedade...

P7: Tem uns que falam isso para mim...

P4: Eu se hoje em dia estiver em uma eu falo.. Porque, você já passou por isso? Como é? Qual é a experiência que você tem? Como 


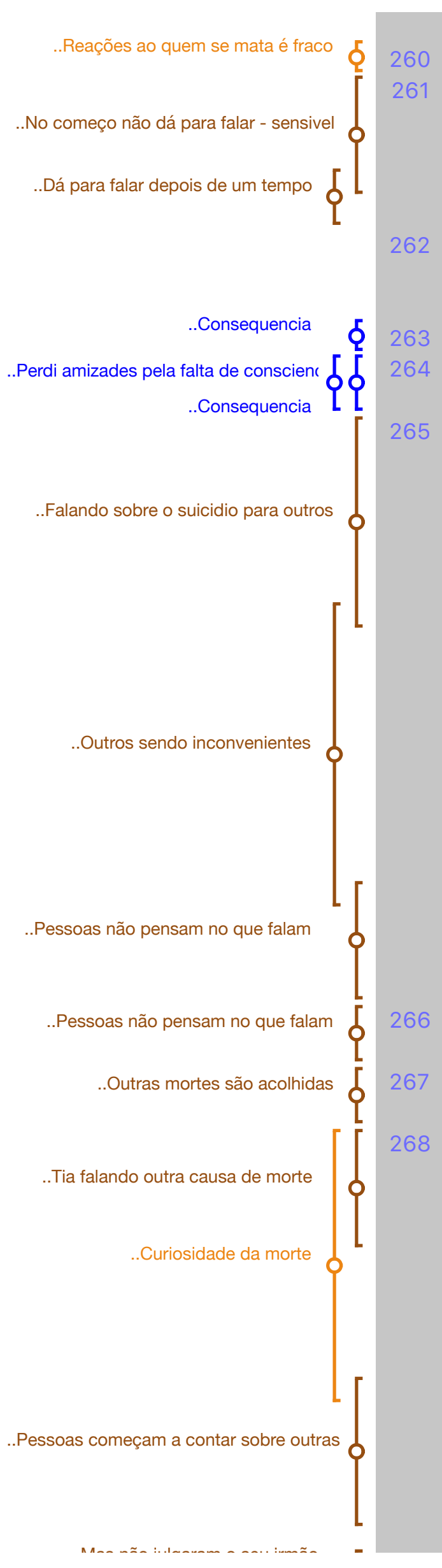

você sabe? Aí eu vou partir já até pra...

P2: Para a defesa né...

P4: É... mas em outras épocas não. No primeiro momento eu acho que você fica muito sensivel, que você não sabe nem que tem que falar, né? Mas depois... você começa né...

E: Vocês já passaram por situações onde essa falta de consciência publica e individual machucou vocês?

P7: Machuca!

P4: Nossa! Eu passei muito. De perder amizades...

P7: O fotógrafo que foi lá apresentar os trabalhos de formatura da minha filha, a que está viva né... mas aí no final ele disse "Mas e então, a formatura da outra, tem aqui... mas cadê ela?" Aî eu olhei.. Minha filha? Morreu. E ele: "ah! morreu, é? Do que ela morreu?" Minha filha se suicidou. E ele, ele é tipo japonês, eu não sei, talvez pela formação e tudo, "Ah, mas suicídio, a pessoa, ela... tem religião até que ela não é nem enterrado junto." Aí começou então a falar... meu deus que inconveniente, e eu olhavapara a minha filha,e eu fiquei olhando para ele, e olhava para a minha filha. Até uma hora ele viu que não tava fazendo "feedback" né. Aí... vou voltar...quer dizer então as pessoas recebem o impacto e começam a botar para fora qualquer coisa e né, não pensa no que está falando...

P8: Mas isso eu acho que é pra qualquer tipo de morte. Não sei..

P3: Acho que não... Eles acolhem tanto todos tipos de morte, sabe? Na outra vez...

P8: Eu tive essa situação de por exemplo a minha tia sair dizendo que o meu irmão morreu de um ataque fulminante. Um ataque cardíaco. E eu sentei numa mesa de uma pessoa que eu não via ha tempo e ela virou assim : "AH! É o seu irmão morreu de um ataque cardíaco fulminante, né?" Eu olhei pra ela e falei assim:"Ah sei lá, né. Se te falaram isso deve ser, né?" Aí ela começou a rir e me contou de umas 5 pessoas que tinham morrido de ataque cardiaco fulminante com 10 anos, com 20 anos, com 60 anos... e as pessoas fazem isso.... 

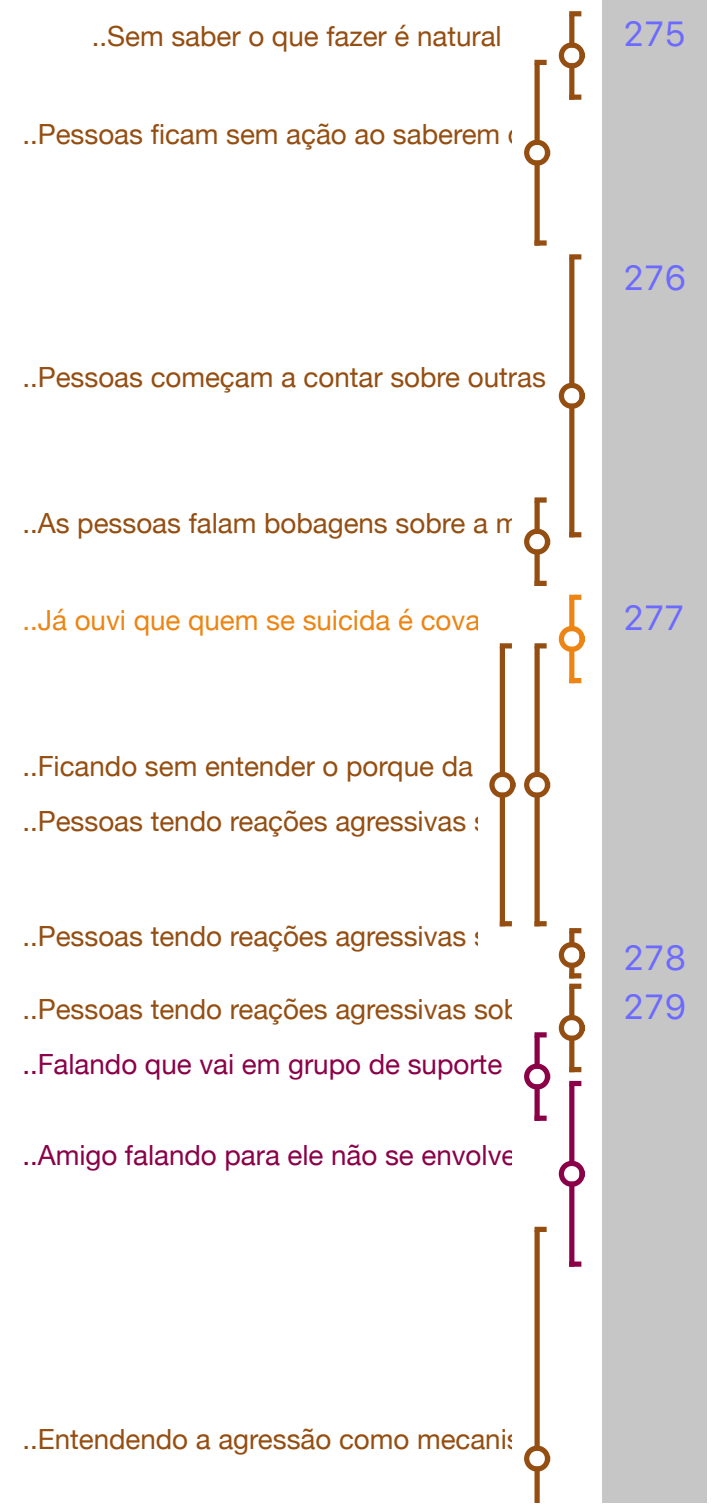

P3: Mas não julgaram o seu irmão...

P8: Então...

P3: Há, se ele teve um ataque cardiaco... e por causa de...

P8: Mas ele não morreu de ataque cardiaco... P3: Sim, mas não foi isso...

P8: Sim, mas as pessoas falam coisas. Elas falam qualquer coisa. De quando eu estou com a minha mãe no cartório pra registrar o óbito o cara fala assim: "Ah, sabe que morreu também essa semana?" Um dia depois que o meu irmão morreu falaram isso pra minha mãe. As pessoas são completamente sem noção. Eu acho que no suicídio talvez as pessoas ficam, eu não sei se julgam ou ficam mais sem saber o que fazer e fica falando...

P7: Sem saber o que fazer é uma reação normal... eu já vi reações, as vezes a pessoa vai perguntando, ah e tal... morreu, e você fala e a pessoa, bum. Fica todo mundo sem ação.

P8: É que com outros tipos de morte a pessoa sabe o que fazer porque conhece alguém, porque não sei o que...aí eles começam a falar essas coisas, de... uma coisa que leu, lá, e começam a falar essas coisas como falaram pra você. As pessoas falam muita bobagem...

P9: Isso que você comentou, né, que quem se suicida é covarde, é o que eu ouvi, assim. De uma pessoa próxima, então eu tive essa experiência e aí eu tive assim, primeiro eu fiquei sem entender porque, a reação, uma reação agressiva da pessoa, de ofender mesmo.

P7: Ela teve a intenção de ofender?

P9: Começou a levantar a voz, falou que eu acho você um individuo... e eu falei, não, eu estou indo em um grupo de suporte... você não devia se envolver com essas coisas... uma pessoa próxima, assim, que eu conheço ha muitos anos. Eu acabei me afastando, eu levei um tempo pra processar isso. E aí, depois é que eu fui entender que é um mecanismo, nesse caso em particular, de defesa dela e da família inteira dela. É a 
esposa de um amigo meu que tem dificuldade de lidar com qualquer tema que é morte ou doença grave, o jeitoda pessoa cortar o assunto é agredindo.

P7: Eu acho que você falou isso um pouco né...

281 P9: É então, eu, é lógico que é doído, assim. Naquele momento que você vai procurar suporte de um amigo... E assim, o curioso é que é o mesmo amigo que falou do "divertidamente", o filme,e que ele comprou pras filhas e falou que todas as emoções, mas na mesma família tem isso. Então, dessa experiência que eu trouxe, assim, que as vezes chegar nesse tema, assim, meio tipo, as vezes eu vejo algumas informações serem passadas com impacto, né, de estatísticas, eu percebo que pra pessoa que já tem dificuldade, cria, talvez uma rejeição, talvez uma maneira de falar das emoções... que a tristeza faz parte, que o luto faz parte... talvez tenha uma resistência menor.

E: Você acha que talvez se as pessoas tivessem reações diferentes, ou mais positivas, vamos dizer assim. Se a sociedade aceitasse melhor essa morte e falasse mais abertamente de suicídio, diminuísse o tabu em relação ao assunto, quer dizer, a reação das pessoas ao lidar com esse comportamento ou ao lidar com alguém que perdeu seria diferente?

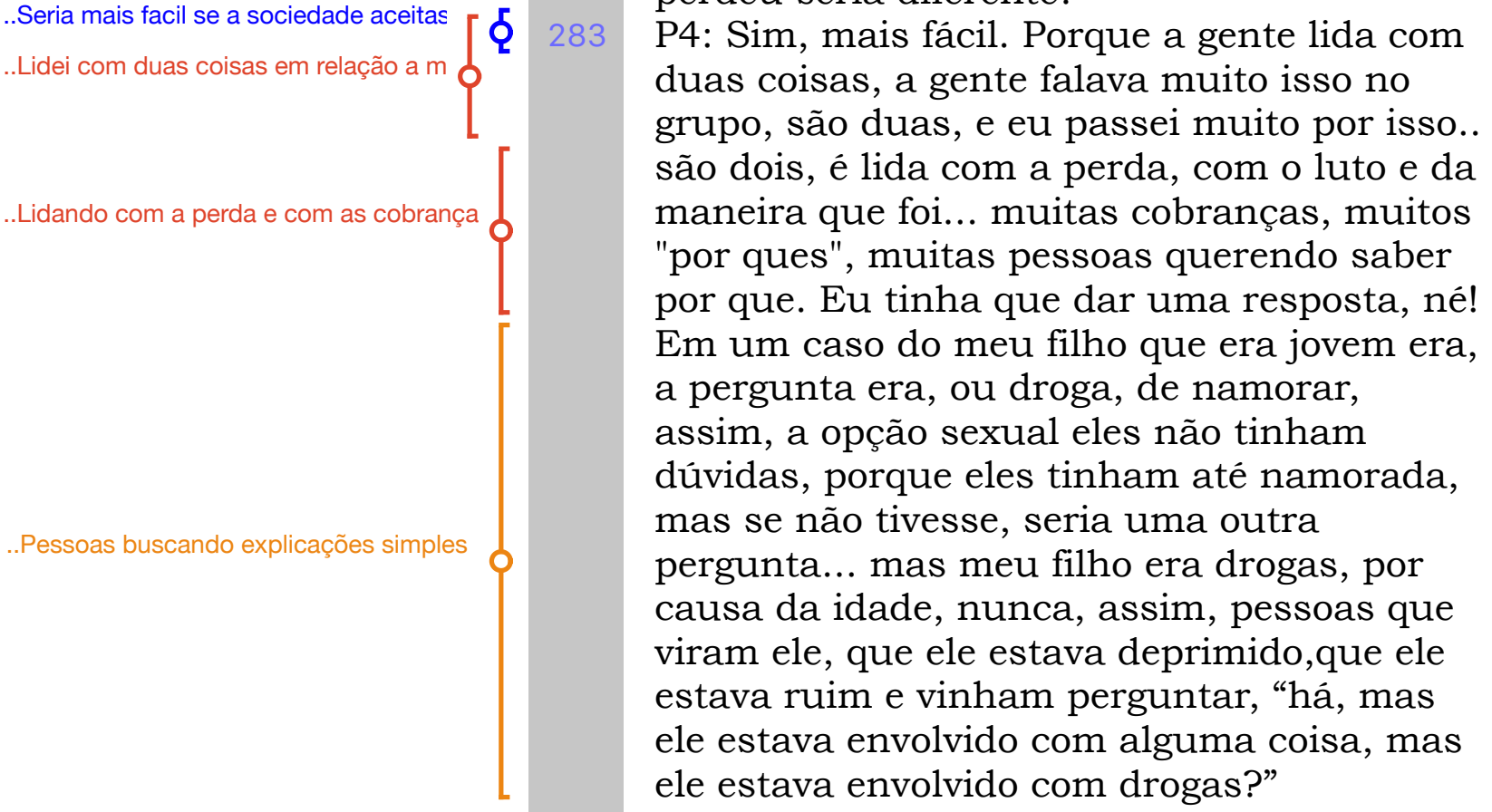




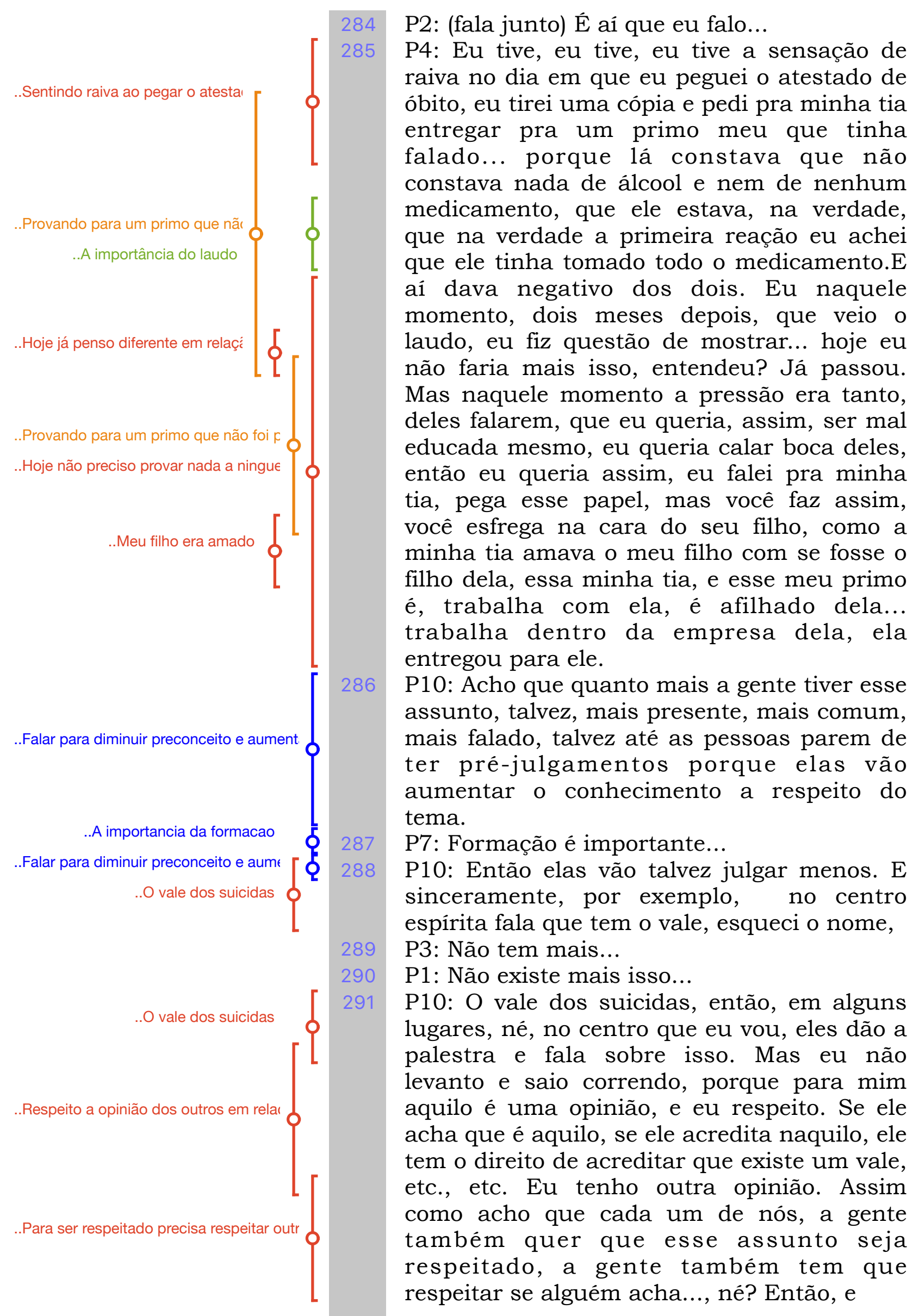




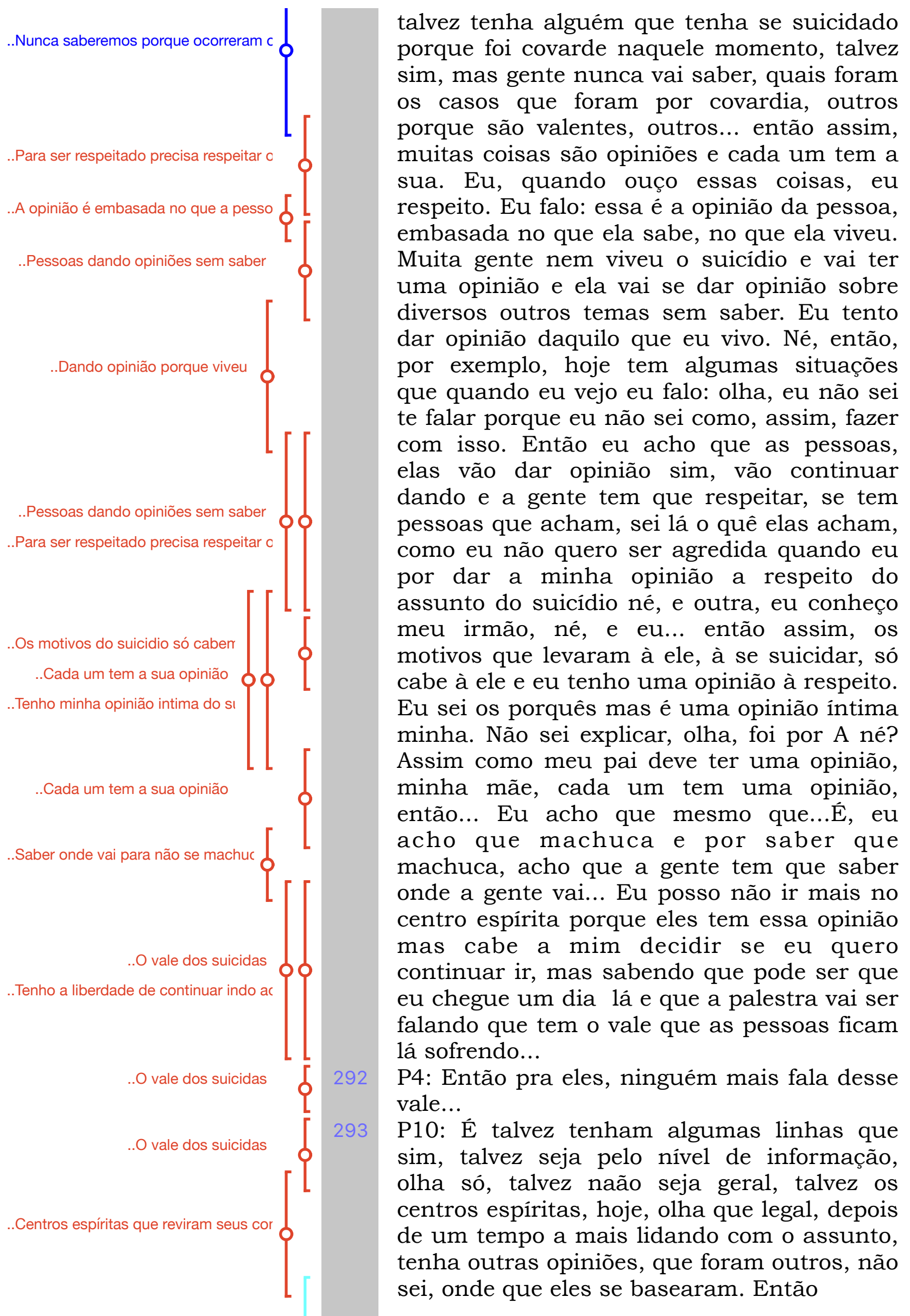




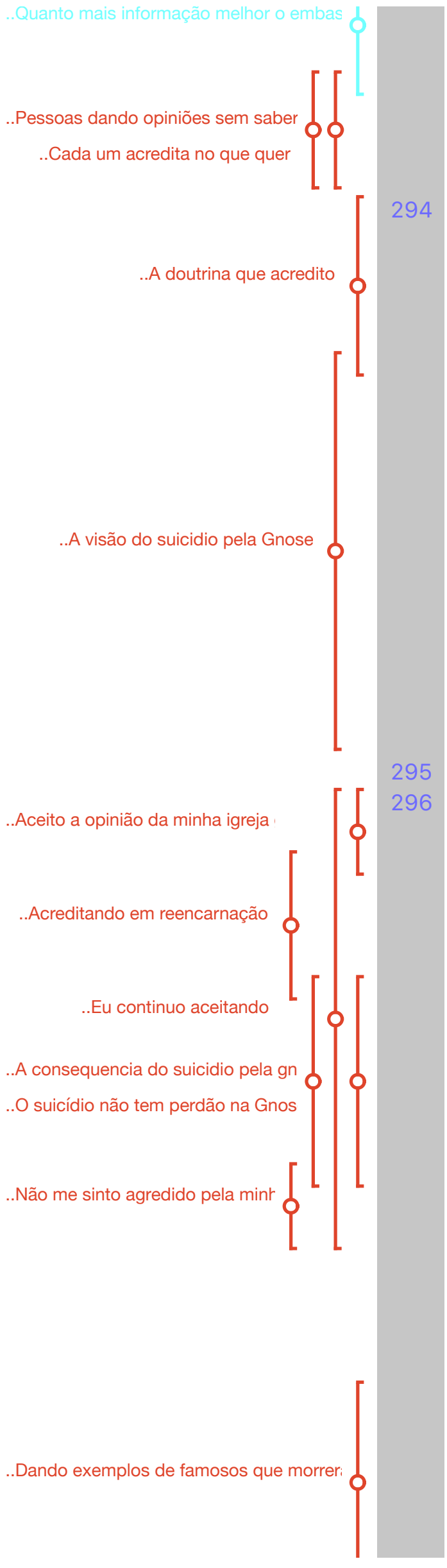

acho que é muito isso. Acho que quanto mais informação tiver aí, as pessoas vão se embasar um pouco melhor. E tem outras que vão se embasar mesmo sem saber e vão achar que é aquilo e cada um acredita no que quer...

P7: No meu meio que eu frequento religioso que é a Gnose, a questão é digamos, mais ou menos, dogmática que parte do princípio da sabedoria do mestre. E o que ele fala, que está registrado nos livros e é o que a gente aceita como doutrina, é que quando a pessoa, quando ela se mata, comete o suicídio, ela volta, vive a vida normalmente conforme o seu carma e darma, conforme o que já tinha, né, mas toda a vida dela vai ser estruturada, e ele vai viver, e na hora em que ele estiver mais feliz e querendo viver, ele vai morrer. Então, por exemplo: aquela pessoa que está prestes a casar, então está na festa de casamento morre aí. Que conseguiu conquistar tudo e vai gozar e morre ali, na hora. Quer dizer, na hora em que ela mais esta querendo viver a vida lhe é tirada.

E: E essa visão que a tua religião dá...

P7: Daí a gente aceita. A gente não fica com raiva. Eu, pelo menos, eu aceito, eu não dei a minha opinião....esse caso eu aceito . Eu entendo que isso é lógico, até porque o que eu falei aqui, a sua vida vai seguir adiante, a sua outra existência, continuarão sendo normal, como qualquer outra.Mas essa é uma coisa que não tem perdão. Não dá para negociar na existência seguinte, pra ela não morrer na hora que ela mais quiser viver. Isso aí tem que acontecer pra que ela fique tão impactada a ponto de nunca mais fazer isso na sequencia das outras existências. Quer dizer, pela lógica que ela contem, ela não me agrediu. Eu continuo aceitando e eu acho, eu sei que a minha filha já nasceu ou vai nascer ou já nasceu, não sei, não tenho esse grau de consciência pra saber e que vai na hora em que ela mais quiser viver a vida lhe vai lhe ser tirada. Por exemplo, os Mamonas Assassinas, aquele grupo, estava no auge do seu sucesso. Bum, morreram todos. Quando mais queriam viver. Quando a vida lhe sorria e tem outros exemplos, né? 


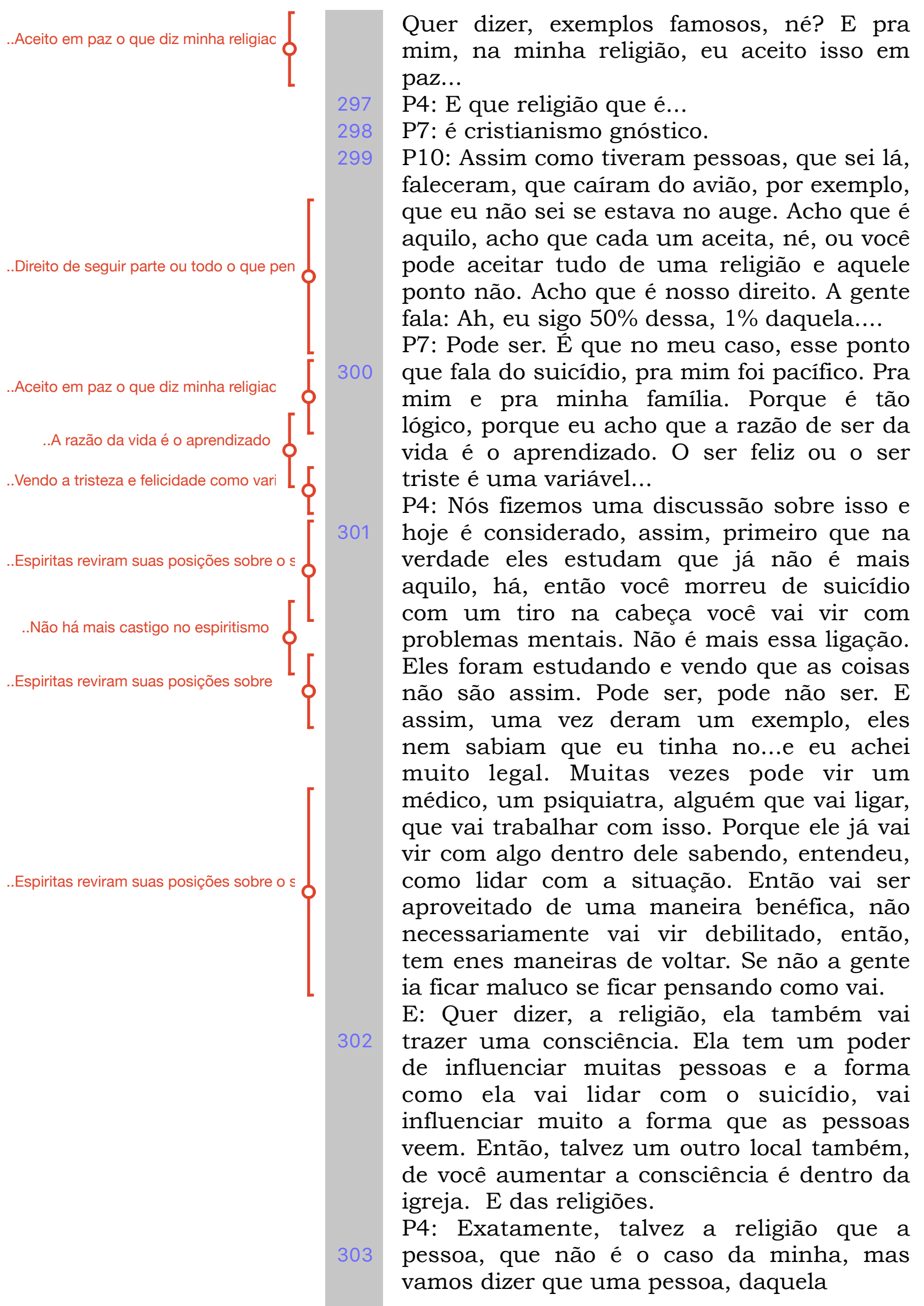




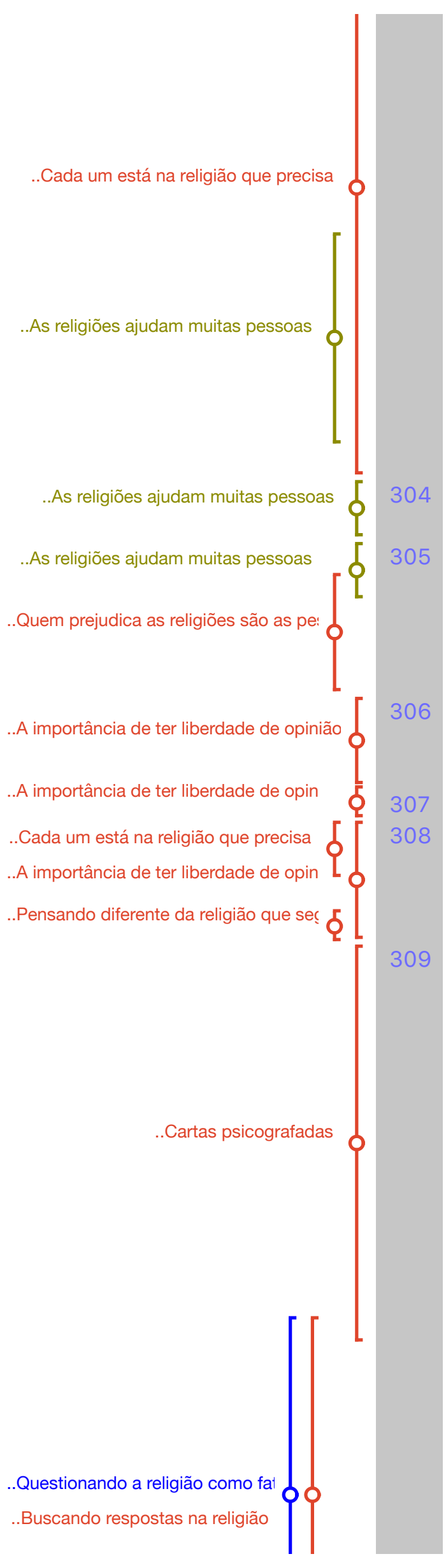

religião, a gente aprende muito isso: cada um está, as vezes, na religião certa e quando não está, não é o momento mais, vai procurar uma outra. Porque muitas vezes a pessoa que estava na igreja evangélica, e aprende, porque é necessário, porque eles tem tantas... de acreditar, é necessário as vezes ainda, porque as vezes lá seguram, um pai de família que está bebendo e as vezes vai lá e por temor a Deus, que na nossa já não é o temor, mas por temor a Deus, para de beber, não bate na mulher, entendeu? Se modifica. Então, são necessárias, depende do grau que você vá buscando. Você vai buscando mais, mais, vai questionando... P3:Eles conseguem, inclusive nas cadeias, recuperam tanta gente...

P4: Tem, tem seu mérito,todas elas tem, na essência um mérito bom... O que as vezes prejudica uma religião ou outra somos nós mesmos, seres humanos que estamos administrando.

P9: Acho que religião, eu acho que é importante, mas é importante frisar a liberdade de cada um ter opinião diferente.

P7: Até de não ter religião

P9: Porque nunca se crê em coisas conflitantes, não é? E aí poder, assim, ter a liberdade de conversar e se abrir, e falar, não, eu penso diferente na minha religião....

P4: Meu filho escreveu muitas cartas, e nas cartas pela religião dele, que ele frequentava ele falava o que ele sabia, que simplesmente ele não sabia qual era o local dele neste mundo. Mas... que ele sabia que ele teria que voltar algum dia e, ele não usa pagar por isso, mas ele fala, resgatar o que ele fez... mas que aqui neste momento ele não estava pronto, que o mundo era um lugar muito escuro pra ele, que ele não sabia qual era a posição que ele tinha que tomar. Então assim, na verdade é dele, não são cartas psicografadas, é dele né? A sensação era maior do que a educação que ele teve de desde os 5 anos de evangelização espírita. Então ele sabia que tinha outra coisa? Eu questionei muito isso, na época. Como então? Mas como? Se a pessoa comete o ato achando que lá não tem mais nada, então eu 


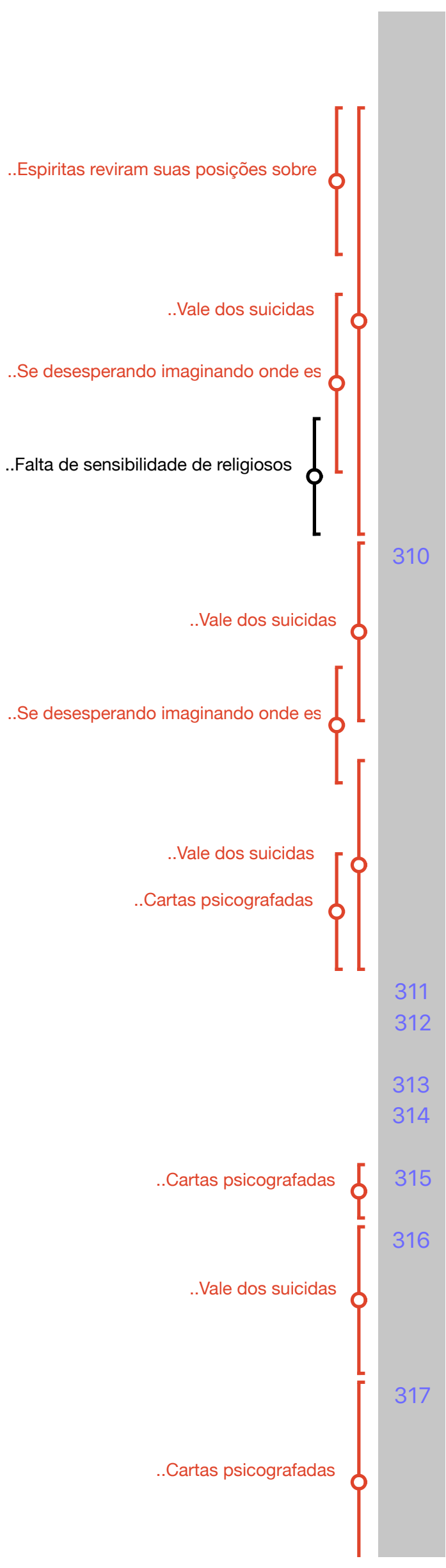

vou tirar a minha dor, como que meu filho fez isso sabendo que tinha alguma coisa? Eu fui pesquisar muito isso na doutrina, conversar com muita gente... ler muito... por isso que eu sei que assim, só os livros muito antigos, os mais antigos que não vão lá continuar estudando, lendo, que ainda revê esse vale dos suicidas, porque falaram isso pra (nome de uma amiga), e ela ligou para mim em desespero, ela chegou pra um senhor e falou: "Como o senhor acha que está meu filho?" Ele falou: " Como você acha? Está no vale dos suicidas. Vai ficar lá até o tempo que ele deveria estar aqui". Ela entrou em desespero então, é um ser humano, a pessoa, você não dá pra falar que aquilo, você falar em nome, né?

P1: Uma colega nossa chegou lá para a (nome da esposa), com um panfleto sobre uma palestra, do vale dos suicidas e disse, Dona (nome da esposa), a senhora não pode perder essa palestra, porque a (nome da filha) está lá, ela ficou assim no desespero né, ficou tal, e foi sair e disse, não deixa de ir não... e a (nome da esposa) ficou, aí, ela pegou o carro e ia, aí no meio do caminho ela disse: " não vou, minha filha não está lá" aí voltou pra casa. Quando foi a própria carta que ela recebeu, ela começa: "Mãe, eu estou falando de um vale, não do vale suicidas." (Risos)

P7: Eu estou falando...

P1: De um vale mas não é o vale dos suicidas...

P7: (fala junto) Nossa, essa menina...

P1: Entendeu, assim, as coisas, aí ela ficou...

P4: (fala junto) A gente ouve cada coisa que as pessoas acham que a gente é maluco...

P1: Ai ela ficou assim, ela não falou isso para ninguém né... pois é... nem eu sabia, fiquei sabendo depois, que a menina tinha dado para ela, que ia ter uma palestra sobre o vale dos suicidas.

P4: Eu fiz uma boa pergunta, é, muito, assim, mentalmente também, assistindo a um filme, na outra carta o meu filho respondeu... Não, aqui nós temos obrigações diárias de afinidades, não de namorados.Eu 
tinha feito uma pergunta, em casa né...

E: A gente tá chegando no final e eu tenho mais uma última pergunta. Depois eu vou mandar pra vocês um roteiro porque a gente fala de muitas coisas, não na ordem, enfim, aí se vocês quiserem complementar...Mas, se vocês falam, porque a gente esta falando até agora de: como que a sociedade pode falar ou como que a gente pode trazer...Agora vocês, vocês conversam sobre suicídio em casa, na família, com os amigos? É uma conversa aberta? Como é que é?

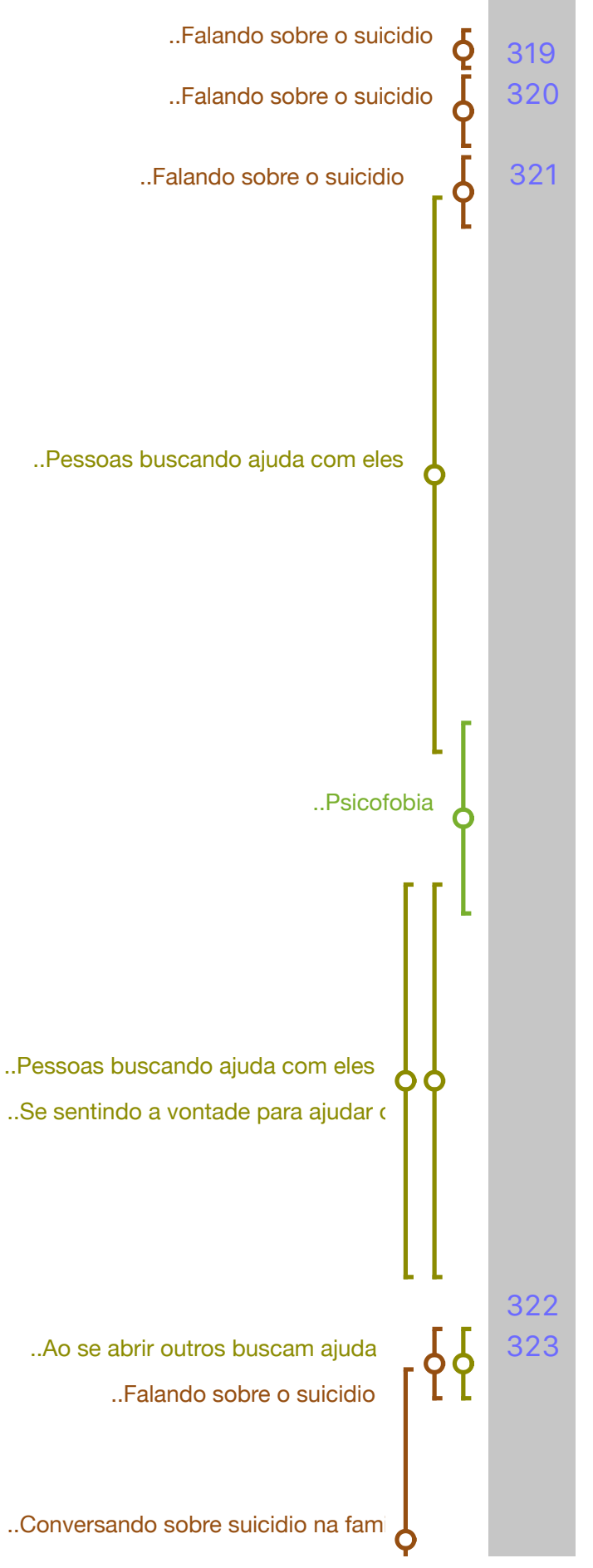

P4: Agora só... de 2 anos para cá...

P7: Com a família sim, mas com a família não, com os amigos sim.

P4: Eu agora na família eu falo, de 2 anos para cá, aliás as pessoas agora, sentindo que eu estou melhor, me procuram pra quando sabe, por exemplo, uma amiga minha, que era uma das que me pressionaram muito, mas por que?... a sobrinha dela está com problemas e se está falando pra mãe, ela toma medicamentos, sérios problemas e ela agora começou a falar pra mãe que não quer mais viver. Já deu muitos problemas. Ela foi convidada a se retirar da escola, uma escola muito boa, aqui em São Paulo. Ia com saia muito curta, você entendeu... só que agora está.. e essa minha amiga, outro dia, veio me procurar. Inclusive pensei em indica-la para a mãe, mas a mãe está restrições de mandar ela pra uma terapia. O psiquiatra tá falando que ela tem que ir. Então ela veio me procurar: "Ah, preciso te contar uma coisa..." Porque ela se sentiu à vontade de me contar e que eu... "Não porque...sei que você né? Tem vários lugares... o que eu posso indicar para a minha cunhada, eu falei, eu acho que terapia, acho que dá para ficar em cima com ela para ela tomar o medicamento, vê o resultado do medicamento... então assim, agora as pessoas estão perguntando.

E: Por causa da sua experiência...

P4: Porque estão vendo que eu tô levando adiante, eu tô falando sobre o assunto. Então eu falo abertamente com o (nome do filho do marido) que mora comigo, que é filho do P5, né, o mais novo que era como 


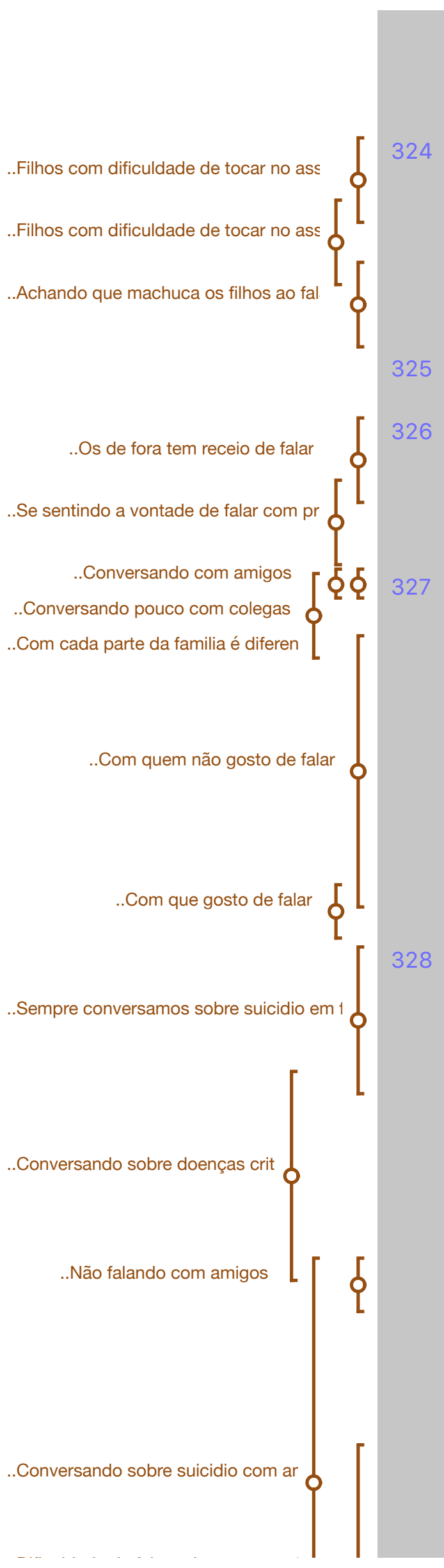

irmão do (nome do filho), então a gente fala, quando a gente ficou preocupado com o meio irmão dele a gente conversa sobre isso. Então, a gente conversa.

P3: Tenho um filho que nunca tocou no assunto. Falou uma vez só mas acho que porque eu perguntei. $O$ outro toca no assunto quando eu quero falar. Mas ele mais me escuta do que ele mesmo fala. Então eu sinto que aquilo machuca...eu procuro evitar.

E: Mas isso com a família próxima. Amigos tocam no assunto?

P3: Não, não. As pessoas tem esse receio. Não sabem como tocar... como eu também não falo. Eu tenho uma prima que é psicóloga. Com essa eu converso muito mas fora isso não.

P2: Com amigos, muito. Com colegas, pouco. Com uma parte da família, muito e outra parte quase nada. Porque a minha sogra, por exemplo, começa com as lamúrias dela e aí eu já tenho que dar uma cortada, "aí, porque ele não me leva também..", aí começa com drama. Aî, porque sempre foi dificil, eu queria ficar com o meu neto. Ai aquilo começa a me dar um desgaste né, aí eu falo "Ai, por favor... não... para com isso". Aí já voulogo para frente. Mas é isso. Agora em casa com o marido falo bastante.

P8: Eu acho que em casa a gente sempre falou, mesmo antes. Sempre foi uma discussão, acho que do ponto de vista intelectual, sempre se conversou um pouco sobre isso. Até por questões de...por exemplo, de ter algumas doenças na família que são muito críticas, a gente sempre conversou: "E se a gente for diagnosticado com isso, o que você faria?" A gente fazia esse exercício, um pouco, porque é complicado também. É... depois com os amigos não. Mas depois do que aconteceu com alguns amigos eu converso sobre isso, falava as vezes alguma coisa mas pouca coisa. Depois do acontecido eu acho que eu tive...eu tenho a sorte talvez de ter muitas pessoas que conseguem conversar isso bem, pessoas que se revelaram bons amigos, depois disso e hoje a gente fala, ainda fala 


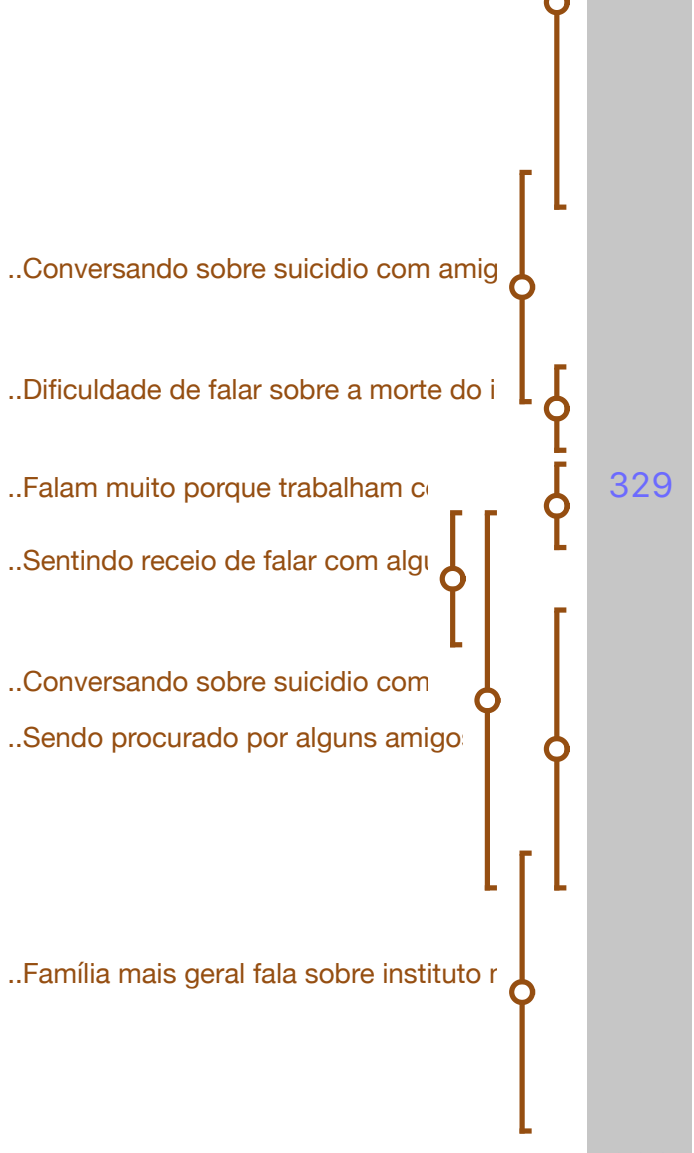

..Família mais geral fala sobre instituto $r$

.Para a familia é transpararente falar dc

331

Achando lindo o trabalho do instituto 6

..Usando a dor para ajudar os outros

..Usando a dor para ajudar os outros

..Com quem eu falo sobre o suicidio

..Escondendo o motivo da morte dos or

L

..Escondendo o motivo da morte dos outrc

..Fala da perda do irmão para os amigo:

..Com quem eu falo sobre o suicidio

..Casos na familia da melhor amiga

Escolhendo não falar sobre o suicidio do mas a gente não fala do meu irmão mas a gente fala do assunto. Meu irmão ainda...acho que a cicatriz...a gente ainda não conversa sobre ele mas a gente fala sobre o assunto. Até por questão de ser uma situação presente pra outras pessoas, eu tenho um primo que esta passando por um depressão profunda e minha irmã está tentando ajudar a minha tia... Então fala-se, mas a gente não fala do meu irmão, ainda.

P1: A gente fala o tempo todinho né, porque a gente trabalha com isso né... Mas assim eu ainda sinto, assim, receio de amigos quando falo no assunto. Mas por outro lado, tem já alguns amigos que eles procuram...já é bastante casos de amigos deles, pra gente ver se pode dar uma ajuda e tal, quer dizer, se ele vem é porque, é porque ele tem uma certa vontade que é de gente conversar. $\mathrm{Na}$ família, fora a família mais íntima né, quer dizer eu, a (nome da esposa) e a (nome da outra filha), não se fala né, fala muito do instituto né, muitas coisas, mas assim fala mais de modo geral...

E: Do suicídio da (nome da filha) não?

P1: É, do suicídio da (nome da filha) não. Mas não é assim tão, assim, para a gente, é transparente...

P4: (fala junto) Isso é lindo, que vocês fazem, de usar essa dor, para ajudar os outros.

P1: Exato, entendem É isso!

P10: Eu falo com minha mãe e meu pai, minha avó, com uma tia e com duas amigas, mas é porque as pessoas não sabem. A gente não falou que foi suicídio, só dentro da família. Meus amigos, teoricamente se eles sabem não foi porque eu contei, não sei se ficaram sabendo e não falaram...Então...nem na empresa, em nenhum lugar as pessoas, eu não falo com ninguém porque eu não falei que foi suicídio. Eu falo da perda do meu irmão. Isso eu falo. Mas não falo do motivo. E na minha família só com as pessoas que são realmente mais próximas, né? Meus pais, a minha avó, essa minha tia... A minha melhor amiga sabe, inclusive na família dela também tiveram alguns casos. Então mais assim. Mas na sociedade, ninguém, né, assim é coisa que eu não falo então eu não 


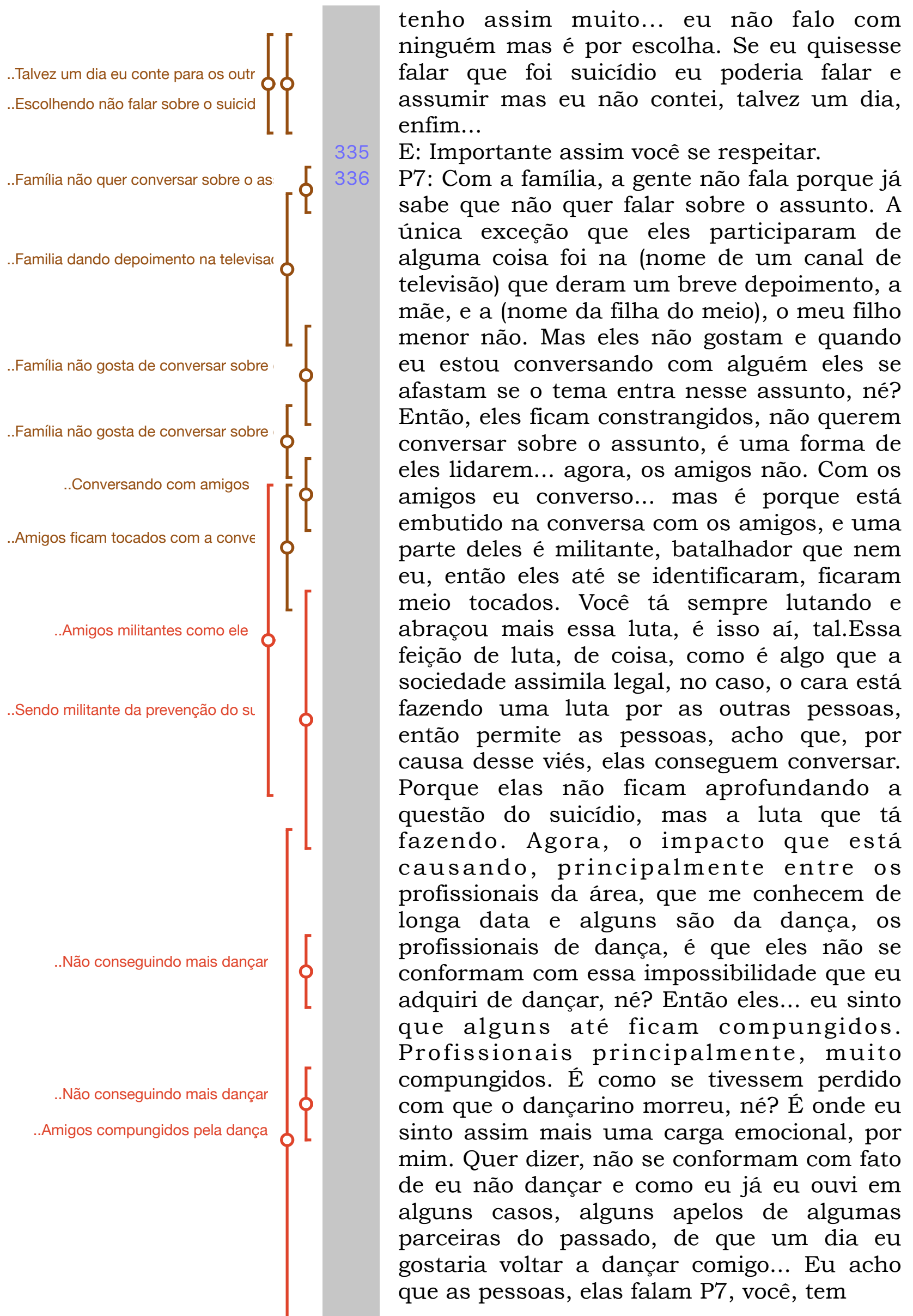




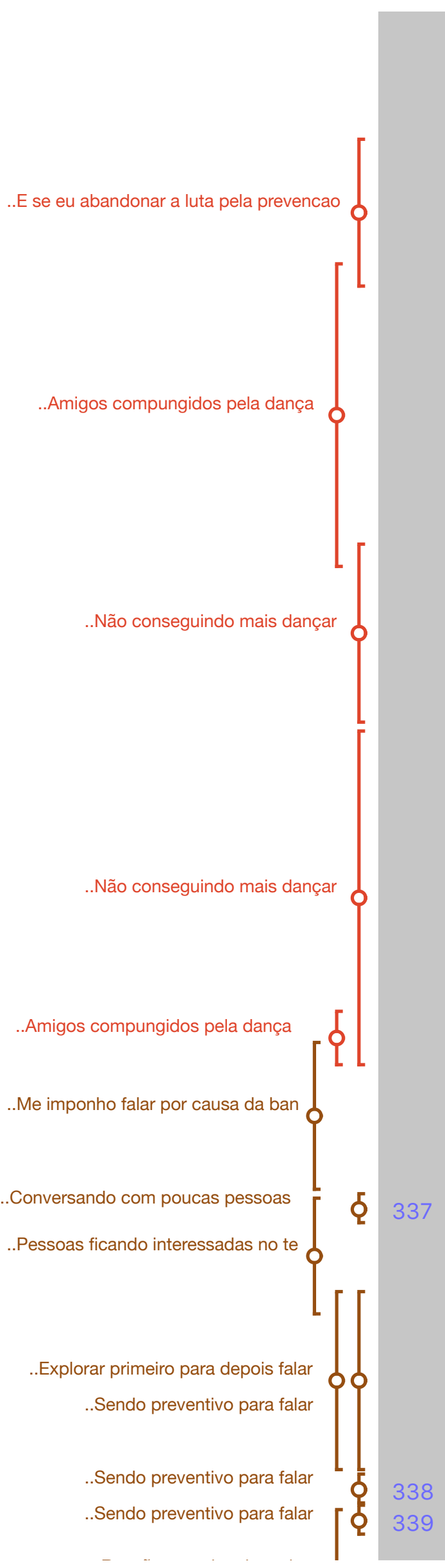

direito a ser feliz, você tem que voltar a dançar porque quem dança é mais feliz...Ainda mais eu que defendia, eu abracei essa bandeira da dança, sabe, é uma bandeira que eu abracei. Imagina eu amanhã eu abandonar a luta pelo suicídio, a luta pela prevenção ao suicídio.; Como vocês vão se sentir? Se eu abandonar essa luta? E não participar? É o que eles estão sentindo porque eu era um grande divulgador, os profissionais de dança ficaram muito agradecidos porque eu ajudava e tal... e onde eu vivo hoje em dia quase não tem mais jantar dançante... eu fiquei espantado, P7, a dança morreu aqui em (nome de uma cidade), Quer dizer então que eu era a chama...então nesse ambiente o impacto é maior. Mas eu falo: "Gente, eu não danço porque eu não quero. Eu não consigo." Aí hoje eu encontrei uma..., hoje não, ha pouco tempo, eu encontrei uma figura, um exemplo, para poder as pessoas entender o que é. Não é exatamente isso mas eu acho que é o que chega mais perto. Imagina você ter que fazer sexo com alguém, sem vontade, apenas pra agradar essa pessoa. Não dá. Não vou conseguir. Então, eu não consigo dançar porque tem que ter emoção, assim como no sexo tem que ter o desejo, a vontade, o impulso, é o sagrado, é o que gera a vida, é o que desenvolve o amor enfim, né? $\mathrm{E}$ você vai fazer uma coisa mecânica. Então, é a mesma coisa a dança. Então, esse contingente está seriamente impactado. Mas eu converso, mesmo, com eles. Eu me imponho começar a falar, mesmo que dói, eu me imponho, por causa dessa bandeira que eu abracei...

P9: Eu converso com poucas pessoas. Acho que teve uma pessoa que eu falei sobre o tema e ela e a pessoa falou: "Nossa que interessante!" Perguntou mais coisas. Ai eu tive experiências ruins, então hoje o que eu percebo, assim, não falo sobre, primeiro que dou uma explorada pra ver como é a visão dela em relação a morte, pra saber se eu posso entrar no assunto.

P10: Você faz um teste.

P9: É, é, por experiência prática. Então, até 


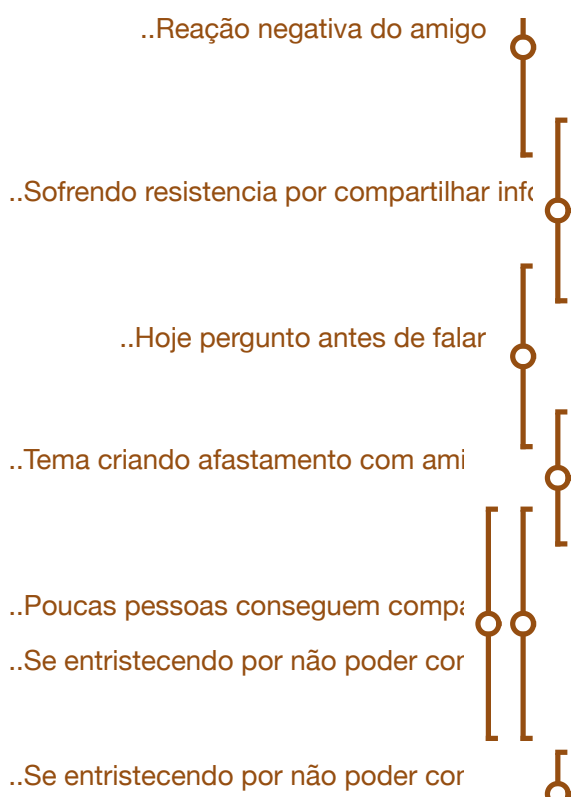

..Se entristecendo por não poder co

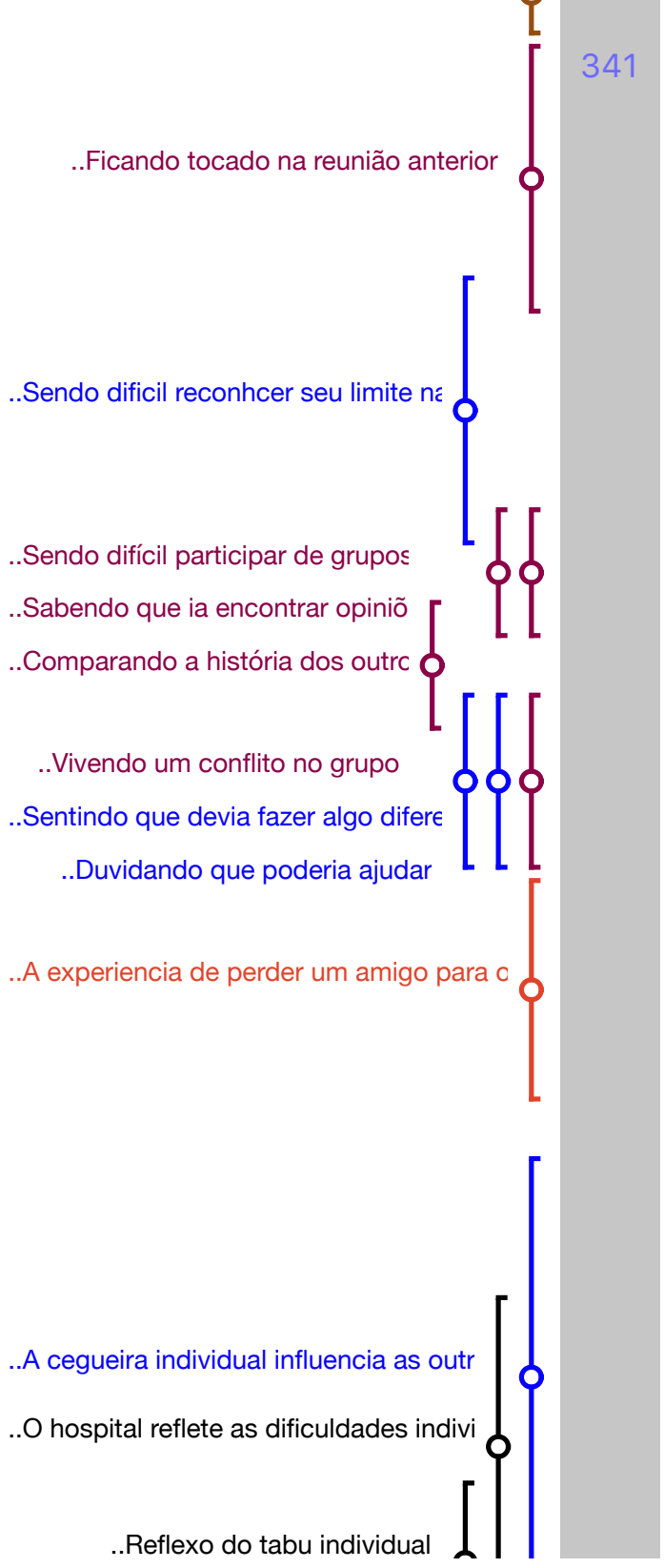

desses amigos, tinha essa, que eu recebi uma reação bem negativa, eles têm duas filhas. Então, tinha um certo conflito, uma angustia, de eu ter muita informação e querer compartilhar e sofrer essa resistência. Então hoje eu consegui assim, ligar e falar assim: "Posso te falar sobre tal, tal, coisa?"E aí, o meu amigo disse, ok... aí de vez enquanto eu passo a informação. Mas criou um afastamento. O tema criou um afastamento. Então, eu encontrei...Apesar de ter tido esse tempo no CVV, eu tive poucas pessoas com quem eu pude compartilhar a experiência. Isso é uma coisa que pra mim entristece bastante.

E: Alguém tem alguma outra observação, quer falar mais alguma coisa?

P9: Eu tenho. Da reunião passada, por exemplo,uma coisa que me tocou e foi o que eu fiquei refletindo né. Quando a P2 falou: "Poxa, eu tenho uma pessoa com depressão mas eu não consigo..." $\mathrm{E}$ falou com esse sofrimento. Então, é a mesma coisa que eu sinto, e é um conflito meu, quando falam assim: "Existe algo que eu posso fazer mas eu tenho que conseguir saber reconhecer o meu limite até onde eu consigo ir. Isso é dificil. Pra mim participar do grupo foi dificil, assim, porque eu sabia que teriam opiniões diferentes né? $\mathrm{E}$ algumas coisas que a gente fala como a história do outro é diferente, às vezes chega, né, de uma maneira dolorosa. Puxa mas então, eu devia fazer algo e será que eu não fiz? É o meu conflito que eu fiquei. Então, tenho algo para acrescentar? Por exemplo: uma experiência que eu particularmente vivi, que foi a perda de um amigo, foi o que muita gente relatou do processo, né, é do atestado de óbito, da polícia e tal. Assim, a minha área administração, então, eu fiquei pensando o que poderia ser feito. Uma das coisas que eu percebo, assim, toda a cegueira que a gente tem individual vai pra cultura. Isso também vai pra cultura das organizações. Então, o sistema de saúde, hospital e plano de saúde ele vai de alguma maneira refletir a dificuldade que cada um individualmente tem com o tema. O tabu que tem, né? É um 


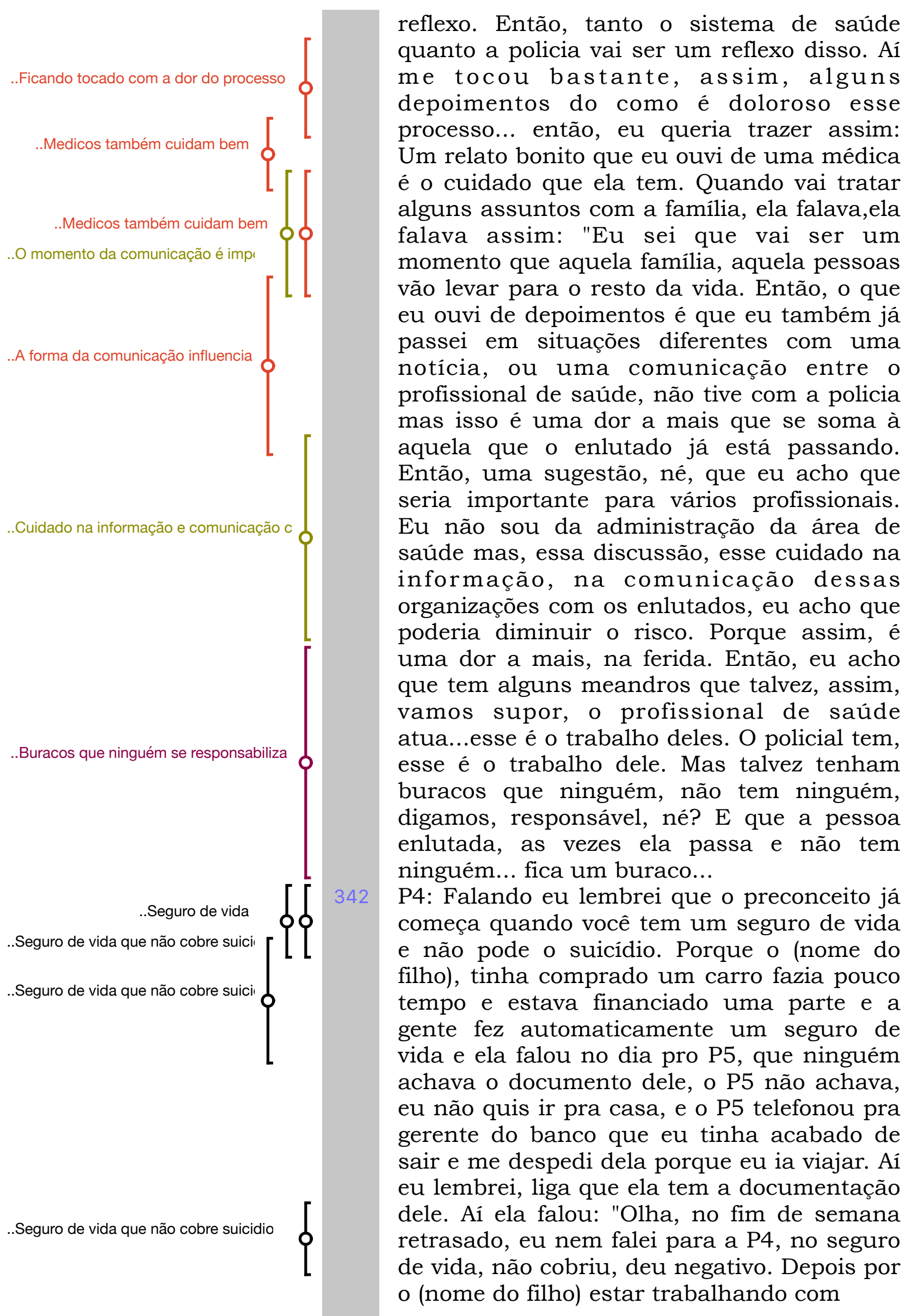




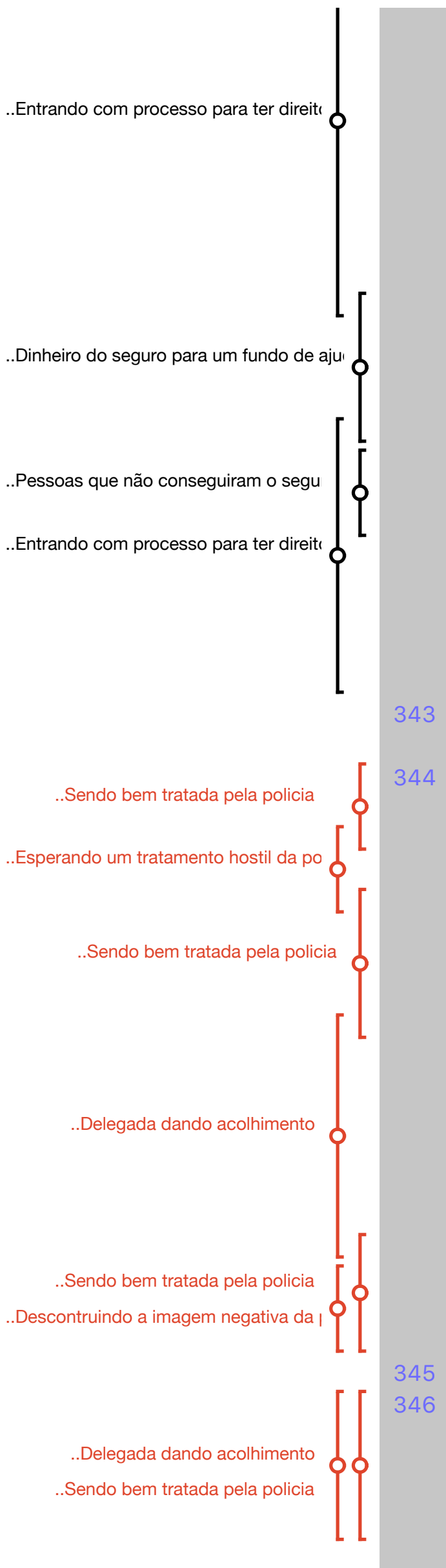

uma grande amiga que era que nem mãe dele né, ela pegou e falou, me dá aqui, meu filho acabou de se formar, que era irmão do grande amigo do (nome do filho), vai ser a primeira causa dele, ela conseguiu no (seguradora) com alguns casos que já tinham acontecido de depressão, ela levou todo o histórico dele dos médicos, ela levou os remédios que ele estava tomando, tudo, fez um processo. Demorou 2 anos e ela sabia que eu não ia usar esse dinheiro... eu queria esse dinheiro não para mim, eu queria deixar esse dinheiro num fundo pra ajudar as coisas. Ela conseguiu no * mas foi assim, uma briga, o da (nome de amiga) tinha e o advogado não conseguiu. $E$ também não quis brigar. Eu também não queria brigar por isso. Eu tinha deixado. Faltavam 5 dias pra expirar o prazo, porque tem um ano só pra entrar. Já tinha vindo uma negativa. Eu só comentei com ela que eu ia entrar aí ela falou assim: "Me da aqui que eu entrego...."

P7: Ah que bom! Gostei muito de saber disso.

P2: Eu queria só acrescentar que eu fiquei muito surpresa com o tratamento que eu tive pela policia. Eu não esperava né. Esperava realmente um tratamento meio hostil e eles não foram em nenhum momento. Desde a delegada, todos que foram... os peritos, todos eles foram tão acolhedores que eu precisei voltar depois pra agradecer, sabe? Eu estava em frangalhos, eu não conseguia nem se manter em pé ea delegada conversou muito comigo, me acalmou e eu perguntei para ela se ela poderia falar essas mesmas palavras para o meu marido. Ela saiu da delegacia, foi até ele e falou tudo aquilo com uma calma, uma mansidão, e todos eles de um respeito que eu fiquei muito surpresa e aí eu tive que desconstruir toda a imagem negativa que eu tinha da policia naquele momento....

P7: Que bom...

P3: Para mim foi também a mesma coisa. Foi uma delegada, era bem mocinha ela, uns 30 e poucos anos, me tratou assim, uma maravilha, nossa, foi uma das pessoas que mais me consolou. Foi assim maravilhoso. 


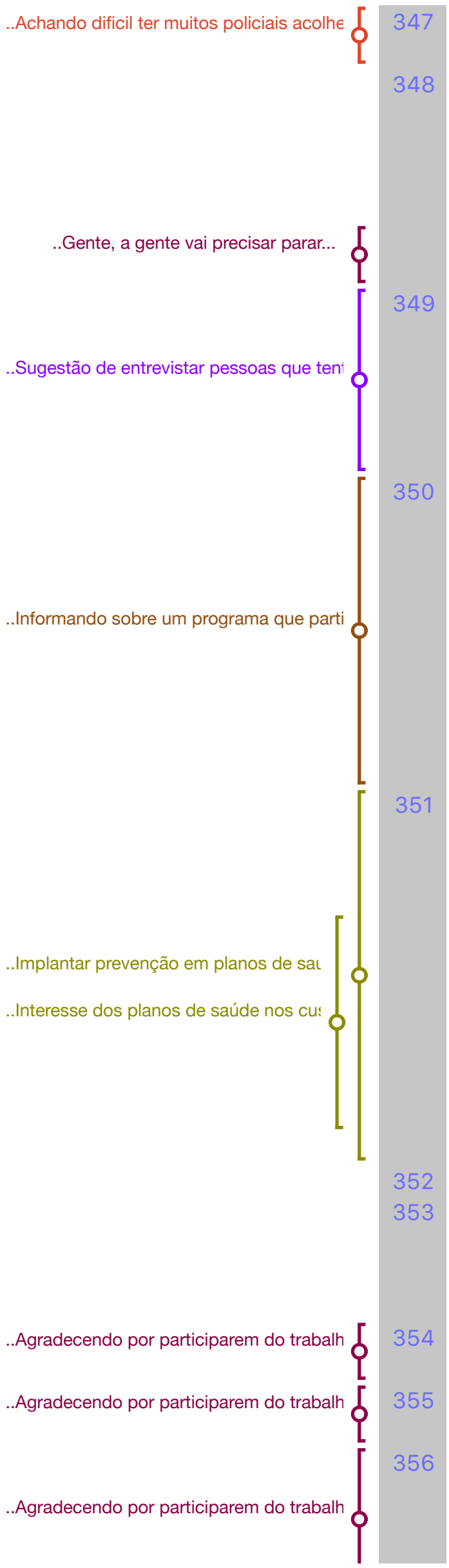

P2: Quer dizer, são raros mas existem né enfim,

E: Então, eu acho que isso que vocês estão falando é que essa forma como essa comunicação chega, principalmente nesse início faz um impacto grande, seja da polícia, da saúde, enfim, isso tem realmente um impacto dentro desse processo todo.... Gente, a gente vai precisar parar...

P10: Eu acho que esse estudo teria que perguntar também para as pessoas que tentaram, tudo isso porque eu acho que ele tem respostas de uma perspectiva bem, talvez, assertiva, né, com relação a muitos dos pontos.

P7: Eu tenho um informe a dar, um informe a dar. É...eu... fui entrevistado pela (nome de canal de televisão) essa semana, eles foram lá em casa né. Eles fizeram vários registros, tal e disseram que é o programa (nome do programa) de toda (data e horário do programa). Dura 50 min. (nome de canal de televisão e nome do programa). Vai ser provavelmente na (dia da semana) feira dia * sem ser a próxima, a outra.

P9: Só uma observação, você falou de locais para atuar, eu tive uma ideia, assim, pensando no lado de administração, assim por exemplo, os planos de saúde eu já participei, tem programas de prevenção, cardiaco, tal, e sim, muitas vezes infelizmente não é por uma consciência, uma conscientização mas é por causa dos custos, mas até por isso, talvez, a partir de alguns dados possa se implantar dentro do programa de saúde, um programa de prevenção nessa linha, né?

P3: Eu acho isso bem interessante...

E: Gente, eu agradeço imensamente a disponibilidade de vocês terem vindo 2 vezes, de estarem aqui na segunda noite, frio chovendo, São Paulo...

P4: Karen acho que nós todos aqui estamos agradecidos com esse trabalho

P7: É o mínimo, imagina, você também nos acolhe.

P4: Nós estamos aqui porque temos uma causa, você está.. tudo bem, você é profissional, mas é para ajudar, então, para 
evitar, então nós que agradecemos.

P3: Desabafar é uma coisa que ajuda muito. E:Eu não tenho como agradecer.Continuo à disposição qualquer coisa vocês entrem em contato comigo. Assim que tiver transcrito eu vou enviar pra vocês o texto e vou enviar as perguntas. Se vocês quiserem complementar alguma coisa nas perguntas complementem, se não, não precisa. Se quiserem alterar alguma coisa no texto, alterem. Eu vou tentar colocar...no texto que eu vou passar pra vocês vai estar o nome de quem está falando. Depois, quando isso for pra análise, porque eu vou fazer a analise, quando isso for ser publicado, ai vai ser P1, P2 pra que não tenha identificação. Mas pra vocês vai o nome até pra vocês verem se vocês querem alterar ou não alguma coisa que vocês falaram ou complementar. Tá bom? Muito obrigada bom descanso e estou a disposição.

359 TOTAL: 02:15:19 HS 


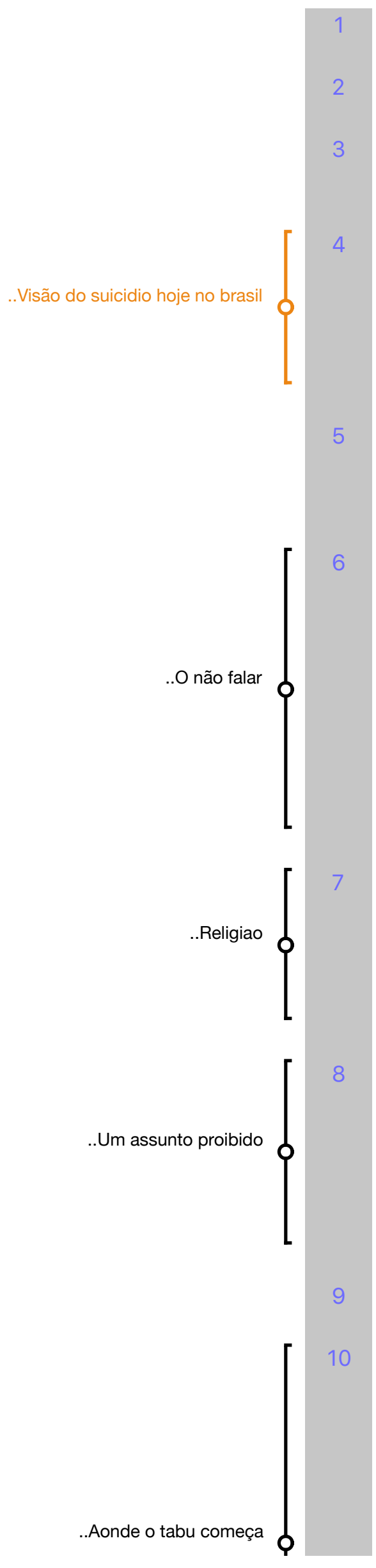

\section{Roteiro de perguntas}

\section{Sobre o tabu e a consciência pública}

- Como você acha que o suicídio é visto hoje no Brasil?

R. O tema suicídio ainda é assunto velado e carregado de preconceito. As discussões ainda geram temor e a maioria das pessoas prefere não olhar para um problema que afeta praticamente a todos.

- Você pensa que o suicídio é um tema tabu no Brasil? Por que você acha que isso acontece?

R. Sim. Ainda é um assunto pouco discutido e muitas vezes evitado até por pessoas que passaram por situação de suicídio na família. Muitas pessoas tem vergonha de ter tentado ou mesmo de ter alguémna família que fez tentativa ou morreu por suicídio. Geralmente o assunto fica velado, por temer o estigma, o julgamento, enfim, o preconceito da sociedade.

Acredito que esse tabu é decorrente de um processo social cultural atrelado a dogmas religiosos, a partir da condenação ao pecado mortal a pessoa que comete suicídio, estendendo as punições também à família.

Assim como tudo que nos causa sofrimento e medo, o suicídio foi ao longo do tempo se tornando assunto proibido na sociedade. Tudo isso, contribuiu de forma significativa para que o problema tomasse dimensão de uma epidemia.

\section{- Vocês acham que o tabu começa aonde?}

R. Na família, quando na tentativa de proteger o seu núcleo, os pais evitar comentar sobre o assunto. Geralmente, assuntos de suicídio e morte são proibidos nas discussões familiares. Nos nossos grupos sociais quando não se permite falar 


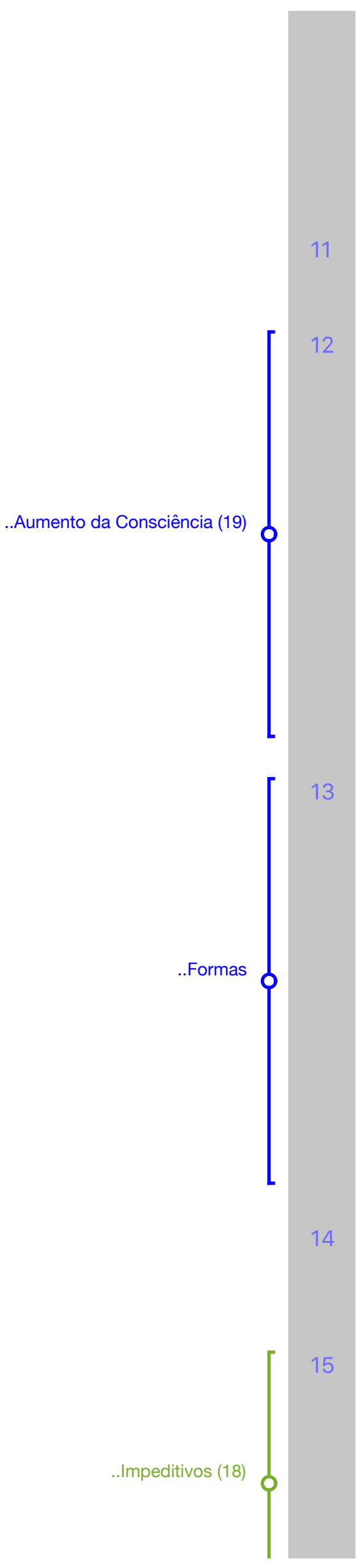

sobre suicídio, porque é assunto pesado e normalmente as pessoas consideram que naquele grupo não tem ninguém com ideação suicida. $\mathrm{Na}$ igreja, quando condena a pessoa com comportamento suicídio ao pecado mortal.

- $\quad$ O que pensa a respeito conscientização da problemática do suicídio?

R. Éimportante e necessária. A falta de informação pode ser considerada como um fator que contribui para o crescimento dos índices de tentativas e de mortes por suicídio.Por falta de informação as pessoas deixam de tomar conhecimento sofre os fatores de risco, sobre os sinais que uma pessoa com ideação suicida apresenta e ainda sobre o que fazer quando alguém faz uma tentativa de suicídio, quais as posturas corretas, como a família deve cuidar desta pessoa e principalmente onde e como a família a deve buscar orientação.

A conscientização deve ser feita de forma que contemple toda a população. $O$ que se percebe atualmente é que algumas pessoas já buscam informação, entretanto, há que se preparar a sociedade para a discussão sobre o assunto, através de estratégias que mostrem a importância da divulgação das campanhas de prevenção e que o suicídio é um problema de saúde pública, é como tal, a população precisa se envolver de forma consciente, como tem se envolvido em outras campanha de promoção de saúde e prevenção de doenças.

- Você acha que falar mais sobre o assunto aumentaria a consciência pública do tema?

R. Sim. Desde que de forma respeitosa e consciente, evitando o senso comum, desmistificando os tabus e desconstruindo o preconceito em torno do tema. É importante informar sobre as formas de prevenção, sobre os fatores de riscos,sobre os fatores 


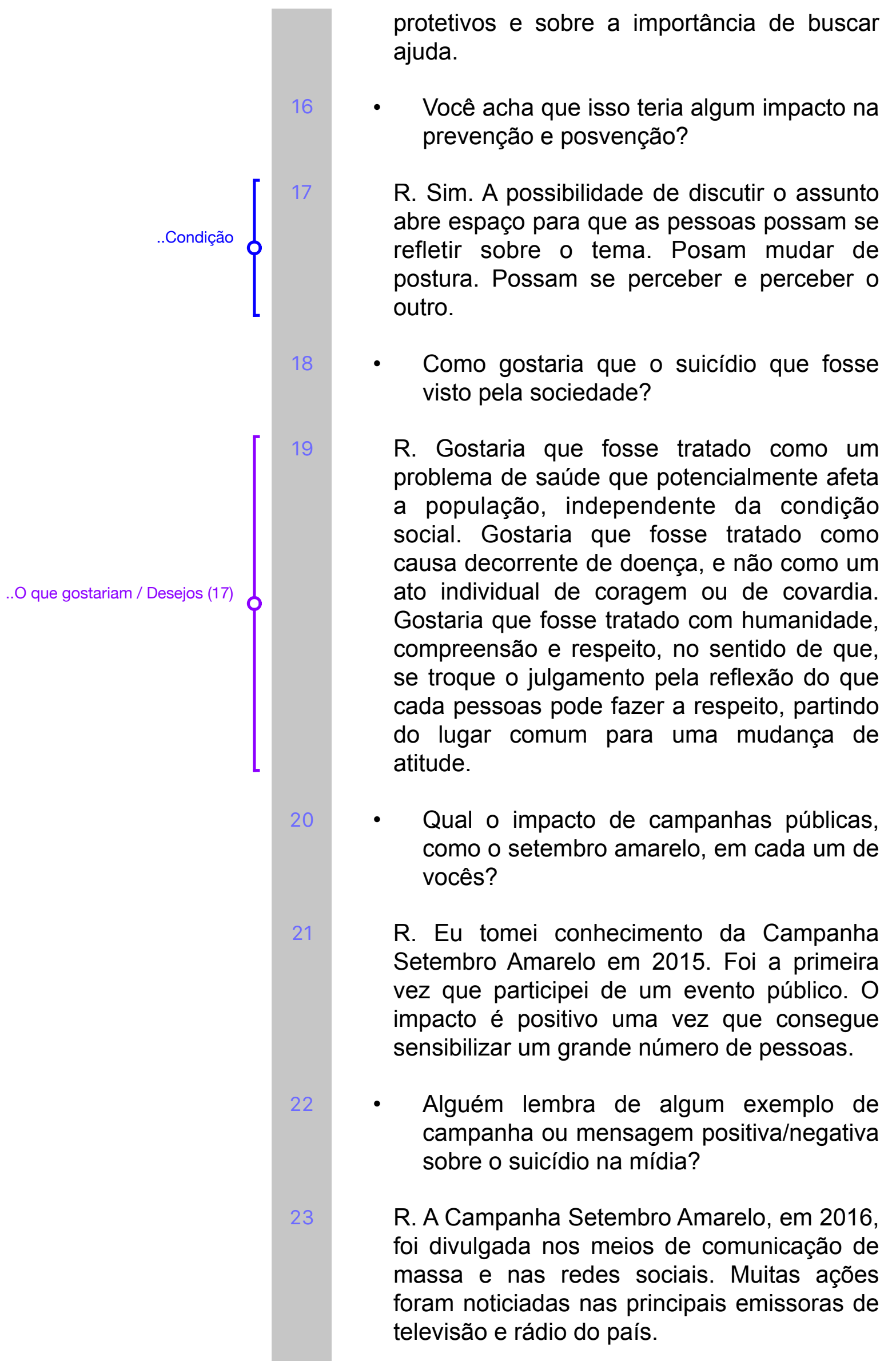




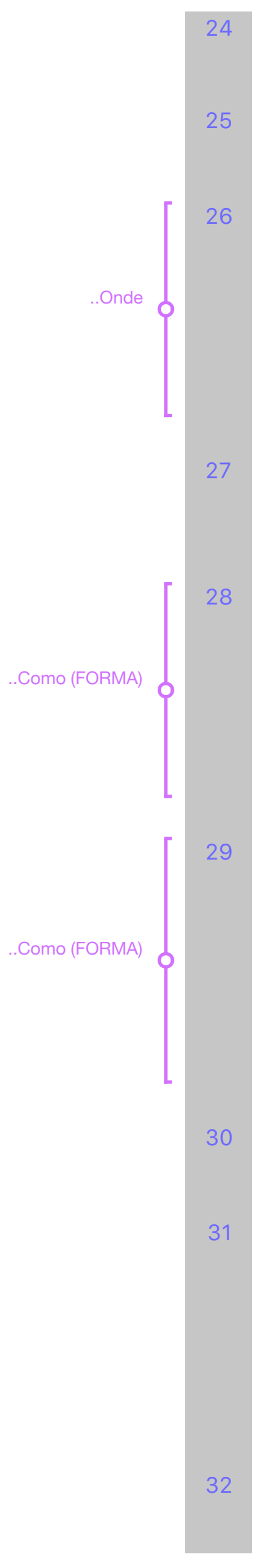
Sobre como aumentar a consciência pública

- Como poderia ocorrer essa conscientização no Brasil?

R. Através de um programa regular de palestras, fóruns e seminários nas escolhas de ensino fundamental, médio e nas universidades. Através da divulgação de informações nos meios de comunicação. Através de peças e filmes que abordem o assunto.

- Como podemos começar a falar sobre o suicídio? O que nos impede de falar sobre o tema?

R. Podemos começar falando sobre prevenção do suicídio, sobre a relação do suicídio com a saúde mental, sobre a importância de discutir o tema para que as pessoas possam buscar ajuda, nos nosso grupos sociais mais próximos, na família, na igreja, no trabalho.

Podemos falar quando alguém abordar o assunto de forma preconceituosa, ou quando julga a pessoa que comete suicídio como um a pessoa "corajosa" ou "covarde" ou mesmo uma pessoa que não tem amor pela vida e não pensa nos familiares. Essas, são oportunidades particulares que podem ser aproveitadas para conscientização.

- Que sugestões você teria para que o suicídio fosse mais falado no país?

R. Seriam importantes campanhas de prevenção do suicídio veiculadas nos meios de comunicação, promovida pelo Ministério da Saúde e pelas Secretarias de Saúde dos estados, a exemplo de outras campanhas que são promovidas quando identificas epidemias ou o avanço de certas doenças.

- Quando e onde você acha que esse tipo de informação deve ocorrer? 


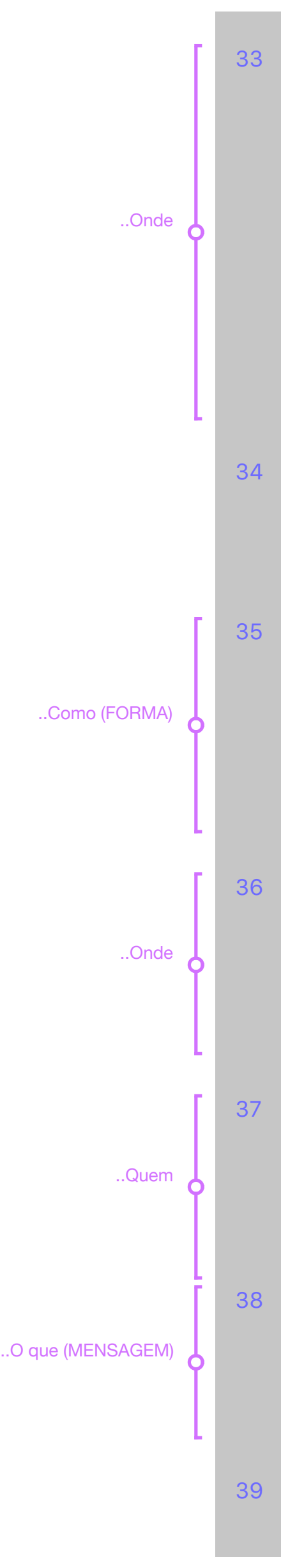

R. Geralmente estes temas tem uma discussão mais ampla através de fóruns, simpósios e congressos, entretanto as discussões ficam mais no meio acadêmico e técnico, o que é importante mas não abrange um grande contingente. As informações devem chegar a sociedade em geral através de palestras nas escolas e nas universidades, organização de grupos de estudos sobre o tema, formação de rodas de conversas mediadas por alguém que já estude o tema

- Como você pensa que deve ser abordada essa questão? (que mensagem deve ser passada?)Que ações seriam necessárias e como elas poderiam ser promovidas?

R. Acredito que o tema deve ser abordado da mesma forma que são abordados os problemas de saúde pública, as epidemias, as questões que afetam a sociedade; com de forma esclarecedora, informativa, com uma linguagem simples e acessível a todas as pessoas.

Devem ser promovidas palestras e oficinas para adolescentes através das escolas, com o objetivo não só de falar sobre o suicídio, mas também de como lidar com os sentimentos, se perceber e perceber o outro, e ainda como e onde buscar ajuda.

Acredito que deverão ser oferecidos programas de conscientização para professores, pais, e cuidadores, com o fim de levar a informação sobre a prevenção do suicídio e como tomar uma atitude ou como buscar ajuda.

Devem ser passadas mensagens de que 0 suicídio pode ser prevenido, que o suicídio na maioria das vezes está relacionado a uma doença mental, que as pessoas que estão com ideação suicida devem buscar ajuda.

Sobre a consciência individual 


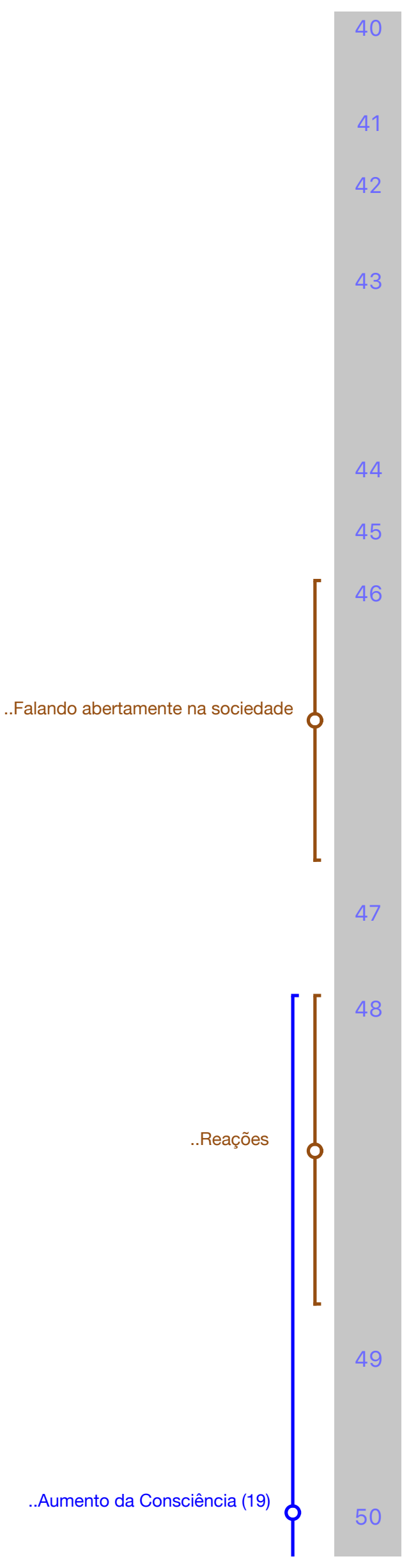

- Vocês acham que a consciência pública influencia a consciência individual, de que forma?

R.

- Vocês acham que a falta de consciência pública pode ter influenciado o suicídio da pessoa que perderam?

R.

\section{Experiências}

- Como é para vocês falar sobre o suicídio?

R. Já foi muito difícil. Nos primeiros anos evitava falar a palavra suicídio (ou termos associados como se matou, tirou a própria vida). Atualmente é um assunto que flui tranquilamente, sem preconceito. Todas as vezes que tenho a oportunidade falo sobre as formas de prevenção, sobre como podem ser percebidos sinais, sobre como os preconceitos devem ser descontruídos.

- A forma como a sociedade e as pessoas encaram o suicídio te toca?

R. Ah, sim. Principalmente pela falta de informação. Pela falta de humanidade e de empatia de entender o sofrimento do outros. $O$ julgamento que grande parte da sociedade faz, ainda é baseado em dogmas religiosos; na questão do pecado.Por outro lado, percebe-se claramente como a sociedade fica perplexa diante de um suicídio e como esta mesma sociedade silencia a morte por suicídio.

- Você já passou por alguma situação que envolvesse a falta ou não de consciência pública e individual em relação ao suicídio?

R. Sim, já passei por várias situações, que 


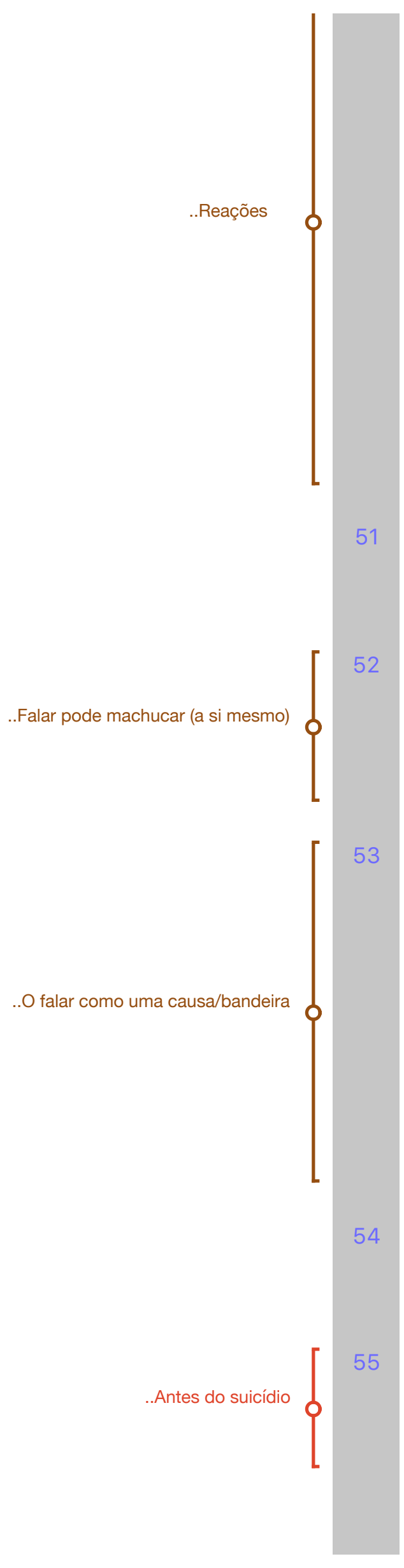

envolveram falta de consciência individual e pública. Primeiro, a busca de um porque, é uma necessidade que angustia a sociedade. Se a família, ainda em choque com o suicídio não consegue encontrar um motivo, a sociedade se encarrega de encontrar um porque, e surge uma lista de porquês, desde coisas mais simples até motivos absurdos. A sociedade faz um julgamento. Os amigos e familiares também fazem seus julgamentos: julgamento de que a família não foi presente; julgamento de que suicídio entre adolescentes ocorrem em famílias desestruturadas; julgamento de que quem comete suicídio é um egoísta, entre outros.

- Como é falar sobre a causa de morte do ente querido e qual a causa de morte que é falada.

R. Ainda é difícil, mas necessário falar; não pelo fato da morte por suicídio, mas pela questão afetiva, pela saudade, pelos planos interrompidos, pelo que ficou no meio do caminho...

Atualmente falo com o intuito de informar, mas também procuro mostrar que não tem porque ter preconceito ou vergonha. Sempre esclareço que a causa foi morte por suicídio. Muitas vezes essa fala choca as pessoas e o assunto se encerra, até como certo pedido de desculpas de quem escuta. Entretanto, se a pessoa ou o grupo der uma abertura para continuidade do assunto, continuamos a conversa, sem constrangimentos. Falar é preciso. Falar é necessário.

- Vocês falam e/ou conversam sobre o suicídio com a família, amigos, conhecidos e/ou desconhecidos? Como?

R. Antes do suicídio, nunca se falou sobre o tema suicídio como algo que pusesse fazer parte da nossa vida. $O$ assunto morte também não se discutia em família. Após o fato, passamos a falar no tema morte, vida após a morte em família e inevitavelmente 


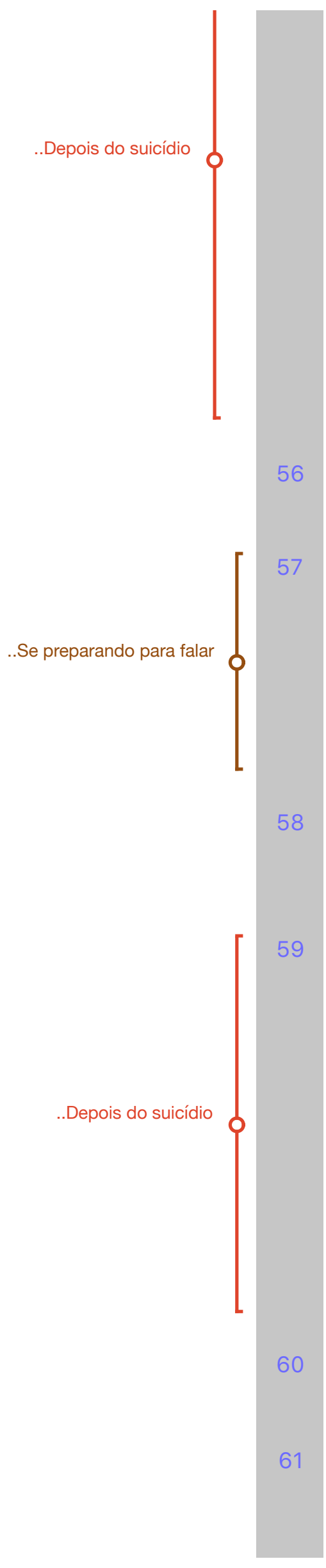

sobre o "morrer por suicídio", mas numa visão muito particular, sobre o que nos afetava, sobre como e como a sociedade julgava o suicídio. Nos primeiros anos este assunto ficou muito restrito a família e amigos próximos. Posteriormente, quando decidimos buscar informações, livros, vídeos, documentários a respeitos do assunto, passamos a discutir o assunto de forma mais aberta e consciente. Atualmente falamos sobre o tema com conhecidos e desconhecidos, através de palestras, rodas de conversas, em pequenos grupos.

- $\quad$ Em que momentos essa comunicação é mais fácil e mais difícil.

R. É uma discussão necessária, entretanto, deve ser conduzida com muito cuidado em qualquer momento, porque depende muito dos fatores emocionais, dos conceitos de cada um a respeito do tema, dos laços de afetividades estabelecidos do tempo decorrido.

- Houve alguma mudança na sua forma de entender o suicídio depois da perda que você viveu? De que maneira?

R. Sim, significativa. Antes eu não julgava, mas também não comentava. Entretanto, sempre que sabia que algum tinha morrido por suicídio tinha uma angústia em imaginar como esta pessoa se sentia desamparada, desesperada ou vazia de si e do mundo naquele momento. Este sentimento eu ainda carrego. Atualmente, eu comento sobre o que já li e ouvi sobre o suicídio e procuro desmistificar o ato, minimizar os atos de tabus e preconceitos. Atualmente procuro conscientizar sobre o assunto.

- Que informações você gostaria de ter tido ao se deparar com esse comportamento?

R. O tema suicídio para que não vivenciou uma situação, é um tema que dá medo, e, tudo que nos apavora, queremos distância; 


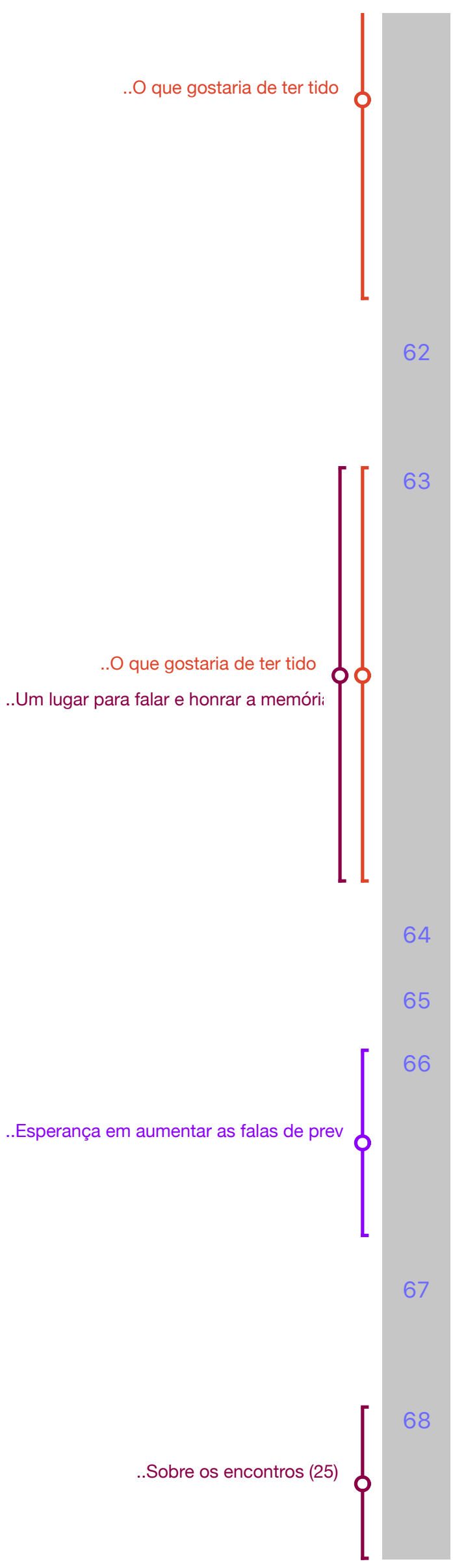

assim era com o tema suicídio. Gostaria de ter sido mais aberto para falar sobre o assunto e saber que a pessoa que está com pensamento suicida dá sinais, pede socorro de uma forma implícita, que somente quem está atento percebe. Gostaria de saber tudo que sei hoje, antes. Certamente eu teria tido uma atitude diferente. Talvez eu pudesse ter mudado a história...

- $\quad$ O que gostaria que tivesse disponível em termos de ajuda e/ou conhecimento para você no luto e para pessoa que faleceu?

R. Para mim, um local para falar sobre o que aconteceu, sobre como estavame sentindo, ver como outras pessoas foram sobrevivendo, e, principalmente falar sobre a minha filha, como ela vivia, sem julgamentos. Para a família sobrevivente este lugar de fala, em uma sociedade que ainda é muito preconceituosa com a pessoa que morre por suicídio e com a família, é muito importante. Para a pessoa que faleceu, um lugar de fala por ela, poder falar sobre sua vida, suas memórias, suas histórias, seus projetos de vida, sobre seus sonhos.

\section{Finalização}

- Quais são suas sugestões sobre o tema?

R. As sugestõessão que o tema seja cada vez mais estudado e discutido, no intuído de desconstruir tabus e estigma e que seja focando no esclarecimento, na informação sobre as formas de prevenção e conscientização.

- Deseja fazer algum comentário, esclarecimento ou consideração adicional?

R.Somente agradece pela oportunidade de falar sobre a temática suicídio e torcer por você para que tenha uma excelente Tese de Doutorado, e que venha a ajudar para desmitificar essa temática. 
Roteiro de perguntas

T: Sobre o tabu e a consciência pública

P: Como você acha que o suicídio é visto hoje no Brasil?

R: De forma geral acho que o suicidio é visto com muito preconceito, e como casos isolados e não na proporção que realmente acontecem.

P: Você pensa que o suicídio é um tema tabu no Brasil?

R: Sim, acredito que é uma das facetas mais dificeis do tema relacionado ao morte, luto e tristeza

P: Por que você acha que isso acontece?

R: Acredito que a origem disso vem da visao equivocada de que felicidade é ausência de tristeza, perdas e luto. Como consequencia todos esas emocoes sao reprimidas e se tornam um tabu.

P:Vocês acham que o tabu começa aonde?

R: Com a crença de que falar no assunto relacionado a morte, suicidio ou doenças, "atraem" o fato. Evitar falar no assunto é como se fosse uma forma de evitar que isso exista ou aconteça. E não de que para vivenciarmos plenamente as emoções como alegria, é necessário também estar aberto para sentir a tristeza. Que não é possível anestesiar apenas uma das emoções sem se anestesiar para as outras.

P: O que pensa a respeito conscientização da problemática do suicídio?

R: Acho muito importante, pois a minha impressão sobre o tema é de que a grande maioria das pessoas só entra em contato com o assunto depois de ter passado por uma perda de alguém próximo. Através da conscientização percebo que a prevenção seria possível, já que é nas relações e nos vínculos entre as pessoas que temos a possibilidade de prevenir.

P: Você acha que falar mais sobre o assunto 


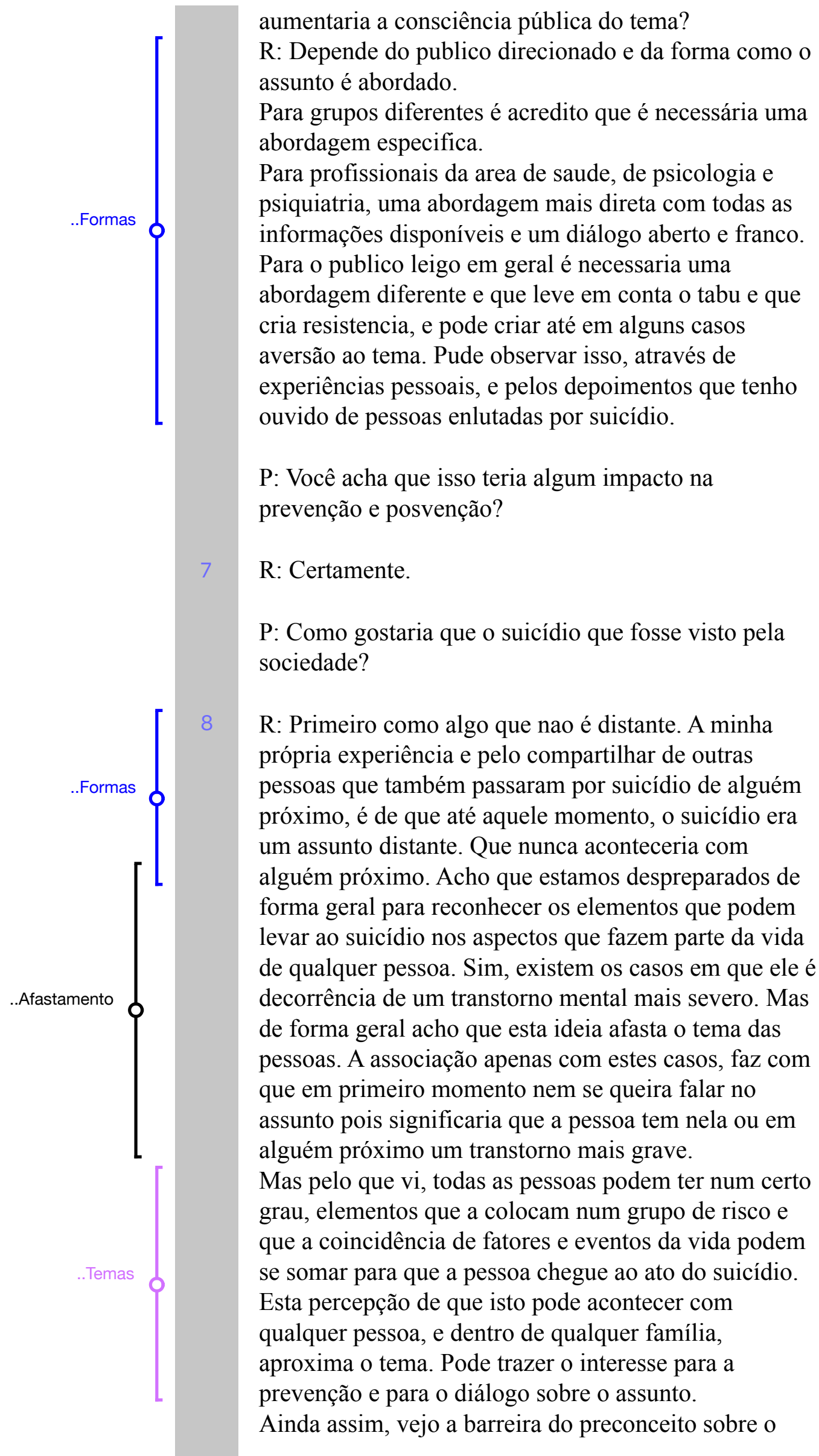




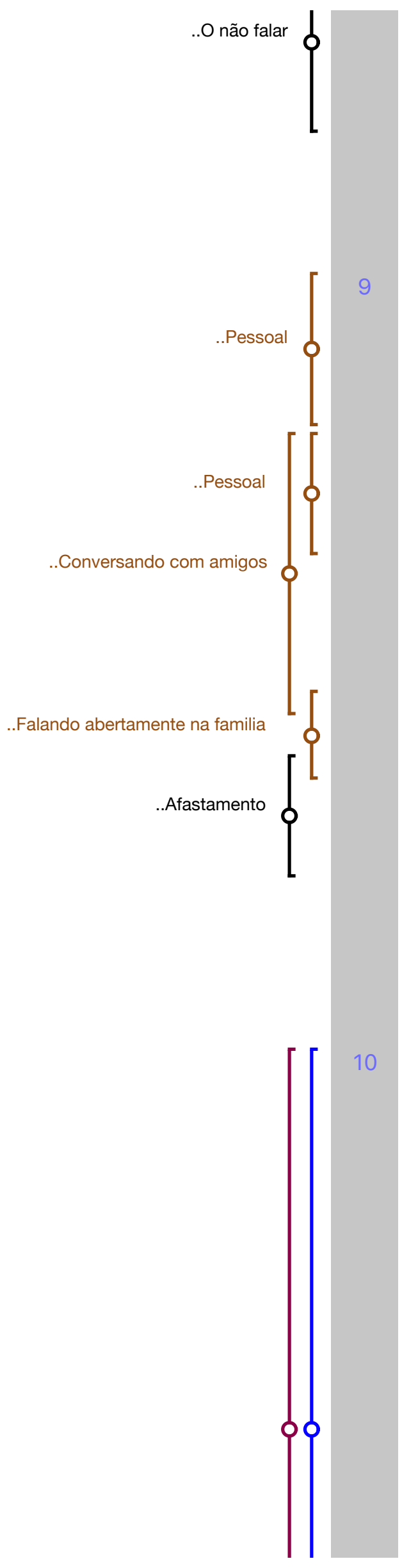

que comumente são chamados de assuntos "negativos", como suicídio, morte, doenças. Isto também cria uma repulsa da discussão e do diálogo sobre o tema.

P: Qual o impacto de campanhas públicas, como o setembro amarelo, em cada um de vocês?

R: Na ocasião do Setembro amarelo passado em 2016, eu estava trabalhando como voluntário do CVV. É com tristeza que relato que não encontrei abertura para falar da campanha com ninguém da família e com a maioria dos amigos mais próximos. Os motivos são os comentados acima. Nas pessoas mais próximas, não consigo ainda hoje entrar no tema do suicídio sem notar um impacto de estranhamento e desconforto nas pessoas. Falar no tema é encarado como mau agouro, ou então percebo o preconceito na causa e até um afastamento e perda de alguns vínculos de amizade. Alguns mais descontraídos brincam sobre ser um assunto negro, e apesar de ser de forma mais educada, desviam-se do tema. Tive apenas uma pessoa da família que achou interessante e quis saber um pouco mais sobre o tema. Mas de forma geral, o fato de eu tocar no assunto sendo apenas leigo, faz com que algumas pessoas me olhem como se eu fosse um problema. Muitas acabam reagindo ou se afastando.

P: Alguém lembra de algum exemplo de campanha ou mensagem positiva/negativa sobre o suicídio na mídia?

R: Lembro de uma campanha de tv muito antiga do $\mathrm{CVV}$, aonde um homem pede dinheiro na rua, e ao receber uma moeda entra num bar. Tudo dá a entender que ele vai comprar bebida alcoólica. Mas ele compra uma ficha e vai a um telefone publico dentro do bar e efetua uma ligação. Do outro lado da linha uma voz diz: "CVV boa noite", e eles começam a conversar. Esta campanha antiga, me marcou a respeito da imagem do CVV e que seria um lugar aonde se pode conversar. Acho uma campanha extremamente positiva e que nos aproxima. A idéia de que ao passar uma situação difícil, o CVV é um lugar aonde se pode conversar e ser ouvido. Acho que a campanha vai exatamente no ponto que é necessário a respeito do assunto. Abordando de forma prática um 


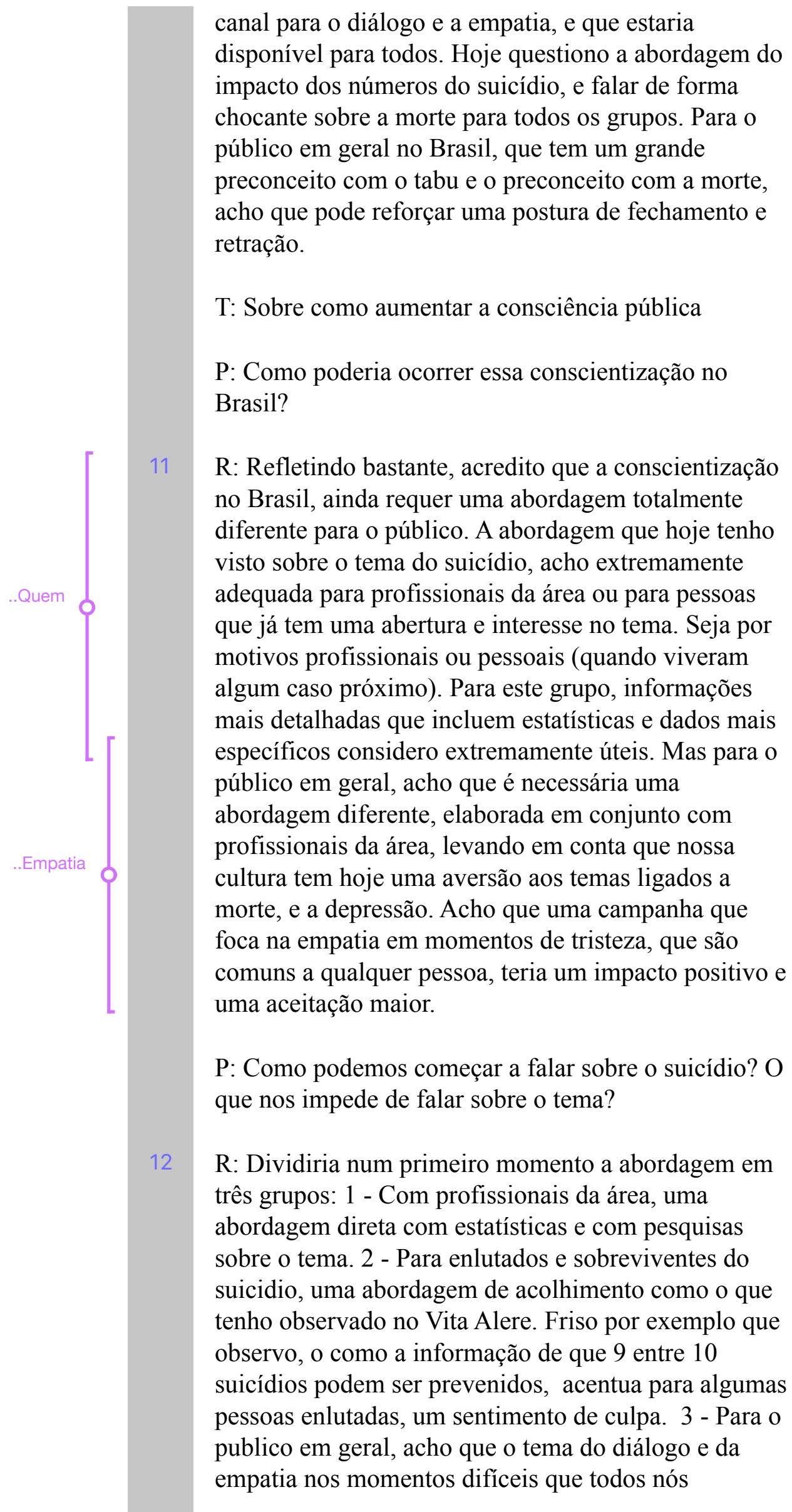




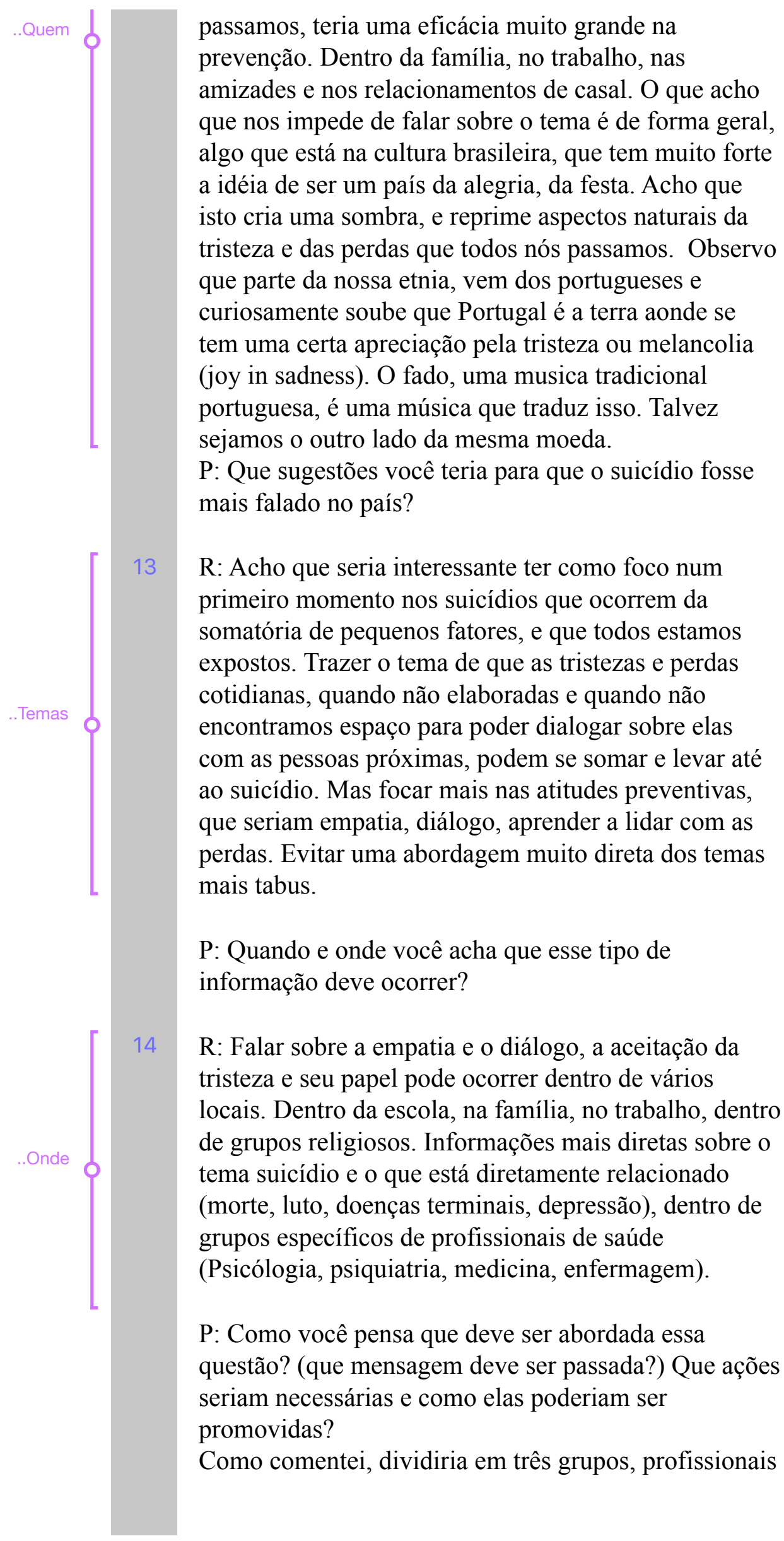




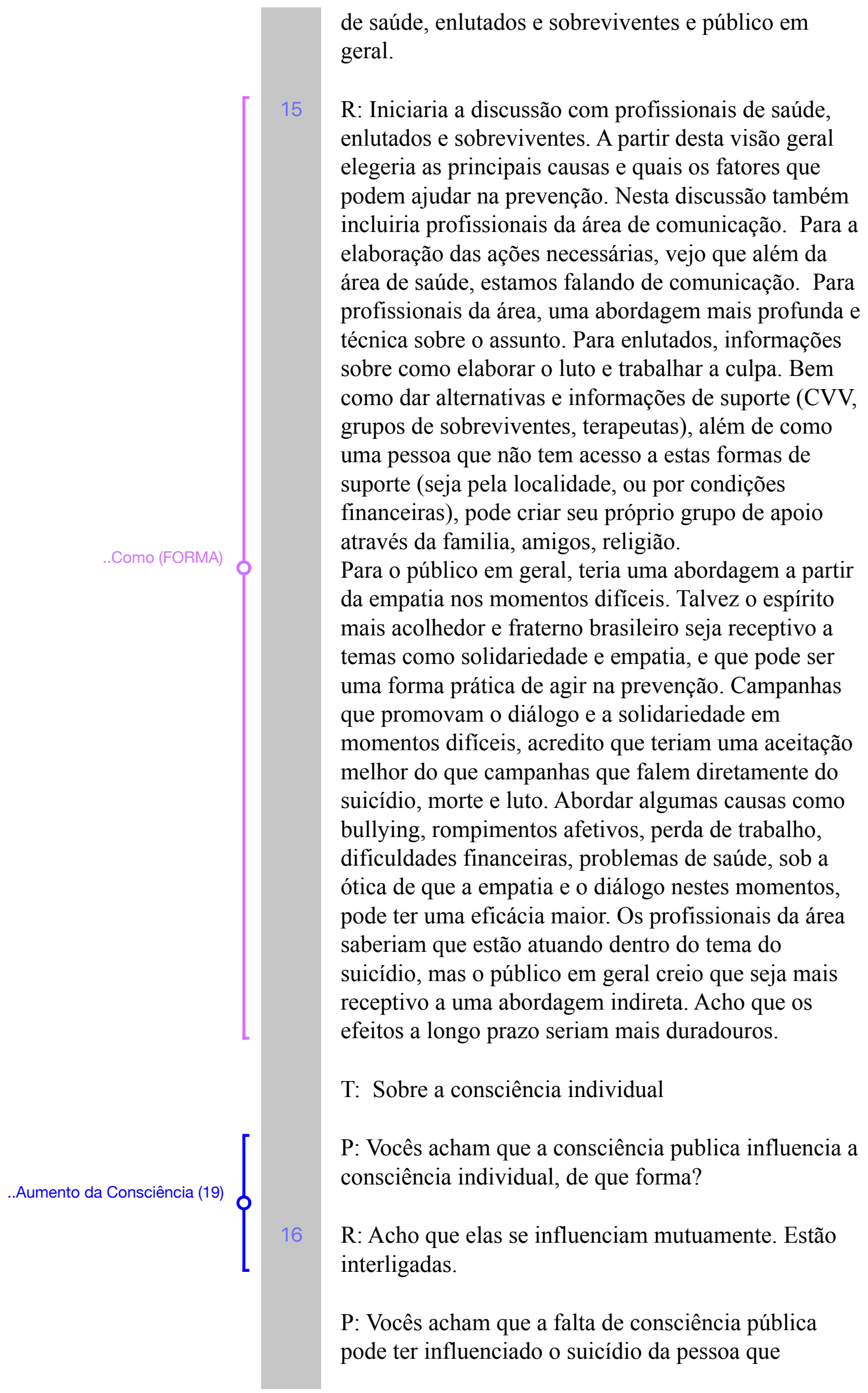




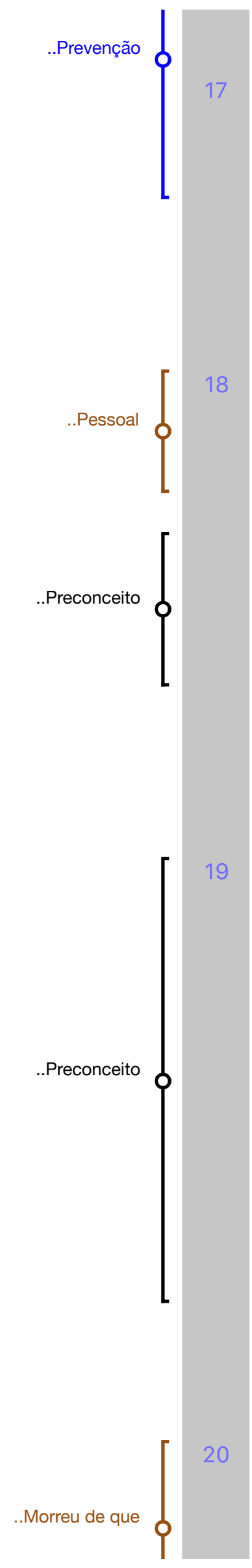

perderam?

R: Sim, alguns no caso da pessoa que perdi, a exclusão social, bullying, acredito que teve uma influência direta. Naquele momento, não havia uma discussão sobre estes assuntos publicamente como há hoje.

T: Experiências

P: Como é para vocês falar sobre o suicídio?

R: Para mim, é um tema importante e que requer uma ação imediata, mas que apesar da gravidade e da urgência, não encontro muitas oportunidades e pessoas com quem conversar a respeito.

P: A forma como a sociedade e as pessoas encaram o suicídio te toca?

R: Bastante, pois sinto que há uma preconceito muito grande. Pois a visão atual só tende a colaborar que isso continue ocorrendo.

P: Você já passou por alguma situação que envolvesse a falta ou não de consciência pública e individual em relação ao suicídio?

R: Sim, passei por várias situações de falta de consciência sobre o suicídio. Desde a pessoa que disse que "quem se suicida é um covarde", que soube depois que era uma forma dela cortar o assunto, pois dentro de toda a família dela, falar em morte e doenças graves, "atrai"... Palavras fortes e com muito julgamento, que hoje entendo que foram uma forma de defesa da pessoa que disse. Uma dificuldade da própria pessoa em lidar com o tema.

Também ao me abrir com um amigo, sobre meu processo de luto, sofri preconceito e afastamento, como se eu a tristeza não fosse parte de um processo natural. Pois para ele, o estado de uma pessoa saudável é de apenas alegria.

P: Como é falar sobre a causa de morte do ente querido e qual a causa de morte que é falada.

R: Meu amigo se suicidou com um tiro na cabeça com um revolver do tio. Para mim, hoje é mais natural, mas como não tive muitas oportunidades de falar no 


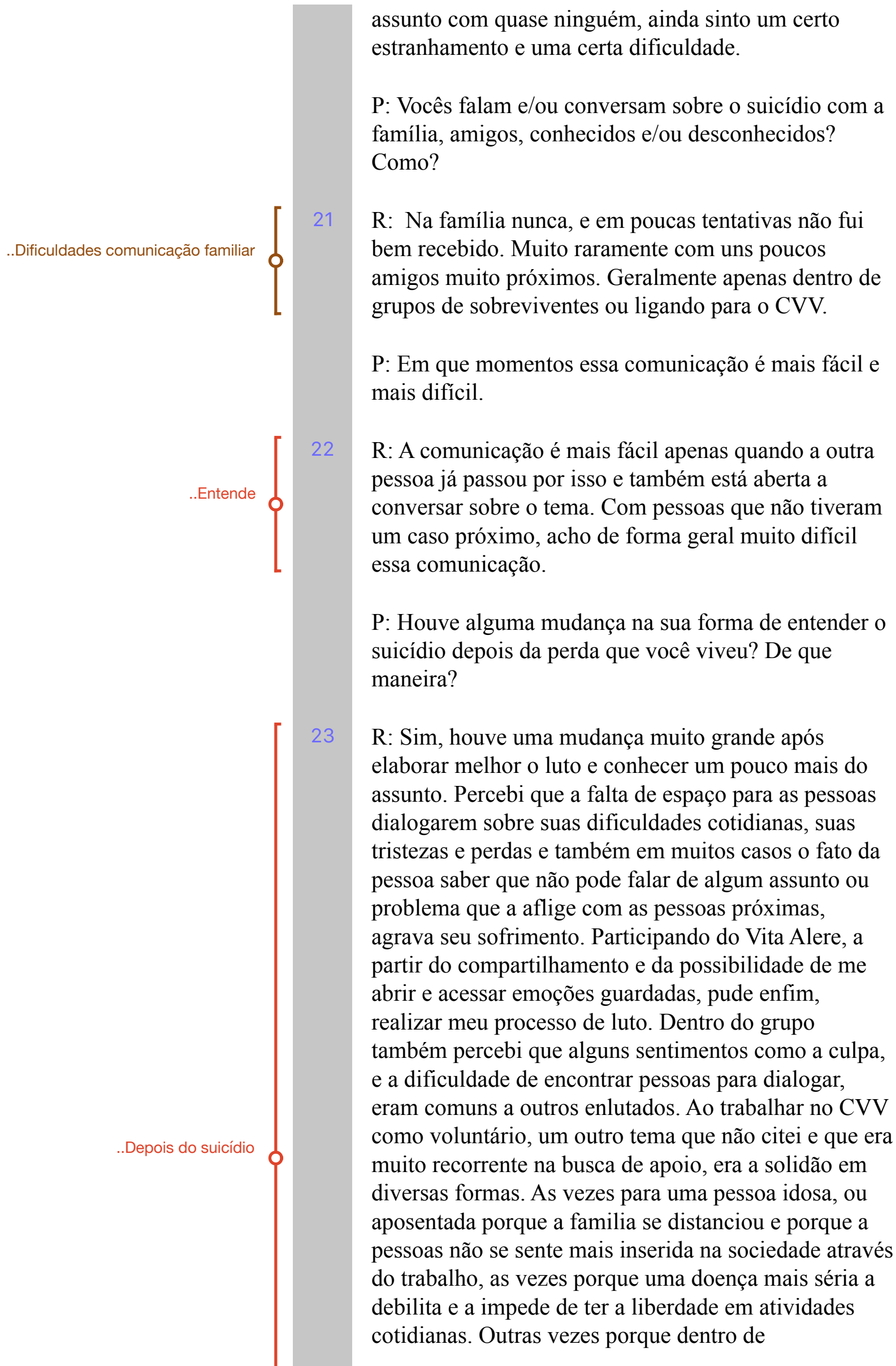




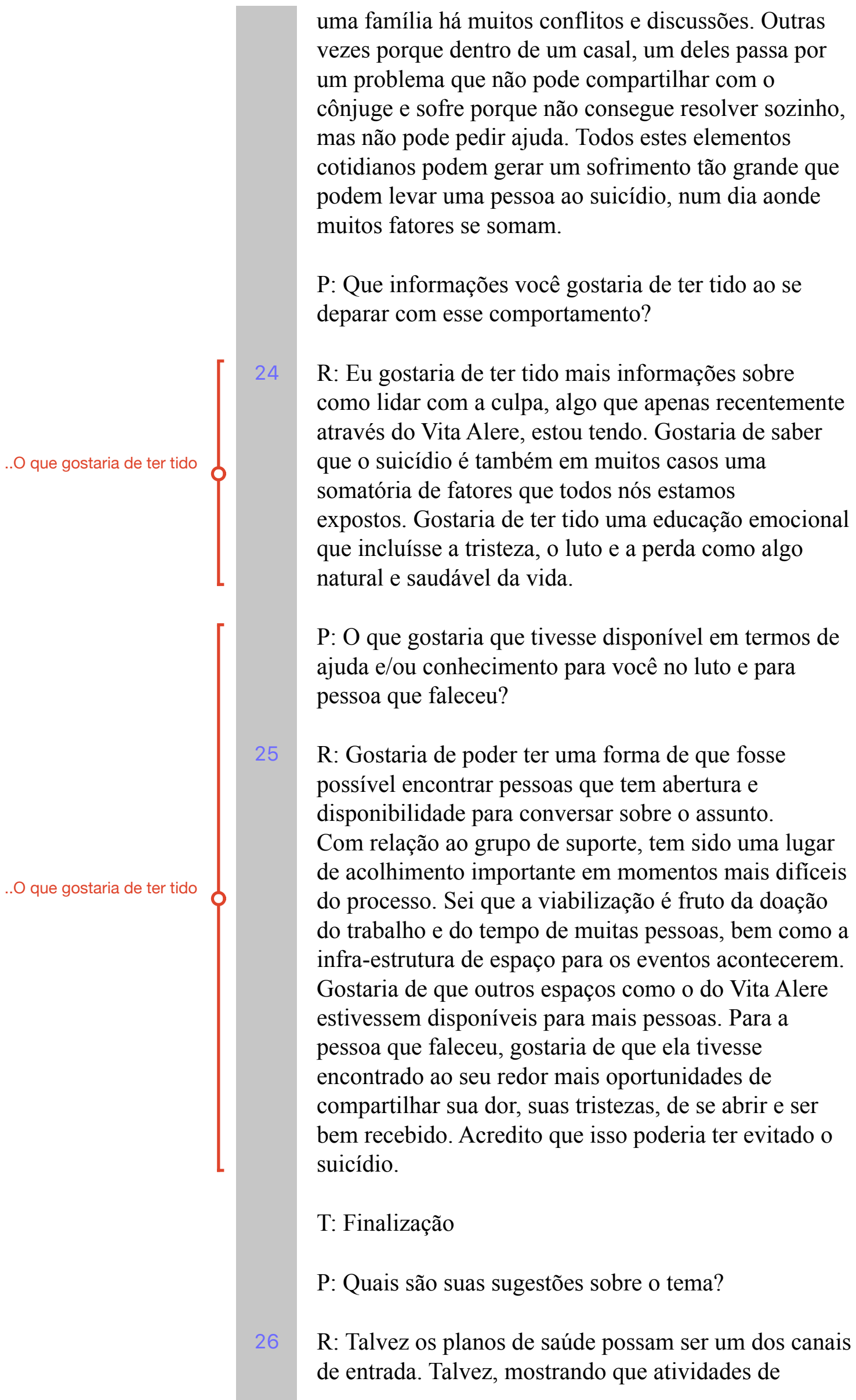




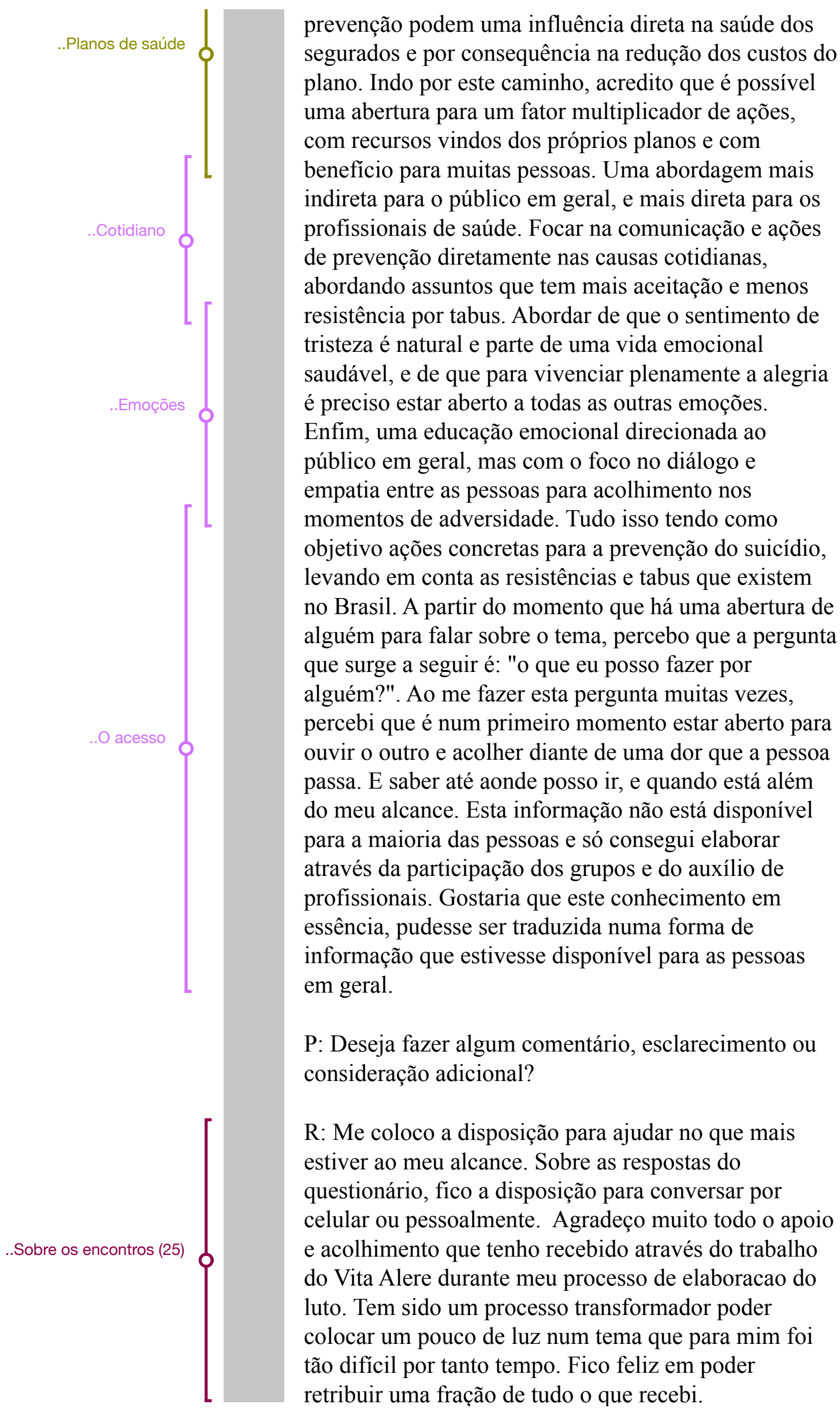


$11 / 11$ 
Anexo M - Visão Geral das Anotações (Memos)

\begin{tabular}{|c|c|c|c|}
\hline Nome do documento & Código & Título & Texto da anotação \\
\hline & Em palestras de suporte & Em palestras de suporte & $\begin{array}{l}\text { Dentro da empresa } \\
\text { Nota feita durante a microanalise }\end{array}$ \\
\hline & Quem não viveu não entende & Quem não viveu não entende & $\begin{array}{l}\text { a realidade } \\
\text { veem como distante } \\
\text { Nota feita durante a microanalise }\end{array}$ \\
\hline & Distanciando-se de reportagens e falas de algo que nao & Distanciando-se de reportagens e falas de algo qu & $\begin{array}{l}\text { De algo que nao vivenciou } \\
\text { Nota feita durante a microanalise } \\
\end{array}$ \\
\hline $\begin{array}{l}\text { Transcricao E1 } \\
\text { revisada_para } \\
\text { maxqda }\end{array}$ & & Nota microanalise 5 & Será que entende? Qual o real significado de um suicidio para ela? \\
\hline \multirow[t]{2}{*}{$\begin{array}{l}\text { Transcricao E1 } \\
\text { revisada_para } \\
\text { maxqda }\end{array}$} & & Nota microanalise 6 & O que é um lugar vulgar??? \\
\hline & Sentindo a morte como longe & Sentindo a morte como longe & $\begin{array}{l}\text { Pensar no distanciamento da morte dos outros, ou das mortes sem nome, de } \\
\text { "alguens", uma dor que nao toca, uma morte que não é sentida } \\
\text { Nota feita durante a microanalise }\end{array}$ \\
\hline $\begin{array}{l}\text { Transcricao E1 } \\
\text { revisada_para } \\
\text { maxqda }\end{array}$ & & Nota microanalise 9 & O suicidio é ficção até que acontece \\
\hline \multirow[t]{5}{*}{$\begin{array}{l}\text { Transcricao E1 } \\
\text { revisada_para } \\
\text { maxqda }\end{array}$} & & Nota microanalise 11 & Porque eu achava que o suicídio nunca ia acontecer comigo \\
\hline & O absurdo do suicidio & O absurdo do suicidio & $\begin{array}{l}\text { Será que isso pode ser uma categoria? } \\
\text { Nota feita durante a microanalise }\end{array}$ \\
\hline & Sentindo-se despreparada & Sentindo-se desprepada & $\begin{array}{l}\text { Ninguem imagina que passara por isso, ninguem nunca esta preparado para lidar } \\
\text { com isso } \\
\text { Nota feita durante a microanalise }\end{array}$ \\
\hline & Possibilidade de adoecer & Possibilidade de adoecer & $\begin{array}{l}\text { Isso é normal e ate esperado } \\
\text { Nota feita durante a microanalise }\end{array}$ \\
\hline & Mudando a percepção sobre o suicidio & Mudando a percepção sobre o suicidio & $\begin{array}{l}\text { Junta com o vivido e nao viido, quem passou e quem nao passou } \\
\text { Nota feita durante a microanalise }\end{array}$ \\
\hline
\end{tabular}

Material integrante da pesquisa de doutorado de Karen Scavacini Proibida a reprodução ou utilização sem autorização prévia do autor - 2018 


\begin{tabular}{|c|c|c|c|}
\hline & Um dia pode acontecer comigo & Um dia pode acontecer comigo & $\begin{array}{l}\text { sobre assaltos, roubos e doencas - faz parte da vida... todo mundo pode passar... } \\
\text { Nota feita durante a microanalise }\end{array}$ \\
\hline & Suicidio como algo da vida do outro / distante de mim & Suicidio como algo da vida do outro & $\begin{array}{l}\text { Nao vai acontecer comigo... só no quintal do outro } \\
\text { Como esse assunto não acontece na minha familia eu nao me preocupo } \\
\text { Nota feita durante a microanalise }\end{array}$ \\
\hline \multirow[t]{2}{*}{$\begin{array}{l}\text { Transcricao E1 } \\
\text { revisada_para } \\
\text { maxqda }\end{array}$} & & Nota microanalise 18 & $\begin{array}{l}\text { Dois provaveis conceitos: } \\
\text { quem passou } \\
\text { quem não passou }\end{array}$ \\
\hline & Pessoas querendo culpados e razoes simples & Pessoas querendo culpados e razoes simples & $\begin{array}{l}\text { Visao causal do suicidio e a busca de um culpado - } \\
\text { Nota feita durante a microanalise }\end{array}$ \\
\hline \multirow[t]{2}{*}{$\begin{array}{l}\text { Transcricao E1 } \\
\text { revisada_para } \\
\text { maxqda }\end{array}$} & & Nota microanalise 20 & $\begin{array}{l}\text { Será que ao achar um culpado as pessoas tiram a culpa de si ou minimizam o que } \\
\text { aconteceu? Assim não precisam conviver com as nao respostas, o nao saber, o } \\
\text { absurdo do ato suicida? Será que assim elas mesmas possa se sentir distantes do } \\
\text { que houve, como se assim, pudessem medir seus sentimentos e se diferenciar de } \\
\text { quem se matou? Distanciar o ato de si mesmo... }\end{array}$ \\
\hline & Sentindo machucada e cutucada & Sentindo machucada e cutucada & $\begin{array}{l}\text { A insensibilidade do outro } \\
\text { Nota feita durante a microanalise }\end{array}$ \\
\hline \multirow[t]{2}{*}{$\begin{array}{l}\text { Transcricao E1 } \\
\text { revisada_para } \\
\text { maxqda }\end{array}$} & & Nota microanálise 22 & $\begin{array}{l}\text { A insensibilidade das perguntas e da curiosidade dos outros. A falta da empatia e } \\
\text { do acolhimento. Desta forma é melhor não falar, pois ao falar se expõe, expõe a } \\
\text { ferida, e o outro pode, mesmo que sem querer, machucar mais. O outro traz } \\
\text { consigo o que? A sua visão da morte? Do suicídio? Do julgamento aos que } \\
\text { ficaram? Traz sua curiosidade mórbida? }\end{array}$ \\
\hline & Sentindo julgamento & Sentindo julgamento & $\begin{array}{l}\text { E críticas por tabela } \\
\text { Nota feita durante a microanálise }\end{array}$ \\
\hline
\end{tabular}




\begin{tabular}{|c|c|c|c|}
\hline \multirow[t]{2}{*}{$\begin{array}{l}\text { Transcrição E1 } \\
\text { revisada_para } \\
\text { maxqda }\end{array}$} & & Nota microanálise 24 & $\begin{array}{l}\text { Isso me deixa pensativa sobre as reportagens e campanhas que falam que } 90 \% \\
\text { dos casos podem ser evitados, isso pode fazer com que aumente na sociedade a } \\
\text { visão/sentimento de que se não preveniu, evitou, é porque não fez o que devia ou } \\
\text { fez errado. Isso é um conceito errôneo? trazido como se fosse simples prever, } \\
\text { identificar e tratar. Acontece que esses } 90 \% \text { são relacionados a depressão e } \\
\text { transtornos mentais, e isso eh falado como se fosse o todo... e os multifatores? } \\
\text { Esses } 90 \% \text { incluem os multifatores e a super. dificuldade de achar atendimento } \\
\text { adequado e digno. Penso se não precisamos mudar a forma de falar... Lembro } \\
\text { daquele gráfico inverso de que se } 1 \text { pessoa se mata é porque tantas outras } \\
\text { sobreviveram... não me lembro onde vi isso, mas devo procurar. } \\
\text { Nota adicionada durante revisão das notas: } \\
\text { As próprias reportagens podem fazer com que essa visão causal prevaleça. E que a } \\
\text { visão de alguém que não viu e não fez... afinal } 90 \% \text { podem ser prevenidos.. } \\
\text { Necessário x suficiente }\end{array}$ \\
\hline & Sentindo-se entendida por quem passou & Sentindo-se entendida por quem passou & $\begin{array}{l}\text { Categoria: Quem viveu? } \\
\text { Nota feita durante a microanálise }\end{array}$ \\
\hline $\begin{array}{l}\text { Transcrição E1 } \\
\text { revisada_para } \\
\text { maxqda }\end{array}$ & & Nota microanálise 26 & $\begin{array}{l}\text { Fico pensando em como eu, que não passei por isso posso ajudar? Será que } \\
\text { devemos fazer essa divisão de quem passou e de quem não passou, ou será que a } \\
\text { divisão é de quem tem empatia, acolhimento e conhecimento e quem não. } \\
\text { Nota adicionada em } 27 / 11 \\
\text { Contar sobre meu primeiro grupo de sobreviventes e como fiquei depois disso. } \\
\text { A impotência sentida por aquele que ajuda. }\end{array}$ \\
\hline $\begin{array}{l}\text { Transcrição E1 } \\
\text { revisada_para } \\
\text { maxqda }\end{array}$ & & Nota microanálise 27 & $\begin{array}{l}\text { Nota metodológica: } \\
\text { Na codificação linha por linha, coloquei as ações, sentimentos percebidos. Para } \\
\text { depois juntar em conceitos mais amplos. Achei que assim estava dando a } \\
\text { importância e realmente mergulhando nos dados. Como se pudesse ouvi-los } \\
\text { falar... para depois construir a teoria. } \\
\text { Fui tentando agrupar os parecidos já durante a microanálise... }\end{array}$ \\
\hline $\begin{array}{l}\text { Transcrição E1 } \\
\text { revisada_para } \\
\text { maxqda }\end{array}$ & & Nota microanálise 28 & Categoria: visão da sociedade? \\
\hline $\begin{array}{l}\text { Transcrição E1 } \\
\text { revisada_para } \\
\text { maxqda }\end{array}$ & & Nota microanálise 29 & $\begin{array}{l}\text { Visão da sociedade. Essa visão vem desde quando? Quem criou essa visão? Qual a } \\
\text { definição de covarde e fraco? Ela tinha essa visão antes? Tem agora? }\end{array}$ \\
\hline $\begin{array}{l}\text { Transcrição E1 } \\
\text { revisada_para } \\
\text { maxqda }\end{array}$ & & Nota microanálise 30 & $\begin{array}{l}\text { Será que coloco a minha experiência com o suicídio, não queria estudar isso na } \\
\text { faculdade... o que me fez prestar atenção? Será que presto atenção a outras } \\
\text { coisas? Câncer de próstata? }\end{array}$ \\
\hline
\end{tabular}




\begin{tabular}{|c|c|c|c|}
\hline $\begin{array}{l}\text { Transcrição E1 } \\
\text { revisada_para } \\
\text { maxqda }\end{array}$ & & Nota microanálise 31 & $\begin{array}{l}\text { Quem não viveu não entende o que? Os motivos? A dor de quem fica? O que } \\
\text { levou a pessoa a fazer? E quem passou, será que entende a complexidade do ato? } \\
\text { Será que é entendimento ou acolhimento? Ou, quando eu entendo, faz sentido } \\
\text { para mim e eu acolho? O não entendimento tem haver com o que?? } \\
\text { Não entende ou não respeita? Não entende ou julga? } \\
\text { Nota incluída em 30/11/17: } \\
\text { Ver descrição observadora sobre o encontro } 1 \\
\text { Falta de acolhimento entre eles mesmos }\end{array}$ \\
\hline \multirow[t]{2}{*}{$\begin{array}{l}\text { Transcrição E1 } \\
\text { revisada_para } \\
\text { maxqda }\end{array}$} & & Nota microanálise 32 & $\begin{array}{l}\text { Categoria: quem viveu } \\
\text { Sub: categoria: antes eu também pensava assim }\end{array}$ \\
\hline & Vendo a irmã morta & Vendo a irmã morta & O medo de passar por isso de novo. A iminência de outra morte na família \\
\hline $\begin{array}{l}\text { Transcrição E1 } \\
\text { revisada_para } \\
\text { maxqda }\end{array}$ & & Microanálise 34 & $\begin{array}{l}\text { O medo de passar por isso de novo. A iminência de outra morte na família. } \\
\text { Será que eles desenvolvem um luto antecipatório ou uma ansiedade de repetição? } \\
\text { Como conviver com o medo de perder mais alguém desta forma? }\end{array}$ \\
\hline \multirow[t]{4}{*}{$\begin{array}{l}\text { Transcrição E1 } \\
\text { revisada_para } \\
\text { maxqda }\end{array}$} & & Microanálise 35 & $\begin{array}{l}\text { De onde inicia o tabu? Como uma família pode se reerguer e falar abertamente } \\
\text { sobre essa ferida? Ferida que ainda sangra e com a possibilidade de passar por } \\
\text { isso de novo? Será um ajustamento criativo disfuncional da família? Ou uma } \\
\text { proteção para conseguir caminhar no dia a dia e não paralisar... }\end{array}$ \\
\hline & Sentindo cortada pelas pessoas & Sentindo cortada pelas pessoas & Mesmo quando tem a oportunidade de falar \\
\hline & Mãe acreditando que a filha está melhor & Mãe acreditando que a filha está melhor & Por causa do psiquiatra e do curso \\
\hline & Sentindo que a irmã não está bem & Sentindo que a irmã não está bem & Mesmo que a família pretenda que sim \\
\hline $\begin{array}{l}\text { Transcrição E1 } \\
\text { revisada_para } \\
\text { maxqda }\end{array}$ & & microanálise 39 & $\begin{array}{l}\text { Com quem podemos falar então? Quem não muda de assunto? Porque eles fazem } \\
\text { isso? Porque as pessoas mudam de assunto? } \\
\text { O que impede de falar no assunto? De onde vem a crença que falar no assunto } \\
\text { não é bom ou que devemos mudar de assunto? } \\
\text { O que passa na cabeça das pessoas nesses momentos? }\end{array}$ \\
\hline $\begin{array}{l}\text { Transcrição E1 } \\
\text { revisada_para } \\
\text { maxqda }\end{array}$ & & Microanálise 40 & $\begin{array}{l}\text { Impressão minha: Não há nada que consiga me tirar dessa dor. Não ha nada que } \\
\text { possa ser falado que vai ajudar. O que ajuda então? }\end{array}$ \\
\hline $\begin{array}{l}\text { Transcrição E1 } \\
\text { revisada_para } \\
\text { maxqda }\end{array}$ & & Microanálise 41 & Possivel categoria: Morreu de que? \\
\hline $\begin{array}{l}\text { Transcrição E1 } \\
\text { revisada_para } \\
\text { maxqda }\end{array}$ & & Microanálise 42 & Categoria possível: negação \\
\hline $\begin{array}{l}\text { Transcrição E1 } \\
\text { revisada_para } \\
\text { maxqda }\end{array}$ & & Microanálise 43 & $\begin{array}{l}\text { Será que todos os enlutados precisam deste tempo? O que ajudou nessa } \\
\text { preparação? Preparação para que? Precisou se preparar para que? Julgamento? } \\
\text { Acudir o outro? }\end{array}$ \\
\hline
\end{tabular}




\begin{tabular}{|c|c|c|}
\hline $\begin{array}{l}\text { Transcrição E1 } \\
\text { revisada_para } \\
\text { maxqda }\end{array}$ & Microanálise 44 & $\begin{array}{l}\text { Me leva a pensar que as pessoas precisam saber se respeitar e falar o que } \\
\text { querem, para quem querem e na hora que querem. Não tem certo ou errado para } \\
\text { nada. Será que devo falar sobre suicídio com todos? Quais são os meus limites e } \\
\text { minhas fronteiras? } \\
\text { Qual o OBJETIVO do falar? O que queremos com isso? } \\
\text { Porque precisamos falar mais??? Para quem isso é importante? Para a pessoa? } \\
\text { Para a família? Para a sociedade? } \\
\text { Será que falar faz bem para todos? } \\
\text { Ou será que é uma maneira da pessoa encontrar ajuda? } \\
\text { Mas daí, onde ela poderá ser atendida? Vamos com isso gerar demanda e } \\
\text { frustração/raiva? Como ficam as pessoas que dependem do SUS ou do plano de } \\
\text { saúde? } \\
\text { O que vamos provocar nas pessoas? Qual o impacto disso tudo? }\end{array}$ \\
\hline $\begin{array}{l}\text { Transcrição E1 } \\
\text { revisada_para } \\
\text { maxqda }\end{array}$ & Microanálise 45 & $\begin{array}{l}\text { Será que são todos mesmo? O que o faz sentir isso? É a partir das experiências } \\
\text { que teve ou da fantasia? Será que curiosidade pode ser confundida com atenção? } \\
\text { O que isso gera neles? } \\
\text { Como isso muda eles? } \\
\text { Seriam perguntas fantasiadas de preocupação que no fundo eram curiosidade? } \\
\text { Como ele faz essa distinção? }\end{array}$ \\
\hline $\begin{array}{l}\text { Transcrição E1 } \\
\text { revisada_para } \\
\text { maxqda }\end{array}$ & Microanálise 46 & $\begin{array}{l}\text { Como as pessoas julgam os mortos? E os vivos que conviviam com esses mortos? } \\
\text { Quais as formas de morte aceitáveis? } \\
\text { O suicídio é uma morte escancarada? } \\
\text { As pessoas fazem um julgamento rápido baseado na causa de morte ou é um jeito } \\
\text { que elas tem para explicar para si mesmas o porque aquela morte ocorreu? Ou } \\
\text { seria para "dar conforto" mostrando um culpado que não seja a família? } \\
\text { O que leva as pessoas a agirem desta forma? } \\
\text { Qual é o senso comum sobre morte por suicídio de jovens e idosos? 10. droga / } \\
\text { amante? (Ver qual a \% de mortalidade e o porque) } \\
\text { Categoria: CAUSA ÚNICA e/ou CULPADOS }\end{array}$ \\
\hline $\begin{array}{l}\text { Transcrição E1 } \\
\text { revisada_para } \\
\text { maxqda }\end{array}$ & Microanálise 47 & $\begin{array}{l}\text { Até entendo que o senso comum faça isso... mas o psiquiatra? } \\
\text { Buscar estudo sobre o tabu entre psiquiatras, disciplina de psiquiatria social do } \\
\text { HCUSP. } \\
\text { CATEGORIA: PROFISSIONAIS DE AJUDA? OU DESAJUDA? } \\
\text { Quem ajuda??????? }\end{array}$ \\
\hline $\begin{array}{l}\text { Transcrição E1 } \\
\text { revisada_para } \\
\text { maxqda }\end{array}$ & Microanálise 48 & $\begin{array}{l}\text { A culpa é do externo, buscam uma causa externa? A culpa é da droga, da amante, } \\
\text { dos amigos? } \\
\text { Há uma dificuldade em pensar que tudo isso vem de dentro? Ou que é uma } \\
\text { interação dentro de fora... } \\
\text { Para que serve isso? } \\
\text { O que é culpa? }\end{array}$ \\
\hline
\end{tabular}

Material integrante da pesquisa de doutorado de Karen Scavacini Proibida a reprodução ou utilização sem autorização prévia do autor - 2018 


\begin{tabular}{|c|c|c|c|}
\hline $\begin{array}{l}\text { Transcrição E1 } \\
\text { revisada_para } \\
\text { maxqda }\end{array}$ & & Microanálise 49 & $\begin{array}{l}\text { Que visão as pessoas tem da depressão hoje em dia? } \\
\text { Continuam achando frescura? } \\
\text { Não entendem a severidade da doença? } \\
\text { Vem como doença? }\end{array}$ \\
\hline $\begin{array}{l}\text { Transcrição E1 } \\
\text { revisada_para } \\
\text { maxqda }\end{array}$ & & Microanálise 50 & $\begin{array}{l}\text { Tudo tem que ser causa e efeito? } \\
\text { Depressão tem justificativa? } \\
\text { O que faz com que as pessoas ajam assim? } \\
\text { Começaria na escola? Com o pensamento dual? } \\
\text { Quando fomos restringidos no pensar? Ou é uma forma de aplacar os medos? }\end{array}$ \\
\hline $\begin{array}{l}\text { Transcrição E1 } \\
\text { revisada_para } \\
\text { maxqda }\end{array}$ & & Anotação 51 & Será que posso ter um TEMA: CRENÇAS ou ele é uma CATEGORIA \\
\hline $\begin{array}{l}\text { Transcrição E1 } \\
\text { revisada_para } \\
\text { maxqda }\end{array}$ & & Microanálise 52 & $\begin{array}{l}\text { Medo do contágio? } \\
\text { Medo de ser igual aquele "depressivo"? }\end{array}$ \\
\hline $\begin{array}{l}\text { Transcrição E1 } \\
\text { revisada_para } \\
\text { maxqda }\end{array}$ & & Microanálise 53 & $\begin{array}{l}\text { Será que a lembrança do que foi difícil pode ajudar? Tendemos a esquecer } \\
\text { situações ruins? Lembrar de que tb sentimos coisas ruins pode aumentar a } \\
\text { empatia? }\end{array}$ \\
\hline & Falta de informação sobre o assunto & Falta de informação sobre o assunto & Como impeditivo do cuidado e do envolvimento \\
\hline $\begin{array}{l}\text { Transcrição E1 } \\
\text { revisada_para } \\
\text { maxqda }\end{array}$ & & Microanálise 55 & Falta de preparação dos profissionais e dos hospitais \\
\hline $\begin{array}{l}\text { Transcrição E1 } \\
\text { revisada_para } \\
\text { maxqda }\end{array}$ & & Anotação 56 & $\begin{array}{l}\text { Começando a ficar preocupada com a quantidade de códigos... como farei para } \\
\text { linkar tudo isso??? } \\
\text { NOTA: Categoria: DAR VOZ CURA? }\end{array}$ \\
\hline $\begin{array}{l}\text { Transcrição E1 } \\
\text { revisada_para } \\
\text { maxqda }\end{array}$ & & Microanálise 57 & $\begin{array}{l}\text { Da onde vem esse medo???? } \\
\text { Medo do que? } \\
\text { Contágio? }\end{array}$ \\
\hline
\end{tabular}




\begin{tabular}{|c|c|c|}
\hline $\begin{array}{l}\text { Transcrição E1 } \\
\text { revisada_para } \\
\text { maxqda }\end{array}$ & Microanálise 58 & \begin{tabular}{|l} 
Porque as faculdade de psi não falam sobre o assunto. \\
O que pensam os profissionais sobre o assunto? \\
Como um ambiente de saúde chega a tanto tabu e despreparo \\
Os números seriam uma forma de mostrar o quão comum é o suicídio? \\
As pessoas acham que não tem porque ninguém fala no assunto. \\
De onde vem essa percepção que esta longe? QUe não acontece? Proteção? \\
As séries são motivadoras de reflexão e discussao. Levam as pessoas a pensarem \\
no que elas acreditam.. mas acho que isso para pessoas que tem mais estrutura, \\
porque podem mostrar os caminhos para quem não sabe a saída. \\
A quem cabe mudar isso? Quem colabora para esse tabu continuar? \\
Quem ganha se não falarmos sobre o assunto, e quem perde? \\
Será que é bom para a sociedade esconder a depressão e o suicídio, ou deixar que \\
a depressão não é doença, as pessoas vendo depressão como doença teria algum \\
impacto na sociedade? E vendo o suicídio como uma fase terminal da depressão? \\
A depressão é vista como hj? Será que ela é vista como multifftorial tambem??? \\
Qual a origem dela? De onde ela vem? \\
Será que a única forma de tratar e ver depressão é pelo viés médico? \\
Ver tese da Ana Célia e visões alternativas sobre o assunto... \\
Ver o que o Guillermo fala sobre depressão... \\
A quem interessa que isso fique assim? Sociedade, religião, escolas, empresas, \\
familias, médicos??? Quem??
\end{tabular} \\
\hline $\begin{array}{l}\text { Transcrição E1 } \\
\text { revisada_para } \\
\text { maxqda }\end{array}$ & Microanálise 59 & $\begin{array}{l}\text { Processo que não funciona... } \\
\text { Mais uma sobrecarga para o medico } \\
\text { Será que a própria notificação compulsória não faz o medico sentir raiva } \\
\text { Ver livro Soraya } \\
\text { Qual o resultado do processo? Quem se beneficia dele? } \\
\text { O medico vai a julgamento para que? Ele é julgado pelo o que??? Qual a } \\
\text { acusação?? Ou ele tem que se defender de algo? Qual o proposito? } \\
\text { O que a família faz? }\end{array}$ \\
\hline $\begin{array}{l}\text { Transcrição E1 } \\
\text { revisada_para } \\
\text { maxqda }\end{array}$ & Microanálise 60 & \begin{tabular}{|l|} 
Qefinitivamente esse é um grande problema no tema \\
Qual é a regra? Todos seguem a mesma? Porque há essas diferenças? \\
E as subnotificações? Hoje ainda é assim? O sistema de informação de \\
mortalidade mudou? Como são geradas as estatísticas do datasus? Mudam depois \\
que sai a conclusão da policia ou se baseiam só naquelas em que há no atestado \\
de óbito na hora? Muda-se o atestado de óbito? \\
VER ESTUDO sobre a religiosidade e a causa da morte dada por legistas, ou, como \\
a crença dos legistas influenciam na causa da morte dada \\
Como essas informações mudaram a compreensão dos participantes'
\end{tabular} \\
\hline
\end{tabular}




\begin{tabular}{|c|c|c|}
\hline $\begin{array}{l}\text { Transcrição E1 } \\
\text { revisada_para } \\
\text { maxqda }\end{array}$ & Microanálise 61 & $\begin{array}{l}\text { Por onde começamos então? } \\
\text { Parece que eles (grupo) começam a se sentirem meio desolados e sem verem } \\
\text { saídas para isso, como se começassem a ver que é grande demais para resolver... } \\
\text { Quais profissionais precisariam de treinamento? }\end{array}$ \\
\hline $\begin{array}{l}\text { Transcrição E1 } \\
\text { revisada_para } \\
\text { maxqda }\end{array}$ & Microanálise 62 & $\begin{array}{l}\text { O que pode ajuda-la? Me parece tão imersa em sua dor que não tem nada que } \\
\text { possa ajudar, nada que ninguém fale, nada... uma dor que é tão imensa e tão } \\
\text { dela? }\end{array}$ \\
\hline $\begin{array}{l}\text { Transcrição E1 } \\
\text { revisada_para } \\
\text { maxqda }\end{array}$ & Microanálise 63 & $\begin{array}{l}\text { Qual o peso dessa palavra? Dessa expressão? } \\
\text { Porque as pessoas tem tanto medo e receio de usá-la? } \\
\text { Talvez seja o mesmo percurso do câncer... } \\
\text { "aquela doença" e "Pensando em besteira" seriam eufemismos para câncer e } \\
\text { suicídio? } \\
\text { Como trabalhar desta forma? }\end{array}$ \\
\hline $\begin{array}{l}\text { Transcrição E1 } \\
\text { revisada_para } \\
\text { maxqda }\end{array}$ & Microanálise 64 & $\begin{array}{l}\text { Penso que ela não enxerga sua capacidade de dar lindas palestras. Como sua } \\
\text { experiência pode mudar alguém. Essa visão de que os profissionais que devem } \\
\text { falar vem da onde? Essa supervalorização do cientifico. } \\
\text { Será que no fundo é se achar culpada por um outro suicídio? } \\
\text { Quem deve falar sobre o assunto? Quem pode falar? } \\
\text { O que seria um profissional capacitado? } \\
\end{array}$ \\
\hline $\begin{array}{l}\text { Transcrição E1 } \\
\text { revisada_para } \\
\text { maxqda }\end{array}$ & 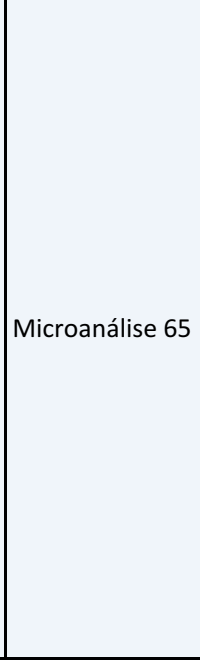 & $\begin{array}{l}\text { A internet e seu papel de escancarar a morte e mostrar suicídio } \\
\text { Penso na sensibilização das pessoas em compartilhar tudo e expor o suicídio desta } \\
\text { maneira } \\
\text { Eles pensam em que? } \\
\text { Talvez as redes sociais tenham mudado a forma em ver o suicídio mas ao mesmo } \\
\text { tempo tenham ajudado a aumentar isso } \\
\text { Papel da internet e das redes sociais } \\
\text { Fico pensando nas fotos e vídeos que achamos pelo google e no comentários } \\
\text { dessas postagens } \\
\text { Esses comentários mostram o que as pessoas pensam.. e isso vem da onde... onde } \\
\text { isso começa, a quem devemos sensibilizar } \\
\text { Será que deveríamos proibir e verificar o que colocam na rede para proteção dos } \\
\text { demais. } \\
\text { Qualquer um pode achar o que quiser sobre suicídio na internet } \\
\text { O maior tabu } \\
\text { Um tabu além da morte }\end{array}$ \\
\hline
\end{tabular}




\begin{tabular}{|c|c|c|}
\hline $\begin{array}{l}\text { Transcrição E1 } \\
\text { revisada_para } \\
\text { maxqda }\end{array}$ & Microanálise 66 & $\begin{array}{l}\text { Quais são as maiores bobagens que as pessoas falam? } \\
\text { Porque elas tem falado mais sobre o suicídio } \\
\text { mas de que forma? } \\
\text { Essa consciência publica é para que? Para gerar empatia? Cuidado? Qual o } \\
\text { objetivo de aumentar consciência publica? É de mostrar que existe? Isso seria fácil } \\
\text { com os números e epidemiologia, mas precisamos chegar mais longe que isso, é } \\
\text { 'só falar? Mas falar como? } \\
\text { Saber que existe é igual a ter consciência? } \\
\text { Se cada um tem um valor, ter consciência não teria relação com os seus valores? } \\
\text { Não é só falar! É ver diferente! Aí posso pensar no conceito de awareness ou } \\
\text { consciência estendida? } \\
\text { Como tocar as pessoas? Tocar para que? Com qual objetivo? } \\
\text { Qual é o objetivo de aumentar consciência publica? Aonde queremos chegar? } \\
\text { Será que isso é uma visão minha do que deve ser? } \\
\text { O que eles acham sobre consciência publica? Como eles acham que deve ser? }\end{array}$ \\
\hline $\begin{array}{l}\text { Transcrição E1 } \\
\text { revisada_para } \\
\text { maxqda }\end{array}$ & Microanálise 67 & $\begin{array}{l}\text { Mas penso que hoje já existe um filme como o divertidamente, será que começa } \\
\text { por onde, será que não começa por um filme assim? Será que não fez sucesso? } \\
\text { Quando que chegamos na supervalorização da felicidade? Me lembrei dos } \\
\text { filósofos depressivos, será que sempre foi assim? Será que sempre demos super } \\
\text { valor a felicidade ou isso também não foi reforçado pelas redes sociais. Onde só } \\
\text { existe o legal. } \\
\text { Penso também na confusão da depressão com tristeza e no aumento do uso de } \\
\text { antidepressivos para tudo. } \\
\text { Como a sociedade vê a tristeza? } \\
\text { Começamos do princípio... no princípio era a tristeza, depois virou depressão, } \\
\text { depois suicídio } \\
\text { E os impulsivos } \\
\text { E a baixa tolerância a frustração } \\
\text { E as crianças mimadas? }\end{array}$ \\
\hline $\begin{array}{l}\text { Transcrição E1 } \\
\text { revisada_para } \\
\text { maxqda }\end{array}$ & Microanálise 68 & $\begin{array}{l}\text { Quem são essas pessoas preparadas para falar? } \\
\text { Será que as pessoas estão realmente prontas para ouvir } \\
\text { Qual a capacidade das pessoas em ouvirem? } \\
\text { Quais são essas perguntas a que ela se refere? } \\
\text { Preparadas para falar O QUE? O QUE elas devem falar? } \\
\text { Para quem? Como? }\end{array}$ \\
\hline
\end{tabular}




\begin{tabular}{|c|c|c|}
\hline $\begin{array}{l}\text { Transcrição E1 } \\
\text { revisada_para } \\
\text { maxqda }\end{array}$ & Microanálise 69 & $\begin{array}{l}\text { Eles ficam desconfortáveis com o que? } \\
\text { Com a dor do outro? } \\
\text { Com o suicídio? } \\
\text { Com a morte? } \\
\text { Com não saberem o que falar? } \\
\text { Quais as causas desse desconforto? } \\
\text { Como o outro pode demostrar se for dor? }\end{array}$ \\
\hline $\begin{array}{l}\text { Transcrição E1 } \\
\text { revisada_para } \\
\text { maxqda }\end{array}$ & $x^{2}$ & $\begin{array}{l}\text { Resolvi parar de encanar com a quantidade de códigos e deixar fluir. Passei horas } \\
\text { do dia de hoje querendo ter certeza ue esta a fazendo certo. } \\
\text { Paragrafo } 196 \text { e } 353 \text { códigos??? Afeee } \\
\text { Escrevo para Mariana para saber se estou no caminho certo e pesquiso vários } \\
\text { sites para ver exemplos de open coding e ver se estou fazendo certo, neste ponto } \\
\text { estou com muito medo de errar e codificar errado. } \\
\text { Além de me preocupar com o tempo que tenho disponível. } \\
\text { Vejo alguns exemplos e abro alguns sites, percebo que é por aí, mas porque } \\
\text { ninguém coloca o numero inicial de códigos... } \\
\text { Mariana me responde no Whatts e diz que é assim mesmo, que isso é normal e } \\
\text { que depois vou acabar renomeando muitos deles. } \\
\text { Ainda estou apreensiva com essa forma de codificação. } \\
\text { Medo de não gerar uma teoria coerente } \\
\text { Fazer desta forma esta me ajudando a não interpretar logo de cara pois me } \\
\text { preocupo se minha experiência pode prejudicar a analise dos dados iniciais. Quero } \\
\text { deixar que os dados falem comigo e não ficar procurando o que acho que já sei } \\
\text { que vou encontrar. Esse é um dilema importante. Sei que minha experiência será } \\
\text { importante em algum momento, mas não quero que ela seja impeditiva. } \\
\text { Resolvi deixar essa nota verdinha para todas de diário pessoal.. ainda não sei o } \\
\text { que farei com isso, mas ajuda escrever durante esse processo. }\end{array}$ \\
\hline $\begin{array}{l}\text { Transcrição E1 } \\
\text { revisada_para } \\
\text { maxqda }\end{array}$ & Microanálise 72 - nota maria Júlia & $\begin{array}{l}\text { Nota da Maria Julia em julho de } 2018 \\
\text { Histórias pessoais tem mais amplitude e aderência e interesse dos outros do que } \\
\text { informações gerais... há mais comoção ou reação quando a historia é pessoal }\end{array}$ \\
\hline $\begin{array}{l}\text { Transcrição E1 } \\
\text { revisada_para } \\
\text { maxqda }\end{array}$ & Microanálise 73 & $\begin{array}{l}\text { O que o chefe esperava? Postagens de tristezas? } \\
\text { Se estou triste e em luto não posso ter momentos felizes nem postar isso? } \\
\text { Penso na visão das pessoas sobre o luto, como deve ser, a figura cultural do } \\
\text { enlutado. }\end{array}$ \\
\hline $\begin{array}{l}\text { Transcrição E1 } \\
\text { revisada_para } \\
\text { maxqda }\end{array}$ & Microanálise 74 & $\begin{array}{l}\text { Novamente isso me lembra das aulas de psiquiatria social. } \\
\text { VER A TESE sobre a fala dos médicos sobre o suicídio (dissertação da ou da } \\
\text { giovanna?) } \\
\text { Como o suicídio é tratado na formação do medico e do enfermeiro? } \\
\text { E na psiquiatria? }\end{array}$ \\
\hline $\begin{array}{l}\text { Transcrição E1 } \\
\text { revisada_para } \\
\text { maxqda }\end{array}$ & Microanálise 76 & $\begin{array}{l}\text { Como conscientizar: } \\
\text { Pela depressão e transtornos psiquiátricos }\end{array}$ \\
\hline
\end{tabular}

Material integrante da pesquisa de doutorado de Karen Scavacini Proibida a reprodução ou utilização sem autorização prévia do autor - 2018 


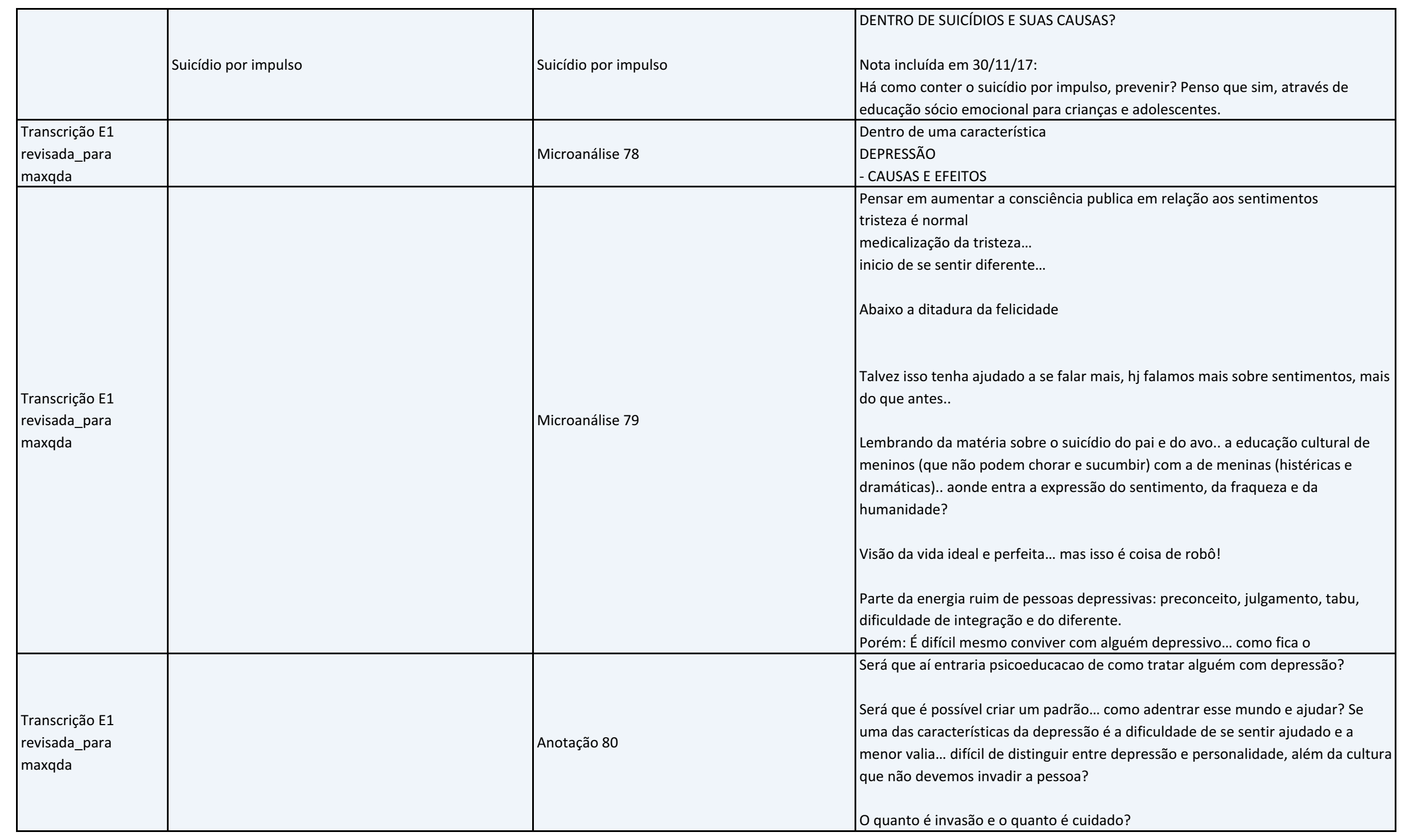




\begin{tabular}{|c|c|c|c|}
\hline $\begin{array}{l}\text { Transcrição E1 } \\
\text { revisada_para } \\
\text { maxqda }\end{array}$ & & Diário pessoal 27/10 & $\begin{array}{l}\text { Paro um pouco e vou pesquisar sobre depressão no pinterest, na esperança de } \\
\text { achar alguma imagem que explique o que está sendo falado, mas acabo me } \\
\text { sentindo mais preocupada e pensando como pode ser possivel ajudar alguém } \\
\text { assim, acabo entrando em consonância com as imagens (transferência) e começo } \\
\text { a me sentir de mãos atadas, impotente. } \\
\text { Penso em como podemos adentrar esse mundo... } \\
\text { E se precisamos falar mais sobre suicídio, precisamos falar mais sobre depressão, } \\
\text { mas não podemos pensar só na parte médica da coisa. Fico pensando nas classes } \\
\text { sociais ena permissão de deprimir... }\end{array}$ \\
\hline \multirow[t]{4}{*}{$\begin{array}{l}\text { Transcrição E1 } \\
\text { revisada_para } \\
\text { maxqda }\end{array}$} & & Microanálise 82 & $\begin{array}{l}\text { Fico pensando no livre arbítrio, no direito que as pessoas tem de não querer ajuda } \\
\text { profissional. } \\
\text { Ou será que elas sentem necessidade de ver um profissional } \\
\text { penso no estigma de ir ao psiquiatra, ao medico de louco } \\
\text { penso na historia da psiquiatria e no medo das pessoas com manicômios } \\
\text { louco é aquele que perde a liberdade e a si mesmo } \\
\text { penso nas tarjas pretas e no aviso de vicio } \\
\text { Será que as novas geraçães veem o psiquiatra da mesma forma que os mais } \\
\text { velhos, que conviveram com os manicômios } \\
\text { Aí tem vários tabus envolvidos: } \\
\text { - o da depressão (ser fraco, covarde, falar de amor a deus) } \\
\text { - o dos remédios psiquiátricos } \\
\text { - o da psicologia (vou ter que pagar para alguém me atender?) } \\
\text { - psicólogo é coisa de rico e psiquiatra é coisa de louco } \\
\text { - de perder a liberdade e ser internado } \\
\text { É engraçado pensar que as pessoas internadas por outras causas também sofrem } \\
\text { a privação da liberdade nos hospitais, quando estão doentes, também ficam lá e } \\
\text { são obrigadas a tomarem remédios que tem efeitos colaterais tb. Talvez ainda } \\
\text { haja no imaginário popular a loucura e os manicômios. Mas, pensando friamente, } \\
\text { como são as alas psiquiátricas e hospitais psiquítricos há, será que são tão } \\
\text { diferentes dos de antigamente, principalmente na rede publica. } \\
\text { O psiquiatra como aquele que pode decidir sobre dopar ou não uma pessoa, fazer } \\
\text { procedimentos invasivos, internar e privar do contato com a familia. } \\
\text { Faltou perguntar como eles acham que a sociedade vê os psiquiatras, a psiquiatria } \\
\text { e os remédios. } \\
\text { Depressão é doença?????? }\end{array}$ \\
\hline & Nem tudo é depressão & Nem tudo é depressão & Banalização da depressão \\
\hline & Complexidade dos sentimentos & Complexidade dos sentimentos & E sua evolução \\
\hline & A identificação do grupo de pertencimento & A identificação do grupo de pertencimento & Sentindo-se despertencido \\
\hline
\end{tabular}




\begin{tabular}{|c|c|c|}
\hline $\begin{array}{l}\text { Transcrição E1 } \\
\text { revisada_para } \\
\text { maxqda }\end{array}$ & Microanálise 86 & $\begin{array}{l}\text { Como poderíamos passar uma mensagem de que a vida tem coisas ruins e isso faz } \\
\text { parte, que tem pessoas que passaram por mais ou menos coisas ruins e isso } \\
\text { influencia como ela é hoje. } \\
\text { Cada um tem uma história, de traumas, medos, superações.. nem todos vão reagir } \\
\text { da mesma maneira as situações. } \\
\text { Uns mudam o jeito de andar, outros se matam. } \\
\text { Essa complexidade do humano e da vida refletem a complexidade do suicídio. } \\
\text { Como explicar de uma maneira simples algo complexo? } \\
\text { Me lembrei da propaganda da NIIKE, em que a pessoa corre e vão caindo dela as } \\
\text { cobranças, irritações, etc.. } \\
\text { Me vem a imagem de uma árvore, que é constituída de muitos galhos, e isso faz } \\
\text { com que ela seja como é. } \\
\text { Primeiro o respeito a singularidade e assim as historias e as cicatrizes que ficam. } \\
\text { Mas como podemos falar sobre isso? Talvez na escola? } \\
\text { Lembro das religiões e suas formas exclusivas, de exclusão. }\end{array}$ \\
\hline
\end{tabular}




\begin{tabular}{|c|c|c|}
\hline $\begin{array}{l}\text { Transcrição E1 } \\
\text { revisada_para } \\
\text { maxqda }\end{array}$ & Microanálise 87 & $\begin{array}{l}\text { Será que precisamos encontrar grupos de iguais? Para pertencer? } \\
\text { Por exemplo: um grupo de adolescentes religiosas virgens x adolescentes grávidas } \\
\text { de estupro. } \\
\text { Onde encontro os meus pares? } \\
\text { Quais seriam os grupos/pares do suicídio? } \\
\text { Quem são essas pessoas que preciso me dirigir? } \\
\text { Qual é o meu público? O que os toca? O que os motiva? O que se torna um gatilho } \\
\text { emocional? } \\
\text { Será que pessoas em depressão conseguem se ajudar, já que cada um está tão } \\
\text { imerso em seu mundo de dor. } \\
\text { Penso nos grupos de apoio de diversas doenças, seria da mesma maneira? } \\
\text { Preciso pesquisar sobre grupos de apoio a pessoas que tentaram e depressivos. } \\
\text { Eles existem? Onde? Seriam esses grupos virtuais agora? se sim, o virtual é uma } \\
\text { boa forma de comunicação. } \\
\text { Precisamos falar mais sobre o assunto.. para que? Como? } \\
\text { Pensa no câncer... na prevenção do câncer... não se fala só de câncer, tem câncer } \\
\text { de mama, próstata, cada um com a sua campanha, pois são diferentes grupos, } \\
\text { idades e formas de falar. Isso talvez também se aplique ao suicídio. } \\
\text { Em quais lugares se fala sobre o câncer? } \\
\text { Como foi o iníío das campanhas de educação sexual? O sexo talvez foi um tabu } \\
\text { como a morte e o suicídio, pois câncer é doença e se origina "passivamente", } \\
\text { cometer suicídio ou praticar sexo está implíito o ato, a ação. Eaí pode estar uma } \\
\text { bela confusão!! } \\
\text { Se pensarmos no ato de se matar como "consciente" como o ato sexual fica } \\
\text { complicado. Precisamos repensar a aORMA de falar sobre o suicídio. Ele NÃO é } \\
\text { um ato consciente, e sim um ato intencional. } \\
\text { Para mim, não existe CONSCIÊNCIA livre com depressão, com dor, com desespero. } \\
\text { Como a } \\
\text { Como a depressão pode se vista como uma doença qualquer? }\end{array}$ \\
\hline $\begin{array}{l}\text { Transcrição E1 } \\
\text { revisada_para } \\
\text { maxqda }\end{array}$ & Microanálise 88 & $\begin{array}{l}\text { Aumentar a consciência também a partir dos grupos } \\
\text { a consciência de quem sofre e que não esta sozinho } \\
\text { a possibilidade de falar abertamente e ser acolhido } \\
\text { um grupo de pares } \\
\text { Fantasia de que se ele soubesse sobre grupos, talvez se sentisse melhor e não se } \\
\text { matasse. } \\
\text { vínculo criado nos grupos e o poder do acolhimento e do pertencimento } \\
\text { Divulgar os grupos (as pessoas saberem que existe) } \\
\text { Capacitar os profissionais para isso } \\
\text { e } \\
\text { empoderar os sobreviventes para eles tocarem grupos, mas será que eles } \\
\text { tocariam grupos de tentativas, talvez isso seja muito complicado... }\end{array}$ \\
\hline
\end{tabular}

Material integrante da pesquisa de doutorado de Karen Scavacini Proibida a reprodução ou utilização sem autorização prévia do autor - 2018 


\begin{tabular}{|c|c|c|c|}
\hline $\begin{array}{l}\text { Transcrição E1 } \\
\text { revisada_para } \\
\text { maxqda }\end{array}$ & & Microanálise 89 & $\begin{array}{l}\text { Refletindo sobre a saturação teórica, não sei se concordo tanto com ela, acho que } \\
\text { o ser humano sempre vai trazer facetas novas, penso na saturação do tempo e da } \\
\text { disponibilidade do pesquisador. } \\
\text { Agora saturar o humano e suas atitudes, pensamentos.. nossa! }\end{array}$ \\
\hline $\begin{array}{l}\text { Transcrição E1 } \\
\text { revisada_para } \\
\text { maxqda }\end{array}$ & & Microanálise 90 & Tipos de reportagens, descritivas, explicativas, sentimentais... \\
\hline $\begin{array}{l}\text { Transcrição E1 } \\
\text { revisada_para } \\
\text { maxqda }\end{array}$ & & Microanálise 91 & $\begin{array}{l}\text { As reportagens são sazonais? } \\
\text { Existem reportagens sobre suicídio que não seja vinculada a nenhuma morte ou } \\
\text { caso, que seja somente explicativa. } \\
\text { Buscar aula do Atílio sobre reportagens de suicídio - suicídio e mídia } \\
\text { Pensar no dossiê suicídio da nova s/b } \\
\text { Toda essa parte de reportagens pode entrar numa categoria : MíDIA } \\
\text { Nota incluída em 30/11/17: } \\
\text { Não foi o Atílio que falou, e sim um jornalista neste mesmo evento no ES. } \\
\text { Consegui os slides. }\end{array}$ \\
\hline $\begin{array}{l}\text { Transcrição E1 } \\
\text { revisada_para } \\
\text { maxqda }\end{array}$ & & Diário pessoal 27/10/17 & $\begin{array}{l}\text { Aqui, a minha ansiedade em perguntar tudo que eu havia programado atrapalhou } \\
\text { o andamento da conversa. } \\
\text { Pelo menos fico com essa sensação. }\end{array}$ \\
\hline & Acreditando que o suicídio é a maior causa de morte & Acreditando que o suicídio é a maior causa de mo & Será??? Mesmo??? \\
\hline $\begin{array}{l}\text { Transcrição E1 } \\
\text { revisada_para } \\
\text { maxqda }\end{array}$ & & Microanálise 94 & $\begin{array}{l}\text { Porque ele quer acreditar nisso? } \\
\text { Isso o ajuda de que forma? }\end{array}$ \\
\hline & Falar abertamente como prevenção & Falar abertamente como prevenção & Para quem passa e para quem lida \\
\hline $\begin{array}{l}\text { Transcrição E1 } \\
\text { revisada_para } \\
\text { maxqda }\end{array}$ & & Microanálise 96 & $\begin{array}{l}\text { Como as outras campanhas lidaram com a paranoia? } \\
\text { Paranoia de não pensar nisso o tempo todo. } \\
\text { Informar sem pirar kkkkkk }\end{array}$ \\
\hline $\begin{array}{l}\text { Transcrição E1 } \\
\text { revisada_para } \\
\text { maxqda }\end{array}$ & & Microanálise 98 & $\begin{array}{l}\text { O poder da comunicação do cotidiano } \\
\text { Do ser visto e ouvido, em tudo... } \\
\text { Vai criando uma barreira com o mundo e com os outros. } \\
\text { Nos expressamos através do cotidiano? } \\
\text { Tirar a pressão da panela } \\
\text { Como falar - criando espaços para conversar e falar do cotidiano - das pessoas } \\
\text { falarem do seu dia a dia e das pequenas dores e frustrações } \\
\text { Discussao - isso tem acontecido pelas redes sociais.. }\end{array}$ \\
\hline & Já se fala mais de suicídio hoje & Já se fala mais de suicídio hoje & Hoje $x$ antigamente \\
\hline
\end{tabular}




\begin{tabular}{|c|c|c|c|}
\hline $\begin{array}{l}\text { Transcrição E1 } \\
\text { revisada_para } \\
\text { maxqda }\end{array}$ & & Microanálise 100 & $\begin{array}{l}\text { Isso é importante... } \\
\text { Onde que se fala hoje? } \\
\text { Em grupos fechados... em algumas faculdades, no grupo dos enlutados... }\end{array}$ \\
\hline \multirow[t]{2}{*}{$\begin{array}{l}\text { Transcrição E1 } \\
\text { revisada_para } \\
\text { maxqda }\end{array}$} & & Microanálise 101 & $\begin{array}{l}\text { Quem mais vê e se interessa? } \\
\text { Ou lhes chama a atenção porque passaram? } \\
\text { Sim, hoje já se fala mais ou já se fala de outra forma. } \\
\text { Ou eles acham que fala mais porque eles prestam atenção e antes não } \\
\text { prestavam? } \\
\text { Ver minha pesquisa sobre citações sobre suicídio na mídia (fiz isso na base de }\end{array}$ \\
\hline & Mídia incluindo os sobreviventes & Mídia incluindo os sobreviventes & $\begin{array}{l}\text { Antes nem se pensava neles... talvez para julgar ou para achar culpado.. agora } \\
\text { começou a falar na dor de quem fica. }\end{array}$ \\
\hline $\begin{array}{l}\text { Transcrição E1 } \\
\text { revisada_para } \\
\text { maxqda }\end{array}$ & & Microanálise 103 & $\begin{array}{l}\text { Sera que ao procurarem suicidio no google eles nao acabem resolvendo fazer } \\
\text { porque encontram mais instruções praticas do que como procurar ajuda? } \\
\text { Será que o fato de estarem tão perdidos e sem saída escolhem pela saída que } \\
\text { encontram. } \\
\text { Porque não é fácil achar onde tem ajuda e receber essa ajuda } \\
\text { Os entraves de receber ajuda são maiores do que os de tentar e cometer o } \\
\text { suicídio } \\
\text { No desespero, não se procura a saída mais rápida. } \\
\text { Então as campanhas precisam trazer informações, instruções praticas de onde } \\
\text { buscar ajuda. } \\
\text { Tudo no mesmo lugar. } \\
\text { Facilitar o acesso a informação de onde achar ajuda. Com o passo a passo!! Com } \\
\text { os telefones e os lugares. } \\
\text { Comparando rapidez de se matar e rapidez de marcar consulta, tomar remédio, } \\
\text { remédio fazer efeito, terapia fazer efeito. O quanto eles conseguem suportar a } \\
\text { dor? } \\
\text { E penso na vergonha de falar que pensam em se matar, pois há uma banalização } \\
\text { da dor do outro. Vergonha de um adolescente em falar que quer se matar por } \\
\text { uma garota, por uma nota baixa. Medos de serem insuficientes e a visão que o } \\
\text { mundo estaria melhor sem ele. A visão do alivio da dor. } \\
\text { Precisamos de centros de atendimento na crise! Lembro dos centros do CVV em } \\
\text { Londres, onde as pessoas ficam hospedadas uma semana. } \\
\text { Como a vida pode ser resgatada? O que pode trazer a esperança? } \\
\text { Talvez as campanhas possam falar em esperança e em outras saídas. } \\
\text { Fico pensando no que pode ter passado na cabeça das pessoas que se matam }\end{array}$ \\
\hline
\end{tabular}




\begin{tabular}{|c|c|c|c|}
\hline $\begin{array}{l}\text { Transcrição E1 } \\
\text { revisada_para } \\
\text { maxqda }\end{array}$ & & Microanálise 104 & $\begin{array}{l}\text { A achicur traaae ae ter atenalmento algno e omeao ao que poae encontrar alliculta } \\
\text { Precisamos falar mais, mas também das formas de tratamento, dos lugares, do } \\
\text { que acontece num psiquiatra, do que acontece numa clinica de repouso? } \\
\text { A pessoa não se mata, pede ajuda e a vida dela acaba? Acaba porque vai ser } \\
\text { estigmatizada, julgada, talvez privada da liberdade. Vai gastar boa parte do que } \\
\text { tem ou se endividar por causa de tratamento. } \\
\text { Ela é vista como doente incapaz? } \\
\text { Como é vista pela sociedade a pessoa que fala em cometer suicídio ou sobrevive a } \\
\text { uma tentativa. } \\
\text { Temos grande necessidade de empoderar essas pessoas. } \\
\text { Porque tratamos diferente pessoas com câncer, aids e suicidas. } \\
\text { Será a imprevisibilidade do ato? } \\
\text { Será o medo da responsabilidade? Da culpa? } \\
\text { Sabemos que uma tentativa aumenta o risco. E porque isso acontece? } \\
\text { Será que parte disso não é por lidar com o tabu, com o julgamento, com a falta de } \\
\text { atendimento? } \\
\text { Porque o atendimento não vem porque ela tentou! Muitas vezes são maltratados } \\
\text { nos hospitais e colocados de volta na mesma situação, não foi lhe dada outra } \\
\text { saída, o grito de socorro não foi ouvido, ele foi punido! } \\
\text { Qual é o tratamento para ideação ou comportamento suicida? Existe um } \\
\text { protocolo? Ou somente protocolo de segurança ambiental? } \\
\text { Posso até pensar em estratégias que as pessoas que tentaram e estão bem } \\
\text { tiveram. Procurar programas internacionais de atendimentos a pessoas com } \\
\text { tentativas de suicídio. }\end{array}$ \\
\hline \multirow[t]{3}{*}{$\begin{array}{l}\text { Transcrição E1 } \\
\text { revisada_para } \\
\text { maxqda }\end{array}$} & & Microanálise 105 & $\begin{array}{l}\text { Quem fiscaliza essas clinicas e o que acontece lá? } \\
\text { Lembrei da reportagem da mulher que se internou } 10 \text { dias em um manicômio de } \\
\text { Londres, e se não tivesse ninguém para tirar ela de lá? } \\
\text { Será que isso ainda não acontece? } \\
\text { Sinto uma fadiga do cuidador, pois não acha tratamento adequado, se acha uma } \\
\text { clinica boa, não pode pagar. O cuidador também se vê sem saída! }\end{array}$ \\
\hline & Suicídio como problema de todos & Suicídio como problema de todos & $\begin{array}{l}\text { O suicídio é problema nosso! } \\
\text { Meu, seu, dele! } \\
\text { SLOGAN? }\end{array}$ \\
\hline & Normalizar o suicídio & Normalizar o suicídio & $\begin{array}{l}\text { O suicídio pode acontecer com todos } \\
\text { Se acontece com todos também pode acontecer comigo, e posso ter solução, } \\
\text { afinal isso é do humano. } \\
\text { Normalizar com é o sexo }\end{array}$ \\
\hline
\end{tabular}

Material integrante da pesquisa de doutorado de Karen Scavacini Proibida a reprodução ou utilização sem autorização prévia do autor -2018 


\begin{tabular}{|c|c|c|c|}
\hline $\begin{array}{l}\text { Transcrição E1 } \\
\text { revisada_para } \\
\text { maxqda }\end{array}$ & & Microanálise 108 & $\begin{array}{l}\text { Normalizar para aproximar. } \\
\text { É algo perto, pode estar ao seu lado... } \\
\text { Não é algo de loucos! Não dá para ver na cara! } \\
\text { Lembro da reportagem sobre as fotos das pessoas com depressão felizes e tristes. } \\
\text { Não dá para saber se não perguntar. } \\
\text { Você já imaginou que seu amigo pode estar pensando em se matar. É mais } \\
\text { comum do que se pensa. }\end{array}$ \\
\hline & Relatos de sobreviventes de tentativas & Relatos de sobreviventes de tentativas & Colocando voz ao tabu, dando rosto ao fenômeno, humanizando o absurdo \\
\hline & Insensibilidade da empresa com o luto & Insensibilidade da empresa com o luto & Linkar com o ser mandada embora \\
\hline $\begin{array}{l}\text { Transcrição E1 } \\
\text { revisada_para } \\
\text { maxqda }\end{array}$ & & Microanálise 111 & $\begin{array}{l}\text { Só se interessa quem foi atrás ou passou pelo problema } \\
\text { A faculdade não desperta nos alunos a importância e a curiosidade } \\
\text { Ou será que os alunos estão tão atarefados com outras coisas que não percebem } \\
\text { Falta um aumento de consciência nos alunos e isso só pode ser provido pelas } \\
\text { universidades } \\
\text { Apos o aumento de suicídios entre universitários isso pode mudar } \\
\text { O suicídio GRITA por resolução, ele escancara a falta de atenção e empatia. } \\
\text { A faculdade não coloca a prevenção do suicídio como um problema de todos. } \\
\text { Eu tenho a fantasia que ao sensibilizar estudantes poderíamos ter médicos e } \\
\text { profissionais da área da saúde e educação mais atentos a isso, mais empáticos a } \\
\text { essa dor. } \\
\text { A faculdade não ensina isso... quem deveria ensinar? Nossa, hoje precisamos } \\
\text { ensinar isso! }\end{array}$ \\
\hline $\begin{array}{l}\text { Transcrição E1 } \\
\text { revisada_para } \\
\text { maxqda }\end{array}$ & & Diário Pessoal 29/10/17 & $\begin{array}{l}\text { Durante a line by line coding passei um bom tempo pesquisando sobre grounded } \\
\text { para ver se estava fazendo certo. Senti muita falta de ter mais coisas ou } \\
\text { experiência no método. Adoraria ver um focus group transcrito e analisado, para } \\
\text { ver se estava fazendo certo. Conforme a quantidade de codes aumentava, mais } \\
\text { aumentava minha insegurança se estava fazendo certo. } \\
\text { No dia } 29 / 10 \text {, ao procurar novamente sobre os codins, pois imprimi os } 831 \\
\text { códigos e coloquei no chão e comecei a analisar, vi que conseguiria fazer com que } \\
\text { eles fizessem sentido, haveria ligação entre tudo. Fiquei tão preocupada em me } \\
\text { perder na metodologia e deixar passar coisas importantes. } \\
\text { A insegurança no método prejudicou no inicio, mas as teorias que começam a se } \\
\text { formar na minha cabeça são muito importantes, sinto que elas são um mix das } \\
\text { minhas experiências, afinal não consigo separar as duas coisas, mas tem uma } \\
\text { parte baseada nos dados. Ou os próprios dados me dão um insight da teoria, e } \\
\text { como parece um pensamento tão natural, fico achando que é meu... mas acho } \\
\text { que eles são a união da reflexão com a codificação. } \\
\text { Estou muito feliz com a escolha do método, do tema e empolgada com os achados } \\
\text { iniciais. } \\
\text { Percebo pelas leituras da grounded que já estou fazendo a open coding, e isso me } \\
\text { acalma. A axial coding pode acontecer ao mesmo tempo... não devo suprimir } \\
\text { nenhum pensamento, mas transforma-lo em dados ;) }\end{array}$ \\
\hline
\end{tabular}

Material integrante da pesquisa de doutorado de Karen Scavacini Proibida a reprodução ou utilização sem autorização prévia do autor -2018 


\begin{tabular}{|c|c|c|}
\hline $\begin{array}{l}\text { Transcrição E2 } \\
\text { revisada }\end{array}$ & Primeira leitura grupo 2 & $\begin{array}{l}\text { Como fazer com que as pessoas não impactadas deem atenção ao tema? } \\
\text { Discussão do conceito "ato consciente" para "ato intencional", pois não acho que } \\
\text { podemos dizer que há consciência com depressão. A pessoa não sente nem ela } \\
\text { nem ao mundo externo direito, fica com pensamento constrito... isso não é } \\
\text { consciência! } \\
\text { Mostrar que todas as pessoas conhecem alguém ou algum caso de suicídio! } \\
\text { Suicídio não está no rosto, não dá para prever (ex Robin Willians) } \\
\text { A informação chega sem procurar, mas quem dá atenção a ela? } \\
\text { Mas será que na aids e câncer as pessoas começaram a dar atenção porque } \\
\text { muitas pessoas passaram ou porque houveram muitas campanhas e as pessoas } \\
\text { perceberam que PODERIA Acontecer COMIGO OU ALGUÉM PRÓxIMO e isso } \\
\text { deixou a questão mais importante? O que fez com que elas se sensibilizassem } \\
\text { para isso? (p.42) Essas campanhas mostram que se eu ou alguém que eu amo não } \\
\text { se cuidarem, podem adoecer e morrer. Elas apelam para o medo, para a } \\
\text { probabilidade de acontecer ou com a esperança de que tem algo que eu posso } \\
\text { fazer a respeito? E hoje as pessoas "assumem" esse câncer para a sociedade } \\
\text { através de campanhas de empatia (os lenços por exemplo). } \\
\text { A importância da mensagem que a mídia passa e as pessoas acreditam (ex Fatima } \\
\text { Bernardes e fantástico). } \\
\text { Porque a mídia aborda o tema? Por causa de famosos ou porque não quer ser a } \\
\text { única a não falar sobre aquele assunto? O que significa o p1 falar que o André }\end{array}$ \\
\hline $\begin{array}{l}\text { Transcrição E2 } \\
\text { revisada }\end{array}$ & Microanálise 188 & $\begin{array}{l}\text { O que ele entende como preocupação de saúde publica? } \\
\text { Ele pensa em ações de saúde pública também? Isso significa que os médicos } \\
\text { tiveram educação para isso... o que ocorreu??? }\end{array}$ \\
\hline $\begin{array}{l}\text { Transcrição E2 } \\
\text { revisada }\end{array}$ & Anotação 189 & Comparar \\
\hline $\begin{array}{l}\text { Transcrição E2 } \\
\text { revisada }\end{array}$ & Microanálise 190 & $\begin{array}{l}\text { Área acadêmica como precursora dos movimentos? Ela que percebe primeiro o } \\
\text { problema? Quem percebe primeiro o problema? Ou ela que traz estudos e }\end{array}$ \\
\hline
\end{tabular}




\begin{tabular}{|c|c|c|c|}
\hline $\begin{array}{l}\text { Transcrição E2 } \\
\text { revisada }\end{array}$ & & Microanálise 191 & $\begin{array}{l}\text { Pensar que ocorreram suicídio sem outras famílias e com famosos, faz que que } \\
\text { eles saiam da casa deles e possam normalizar o suicídio, ver como uma coisa } \\
\text { comum que acontece com todos, inclusive com os famosos, que teoricamente não } \\
\text { tem problemas. Então ao mostrar famosos, mostra que é possível que todos } \\
\text { tenham e que todos achem tratamento. } \\
\text { Lembrei do lúpus da Selena gomes. Quando soube da notícia pensei que nossa, } \\
\text { como isso pode ocorrer com ela, mas poxa, ela é de carne e osso como eu, o que } \\
\text { nos separa? Somos seres humanos e podemos adoecer, qualquer um, assim como } \\
\text { qualquer pessoa pode pensar em suicídio. }\end{array}$ \\
\hline \multirow[t]{4}{*}{$\begin{array}{l}\text { Transcrição E2 } \\
\text { revisada }\end{array}$} & & Microanálise 192 & $\begin{array}{l}\text { Pensei em ver os índices de câncer e de aids antes e depois do inicio das } \\
\text { campanhas. } \\
\text { E o investimento financeiro nessas campanhas.. } \\
\text { Lembrei do dia de awareness que foi feito no congresso americano que eles } \\
\text { mostravam o quanto de dinheiro foi investido em campanhas e pesquisas da aids }\end{array}$ \\
\hline & Assuntos escancarados & Assuntos escancarados & $\begin{array}{l}\text { Diminuição do medo e da vergonha } \\
\text { Luta por causas }\end{array}$ \\
\hline & Aumento da liberdade de expressão & Aumento da liberdade de expressão & E diminuição do preconceito \\
\hline & Há ajuda disponível & Há ajuda disponível & Pela psiquiatria e psicologia \\
\hline
\end{tabular}




\begin{tabular}{|c|c|c|c|}
\hline $\begin{array}{l}\text { Transcrição E2 } \\
\text { revisada }\end{array}$ & & Microanálise 196 & $\begin{array}{l}\text { O câncer tem um rosto, um sinal, a aids também (ou no imaginário popular). } \\
\text { Como se reconhecem as pessoas com ideação suicida? Que rosto elas tem? Que } \\
\text { perfil elas tem. } \\
\text { Penso que muito da aids ainda se transmite por causa de pessoas com rosto } \\
\text { saudável. Talvez as pessoas ainda tenham aquela visão que tinham do aidético de } \\
20 \text { anos atrás. A Aids hoje é vista como uma doença crônica. Fico pensando se ela } \\
\text { ainda está ligada a promiscuidade ou meio burrice de não usar camisinha. } \\
\text { A pessoa em tratamento da câncer, perde o cabelo, tem uma identidade visual e } \\
\text { de grupo de pertencimento, além de estar associado a pessoas que lutam CONTRA } \\
\text { a morte, que querem viver. } \\
\text { Já qual seria a "cara" do suicida? Como podemos prever? Será que esse não saber } \\
\text { faz com que não exista? } \\
\text { Como não está na cara das pessoas que elas um dia pensaram ou até tentaram se } \\
\text { matar, dá a impressão que está bem longe de todos. Só está perto das famílias } \\
\text { problemáticas, e aí entra um julgamento. Se a pessoa pensa em suicídio, se ela } \\
\text { tem depressão, ela tem problema.. mas as pessoas não entendem que parte desse } \\
\text { problema é físico, uma parte é social e uma parte é individual. } \\
\text { Será que com a aids e o câncer também não é assim. Eles não tem as partes dos } \\
\text { hábitos, do autocuidado, do comportamento e julgamento da sociedade? } \\
\text { O câncer me dá uma impressão maior de "não pode ser evitado - foi uma tragédia } \\
\text { que aconteceu - eu não queria". } \\
\text { A aids me dá uma impressão de "aconteceu - a culpa não foi minha - eu não } \\
\text { queria" } \\
\text { Os acidentes de transito é um pouco de "aconteceu - foi passivo (mesmo a pessoa } \\
\text { estivesse correndo) - um ato fora de seu controle". } \\
\text { O suicídio traz consigo a ideia de controle, a pessoa decidiu, pessoa quis, ela } \\
\text { estava no controle, ela estava A FAVOR da morte, buscando a MORTE. } \\
\text { E aí, como as pessoas não falam sobre o assunto, isso faz com que ele não exista. }\end{array}$ \\
\hline \multirow[t]{2}{*}{$\begin{array}{l}\text { Transcrição E2 } \\
\text { revisada }\end{array}$} & & 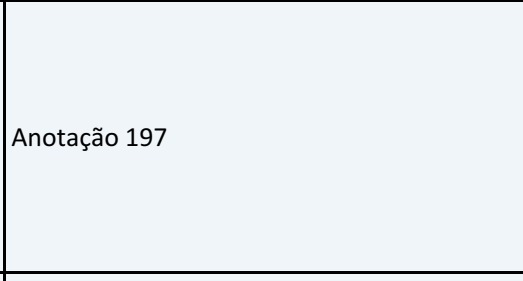 & $\begin{array}{l}\text { Elas podem ser ajudadas, mas ONDE? Isso me tira a paz, pois onde vão achar } \\
\text { ajuda? As empresas vão liberar como liberam alguém com câncer? } \\
\text { Câncer = vítima } \\
\text { Depressão = causador, covarde, fraco } \\
\text { AIDS = inconsequente } \\
\text { Suicida = louco }\end{array}$ \\
\hline & Hoje já se fala em grupos pequenos também & Hoje já se fala em grupos pequenos também & \\
\hline $\begin{array}{l}\text { Transcrição E2 } \\
\text { revisada }\end{array}$ & & Microanálise 199 & $\begin{array}{l}\text { Consciência trazida pela mídia, afeta a consciência individual, e as pessoas se } \\
\text { comunicando mais tornam o assunto mais comum. Porem não falam sobre o } \\
\text { assunto! } \\
\text { Pessoas descobrindo o comum do suicídio, o suicídio como algo mais comum do } \\
\text { que sabiam. } \\
\text { Será que ao trazer isso para mais comum gere mais interesse? Ou preocupação? }\end{array}$ \\
\hline
\end{tabular}

Material integrante da pesquisa de doutorado de Karen Scavacini Proibida a reprodução ou utilização sem autorização prévia do autor - 2018 


\begin{tabular}{|c|c|c|c|}
\hline $\begin{array}{l}\text { Transcrição E2 } \\
\text { revisada }\end{array}$ & & Método 200 & $\begin{array}{l}\text { Será que depôs eu preciso separar o que é causa, efeito, sentimento, reação, } \\
\text { forma de comunicação, impeditivo de comunicação, reação de tabu??? }\end{array}$ \\
\hline $\begin{array}{l}\text { Transcrição E2 } \\
\text { revisada }\end{array}$ & & Anotação 201 & $\begin{array}{l}\text { Para a criança o suicídio é uma forma de morrer, não choca. } \\
\text { Quem se choca é o adulto. } \\
\text { Quando o suicídio de alguém é falado na mesa, o assunto não vira tabu, pode ser } \\
\text { falado abertamente - MASSSS isso não impediu que o irmão dela cometesse } \\
\text { suicídio, então, falar sobre o assunto é uma parte da história. } \\
\text { Olhar a página do Face "Quebrando o tabu" } \\
\text { Como tu acho que a consclencla atetarla, quals sao as IVIIVHAS Tantastas: }\end{array}$ \\
\hline $\begin{array}{l}\text { Transcrição E2 } \\
\text { revisada }\end{array}$ & & Diário pessoal 31/10/17 & $\begin{array}{l}\text { Falando mais diminui o tabu } \\
\text { Diminui o tabu diminui a culpa e o preconceito } \\
\text { Vê como uma parte das pessoas onde e possível ser ajudado } \\
\text { Entendedor mais sabe o que fazer e onde pedir ajuda } \\
\text { Recebe a ajuda } \\
\text { EU ACREDITO que falar ajuda, falar faz diferença, que a fala é uma forma de } \\
\text { "cura”. } \\
\text { As pessoas podendo falar sobre seus sentimentos, podem receber a ajuda que } \\
\text { procuram. } \\
\text { Mas é mais do que falar sobre sentimentos, conforme um dos participantes } \\
\text { colocou, é falar sobre tudo sobre a vida. } \\
\text { Para mim falar é EXISTIR. } \\
\text { Ao existir eu posso fazer muitas coisas. } \\
\text { O caminho da recuperação é muitas vezes LONGO acho que isso é uma parte } \\
\text { importam-te que precisa ser falada (embora não tenha aparecido tão } \\
\text { abertamente isso na pesquisa, formo essa ideia ao analisar os dados, mesmo que } \\
\text { não contenha nada explicito sobre isso). } \\
\text { Quanto mais adoecido (em todas as relações, sociais, familiares, físicas, } \\
\text { psicológicas), mais longo o caminho. } \\
\text { “Mas já tomei remédio e não funcionou. Antidepressivo não é antitérmico”!! } \\
\text { P31 E2 } \\
\text { As pessoas ficam tão angustiadas com o NÃO saber, elas precisam saber tudo } \\
\text { hoje, não tem tempo para a descoberta, para a experimentação, para o tempo do } \\
\text { efeito dos remédios. Estaríamos com uma fratura no TEMPO? e no não saber? }\end{array}$ \\
\hline & Descobrindo o suicídio como próximo & Descobrindo o suicídio como próximo & 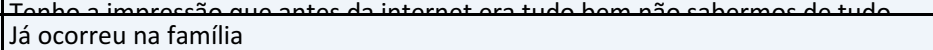 \\
\hline
\end{tabular}




\begin{tabular}{|c|c|c|c|}
\hline $\begin{array}{l}\text { Transcrição E2 } \\
\text { revisada }\end{array}$ & & Microanálise 204 & $\begin{array}{l}\text { Fico pensando numa campanha: } \\
\text { Você já parou para pensar quantas pessoas perto ou longe você conhece ou ouviu } \\
\text { falar que cometeram o suicídio. Ficou impressionado? O suicídio está mais perto } \\
\text { de nós do que pensamos, e atinge mais pessoas que sabemos. E porque ninguém } \\
\text { fala sobre isso? São seja mais um. Vamos falar abertamente sobre o assunto. } \\
\end{array}$ \\
\hline & Sentindo menos desconforto em falar sobre o assunto & Sentindo menos desconforto em falar sobre $\mathrm{o}$ ass & Porque hoje as pessoas falam mais \\
\hline & Porque estamos falando mais & Porque estamos falando mais & $\begin{array}{l}\text { Mais casos? } \\
\text { ou } \\
\text { Porque passaram dão atenção. }\end{array}$ \\
\hline & A visão do suicídio para a criança & A visão do suicídio para a criança & E a diferença da visão do adulto \\
\hline $\begin{array}{l}\text { Transcrição E2 } \\
\text { revisada }\end{array}$ & & Anotação 208 & Pelo número de casos ou pela empatia? \\
\hline \multirow[t]{3}{*}{$\begin{array}{l}\text { Transcrição E2 } \\
\text { revisada }\end{array}$} & & Microanálise 209 & $\begin{array}{l}\text { O que faz as pessoas se preocuparem? } \\
\text { O que faz com que elas se importem com o assunto? } \\
\text { O que faz com que aquilo tenha sentido para elas? } \\
\text { Como os publicitários fazem isso? Precisaríamos pensar em técnicas publicitárias? } \\
\text { Se mobiliza como? Pela proximidade, experiência, medo??? } \\
\text { Google : Como mobilizar pessoas } \\
5 \text { passos para mobilizar milhares de pessoas | Endeavor Brasil } \\
\text { O que Líderes e Facilitadores precisam saber para mobilizar as } \\
\text {...http://observatorio3setor.org.br/carrossel/como-mobilizar-pessoas-e-recursos- } \\
\text { pelas-causas-sociais/ }\end{array}$ \\
\hline & Formação acadêmica & Formação acadêmica & Ajudando a falar mais \\
\hline & Não é um tema como outro qualquer & Não é um tema como outro qualquer & $\begin{array}{l}\text { Que as pessoas vão ficar falando. } \\
\text { Porque não??? } \\
\text { Porque não pode ser um assunto como outro qualquer? Quais assuntos as pessoas } \\
\text { tratam em conversas? }\end{array}$ \\
\hline
\end{tabular}




\begin{tabular}{|c|c|c|c|}
\hline \multirow[t]{4}{*}{$\begin{array}{l}\text { Transcrição E2 } \\
\text { revisada }\end{array}$} & & Microanálise 212 & $\begin{array}{l}\text { Tento pensar quais que acontecem nas minhas rodas de conversas com amigos. } \\
\text { Quando são da área psi até podemos falar sobre suicídio, mas no contexto de } \\
\text { alguém querer contar um caso, alguém querendo uma sugestão, já que eu } \\
\text { trabalho sobre o assunto, alguém com alguma dúvida. Eu mesma, quando começo } \\
\text { a falar muito sobre o assunto, fico me preocupando se a pessoa está gostando ou } \\
\text { não, afinal eu sempre trago esse assunto em pauta com as amigas. } \\
\text { Quando são pessoas de áreas distintas, conversa-se sobre as notícias do jornal, } \\
\text { trivialidades, alguma história sobre alguém, piadas, sobre o tempo, planos para o } \\
\text { futuro (como viagens), coisas em comuns (como filhos e escola), as vezes alguém } \\
\text { fala de algum médico que foi e gostou, fala-se sobre comidas. As conversas não } \\
\text { são profundas. Como eu estudo o assunto, algumas pessoas vem tirar dúvidas ou } \\
\text { trazem curiosidades sobre o assunto, também escuto sobre casos que eles } \\
\text { ouviram e querem minha opinião sobre o que aconteceu. Se alguém do grupo } \\
\text { teve depressão ou já tomou remédio ou fez terapia acaba me contando, mas } \\
\text { porque eu trabalho com isso. } \\
\text { A maioria das pessoas falam que não sabiam sobre os números ou nunca tinham } \\
\text { falado sobre isso, sempre falam da importância de falarem sobre o assunto, mas é } \\
\text { um assunto no qual não se toca usualmente. } \\
\text { A partir disso posso pensar que séries e jornais, propagandas, campanhas nas } \\
\text { redes sociais podem sim mobilizar as conversas. Não sei o quanto essas conversas } \\
\text { ficam nas trivialidades ou se aprofundam. O que me parece é que só há um } \\
\text { interesse pelo tema quando ele se torna mais real ou mais próximo. } \\
\text { Me lembrei do encontro de sobreviventes e das estudantes de psicologia que } \\
\text { tiveram tentativas relatarem preconceito dos professores e colegas do curso. } \\
\text { Quando uma delas se abriu para o grupo com a intensão de dizer que ela tinha } \\
\text { tido a experiência e pensado em suicídio, e tinha melhorado, como a professora } \\
\text { farara }\end{array}$ \\
\hline & O que aumentou foi a relevância do tema & O que aumentou foi a relevância do tema & $\begin{array}{l}\text { Não necessariamente os números de suicídios } \\
\text { Aumentou a relevância e a importância do tema }\end{array}$ \\
\hline & A mídia não dá importância de graça & A mídia não dá importância de graça & $\mathrm{O}$ que levou eles a falarem mais sobre o assunto \\
\hline & O suicídio incomoda ao invés de distrair (Gera incomodg & O suicídio incomoda ao invés de distrair & $\begin{array}{l}\text { Como a distração sendo o objetivo de uma novela. Quantas novelas já trouxeram } \\
\text { assuntos tabus e mudaram a visão da sociedade? } \\
\text { Penso: Qual a visão que a mídia interessa que se tenha para o suicídio. }\end{array}$ \\
\hline
\end{tabular}




\begin{tabular}{|c|c|c|c|}
\hline \multirow[t]{2}{*}{$\begin{array}{l}\text { Transcrição E2 } \\
\text { revisada }\end{array}$} & & Microanálise 216 & $\begin{array}{l}\text { O que foi feito a partir de então? } \\
\text { De fato o poder público ter interesse ou é porque a pessoa tem um interesse } \\
\text { pessoal em se engajar. } \\
\text { CATEGORIA POSŚ́VEL : O que motiva o poder público? } \\
\text { O que chama a atenção do poder publico e politico? } \\
\text { O que motiva o interesse social? } \\
\text { O que motiva a pessoa. } \\
\text { Ver o outubro rosa. O que motivou as pessoas a darem tanta importância ao } \\
\text { câncer de mama ao invés de outros canceres. Será que tem envolvimento da } \\
\text { indústria farmacêutica. Quem patrocina essas campanhas? Aí a proporção das } \\
\text { pessoas atingidas. } \\
\text { Sofrimento não tem rosto. Só sabem se você contar. E se vier como boderline isso } \\
\text { vem mascarado. } \\
\text { O suicídio tambem não eh só depressão e bullying, ou da auto mutilação. }\end{array}$ \\
\hline & Quem recebe a informação é quem procura & Quem recebe a informação é quem procura & Mas o paciente fala que a informação não chega nele. \\
\hline $\begin{array}{l}\text { Transcrição E2 } \\
\text { revisada }\end{array}$ & & Microanálise 218 & $\begin{array}{l}\text { Visão: violência e fracasso } \\
\text { Últimas noticias. Campinas e Goiás. } \\
\text { Pegar casos mais impactantes. } \\
\text { Que casos que a TV passa? Casos distorcidos. Justificativas sem que as pessoas } \\
\text { nem saibam o que aconteceu. } \\
\text { Séries que impactam, porque impactam. Porque as pessoas tem tanta resistência } \\
\text { a discutir filmes e series em relação ao suicídio. Como as pessoas resistem a } \\
\text { discutir o tema. Isso é banalizado pela população em geral. } \\
\text { Campanhas do CVV de antigamente. E de como as pessoas reagiam a elas. } \\
\text { Banalizavam aquilo, mas para quem fazia sentido, aquelas brincadeiras }\end{array}$ \\
\hline \multirow[t]{2}{*}{$\begin{array}{l}\text { Transcrição E2 } \\
\text { revisada }\end{array}$} & & Microanálise 219 & $\begin{array}{l}\text { Existe essa confusão do maio amarelo e setembro amarelo. } \\
\text { O outubro rosa levou as pessoas a pensarem em meses. } \\
\text { Onde elas acham? Então não eh fácil de achar? } \\
\text { Se vc não procurar muito vc não acha! } \\
\text { Como isso não fazia parte do universo das pessoas. }\end{array}$ \\
\hline & Figura publica que fala sobre suicídio & Figura publica que fala sobre suicídio & $\begin{array}{l}\text { Mas isso não chega na mídia, como ela chegou a isso, pesquisando. } \\
\text { Porque a própria miia não mostra. } \\
\text { A fantasia que as pesos tem que isso não acontece na casa dos famosos. }\end{array}$ \\
\hline
\end{tabular}




\begin{tabular}{|c|c|c|c|}
\hline $\begin{array}{l}\text { Transcrição E2 } \\
\text { revisada }\end{array}$ & & Microanálise 221 & $\begin{array}{l}\text { Quem fala sobre o tema tem uma cara? } \\
\text { Porque ela nunca imaginou que ele falasse sobre isso? } \\
\text { São falas mais escondidas, só vê quem procura? Porque na tevê é passiva, a tevê } \\
\text { decide o que passa, na internet, muitas vezes a busca é ativa, a pessoa procura o } \\
\text { que quer ver. }\end{array}$ \\
\hline \multirow[t]{4}{*}{$\begin{array}{l}\text { Transcrição E2 } \\
\text { revisada }\end{array}$} & & Microanálise 222 & $\begin{array}{l}\text { Quais seriam as emoç̃̃es com maior estigma? } \\
\text { Será que existe algum estudo sobre isso? } \\
\text { De bate pronto penso que as emoções estigmatizadas são: tristeza, raiva, } \\
\text { saudade, falta, frustração... } \\
\text { Não adianta lançar campanhas em assuntos que são pontos cegos, ninguém vai } \\
\text { prestar atenção, ninguém vai ver. E mesmo se ver, não vai falar... } \\
\text { Existe preconceito na campanha do novembro azul? Já recebi piadas sobre isso. } \\
\text { Como se o homem ao ir ao médico é porque quer o exame de toque. }\end{array}$ \\
\hline & Campanhas não surtem efeito em pontos cegos da socie & Campanhas não surtem efeito em pontos cegos $d$ & Mas por onde começar então? \\
\hline & Pessoas não querendo participar & Pessoas não querendo participar & De grupos de ajuda e nem de falar sobre o assunto \\
\hline & Funcionaria se falasse sobre depressão & Funcionaria se falasse sobre depressão & $\begin{array}{l}\text { Pois a depressão já é mais socialmente aceita } \\
\text { saúde publica por ter mais abrangência no sus? } \\
\text { como - saúde publica - envolvimento do governo... - demonstra a importância - } \\
\text { campanhas periódicas - aproxima da aids e do câncer - com a forma de tratar e } \\
\text { dar seriedade ao assunto.. (não é o que falar, é o como tratar a questão) } \\
\text { através da saúde publica - com o envolvimento do governo.... } \\
\text { Mensagem - saúde publica - é um problema de saúde (não é frescura ou falta de } \\
\text { Deus no coração) }\end{array}$ \\
\hline \multirow[t]{2}{*}{$\begin{array}{l}\text { Transcrição E2 } \\
\text { revisada }\end{array}$} & & Microanálise 226 & CÓDIGO: A Comunicação suicida ou A pessoa precisa falar \\
\hline & Com adolescente é mais possível prevenir & Com adolescente é mais possível prevenir & $\begin{array}{l}\text { Como se ele demostrasse mais, como se fosse mais fácil fazer a prevenção. } \\
\text { Isso é visão sobre o assunto. }\end{array}$ \\
\hline
\end{tabular}




\begin{tabular}{|c|c|c|c|}
\hline $\begin{array}{l}\text { Transcrição E2 } \\
\text { revisada }\end{array}$ & & Microanálise 228 & $\begin{array}{l}\text { Aqui ela levanta uma hipótese de que é mais possível prevenir suicídio em jovens } \\
\text { do que em adultos, pois os adultos camuflam mais. } \\
\text { Não sei se é assim mesmo, preciso pesquisar campanhas entre adultos e jovens e } \\
\text { ver as diferenças. Além de ver os números, se conseguimos tirar essa conclusão } \\
\text { via epidemiologia. } \\
\text { Penso que talvez os jovens vão tentar mais do que os adultos, por conta dos } \\
\text { métodos, e por isso morrem menos, mas não sei se isso é porque houve uma } \\
\text { prevenção ou por causa do método escolhido. } \\
\text { É um bom ponto para se pensar. } \\
\text { Será que quem é mais suscetível a prevenção. Penso na impulsividade do } \\
\text { adolescente x os desafios e cansaços da vida adulta } \\
\end{array}$ \\
\hline \multirow[t]{2}{*}{$\begin{array}{l}\text { Transcrição E2 } \\
\text { revisada }\end{array}$} & & Microanálise 229 & $\begin{array}{l}\text { Aqui ela traz uma noção de processo, como se fosse em níveis, como em jogos, } \\
\text { você vai passando dos níveis. } \\
\text { Como se a tristeza fosse o nível } 1 \text { e o suicídio o nível final. }\end{array}$ \\
\hline & O que me leva a ser engajada no GLBTA & O que me leva a ser engajada no GLBTA & $\begin{array}{l}\text { Tem algo que leva, que motiva, ninguém se engaja do nada, se não tiver algo da } \\
\text { essência, algo que toque ou motive, ou se for obrigado (tipo os chefes) }\end{array}$ \\
\hline \multirow[t]{3}{*}{$\begin{array}{l}\text { Transcrição E2 } \\
\text { revisada }\end{array}$} & & Microanálise 231 & $\begin{array}{l}\text { As campanhas precisam ser feitas só pela mídia?? } \\
\text { Campanha é igual aumento de consciência publica? } \\
\text { Quais são os passos para se aumentar consciência? } \\
\text { Campanhas, educação, terapia... } \\
\text { Quais são os tipos de consciência? } \\
\text { Pública, social, individual, familiar... } \\
\text { Isso é consciência ou cultura, valores? }\end{array}$ \\
\hline & Se engaja quem tem proposito & Se engaja quem tem proposito & Como os jovens \\
\hline & Campanha sendo falada por quem passou & Campanha sendo falada por quem passou & E que mudou a vida depois disso \\
\hline $\begin{array}{l}\text { Transcrição E2 } \\
\text { revisada }\end{array}$ & & Microanálise 234 & $\begin{array}{l}\text { Fico pensando que nesta campanha do transito, tem historia, superação, vida, traz } \\
\text { a pessoa contando... acaba trazendo para o pessoal, para a empatia. } \\
\text { Depois preciso ver essa campanha, prestar atenção nas cores, sons, velocidade, } \\
\text { gráficos.. } \\
\text { Mesmo assim ela mexeu com algumas pessoas do grupo e com outras não. } \\
\text { Será que a personalidade da pessoa tem relação. Essas duas do grupo são muito } \\
\text { empáticas, mas tiveram reações diferentes. }\end{array}$ \\
\hline \multirow[t]{3}{*}{$\begin{array}{l}\text { Transcrição E2 } \\
\text { revisada }\end{array}$} & & Microanálise 235 & CÓDIGO: TRANSTORNOS MENTAIS? \\
\hline & Sentindo que as campanhas falham & Sentindo que as campanhas falham & Se isso não tem a ver comigo \\
\hline & Palestras na empresa & Palestras na empresa & $\begin{array}{l}\text { Mas isso precisa ter ligação com, mesmo sendo falado na empresa as pessoas não } \\
\text { ligam }\end{array}$ \\
\hline $\begin{array}{l}\text { Transcrição E2 } \\
\text { revisada }\end{array}$ & & Microanálise 238 & $\begin{array}{l}\text { Um outro estudo seria da procura de pessoas com ideação suicida nesses serviços } \\
\text { de auxilio ao empregado. }\end{array}$ \\
\hline $\begin{array}{l}\text { Transcrição E2 } \\
\text { revisada }\end{array}$ & & Microanálise 239 & $\begin{array}{l}\text { O que é suficiente para a pessoa ir ver uma campanha e prestar atenção nela? } \\
\text { Fico curiosa de ouvir publicitários }\end{array}$ \\
\hline
\end{tabular}

Material integrante da pesquisa de doutorado de Karen Scavacini Proibida a reprodução ou utilização sem autorização prévia do autor - 2018 


\begin{tabular}{|c|c|c|c|}
\hline $\begin{array}{l}\text { Transcrição E2 } \\
\text { revisada }\end{array}$ & & Microanálise 240 & $\begin{array}{l}\text { Ou será que ninguém iria falar abertamente sobre isso sob o risco de ser julgado } \\
\text { pelos demais? } \\
\text { Quem assumiria isso nesse jeito de brincadeira da empresa. } \\
\text { Precisaria saber se as pessoas brincam com tudo ou só com esse tema. } \\
\text { NOTA METODOLÓGICA: Pois no grupo eu tinha pessoas de varias idades, } \\
\text { profissões e realidades. O grupo representava uma parcela da sociedade. }\end{array}$ \\
\hline & Quem é que vai fazer isso & Quem é que vai fazer isso & $\begin{array}{l}\text { Sentimento de ser longe deles. Nesse sentido humanizar a tristeza pode trazer } \\
\text { mais perto. }\end{array}$ \\
\hline & Trabalhos científicos são um começo & Trabalhos científicos são um começo & Como este aqui \\
\hline $\begin{array}{l}\text { Transcrição E2 } \\
\text { revisada }\end{array}$ & & Diário pessoal 06/11/2017 & $\begin{array}{l}\text { Achei que teria um trabalho que trouxesse um esquema, um final, mas fico com } \\
\text { mais questões que certezas. } \\
\text { Eles me fazem pensar em quantas coisas preciso pensar para aumentar } \\
\text { consciência publica e como tudo isso é complexo e interligado. } \\
\text { Me lembro do preventing suicide da OMS e do esquema para prevenção... o } \\
\text { aumento da awareness é um ponto dentro daquilo tudo. } \\
\text { Fico lembrando do que me fez escrever sobre awareness, pensei primeiro na dor } \\
\text { dos que ficaram e na dificuldade em falarem na sociedade sobre o assunto. NO } \\
\text { preconceito que recebem e no medo de serem julgados. E daí pensei em } \\
\text { aumentar a consciência publica. }\end{array}$ \\
\hline \multirow[t]{3}{*}{$\begin{array}{l}\text { Transcrição E2 } \\
\text { revisada }\end{array}$} & & Mico 244 & A quem interessa o que? \\
\hline & Uso politico de um suicídio & Uso politico de um suicídio & $\begin{array}{l}\text { A quem interessa o que? } \\
\text { Que USO fazem do suicídio? } \\
\text { Político, médico, jornalístico....??? }\end{array}$ \\
\hline & Suicídio como espetáculo & Suicídio como espetáculo & Da metrópole e das redes sociais \\
\hline \multirow[t]{5}{*}{$\begin{array}{l}\text { Transcrição E2 } \\
\text { revisada }\end{array}$} & & Microanálise 247 & $\begin{array}{l}\text { O outro lado - a família que ficou } \\
\text { O que as redes sociais falam das famílias? E dos suicidas? }\end{array}$ \\
\hline & Outros esquecendo da família de quem se matou & Outros esquecendo da família de quem se matou & Ao expor um suicídio \\
\hline & O que leva os outros a compartilharem um suicídio & O que leva os outros a compartilharem um suicíd & O que significa compartilhar? \\
\hline & A curiosidade das pessoas & A curiosidade das pessoas & O que as pessoas querem saber \\
\hline & Visão de que suicídio ocorre pela falta de trabalho & Visão de que suicídio ocorre pela falta de trabalh & Mas como piada \\
\hline \multirow[t]{2}{*}{$\begin{array}{l}\text { Transcrição E2 } \\
\text { revisada }\end{array}$} & & Anotação 252 & $\begin{array}{l}\text { Depois preciso ver as similaridades e diferenças nos discursos dos próprios } \\
\text { participantes do grupo }\end{array}$ \\
\hline & Pensando no piloto & Pensando no piloto & Quase defendendo ele \\
\hline \multirow[t]{2}{*}{$\begin{array}{l}\text { Transcrição E2 } \\
\text { revisada }\end{array}$} & & Microanálise 254 & $\begin{array}{l}\text { Mesmo ela tem duvidas de como funciona o CVV, acho que muitas pessoas } \\
\text { também tem, ou não conhecem o serviço ou não sabem como funciona. }\end{array}$ \\
\hline & Campanhas na TV & Campanhas na TV & $\begin{array}{l}\text { Pois atingem muita gente } \\
\text { E falando do CVV? }\end{array}$ \\
\hline
\end{tabular}




\begin{tabular}{|c|c|c|c|}
\hline $\begin{array}{l}\text { Transcrição E2 } \\
\text { revisada }\end{array}$ & & Microanálise 256 & $\begin{array}{l}\text { Concordo em parte, e o poder público, ele que deveria prover esse serviço, mas as } \\
\text { pessoas além de não conhecerem o serviço do governo, nem contam com ele, ou } \\
\text { se já precisaram dele, não buscam mais. } \\
\text { Gosto das ideias das universidades, mas e o governo? E os CAPS? E o SUS? }\end{array}$ \\
\hline $\begin{array}{l}\text { Transcrição E2 } \\
\text { revisada }\end{array}$ & & Microanálise 257 & $\begin{array}{l}\text { Essa pergunta veio a partir da entrevista que fiz com o colaborador 1, que era } \\
\text { especialista na área. A entrevista não será aproveitada??? Ou será? } \\
\text { Não posso esquecer de agradecer ele também. }\end{array}$ \\
\hline $\begin{array}{l}\text { Transcrição E2 } \\
\text { revisada }\end{array}$ & & Anotação 258 & $\begin{array}{l}\text { Os participantes também não sabem responder essa pergunta. E mesmo eles que } \\
\text { foram atingidos por isso, não conhecem os serviços disponiveis. } \\
\text { Há uma confusão do serviço do CVV ou há uma dificuldade tão grande em } \\
\text { conseguir atendimento para essa demanda que as pessoas só pensam no CVV, } \\
\text { porque é o único serviço disponivel? } \\
\text { Encaminhar para onde?? }\end{array}$ \\
\hline $\begin{array}{l}\text { Transcrição E2 } \\
\text { revisada }\end{array}$ & & Microanálise 259 & $\begin{array}{l}\text { De coisas do cotidiano, de problemas usuais, que uma conversa poderia ajudar, } \\
\text { mas que as pessoas não estão a fim, isso somado gota a gota, pode levar ao } \\
\text { suicídio. } \\
\text { Talvez se as pessoas perdessem o medo de ter diálogos e falar sobre emoções elas } \\
\text { poderiam se aproximar das outras. } \\
\\
\text { Talvez se aproximar de alguém que já fala sobre suicídio seja pesado demais. As } \\
\text { ações podem vir antes, e isso seria uma bela prevenção, mas daí precisaria pensar }\end{array}$ \\
\hline & Falta de diálogo & Falta de diálogo & $\begin{array}{l}\text { Tem haver com todo mundo e isso pode aproximar o tema ao invés de afastar } \\
\text { porque o suicídio é como se acontecesse longe. } \\
\text { Falta de dialogo e falar das emoções é comum. }\end{array}$ \\
\hline
\end{tabular}




\begin{tabular}{|c|c|c|c|}
\hline $\begin{array}{l}\text { Transcrição E2 } \\
\text { revisada }\end{array}$ & & Anotação 261 & $\begin{array}{l}\text { Qualquer profissão deve ser conscientizada? } \\
\text { Porque eles falaram que engenharia não? } \\
\text { E se o engenheiro civil se conscientizasse da necessidade de fazer prédios e } \\
\text { construções que colaborassem com a prevenção do suicídio. } \\
\text { E se o agrônomo pensasse em como prevenir suicídio guardando adequadamente } \\
\text { o pesticida, ou sabendo que pesticidas provocam depressão? } \\
\text { E se o historiador soubesse como se dá o significado que damos para a morte hoje } \\
\text { e estudasse como as religiões ou a história pensou sobre o suicídio e como isso } \\
\text { influencia hoje? } \\
\text { Porque eles pensam mais na área da saúde? } \\
\text { E se todos tivessem uma educação básica de como prevenir suicídios, eles } \\
\text { poderiam aplicar isso na sua prática profissional, nas suas relações profissionais e } \\
\text { pessoais. } \\
\text { Porque não falar de prevenção numa faculdade de veterinária? Eles tem acesso a } \\
\text { medicação e lidam com a morte! E o suicídio daquela veterinária que sacrificava } \\
\text { animais na China? } \\
\text { E nas faculdades de jornalismo, comunicação... isso tambem não seria necessário? } \\
\text { Nas de educação, pedagogia... e nas de educação física, sobre como incluir alunos } \\
\text { com depressão e que sofrem de bullying, ou como estimular a incluir todas as } \\
\text { crianças e não somente aquelas com bons dotes esportivos. } \\
\text { E nas de artes, quanto sentimento é expresso pela arte? Tanto para professores } \\
\text { de artes, músicas... }\end{array}$ \\
\hline $\begin{array}{l}\text { Transcrição E2 } \\
\text { revisada }\end{array}$ & & Microanálise 262 & $\begin{array}{l}\text { Mas se a pessoa não souber do que se trata, como ela pode se conscientizar, se } \\
\text { identificar? }\end{array}$ \\
\hline \multirow[t]{4}{*}{$\begin{array}{l}\text { Transcrição E2 } \\
\text { revisada }\end{array}$} & & Microanálise 263 & $\begin{array}{l}\text { A mudança vindo pelos sobreviventes, pelas pessoas indo nos grupos, se sentindo } \\
\text { acolhidas, fazendo disso um habito semanal, e divulgando e fomentando } \\
\text { discussao com outras pessoas, e assim mudando a visão delas. } \\
\text { Nota incluída em 30/11/17 - e eles, não podem ser multiplicadores? }\end{array}$ \\
\hline & Criando Instituto para ajudar outros & Criando Instituto para ajudar outros & $\begin{array}{l}\text { Sobre o suicídio } \\
\text { A dor que constrói e ampara. } \\
\text { Da dor ao luto e do luto a luta }\end{array}$ \\
\hline & As pessoas estão buscando informação por palestras & As pessoas estão buscando informação por pales & Para alunos e professores \\
\hline & Começar com pequenos focos & Começar com pequenos focos & E depois expandir \\
\hline
\end{tabular}




\begin{tabular}{|c|c|c|c|}
\hline $\begin{array}{l}\text { Transcrição E2 } \\
\text { revisada }\end{array}$ & & Microanálise 267 & $\begin{array}{l}\text { Busca ativa x busca passiva } \\
\text { Talvez campanhas sejam buscas passivas, a informação chega até vc e vc pode ou } \\
\text { não dar atenção } \\
\text { No google a busca é ativa, se ela busca é porque tem alguma coisa a ver com isso. } \\
\text { Pensar mais nisso! }\end{array}$ \\
\hline & Deus é muito subjetivo & Deus é muito subjetivo & Ele traz a mensagem de Deus (Nikki) \\
\hline & Tirar toda a carga de uma pessoa só & Tirar toda a carga de uma pessoa só & Tem o profissional para ajudar. Você não precisa resolver tudo sozinho. \\
\hline \multirow[t]{3}{*}{$\begin{array}{l}\text { Transcrição E2 } \\
\text { revisada }\end{array}$} & & Microanálise 270 & O que gera a resistência??? \\
\hline & Frequentava a igreja católica & Frequentava a igreja católica & Isso era importante para ela \\
\hline & Profissionais a disposição (cvv católico?) & Profissionais a disposição & Que dariam grande ajuda \\
\hline $\begin{array}{l}\text { Transcrição E2 } \\
\text { revisada }\end{array}$ & & Microanálise 273 & $\begin{array}{l}\text { Alguém precisa estar a disposição para ouvir. } \\
\text { Ela fala isso aqui. } \\
\text { Que ajuda muito ter alguém para conversar, com disposição para ouvir. } \\
\text { Há uma urgência, não dá para ser outra hora. } \\
\text { Já é difícil procurar. }\end{array}$ \\
\hline \multirow[t]{2}{*}{$\begin{array}{l}\text { Transcrição E2 } \\
\text { revisada }\end{array}$} & & Microanálise 274 & $\begin{array}{l}\text { Será que tem um lado não saudável da terapia, ou as pessoas veem como } \\
\text { tratamento de doença e promoção de saúde? } \\
\text { Será que não é um lado mais leve? }\end{array}$ \\
\hline & Perguntar para quem tentou & Perguntar para quem tentou & Saber deles quem eles ouvem \\
\hline \multirow[t]{3}{*}{$\begin{array}{l}\text { Transcrição E2 } \\
\text { revisada }\end{array}$} & & Microanálise 276 & $\begin{array}{l}\text { E se a forma de ser aceito for pelo suicídio? } \\
\text { E se a pessoa estiver num núcleo suicida? } \\
\text { E se ela fizer isso para ser aceito, descolado? }\end{array}$ \\
\hline & Curiosidade da morte & Curiosidade da morte & Morreu de que? \\
\hline & Falar com impacto ou estatísticas pode causar rejeição & Falar com impacto ou estatísticas pode causar rej & j Em quem já tem dificuldades \\
\hline \multirow[t]{2}{*}{$\begin{array}{l}\text { Transcrição E2 } \\
\text { revisada }\end{array}$} & & Microanálise 280 & $\begin{array}{l}\text { Aumentar a consciência na religião pode ajudar os enlutados e as pessoas que } \\
\text { pensam, pois a religião é uma fonte de ajuda, pertencimento, acolhimento e } \\
\text { crença. } \\
\text { Para onde vai depois da morte? }\end{array}$ \\
\hline & Vale dos suicidas & Vale dos suicidas & Crenças religiosas... \\
\hline \multirow[t]{3}{*}{$\begin{array}{l}\text { Transcrição E2 } \\
\text { revisada }\end{array}$} & & Microanálise 282 & $\begin{array}{l}\text { O quanto elas são fatores de risco e o quanto são fatores de proteção. } \\
\text { Eu sei que agora pode fazer algo, depois eu não sei o que acontece. }\end{array}$ \\
\hline & Se sentindo a vontade para ajudar outros & Se sentindo a vontade para ajudar outros & sobre suicídio \\
\hline & Ao se abrir outros buscam ajuda & Ao se abrir outros buscam ajuda & Pela experiência \\
\hline \multirow[t]{2}{*}{$\begin{array}{l}\text { Transcrição E2 } \\
\text { revisada }\end{array}$} & & Microanálise 285 & $\begin{array}{l}\text { O que faz com que ela fale tanto? } \\
\text { Eles tem necessidade de falar, de serem ouvidos. } \\
\text { Será que tem alguma ansiedade em ajudar outros? }\end{array}$ \\
\hline & Dificuldade de falar sobre a morte do irmão com amigo\$ & Dificuldade de falar sobre a morte do irmão com & Relacionado a conversando sobre suicídio com amigos \\
\hline
\end{tabular}

Material integrante da pesquisa de doutorado de Karen Scavacini Proibida a reprodução ou utilização sem autorização prévia do autor - 2018 


\begin{tabular}{|c|c|c|c|}
\hline $\begin{array}{l}\text { Transcrição E2 } \\
\text { revisada }\end{array}$ & & Microanálise 287 & $\begin{array}{l}\text { Aqui tem um padrão junto com a P8 } \\
\text { Fala-se sobre suicídio mas não fala sobre a quem morreu. } \\
\text { Será a crença de que não devemos falar sobre a morte, pois pode machucar? } \\
\text { Acho que precisamos de uma campanha que fale "podemos falar de quem } \\
\text { morreu". Conte histórias, fale o nome... isso ajuda... mantenha a pessoa viva nas } \\
\text { conversas. }\end{array}$ \\
\hline & Fala da perda do irmão para os amigos & Fala da perda do irmão para os amigos & Mas não fala que foi suicídio \\
\hline \multirow[t]{3}{*}{$\begin{array}{l}\text { Transcrição E2 } \\
\text { revisada }\end{array}$} & & Microanálise 289 & $\begin{array}{l}\text { Quais as razoes dessa escolha? } \\
\text { O que leva o não falar? } \\
\text { Aí tem um tabu? } \\
\text { E se as campanhas falassem que "podemos contar que foi por suicídio", como se } \\
\text { as pessoas contassem o real motivo isso diminuiria o tabu, pois as pessoas veriam } \\
\text { que é bem mais comum do que é falado ou divulgado. } \\
\text { Me deu a ideia de fazer um vídeo falado: Não tenham vergonha de dizer que foi } \\
\text { por suicídio. Isso pode até ajudar os outros a entenderem que isso acontece } \\
\text { mesmo, que não há nada de errado com vocês. Foi uma causa de morte e não } \\
\text { uma causa de julgamento e exclusão... (enfim... divagando sobre o assunto) }\end{array}$ \\
\hline & Buracos que ninguém se responsabiliza & Buracos que ninguém se responsabiliza & Enlutados \\
\hline & Outros achando que família tem problemas & Outros achando que família tem problemas & \\
\hline $\begin{array}{l}\text { Transcrição E1 } \\
\text { revisada_para } \\
\text { maxqda }\end{array}$ & & Analise 293 & $\begin{array}{l}\text { Pessoas buscam motivos e tem receitas prontas } \\
\text { Cadê a singularidade? } \\
\text { Cada um é colocado em um quadrado e julgado por isso? } \\
\text { Paragrafo } 89 \text { E1 }\end{array}$ \\
\hline
\end{tabular}




\begin{tabular}{|c|c|c|c|}
\hline \multirow[t]{2}{*}{$\begin{array}{l}\text { Transcrição E1 } \\
\text { revisada_para } \\
\text { maxqda }\end{array}$} & & Iniciando a codificação aberta & 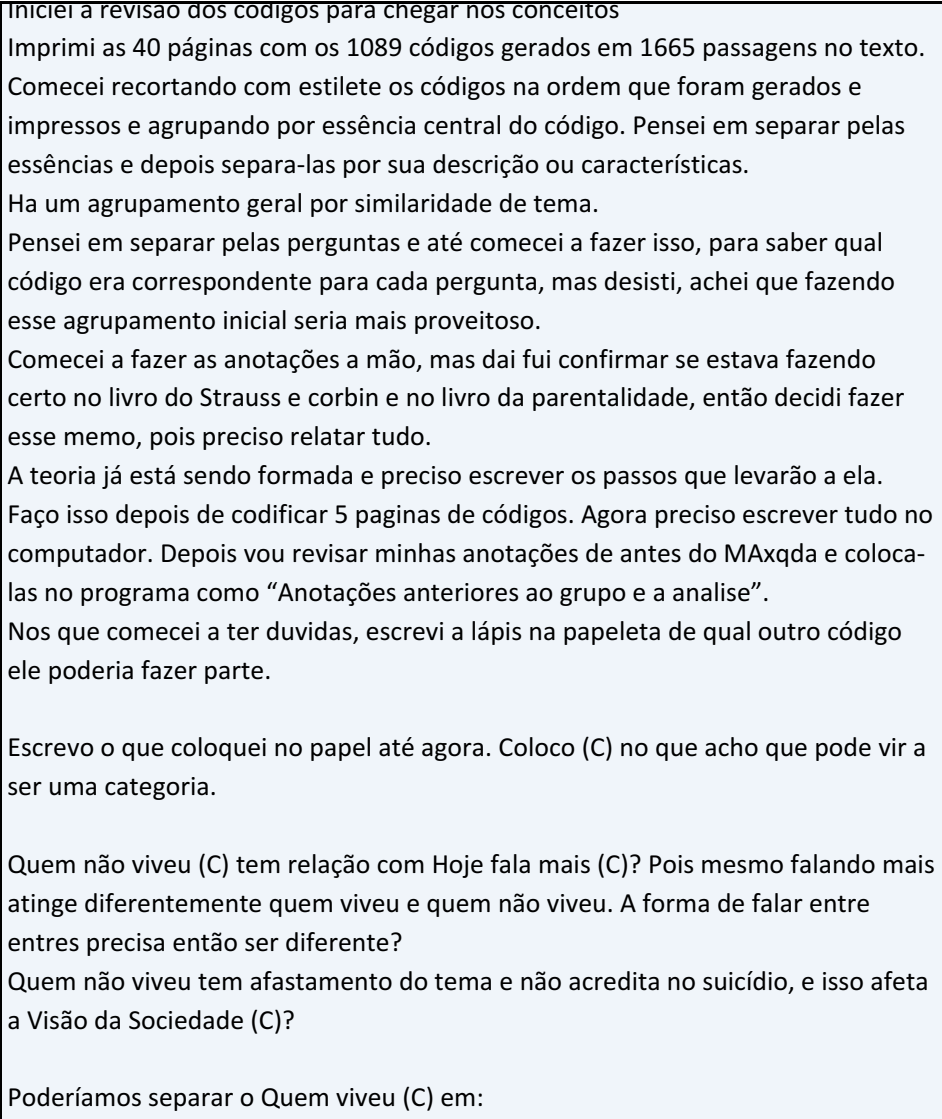 \\
\hline & Culpabilizando??? & Culpabilizando??? & \\
\hline $\begin{array}{l}\text { Transcrição E2 } \\
\text { revisada }\end{array}$ & & Codificação temática - Depressão & $\begin{array}{l}42 \text { conceitos agregados a depressão. } \\
\text { Subcategorias: } \\
\text { - O tabu e a depressão - } 9 \text { códigos } \\
\text { - Falta de entendimento da depressão - } 9 \\
\text { - Consequências da depressão - } 3 \\
\text { - Depressão é doença - } 12 \\
\text { - limites, dificuldades, tratamento } \\
\text { - A exclusão dos depressivos - } 4 \\
\text { - Mensagem que falta - } 4 \\
\text { - Depressão a doença da moda - } 1\end{array}$ \\
\hline
\end{tabular}

Material integrante da pesquisa de doutorado de Karen Scavacini Proibida a reprodução ou utilização sem autorização prévia do autor - 2018 


\begin{tabular}{|c|c|c|}
\hline $\begin{array}{l}\text { Transcrição E2 } \\
\text { revisada }\end{array}$ & Nota metodológica Axial coding & $\begin{array}{l}\text { A partir dos códigos gerados, separei em categorias iniciais. } \\
\text { Essas categorias iniciais foram } 32 \text {. } \\
\text { Os códigos foram colocados em envelopes com o nome das categorias iniciais. } \\
\text { Organizei os envelopes na ordem em que as categorias foram geradas, que tinham } \\
\text { relação com as perguntas, o questionário, já que os códigos foram impressos na } \\
\text { ordem que foram gerados. } \\
\text { Isso já ajuda a ter uma lógica de pensamento e de organização do trabalho. } \\
\end{array}$ \\
\hline \multirow[t]{2}{*}{$\begin{array}{l}\text { Transcriç̃̃o E2 } \\
\text { revisada }\end{array}$} & Codificação temática: Tabu / preconceito / O não & 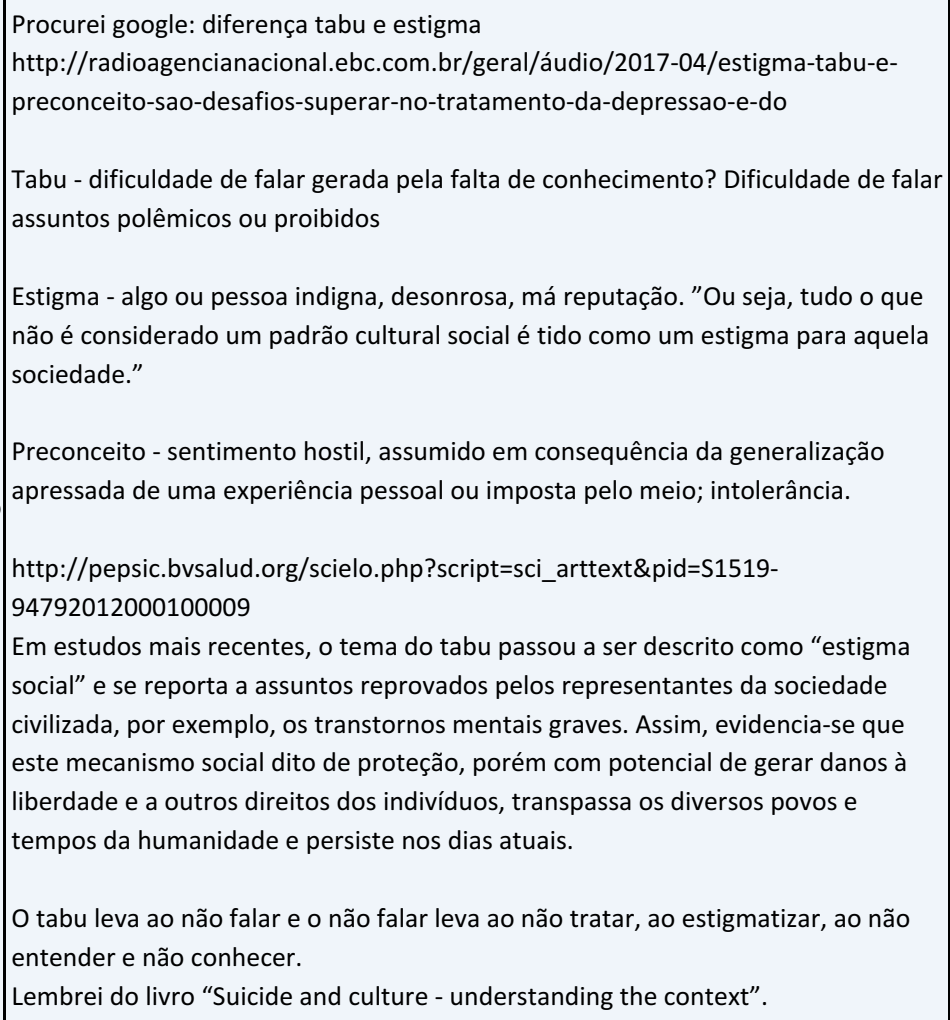 \\
\hline & Diário de bordo 11/11/17 & $\begin{array}{l}\text { Começo a ler as anotações que fiz durante a microanálise e vejo a riqueza desse } \\
\text { método, não pensaria nisso agora, por isso é importante escrever quando vem a } \\
\text { mente. Registrar tudo. } \\
\text { Começo a visualizar uma forma e fico feliz. }\end{array}$ \\
\hline
\end{tabular}




\begin{tabular}{|c|c|c|}
\hline & Não é um tema como outro qualquer & $\begin{array}{l}\text { Que as pessoas vão ficar falando. } \\
\text { Porque não??? } \\
\text { Porque não pode ser um assunto como outro qualquer? Quais assuntos as pessoas } \\
\text { tratam em conversas? }\end{array}$ \\
\hline & Codificação temática: Sociedade (visão) & $\begin{array}{l}\text { Iniciando a codificação do segundo envelope, sociedade (visão) } \\
\text { Fico na duvida se ela seria uma categoria ou deveria ser uma subcategoria de } \\
\text { TABU, dentro do Visão do suicídio no brasil } \\
\text { Por isso voltei nos livros para pesquisar codificação. }\end{array}$ \\
\hline & Nota durante pesquisa bibliográfica & $\begin{array}{l}\text { Nota referente a pensamentos após procura de artigos sobre suicídio na base de } \\
\text { dados da USP. } \\
\text { Usar a internet e redes sociais não só como aumento de consciência, mas também } \\
\text { para tratamento. } \\
\text { Falar sobre os programas de suicide awareness e como eles se classificam. } \\
\text { Suicide awareness x suicide literacy x mas media campaings } \\
\text { E as campanhas entre os alunos na faculdade } \\
\text { Professores usarem livros com o tema prevenção nas escolas } \\
\text { TITULO: Do que precisamos para falar mais sobre o suicídio? } \\
\text { Ninguém falou da colha como aumento da consciência publica.... }\end{array}$ \\
\hline $\begin{array}{l}\text { Transcriç̃̃o E2 } \\
\text { revisada }\end{array}$ & Codificação temática: Comunicação & \begin{tabular}{|l|}
116 códigos \\
A primeira vista tinha escolhido o “Fala mais”, mas achei que "Comunicação" seria \\
melhor. \\
Neste sentido ao dividir as categorias, fico pensando se o “O falar", outro \\
envelope, não entraria aqui como comunicação pessoal. \\
Talvez pudesse ter: \\
- comunicação social \\
- comunicação virtual \\
- comunicação pessoal e familiar? \\
Comecei a rever os objetivos para não me perder. Aonde quero chegar? Qual o \\
objetivo da tese? \\
Procurar google: competência em saúde mental brasil / suicide literacy
\end{tabular} \\
\hline
\end{tabular}

Material integrante da pesquisa de doutorado de Karen Scavacini Proibida a reprodução ou utilização sem autorização prévia do autor - 2018 


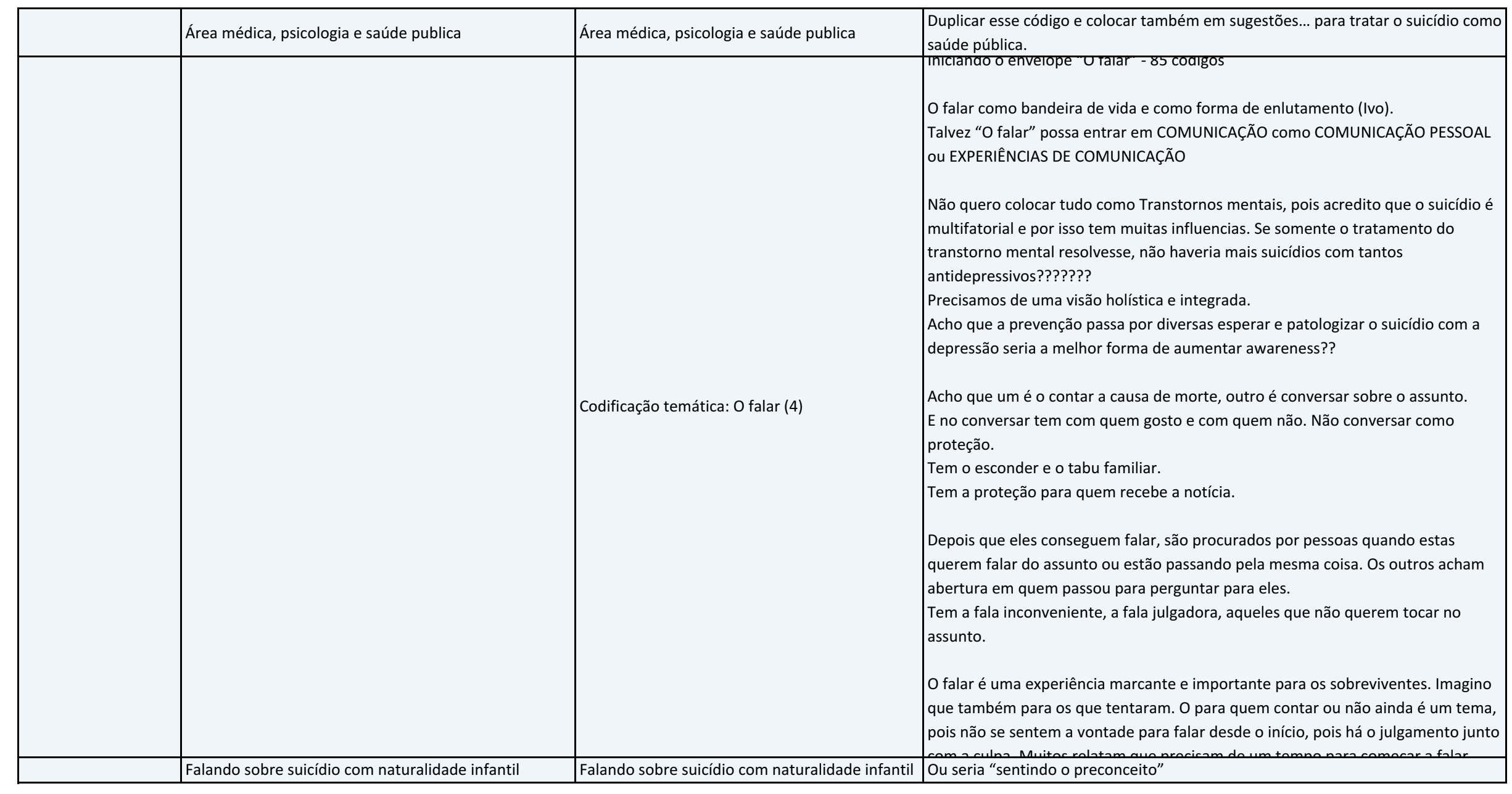




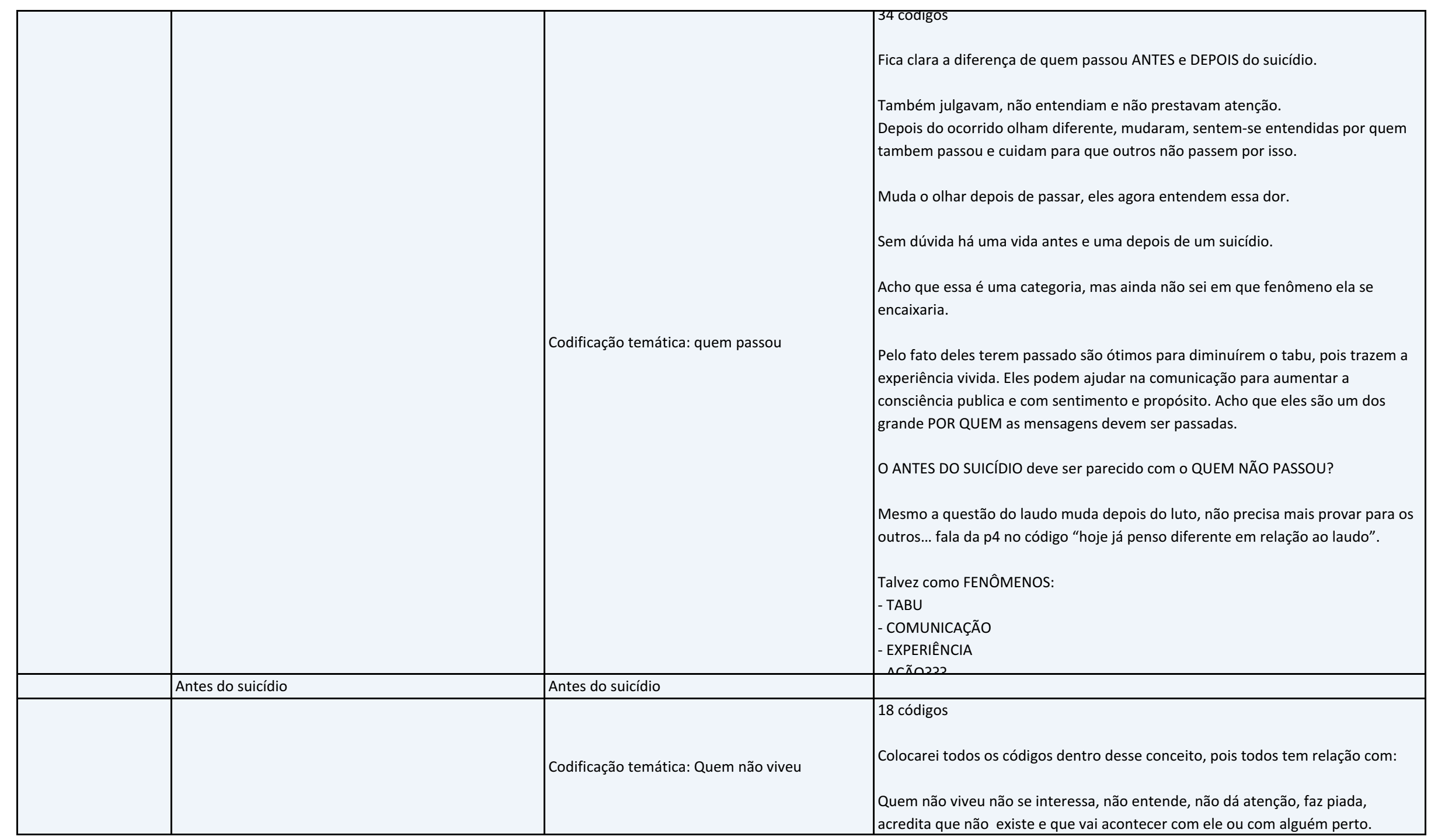




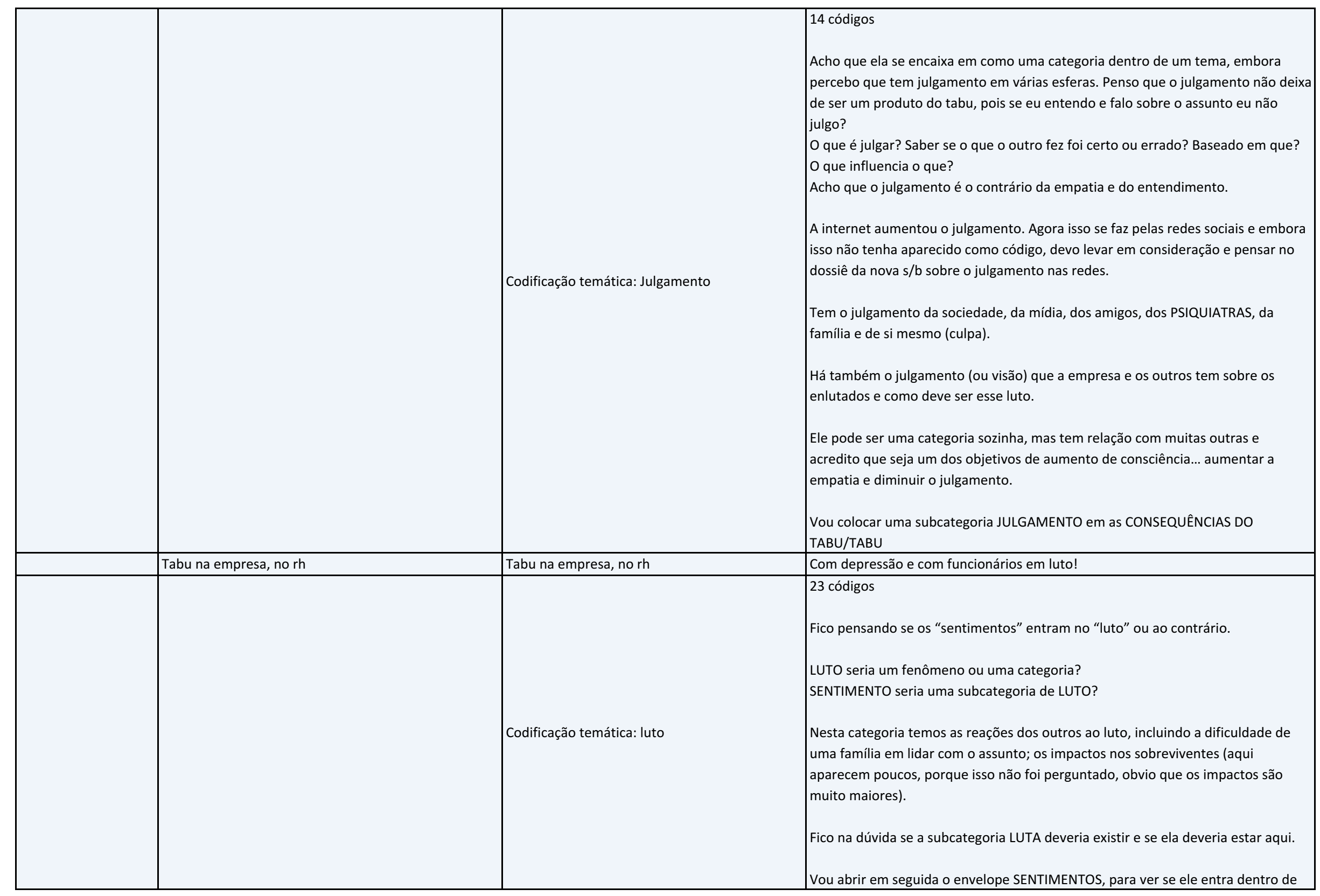

Material integrante da pesquisa de doutorado de Karen Scavacini Proibida a reprodução ou utilização sem autorização prévia do autor - 2018 


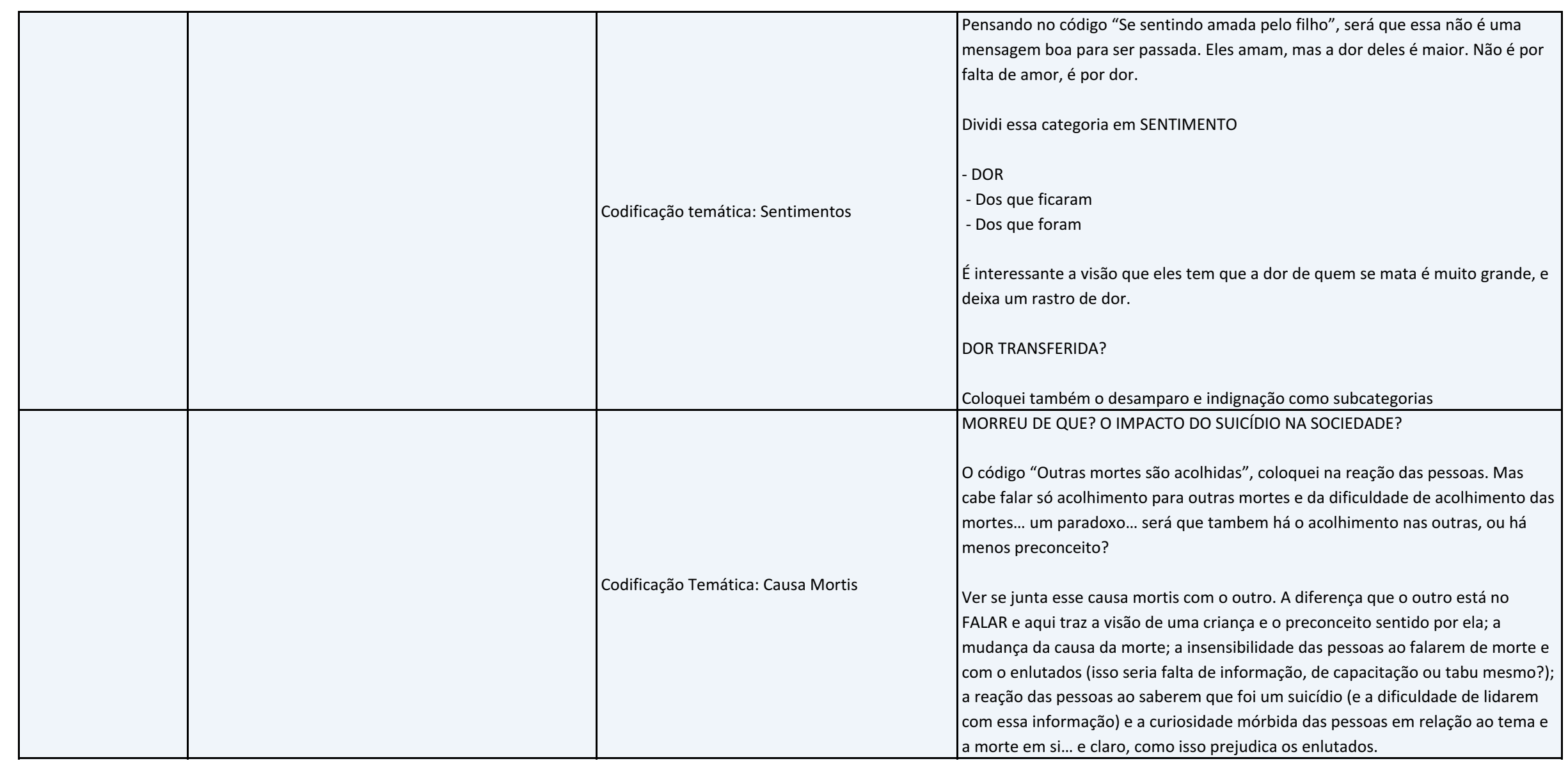




\begin{tabular}{|c|c|c|c|}
\hline & & (1) & $\begin{array}{l}\text { Acabei juntando nessa categoria os envelopes } \\
\text { “o possivel e o impensável” } \\
\text { e "outros suicídios" } \\
\text { Fico pensando na impotência que o suicídio traz, desde a falta de rastros e sinais, } \\
\text { eles fazendo coisas para que os outros não percebessem. - A IMPOTÊNCIA DO } \\
\text { SABER } \\
\text { Traz a sensação de que é muita coisa para fazer, que ainda falta muito e não } \\
\text { vamos dar conta - A Impotência DO FAZER } \\
\text { Além de mostrar que tem mais suicídios próximos do que falamos e lembramos. O } \\
\text { suicídio é algo próximo. Não sei se essa subcategoria se encaixa aqui... } \\
\text { A IMPOTÊNCIA DA RAZÃO - é tão absurdo que não conseguimos nem imaginar que } \\
\text { pode acontecer conosco. } \\
\text { A IMPOTÊNCIA DA AJUDA - Temos limitaç̃̃es e não conseguimos ajudar todos a } \\
\text { todo o tempo!! } \\
\text { A IMPOTÊNCIA DA ESPERANÇA = SUICÍDIO } \\
\text { A IMPOTÊNCIA DA PREVISÃO } \\
\text { A IMPOTÊNCIA DA HISTORIA - se tivemos tantos suicídios próximos, porque ainda } \\
\text { não conseguimos mudar isso? }\end{array}$ \\
\hline & & & \\
\hline
\end{tabular}




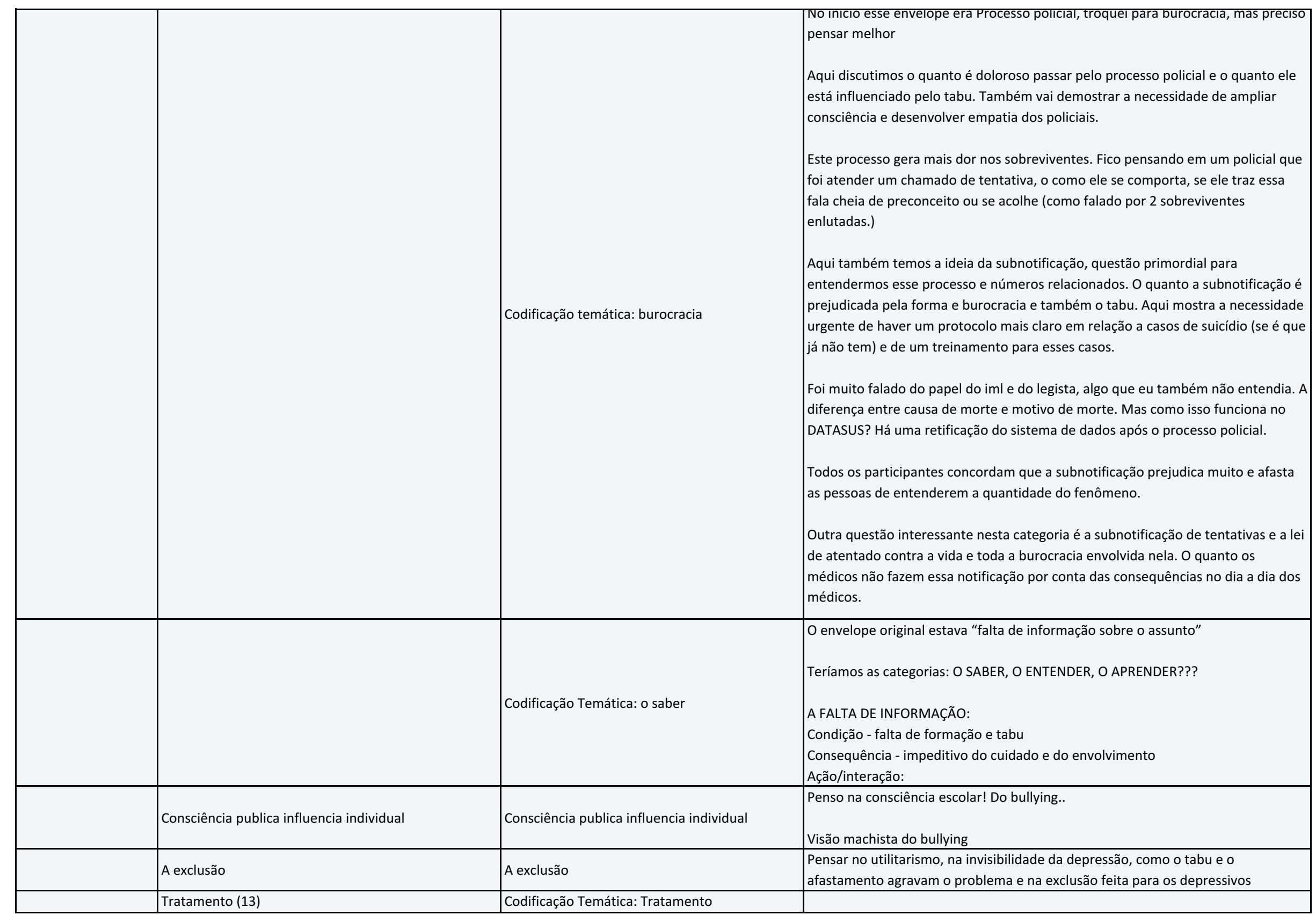

Material integrante da pesquisa de doutorado de Karen Scavacini Proibida a reprodução ou utilização sem autorização prévia do autor - 2018 


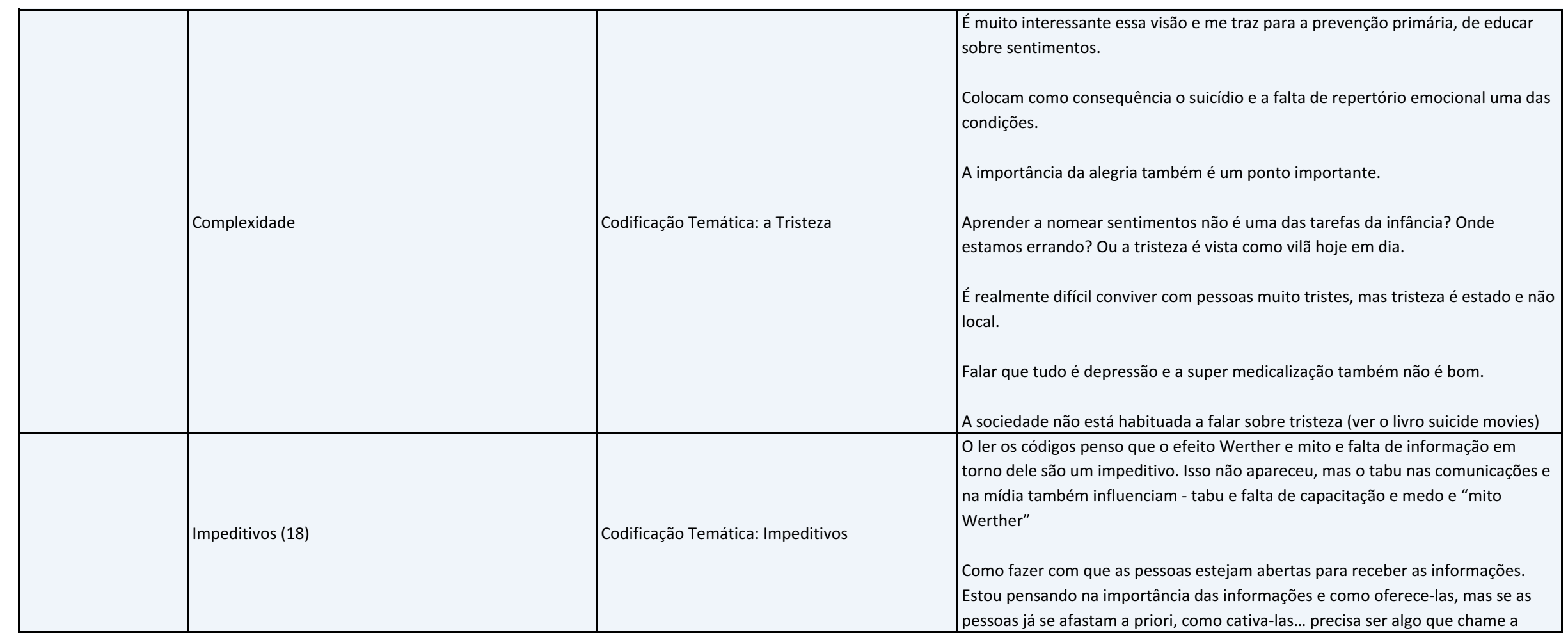




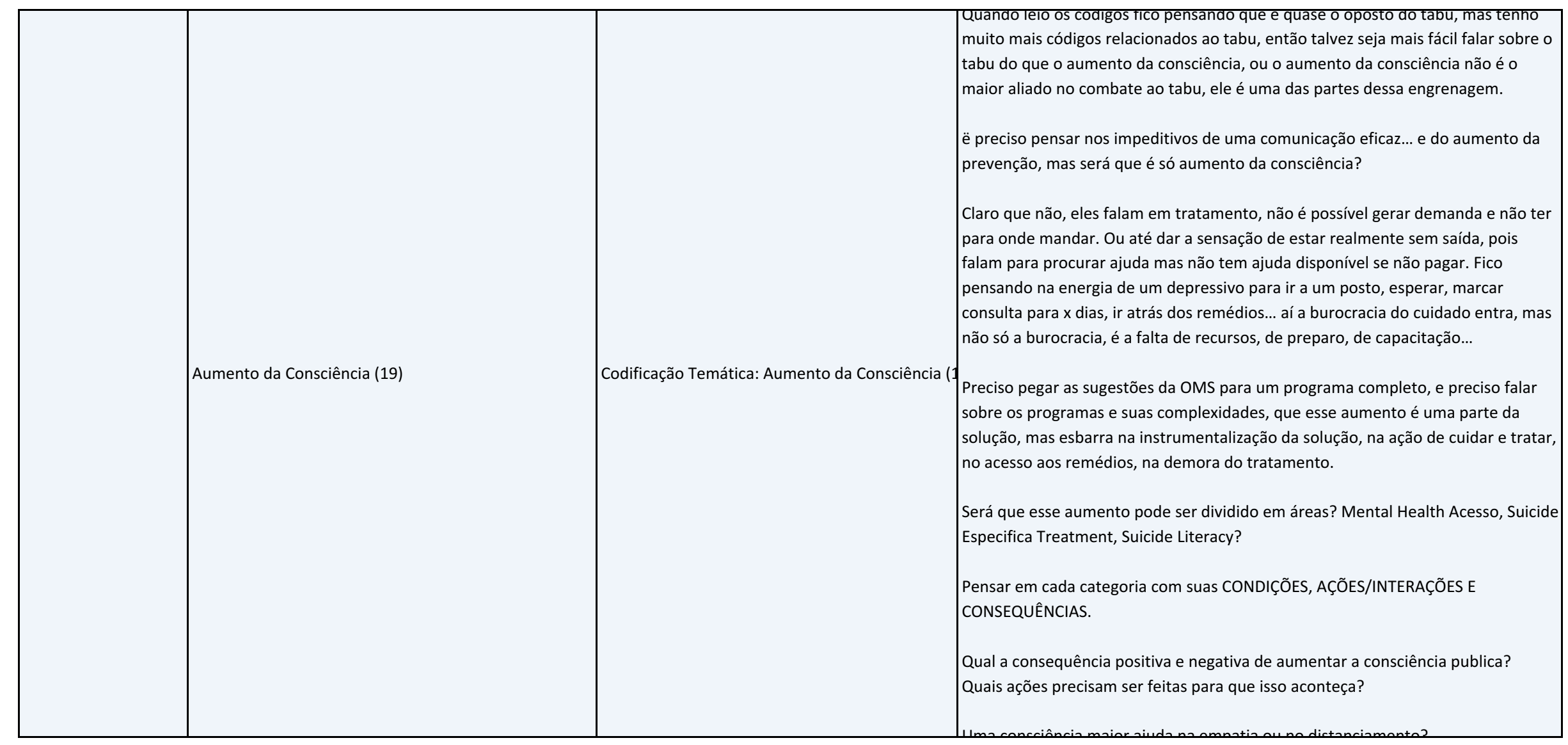




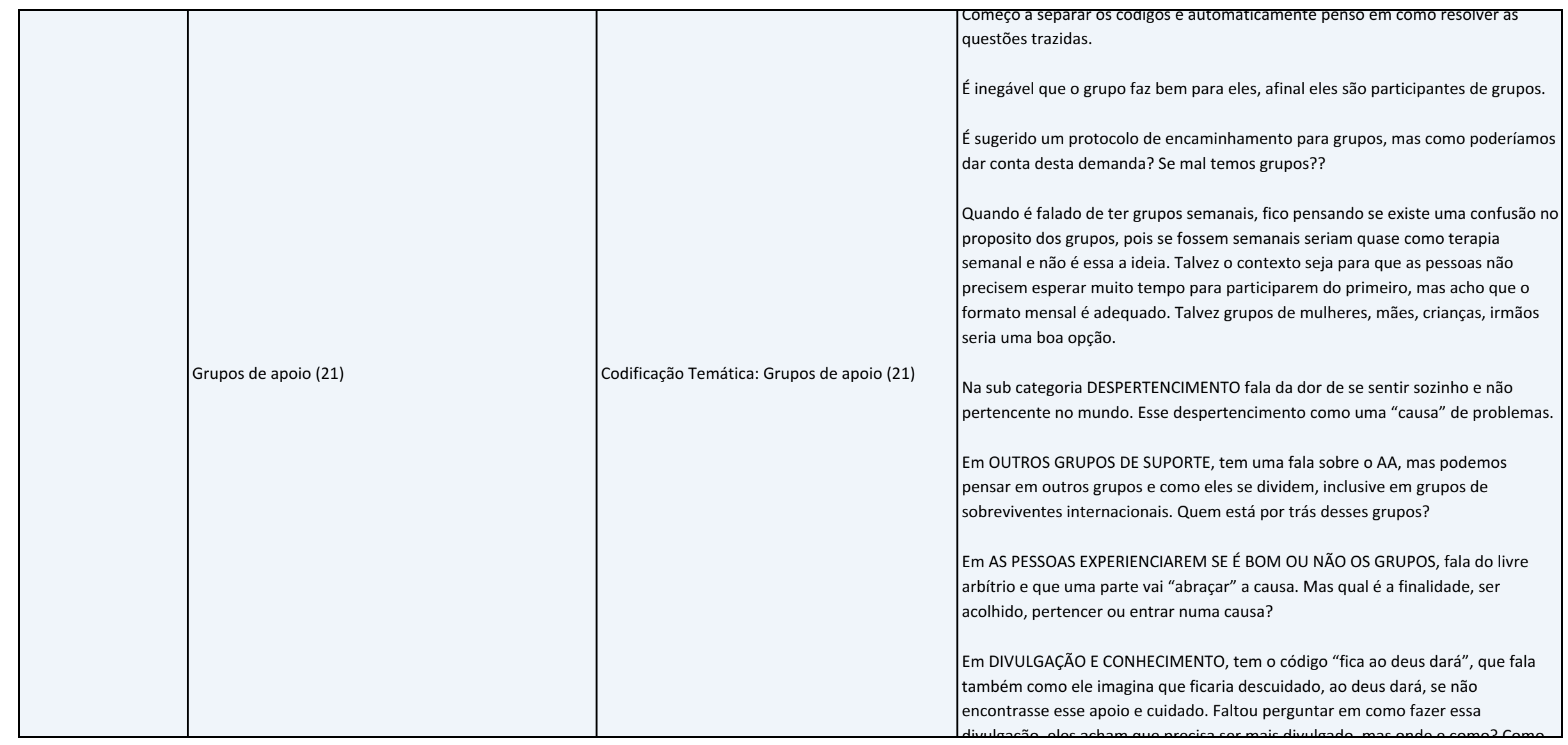




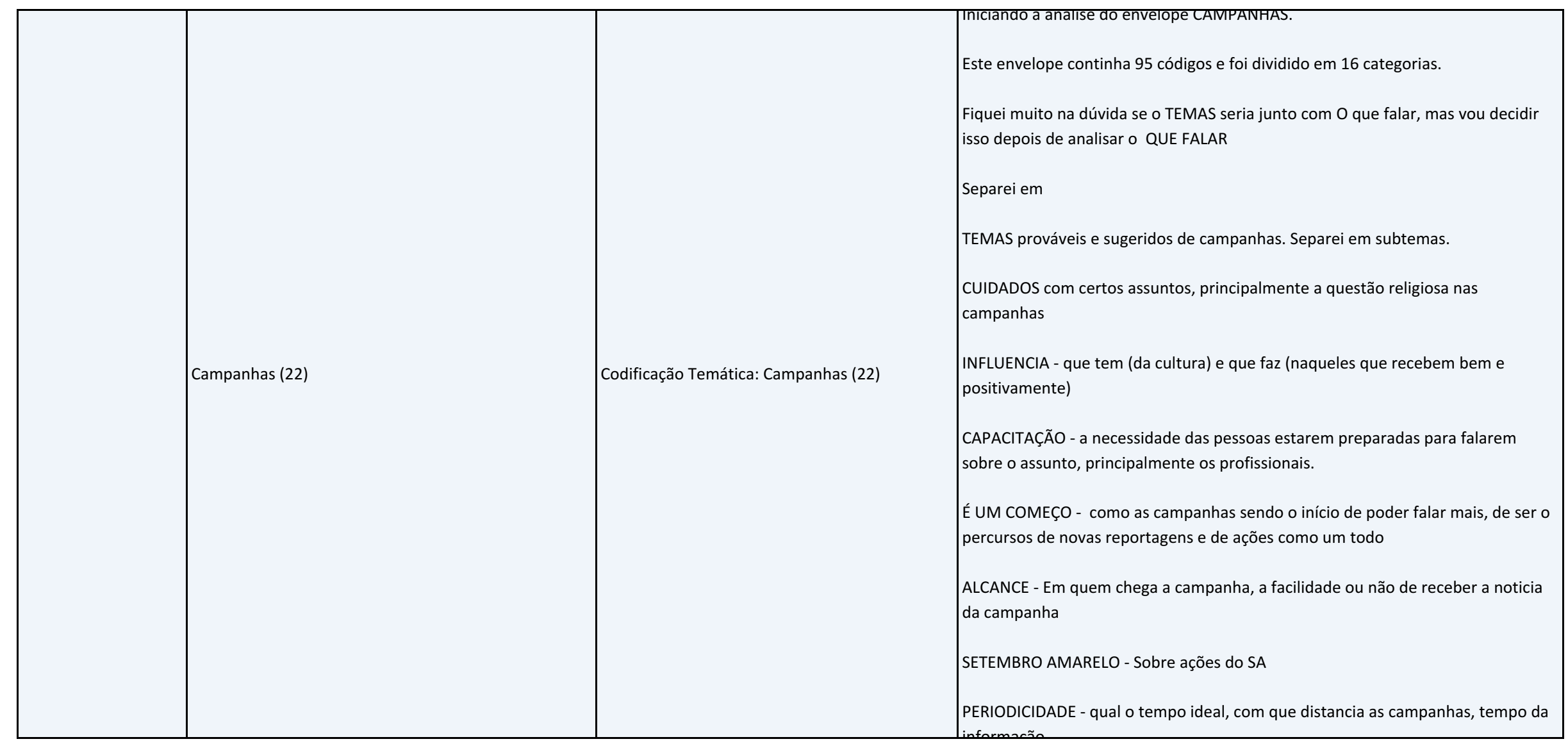




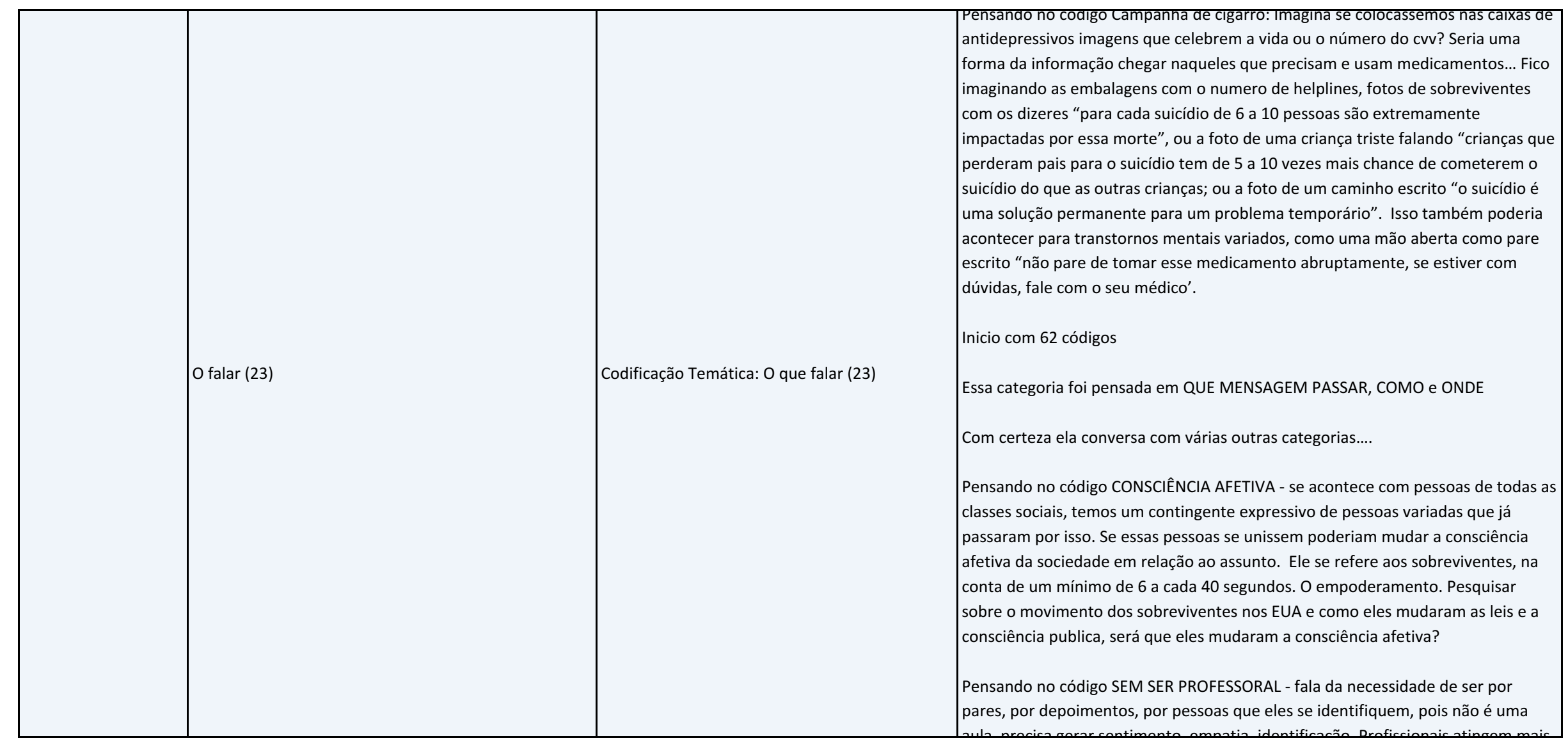




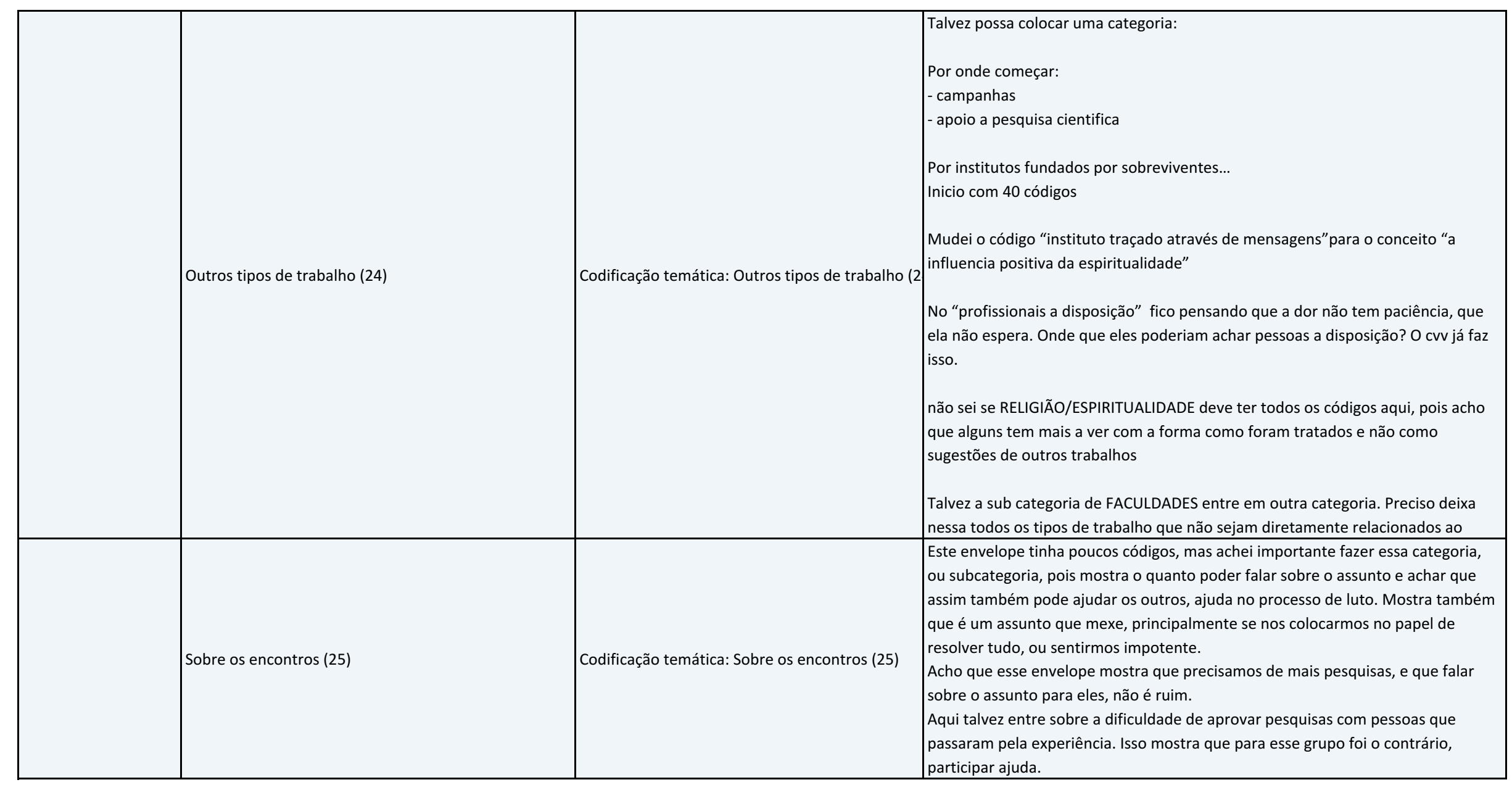




\begin{tabular}{|l|l|l|l|}
\hline & $\mid \begin{array}{l}\text { Dentro das crenças, separarei: } \\
\text { Co motivo do suicídio - qual a opinião que eles tem do porque aqueles que } \\
\text { amavam se matou (isso não foi uma pergunta), surgiu durante o debate. } \\
\text { Um dos participantes falou bastante sobre a Gnose, sua religião e como ele } \\
\text { acredita na doutrina e isso traz conforto e aceitação. Acho que esse é o ponto, } \\
\text { cada um achar o que conforta e explica, porque não tem explicação fácil. } \\
\text { Penso no que significa CRENÇAS, será que são só religiosas? } \\
\text { Coderia incluir a experiência com a falta de acolhimento na religião? } \\
\text { Cerá que é a religião que precisa mudar a forma ou a pessoa precisa encontrar um } \\
\text { local onde se sinta bem. Isso é fácil em termos de sp, mas e do interior? Como } \\
\text { ficam essas pessoas? (pensando no código SABER ONDE VAI PARA NÃO SE } \\
\text { MACHUCAR) } \\
\text { A importância da liberdade de opiniões na igreja tambem é um fator a ser levado } \\
\text { em consideração. Mas e se a visão daquela igreja for preconceituosa? } \\
\text { O vale dos suicidas trouxe bastante debate, e as novas visões da religião espirita. } \\
\text { É fato que as pessoas buscam respostas na religião, assim como o fazem para }\end{array}$ \\
\hline
\end{tabular}




\begin{tabular}{|l|l|l|l|}
\hline & & $\begin{array}{l}\text { O sem saber o que falar para ajudar pode impedir muita gente de oferecer ajuda, } \\
\text { as pessoas acham que precisam saber exatamente by the book o que falar. Mas aí } \\
\text { que está, será que o mais importante é falar ou é ouvir? - Coloquei esse código em } \\
\text { O QUE FALAR/ENSINAR COMO AGIR } \\
\text { Talvez esses códigos entrem em outras categorias... ou sejam todos pertencentes } \\
\text { a uma categoria só } \\
6 \text { códigos }\end{array}$ \\
Dificuldades (28) & $\begin{array}{l}\text { Codificação Temática: Dificuldades (28) } \\
\text { Em DIVERSOS CUIDADORES, traz duas questões, quem deve ser } \\
\text { alertado/treinado? E aonde estão esses pais, que não se responsabilizam mais por } \\
\text { esses adolescentes. } \\
\text { Essa é uma crença, de que COM ADOLESCENTE É MAIS POSSívEL PREVENIR, é uma } \\
\text { visão que adolescente fala mais, demonstra mais, porém vejo tantos impeditivos } \\
\text { nisso, o adolescente é mais impulsivo, tem um memo. falando disso.... há uma } \\
\text { confusão sobre o que é adolescência e o que é anormal, tem uma desvalorização } \\
\text { do sentimento e da dor do adolescente... } \\
\text { Vou colocar ele dentro de impeditivos, pois faz mais sentido... }\end{array}$ \\
\hline
\end{tabular}




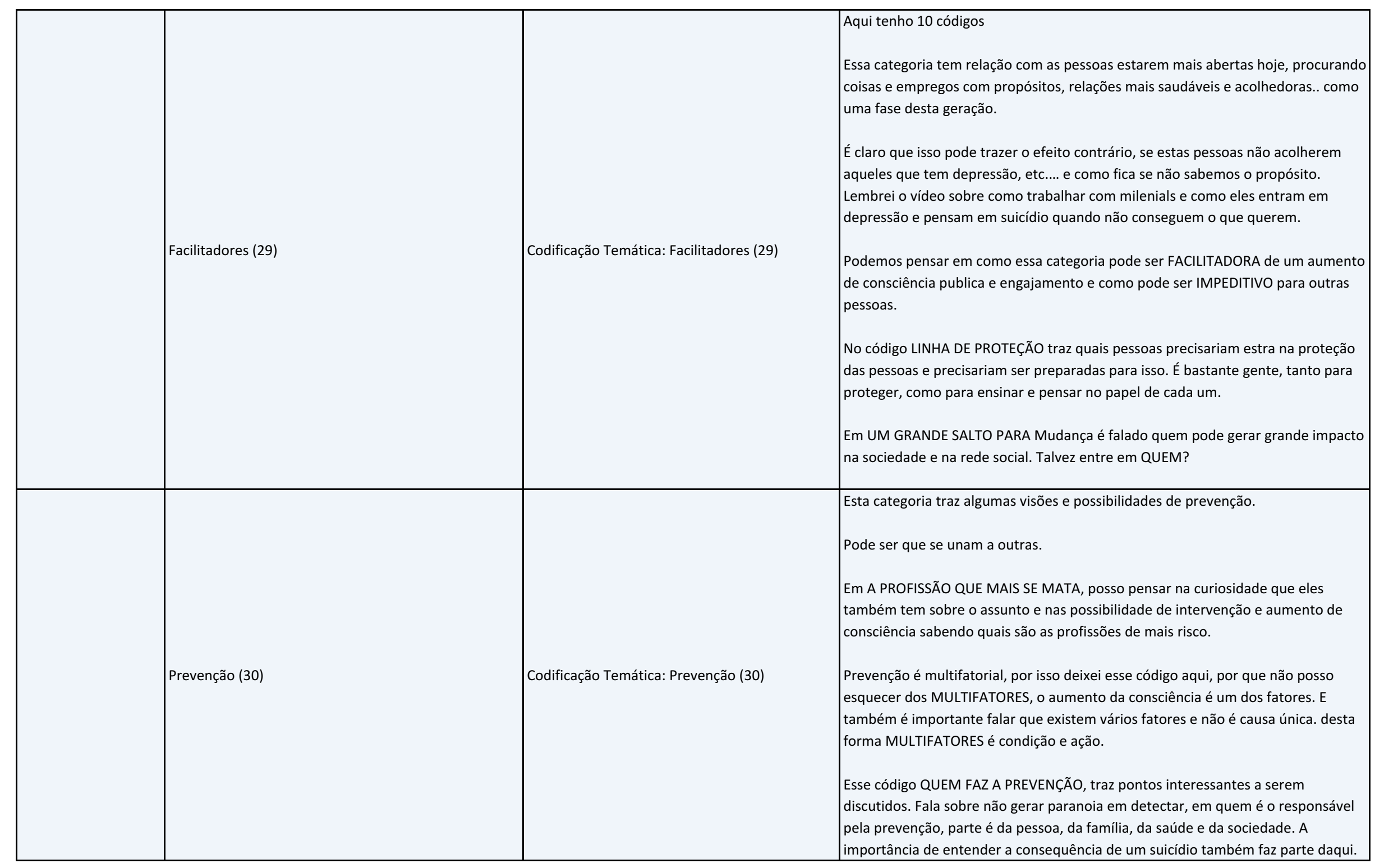




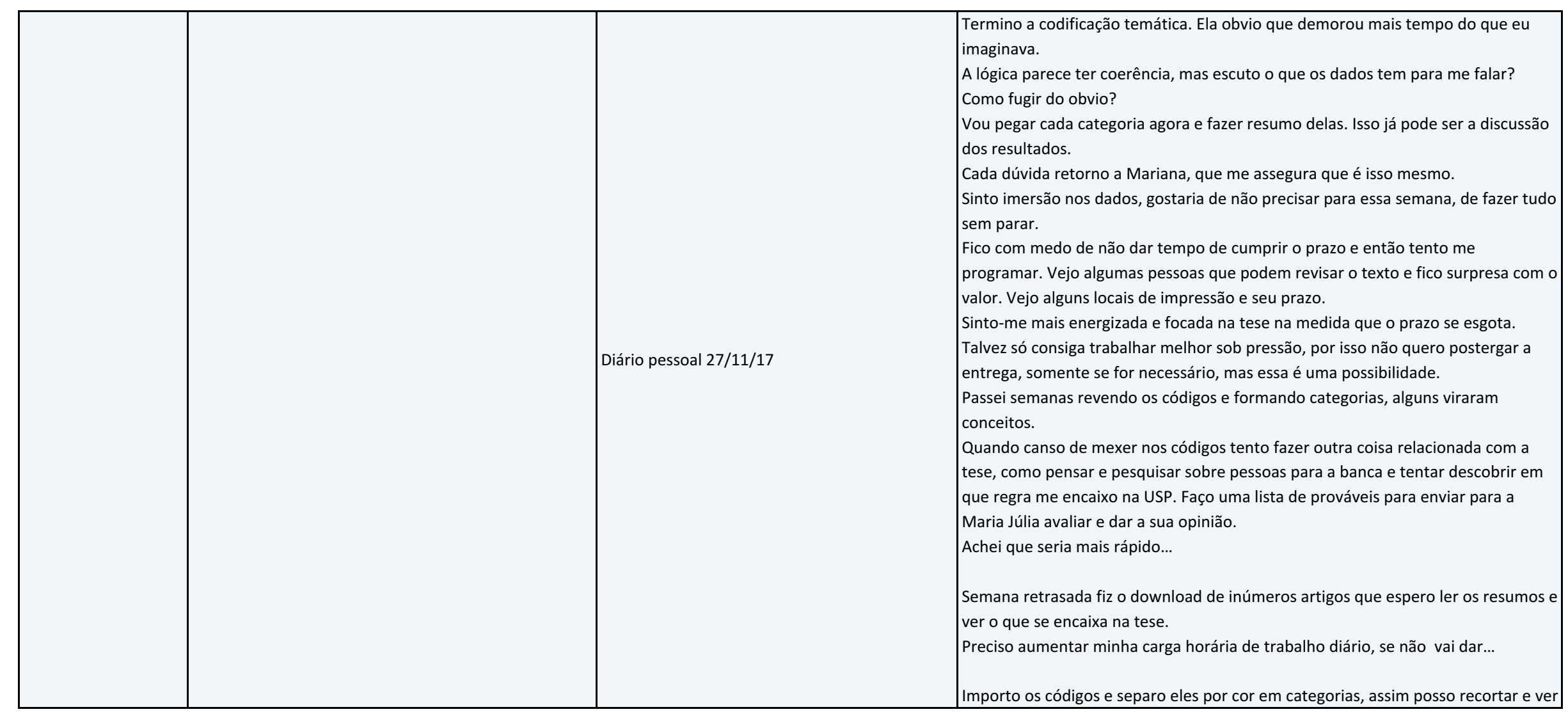




\begin{tabular}{|c|c|c|c|}
\hline & & 更 & 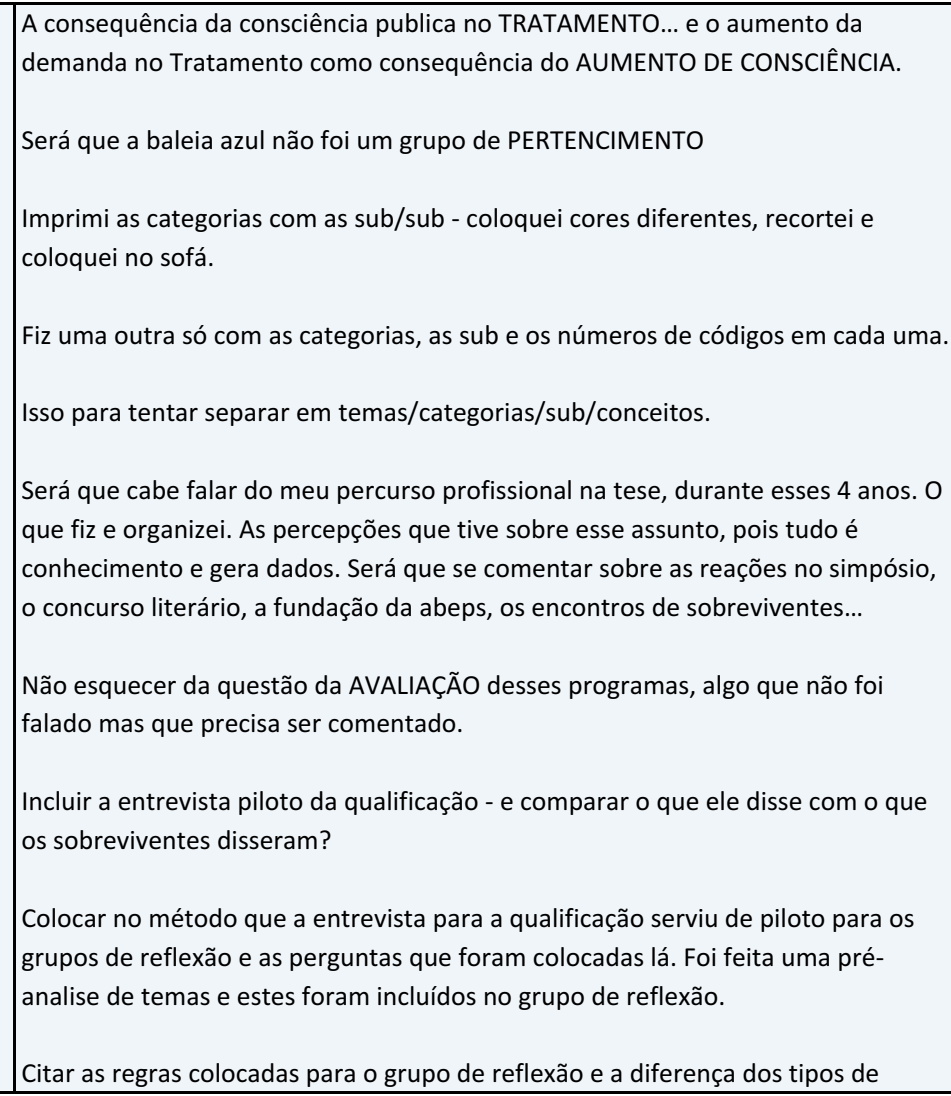 \\
\hline
\end{tabular}




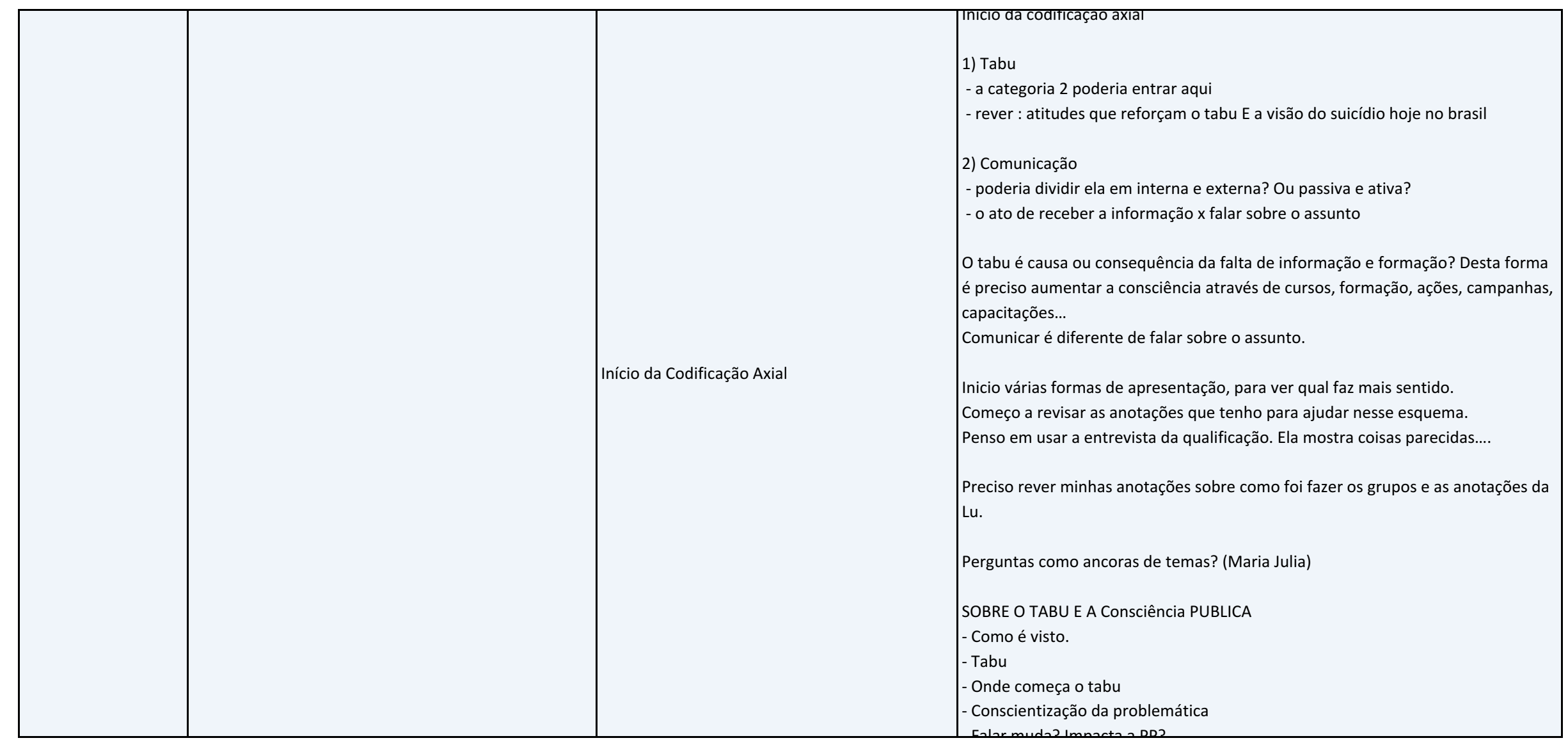




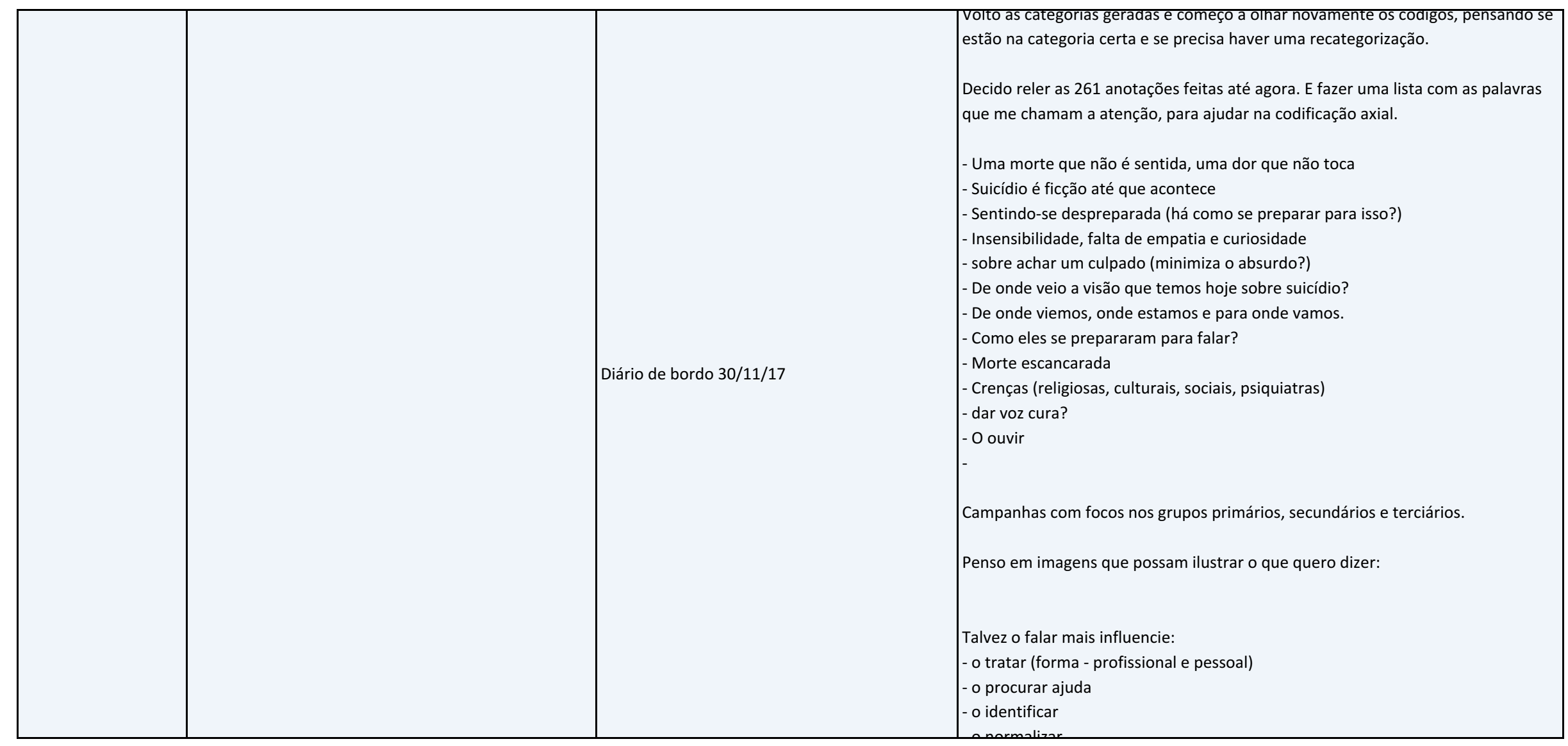




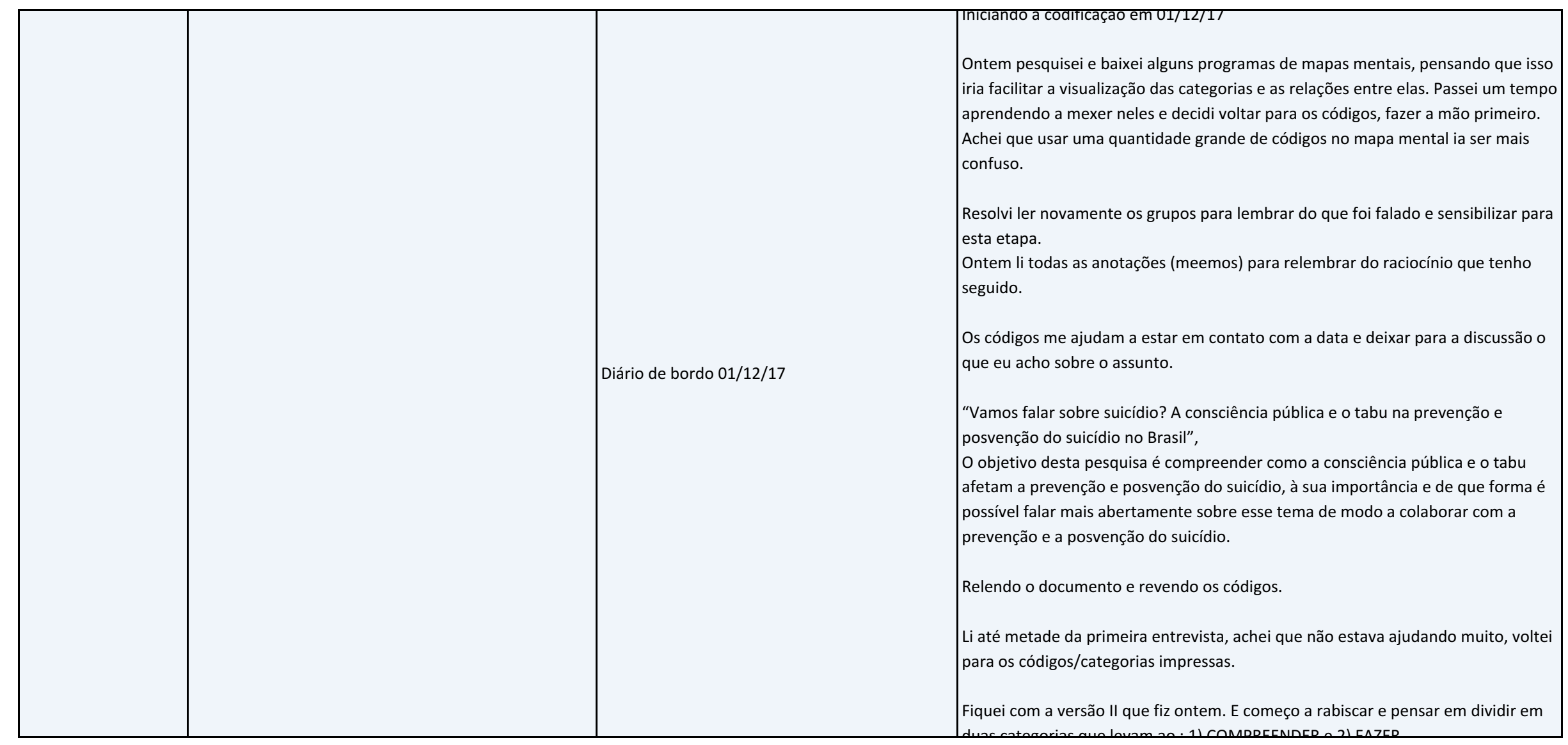




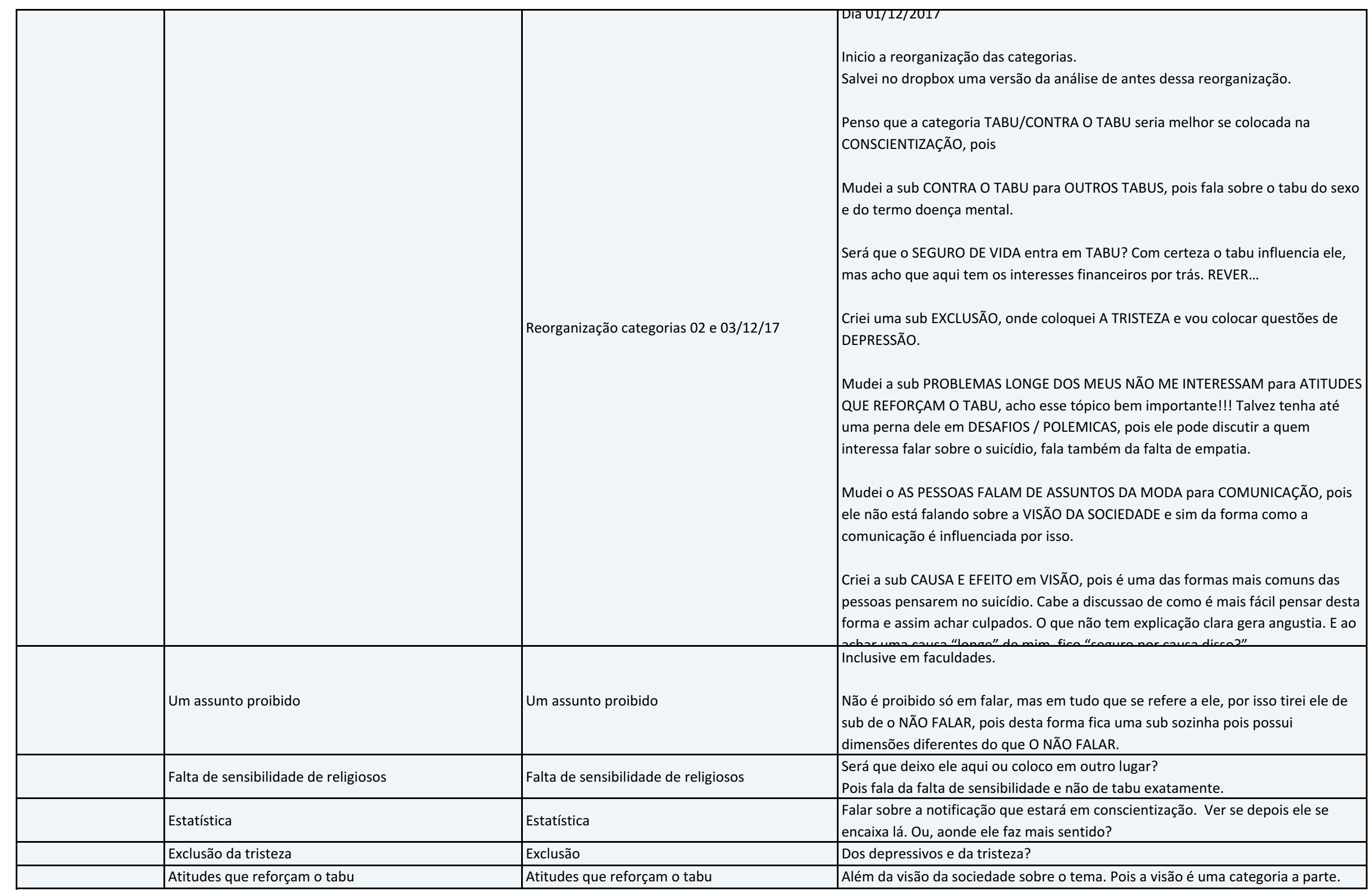




\begin{tabular}{|l|l|l|l|}
\hline & & & $\begin{array}{l}\text { O que mais chama atenção aqui é o bom tratamento recebido pela polícia e a } \\
\text { sensação de que ia ser maltratada mas não foi. Aqui talvez caiba uma discussão da } \\
\text { visão que as pessoas tem da policia e de talvez sentirem-se desamparadas e } \\
\text { ficarem surpresas pelo bom tratamento. Mas o bom tratamento deveria ser regra } \\
\text { e não exceção. Isso também mostra a importância do contato nessas primeiras } \\
\text { horas, e a lembrança que fica desse tratamento. A policia pode ou não ser mais } \\
\text { um neste elo de cuidado. Aí a importância de aumentar a conscientização em } \\
\text { policiais. Podemos estender isso para o atendimento a pessoas que tentaram? Se } \\
\text { elas recebem acolhimento isso ajuda em seu processo de prevenção? Se sim, é } \\
\text { uma prova que aumentar a consciência para ter uma reação acolhedora muda o }\end{array}$ \\
\hline & Sendo bem cuidada (polícia e médicos) & $\begin{array}{l}\text { Reações agressivas do amigo em relação ao suicídio talvez mostrem a dificuldade } \\
\text { das pessoas falarem do assunto, ou a dificuldade que ESSE amigo tem em falar } \\
\text { sobre isso. As pessoas tem limitações e talvez ele não goste ou não queira entrar } \\
\text { nesse assunto, aí pensamos nos LIMITES do cuidado, inclusive daqueles que } \\
\text { ouvem e cuidam. O que faz com que a pessoa não queira falar. Se ela agride deve e médicos) } \\
\text { ser por defesa... talvez tenha a visão de quem não devemos falar sobre isso. }\end{array}$ \\
\hline & Falta de suporte e agressão & Falta de suporte e agressão & Digital media education e dos inúmeros tipos de mídia existentes hoje... \\
\hline & Era digital & $\begin{array}{l}\text { Fiquei pensando se essa sub ia aqui ou não. Acho que vou ver, pois ela é } \\
\text { necessária na conscientização porem tem pitadas no que falar... }\end{array}$ & Eor onde começar \\
\hline
\end{tabular}




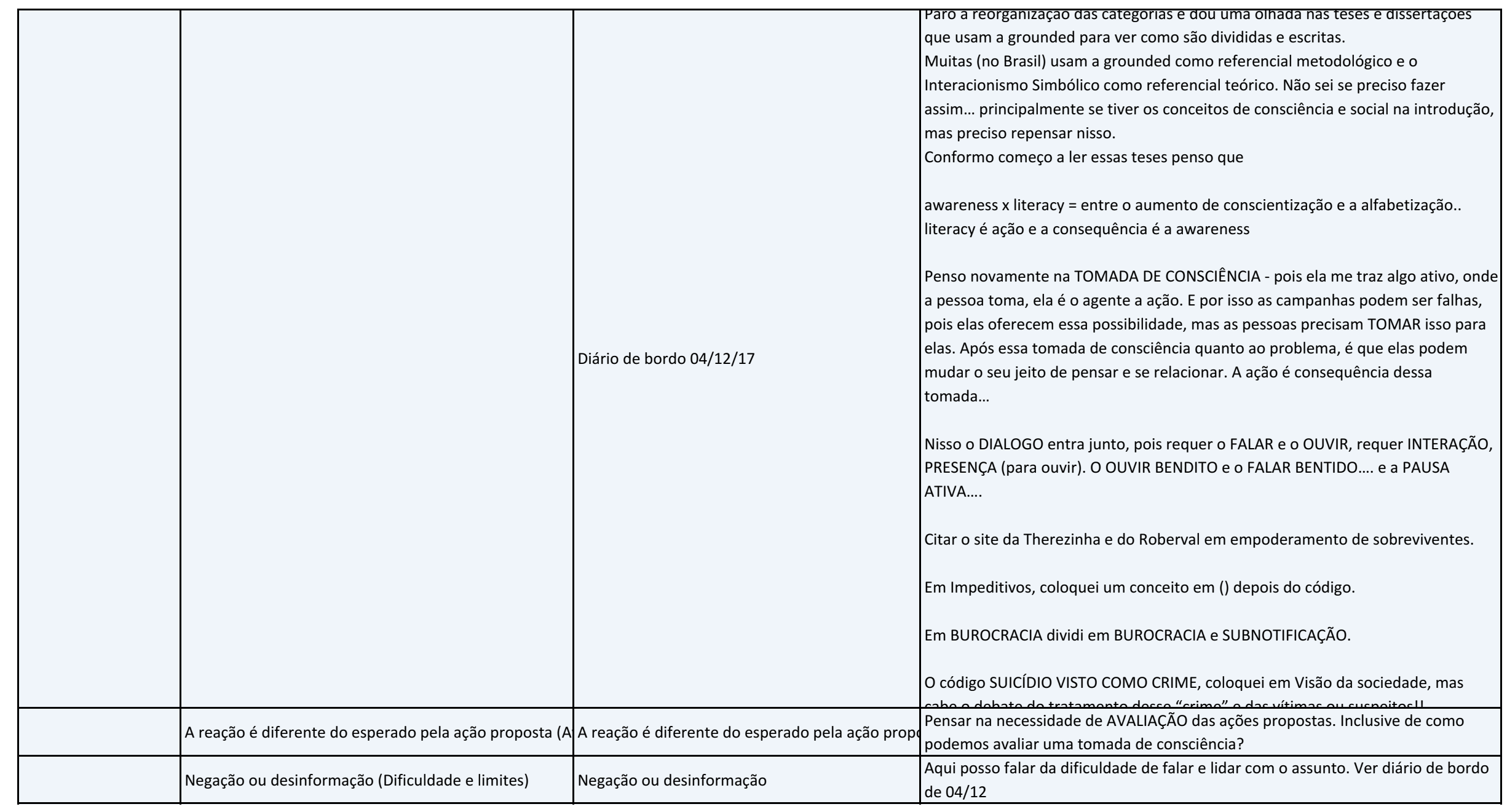




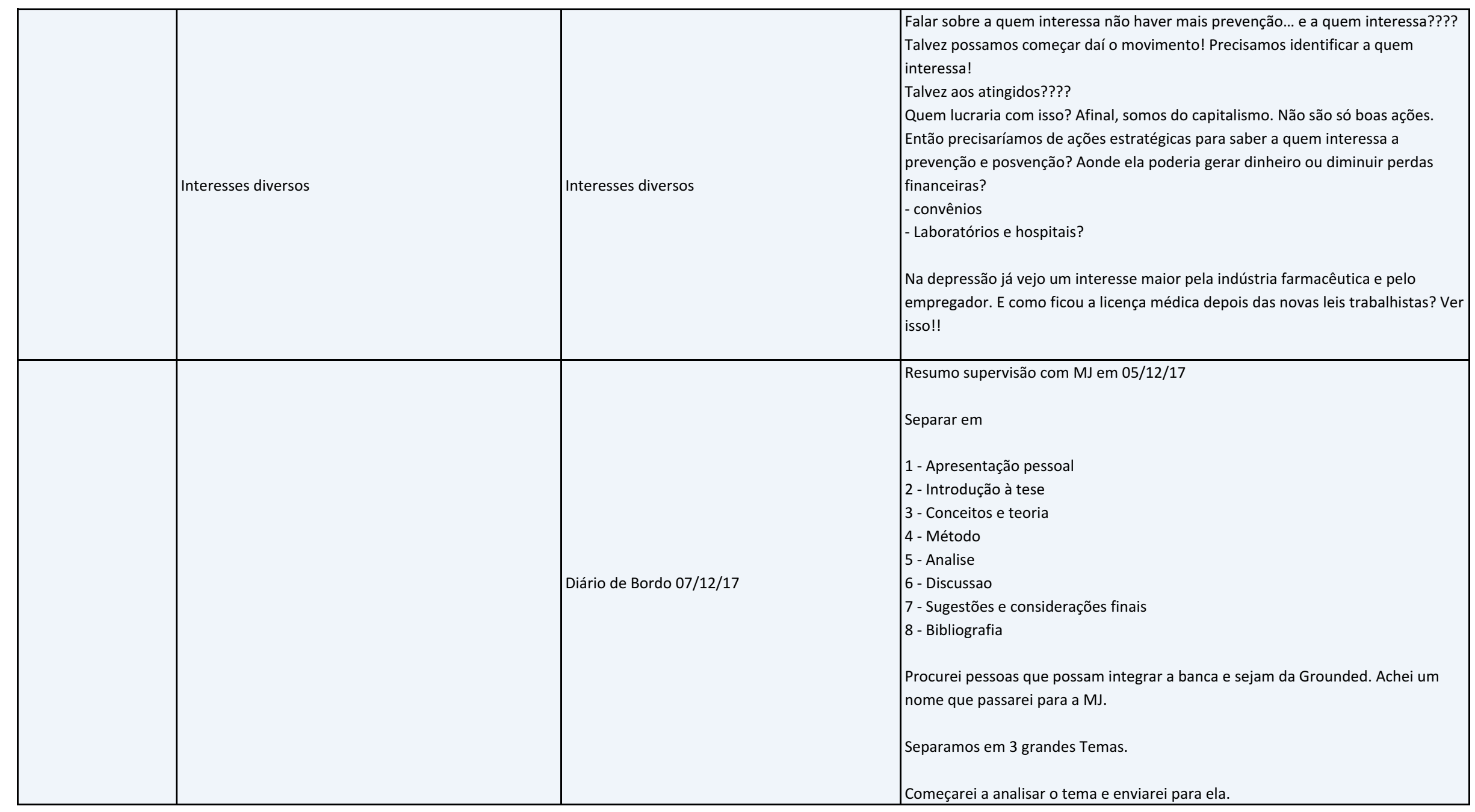




\begin{tabular}{|c|c|c|c|}
\hline & & $x^{2}$ & 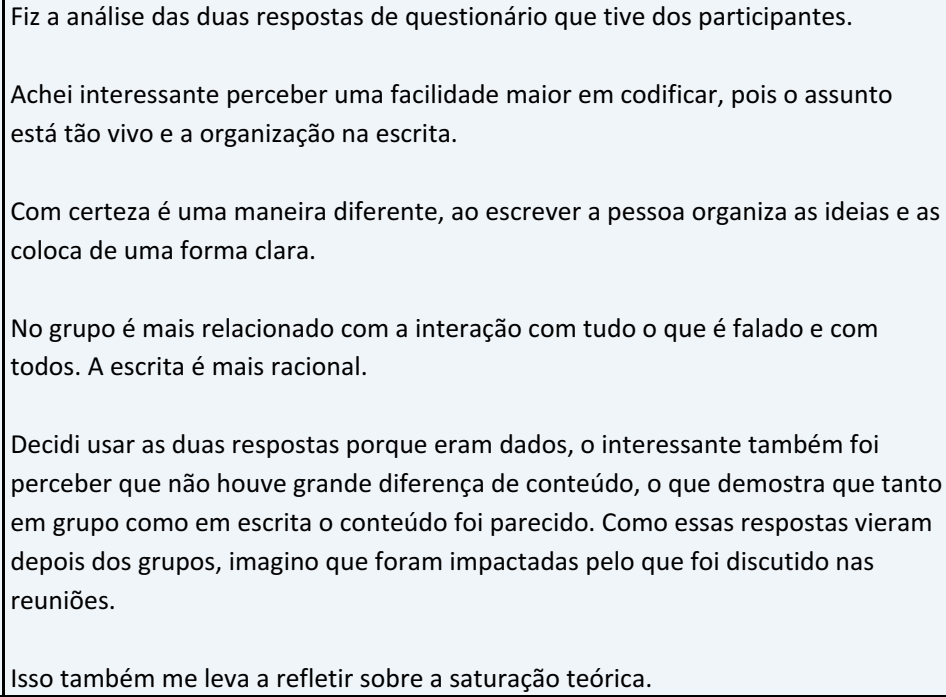 \\
\hline & & 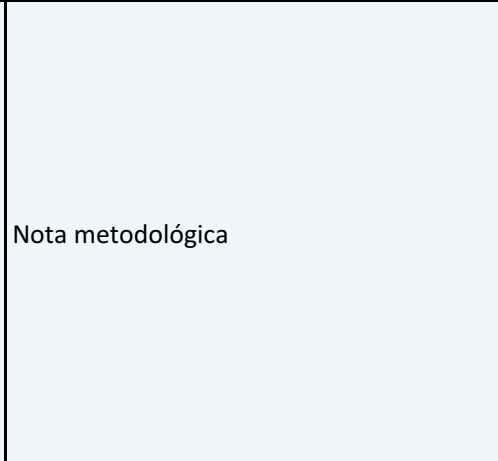 & $\begin{array}{l}\text { Dia 11/12 } \\
\text { Revejo as codificações e categorias e temas. } \\
\text { Coloco as categorias em ordem... na ordem que acho que elas devem ser faladas e } \\
\text { que faz mais sentido na organização do texto } \\
\text { Separo o Tabu de Visão e ele fica como uma categoria separada. } \\
\text { COMPREENSÃO } \\
\text { TABU -> VISÃO -> COMUNICAÇ̃̃O -> EXPERIÊNCIA }\end{array}$ \\
\hline
\end{tabular}




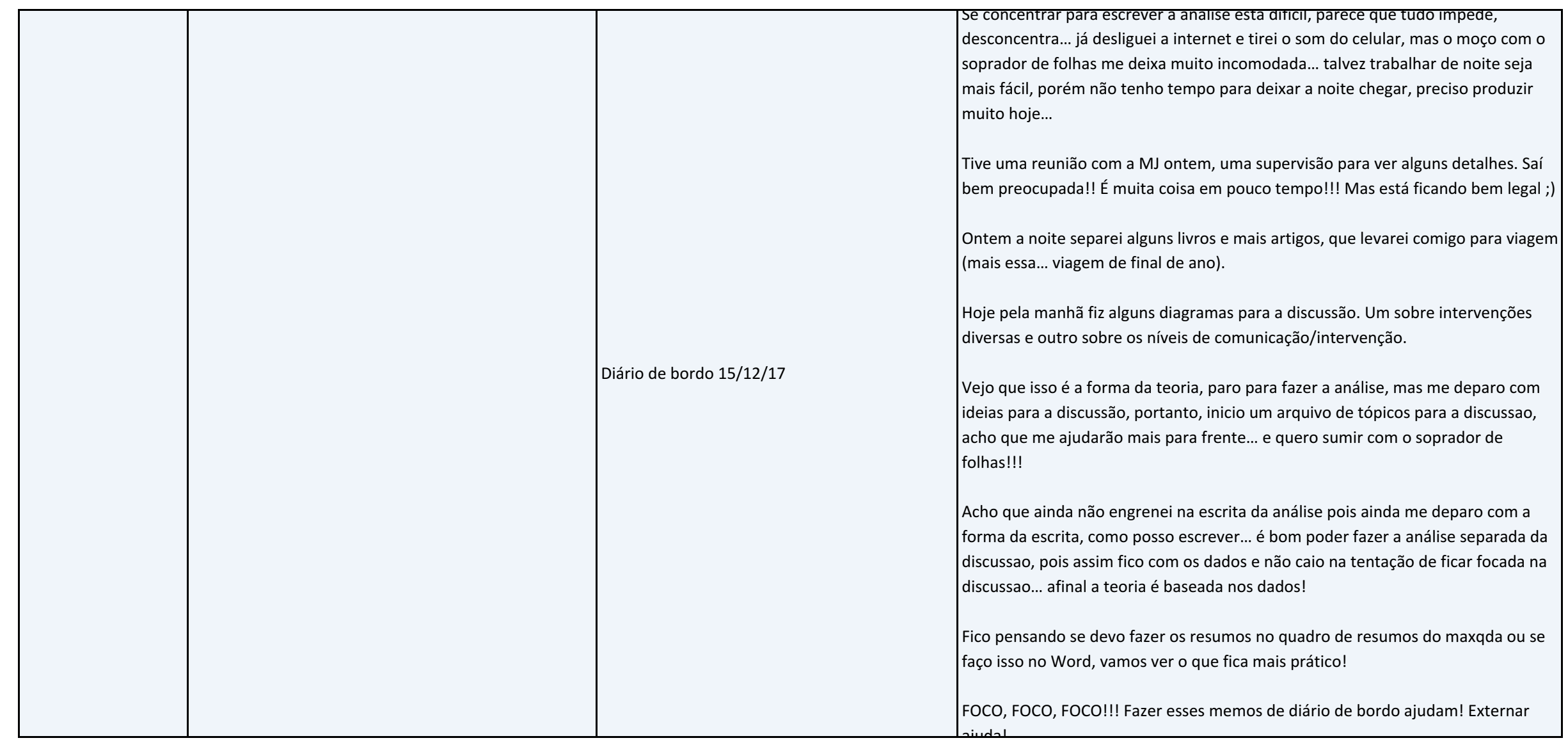




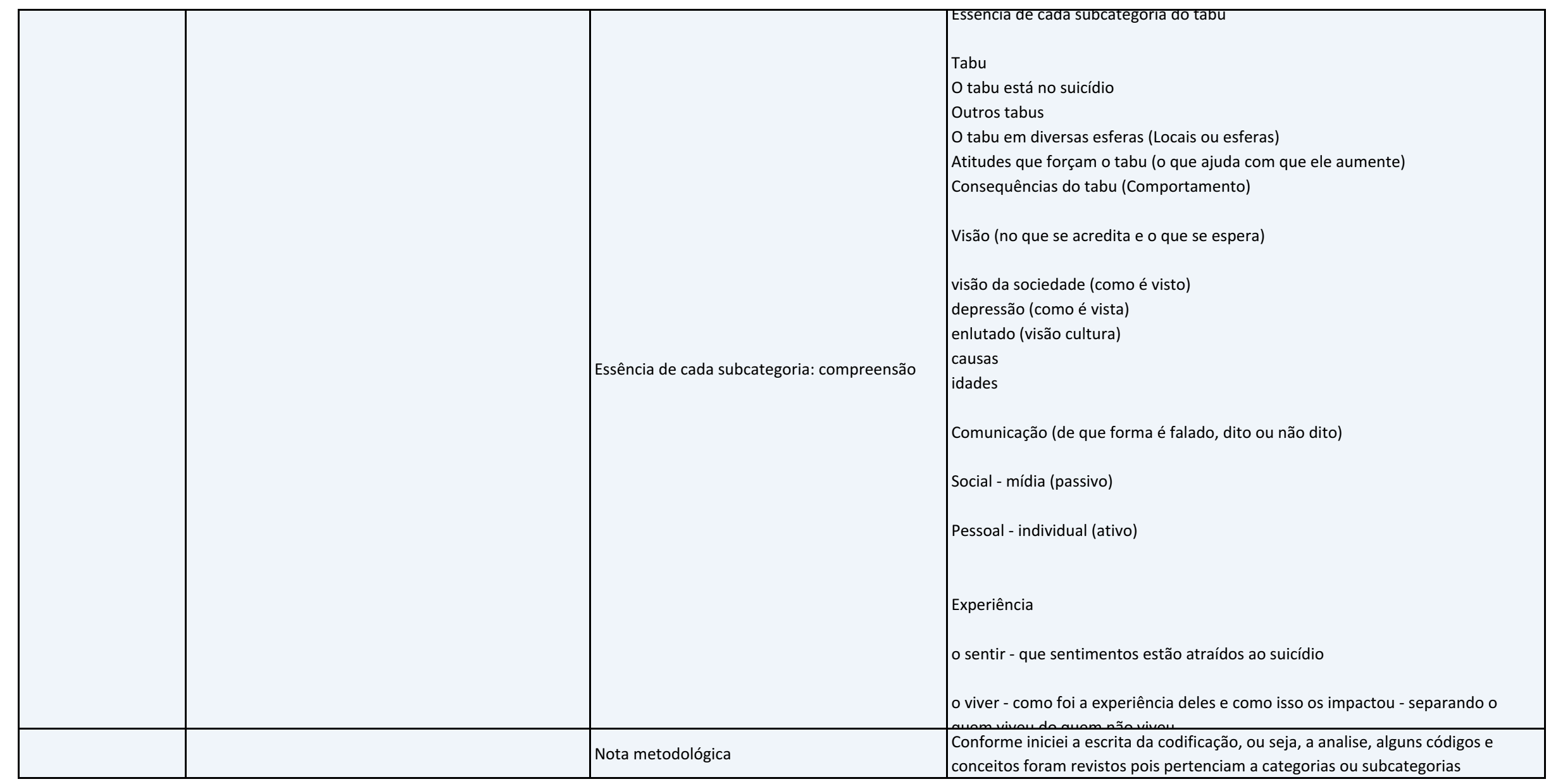




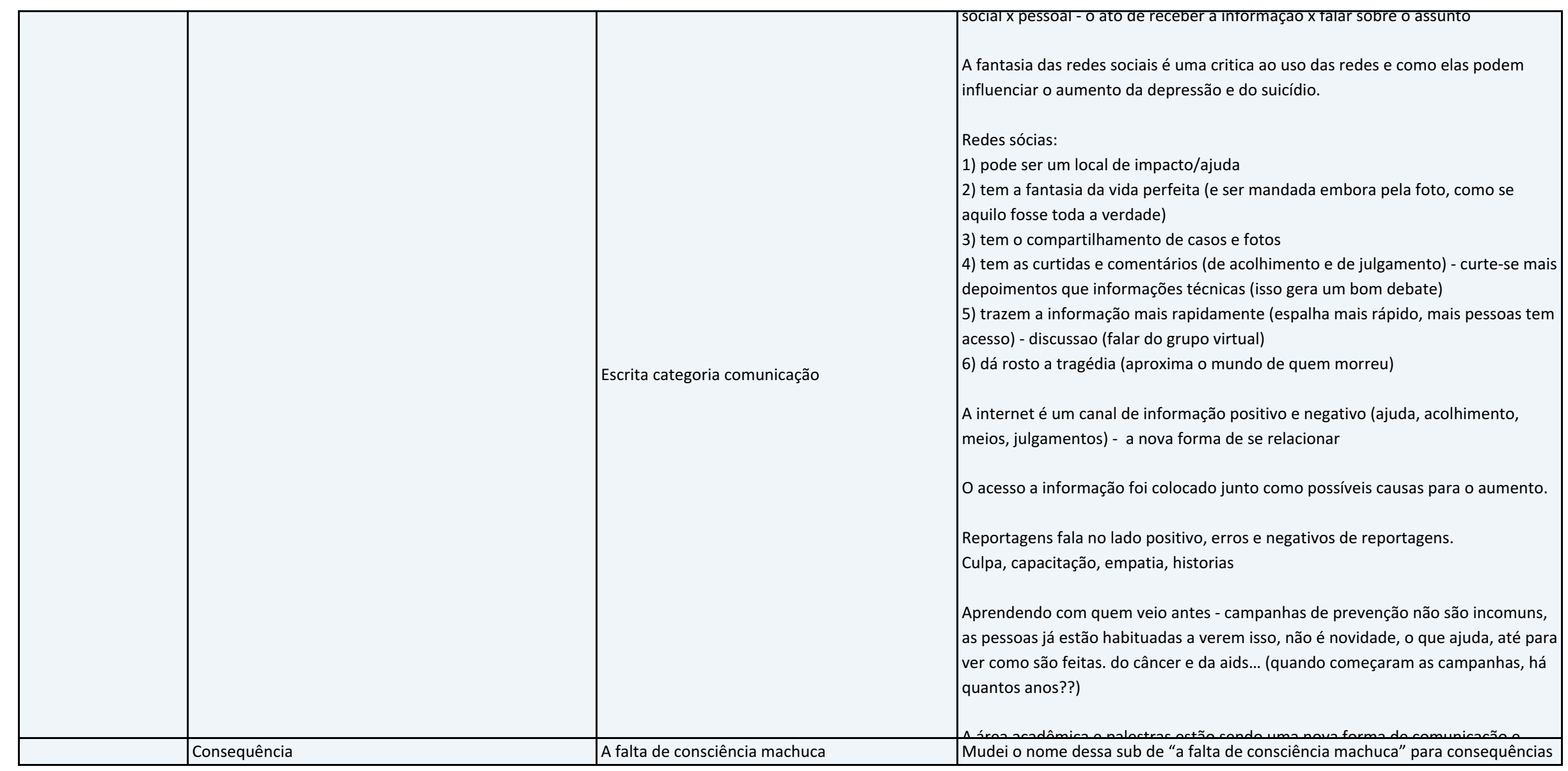




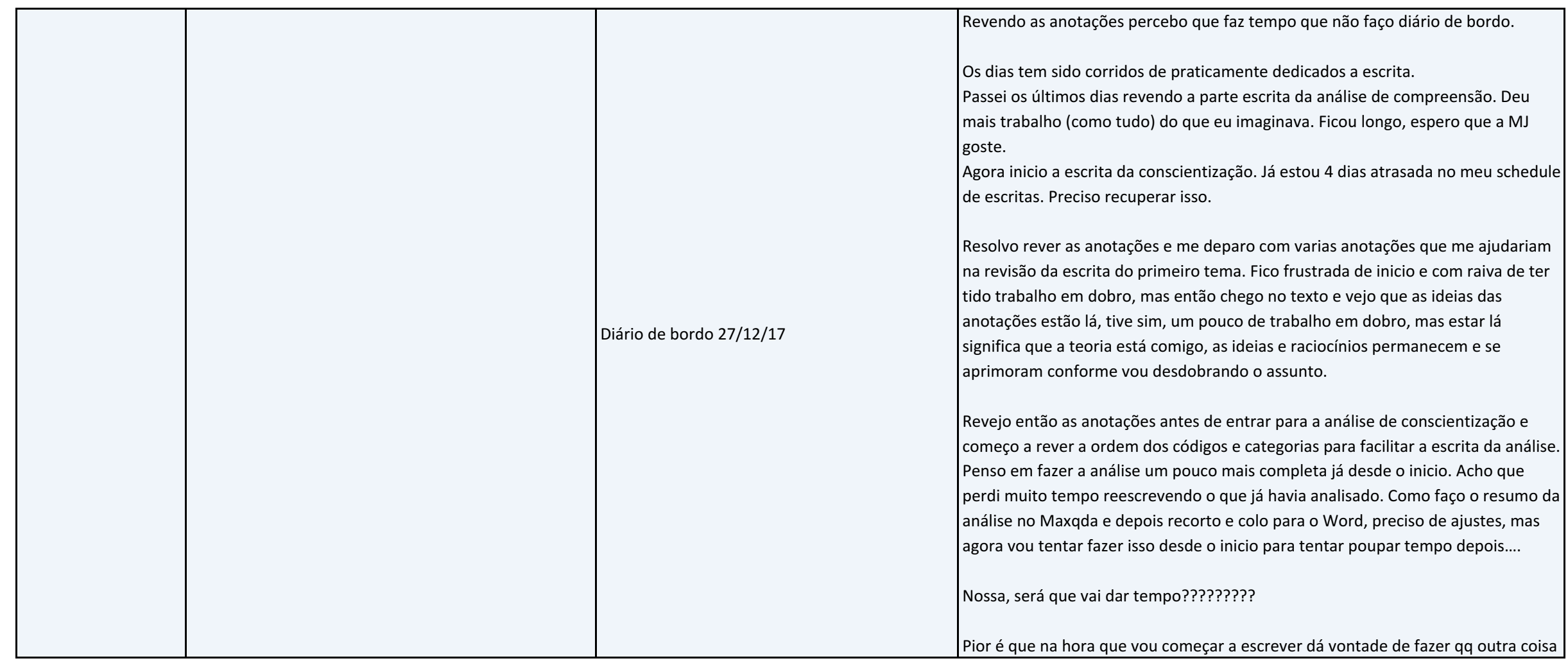




\begin{tabular}{|c|c|c|c|}
\hline & & Essência de cada subcategoria: Conscientização & $\begin{array}{l}\text { Aumento de consciência - quais são as condições para que ela exista e se ela } \\
\text { realmente influencia as pessoas, } \\
\text { Consequências - não tenho certeza se essa é a forma correta de dizer isso. Seriam } \\
\text { consequências sentidas pelos colaboradores (além do tabu?) da falta de consc } \\
\text { publica. Talvez possa linkar isso no aumento de consciência } \\
\text { Prevenção - o quanto a conscientização pode ajudar na prevenção (não esquecer } \\
\text { de discutir que a consciente vai além da prevenção... ela abraça quais áreas????? } \\
\text { pois o obj do trabalho é consc p chegar a prev.... é muito difíil de mensurar os } \\
\text { ganhos reais... ao tratar melhor, pode diminuir suicídios, mas não temos como } \\
\text { medir isso } \\
\text { Formas - exemplos de projetos e ideias para aumentar a consc publica } \\
\text { O absurdo do suicídio - isso era antes o impotência, traz todos os sentimentos } \\
\text { relacionados a impotência e aos questionamentos existenciais que o suicídio gera, } \\
\text { além da prevenção e previsão. } \\
\text { Epidemiologia - a importância dos números e da notificação correta para o aum. } \\
\text { da consc e da prevenção correta, aos sabermos os números podemos focar onde } \\
\text { mais precisa. os números como facilitadores da compreensão da consciencia. falar } \\
\text { da diferença da epidemiologia para a subnotificação... } \\
\text { Complexidade - antes era complexidade de sentimentos - o sh é complexo, assim } \\
\text { como os seus sentimentos, precisa consc disso }\end{array}$ \\
\hline & & Temas centrais? & $\begin{array}{l}\text { Tomada de consciência e diálogo: os desafios para a prevenção e posvenção do } \\
\text { suicídio no Brasil } \\
\text { Tomada de sentido e diálogo: os desafios para o aumento da consciência pública } \\
\text { na prevenção e posvenção do suicídio no Brasil } \\
\text { Tomada de consciência traz envolvimento! }\end{array}$ \\
\hline
\end{tabular}




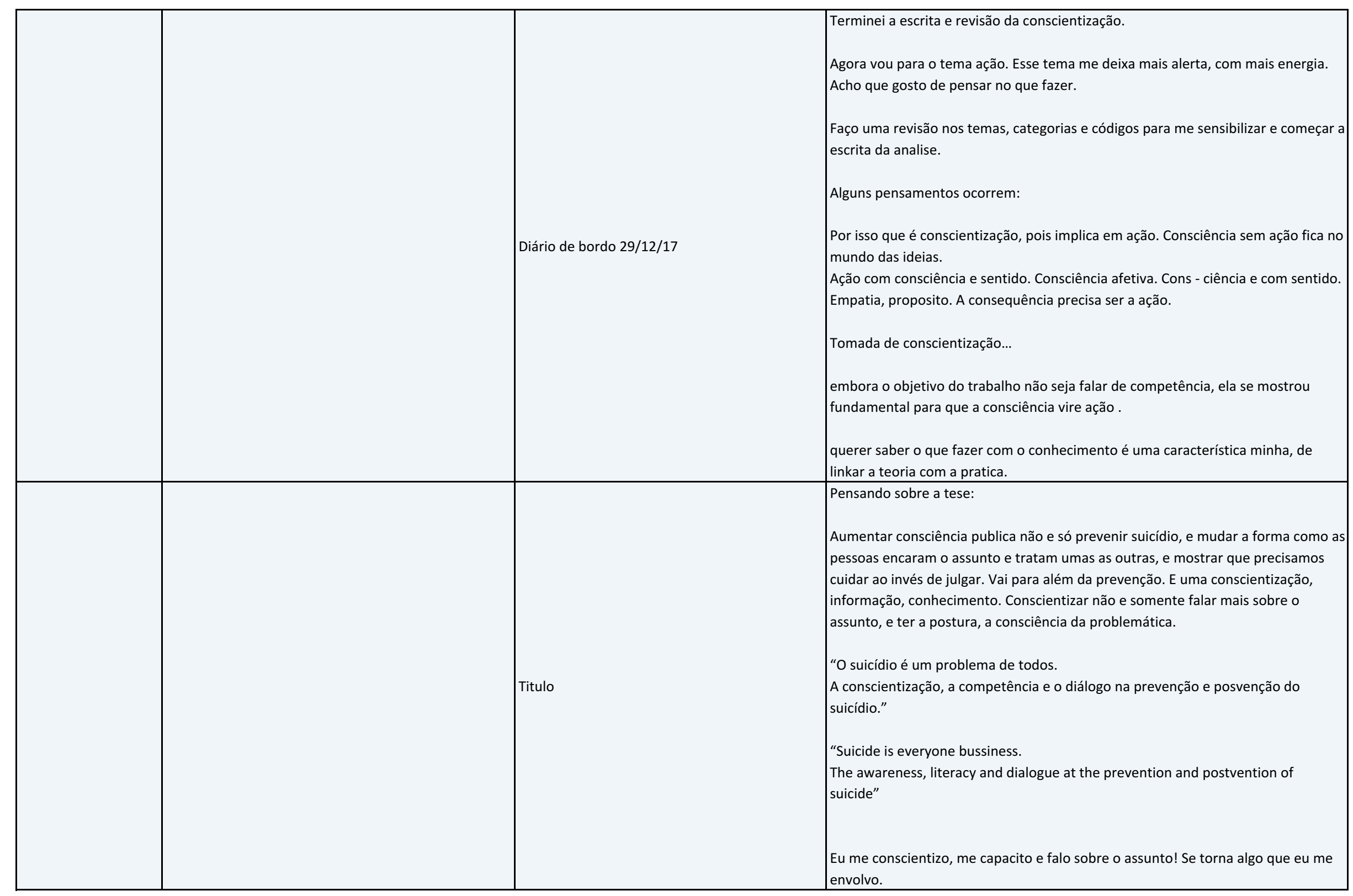




\begin{tabular}{|l|l|l|l|}
\hline & & COISAS PARA REVER & $\begin{array}{l}\text { - sobre o cigarro, não foi uma sugestão de forma, e sim um exemplo de } \\
\text { campanhas que são feitas, que umas pessoas vão aderir e outras não, porém eu } \\
\text { posso colocar isso na discussao!! }\end{array}$ \\
\hline & & Anotação 374 & $\begin{array}{l}\text { A forma do texto da analise vai mudando, isso é um exemplo real de como a } \\
\text { teoria e as ideias vão se formando, se somando e se transformando. }\end{array}$ \\
\hline $\begin{array}{l}\text { Roteiro de perguntas } \\
\text { TL }\end{array}$ & Roteiro de perguntas TL & \\
\hline
\end{tabular}

Material integrante da pesquisa de doutorado de Karen Scavacini

Proibida a reprodução ou utilização sem autorização do autor 2018 
Anexo N - Tabela dos códigos

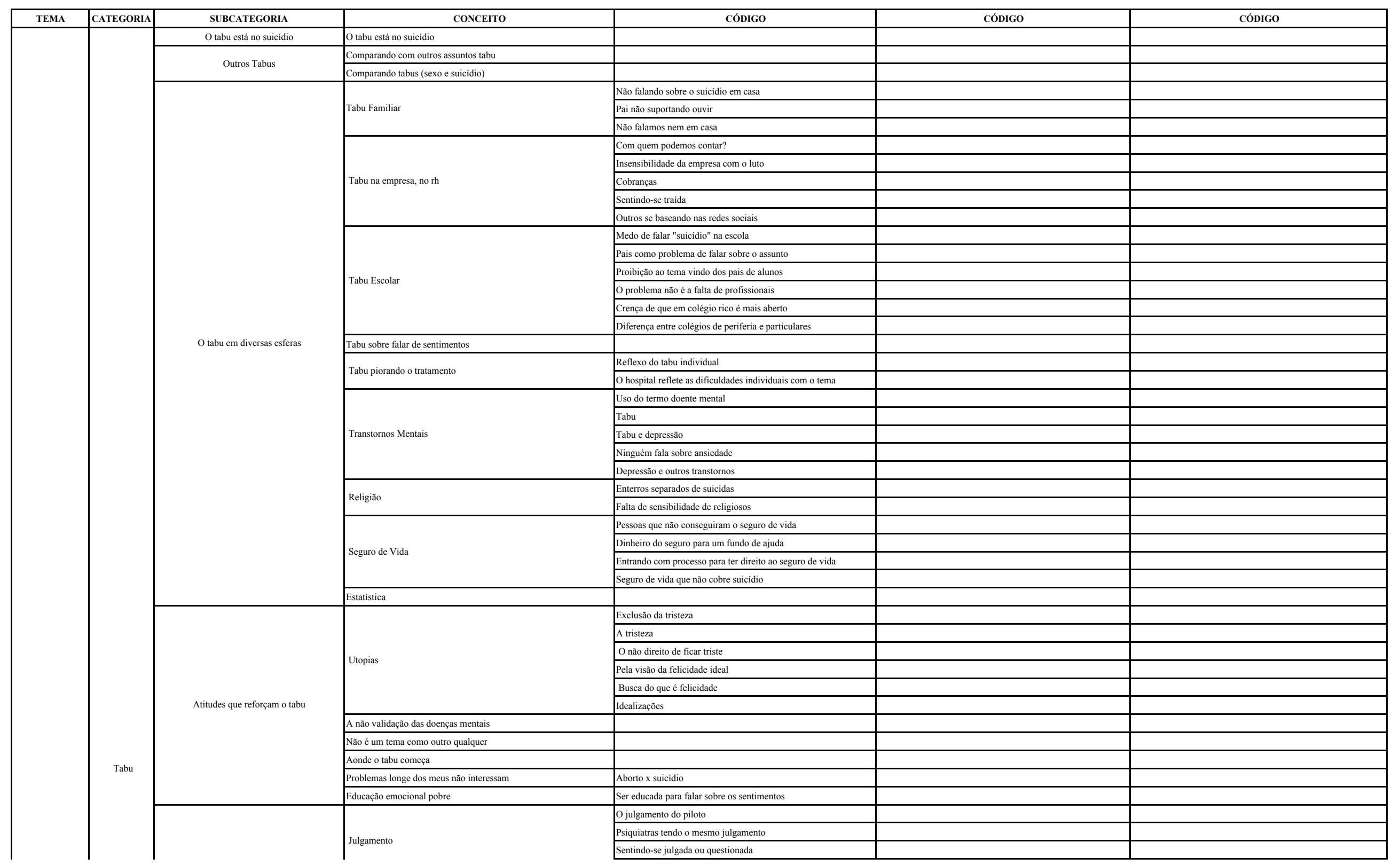

Material integrante da pesquisa de doutorado de Karen Scavacini Proibida a reprodução ou utilização sem autorização prévia do autor - 2018 


\begin{tabular}{|c|c|c|c|c|}
\hline \multirow{36}{*}{ Consequências do tabu } & \multirow{4}{*}{\begin{tabular}{|l} 
\\
Preconceito
\end{tabular}} & \multicolumn{2}{|l|}{\begin{tabular}{|l|} 
Sentindo-se testado e/ou julgado \\
\end{tabular}} & \\
\hline & & & & \\
\hline & & \begin{tabular}{|l|} 
Assunto que as pessoas não falam \\
\end{tabular} & & \\
\hline & & \begin{tabular}{|l|} 
Preconceito e depressão \\
\end{tabular} & & \\
\hline & \multirow{3}{*}{ Estigma } & \begin{tabular}{|l|} 
Estigma da doença mental \\
\end{tabular} & & \\
\hline & & Estigma atrelado a algumas emơ̌̃õs & & \\
\hline & & \begin{tabular}{|l|} 
Preconceito e estigma em falar do assunto \\
\end{tabular} & & \\
\hline & \multirow{7}{*}{ Um assunto proibido } & \begin{tabular}{|l|} 
Recusando aprovar o tabu do tema \\
\end{tabular} & & \\
\hline & & \begin{tabular}{|l|} 
Suicídio era assunto proibido \\
\end{tabular} & & \\
\hline & & \begin{tabular}{|l|}
$\mathrm{O}$ tabu não me surprende \\
\end{tabular} & & \\
\hline & & \begin{tabular}{|l|} 
Quem proibe? \\
\end{tabular} & & \\
\hline & & \begin{tabular}{|l|} 
Vendo o suicídio como algo antigo \\
\end{tabular} & & \\
\hline & & Parecido com a morte & & \\
\hline & & \begin{tabular}{|l|} 
Suicidio é um assunto proibido \\
\end{tabular} & & \\
\hline & \multirow{7}{*}{ O não falar } & Ninguém admite pensar em suicídio & & \\
\hline & & \begin{tabular}{|l|} 
O não falar/dividir levando a pensar na morte \\
\end{tabular} & & \\
\hline & & Não ter que falar & & \\
\hline & & Não falar de dor e luto como defesa do outro & & \\
\hline & & Pessoas não sabem falar sobre o suicídio & & \\
\hline & & \begin{tabular}{|l|} 
Dificuldade de falar sobre o suicidio \\
\end{tabular} & & \\
\hline & & \begin{tabular}{|l|} 
Ninguém gostando de falar sobre o assunto \\
\end{tabular} & & \\
\hline & \multirow{3}{*}{ Afastamento } & \begin{tabular}{|l|} 
Reaçōes negativas das pessoas \\
\end{tabular} & & \\
\hline & & Tabu do suicídio e da morte geram afastamento & & \\
\hline & & Falta de apoio e ajuda amigos e familiares & & \\
\hline & \multirow{5}{*}{ Exclusão } & \begin{tabular}{|l|l|} 
A exclusão \\
\end{tabular} & & \\
\hline & & \begin{tabular}{|l|l} 
O direito conviver com outros - depressão \\
\end{tabular} & & \\
\hline & & \begin{tabular}{|l|} 
Falta de amor \\
\end{tabular} & & \\
\hline & & Agravamento do problema & & \\
\hline & & Culpabilizando??? & & \\
\hline & \multirow{7}{*}{ Mitos } & Sentindo medo de falar & & \\
\hline & & \begin{tabular}{|l|} 
Mito de que as pessoas não falam sobre isso \\
\end{tabular} & & \\
\hline & & \begin{tabular}{|l|} 
Prevenindo ou incentivando \\
\end{tabular} & & \\
\hline & & Falar sobre suicídio gera problema & & \\
\hline & & Falar não faz com que faça & & \\
\hline & & \begin{tabular}{|l|} 
Mito do contágio e da indução \\
\end{tabular} & & \\
\hline & & Pessoas tendo medo em falar sobre suicidio & & \\
\hline & \multirow{8}{*}{ Visão do suicídio hoje no brasil } & Suicídio visto (e tratado?) como crime & & \\
\hline & & \multirow{6}{*}{ Suicida é fraco e covarde } & Já ouvi que quem se suicida é covarde & \\
\hline & & & \begin{tabular}{|l|l|l} 
Visto como fraqueza \\
\end{tabular} & \\
\hline & & & Visto como pecado & \\
\hline & & & Reações ao quem se mata é fraco & \\
\hline & & & Já ouvi falarem que quem se mata é fraco & \\
\hline & & & suicida sendo visto como fraco e covarde & \\
\hline & & A visão cultural do enlutado & Pode enlutar, mas não aqui & \\
\hline & & \multirow{5}{*}{ Causa e efeito } & \begin{tabular}{|l|l|} 
Causa única \\
\end{tabular} & \\
\hline & & & \multirow{4}{*}{ Pessoas (e psiquiatras) procurando razão única } & Provando para um primo que não foi por drogas \\
\hline & & & & A forma pronta \\
\hline & & & & \begin{tabular}{|l} 
Psiquiatras buscando causa única? \\
\end{tabular} \\
\hline & & & & Pessoas querendo culpados e razoes simples \\
\hline
\end{tabular}

Material integrante da pesquisa de doutorado de Karen Scavacini Proibida a reprodução ou utilização sem autorização prévia do autor - 2018 


\begin{tabular}{|c|c|c|c|c|c|}
\hline & & & & & \begin{tabular}{|l|} 
Suicidioc como causa e efeito \\
Visto de forma simplista
\end{tabular} \\
\hline & & Causas do sucicidio & & & Pessoas buscando explicaçöes simple \\
\hline & & & & Crenças sobre suicidio de jovens & Jovens se matam por causa de de rogas \\
\hline & Visão da sociedade & & Culpando differente pelas idades & Crengas de suicidio de mais velhos & \\
\hline & & & \begin{tabular}{|l} 
Suicidio por impulso \\
\end{tabular} & & \\
\hline & & & Suicidio e depressào & Culpa da depressão & \\
\hline & & & Suicidio e familiaia & & \\
\hline & & & Suicidio e orgulho & & \\
\hline Visão & & & & \begin{tabular}{|l|l} 
Amigos achando que depressão não tem haver com eles \\
\end{tabular} & \\
\hline & & & & \begin{tabular}{|l|l} 
Depressăo como mentira para não traballar \\
\end{tabular} & \\
\hline & & & Tabue depressăa & Socicdade trazendo os significados ruins da depressão & \\
\hline & & & & \begin{tabular}{|l|l|l} 
Eepressão e frescura \\
\end{tabular} & \\
\hline & & & & \begin{tabular}{|l} 
Outros achando que familia tem problemas \\
\end{tabular} & \\
\hline & & & & Dificil de compreender a depressăo & \\
\hline & & Depressāo & & \begin{tabular}{|l} 
Ninguém notando a depressão e a ideação \\
\end{tabular} & \\
\hline & & & & \begin{tabular}{|l|l} 
Sentindo que depressão não se explica fácil \\
\end{tabular} & \\
\hline & & & & \begin{tabular}{|l|} 
Buscando motivo para depressão \\
\end{tabular} & \\
\hline & & & Falta de entendimento & 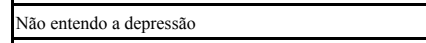 & \\
\hline & & & & \begin{tabular}{|l} 
Pessoas nă e entendem a depressăóo \\
\end{tabular} & \\
\hline & & & & \begin{tabular}{|l|} 
Pessoas nãa acreditando na depressão \\
\end{tabular} & \\
\hline & & & & Pessoas buscando justificativa para depressão & \\
\hline & & & \begin{tabular}{|l|l} 
A visão do suicidio para a criança \\
\end{tabular} & & \\
\hline & & Visão infantil & Suicidio como forma de morrer & & \\
\hline & & & Diferencas familiares na fala sobre o suicidio & & \\
\hline & & & Curiosidade da morte & & \\
\hline & & & \begin{tabular}{|l|l} 
detathlhs mórbbidos \\
\end{tabular} & & \\
\hline & Causa Mortis(9) & & \begin{tabular}{|l|l} 
curiosidated das pesssas \\
\end{tabular} & & \\
\hline & & Curiosidade mórbida & Suicidio como espetíaulo & & \\
\hline & & & \begin{tabular}{|l|} 
Pessoas sendo curiosas \\
\end{tabular} & & \\
\hline & & & Todas as pessoas só querendo isso? & & \\
\hline & & & Outros buscando a forma da morte & & \\
\hline & & & Jis se fala mais de suicidio hoje & & \\
\hline & & & $\begin{array}{l}\text { Hoje jaja se falla mais sobre o suicicioio } \\
\end{array}$ & & \\
\hline & & & \begin{tabular}{|l|l|l} 
Assunto na midia \\
\end{tabular} & & \\
\hline & & & \begin{tabular}{|l|} 
A mídia já fala mais \\
\end{tabular} & & \\
\hline & & & Hoje se fala mais & & \\
\hline & & & 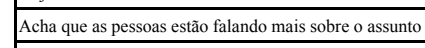 & & \\
\hline & & & Em palestras de suporte & & \\
\hline & & Aumento da comunicazăá & \begin{tabular}{|l|} 
Ouvindo dentro da empresa \\
\end{tabular} & & \\
\hline & & & \begin{tabular}{|l|} 
A informaăăo chega mesmo sem procurar \\
\end{tabular} & & \\
\hline & & & \begin{tabular}{|l|l} 
Năo vêu um aumento no falar sobre o assunto \\
\end{tabular} & & \\
\hline & & & 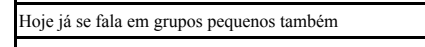 & & \\
\hline & & & & Falando do assunto para a midia & \\
\hline & & & Midiai incluindo os sobreviventes & Informando sobre um programa que participou & \\
\hline & & & & Familia dando depoimento na televisião & \\
\hline & & & \begin{tabular}{|l|} 
Suicidio como assunto da moda \\
\end{tabular} & As pessoas falam de assuntos da moda & Depressão - a doença da moda \\
\hline & & & \begin{tabular}{|l|} 
O que aumentou foi a relevancia do toma \\
\end{tabular} & & \\
\hline & & & \begin{tabular}{|l|} 
Suicídio está ficando mais comum \\
\end{tabular} & & \\
\hline
\end{tabular}




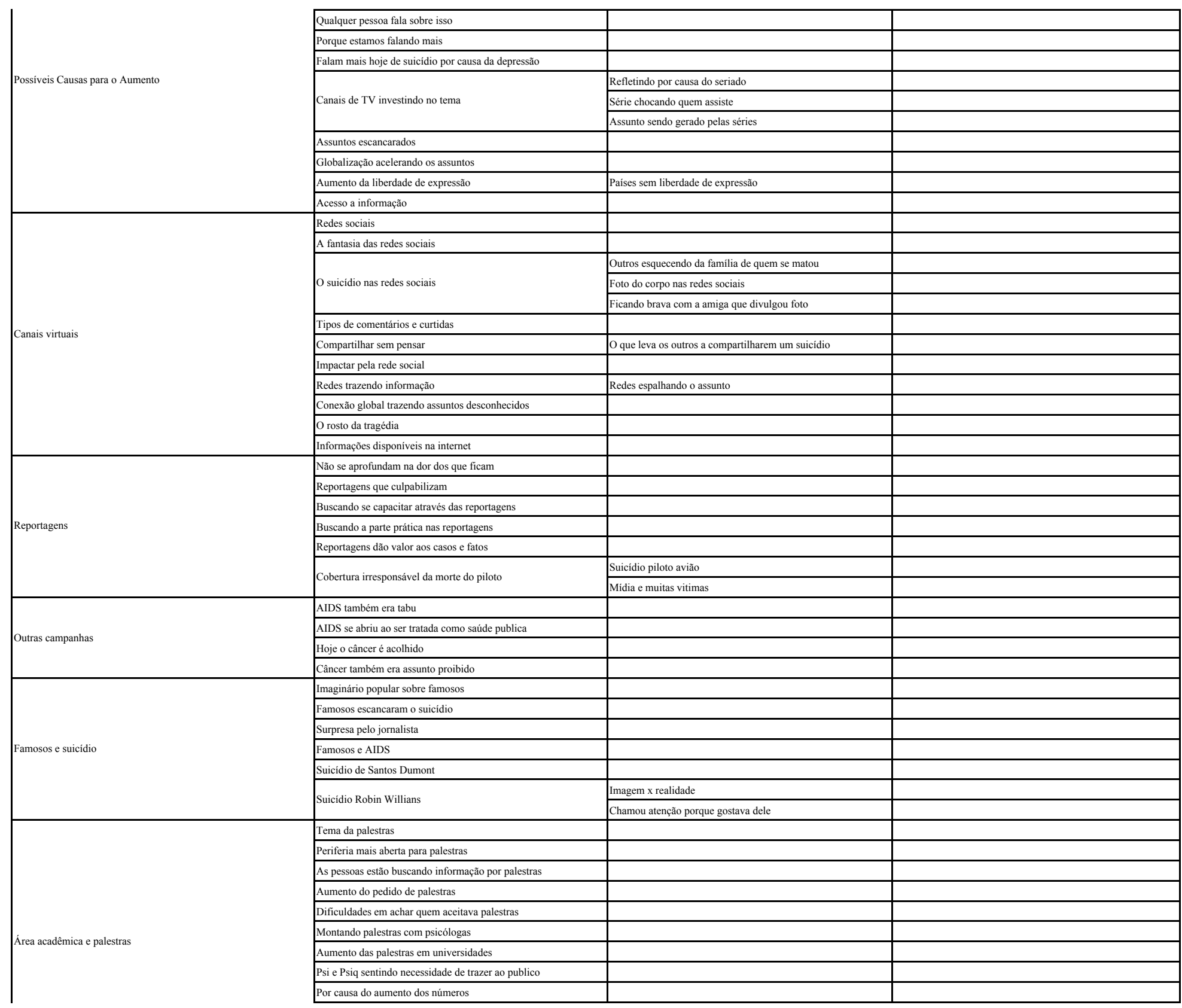

Material integrante da pesquisa de doutorado de Karen Scavacini Proibida a reprodução ou utilização sem autorização prévia do autor - 2018 


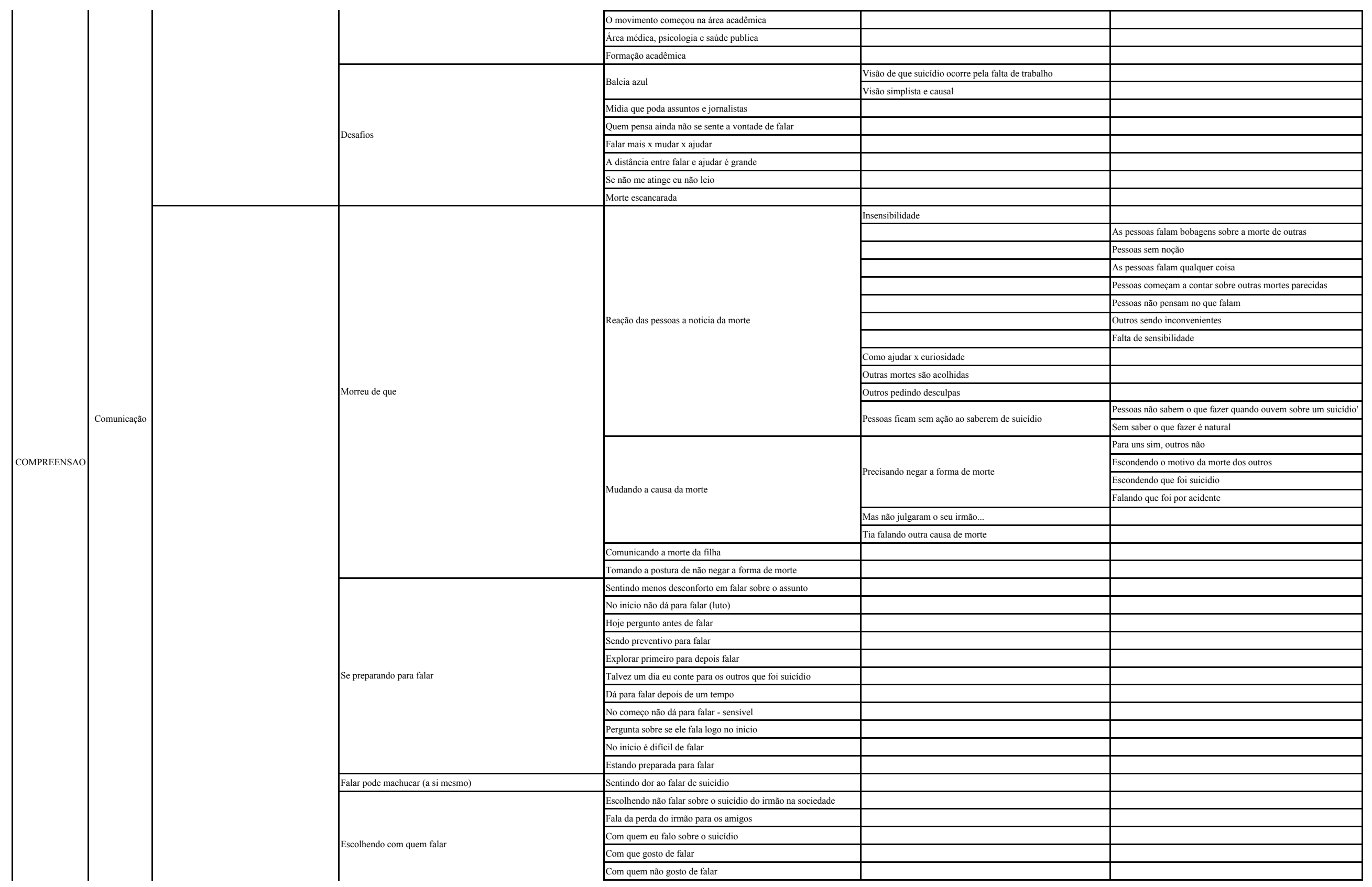




\begin{tabular}{|c|c|c|c|}
\hline & \multirow{2}{*}{\multicolumn{2}{|c|}{ Se sentindo a vontade de falar com prima psicóloga }} & \\
\hline & & & \\
\hline \multirow{9}{*}{ Dificuldades comunicação familiar } & Família não gosta de conversar sobre o assunto & & \\
\hline & Familia não quer conversar sobre o assunto & & \\
\hline & Familia mais geral fala sobre instituto não sobre a fillha que $m$ & & \\
\hline & \begin{tabular}{|l|} 
Achando que machuca os fillos ao falar \\
\end{tabular} & & \\
\hline & Filhos com dificuldade de tocar no assunto & & \\
\hline & Falta de comunicação & & \\
\hline & Não falando do assunto em família & & \\
\hline & Não falando abertamente na família & & \\
\hline & Ela não querendo falar sobre o assunto & & \\
\hline \multirow{4}{*}{ Falando abertamente na sociedade } & Colocando para fora o que aconteceu & & \\
\hline & Falando sobre suicidio com naturalidade infantil & & \\
\hline & Falando sobre o suicidio para outros & & \\
\hline & \begin{tabular}{|l|l} 
Estando aberta para falar \\
\end{tabular} & & \\
\hline \multirow{8}{*}{ Falando abertamente na familia } & Para a familia é transparente falar do suicídio da fillha & & \\
\hline & \begin{tabular}{|l|} 
Conversando sobre doenças criticas com a familia \\
\end{tabular} & & \\
\hline & \begin{tabular}{|l|} 
Sempre conversamos sobre suicidio em família \\
\end{tabular} & & \\
\hline & Com cada parte da família é diferente a conversa & & \\
\hline & \begin{tabular}{|l|} 
Conversando sobre suicidio na família \\
\end{tabular} & & \\
\hline & \begin{tabular}{|l|l|l|l|l} 
Falando sobre o suicídio \\
\end{tabular} & & \\
\hline & \begin{tabular}{|l|l} 
Familia falando mais sobre o assunto \\
\end{tabular} & & \\
\hline & Falando abertamente sobre suicídio em família & & \\
\hline \multirow{12}{*}{ Conversando com amigos } & Filme x experiência pessoal & & \\
\hline & Procurando os amigos para conversar & & \\
\hline & \begin{tabular}{|l|} 
Conhecidos mudando o assunto \\
\end{tabular} & & \\
\hline & Tocando no assunto com conhecidos & & \\
\hline & \begin{tabular}{|l|} 
Conversando com poucas pessoas \\
\end{tabular} & & \\
\hline & \begin{tabular}{|l|} 
Sentindo receio de falar com alguns amigos \\
\end{tabular} & & \\
\hline & Dificuldade de falar sobre a morte do irmão com amigos & & \\
\hline & \begin{tabular}{|l|} 
Conversando sobre suicidio com amigos \\
\end{tabular} & & \\
\hline & \begin{tabular}{|l|} 
Não falando com amigos \\
\end{tabular} & & \\
\hline & Tentando falar com os amigos & & \\
\hline & \begin{tabular}{|l|} 
Os de fora tem receio de falar \\
\end{tabular} & & \\
\hline & Conversando pouco com colegas & & \\
\hline \multirow{15}{*}{ Reaçōes } & \multirow{14}{*}{ Negativas } & Sofrendo resistência por compartilhar informação & \\
\hline & & \begin{tabular}{|l|} 
Tema criando afastamento com amigo \\
\end{tabular} & \\
\hline & & \begin{tabular}{|l|} 
Reação negativa do amigo \\
\end{tabular} & \\
\hline & & Pessoas tendo reaçōes agressivas sobre suicídio & \\
\hline & & \begin{tabular}{|l|} 
Sentindo cortada pelas pessoas \\
\end{tabular} & \\
\hline & & \begin{tabular}{|l|l} 
O que me impede de falar \\
\end{tabular} & \\
\hline & & \begin{tabular}{|l|} 
A necessidade de defesa \\
\end{tabular} & \\
\hline & & \begin{tabular}{|l|} 
Sentindo julgamento \\
\end{tabular} & \\
\hline & & \begin{tabular}{|l|} 
Sentindo machucada e cutucada \\
\end{tabular} & \\
\hline & & \begin{tabular}{|l|} 
Desconforto \\
\end{tabular} & Outros com mais desconforto do que dor \\
\hline & & \multirow{4}{*}{ Falta de suporte e agressão } & Solidão \\
\hline & & & \begin{tabular}{|l|} 
Não tendo o suporte do amigo \\
\end{tabular} \\
\hline & & & Entendendo a agressão como mecanismo de defesa \\
\hline & & & Ficando sem entender o porque da reação \\
\hline & & Pessoas ficando interessadas no tema & \\
\hline
\end{tabular}

Material integrante da pesquisa de doutorado de Karen Scavacini Proibida a reprodução ou utilização sem autorização prévia do autor - 2018 


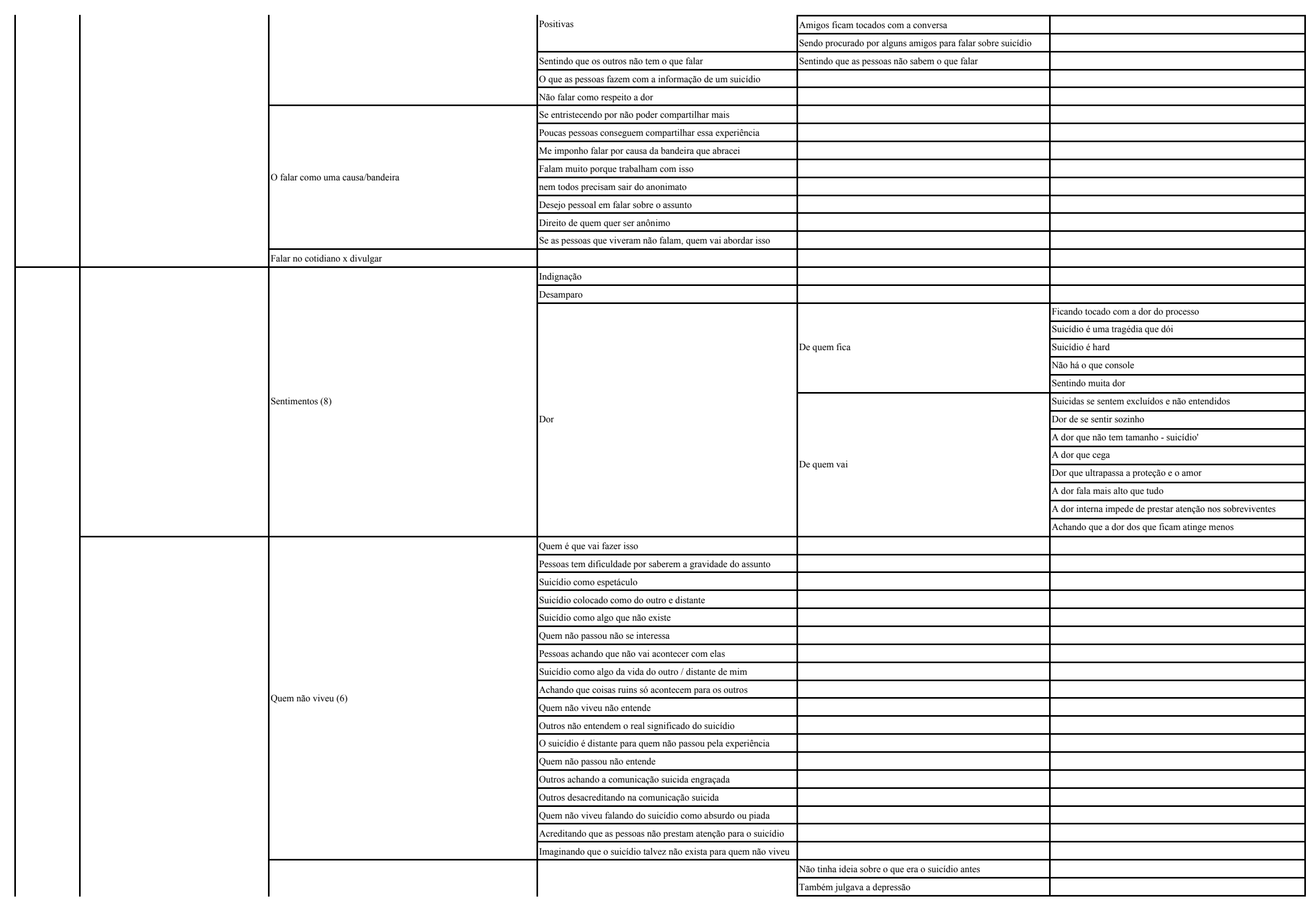




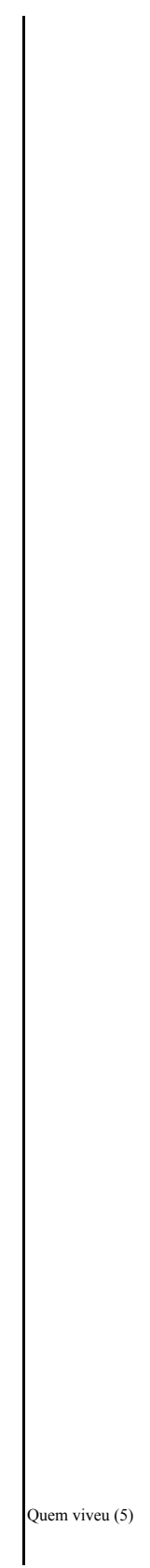

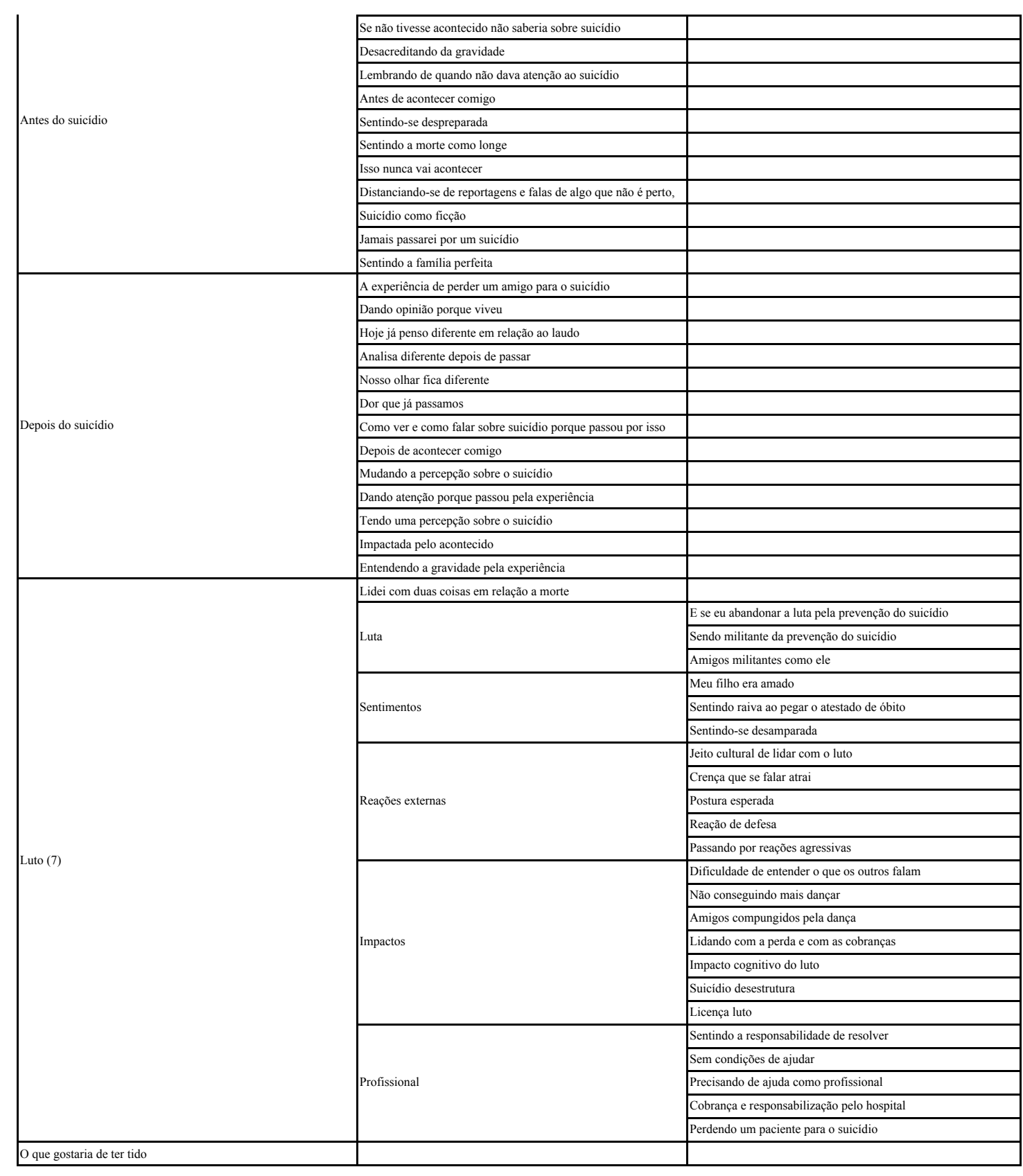

Material integrante da pesquisa de doutorado de Karen Scavacini Proibida a reprodução ou utilização sem autorização prévia do autor - 2018 


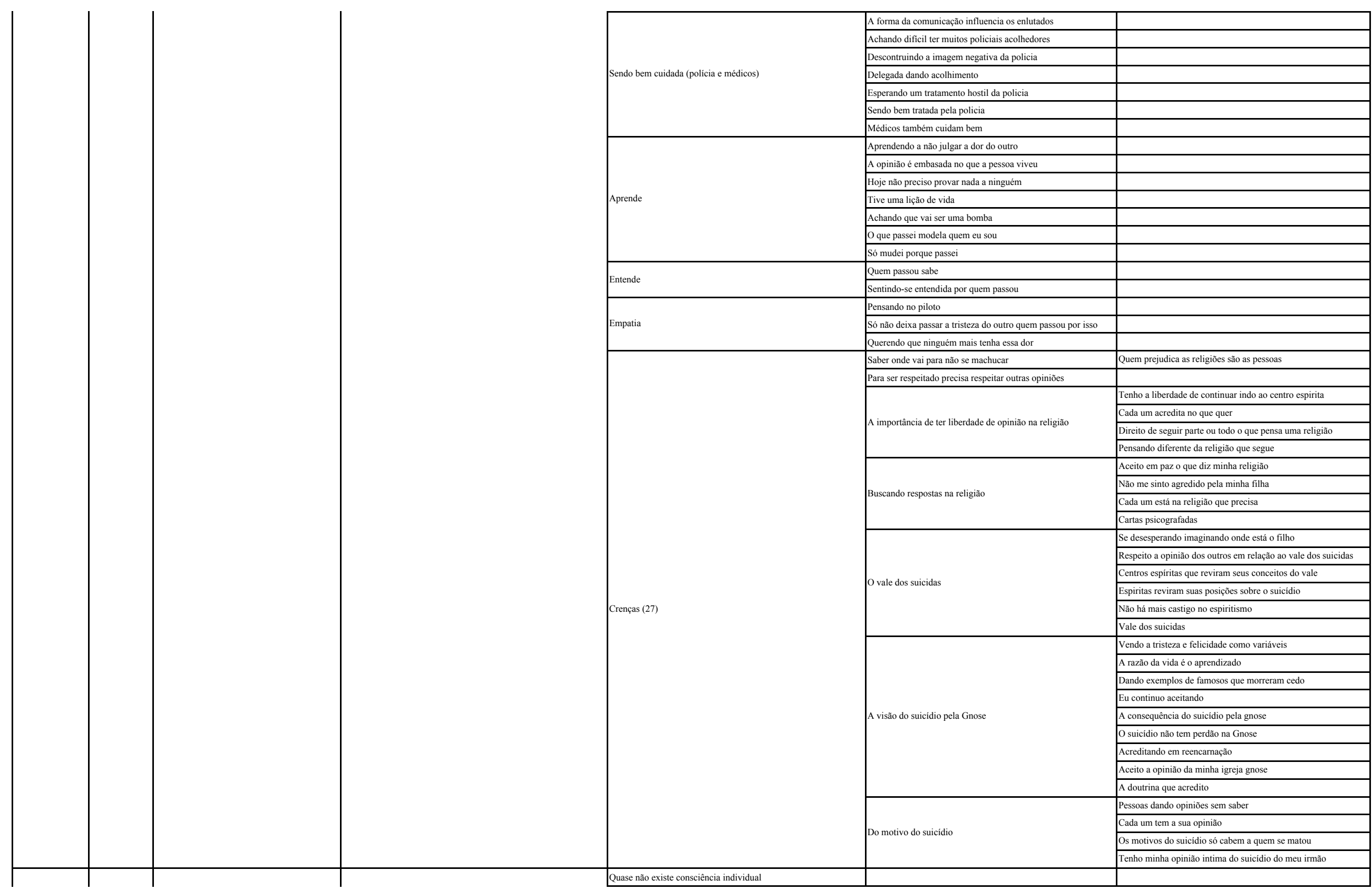

Material integrante da pesquisa de doutorado de Karen Scavacini Proibida a reprodução ou utilização sem autorização prévia do autor - 2018 


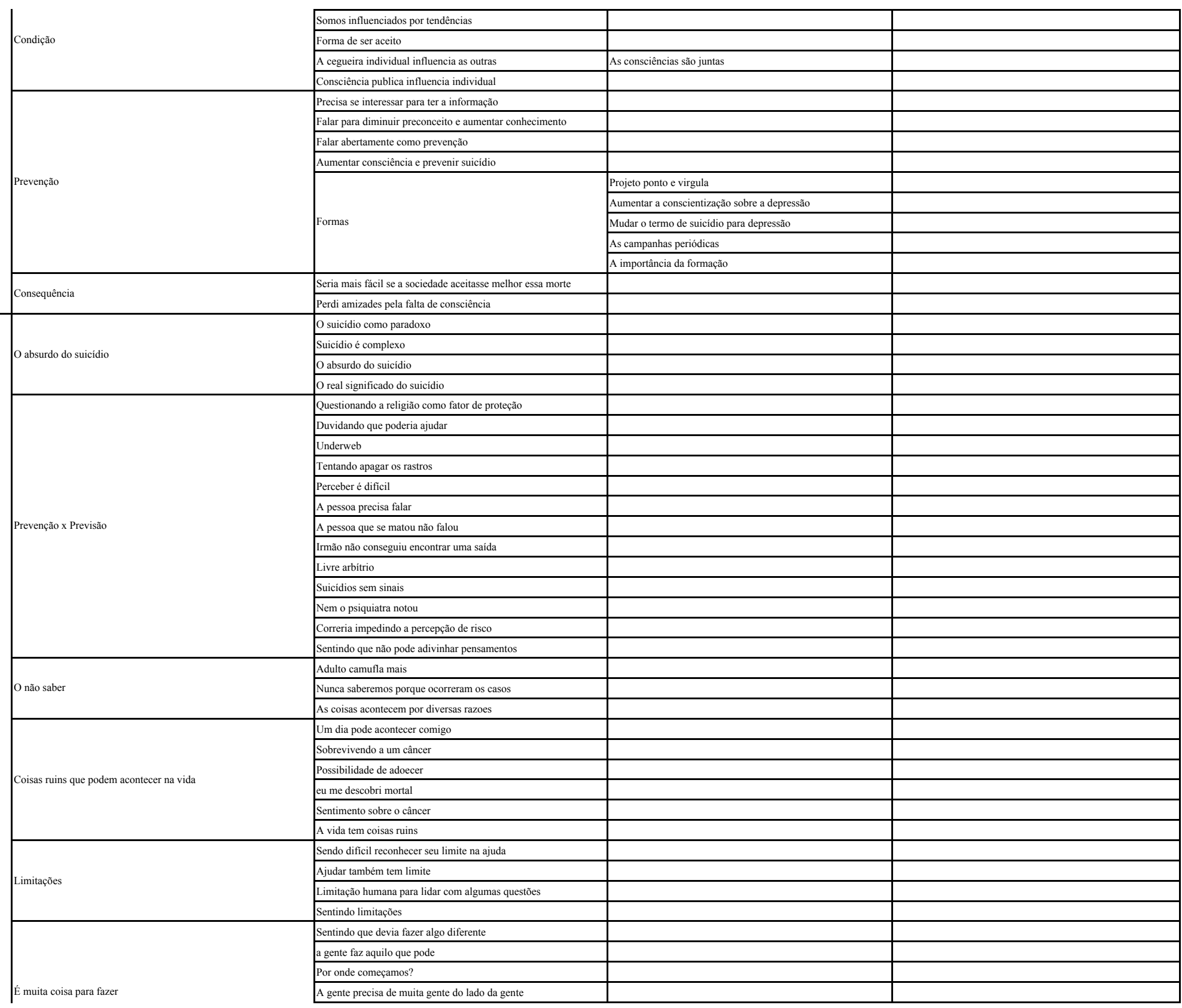

Material integrante da pesquisa de doutorado de Karen Scavacini Proibida a reprodução ou utilização sem autorização prévia do autor - 2018 


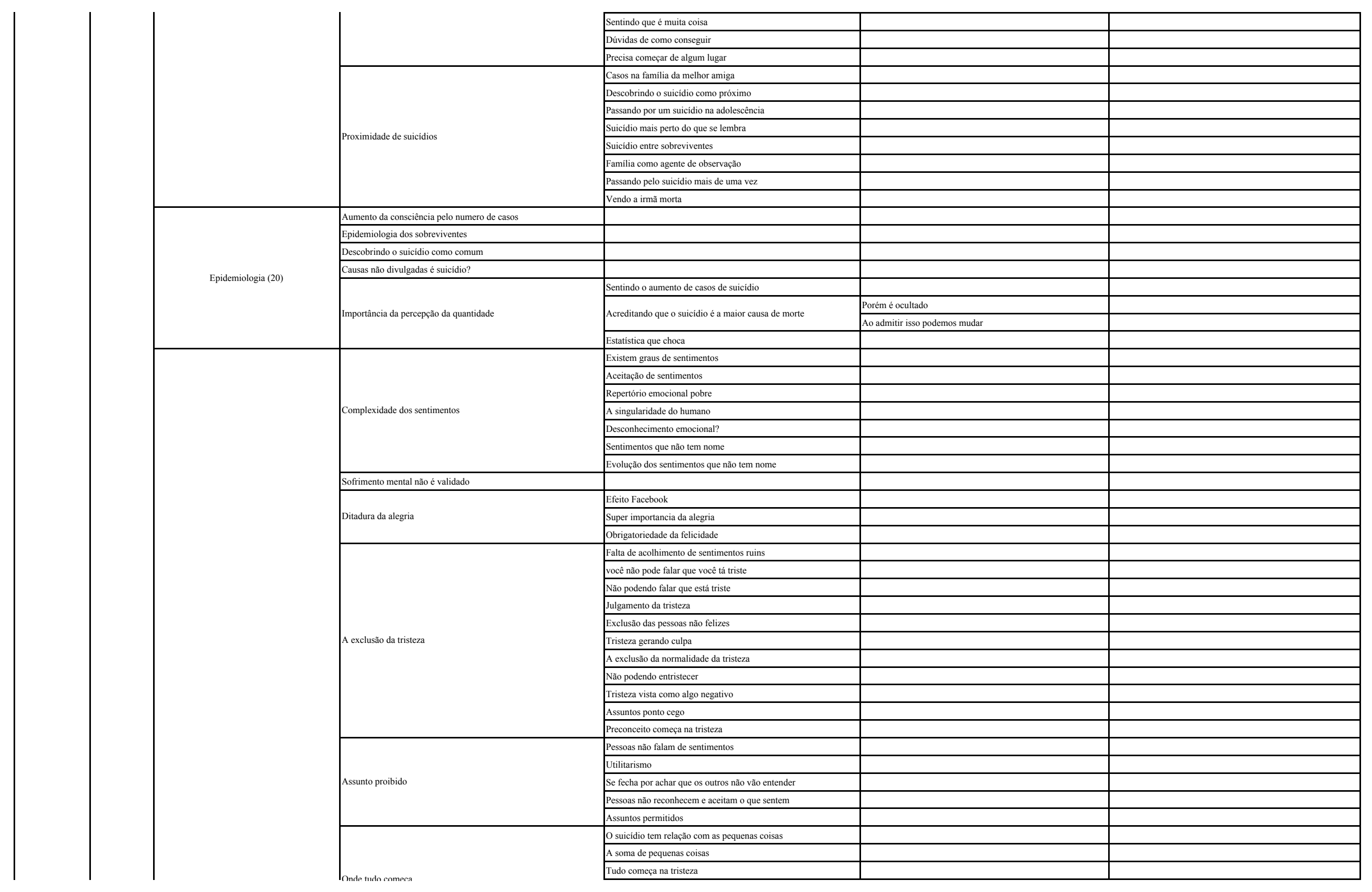




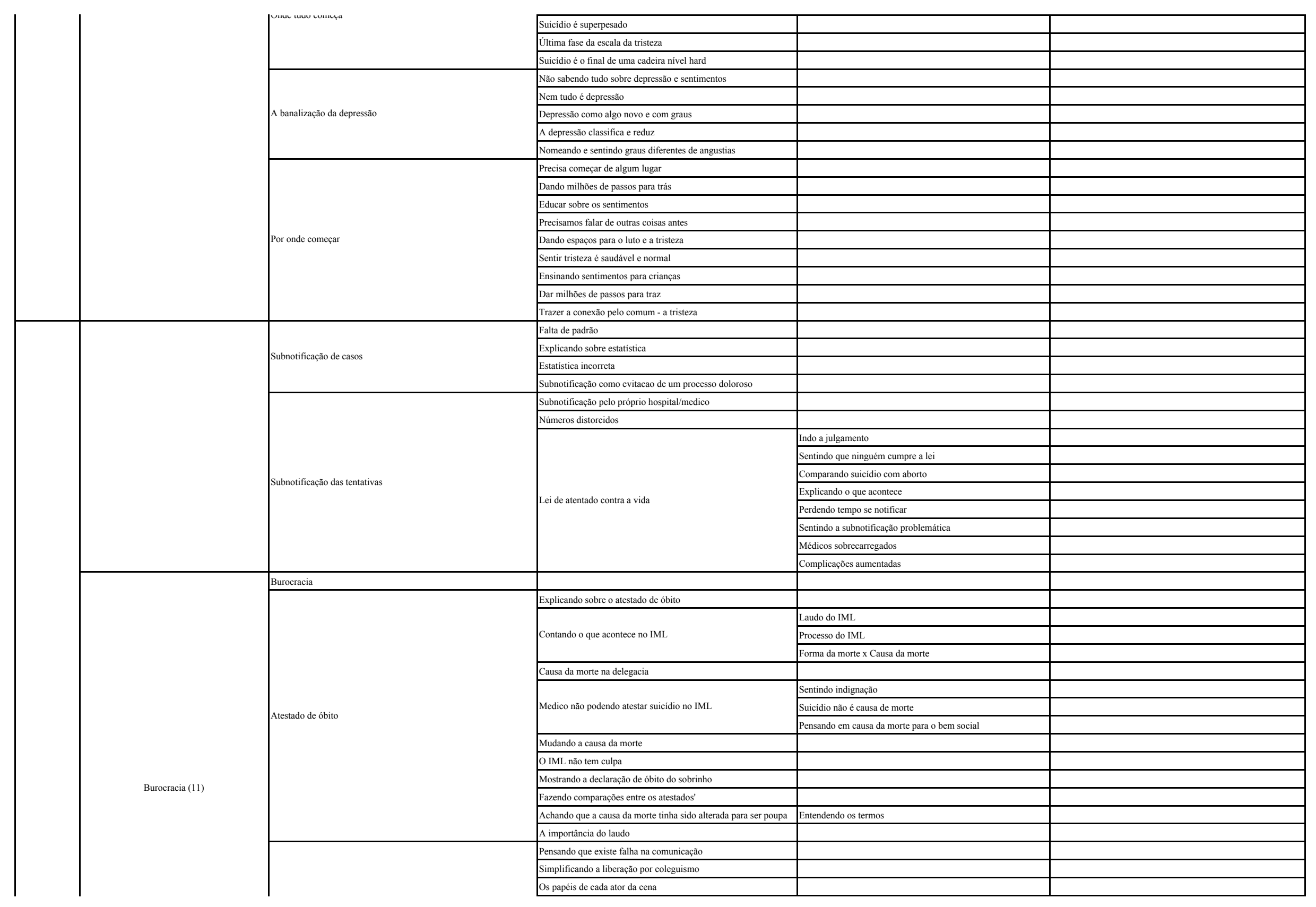




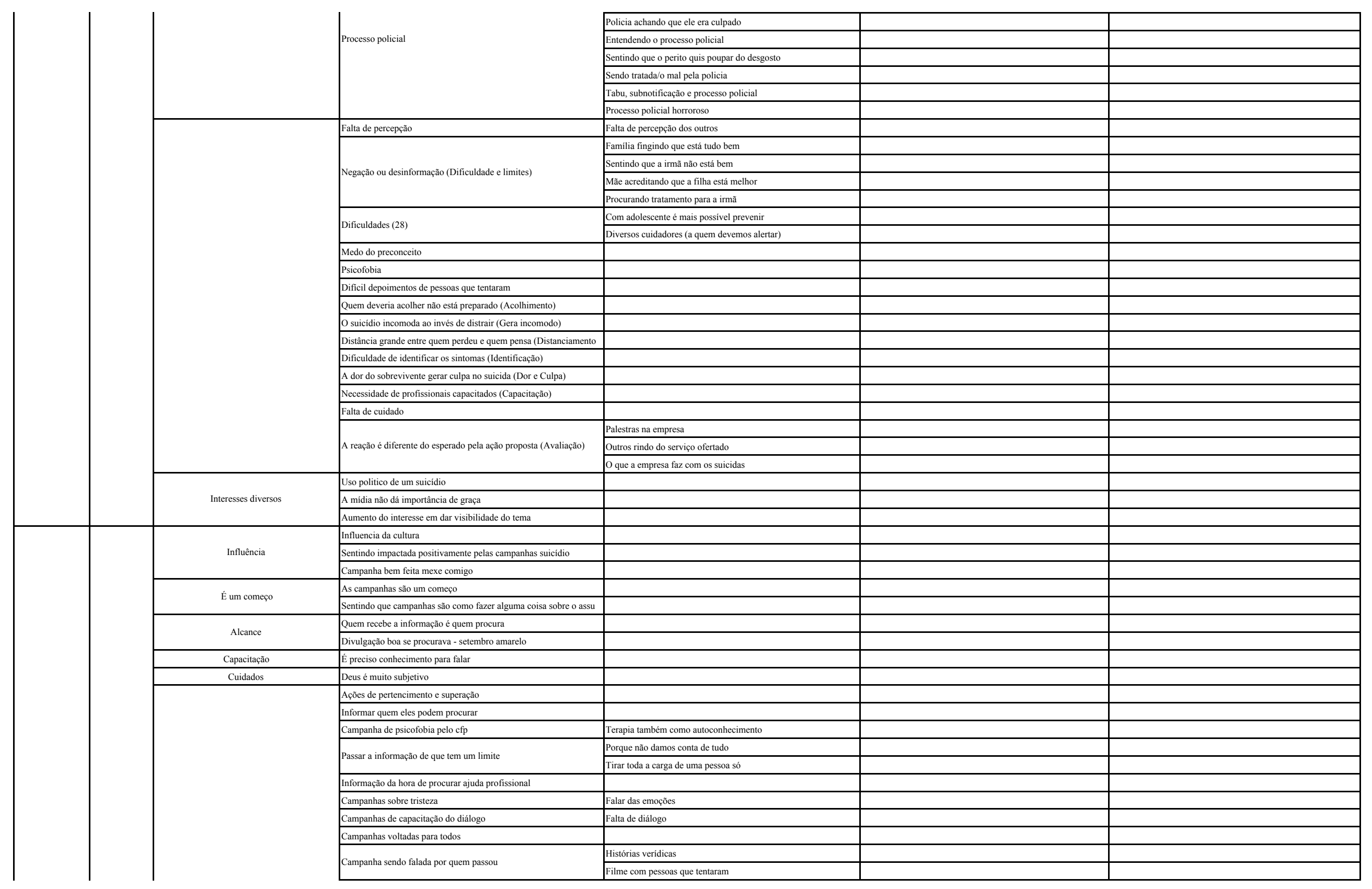




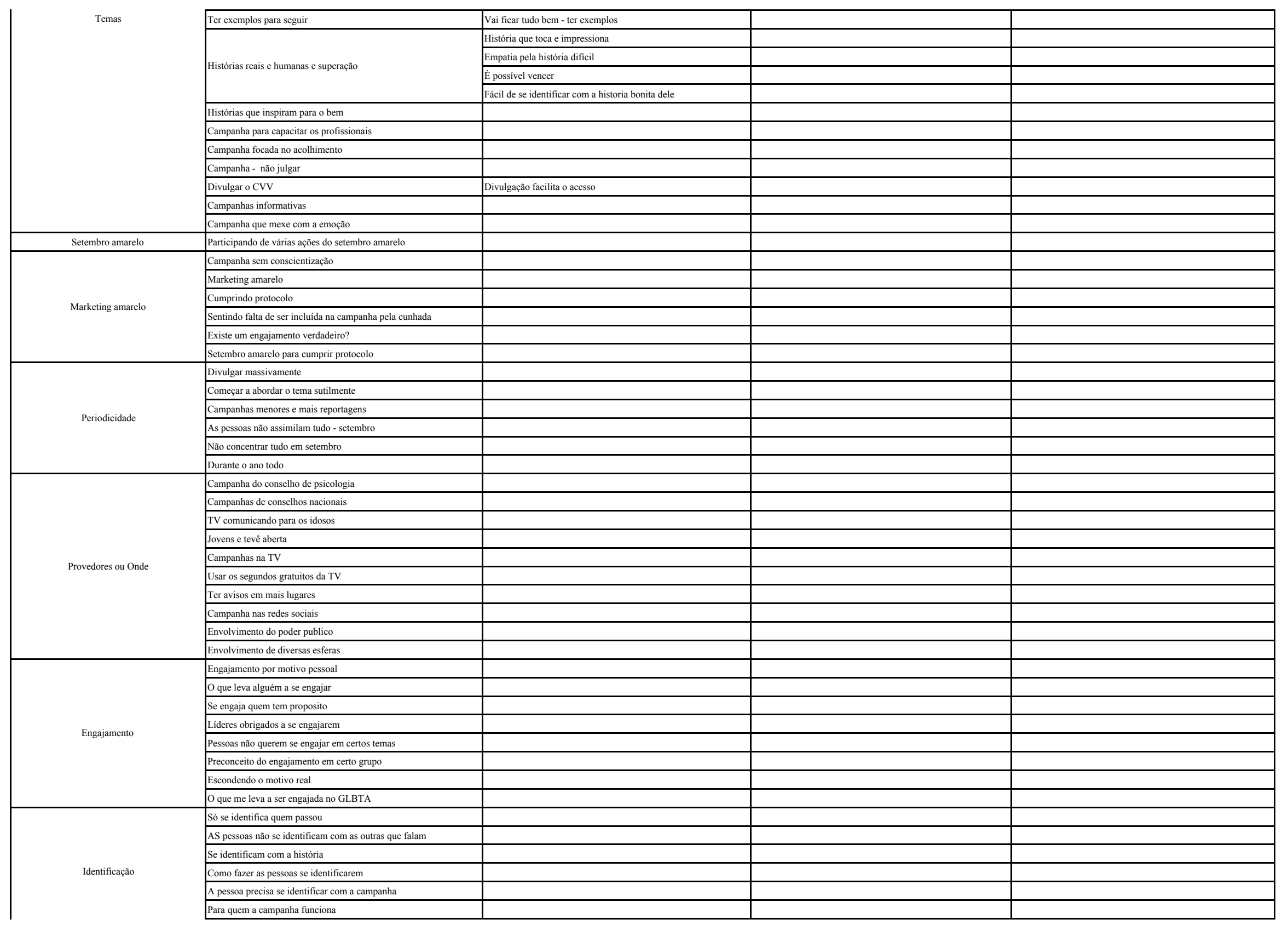




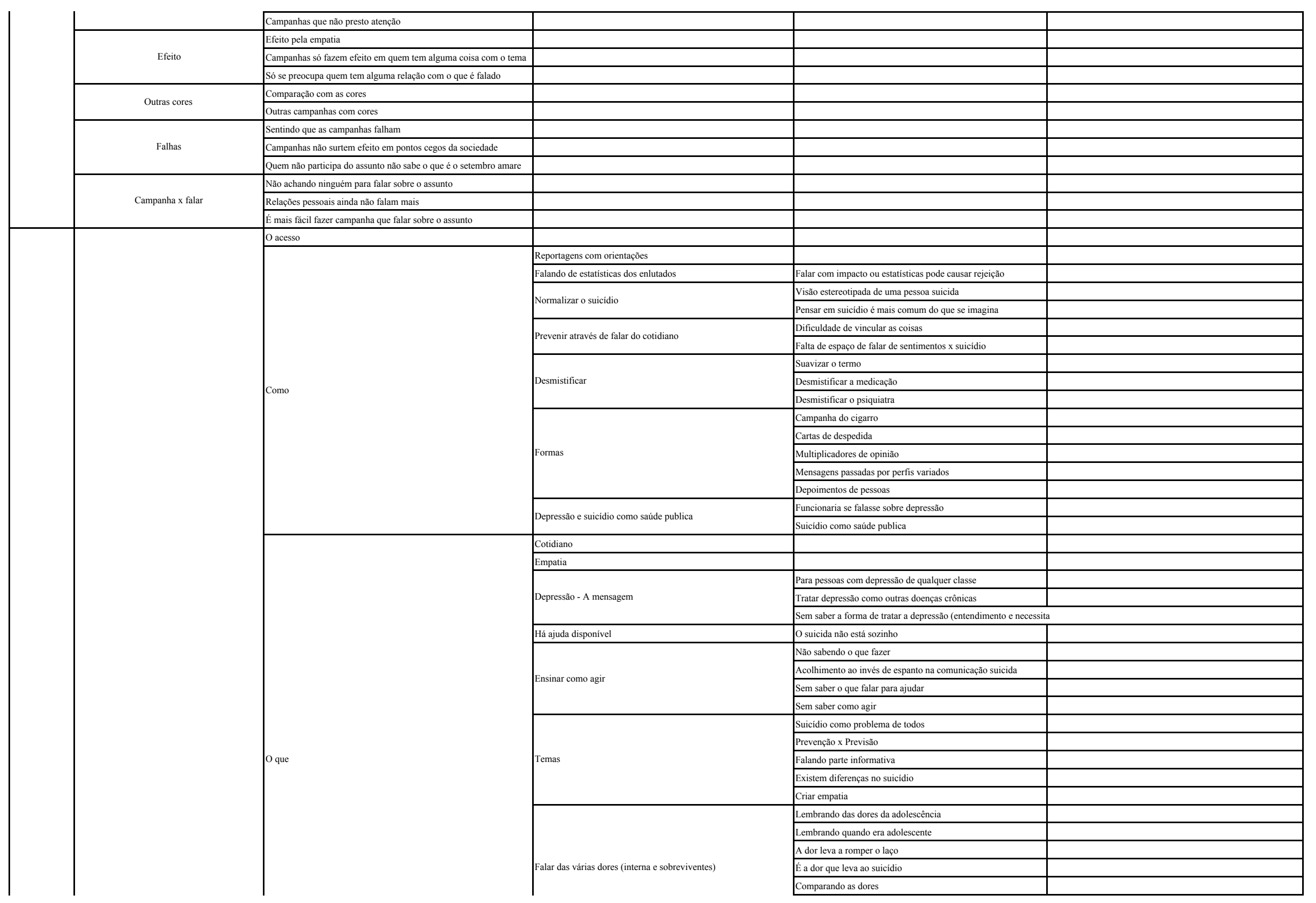




\begin{tabular}{|c|c|c|c|c|}
\hline \multirow{5}{*}{\multicolumn{2}{|c|}{ O falar (23) }} & \multirow{4}{*}{\begin{tabular}{|l|} 
\\
Ansiedade
\end{tabular}} & Uma dor maior que a minha & \\
\hline & & & \begin{tabular}{|l} 
Se sentindo amada pelo filho \\
\end{tabular} & \\
\hline & & & Falar sobre a ansiedade & \\
\hline & & & \begin{tabular}{|l|} 
Acho que meu caso foi ansiedade \\
\end{tabular} & \\
\hline & & Emocōōs & Menor resistência se falar de emocōoss & \\
\hline & \multirow{27}{*}{ Quem } & \begin{tabular}{|l} 
Reportagens voltadas para leigos \\
\end{tabular} & & \\
\hline & & \multirow{5}{*}{ Famosos } & Figura publica que fala sobre suicidio & \\
\hline & & & \begin{tabular}{|l|l|} 
Famosos humanizam o assunto \\
\end{tabular} & \\
\hline & & & Famosos que tiveram fazem que as pessoas pensem no assunto & \\
\hline & & & Relatos de famosos & \\
\hline & & & De suicidio de famosos se fala & \\
\hline & & \multirow{9}{*}{ Sobreviventes enlutados } & Pega muitas pessoas & \\
\hline & & & \begin{tabular}{|l} 
Prevenindo ao mostrar a dor dos sobreviventes \\
\end{tabular} & \\
\hline & & & \begin{tabular}{|l|} 
Causando impacto com o seu relato \\
\end{tabular} & \\
\hline & & & \begin{tabular}{|l|l} 
A dor dos sobreviventes prevenindo suicídios \\
\end{tabular} & \\
\hline & & & Acreditando ter a chave para derrubar essa barreira & \\
\hline & & & \begin{tabular}{|l|} 
Sobreviventes como formadores de opinião \\
\end{tabular} & \\
\hline & & & Consciência afetiva & \\
\hline & & & Falar da dor dos que ficam & \\
\hline & & & 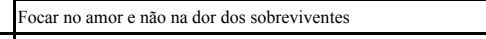 & \\
\hline & & \multirow{3}{*}{ Sobreviventes tentativas } & Ouvir de quem passou & \\
\hline & & & \begin{tabular}{|l|} 
Depoimento de quem já pensou \\
\end{tabular} & \\
\hline & & & Relatos de sobreviventes de tentativas & \\
\hline & & \multirow{3}{*}{ De um par } & Ouvir uma pessoa como ele & \\
\hline & & & De quem ele se vê e se identifica & \\
\hline & & & Ouvir de um par & \\
\hline & & \multirow{4}{*}{ Profissionais } & Sem ser professoral & \\
\hline & & & Resistência se for de profissional & \\
\hline & & & \begin{tabular}{|l|l|} 
Pessoas tem resistência a autoridades no assunto \\
\end{tabular} & \\
\hline & & & Autoridade no assunto para aqueles que buscam isso & \\
\hline & & \multirow{2}{*}{ Adolescentes } & Ensinando alunos a identificar e a ouvir & \\
\hline & & & \begin{tabular}{|l|} 
Alertar como abordar adolescente \\
\end{tabular} & \\
\hline & \multirow{7}{*}{ Onde } & \multirow{2}{*}{ Comecar conscientização pelas faculdades com assuntos relaciona } & Não imaginando pessoas de outras áreas & \\
\hline & & & Começar com os cursos que tem relação & \\
\hline & & Escola da vida para coisas subjetivas & & \\
\hline & & Midia pode instruir as pessoas & & \\
\hline & & Abordar suicídio em novelas & & \\
\hline & & Locais & Falando sobre suicidio na faculdade & \\
\hline & & Lovalis & Falando em grupos fechados & \\
\hline \multirow{4}{*}{ Ouvir } & A dificuldade está em ouvir e não neles falarem & & & \\
\hline & \begin{tabular}{|l|l} 
ificiculdade dos outros ouvirem sobre suicidio \\
\end{tabular} & & & \\
\hline & \multirow{2}{*}{ Pessoas não tem com quem conversar } & Não ter com quem conversar sobre coisas cotidianas & & \\
\hline & & Quem vai escuta-las & & \\
\hline \multirow{2}{*}{ O contato muda } & Trabalhando com essa demanda & & & \\
\hline & Eu não era assim - antes de ter contato & & & \\
\hline & \multirow{2}{*}{ Ter informação normaliza o assunto } & Comparando com o câncer de mama & & \\
\hline & & Para o câncer há informação & & \\
\hline & As pessoas tratam mal porque não entendem & & & \\
\hline & \begin{tabular}{|l} 
Médicos angustiados com o jeito de falar de colegas \\
\end{tabular} & & & \\
\hline
\end{tabular}

Material integrante da pesquisa de doutorado de Karen Scavacini Proibida a reprodução ou utilização sem autorização prévia do autor - 2018 


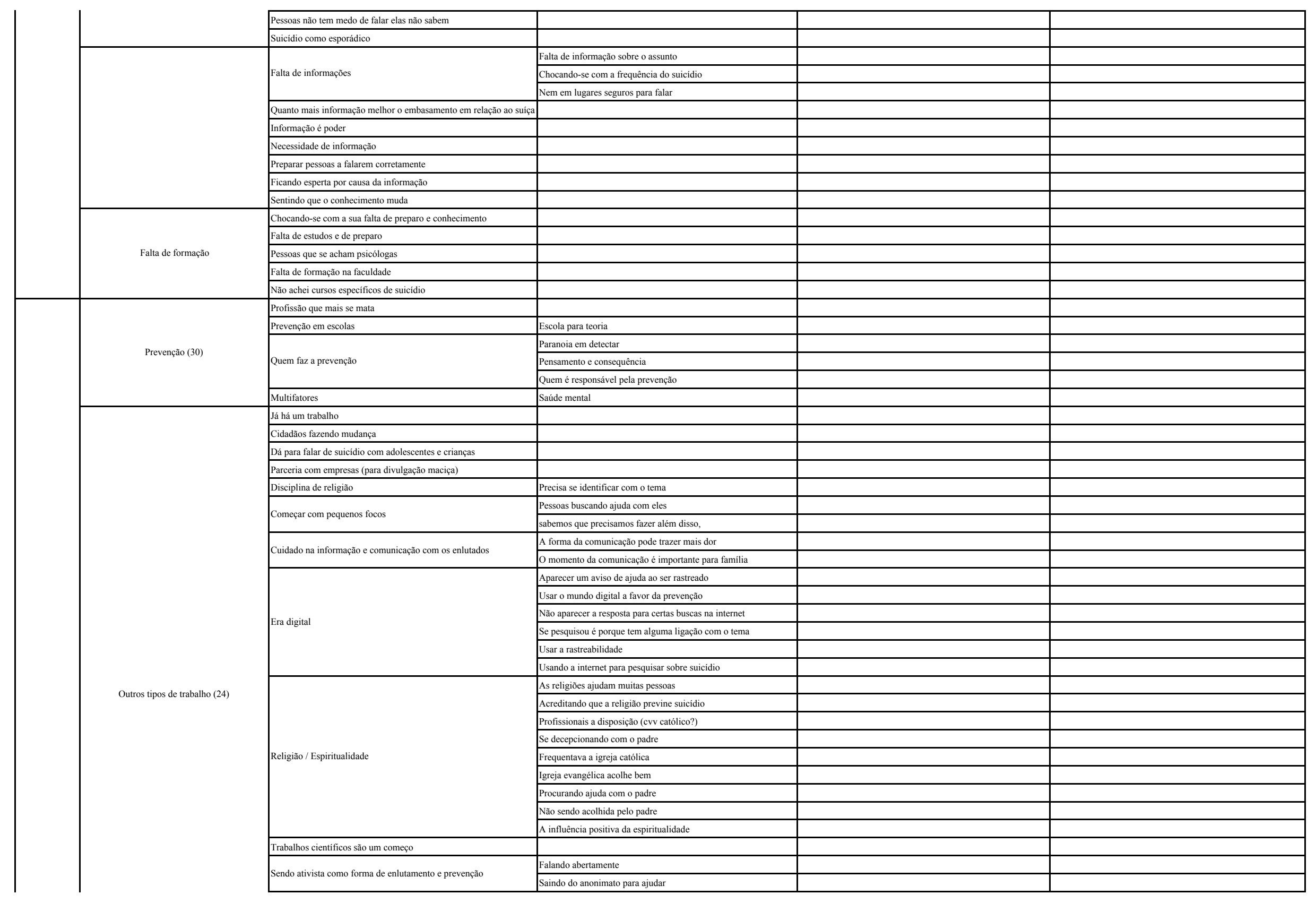

Material integrante da pesquisa de doutorado de Karen Scavacini Proibida a reprodução ou utilização sem autorização prévia do autor -2018 


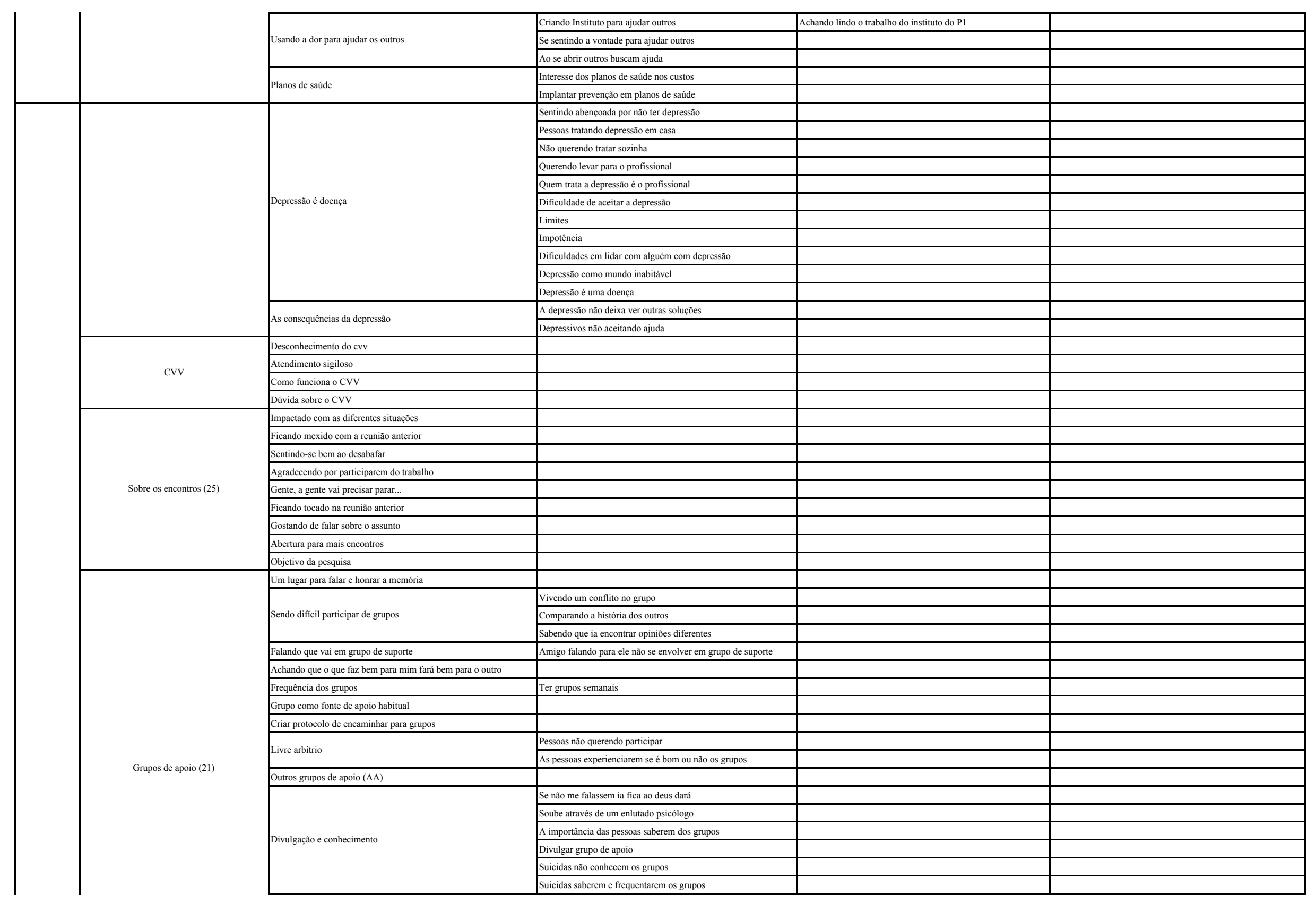

Material integrante da pesquisa de doutorado de Karen Scavacini Proibida a reprodução ou utilização sem autorização prévia do autor - 2018 


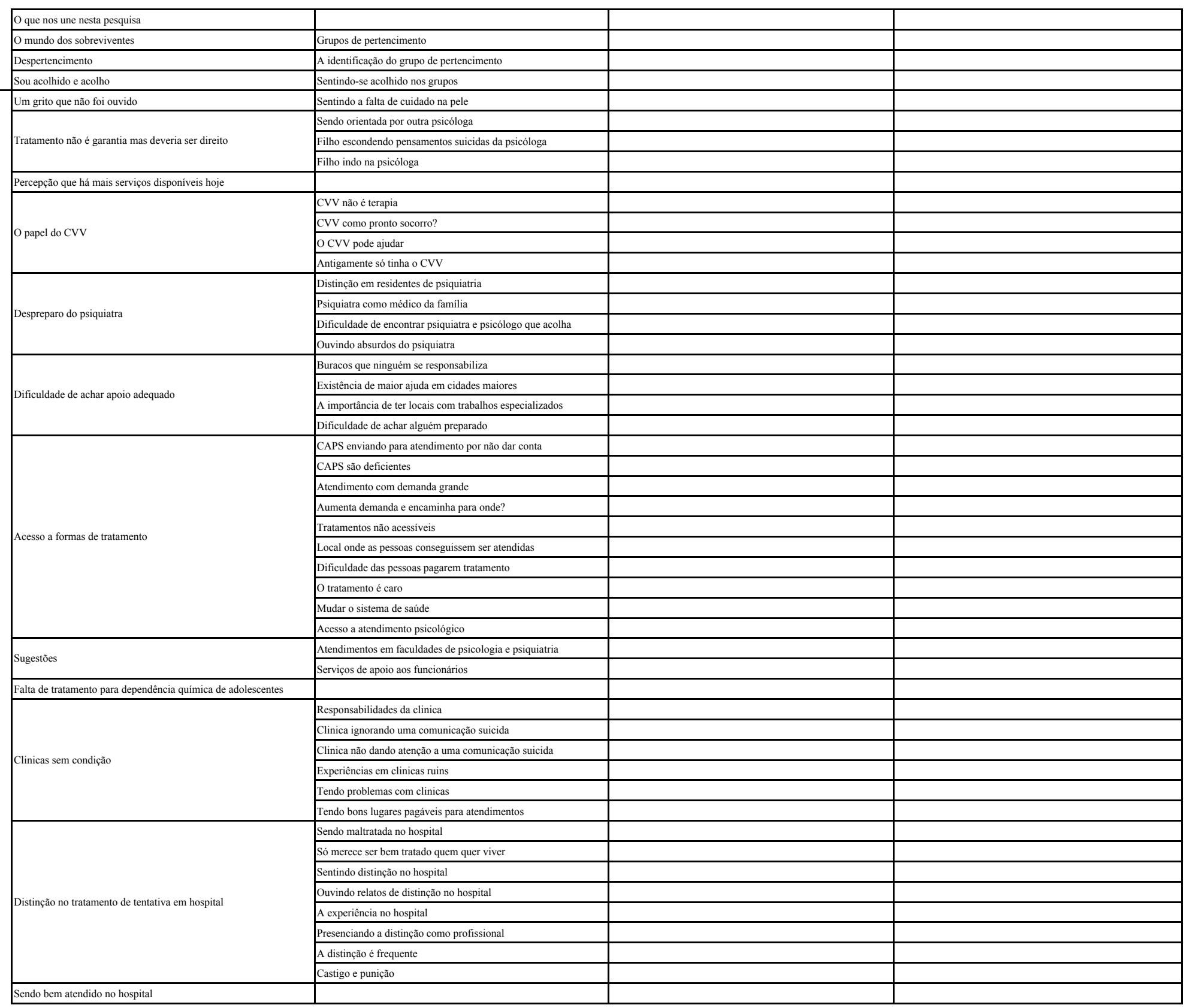

Material integrante da pesquisa de doutorado de Karen Scavacini Proibida a reprodução ou utilização sem autorização prévia do autor - 2018 


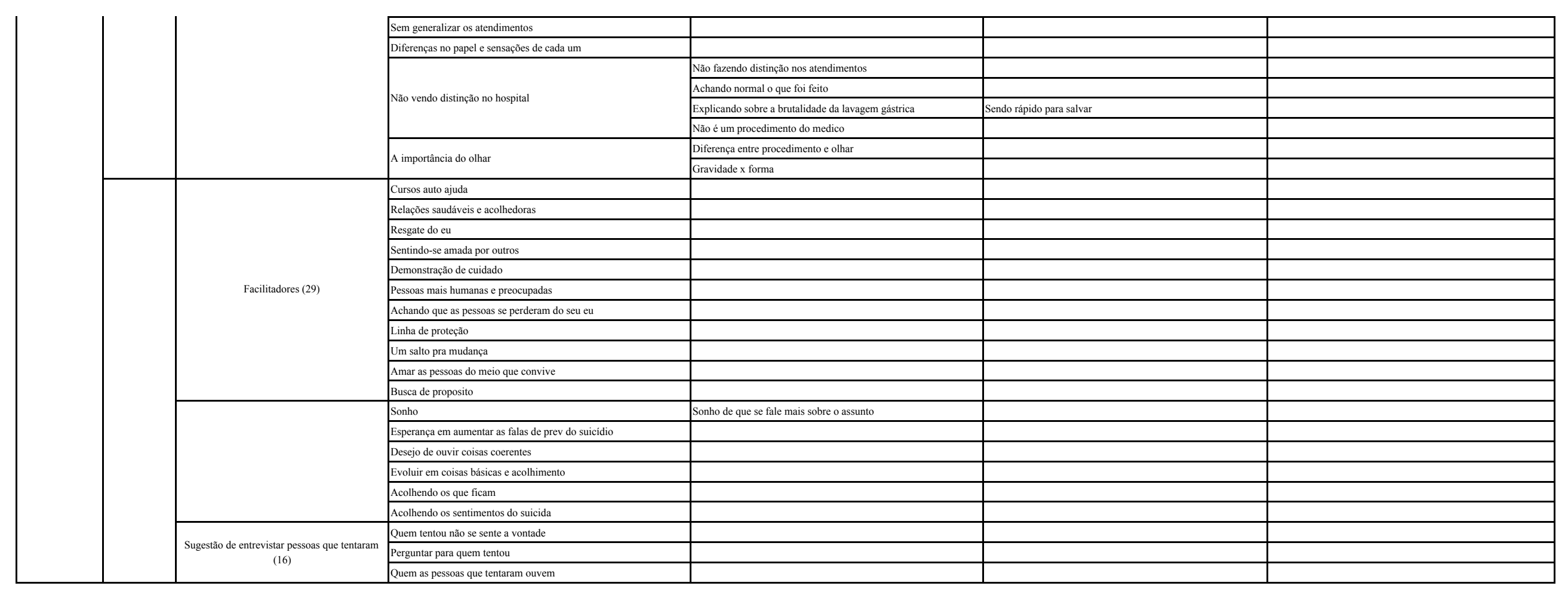

Material integrante da pesquisa de doutorado de Karen Scavacini

Proibida a reprodução ou utilização sem autorização do autor 2018 


\section{Anexo O - Diário de Bordo}

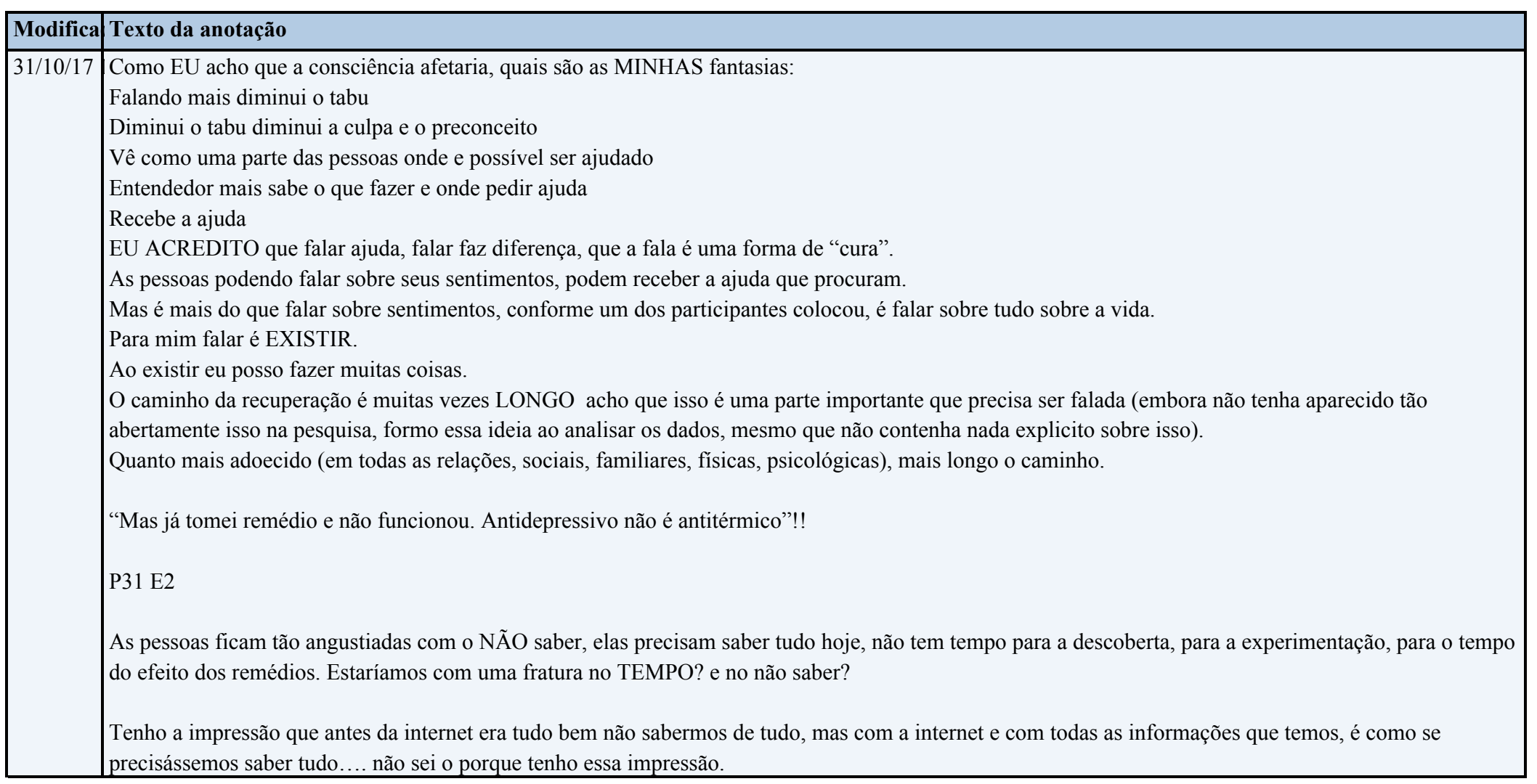




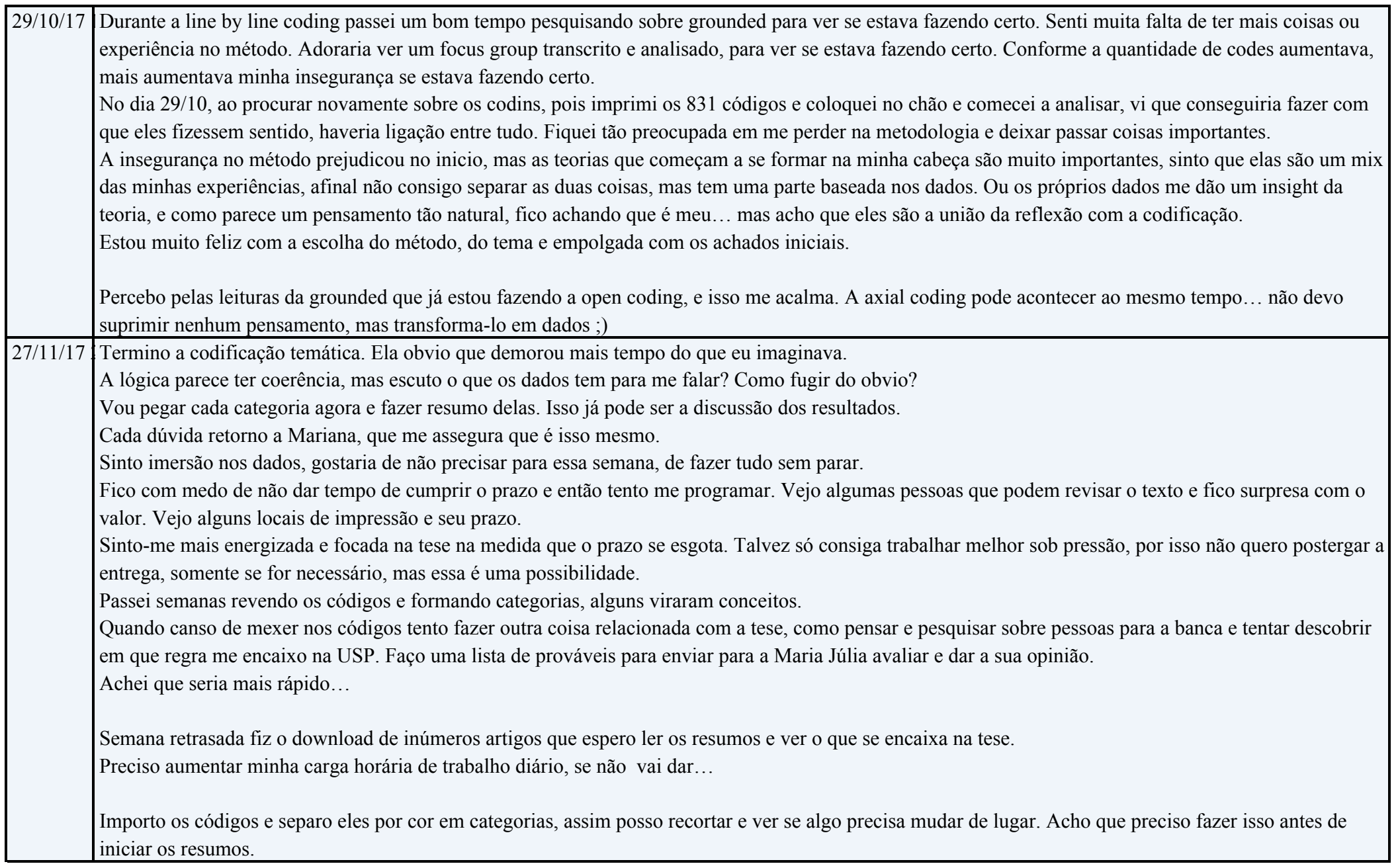




\begin{tabular}{|c|c|}
\hline 27/10/17 & $\begin{array}{l}\text { ui, a minha ansiedade em perguntar tudo que eu havia programado atrapalhou o andamento da conversa. } \\
\text { o menos fico com essa sensação. }\end{array}$ \\
\hline 06/11/17 & $\begin{array}{l}\text { Achei que teria um trabalho que trouxesse um esquema, um final, mas fico com mais questões que certezas. } \\
\text { Eles me fazem pensar em quantas coisas preciso pensar para aumentar consciência publica e como tudo isso é complexo e interligado. } \\
\text { Me lembro do preventing suicide da OMS e do esquema para prevenção... o aumento da awareness é um ponto dentro daquilo tudo. } \\
\text { Fico lembrando do que me fez escrever sobre awareness, pensei primeiro na dor dos que ficaram e na dificuldade em falarem na sociedade sobre o assunto. } \\
\text { NO preconceito que recebem e no medo de serem julgados. E daí pensei em aumentar a consciência publica. }\end{array}$ \\
\hline
\end{tabular}




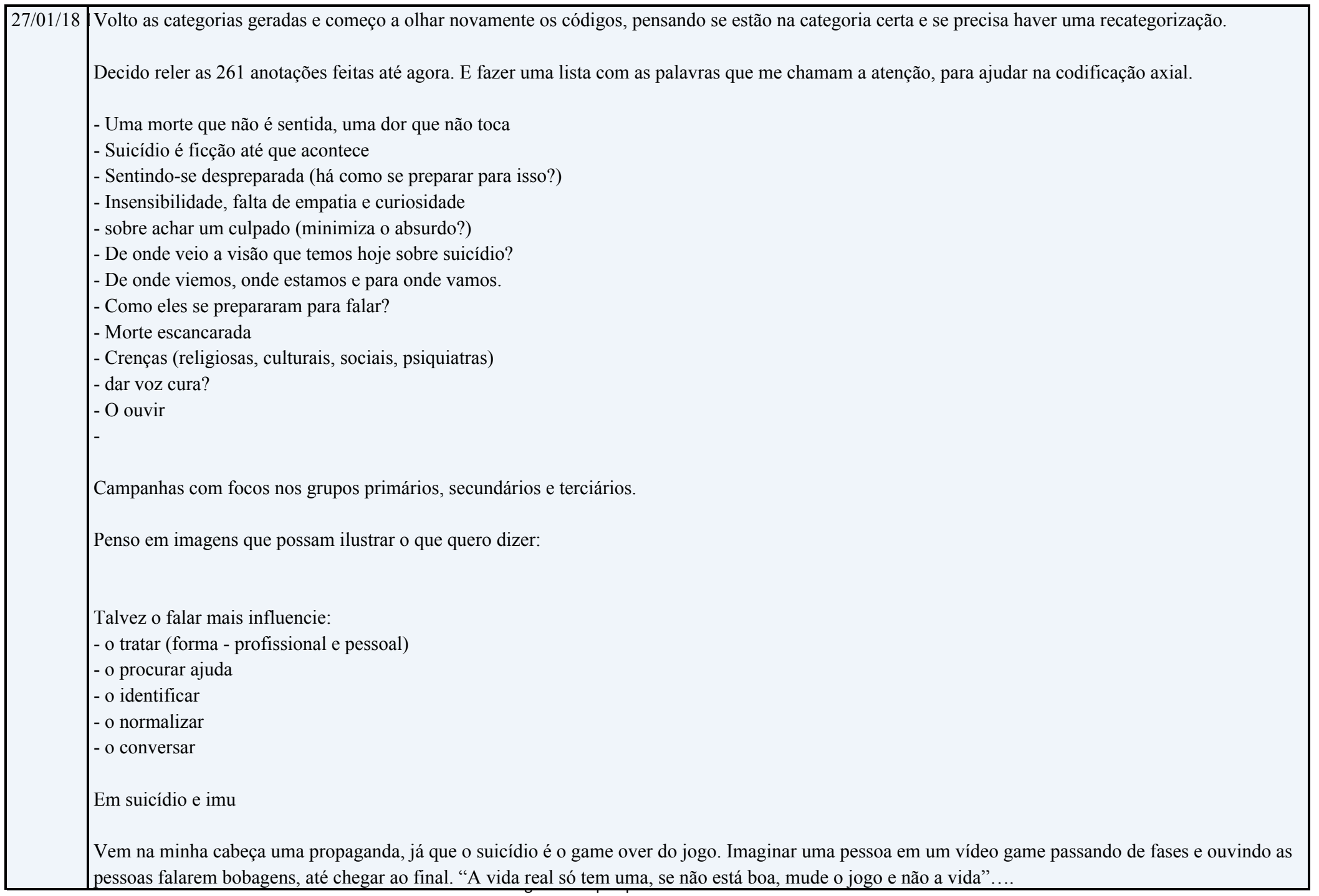




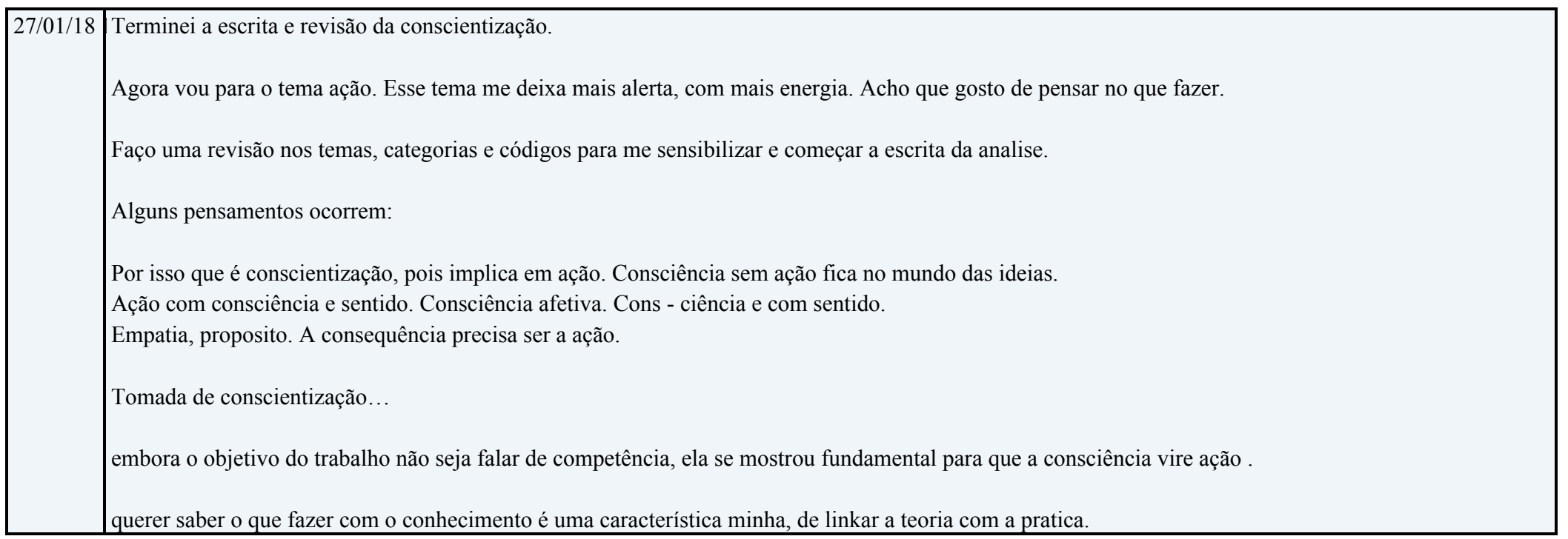




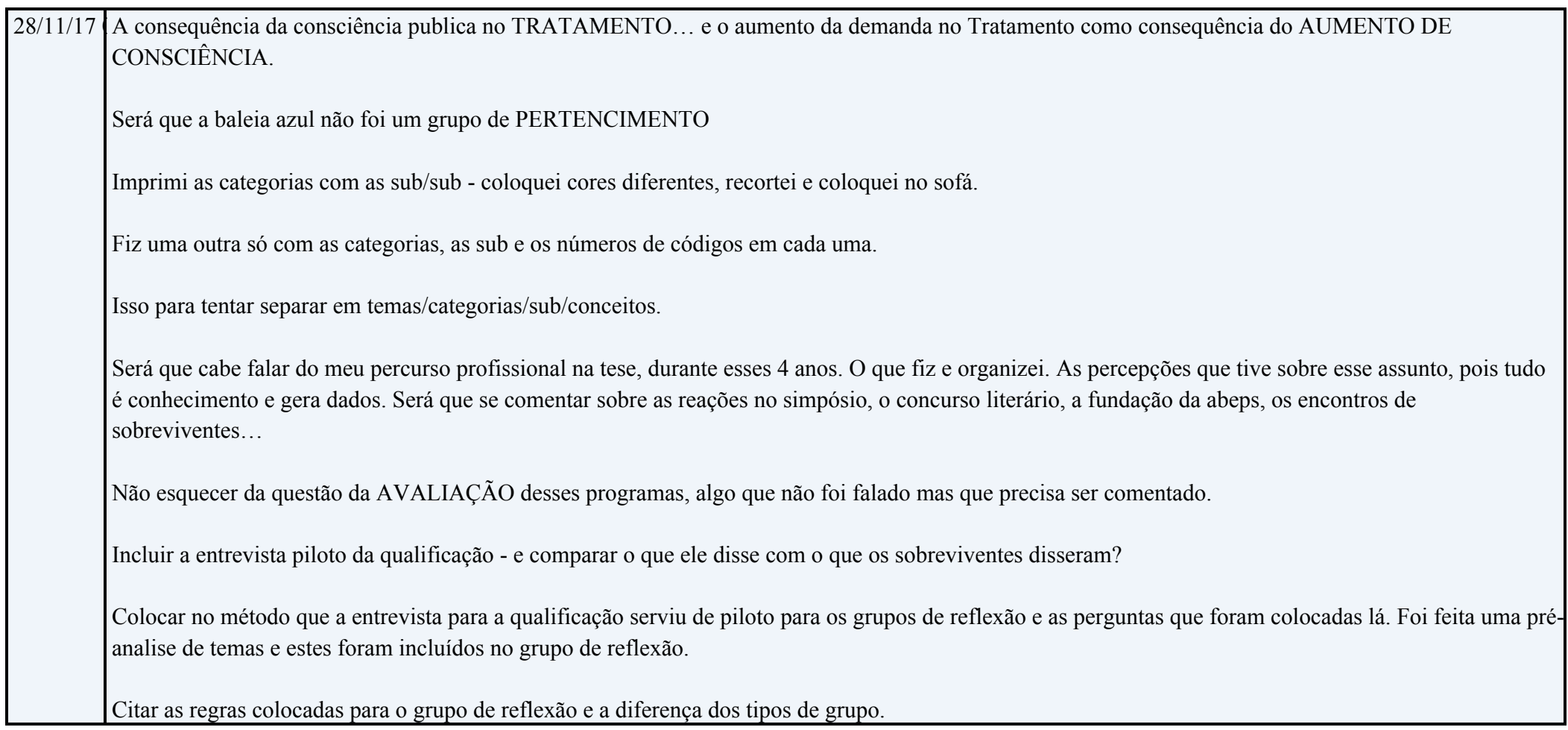




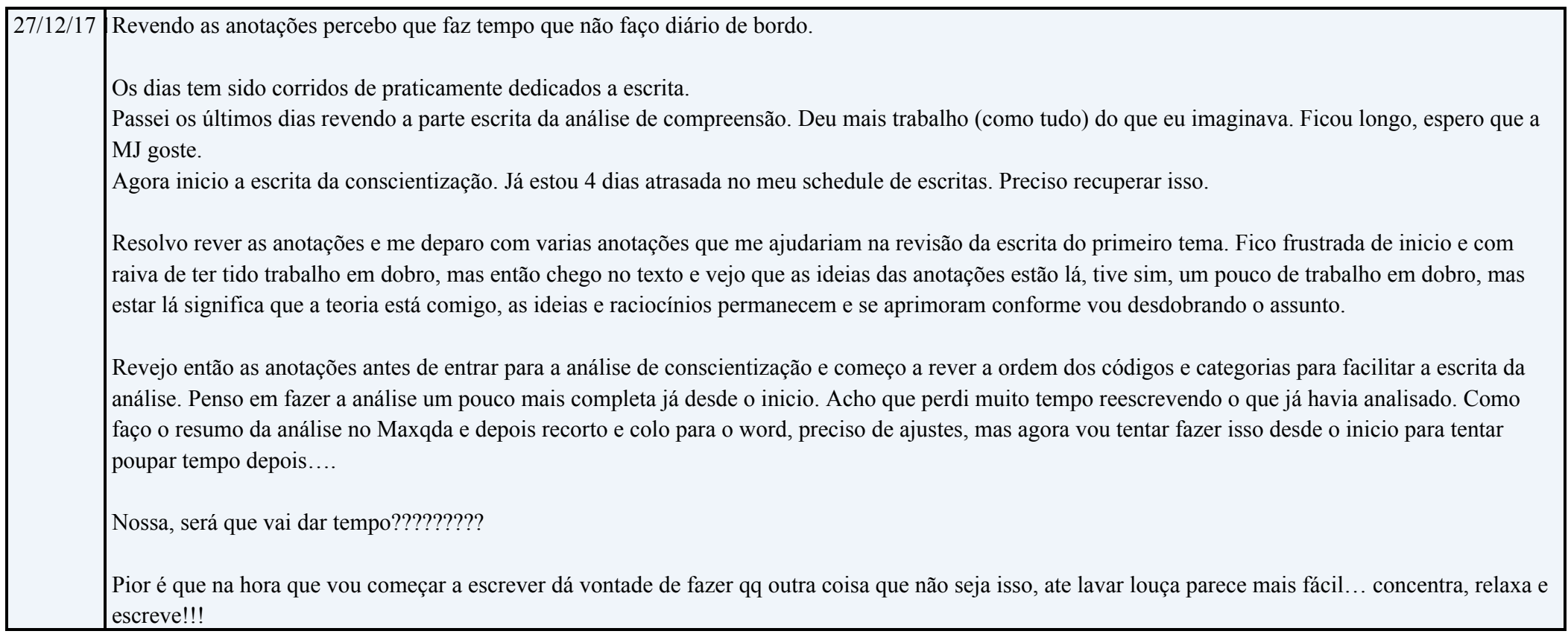




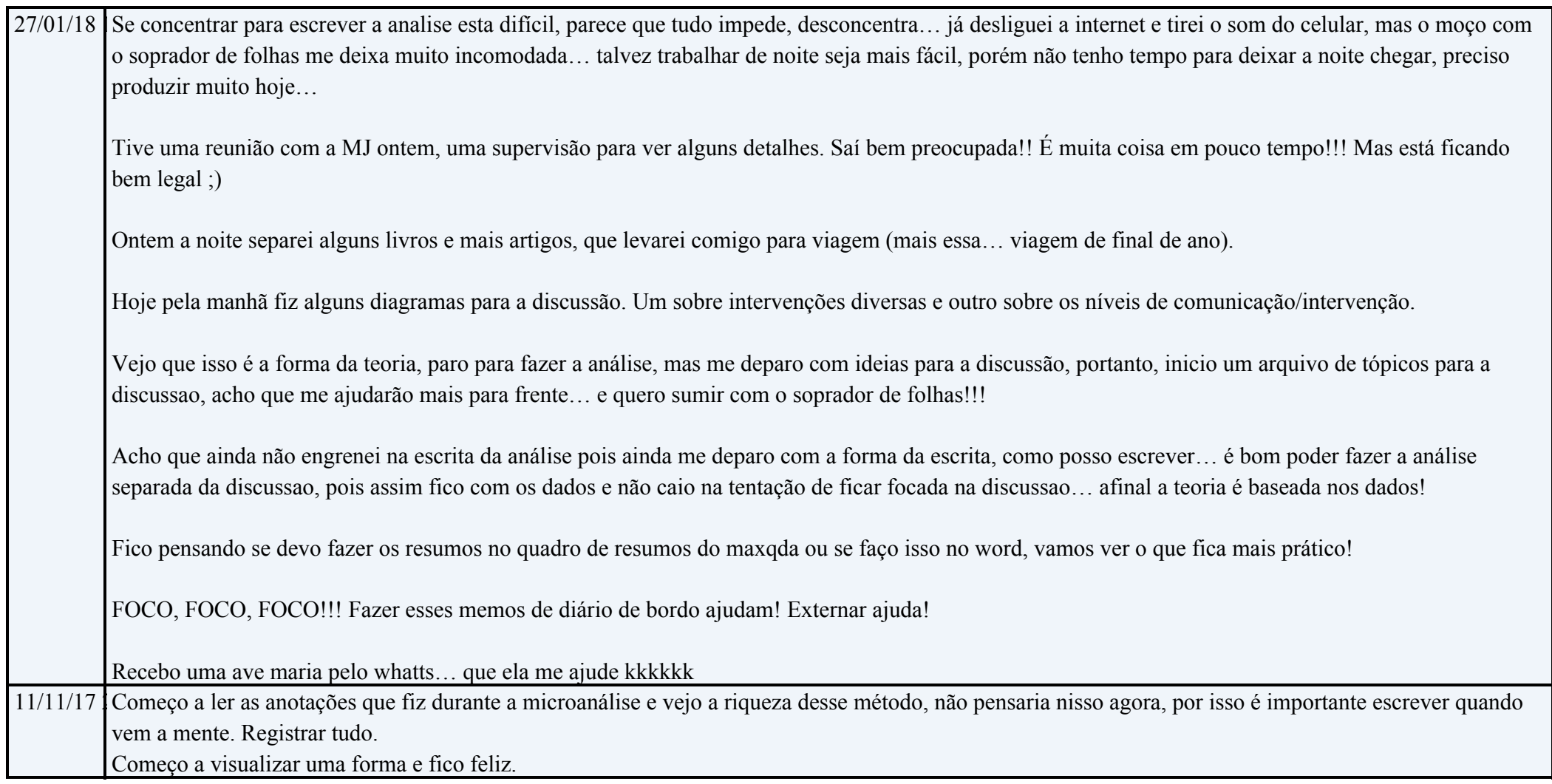




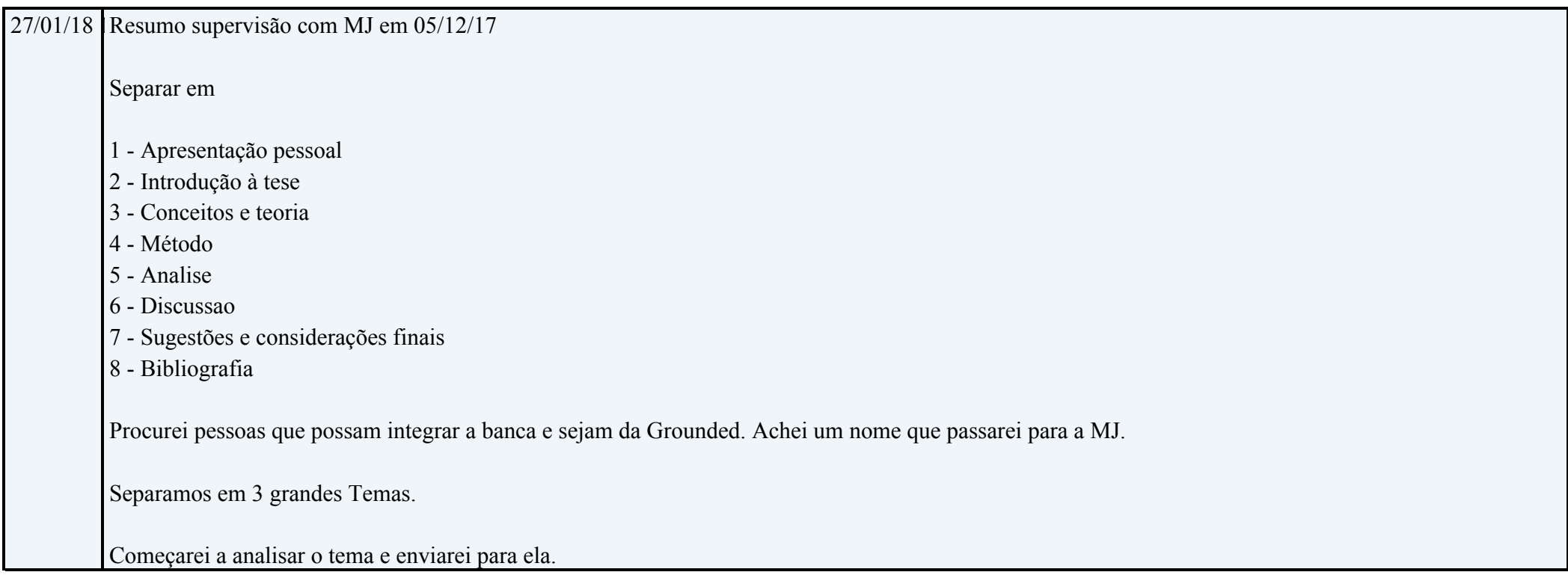




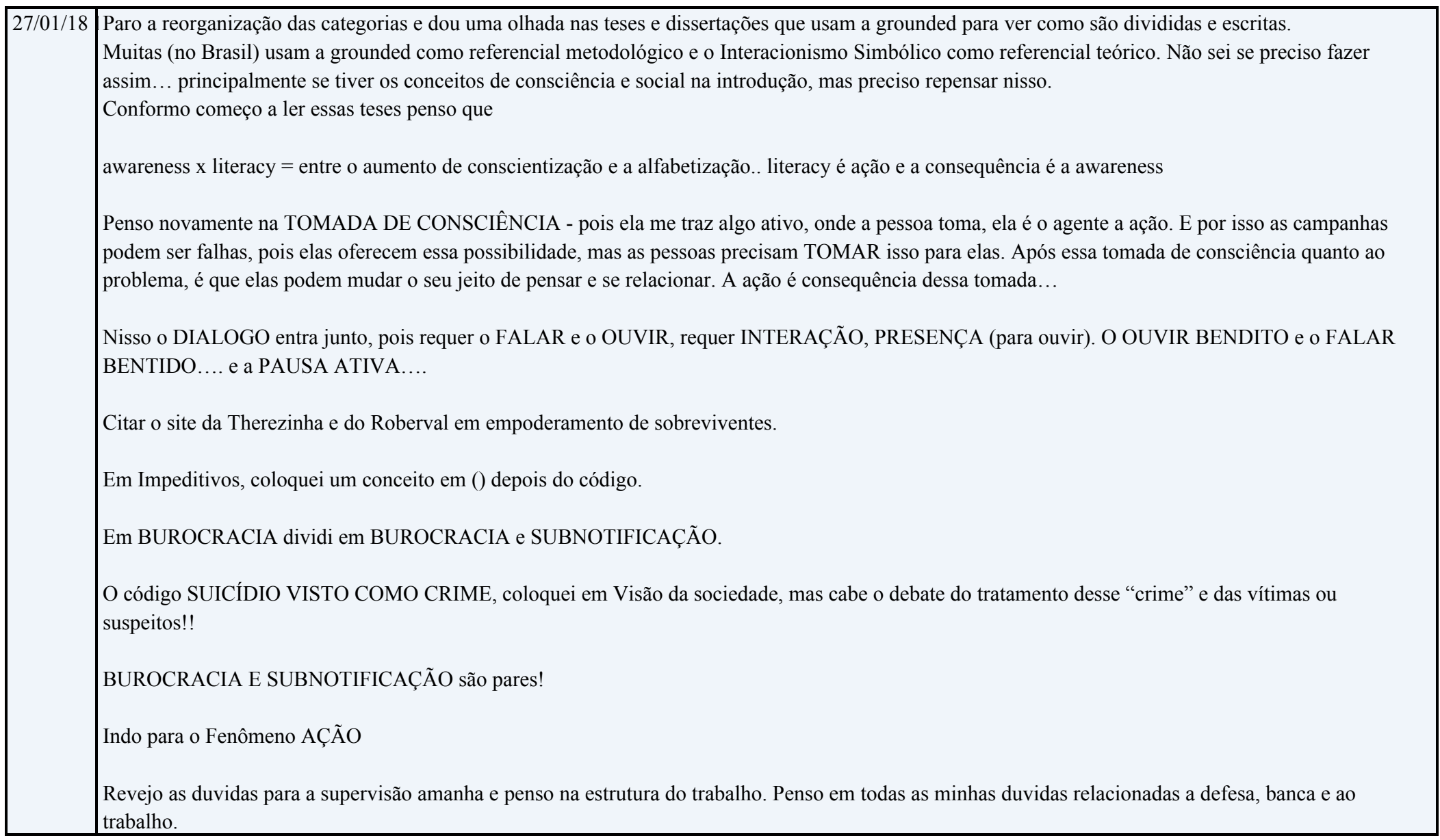




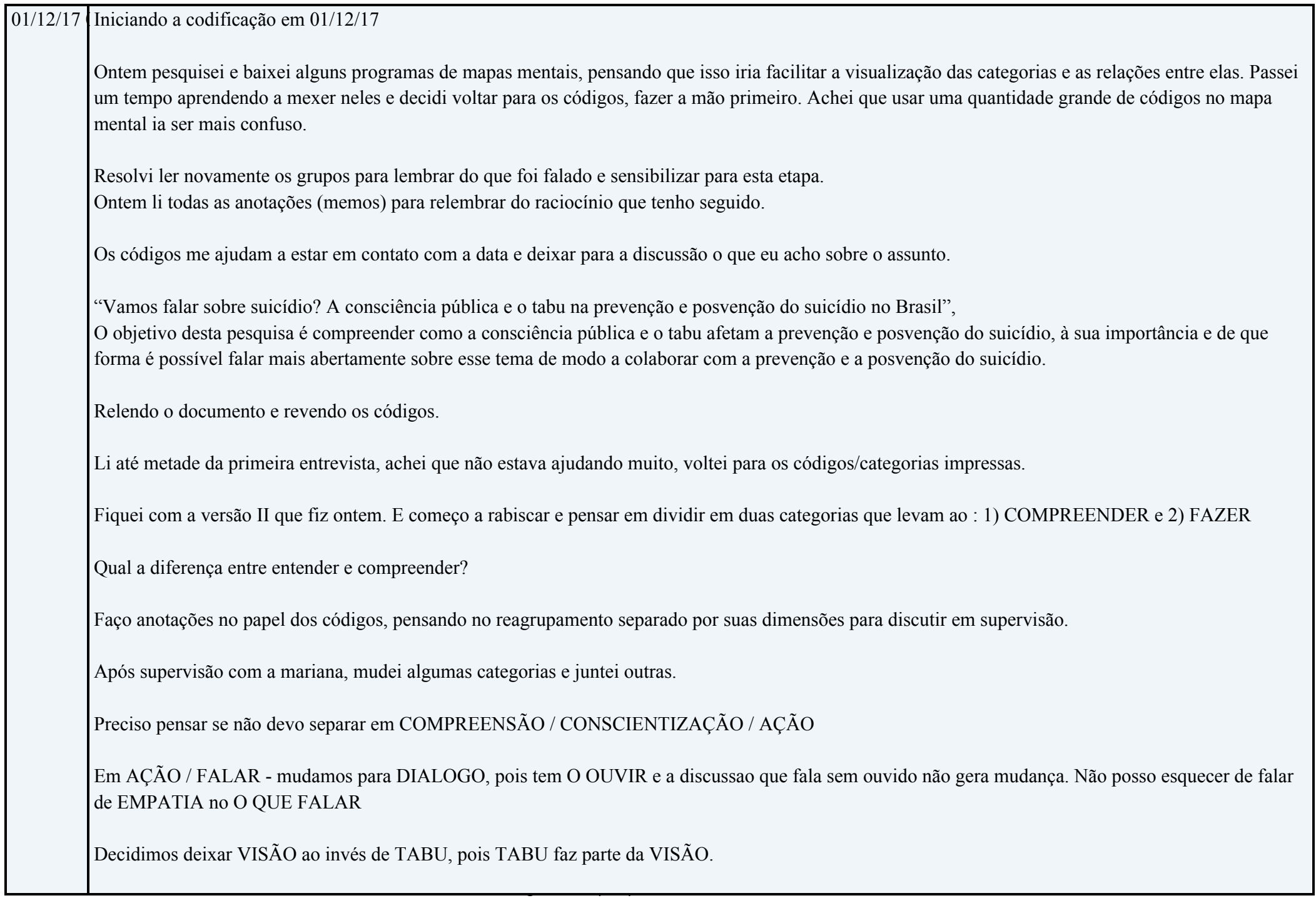

Proibida a reprodução ou utilização sem autorização do autor 2018 
Material integrante da pesquisa de doutorado de Karen Scavacini Proibida a reprodução ou utilização sem autorização do autor 2018

Material integrante da pesquisa de doutorado de Karen Scavacini Proibida a reprodução ou utilização sem autorização do autor 2018 
Anexo P - Segmentos Codificados

\begin{tabular}{|c|c|c|}
\hline Nome do documento & Código & Segmento \\
\hline $\begin{array}{l}\text { Transcrição E1 } \\
\text { revisada_para maxqda }\end{array}$ & AÇÃO|Cuidar|Sobre os encontros (25)\Objetivo da pesquisa & $\begin{array}{l}\text { O objetivo desta pesquisa é compreender como a consciência pública e o tabu } \\
\text { afetam a prevenção e posvenção do suicídio, à sua importância e de que forma é } \\
\text { possível falar mais abertamente sobre esse tema de modo a colaborar com a } \\
\text { prevenção e a posvenção do suicídio }\end{array}$ \\
\hline $\begin{array}{l}\text { Transcrição E1 } \\
\text { revisada_para maxqda }\end{array}$ & AÇÃO\Cuidar|Sobre os encontros (25)\Objetivo da pesquisa & Ou em outros, se precisar faz mais \\
\hline $\begin{array}{l}\text { Transcrição E1 } \\
\text { revisada_para maxqda }\end{array}$ & COMPREENSÃO|VisãolVisão da Sociedade (2)\Visão do suicídio hoje no brasil & Ainda com bastante tabu \\
\hline $\begin{array}{l}\text { Transcrição E1 } \\
\text { revisada_para maxqda }\end{array}$ & COMPREENSÃO|Comunicação|Social\Aumento da comunicação\Hoje já se fala mais sobre o suicídio & Mesmo falando bastante \\
\hline $\begin{array}{l}\text { Transcrição E1 } \\
\text { revisada_para maxqda }\end{array}$ & COMPREENSÃo|Visão|Visão da Sociedade (2) \Visão do suicídio hoje no brasil|Suicida é fraco e covarde|suicida sendo visto como fraco e & suicida é vista como fraca, um covarde \\
\hline $\begin{array}{l}\text { Transcrição E1 } \\
\text { revisada_para maxqda }\end{array}$ & COMPREENSÃO\Experiência\O viver \Quem não viveu (6)\Imaginando que o suicídio talvez não exista para quem não viveu & $\begin{array}{l}\text { Eu acho que as pessoas que não viveram isso talvez nem saibam que o suicídio } \\
\text { existe }\end{array}$ \\
\hline $\begin{array}{l}\text { Transcrição E1 } \\
\text { revisada_para maxqda }\end{array}$ & COMPREENSÃO\Experiência\O viver|Quem não viveu (6)\Acreditando que as pessoas não prestam atenção para o suicídio & porque eu acho que não é uma coisa que as pessoas prestam atenção \\
\hline $\begin{array}{l}\text { Transcrição E1 } \\
\text { revisada_para maxqda }\end{array}$ & COMPREENSÃO\Experiência|O viver|Quem viveu (5)\Antes do suicídio〈Lembrando de quando não dava atenção ao suicídio & $\begin{array}{l}\text { porque eu acho que não é uma coisa que as pessoas prestam atenção. Não sei, } \\
\text { pelo menos no meu caso, mesmo quando eu via na TV eu acho que eu não.. }\end{array}$ \\
\hline \begin{tabular}{|l} 
Transcrição E1 \\
revisada_para maxqda
\end{tabular} & COMPREENSÃO\Experiência\O viver\Quem viveu (5)\Antes do suicídio|Distanciando-se de reportagens e falas de algo que não é perto, & acho que é a mesma coisa de você ver reportagem de assalto, de roubo \\
\hline $\begin{array}{l}\text { Transcrição E1 } \\
\text { revisada_para maxqda }\end{array}$ & COMPREENSÃO\Experiência\O viver\Quem viveu (5)\Depois do suicídio\Entendendo a gravidade pela experiência & $\begin{array}{l}\text { Acho que assim, não sei se você não entende a gravidade do suicídio enquanto não } \\
\text { acontece com você, né, com alguém próximo }\end{array}$ \\
\hline $\begin{array}{l}\text { Transcrição E1 } \\
\text { revisada_para maxqda }\end{array}$ & COMPREENSÃO\Experiência\O viver|Quem viveu (5)\Depois do suicídio\Dando atenção porque passou pela experiência & $\begin{array}{l}\text { Eu acho que acaba sendo um tema não muito, não sei, eu acho que só quem } \\
\text { passou mesmo, dá a atenção. }\end{array}$ \\
\hline \begin{tabular}{|l|l} 
Transcrição E1 \\
revisada_para maxqda
\end{tabular} & COMPREENSÃO\Comunicação|Social|Possiveis Causas para o AumentolCanais de TV investindo no temalAssunto sendo gerado pelas sér & $\begin{array}{l}\text { acho que agora com a série lá dos "13" e da "baleia", talvez isso gerou né esse } \\
\text { assunto em mais rodas }\end{array}$ \\
\hline \begin{tabular}{|l|l} 
Transcrição E1 \\
revisada_para maxqda
\end{tabular} & COMPREENSÃO|Comunicação|Social|Possíveis Causas para o Aumento|Canais de TV investindo no tema|Série chocando quem assiste & porque é uma série, é uma coisa que todo mundo ficou chocado \\
\hline \begin{tabular}{|l|l} 
Transcrição E1 \\
revisada_para maxqda
\end{tabular} & COMPREENSÃO\Experiência\O viver\Quem não viveu (6)\Acreditando que as pessoas não prestam atenção para o suicídio & $\begin{array}{l}\text { Mas senão eu não acho que, eu acho que é uma coisa que passa meio batida } \\
\text { assim, se as pessoas não }\end{array}$ \\
\hline \begin{tabular}{|l|l} 
Transcrição E1 \\
revisada_para maxqda
\end{tabular} & COMPREENSÃO\Experiência|O viver|Quem não viveu (6)\Quem não viveu falando do suicídio como absurdo ou piada & $\begin{array}{l}\text { ou quando é falado talvez quem não viveu até acha assim "ah, absurdo" ou dá } \\
\text { risada. }\end{array}$ \\
\hline $\begin{array}{l}\text { Transcrição E1 } \\
\text { revisada_para maxqda }\end{array}$ & COMPREENSÃO|Comunicação|Social|Aumento da comunicação|Ouvindo dentro da empresa & Eu já ouvi assim em empresa inclusive \\
\hline \begin{tabular}{|l} 
Transcrição E1 \\
revisada_para maxqda
\end{tabular} & COMPREENSÃO|Comunicação|Social|Aumento da comunicação|Em palestras de suporte & palestra que dão suporte \\
\hline \begin{tabular}{|l} 
Transcrição E1 \\
revisada_para maxqda
\end{tabular} & COMPREENSÃO\Experiência|O viver|Quem não viveu (6)\Outros desacreditando na comunicação suicida & $\begin{array}{l}\text { dão exemplo: "porque tem gente que liga que fala que vai se suicidar" e tem gente } \\
\text { que fala: "pff, até parece." }\end{array}$ \\
\hline $\begin{array}{l}\text { Transcrição E1 } \\
\text { revisada_para maxqda }\end{array}$ & COMPREENSÃO\Experiência\O viver\Quem não viveu (6)\Outros achando a comunicação suicida engraçada & E dá risada, acha engraçado \\
\hline $\begin{array}{l}\text { Transcrição E1 } \\
\text { revisada_para maxqda }\end{array}$ & COMPREENSÃO\Experiência\O viver|Quem não viveu (6)\Quem não viveu não entende & $\begin{array}{l}\text { Que eu acho que talvez eles não entendam que isso é realidade, as pessoas que } \\
\text { acho que não vivem talvez... não vejam como algo... }\end{array}$ \\
\hline $\begin{array}{l}\text { Transcrição E1 } \\
\text { revisada_para maxqda }\end{array}$ & COMPREENSÃO\Experiência\O viver|Quem não viveu (6)\O suicídio é distante para quem não passou pela experiência & Vejam como algo distante... \\
\hline $\begin{array}{l}\text { Transcrição E1 } \\
\text { revisada_para maxqda }\end{array}$ & COMPREENSÃO\Experiência\O viver\Quem viveu (5)\Antes do suicídio\Distanciando-se de reportagens e falas de algo que não é perto, & É, sabe quando te falam sobre algum assalto, sabe... \\
\hline
\end{tabular}

Material integrante da pesquisa de doutorado de Karen Scavacini - USP Proibida a reprodução ou utilização sem autorização do autor - 2018 


\begin{tabular}{|c|c|c|}
\hline $\begin{array}{l}\text { Transcrição E1 } \\
\text { revisada_para maxqda }\end{array}$ & COMPREENSÃO\Experiência\O viver\Quem não viveu (6)\Outros não entendem o real significado do suicídio & não sei se as pessoas entendem o real significado do que é um suicídio \\
\hline \begin{tabular}{|l} 
Transcrição E1 \\
revisada_para maxqda
\end{tabular} & COMPREENSÃO\Experiência|O viver|Quem viveu (5)\Antes do suicídio〈Lembrando de quando não dava atenção ao suicídio & $\begin{array}{l}\text { Eu mesmo antes de acontecer comigo, por exemplo, mesmo se eu visse em um } \\
\text { filme ou na reportagem, ou em qualquer lugar assim "vulgar", eu achava que não.. } \\
\text { O real significado do suicídio... }\end{array}$ \\
\hline $\begin{array}{l}\text { Transcrição E1 } \\
\text { revisada_para maxqda }\end{array}$ & COMPREENSÃO|Experiência|O viver|Quem viveu (5)\Antes do suicídio\Antes de acontecer comigo & Eu mesmo antes de acontecer comigo \\
\hline $\begin{array}{l}\text { Transcrição E1 } \\
\text { revisada_para maxqda }\end{array}$ & CONSCIENTIZAÇÃO|Consciência \O absurdo do suicídio\O absurdo do suicídiolO real significado do suicídio & O real significado do suicídio \\
\hline \begin{tabular}{|l|} 
Transcrição E1 \\
revisada_para maxqda
\end{tabular} & COMPREENSÃO\Experiência|O viver|Quem viveu (5)\Antes do suicídio\Lembrando de quando não dava atenção ao suicídio & Não tocava dessa maneira... \\
\hline \begin{tabular}{|l|} 
Transcrição E1 \\
revisada_para maxqda
\end{tabular} & COMPREENSÃO\Experiência\O viver\Quem viveu (5)\Depois do suicídio\Dando atenção porque passou pela experiência & Não tocava dessa maneira... \\
\hline \begin{tabular}{|l|} 
Transcrição E1 \\
revisada_para maxqda
\end{tabular} & COMPREENSÃO\Experiência\O viver|Quem viveu (5)\Antes do suicídio|Sentindo a morte como longe & É, como se fosse algo "alguém morreu", sei lá. \\
\hline $\begin{array}{l}\text { Transcrição E1 } \\
\text { revisada_para maxqda }\end{array}$ & CONSCIENTIZAÇÃO|Consciência\O absurdo do suicídio|Coisas ruins que podem acontecer na vida\A vida tem coisas ruins & Como tudo de ruim nessa vida \\
\hline $\begin{array}{l}\text { Transcrição E1 } \\
\text { revisada_para maxqda }\end{array}$ & COMPREENSÃO\Experiência\O viver \Quem não viveu (6)\Achando que coisas ruins só acontecem para os outros & $\begin{array}{l}\text { Como tudo de ruim nessa vida, a gente acha que com a gente não vai acontecer, } \\
\text { sempre com os outros. Eu por exemplo, eu tive um câncer e achava "imagine } \\
\text { comigo não vai acontecer" }\end{array}$ \\
\hline $\begin{array}{l}\text { Transcrição E1 } \\
\text { revisada_para maxqda }\end{array}$ & CONSCIENTIZAÇÃO|Consciência|O absurdo do suicídio|Coisas ruins que podem acontecer na vida|Sobrevivendo a um câncer & Eu por exemplo, eu tive um câncer \\
\hline $\begin{array}{l}\text { Transcrição E1 } \\
\text { revisada_para maxqda }\end{array}$ & COMPREENSÃO\Experiência\O viver\Quem viveu (5)\Antes do suicídio\Jamais passarei por um suicídio & ter um suicídio na família jamais \\
\hline \begin{tabular}{|l|} 
Transcrição E1 \\
revisada_para maxqda
\end{tabular} & COMPREENSÃO\Experiência\O viver|Quem viveu (5)\Luto (7)|Sentimentos|Sentindo-se desamparada & porque parece que ninguém tem como ajudar né \\
\hline $\begin{array}{l}\text { Transcrição E1 } \\
\text { revisada_para maxqda }\end{array}$ & COMPREENSÃO\Experiência\O viver|Quem viveu (5)\Antes do suicídio|Isso nunca vai acontecer & $\begin{array}{l}\text { minha família é tão bem estruturada, tudo lindo maravilhoso, isso nunca vai } \\
\text { acontecer. }\end{array}$ \\
\hline \begin{tabular}{|l|} 
Transcrição E1 \\
revisada_para maxqda
\end{tabular} & COMPREENSÃO\ExperiêncialO viver|Quem viveu (5)\Antes do suicídio/Sentindo a família perfeita & minha família é tão bem estruturada, tudo lindo maravilhoso, \\
\hline \begin{tabular}{|l|} 
Transcrição E1 \\
revisada_para maxqda
\end{tabular} & COMPREENSÃO\Experiência\O viver|Quem viveu (5)\Depois do suicídio\Impactada pelo acontecido & Até que a hora que acontece, que você... eu me descobri mortal \\
\hline \begin{tabular}{|l|} 
Transcrição E1 \\
revisada_para maxqda
\end{tabular} & CONSCIENTIZAÇÃOIConsciência\O absurdo do suicídio|Coisas ruins que podem acontecer na vida|Sentimento sobre o câncer & eu me descobri mortal \\
\hline $\begin{array}{l}\text { Transcrição E1 } \\
\text { revisada_para maxqda }\end{array}$ & CONSCIENTIZAÇÃO|Consciência \O absurdo do suicídio|Coisas ruins que podem acontecer na vidaleu me descobri mortal & eu me descobri mortal \\
\hline \begin{tabular}{|l} 
Transcrição E1 \\
revisada_para maxqda
\end{tabular} & CONSCIENTIZAÇÃO\Consciência $\ O$ absurdo do suicídio\O absurdo do suicídiolO absurdo do suicídio & $\begin{array}{l}\text { Até que a hora que acontece, que você... eu me descobri mortal, eu me descobri a } \\
\text { coisa mais absurda que poderia ter acontecido na minha vida seria um suicídio, e, } \\
\text { no entanto, aconteceu .. }\end{array}$ \\
\hline \begin{tabular}{|l|} 
Transcrição E1 \\
revisada_para maxqda
\end{tabular} & COMPREENSÃO\Experiência\O viver|Quem viveu (5)\Antes do suicídio|Sentindo-se despreparada & e hoje em dia.... não está preparada nunca pra que uma coisa dessas aconteça \\
\hline $\begin{array}{l}\text { Transcrição E1 } \\
\text { revisada_para maxqda }\end{array}$ & CONSCIENTIZAÇÃo|Consciência \O absurdo do suicídio|Coisas ruins que podem acontecer na vida \Possibilidade de adoecer & doença até a gente sabe que pode acontecer \\
\hline $\begin{array}{l}\text { Transcrição E1 } \\
\text { revisada_para maxqda }\end{array}$ & COMPREENSÃO\ExperiêncialO viver|Quem viveu (5)\Antes do suicídio\Isso nunca vai acontecer & doença até a gente sabe que pode acontecer, mas suicídio... Nunca! \\
\hline $\begin{array}{l}\text { Transcrição E1 } \\
\text { revisada_para maxqda }\end{array}$ & COMPREENSÃo|Experiência|O viver|Quem viveu (5)\Depois do suicídio|Tendo uma percepção sobre o suicídio & a minha percepção de suicídio, \\
\hline
\end{tabular}




\begin{tabular}{|c|c|c|}
\hline $\begin{array}{l}\text { Transcrição E1 } \\
\text { revisada_para maxqda }\end{array}$ & COMPREENSÃO|Experiência|O viver|Quem viveu (5)\Depois do suicídio\Mudando a percepção sobre o suicídio & $\begin{array}{l}\text { que acho que eu tinha e que eu mudei depois é.... que eu passei ao conversar com } \\
\text { as pessoas é que eu acho que a maioria enxerga como algo que não tem nada a ver } \\
\text { com a própria realidade.. }\end{array}$ \\
\hline \begin{tabular}{|l} 
Transcrição E1 \\
revisada_para maxqda
\end{tabular} & COMPREENSÃO\Experiência\O viver|Quem não viveu (6) \Imaginando que o suicídio talvez não exista para quem não viveu & $\begin{array}{l}\text { que eu passei ao conversar com as pessoas é que eu acho que a maioria enxerga } \\
\text { como algo que não tem nada a ver com a própria realidade.. }\end{array}$ \\
\hline $\begin{array}{l}\text { Transcrição E1 } \\
\text { revisada_para maxqda }\end{array}$ & CONSCIENTIZAÇÃO|Consciência $\mid \mathrm{O}$ absurdo do suicídio|Coisas ruins que podem acontecer na vida|Um dia pode acontecer comigo & $\begin{array}{l}\text { é como se assim, por exemplo, um assalto até, a maioria das pessoas "um dia pode } \\
\text { acontecer comigo" }\end{array}$ \\
\hline $\begin{array}{l}\text { Transcrição E1 } \\
\text { revisada_para maxqda }\end{array}$ & COMPREENSÃO\Experiência\O viver|Quem viveu (5)\Antes do suicídio|Isso nunca vai acontecer & $\begin{array}{l}\text { é como se assim, por exemplo, um assalto até, a maioria das pessoas "um dia pode } \\
\text { acontecer comigo", mas um suicídio... é assim... eu }\end{array}$ \\
\hline $\begin{array}{l}\text { Transcrição E1 } \\
\text { revisada_para maxqda }\end{array}$ & CONSCIENTIZAÇÃo|Consciência \O absurdo do suicídio\O absurdo do suicídio\O absurdo do suicídio & é que é tão absurdo que... \\
\hline $\begin{array}{l}\text { Transcrição E1 } \\
\text { revisada_para maxqda }\end{array}$ & COMPREENSÃO|Experiência\O viver|Quem não viveu (6)|Suicídio como algo da vida do outro / distante de mim & é assim, é assunto que não tem nada a ver comigo, a maioria pensa assim \\
\hline \begin{tabular}{|l|l} 
& \\
Transcrição E1 \\
revisada_para maxqda
\end{tabular} & COMPREENSÃO\Experiência\O viver|Quem viveu (5)\Depois do suicídio\Dando atenção porque passou pela experiência & $\begin{array}{l}\text { é assim, é assunto que não tem nada a ver comigo, a maioria pensa assim, acho } \\
\text { que em parte.... eu também pensava, né. }\end{array}$ \\
\hline $\begin{array}{l}\text { Transcrição E1 } \\
\text { revisada_para maxqda }\end{array}$ & COMPREENSÃO|Comunicação|Pessoal|Conversando com amigos\Procurando os amigos para conversar & $\begin{array}{l}\text { Então a minha vivência depois até que eu fui conversar com as pessoas né, } \\
\text { procurar ajuda pra me abrir com os amigos }\end{array}$ \\
\hline $\begin{array}{l}\text { Transcrição E1 } \\
\text { revisada_para maxqda }\end{array}$ & COMPREENSÃO|Experiência|O viver|Quem não viveu (6)|Suicídio como algo da vida do outro / distante de mim & $\begin{array}{l}\text { Então a minha vivência depois até que eu fui conversar com as pessoas né, } \\
\text { procurar ajuda pra me abrir com os amigos, tal, é como se pra eles isso é uma } \\
\text { realidade que não tem nada a ver com eles. }\end{array}$ \\
\hline \begin{tabular}{|l|} 
Transcrição E1 \\
revisada_para maxqda
\end{tabular} & COMPREENSÃO\Tabu (1)\Consequências do Tabu\Preconceito & $\begin{array}{l}\text { E aí o tratamento é com esse, um tabu, um preconceito de algo bem distante } \\
\text { assim... }\end{array}$ \\
\hline $\begin{array}{l}\text { Transcrição E1 } \\
\text { revisada_para maxqda }\end{array}$ & COMPREENSÃO|Experiência\O viver|Quem não viveu (6)|Suicídio como algo da vida do outro / distante de mim & $\begin{array}{l}\text { E aí o tratamento é com esse, um tabu, um preconceito de algo bem distante } \\
\text { assim... }\end{array}$ \\
\hline $\begin{array}{l}\text { Transcrição E1 } \\
\text { revisada_para maxqda }\end{array}$ & COMPREENSÃO\Tabu (1)\Consequências do Tabu\O não falar|Ninguém gostando de falar sobre o assunto & $\begin{array}{l}\text { não é distância né, eu acho que ninguém gosta de falar nem quem não passou por } \\
\text { isso né, }\end{array}$ \\
\hline $\begin{array}{l}\text { Transcrição E1 } \\
\text { revisada_para maxqda }\end{array}$ & COMPREENSÃO\Experiência\O viver|Quem viveu (5)\Antes do suicídio\Isso nunca vai acontecer & $\begin{array}{l}\text { eu acho que ninguém gosta de falar nem quem não passou por isso né, então acha } \\
\text { que nunca vai acontecer, não precisa falar, }\end{array}$ \\
\hline \begin{tabular}{|l|l} 
Transcrição E1 \\
revisada_para maxqda
\end{tabular} & COMPREENSÃO|Comunicação|Pessoal|Falar pode machucar (a si mesmo)|Sentindo dor ao falar de suicídio & e quem passou também eu vejo que é muito dolorido falar então, \\
\hline $\begin{array}{l}\text { Transcrição E1 } \\
\text { revisada_para maxqda }\end{array}$ & COMPREENSÃO\Tabu (1)\Consequências do Tabu|Preconceito\O preconceito levando a não falar & $\begin{array}{l}\text { e quem passou também eu vejo que é muito dolorido falar então, por ter um } \\
\text { preconceito também, por ser uma coisa que parece que as pessoas querem achar } \\
\text { um culpado, querem achar um motivo, tem que ter uma razão né, então quanto } \\
\text { mais você fala, mais vão te cutucar, mais vão te machucar, mais vão né, as vezes } \\
\text { sem querer mesmo né, mas acabam te deixando mal. }\end{array}$ \\
\hline $\begin{array}{l}\text { Transcrição E1 } \\
\text { revisada_para maxqda }\end{array}$ & COMPREENSÃo|Visão|Visão da Sociedade (2)\Causas do suicídio|Causa e efeito|Pessoas (e psiquiatras) procurando razão única|Pessoas & $\begin{array}{l}\text { por ter um preconceito também, por ser uma coisa que parece que as pessoas } \\
\text { querem achar um culpado, querem achar um motivo, tem que ter uma razão né, }\end{array}$ \\
\hline $\begin{array}{l}\text { Transcrição E1 } \\
\text { revisada_para maxqda }\end{array}$ & COMPREENSÃO|Comunicação|Pessoal|Reações|Negativas|Sentindo machucada e cutucada & $\begin{array}{l}\text { então quanto mais você fala, mais vão te cutucar, mais vão te machucar, mais vão } \\
\text { né, as vezes sem querer mesmo né, mas acabam te deixando mal. }\end{array}$ \\
\hline $\begin{array}{l}\text { Transcrição E1 } \\
\text { revisada_para maxqda }\end{array}$ & COMPREENSÃO\Comunicação|Pessoal|Reações\Negativas|Sentindo julgamento & $\begin{array}{l}\text { "Ah, mas então ninguém percebeu..." Se tivesse percebido, não teria acontecido, } \\
\text { né se tivesse percebido a gente teria feito alguma coisa pra evitar. Então assim, é } \\
\text { as vezes a gente não fala por conta disso também entendeu? }\end{array}$ \\
\hline $\begin{array}{l}\text { Transcrição E1 } \\
\text { revisada_para maxqda }\end{array}$ & COMPREENSÃO|Comunicação|Pessoal|Reações/Negativas\A necessidade de defesa & $\begin{array}{l}\text { "Ah, mas então ninguém percebeu..." Se tivesse percebido, não teria acontecido, } \\
\text { né se tivesse percebido a gente teria feito alguma coisa pra evitar. Então assim, é } \\
\text { as vezes a gente não fala por conta disso também entendeu? }\end{array}$ \\
\hline $\begin{array}{l}\text { Transcrição E1 } \\
\text { revisada_para maxqda }\end{array}$ & COMPREENSÃO|Comunicação|Pessoal|Reações $\backslash$ Negativas $\backslash O$ que me impede de falar & $\begin{array}{l}\text { "Ah, mas então ninguém percebeu..." Se tivesse percebido, não teria acontecido, } \\
\text { né se tivesse percebido a gente teria feito alguma coisa pra evitar. Então assim, é } \\
\text { as vezes a gente não fala por conta disso também entendeu? }\end{array}$ \\
\hline
\end{tabular}

Material integrante da pesquisa de doutorado de Karen Scavacini - USP Proibida a reprodução ou utilização sem autorização do autor - 2018 


\begin{tabular}{|c|c|c|}
\hline $\begin{array}{l}\text { Transcrição E1 } \\
\text { revisada_para maxqda }\end{array}$ & COMPREENSÃO\Experiência\O viver\Quem viveu (5)\EmpatialQuerendo que ninguém mais tenha essa dor & $\begin{array}{l}\text { Quem não passou não entende, e nunca vai entender, graças a Deus por isso } \\
\text { também, porque eu acho que é uma dor que ... só quem viveu mesmo que sabe o } \\
\text { que significa né, }\end{array}$ \\
\hline $\begin{array}{l}\text { Transcrição E1 } \\
\text { revisada_para maxqda }\end{array}$ & COMPREENSÃO\Experiência\O viver\Quem viveu (5)\Entende|Sentindo-se entendida por quem passou & $\begin{array}{l}\text { Quem não passou não entende, e nunca vai entender, graças a Deus por isso } \\
\text { também, porque eu acho que é uma dor que ... só quem viveu mesmo que sabe o } \\
\text { que significa né, }\end{array}$ \\
\hline $\begin{array}{l}\text { Transcrição E1 } \\
\text { revisada_para maxqda }\end{array}$ & COMPREENSÃO\Experiência\O viver\Quem não viveu (6)\Quem não passou não entende & $\begin{array}{l}\text { Quem não passou não entende, e nunca vai entender, graças a Deus por isso } \\
\text { também, porque eu acho que é uma dor que ... só quem viveu mesmo que sabe o } \\
\text { que significa né, }\end{array}$ \\
\hline $\begin{array}{l}\text { Transcrição E1 } \\
\text { revisada_para maxqda }\end{array}$ & COMPREENSÃO\Tabu (1)\Consequências do Tabu\Preconceito|O preconceito levando a não falar\Assunto que as pessoas não falam & é um assunto assim que as pessoas não falam. \\
\hline $\begin{array}{l}\text { Transcrição E1 } \\
\text { revisada_para maxqda }\end{array}$ & CONSCIENTIZAÇÃO|Consciência\O absurdo do suicídio|Proximidade de suicídios\Passando pelo suicido mais de uma vez & $\begin{array}{l}\text { e eu tenho assim mesmo na minha família o meu sobrinho que se matou, a minha } \\
\text { irmã que já tinha tentado se matar várias vezes e depois que ele se matou ela } \\
\text { tentou mais duas vezes né, }\end{array}$ \\
\hline $\begin{array}{l}\text { Transcrição E1 } \\
\text { revisada_para maxqda }\end{array}$ & CONSCIENTIZAÇÃO|Consciência|O absurdo do suicídio|Proximidade de suicídios|Vendo a irmã morta & $\begin{array}{l}\text { uma agora em fevereiro e ela, eu realmente vi minha irmã morta assim na minha } \\
\text { frente, porque ela tomou um remédio pra pressão, então quase que parou o } \\
\text { coração dela }\end{array}$ \\
\hline $\begin{array}{l}\text { Transcrição E1 } \\
\text { revisada_para maxqda }\end{array}$ & COMPREENSÃO\Tabu (1)\O tabu em diversas esferas\Tabu familiar\Não falando sobre o suicídio em casa & $\begin{array}{l}\text { má agora em fevereiro e ela, eu realmente vi minha irmã morta assim na minha } \\
\text { frente, porque ela tomou um remédio pra pressão, então quase que parou o } \\
\text { coração dela, mas a gente não fala mais nada. }\end{array}$ \\
\hline $\begin{array}{l}\text { Transcrição E1 } \\
\text { revisada_para maxqda }\end{array}$ & COMPREENSÃO\Tabu (1)\O tabu em diversas esferas\Tabu familiar\Não falamos nem em casa & $\begin{array}{l}\text { É como se ela não tivesse feito isso nem dentro da minha casa, que a gente perdeu } \\
\text { já o nosso sobrinho, quer dizer, meu pai não suporta ouvir é, minha mãe evita, } \\
\text { finge que tá tudo bem, então a gente segue assim... né é um assunto assim que as } \\
\text { pessoas não falam. }\end{array}$ \\
\hline $\begin{array}{l}\text { Transcrição E1 } \\
\text { revisada_para maxqda }\end{array}$ & COMPREENSÃO\Tabu (1)\O tabu em diversas esferas\Tabu familiar|Pai não suportando ouvir & \begin{tabular}{|l} 
É como se ela não tivesse feito isso nem dentro da minha casa, que a gente perdeu \\
já o nosso sobrinho, quer dizer, meu pai não suporta ouvir é
\end{tabular} \\
\hline $\begin{array}{l}\text { Transcrição E1 } \\
\text { revisada_para maxqda }\end{array}$ & COMPREENSÃO|Comunicação|Pessoal|Reações|Negativas|Sentindo cortada pelas pessoas & $\begin{array}{l}\text { quando você tem a oportunidade de falar né, as pessoas já cortam logo o assunto } \\
\text { pra não ter que falar... }\end{array}$ \\
\hline $\begin{array}{l}\text { Transcrição E1 } \\
\text { revisada_para maxqda }\end{array}$ & CONSCIENTIZAÇão|Desafios\Impeditivos (18)\Negação ou desinformação (Dificuldade e limites)\Procurando tratamento para a irmã & sim, eu procurei a Karen, eu pedi, ela me indicou tratamento e tudo \\
\hline $\begin{array}{l}\text { Transcrição E1 } \\
\text { revisada_para maxqda }\end{array}$ & CONSCIENTIZAÇÃo|Desafios\Impeditivos (18)\Negação ou desinformação (Dificuldade e limites)\Mãe acreditando que a filha está melho & $\begin{array}{l}\text { aí minha mãe levou ela numa psiquiatra que mudou o remédio dela e ela foi fazer } \\
\text { um curso, então tá tudo bem porque então ela tá bem, ela tá fazendo um curso }\end{array}$ \\
\hline $\begin{array}{l}\text { Transcrição E1 } \\
\text { revisada_para maxqda }\end{array}$ & CONSCIENTIZAÇÃO\Desafios\Impeditivos (18)\Negação ou desinformação (Dificuldade e limites)\Sentindo que a irmã não está bem & $\begin{array}{l}\text { então tá tudo bem porque então ela tá bem, ela tá fazendo um curso. Não, ela não } \\
\text { tá bem, né }\end{array}$ \\
\hline $\begin{array}{l}\text { Transcrição E1 } \\
\text { revisada_para maxqda }\end{array}$ & CONSCIENTIZAÇÃO\Desafios\Impeditivos (18)\Negação ou desinformação (Dificuldade e limites)\Família fingindo que está tudo bem & $\begin{array}{l}\text { aí minha mãe levou ela numa psiquiatra que mudou o remédio dela e ela foi fazer } \\
\text { um curso, então tá tudo bem porque então ela tá bem, ela tá fazendo um curso. } \\
\text { Não, ela não tá bem, né }\end{array}$ \\
\hline $\begin{array}{l}\text { Transcrição E1 } \\
\text { revisada_para maxqda }\end{array}$ & COMPREENSÃO|Comunicação|Pessoal|Conversando com amigos|Tocando no assunto com conhecidos & $\begin{array}{l}\text { ela está falando assim, em termos, de um modo geral, quando se toca no assunto, } \\
\text { que aconteceu com a sua filha, com o seu filho, o seu neto, seu familiar, para um } \\
\text { amigo e você percebe que ele começa a mudar de assunto né, pra não ter que mai } \\
\text { falar sobre o assunto... }\end{array}$ \\
\hline $\begin{array}{l}\text { Transcrição E1 } \\
\text { revisada_para maxqda }\end{array}$ & COMPREENSÃO|Comunicação|Pessoal|Conversando com amigos|Conhecidos mudando o assunto & $\begin{array}{l}\text { ela está falando assim, em termos, de um modo geral, quando se toca no assunto, } \\
\text { que aconteceu com a sua filha, com o seu filho, o seu neto, seu familiar, para um } \\
\text { amigo e você percebe que ele começa a mudar de assunto né, pra não ter que mai } \\
\text { falar sobre o assunto... }\end{array}$ \\
\hline $\begin{array}{l}\text { Transcrição E1 } \\
\text { revisada_para maxqda }\end{array}$ & COMPREENSÃO|Comunicação|Pessoal|Reações|Sentindo que os outros não tem o que falar|Sentindo que as pessoas não sabem o que & é, porque as pessoas também não sabem o que falar. \\
\hline $\begin{array}{l}\text { Transcrição E1 } \\
\text { revisada para maxqda }\end{array}$ & COMPREENSÃo|Comunicação|Pessoal|Reações|Sentindo que os outros não tem o que falar & Não tem o que falar. \\
\hline
\end{tabular}

Material integrante da pesquisa de doutorado de Karen Scavacini - USP Proibida a reprodução ou utilização sem autorização do autor - 2018 


\begin{tabular}{|c|c|c|}
\hline $\begin{array}{l}\text { Transcrição E1 } \\
\text { revisada_para maxqda }\end{array}$ & COMPREENSÃO\Experiência\O sentir|Sentimentos (8)|Desamparo & Não tem o que falar. \\
\hline $\begin{array}{l}\text { Transcrição E1 } \\
\text { revisada_para maxqda }\end{array}$ & COMPREENSÃO|Comunicação|Pessoal|Morreu de quelReação das pessoas a noticia da mortelOutros pedindo desculpas & Uns pedem desculpas eu já me peguei... \\
\hline $\begin{array}{l}\text { Transcrição E1 } \\
\text { revisada_para maxqda }\end{array}$ & COMPREENSÃO|Visão|Causa Mortis (9)\Curiosidade mórbida|Outros buscando a forma da morte & $\begin{array}{l}\text { quando falam assim, ainda mais por ser jovem acham... foi acidente? Aí se você } \\
\text { fala que não, que agora eu ... }\end{array}$ \\
\hline $\begin{array}{l}\text { Transcrição E1 } \\
\text { revisada_para maxqda }\end{array}$ & COMPREENSÃo|Comunicação|Pessoal|Morreu de que\Mudando a causa da morte|Precisando negar a forma de morte & $\begin{array}{l}\text { quando falam assim, ainda mais por ser jovem acham... foi acidente? Aí se você } \\
\text { fala que não, que agora eu ... }\end{array}$ \\
\hline $\begin{array}{l}\text { Transcrição E1 } \\
\text { revisada_para maxqda }\end{array}$ & COMPREENSÃO|Comunicação|Pessoal\Morreu de que\Tomando a postura de não negar a forma de morte & tomei a postura de já não \\
\hline $\begin{array}{l}\text { Transcrição E1 } \\
\text { revisada_para maxqda }\end{array}$ & COMPREENSÃO\Comunicação\Pessoal\Morreu de que\Mudando a causa da morte\Precisando negar a forma de morte $\backslash$ Falando que foi $\mathrm{p}$ & no começo eu tinha até de falar que era acidente, \\
\hline $\begin{array}{l}\text { Transcrição E1 } \\
\text { revisada_para maxqda }\end{array}$ & |COMPREENSÃO|Comunicação|Pessoal|Se preparando para falar|Estando preparada para falar & $\begin{array}{l}\text { agora eu tomei a postura de falar... "aí desculpa", não, eu prefiro que fale... aí eu } \\
\text { já entro porque agora também eu já estou mais preparada }\end{array}$ \\
\hline $\begin{array}{l}\text { Transcrição E1 } \\
\text { revisada_para maxqda }\end{array}$ & COMPREENSÃO\Comunicação|Pessoal|Dificuldades comunicação familiar|Ela não querendo falar sobre o assunto & porque teve uma época que eu também não queria falar né. \\
\hline \begin{tabular}{|l} 
Transcrição E1 \\
revisada_para maxqda
\end{tabular} & COMPREENSÃO|Visão|Causa Mortis (9)\Curiosidade mórbida|Pessoas sendo curiosas & as pessoas vinham falar por curiosidade \\
\hline $\begin{array}{l}\text { Transcrição E1 } \\
\text { revisada_para maxqda }\end{array}$ & COMPREENSÃo|Visão|Visão da Sociedade (2)\Causas do suicídio|Causa e efeito|Pessoas (e psiquiatras) procurando razão única|Pessoas & pra saber um porque e achar um culpado.. \\
\hline \begin{tabular}{|l|l} 
Transcrição E1 \\
revisada_para maxqda
\end{tabular} & COMPREENSÃO|Visão|Causa Mortis (9)\Curiosidade mórbida|Todas as pessoas só querendo isso? & $\begin{array}{l}\text { as pessoas vinham falar por curiosidade, pra saber um porque e achar um } \\
\text { culpado... toda pessoa... }\end{array}$ \\
\hline $\begin{array}{l}\text { Transcrição E1 } \\
\text { revisada_para maxqda }\end{array}$ & COMPREENSÃO|Visão|Causa Mortis (9)|Curiosidade mórbida|Todas as pessoas só querendo isso? & $\begin{array}{l}\text { pra achar um culpado... } \\
\text { P5: é, toda pergunta de qualquer pessoa é no fundo ela está querendo, quem não } \\
\text { passou por isso tá... }\end{array}$ \\
\hline $\begin{array}{l}\text { Transcrição E1 } \\
\text { revisada_para maxqda }\end{array}$ & COMPREENSÃo|Visão|Visão da Sociedade (2)\Causas do suicídio|Causa e efeito|Pessoas (e psiquiatras) procurando razão única|Pessoas & $\begin{array}{l}\text { pra achar um culpado... } \\
\text { P5: é, toda pergunta de qualquer pessoa é no fundo ela está querendo, quem não } \\
\text { passou por isso tá... }\end{array}$ \\
\hline $\begin{array}{l}\text { Transcrição E1 } \\
\text { revisada_para maxqda }\end{array}$ & COMPREENSÃO\Tabu (1)\Consequências do Tabu|Julgamento|Sentindo-se testado e/ou julgado & $\begin{array}{l}\text { é, toda pergunta de qualquer pessoa é no fundo ela está querendo, quem não } \\
\text { passou por isso tá... }\end{array}$ \\
\hline \begin{tabular}{|l} 
Transcrição E1 \\
revisada_para maxqda
\end{tabular} & COMPREENSÃO\Visão|Visão da Sociedade (2)\Causas do suicídio|Culpando diferente pelas idades & eu acho que têm idades né \\
\hline $\begin{array}{l}\text { Transcrição E1 } \\
\text { revisada_para maxqda }\end{array}$ & COMPREENSÃO\Tabu (1)\Consequências do Tabu\Julgamento|Sentindo-se julgada ou questionada & segundo é que você, então se não era, como você não percebeu se era depressão, \\
\hline $\begin{array}{l}\text { Transcrição E1 } \\
\text { revisada_para maxqda }\end{array}$ & COMPREENSÃo|Visão\Visão da Sociedade (2)\Causas do suicídio|Culpando diferente pelas idades\Crenças sobre suicídio de jovens\Joven & $\begin{array}{l}\text { então assim no meu caso, jovem, das questões ... drogas, acho que é uma das } \\
\text { primeiras, que estava usando droga, ahh ... embora às vezes até se estivesse } \\
\text { poderia já ser o fato da depressão mas isso eu vim aprender depois, então assim, } \\
\text { primeiro é droga }\end{array}$ \\
\hline $\begin{array}{l}\text { Transcrição E1 } \\
\text { revisada_para maxqda }\end{array}$ & COMPREENSÃO|Visão|Visão da Sociedade (2)\Causas do suicídio|Causa e efeito\Pessoas (e psiquiatras) procurando razão única & $\begin{array}{l}\text { então assim no meu caso, jovem, das questões ... drogas, acho que é uma das } \\
\text { primeiras, que estava usando droga, ahh ... embora às vezes até se estivesse } \\
\text { poderia já ser o fato da depressão mas isso eu vim aprender depois, então assim, } \\
\text { primeiro é droga }\end{array}$ \\
\hline $\begin{array}{l}\text { Transcrição E1 } \\
\text { revisada_para maxqda }\end{array}$ & |COMPREENSÃo|Visão|Visão da Sociedade (2)\Causas do suicídio|Culpando diferente pelas idades)Crenças de suicídio de mais velhos & $\begin{array}{l}\text { acho que quando a pessoa vai mais velha, questiona-se se tinha uma doença grave, } \\
\text { se tinha uma amante, que foi um amor, uma amante, a mulher... }\end{array}$ \\
\hline
\end{tabular}

Material integrante da pesquisa de doutorado de Karen Scavacini - USP Proibida a reprodução ou utilização sem autorização do autor - 2018 


\begin{tabular}{|c|c|c|}
\hline $\begin{array}{l}\text { Transcrição E1 } \\
\text { revisada_para maxqda }\end{array}$ & COMPREENSÃo|Visão|Visão da Sociedade (2)\Causas do suicídio|Culpando diferente pelas idades\Crenças sobre suicídio de jovens & $\begin{array}{l}\text { eu acho que têm idades né, então assim no meu caso, jovem, das questões ... } \\
\text { drogas, acho que é uma das primeiras, que estava usando droga, ahh ... embora às } \\
\text { vezes até se estivesse poderia já ser o fato da depressão mas isso eu vim aprender } \\
\text { depois, então assim, primeiro é droga }\end{array}$ \\
\hline $\begin{array}{l}\text { Transcrição E1 } \\
\text { revisada_para maxqda }\end{array}$ & COMPREENSÃO\Tabu (1)\Consequências do Tabu\Julgamento|Psiquiatras tendo o mesmo julgamento & o psiquiatra perguntou pra mim a primeira coisa "a amante?" \\
\hline $\begin{array}{l}\text { Transcrição E1 } \\
\text { revisada_para maxqda }\end{array}$ & COMPREENSÃo|Visão|Visão da Sociedade (2)\Causas do suicídio|Causa e efeito|Pessoas (e psiquiatras) procurando razão única|Psiquiatr & I o psiquiatra perguntou pra mim a primeira coisa "a amante?" \\
\hline $\begin{array}{l}\text { Transcrição E1 } \\
\text { revisada_para maxqda }\end{array}$ & COMPREENSÃO\Tabu (1)\Consequências do Tabu\Julgamento|Psiquiatras tendo o mesmo julgamento & Ou perdeu o dinheiro, \\
\hline $\begin{array}{l}\text { Transcrição E1 } \\
\text { revisada_para maxqda }\end{array}$ & COMPREENSÃo|Visão|Visão da Sociedade (2)\Causas do suicídio|Causa e efeito|Pessoas (e psiquiatras) procurando razão única|Psiquiatr & r Ou perdeu o dinheiro, \\
\hline $\begin{array}{l}\text { Transcrição E1 } \\
\text { revisada_para maxqda }\end{array}$ & COMPREENSÃo|Visão|Visão da Sociedade (2)\Causas do suicídio|Causa e efeito|Pessoas (e psiquiatras) procurando razão única|A forma & $\begin{array}{l}\text { Ou se é pessoa mais velha, se está sem dinheiro, então assim, eles já vêm com } \\
\text { aquela forma pronta. }\end{array}$ \\
\hline \begin{tabular}{|l|l} 
Transcrição E1 \\
revisada_para maxqda
\end{tabular} & COMPREENSÃO|Visão|Visão da Sociedade (2)\Causas do suicídio|Culpando diferente pelas idades/Crenças de suicídio de mais velhos & $\begin{array}{l}\text { Ou se é pessoa mais velha, se está sem dinheiro, então assim, eles já vêm com } \\
\text { aquela forma pronta. }\end{array}$ \\
\hline $\begin{array}{l}\text { Transcrição E1 } \\
\text { revisada_para maxqda }\end{array}$ & COMPREENSÃo|Visão|Visão da Sociedade (2)\Causas do suicídio|Causa e efeito|Pessoas (e psiquiatras) procurando razão única|Visto de & é visto de uma forma simplista \\
\hline \begin{tabular}{|l|l} 
Transcrição E1 \\
revisada_para maxqda
\end{tabular} & COMPREENSÃo|Visão|Visão da Sociedade (2)\Causas do suicídio|Culpando diferente pelas idades|Crenças sobre suicídio de jovens & $\begin{array}{l}\text { é, pra jovem eu acho que é a primeira pergunta "está usando droga?" "Se meteu } \\
\text { com quem não devia?" }\end{array}$ \\
\hline $\begin{array}{l}\text { Transcrição E1 } \\
\text { revisada_para maxqda }\end{array}$ & COMPREENSÃo|Visão|Causa Mortis (9)|Curiosidade mórbida|Pessoas sendo curiosas & $\begin{array}{l}\text { é, pra jovem eu acho que é a primeira pergunta "está usando droga?" "Se meteu } \\
\text { com quem não devia?" }\end{array}$ \\
\hline \begin{tabular}{|l|l} 
Transcrição E1 \\
revisada_para maxqda
\end{tabular} & COMPREENSÃo|Visão|Visão da Sociedade (2)\Causas do suicídio|Causa e efeito|Pessoas (e psiquiatras) procurando razão única & $\begin{array}{l}\text { é, pra jovem eu acho que é a primeira pergunta "está usando droga?" "Se meteu } \\
\text { com quem não devia?" }\end{array}$ \\
\hline $\begin{array}{l}\text { Transcrição E1 } \\
\text { revisada_para maxqda }\end{array}$ & COMPREENSÃo|Visão|Visão da Sociedade (2)\Causas do suicídio|Culpando diferente pelas idades\Crenças sobre suicídio de jovens & com amigos, coisa assim... \\
\hline $\begin{array}{l}\text { Transcrição E1 } \\
\text { revisada_para maxqda }\end{array}$ & COMPREENSÃO|Visão|Visão da Sociedade (2)\Causas do suicídio|Culpando diferente pelas idades/Crenças de suicídio de mais velhos & $\begin{array}{l}\text { é então e aí quando passa de uma certa idade você ouve as outras perguntas, } \\
\text { então acho que as pessoas têm... }\end{array}$ \\
\hline $\begin{array}{l}\text { Transcrição E1 } \\
\text { revisada_para maxqda }\end{array}$ & COMPREENSÃO|Visão|Visão da Sociedade (2)\Depressão|Falta de entendimento|Pessoas não acreditando na depressão & $\begin{array}{l}\text { e aí não querem ouvir depressão ainda fica no sentido assim, eu já vi caras de } \\
\text { pessoas assim tipo "nossa essa mãe está se enganando" }\end{array}$ \\
\hline $\begin{array}{l}\text { Transcrição E1 } \\
\text { revisada_para maxqda }\end{array}$ & COMPREENSÃO|Visão|Visão da Sociedade (2)\Depressão|Falta de entendimento|Pessoas buscando justificativa para depressão & quando é mesmo uma depressão as pessoas têm que achar uma justificativa. \\
\hline $\begin{array}{l}\text { Transcrição E1 } \\
\text { revisada_para maxqda }\end{array}$ & COMPREENSÃO|Visão|Visão da Sociedade (2)\Depressão|Falta de entendimento|Pessoas buscando justificativa para depressão & quem não tem nada né, \\
\hline $\begin{array}{l}\text { Transcrição E1 } \\
\text { revisada_para maxqda }\end{array}$ & COMPREENSÃo|Visão|Visão da Sociedade (2)〈Depressão|Falta de entendimento|Pessoas buscando justificativa para depressão & porque ela a pessoa tem uma depressão, se ela tem uma condição tal e tal \\
\hline $\begin{array}{l}\text { Transcrição E1 } \\
\text { revisada_para maxqda }\end{array}$ & COMPREENSÃo|Visão|Visão da Sociedade (2)|Depressão|Falta de entendimento|Sentindo que depressão não se explica fácil & e depressão é uma coisa que você não explica necessariamente \\
\hline $\begin{array}{l}\text { Transcrição E1 } \\
\text { revisada_para maxqda }\end{array}$ & COMPREENSÃo|Visão|Visão da Sociedade (2)\Depressão|Falta de entendimento|Não entendo a depressão & pro meu próprio filho eu fazia essa pergunta né, o que ele tinha? \\
\hline $\begin{array}{l}\text { Transcrição E1 } \\
\text { revisada_para maxqda }\end{array}$ & COMPREENSÃo|Visão|Visão da Sociedade (2)\Depressão|Falta de entendimento|Buscando motivo para depressão & que ele não tinha motivo, e então ele falava o que eu tenho? \\
\hline $\begin{array}{l}\text { Transcrição E1 } \\
\text { revisada_para maxqda }\end{array}$ & COMPREENSÃO|Visão|Visão da Sociedade (2)\Depressão|Falta de entendimento|Pessoas buscando justificativa para depressão & $\begin{array}{l}\text { as coisas têm que ter motivo, eu acho que é essa coisa de todo mundo tentar } \\
\text { encaixar um pouco um conjunto de respostas.. }\end{array}$ \\
\hline \begin{tabular}{|l|} 
Transcrição E1 \\
revisada_para maxqda
\end{tabular} & COMPREENSÃo|Visão|Visão da Sociedade (2)|Depressão|Falta de entendimento|Pessoas não entendem a depressão & $\begin{array}{l}\text { é e disso ser visto assim, como as pessoas não entendem elas têm que trabalhar } \\
\text { com esse repertório que elas têm que é limitado e fica encaixando dentro dessa, } \\
\text { dessa lista de coisas o que elas acham, então... }\end{array}$ \\
\hline
\end{tabular}




\begin{tabular}{|c|c|c|}
\hline $\begin{array}{l}\text { Transcrição E1 } \\
\text { revisada_para maxqda }\end{array}$ & COMPREENSÃO\Experiência\O viver|Quem não viveu (6)\Pessoas achando que não vai acontecer com elas & $\begin{array}{l}\text { acho que ainda as pessoas ficam têm essa coisa de "não vai acontecer comigo } \\
\text { porque eu estou bem, minha vida é ótima", e então mais a vida pode ser ótima e } \\
\text { pode acontecer, é isso! }\end{array}$ \\
\hline $\begin{array}{l}\text { Transcrição E1 } \\
\text { revisada_para maxqda }\end{array}$ & COMPREENSÃO|VisãolVisão da Sociedade (2)\Depressão|Tabu e depressãolOutros achando que família tem problemas & \begin{tabular}{|l} 
É isso, então... se aconteceu com você, se aconteceu com a sua família é porque \\
vocês têm problemas...
\end{tabular} \\
\hline $\begin{array}{l}\text { Transcrição E1 } \\
\text { revisada_para maxqda }\end{array}$ & CONSCIENTIZAÇão|Consciência|O absurdo do suicídio|Prevenção x Previsão|Sentindo que não pode adivinhar pensamentos & $\begin{array}{l}\text { A pessoa pode estar pensando né, só que hoje o que eu entendo e até que esse } \\
\text { seriado me levou a pensar isso, é que muitas vezes dentro da sua casa você não } \\
\text { sabe o que está acontecendo com o seu filho, com seu sobrinho, na cabeça deles } \\
\text { né }\end{array}$ \\
\hline $\begin{array}{l}\text { Transcrição E1 } \\
\text { revisada_para maxqda }\end{array}$ & CONSCIENTIZAÇão|Consciência|O absurdo do suicídio|Limitaç̃oes|Sentindo limitações & $\begin{array}{l}\text { A pessoa pode estar pensando né, só que hoje o que eu entendo e até que esse } \\
\text { seriado me levou a pensar isso, é que muitas vezes dentro da sua casa você não } \\
\text { sabe o que está acontecendo com o seu filho, com seu sobrinho, na cabeça deles } \\
\text { né }\end{array}$ \\
\hline $\begin{array}{l}\text { Transcrição E1 } \\
\text { revisada_para maxqda }\end{array}$ & COMPREENSÃO|Comunicação|Social|Possiveis Causas para o Aumento|Canais de TV investindo no temalRefletindo por causa do seriado & $\begin{array}{l}\text { e até que esse seriado me levou a pensar isso, é que muitas vezes dentro da sua } \\
\text { casa você não sabe o que está acontecendo com o seu filho, com seu sobrinho, na } \\
\text { cabeça deles né }\end{array}$ \\
\hline $\begin{array}{l}\text { Transcrição E1 } \\
\text { revisada_para maxqda }\end{array}$ & COMPREENSÃO|Comunicação|Social|Possiveis Causas para o Aumento|Canais de TV investindo no tema\Refletindo por causa do seriado & $\begin{array}{l}\text { por que eu achei assim, do seriado tão, estava falando hoje para a P2, na hora eu e } \\
\text { o P5 assistimos juntos }\end{array}$ \\
\hline $\begin{array}{l}\text { Transcrição E1 } \\
\text { revisada_para maxqda }\end{array}$ & AÇÃO\Diálogo\O falar (23)\O que (MENSAGEM)\Falar das várias dores (interna e sobreviventes) (Lembrando quando era adolescente & $\begin{array}{l}\text { "nossa, mas as coisas eram assim, de repente, a gente falou, não, não era } \\
\text { insignificante... nossa eu lembrei que eu já falsifiquei minha nota por que meu pai, } \\
\text { porque aquilo era "TÃo", pra mim dolorido mostrar que eu tirei uma nota ruim, } \\
\text { então assim naquela época era aquilo, então de adolescência eu acho que a gente } \\
\text { não sabe o que é. }\end{array}$ \\
\hline $\begin{array}{l}\text { Transcrição E1 } \\
\text { revisada_para maxqda }\end{array}$ & AÇÃO\Diálogo\O falar (23)\O que (MENSAGEM)\Falar das várias dores (interna e sobreviventes) (Lembrando das dores da adolescência & $\begin{array}{l}\text { "nossa, mas as coisas eram assim, de repente, a gente falou, não, não era } \\
\text { insignificante... nossa eu lembrei que eu já falsifiquei minha nota por que meu pai, } \\
\text { porque aquilo era "TÃo", pra mim dolorido mostrar que eu tirei uma nota ruim, } \\
\text { então assim naquela época era aquilo, então de adolescência eu acho que a gente } \\
\text { não sabe o que é. }\end{array}$ \\
\hline \begin{tabular}{|l|l} 
Transcrição E1 \\
revisada_para maxqda
\end{tabular} & COMPREENSÃO\Experiência\O viver\Quem viveu (5)\Aprende\Aprendendo a não julgar a dor do outro & \begin{tabular}{|l|} 
Eu aprendi depois a não julgar é.... qual é a dor, qual o tamanho daquela dor, \\
daquele problema que eu acho que não é nada, que daria para ser resolvido.
\end{tabular} \\
\hline \begin{tabular}{|l|l} 
Transcrição E1 \\
revisada_para maxqda
\end{tabular} & COMPREENSÃO\Experiência\O viver|Quem viveu (5)\Depois do suicídio\Depois de acontecer comigo & \begin{tabular}{|l|} 
Eu aprendi depois a não julgar é.... qual é a dor, qual o tamanho daquela dor, \\
daquele problema que eu acho que não é nada, que daria para ser resolvido.
\end{tabular} \\
\hline \begin{tabular}{|l} 
Transcrição E1 \\
revisada_para maxqda
\end{tabular} & CONSCIENTIZAÇÃo|Consciência \O absurdo do suicídio|Prevenção x Previsão|Correria impedindo a percepção de risco & $\begin{array}{l}\text { porque o que está acontecendo ali dentro, com os filhos e ninguém ta percebendo, } \\
\text { com essa correria do dia a dia né, acha que está tudo bem }\end{array}$ \\
\hline $\begin{array}{l}\text { Transcrição E1 } \\
\text { revisada_para maxqda }\end{array}$ & COMPREENSÃO|Experiência\O viver|Quem viveu (5)\Aprende|Só mudei porque passei & \begin{tabular}{|l|} 
Então se eu vivendo ali na minha casa, só consegui, só conseguia mudar meu \\
pensamento depois, então eu imagino quem ainda acha que não está vivendo né
\end{tabular} \\
\hline $\begin{array}{l}\text { Transcrição E1 } \\
\text { revisada_para maxqda }\end{array}$ & COMPREENSÃO\Experiência\O viver \Quem não viveu (6)\Achando que coisas ruins só acontecem para os outros & $\begin{array}{l}\text { Então se eu vivendo ali na minha casa, só consegui, só conseguia mudar meu } \\
\text { pensamento depois, então eu imagino quem ainda acha que não está vivendo né } \\
\text { porque o que está acontecendo ali dentro, com os filhos e ninguémtá percebendo, } \\
\text { com essa correria do dia a dia né, acha que está tudo bem }\end{array}$ \\
\hline $\begin{array}{l}\text { Transcrição E1 } \\
\text { revisada_para maxqda }\end{array}$ & COMPREENSÃO\Tabu (1)\Consequências do Tabu|Preconceito & Eu penso, que... o tabu ele é muito grande, a dificuldade de falar mas \\
\hline $\begin{array}{l}\text { Transcrição E1 } \\
\text { revisada_para maxqda }\end{array}$ & AÇÃOlO saber (12)\Saber é poder|Falta de informações\Falta de informação sobre o assunto & assim..., pelo que eu passei eu vejo muito a questão da falta de informação \\
\hline $\begin{array}{l}\text { Transcrição E1 } \\
\text { revisada_para maxqda }\end{array}$ & COMPREENSÃO\Experiência\O viver|Quem viveu (5)\Depois do suicídio\Entendendo a gravidade pela experiência & porque quando eu passei por uma situação, \\
\hline $\begin{array}{l}\text { Transcrição E1 } \\
\text { revisada_para maxqda }\end{array}$ & AÇÃo\O saber (12)\Consequências do não saber|Suicídio como esporádico & $\begin{array}{l}\text { embora né alguns anos já dentro do hospital e atendendo assim essas pessoas, } \\
\text { mas a fala delas assim é como se fosse uma notícia da TV, um homicídio, algo assim } \\
\text { esporádico }\end{array}$ \\
\hline
\end{tabular}

Material integrante da pesquisa de doutorado de Karen Scavacini - USP Proibida a reprodução ou utilização sem autorização do autor - 2018 


\begin{tabular}{|c|c|c|}
\hline $\begin{array}{l}\text { Transcrição E1 } \\
\text { revisada_para maxqda }\end{array}$ & COMPREENSÃO\Experiência\O viver\Quem viveu (5)\Depois do suicídio\Entendendo a gravidade pela experiência & $\begin{array}{l}\text { mas quando eu passei aquela situação que eu comecei a pesquisar, ler, e eu } \\
\text { comecei a ter um pouco mais de compreensão da realidade do Suicídio aquilo foi } \\
\text { muito assustador pra mim }\end{array}$ \\
\hline $\begin{array}{l}\text { Transcrição E1 } \\
\text { revisada_para maxqda }\end{array}$ & AÇÃO\O saber (12)\Saber é poder|Falta de informações|Chocando-se com a frequência do suicídio & $\begin{array}{l}\text { por que eu falei isso não é esporádico, isso acontece sim em número muito grande, } \\
\text { todos os dias }\end{array}$ \\
\hline $\begin{array}{l}\text { Transcrição E1 } \\
\text { revisada_para maxqda }\end{array}$ & AÇÃO\O saber (12)\Saber é poder|Falta de informações\Falta de informação sobre o assunto & então saí eu comecei a pensar o quanto eu tinha pouca informação, \\
\hline $\begin{array}{l}\text { Transcrição E1 } \\
\text { revisada_para maxqda }\end{array}$ & AÇÃO\O saber (12)\Falta de formaçãolChocando-se com a sua falta de preparo e conhecimento & $\begin{array}{l}\text { então saí eu comecei a pensar o quanto eu tinha pouca informação, o quanto eu } \\
\text { estava tanto tempo dentro de um hospital, atendendo essas pessoas, mas sem ter } \\
\text { o conhecimento da realidade e da problemática mesmo né, }\end{array}$ \\
\hline $\begin{array}{l}\text { Transcrição E1 } \\
\text { revisada_para maxqda }\end{array}$ & AÇÃO\O saber (12)\Saber é poder|Ter informação normaliza o assunto|Comparando com o câncer de mama & $\begin{array}{l}\text { hoje a gente ouve falar muito da prevenção do câncer de mama, por exemplo, se } \\
\text { de repente eu sentir alguma coisa pra mim vai ser normal ir ao ginecologista e } \\
\text { pedir um exame }\end{array}$ \\
\hline $\begin{array}{l}\text { Transcrição E1 } \\
\text { revisada_para maxqda }\end{array}$ & AÇÃO\O saber (12)\O contato muda|Eu não era assim - antes de ter contato & $\begin{array}{l}\text { talvez se eu tivesse mais conhecimento também me ligaria muito mais, sei lá... nos } \\
\text { sinais, nos fatores então hoje que eu estudei um pouco mais que eu tenho } \\
\text { buscado cada vez mais, quando a pessoa tem alguma fala perto de mim né, ou da } \\
\text { minha família ou não, eu já fico mais esperta, mas eu sei que a um tempo atrás não } \\
\text { era assim }\end{array}$ \\
\hline $\begin{array}{l}\text { Transcrição E1 } \\
\text { revisada_para maxqda }\end{array}$ & AçÃo|O saber (12)|Saber é poder|Falta de informações\Falta de informação sobre o assunto & $\begin{array}{l}\text { então hoje que eu estudei um pouco mais que eu tenho buscado cada vez mais, } \\
\text { quando a pessoa tem alguma fala perto de mim né, ou da minha família ou não, eu } \\
\text { já fico mais esperta, mas eu sei que a um tempo atrás não era assim, então eu ligo } \\
\text { muito essa questão com a falta de informação, nós não temos informações, }\end{array}$ \\
\hline $\begin{array}{l}\text { Transcrição E1 } \\
\text { revisada_para maxqda }\end{array}$ & AÇÃOlO saber (12)\O contato muda \rabalhando com essa demanda & até por estar mais próxima disso hoje, de trabalhar com essa demanda hoje, \\
\hline $\begin{array}{l}\text { Transcrição E1 } \\
\text { revisada_para maxqda }\end{array}$ & COMPREENSÃO\Tabu (1)\Consequências do Tabu\Mitos\Pessoas tendo medo em falar sobre suicídio & $\begin{array}{l}\text { é isso incomoda as pessoas, elas não querem falar sobre isso né, elas não, as } \\
\text { pessoas elas me pedem palestras e falam assim "olha eu quero palestra, mas não é } \\
\text { pra falar sobre Suicídio" }\end{array}$ \\
\hline $\begin{array}{l}\text { Transcrição E1 } \\
\text { revisada_para maxqda }\end{array}$ & COMPREENSÃO\Tabu (1)\Consequências do Tabu\Um assunto proibido\Recusando aprovar o tabu do tema & $\begin{array}{l}\text { as pessoas elas me pedem palestras e falam assim "olha eu quero palestra, mas } \\
\text { não é pra falar sobre Suicídio", né então, esses dias no hospital o cara me chamou } \\
\text { e falou isso, e eu falei "olha, mas não dá, como vamos fazer prevenção do Suicídio } \\
\text { sem falar do Suicídio" }\end{array}$ \\
\hline $\begin{array}{l}\text { Transcrição E1 } \\
\text { revisada_para maxqda }\end{array}$ & COMPREENSÃo|Comunicação|Social\Aumento da comunicação\Hoje já se fala mais sobre o suicídio & $\begin{array}{l}\text { então é eu percebo essa dificuldade, embora estejam né falando muito mais sobre } \\
\text { isso às séries tudo que a gente tem visto aí, os acontecimentos, as pessoas estão } \\
\text { falando muito mais mas }\end{array}$ \\
\hline $\begin{array}{l}\text { Transcrição E1 } \\
\text { revisada_para maxqda }\end{array}$ & COMPREENSÃo|Comunicação|Social|Possiveis Causas para o Aumento|Canais de TV investindo no tema\Assunto sendo gerado pelas sér & $\begin{array}{l}\text { então é eu percebo essa dificuldade, embora estejam né falando muito mais sobre } \\
\text { isso às séries tudo que a gente tem visto aí, os acontecimentos, as pessoas estão } \\
\text { falando muito mais mas }\end{array}$ \\
\hline $\begin{array}{l}\text { Transcrição E1 } \\
\text { revisada_para maxqda }\end{array}$ & COMPREENSÃO\Tabu (1)\Consequências do Tabu\Um assunto proibido|Vendo o suicídio como algo antigo & $\begin{array}{l}\text { suicidio é uma coisa que acontece a muitos anos nessa proporção e só tem } \\
\text { aumentado, não é nada novo, esses dias eu até falei para uma pessoa "olha o } \\
\text { Suicídio não é algo novo, a Bíblia já tem relatos de Suicídio é algo que acontece a } \\
\text { muito tempo" }\end{array}$ \\
\hline $\begin{array}{l}\text { Transcrição E1 } \\
\text { revisada_para maxqda }\end{array}$ & CONSCIENTIZAÇÃo|Consciência\Epidemiologia (20)\Importância da percepção da quantidade〈Sentindo o aumento de casos de suicídio & $\begin{array}{l}\text { isso é uma coisa que acontece a muitos anos nessa proporção e só tem } \\
\text { aumentado, }\end{array}$ \\
\hline $\begin{array}{l}\text { Transcrição E1 } \\
\text { revisada_para maxqda }\end{array}$ & AÇãolO saber (12)|Saber é poder|Falta de informações & \begin{tabular}{|l} 
"olha o Suicídio não é algo novo, a Bíblia já tem relatos de Suicídio é algo que \\
acontece a muito tempo" mas nós não temos informações e nunca tivemos né,
\end{tabular} \\
\hline $\begin{array}{l}\text { Transcrição E1 } \\
\text { revisada_para maxqda }\end{array}$ & AÇÃO\Semear\O que gostariam / Desejos (17)\Esperança em aumentar as falas de prev do suicídio & $\begin{array}{l}\text { eu creio que isso tá aumentando e eu tenho esperança que isso seja tão comum } \\
\text { como hoje é falado da prevenção do câncer de mama, próstata, enfim... }\end{array}$ \\
\hline $\begin{array}{l}\text { Transcrição E1 } \\
\text { revisada_para maxqda }\end{array}$ & CONSCIENTIZAÇão|Desafios|Subnotificação|Subnotificação das tentativas/Números distorcidos & $\begin{array}{l}\text { E é distorcido também porque eu vi é, no atestado de óbito do meu sobrinho não } \\
\text { saiu né... }\end{array}$ \\
\hline
\end{tabular}

Material integrante da pesquisa de doutorado de Karen Scavacini - USP Proibida a reprodução ou utilização sem autorização do autor - 2018 


\begin{tabular}{|c|c|c|}
\hline \begin{tabular}{|l} 
Transcrição E1 \\
revisada_para maxqda
\end{tabular} & CONSCIENTIZAÇÃO\Desafios|Burocracia (11)\Atestado de óbito & $\begin{array}{l}\text { E é distorcido também porque eu vi é, no atestado de óbito do meu sobrinho não } \\
\text { saiu né... }\end{array}$ \\
\hline $\begin{array}{l}\text { Transcrição E1 } \\
\text { revisada_para maxqda }\end{array}$ & CONSCIENTIZAÇÃo|Desafios/Burocracia (11)\Atestado de óbito & No da minha filha também não \\
\hline $\begin{array}{l}\text { Transcrição E1 } \\
\text { revisada_para maxqda }\end{array}$ & CONSCIENTIZAÇÃO|Desafios|Subnotificação|Subnotificação das tentativas|Números distorcidos & Então assim, são quantos e quantos e quantos né, que não são né contabilizados. \\
\hline $\begin{array}{l}\text { Transcrição E1 } \\
\text { revisada_para maxqda }\end{array}$ & CONSCIENTIZAÇÃO|Desafios|Subnotificação|Subnotificação de casos & É subnotificado. \\
\hline $\begin{array}{l}\text { Transcrição E1 } \\
\text { revisada_para maxqda }\end{array}$ & COMPREENSÃo|Visão|Visão da Sociedade (2)\Visão do suicídio hoje no brasill Suicídio visto (e tratado?) como crime & $\begin{array}{l}\text { Mas acho que o grande problema disso que eu vejo é que a questão de que o } \\
\text { Suicídio é que ele ainda é uma de espécie de um crime }\end{array}$ \\
\hline $\begin{array}{l}\text { Transcrição E1 } \\
\text { revisada_para maxqda }\end{array}$ & CONSCIENTIZAÇÃO|Desafios|Subnotificação|Subnotificação de casos|Subnotificação como evitarão de um processo doloroso & $\begin{array}{l}\text { por questão de às vezes um médico ou o que quer que seja tentando evitar, então } \\
\text { por que é um processo também muito doloroso, }\end{array}$ \\
\hline $\begin{array}{l}\text { Transcrição E1 } \\
\text { revisada_para maxqda }\end{array}$ & CONSCIENTIZAÇÃO|Desafios\Burocracia (11)\Processo policial|Processo policial horroroso & $\begin{array}{l}\text { é você, é muita gente, você além do Suicídio, você tem que passar por polícia } \\
\text { dentro da sua casa, existe um processo horroroso dentro de tudo isso, }\end{array}$ \\
\hline $\begin{array}{l}\text { Transcrição E1 } \\
\text { revisada_para maxqda }\end{array}$ & CONSCIENTIZAÇÃO|Desafios\Burocracia (11)\Processo policial|Tabu, subnotificação e processo policial & Então, se não fosse tabu e se não tivesse toda essa questão... \\
\hline $\begin{array}{l}\text { Transcrição E1 } \\
\text { revisada_para maxqda }\end{array}$ & CONSCIENTIZAÇÃO|Desafios\Burocracia (11)\Processo policial|Sendo tratada/o mal pela policia & $\begin{array}{l}\text { Claro, mas só que a polícia trata isso de uma forma que é uma coisa horrorosa, aí } \\
\text { tivemos que dar depoimento e você vai numa delegacia e eles não te tratam bem }\end{array}$ \\
\hline \begin{tabular}{|l} 
Transcrição E1 \\
revisada_para maxqda
\end{tabular} & CONSCIENTIZAÇÃO|Desafios\Burocracia (11)\Processo policial\Tabu, subnotificação e processo policial & $\begin{array}{l}\text { Claro, mas só que a polícia trata isso de uma forma que é uma coisa horrorosa, aí } \\
\text { tivemos que dar depoimento e você vai numa delegacia e eles não te tratam bem, } \\
\text { então isso tem também um questão meio complicada que eu acho que é uma } \\
\text { tentativa complicada por conta desse tabu, }\end{array}$ \\
\hline $\begin{array}{l}\text { Transcrição E1 } \\
\text { revisada_para maxqda }\end{array}$ & CONSCIENTIZAÇÃO|Desafios\Subnotificação|Subnotificação das tentativas & \begin{tabular}{|l|} 
mas por exemplo o meu outro irmão que não morreu, ele já tentou Suicídio 3 \\
vezes, e nenhuma das vezes estava notificado como tentativa de suicídio
\end{tabular} \\
\hline \begin{tabular}{|l} 
Transcrição E1 \\
revisada_para maxqda
\end{tabular} & CONSCIENTIZAÇÃO|Desafios|Subnotificação|Subnotificação das tentativas|Subnotificação pelo próprio hospital/medico & $\begin{array}{l}\text { mas por exemplo o meu outro irmão que não morreu, ele já tentou Suicídio } 3 \\
\text { vezes, e nenhuma das vezes estava notificado como tentativa de suicídio, porque } \\
\text { se não ele ia ter que passar por um processo e o médico falou "ele vai ter que } \\
\text { passar por um processo, por uma investigação, por um... o hospital não dá... }\end{array}$ \\
\hline \begin{tabular}{|l|l} 
Transcrição E1 \\
revisada_para maxqda
\end{tabular} & CONSCIENTIZAÇÃO|Desafios|Subnotificação|Subnotificação das tentativas|Subnotificação pelo próprio hospital/medico & É isso.... Eu sou médico tá, \\
\hline \begin{tabular}{|l|l} 
Transcrição E1 \\
revisada_para maxqda
\end{tabular} & CONSCIENTIZAÇÃO|Desafios|Subnotificação|Subnotificação das tentativas|Lei de atentado contra a vida & suicidio é uma lei, você tem que notificar polícia que é atentado contra a vida \\
\hline $\begin{array}{l}\text { Transcrição E1 } \\
\text { revisada_para maxqda }\end{array}$ & CONSCIENTIZAÇÃO|Desafios|Subnotificação|Subnotificação das tentativas|Lei de atentado contra a vida & Porque é atentado contra avida, e como é que você fica passando por isso né... \\
\hline $\begin{array}{l}\text { Transcrição E1 } \\
\text { revisada_para maxqda }\end{array}$ & CONSCIENTIZAÇÃo|Desafios|Subnotificação|Subnotificação das tentativas|Lei de atentado contra a vida|Médicos sobrecarregados & $\begin{array}{l}\text { Só que acontece o seguinte, agora olha só para o médico, que tem um milhão de } \\
\text { pacientes pra atender tá }\end{array}$ \\
\hline $\begin{array}{l}\text { Transcrição E1 } \\
\text { revisada_para maxqda }\end{array}$ & CONSCIENTIZAÇÃO|Desafios|Subnotificação|Subnotificação das tentativas\Lei de atentado contra a vida)Indo a julgamento & e aí o que acontece ele vai ter que ir em julgamento, no fórum, \\
\hline \begin{tabular}{|l|} 
Transcrição E1 \\
revisada_para maxqda
\end{tabular} & CONSCIENTIZAÇÃO|Desafios|Subnotificação|Subnotificação das tentativas|Lei de atentado contra a vida & $\begin{array}{l}\text { Só que acontece o seguinte, agora olha só para o médico, que tem um milhão de } \\
\text { pacientes pra atender tá, e aí o que acontece ele vai ter que ir em julgamento, no } \\
\text { fórum, aquela baita encheção de saco, pra não dar em nada, E a família vai lá e } \\
\text { acaba fazendo tudo, então para que ele vai? }\end{array}$ \\
\hline $\begin{array}{l}\text { Transcrição E1 } \\
\text { revisada_para maxqda }\end{array}$ & CONSCIENTIZAÇÃO|Desafios|Subnotificação|Subnotificação das tentativas|Lei de atentado contra a vida & Isso só aumenta as complicações... E eu não estou nem justificando... \\
\hline $\begin{array}{l}\text { Transcrição E1 } \\
\text { revisada_para maxqda }\end{array}$ & CONSCIENTIZAÇÃO|Desafios|Subnotificação|Subnotificação das tentativas\Lei de atentado contra a vida|Complicações aumentadas & Isso só aumenta as complicações... E eu não estou nem justificando... \\
\hline $\begin{array}{l}\text { Transcrição E1 } \\
\text { revisada_para maxqda }\end{array}$ & CONSCIENTIZAÇÃO|Desafios/Subnotificação|Subnotificação das tentativas\Lei de atentado contra a vida|Sentindo que ninguém cumpre & lei existe, mas ninguém cumpre a lei tá... \\
\hline
\end{tabular}




\begin{tabular}{|c|c|c|}
\hline $\begin{array}{l}\text { Transcrição E1 } \\
\text { revisada_para maxqda }\end{array}$ & CONSCIENTIZAÇÃo|Desafios/Subnotificação|Subnotificação das tentativas\Lei de atentado contra a vida|Comparando suicídio com abort & $\begin{array}{l}\text { é igual aborto tá, aborto é proibido? É, e se o médico notificar um aborto ele vai } \\
\text { ter que passar } 10 \text { anos da vida dele indo na delegacia... justificando o por que... }\end{array}$ \\
\hline $\begin{array}{l}\text { Transcrição E1 } \\
\text { revisada_para maxqda }\end{array}$ & CONSCIENTIZAÇÃo|Desafios|Subnotificação|Subnotificação das tentativas\Lei de atentado contra a vida|Explicando o que acontece & Eu só estou explicando o que acontece \\
\hline $\begin{array}{l}\text { Transcrição E1 } \\
\text { revisada_para maxqda }\end{array}$ & CONSCIENTIZAÇÃO|Desafios/Subnotificação|Subnotificação das tentativas\Lei de atentado contra a vida|Perdendo tempo se notificar & $\begin{array}{l}\text { o que acontece, o médico, se você notificar } 10 \text { casos desse, eu tô perdido, eu vou } \\
\text { passar o ano inteiro indo no fórum, eu não saio mais do fórum. }\end{array}$ \\
\hline $\begin{array}{l}\text { Transcrição E1 } \\
\text { revisada_para maxqda }\end{array}$ & CONSCIENTIZAÇÃO|Desafios/Subnotificação|Subnotificação das tentativas|Lei de atentado contra a vida|Sentindo a subnotificação probl & IfE isso é super problemático \\
\hline $\begin{array}{l}\text { Transcrição E1 } \\
\text { revisada_para maxqda }\end{array}$ & CONSCIENTIZAÇÃO\Desafios\Burocracia (11)\Atestado de óbito|Explicando sobre o atestado de óbito & $\begin{array}{l}\text { Agora, quanto a esse atestado de óbito que você tá falando, é que é o seguinte, o } \\
\text { atestado de óbito é do que morreu, não é a causa. A causa tá na delegacia. }\end{array}$ \\
\hline $\begin{array}{l}\text { Transcrição E1 } \\
\text { revisada_para maxqda }\end{array}$ & CONSCIENTIZAÇÃO|Desafios|Burocracia (11)\Atestado de óbito|Contando o que acontece no IML|Laudo do IML & não é o atestado, é o laudo do IML mesmo, atestando que... \\
\hline $\begin{array}{l}\text { Transcrição E1 } \\
\text { revisada_para maxqda }\end{array}$ & CONSCIENTIZAÇÃO|Desafios|Burocracia (11)|Atestado de óbito|Contando o que acontece no IML|Laudo do IML & o laudo do IML, o IML fala do que morreu... \\
\hline $\begin{array}{l}\text { Transcrição E1 } \\
\text { revisada_para maxqda }\end{array}$ & CONSCIENTIZAÇÃO|Desafios|Burocracia (11)|Atestado de óbito|Contando o que acontece no IML|Laudo do IML & sufocamento e acabou. \\
\hline $\begin{array}{l}\text { Transcrição E1 } \\
\text { revisada_para maxqda }\end{array}$ & CONSCIENTIZAÇÃO|Desafios|Burocracia (11)\Atestado de óbito|Contando o que acontece no IML|Laudo do IML & Sufocamento e acabou... agora... \\
\hline $\begin{array}{l}\text { Transcrição E1 } \\
\text { revisada_para maxqda }\end{array}$ & CONSCIENTIZAÇÃO|Desafios|Burocracia (11)\Atestado de óbito|Contando o que acontece no IML|Laudo do IML & Aquelas causas externas \\
\hline \begin{tabular}{|l|l} 
Transcrição E1 \\
revisada_para maxqda
\end{tabular} & CONSCIENTIZAÇÃO|Desafios\Burocracia (11)\Atestado de óbito|Causa da morte na delegacia & $\begin{array}{l}\text { agora como foi o sufocamento, o porque do sufocamento é uma questão policial } \\
\text { feita na delegacia igual ela falou. }\end{array}$ \\
\hline $\begin{array}{l}\text { Transcrição E1 } \\
\text { revisada_para maxqda }\end{array}$ & CONSCIENTIZAÇÃO\Desafios|Burocracia (11)\Atestado de óbito & $\begin{array}{l}\text { Mas do meu irmão está suicídio } \\
\text { E: no atestado de óbito }\end{array}$ \\
\hline $\begin{array}{l}\text { Transcrição E1 } \\
\text { revisada_para maxqda }\end{array}$ & CONSCIENTIZAÇÃO|Desafios\Burocracia (11)\Atestado de óbito|Medico não podendo atestar suicídio no IML & $\begin{array}{l}\text { segundo lugar É difícil sair dessa maneira, porque ele não pode colocar, o médico } \\
\text { não pode colocar "Suicídio". }\end{array}$ \\
\hline $\begin{array}{l}\text { Transcrição E1 } \\
\text { revisada_para maxqda }\end{array}$ & CONSCIENTIZAÇÃO|Desafios|Burocracia (11)\Atestado de óbito|Medico não podendo atestar suicídio no IML|Sentindo indignação & ( : \\
\hline $\begin{array}{l}\text { Transcrição E1 } \\
\text { revisada_para maxqda }\end{array}$ & CONSCIENTIZAÇÃO|Desafios|Burocracia (11)\Atestado de óbito|Medico não podendo atestar suicídio no IML|Suicídio não é causa de mo & suicídio... mas espera um pouquinho, o Suicídio não é causa de morte \\
\hline $\begin{array}{l}\text { Transcrição E1 } \\
\text { revisada_para maxqda }\end{array}$ & CONSCIENTIZAÇÃO|Desafios|Burocracia (11)\Atestado de óbito|Medico não podendo atestar suicídio no IML|Suicídio não é causa de mo & legalmente \\
\hline $\begin{array}{l}\text { Transcrição E1 } \\
\text { revisada_para maxqda }\end{array}$ & CONSCIENTIZAÇÃo|Desafios|Burocracia (11)\Atestado de óbito|Medico não podendo atestar suicídio no IMLIPensando em causa da mor & mas para o bem social... \\
\hline $\begin{array}{l}\text { Transcrição E1 } \\
\text { revisada_para maxqda }\end{array}$ & CONSCIENTIZAÇÃO|Desafios/Burocracia (11)\Atestado de óbito & \begin{tabular}{|l} 
não existe um médico que possa dar um atestado de óbito de um suicida \\
legalmente tá.
\end{tabular} \\
\hline $\begin{array}{l}\text { Transcrição E1 } \\
\text { revisada_para maxqda }\end{array}$ & CONSCIENTIZAÇÃO|Desafios\Burocracia (11)\Atestado de óbito\Mudando a causa da morte & $\begin{array}{l}\text { Eu posso ir lá sou seu amigo, botar que ele morreu de outra causa, mas foi Suicídio. } \\
\text { Eu estou escondendo um crime da polícia. }\end{array}$ \\
\hline $\begin{array}{l}\text { Transcrição E1 } \\
\text { revisada_para maxqda }\end{array}$ & CONSCIENTIZAÇÃO|Desafios\Burocracia (11)\Atestado de óbito\Explicando sobre o atestado de óbito & $\begin{array}{l}\text { Bom, outra coisa é independente do que saia o laudo do IML, o teu problema está } \\
\text { na delegacia, igual fizeram com você, com todos que passaram na delegacia. }\end{array}$ \\
\hline $\begin{array}{l}\text { Transcrição E1 } \\
\text { revisada_para maxqda }\end{array}$ & CONSCIENTIZAÇÃO\Desafios\Burocracia (11)\Atestado de óbito\O IML não tem culpa & $\begin{array}{l}\text { Bom, outra coisa é independente do que saia o laudo do IML, o teu problema está } \\
\text { na delegacia, igual fizeram com você, com todos que passaram na delegacia. }\end{array}$ \\
\hline $\begin{array}{l}\text { Transcrição E1 } \\
\text { revisada_para maxqda }\end{array}$ & CONSCIENTIZAÇÃO\Desafios\Burocracia (11)\Atestado de óbito|Causa da morte na delegacia & $\begin{array}{l}\text { Bom, outra coisa é independente do que saia o laudo do IML, o teu problema está } \\
\text { na delegacia, igual fizeram com você, com todos que passaram na delegacia. }\end{array}$ \\
\hline $\begin{array}{l}\text { Transcrição E1 } \\
\text { revisada_para maxqda }\end{array}$ & CONSCIENTIZAÇÃO|Desafios|Subnotificação|Subnotificação de casos & eu tenho uma tia que foi e que não tá dizendo Suicídio \\
\hline $\begin{array}{l}\text { Transcrição E1 } \\
\text { revisada_para maxqda }\end{array}$ & CONSCIENTIZAÇÃO|Desafios\Burocracia (11)\Atestado de óbito & $\begin{array}{l}\text { mas o meu irmão está dizendo assim é exatamente nessas palavras, assim que o } \\
\text { remédio que ele tomou e por Suicídio. }\end{array}$ \\
\hline
\end{tabular}

Material integrante da pesquisa de doutorado de Karen Scavacini - USP Proibida a reprodução ou utilização sem autorização do autor - 2018 


\begin{tabular}{|c|c|c|}
\hline $\begin{array}{l}\text { Transcrição E1 } \\
\text { revisada_para maxqda }\end{array}$ & CONSCIENTIZAÇão|Desafios|Subnotificação|Subnotificação de casos\Estatística incorreta & você não tem nem uma estatística \\
\hline $\begin{array}{l}\text { Transcrição E1 } \\
\text { revisada_para maxqda }\end{array}$ & CONSCIENTIZAÇÃO|Desafios|Subnotificação|Subnotificação de casos\Estatística incorreta & $\begin{array}{l}\text { a gente está falando que não temos uma estatística correta porque não é } \\
\text { notificado da forma como deveria. }\end{array}$ \\
\hline $\begin{array}{l}\text { Transcrição E1 } \\
\text { revisada_para maxqda }\end{array}$ & CONSCIENTIZAÇÃO|Desafios|Subnotificação|Subnotificação de casos\Explicando sobre estatística & mas essa estatística é feita no IML junto com a polícia tá. \\
\hline $\begin{array}{l}\text { Transcrição E1 } \\
\text { revisada_para maxqda }\end{array}$ & CONSCIENTIZAÇÃO|Desafios\Burocracia (11)\Atestado de óbito\Mostrando a declaração de óbito do sobrinho & $\begin{array}{l}\text { então, mas olha aqui. Declaração de óbito, que é justamente do serviço funerário } \\
\text { lá do município }\end{array}$ \\
\hline $\begin{array}{l}\text { Transcrição E1 } \\
\text { revisada_para maxqda }\end{array}$ & CONSCIENTIZAÇÃO|Desafios|Subnotificação|Subnotificação de casos & $\begin{array}{l}\text { Aí tem um campo aqui que diz "causas externas", aí tá "prováveis circunstâncias de } \\
\text { morte não natural", aí tem o tipo "acidente, Suicídio, homicídio, outros e } \\
\text { ignorado", ele está como ignorado. } \\
\text { P5: porque } \\
\text { P8: mas tá provado }\end{array}$ \\
\hline $\begin{array}{l}\text { Transcrição E1 } \\
\text { revisada_para maxqda }\end{array}$ & CONSCIENTIZAÇÃO\Desafios\Burocracia (11)\Atestado de óbito|Contando o que acontece no IML & $\begin{array}{l}\text { por favor, deixa eu te contar o que acontece no IML, eu trabalho no IML tá, deixa } \\
\text { eu te contar o que acontece.. }\end{array}$ \\
\hline $\begin{array}{l}\text { Transcrição E1 } \\
\text { revisada_para maxqda }\end{array}$ & CONSCIENTIZAÇÃO\Desafios\Burocracia (11)\Atestado de óbito|Contando o que acontece no IMLIProcesso do IML & $\begin{array}{l}\text { o corpo chega lá, como é que eu posso falar que ele estava amarrado em uma } \\
\text { corda? Eu posso colocar que tem lesões no pescoço indicando que parecia } \\
\text { enforcamento por corda. }\end{array}$ \\
\hline $\begin{array}{l}\text { Transcrição E1 } \\
\text { revisada_para maxqda }\end{array}$ & CONSCIENTIZAÇÃO|Desafios\Burocracia (11)\Atestado de óbito|Contando o que acontece no IMLIForma da morte $x$ Causa da morte & $\begin{array}{l}\text { o corpo chega lá, como é que eu posso falar que ele estava amarrado em uma } \\
\text { corda? Eu posso colocar que tem lesões no pescoço indicando que parecia } \\
\text { enforcamento por corda. }\end{array}$ \\
\hline $\begin{array}{l}\text { Transcrição E1 } \\
\text { revisada_para maxqda }\end{array}$ & CONSCIENTIZAÇÃO|Desafios\Burocracia (11)\Processo policial & $\begin{array}{l}\text { doutor, no meu caso antes do corpo da minha filha sair de casa veio a polícia } \\
\text { científica, polícia técnica e eles fotografaram e tal e depois levaram pra aquele } \\
\text { caixão de zinco que foi pro IML e foi liberado no dia seguinte }\end{array}$ \\
\hline $\begin{array}{l}\text { Transcrição E1 } \\
\text { revisada_para maxqda }\end{array}$ & CONSCIENTIZAÇÃO|Desafios\Burocracia (11)\Processo policial|Simplificando a liberação por coleguismo & $\begin{array}{l}\text { levaram pra aquele caixão de zinco que foi pro IML e foi liberado no dia seguinte só } \\
\text { que eu sei que o perito ele quando ele soube que eu era um oficial de justiça eu sei } \\
\text { que tudo ficou simplificado e a liberação do corpo, e saiu como sufocamento }\end{array}$ \\
\hline $\begin{array}{l}\text { Transcrição E1 } \\
\text { revisada_para maxqda }\end{array}$ & CONSCIENTIZAÇÃO\Desafios\Burocracia (11)\Processo policial|Sentindo que o perito quis poupar do desgosto & $\begin{array}{l}\text { e saiu como sufocamento, e eu entendi que ele no intuito da mente dele de me } \\
\text { poupar, do desgosto de estar a nomenclatura "Suicídio" ele colocou sufocamento. }\end{array}$ \\
\hline \begin{tabular}{|l} 
Transcrição E1 \\
revisada_para maxqda
\end{tabular} & CONSCIENTIZAÇÃO|Desafios\Burocracia (11)\Atestado de óbito\Achando que a causa da morte tinha sido alterada para ser poupa & $\begin{array}{l}\text { e saiu como sufocamento, e eu entendi que ele no intuito da mente dele de me } \\
\text { poupar, do desgosto de estar a nomenclatura "Suicídio" ele colocou sufocamento. }\end{array}$ \\
\hline $\begin{array}{l}\text { Transcrição E1 } \\
\text { revisada_para maxqda }\end{array}$ & CONSCIENTIZAÇÃO\Desafios\Burocracia (11)\Atestado de óbito|Contando o que acontece no IML\Forma da morte $x$ Causa da morte & o certo é ele colocar sufocamento e não suicídio \\
\hline \begin{tabular}{|l} 
Transcrição E1 \\
revisada_para maxqda
\end{tabular} & CONSCIENTIZAÇÃO|Desafios|Burocracia (11)\Atestado de óbito\Achando que a causa da morte tinha sido alterada para ser poupa\Enten & agora eu estou entendendo \\
\hline $\begin{array}{l}\text { Transcrição E1 } \\
\text { revisada_para maxqda }\end{array}$ & CONSCIENTIZAÇÃO\Desafios\Burocracia (11)\Processo policial\Os papéis de cada ator da cena & $\begin{array}{l}\text { Eu não sei do que a pessoa, como é que a pessoa, qual é a técnica lá na sua casa vê } \\
\text { uma pessoa lá... e fotografa... e tudo aquela coisa... }\end{array}$ \\
\hline $\begin{array}{l}\text { Transcrição E1 } \\
\text { revisada_para maxqda }\end{array}$ & |CONSCIENTIZAÇÃO|Desafios/Burocracia (11)\Processo policial & mas eles sabiam que foi por suicídio... porque foi fotografado. \\
\hline $\begin{array}{l}\text { Transcrição E1 } \\
\text { revisada_para maxqda }\end{array}$ & CONSCIENTIZAÇÃO\Desafios\Burocracia (11)\Processo policial & $\begin{array}{l}\text { Eu não sei do que a pessoa, como é que a pessoa, qual é a técnica lá na sua casa vê } \\
\text { uma pessoa lá... e fotografa... e tudo aquela coisa... }\end{array}$ \\
\hline $\begin{array}{l}\text { Transcrição E1 } \\
\text { revisada_para maxqda }\end{array}$ & CONSCIENTIZAÇÃO|Desafios/Burocracia (11)\Atestado de óbito|Contando o que acontece no IMLIProcesso do IML & mas isso não vai pro médico, \\
\hline $\begin{array}{l}\text { Transcrição E1 } \\
\text { revisada_para maxqda }\end{array}$ & CONSCIENTIZAÇÃO|Desafios\Burocracia (11)\Processo policial|Pensando que existe falha na comunicação & mas não tem uma falha de comunicação? \\
\hline $\begin{array}{l}\text { Transcrição E1 } \\
\text { revisada_para maxqda }\end{array}$ & |CONSCIENTIZAÇÃO|Desafios\Burocracia (11)\Processo policial & $\begin{array}{l}\text { não, isso não vai para o médico, vai para a polícia científica na polícia, feito pelo } \\
\text { policial... pro médico chega o corpo lá, }\end{array}$ \\
\hline
\end{tabular}

Material integrante da pesquisa de doutorado de Karen Scavacini - USP Proibida a reprodução ou utilização sem autorização do autor - 2018 


\begin{tabular}{|c|c|c|}
\hline \begin{tabular}{|l} 
Transcrição E1 \\
revisada_para maxqda
\end{tabular} & CONSCIENTIZAÇÃO|Desafios\Burocracia (11)\Atestado de óbito|Contando o que acontece no IMLIProcesso do IML & $\begin{array}{l}\begin{array}{l}\text { não, isso não vai para o médico, vai para a polícia científica na polícia, feito pelo } \\
\text { policial... pro médico chega o corpo lá, }\end{array} \\
\end{array}$ \\
\hline $\begin{array}{l}\text { Transcrição E1 } \\
\text { revisada_para maxqda }\end{array}$ & CONSCIENTIZAÇÃO|Desafios\Burocracia (11)\Atestado de óbito|Medico não podendo atestar suicídio no IML & é só o que eu estou vendo no corpo, eu não posso supor nada. \\
\hline $\begin{array}{l}\text { Transcrição E1 } \\
\text { revisada_para maxqda }\end{array}$ & CONSCIENTIZAÇÃO\Desafios\Burocracia (11)\Processo policial\Os papéis de cada ator da cena & é só o que eu estou vendo no corpo, eu não posso supor nada. \\
\hline $\begin{array}{l}\text { Transcrição E1 } \\
\text { revisada_para maxqda }\end{array}$ & CONSCIENTIZAÇÃO|Desafios\Burocracia (11)\Atestado de óbito|Contando o que acontece no IML|Processo do IML & $\begin{array}{l}\text { Não tenho que colocar lá "tá grávida" ou não tá grávida, se é mulher você tem que } \\
\text { fazer exame ginecológico, independente de qualquer coisa, se houve estupro ou } \\
\text { não houve estupro, independente do que foi a causa da morte. }\end{array}$ \\
\hline $\begin{array}{l}\text { Transcrição E1 } \\
\text { revisada_para maxqda }\end{array}$ & CONSCIENTIZAÇÃO|Desafios\Burocracia (11)\Atestado de óbito|Contando o que acontece no IMLIProcesso do IML & $\begin{array}{l}\text { Tudo isso você tem que averiguar no corpo, mas eu não posso colocar opinião } \\
\text { minha "ah, eu acho que foi por isso aquilo lá..." }\end{array}$ \\
\hline $\begin{array}{l}\text { Transcrição E1 } \\
\text { revisada_para maxqda }\end{array}$ & CONSCIENTIZAÇÃO|Desafios\Burocracia (11)\Atestado de óbito|Contando o que acontece no IML|Forma da morte x Causa da morte & isso quem vai determinar é a polícia depois de uma investigação \\
\hline \begin{tabular}{|l} 
Transcrição E1 \\
revisada_para maxqda
\end{tabular} & CONSCIENTIZAÇÃO\Desafios|Burocracia (11)\Processo policial\Os papéis de cada ator da cena & isso quem vai determinar é a polícia depois de uma investigação \\
\hline \begin{tabular}{|l|} 
Transcrição E1 \\
revisada_para maxqda
\end{tabular} & CONSCIENTIZAÇÃO\Desafios\Burocracia (11)\Processo policial\Os papéis de cada ator da cena & aí quem vai investigar essa outra parte é a equipe cientifica junto com a polícia. \\
\hline \begin{tabular}{|l} 
Transcrição E1 \\
revisada_para maxqda
\end{tabular} & CONSCIENTIZAÇÃO|Desafios\Burocracia (11)\Atestado de óbito|Contando o que acontece no IML\Forma da morte x Causa da morte & $\begin{array}{l}\text { Até porque quem sufocou você não sabe se foi a pessoa mesmo ou outra pessoa, } \\
\text { se foi... }\end{array}$ \\
\hline $\begin{array}{l}\text { Transcrição E1 } \\
\text { revisada_para maxqda }\end{array}$ & CONSCIENTIZAÇÃO|Desafios\Burocracia (11)\Atestado de óbito|Contando o que acontece no IML\Forma da morte x Causa da morte & Sim, por isso que você toma parte da delegacia. \\
\hline $\begin{array}{l}\text { Transcrição E1 } \\
\text { revisada_para maxqda }\end{array}$ & CONSCIENTIZAÇÃO\Desafios\Burocracia (11)\Processo policial & Sim, por isso que você toma parte da delegacia. \\
\hline $\begin{array}{l}\text { Transcrição E1 } \\
\text { revisada_para maxqda }\end{array}$ & CONSCIENTIZAÇÃO\Desafios\Burocracia (11)\Processo policial|Sendo tratada/o mal pela policia & Eu fui maltratado na delegacia \\
\hline $\begin{array}{l}\text { Transcrição E1 } \\
\text { revisada_para maxqda }\end{array}$ & CONSCIENTIZAÇÃO\Desafios\Burocracia (11)\Processo policial\Sendo tratada/o mal pela policia & Não, eu não, meus pais....... \\
\hline $\begin{array}{l}\text { Transcrição E1 } \\
\text { revisada_para maxqda }\end{array}$ & CONSCIENTIZAÇÃO|Desafios\Burocracia (11)|Processo policial|Sendo tratada/o mal pela policia & $\begin{array}{l}\text { Eu fui... porque eles acharam que eu era o culpado, talvez... então eles foram para } \\
\text { cima de mim... me apertaram, fizeram um monte de pergunta, um monte de } \\
\text { encheção de saco... quiseram ouvir ela sozinha, pra saber se ele tinha problemas } \\
\text { comigo, se eu brigava com ele }\end{array}$ \\
\hline $\begin{array}{l}\text { Transcrição E1 } \\
\text { revisada_para maxqda }\end{array}$ & CONSCIENTIZAÇÃO|Desafios/Burocracia (11)\Processo policial|Entendendo o processo policial & $\begin{array}{l}\text { mas escuta, eu tenho que entender, mas é óbvio, o cara não me conhece. O cara } \\
\text { nunca me viu, não sabe quem eu sou, }\end{array}$ \\
\hline \begin{tabular}{|l} 
Transcrição E1 \\
revisada_para maxqda
\end{tabular} & CONSCIENTIZAÇÃO|Desafios/Burocracia (11)|Processo policial|Policia achando que ele era culpado & $\begin{array}{l}\text { Eu fui... porque eles acharam que eu era o culpado, talvez... então eles foram para } \\
\text { cima de mim... me apertaram, fizeram um monte de pergunta, um monte de } \\
\text { encheção de saco.. }\end{array}$ \\
\hline \begin{tabular}{|l|} 
Transcrição E1 \\
revisada_para maxqda
\end{tabular} & CONSCIENTIZAÇÃO\Desafios\Burocracia (11)\Processo policial|Entendendo o processo policial & Ossos do ofício \\
\hline $\begin{array}{l}\text { Transcrição E1 } \\
\text { revisada_para maxqda }\end{array}$ & CONSCIENTIZAÇÃO|Desafios\Burocracia (11)\Processo policial|Entendendo o processo policial & ele tem... o delegado tem que fazer a parte dele. \\
\hline $\begin{array}{l}\text { Transcrição E1 } \\
\text { revisada_para maxqda }\end{array}$ & CONSCIENTIZAÇÃO\Desafios\Burocracia (11)\Processo policial\Sendo tratada/o mal pela policia & Nós fomos ouvidos separadamente. E foram muito grossos comigo e com ela. \\
\hline $\begin{array}{l}\text { Transcrição E1 } \\
\text { revisada_para maxqda }\end{array}$ & CONSCIENTIZAÇÃO|Desafios|Burocracia (11)\Atestado de óbito\Fazendo comparações entre os atestados' & $\begin{array}{l}\text { é, no caso eu acho que f colocaram no atestado de óbito que o meu irmão ele } \\
\text { deixou tudo muito explicado, ele colocou a dose, ele colocou tudo assim, bem } \\
\text { explicadinho }\end{array}$ \\
\hline $\begin{array}{l}\text { Transcrição E1 } \\
\text { revisada_para maxqda }\end{array}$ & CONSCIENTIZAÇÃO|Desafios/Subnotificação|Subnotificação de casos & $\begin{array}{l}\text { Pra não dar dúvida tal, mas eu acho que é essa a questão, só meio pra tentar estar } \\
\text { dentro né, eu acho que o grande problema da subnotificação é isso, é não ter } \\
\text { aonde isso tá, }\end{array}$ \\
\hline
\end{tabular}

Material integrante da pesquisa de doutorado de Karen Scavacini - USP Proibida a reprodução ou utilização sem autorização do autor - 2018 


\begin{tabular}{|c|c|c|}
\hline $\begin{array}{l}\text { Transcrição E1 } \\
\text { revisada_para maxqda }\end{array}$ & CONSCIENTIZAÇÃO|Desafios|Subnotificação|Subnotificação de casos & não ter um padrão... \\
\hline $\begin{array}{l}\text { Transcrição E1 } \\
\text { revisada_para maxqda }\end{array}$ & CONSCIENTIZAÇÃO|Desafios|Subnotificação|Subnotificação de casos|Falta de padrão & não ter um padrão... \\
\hline $\begin{array}{l}\text { Transcrição E1 } \\
\text { revisada_para maxqda }\end{array}$ & CONSCIENTIZAÇÃO|Desafios|Subnotificação|Subnotificação de casos|Falta de padrão & $\begin{array}{l}\text { não ter um padrão de como isso é registrado, se é no atestado de óbito, se é num } \\
\text { lugar, se é no outro, os próprios }\end{array}$ \\
\hline $\begin{array}{l}\text { Transcrição E1 } \\
\text { revisada_para maxqda }\end{array}$ & COMPREENSÃo|Visão|Visão da Sociedade (2)|Visão do suicídio hoje no brasillSuicídio visto (e tratado?) como crime & $\begin{array}{l}\text { e eu acho que todo esse problema também por ser um crime, é acaba tornando } \\
\text { isso um tabu ainda maior. Piora o tratamento das pessoas que precisam de ajuda. }\end{array}$ \\
\hline $\begin{array}{l}\text { Transcrição E1 } \\
\text { revisada_para maxqda }\end{array}$ & CONSCIENTIZAÇÃO|Desafios\Subnotificação|Subnotificação das tentativas & $\begin{array}{l}\text { as próprias tentativas do suicídio que também não são notificadas, por causa de... } \\
\text { e eu acho que todo esse problema também por ser um crime, é acaba tornando } \\
\text { isso um tabu ainda maior. }\end{array}$ \\
\hline $\begin{array}{l}\text { Transcrição E1 } \\
\text { revisada_para maxqda }\end{array}$ & CONSCIENTIZAÇÃO|Desafios|Burocracia (11)\Atestado de óbito & $\begin{array}{l}\text { só poderia colocar suicídio no atestado de óbito, botar assim como queira, pelo } \\
\text { seguinte... pelos dados do atestado de óbito ele precisa colocar do ele morreu. }\end{array}$ \\
\hline $\begin{array}{l}\text { Transcrição E1 } \\
\text { revisada_para maxqda }\end{array}$ & CONSCIENTIZAÇÃO\Desafios\Burocracia (11)\Atestado de óbito & $\begin{array}{l}\text { Aí quando vem os outros } 30,40 \text { dias depois vem a dosagem de sangue, se tinha } \\
\text { álcool, se tinha droga... foi aí que comprovou se teu irmão tomou remédio ou não, } \\
\text { ou que seja. }\end{array}$ \\
\hline \begin{tabular}{|l} 
Transcrição E1 \\
revisada_para maxqda
\end{tabular} & CONSCIENTIZAÇÃO\Desafios\Burocracia (11)\Atestado de óbito\Medico não podendo atestar suicídio no IML & $\begin{array}{l}\text { Antes disso, o médico foi contratado só pra enterrar, ele não tem, ele não sabe } \\
\text { disso. }\end{array}$ \\
\hline $\begin{array}{l}\text { Transcrição E1 } \\
\text { revisada_para maxqda }\end{array}$ & COMPREENSÃO\Experiência|O viver|Quem não viveu (6)\Suicídio como algo da vida do outro / distante de mim & $\begin{array}{l}\text { então olha a gente esta falando que o suicídio não é visto, quando ele é visto, ele é } \\
\text { visto como algo alheio, longe da realidade de cada um }\end{array}$ \\
\hline \begin{tabular}{|l|l} 
Transcrição E1 \\
revisada_para maxqda
\end{tabular} & CONSCIENTIZAÇÃo|Desafios|Subnotificação|Subnotificação de casos & $\begin{array}{l}\text { A gente está falando que o fato dos números não serem fidedignos também } \\
\text { dificulta que ele seja visto por essa sociedade com a quantidade que ele ocorre. }\end{array}$ \\
\hline $\begin{array}{l}\text { Transcrição E1 } \\
\text { revisada_para maxqda }\end{array}$ & CONSCIENTIZAÇÃO|Consciência|Epidemiologia (20)\Aumento da consciência pelo numero de casos & $\begin{array}{l}\text { Então a gente também pode pensar se a gente tivesse esses números, passasse } \\
\text { esses números talvez aumentasse uma consciência, quando as pessoas } \\
\text { percebessem o número de casos, né. }\end{array}$ \\
\hline $\begin{array}{l}\text { Transcrição E1 } \\
\text { revisada_para maxqda }\end{array}$ & CONSCIENTIZAÇÃO\Desafios\Burocracia (11)\Burocracia & A burocracia \\
\hline $\begin{array}{l}\text { Transcrição E1 } \\
\text { revisada_para maxqda }\end{array}$ & |CONSCIENTIZAÇÃO|Desafios\Burocracia (11)\Burocracia & Tem a burocracia que atrapalha, \\
\hline $\begin{array}{l}\text { Transcrição E1 } \\
\text { revisada_para maxqda }\end{array}$ & CONSCIENTIZAÇÃO|Desafios $\backslash$ Impeditivos (18)\Falta de cuidado & $\begin{array}{l}\text { tem uma falta de cuidado das pessoas ao lidar com o tema, e a gente está falando } \\
\text { também que... }\end{array}$ \\
\hline $\begin{array}{l}\text { Transcrição E1 } \\
\text { revisada_para maxqda }\end{array}$ & COMPREENSÃo|Visão|Visão da Sociedade (2)\Causas do suicídio|Causa e efeito|Pessoas (e psiquiatras) procurando razão única|Pessoas & $\begin{array}{l}\text { tende-se a procurar um culpado. Ou a droga, ou é a falência financeira ou é a } \\
\text { familia ou } \\
\text { P11: N motivos }\end{array}$ \\
\hline $\begin{array}{l}\text { Transcrição E1 } \\
\text { revisada_para maxqda }\end{array}$ & COMPREENSÃo|Visão|Visão da Sociedade (2)\Causas do suicídio|Causa e efeito|Pessoas (e psiquiatras) procurando razão única|Suicídio & os profissionais... então tende-se a olhar o suicídio como um causa e efeito. \\
\hline $\begin{array}{l}\text { Transcrição E1 } \\
\text { revisada_para maxqda }\end{array}$ & AÇÃO\O saber (12)\Falta de formação\Falta de estudos e de preparo & $\begin{array}{l}\text { então, mas eu acho que tem também a questão dos estudos e do preparo dos } \\
\text { profissionais, nas diferentes áreas que entram no contexto. Que por exemplo, pelo } \\
\text { que eu saiba não fala sobre suicídio, por exemplo, num curso de psicologia, na } \\
\text { medicina, etc., etc... ou por exemplo, mesmo para os policiais, eu imagino assim } \\
\text { nem eles têm a informação teoricamente de uma forma mais né científica, } \\
\text { estruturada, com mais estudos, como que eles vão às vezes autuar nos seus } \\
\text { ambientes aonde esse assunto surge mais }\end{array}$ \\
\hline $\begin{array}{l}\text { Transcrição E1 } \\
\text { revisada_para maxqda }\end{array}$ & AÇÃO\O saber (12)\Saber é poder|Ter informação normaliza o assunto|Para o câncer há informação & $\begin{array}{l}\text { por exemplo a questão do câncer, cada vez mais foi estudado, as pessoas vão atrás } \\
\text { entendeu... eles se especializam nesse tema, então eles estão mais preparados pra } \\
\text { lidar com isso, }\end{array}$ \\
\hline $\begin{array}{l}\text { Transcrição E1 } \\
\text { revisada_para maxqda }\end{array}$ & AÇÃOlO saber (12)\Falta de formaçãolFalta de estudos e de preparo & $\begin{array}{l}\text { mas por exemplo o suicídio se ele não é nem abordado nesses ambientes que são } \\
\text { seguros, confiáveis, imagina no resto. }\end{array}$ \\
\hline
\end{tabular}

Material integrante da pesquisa de doutorado de Karen Scavacini - USP Proibida a reprodução ou utilização sem autorização do autor - 2018 


\begin{tabular}{|c|c|c|}
\hline $\begin{array}{l}\text { Transcrição E1 } \\
\text { revisada_para maxqda }\end{array}$ & AÇÃO\O saber (12)|Saber é poder|Falta de informações\Nem em lugares seguros para falar & $\begin{array}{l}\text { mas por exemplo o suicídio se ele não é nem abordado nesses ambientes que são } \\
\text { seguros, confiáveis, imagina no resto. }\end{array}$ \\
\hline $\begin{array}{l}\text { Transcrição E1 } \\
\text { revisada_para maxqda }\end{array}$ & COMPREENSÃo|ComunicaçãolPessoal|Morreu de quelMudando a causa da mortelPrecisando negar a forma de mortelEscondendo que & $\begin{array}{l}\text { E para mim continua essa questão, de que eu acho que, que nem, uma vez, é que } \\
\text { eu não falo né que meu irmão se suicidou, então eu não vivi muitas situações, }\end{array}$ \\
\hline $\begin{array}{l}\text { Transcrição E1 } \\
\text { revisada_para maxqda }\end{array}$ & COMPREENSÃO\Comunicação\Pessoal\Reações\O que as pessoas fazem com a informação de um suicídio & $\begin{array}{l}\text { mas quando eu vi uma menina falando... tipo, as pessoas não fizeram nada com } \\
\text { aquela informação eu fiquei: falei, putz, será que depois alguém vai vir falar pra } \\
\text { mim "nossa, P10 viu a Irma Dela se suicidou" Ninguém fez nada com aquela } \\
\text { informação }\end{array}$ \\
\hline $\begin{array}{l}\text { Transcrição E1 } \\
\text { revisada_para maxqda }\end{array}$ & COMPREENSÃO\Experiência\O viver|Quem não viveu (6)\Quem não viveu não entende & $\begin{array}{l}\text { então eu não sei se é porque, é que nem como se fosse qualquer outra coisa } \\
\text { porque a pessoa não entende o quão grande é aquilo, e aí eles nem comentam } \\
\text { nada. }\end{array}$ \\
\hline $\begin{array}{l}\text { Transcrição E1 } \\
\text { revisada_para maxqda }\end{array}$ & COMPREENSÃO\Experiência\O viver|Quem não viveu (6)\O suicídio é distante para quem não passou pela experiência & $\begin{array}{l}\text { Por um lado eu fiquei contente deles não terem comentado no sentido de tipo "aí } \\
\text { credo então a família Dela" que eles não julgaram, mas também não falaram nada } \\
\text { então mostra talvez que a percepção é de algo distante né, algo que sei lá... tipo } \\
\text { que não é faz parte da realidade. }\end{array}$ \\
\hline \begin{tabular}{|l} 
Transcrição E1 \\
revisada_para maxqda
\end{tabular} & COMPREENSÃO\Comunicação|Pessoal\O falar como uma causa/bandeira|Se as pessoas que viveram não falam, quem vai abordar isso & $\begin{array}{l}\text { Ainda mais as pessoas que viveram isso, igual eu... não falam em menos lugares } \\
\text { isso vai ser abordado e talvez é discutido ou não sei }\end{array}$ \\
\hline $\begin{array}{l}\text { Transcrição E1 } \\
\text { revisada_para maxqda }\end{array}$ & COMPREENSÃO\Comunicação|Pessoal\O falar como uma causa/bandeira|Se as pessoas que viveram não falam, quem vai abordar isso & vai continuar a ficar no fechado \\
\hline $\begin{array}{l}\text { Transcrição E1 } \\
\text { revisada_para maxqda }\end{array}$ & COMPREENSÃO|Tabu (1)\Consequências do Tabu\Um assunto proibido|Suicídio é um assunto proibido & $\begin{array}{l}\text { vocês acham que as pessoas percebem o suicídio como algo proibido de ser } \\
\text { falado? }\end{array}$ \\
\hline $\begin{array}{l}\text { Transcrição E1 } \\
\text { revisada_para maxqda }\end{array}$ & COMPREENSÃO\Tabu (1)\Consequências do Tabu\Um assunto proibido\Parecido com a morte & Acho que igual a morte, não que a morte, não que a morte não... \\
\hline \begin{tabular}{|l} 
Transcrição E1 \\
revisada_para maxqda
\end{tabular} & COMPREENSÃO\Experiência\O viver|Quem não viveu (6)\Pessoas tem dificuldade por saberem a gravidade do assunto & $\begin{array}{l}\text { eu entendo que as pessoas têm muita dificuldade. Elas sabem a gravidade do } \\
\text { assunto ... tem dificuldade em falar, }\end{array}$ \\
\hline $\begin{array}{l}\text { Transcrição E1 } \\
\text { revisada_para maxqda }\end{array}$ & COMPREENSÃO\Experiência|O sentir|Sentimentos (8)\Dor|De quem fica|Sentindo muita dor & $\begin{array}{l}\text { e sabem o quanto é doloroso, eu já entendo diferente aqui de todo mundo, eu } \\
\text { acho que não falam porque, por pena, e porque sabem o quanto aquilo é doloroso. } \\
\text { Não tem o que... nada que console. }\end{array}$ \\
\hline $\begin{array}{l}\text { Transcrição E1 } \\
\text { revisada_para maxqda }\end{array}$ & COMPREENSÃO\Experiência\O sentir|Sentimentos (8)\Dor|De quem fica\Não há o que console & $\begin{array}{l}\text { tem dificuldade em falar, que eles sabem que aquilo é tão doloroso pra quem tá } \\
\text { passando, e ela não imagina que aquilo possa chegar até ela de tão doloroso que é, } \\
\text { então as pessoas evitam de falar, porque não tem o que falar e sabem o quanto é } \\
\text { doloroso, eu já entendo diferente aqui de todo mundo, eu acho que não falam } \\
\text { porque, por pena, e porque sabem o quanto aquilo é doloroso. Não tem o que... } \\
\text { nada que console. }\end{array}$ \\
\hline $\begin{array}{l}\text { Transcrição E1 } \\
\text { revisada_para maxqda }\end{array}$ & COMPREENSÃO\Tabu (1)\Consequências do Tabu\Um assunto proibido|Suicídio é um assunto proibido & $\begin{array}{l}\text { gente foi convidado pra dar uma palestra sobre a valorização da vida, prevenção } \\
\text { do suicídio e a valorização da vida e estava tudo certo aí no dia anterior liga a } \\
\text { professora pedindo pra não falar de suicídio na palestra. Porque os diretores não } \\
\text { estavam concordando. }\end{array}$ \\
\hline $\begin{array}{l}\text { Transcrição E1 } \\
\text { revisada_para maxqda }\end{array}$ & COMPREENSÃO\Tabu (1)\O tabu em diversas esferas\Tabu Escolar\Medo de falar "suicídio" na escola & $\begin{array}{l}\text { a gente foi convidado pra dar uma palestra sobre a valorização da vida, prevenção } \\
\text { do suicídio e a valorização da vida e estava tudo certo aí no dia anterior liga a } \\
\text { professora pedindo pra não falar de suicídio na palestra. Porque os diretores não } \\
\text { estavam concordando. }\end{array}$ \\
\hline $\begin{array}{l}\text { Transcrição E1 } \\
\text { revisada_para maxqda }\end{array}$ & COMPREENSÃO\Tabu (1)\O tabu em diversas esferas\Tabu Escolar\Medo de falar "suicídio" na escola \Crença de que e & $\begin{array}{l}\text { Um colégio assim, de um nivel bem elevado... e começa que como eu vou fazer } \\
\text { uma palestra sobre suicídio sem falar de suicídio? Não... você pode falar assim de } \\
\text { outro jeito e tal ... mas você não pode falar... (risos), então fica difícil né, por causa } \\
\text { disso, você fica... }\end{array}$ \\
\hline
\end{tabular}

Material integrante da pesquisa de doutorado de Karen Scavacini - USP Proibida a reprodução ou utilização sem autorização do autor - 2018 


\begin{tabular}{|c|c|c|}
\hline $\begin{array}{l}\text { Transcrição E1 } \\
\text { revisada_para maxqda }\end{array}$ & COMPREENSÃO\Tabu (1)\Consequências do Tabu\Um assunto proibido & $\begin{array}{l}\text { Um colégio assim, de um nível bem elevado... e começa que como eu vou fazer } \\
\text { uma palestra sobre suicídio sem falar de suicídio? Não... você pode falar assim de } \\
\text { outro jeito e tal ... mas você não pode falar... (risos), então fica dificil né, por causa } \\
\text { disso, você fica... }\end{array}$ \\
\hline $\begin{array}{l}\text { Transcrição E1 } \\
\text { revisada_para maxqda }\end{array}$ & 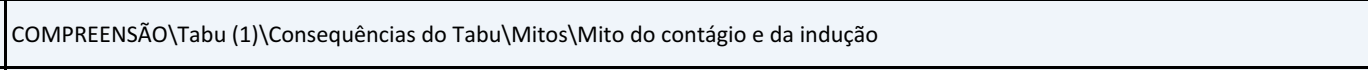 & $\begin{array}{l}\text { As pessoas acham que se você falar... que você está querendo estimular né. Que } \\
\text { você está querendo induzir... }\end{array}$ \\
\hline $\begin{array}{l}\text { Transcrição E1 } \\
\text { revisada_para maxqda }\end{array}$ & COMPREENSÃO\Tabu (1)\Outros Tabus\Comparando tabus (sexo e suicídio) & $\begin{array}{l}\text { antigamente não se falava em sexo né, na minha época em que eu fiz colégio eu } \\
\text { tive aula né de educação sexual. A professora falava da camisinha tal e tal e isso } \\
\text { não fazia com que a você saísse por aí né... a torto e a direita... (risos) }\end{array}$ \\
\hline $\begin{array}{l}\text { Transcrição E1 } \\
\text { revisada_para maxqda }\end{array}$ & COMPREENSÃO\Tabu (1)\Consequências do Tabu\Mitos\Falar não faz com que faça & $\begin{array}{l}\text { antigamente não se falava em sexo né, na minha época em que eu fiz colégio eu } \\
\text { tive aula né de educação sexual. A professora falava da camisinha tal e tal e isso } \\
\text { não fazia com que a você saísse por aí né... a torto e a direita... (risos) }\end{array}$ \\
\hline $\begin{array}{l}\text { Transcrição E1 } \\
\text { revisada_para maxqda }\end{array}$ & COMPREENSÃO\Tabu (1)\Consequências do Tabu\Mitos\Mito do contágio e da indução & $\begin{array}{l}\text { eles falam que se a gente falar de suicídio como se fosse... quem está com algum } \\
\text { tipo de problema... como se fosse incentivar as pessoas que tem algum tipo de } \\
\text { problema. }\end{array}$ \\
\hline $\begin{array}{l}\text { Transcrição E1 } \\
\text { revisada_para maxqda }\end{array}$ & COMPREENSÃO\Tabu (1)\Consequências do Tabu\Mitos|Falar sobre suicídio gera problema & $\begin{array}{l}\text { eles falam que se a gente falar de suicídio como se fosse... quem está com algum } \\
\text { tipo de problema... como se fosse incentivar as pessoas que tem algum tipo de } \\
\text { problema. }\end{array}$ \\
\hline $\begin{array}{l}\text { Transcrição E1 } \\
\text { revisada_para maxqda }\end{array}$ & AÇÃOlO saber (12)\Saber é poder|Preparar pessoas a falarem corretamente & $\begin{array}{l}\text { então eu acho que deveria começar, quer dizer..., acho que a discussão toda é } \\
\text { essa, dentro do trabalho da Karen... é começar a preparar pessoas para falar de } \\
\text { uma maneira correta. }\end{array}$ \\
\hline $\begin{array}{l}\text { Transcrição E1 } \\
\text { revisada_para maxqda }\end{array}$ & COMPREENSÃO\Tabu (1)|Consequências do Tabu\Mitos|Sentindo medo de falar & $\begin{array}{l}\text { Porque eu acho que alinha muito... entre o } \ldots \text { você falar e despertar a curiosidade } \\
\text { do adolescente para aquilo, eu tenho muito medo. }\end{array}$ \\
\hline $\begin{array}{l}\text { Transcrição E1 } \\
\text { revisada_para maxqda }\end{array}$ & COMPREENSÃO\Tabu (1)\Consequências do Tabu\Mitos|Prevenindo ou incentivando & $\begin{array}{l}\text { Porque eu acho que alinha muito... entre o ... você falar e despertar a curiosidade } \\
\text { do adolescente para aquilo, eu tenho muito medo. Assim, se eu tivesse que falar } \\
\text { eu não sei aonde seria a linha de você falar com prevenção pra que ele... chamar } \\
\text { atenção para que a família ele peça ajuda né ou incentivar, acho que a linha... é ali } \\
\text { aonde fica o pessoal não sabe a linha aonde começa, aonde você tá incentivando e } \\
\text { onde não está, }\end{array}$ \\
\hline $\begin{array}{l}\text { Transcrição E1 } \\
\text { revisada_para maxqda }\end{array}$ & |CONSCIENTIZAÇÃO|Desafios\\
mpeditivos (18)\Necessidade de profissionais capacitados (Capacitação) & $\begin{array}{l}\text { então eu acho que deve ter profissionais muito mais capacitados pra dar uma } \\
\text { palestra... que disse que... }\end{array}$ \\
\hline \begin{tabular}{|l} 
Transcrição E1 \\
revisada_para maxqda
\end{tabular} & COMPREENSÃO\Tabu (1)\O tabu em diversas esferas\Tabu Escolar\Medo de falar "suicídio" na escola \O problema não é a falta de profiss & mas tem profissionais capacitados, é o outro lado né que tá... \\
\hline $\begin{array}{l}\text { Transcrição E1 } \\
\text { revisada_para maxqda }\end{array}$ & COMPREENSÃO\Tabu (1)\Consequências do Tabu\Um assunto proibidolQuem proíbe? & $\begin{array}{l}\text { mas tem profissionais capacitados, é o outro lado né que tá... } \\
\text { P4: proíbe né... }\end{array}$ \\
\hline $\begin{array}{l}\text { Transcrição E1 } \\
\text { revisada_para maxqda }\end{array}$ & COMPREENSÃO\Tabu (1)|Consequências do TabulPreconceito & Acho que isso é mais uma questão do tabu em si... é o tabu mesmo... \\
\hline $\begin{array}{l}\text { Transcrição E1 } \\
\text { revisada_para maxqda }\end{array}$ & COMPREENSÃO\Tabu (1)\Consequências do Tabu\Mitos|Falar sobre suicídio gera problema & $\begin{array}{l}\text { você tem professores que querem... mas tem diretor que acha que isso é } \\
\text { prejudicial aos seus alunos. }\end{array}$ \\
\hline $\begin{array}{l}\text { Transcrição E1 } \\
\text { revisada_para maxqda }\end{array}$ & COMPREENSÃO\Tabu (1)\Consequências do Tabu\Mitos|Falar sobre suicídio gera problema & porque tem os pais, que não vão querer... aí... porque aí eu vou tirar... e tal... \\
\hline $\begin{array}{l}\text { Transcrição E1 } \\
\text { revisada_para maxqda }\end{array}$ & COMPREENSÃO\Tabu (1)\O tabu em diversas esferas\Tabu Escolar\Medo de falar "suicídio" na escola|Proibição ao tema vindo dos pais d & $\begin{array}{l}\text { porque tem os pais, que não vão querer... aí... porque aí eu vou tirar... e tal... } \\
\text { P1: exatamente... os pais que não querem... e é colégio caro e tal... é isso aí }\end{array}$ \\
\hline $\begin{array}{l}\text { Transcrição E1 } \\
\text { revisada_para maxqda }\end{array}$ & COMPREENSÃO\Tabu (1)\O tabu em diversas esferas\Tabu Escolar\Medo de falar "suicídio" na escola \Pais como problema de falar sobre & porque tem os pais, que não vão querer... aí... porque aí eu vou tirar... e tal... \\
\hline $\begin{array}{l}\text { Transcrição E1 } \\
\text { revisada_para maxqda }\end{array}$ & COMPREENSÃO\Tabu (1)\O tabu em diversas esferas\Tabu Escolar\Medo de falar "suicídio" na escola\Pais como problema de falar sobre & exatamente... os pais que não querem... e é colégio caro e tal... é isso aí \\
\hline
\end{tabular}

Material integrante da pesquisa de doutorado de Karen Scavacini - USP Proibida a reprodução ou utilização sem autorização do autor - 2018 


\begin{tabular}{|c|c|c|}
\hline \begin{tabular}{|l} 
Transcrição E1 \\
revisada_para maxqda
\end{tabular} & COMPREENSÃO\Tabu (1)\O tabu em diversas esferas\Tabu Escolar\Medo de falar "suicídio" na escola\Pais como problema de falar sobre & $\begin{array}{l}\text { pode ver que deve ser o maior problema dos colégios... os pais... não vamos falar } \\
\text { sobre isso... }\end{array}$ \\
\hline \begin{tabular}{|l} 
Transcrição E1 \\
revisada_para maxqda
\end{tabular} & COMPREENSÃO\Tabu (1)\O tabu em diversas esferas\Tabu Escolar\Medo de falar "suicídio" na escola\Diferença entre colégios de perifer & $\begin{array}{l}\text { De certa forma os colégios de periferia, de certa forma, a gente não tem problema } \\
\text { de... }\end{array}$ \\
\hline $\begin{array}{l}\text { Transcrição E1 } \\
\text { revisada_para maxqda }\end{array}$ & COMPREENSÃO|Comunicação|Social|Desafios\Morte escancarada & $\begin{array}{l}\text { eu vejo que o problema maior é questão do suicídio em si, porque ... a morte ela é } \\
\text { jogada dentro da nossa casa todos os dias da forma mais banal que existe né, é só } \\
\text { você ligar no Datena que você vai ver corpos e corpos estirados ali e eu, por } \\
\text { exemplo, que eu tenho duas crianças em casa, se eu não tomar cuidado os meus } \\
\text { filhos vão ver aquilo totalmente, todos os dias né, e isso é banalizado. }\end{array}$ \\
\hline \begin{tabular}{|l|} 
Transcrição E1 \\
revisada_para maxqda
\end{tabular} & COMPREENSÃO\Tabu (1)\O tabu está no suicídio & $\begin{array}{l}\text { eu vejo que o problema maior é questão do suicídio em si, porque ... a morte ela é } \\
\text { jogada dentro da nossa casa todos os dias da forma mais banal que existe né, é só } \\
\text { você ligar no Datena que você vai ver corpos e corpos estirados ali e eu, por } \\
\text { exemplo, que eu tenho duas crianças em casa, se eu não tomar cuidado os meus } \\
\text { filhos vão ver aquilo totalmente, todos os dias né, e isso é banalizado. }\end{array}$ \\
\hline $\begin{array}{l}\text { Transcrição E1 } \\
\text { revisada_para maxqda }\end{array}$ & COMPREENSÃO\Tabu (1)\Consequências do Tabu\Preconceito & $\begin{array}{l}\text { A internet mesmo a gente vê, pessoas que se suicidam, o funcionário chega mais } \\
\text { cedo na empresa, vê, tira foto, posta e daqui a pouco aquilo se espalha de uma tal } \\
\text { maneira e todo mundo vê, então eu vejo que o problema é a questão do tabu, é o } \\
\text { preconceito né?! }\end{array}$ \\
\hline \begin{tabular}{|l|} 
Transcrição E1 \\
revisada_para maxqda
\end{tabular} & COMPREENSÃO|Comunicação|Social|Desafios\Morte escancarada & $\begin{array}{l}\text { A internet mesmo a gente vê, pessoas que se suicidam, o funcionário chega mais } \\
\text { cedo na empresa, vê, tira foto, posta e daqui a pouco aquilo se espalha de uma tal } \\
\text { maneira e todo mundo vê, então eu vejo que o problema é a questão do tabu, é o } \\
\text { preconceito né?! }\end{array}$ \\
\hline \begin{tabular}{|l|} 
Transcrição E1 \\
revisada_para maxqda
\end{tabular} & CONSCIENTIZAÇÃO|Desafios\Impeditivos (18)\Necessidade de profissionais capacitados (Capacitação) & $\begin{array}{l}\text { É claro que tem que ter profissionais preparados pra falar de todos os assuntos, } \\
\text { não só do suicídio, uma pessoa que não entende, se ela falar bobagem, falar } \\
\text { besteira, é claro que aquilo não vai ser produtivo, }\end{array}$ \\
\hline $\begin{array}{l}\text { Transcrição E1 } \\
\text { revisada_para maxqda }\end{array}$ & COMPREENSÃO\Tabu (1)\O tabu está no suicídio & $\begin{array}{l}\text { mas eu vejo que assim a barreira mesmo, é a questão do suicídio né, não a morte, } \\
\text { claro a morte, mas a questão é do tabu mesmo com a situação, com o tema... }\end{array}$ \\
\hline \begin{tabular}{|l|l} 
Transcrição E1 \\
revisada_para maxqda
\end{tabular} & COMPREENSÃO\Tabu (1)\O tabu está no suicídio & do absurdo a pessoa ter escolhido partir né \\
\hline \begin{tabular}{|l|l} 
Transcrição E1 \\
revisada_para maxqda
\end{tabular} & CONSCIENTIZAÇÃO\Consciência \O absurdo do suicídio\O absurdo do suicídio\O absurdo do suicídio & do absurdo a pessoa ter escolhido partir né \\
\hline $\begin{array}{l}\text { Transcrição E1 } \\
\text { revisada_para maxqda }\end{array}$ & CONSCIENTIZAÇÃO|Consciência|Complexidade|Por onde começar|Dando milhões de passos para trás & mas gente, sabe o que eu acho, a gente tem que dar milhões de passos pra trás. \\
\hline $\begin{array}{l}\text { Transcrição E1 } \\
\text { revisada_para maxqda }\end{array}$ & COMPREENSÃO\Experiência\O sentir|Sentimentos (8)\Dor|De quem fica|Suicídio é hard & Pra mim, suicídio é o nível mais hard da humanidade. \\
\hline $\begin{array}{l}\text { Transcrição E1 } \\
\text { revisada_para maxqda }\end{array}$ & CONSCIENTIZAÇÃO|Consciência|ComplexidadelOnde tudo começa|Tudo começa na tristeza & $\begin{array}{l}\text { A gente não consegue acolher uma tristeza, quanto mais tipo um suicídio } \\
\text { entendeu? }\end{array}$ \\
\hline \begin{tabular}{|l} 
Transcrição E1 \\
revisada_para maxqda
\end{tabular} & CONSCIENTIZAÇÃO|Consciência|Complexidade)Por onde começar|Educar sobre os sentimentos & $\begin{array}{l}\begin{array}{l}\text { Então eu acho que enquanto sabe não tiver educação base pra falar de tipo } \\
\text { "sentimentos" }\end{array} \\
\end{array}$ \\
\hline $\begin{array}{l}\text { Transcrição E1 } \\
\text { revisada_para maxqda }\end{array}$ & CONSCIENTIZAÇÃO\Consciência|Complexidade\A exclusão da tristeza\Falta de acolhimento de sentimentos ruins & $\begin{array}{l}\text { que tipo um dia você está triste, você não pode falar que você tá triste, as pessoas, } \\
\text { o mundo não consegue acolher os sentimentos ruins que acontecem na nossa vida. }\end{array}$ \\
\hline $\begin{array}{l}\text { Transcrição E1 } \\
\text { revisada_para maxqda }\end{array}$ & CONSCIENTIZAÇÃO|Consciência|Complexidade\A exclusão da tristezalvocê não pode falar que você tá triste & você não pode falar que você tá triste \\
\hline $\begin{array}{l}\text { Transcrição E1 } \\
\text { revisada_para maxqda }\end{array}$ & AÇÃO|Semear\O que gostariam / Desejos (17)\Acolhendo os sentimentos do suicida & $\begin{array}{l}\text { Então imagina acolher tudo aquilo que a pessoa, assim, que a pessoa que se suicida } \\
\text { sente, }\end{array}$ \\
\hline $\begin{array}{l}\text { Transcrição E1 } \\
\text { revisada_para maxqda }\end{array}$ & AÇÃO|SemearlO que gostariam / Desejos (17)\Acolhendo os que ficam & e ainda o fato do suicídio depois pros que ficam \\
\hline
\end{tabular}




\begin{tabular}{|c|c|c|}
\hline $\begin{array}{l}\text { Transcrição E1 } \\
\text { revisada_para maxqda }\end{array}$ & CONSCIENTIZAÇÃO|Consciência|Complexidade|Por onde começar|Precisamos falar de outras coisas antes & Então acho que antes do suicídio virar um tema, que a gente consiga conversar, \\
\hline $\begin{array}{l}\text { Transcrição E1 } \\
\text { revisada_para maxqda }\end{array}$ & AÇÃO|Semear\O que gostariam / Desejos (17)\Evoluir em coisas básicas e acolhimento & $\begin{array}{l}\text { eu acho que a humanidade tem que evoluir muito em coisas básicas sabe, tem } \\
\text { uma base do ser humano que não está formada, que é de acolher assim, falar um } \\
\text { oi tudo bem ou tipo de dar bom dia, tem gente que não dá bom dia }\end{array}$ \\
\hline $\begin{array}{l}\text { Transcrição E1 } \\
\text { revisada_para maxqda }\end{array}$ & CONSCIENTIZAÇÃo|Consciência|Complexidade\A exclusão da tristeza|Falta de acolhimento de sentimentos ruins & $\begin{array}{l}\text { então eu acho que a gente não evoluiu assim em coisas que a gente não consegue } \\
\text { acolher a tristeza }\end{array}$ \\
\hline $\begin{array}{l}\text { Transcrição E1 } \\
\text { revisada_para maxqda }\end{array}$ & CONSCIENTIZAÇão|Desafios\Impeditivos (18)\Falta de percepçãolFalta de percepção dos outros & A gente não percebe os outros \\
\hline $\begin{array}{l}\text { Transcrição E1 } \\
\text { revisada_para maxqda }\end{array}$ & CONSCIENTIZAÇÃO\Desafios\Impeditivos (18)\Falta de percepção & $\begin{array}{l}\text { A gente não percebe os outros, a gente não consegue falar com essas pessoas, } \\
\text { então assim, o suicídio pra mim é uma coisa complexa }\end{array}$ \\
\hline $\begin{array}{l}\text { Transcrição E1 } \\
\text { revisada_para maxqda }\end{array}$ & CONSCIENTIZAÇÃO|Consciência \O absurdo do suicídio\O absurdo do suicídio|Suicídio é complexo & então assim, o suicídio pra mim é uma coisa complexa, a última fase sabe da escala \\
\hline \begin{tabular}{|l} 
Transcrição E1 \\
revisada_para maxqda
\end{tabular} & CONSCIENTIZAÇÃO|Consciência|Complexidade\Onde tudo começa|Última fase da escala da tristeza & então assim, o suicídio pra mim é uma coisa complexa, a última fase sabe da escala \\
\hline \begin{tabular}{|l} 
Transcrição E1 \\
revisada_para maxqda
\end{tabular} & CONSCIENTIZAÇÃO|Consciência|Complexidade|Ditadura da alegria|Obrigatoriedade da felicidade & $\begin{array}{l}\text { as pessoas têm que ser feliz hoje todos os dias. Essa coisa da felicidade, da busca } \\
\text { da felicidade, que todo dia você tem que estar bem }\end{array}$ \\
\hline $\begin{array}{l}\text { Transcrição E1 } \\
\text { revisada_para maxqda }\end{array}$ & CONSCIENTIZAÇÃO|Consciência|Complexidade\Onde tudo começa|Suicídio é superpesado & Então assim, imagina falar de suicídio, isso aí... porque é um assunto superpesado, \\
\hline $\begin{array}{l}\text { Transcrição E1 } \\
\text { revisada_para maxqda }\end{array}$ & CONSCIENTIZAÇÃO|Consciência|Complexidade\A exclusão da tristezalvocê não pode falar que você tá triste & a gente não consegue falar da tristeza. \\
\hline $\begin{array}{l}\text { Transcrição E1 } \\
\text { revisada_para maxqda }\end{array}$ & CONSCIENTIZAÇÃO|Consciência|Complexidade\A exclusão da tristeza|Falta de acolhimento de sentimentos ruins & $\begin{array}{l}\text { Aquele filme do "Divertidamente", aquilo não fez sucesso, porque as pessoas não } \\
\text { vão falar de sentimento, eles não querem ver lá que a tristeza, }\end{array}$ \\
\hline $\begin{array}{l}\text { Transcrição E1 } \\
\text { revisada_para maxqda }\end{array}$ & CONSCIENTIZAÇÃO|Consciência|Complexidade) \Assunto proibido|Pessoas não falam de sentimentos & $\begin{array}{l}\text { Aquele filme do "Divertidamente", aquilo não fez sucesso, porque as pessoas não } \\
\text { vão falar de sentimento, }\end{array}$ \\
\hline $\begin{array}{l}\text { Transcrição E1 } \\
\text { revisada_para maxqda }\end{array}$ & CONSCIENTIZAÇÃO|Consciência|Complexidade|Ditadura da alegria|Super importancia da alegria & que nem, a alegria é o sentimento mais importante no filme, \\
\hline $\begin{array}{l}\text { Transcrição E1 } \\
\text { revisada_para maxqda }\end{array}$ & CONSCIENTIZAÇÃOIConsciência|Complexidade\A exclusão da tristezalFalta de acolhimento de sentimentos ruins & $\begin{array}{l}\text { ainda bem que mostraram a importância da tristeza, mesmo assim a gente não } \\
\text { acolhe muito as outras coisas, então quanto mais eu acho que é esse tema né, mas } \\
\text { é lógico que o quanto mais a gente conseguir trazer acho que ajuda todos os } \\
\text { outros que muitas vezes vem junto, outra pessoa. }\end{array}$ \\
\hline $\begin{array}{l}\text { Transcrição E1 } \\
\text { revisada_para maxqda }\end{array}$ & AÇÃO|SemearlO que gostariam / Desejos (17)|Desejo de ouvir coisas coerentes & $\begin{array}{l}\text { mas eu ainda acho que quebrar o tabu vai ser a hora que estiver muito mais } \\
\text { pessoas preparadas pra falar porque a gente está preparado pra ouvir uma coisa } \\
\text { coerente né. Não essas perguntas né?! }\end{array}$ \\
\hline $\begin{array}{l}\text { Transcrição E1 } \\
\text { revisada_para maxqda }\end{array}$ & AÇÃO\O saber (12)\Saber é poder|Preparar pessoas a falarem corretamente & $\begin{array}{l}\text { mas eu ainda acho que quebrar o tabu vai ser a hora que estiver muito mais } \\
\text { pessoas preparadas pra falar porque a gente está preparado pra ouvir uma coisa } \\
\text { coerente né. Não essas perguntas né?! }\end{array}$ \\
\hline $\begin{array}{l}\text { Transcrição E1 } \\
\text { revisada_para maxqda }\end{array}$ & COMPREENSÃO\Tabu (1)\Consequências do Tabu\O não falar|Pessoas não sabem falar sobre o suicídio & não, elas não sabem \\
\hline $\begin{array}{l}\text { Transcrição E1 } \\
\text { revisada_para maxqda }\end{array}$ & AÇÃO\O saber (12)\Consequências do não saber|Pessoas não tem medo de falar elas não sabem & Não acho que tem medo não \\
\hline $\begin{array}{l}\text { Transcrição E1 } \\
\text { revisada_para maxqda }\end{array}$ & COMPREENSÃO|Experiência|O sentir|Sentimentos (8)\Dor|De quem fica|Suicídio é uma tragédia que dói & é, uma coisa que eu percebo é que essa tragédia que é o suicídio ela dói. \\
\hline $\begin{array}{l}\text { Transcrição E1 } \\
\text { revisada_para maxqda }\end{array}$ & COMPREENSÃO\Comunicação|Pessoal|Reações\Negativas|Desconforto|Outros com mais desconforto do que dor & $\begin{array}{l}\text { Mas para os outros que recebem a noticia, tomam conhecimento, pode até haver } \\
\text { dor, mas o que há mais é o desconforto, e eu percebo, dou alguns exemplos }\end{array}$ \\
\hline $\begin{array}{l}\text { Transcrição E1 } \\
\text { revisada_para maxqda }\end{array}$ & COMPREENSÃO|Comunicação|Pessoal|Morreu de que|Comunicando a morte da filha & $\begin{array}{l}\text { fui eu que comuniquei a superiora da mãe da minha filha o que estava } \\
\text { acontecendo, por que ela não podia atender... }\end{array}$ \\
\hline
\end{tabular}




\begin{tabular}{|c|c|c|}
\hline $\begin{array}{l}\text { Transcrição E1 } \\
\text { revisada_para maxqda }\end{array}$ & 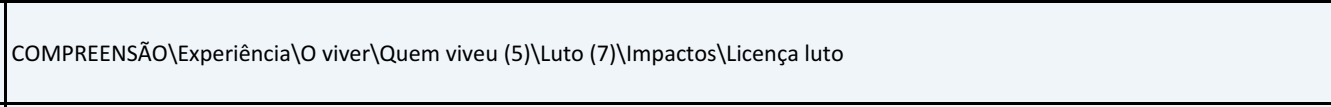 & $\begin{array}{l}\text { bom, o fato é que pela lei, são } 3 \text { dias de licença por causa da morte. Eles deram } 2 \\
\text { semanas e depois prorrogaram mais 1, porque simplesmente aquilo... ela não } \\
\text { pediu demissão... }\end{array}$ \\
\hline \begin{tabular}{|l} 
Transcrição E1 \\
revisada_para maxqda
\end{tabular} & |COMPREENSÃO\Experiência\O viver\Quem viveu (5)\Luto (7)\Impactos\Suicídio desestrutura & aquilo desestruturou todo mundo... aquilo né. \\
\hline $\begin{array}{l}\text { Transcrição E1 } \\
\text { revisada_para maxqda }\end{array}$ & AÇÃO\Fazer\Outros tipos de trabalho (24)\Sendo ativista como forma de enlutamento e prevenção|Falando abertamente & Quando eu faço a postagem, eu sou ativista e abri mão do anonimato... \\
\hline $\begin{array}{l}\text { Transcrição E1 } \\
\text { revisada_para maxqda }\end{array}$ & COMPREENSÃO\Comunicação|Social\Canais virtuais\Tipos de comentários e curtidas & $\begin{array}{l}\text { Quando eu faço a postagem, eu sou ativista e abri mão do anonimato... então } \\
\text { quando eu faço a postagem... quando é algo que está expondo, digamos a tragédia } \\
\text { pessoal, a minha tragédia pessoal aí tem bastante curtida, tem bastante } \\
\text { comentário, tem a solidariedade, aí quando eu faço uma postagem que é sobre } \\
\text { prevenção e Posvenção ao suicídio... com bastante informação e tal, tem uma meia } \\
\text { dúzia de curtidas e nenhum comentário. Quer dizer, a dor alheia, as pessoas têm } \\
\text { um ímpeto de vim lá se solidarizar. A minha dor, no caso, então eles vem, eles se } \\
\text { sentem até à vontade e fazem comentários, alguns cabíveis, alguns impertinentes } \\
\text { é mas a maioria é de boa vontade, ok? Mas assim, o ser humano tende a ser } \\
\text { solidário. Então a solidariedade de uma dor e de uma tristeza? ok. Agora... a } \\
\text { tragédia, lidar com a tragédia, o mecanismo, enfim a face, o rosto da tragédia isso } \\
\text { gera um desconforto absurdo, até porque é uma inversão da lógica do instinto da } \\
\text { autopreservação, então as pessoas ficam sem ação. }\end{array}$ \\
\hline $\begin{array}{l}\text { Transcrição E1 } \\
\text { revisada_para maxqda }\end{array}$ & COMPREENSÃO\Comunicação|Social|Canais virtuais\O rosto da tragédia & $\begin{array}{l}\text { Agora... a tragédia, lidar com a tragédia, o mecanismo, enfim a face, o rosto da } \\
\text { tragédia isso gera um desconforto absurdo, até porque é uma inversão da lógica do } \\
\text { instinto da autopreservação, então as pessoas ficam sem ação. }\end{array}$ \\
\hline $\begin{array}{l}\text { Transcrição E1 } \\
\text { revisada_para maxqda }\end{array}$ & COMPREENSÃO|Comunicação|Pessoal|Reações/Negativas|Desconforto & $\begin{array}{l}\text { Agora... a tragédia, lidar com a tragédia, o mecanismo, enfim a face, o rosto da } \\
\text { tragédia isso gera um desconforto absurdo, até porque é uma inversão da lógica do } \\
\text { instinto da autopreservação, então as pessoas ficam sem ação }\end{array}$ \\
\hline \begin{tabular}{|l|l} 
Transcrição E1 \\
revisada_para maxqda
\end{tabular} & CONSCIENTIZAÇÃO\Consciência \O absurdo do suicídio\O absurdo do suicídio\O absurdo do suicídio & $\begin{array}{l}\text { até porque é uma inversão da lógica do instinto da autopreservação, então as } \\
\text { pessoas ficam sem ação }\end{array}$ \\
\hline \begin{tabular}{|l|l} 
Transcrição E1 \\
revisada_para maxqda
\end{tabular} & COMPREENSÃO\Tabu (1)\Consequências do Tabu\Preconceito|O preconceito levando a não falar\Assunto que as pessoas não falam & e ninguém quer discutir suicídio, igual ele falou aqui... \\
\hline \begin{tabular}{|l|l} 
Transcrição E1 \\
revisada_para maxqda
\end{tabular} & COMPREENSÃO\Tabu (1)\Consequências do Tabu\Um assunto proibido|O tabu não me surpreende & não estou perplexo... \\
\hline $\begin{array}{l}\text { Transcrição E1 } \\
\text { revisada_para maxqda }\end{array}$ & COMPREENSÃO\Experiência\O viver|Quem não viveu (6)।Suicídio como algo da vida do outro / distante de mim & $\begin{array}{l}\text { vai falar o que... Passa batido, porque todo mundo acha que a família dele é } \\
\text { "Doriana" é saudável e não vai passar por esse problema. Então, eles nem vão ler } \\
\text { aquilo, tá? Quem não passou pelo problema, não lê. } \\
\end{array}$ \\
\hline $\begin{array}{l}\text { Transcrição E1 } \\
\text { revisada_para maxqda }\end{array}$ & COMPREENSÃO|Comunicação|Social|Desafios|Se não me atinge eu não leio & $\begin{array}{l}\text { vai falar o que... Passa batido, porque todo mundo acha que a família dele é } \\
\text { "Doriana" é saudável e não vai passar por esse problema. Então, eles nem vão ler } \\
\text { aquilo, tá? Quem não passou pelo problema, não lê. } \\
\end{array}$ \\
\hline \begin{tabular}{|l} 
Transcrição E1 \\
revisada_para maxqda
\end{tabular} & CONSCIENTIZAÇÃO|Consciência|Complexidade\A exclusão da tristeza|Não podendo falar que está triste & $\begin{array}{l}\text { então tem isso também de, você não pode falar que tá triste, você não pode falar } \\
\text { que não tá legal, né, então, se você chorou você é fraco, e se você não está bem... }\end{array}$ \\
\hline $\begin{array}{l}\text { Transcrição E1 } \\
\text { revisada_para maxqda }\end{array}$ & CONSCIENTIZAÇÃO|Consciência|Complexidade\A exclusão da tristeza|Julgamento da tristeza & $\begin{array}{l}\text { então tem isso também de, você não pode falar que tá triste, você não pode falar } \\
\text { que não tá legal, né, então, se você chorou você é fraco, e se você não está bem... }\end{array}$ \\
\hline \begin{tabular}{|l} 
Transcrição E1 \\
revisada_para maxqda
\end{tabular} & CONSCIENTIZAÇÃO|Consciência|Complexidade|Ditadura da alegria & $\begin{array}{l}\text { então tem isso também de, você não pode falar que tá triste, você não pode falar } \\
\text { que não tá legal, né, então, se você chorou você é fraco, e se você não está bem... }\end{array}$ \\
\hline $\begin{array}{l}\text { Transcrição E1 } \\
\text { revisada_para maxqda }\end{array}$ & 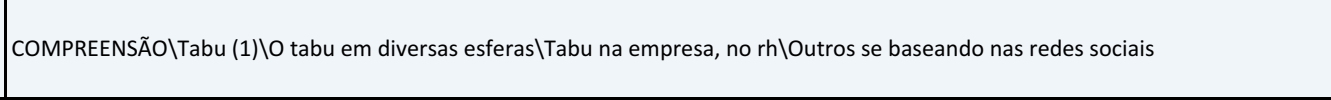 & $\begin{array}{l}\text { eu fui demitida em janeiro e uma das coisas que usaram foram as minhas fotos, } \\
\text { depois da morte do meu sobrinho. Só que eu conversei com o meu chefe e ele me } \\
\text { autorizou a ficar em casa e aí ele depois se juntou lá e me mandou embora. }\end{array}$ \\
\hline
\end{tabular}

Material integrante da pesquisa de doutorado de Karen Scavacini - USP Proibida a reprodução ou utilização sem autorização do autor - 2018 


\begin{tabular}{|c|c|c|}
\hline \begin{tabular}{|l|} 
Transcrição E1 \\
revisada_para maxqda
\end{tabular} & COMPREENSÃO\Tabu (1)\O tabu em diversas esferas \Tabu na empresa, no rh $\backslash$ Sentindo-se traída & $\begin{array}{l}\text { Eu achei uma covardia, uma coisa assim, que você acha que pode contar com as } \\
\text { pessoas mas você não pode. Você acha que estão te apoiando, quando na verdade } \\
\text { estão criando, às vezes, alguma coisa pra usar contra você. Então isso pra mim foi } \\
\text { terrivel... foi... eu achei muito cruel, entendeu? }\end{array}$ \\
\hline $\begin{array}{l}\text { Transcrição E1 } \\
\text { revisada_para maxqda }\end{array}$ & 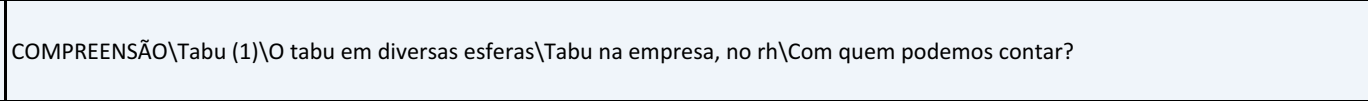 & $\begin{array}{l}\text { que você acha que pode contar com as pessoas mas você não pode. Você acha que } \\
\text { estão te apoiando, quando na verdade estão criando, às vezes, alguma coisa pra } \\
\text { usar contra você }\end{array}$ \\
\hline \begin{tabular}{|l} 
Transcrição E1 \\
revisada_para maxqda
\end{tabular} & 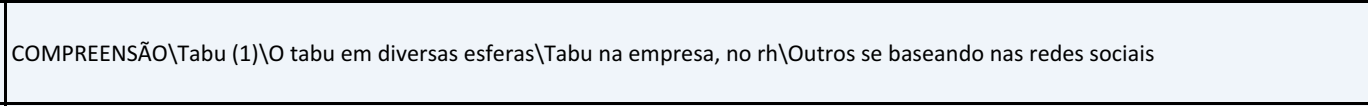 & $\begin{array}{l}\text { Podiam me mandar embora por qualquer outro motivo, mas por aquelas fotos...eu } \\
\text { pedi férias e não me deu. Ele me mandou ficar em casa né, então... mas isso não é } \\
\text { fato... }\end{array}$ \\
\hline \begin{tabular}{|l} 
Transcrição E1 \\
revisada_para maxqda
\end{tabular} & COMPREENSÃo|Visão|Visão da Sociedade (2) VVisão do suicídio hoje no brasil|A visão cultural do enlutado & $\begin{array}{l}\text { eu fui demitida em janeiro e uma das coisas que usaram foram as minhas fotos, } \\
\text { depois da morte do meu sobrinho. Só que eu conversei com o meu chefe e ele me } \\
\text { autorizou a ficar em casa e aí ele depois se juntou lá e me mandou embora. Eu } \\
\text { achei uma covardia, uma coisa assim, que você acha que pode contar com as } \\
\text { pessoas mas você não pode. Você acha que estão te apoiando, quando na verdade } \\
\text { estão criando, às vezes, alguma coisa pra usar contra você. Então isso pra mim foi } \\
\text { terrível... foi... eu achei muito cruel, entendeu? Podiam me mandar embora por } \\
\text { qualquer outro motivo, mas por aquelas fotos...eu pedi férias e não me deu. Ele } \\
\text { me mandou ficar em casa né, então... mas isso não é fato... }\end{array}$ \\
\hline \begin{tabular}{|l|} 
Transcrição E1 \\
revisada_para maxqda
\end{tabular} & COMPREENSÃO\Tabu (1)\O tabu em diversas esferas & $\begin{array}{l}\text { O tabu ele vai estar em várias esferas. Ele está na esfera pública, de quando a } \\
\text { gente fala do assunto na mídia, tá na escola que não quer trabalhar o assunto, tá } \\
\text { na empresa que não entende e quer que a pessoa trabalhe... }\end{array}$ \\
\hline $\begin{array}{l}\text { Transcrição E1 } \\
\text { revisada_para maxqda }\end{array}$ & COMPREENSÃo|Visão|Visão da Sociedade (2) \Visão do suicídio hoje no brasil\A visão cultural do enlutado|Pode enlutar, mas não aqui & esteja bem e produtiva... sendo que não tem como... \\
\hline \begin{tabular}{|l} 
Transcrição E1 \\
revisada_para maxqda
\end{tabular} & AÇÃo|Cuidar|Tratamento (13)\Hospitalar|Distinção no tratamento de tentativa em hospital & $\begin{array}{l}\text { Porque você passou agora com a sua irmã, não consumou então foi atendida no } \\
\text { hospital, isso eu estava conversando com a P2 hoje, que era uma dúvida, que eu já } \\
\text { ouvi de algumas pessoas. Perguntei e o P5 falou eu nunca vi distinção, mais aí eu } \\
\text { não sei. Você notou que quem atendia a sua irmã fazia uma diferença, assim, se ela } \\
\text { tivesse lá sendo atendida por câncer, uma dor? }\end{array}$ \\
\hline \begin{tabular}{|l|} 
Transcrição E1 \\
revisada_para maxqda
\end{tabular} & AÇÃo|Cuidar|Tratamento (13)\Hospitalar|Distinção no tratamento de tentativa em hospital & Com certeza, ela foi bem maltratada, assim, a gente foi no (nome de um hospital).. \\
\hline \begin{tabular}{|l|} 
Transcrição E1 \\
revisada_para maxqda
\end{tabular} & AÇÃO|Cuidar|Tratamento (13)\Hospitalar\Distinção no tratamento de tentativa em hospital|Sendo maltratada no hospital & Com certeza, ela foi bem maltratada, assim, a gente foi no (nome de um hospital).. \\
\hline \begin{tabular}{|l|} 
Transcrição E1 \\
revisada_para maxqda
\end{tabular} & AÇÃo|Cuidar|Tratamento (13)\Hospitalar|Distinção no tratamento de tentativa em hospital & Então, eu já ouvi muito isso. \\
\hline \begin{tabular}{|l|} 
Transcrição E1 \\
revisada_para maxqda
\end{tabular} & AÇÃo|Cuidar|Tratamento (13)\Hospitalar|Distinção no tratamento de tentativa em hospital & eu também já ouvi \\
\hline \begin{tabular}{|l} 
Transcrição E1 \\
revisada_para maxqda
\end{tabular} & AÇÃo|Cuidar|Tratamento (13)\Hospitalar|Distinção no tratamento de tentativa em hospital & $\begin{array}{l}\text { Ela tinha tomado uma caixa de remédios pra pressão do meu cunhado, então tinha } \\
\text { que fazer uma lavagem com carvão, né, e as enfermeiras...eu nunca vi aquele } \\
\text { tratamento lá no (nome de um hospital)... mas assim...Super grosseiras, ela } \\
\text { passando mal, ela vomitando e elas lá, nem aí injetando... O médico saiu com } \\
\text { cobertor pra ir dormir, largou ela lá... porque entendeu }\end{array}$ \\
\hline \begin{tabular}{|l} 
Transcrição E1 \\
revisada_para maxqda
\end{tabular} & AÇÃo|Cuidar|Tratamento (13)\Hospitalar|Distinção no tratamento de tentativa em hospital|Sendo maltratada no hospital & $\begin{array}{l}\text { Ela tinha tomado uma caixa de remédios pra pressão do meu cunhado, então tinha } \\
\text { que fazer uma lavagem com carvão, né, e as enfermeiras...eu nunca vi aquele } \\
\text { tratamento lá no (nome de um hospital)... mas assim...Super grosseiras, ela } \\
\text { passando mal, ela vomitando e elas lá, nem aí injetando... O médico saiu com } \\
\text { cobertor pra ir dormir, largou ela lá... porque entendeu }\end{array}$ \\
\hline \begin{tabular}{|l|} 
Transcrição E1 \\
revisada_para maxqda
\end{tabular} & AÇÃo|Cuidar|Tratamento (13)\Hospitalar|Distinção no tratamento de tentativa em hospital|Só merece ser bem tratado quem quer viver & tipo assim, tem tanta gente aqui que precisa... \\
\hline
\end{tabular}

Material integrante da pesquisa de doutorado de Karen Scavacini - USP Proibida a reprodução ou utilização sem autorização do autor - 2018 


\begin{tabular}{|c|c|c|}
\hline $\begin{array}{l}\text { Transcrição E1 } \\
\text { revisada_para maxqda }\end{array}$ & AÇÃo|Cuidar|Tratamento (13)\Hospitalar|Distinção no tratamento de tentativa em hospital|Só merece ser bem tratado quem quer viver & é tipo... é, "se você quer morrer o problema é seu" \\
\hline $\begin{array}{l}\text { Transcrição E1 } \\
\text { revisada_para maxqda }\end{array}$ & AÇÃo|Cuidar|Tratamento (13)\Hospitalar|Distinção no tratamento de tentativa em hospital & $\begin{array}{l}\text { Eu já ouvi muito isso. Eu não passei porque meu filho não chegou a ser atendido. } \\
\text { Mas hoje eu falei porque eu já tinha perguntado para o P5. Eu falei: Olha, fala a } \\
\text { verdade pra mim, tem? }\end{array}$ \\
\hline \begin{tabular}{|l} 
Transcrição E1 \\
revisada_para maxqda
\end{tabular} & AÇÃO|Cuidar|Tratamento (13)\Hospitalar|Distinção no tratamento de tentativa em hospital & Tem \\
\hline \begin{tabular}{|l|} 
Transcrição E1 \\
revisada_para maxqda
\end{tabular} & AÇÃO|Cuidar|Tratamento (13)\Hospitalar\Não vendo distinção no hospital|Não fazendo distinção nos atendimentos & eu não tenho \\
\hline \begin{tabular}{|l|} 
Transcrição E1 \\
revisada_para maxqda
\end{tabular} & AÇÃO|Cuidar|Tratamento (13)\Hospitalar|Distinção no tratamento de tentativa em hospital & mas eu há ouvi também \\
\hline \begin{tabular}{|l|} 
Transcrição E1 \\
revisada_para maxqda
\end{tabular} & 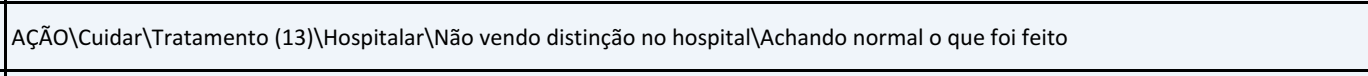 & $\begin{array}{l}\text { o que ela está acabando de falar aí, é o tratamento normal...eles estavam tentando } \\
\text { forçar ela, por essa sonda...a vomitar, ou botar para fora }\end{array}$ \\
\hline \begin{tabular}{|l|} 
Transcrição E1 \\
revisada_para maxqda
\end{tabular} & AÇÃo|Cuidar|Tratamento (13)\Hospitalar|Distinção no tratamento de tentativa em hospital|Sentindo distinção no hospital & Estou falando sobre o que aconteceu no (nome de hospital) tá... \\
\hline \begin{tabular}{|l|} 
Transcrição E1 \\
revisada_para maxqda
\end{tabular} & AÇÃo|Cuidar|Tratamento (13)\Hospitalar|Distinção no tratamento de tentativa em hospital|Ouvindo relatos de distinção no hospital & A gente ouviu também... \\
\hline \begin{tabular}{|l|} 
Transcrição E1 \\
revisada_para maxqda
\end{tabular} & AÇÃo|Cuidar|Tratamento (13)\Hospitalar|Distinção no tratamento de tentativa em hospital\Ouvindo relatos de distinção no hospital & mas eu há ouvi também \\
\hline $\begin{array}{l}\text { Transcrição E1 } \\
\text { revisada_para maxqda }\end{array}$ & AÇÃo|Cuidar\Tratamento (13)\Hospitalar\Não vendo distinção no hospital\Explicando sobre a brutalidade da lavagem gástrica & $\begin{array}{l}\text { É o seguinte, é que é um tratamento bruto mesmo. Você vai passar um cano dessa } \\
\text { grossura pelo nariz da pessoa, pelo esôfago, vai colocar lá no estômago, quando vai } \\
\text { passar na garganta a pessoa vai vomitar, vai ficar daquele jeito. Mas é o único meio } \\
\text { de você lavar o estômago é colocar o carvão ativado. O carvão ativado lá dentro } \\
\text { vai... o cartão ativado que você acabou de falar é pra que? É pra que o remédio } \\
\text { não seja absorvido }\end{array}$ \\
\hline $\begin{array}{l}\text { Transcrição E1 } \\
\text { revisada_para maxqda }\end{array}$ & AÇÃO|Cuidar|Tratamento (13)\Hospitalar\A importância do olhar|Diferença entre procedimento e olhar & mas não é procedimento, acho que é o olhar \\
\hline $\begin{array}{l}\text { Transcrição E1 } \\
\text { revisada_para maxqda }\end{array}$ & AÇÃo|Cuidar|Tratamento (13)\Hospitalar|A importância do olhar & é o olhar, não é... \\
\hline \begin{tabular}{|l|} 
Transcrição E1 \\
revisada_para maxqda
\end{tabular} & AÇÃo|Cuidar|Tratamento (13)\Hospitalar|Não vendo distinção no hospital|Não é um procedimento do medico & e é um procedimento da enfermagem, não é do médico... \\
\hline \begin{tabular}{|l|} 
Transcrição E1 \\
revisada_para maxqda
\end{tabular} & AÇÃO\Cuidar\Tratamento (13)\Hospitalar\Não vendo distinção no hospital & $\begin{array}{l}\text { olha, eu nunca vi esse negocio. É o seguinte, quando você chega lá, quem tá em } \\
\text { prioridade é que vai ser atendido? Quem mais tiver grave tá }\end{array}$ \\
\hline \begin{tabular}{|l|} 
Transcrição E1 \\
revisada_para maxqda
\end{tabular} & AÇÃo|Cuidar\Tratamento (13)\Hospitalar|Não vendo distinção no hospital & é a mesma pra todos os casos, não é diferente. \\
\hline $\begin{array}{l}\text { Transcrição E1 } \\
\text { revisada_para maxqda }\end{array}$ & AÇÃo|Cuidar|Tratamento (13)\Hospitalar|Distinção no tratamento de tentativa em hospital & na tua já é diferente, na tua experiência.... é diferente \\
\hline \begin{tabular}{|l} 
Transcrição E1 \\
revisada_para maxqda
\end{tabular} & AÇÃo|Cuidar\Tratamento (13)\Hospitalar\Distinção no tratamento de tentativa em hospital & $\begin{array}{l}\text { a minha mãe enfartando foi tratada de um jeito, e a minha irmã totalmente de } \\
\text { outro. E eu mesma já fiquei internada lá varias vezes também, outro tipo de } \\
\text { tratamento e outra coisa que aconteceu foi que a pressão dela foi baixando, foi } \\
\text { baixando, foi baixando muito, e estava acho que } 4 \text { por } 2 \text {, assim, uma coisa que } \\
\text { estava parando, e eu toda hora ia falar: "Olha... a pressão dela." E elas: "Ah, não, a } \\
\text { gente deu não sei o que lá e ela vai subir". }\end{array}$ \\
\hline $\begin{array}{l}\text { Transcrição E1 } \\
\text { revisada_para maxqda }\end{array}$ & AÇÃO|Cuidar|Tratamento (13)\Hospitalar|Distinção no tratamento de tentativa em hospital|A experiência no hospital & $\begin{array}{l}\text { e outra coisa que aconteceu foi que a pressão dela foi baixando, foi baixando, foi } \\
\text { baixando muito, e estava acho que } 4 \text { por } 2 \text {, assim, uma coisa que estava parando, e } \\
\text { eu toda hora ia falar: "Olha... a pressão dela." E elas: "Ah, não, a gente deu não sei } \\
\text { o que lá e ela vai subir". }\end{array}$ \\
\hline
\end{tabular}




\begin{tabular}{|c|c|c|}
\hline $\begin{array}{l}\text { Transcrição E1 } \\
\text { revisada_para maxqda }\end{array}$ & AÇÃo|Cuidar|Tratamento (13)\Hospitalar|Distinção no tratamento de tentativa em hospital|A experiência no hospital & $\begin{array}{l}\text { "Ah, daqui a pouco sobe. Daqui a pouco sobe". E eu que tinha que ir lá: "Olha, está } \\
\text { baixando mais, tá baixando mais." Aí eles pegaram uma veia no outro braço, acho } \\
\text { que a adrenalina, sei lá o que é que dá, né dr? Eu sei que na hora que eles deram, } \\
\text { ela subiu, ela ficou roxa, assim, o peito roxo, e ela: "Ai que eu vou morrer..." } \\
\text { porque a pressão dela subiu de } 4 \text { por } 2 \text { pra } 14,15 \text {, sei lá. Subiu muito, muito rápido } \\
\text { e ela gritando que ia morrer e eles continuavam. }\end{array}$ \\
\hline $\begin{array}{l}\text { Transcrição E1 } \\
\text { revisada_para maxqda }\end{array}$ & AÇÃO|Cuidar|Tratamento (13)\Hospitalar\Distinção no tratamento de tentativa em hospital|Sendo maltratada no hospital & $\begin{array}{l}\text { Subiu muito, muito rápido e ela gritando que ia morrer e eles continuavam. Eu } \\
\text { falava: "Para, pelo amor de Deus". Aí eles pararam e aí viram que a pressão tinha } \\
\text { subido muito realmente, mas ela, assim, foi uma questão disso daqui. Eles parecem } \\
\text { que não acreditavam nela, no que ela falou: "Minha cabeça está explodindo, eu } \\
\text { vou morrer", né, e continuaram. Então... }\end{array}$ \\
\hline $\begin{array}{l}\text { Transcrição E1 } \\
\text { revisada_para maxqda }\end{array}$ & AÇÃO|Cuidar|Tratamento (13)\Hospitalar|Diferenças no papel e sensações de cada um & $\begin{array}{l}\text { Talvez tenha uma diferença, aí, entre a forma como o enfermeiro vê o que ele tá } \\
\text { fazendo, e a forma como a família sente que aquilo está sendo feito, a necessidade } \\
\text { da família também. }\end{array}$ \\
\hline $\begin{array}{l}\text { Transcrição E1 } \\
\text { revisada_para maxqda }\end{array}$ & AÇÃO\Cuidar\Tratamento (13)\Hospitalar|Diferenças no papel e sensações de cada um & É essa a diferença. \\
\hline $\begin{array}{l}\text { Transcrição E1 } \\
\text { revisada_para maxqda }\end{array}$ & AÇÃO\Cuidar\Tratamento (13)\Hospitalar|Sem generalizar os atendimentos & $\begin{array}{l}\text { E também tem enfermeiros que não vão fazer distinção e enfermeiros que fazem } \\
\text { distinção e vão tratar de formas diferentes. }\end{array}$ \\
\hline $\begin{array}{l}\text { Transcrição E1 } \\
\text { revisada_para maxqda }\end{array}$ & AÇÃO|Cuidar|Tratamento (13)\Hospitalar|Sem generalizar os atendimentos & Com certeza a gente não pode generalizar nada \\
\hline $\begin{array}{l}\text { Transcrição E1 } \\
\text { revisada_para maxqda }\end{array}$ & AÇÃO|Cuidar|Tratamento (13)\Hospitalar|Sendo bem atendido no hospital & $\begin{array}{l}\text { É, eu não participei mas a minha filha de } 15 \text { anos, né, participou, porque eu não } \\
\text { estava na cidade, estava em outra cidade, minha esposa estava vindo do trabalho, } \\
\text { mas fui muito bem atendido, e fez todos aqueles processos embora um pouco } \\
\text { assim.. }\end{array}$ \\
\hline $\begin{array}{l}\text { Transcrição E1 } \\
\text { revisada_para maxqda }\end{array}$ & AÇÃo|Cuidar|Tratamento (13)\Hospitalar\Não vendo distinção no hospital|Explicando sobre a brutalidade da lavagem gástrica & É bruto... \\
\hline $\begin{array}{l}\text { Transcrição E1 } \\
\text { revisada_para maxqda }\end{array}$ & AÇÃO|Cuidar|Tratamento (13)\Hospitalar|Sendo bem atendido no hospital & $\begin{array}{l}\text { ela colocou na hora o tubo, tudo, tudo e na cabeça da minha filha, né, quer dizer, } \\
\text { que é uma criança né, se fosse um adulto pode até ser que seria mais até mais, } \\
\text { mas não, pelo menos foi bem feito o serviço, é, tanto que com um dia e meio de } \\
\text { manhã (vendendo coco ???) mas não deu... }\end{array}$ \\
\hline $\begin{array}{l}\text { Transcrição E1 } \\
\text { revisada_para maxqda }\end{array}$ & AÇÃo|Cuidar|Tratamento (13)\Hospitalar|Não vendo distinção no hospital|Explicando sobre a brutalidade da lavagem gástrica|Sendo ráp & $\begin{array}{l}\text { quanto antes você fizer, mais rápido você fizer, mais você vai salvar. Então tem que } \\
\text { ver... Na verdade eu vou te falar uma coisa, }\end{array}$ \\
\hline $\begin{array}{l}\text { Transcrição E1 } \\
\text { revisada_para maxqda }\end{array}$ & AÇÃo|Cuidar|Tratamento (13)\Hospitalar\Não vendo distinção no hospital & $\begin{array}{l}\text { só um minutinho... é de suicídio que você tá falando. Eu estou lá no pronto } \\
\text { socorro e chega baleado um bandido e um policial. Não tem essa preferência. É o } \\
\text { que estiver mais grave você vai atender. }\end{array}$ \\
\hline $\begin{array}{l}\text { Transcrição E1 } \\
\text { revisada_para maxqda }\end{array}$ & AÇÃO|Cuidar|Tratamento (13)\Hospitalar\A importância do olhar|Gravidade x forma & sim, acho que a questão não é essa, a gravidade e sim a forma como é tratado \\
\hline $\begin{array}{l}\text { Transcrição E1 } \\
\text { revisada_para maxqda }\end{array}$ & AÇÃO\Cuidar\Tratamento (13)\Hospitalar\Não vendo distinção no hospital & na hora você não sabe o que é \\
\hline $\begin{array}{l}\text { Transcrição E1 } \\
\text { revisada_para maxqda }\end{array}$ & AÇÃo|Cuidar|Tratamento (13)\Hospitalar|Não vendo distinção no hospital & É difícil você saber o que é na hora que entrou lá \\
\hline $\begin{array}{l}\text { Transcrição E1 } \\
\text { revisada_para maxqda }\end{array}$ & AÇÃO|Cuidar|Tratamento (13)\Hospitalar\A importância do olhar|Gravidade x forma & $\begin{array}{l}\text { eu acho que a colocação dela é no sentido de não fazer distinção em quem } \\
\text { atender, eu vejo que é no sentido de que você pode atender } \\
\text { P11: ... como atender. }\end{array}$ \\
\hline $\begin{array}{l}\text { Transcrição E1 } \\
\text { revisada_para maxqda }\end{array}$ & AÇÃO\Cuidar\Tratamento (13)\Hospitalar|A importância do olhar & uma tentativa de suicídio de uma forma empática e acolhedora \\
\hline $\begin{array}{l}\text { Transcrição E1 } \\
\text { revisada_para maxqda }\end{array}$ & AÇÃO|Cuidar|Tratamento (13)\Hospitalar|A importância do olhar &.. sim, exatamente... \\
\hline
\end{tabular}

Material integrante da pesquisa de doutorado de Karen Scavacini - USP Proibida a reprodução ou utilização sem autorização do autor - 2018 


\begin{tabular}{|c|c|c|}
\hline $\begin{array}{l}\text { Transcrição E1 } \\
\text { revisada_para maxqda }\end{array}$ & AÇÃo|Cuidar|Tratamento (13)|Hospitalar|Distinção no tratamento de tentativa em hospital|Presenciando a distinção como profissional & $\begin{array}{l}\text { E eu infelizmente já vi. Eu presenciei muito. (?) e isso acontece com muita } \\
\text { frequência tá. }\end{array}$ \\
\hline \begin{tabular}{|l} 
Transcrição E1 \\
revisada_para maxqda
\end{tabular} & AÇÃolCuidar|Tratamento (13)\Hospitalar|Distinção no tratamento de tentativa em hospital|Só merece ser bem tratado quem quer viver & $\begin{array}{l}\text { Já trabalhei... esse hospital que eu trabalho hoje já é o } 40 \text { hospital que eu trabalho } \\
\text { e por diversas vezes eu fui chamada para atender pacientes com tentativa de } \\
\text { suicídio com uma fala assim, do profissional. "A gente está aqui preocupada em } \\
\text { salvar a vida e tem um querendo fazer graça". }\end{array}$ \\
\hline $\begin{array}{l}\text { Transcrição E1 } \\
\text { revisada_para maxqda }\end{array}$ & AÇÃO|Cuidar|Tratamento (13)\Hospitalar\Distinção no tratamento de tentativa em hospital|A distinção é frequente & Eu presenciei muito. (?) e isso acontece com muita frequência tá. \\
\hline $\begin{array}{l}\text { Transcrição E1 } \\
\text { revisada_para maxqda }\end{array}$ & AÇÃo|Cuidar|Tratamento (13)\Hospitalar|Distinção no tratamento de tentativa em hospital\A distinção é frequente & Eu já escutei isso diversas vezes. \\
\hline \begin{tabular}{|l|} 
Transcrição E1 \\
revisada_para maxqda
\end{tabular} & AÇÃolCuidar|Tratamento (13)\Hospitalar|Distinção no tratamento de tentativa em hospital|Presenciando a distinção como profissional & $\begin{array}{l}\text { E eu participei de um grupo de estudos de prevenção de suicídio com um médico lá } \\
\text { da minha cidade, um psiquiatra e ele falou: **** "Infelizmente á no PS a gente } \\
\text { escuta isso todo dia dos meus residentes. Os meus residentes falam isso" ."Agora } \\
\text { eu vou te ensinar como se suicida, porque você fez tudo errado" }\end{array}$ \\
\hline $\begin{array}{l}\text { Transcrição E1 } \\
\text { revisada_para maxqda }\end{array}$ & AÇÃo|Cuidar|Tratamento (13)|Despreparo do psiquiatra|Distinção em residentes de psiquiatria & $\begin{array}{l}\text { Ele falou: "Eu tive que chamar o residente meu e falar: "não, pode parar. Tá tudo } \\
\text { errado". Porque o residente de psiquiatria tem essa fala e infelizmente acontece } \\
\text { em alguns serviços sim }\end{array}$ \\
\hline \begin{tabular}{|l} 
Transcrição E1 \\
revisada_para maxqda
\end{tabular} & AÇÃO|Cuidar|Tratamento (13)\Hospitalar|Distinção no tratamento de tentativa em hospital\Castigo e punição & $\begin{array}{l}\text { Parece até quando a criança... só rapidinho... quando a criança faz alguma coisa } \\
\text { que a mãe fala: "Agora que você se machucou você vai apanhar mais?" Então } \\
\text { parece que é um castigo mesmo. Foi o que eu percebi. }\end{array}$ \\
\hline $\begin{array}{l}\text { Transcrição E1 } \\
\text { revisada_para maxqda }\end{array}$ & AÇÃO\O saber (12)\Falta de formação|Não achei cursos específicos de suicídio & Não tem nada específico de suicídio. \\
\hline $\begin{array}{l}\text { Transcrição E1 } \\
\text { revisada_para maxqda }\end{array}$ & AÇÃO\O saber (12)\Consequências do não saber|Médicos angustiados com o jeito de falar de colegas & $\begin{array}{l}\text { assim, os próprios médicos traziam situações onde eles tinham que comunicar } \\
\text { uma notícia grave ou difícil pro paciente e eles relatavam que viam colegas falando } \\
\text { de um jeito que não era legal. Então eles traziam isso como uma angustia, }\end{array}$ \\
\hline $\begin{array}{l}\text { Transcrição E1 } \\
\text { revisada_para maxqda }\end{array}$ & AÇÃO\O saber (12)\Consequências do não saber\Médicos angustiados com o jeito de falar de colegas & $\begin{array}{l}\text { Olha... "Como poderia ser falado? “ Muitas vezes passava-se por cima, tipo, a } \\
\text { pessoa faleceu, a pessoa não tinha nenhum cuidado de falar. E era trazido isso }\end{array}$ \\
\hline $\begin{array}{l}\text { Transcrição E1 } \\
\text { revisada_para maxqda }\end{array}$ & CONSCIENTIZAÇÃOIConsciência\O absurdo do suicídio|Limitações\Limitação humana para lidar com algumas questões & $\begin{array}{l}\text { Aí a minha opinião né...eu acho que esbarra na própria dificuldade que o próprio } \\
\text { médico ou as próprias pessoas têm de lidar com algumas questões. Acho que é } \\
\text { uma limitação humana }\end{array}$ \\
\hline $\begin{array}{l}\text { Transcrição E1 } \\
\text { revisada_para maxqda }\end{array}$ & COMPREENSÃO\Experiência|O viver|Quem viveu (5)\Luto (7)\Reaç̃̃es externas & $\begin{array}{l}\text { Eu mesmo, assim, no relatar com amigos, eu tive reaç̃̃es, assim, desde pessoas } \\
\text { que se afastaram, cortou o assunto e saiu fora mesmo e outras pessoas tinham } \\
\text { reação agressiva. }\end{array}$ \\
\hline \begin{tabular}{|l|} 
Transcrição E1 \\
revisada_para maxqda
\end{tabular} & 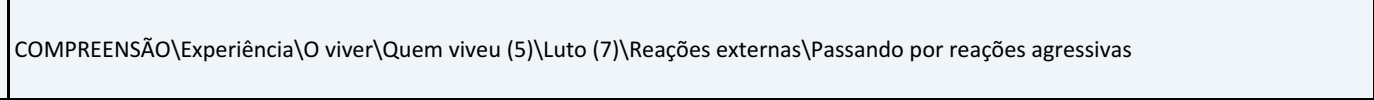 & $\begin{array}{l}\text { Eu mesmo, assim, no relatar com amigos, eu tive reações, assim, desde pessoas } \\
\text { que se afastaram, cortou o assunto e saiu fora mesmo e outras pessoas tinham } \\
\text { reação agressiva. }\end{array}$ \\
\hline $\begin{array}{l}\text { Transcrição E1 } \\
\text { revisada_para maxqda }\end{array}$ & COMPREENSÃO|Comunicação|Pessoal|Conversando com amigos|Conhecidos mudando o assunto & desde pessoas que se afastaram, cortou o assunto e saiu fora mesmo \\
\hline \begin{tabular}{|l|} 
Transcrição E1 \\
revisada_para maxqda
\end{tabular} & 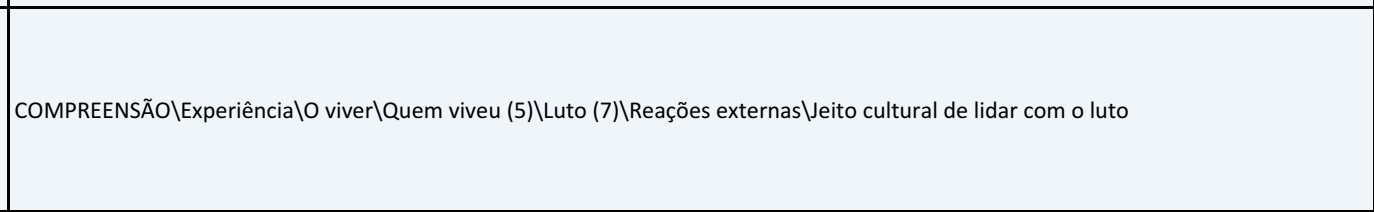 & $\begin{array}{l}\text { Depois eu pude entender, conversando né, que era uma coisa cultural da pessoa e } \\
\text { da família inteira dela. Tudo que tinha haver com morte ou doença grave a pessoa } \\
\text { não falava porque ela achava que atraia. Era uma coisa assim, muito recorrente: } \\
\text { "se eu falar atrai" então na família inteira ninguém falava de nada de morte. Então } \\
\text { o jeito que a pessoa reagia, nem era falando de uma maneira educada, era } \\
\text { agredindo pra cortar o assunto }\end{array}$ \\
\hline
\end{tabular}

Material integrante da pesquisa de doutorado de Karen Scavacini - USP Proibida a reprodução ou utilização sem autorização do autor - 2018 


\begin{tabular}{|c|c|c|}
\hline $\begin{array}{l}\text { Transcrição E1 } \\
\text { revisada_para maxqda }\end{array}$ & 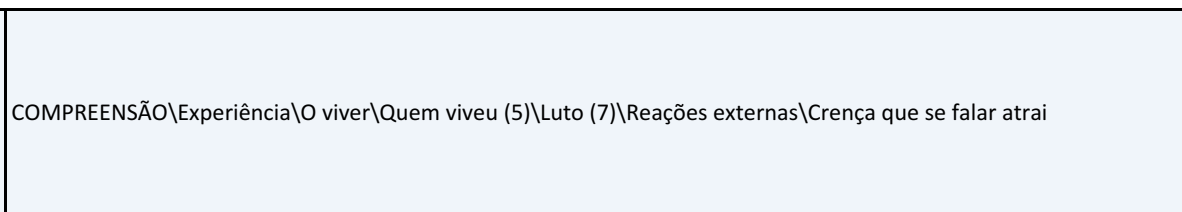 & $\begin{array}{l}\text { Depois eu pude entender, conversando né, que era uma coisa cultural da pessoa e } \\
\text { da família inteira dela. Tudo que tinha haver com morte ou doença grave a pessoa } \\
\text { não falava porque ela achava que atraia. Era uma coisa assim, muito recorrente: } \\
\text { "se eu falar atrai" então na família inteira ninguém falava de nada de morte. Então } \\
\text { o jeito que a pessoa reagia, nem era falando de uma maneira educada, era } \\
\text { agredindo pra cortar o assunto }\end{array}$ \\
\hline $\begin{array}{l}\text { Transcrição E1 } \\
\text { revisada_para maxqda }\end{array}$ & 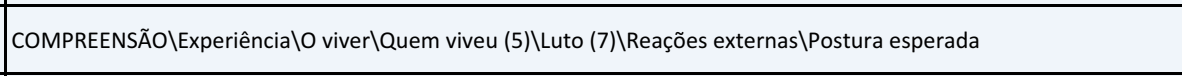 & $\begin{array}{l}\text { Então por exemplo, uma postura... tanta pessoa (pra ele?): "olha, eu prefiro não } \\
\text { falar... Eu penso assim..." não. }\end{array}$ \\
\hline $\begin{array}{l}\text { Transcrição E1 } \\
\text { revisada_para maxqda }\end{array}$ & 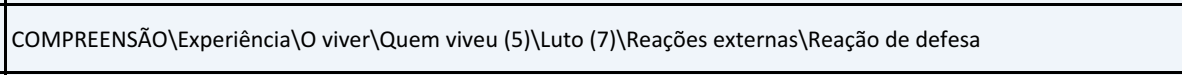 & $\begin{array}{l}\text { Aí eu entendi como era. Eu tenho amizade com a pessoa há muito tempo... eu } \\
\text { entendi que é uma reação de defesa dela, um mecanismo dela... }\end{array}$ \\
\hline $\begin{array}{l}\text { Transcrição E1 } \\
\text { revisada_para maxqda }\end{array}$ & CONSCIENTIZAÇÃO\Consciência|Complexidade\A exclusão da tristeza\Julgamento da tristeza & $\begin{array}{l}\text { então eu acho que uma das coisas que eu acho que é mais grave, é um pouco o } \\
\text { que a P9 falou, né, tudo que tem a ver com tristeza ou assuntos difíceis são tabu e } \\
\text { as pessoas, }\end{array}$ \\
\hline $\begin{array}{l}\text { Transcrição E1 } \\
\text { revisada_para maxqda }\end{array}$ & COMPREENSÃO|Comunicação|Pessoal|Reações/Negativas|Desconforto & causam desconforto \\
\hline $\begin{array}{l}\text { Transcrição E1 } \\
\text { revisada_para maxqda }\end{array}$ & COMPREENSÃO\Tabu (1)\Consequências do TabulUm assunto proibido & $\begin{array}{l}\text { Eu mesmo, assim, no relatar com amigos, eu tive reações, assim, desde pessoas } \\
\text { que se afastaram, cortou o assunto e saiu fora mesmo e outras pessoas tinham } \\
\text { reação agressiva }\end{array}$ \\
\hline $\begin{array}{l}\text { Transcrição E1 } \\
\text { revisada_para maxqda }\end{array}$ & CONSCIENTIZAÇÃO|Consciência|Complexidade\A exclusão da tristeza|Não podendo falar que está triste & $\begin{array}{l}\text { Não falam. Eu mesmo sofri... quando eu fui me abrir, com meus amigos, era assim } \\
\text { meio tipo, levar uma bronca porque você está triste. "Para com isso." }\end{array}$ \\
\hline $\begin{array}{l}\text { Transcrição E1 } \\
\text { revisada_para maxqda }\end{array}$ & CONSCIENTIZAÇÃO|Consciência|Complexidade\A exclusão da tristeza|Não podendo falar que está triste & $\begin{array}{l}\text { Eles estão desconfortáveis de ver você triste. Então às vezes eles estão fazendo } \\
\text { isso não pelo preocupado com você, mas por eles mesmos... }\end{array}$ \\
\hline $\begin{array}{l}\text { Transcrição E1 } \\
\text { revisada_para maxqda }\end{array}$ & COMPREENSÃO\Tabu (1)\Consequências do Tabu\O não falar|Não falar de dor e luto como defesa do outro & $\begin{array}{l}\text { É uma forma de defesa. Então, dar espaço pros sentimentos de luto ou de tristeza, } \\
\text { eu acho é, eu sinto como uma necessidade. }\end{array}$ \\
\hline $\begin{array}{l}\text { Transcrição E1 } \\
\text { revisada_para maxqda }\end{array}$ & CONSCIENTIZAÇÃO|Consciência|Complexidade|Por onde começar|Dando espaços para o luto e a tristeza & $\begin{array}{l}\text { Então, dar espaço pros sentimentos de luto ou de tristeza, eu acho é, eu sinto } \\
\text { como uma necessidade. }\end{array}$ \\
\hline $\begin{array}{l}\text { Transcrição E1 } \\
\text { revisada_para maxqda }\end{array}$ & COMPREENSÃO\Tabu (1)\Consequências do Tabu\Preconceito\O preconceito levando a não falar & $\begin{array}{l}\text { Mas nem na escola nem na família porque na família não falam e na escola } \\
\text { também não... }\end{array}$ \\
\hline $\begin{array}{l}\text { Transcrição E1 } \\
\text { revisada_para maxqda }\end{array}$ & AçÃo|Fazer|Prevenção (30)\Prevenção em escolas\Escola para teoria & E sabe o que é, eu acho que a gente aprende coisas na escola que são teóricas, \\
\hline $\begin{array}{l}\text { Transcrição E1 } \\
\text { revisada_para maxqda }\end{array}$ & AÇÃO\DiálogolO falar (23)\Onde\Escola da vida para coisas subjetivas & $\begin{array}{l}\text { e como lidar com transições, perdas, mudanças, essas coisas subjetivas você não } \\
\text { aprende em nenhum lugar, se aprende na vida mesmo, passando. Então eu acho } \\
\text { que é por isso que é tão difícil, porque é a escola da vida né, que você acaba } \\
\text { lidando com essas situações subjetivas. }\end{array}$ \\
\hline $\begin{array}{l}\text { Transcrição E1 } \\
\text { revisada_para maxqda }\end{array}$ & COMPREENSÃO\Tabu (1)\O tabu em diversas esferas\Transtornos mentais & $\begin{array}{l}\text { Já falaram várias, mas vocês acham que tem mais coisas que influenciam nesse } \\
\text { tabu? }\end{array}$ \\
\hline $\begin{array}{l}\text { Transcrição E1 } \\
\text { revisada_para maxqda }\end{array}$ & COMPREENSÃO\Tabu (1)\O tabu em diversas esferas\Religião & Religião \\
\hline $\begin{array}{l}\text { Transcrição E1 } \\
\text { revisada_para maxqda }\end{array}$ & COMPREENSÃO\Tabu (1)\O tabu em diversas esferas\Religião & religião com certeza... \\
\hline \begin{tabular}{|l} 
Transcrição E1 \\
revisada_para maxqda
\end{tabular} & COMPREENSÃO\Tabu (1)\O tabu em diversas esferas\Transtornos mentais|Depressão e outros transtornos & $\begin{array}{l}\text { Eu acho que a grande maioria dos casos envolve depressão, e a depressão não é } \\
\text { respeitada como uma doença, não é tratada como uma doença, muitas das vezes } \\
\text { ela é vista como uma frescura, como uma coisa assim, então talvez se tivesse uma } \\
\text { conscientização maior sobre a depressão e outros problemas psiquiátricos também } \\
\text { as pessoas compreendessem mais e ajudassem mais quem está passando por isso. }\end{array}$ \\
\hline $\begin{array}{l}\text { Transcrição E1 } \\
\text { revisada_para maxqda }\end{array}$ & COMPREENSÃo|Visão|Visão da Sociedade (2)\Depressão|Falta de entendimento|Pessoas não entendem a depressão & $\begin{array}{l}\text { e a depressão não é respeitada como uma doença, não é tratada como uma } \\
\text { doença, muitas das vezes ela é vista como uma frescura, }\end{array}$ \\
\hline
\end{tabular}




\begin{tabular}{|c|c|c|}
\hline $\begin{array}{l}\text { Transcrição E1 } \\
\text { revisada_para maxqda }\end{array}$ & CONSCIENTIZAÇÃO|Consciência\Aumento da Consciência (19)|Prevenção\Formas\Aumentar a conscientização sobre a depressão & $\begin{array}{l}\text { então talvez se tivesse uma conscientização maior sobre a depressão e outros } \\
\text { problemas psiquiátricos também as pessoas compreendessem mais e ajudassem } \\
\text { mais quem está passando por isso. }\end{array}$ \\
\hline $\begin{array}{l}\text { Transcrição E1 } \\
\text { revisada_para maxqda }\end{array}$ & CONSCIENTIZAÇÃOIConsciência|Aumento da Consciência (19)\Prevenção|Formas\Mudar o termo de suicídio para depressão & $\begin{array}{l}\text { Eu acho que a depressão como doença, que hoje é doença, tá lá no CID e tudo } \\
\text { mais, eu acho que, nunca escutei de ninguém que se suicidou sem depressão. } \\
\text { Então se eu mudasse o termo suicídio pra depressão, você poderia conversar sobre } \\
\text { o assunto, resolver o problema e sem falar em suicídio. Porque a maioria do } \\
\text { pessoal, eu nunca escutei falar de ninguém que estava bem alegre e contente e se } \\
\text { matou. }\end{array}$ \\
\hline $\begin{array}{l}\text { Transcrição E1 } \\
\text { revisada_para maxqda }\end{array}$ & COMPREENSÃo|Visão|Visão da Sociedade (2)\Causas do suicídio|Suicídio e depressão (culpa da doença) & \begin{tabular}{|l} 
Eu acho que a depressão como doença, que hoje é doença, tá lá no CID e tudo \\
mais, eu acho que, nunca escutei de ninguém que se suicidou sem depressão.
\end{tabular} \\
\hline $\begin{array}{l}\text { Transcrição E1 } \\
\text { revisada_para maxqda }\end{array}$ & AÇÃo|Cuidar|Depressão|Depressão é doença|Depressão é uma doença & $\begin{array}{l}\text { Eu acho que a depressão como doença, que hoje é doença, tá lá no CID e tudo } \\
\text { mais, eu acho que, nunca escutei de ninguém que se suicidou sem depressão. }\end{array}$ \\
\hline $\begin{array}{l}\text { Transcrição E1 } \\
\text { revisada_para maxqda }\end{array}$ & COMPREENSÃo|Visão|Visão da Sociedade (2)\Causas do suicídio|Suicídio e depressão (culpa da doença) & por isso que eu falei \\
\hline \begin{tabular}{|l|l} 
& \\
Transcrição E1 \\
revisada_para maxqda
\end{tabular} & CONSCIENTIZAÇÃO|Consciência|Aumento da Consciência (19)\Prevenção|Formas\Mudar o termo de suicídio para depressão & $\begin{array}{l}\text { Então eu concordo com você com esse negócio de depressão... eu acho que se } \\
\text { mudasse o termo de suicídio para prevenção à depressão já melhoraria. }\end{array}$ \\
\hline \begin{tabular}{|l|l} 
\\
Transcrição E1 \\
revisada_para maxqda
\end{tabular} & CONSCIENTIZAÇÃO|Consciência|Aumento da Consciência (19)\Prevenção|Formas\Mudar o termo de suicídio para depressão & Seria bem mais fácil de lidar com o tema. Tá? \\
\hline $\begin{array}{l}\text { Transcrição E1 } \\
\text { revisada_para maxqda }\end{array}$ & COMPREENSÃo|VisãolVisão da Sociedade (2)\Causas do suicídio|Suicídio por impulso & $\begin{array}{l}\text { Apesar que tem suicídios que não é por depressão, e sim por exemplo, por } \\
\text { impulso. Aquele rapaz de } 23 \text { anos que se atirou lá do Fórum da Barra Funda, tinha } \\
\text { acabado de sair da audiência, a audiência não foi sido favorável pra ele, ele atirou } \\
\text { primeiro o celular que até acertou a barriga de uma grávida mas não causou danos } \\
\text { maiores, e em seguida ele se atirou. Foi impulso. Não planejado... }\end{array}$ \\
\hline $\begin{array}{l}\text { Transcrição E1 } \\
\text { revisada_para maxqda }\end{array}$ & COMPREENSÃo|Visão|Visão da Sociedade (2)\Causas do suicídio & $\begin{array}{l}\text { Apesar que tem suicídios que não é por depressão, e sim por exemplo, por } \\
\text { impulso. Aquele rapaz de } 23 \text { anos que se atirou lá do Fórum da Barra Funda, tinha } \\
\text { acabado de sair da audiência, a audiência não foi sido favorável pra ele, ele atirou } \\
\text { primeiro o celular que até acertou a barriga de uma grávida mas não causou danos } \\
\text { maiores, e em seguida ele se atirou. Foi impulso. Não planejado... }\end{array}$ \\
\hline $\begin{array}{l}\text { Transcrição E1 } \\
\text { revisada_para maxqda }\end{array}$ & COMPREENSÃo|Visão|Visão da Sociedade (2)\Causas do suicídio|Suicídio e família & Mas se pesquisasse na família dele, antes de ir pra lá... \\
\hline \begin{tabular}{|l} 
Transcrição E1 \\
revisada_para maxqda
\end{tabular} & COMPREENSÃo|Visão|Visão da Sociedade (2)\Causas do suicídio|Suicídio e depressão (culpa da doença) & $\begin{array}{l}\text {... antes dele vir para lá... ele já estaria em depressão tá. Eu nunca vi nenhum caso } \\
\text { de suicídio que a pessoa não tivesse com depressão antes. Talvez ninguém notou, } \\
\text { ninguém viu, ninguém ... }\end{array}$ \\
\hline $\begin{array}{l}\text { Transcrição E1 } \\
\text { revisada_para maxqda }\end{array}$ & COMPREENSÃo|Visão|Visão da Sociedade (2)\Depressão|Falta de entendimento|Ninguém notando a depressão e a ideação & Talvez ninguém notou, ninguém viu, ninguém ... \\
\hline \begin{tabular}{|l} 
Transcrição E1 \\
revisada_para maxqda
\end{tabular} & COMPREENSÃO\Tabu (1)\Consequências do Tabu\Exclusão|A exclusão|Culpabilizando??? & Talvez ninguém notou, ninguém viu, ninguém ... \\
\hline \begin{tabular}{|l} 
Transcrição E1 \\
revisada_para maxqda
\end{tabular} & AÇÃo|Cuidar|Depressão\As consequências da depressão & Talvez até tenha cometido algum crime por depressão \\
\hline \begin{tabular}{|l} 
\\
Transcrição E1 \\
revisada_para maxqda
\end{tabular} & COMPREENSÃo|Visão|Visão da Sociedade (2)\Depressão\Tabu e depressão|Depressão é frescura & $\begin{array}{l}\text { O maior problema então é o seguinte, a depressão não é nada... igual ela falou... } \\
\text { depressão é "frescura"... }\end{array}$ \\
\hline $\begin{array}{l}\text { Transcrição E1 } \\
\text { revisada_para maxqda }\end{array}$ & COMPREENSÃo|Visão|Visão da Sociedade (2)\Depressão\Tabu e depressão|Depressão é frescura & É frescura... \\
\hline $\begin{array}{l}\text { Transcrição E1 } \\
\text { revisada_para maxqda }\end{array}$ & COMPREENSÃO|Visão|Visão da Sociedade (2)\Depressão\Tabu e depressão|Depressão é frescura & ..se você acha que a depressão é frescura então não se trata. \\
\hline $\begin{array}{l}\text { Transcrição E1 } \\
\text { revisada_para maxqda }\end{array}$ & CONSCIENTIZAÇÃO|Consciência|O absurdo do suicídio|Prevenção x Previsão|Suicídios sem sinais & $\begin{array}{l}\text { Eu acho que tem pessoas que se suicidam que não demonstram em momento } \\
\text { algum depressão. Minha filha foi um caso... }\end{array}$ \\
\hline
\end{tabular}

Material integrante da pesquisa de doutorado de Karen Scavacini - USP Proibida a reprodução ou utilização sem autorização do autor - 2018 


\begin{tabular}{|c|c|c|}
\hline $\begin{array}{l}\text { Transcrição E1 } \\
\text { revisada_para maxqda }\end{array}$ & COMPREENSÃo|Visão|Visão da Sociedade (2)\Causas do suicídio|Suicídio e depressão (culpa da doença) & $\begin{array}{l}\text { Ter depressão não significa que as pessoas mostrem ou que ela tenha sido } \\
\text { diagnosticada ou tratada }\end{array}$ \\
\hline $\begin{array}{l}\text { Transcrição E1 } \\
\text { revisada_para maxqda }\end{array}$ & CONSCIENTIZAÇÃO|ConsciêncialO absurdo do suicídio|Prevenção x Previsão|Suicídios sem sinais & $\begin{array}{l}\text { nunca mostraram.... A conversa que tivemos na hora do almoço, estava } \\
\text { perguntando do fim de semana... de tirar a carteira de motorista... (falando sobre a } \\
\text { filha) }\end{array}$ \\
\hline $\begin{array}{l}\text { Transcrição E1 } \\
\text { revisada_para maxqda }\end{array}$ & CONSCIENTIZAÇÃO|Consciência\O absurdo do suicídio|Prevenção x Previsão|Suicídios sem sinais & $\begin{array}{l}\text { Meu filho ia viajar para o Guarujá com a namorada... foi na casa dela e (???) e daí } \\
\text { em meia hora ele fez isso }\end{array}$ \\
\hline $\begin{array}{l}\text { Transcrição E1 } \\
\text { revisada_para maxqda }\end{array}$ & CONSCIENTIZAÇÃO|ConsciêncialO absurdo do suicídio|Prevenção x Previsão|Suicídios sem sinais & Orgulho... \\
\hline \begin{tabular}{|l} 
\\
Transcrição E1 \\
revisada_para maxqda
\end{tabular} & COMPREENSÃO\VisãolVisão da Sociedade (2)\Causas do suicídio|Suicídio e orgulho & $\begin{array}{l}\text { E tem... acho que ainda mais antigamente, a pessoa tinha orgulho e tal e como que } \\
\text { a sociedade vai me ver.... aí eu acho que... }\end{array}$ \\
\hline \begin{tabular}{|l} 
Transcrição E1 \\
revisada_para maxqda
\end{tabular} & CONSCIENTIZAÇÃO|ConsciêncialO absurdo do suicídio|Prevenção x Previsão|Suicídios sem sinais & mas eu ainda acho que tem processos que (???) ninguém via \\
\hline \begin{tabular}{|l|l} 
& \\
Transcrição E1 \\
revisada_para maxqda
\end{tabular} & CONSCIENTIZAÇÃO|ConsciêncialO absurdo do suicídio|Prevenção x Previsão|Suicídios sem sinais & ninguém notava... ia no psiquiatra e o psiquiatra dava alta para ele.... \\
\hline $\begin{array}{l}\text { Transcrição E1 } \\
\text { revisada_para maxqda }\end{array}$ & CONSCIENTIZAÇÃO|Consciência|O absurdo do suicídio|Prevenção x Previsão|Nem o psiquiatra notou & ninguém notava... ia no psiquiatra e o psiquiatra dava alta para ele.... \\
\hline $\begin{array}{l}\text { Transcrição E1 } \\
\text { revisada_para maxqda }\end{array}$ & COMPREENSÃo|Visão|Visão da Sociedade (2)\Causas do suicídio|Suicídio e orgulho & $\begin{array}{l}\text { que eu não entra isso muito nos jovens hoje mas as pessoas... acho que } \\
\text { antigamente... era um alto índice (sobre o orgulho) }\end{array}$ \\
\hline \begin{tabular}{|l} 
Transcrição E1 \\
revisada_para maxqda
\end{tabular} & COMPREENSÃO|Visão|Visão da Sociedade (2)\Causas do suicídio|Suicídio e orgulho & Olha, eles se suicidam por qualquer coisa assim... pela honra, orgulho... \\
\hline $\begin{array}{l}\text { Transcrição E1 } \\
\text { revisada_para maxqda }\end{array}$ & COMPREENSÃO\Tabu (1)\Atitudes que reforçam o tabu & $\begin{array}{l}\text { E vocês acham que esse tabu, ele começa aonde? Ele começa na sociedade, na } \\
\text { família, na escola? Onde que ele começa? }\end{array}$ \\
\hline $\begin{array}{l}\text { Transcrição E1 } \\
\text { revisada_para maxqda }\end{array}$ & COMPREENSÃO\Tabu (1)\Atitudes que reforçam o tabu\Aonde o tabu começa & em todos os lugares. \\
\hline $\begin{array}{l}\text { Transcrição E1 } \\
\text { revisada_para maxqda }\end{array}$ & COMPREENSÃo|Visão|Visão da Sociedade (2)\Visão do suicídio hoje no brasil|Suicida é fraco e covardelVisto como fraqueza & E é o que ela falou também, é visto como uma fraqueza, né quer dizer... \\
\hline $\begin{array}{l}\text { Transcrição E1 } \\
\text { revisada_para maxqda }\end{array}$ & COMPREENSÃO|Visão|Visão da Sociedade (2)|Visão do suicídio hoje no brasillSuicida é fraco e covarde|Visto como pecado & Um pecado, em algumas religiões... \\
\hline $\begin{array}{l}\text { Transcrição E1 } \\
\text { revisada_para maxqda }\end{array}$ & 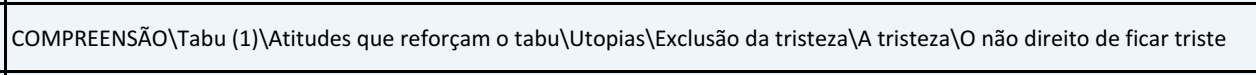 & $\begin{array}{l}\text {.é "poxa, mas você tem tudo, você tem uma família, você uma casa, você tem } \\
\text { carro, você tem emprego, então porque você está triste?" }\end{array}$ \\
\hline $\begin{array}{l}\text { Transcrição E1 } \\
\text { revisada_para maxqda }\end{array}$ & 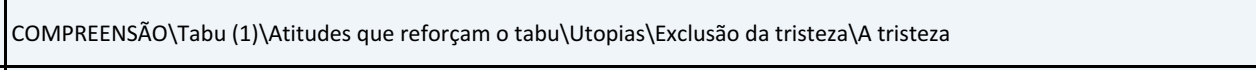 & Exato, tristeza né... \\
\hline $\begin{array}{l}\text { Transcrição E1 } \\
\text { revisada_para maxqda }\end{array}$ & COMPREENSÃO\Tabu (1)\Atitudes que reforçam o tabu|Utopias|Pela visão da felicidade ideal & $\begin{array}{l}\text {... é saber que felicidade não é tudo aquilo maravilhoso a toda hora, felicidade é } \\
\text { você estar bem, fazer um pouco do que você gosta, se não é hoje é ter sonhos pra } \\
\text { fazer depois, momentos, mas é tirar essa coisa de felicidade que tem que ser } \\
\text { aquela coisa assim (?)... maravilhosa... }\end{array}$ \\
\hline $\begin{array}{l}\text { Transcrição E1 } \\
\text { revisada_para maxqda }\end{array}$ & COMPREENSÃO\Tabu (1)\Atitudes que reforçam o tabu\Utopias|Pela visão da felicidade ideal\Busca do que é felicidade & Onde é aí que está a busca do que é felicidade também. \\
\hline $\begin{array}{l}\text { Transcrição E1 } \\
\text { revisada_para maxqda }\end{array}$ & COMPREENSÃO\Tabu (1)\Atitudes que reforçam o tabu|Utopias\Pela visão da felicidade ideal & Como uma visão errada \\
\hline $\begin{array}{l}\text { Transcrição E1 } \\
\text { revisada_para maxqda }\end{array}$ & 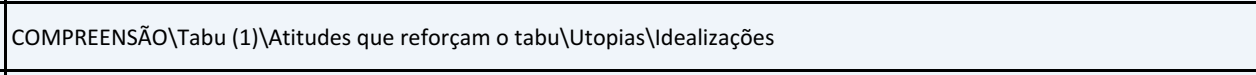 & $\begin{array}{l}\text { Assim como existe sobre a beleza, quer dizer, então o que é uma mulher ideal... é } \\
\text { um casamento ideal... }\end{array}$ \\
\hline $\begin{array}{l}\text { Transcrição E1 } \\
\text { revisada_para maxqda }\end{array}$ & |COMPREENSÃo|Tabu (1)\Atitudes que reforçam o tabu\Utopias|Exclusão da tristeza\A tristeza & $\begin{array}{l}\text { eu acho que começa a quebrar daí... porque eu acho que daí a pessoa poderia } \\
\text { começar a pensar assim, não, esses momentos de tristeza é normal, então... eu } \\
\text { vou ter que trabalhar, ver o que está me deixando triste e me sentir melhor, e não } \\
\text { se sentir tão culpados que eles estão tão tristes sem um motivo. Então eu acho } \\
\text { assim, que tem que começar bem no que a P10 falou, muito lá de baixo, muito } \\
\text { cultural... mas tem que começar... }\end{array}$ \\
\hline
\end{tabular}

Material integrante da pesquisa de doutorado de Karen Scavacini - USP Proibida a reprodução ou utilização sem autorização do autor - 2018 


\begin{tabular}{|c|c|c|}
\hline $\begin{array}{l}\text { Transcrição E1 } \\
\text { revisada_para maxqda }\end{array}$ & CONSCIENTIZAÇÃO|Consciência|Complexidade)Por onde começar|Precisa começar de algum lugar & $\begin{array}{l}\text { Então eu acho assim, que tem que começar bem no que a P10 falou, muito lá de } \\
\text { baixo, muito cultural... mas tem que começar.. }\end{array}$ \\
\hline $\begin{array}{l}\text { Transcrição E1 } \\
\text { revisada_para maxqda }\end{array}$ & CONSCIENTIZAÇÃO|Consciência|Complexidade\A exclusão da tristeza|Tristeza gerando culpa & e não se sentir tão culpados que eles estão tão tristes sem um motivo. \\
\hline $\begin{array}{l}\text { Transcrição E1 } \\
\text { revisada_para maxqda }\end{array}$ & CONSCIENTIZAÇÃO|Consciência|Complexidade\A exclusão da tristeza|Exclusão das pessoas não felizes & $\begin{array}{l}\text { é que as pessoas, a gente têm a tendência de falar "ah, aquela pessoa ela é } \\
\text { depressiva, ela é negativa, ela tem uma energia ruim" As pessoas põem de lado as } \\
\text { pessoas que não estão felizes por um momento, elas são postas de lado pelas } \\
\text { pessoas }\end{array}$ \\
\hline $\begin{array}{l}\text { Transcrição E1 } \\
\text { revisada_para maxqda }\end{array}$ & CONSCIENTIZAÇÃO\Consciência|Complexidade\A exclusão da tristeza\Exclusão das pessoas não felizes & também... e também não são nem convidadas pros lugares pelas pessoas... \\
\hline $\begin{array}{l}\text { Transcrição E1 } \\
\text { revisada_para maxqda }\end{array}$ & CONSCIENTIZAÇÃO|Consciência|Complexidade\A exclusão da tristeza|Exclusão das pessoas não felizes & $\begin{array}{l}\text { elas não são convidadas, elas não são... é, existe essa obrigação de ser feliz, acho } \\
\text { que é mais que do que você colocar ou postar... é você as pessoas dizem: "Não } \\
\text { chegue perto daquela pessoa porque ela é triste, ela é deprimida e ela..." }\end{array}$ \\
\hline $\begin{array}{l}\text { Transcrição E1 } \\
\text { revisada_para maxqda }\end{array}$ & CONSCIENTIZAÇÃO|Consciência|Complexidade\Ditadura da alegria & é, existe essa obrigação de ser feliz \\
\hline $\begin{array}{l}\text { Transcrição E1 } \\
\text { revisada_para maxqda }\end{array}$ & CONSCIENTIZAÇÃ̃|Consciência|Complexidade\A exclusão da tristeza\Julgamento da tristeza & Eu já ouvi falarem a pessoa é depressiva, ela tem uma energia ruim. \\
\hline $\begin{array}{l}\text { Transcrição E1 } \\
\text { revisada_para maxqda }\end{array}$ & CONSCIENTIZAÇÃO|Consciência|Complexidade\A exclusão da tristeza|Exclusão das pessoas não felizes & $\begin{array}{l}\text { E então, você já começa com as pessoas pondo de lado.... Então você já tem uma } \\
\text { pessoa que está com um problema, e aquilo agrava porque ela é posta de lado } \\
\text { porque ela não está ali sorrindo... }\end{array}$ \\
\hline $\begin{array}{l}\text { Transcrição E1 } \\
\text { revisada_para maxqda }\end{array}$ & COMPREENSÃO\Tabu (1)\Consequências do Tabu\Exclusão\A exclusão\Agravamento do problema & $\begin{array}{l}\text { Então você já tem uma pessoa que está com um problema, e aquilo agrava porque } \\
\text { ela é posta de lado porque ela não está ali sorrindo... }\end{array}$ \\
\hline $\begin{array}{l}\text { Transcrição E1 } \\
\text { revisada_para maxqda }\end{array}$ & CONSCIENTIZAÇÃO|Consciência|Complexidade\Assunto proibido|Utilitarismo & Porque não serve. É utilitarismo, isso é utilitarismo \\
\hline $\begin{array}{l}\text { Transcrição E1 } \\
\text { revisada_para maxqda }\end{array}$ & CONSCIENTIZAÇão|Consciência|Complexidade\Assunto proibido|Utilitarismo & é.... é exatamente... ela não serve para o que preciso... \\
\hline $\begin{array}{l}\text { Transcrição E1 } \\
\text { revisada_para maxqda }\end{array}$ & CONSCIENTIZAÇÃO|Consciência|Complexidade \Assunto proibido|Utilitarismo & $\begin{array}{l}\text { só as pessoas que servem pros meus próprios interesses, e as pessoas não me } \\
\text { servem, que servem para o meu sucesso profissional, financeiro... e as que não me } \\
\text { servem. }\end{array}$ \\
\hline $\begin{array}{l}\text { Transcrição E1 } \\
\text { revisada_para maxqda }\end{array}$ & CONSCIENTIZAÇÃO|Consciência|Complexidade\Assunto proibido|Utilitarismo & fala junto - Eles maltratam \\
\hline $\begin{array}{l}\text { Transcrição E1 } \\
\text { revisada_para maxqda }\end{array}$ & CONSCIENTIZAÇÃO|Consciência|Complexidade\Assunto proibido|Utilitarismo & $\begin{array}{l}\text { É utilitarismo. Na verdade a pessoa está vendo um mundo à parte de si mesmo e } \\
\text { as pessoas ao seu redor elas apenas estão à serviço dos seus próprios interesses. } \\
\text { Há aquelas que servem e aquelas que não servem. Isso é utilitarismo. }\end{array}$ \\
\hline $\begin{array}{l}\text { Transcrição E1 } \\
\text { revisada_para maxqda }\end{array}$ & COMPREENSÃO|Tabu (1)|Consequências do Tabu|Exclusão|A exclusão|Falta de amor & $\begin{array}{l}\text { É utilitarismo. Na verdade a pessoa está vendo um mundo à parte de si mesmo e } \\
\text { as pessoas ao seu redor elas apenas estão à serviço dos seus próprios interesses. } \\
\text { Há aquelas que servem e aquelas que não servem. Isso é utilitarismo. Não existe } \\
\text { amor. Não existe... }\end{array}$ \\
\hline $\begin{array}{l}\text { Transcrição E1 } \\
\text { revisada_para maxqda }\end{array}$ & AÇÃo|Cuidar|Depressão|Depressão é doença|Depressão como mundo inabitável & $\begin{array}{l}\text { Mas eu não sei, porque eu lido com uma pessoa que tem depressão, a ****, e é } \\
\text { muito difícil pra gente tentar penetrar naquele mundo... é inabitável. }\end{array}$ \\
\hline $\begin{array}{l}\text { Transcrição E1 } \\
\text { revisada_para maxqda }\end{array}$ & AÇÃO|Cuidar|Depressão|Depressão é doença|Dificuldades em lidar com alguém com depressão & $\begin{array}{l}\text { Por mais que você queira ajudar, a pessoa se recusa, a pessoa não quer ajuda, a } \\
\text { pessoa te dá pistas de que tá bem, e de repente de que está mal. Aí você diz:" Você } \\
\text { não está bem?" aí ela fala: "Mas agora eu estou bem, você é quem tá querendo } \\
\text { que eu fique mal". É muito difícil. }\end{array}$ \\
\hline $\begin{array}{l}\text { Transcrição E1 } \\
\text { revisada_para maxqda }\end{array}$ & AÇÃo|Cuidar|Depressão|Depressão é doença|Depressão como mundo inabitável & É muito difícil. É um universo que eu desconheço gente, não dá pra habitar \\
\hline $\begin{array}{l}\text { Transcrição E1 } \\
\text { revisada_para maxqda }\end{array}$ & AÇÃO|Cuidar|Depressão|Depressão é doença|Dificuldades em lidar com alguém com depressão & $\begin{array}{l}\text { Por mais que você queira, você fala: "E agora, o que eu faço? Eu me sinto de mãos } \\
\text { atadas }\end{array}$ \\
\hline
\end{tabular}




\begin{tabular}{|c|c|c|}
\hline $\begin{array}{l}\text { Transcrição E1 } \\
\text { revisada_para maxqda }\end{array}$ & COMPREENSÃo|Visão|Visão da Sociedade (2)\Depressão|Falta de entendimento|Dificil de compreender a depressão & É... A energia dela é difícil? É.... porque eu não consigo compreendê-la. \\
\hline $\begin{array}{l}\text { Transcrição E1 } \\
\text { revisada_para maxqda }\end{array}$ & 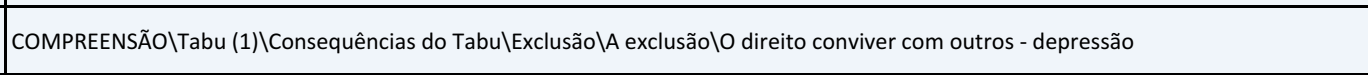 & Mas ela tem o direito de estar ali. \\
\hline $\begin{array}{l}\text { Transcrição E1 } \\
\text { revisada_para maxqda }\end{array}$ & COMPREENSÃO\Tabu (1)\Consequências do Tabu|Exclusão\A exclusão\O direito conviver com outros - depressão & Isso é que é a questão. \\
\hline $\begin{array}{l}\text { Transcrição E1 } \\
\text { revisada_para maxqda }\end{array}$ & COMPREENSÃO\Tabu (1)\Consequências do Tabu|Preconceito|Preconceito e depressão & $\begin{array}{l}\text { Ao mesmo tempo te pede ajuda e ai você tenta ajudar e ela recua. Eu acho que } \\
\text { esse preconceito... }\end{array}$ \\
\hline \begin{tabular}{|l|} 
Transcrição E1 \\
revisada_para maxqda
\end{tabular} & AçÃo|Cuidar|Depressão|Depressão é doençalımpotência & $\begin{array}{l}\text { Mas assim, é muito difícil você olhar pra pessoa e a pessoa se auto destruir e você } \\
\text { ficar de camarote porque ela não deixa você fazer nada. Ao mesmo tempo te pede } \\
\text { ajuda e aí você tenta ajudar e ela recua. }\end{array}$ \\
\hline $\begin{array}{l}\text { Transcrição E1 } \\
\text { revisada_para maxqda }\end{array}$ & AÇÃo|Cuidar|Depressão|Depressão é doença|Limites & $\begin{array}{l}\text { É, mas a gente tem que entender também que... tem coisas que... porque o meu } \\
\text { irmão a gente viu acontecer, a gente sabia que ia acontecer, (risos nervosos) e não } \\
\text { tinha nada que pudesse ser feito. Tudo que a gente podia ter feito a gente fez. }\end{array}$ \\
\hline $\begin{array}{l}\text { Transcrição E1 } \\
\text { revisada_para maxqda }\end{array}$ & AÇÃo|Cuidar|Depressão|Depressão é doença|Limites & Então, nós também... \\
\hline \begin{tabular}{|l} 
Transcrição E1 \\
revisada_para maxqda
\end{tabular} & AÇÃo|Cuidar|Depressão|Depressão é doençalımpotência & $\begin{array}{l}\text { É, mas a gente tem que entender também que... tem coisas que... porque o meu } \\
\text { irmão a gente viu acontecer, a gente sabia que ia acontecer, (risos nervosos) e não } \\
\text { tinha nada que pudesse ser feito. Tudo que a gente podia ter feito a gente fez. }\end{array}$ \\
\hline \begin{tabular}{|l} 
Transcrição E1 \\
revisada_para maxqda
\end{tabular} & AÇÃo|Cuidar|Depressão\As consequências da depressão|Depressivos não aceitando ajuda & acho que o problema... é que eles não aceitam isso. Eles não querem que ajuda. \\
\hline $\begin{array}{l}\text { Transcrição E1 } \\
\text { revisada_para maxqda }\end{array}$ & COMPREENSÃo|Visão|Visão da Sociedade (2)\Depressão|Tabu e depressão|Sociedade trazendo os significados ruins da depressão & $\begin{array}{l}\text { O preconceito, o tabu é tão violento que pra pessoa aceitar que ela tem a } \\
\text { depressão, "Ah, como é que eu vou me intitular de fraco, né? Vou ter que assumir } \\
\text { que eu sou fraco, que eu sou preguiçoso, que eu sou covarde... que eu sou... }\end{array}$ \\
\hline $\begin{array}{l}\text { Transcrição E1 } \\
\text { revisada_para maxqda }\end{array}$ & COMPREENSÃo|Visão|Visão da Sociedade (2)\Depressão|Tabu e depressão|Sociedade trazendo os significados ruins da depressão & É porque as pessoas dizem que depressão é isso, e não é... \\
\hline $\begin{array}{l}\text { Transcrição E1 } \\
\text { revisada_para maxqda }\end{array}$ & COMPREENSÃO|Tabu (1)\O tabu em diversas esferas \Transtornos mentais|Tabu e depressão & não é isso, então... então, o problema tá nisso, no tabu, é depressão. \\
\hline \begin{tabular}{|l|l} 
Transcrição E1 \\
revisada_para maxqda
\end{tabular} & AÇÃO\Diálogo\O falar (23)\O que (MENSAGEM)\Depressão - A mensagem\Sem saber a forma de tratar a depressão (entendimento e nec & $\begin{array}{l}\text { Se a gente conseguisse de alguma forma, que eu não sei qual é....não sei qual é, } \\
\text { gostaria muito que alguém descobrisse, }\end{array}$ \\
\hline \begin{tabular}{|l|l} 
Transcrição E1 \\
revisada_para maxqda
\end{tabular} & AÇÃO\Diálogo\O falar (23)\O que (MENSAGEM)\Depressão - A mensagem|Tratar depressão como outras doenças crônicas & \begin{tabular}{|l} 
não sei qual é, gostaria muito que alguém descobrisse, é desmistificar mesmo pra \\
gente poder olhar pra coisa como uma pressão alta né, como uma diabetes, né?
\end{tabular} \\
\hline \begin{tabular}{|l} 
Transcrição E1 \\
revisada_para maxqda
\end{tabular} & 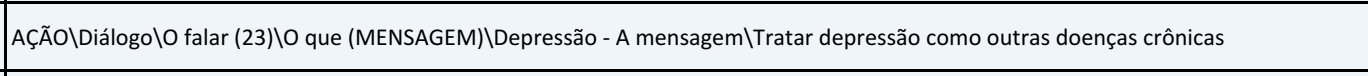 & Exato, quando eu paro para pensar... \\
\hline $\begin{array}{l}\text { Transcrição E1 } \\
\text { revisada_para maxqda }\end{array}$ & AÇÃo|Cuidar|Depressão|Depressão é doença|Quem trata a depressão é o profissional & $\begin{array}{l}\text { deixa eu falar uma coisa aqui ... a depressão tem que ser tratada por um } \\
\text { profissional, a gente querer tratar, é igual você querer tratar uma pressão alta... } \\
\text { você consegue tratar uma pressão alta? }\end{array}$ \\
\hline $\begin{array}{l}\text { Transcrição E1 } \\
\text { revisada_para maxqda }\end{array}$ & AÇÃo|Cuidar|Depressão|Depressão é doença|Querendo levar para o profissional & Mas eu não quero tratar... eu quero levar para um profissional \\
\hline $\begin{array}{l}\text { Transcrição E1 } \\
\text { revisada_para maxqda }\end{array}$ & AÇÃo|Cuidar|Depressão|Depressão é doença|Não querendo tratar sozinha & Mas eu não quero tratar... eu quero levar para um profissional \\
\hline $\begin{array}{l}\text { Transcrição E1 } \\
\text { revisada_para maxqda }\end{array}$ & AÇÃo|Cuidar|Depressão|Depressão é doença|Pessoas tratando depressão em casa & e as pessoas geralmente põe em casa e ficam tentando tratar em casa a depressão \\
\hline $\begin{array}{l}\text { Transcrição E1 } \\
\text { revisada_para maxqda }\end{array}$ & AÇÃo|Cuidar|Depressão|Depressão é doença|Quem trata a depressão é o profissional & $\begin{array}{l}\text { e as pessoas geralmente põe em casa e ficam tentando tratar em casa a depressão } \\
\text { Sem a ajuda de um profissional, sem a ajuda de nada. Bom, psiquiatra estuda lá } \\
\text { não sei quantos anos para ser... }\end{array}$ \\
\hline $\begin{array}{l}\text { Transcrição E1 } \\
\text { revisada_para maxqda }\end{array}$ & AÇÃo|Cuidar|Depressão|As consequências da depressão|Depressivos não aceitando ajuda & mas, sabe P5 as vezes o difícil é porque a pessoa nem quer ir pro psiquiatra \\
\hline
\end{tabular}




\begin{tabular}{|c|c|c|}
\hline $\begin{array}{l}\text { Transcrição E1 } \\
\text { revisada_para maxqda }\end{array}$ & AÇÃo|Cuidar|Depressão|As consequências da depressão|Depressivos não aceitando ajuda & Você quer que ela vá no psicólogo mas ela não vai no psicólogo. \\
\hline $\begin{array}{l}\text { Transcrição E1 } \\
\text { revisada_para maxqda }\end{array}$ & CONSCIENTIZAÇÃO|Consciência|Complexidade|Complexidade dos sentimentos/Sentimentos que não tem nome & $\begin{array}{l}\text { a gente só fala de depressão agora, mas eu acho que existem variações de } \\
\text { sentimentos que não tem nem nomes porque nem tudo é só tristeza, nem tudo é } \\
\text { só fraqueza. }\end{array}$ \\
\hline $\begin{array}{l}\text { Transcrição E1 } \\
\text { revisada_para maxqda }\end{array}$ & CONSCIENTIZAÇÃO|Consciência|Complexidade\A banalização da depressão|Não sabendo tudo sobre depressão e sentimentos & eu acho nem que a gente sabe, tipo, tudo \\
\hline $\begin{array}{l}\text { Transcrição E1 } \\
\text { revisada_para maxqda }\end{array}$ & CONSCIENTIZAÇÃO|Consciência|Complexidade|Complexidade dos sentimentos\Evolução dos sentimentos que não tem nome & $\begin{array}{l}\text { Assim como a tecnologia evoluiu, as doenças, eu acho que os sentimentos, hoje os } \\
\text { seres sentem diversas coisas, a gente não tem nome pras coisas. É tipo: tristeza, } \\
\text { fraqueza e alegria. Só existe isso. Eu não posso sentir um meio termo? Primeiro eu } \\
\text { acho esse ponto. }\end{array}$ \\
\hline $\begin{array}{l}\text { Transcrição E1 } \\
\text { revisada_para maxqda }\end{array}$ & CONSCIENTIZAÇÃOIConsciência|Complexidade|Complexidade dos sentimentos & $\begin{array}{l}\text { eu acho nem que a gente sabe, tipo, tudo, a gente só fala de depressão agora, mas } \\
\text { eu acho que existem variações de sentimentos que não tem nem nomes porque } \\
\text { nem tudo é só tristeza, nem tudo é só fraqueza. Assim como a tecnologia evoluiu, } \\
\text { as doenças, eu acho que os sentimentos, hoje os seres sentem diversas coisas, a } \\
\text { gente não tem nome pras coisas. }\end{array}$ \\
\hline $\begin{array}{l}\text { Transcrição E1 } \\
\text { revisada_para maxqda }\end{array}$ & CONSCIENTIZAÇÃo|Consciência|Complexidade\A banalização da depressão|Nem tudo é depressão & Outro: eu acho que nem tudo é depressão nem tudo não é. \\
\hline \begin{tabular}{|l} 
Transcrição E1 \\
revisada_para maxqda
\end{tabular} & CONSCIENTIZAÇÃO|Consciência|Complexidade|Complexidade dos sentimentos|Sentimentos que não tem nome & $\begin{array}{l}\text { Outro: eu acho que nem tudo é depressão nem tudo não é. Eu acho que existem } \\
\text { variações de coisas na nossa vida que a gente ainda não consegue... não sei se é } \\
\text { dar um nome, qual seria a palavra a respeito, entendeu? Porque não encaixa nem } \\
\text { só aqui nem só ali. São outras coisas que a gente está vivendo, entende? }\end{array}$ \\
\hline $\begin{array}{l}\text { Transcrição E1 } \\
\text { revisada_para maxqda }\end{array}$ & CONSCIENTIZAÇÃOIConsciêncialComplexidadelComplexidade dos sentimentos & $\begin{array}{l}\text { Outro: eu acho que nem tudo é depressão nem tudo não é. Eu acho que existem } \\
\text { variações de coisas na nossa vida que a gente ainda não consegue... não sei se é } \\
\text { dar um nome, qual seria a palavra a respeito, entendeu? Porque não encaixa nem } \\
\text { só aqui nem só ali. São outras coisas que a gente está vivendo, entende? }\end{array}$ \\
\hline \begin{tabular}{|l|} 
Transcrição E1 \\
revisada_para maxqda
\end{tabular} & CONSCIENTIZAÇÃO|Consciência|Complexidade\A banalização da depressão|Nem tudo é depressão & $\begin{array}{l}\text { Eu acho que falta um avanço nesse sentido, porque a pessoa fala "putz, mas eu } \\
\text { não estou com depressão", ou tipo "não posso estar triste um dia". Mas será que } \\
\text { não existe uma variação? Você não precisa ser uma pessoa depressiva mas tem um } \\
\text { dia que você está sentindo algo que não tem nem nome ainda }\end{array}$ \\
\hline \begin{tabular}{|l|} 
Transcrição E1 \\
revisada_para maxqda
\end{tabular} & CONSCIENTIZAÇÃo|Consciência|Complexidade|Complexidade dos sentimentos|Desconhecimento emocional? & $\begin{array}{l}\text { Eu acho que falta um avanço nesse sentido, porque a pessoa fala "putz, mas eu } \\
\text { não estou com depressão", ou tipo "não posso estar triste um dia". Mas será que } \\
\text { não existe uma variação? Você não precisa ser uma pessoa depressiva mas tem um } \\
\text { dia que você está sentindo algo que não tem nem nome ainda }\end{array}$ \\
\hline \begin{tabular}{|l} 
Transcrição E1 \\
revisada_para maxqda
\end{tabular} & CONSCIENTIZAÇÃOIConsciência|ComplexidadelComplexidade dos sentimentos & $\begin{array}{l}\text { A gente tem que voltar muito ainda pra dentro do ser humano, olhar outras } \\
\text { questões porque não está dando para definir. A gente não tem hoje palavras, } \\
\text { estudos e eu acho que..., não sei o que é, pra conseguir...porque tem muito mais } \\
\text { variação. }\end{array}$ \\
\hline \begin{tabular}{|l} 
Transcrição E1 \\
revisada_para maxqda
\end{tabular} & CONSCIENTIZAÇÃO|Consciência|Complexidade\A banalização da depressão|Nem tudo é depressão & $\begin{array}{l}\text { Tudo evoluiu, agora, os sentimentos do ser humano não, continua tudo com o } \\
\text { mesmo nome, e aí é depressão. }\end{array}$ \\
\hline \begin{tabular}{|l} 
\\
Transcrição E1 \\
revisada_para maxqda
\end{tabular} & CONSCIENTIZAÇÃO|Consciência|Complexidade\A banalização da depressão|Depressão como algo novo e com graus & $\begin{array}{l}\text { a depressão é coisa nova...mas eu acho que você tem graus de depressão, você } \\
\text { entendeu? }\end{array}$ \\
\hline $\begin{array}{l}\text { Transcrição E1 } \\
\text { revisada_para maxqda }\end{array}$ & CONSCIENTIZAÇÃO|Consciência|Complexidade\A banalização da depressão\A depressão classifica e reduz & $\begin{array}{l}\text { Isso e outras coisas também, só que tipo ou a pessoa é classificada assim, ou ela é } \\
\text { assim, e não é assim. }\end{array}$ \\
\hline $\begin{array}{l}\text { Transcrição E1 } \\
\text { revisada_para maxqda }\end{array}$ & CONSCIENTIZAÇÃO|Consciência|Complexidade\A exclusão da tristeza\A exclusão da normalidade da tristeza & Eu acho que tem outro sentimento de tristeza natural que é excluído \\
\hline $\begin{array}{l}\text { Transcrição E1 } \\
\text { revisada_para maxqda }\end{array}$ & CONSCIENTIZAÇÃO|Consciência|Complexidade\A exclusão da tristeza|Não podendo entristecer & Ninguém pode ficar triste. E é normal, eu entendo hoje como algo normal \\
\hline
\end{tabular}




\begin{tabular}{|c|c|c|}
\hline $\begin{array}{l}\text { Transcrição E1 } \\
\text { revisada_para maxqda }\end{array}$ & CONSCIENTIZAÇÃOIConsciência|Complexidade|Por onde começar|Sentir tristeza é saudável e normal & $\begin{array}{l}\text { Quando acontece algo ruim, ou você tem alguma perda, é normal e é saudável } \\
\text { você poder ficar triste e conversar com alguém. }\end{array}$ \\
\hline $\begin{array}{l}\text { Transcrição E1 } \\
\text { revisada_para maxqda }\end{array}$ & CONSCIENTIZAÇÃO|Consciência|Complexidade\A exclusão da tristeza & $\begin{array}{l}\text { Mas isso é excluído, eu acho que isso, parte do tabu começa daí. Então se você vai } \\
\text { procurar um amigo e você tá feliz ok! Mas se você tá triste, você é excluído. }\end{array}$ \\
\hline $\begin{array}{l}\text { Transcrição E1 } \\
\text { revisada_para maxqda }\end{array}$ & COMPREENSÃO\Tabu (1)\Atitudes que reforçam o tabu\Utopias\Exclusão da tristeza\A tristeza & $\begin{array}{l}\text { Mas isso é excluído, eu acho que isso, parte do tabu começa daí. Então se você vai } \\
\text { procurar um amigo e você tá feliz ok! Mas se você tá triste, você é excluído. }\end{array}$ \\
\hline $\begin{array}{l}\text { Transcrição E1 } \\
\text { revisada_para maxqda }\end{array}$ & AÇÃO\Cuidar|Grupos de apoio (21)\Despertencimento\A identificação do grupo de pertencimento & $\begin{array}{l}\text { O despertencimento também, né? Quando você não se identifica com nenhum } \\
\text { grupo, quando você acha que ninguém entende o que você sente, né? }\end{array}$ \\
\hline $\begin{array}{l}\text { Transcrição E1 } \\
\text { revisada_para maxqda }\end{array}$ & CONSCIENTIZAÇÃO|Consciência|Complexidade|Complexidade dos sentimentos\A singularidade do humano & $\begin{array}{l}\text { Um pouco disso que ela tá falando que é.... mas isso eu acho que isso todo mundo } \\
\text { sente, porque gente, cada um tem a sua história, cada um teve as suas dores, cada } \\
\text { um passou pelos seus traumas, então você nunca vai encontrar alguém que saiba } \\
\text { exatamente o que você sente, e é por isso que não tem o nome, porque não existe. } \\
\text { Assim como cada um tem a sua impressão digital, eu acho que o jeito que a gente } \\
\text { sente é muito pessoal e não existe nome, não existe... né? }\end{array}$ \\
\hline $\begin{array}{l}\text { Transcrição E1 } \\
\text { revisada_para maxqda }\end{array}$ & CONSCIENTIZAÇÃO|Consciência|Complexidade|Complexidade dos sentimentos|Sentimentos que não tem nome & $\begin{array}{l}\text { você nunca vai encontrar alguém que saiba exatamente o que você sente, e é por } \\
\text { isso que não tem o nome, porque não existe. Assim como cada um tem a sua } \\
\text { impressão digital, eu acho que o jeito que a gente sente é muito pessoal e não } \\
\text { existe nome, não existe... né? }\end{array}$ \\
\hline $\begin{array}{l}\text { Transcrição E1 } \\
\text { revisada_para maxqda }\end{array}$ & COMPREENSÃO\Experiência\O viver|Quem viveu (5)\Aprende\O que passei modela quem eu sou & $\begin{array}{l}\text { Então, se eu ando de uma forma, ou se eu me visto ou se eu falo, é por tudo que } \\
\text { eu passei, pelo acidente que eu sofri, pelo estupro, pelo suicídio... por tudo! } \\
\text { Entendeu? }\end{array}$ \\
\hline $\begin{array}{l}\text { Transcrição E1 } \\
\text { revisada_para maxqda }\end{array}$ & CONSCIENTIZAÇÃO|Consciência\O absurdo do suicídio\O não saber\As coisas acontecem por diversas razoes & $\begin{array}{l}\text { Porque às vezes as pessoas questionam, e aí nem a gente sabe porque a gente faz } \\
\text { aquilo, mas quando você buscar... não, eu parei de andar sozinha, por causa disso } \\
\text { ou daquilo, né... }\end{array}$ \\
\hline \begin{tabular}{|l|} 
Transcrição E1 \\
revisada_para maxqda
\end{tabular} & CONSCIENTIZAÇÃO|Consciência|Complexidade/Assunto proibido|Se fecha por achar que os outros não vão entender & $\begin{array}{l}\text { então eu acho que tem essa questão do despertencimento de talvez você ter tanta } \\
\text { dor e tantas coisas que as pessoas não passaram que você nem fala, né? Porque } \\
\text { acha que não vão te entender. Aí você vai se fechando ... e é isso }\end{array}$ \\
\hline \begin{tabular}{|l} 
Transcrição E1 \\
revisada_para maxqda
\end{tabular} & AÇÃO|Cuidar|Grupos de apoio (21)|Despertencimento & $\begin{array}{l}\text { então eu acho que tem essa questão do despertencimento de talvez você ter tanta } \\
\text { dor e tantas coisas que as pessoas não passaram que você nem fala, né? Porque } \\
\text { acha que não vão te entender. Aí você vai se fechando ... e é isso }\end{array}$ \\
\hline $\begin{array}{l}\text { Transcrição E1 } \\
\text { revisada_para maxqda }\end{array}$ & AÇÃo|Cuidar\Grupos de apoio (21)\O mundo dos sobreviventes|Grupos de pertencimento & $\begin{array}{l}\text { eu acho que esses grupos que nós estamos como esse e outros que a gente tem } \\
\text { em vários lugares, é um lugar de pertencimento }\end{array}$ \\
\hline $\begin{array}{l}\text { Transcrição E1 } \\
\text { revisada_para maxqda }\end{array}$ & AÇÃo|Cuidar|Grupos de apoio (21)\Sou acolhido e acolho|Sentindo-se acolhido nos grupos & $\begin{array}{l}\text { porque toda vez que eu vou num grupo desses eu me sinto assim, não é que } \\
\text { digamos estou à vontade, mas eu me sinto bem situado porque eu vejo que eu } \\
\text { diante de pessoas que tão vivendo histórias parecidas e que estão tendo o } \\
\text { sofrimento parecido, a angústia parecida, as dúvidas, as indagações parecidas, } \\
\text { então eu de alguma forma eu me sinto acolhido }\end{array}$ \\
\hline $\begin{array}{l}\text { Transcrição E1 } \\
\text { revisada_para maxqda }\end{array}$ & AÇÃO\Cuidar|Grupos de apoio (21)\O mundo dos sobreviventes & $\begin{array}{l}\text { E eu também me sinto à vontade de ir acolher, eu vejo por exemplo vocês como os } \\
\text { meus pares, são os meus iguais, então é um momento que nós estamos } \\
\text { encontrando com os nossos iguais. Aqueles que entraram nesse mundo, no mundo } \\
\text { dos sobreviventes }\end{array}$ \\
\hline $\begin{array}{l}\text { Transcrição E1 } \\
\text { revisada_para maxqda }\end{array}$ & AÇÃo|Cuidar|Grupos de apoio (21)\Sou acolhido e acolho & $\begin{array}{l}\text { E eu também me sinto à vontade de ir acolher, eu vejo por exemplo vocês como os } \\
\text { meus pares, são os meus iguais, então é um momento que nós estamos } \\
\text { encontrando com os nossos iguais. Aqueles que entraram nesse mundo, no mundo } \\
\text { dos sobreviventes }\end{array}$ \\
\hline $\begin{array}{l}\text { Transcrição E1 } \\
\text { revisada_para maxqda }\end{array}$ & AÇÃO\Cuidar|Grupos de apoio (21)\O mundo dos sobreviventes & $\begin{array}{l}\text { Então a gente consegue. Nossa! Existe um mundo que é o mundo dos } \\
\text { sobreviventes, e eu vejo a cara deles, eu vejo eles falarem, eles sentirem. }\end{array}$ \\
\hline
\end{tabular}




\begin{tabular}{|c|c|c|}
\hline \begin{tabular}{|l} 
Transcrição E1 \\
revisada_para maxqda
\end{tabular} & AÇÃO|Cuidar|Grupos de apoio (21)\Sou acolhido e acolho|Sentindo-se acolhido nos grupos & $\begin{array}{l}\text { Então, essas dinâmicas essa... e outras e ocorrem no (local onde ocorrem grupos), } \\
\text { no (local onde ocorrem grupos) eu acho que são muito boas, e eu acho que esse é } \\
\text { o caminho, é buscar esses lugares porque a gente vai se reconhecer. } \\
\end{array}$ \\
\hline $\begin{array}{l}\text { Transcrição E1 } \\
\text { revisada_para maxqda }\end{array}$ & AÇÃO\Cuidar|Grupos de apoio (21)\O mundo dos sobreviventes\O que nos une nesta pesquisa & Mas a gente tá aqui é porque a gente passou por isso, \\
\hline $\begin{array}{l}\text { Transcrição E1 } \\
\text { revisada_para maxqda }\end{array}$ & AÇÃO\Cuidar|Grupos de apoio (21)\O mundo dos sobreviventes\O que nos une nesta pesquisa & Isso... só isso que nos une aqui... \\
\hline $\begin{array}{l}\text { Transcrição E1 } \\
\text { revisada_para maxqda }\end{array}$ & AÇÃo|Cuidar|Grupos de apoio (21)\Divulgação e conhecimento|Suicidas não conhecem os grupos & $\begin{array}{l}\text { isso que eu acho que pra quem chega a se matar, quer dizer, ele não sabe, ele não, } \\
\text { ele não... porque não é falado. }\end{array}$ \\
\hline $\begin{array}{l}\text { Transcrição E1 } \\
\text { revisada_para maxqda }\end{array}$ & AÇÃo|Cuidar|Grupos de apoio (21)\Divulgação e conhecimento|Suicidas saberem e frequentarem os grupos & $\begin{array}{l}\text { Então ele não sabe que existe um grupo desse que ele pode procurar, e que ele } \\
\text { pode se sentir bem e acolhido e respeitado, e falar que... }\end{array}$ \\
\hline $\begin{array}{l}\text { Transcrição E1 } \\
\text { revisada_para maxqda }\end{array}$ & CONSCIENTIZAÇÃO|Consciência|Aumento da Consciência (19)|Prevenção & $\begin{array}{l}\text { Então ele não sabe que existe um grupo desse que ele pode procurar, e que ele } \\
\text { pode se sentir bem e acolhido e respeitado, e falar que... }\end{array}$ \\
\hline \begin{tabular}{|l|l} 
\\
Transcrição E1 \\
revisada_para maxqda
\end{tabular} & AÇÃO|Cuidar|Grupos de apoio (21)\Divulgação e conhecimento|Suicidas saberem e frequentarem os grupos & ..é exatamente, e eu acho que é aí que falta... \\
\hline $\begin{array}{l}\text { Transcrição E1 } \\
\text { revisada_para maxqda }\end{array}$ & COMPREENSÃO\Comunicação|Social|Reportagens\Reportagens dão valor aos casos e fatos & $\begin{array}{l}\text { eu vou tirar por mim... em reportagens, que eu acho que é meio o tema abordado } \\
\text { aqui, que eu leio mais em reportagem que eu procuro ler, e eu acho que dão um } \\
\text { pouquinho menos de valor, as reportagens normalmente dão um valor aos casos, } \\
\text { né, como foi }\end{array}$ \\
\hline $\begin{array}{l}\text { Transcrição E1 } \\
\text { revisada_para maxqda }\end{array}$ & COMPREENSÃO|Comunicação|Social\Reportagens\Buscando a parte prática nas reportagens & $\begin{array}{l}\text { Para mim eu vou para a última parte, quando se é falado o que a gente pode fazer, } \\
\text { praticamente. Porque aí fica mais claro nos tópicos. }\end{array}$ \\
\hline $\begin{array}{l}\text { Transcrição E1 } \\
\text { revisada_para maxqda }\end{array}$ & COMPREENSÃO|Comunicação|Social|Reportagens|Buscando se capacitar através das reportagens & $\begin{array}{l}\text { Olha, te deixa a disposição, eu vou muito naquilo porque como eu não soube fazer } \\
\text { antes, eu tento então saber como fazer agora. }\end{array}$ \\
\hline \begin{tabular}{|l} 
Transcrição E1 \\
revisada_para maxqda
\end{tabular} & AÇÃO\Diálogo\O falar (23)\Quem\Profissionais\Reportagens voltadas para leigos & $\begin{array}{l}\text { Então eu acho que teria que ter mais reportagens, a reportagem dar mais ênfase, } \\
\text { até pra um leigo num falando, tentando falar né com nenhum profissional, que as } \\
\text { vezes quem vai estar lendo na sua casa você não vai ter um profissional }\end{array}$ \\
\hline \begin{tabular}{|l} 
Transcrição E1 \\
revisada_para maxqda
\end{tabular} & AÇÃO\Diálogo\O falar (23)\O que (MENSAGEM)\Ensinar como agir|Não sabendo o que fazer & $\begin{array}{l}\text { Como pelo menos de princípio como ajudar mais né, porque é isso que a P2 falou, } \\
\text { que a gente não sabe o que fazer. Então eu gosto muito daquela parte da } \\
\text { reportagem aonde est bem claro, ali... }\end{array}$ \\
\hline $\begin{array}{l}\text { Transcrição E1 } \\
\text { revisada_para maxqda }\end{array}$ & COMPREENSÃO|Comunicação|Social|Reportagens|Buscando a parte prática nas reportagens & $\begin{array}{l}\text { Como pelo menos de princípio como ajudar mais né, porque é isso que a P2 falou, } \\
\text { que a gente não sabe o que fazer. Então eu gosto muito daquela parte da } \\
\text { reportagem aonde est bem claro, ali... }\end{array}$ \\
\hline \begin{tabular}{|l} 
Transcrição E1 \\
revisada_para maxqda
\end{tabular} & COMPREENSÃO|Comunicação|Social\Reportagens\Buscando a parte prática nas reportagens & Então...mas a maioria não tem \\
\hline $\begin{array}{l}\text { Transcrição E1 } \\
\text { revisada_para maxqda }\end{array}$ & COMPREENSÃO|Comunicação|Social/Reportagens\Reportagens dão valor aos casos e fatos & $\begin{array}{l}\text { A maioria sempre, não estou criticando as reportagens, mas eles dão muito ênfase } \\
\text { ao que tá acontecendo. }\end{array}$ \\
\hline $\begin{array}{l}\text { Transcrição E1 } \\
\text { revisada_para maxqda }\end{array}$ & COMPREENSÃO|Comunicação|Social/Reportagens\Reportagens dão valor aos casos e fatos & $\begin{array}{l}\text { Agora tá tendo muito por causa da baleia azul, do seriado, vai ter setembro, já } \\
\text { começa no final de agosto já começa as reportagens... }\end{array}$ \\
\hline $\begin{array}{l}\text { Transcrição E1 } \\
\text { revisada_para maxqda }\end{array}$ & AÇÃO\Diálogo\O falar (23)\O que (MENSAGEM)\Ensinar como agir|Reportagens com orientações & quer dizer orientações né?! \\
\hline $\begin{array}{l}\text { Transcrição E1 } \\
\text { revisada_para maxqda }\end{array}$ & AÇÃO\Diálogo\O falar (23)\O que (MENSAGEM)\Ensinar como agir|Reportagens com orientações & As orientações práticas pro leigo né eu acho que isso seria muito importante. \\
\hline \begin{tabular}{|l} 
Transcrição E1 \\
revisada_para maxqda
\end{tabular} & CONSCIENTIZAÇÃO\Consciência\Aumento da Consciência (19)\Prevenção\Aumentar consciência e prevenir suicídio & $\begin{array}{l}\text { Como que vocês acham que essa consciência pode ser aumentada. Vocês acham } \\
\text { que falando mais sobre o assunto, aumenta a consciência pública? Se isso } \\
\text { influenciaria na prevenção e posvenção do suicídio? }\end{array}$ \\
\hline \begin{tabular}{|l} 
Transcrição E1 \\
revisada_para maxqda
\end{tabular} & CONSCIENTIZAÇÃO|Consciência|Aumento da Consciência (19)\Prevenção\Aumentar consciência e prevenir suicídio & Sim, sim, sim.... \\
\hline
\end{tabular}

Material integrante da pesquisa de doutorado de Karen Scavacini - USP Proibida a reprodução ou utilização sem autorização do autor - 2018 


\begin{tabular}{|c|c|c|}
\hline $\begin{array}{l}\text { Transcrição E1 } \\
\text { revisada_para maxqda }\end{array}$ & CONSCIENTIZAÇÃO|Consciência|Epidemiologia (20)\Importância da percepção da quantidade & $\begin{array}{l}\text { Eu acho que um dado muito importante é fazer as pessoas perceberem a } \\
\text { quantidade de mortes que ocorrem a cada... a cada segundo ou a cada minuto né? } \\
\text { Então isso é algo acho que eu considero importante porque quando eu falo pra } \\
\text { pessoa: "Olha, enquanto a gente esteve conversando, agora, já morreram umas } \\
\text { dez pessoas. }\end{array}$ \\
\hline $\begin{array}{l}\text { Transcrição E1 } \\
\text { revisada_para maxqda }\end{array}$ & CONSCIENTIZAÇÃO\Consciência\Epidemiologia (20)\Importância da percepção da quantidade\Acreditando que o suicídio é a maior causa & $\begin{array}{l}\text { Pra pessoa perceber a grandeza, a dimensão, eu inclusive me permito, e aí eu } \\
\text { sempre falo isso a título de conjectura pessoal que para mim, a minha convição } \\
\text { pessoal é que a maior causa de morte provocada da humanidade através da } \\
\text { história é não só agora, é e sempre foi o suicídio }\end{array}$ \\
\hline $\begin{array}{l}\text { Transcrição E1 } \\
\text { revisada_para maxqda }\end{array}$ & CONSCIENTIZAÇÃO|Consciência|Epidemiologia (20)\Importância da percepção da quantidade\Acreditando que o suicídio é a maior causa & Mas é que sempre é ocultado, é uma das maiores, mas com certeza ela é a maior. \\
\hline $\begin{array}{l}\text { Transcrição E1 } \\
\text { revisada_para maxqda }\end{array}$ & COMPREENSÃO\Tabu (1)\O tabu em diversas esferas\Estatística & $\begin{array}{l}\text { Porque as outras, estatísticas... são colocadas estatísticas fiéis, e não tem tabu em } \\
\text { cima. E aqui não, é tudo escondido. }\end{array}$ \\
\hline $\begin{array}{l}\text { Transcrição E1 } \\
\text { revisada_para maxqda }\end{array}$ & CONSCIENTIZAÇÃO|Consciência|Epidemiologia (20)\Importância da percepção da quantidade\Acreditando que o suicídio é a maior causa & $\begin{array}{l}\text { E eu falei... eu me permito acreditar que talvez a humanidade, a maior causa de } \\
\text { morte da humanidade é o suicídio. }\end{array}$ \\
\hline $\begin{array}{l}\text { Transcrição E1 } \\
\text { revisada_para maxqda }\end{array}$ & CONSCIENTIZAÇÃO\Consciência|Epidemiologia (20)\Importância da percepção da quantidade\Acreditando que o suicídio é a maior causa & $\begin{array}{l}\text { O que é um grande paradoxo. E eu acho que se um dia as autoridades, os } \\
\text { formadores de opinião, enfim, as elites pensantes, enfim, começarem a admitir } \\
\text { uma possibilidade como essa... paradoxal, contraditória, assustadora, eu acho que } \\
\text { a gente revoluciona, a gente muda, não sei. }\end{array}$ \\
\hline $\begin{array}{l}\text { Transcrição E1 } \\
\text { revisada_para maxqda }\end{array}$ & CONSCIENTIZAÇÃO|Consciência \O absurdo do suicídio\O absurdo do suicídio\O suicídio como paradoxo & O que é um grande paradoxo. \\
\hline $\begin{array}{l}\text { Transcrição E1 } \\
\text { revisada_para maxqda }\end{array}$ & AÇÃO\Fazer|Prevenção (30)\Quem faz a prevenção & $\begin{array}{l}\text { Eu acho que no falar, ele é tem alguma coisa que ainda eu ainda não consegui } \\
\text { pensar muito bem, é a respeito sobre essa questão da prevenção. }\end{array}$ \\
\hline $\begin{array}{l}\text { Transcrição E1 } \\
\text { revisada_para maxqda }\end{array}$ & AÇÃO\Fazer\Prevenção (30)\Quem faz a prevenção|Quem é responsável pela prevenção & $\begin{array}{l}\text { É.... e de que a prevenção ela tá mais na mão da própria pessoa do que na dos } \\
\text { outros. }\end{array}$ \\
\hline $\begin{array}{l}\text { Transcrição E1 } \\
\text { revisada_para maxqda }\end{array}$ & AÇÃO\Fazer|Prevenção (30)\Quem faz a prevenção|Pensamento e consequência & $\begin{array}{l}\text { Então que também tem essa coisa, eu acho que falar é importante para que as } \\
\text { pessoas que pensam nisso entendam também a consequência daquilo }\end{array}$ \\
\hline $\begin{array}{l}\text { Transcrição E1 } \\
\text { revisada_para maxqda }\end{array}$ & AÇÃO\Fazer|Prevenção (30)\Quem faz a prevenção|Paranoia em detectar & $\begin{array}{l}\text { E mais do que falar para que os outros em torno, porque possam detectar, porque } \\
\text { senão também tem aquela paranoia. A pessoa então começa com alguma coisinha } \\
\text { todo mundo já "ah, ah..." mas sabe, tipo... a gente tem que ficar atento com uma } \\
\text { série de coisas }\end{array}$ \\
\hline \begin{tabular}{|l} 
Transcrição E1 \\
revisada_para maxqda
\end{tabular} & COMPREENSÃO\Comunicação|Pessoal|Falando abertamente na família & $\begin{array}{l}\text { Na minha família isso é um assunto, de um dos lados, é um assunto que se fala } \\
\text { abertamente }\end{array}$ \\
\hline $\begin{array}{l}\text { Transcrição E1 } \\
\text { revisada_para maxqda }\end{array}$ & COMPREENSÃO\Comunicação|Pessoal\Dificuldades comunicação familiar|Não falando abertamente na família & Do lado do meu pai não. Do lado do meu pai ninguém fala a palavra \\
\hline $\begin{array}{l}\text { Transcrição E1 } \\
\text { revisada_para maxqda }\end{array}$ & CONSCIENTIZAÇÃo|Consciência \O absurdo do suicídio|Proximidade de suicídios\Família como agente de observação & $\begin{array}{l}\text { Do lado da minha mãe não, então já tem aquela coisa... a gente est com um primo } \\
\text { que tá com uma depressão muito profunda, o pessoal tá de olho. }\end{array}$ \\
\hline $\begin{array}{l}\text { Transcrição E1 } \\
\text { revisada_para maxqda }\end{array}$ & AÇÃO|Fazer|Prevenção (30)\Quem faz a prevenção|Paranoia em detectar & Mas também não pode ficar com uma paranoia em cima, de tipo qualquer coisa \\
\hline $\begin{array}{l}\text { Transcrição E1 } \\
\text { revisada_para maxqda }\end{array}$ & CONSCIENTIZAÇÃO|Consciência|Aumento da Consciência (19)\Prevenção|Falar abertamente como prevenção & $\begin{array}{l}\text { mas eu acho que a prevenção ela passa mais o poder falar abertamente sobre isso, } \\
\text { é mais importante pra pessoa que pensa no assunto, do que propriamente para as } \\
\text { pessoas que estão no entorno dela, né, é mais isso... }\end{array}$ \\
\hline $\begin{array}{l}\text { Transcrição E1 } \\
\text { revisada_para maxqda }\end{array}$ & AÇÃO|DiálogolOuvir|Pessoas não tem com quem conversar|Não ter com quem conversar sobre coisas cotidianas & $\begin{array}{l}\text { Eu fiquei um tempo atendendo ligações das pessoas que ligam, que procuram né, e } \\
\text { a minha experiência assim foi de que a maioria do que é falado, e que as pessoas } \\
\text { sentem angústia porque não tem com quem conversar..., porque são coisas } \\
\text { cotidianas, então o que eu percebo e que eu acho que a grande dificuldade que a } \\
\text { gente não relaciona esse cotidiano com digamos o fato em si é de que as pessoas } \\
\text { não tem espaço pra falar do que elas estão sentindo: pergunta o que aconteceu, } \\
\text { ou como foi o seu dia, ou falam de coisas práticas. }\end{array}$ \\
\hline
\end{tabular}

Material integrante da pesquisa de doutorado de Karen Scavacini - USP Proibida a reprodução ou utilização sem autorização do autor - 2018 


\begin{tabular}{|c|c|c|}
\hline $\begin{array}{l}\text { Transcrição E1 } \\
\text { revisada_para maxqda }\end{array}$ & AÇÃO\Diálogo|O falar (23)\Como (FORMA)\Prevenir através de falar do cotidiano & $\begin{array}{l}\text { Eu fiquei um tempo atendendo ligações das pessoas que ligam, que procuram né, e } \\
\text { a minha experiência assim foi de que a maioria do que é falado, e que as pessoas } \\
\text { sentem angústia porque não tem com quem conversar..., porque são coisas } \\
\text { cotidianas, então o que eu percebo e que eu acho que a grande dificuldade que a } \\
\text { gente não relaciona esse cotidiano com digamos o fato em si é de que as pessoas } \\
\text { não tem espaço pra falar do que elas estão sentindo: pergunta o que aconteceu, } \\
\text { ou como foi o seu dia, ou falam de coisas práticas. }\end{array}$ \\
\hline $\begin{array}{l}\text { Transcrição E1 } \\
\text { revisada_para maxqda }\end{array}$ & COMPREENSÃO\Tabu (1)\Consequências do Tabu\O não falar\O não falar/dividir levando a pensar na morte & $\begin{array}{l}\text { Mas quando a pessoa tem algo, que ela não sente à vontade de falar com alguém } \\
\text { da família, com amigo, com marido, com esposa, com filhos, com os pais, isso é o } \\
\text { que vai acumulando aí chega num ponto que a pessoa chega a tirar a própria vida. }\end{array}$ \\
\hline $\begin{array}{l}\text { Transcrição E1 } \\
\text { revisada_para maxqda }\end{array}$ & AÇão|DiálogolO falar (23)\Como (FORMA)\Prevenir através de falar do cotidiano\Falta de espaço de falar de sentimentos $x$ suicídio & $\begin{array}{l}\text { Então, o que eu senti de grave, e aí eu estou tentando trazer isso na minha relação } \\
\text { pessoal dos amigos, é que mesmo com os amigos quando eu vou conversar, eu } \\
\text { percebo que eles não conseguem relacionar que não falar do sentimento, tem } \\
\text { vínculo com chegar nesse ponto, que a angústia pode acrescentar até que chega a } \\
\text { gota d'água de algo que acontece, mas que é, muitas vezes, só o desencadeador do } \\
\text { fato, mas é falta de espaço de falar dos sentimentos. }\end{array}$ \\
\hline $\begin{array}{l}\text { Transcrição E1 } \\
\text { revisada_para maxqda }\end{array}$ & COMPREENSÃO\Tabu (1)\Atitudes que reforçam o tabu\Educação emocional pobre & $\begin{array}{l}\text { Isso que você falou de tem sentimentos que a gente não sabe nem nomear, e acho } \\
\text { que a gente tem uma educação emocional muito pobre de forma geral, e acho que } \\
\text { isso, à na causa do tabu. }\end{array}$ \\
\hline \begin{tabular}{|l} 
Transcrição E1 \\
revisada_para maxqda
\end{tabular} & COMPREENSÃO\Tabu (1)\Atitudes que reforçam o tabu|Educação emocional pobre|Ser educada para falar sobre os sentimentos & $\begin{array}{l}\text { Então a dificuldade, por exemplo, eu encontro amigos e às vezes a pessoa tá } \\
\text { passando uma angustia grande mas ela não consegue falar, ela não foi educada, eu } \\
\text { também não fui, então eu estou fazendo esse exercício. }\end{array}$ \\
\hline $\begin{array}{l}\text { Transcrição E1 } \\
\text { revisada_para maxqda }\end{array}$ & COMPREENSÃO\Tabu (1)\O tabu em diversas esferas\Tabu sobre falar de sentimentos & $\begin{array}{l}\text { Existe um tabu de falar o que tá sentindo, que é visto como uma pessoa fraca, com } \\
\text { defeito.... É excluído sim... }\end{array}$ \\
\hline $\begin{array}{l}\text { Transcrição E1 } \\
\text { revisada_para maxqda }\end{array}$ & COMPREENSÃO|Comunicação|Social|Aumento da comunicação|Já se fala mais de suicídio hoje & $\begin{array}{l}\text { Olha eu acho que já é bem visto hoje, porque eu sou um pouquinho mais antigo } \\
\text { né, porque o que acontece? }\end{array}$ \\
\hline $\begin{array}{l}\text { Transcrição E1 } \\
\text { revisada_para maxqda }\end{array}$ & COMPREENSÃO|Tabu (1)\Consequências do TabulUm assunto proibido|Suicídio é um assunto proibido & $\begin{array}{l}\text { Na nossa época o suicídio era um... a família não comentava. Todo mundo } \\
\text { escondia, todo mundo guardava aquilo, desaparecia e ninguém sabia nem o que } \\
\text { aconteceu. Era proibido falar suicídio }\end{array}$ \\
\hline $\begin{array}{l}\text { Transcrição E1 } \\
\text { revisada_para maxqda }\end{array}$ & COMPREENSÃO\Tabu (1)\Consequências do Tabu\Um assunto proibido|Suicídio era assunto proibido & $\begin{array}{l}\text { A família era excretada da sociedade. Toda a família daquele que suicidou-se. Não } \\
\text { existia, era um disparate. }\end{array}$ \\
\hline $\begin{array}{l}\text { Transcrição E1 } \\
\text { revisada_para maxqda }\end{array}$ & COMPREENSÃO\Tabu (1)\Consequências do Tabu\Um assunto proibido|Suicídio era assunto proibido & era um disparate \\
\hline $\begin{array}{l}\text { Transcrição E1 } \\
\text { revisada_para maxqda }\end{array}$ & COMPREENSÃO|VisãolVisão da Sociedade (2)\Causas do suicídio|Culpando diferente pelas idades\Crenças de suicídio de mais velhos & $\begin{array}{l}\text { principalmente o que eram mais idosos, que se suicidavam e geralmente amante } \\
\text { ou financeiros o problema. Antigamente era esse o problema. }\end{array}$ \\
\hline $\begin{array}{l}\text { Transcrição E1 } \\
\text { revisada_para maxqda }\end{array}$ & COMPREENSÃO\Tabu (1)\Consequências do Tabu\Um assunto proibido|Suicídio era assunto proibido & $\begin{array}{l}\text { E isso era proibido, era terminantemente proibido... não podia comentar em casa } \\
\text { que o vizinho se suicidou, meu pai vinha e me dava uma surra. }\end{array}$ \\
\hline $\begin{array}{l}\text { Transcrição E1 } \\
\text { revisada_para maxqda }\end{array}$ & COMPREENSÃO\Tabu (1)\O tabu em diversas esferas\Religião\Enterros separados de suicidas & Tinha cemitérios que não se podia nem enterrar. \\
\hline $\begin{array}{l}\text { Transcrição E1 } \\
\text { revisada_para maxqda }\end{array}$ & COMPREENSÃO\Tabu (1)\O tabu em diversas esferas\Religião\Enterros separados de suicidas & Não podia enterrar, é verdade. \\
\hline $\begin{array}{l}\text { Transcrição E1 } \\
\text { revisada_para maxqda }\end{array}$ & COMPREENSÃO|Comunicação|Social|Famosos e suicídio|Suicídio de Santos Dumont & Igual uma coisa que pouca gente sabe, Santos Dummont suicidou-se, né? \\
\hline $\begin{array}{l}\text { Transcrição E1 } \\
\text { revisada_para maxqda }\end{array}$ & COMPREENSÃO|Comunicação|Social|Famosos e suicídio|Suicídio de Santos Dumont & E ninguém divulga isso, né? . \\
\hline $\begin{array}{l}\text { Transcrição E1 } \\
\text { revisada_para maxqda }\end{array}$ & COMPREENSÃO|Comunicação|Social|Famosos e suicídio|Suicídio de Santos Dumont & $\begin{array}{l}\text { Ele suicidou-se no Guarujá. Só quem passou por isso sabe, se você fizer uma } \\
\text { pesquisa aí de quem não passou por suicídio, você vai ver que } 90 \% \text { não sabe do } \\
\text { que Santos Dummont morreu, de tanto que era escondida a coisa. }\end{array}$ \\
\hline
\end{tabular}

Material integrante da pesquisa de doutorado de Karen Scavacini - USP Proibida a reprodução ou utilização sem autorização do autor - 2018 


\begin{tabular}{|c|c|c|}
\hline $\begin{array}{l}\text { Transcrição E1 } \\
\text { revisada_para maxqda }\end{array}$ & COMPREENSÃO\Experiência\O viver|Quem viveu (5)\Entende\Quem passou sabe & $\begin{array}{l}\text { Só quem passou por isso sabe, se você fizer uma pesquisa aí de quem não passou } \\
\text { por suicídio, você vai ver que } 90 \% \text { não sabe do que Santos Dummont morreu, de } \\
\text { tanto que era escondida a coisa. }\end{array}$ \\
\hline \begin{tabular}{|l|} 
Transcrição E1 \\
revisada_para maxqda
\end{tabular} & COMPREENSÃO|Comunicação|Social|Aumento da comunicação|Já se fala mais de suicídio hoje & Não, mas hoje já se fala muito mais.. \\
\hline $\begin{array}{l}\text { Transcrição E1 } \\
\text { revisada_para maxqda }\end{array}$ & COMPREENSÃO\Comunicação|Social|Aumento da comunicação|Já se fala mais de suicídio hoje & Sim, hoje se fala mais de suicídio... eu estou falando como era antigamente. \\
\hline $\begin{array}{l}\text { Transcrição E1 } \\
\text { revisada_para maxqda }\end{array}$ & AÇÃO\DiálogolO falar (23)\Onde\Locais\Falando sobre suicídio na faculdade & $\begin{array}{l}\text { minha esposa tá fazendo psicologia então, no mundo dela, na faculdade tudo... a } \\
\text { quase toda semana tem temas que envolvem suicídio }\end{array}$ \\
\hline $\begin{array}{l}\text { Transcrição E1 } \\
\text { revisada_para maxqda }\end{array}$ & AÇÃO\Diálogo\O falar (23)\Onde\Locais\Falando sobre suicídio na faculdade & $\begin{array}{l}\text { Na faculdade se fala bastante, pode não ter uma disciplina sobre isso mas, se fala } \\
\text { bastante. É palestras e tal tal tal. }\end{array}$ \\
\hline $\begin{array}{l}\text { Transcrição E1 } \\
\text { revisada_para maxqda }\end{array}$ & AÇÃO\Diálogo\O falar (23)\Onde\Locais\Falando em grupos fechados & $\begin{array}{l}\text { Mas são grupos fechados né, dentro da universidade. Não leva pra fora né... a } \\
\text { gente espera que... }\end{array}$ \\
\hline $\begin{array}{l}\text { Transcrição E1 } \\
\text { revisada_para maxqda }\end{array}$ & COMPREENSÃO\Comunicação|Social|Aumento da comunicação|Já se fala mais de suicídio hoje & $\begin{array}{l}\text { Mas mesmo assim a gente já vê que já tá que está mudando, você vê que se fala } \\
\text { mais, já sai na televisão, é tem canais que vai... a Globo não pode falar...ou só a } \\
\text { partir de tal horário, tem umas normas né. }\end{array}$ \\
\hline \begin{tabular}{|l|} 
Transcrição E1 \\
revisada_para maxqda
\end{tabular} & COMPREENSÃO|Comunicação|Social|Aumento da comunicação|Assunto na mídia & $\begin{array}{l}\text { Mas mesmo assim a gente já vê que já tá que está mudando, você vê que se fala } \\
\text { mais, já sai na televisão, é tem canais que vai... a Globo não pode falar...ou só a } \\
\text { partir de tal horário, tem umas normas né. }\end{array}$ \\
\hline \begin{tabular}{|l|} 
Transcrição E1 \\
revisada_para maxqda
\end{tabular} & |COMPREENSÃo|Comunicação|Social|Aumento da comunicação|Assunto na mídia & fala junto - os famosos, pelo menos ela falou... \\
\hline $\begin{array}{l}\text { Transcrição E1 } \\
\text { revisada_para maxqda }\end{array}$ & AÇÃO\Diálogo\O falar (23)\Quem\Famosos\De suicídio de famosos se fala & fala junto - os famosos, pelo menos ela falou... \\
\hline \begin{tabular}{|l|l} 
Transcrição E1 \\
revisada_para maxqda
\end{tabular} & |COMPREENSÃo|Comunicação|Social|Aumento da comunicação|Assunto na mídia & $\begin{array}{l}\text { Então eu acho que isso, por exemplo a parte da manhã é hora que tem muito ?, } \\
\text { você não pode falar isso no jornal nem nada. }\end{array}$ \\
\hline $\begin{array}{l}\text { Transcrição E1 } \\
\text { revisada_para maxqda }\end{array}$ & |COMPREENSÃo|Comunicação|Social\Aumento da comunicação|Assunto na mídia & $\begin{array}{l}\text { No ... de prevenção ao suicídio do ano retrasado, saiu uma matéria que inclusive } \\
\text { um dos que foi entrevistados fui eu, foi no(nome do programa e do canal), que é o } \\
\text { jornal da .... }\end{array}$ \\
\hline $\begin{array}{l}\text { Transcrição E1 } \\
\text { revisada_para maxqda }\end{array}$ & COMPREENSÃo|Comunicação|Social|Aumento da comunicação|Mídia incluindo os sobreviventes\Falando do assunto para a mídia & $\begin{array}{l}\text { No ... de prevenção ao suicídio do ano retrasado, saiu uma matéria que inclusive } \\
\text { um dos que foi entrevistados fui eu, foi no(nome do programa e do canal), que é o } \\
\text { jornal da (...) }\end{array}$ \\
\hline $\begin{array}{l}\text { Transcrição E1 } \\
\text { revisada_para maxqda }\end{array}$ & COMPREENSÃO|Comunicação|Social\Aumento da comunicação|Assunto na mídia & $\begin{array}{l}\text { Saiu também, na mesma (nome do canal e nome do programa) que eu também } \\
\text { contribui...na do no passado...também no dia mundial da prevenção ao suicídio, no } \\
\text { início da noite, as } 7,8 \text { horas da noite, que é o (nome do programa) }\end{array}$ \\
\hline \begin{tabular}{|l|} 
Transcrição E1 \\
revisada_para maxqda
\end{tabular} & |COMPREENSÃo|Comunicação|Social|Aumento da comunicação|Assunto na mídia & Há duas semanas, naquele programa da Fátima Bernardes foi falado de suicídio. \\
\hline \begin{tabular}{|l|} 
Transcrição E1 \\
revisada_para maxqda
\end{tabular} & COMPREENSÃO|Comunicação|Social\Aumento da comunicação|Assunto na mídia & $\begin{array}{l}\text { Hoje no jornal da (nome de emissora de tevê) eu vi a sua entrevista, eu vi... eu ate } \\
\text { gravei... eu vi a sua entrevista, ela deu uma entrevista né, explicando a questão do } \\
\text { suicídio, então isso já é uma vitória, né? }\end{array}$ \\
\hline $\begin{array}{l}\text { Transcrição E1 } \\
\text { revisada_para maxqda }\end{array}$ & COMPREENSÃO|Comunicação|Social\Aumento da comunicação|Assunto na mídia & $\begin{array}{l}\text { Ah,(nome do programa) quis fazer um trabalho sobre a questão do suicídio em } 4 \\
\text { semanas, eu ia participar de uma delas e depois a cúpula da (nome do canal) } \\
\text { vetou. O (nome do repórter) comprou o negócio, veio a moça, lá, que me } \\
\text { entrevistou tal e depois veio explicar lá no mês seguinte que a cúpula apagou ... }\end{array}$ \\
\hline $\begin{array}{l}\text { Transcrição E1 } \\
\text { revisada_para maxqda }\end{array}$ & COMPREENSÃO\Comunicação|Social\Aumento da comunicação\لá se fala mais de suicídio hoje & vocês estão falando que hoje já se fala mais do que falava antes! \\
\hline \begin{tabular}{|l|} 
Transcrição E1 \\
revisada_para maxqda
\end{tabular} & COMPREENSÃO|Comunicação|Social|Aumento da comunicação\Já se fala mais de suicídio hoje & a sim, bem mais.... até na hora do.... \\
\hline
\end{tabular}




\begin{tabular}{|c|c|c|}
\hline \begin{tabular}{|l} 
Transcrição E1 \\
revisada_para maxqda
\end{tabular} & AÇÃO\Diálogo\O falar (23)\O que (MENSAGEM)\Temas\Falando parte informativa & $\begin{array}{l}\text { eles pegam uma entrevista e eles me exploram na parte informativa e aquela coisa } \\
\text { e vai retratar o episódio, e os depoimentos profissionais, agora saiu uma revista da } \\
\text { (nome de revista) muito boa, tal. }\end{array}$ \\
\hline \begin{tabular}{|l|} 
Transcrição E1 \\
revisada_para maxqda
\end{tabular} & AÇÃO|Diálogo|O falar (23)\Quem/Sobreviventes enlutados\Falar da dor dos que ficam & $\begin{array}{l}\text { Agora... nenhuma abordagem tá sendo feita de mostrar a dor e o sofrimento dos } \\
\text { que ficam. }\end{array}$ \\
\hline $\begin{array}{l}\text { Transcrição E1 } \\
\text { revisada_para maxqda }\end{array}$ & AÇÃO\DiálogolO falar (23)\O que (MENSAGEM)\Falando de estatísticas dos enlutados & $\begin{array}{l}\text { Porque fala só em estatística, que é em média } 6 \text { pessoas ficam impactadas por } \\
\text { aquele suicídio... em média, } 6 \text { pessoas. }\end{array}$ \\
\hline $\begin{array}{l}\text { Transcrição E1 } \\
\text { revisada_para maxqda }\end{array}$ & AÇÃO\DiálogolO falar (23)\Quem/Sobreviventes enlutados\Falar da dor dos que ficam & $\begin{array}{l}\text { Mas não falam como é que é o impacto, que essas as famílias ficam destroçadas, } \\
\text { enfim todos desgastes que cabem em eventuais suicídios dessas pessoas. }\end{array}$ \\
\hline $\begin{array}{l}\text { Transcrição E1 } \\
\text { revisada_para maxqda }\end{array}$ & CONSCIENTIZAÇÃo|Consciência\Aumento da Consciência (19)\Prevenção\Formas\Projeto ponto e virgula & $\begin{array}{l}\text { Por exemplo aquela moça jovem que o pai se suicidou lá na Europa e por causa } \\
\text { disso ela criou aquele projeto, "semicolon Project" ou "Projeto ponto e virgula", eu } \\
\text { vou tatuar o ponto e vírgula, até nessa matéria da (nome de revista) eu falei "eu } \\
\text { vou tatuar eu vou incorporar isso". }\end{array}$ \\
\hline $\begin{array}{l}\text { Transcrição E1 } \\
\text { revisada_para maxqda }\end{array}$ & AÇÃo|Campanhas (22)\Temas\Ações de pertencimento e superação & $\begin{array}{l}\text { Por exemplo aquela moça jovem que o pai se suicidou lá na Europa e por causa } \\
\text { disso ela criou aquele projeto, "semicolon Project" ou "Projeto ponto e vírgula", eu } \\
\text { vou tatuar o ponto e vírgula, até nessa matéria da (nome de revista) eu falei "eu } \\
\text { vou tatuar eu vou incorporar isso". }\end{array}$ \\
\hline $\begin{array}{l}\text { Transcrição E1 } \\
\text { revisada_para maxqda }\end{array}$ & CONSCIENTIZAÇÃO|Consciência\O absurdo do suicídio|Proximidade de suicídios\Suicídio entre sobreviventes & $\begin{array}{l}\text { Ela levou avante por anos e sucumbiu ela também se suicidou. Ela não aguentou, } \\
\text { ela também se suicidou }\end{array}$ \\
\hline $\begin{array}{l}\text { Transcrição E1 } \\
\text { revisada_para maxqda }\end{array}$ & AÇÃO\Diálogo\O falar (23)\Quem\Sobreviventes enlutados|Causando impacto com o seu relato & $\begin{array}{l}\text { Então eu mesmo uma vez numa reunião do (local de atendimento), eu vi o impacto } \\
\text { que eu causei a uma moça da mesma idade da minha filha, só de começar a relatar } \\
\text { né, que eu relatei que minha filha com } 18 \text { anos, até então ela tinha ouvido os } \\
\text { outros relatos e quando ela ouviu o meu ela desabou. }\end{array}$ \\
\hline $\begin{array}{l}\text { Transcrição E1 } \\
\text { revisada_para maxqda }\end{array}$ & AÇÃO\Diálogo\O falar (23)\Quem|Sobreviventes enlutados\Prevenindo ao mostrar a dor dos sobreviventes & $\begin{array}{l}\text { Então eu mesmo uma vez numa reunião do (local de atendimento), eu vi o impacto } \\
\text { que eu causei a uma moça da mesma idade da minha filha, só de começar a relatar } \\
\text { né, que eu relatei que minha filha com } 18 \text { anos, até então ela tinha ouvido os } \\
\text { outros relatos e quando ela ouviu o meu ela desabou. No final ela me abraçou e } \\
\text { falou palavras agradecendo e tal... enfim, e eu sei que aí aquela moça diante do } \\
\text { que ela viu do que o pai se tornou, ela jamais, ela não vai mais fazer isso porque } \\
\text { ela sabe como é que o pai dela, a mãe dela vai sentir o sufoco todo. }\end{array}$ \\
\hline $\begin{array}{l}\text { Transcrição E1 } \\
\text { revisada_para maxqda }\end{array}$ & COMPREENSÃO|Comunicação|Pessoal\O falar como uma causa/bandeira|Direito de quem quer ser anônimo & É o direito. (Participando gaguejando muito) eu sei... \\
\hline $\begin{array}{l}\text { Transcrição E1 } \\
\text { revisada_para maxqda }\end{array}$ & AÇÃO\Diálogo\O falar (23)\Quem|Sobreviventes enlutados\Prevenindo ao mostrar a dor dos sobreviventes & $\begin{array}{l}\text { Mas eu sinto como eu estou sendo aproveitado nessa parte, mas eu acho que se os } \\
\text { prováveis suicidas conseguirem atinar no mal, em como destroçam a família e as } \\
\text { pessoas que ela mais ama... }\end{array}$ \\
\hline $\begin{array}{l}\text { Transcrição E1 } \\
\text { revisada_para maxqda }\end{array}$ & AÇÃO)|Fazer|Outros tipos de trabalho (24)|Sendo ativista como forma de enlutamento e prevenção & $\begin{array}{l}\text { Então, tem que ver.... tem que haver... onde eu quero chegar é que ao eles abrirem } \\
\text { essa possibilidade de externar também o problema é o anonimato né, esse é o } \\
\text { problema, mas tudo bem. É o direito. (Participando gaguejando muito) eu sei... } \\
\text { Mas eu sinto como eu estou sendo aproveitado nessa parte, mas eu acho que se os } \\
\text { prováveis suicidas conseguirem atinar no mal, em como destroçam a família e as } \\
\text { pessoas que ela mais ama... }\end{array}$ \\
\hline $\begin{array}{l}\text { Transcrição E1 } \\
\text { revisada_para maxqda }\end{array}$ & AÇÃO\Diálogo|O falar (23)\O que (MENSAGEM)\Falando de estatísticas dos enlutados & ... e os amigos e todos que estão em volta...não são 6, são muito mais \\
\hline $\begin{array}{l}\text { Transcrição E1 } \\
\text { revisada_para maxqda }\end{array}$ & AÇÃO\Diálogo\O falar (23)\Quem|Sobreviventes enlutados\A dor dos sobreviventes prevenindo suicídios & $\begin{array}{l}\text {..como ele vai acabar com a vida daquelas, a vida daquelas pessoas daquele jeito, } \\
\text { nunca mais vai ser a mesma, né, o grau... E se elas tivessem noção como essa moça } \\
\text { teve, é isso que eu quero mostrar, seria um ótimo elemento, um elemento de } \\
\text { impacto, né. }\end{array}$ \\
\hline
\end{tabular}




\begin{tabular}{|c|c|c|}
\hline $\begin{array}{l}\text { Transcrição E1 } \\
\text { revisada_para maxqda }\end{array}$ & AÇÃO\Diálogo|O falar (23)\Como (FORMA)\Formas\Campanha do cigarro & $\begin{array}{l}\text { É como o cigarro que eles colocam o maço de cigarro mostrando como é que o } \\
\text { cara fica e tal, ajuda. Tudo bem. Vai ter gente que vai pegar aquilo e vai pegar e vai } \\
\text { fumar, mas com certeza tá ajudando }\end{array}$ \\
\hline $\begin{array}{l}\text { Transcrição E1 } \\
\text { revisada_para maxqda }\end{array}$ & CONSCIENTIZAÇÃO|ConsciêncialO absurdo do suicídio|Prevenção x Previsão|Livre arbítrio & $\begin{array}{l}\text { É como o cigarro que eles colocam o maço de cigarro mostrando como é que o } \\
\text { cara fica e tal, ajuda. Tudo bem. Vai ter gente que vai pegar aquilo e vai pegar e vai } \\
\text { fumar, mas com certeza tá ajudando. }\end{array}$ \\
\hline $\begin{array}{l}\text { Transcrição E1 } \\
\text { revisada_para maxqda }\end{array}$ & AÇÃO\DiálogolO falar (23)\Quem|Sobreviventes enlutados\A dor dos sobreviventes prevenindo suicídios & $\begin{array}{l}\text { Eles me disseram que como eu saí na outra entrevista..., porque outros abriram } \\
\text { mão do anonimato, então estão havendo outras pessoas, além de mim, que estão } \\
\text { abrindo mão do anonimato, e isso é legal, porque quando a sociedade começar a } \\
\text { ver a cara dos que ficam, a dor dos que ficam... }\end{array}$ \\
\hline $\begin{array}{l}\text { Transcrição E1 } \\
\text { revisada_para maxqda }\end{array}$ & COMPREENSÃO|Comunicação|Social/Aumento da comunicação|Mídia incluindo os sobreviventes & $\begin{array}{l}\text { Então eu acho que mostrar Não, é claro que isso vai demandar eventualmente, e } \\
\text { eu fico feliz com que aconteceu nessa revista } * * * * * \text { apesar de eu ter sido } \\
\text { entrevistado eu não fui aproveitado. Eles me disseram que como eu saí na outra } \\
\text { entrevista..., porque outros abriram mão do anonimato, então estão havendo } \\
\text { outras pessoas, além de mim, que estão abrindo mão do anonimato, e isso é legal, } \\
\text { porque quando a sociedade começar a ver a cara dos que ficam, a dor dos que } \\
\text { ficam... }\end{array}$ \\
\hline \begin{tabular}{|l|l} 
\\
Transcrição E1 \\
revisada_para maxqda
\end{tabular} & AÇÃO|DiálogolO falar (23)\Quem/Sobreviventes enlutados\Falar da dor dos que ficam & $\begin{array}{l}\text { então você tá falando assim, que, ao invés deles usarem somente informações } \\
\text { sobre o fato, como eles costumam utilizar... }\end{array}$ \\
\hline $\begin{array}{l}\text { Transcrição E1 } \\
\text { revisada_para maxqda }\end{array}$ & AÇÃO|DiálogolO falar (23)\Quem|Sobreviventes enlutados\Falar da dor dos que ficam & ... isso, além, colocar da dor daqueles que ficam? \\
\hline $\begin{array}{l}\text { Transcrição E1 } \\
\text { revisada_para maxqda }\end{array}$ & AÇÃO|DiálogolO falar (23)\Quem/Sobreviventes enlutados\Falar da dor dos que ficam & Isso, a dor dos que ficam \\
\hline $\begin{array}{l}\text { Transcrição E1 } \\
\text { revisada_para maxqda }\end{array}$ & COMPREENSÃO\Experiência\O sentir|Sentimentos (8)\Dor|De quem vailAchando que a dor dos que ficam atinge menos & $\begin{array}{l}\text { Eu discordo um pouquinho, porque eu acho se a gente falou de todo esse processo } \\
\text { que a pessoa está passando, isso aí não... eu acho que estatisticamente vai ser } \\
\text { difíici...menos do que você acha que vai atingir }\end{array}$ \\
\hline \begin{tabular}{|l|l} 
Transcrição E1 \\
revisada_para maxqda
\end{tabular} & COMPREENSÃO\ExperiêncialO sentir|Sentimentos (8)\Dor|De quem vai\A dor interna impede de prestar atenção nos sobreviventes & $\begin{array}{l}\text { Eu acho que o processo interno da pessoa a dor é tanta que ele não vai prestar } \\
\text { atenção naquele momento quem tá passando... }\end{array}$ \\
\hline \begin{tabular}{|l|l} 
Transcrição E1 \\
revisada_para maxqda
\end{tabular} & 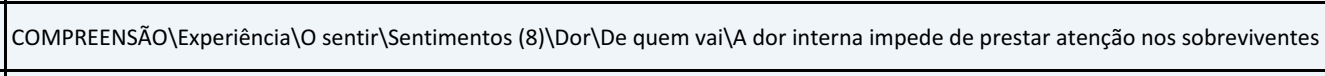 & a dor maior é ele \\
\hline $\begin{array}{l}\text { Transcrição E1 } \\
\text { revisada_para maxqda }\end{array}$ & COMPREENSÃO|Experiência|O sentir|Sentimentos (8)\Dor|De quem vailA dor interna impede de prestar atenção nos sobreviventes & A dor é ele, ele porque senão todos aqui os nossos filhos amavam a gente \\
\hline \begin{tabular}{|l} 
Transcrição E1 \\
revisada_para maxqda
\end{tabular} & AÇÃO|Diálogo\O falar (23)|Como (FORMA)\Formas|Cartas de despedida & $\begin{array}{l}\text { O meu deixou cartas, o que a maioria não deixou, o meu deixou muitas cartas... } \\
\text { que a gente não tinha culpa, que ele amava, que o P5 era exemplo de pai, que ele } \\
\text { queria ser igual a ele, então assim, ele deixou. }\end{array}$ \\
\hline $\begin{array}{l}\text { Transcrição E1 } \\
\text { revisada_para maxqda }\end{array}$ & 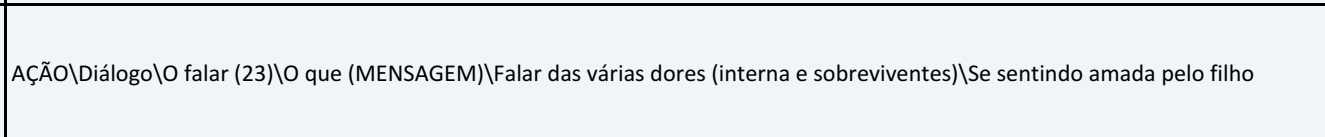 & $\begin{array}{l}\text { A dor é ele, ele porque senão todos aqui os nossos filhos amavam a gente. O meu } \\
\text { deixou cartas, o que a maioria não deixou, o meu deixou muitas cartas... que a } \\
\text { gente não tinha culpa, que ele amava, que o P5 era exemplo de pai, que ele queria } \\
\text { ser igual a ele, então assim, ele deixou. }\end{array}$ \\
\hline
\end{tabular}

Material integrante da pesquisa de doutorado de Karen Scavacini - USP 


\begin{tabular}{|c|c|c|}
\hline $\begin{array}{l}\text { Transcrição E1 } \\
\text { revisada_para maxqda }\end{array}$ & COMPREENSÃO\ExperiêncialO sentir|Sentimentos (8)\Dor|De quem vai|Dor que ultrapassa a proteção e o amor & $\begin{array}{l}\text { A dor é ele, ele porque senão todos aqui os nossos filhos amavam a gente. O meu } \\
\text { deixou cartas, o que a maioria não deixou, o meu deixou muitas cartas... que a } \\
\text { gente não tinha culpa, que ele amava, que o P5 era exemplo de pai, que ele queria } \\
\text { ser igual a ele, então assim, ele deixou. Tanto que eu falei muito na revista talvez } \\
\text { porque aproveitaram. Porque ela viu... assim, ela leu as cartas... a menina. Então, } \\
\text { ele deixou muito claro... então que a dor era tamanha que ele não sabia o que } \\
\text { fazer com ela. E meu filho tinha um fundamento religioso também, não ia falar que } \\
\text { ele era um adolescente que nem pensava em nada . Não, ele tinha um medo, ele } \\
\text { tinha... e falava "vou pagar por isso mas eu não estou conseguindo lidar com a } \\
\text { minha tristeza", então eu acho que no momento que eles estão passando a dor... } \\
\text { não seria... }\end{array}$ \\
\hline $\begin{array}{l}\text { Transcrição E1 } \\
\text { revisada_para maxqda }\end{array}$ & COMPREENSÃO|Comunicação|Social/Aumento da comunicação|Mídia incluindo os sobreviventes & $\begin{array}{l}\text { Tanto que eu falei muito na revista talvez porque aproveitaram. Porque ela viu... } \\
\text { assim, ela leu as cartas... a menina. }\end{array}$ \\
\hline \begin{tabular}{|l} 
Transcrição E1 \\
revisada_para maxqda
\end{tabular} & COMPREENSÃO|Experiência|O sentir|Sentimentos (8)|Dor|De quem vailA dor que não tem tamanho - suicídio' & $\begin{array}{l}\text { Então, ele deixou muito claro... então que a dor era tamanha que ele não sabia o } \\
\text { que fazer com ela. }\end{array}$ \\
\hline $\begin{array}{l}\text { Transcrição E1 } \\
\text { revisada_para maxqda }\end{array}$ & COMPREENSÃO\ExperiêncialO sentir|Sentimentos (8)\Dor|De quem vai|A dor fala mais alto que tudo & $\begin{array}{l}\text { E meu filho tinha um fundamento religioso também, não ia falar que ele era um } \\
\text { adolescente que nem pensava em nada . Não, ele tinha um medo, ele tinha... e } \\
\text { falava "vou pagar por isso mas eu não estou conseguindo lidar com a minha } \\
\text { tristeza", então eu acho que no momento que eles estão passando a dor... não } \\
\text { seria... }\end{array}$ \\
\hline $\begin{array}{l}\text { Transcrição E1 } \\
\text { revisada_para maxqda }\end{array}$ & COMPREENSÃO|Experiência|O sentir|Sentimentos (8)|Dor|De quem vailA dor que não tem tamanho - suicídio' & então mostrar essa relação bem forte entre o suicídio e dor. \\
\hline $\begin{array}{l}\text { Transcrição E1 } \\
\text { revisada_para maxqda }\end{array}$ & AÇÃo\Diálogo\O falar (23)\Como (FORMA)\Depressão e suicídio como saúde publica|Suicídio como saúde publica & É e eu acho que pra mim basicamente assim começar a tratar como saúde pública. \\
\hline $\begin{array}{l}\text { Transcrição E1 } \\
\text { revisada_para maxqda }\end{array}$ & AÇÃO|Diálogo|O falar (23)\Como (FORMA)\Depressão e suicídio como saúde publica|Suicídio como saúde publica & |Isso seria o ideal...pra começar... \\
\hline $\begin{array}{l}\text { Transcrição E1 } \\
\text { revisada_para maxqda }\end{array}$ & COMPREENSÃO|Experiência|O sentir|Sentimentos (8)|Dor|De quem vailA dor que não tem tamanho - suicídio' & $\begin{array}{l}\text { mas como que vocês, que ideia... então, de que é motivado por uma dor muito } \\
\text { grande que ela ultrapassa o sentimento... }\end{array}$ \\
\hline $\begin{array}{l}\text { Transcrição E1 } \\
\text { revisada_para maxqda }\end{array}$ & COMPREENSÃO\Experiência\O sentir|Sentimentos (8)\Dor|De quem vai|Dor que ultrapassa a proteção e o amor & | o amor... pelos familiares.. \\
\hline $\begin{array}{l}\text { Transcrição E1 } \\
\text { revisada_para maxqda }\end{array}$ & COMPREENSÃO\Experiência\O sentir|Sentimentos (8)\Dor\De quem vai\Dor que ultrapassa a proteção e o amor & que se tem pelos outros, que causa muita dor também... \\
\hline \begin{tabular}{|l} 
Transcrição E1 \\
revisada_para maxqda
\end{tabular} & AÇÃO\DiálogolO falar (23)\Quem|Sobreviventes enlutados|Falar da dor dos que ficam & mas eu acho que tem que ser falado viu... \\
\hline $\begin{array}{l}\text { Transcrição E1 } \\
\text { revisada_para maxqda }\end{array}$ & AÇÃO|Diálogo\O falar (23)\O que (MENSAGEM)\Falar das várias dores (interna e sobreviventes) & Não, também. \\
\hline $\begin{array}{l}\text { Transcrição E1 } \\
\text { revisada_para maxqda }\end{array}$ & AÇÃO\Diálogo\O falar (23)\O que (MENSAGEM)\Falar das várias dores (interna e sobreviventes) & mesmo que, mesmo que seja em vão... \\
\hline $\begin{array}{l}\text { Transcrição E1 } \\
\text { revisada_para maxqda }\end{array}$ & AÇÃO\Diálogo\O falar (23)\O que (MENSAGEM)\Falar das várias dores (interna e sobreviventes) & acho que todos os temas... pra todos \\
\hline $\begin{array}{l}\text { Transcrição E1 } \\
\text { revisada_para maxqda }\end{array}$ & COMPREENSÃO\Experiência|O sentir|Sentimentos (8)\Dor|De quem vai\A dor que cega & $\begin{array}{l}\text { Se o ser humano esta passando a dor é tamanha ele não consegue enxergar, ele } \\
\text { não consegue resolver a dor interna que ele tá tendo, ele não vai conseguir } \\
\text { naquele momento lembrar que o pai e a mãe vão sofrer. }\end{array}$ \\
\hline $\begin{array}{l}\text { Transcrição E1 } \\
\text { revisada_para maxqda }\end{array}$ & COMPREENSÃO\Experiência\O sentir|Sentimentos (8)\Dor|De quem vailAchando que a dor dos que ficam atinge menos & só por isso que ele falou você não vai resolver o problema \\
\hline $\begin{array}{l}\text { Transcrição E1 } \\
\text { revisada_para maxqda }\end{array}$ & COMPREENSÃO\ExperiêncialO sentir|Sentimentos (8)\Dor|De quem vai\Achando que a dor dos que ficam atinge menos & mas vai ajudar, é, mas só por isso... não resolve \\
\hline $\begin{array}{l}\text { Transcrição E1 } \\
\text { revisada_para maxqda }\end{array}$ & AÇÃO\DiálogolO falar (23)\Quem|Sobreviventes enlutados\Falar da dor dos que ficam & mas vai ter gente que vai pensar mais vezes... \\
\hline
\end{tabular}

Material integrante da pesquisa de doutorado de Karen Scavacini - USP Proibida a reprodução ou utilização sem autorização do autor - 2018 


\begin{tabular}{|c|c|c|}
\hline $\begin{array}{l}\text { Transcrição E1 } \\
\text { revisada_para maxqda }\end{array}$ & AÇÃO\Diálogo\O falar (23)\Como (FORMA)\Depressão e suicídio como saúde publica|Suicídio como saúde publica & que os políticos tratar como saúde pública \\
\hline $\begin{array}{l}\text { Transcrição E1 } \\
\text { revisada_para maxqda }\end{array}$ & AÇÃO\Diálogo\O falar (23)\O que (MENSAGEM)\Desmistificar|Desmistificar o psiquiatra & e a parte psiquiátrica, desmistificar que o psiquiatra é médico de louco \\
\hline $\begin{array}{l}\text { Transcrição E1 } \\
\text { revisada_para maxqda }\end{array}$ & AÇÃo|Cuidar\Tratamento (13)\Clinicas sem condição|Tendo bons lugares pagáveis para atendimentos & que o lugar...ter mais lugares pra quem não tem condições financeiras, \\
\hline $\begin{array}{l}\text { Transcrição E1 } \\
\text { revisada_para maxqda }\end{array}$ & AÇÃO\Cuidar|Tratamento (13)\Clinicas sem condição\Tendo bons lugares pagáveis para atendimentos & $\begin{array}{l}\text { então assim, uma pessoa, a gente tá vendo, uma pessoa de classe média hoje... } \\
\text { não é nem uma pessoa de classe muito baixa vamos dizer, de classe média não } \\
\text { consegue as vezes manter em uma clínica ideal. }\end{array}$ \\
\hline $\begin{array}{l}\text { Transcrição E1 } \\
\text { revisada_para maxqda }\end{array}$ & AÇÃO\Cuidar|Tratamento (13)\Clinicas sem condição\Experiências em clinicas ruins & $\begin{array}{l}\text { Porque tá tendo... tá dopando o filho, o filho né, não tá tendo assistência, tá } \\
\text { simplesmente jogando o ser humano lá e fala: "toma remédio aí, dorme , para ver } \\
\text { se você se acalma". }\end{array}$ \\
\hline $\begin{array}{l}\text { Transcrição E1 } \\
\text { revisada_para maxqda }\end{array}$ & AÇÃO\Cuidar|Tratamento (13)\Clinicas sem condição\Tendo bons lugares pagáveis para atendimentos & $\begin{array}{l}\text { Então é isso que eu estou achando, que é uma questão de saúde pública. De ter } \\
\text { mais... O governo começar a pensar que tem que ter hospitais... tratamento, pra } \\
\text { quem não tem condições de pagar uma clínica elite, né }\end{array}$ \\
\hline $\begin{array}{l}\text { Transcrição E1 } \\
\text { revisada_para maxqda }\end{array}$ & AÇÃO\Diálogo\O falar (23)\Como (FORMA)\Depressão e suicídio como saúde publica|Suicídio como saúde publica & $\begin{array}{l}\text { Então é isso que eu estou achando, que é uma questão de saúde pública. De ter } \\
\text { mais... O governo começar a pensar que tem que ter hospitais... tratamento, pra } \\
\text { quem não tem condições de pagar uma clínica elite, né }\end{array}$ \\
\hline $\begin{array}{l}\text { Transcrição E1 } \\
\text { revisada_para maxqda }\end{array}$ & AÇÃO\Diálogo\O falar (23)\Como (FORMA)\Depressão e suicídio como saúde publica|Suicídio como saúde publica & $\begin{array}{l}\text { desmistificar psiquiatra que é médico de louco, de que não, de que é uma pessoa } \\
\text { que você pode tratar, }\end{array}$ \\
\hline \begin{tabular}{|l|l} 
Transcrição E1 \\
revisada_para maxqda
\end{tabular} & AÇÃO|Diálogo\O falar (23)\O que (MENSAGEM)\Desmistificar|Desmistificar o psiquiatra & $\begin{array}{l}\text { desmistificar psiquiatra que é médico de louco, de que não, de que é uma pessoa } \\
\text { que você pode tratar, }\end{array}$ \\
\hline \begin{tabular}{|l|l} 
Transcrição E1 \\
revisada_para maxqda
\end{tabular} & AÇÃo|Cuidar|Tratamento (13)\Acesso a formas de tratamento\Acesso a atendimento psicológico & psicólogos... os psicólogo seu acho ainda que o acesso é mais...eles gostam mais. \\
\hline $\begin{array}{l}\text { Transcrição E1 } \\
\text { revisada_para maxqda }\end{array}$ & AÇÃO\Diálogo\O falar (23)\O que (MENSAGEM)\Desmistificar|Desmistificar o psiquiatra & $\begin{array}{l}\text { chão que quando tá também né o psicólogo é mais leve (?) né do que o psiquiatra. } \\
\text { Que às vezes medicação é necessária e o jovem acha que não, o mais velho: "Oh, } \\
\text { eu estou ficando louco"... }\end{array}$ \\
\hline $\begin{array}{l}\text { Transcrição E1 } \\
\text { revisada_para maxqda }\end{array}$ & AÇÃO\Cuidar \Tratamento (13)\Acesso a formas de tratamento & quer dizer, as formas de tratamento. \\
\hline $\begin{array}{l}\text { Transcrição E1 } \\
\text { revisada_para maxqda }\end{array}$ & AÇÃO|Cuidar|Tratamento (13)\Acesso a formas de tratamento & $\begin{array}{l}\text { as formas de tratamento... tem que desmistificar... que nem, uma coisa que o P5 } \\
\text { falava muito pro****. }\end{array}$ \\
\hline $\begin{array}{l}\text { Transcrição E1 } \\
\text { revisada_para maxqda }\end{array}$ & AÇÃO\Diálogo\O falar (23)\O que (MENSAGEM)\Desmistificar|Desmistificar o psiquiatra & $\begin{array}{l}\text { as formas de tratamento... tem que desmistificar... que nem, uma coisa que o P5 } \\
\text { falava muito pro*****. }\end{array}$ \\
\hline $\begin{array}{l}\text { Transcrição E1 } \\
\text { revisada_para maxqda }\end{array}$ & AÇÃO\Diálogo\O falar (23)\O que (MENSAGEM)\Desmistificar|Desmistificar a medicação & $\begin{array}{l}\text { quando deram o medicamento pra ele. O P5 falava muito: "***** você tem que } \\
\text { canalizar o seguinte: se eu não tenho problema de coração enfartei eu não tenho } \\
\text { que tomar a vida inteira o meu remédio? }\end{array}$ \\
\hline $\begin{array}{l}\text { Transcrição E1 } \\
\text { revisada_para maxqda }\end{array}$ & AÇÃO\Diálogo\O falar (23)\O que (MENSAGEM)\Desmistificar|Desmistificar a medicação & $\begin{array}{l}\text { É porque quando ele começou a tomar remédio psiquiátrico fica não... eu não vou } \\
\text { tomar isso a vida inteira eu não posso tomar isso a vida inteira }\end{array}$ \\
\hline $\begin{array}{l}\text { Transcrição E1 } \\
\text { revisada_para maxqda }\end{array}$ & AÇÃO\Diálogo\O falar (23)\O que (MENSAGEM)\Desmistificar|Desmistificar a medicação & $\begin{array}{l}\text { Aí o P5 falou assim , se você tiver que tomar a vida inteira e se ajustar com o } \\
\text { medicamento, você tem que tomar a vida inteira e não se preocupa com isso. } \\
\text { Diabético não tem que tomar insulina? Então o *** usava muito isso para ele... } \\
\text { desmistificar também essa coisa do remédio. }\end{array}$ \\
\hline $\begin{array}{l}\text { Transcrição E1 } \\
\text { revisada_para maxqda }\end{array}$ & CONSCIENTIZAÇÃO\Desafios \Impeditivos (18)\A dor do sobrevivente gerar culpa no suicida (Dor e Culpa) & $\begin{array}{l}\text { com relação à dor de quem fica eu acho que mais do que você colocar a dor como } \\
\text { porque talvez a pessoa sinta o peso da responsabilidade, quer dizer, "poxa nem me } \\
\text { matar eu posso né, eu estou sofrendo tanto e eu ainda tenho que ficar aqui } \\
\text { aguentando tudo isso só pro outro ficar feliz?" }\end{array}$ \\
\hline
\end{tabular}

Material integrante da pesquisa de doutorado de Karen Scavacini - USP Proibida a reprodução ou utilização sem autorização do autor - 2018 


\begin{tabular}{|c|c|c|}
\hline \begin{tabular}{|l|} 
Transcrição E1 \\
revisada_para maxqda
\end{tabular} & AÇÃO\Diálogo\O falar (23)\Quem\Sobreviventes enlutados\Focar no amor e não na dor dos sobreviventes & $\begin{array}{l}\text { Mas é de saber que ali tem tanto amor que aquelas pessoas estão dispostas a } \\
\text { ajudar né, então que ele pode contar. Então assim, nós estamos aqui, nós vamos } \\
\text { sofrer porque nós te amamos e nós queremos te ajudar né, então no sentido de } \\
\text { envolver a família envolver... }\end{array}$ \\
\hline $\begin{array}{l}\text { Transcrição E1 } \\
\text { revisada_para maxqda }\end{array}$ & AÇÃO\Diálogo\O falar (23)\O que (MENSAGEM)\Há ajuda disponivel\O suicida não está sozinho & ou seja, ele não está sozinho. \\
\hline $\begin{array}{l}\text { Transcrição E1 } \\
\text { revisada_para maxqda }\end{array}$ & AÇÃO\Diálogo\O falar (23)\O que (MENSAGEM)\Há ajuda disponível\O suicida não está sozinho & Ele não está sozinho, porque eu acho que tem muito essa dor. \\
\hline $\begin{array}{l}\text { Transcrição E1 } \\
\text { revisada_para maxqda }\end{array}$ & COMPREENSÃO\Experiência\O sentir|Sentimentos (8)\Dor|De quem vailDor de se sentir sozinho & Ele não está sozinho, porque eu acho que tem muito essa dor. \\
\hline $\begin{array}{l}\text { Transcrição E1 } \\
\text { revisada_para maxqda }\end{array}$ & COMPREENSÃO\Experiência|O sentir|Sentimentos (8)|Dor|De quem vai|Suicidas se sentem excluídos e não entendidos & $\begin{array}{l}\text { Essa grande... eu vejo pelo que eu passei né, de que eles não sentem entendidos, } \\
\text { não se sentem pertencentes, quer dizer, "poxa, eu estou aqui, a minha dor é tão } \\
\text { grande, ninguém faz nada por mim, então eu vou embora" né, talvez. }\end{array}$ \\
\hline \begin{tabular}{|l} 
Transcrição E1 \\
revisada_para maxqda
\end{tabular} & AÇÃO\Cuidar\Tratamento (13)\Dificuldade de achar apoio adequado\Falta de tratamento para dependência química de adolescentes & $\begin{array}{l}\text { É um pouco do que eu vi né, então, meu sobrinho era dependente químico, é uma } \\
\text { outra questão de saúde pública porque um adolescente não tem tratamento, } \\
\text { simplesmente não tem. Pra você internar tem que ser maior de idade, é clínica pra } \\
\text { dependente químico tem um monte, mas pra menor de idade não tem, entendeu? }\end{array}$ \\
\hline $\begin{array}{l}\text { Transcrição E1 } \\
\text { revisada_para maxqda }\end{array}$ & AÇÃo|Cuidar\Tratamento (13)\Clinicas sem condição & $\begin{array}{l}\text { As pouquíssimas que a gente encontrou a gente não tinha condição de manter. E } \\
\text { ele passou por duas: uma teve um incêndio que morreram acho que sete pessoas, } \\
\text { acho que eu te falei disso e na outra ele se matou né. }\end{array}$ \\
\hline $\begin{array}{l}\text { Transcrição E1 } \\
\text { revisada_para maxqda }\end{array}$ & AÇÃo|Cuidar\Tratamento (13)\Clinicas sem condição|Tendo problemas com clinicas & $\begin{array}{l}\text { Então de três clínicas, uma a gente não tinha condição de pagar, uma ele disse que } \\
\text { estava sendo agredido, e a agente até...eu até duvidei mas depois que teve um } \\
\text { incêndio e as pessoas morreram e eu vi o depoimento de pessoas que estavam lá e } \\
\text { que relataram tudo o que ele falava pra gente, e na outra ele não era cuidado né, } \\
\text { então não tem tratamento. }\end{array}$ \\
\hline \begin{tabular}{|l} 
Transcrição E1 \\
revisada_para maxqda
\end{tabular} & AÇÃO\Cuidar|Tratamento (13)\Clinicas sem condição\Tendo bons lugares pagáveis para atendimentos & $\begin{array}{l}\text { Então, quer dizer, ele tem uma doença que tem a dependência química além da } \\
\text { depressão, quer dizer, que se foi pra droga tinha alguma coisa. E a gente não } \\
\text { conseguia tratar porque simplesmente não tem opção. }\end{array}$ \\
\hline $\begin{array}{l}\text { Transcrição E1 } \\
\text { revisada_para maxqda }\end{array}$ & AÇÃO\Fazer|Prevenção (30)|Multifatores & ..então visto é trabalhado de uma forma multifatorial. \\
\hline $\begin{array}{l}\text { Transcrição E1 } \\
\text { revisada_para maxqda }\end{array}$ & AÇÃO\Fazer|Prevenção (30)|Multifatores & Com certeza \\
\hline $\begin{array}{l}\text { Transcrição E1 } \\
\text { revisada_para maxqda }\end{array}$ & AÇÃO\Diálogo\O falar (23)\O que (MENSAGEM)\Temas|Suicídio como problema de todos & $\begin{array}{l}\text { Sobre a pergunta "como eu gostaria que o suicídio fosse visto na sociedade?" Eu } \\
\text { gostaria que fosse visto como algo que não é distante, que é um tema que envolve } \\
\text { todas as pessoas. Mesmo as que não passaram por isso. } \\
\end{array}$ \\
\hline \begin{tabular}{|l|} 
Transcrição E1 \\
revisada_para maxqda
\end{tabular} & COMPREENSÃO\Experiência|O viver|Quem não viveu (6)\Quem não passou não se interessa & $\begin{array}{l}\text { Que eu acho que esse é o maior problema, porque senão, vamos supor, tem uma } \\
\text { palestra, tem um artigo, quem nunca passou acha que não tem nada a ver com ela. } \\
\text { Nem vai ler, nem vai se interessar. }\end{array}$ \\
\hline \begin{tabular}{|l} 
Transcrição E1 \\
revisada_para maxqda
\end{tabular} & AÇÃO\Diálogo\O falar (23)\O que (MENSAGEM)\Normalizar o suicídio|Pensar em suicídio é mais comum do que se imagina & $\begin{array}{l}\text { é de que é muito mais comum do que a gente imagina, passar pela cabeça da } \\
\text { maioria das pessoas o suicídio. Só que ninguém fala, e aí ninguém vai admitir isso } \\
\text { socialmente, então é esse tipo de coisa que fica guardado e a gente acha que não } \\
\text { tem nada a ver com todas as pessoas, não só os envolvidos é que eu acho que é } \\
\text { uma das causas pra que culturalmente a gente não consiga fazer a prevenção. }\end{array}$ \\
\hline $\begin{array}{l}\text { Transcrição E1 } \\
\text { revisada_para maxqda }\end{array}$ & COMPREENSÃO\Tabu (1)\Consequências do Tabu\O não falar|Ninguém admite pensar em suicídio & $\begin{array}{l}\text { Só que ninguém fala, e aí ninguém vai admitir isso socialmente, então é esse tipo } \\
\text { de coisa que fica guardado }\end{array}$ \\
\hline
\end{tabular}

Material integrante da pesquisa de doutorado de Karen Scavacini - USP Proibida a reprodução ou utilização sem autorização do autor - 2018 


\begin{tabular}{|c|c|c|}
\hline $\begin{array}{l}\text { Transcrição E1 } \\
\text { revisada_para maxqda }\end{array}$ & AÇÃO\Diálogo\O falar (23)\O que (MENSAGEM)\Temas|Suicídio como problema de todos & $\begin{array}{l}\text { é de que é muito mais comum do que a gente imagina, passar pela cabeça da } \\
\text { maioria das pessoas o suicídio. Só que ninguém fala, e aí ninguém vai admitir isso } \\
\text { socialmente, então é esse tipo de coisa que fica guardado e a gente acha que não } \\
\text { tem nada a ver com todas as pessoas, não só os envolvidos é que eu acho que é } \\
\text { uma das causas pra que culturalmente a gente não consiga fazer a prevenção. }\end{array}$ \\
\hline $\begin{array}{l}\text { Transcrição E1 } \\
\text { revisada_para maxqda }\end{array}$ & AÇÃO\Diálogo\O falar (23)\O que (MENSAGEM)\Temas\Suicídio como problema de todos & $\begin{array}{l}\text { Que quando entra o trabalho de prevenção... não tem nada a ver comigo, não vou } \\
\text { ler, não me interessa... se o amigo fala não quero nem saber. }\end{array}$ \\
\hline $\begin{array}{l}\text { Transcrição E1 } \\
\text { revisada_para maxqda }\end{array}$ & COMPREENSÃO|Tabu (1)\Atitudes que reforçam o tabu|Problemas longe dos meus não interessam & $\begin{array}{l}\text { É o caso do, quando você vai na página do seu amigo, que que te dar algo da } \\
\text { prevenção de mama né, aquele negócio de mamas ou então de drogas, não é só } \\
\text { pra quem tá viciado né, é também para quem né...então é pra ser uma coisa no } \\
\text { geral. }\end{array}$ \\
\hline $\begin{array}{l}\text { Transcrição E1 } \\
\text { revisada_para maxqda }\end{array}$ & COMPREENSÃO\Tabu (1)\Atitudes que reforçam o tabu|Problemas longe dos meus não interessam & $\begin{array}{l}\text { O pessoal sempre tem essa mania né, só porque é dos outros, dos outros não quer } \\
\text { nem saber. }\end{array}$ \\
\hline $\begin{array}{l}\text { Transcrição E1 } \\
\text { revisada_para maxqda }\end{array}$ & COMPREENSÃO\Tabu (1)\Atitudes que reforçam o tabu|Problemas longe dos meus não interessam\Aborto x suicídio & $\begin{array}{l}\text { O pessoal sempre tem essa mania né, só porque é dos outros, dos outros não quer } \\
\text { nem saber. Não sou favor do aborto, mas há muito tempo atrás teve uma pesquisa } \\
\text { pra liberar o aborto no Brasil, aí chegaram a seguinte conclusão da pesquisa, que } \\
\text { jamais seria liberado no Brasil, por que ? Porque só a mulher quer fazer aborto, o } \\
\text { homem não quer, então não é problema do homem. Se você pensar como o } \\
\text { suicídio tá... Aí o que acontece...estava lá na faixa etária, quem tem menos de } 15 \\
\text { anos não ia engravidar naquela época, é bem antiga a pesquisa tá... então ela é } \\
\text { contra porque também não ia engravidar tá. E quem tinha mais de } 40 \text { e estava } \\
\text { entrando na menopausa, das mulheres, também são contra porque elas não } \\
\text { passariam pelo problema. Então, só quem votaria a favor seria de } 18 \text { a } 40 \text { anos, } \\
\text { portanto nunca foi aprovado. Eles pouco ligam pro problema dos outros. }\end{array}$ \\
\hline $\begin{array}{l}\text { Transcrição E1 } \\
\text { revisada_para maxqda }\end{array}$ & 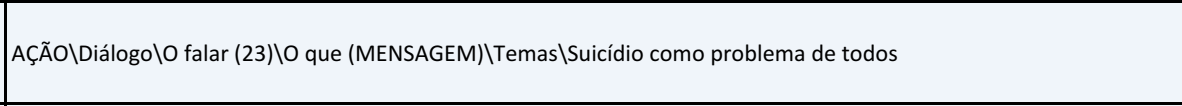 & $\begin{array}{l}\text { Eles pouco ligam pro problema dos outros. A sociedade tem que se conscientizar } \\
\text { que o problema do suicídio é de todos. Não é classe financeira, não é cor, não é } \\
\text { credo, não é nada. De que todos tem esse problema }\end{array}$ \\
\hline $\begin{array}{l}\text { Transcrição E1 } \\
\text { revisada_para maxqda }\end{array}$ & COMPREENSÃO\Tabu (1)\Atitudes que reforçam o tabu|Problemas longe dos meus não interessam & $\begin{array}{l}\text { Só que o pessoal tem a mania de ver o problema como dos outros sabe, é bem } \\
\text { típico né, é dos outros é dos outros. }\end{array}$ \\
\hline $\begin{array}{l}\text { Transcrição E1 } \\
\text { revisada_para maxqda }\end{array}$ & AÇÃO\Diálogo\O falar (23)\O que (MENSAGEM)\Temas\Suicídio como problema de todos & $\begin{array}{l}\text { Não é nosso. Então tinha que ter uma conscientização para todos se envolverem } \\
\text { no problema. }\end{array}$ \\
\hline $\begin{array}{l}\text { Transcrição E1 } \\
\text { revisada_para maxqda }\end{array}$ & AÇÃO\Diálogo\O falar (23)\O que (MENSAGEM)\Normalizar o suicídio & $\begin{array}{l}\text { acho que se a gente associasse o suicídio a coisas normais do dia a dia, talvez as } \\
\text { pessoas conseguissem criar mais empatia com o tema. }\end{array}$ \\
\hline $\begin{array}{l}\text { Transcrição E1 } \\
\text { revisada_para maxqda }\end{array}$ & CONSCIENTIZAÇÃO|Desafios\Impeditivos (18)\Dificuldade de identificar os sintomas (Identificação) & é que suicídio é uma coisa assim que é tão difícil né de identificar os sintomas \\
\hline $\begin{array}{l}\text { Transcrição E1 } \\
\text { revisada_para maxqda }\end{array}$ & AÇÃO\Diálogo\O falar (23)\O que (MENSAGEM)\Normalizar o suicídio & $\begin{array}{l}\text { mas talvez se a gente conseguisse trazer o suicídio linkado a temas mais normais, } \\
\text { sentimentos, ou assim, relatos de coisas que a pessoa pode ver e falar: "Putz, eu já } \\
\text { senti, eu já ouvi de um amigo, tal, talvez ela tivesse mais interesse no tema. }\end{array}$ \\
\hline $\begin{array}{l}\text { Transcrição E1 } \\
\text { revisada_para maxqda }\end{array}$ & AÇÃO\Diálogo|O falar (23)\O que (MENSAGEM) \Normalizar o suicídio|Visão estereotipada de uma pessoa suicida & $\begin{array}{l}\text { Porque, quando você fala de suicídio talvez ele pense: "Putz, uma pessoa que é } \\
\text { louca está com muito problema" e a pessoa não, talvez não crie empatia, eu não } \\
\text { sei. }\end{array}$ \\
\hline $\begin{array}{l}\text { Transcrição E1 } \\
\text { revisada_para maxqda }\end{array}$ & 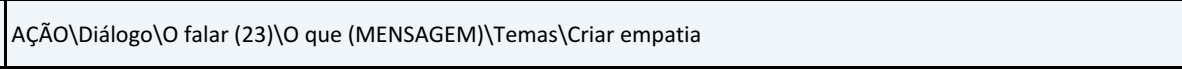 & $\begin{array}{l}\text { Abordar o tema de alguma forma que traga empatia, pra pessoa ter interesse em } \\
\text { saber, ler...não sei, se envolver mais. Não achar que é uma coisa tão distante }\end{array}$ \\
\hline $\begin{array}{l}\text { Transcrição E1 } \\
\text { revisada_para maxqda }\end{array}$ & AÇÃO\Diálogo\O falar (23)\O que (MENSAGEM)\Normalizar o suicídio & $\begin{array}{l}\text { Abordar o tema de alguma forma que traga empatia, pra pessoa ter interesse em } \\
\text { saber, ler...não sei, se envolver mais. Não achar que é uma coisa tão distante }\end{array}$ \\
\hline $\begin{array}{l}\text { Transcrição E1 } \\
\text { revisada_para maxqda }\end{array}$ & COMPREENSÃO\Experiência \O viver|Quem não viveu (6)\Suicídio como algo que não existe & Porque acham que é assim, uma coisa nada a ver que nem existe no mundo. \\
\hline $\begin{array}{l}\text { Transcrição E1 } \\
\text { revisada_para maxqda }\end{array}$ & COMPREENSÃO\Experiência\O viver|Quem viveu (5)\Antes do suicídio\Antes de acontecer comigo & Eu, é aquilo, eu não sabia que isso existia, eu não tinha... \\
\hline
\end{tabular}

Material integrante da pesquisa de doutorado de Karen Scavacini - USP Proibida a reprodução ou utilização sem autorização do autor - 2018 


\begin{tabular}{|c|c|c|}
\hline $\begin{array}{l}\text { Transcrição E1 } \\
\text { revisada_para maxqda }\end{array}$ & COMPREENSÃO\Experiência\O viver|Quem viveu (5)\Depois do suicídio\Dando atenção porque passou pela experiência & $\begin{array}{l}\text { acho que todos nós fazíamos parte dessa fatia do bolo... eu acho que até bem } \\
\text { pouco tempo nós fazímos parte né dessa grande maioria aqui né, que não } \\
\text { imaginava o suicídio como uma coisa real. }\end{array}$ \\
\hline $\begin{array}{l}\text { Transcrição E1 } \\
\text { revisada_para maxqda }\end{array}$ & 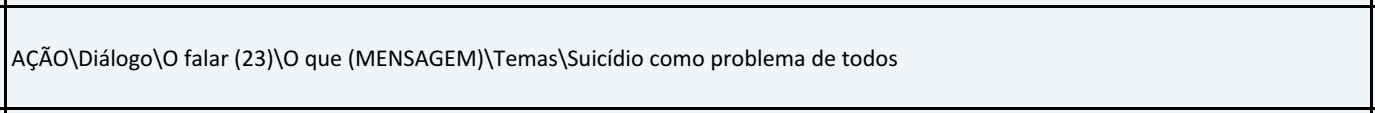 & $\begin{array}{l}\text { talvez a sociedade veja o suicídio pode acontecer em qualquer lugar com qualquer } \\
\text { pessoa e todo mundo pode ser tanto responsável por ajudar alguém com a } \\
\text { prevenção, como também pode acontecer em qualquer família. }\end{array}$ \\
\hline $\begin{array}{l}\text { Transcrição E1 } \\
\text { revisada_para maxqda }\end{array}$ & AÇÃO\DiálogolO falar (23)\Quem|Sobreviventes tentativas|Relatos de sobreviventes de tentativas & $\begin{array}{l}\text { Uma coisa que me ocorreu na fala dela é que talvez se a gente tivesse relatos de } \\
\text { sobreviventes mas não os familiares, por exemplo a minha irmã falando, quer } \\
\text { dizer... o que que... como aquilo impactou a vida dela e porque ela desistiu de } \\
\text { desistir? Entendeu? }\end{array}$ \\
\hline $\begin{array}{l}\text { Transcrição E1 } \\
\text { revisada_para maxqda }\end{array}$ & AÇÃO\DiálogolO falar (23)\Quem\Famosos\Relatos de famosos & $\begin{array}{l}\text { Com certeza tem pessoas famosas que tentaram, que ninguém nunca fica sabendo, } \\
\text { então assim }\end{array}$ \\
\hline $\begin{array}{l}\text { Transcrição E1 } \\
\text { revisada_para maxqda }\end{array}$ & AÇÃO\Diálogo\O falar (23)\O que (MENSAGEM)\Normalizar o suicídio & $\begin{array}{l}\text { talvez levantasse o tema de uma maneira que as pessoas pensassem assim "não, } \\
\text { isso acontece com todo mundo e eu posso buscar um tratamento, eu posso sair } \\
\text { dessa." }\end{array}$ \\
\hline $\begin{array}{l}\text { Transcrição E1 } \\
\text { revisada_para maxqda }\end{array}$ & AÇÃO|Diálogo|O falar (23)\O que (MENSAGEM) \Normalizar o suicídio & $\begin{array}{l}\text { E com transparência sabe, acho que faz exatamente as coisas que você sentiu. Pra } \\
\text { não achar aquela coisa: "Nossa, aquela pessoa que se suicidou sentiu uma coisa... } \\
\text { uau." }\end{array}$ \\
\hline $\begin{array}{l}\text { Transcrição E1 } \\
\text { revisada_para maxqda }\end{array}$ & AÇÃO\Diálogo\O falar (23)\Quem\Famosos\Relatos de famosos & $\begin{array}{l}\text { Que nem a Luiza Brunet, que foi agredida pelo marido, quer dizer, as pessoas estão } \\
\text { falando "oh, eu fui estuprada, oh, eu fui agredida, oh, ..." não estão mais } \\
\text { escondendo. Eu vejo isso das mulheres agora né. E eu acho que a gente pode viver } \\
\text { isso também com relação ao suicídio, ... }\end{array}$ \\
\hline $\begin{array}{l}\text { Transcrição E1 } \\
\text { revisada_para maxqda }\end{array}$ & AÇÃo|Diálogo|O falar (23)\Quem|Sobreviventes tentativas\Relatos de sobreviventes de tentativas & através de quem passou... \\
\hline $\begin{array}{l}\text { Transcrição E1 } \\
\text { revisada_para maxqda }\end{array}$ & AÇÃO\DiálogolO falar (23)\Quem|Sobreviventes tentativas|Relatos de sobreviventes de tentativas & ao suicídio... de quem passou. \\
\hline $\begin{array}{l}\text { Transcrição E1 } \\
\text { revisada_para maxqda }\end{array}$ & COMPREENSÃO\Comunicação|Social\Aprendendo com quem veio antes ou Outras campanhas(rever)\Câncer também era assunto proibi & $\begin{array}{l}\text { mas quando eu era criança eu lembro que minha avó falava muito "Aquela } \\
\text { doença". Que é o câncer. Não podia falar câncer. É aquela doença. E não podia } \\
\text { nem apontar aonde a pessoa tinha, porque senão você corria o risco de ter. E hoje } \\
\text { as pessoas falam muito mais abertamente. }\end{array}$ \\
\hline $\begin{array}{l}\text { Transcrição E1 } \\
\text { revisada_para maxqda }\end{array}$ & AÇÃO\DiálogolO falar (23)\O que (MENSAGEM)\Ensinar como agir|Acolhimento ao invés de espanto na comunicação suicida & $\begin{array}{l}\text { Eu tenho uma visão utópica de que a pessoa chegue e fale: olha eu estou pensando } \\
\text { em me suicidar, mas que a sociedade como um todo também não se espante ao } \\
\text { ouvir isso. Que ela seja tão informada que ela consiga colher esse sofrimento da } \\
\text { pessoa. }\end{array}$ \\
\hline $\begin{array}{l}\text { Transcrição E1 } \\
\text { revisada_para maxqda }\end{array}$ & CONSCIENTIZAÇÃO|Consciência|Complexidade|Sofrimento mental não é validado & $\begin{array}{l}\text { Então por isso que eu sempre volto na informação, porque o sofrimento mental ele } \\
\text { não é validado. }\end{array}$ \\
\hline $\begin{array}{l}\text { Transcrição E1 } \\
\text { revisada_para maxqda }\end{array}$ & COMPREENSÃO\Comunicação|Social|Aprendendo com quem veio antes ou Outras campanhas(rever)\Hoje o câncer é acolhido & $\begin{array}{l}\text { Se você chega na sua empresa e fala assim "eu descobri um câncer" todo mundo } \\
\text { tem dó de você: "Você precisa de alguma coisa? }\end{array}$ \\
\hline $\begin{array}{l}\text { Transcrição E1 } \\
\text { revisada_para maxqda }\end{array}$ & COMPREENSÃO|Visão|Visão da Sociedade (2)\Depressão|Tabu e depressão|Depressão como mentira para não trabalhar & se você chega e leva um atestado de depressão, é vagabundo, não quer trabalhar. \\
\hline $\begin{array}{l}\text { Transcrição E1 } \\
\text { revisada_para maxqda }\end{array}$ & COMPREENSÃO\Tabu (1)\O tabu em diversas esferas \Tabu na empresa, no rh & $\begin{array}{l}\text { A primeira oportunidade que a empresa tem o que ela faz? Manda embora. Isso é } \\
\text { uma realidade né? É assim, eu vivo isso, no trabalho, em todos os lugares que eu } \\
\text { já trabalhei eu já convivi com pessoas assim, que na primeira oportunidade o RH } \\
\text { mandava embora porque tá dando muito atestado. Tá com depressão. }\end{array}$ \\
\hline $\begin{array}{l}\text { Transcrição E1 } \\
\text { revisada_para maxqda }\end{array}$ & CONSCIENTIZAÇÃO|Consciência|Complexidade|Sofrimento mental não é validado & $\begin{array}{l}\text { A doença mental ela não é validada, né....mas é por causa do preconceito, é um } \\
\text { mito, é o tabu. }\end{array}$ \\
\hline $\begin{array}{l}\text { Transcrição E1 } \\
\text { revisada_para maxqda }\end{array}$ & COMPREENSÃO\Tabu (1)\O tabu em diversas esferas\Transtornos mentais\Tabu & $\begin{array}{l}\text { A doença mental ela não é validada, né...mas é por causa do preconceito, é um } \\
\text { mito, é o tabu. }\end{array}$ \\
\hline
\end{tabular}




\begin{tabular}{|c|c|c|}
\hline $\begin{array}{l}\text { Transcrição E1 } \\
\text { revisada_para maxqda }\end{array}$ & COMPREENSÃO\Tabu (1)\Atitudes que reforçam o tabu\A não validação das doenças mentais & $\begin{array}{l}\text { A doença mental ela não é validada, né...mas é por causa do preconceito, é um } \\
\text { mito, é o tabu. A pessoa pode ter qualquer doença que ela não escolheu, "ah, mas } \\
\text { a saúde emocional?" Não, você pode evitar, né? "É falta do que fazer né?! É falta } \\
\text { do que se animar" }\end{array}$ \\
\hline $\begin{array}{l}\text { Transcrição E1 } \\
\text { revisada_para maxqda }\end{array}$ & AÇÃO\O saber (12)\Saber é poder|Necessidade de informação & Então eu vejo que a questão da informação ela tem que ser trabalhada \\
\hline $\begin{array}{l}\text { Transcrição E1 } \\
\text { revisada_para maxqda }\end{array}$ & AÇÃO\Fazer|Prevenção (30)\Prevenção em escolas & $\begin{array}{l}\text { quando a gente vai dar palestra de prevenção, de informação em escola infantil. } \\
\text { "Mas como vocês vai fazer prevenção de suicídio em escola infantil?" A gente } \\
\text { ensina as crianças a nomearem os sentimentos, a gente trabalha aqueles } \\
\text { bonequinhos do filme "Divertidamente" pra que a criança saiba nomear o que estáa } \\
\text { sentindo: "Ah, olha, hoje eu estou triste ok?" }\end{array}$ \\
\hline $\begin{array}{l}\text { Transcrição E1 } \\
\text { revisada_para maxqda }\end{array}$ & CONSCIENTIZAÇÃO|Consciência|Complexidade|Por onde começar|Ensinando sentimentos para crianças & $\begin{array}{l}\text { usando a gente vai dar palestra de prevenção, de informação em escola infantil. } \\
\text { "Mas como vocês vai fazer prevenção de suicídio em escola infantil?" A gente } \\
\text { ensina as crianças a nomearem os sentimentos, a gente trabalha aqueles } \\
\text { bonequinhos do filme "Divertidamente" pra que a criança saiba nomear o que está } \\
\text { sentindo: "Ah, olha, hoje eu estou triste ok? }\end{array}$ \\
\hline \begin{tabular}{|l} 
Transcrição E1 \\
revisada_para maxqda
\end{tabular} & CONSCIENTIZAÇão|Consciência|Complexidade\A exclusão da tristeza\A exclusão da normalidade da tristeza & Tudo bem, é normal ficar triste de vez em quando né, \\
\hline $\begin{array}{l}\text { Transcrição E1 } \\
\text { revisada_para maxqda }\end{array}$ & CONSCIENTIZAÇÃO|Consciência|Complexidade|Complexidade dos sentimentos|Repertório emocional pobre & $\begin{array}{l}\text { Tudo bem, é normal ficar triste de vez em quando né, mas hoje as pessoas não } \\
\text { sabem nomear o que elas sentem, elas não conseguem dar nome, elas não } \\
\text { conseguem explicar }\end{array}$ \\
\hline $\begin{array}{l}\text { Transcrição E1 } \\
\text { revisada_para maxqda }\end{array}$ & AÇÃo|Diálogo|Ouvir|Pessoas não tem com quem conversar|Quem vai escuta-las & $\begin{array}{l}\text { mas não conseguem pessoas que também as escutem, em sua grande maioria. As } \\
\text { pessoas estão muito ocupadas, né. Elas não tem tempo pra ouvir... }\end{array}$ \\
\hline $\begin{array}{l}\text { Transcrição E1 } \\
\text { revisada_para maxqda }\end{array}$ & CONSCIENTIZAÇÃO|Consciência|Complexidade \Assunto proibido|Pessoas não reconhecem e aceitam o que sentem & $\begin{array}{l}\text { Elas não aceitam o que elas sentem, não é nem só renomear mas é tipo } \\
\text { reconhecer e falar "Nossa, eu estou sentindo isso" e é exatamente isso. E tudo } \\
\text { bem! }\end{array}$ \\
\hline $\begin{array}{l}\text { Transcrição E1 } \\
\text { revisada_para maxqda }\end{array}$ & CONSCIENTIZAÇÃO|Consciência|Complexidade|Complexidade dos sentimentos\Aceitação de sentimentos & $\begin{array}{l}\text { Elas não aceitam o que elas sentem, não é nem só renomear mas é tipo } \\
\text { reconhecer e falar "Nossa, eu estou sentindo isso" e é exatamente isso. E tudo } \\
\text { bem! }\end{array}$ \\
\hline $\begin{array}{l}\text { Transcrição E1 } \\
\text { revisada_para maxqda }\end{array}$ & CONSCIENTIZAÇÃO\Consciência \O absurdo do suicídio\O absurdo do suicídio $\backslash \mathrm{O}$ absurdo do suicídio & E dai como o suicídio é algo que foge da nossa compreensão, \\
\hline $\begin{array}{l}\text { Transcrição E1 } \\
\text { revisada_para maxqda }\end{array}$ & AÇÃO|Cuidar|Tratamento (13)\Hospitalar|Distinção no tratamento de tentativa em hospital|Só merece ser bem tratado quem quer viver & $\begin{array}{l}\text { E daí como o suicídio é algo que foge da nossa compreensão, muitas vezes o que } \\
\text { acontece a pessoa ela sai de lá, ela não quer saber, ela não quer ouvir, eu tenho } \\
\text { outro paciente mais grave pra cuidar do que esse que tá pensando em tirar sua } \\
\text { própria vida, }\end{array}$ \\
\hline $\begin{array}{l}\text { Transcrição E1 } \\
\text { revisada_para maxqda }\end{array}$ & AÇÃO\O saber (12)\Consequências do não saber\As pessoas tratam mal porque não entendem & $\begin{array}{l}\text { E daí como o suicídio é algo que foge da nossa compreensão, muitas vezes o que } \\
\text { acontece a pessoa ela sai de lá, ela não quer saber, ela não quer ouvir, eu tenho } \\
\text { outro paciente mais grave pra cuidar do que esse que tá pensando em tirar sua } \\
\text { própria vida, mas eu sempre volto na questão da informação. }\end{array}$ \\
\hline $\begin{array}{l}\text { Transcrição E1 } \\
\text { revisada_para maxqda }\end{array}$ & AÇÃO|Semear\O que gostariam / Desejos (17)\Sonho|Sonho de que se fale mais sobre o assunto & $\begin{array}{l}\text { Eu tenho um sonho de que fale muito sobre isso. Que deem informações, não só } \\
\text { prevenção. }\end{array}$ \\
\hline $\begin{array}{l}\text { Transcrição E1 } \\
\text { revisada_para maxqda }\end{array}$ & AÇÃO\Diálogo\O falar (23)\O que (MENSAGEM)\Temas|Prevenção x Previsão & $\begin{array}{l}\text { Porque assim também como ela falou e a gente sabe, tem situações que não vai } \\
\text { prevenir, infelizmente tem suicídios que eles vão acontecer né }\end{array}$ \\
\hline $\begin{array}{l}\text { Transcrição E1 } \\
\text { revisada_para maxqda }\end{array}$ & AÇÃOlO saber (12)\Saber é poder|Necessidade de informação & Só que é assim, a informação: as pessoas precisam ser informadas, todas elas. \\
\hline $\begin{array}{l}\text { Transcrição E1 } \\
\text { revisada_para maxqda }\end{array}$ & COMPREENSÃO\Experiência\O viver|Quem viveu (5)〈Luto (7)\Profissional\Perdendo um paciente para o suicídio & $\begin{array}{l}\text { Quando eu passei por essa perda foi muito difícil, porque ligaram 5:30 da manhã } \\
\text { em casa. "Você precisa vir aqui! “. Mais ou menos assim: "Oh, seu paciente se } \\
\text { suicidou e agora você vem aqui atender a família" foi isso que fizeram comigo e eu } \\
\text { estava destruída. }\end{array}$ \\
\hline
\end{tabular}

Material integrante da pesquisa de doutorado de Karen Scavacini - USP Proibida a reprodução ou utilização sem autorização do autor - 2018 


\begin{tabular}{|c|c|c|}
\hline \begin{tabular}{|l} 
Transcrição E1 \\
revisada_para maxqda
\end{tabular} & COMPREENSÃO\Experiência|O viver|Quem viveu (5)\Luto (7)\Profissional\Cobrança e responsabilização pelo hospital & $\begin{array}{l}\text { Quando eu passei por essa perda foi muito difícil, porque ligaram 5:30 da manhã } \\
\text { em casa. "Você precisa vir aqui! ". Mais ou menos assim: "Oh, seu paciente se } \\
\text { suicidou e agora você vem aqui atender a familia" }\end{array}$ \\
\hline $\begin{array}{l}\text { Transcrição E1 } \\
\text { revisada_para maxqda }\end{array}$ & 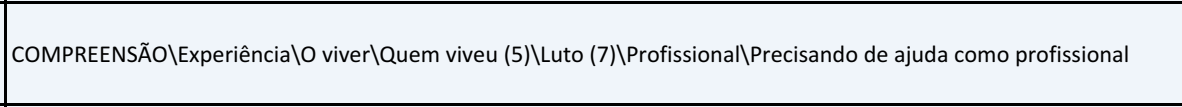 & $\begin{array}{l}\text { foi isso que fizeram comigo e eu estava destruída. Eu não tinha condições de ir pro } \\
\text { hospital e atender aquela família. Mas eu fui, mas naquele momento eu precisava } \\
\text { de ajuda. }\end{array}$ \\
\hline $\begin{array}{l}\text { Transcrição E1 } \\
\text { revisada_para maxqda }\end{array}$ & COMPREENSÃO\Experiência\O viver\Quem viveu (5)〈Luto (7)\Profissional\Sem condições de ajudar & $\begin{array}{l}\text { Meu marido falou "você não vai sair de casa, olha pra você? Você vai fazer o que } \\
\text { lá?" }\end{array}$ \\
\hline $\begin{array}{l}\text { Transcrição E1 } \\
\text { revisada_para maxqda }\end{array}$ & COMPREENSÃO\Experiência\O viver|Quem viveu (5)\Luto (7)\Profissional\Sentindo a responsabilidade de resolver & Aí eu falei: "não tem ninguém, eu preciso ir" e eu fui. \\
\hline $\begin{array}{l}\text { Transcrição E1 } \\
\text { revisada_para maxqda }\end{array}$ & 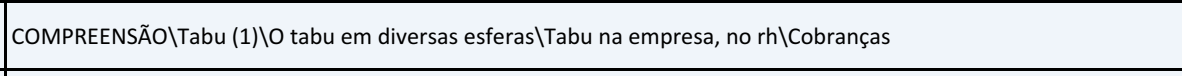 & Então assim, é cobrança de todos os lados. \\
\hline $\begin{array}{l}\text { Transcrição E1 } \\
\text { revisada_para maxqda }\end{array}$ & COMPREENSÃO\Experiência\O viver\Quem viveu (5)\Luto (7)\Profissional\Perdendo um paciente para o suicídio & $\begin{array}{l}\text { Já sei...e isso aconteceu de sexta pro sábado. Sábado de manhã eu fui lá, eu atendi } \\
\text { a família e na segunda feira eu fui trabalhar. E assim, a empresa não me chamou, a } \\
\text { empresa não perguntou se eu queria um ou dois dias, se eu precisava de ajuda, e } \\
\text { eu estava péssima. Fiquei dois dias no quarto sem comer porque foi muito assim, } \\
\text { foi terrível pra eu passar por essa situação. }\end{array}$ \\
\hline $\begin{array}{l}\text { Transcrição E1 } \\
\text { revisada_para maxqda }\end{array}$ & 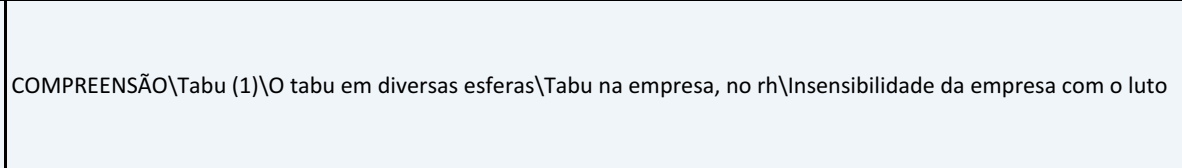 & $\begin{array}{l}\text { Já sei...e isso aconteceu de sexta pro sábado. Sábado de manhã eu fui lá, eu atendi } \\
\text { a família e na segunda feira eu fui trabalhar. E assim, a empresa não me chamou, a } \\
\text { empresa não perguntou se eu queria um ou dois dias, se eu precisava de ajuda, e } \\
\text { eu estava péssima. Fiquei dois dias no quarto sem comer porque foi muito assim, } \\
\text { foi terrível pra eu passar por essa situação. }\end{array}$ \\
\hline $\begin{array}{l}\text { Transcrição E1 } \\
\text { revisada_para maxqda }\end{array}$ & AÇÃO।O saber (12)\Saber é poder|Necessidade de informação & $\begin{array}{l}\text { Falta de informação. O RH da empresa não sabia o que fazer comigo, a equipe toda } \\
\text { destruída, ninguém sabia fazer nada, ninguém sabia nada cara... }\end{array}$ \\
\hline \begin{tabular}{|l|l} 
Transcrição E1 \\
revisada_para maxqda
\end{tabular} & COMPREENSÃO\Experiência\O viver|Quem viveu (5)\Luto (7)\Profissional|Perdendo um paciente para o suicídio & $\begin{array}{l}\text { Falta de informação. O RH da empresa não sabia o que fazer comigo, a equipe toda } \\
\text { destruída, ninguém sabia fazer nada, ninguém sabia nada cara... }\end{array}$ \\
\hline $\begin{array}{l}\text { Transcrição E1 } \\
\text { revisada_para maxqda }\end{array}$ & AÇÃO\O saber (12)\Saber é poder|Necessidade de informação & $\begin{array}{l}\text { Falta de informação... então assim, eu sempre volto na informação, então eu acho } \\
\text { que a informação ela vai ajudar e muito, não só a prevenção, porque as vezes não } \\
\text { vai prevenir, mas todos impactados... }\end{array}$ \\
\hline $\begin{array}{l}\text { Transcrição E1 } \\
\text { revisada_para maxqda }\end{array}$ & AÇÃO।O saber (12)\Falta de formaçãolFalta de formação na faculdade & $\begin{array}{l}\text { Eu não sei você P6, mas eu não tive nenhuma aula de prevenção de suicídio na } \\
\text { universidade toda. }\end{array}$ \\
\hline $\begin{array}{l}\text { Transcrição E1 } \\
\text { revisada_para maxqda }\end{array}$ & AÇÃO\O saber (12) \Falta de formaçãolFalta de formação na faculdade & Nenhuma. Nunca tive. \\
\hline $\begin{array}{l}\text { Transcrição E1 } \\
\text { revisada_para maxqda }\end{array}$ & AÇÃO\O saber (12) \Falta de formação\Falta de formação na faculdade & $\begin{array}{l}\text { Não se tem aula de prevenção de suicídio nas universidades de psicologia. Ela } \\
\text { (sobre a esposa do P1) ainda está tendo, é um currículo novo. }\end{array}$ \\
\hline $\begin{array}{l}\text { Transcrição E1 } \\
\text { revisada_para maxqda }\end{array}$ & COMPREENSÃO\Experiência\O sentir|Sentimentos (8)\Indignação & $\begin{array}{l}\text { O RH da empresa não sabia o que fazer comigo, a equipe toda destruída, ninguém } \\
\text { sabia fazer nada, ninguém sabia nada cara... }\end{array}$ \\
\hline $\begin{array}{l}\text { Transcrição E1 } \\
\text { revisada_para maxqda }\end{array}$ & AÇÃO\O saber (12)\Falta de formação|Falta de formação na faculdade & não é matéria... \\
\hline $\begin{array}{l}\text { Transcrição E1 } \\
\text { revisada_para maxqda }\end{array}$ & AÇÃO\O saber (12)\Falta de formação|Falta de formação na faculdade & a matéria não tem? \\
\hline $\begin{array}{l}\text { Transcrição E1 } \\
\text { revisada_para maxqda }\end{array}$ & AÇÃO\O saber (12)\Falta de formação|Falta de formação na faculdade & não, matéria não tem, é palestra... \\
\hline $\begin{array}{l}\text { Transcrição E1 } \\
\text { revisada_para maxqda }\end{array}$ & AÇÃO|Cuidar|Tratamento (13)\Despreparo do psiquiatra & $\begin{array}{l}\text { eu ia falar exatamente sobre isso, porque muito psiquiatra não tá preparado pra } \\
\text { tratar disso. }\end{array}$ \\
\hline $\begin{array}{l}\text { Transcrição E1 } \\
\text { revisada_para maxqda }\end{array}$ & AÇÃO\Cuidar|Tratamento (13)\Despreparo do psiquiatra\Ouvindo absurdos do psiquiatra & Eu já ouvi de um psiquiatra coisas, já ouvi absurdos, assim. \\
\hline
\end{tabular}




\begin{tabular}{|c|c|c|}
\hline $\begin{array}{l}\text { Transcrição E1 } \\
\text { revisada_para maxqda }\end{array}$ & AÇÃO|Cuidar|Tratamento (13)|Despreparo do psiquiatra|Psiquiatra como médico da família & $\begin{array}{l}\text { Eu vou ao psiquiatra há muitos anos, a gente até lá em casa sempre brincou que é } \\
\text { o médico da família sempre foi o psiquiatra, meus irmãos vão e tal, meu irmão ia, } \\
\text { meu outro irmão a gente tem , hoje a gente conseguiu achar um que a gente } \\
\text { confia muito. }\end{array}$ \\
\hline $\begin{array}{l}\text { Transcrição E1 } \\
\text { revisada_para maxqda }\end{array}$ & AÇÃO|Cuidar|Tratamento (13)|Despreparo do psiquiatra|Ouvindo absurdos do psiquiatra & $\begin{array}{l}\text { Mas a gente ouviu muitos absurdos ao longo da vida, e uma das coisas é aquela } \\
\text { coisa, "eu estou aqui pra tratar a vida, e não pra tratar a morte". Então ele já fecha } \\
\text { aí uma porta de que a minha educação e minha formação foi feita... se você está } \\
\text { interessada em morrer, não fale isso comigo. }\end{array}$ \\
\hline $\begin{array}{l}\text { Transcrição E1 } \\
\text { revisada_para maxqda }\end{array}$ & AÇÃO\Cuidar|Tratamento (13)|Despreparo do psiquiatra & $\begin{array}{l}\text { Então ele já fecha aí uma porta de que a minha educação e minha formação foi } \\
\text { feita... se você está interessada em morrer, não fale isso comigo. Essa, essa é a } \\
\text { parede também, }\end{array}$ \\
\hline $\begin{array}{l}\text { Transcrição E1 } \\
\text { revisada_para maxqda }\end{array}$ & AÇÃo|Cuidar|Tratamento (13)\Despreparo do psiquiatra|Dificuldade de encontrar psiquiatra e psicólogo que acolha & $\begin{array}{l}\text { acho que o próprio sistema de saúde, ele... mesmo psicólogos, é muito difíil você } \\
\text { achar alguém que acolha e que ouça. }\end{array}$ \\
\hline $\begin{array}{l}\text { Transcrição E1 } \\
\text { revisada_para maxqda }\end{array}$ & AÇÃO\Cuidar\Tratamento (13)\Acesso a formas de tratamento\Mudar o sistema de saúde & $\begin{array}{l}\text { se a pergunta é assim, que o que você acha que tem que mudar, então eu acho } \\
\text { que o próprio sistema de saúde, ele... mesmo psicólogos, é muito difíil você achar } \\
\text { alguém que acolha e que ouça. }\end{array}$ \\
\hline $\begin{array}{l}\text { Transcrição E1 } \\
\text { revisada_para maxqda }\end{array}$ & CONSCIENTIZAÇão|Consciência|O absurdo do suicídio|Prevenção x Previsão|Irmão não conseguiu encontrar uma saída & $\begin{array}{l}\text { Hoje eu encontrei, mas a gente sim...o meu irmão passou por uma... meu irmão } \\
\text { estava desesperado procurando uma forma de sair daquilo e simplesmente não } \\
\text { conseguia encontrar, não conseguia encontrar... }\end{array}$ \\
\hline $\begin{array}{l}\text { Transcrição E1 } \\
\text { revisada_para maxqda }\end{array}$ & AÇÃO\Cuidar\Tratamento (13)\Dificuldade de achar apoio adequado & $\begin{array}{l}\text { Hoje eu encontrei, mas a gente sim.... meu irmão passou por uma... meu irmão } \\
\text { estava desesperado procurando uma forma de sair daquilo e simplesmente não } \\
\text { conseguia encontrar, não conseguia encontrar... }\end{array}$ \\
\hline $\begin{array}{l}\text { Transcrição E1 } \\
\text { revisada_para maxqda }\end{array}$ & AÇÃO|Cuidar|Tratamento (13)\Tratamento não é garantia mas deveria ser direitolFilho indo na psicóloga & $\begin{array}{l}\text { O meu filho ia e falava de outras coisas, e nenhuma psicóloga chegou, me chamou } \\
\text { das que ele foi... chegou e me chamou lá pra me falar: "olha, corre-se o risco." } \\
\text { Porque não conseguia tirar dele, }\end{array}$ \\
\hline $\begin{array}{l}\text { Transcrição E1 } \\
\text { revisada_para maxqda }\end{array}$ & AÇÃO|Cuidar|Tratamento (13)\Tratamento não é garantia mas deveria ser direito|Filho escondendo pensamentos suicidas da psicóloga & $\begin{array}{l}\text { O meu filho ia e falava de outras coisas, e nenhuma psicóloga chegou, me chamou } \\
\text { das que ele foi... chegou e me chamou lá pra me falar: "olha, corre-se o risco." } \\
\text { Porque não conseguia tirar dele, }\end{array}$ \\
\hline $\begin{array}{l}\text { Transcrição E1 } \\
\text { revisada_para maxqda }\end{array}$ & AÇÃo|Cuidar|Tratamento (13)\Tratamento não é garantia mas deveria ser direito|Sendo orientada por outra psicóloga & $\begin{array}{l}\text { e aí a única pessoa que me falou foi uma psicóloga que na verdade nem atendeu o } \\
\text { meu filho. }\end{array}$ \\
\hline $\begin{array}{l}\text { Transcrição E1 } \\
\text { revisada_para maxqda }\end{array}$ & AÇÃO\Cuidar\Tratamento (13)\Tratamento não é garantia mas deveria ser direito|Sendo orientada por outra psicóloga & $\begin{array}{l}\text { Isso foi uma semana antes, ela foi a única que se preocupou, assim escutando o } \\
\text { meu relato, ela nem tinha visto, e ela me ligava outro dia e falava "olha, eu } \\
\text { conversei com o psiquiatra assim, se você sentir necessidade vamos por ele numa } \\
\text { clínica" Ainda ela me orientou que eu nunca vou esquecer : "Pega o seu colchão e } \\
\text { dorme com ele, põe no quarto". Mas assim... eu não fiz isso }\end{array}$ \\
\hline \begin{tabular}{|l} 
Transcrição E1 \\
revisada_para maxqda
\end{tabular} & COMPREENSÃO\Experiência\O viver|Quem viveu (5)\Antes do suicídio|Desacreditando da gravidade & $\begin{array}{l}\text { Mas assim... eu não fiz isso. Porque eu também falei: "Mas ela nem viu, né, ... será } \\
\text { que esse caso é tão grave?" }\end{array}$ \\
\hline $\begin{array}{l}\text { Transcrição E1 } \\
\text { revisada_para maxqda }\end{array}$ & AÇÃO|Cuidar|Tratamento (13)\Despreparo do psiquiatra|Dificuldade de achar alguém preparado & $\begin{array}{l}\text { Não vem ao caso... mas eu digo é difíiil mesmo, é difícil achar alguém que está } \\
\text { preparado. }\end{array}$ \\
\hline $\begin{array}{l}\text { Transcrição E1 } \\
\text { revisada_para maxqda }\end{array}$ & AÇÃo|Cuidar\Tratamento (13)|Despreparo do psiquiatra|Dificuldade de achar alguém preparado & $\begin{array}{l}\text { difícil achar alguém que esteja preparado pra ouvir e dar a atenção que a pessoa } \\
\text { esteja precisando assim... }\end{array}$ \\
\hline $\begin{array}{l}\text { Transcrição E1 } \\
\text { revisada_para maxqda }\end{array}$ & AÇÃo|Cuidar\Tratamento (13)\Despreparo do psiquiatra|Dificuldade de achar alguém preparado & ) - ou chamar a família depois a parte, orientar a família. \\
\hline $\begin{array}{l}\text { Transcrição E1 } \\
\text { revisada_para maxqda }\end{array}$ & AÇÃO\O saber (12) \Falta de formaçãolFalta de formação na faculdade & $\begin{array}{l}\text { O quer que seja, eu acho que o que precisa mesmo também é isso ser mais falado } \\
\text { dentro das universidades, das faculdades de medicina e de psicologia. É um } \\
\text { assunto que ainda ... }\end{array}$ \\
\hline $\begin{array}{l}\text { Transcrição E1 } \\
\text { revisada_para maxqda }\end{array}$ & AÇÃO\O saber (12)\Falta de formação|Falta de formação na faculdade & $\begin{array}{l}\text { é exatamente... ele muito precário... a forma como é tratada dentro das faculdades } \\
\text { mesmo. Ainda é uma coisa que só aquela pessoa que se interessou e foi atrás, e } \\
\text { não é uma matéria. }\end{array}$ \\
\hline
\end{tabular}

Material integrante da pesquisa de doutorado de Karen Scavacini - USP Proibida a reprodução ou utilização sem autorização do autor - 2018 


\begin{tabular}{|c|c|c|}
\hline \begin{tabular}{|l} 
Transcrição E1 \\
revisada_para maxqda
\end{tabular} & CONSCIENTIZAÇÃO|Consciência|Aumento da Consciência (19)|Prevenção|Precisa se interessar para ter a informação & $\begin{array}{l}\text { a forma como é tratada dentro das faculdades mesmo. Ainda é uma coisa que só } \\
\text { aquela pessoa que se interessou e foi atrás, e não é uma matéria. }\end{array}$ \\
\hline \begin{tabular}{|l} 
Transcrição E1 \\
revisada_para maxqda
\end{tabular} & CONSCIENTIZAÇÃO|Consciência|Aumento da Consciência (19)|Prevenção|Precisa se interessar para ter a informação & eu acho que quem passou pelo problema \\
\hline $\begin{array}{l}\text { Transcrição E1 } \\
\text { revisada_para maxqda }\end{array}$ & AÇÃo|Cuidar|Tratamento (13)\Clinicas sem condição|Clinica não dando atenção a uma comunicação suicida & $\begin{array}{l}\text { outra coisa que vocês tão falando é de perceber ou não...é o depois que meu } \\
\text { sobrinho morreu, lendo a ficha dele na penúltima clínica que ele passou, tinha que } \\
\text { ele tinha acompanhamento lá e tinha coisas que ele escrevia e tinha coisas que a } \\
\text { psicóloga escrevia. }\end{array}$ \\
\hline $\begin{array}{l}\text { Transcrição E1 } \\
\text { revisada_para maxqda }\end{array}$ & AÇÃo|Cuidar|Tratamento (13)\Clinicas sem condição|Clinica não dando atenção a uma comunicação suicida & $\begin{array}{l}\text { Tinha uma pergunta lá "pensa ou já pensou em suicídio?" E aí estava escrito assim: } \\
\text { "sim, é o que mais penso ultimamente, mas não tenho coragem pois..." e aí não } \\
\text { terminou de escrever a frase. Isso o psicólogo não finalizou ali, só que assim, isso } \\
\text { não foi comunicado pra nós e nem na outra clínica que eles tiveram acesso a isso, } \\
\text { porque a ficha foi de uma pra outra, não ficou com a gente né, a gente foi receber } \\
\text { depois }\end{array}$ \\
\hline $\begin{array}{l}\text { Transcrição E1 } \\
\text { revisada_para maxqda }\end{array}$ & AÇÃo|Cuidar|Tratamento (13) \Clinicas sem condição|Clinica ignorando uma comunicação suicida & $\begin{array}{l}\text { Isso foi completamente ignorado pela psicóloga de lá também, entendeu, porque } \\
\text { se tivesse sido dado atenção, quer dizer, você pega um adolescente que fala que o } \\
\text { que ele mais pensa é em se matar, que tem problema de droga e ele tá lá, você vai } \\
\text { deixar ele horas sozinho dentro do quarto? Entendeu? Então assim, o que que faz } \\
\text { com a informação? Também não adianta as vezes a pessoa pede, implora socorro e } \\
\text { aí... }\end{array}$ \\
\hline $\begin{array}{l}\text { Transcrição E1 } \\
\text { revisada_para maxqda }\end{array}$ & AÇÃO\Cuidar\Tratamento (13)\Clinicas sem condição|Responsabilidades da clinica & $\begin{array}{l}\text { Isso foi completamente ignorado pela psicóloga de lá também, entendeu, porque } \\
\text { se tivesse sido dado atenção, quer dizer, você pega um adolescente que fala que o } \\
\text { que ele mais pensa é em se matar, que tem problema de droga e ele tá lá, você vai } \\
\text { deixar ele horas sozinho dentro do quarto? Entendeu? Então assim, o que que faz } \\
\text { com a informação? Também não adianta as vezes a pessoa pede, implora socorro e } \\
\text { aí... }\end{array}$ \\
\hline $\begin{array}{l}\text { Transcrição E1 } \\
\text { revisada_para maxqda }\end{array}$ & AÇÃo|Cuidar\Tratamento (13)\Clinicas sem condição|Um grito que não foi ouvido|Sentindo a falta de cuidado na pele & $\begin{array}{l}\text { Isso foi completamente ignorado pela psicóloga de lá também, entendeu, porque } \\
\text { se tivesse sido dado atenção, quer dizer, você pega um adolescente que fala que o } \\
\text { que ele mais pensa é em se matar, que tem problema de droga e ele tá lá, você vai } \\
\text { deixar ele horas sozinho dentro do quarto? Entendeu? Então assim, o que que faz } \\
\text { com a informação? Também não adianta as vezes a pessoa pede, implora socorro e } \\
\text { aí... }\end{array}$ \\
\hline \begin{tabular}{|l} 
Transcrição E1 \\
revisada_para maxqda
\end{tabular} & AÇÃo|Cuidar\Tratamento (13)\Clinicas sem condição|Um grito que não foi ouvido & $\begin{array}{l}\text { Isso foi completamente ignorado pela psicóloga de lá também, entendeu, porque } \\
\text { se tivesse sido dado atenção, quer dizer, você pega um adolescente que fala que o } \\
\text { que ele mais pensa é em se matar, que tem problema de droga e ele tá lá, você vai } \\
\text { deixar ele horas sozinho dentro do quarto? Entendeu? Então assim, o que que faz } \\
\text { com a informação? Também não adianta as vezes a pessoa pede, implora socorro e } \\
\text { aí... }\end{array}$ \\
\hline \begin{tabular}{|l} 
Transcrição E1 \\
revisada_para maxqda
\end{tabular} & AÇÃo|Cuidar|Tratamento (13)\Clinicas sem condição|Clinica ignorando uma comunicação suicida & e aí essa informação é ignorada. \\
\hline \begin{tabular}{|l} 
\\
Transcrição E1 \\
revisada_para maxqda
\end{tabular} & AÇÃo|Cuidar|Tratamento (13)\Clinicas sem condição|Clinica ignorando uma comunicação suicida & Ignorada completamente \\
\hline $\begin{array}{l}\text { Transcrição E1 } \\
\text { revisada_para maxqda }\end{array}$ & AÇÃO|Fazer|Prevenção (30)\Profissão que mais se mata & $\begin{array}{l}\text { Posso fazer uma pergunta para ti, qual é a profissão e o que é dos maiores índices, } \\
\text { você tem aí dessas pesquisas aí de suicidas }\end{array}$ \\
\hline $\begin{array}{l}\text { Transcrição E1 } \\
\text { revisada_para maxqda }\end{array}$ & AÇÃO|Fazer|Prevenção (30)\Profissão que mais se mata & não são os médicos? \\
\hline \begin{tabular}{|l} 
Transcrição E1 \\
revisada_para maxqda
\end{tabular} & AÇÃO\Fazer|Prevenção (30)\Profissão que mais se mata & As médicas. \\
\hline
\end{tabular}




\begin{tabular}{|c|c|c|}
\hline $\begin{array}{l}\text { Transcrição E1 } \\
\text { revisada_para maxqda }\end{array}$ & AÇÃolFazer|Prevenção (30)\Profissão que mais se mata & antigamente era tá, por isso eu queria saber. \\
\hline $\begin{array}{l}\text { Transcrição E1 } \\
\text { revisada_para maxqda }\end{array}$ & AÇÃOlFazer|Prevenção (30)\Profissão que mais se mata & $\begin{array}{l}\text { Nos anos } 80 \text {, eu li uma pesquisa, a maior quantia de pessoas que se suicidava era } \\
\text { os médicos. Médicas, e sabe qual era a especialidade...anestesistas. }\end{array}$ \\
\hline $\begin{array}{l}\text { Transcrição E1 } \\
\text { revisada_para maxqda }\end{array}$ & AÇÃolFazer|Prevenção (30)\Profissão que mais se mata & Isso, continua. \\
\hline $\begin{array}{l}\text { Transcrição E1 } \\
\text { revisada_para maxqda }\end{array}$ & AÇÃo\Fazer|Prevenção (30)\Profissão que mais se mata & Continua? \\
\hline $\begin{array}{l}\text { Transcrição E1 } \\
\text { revisada_para maxqda }\end{array}$ & AÇÃOlFazer|Prevenção (30)\Profissão que mais se mata & Porque anestesia? \\
\hline $\begin{array}{l}\text { Transcrição E1 } \\
\text { revisada_para maxqda }\end{array}$ & AÇã̃)|Fazer|Prevenção (30)\Profissão que mais se mata & Porque eles têm acesso muito fácil as drogas. \\
\hline $\begin{array}{l}\text { Transcrição E1 } \\
\text { revisada_para maxqda }\end{array}$ & AÇÃOlFazer|Prevenção (30)\Profissão que mais se mata & $\begin{array}{l}\text { eu vi uma outra reportagem, desculpa, eu vi uma outra reportagem... aquela lá que } \\
\text { vivenciam muito a morte... ? }\end{array}$ \\
\hline $\begin{array}{l}\text { Transcrição E1 } \\
\text { revisada_para maxqda }\end{array}$ & AÇÃO\Fazer|Prevenção (30)\Profissão que mais se mata & Tem muitas pessoas que morrem com eles \\
\hline $\begin{array}{l}\text { Transcrição E1 } \\
\text { revisada_para maxqda }\end{array}$ & AÇÃO|Fazer|Prevenção (30)\Profissão que mais se mata & vivenciam muito a morte... \\
\hline Transcrição E2 revisada & AÇÃO|Cuidar|Sobre os encontros (25)\Ficando mexido com a reunião anterior & Eu fiquei um pouco mexido, e até a gente conversou depois, mas agora estou bem. \\
\hline Transcrição E2 revisada & AÇÃ̃OCuidar|Sobre os encontros (25)\Impactado com as diferentes situaç̃es & $\begin{array}{l}\text { como eu vi que são várias histórias diferentes, aquilo que muitas vezes a gente trás } \\
\text { de ideia impacta outras pessoas e vice-versa. São situações diferentes. Isso me } \\
\text { impactou. }\end{array}$ \\
\hline Transcrição E2 revisada & AÇÃo|Cuidar|Sobre os encontros (25)\Gostando de falar sobre o assunto & $\begin{array}{l}\text { Eu fiquei bem. Inclusive eu achei bom que na mesma semana teve uma reunião a } \\
\text { mais. Quer dizer... aqui né, mesmo assim, uma vez a mais. }\end{array}$ \\
\hline Transcrição E2 revisada & AÇÃo|Cuidar|Sobre os encontros (25)\Gostando de falar sobre o assunto & $\begin{array}{l}\text { Bem, primeiro porque você não tinha ainda nada acontecendo com você ou com } \\
\text { sua família então você não se preocupava. }\end{array}$ \\
\hline Transcrição E2 revisada & COMPREENSÃO\Experiência\O viver|Quem viveu (5)\Depois do suicídio\Dando atenção porque passou pela experiência & $\begin{array}{l}\text { Você passou ser o centro, aí você tem uma maior preocupação, tanto de você vê } \\
\text { como de repassar a notícia. }\end{array}$ \\
\hline Transcrição E2 revisada & COMPREENSÃO\Experiência\O viver\Quem viveu (5)\Depois do suicídio|Como ver e como falar sobre suicídio porque passou por isso & $\begin{array}{l}\text { Você passou ser o centro, aí você tem uma maior preocupação, tanto de você vê } \\
\text { como de repassar a notícia. }\end{array}$ \\
\hline Transcrição E2 revisada & COMPREENSÃO\Comunicação|Pessoal|Se preparando para falar|No início não dá para falar (luto) & No início você fica com aquele impacto de ficar aquilo reservado, \\
\hline Transcrição E2 revisada & COMPREENSÃO|Comunicação|Pessoal|Falando abertamente na sociedade |Colocando para fora o que aconteceu & $\begin{array}{l}\text { mas pelo menos a gente, a gente pois para fora, entendeu, acho que foi uma das } \\
\text { maneiras de se dar, é botar isso para fora e não ficar com aquilo dentro esconder, } \\
\text { como se fazia antigamente. }\end{array}$ \\
\hline Transcrição E2 revisada & COMPREENSÃO\Comunicação|Social\Aprendendo com quem veio antes ou Outras campanhas(rever)\AIDS se abriu ao ser tratada como & $\begin{array}{l}\text { quando começou a AIDS aí a um tempo atrás, não sei, uns } 18 \text { anos, então no } \\
\text { começo também era um tabu se falar em AIDS né, aí quando passou a ser } \\
\text { considerado uma preocupação de saúde pública, então se abriu. }\end{array}$ \\
\hline Transcrição E2 revisada & COMPREENSÃO|Comunicação|Social\Aprendendo com quem veio antes ou Outras campanhas(rever)\AIDS também era tabu & $\begin{array}{l}\text { quando começou a AIDS aí a um tempo atrás, não sei, uns } 18 \text { anos, então no } \\
\text { começo também era um tabu se falar em AIDS né }\end{array}$ \\
\hline Transcrição E2 revisada & COMPREENSÃO|Comunicação|Social|Aumento da comunicação|Acha que as pessoas estão falando mais sobre o assunto & Eu acho que sim. \\
\hline Transcrição E2 revisada & COMPREENSÃO\Tabu (1)\Outros Tabus/Comparando com outros assuntos tabu & $\begin{array}{l}\text { Não só porque você passou por isso mas.... éééééé porque já assim, ééééé como } \\
\text { outros problemas aí, quando começou a AIDS aí a um tempo atrás, não sei, uns } 18 \\
\text { anos, então no começo também era um tabu se falar em AIDS né, aí quando } \\
\text { passou a ser considerado uma preocupação de saúde pública, então se abriu. }\end{array}$ \\
\hline
\end{tabular}

Material integrante da pesquisa de doutorado de Karen Scavacini - USP Proibida a reprodução ou utilização sem autorização do autor - 2018 


\begin{tabular}{|c|c|c|}
\hline Transcrição E2 revisada & AÇÃO\Diálogo\O falar (23)\Como (FORMA)\Depressão e suicídio como saúde publica & $\begin{array}{l}\text { Hoje eu sei, pelo menos quem trabalha na área, como da psicologia, da psiquiatria, } \\
\text { ou seja, da área médica de um modo geral. Eles tão trabalhando no intuito de levar } \\
\text { também a questão da depressão, pra mim assim, vai juntando a depressão com o } \\
\text { suicídio, com também algo de preocupação de saúde pública, pra ter campanhas } \\
\text { periódicas para poder, tipo o câncer, AIDS, né. }\end{array}$ \\
\hline Transcrição E2 revisada & |COMPREENSÃO\Comunicação|Social\Área acadêmica e palestras\Área médica, psicologia e saúde publica & $\begin{array}{l}\text { Hoje eu sei, pelo menos quem trabalha na área, como da psicologia, da psiquiatria, } \\
\text { ou seja, da área médica de um modo geral. Eles tão trabalhando no intuito de levar } \\
\text { também a questão da depressão, pra mim assim, vai juntando a depressão com o } \\
\text { suicídio, com também algo de preocupação de saúde pública, pra ter campanhas } \\
\text { periódicas para poder, tipo o câncer, AIDS, né. }\end{array}$ \\
\hline Transcrição E2 revisada & COMPREENSÃO\Comunicação|Social|Área acadêmica e palestras\O movimento começou na área acadêmica & $\begin{array}{l}\text { Então isso tem movimento e esse movimento, queira ou não queira, embora seja } \\
\text { na área acadêmica, mas chega de um modo geral. }\end{array}$ \\
\hline Transcrição E2 revisada & |COMPREENSÃO|Comunicação|Social\Aumento da comunicação|Hoje se fala mais & $\begin{array}{l}\text { Então há essa preocupação hoje de fazer com que se procure dar uma atenção } \\
\text { maior a essa problemática, então eu acho assim... tá sendo bem mais comentado } \\
\text { atualmente }\end{array}$ \\
\hline Transcrição E2 revisada & CONSCIENTIZAÇão|Consciência\Aumento da Consciência (19)\Prevenção|Formas\As campanhas periódicas & $\begin{array}{l}\text { Eles tão trabalhando no intuito de levar também a questão da depressão, pra mim } \\
\text { assim, vai juntando a depressão com o suicídio, com também algo de preocupação } \\
\text { de saúde pública, pra ter campanhas periódicas para poder, tipo o câncer, AIDS, } \\
\text { né. }\end{array}$ \\
\hline Transcrição E2 revisada & COMPREENSÃO|Comunicação|Social|Possíveis Causas para o Aumento|Falam mais hoje de suicídio por causa da depressão & $\begin{array}{l}\text { Eu acho que pela própria, pela depressão. Eu acho que começou a se falar muito } \\
\text { em depressão, né? }\end{array}$ \\
\hline Transcrição E2 revisada & CONSCIENTIZAÇÃO|Consciência|Complexidade|Complexidade dos sentimentos\Existem graus de sentimentos & $\begin{array}{l}\text { Os sentimentos da perda vão existir sempre, eu acho mas não denominava esse } \\
\text { nome e eu acho que de repente começou, de uns anos pra cá, a todo mundo } \\
\text { sentir, raramente você ouve as pessoas falarem em graus diferentes mas as } \\
\text { pessoas sentem e até tentam por pra fora aquela angustia, aquela denominada } \\
\text { vários nomes: angustia, tristeza, tal. }\end{array}$ \\
\hline Transcrição E2 revisada & CONSCIENTIZAÇÃO|Consciência|Complexidade\A banalização da depressão|Nomeando e sentindo graus diferentes de angustias & $\begin{array}{l}\text { Os sentimentos da perda vão existir sempre, eu acho mas não denominava esse } \\
\text { nome e eu acho que de repente começou, de uns anos pra cá, a todo mundo } \\
\text { sentir, raramente você ouve as pessoas falarem em graus diferentes mas as } \\
\text { pessoas sentem e até tentam por pra fora aquela angustia, aquela denominada } \\
\text { vários nomes: angustia, tristeza, tal. }\end{array}$ \\
\hline Transcrição E2 revisada & COMPREENSÃo|Comunicação|Social|Possiveis Causas para o Aumento|Suicídio como assunto da moda\As pessoas falam de assuntos da & $\begin{array}{l}\text { Quando depressão alguns falam: "Ah, a doença da moda". Não é, mas eu acho que } \\
\text { dai começou a falar nisso e isso começou... por que? Eu acho que tá muito } \\
\text { associado. }\end{array}$ \\
\hline Transcrição E2 revisada & COMPREENSÃO|Comunicação|Social|Possíveis Causas para o Aumento|Falam mais hoje de suicídio por causa da depressão & $\begin{array}{l}\text { Quando depressão alguns falam: "Ah, a doença da moda". Não é, mas eu acho que } \\
\text { daí começou a falar nisso e isso começou... por que? Eu acho que tá muito } \\
\text { associado. }\end{array}$ \\
\hline Transcrição E2 revisada & AÇÃO\Diálogo\O falar (23)\O que (MENSAGEM)\Temas\Existem diferenças no suicídio & $\begin{array}{l}\text { Isso a gente até na saída daqui a gente foi conversando, aquele dia, porque a gente } \\
\text { levantou que as diferenças... as vezes o suicídio dá aquele impacto ou por uma } \\
\text { questão econômica, }\end{array}$ \\
\hline Transcrição E2 revisada & AÇÃ̃o|Cuidar|Depressão|As consequências da depressão|A depressão não deixa ver outras soluções & $\begin{array}{l}\text { "Naquele momento ele estava deprimido pra fazer aquilo porque se não você vai } \\
\text { pensar outras soluções, bom enfim, aí pensar em outras soluções pra ou começar } \\
\text { de outro caminho. }\end{array}$ \\
\hline Transcrição E2 revisada & COMPREENSÃo|Visão|Visão da Sociedade (2)\Causas do suicídio|Suicídio e depressão (culpa da doença)\Culpa da depressão & $\begin{array}{l}\text { mas é que vocês estão falando em depressão, assim, de uma pessoa deprimida há } \\
\text { muito tempo, fazendo um tratamento. }\end{array}$ \\
\hline Transcrição E2 revisada & COMPREENSÃO|Comunicação|Social|Possiveis Causas para o Aumento|Falam mais hoje de suicídio por causa da depressão & $\begin{array}{l}\text { "Naquele momento ele estava deprimido pra fazer aquilo porque se não você vai } \\
\text { pensar outras soluções, bom enfim, aí pensar em outras soluções pra ou começar } \\
\text { de outro caminho. Eu acho que está muito associado por isso que eu acho que } \\
\text { começou a falar mais. }\end{array}$ \\
\hline
\end{tabular}

Material integrante da pesquisa de doutorado de Karen Scavacini - USP Proibida a reprodução ou utilização sem autorização do autor - 2018 


\begin{tabular}{|c|c|c|}
\hline Transcrição E2 revisada & COMPREENSÃO|Comunicação|Social|Aumento da comunicação|A mídia já fala mais & Eu acho que a mídia também, né? \\
\hline Transcrição E2 revisada & COMPREENSÃO|Comunicação|Social|Famosos e suicídio|Famosos e AIDS & $\begin{array}{l}\text { Como, quando o P1 falou da AIDS, a gente costuma tomar conhecimento da AIDS } \\
\text { quando a gente ouve do Michael Jordon e o Cazuza, e ultimamente a gente tem } \\
\text { ouvido também né, várias personalidades, né, que morreram por suicídio. }\end{array}$ \\
\hline Transcrição E2 revisada & COMPREENSÃo|Comunicação|Social|Famosos e suicídio & $\begin{array}{l}\text { Eu acho que a mídia também, né? Como, quando o P1 falou da AIDS, a gente } \\
\text { costuma tomar conhecimento da AIDS quando a gente ouve do Michael Jordon e o } \\
\text { Cazuza, e ultimamente a gente tem ouvido também né, várias personalidades, né, } \\
\text { que morreram por suicídio. E isso faz com que as pessoas parem e pensem: "Puxa, } \\
\text { o famoso, teoricamente não tem problema, tem fama, né? Então eu acho que isso } \\
\text { leva as pessoas a comentarem, pelo menos, um pouco mais assunto, e a gente sai } \\
\text { da casa da gente, né? Que eu tive. Depois que o (nome do filho) se foi eu lembrei } \\
\text { que eu tive um primo que se suicidou ha alguns anos atrás e que meu marido } \\
\text { também teve um primo que se suicidou. Mas foi tão... as pessoas não falam. A } \\
\text { família não falou. E quando é uma personalidade, eu acho que torna tão público } \\
\text { que fica difíiil a gente colocar um véu e fingir que não está sabendo de nada. Eu } \\
\text { acho que acaba contribuindo de alguma forma também para que a gente perceba } \\
\text { e olhe para o assunto né, para essa questão }\end{array}$ \\
\hline Transcrição E2 revisada & AÇÃO|DiálogolO falar (23)\Quem\Famosos\Famosos que tiveram fazem que as pessoas pensem no assunto & $\begin{array}{l}\text { E isso faz com que as pessoas parem e pensem: "Puxa, o famoso, teoricamente } \\
\text { não tem problema, tem fama, né? Então eu acho que isso leva as pessoas a } \\
\text { comentarem, pelo menos, um pouco mais assunto, e a gente sai da casa da gente, } \\
\text { né? }\end{array}$ \\
\hline Transcrição E2 revisada & CONSCIENTIZAÇÃO|Consciência\O absurdo do suicídio|Proximidade de suicídios|Suicídio mais perto do que se lembra & $\begin{array}{l}\text { Então eu acho que isso leva as pessoas a comentarem, pelo menos, um pouco mais } \\
\text { assunto, e a gente sai da casa da gente, né? Que eu tive. Depois que o (nome do } \\
\text { filho) se foi eu lembrei que eu tive um primo que se suicidou ha alguns anos atrás e } \\
\text { que meu marido também teve um primo que se suicidou. }\end{array}$ \\
\hline Transcrição E2 revisada & COMPREENSÃO\Tabu (1)\O tabu em diversas esferas\Tabu familiar & $\begin{array}{l}\text { Depois que o (nome do filho) se foi eu lembrei que eu tive um primo que se } \\
\text { suicidou ha alguns anos atrás e que meu marido também teve um primo que se } \\
\text { suicidou. Mas foi tão... as pessoas não falam. A família não falou. }\end{array}$ \\
\hline Transcrição E2 revisada & COMPREENSÃO|Comunicação|Social|Famosos e suicídio|Famosos escancaram o suicídio & $\begin{array}{l}\text { E quando é uma personalidade, eu acho que torna tão público que fica difícil a } \\
\text { gente colocar um véu e fingir que não está sabendo de nada. }\end{array}$ \\
\hline Transcrição E2 revisada & AÇÃO\Diálogo\O falar (23)\Quem\Famosos\Famosos que tiveram fazem que as pessoas pensem no assunto & $\begin{array}{l}\text { Eu acho que acaba contribuindo de alguma forma também para que a gente } \\
\text { perceba e olhe para o assunto né, para essa questão. }\end{array}$ \\
\hline Transcrição E2 revisada & COMPREENSÃO|Comunicação|Social|Possiveis Causas para o Aumento|Globalização acelerando os assuntos & $\begin{array}{l}\text { Assim, a sociedade ela vem..., hoje a gente fala né da globalização é etc. e eu acho } \\
\text { que isso ajuda bastante porque tá tudo muito conectado, as pessoas ficam } \\
\text { sabendo de tudo mais rápido, }\end{array}$ \\
\hline Transcrição E2 revisada & COMPREENSÃO|Comunicação|Social|Canais virtuais|Conexão global trazendo assuntos desconhecidos & $\begin{array}{l}\text { e eu acho que isso ajuda bastante porque tá tudo muito conectado, as pessoas } \\
\text { ficam sabendo de tudo mais rápido, então desse assunto também, assim como } \\
\text { outros assuntos que a gente vai descobrindo e vai vendo né que existe e aí a } \\
\text { sociedade começa a tentar a trabalhar em cima, ou por exemplo, uma doença, } \\
\text { tenta achar a cura... teoricamente... }\end{array}$ \\
\hline Transcrição E2 revisada & COMPREENSÃo|Comunicação|Social|Canais virtuais|Redes trazendo informação|Redes espalhando o assunto & $\begin{array}{l}\text { Então eu acho que o suicídio é um assunto também que vem aí nessa...como se } \\
\text { torna cada vez mais comum, dele acontecer e hoje com as redes você consegue ter } \\
\text { mais informação, eu acho que isso acaba se espalhando bem mais do que } \\
\text { antigamente, então eu acho que acaba, assim como outros assuntos também } \\
\text { vindo mais à tona. }\end{array}$ \\
\hline
\end{tabular}




\begin{tabular}{|c|c|c|}
\hline Transcrição E2 revisada & COMPREENSÃO\Comunicação|Social|Canais virtuais\Redes trazendo informação & $\begin{array}{l}\text { Então eu acho que o suicídio é um assunto também que vem aí nessa...como se } \\
\text { torna cada vez mais comum, dele acontecer e hoje com as redes você consegue ter } \\
\text { mais informação, eu acho que isso acaba se espalhando bem mais do que } \\
\text { antigamente, então eu acho que acaba, assim como outros assuntos também } \\
\text { vindo mais à tona. }\end{array}$ \\
\hline Transcrição E2 revisada & COMPREENSÃo|Comunicação|Social|Possíveis Causas para o Aumento|Suicídio está ficando mais comum & como se torna cada vez mais comum, dele acontecer \\
\hline Transcrição E2 revisada & COMPREENSÃO|Comunicação|Social|Possiveis Causas para o Aumento|Aumento da liberdade de expressão & $\begin{array}{l}\text { Eu acho que a questão de liberdade de expressão também, acho que os seres } \\
\text { humanos eles tem se sentindo acho mais empoderados a falar de certos assuntos } \\
\text { que antes eram difíceis. }\end{array}$ \\
\hline Transcrição E2 revisada & COMPREENSÃO\Comunicação|Social|Possiveis Causas para o Aumento|Assuntos escancarados & $\begin{array}{l}\text { Então eu acho que esse é um assunto também que é difíiil que cada vez mais as } \\
\text { pessoas assim, não tem mais medo, não tem mais vergonha, assim como alguns } \\
\text { outros assuntos dificeis que a gente tem hoje que as pessoas, por exemplo, } \\
\text { levantam bandeira e lutam por certas causas que antes não era uma coisa tão } \\
\text { escancarada. }\end{array}$ \\
\hline Transcrição E2 revisada & COMPREENSÃO|Comunicação|Social|Possiveis Causas para o Aumento|Aumento da liberdade de expressão & $\begin{array}{l}\text { Você talvez ia sofrer muito mais preconceito ou sofrer muito mais por levantar } \\
\text { uma certa bandeira ou tocar em determinado assunto. Acho que a gente, não } \\
\text { todos, a gente é um pouco mais livre do que antes, }\end{array}$ \\
\hline Transcrição E2 revisada & COMPREENSÃO|Comunicação|Social|Possiveis Causas para o Aumento|Aumento da liberdade de expressão|Países sem liberdade de exp & $\begin{array}{l}\text { acho que ainda existem países em que muita coisa ainda fica escondida, velada e } \\
\text { as pessoas sofrem porque elas não poderem falar.. }\end{array}$ \\
\hline Transcrição E2 revisada & COMPREENSÃO|Comunicação|Social|Possiveis Causas para o Aumento|Assuntos escancarados & $\begin{array}{l}\text { Mas eu acho que cada vez mais a gente tem...te dão mais liberdade, enfim, e não } \\
\text { tem mais vergonha, nem medo, nem se sente oprimido por falar de certos temas. }\end{array}$ \\
\hline Transcrição E2 revisada & COMPREENSÃO|Comunicação|Social|Possiveis Causas para o Aumento|Aumento da liberdade de expressão & $\begin{array}{l}\text { Mas eu acho que cada vez mais a gente tem...te dão mais liberdade, enfim, e não } \\
\text { tem mais vergonha, nem medo, nem se sente oprimido por falar de certos temas. }\end{array}$ \\
\hline Transcrição E2 revisada & COMPREENSÃo|Comunicação|Social|Famosos e suicídio & $\begin{array}{l}\text { o Robin Williams, eu sempre gostei dos filmes dele e via ele como uma referencia } \\
\text { de uma pessoa alegre e os filmes eram auto astral, assim, me chocou o suicídio } \\
\text { dele. }\end{array}$ \\
\hline Transcrição E2 revisada & AÇÃO\Diálogo\O falar (23)\Quem\Famosos\Famosos que tiveram fazem que as pessoas pensem no assunto & $\begin{array}{l}\text { o Robin Williams, eu sempre gostei dos filmes dele e via ele como uma referencia } \\
\text { de uma pessoa alegre e os filmes eram auto astral, assim, me chocou o suicídio } \\
\text { dele. Então isso me marcou e ainda me fez parar pra pensar, assim, que eu tinha } \\
\text { uma imagem dele, do trabalho dele, e ele vivia uma outra coisa, assim. Foi algo que } \\
\text { me marcou. }\end{array}$ \\
\hline Transcrição E2 revisada & COMPREENSÃO\Comunicação|Social|Aumento da comunicação|A mídia já fala mais & $\begin{array}{l}\text { E eu acho que aí foi falado muito. E foi um momento, assim. Particularmente que } \\
\text { me marcou e tem a ver com essa mídia, assim. }\end{array}$ \\
\hline Transcrição E2 revisada & COMPREENSÃO|Comunicação|Social|Famosos e suicídio|Suicídio Robin Willians/Chamou atenção porque gostava dele & $\begin{array}{l}\text { Se não fosse um ator que eu acompanhasse, gostasse dos filmes, talvez passasse } \\
\text { batido mas chama a atenção. }\end{array}$ \\
\hline Transcrição E2 revisada & COMPREENSÃo|Comunicação|Social|Famosos e suicídio|Suicídio Robin Willians & $\begin{array}{l}\text { é "Amor além da vida" eu assisti 10/15 vezes tá certo? Então eu tinha aquilo } \\
\text { assim... você associa no caso ao ator, né? À pessoa, né? Que são coisas distintas } \\
\text { mas você associa, se você ficou chocado e também fiquei, da mesma forma porque } \\
\text { aquele filme pra mim, eu assisti 10/12/15 vezes e eu fiquei pensando: mas ele vai } \\
\text { buscar a mulher dele no inferno, como ele diz, foi buscar no inferno, e ele comete } \\
\text { o suicídio, entendeu? Pra mim, realmente foi um choque. }\end{array}$ \\
\hline Transcrição E2 revisada & COMPREENSÃO|Comunicação|Social|Famosos e suicídio|Suicídio Robin Willians & $\begin{array}{l}\text { Então como exemplo, particularmente, uns anos atrás, o Robin Williams, eu } \\
\text { sempre gostei dos filmes dele e via ele como uma referencia de uma pessoa alegre } \\
\text { e os filmes eram auto astral, assim, me chocou o suicídio dele. }\end{array}$ \\
\hline Transcrição E2 revisada & |COMPREENSÃO|Comunicação|Social|Famosos e suicídio|Suicídio Robin Willians\|magem $\times$ realidade & $\begin{array}{l}\text { À pessoa, né? Que são coisas distintas mas você associa, se você ficou chocado e } \\
\text { também fiquei, da mesma forma porque aquele filme pra mim, eu assisti 10/12/15 } \\
\text { vezes e eu fiquei pensando: mas ele vai buscar a mulher dele no inferno, como ele } \\
\text { diz, foi buscar no inferno, e ele comete o suicídio, entendeu? Pra mim, realmente } \\
\text { foi um choque. }\end{array}$ \\
\hline
\end{tabular}

Material integrante da pesquisa de doutorado de Karen Scavacini - USP Proibida a reprodução ou utilização sem autorização do autor - 2018 


\begin{tabular}{|c|c|c|}
\hline Transcrição E2 revisada & COMPREENSÃo|Comunicação|Social|Área acadêmica e palestras|Psi e Psiq sentindo necessidade de trazer ao publico & $\begin{array}{l}\text { Eu acho que a própria psicologia, psiquiatria está percebendo que há necessidade } \\
\text { de se colocar isso público }\end{array}$ \\
\hline Transcrição E2 revisada & COMPREENSÃO|Comunicação|Social|Área acadêmica e palestras|Por causa do aumento dos números & $\begin{array}{l}\text { e que como está aumentando o número, então, se tem essa necessidade de dar } \\
\text { mais informação ao público em geral, }\end{array}$ \\
\hline Transcrição E2 revisada & AÇÃO\DiálogolO falar (23)\O que (MENSAGEM)\Há ajuda disponivel & $\begin{array}{l}\text { então, se tem essa necessidade de dar mais informação ao público em geral, as } \\
\text { pessoas deprimidas e que podem ser ajudadas e que não precisam chegar a esse } \\
\text { extremo que, através da psicologia e da psiquiatria ha uma grande ajuda. }\end{array}$ \\
\hline Transcrição E2 revisada & AÇÃo|DiálogolO falar (23)\O que (MENSAGEM)\Há ajuda disponivel & $\begin{array}{l}\text { Eu acho que isso é muito importante. Chegar a público e a imprensa em geral pra } \\
\text { dar essa informação que as pessoas podem ser ajudadas. }\end{array}$ \\
\hline Transcrição E2 revisada & AÇÃo|Cuidar\Tratamento (13)\Dificuldade de achar apoio adequado\A importância de ter locais com trabalhos especializados & $\begin{array}{l}\text { O trabalho, né, do (nome de uma instituição), né, porque eu acho assim.... } \\
\text { importante... }\end{array}$ \\
\hline Transcrição E2 revisada & AÇÃo|Cuidar\Tratamento (13)\Dificuldade de achar apoio adequado|Existência de maior ajuda em cidades maiores & $\begin{array}{l}\text { em São Paulo é comum e em (nome de uma capital) é bem menor do que São } \\
\text { Paulo, né? É que aqui é a capital do país, viu! }\end{array}$ \\
\hline Transcrição E2 revisada & AÇÃOlCuidar\CVV\O papel do CVV\Antigamente só tinha o CVV & $\begin{array}{l}\text { Então, São Paulo é... (nome de uma capital) até um pouco tempo atrás você não } \\
\text { tinha o que tem hoje, só o CVV né, não tinha entendeu, aí hoje, já tem... }\end{array}$ \\
\hline Transcrição E2 revisada & AÇÃo|Cuidar|Tratamento (13)|Acesso a formas de tratamento|Percepção que há mais serviços disponíveis hoje & $\begin{array}{l}\text { Então, São Paulo é... (nome de uma capital) até um pouco tempo atrás você não } \\
\text { tinha o que tem hoje, só o CVV né, não tinha entendeu, ai hoje, já tem... }\end{array}$ \\
\hline Transcrição E2 revisada & COMPREENSÃO|Comunicação|Social\Aumento da comunicação|A mídia já fala mais & $\begin{array}{l}\text { Mas eu digo assim, a imprensa em geral. Você liga a televisão as pessoas estão } \\
\text { dando informação... }\end{array}$ \\
\hline Transcrição E2 revisada & COMPREENSÃO\Comunicação|Social\Aumento da comunicação|Hoje já se fala em grupos pequenos também & $\begin{array}{l}\text { Exato, exato, assim, esse de boca a boca assim, também é muito pequeno, } \\
\text { pequeno né, assim aqui, pequeno né, tem 10, } 12 \text { pessoas né, mas cada pessoa ela } \\
\text { multiplica faz alguma ação, faz alguma coisa que divulga né, quer dizer, antes você } \\
\text { não tinha isso também não. }\end{array}$ \\
\hline Transcrição E2 revisada & COMPREENSÃO|Comunicação|Social|Aumento da comunicação|A informação chega mesmo sem procurar & $\begin{array}{l}\text { Sim, mas mesmo que você não vá procurar a informação chega até você, através } \\
\text { do jornal, imprensa, televisão. As informações estão chegando sem você procurar. } \\
\text { Isso eu acho muito importante. }\end{array}$ \\
\hline Transcrição E2 revisada & COMPREENSÃO|Comunicação|Social|Aumento da comunicação|A mídia já fala mais & Não saia, não tinha algo na imprensa... Hoje se vê mais na imprensa. \\
\hline Transcrição E2 revisada & CONSCIENTIZAÇÃO|Consciência|Epidemiologia (20)\Causas não divulgadas é suicídio? & $\begin{array}{l}\text { E aquelas causas não divulgadas. Eu não sei se aumentou tanto o número. Se } \\
\text { aumentou, se diminuiu, acho que esse receio de se divulgar que uma causa de uma } \\
\text { morte é por suicídio ou não. }\end{array}$ \\
\hline Transcrição E2 revisada & CONSCIENTIZAÇÃO|Consciência|Epidemiologia (20)\Descobrindo o suicídio como comum & $\begin{array}{l}\text { Acho que não sei dizer. Eu acho que de fato é essa questão de você ter os meios de } \\
\text { comunicação falando mais, eu acho que as pessoas se comunicando mais e de } \\
\text { repente descobrindo que elas tem mais em comum porque aquela coisa acho } \\
\text { que...quase todo mundo tem de alguma forma é... alguém no seu ciclo que já } \\
\text { passou por isso. }\end{array}$ \\
\hline Transcrição E2 revisada & COMPREENSÃO\Tabu (1)\Consequências do Tabu\O não falar|Dificuldade de falar sobre o suicídio & $\begin{array}{l}\text { Eu acho que de fato é essa questão de você ter os meios de comunicação falando } \\
\text { mais, eu acho que as pessoas se comunicando mais e de repente descobrindo que } \\
\text { elas tem mais em comum porque aquela coisa acho que...quase todo mundo tem } \\
\text { de alguma forma é... alguém no seu ciclo que já passou por isso. Mas não } \\
\text { comunica, não fala. }\end{array}$ \\
\hline Transcrição E2 revisada & CONSCIENTIZAÇÃO|Consciência\O absurdo do suicídio|Proximidade de suicídios\Passando por um suicídio na adolescência & $\begin{array}{l}\text { É como se fosse uma... eu acho que ... me lembro a primeira vez que eu falei } \\
\text { alguma coisa sobre isso com alguém, eu devia ter uns } 13 / 14 \text { anos porque a esposa } \\
\text { do meu tio tinha acabado de se suicidar... eu tinha é uns } 12 \text { anos quando ela fez } \\
\text { isso, a esposa do meu tio. }\end{array}$ \\
\hline Transcrição E2 revisada & COMPREENSÃO|Visão|Causa Mortis (9)\Visão infantillDiferenças familiares na fala sobre o suicídio & $\begin{array}{l}\text { "Ué, mas..." Porque era um assunto que em casa, assim, um lado da família falava } \\
\text { o outro não... mas porque a minha mãe também tinha tido uma tia que tinha se } \\
\text { suicidado. Então era uma coisa que se falava de certa forma, à mesa, né? }\end{array}$ \\
\hline
\end{tabular}

Material integrante da pesquisa de doutorado de Karen Scavacini - USP Proibida a reprodução ou utilização sem autorização do autor - 2018 


\begin{tabular}{|c|c|c|}
\hline Transcrição E2 revisada & COMPREENSÃO|Comunicação|Pessoal|Falando abertamente na família|Falando abertamente sobre suicídio em família & $\begin{array}{l}\text { "Ué, mas..." Porque era um assunto que em casa, assim, um lado da família falava } \\
\text { o outro não... mas porque a minha mãe também tinha tido uma tia que tinha se } \\
\text { suicidado. Então era uma coisa que se falava de certa forma, à mesa, né? }\end{array}$ \\
\hline Transcrição E2 revisada & COMPREENSÃO|Comunicação|Pessoal|Falando abertamente na sociedade|Falando sobre suicídio com naturalidade infantil & $\begin{array}{l}\text { me lembro a primeira vez que eu falei alguma coisa sobre isso com alguém, eu } \\
\text { devia ter uns } 13 / 14 \text { anos porque a esposa do meu tio tinha acabado de se } \\
\text { suicidar... eu tinha é uns } 12 \text { anos quando ela fez isso, a esposa do meu tio. Ela era } \\
\text { nova tal mas eu falei assim como se fosse a mesma coisa que ela tivesse morrido } \\
\text { do coração e aí me arregalaram o olho, assim, e eu fiquei: "Ué, mas..." }\end{array}$ \\
\hline Transcrição E2 revisada & AÇÃO|DiálogolOuvir|Dificuldade dos outros ouvirem sobre suicídio & $\begin{array}{l}\text { Mas eu me lembro desse, desse choque das pessoas. E eu não falava pra chocar. } \\
\text { Eu falava porque sei lá, na minha cabeça era uma forma de morrer. }\end{array}$ \\
\hline Transcrição E2 revisada & COMPREENSÃo|Visão|Causa Mortis (9)|Visão infantil|Suicídio como forma de morrer & $\begin{array}{l}\text { Mas eu me lembro desse, desse choque das pessoas. E eu não falava pra chocar. } \\
\text { Eu falava porque sei lá, na minha cabeça era uma forma de morrer. }\end{array}$ \\
\hline Transcrição E2 revisada & COMPREENSÃo|Visão|Causa Mortis (9)|Visão infantil|Suicídio como forma de morrer & Não tinha preconceito, né, era uma forma de morrer... \\
\hline Transcrição E2 revisada & COMPREENSÃo|Visão|Causa Mortis (9)|Visão infantil|Suicídio como forma de morrer & $\begin{array}{l}\text { Não tinha. Era uma forma de morrer. Era uma forma de morrer e a gente } \\
\text { conversava sobre isso... Sempre se conversou sobre isso, em casa. }\end{array}$ \\
\hline Transcrição E2 revisada & COMPREENSÃO|Comunicação|Pessoal|Falando abertamente na família|Falando abertamente sobre suicídio em família & $\begin{array}{l}\text { Era uma forma de morrer e a gente conversava sobre isso... Sempre se conversou } \\
\text { sobre isso, em casa. E sempre se falou sobre isso, sobre outras questões delicadas, } \\
\text { assim, a gente sempre falou. }\end{array}$ \\
\hline Transcrição E2 revisada & CONSCIENTIZAÇÃO|Consciência|Epidemiologia (20)\Descobrindo o suicídio como comum & $\begin{array}{l}\text { E eu acho que, depois de um tempo que as pessoas foram começando a ver que se } \\
\text { elas forem parar pra pensar elas tem mais pessoas próximas do que ela imaginam } \\
\text { mas por alguma razão elas não falam e hoje eu acho que elas começaram a falar e } \\
\text { ver: "Olha, e não é que é verdade que tem alguém próximo e que isso já aconteceu } \\
\text { mas eu não quis enxergar". }\end{array}$ \\
\hline Transcrição E2 revisada & CONSCIENTIZAÇÃO|Consciência \O absurdo do suicídio|Proximidade de suicídios|Descobrindo o suicídio como próximo & $\begin{array}{l}\text { E eu acho que, depois de um tempo que as pessoas foram começando a ver que se } \\
\text { elas forem parar pra pensar elas tem mais pessoas próximas do que ela imaginam } \\
\text { mas por alguma razão elas não falam e hoje eu acho que elas começaram a falar e } \\
\text { ver: "Olha, e não é que é verdade que tem alguém próximo e que isso já aconteceu } \\
\text { mas eu não quis enxergar". }\end{array}$ \\
\hline Transcrição E2 revisada & COMPREENSÃO|Comunicação|Social|Possíveis Causas para o Aumento|Aumento da liberdade de expressão & $\begin{array}{l}\text { Eu acho que tem isso. Acho que as pessoas estão se comunicando mais. Falando } \\
\text { mais sobre assuntos... }\end{array}$ \\
\hline Transcrição E2 revisada & COMPREENSÃO|Comunicação|Pessoal|Falando abertamente na família|Família falando mais sobre o assunto & Quer dizer, mesmo dentro da própria família. \\
\hline Transcrição E2 revisada & COMPREENSÃO|Comunicação|Social|Aumento da comunicação|Hoje se fala mais & Família, amigos, círculo social... \\
\hline Transcrição E2 revisada & COMPREENSÃO|Comunicação|Social\Aumento da comunicação\Hoje se fala mais & As pessoas estão falando mais no assunto, no geral. \\
\hline Transcrição E2 revisada & COMPREENSÃO\Comunicação|Social\Aumento da comunicação\Hoje se fala mais & Eu acho que sim...não sei...dá uma impressão \\
\hline Transcrição E2 revisada & COMPREENSÃO|Comunicação|Pessoal|Falando abertamente na família|Falando abertamente sobre suicídio em família & $\begin{array}{l}\text { Assim, como isso sempre foi um assunto dentro da minha casa... mas eu sei que se } \\
\text { falasse fora arregalava-se o olho, }\end{array}$ \\
\hline Transcrição E2 revisada & AÇÃO|Diálogo|Ouvir|Dificuldade dos outros ouvirem sobre suicídio & $\begin{array}{l}\text { Assim, como isso sempre foi um assunto dentro da minha casa... mas eu sei que se } \\
\text { falasse fora arregalava-se o olho, }\end{array}$ \\
\hline Transcrição E2 revisada & COMPREENSÃO|Comunicação|Pessoal|Se preparando para falar|Sentindo menos desconforto em falar sobre o assunto & $\begin{array}{l}\text { hoje eu já não sinto mais tanto desconforto de falar isso, sobre o assunto, como eu } \\
\text { sentia, ééé, assim.... }\end{array}$ \\
\hline Transcrição E2 revisada & COMPREENSÃO|Comunicação|Social|Possiveis Causas para o Aumento|Porque estamos falando mais & $\begin{array}{l}\text { E aí eu fico pensando, né, se, assim, a gente está falando mais porque não sei se } \\
\text { tem mais casos ou não e quem passa a entender que isso é uma realidade por que } \\
\text { passou consegue falar do assunto. Porque, será que a gente tá falando mais ou } \\
\text { tem mais casos e as pessoas entendeu, que vivem isso estão, sabe porque aquilo } \\
\text { que eu falei na sessão passada: Pra mim o suicídio só se torna real na sua vida } \\
\text { depois que você realmente... porque se não, acho que é uma coisa.. }\end{array}$ \\
\hline Transcrição E2 revisada & CONSCIENTIZAÇÃO|Consciência|Epidemiologia (20)\Aumento da consciência pelo numero de casos & a gente está falando mais porque não sei se tem mais casos \\
\hline Transcrição E2 revisada & CONSCIENTIZAÇÃO|Consciência|Epidemiologia (20)\Aumento da consciência pelo numero de casos & Porque, será que a gente tá falando mais ou tem mais casos e \\
\hline
\end{tabular}

Material integrante da pesquisa de doutorado de Karen Scavacini - USP Proibida a reprodução ou utilização sem autorização do autor - 2018 


\begin{tabular}{|c|c|c|}
\hline Transcrição E2 revisada & COMPREENSÃO|Experiência\O viver|Quem viveu (5)\Depois do suicídio|Dando atenção porque passou pela experiência & $\begin{array}{l}\text { ou não e quem passa a entender que isso é uma realidade por que passou } \\
\text { consegue falar do assunto. }\end{array}$ \\
\hline Transcrição E2 revisada & COMPREENSÃO\Experiência\O viver|Quem viveu (5)\Depois do suicídio\Dando atenção porque passou pela experiência & $\begin{array}{l}\text { e as pessoas entendeu, que vivem isso estão, sabe porque aquilo que eu falei na } \\
\text { sessão passada: Pra mim o suicídio só se torna real na sua vida depois que você } \\
\text { realmente... porque se não, acho que é uma coisa.. }\end{array}$ \\
\hline Transcrição E2 revisada & COMPREENSÃo|Visão|Causa Mortis (9)|Visão infantil\A visão do suicídio para a criança & $\begin{array}{l}\text { Até você estava falando, eu lembrei que a minha melhor amiga, a tia dela tinha } \\
\text { tentado e quando eu era menor eu acho que fiquei sabendo dessa história, mas eu } \\
\text { nem achei nada a respeito. Sabe quando você nem... acha que é grave, nem que } \\
\text { não acha nada. }\end{array}$ \\
\hline Transcrição E2 revisada & COMPREENSÃO|Visão|Causa Mortis (9)|Visão infantill\A visão do suicídio para a criança & $\begin{array}{l}\text { É como se fosse uma... eu acho que ... me lembro a primeira vez que eu falei } \\
\text { alguma coisa sobre isso com alguém, eu devia ter uns } 13 / 14 \text { anos porque a esposa } \\
\text { do meu tio tinha acabado de se suicidar... eu tinha é uns } 12 \text { anos quando ela fez } \\
\text { isso, a esposa do meu tio. Ela era nova tal mas eu falei assim como se fosse a } \\
\text { mesma coisa que ela tivesse morrido do coração e aí me arregalaram o olho, }\end{array}$ \\
\hline Transcrição E2 revisada & COMPREENSÃO\Experiência\O viver|Quem viveu (5)\Depois do suicídio|Dando atenção porque passou pela experiência & $\begin{array}{l}\text { Mas hoje, quando ela me conta eu falou: "Nossa!" eu entendo mas porque agora } \\
\text { eu passei. Então eu não sei se..., }\end{array}$ \\
\hline Transcrição E2 revisada & COMPREENSÃO|Comunicação|Social|Possiveis Causas para o Aumento|Porque estamos falando mais & $\begin{array}{l}\text { O que está fazendo com que as pessoas falem mais. Será que é porque temos mais } \\
\text { casos e elas passaram a enxergar isso como putz acontece, ou...qualquer ser } \\
\text { humano consegue falar mais sobre isso }\end{array}$ \\
\hline Transcrição E2 revisada & CONSCIENTIZAÇÃO|Consciência\Epidemiologia (20)\Aumento da consciência pelo numero de casos & $\begin{array}{l}\text { O que está fazendo com que as pessoas falem mais. Será que é porque temos mais } \\
\text { casos e elas passaram a enxergar isso como putz acontece, }\end{array}$ \\
\hline Transcrição E2 revisada & COMPREENSÃO|Comunicação|Social|Possíveis Causas para o AumentolQualquer pessoa fala sobre isso & qualquer ser humano consegue falar mais sobre isso \\
\hline Transcrição E2 revisada & COMPREENSÃo|Comunicação|Social|Possíveis Causas para o Aumento|Qualquer pessoa fala sobre isso & $\begin{array}{l}\text { Porque eu não sei se as pessoas têm empatia e elas estão falando: "Noooossa, } \\
\text { realmente, assim, uau!" }\end{array}$ \\
\hline Transcrição E2 revisada & AÇÃO\Diálogo\O falar (23)\O que (MENSAGEM)\Temas\Criar empatia\Empatia & $\begin{array}{l}\text { Porque eu não sei se as pessoas têm empatia e elas estão falando: "Noooossa, } \\
\text { realmente, assim, uau!" }\end{array}$ \\
\hline Transcrição E2 revisada & COMPREENSÃO\Experiência|O viver|Quem não viveu (6)\Quem não viveu falando do suicídio como absurdo ou piada & $\begin{array}{l}\text { Mas se não é algo...Porque não é um assunto assim tão... Por exemplo, você esta } \\
\text { na roda de amigos, ninguém fica falando sobre isso. Ou tem gente que ainda faz } \\
\text { brincadeira, sabe? }\end{array}$ \\
\hline Transcrição E2 revisada & COMPREENSÃO\Tabu (1)\Consequências do Tabu\Preconceito|O preconceito levando a não falar\Assunto que as pessoas não falam & $\begin{array}{l}\text { Mas se não é algo...Porque não é um assunto assim tão... Por exemplo, você esta } \\
\text { na roda de amigos, ninguém fica falando sobre isso. Ou tem gente que ainda faz } \\
\text { brincadeira, sabe? }\end{array}$ \\
\hline Transcrição E2 revisada & CONSCIENTIZAÇÃo|Consciência \O absurdo do suicídio|Prevenção x Previsão|A pessoa que se matou não falou & $\begin{array}{l}\text { Eu acho que nem nas nossas experiências, nem eles mesmos nos falaram, nem a } \\
\text { pessoa que está sentindo... }\end{array}$ \\
\hline Transcrição E2 revisada & COMPREENSÃO|Comunicação|Social\Aumento da comunicação|Não vê um aumento no falar sobre o assunto & Eu não vejo esse falar muito também, não. \\
\hline Transcrição E2 revisada & COMPREENSÃO\Experiência\O viver\Quem viveu (5)\Aprende\Achando que vai ser uma bomba & a gente acha que ainda está assim, vai ser uma bomba \\
\hline Transcrição E2 revisada & COMPREENSÃO\Experiência\O viver\Quem viveu (5)\Depois do suicídio\Dor que já passamos & $\begin{array}{l}\text { mas não tão mais como era antigamente, para a gente, porque a gente já passou } \\
\text { por essa dor, estava passando e vai, cada um acaba sentindo... }\end{array}$ \\
\hline Transcrição E2 revisada & COMPREENSÃO\Experiência|O viver|Quem viveu (5)\Antes do suicídio|Se não tivesse acontecido não saberia sobre suicídio & $\begin{array}{l}\text { a gente acaba sentindo que talvez se não tivesse acontecido com a gente a gente } \\
\text { nem saberia sobre isso. }\end{array}$ \\
\hline Transcrição E2 revisada & COMPREENSÃO|Comunicação|Pessoal|Falando abertamente na sociedade & $\begin{array}{l}\text { a gente fala assim, as vezes é normal, mas a gente não esconde, a gente conversa } \\
\text { tal, quem quiser ouvir... }\end{array}$ \\
\hline Transcrição E2 revisada & AÇÃo|Diálogo|Ouvir|Dificuldade dos outros ouvirem sobre suicídio & $\begin{array}{l}\text { aí eles decidem se tem que mudar de assunto, porque... as outras pessoas que } \\
\text { estão do outro lado tão com medo e não querem ouvir.. }\end{array}$ \\
\hline Transcrição E2 revisada & AÇão|Diálogo|Ouvir|A dificuldade está em ouvir e não neles falarem & $\begin{array}{l}\text { a gente fala assim, as vezes é normal, mas a gente não esconde, a gente conversa } \\
\text { tal, quem quiser ouvir... aí eles decidem se tem que mudar de assunto, porque... as } \\
\text { outras pessoas que estão do outro lado tão com medo e não querem ouvir.. } \\
\text { porque acha que né, mas assim, eu também assim, eu acho que.. difíil falar não, } \\
\text { mas ... }\end{array}$ \\
\hline
\end{tabular}

Material integrante da pesquisa de doutorado de Karen Scavacini - USP Proibida a reprodução ou utilização sem autorização do autor - 2018 


\begin{tabular}{|c|c|c|}
\hline Transcrição E2 revisada & COMPREENSÃO|Comunicação|Social|Desafios\A distância entre falar e ajudar é grande & $\begin{array}{l}\text { diminuiu esse tabu mas ao mesmo tempo isso não tem reflexos pra quem tá } \\
\text { passando por esses pensamentos. Isso é uma coisa que eu acho que ainda é um } \\
\text { tema e a distância é grande. }\end{array}$ \\
\hline Transcrição E2 revisada & CONSCIENTIZAÇÃO|Desafios \Impeditivos (18)\Distância grande entre quem perdeu e quem pensa (Distanciamento & $\begin{array}{l}\text { Eu acho que tem uma distância também muito grande, e assim, muito grande } \\
\text { mesmo entre as pessoas que são os familiares, as pessoas próximas de alguém que } \\
\text { se suicidou da pessoa que tem vontade, de que quer, que pensa no assunto, eu } \\
\text { acho que essa distância ela ainda é muito grande }\end{array}$ \\
\hline Transcrição E2 revisada & COMPREENSÃO\Comunicação|Social|Desafios\Falar mais $x$ mudar $x$ ajudar & $\begin{array}{l}\text { porque a gente está falando, eu acho que está se falando muito disso mas eu acho } \\
\text { que não...a um ponto de que ainda dê segurança pra uma pessoa que pensa no } \\
\text { assunto, se sentir à vontade, suficientemente à vontade de tratar esse assunto em } \\
\text { qualquer situação. }\end{array}$ \\
\hline Transcrição E2 revisada & COMPREENSÃO|Comunicação|Social|Desafios\Quem pensa ainda não se sente a vontade de falar & $\begin{array}{l}\text { a um ponto de que ainda dê segurança pra uma pessoa que pensa no assunto, se } \\
\text { sentir à vontade, suficientemente à vontade de tratar esse assunto em qualquer } \\
\text { situação }\end{array}$ \\
\hline Transcrição E2 revisada & CONSCIENTIZAÇÃO\Desafios\Impeditivos (18) \Distância grande entre quem perdeu e quem pensa (Distanciamento & Eu acho que é essa a distância que ainda tá muito grande. \\
\hline Transcrição E2 revisada & COMPREENSÃO|Comunicação|Social|Desafios\Falar mais x mudar x ajudar & $\begin{array}{l}\text { Então, eu acho que, fala-se mais, encontra mais respaldo aí de falar né ninguém, } \\
\text { assim... diminuiu esse tabu mas ao mesmo tempo isso não tem reflexos pra quem } \\
\text { tá passando por esses pensamentos }\end{array}$ \\
\hline Transcrição E2 revisada & COMPREENSÃo|Comunicação|Social|Possiveis Causas para o Aumento|Suicídio como assunto da moda\As pessoas falam de assuntos da & $\begin{array}{l}\text { almoço corporativo, que você sai pra almoçar com as pessoas, elas falam que está } \\
\text { na moda naquele momento. }\end{array}$ \\
\hline Transcrição E2 revisada & COMPREENSÃO|Comunicação|Social|Possíveis Causas para o Aumento|Suicídio como assunto da moda|As pessoas falam de assuntos da & $\begin{array}{l}\text { Então se o problema tá agora na política, eles vão falar no almoço da política, se } \\
\text { são os } 13 \text { porquês da série, eles vão falar da série. }\end{array}$ \\
\hline Transcrição E2 revisada & AÇão|Campanhas (22)\Efeito|Só se preocupa quem tem alguma relação com o que é falado & $\begin{array}{l}\text { Se é a baleia azul, entendeu, as mães vão se preocupar: "Meu Deus e esse negócio } \\
\text { da baleia azul..." mas porque ela tem filhos. Talvez se elas nem filhos tivessem, eu } \\
\text { não sei se elas falariam desse tema aí. Entendeu? }\end{array}$ \\
\hline Transcrição E2 revisada & AÇÃo|Campanhas (22)\Efeito|Só se preocupa quem tem alguma relação com o que é falado & $\begin{array}{l}\text { não sei se falava porque estava na moda, enfim, as pessoas realmente... ou porque } \\
\text { pode ser porque quando é com adolescentes....Putz, eu tenho um filho", né? Estou } \\
\text { criando então pode ser que chegue em mim né, então acho que ela né... vê um } \\
\text { pouco, né? Então não sei se, não dá para... }\end{array}$ \\
\hline Transcrição E2 revisada & COMPREENSÃO|Comunicação|Pessoal|Falar no cotidiano x divulgar & uma é esse dia a dia e a outra é a questão da divulgação \\
\hline Transcrição E2 revisada & COMPREENSÃo|Comunicação|Social|Possiveis Causas para o Aumento|Suicídio como assunto da moda & o que tem de palestra em que a moda do tema é falar sobre o suicídio \\
\hline Transcrição E2 revisada & COMPREENSÃO\Comunicação|Social|Área acadêmica e palestras\Aumento das palestras em universidades & $\begin{array}{l}\text { eu não sou da área mas a minha esposa faz psicologia e eu fico acompanhando a * } \\
\text { em algumas coisas, palestras e tal e então ela já comentou que nesse último ano, } \\
\text { do ano passado para esse ano, o que tem de palestra em que a moda do tema é } \\
\text { falar sobre o suicídio porque antes não se falava né, eu acho que nem disciplina } \\
\text { tem que se fale sobre isso, então, só esse ano já foi 2, e nós estamos perto do meio } \\
\text { do ano né, ou seja 4meses só de aula, veja bem, uma foi em uma universidade } \\
\text { federal, e a outra na (nome de universidade), que é particular também e assim, } \\
\text { muito conceituada, dois cursos bons de psicologia, os dois na semana de } \\
\text { psicologia, esses encontros e os temas eles falavam sobre a questão do suicídio, } \\
\text { Então, assim, ela está só no primeiro semestre, então esse ano ela sentiu... }\end{array}$ \\
\hline Transcrição E2 revisada & COMPREENSÃO\Comunicação|Social|Área acadêmica e palestras\Aumento das palestras em universidades & Quer dizer, os estudantes já tem mais contato que também não tinham antes... \\
\hline Transcrição E2 revisada & COMPREENSÃO\Comunicação|Social\Área acadêmica e palestras\Formação acadêmica & Uma é a questão da formação acadêmica \\
\hline Transcrição E2 revisada & COMPREENSÃO\Tabu (1)\Atitudes que reforçam o tabu|Não é um tema como outro qualquer & $\begin{array}{l}\text { E a outra é essa questão que eu acho que ia estar, como você falou, é um assunto } \\
\text { que você não vai ficar falando, não é um tema como outro qualquer, assim, que as } \\
\text { pessoas vão ficar falando... }\end{array}$ \\
\hline Transcrição E2 revisada & COMPREENSÃo|Comunicação|Social\Aumento da comunicação\A mídia já fala mais & $\begin{array}{l}\text { Mas você pega o programa da Fátima Bernardes, falaram sobre suicídio, e é uma } \\
\text { coisa assim que estão instruindo as pessoas... }\end{array}$ \\
\hline
\end{tabular}

Material integrante da pesquisa de doutorado de Karen Scavacini - USP Proibida a reprodução ou utilização sem autorização do autor - 2018 


\begin{tabular}{|c|c|c|}
\hline Transcrição E2 revisada & AÇÃo|DiálogolO falar (23)\Onde\Mídia pode instruir as pessoas & $\begin{array}{l}\text { Mas você pega o programa da Fátima Bernardes, falaram sobre suicídio, e é uma } \\
\text { coisa assim que estão instruindo as pessoas... }\end{array}$ \\
\hline Transcrição E2 revisada & AÇÃO\Diálogo\O falar (23)\Onde\Mídia pode instruir as pessoas & E que atinge muita gente... \\
\hline Transcrição E2 revisada & AÇÃO\Diálogo\O falar (23)\Onde\Mídia pode instruir as pessoas & Sim, Sim, perfeito... \\
\hline Transcrição E2 revisada & COMPREENSÃO|Comunicação|Social\Aumento da comunicação|A mídia já fala mais & $\begin{array}{l}\text { Então, o que eu te disse é isso, você liga a televisão, você vê um jornal, qualquer } \\
\text { coisa, existe esse tema que antes não existia... }\end{array}$ \\
\hline Transcrição E2 revisada & COMPREENSÃO|Comunicação|Social|Possiveis Causas para o Aumento|O que aumentou foi a relevância do tema & $\begin{array}{l}\text { Talvez não seja a quantidade, mas a importância que estão dando pro tema, não } \\
\text { sei se é porque aumentou ou não aumentou, mas talvez a relevância do tema } \\
\text { tenha aumentado }\end{array}$ \\
\hline Transcrição E2 revisada & CONSCIENTIZAÇÃO|Desafios\Interesses diversos\A mídia não dá importância de graça & E você só dá essa importância, principalmente a mídia, não faz isso de graça... \\
\hline Transcrição E2 revisada & COMPREENSÃO|Comunicação|Social|Famosos e suicídio|Famosos escancaram o suicídio & $\begin{array}{l}\text { ou é porque está tendo mais importância porque é abcd morreram por suicídio e aí } \\
\text { são pessoas que são famosas e tal, e elas dão certa importância que tem a mídia } \\
\text { vai fazer algo que não tem volta. }\end{array}$ \\
\hline Transcrição E2 revisada & AÇÃO\Diálogo\O falar (23)\Onde\Abordar suicídio em novelas & $\begin{array}{l}\text { Deviam abordar em novela esse tema, porque eles abordam tanto transplante de } \\
\text { coração, não sei o que... não estou acompanhando mas parece que essa novela } \\
\text { está rodando no estrangeiro. Nunca que eu me lembre, nunca teve nenhuma } \\
\text { novela que abordasse, assim, depressão as vezes, (falatório).... }\end{array}$ \\
\hline Transcrição E2 revisada & CONSCIENTIZAÇÃO\Desafios \Impeditivos (18)\O suicídio incomoda ao invés de distrair (Gera incomodo) & \begin{tabular}{|l}
$\ddot{E}$ que incomoda as pessoas, ao invés de ser uma distração, vai incomodar as \\
pessoas...
\end{tabular} \\
\hline Transcrição E2 revisada & AÇÃO\Diálogo\O falar (23)\Onde\Abordar suicídio em novelas & $\begin{array}{l}\text { Ou não sei se não pode... antigamente achava que seria incentivo, então, também } \\
\text { não sei pra que lado... teria que ser uma coisa muito cuidadosa, muito... }\end{array}$ \\
\hline Transcrição E2 revisada & AÇÃO\Diálogo\O falar (23)\Onde\Abordar suicídio em novelas & $\begin{array}{l}\text { Mas tem outros temas que super incomodam também, entendeu? Acho que tem } \\
\text { vários temas que eles abordam as vezes nas novelas que também incomodam, eu } \\
\text { não sei também o quanto de um quanto do outro, mas... }\end{array}$ \\
\hline Transcrição E2 revisada & AÇÃO\Campanhas (22)\Setembro amarelo & Foi mais o ano passado que eu senti que estava falando mais, o retrasado... \\
\hline Transcrição E2 revisada & AÇÃO\Campanhas (22) \Setembro amarelo & só fiquei sabendo através do nosso amigo aqui... (referindo-se ao P7) \\
\hline Transcrição E2 revisada & AÇÃO\Campanhas (22)\Outras cores\Outras campanhas com cores & Mas mesmo assim o outubro rosa todo mundo sabe o que é, o maio amarelo... \\
\hline Transcrição E2 revisada & AÇÃO\Campanhas (22)\Outras cores\Outras campanhas com cores & O novembro azul... \\
\hline Transcrição E2 revisada & AÇÃo|Campanhas (22)\Falhas\Quem não participa do assunto não sabe o que é o setembro amare & $\begin{array}{l}\text { uma pessoa que não está, assim, participando do assunto, as pessoas sabem o que } \\
\text { é o setembro amarelo, mas se você perguntar para alguém ninguém sabe o que é. }\end{array}$ \\
\hline Transcrição E2 revisada & AÇÃo|Campanhas (22)।Falhas \Quem não participa do assunto não sabe o que é o setembro amare & Eu também acho que não. Acho que é ainda é muito pouco... \\
\hline Transcrição E2 revisada & AÇÃO\Campanhas (22)|Setembro amarelo & É, mas já foi mais divulgado, esse do ano passado... \\
\hline Transcrição E2 revisada & AÇÃo|Campanhas (22)\Alcance \Divulgação boa se procurava - setembro amarelo & $\begin{array}{l}\text { Pra quem procurava estava divulgado e estava uma divulgação boa mas você } \\
\text { procurando.... }\end{array}$ \\
\hline Transcrição E2 revisada & AÇÃOlCampanhas (22)\Provedores ou Onde\Envolvimento de diversas esferas & $\begin{array}{l}\text { Porque lá em (nome de capital) teve um deputado estadual, que provocou uma } \\
\text { audiência pública na Assembleia e levou o pessoal do CVV, do (nome de Instituto), } \\
\text { levou o pessoal do núcleo da (nome de universidade), da psicologia e tal, já no } \\
\text { intuito de buscar maior ferramenta do poder público, do governo do Estado, né? } \\
\text { Da secretaria de Saúde pra essa problemática. }\end{array}$ \\
\hline Transcrição E2 revisada & CONSCIENTIZAÇÃO|Desafios\Interesses diversos\Aumento do interesse em dar visibilidade do tema & $\begin{array}{l}\text { Então ele já começou a fazer isso, e assim, começam os movimentos né, é, estão } \\
\text { começando e foi muito assim, difíil, porque a gente participou muito então a } \\
\text { gente acaba, nosso dever público é tão bom que você acaba engajado né, mas eu } \\
\text { acho que esse também vai ser, assim, já começou né.. }\end{array}$ \\
\hline
\end{tabular}




\begin{tabular}{|c|c|c|}
\hline Transcrição E2 revisada & AÇÃolCampanhas (22)\Provedores ou Onde|Envolvimento do poder publico & $\begin{array}{l}\text { Porque lá em (nome de capital) teve um deputado estadual, que provocou uma } \\
\text { audiência pública na Assembleia e levou o pessoal do CVV, do (nome de Instituto), } \\
\text { levou o pessoal do núcleo da (nome de universidade), da psicologia e tal, já no } \\
\text { intuito de buscar maior ferramenta do poder público, do governo do Estado, né? } \\
\text { Da secretaria de Saúde pra essa problemática. Então ele já começou a fazer isso, e } \\
\text { assim, começam os movimentos né, é, estão começando e foi muito assim, difícil, } \\
\text { porque a gente participou muito então a gente acaba, nosso dever público é tão } \\
\text { bom que você acaba engajado né, mas eu acho que esse também vai ser, assim, já } \\
\text { começou né.. }\end{array}$ \\
\hline Transcrição E2 revisada & AÇÃO\Campanhas (22)\Alcance\Quem recebe a informação é quem procura & $\begin{array}{l}\text { Você acha que por enquanto quem recebe a informação é aquele que procura, ela } \\
\text { não é uma informação ainda que ela chega para todas as pessoas... }\end{array}$ \\
\hline Transcrição E2 revisada & AÇã̃o|Campanhas (22)\Alcance|Divulgação boa se procurava - setembro amarelo & $\begin{array}{l}\text { Se a gente procura a gente acha coisa e acha coisa muito interessante, agora, não é } \\
\text { uma coisa que chega em você. }\end{array}$ \\
\hline Transcrição E2 revisada & COMPREENSÃO|Comunicação|Social|Possiveis Causas para o Aumento|Acesso a informação & $\begin{array}{l}\text { Isso, se a gente procura a gente acha coisa e acha coisa muito interessante, agora, } \\
\text { não é uma coisa que chega em você. V }\end{array}$ \\
\hline Transcrição E2 revisada & CONSCIENTIZAÇÃO|Consciência\Aumento da Consciência (19)〈Condição & "Nossa! existia esse assunto!" ... \\
\hline Transcrição E2 revisada & AÇÃo|Campanhas (22)\Outras cores\Comparação com as cores & $\begin{array}{l}\text { Mas por exemplo, o maio amarelo, que é do trânsito. Todo mundo...é uma coisa } \\
\text { que você percebe... }\end{array}$ \\
\hline Transcrição E2 revisada & COMPREENSÃO|Comunicação|Social|Possiveis Causas para o Aumento|Acesso a informação & $\begin{array}{l}\text { assim, aquele repórter da Globo, o André Trigueiro... ele tem uma palestra desde } \\
2012 \text {, que eu vi, outro dia eu fui numa palestra dele, que ele veio em São Paulo, foi } \\
\text { ótimo, mas ele tem, desde } 2012 \text { que ele fala sobre o tema e eu não sabia, quer } \\
\text { dizer, foi pesquisando na internet, você vê, uma pessoa da globo e ninguém } \\
\text { comenta nada, e ninguém faz isso fora o André Trigueiro. Uma palestra excelente } \\
\text { dele. }\end{array}$ \\
\hline Transcrição E2 revisada & AÇÃO\Diálogo\O falar (23)\Quem\Famosos\Figura publica que fala sobre suicídio & $\begin{array}{l}\text { assim, aquele repórter da Globo, o André Trigueiro... ele tem uma palestra desde } \\
\text { 2012, que eu vi, outro dia eu fui numa palestra dele, que ele veio em São Paulo, foi } \\
\text { ótimo, mas ele tem, desde } 2012 \text { que ele fala sobre o tema e eu não sabia, quer } \\
\text { dizer, foi pesquisando na internet, você vê, uma pessoa da globo e ninguém } \\
\text { comenta nada, e ninguém faz isso fora o André Trigueiro. Uma palestra excelente } \\
\text { dele. }\end{array}$ \\
\hline Transcrição E2 revisada & COMPREENSÃO|Comunicação|Social|Famosos e suicídio|Imaginário popular sobre famosos & $\begin{array}{l}\text { assim, aquele repórter da Globo, o André Trigueiro... ele tem uma palestra desde } \\
\text { 2012, que eu vi, outro dia eu fui numa palestra dele, que ele veio em São Paulo, foi } \\
\text { ótimo, mas ele tem, desde } 2012 \text { que ele fala sobre o tema e eu não sabia, quer } \\
\text { dizer, foi pesquisando na internet, você vê, uma pessoa da globo e ninguém } \\
\text { comenta nada, e ninguém faz isso fora o André Trigueiro. Uma palestra excelente } \\
\text { dele. }\end{array}$ \\
\hline Transcrição E2 revisada & COMPREENSÃO|Comunicação|Social|Desafios\Mídia que poda assuntos e jornalistas & Ele sempre faz André, sem ser o André da Globo, que ele quer ser livre... \\
\hline Transcrição E2 revisada & COMPREENSÃO\Comunicação|Pessoal\O falar como uma causa/bandeira\Desejo pessoal em falar sobre o assunto & Ele sempre faz André, sem ser o André da Globo, que ele quer ser livre... \\
\hline Transcrição E2 revisada & COMPREENSÃO|Comunicação|Social|Canais virtuais\Informações disponiveis na internet & Peguei na internet também \\
\hline Transcrição E2 revisada & COMPREENSÃO\Comunicação|Social|Famosos e suicídio|Surpresa pelo jornalista & $\begin{array}{l}\text { Me surpreendi porque eu já gostava dele como repórter, tal, mas eu nunca } \\
\text { imaginei que ele falasse sobre o tema.. }\end{array}$ \\
\hline Transcrição E2 revisada & AÇÃO|Campanhas (22)\Marketing amarelo|Setembro amarelo para cumprir protocolo & $\begin{array}{l}\text { Aí eu fico me questionando, será que muitas vezes a campanha não é apenas pra } \\
\text { cumprir o protocolo? }\end{array}$ \\
\hline Transcrição E2 revisada & AÇÃO|Campanhas (22)\Marketing amarelo|Existe um engajamento verdadeiro? & Será que ela acontece de verdade? \\
\hline Transcrição E2 revisada & AÇÃO\Campanhas (22)\Campanha $x$ falar\É mais fácil fazer campanha que falar sobre o assunto & $\begin{array}{l}\text { Eu vou citar um exemplo muito prático: Minha cunhada é assistente social numa } \\
\text { unidade de saúde, o ano passado no Facebook apareceu ela com o lacinho amarelo } \\
\text { com toda a turma fazendo pose, tá, ela nunca conversou comigo sobre o assunto. }\end{array}$ \\
\hline
\end{tabular}




\begin{tabular}{|c|c|c|}
\hline Transcrição E2 revisada & AÇÃOICampanhas (22) (Provedores ou OndelCampanha nas redes sociais & $\begin{array}{l}\text { Eu vou citar um exemplo muito prático: Minha cunhada é assistente social numa } \\
\text { unidade de saúde, o ano passado no Facebook apareceu ela com o lacinho amarelo } \\
\text { com toda a turma fazendo pose, tá, ela nunca conversou comigo sobre o assunto. }\end{array}$ \\
\hline Transcrição E2 revisada & AÇÃO|Campanhas (22)\Campanha $x$ falar|É mais fácil fazer campanha que falar sobre o assunto & $\begin{array}{l}\text { não, essa é a outra que contou que o filhinho né, mas contou para o filho depois de } \\
\text { algum tempo, no começo ela não tocou no assunto, ela nunca conversou comigo } \\
\text { sobre o assunto. }\end{array}$ \\
\hline Transcrição E2 revisada & COMPREENSÃO|Comunicação|Pessoal|Falando abertamente na sociedade|Estando aberta para falar & $\begin{array}{l}\text { Nunca, e assim, ela sabe que eu tenho, que eu sou aberta para qualquer tipo de } \\
\text { assunto. }\end{array}$ \\
\hline Transcrição E2 revisada & COMPREENSÃo|Comunicação|Pessoal|Dificuldades comunicação familiar|Não falando do assunto em família & $\begin{array}{l}\text { não, essa é a outra que contou que o filhinho né, mas contou para o filho depois de } \\
\text { algum tempo, no começo ela não tocou no assunto, ela nunca conversou comigo } \\
\text { sobre o assunto. }\end{array}$ \\
\hline Transcrição E2 revisada & COMPREENSÃO|Comunicação|Pessoal|Dificuldades comunicação familiar|Falta de comunicação & Não sei se a dor dela está tão violenta, não sei o que se passa na cabeça dela. \\
\hline Transcrição E2 revisada & AÇÃO\Campanhas (22)\Marketing amarelo|Sentindo falta de ser incluída na campanha pela cunhada & $\begin{array}{l}\text { E, o que você acha? O que eu posso fazer pra ajudar? Você conhece algum } \\
\text { órgão?". Não. É como se fosse um assunto que não me diz respeito... }\end{array}$ \\
\hline Transcrição E2 revisada & AÇÃO|Campanhas (22)\CapacitaçãolÉ preciso conhecimento para falar & .. deveria ter algum conhecimento... \\
\hline Transcrição E2 revisada & AÇÃO\Campanhas (22)\Capacitação\É preciso conhecimento para falar & $\begin{array}{l}\text { Acolhimento né... e ela sabe que eu sou engajada, ela sabe que eu participo de } \\
\text { muita coisa }\end{array}$ \\
\hline Transcrição E2 revisada & AÇÃo|Campanhas (22)\CapacitaçãolÉ preciso conhecimento para falar & $\begin{array}{l}\text { de alguma maneira participando, engajado em alguma coisa é de pelo menos ter } \\
\text { um...Se a pessoa vai te perguntar pelo menos saber como ajudar, como te acolher. }\end{array}$ \\
\hline Transcrição E2 revisada & AÇÃO\Campanhas (22)\Marketing amarelo|Cumprindo protocolo & Cumpre o protocolo, sei lá. Cumpre o amarelo. \\
\hline Transcrição E2 revisada & AÇÃO\Campanhas (22)\Marketing amarelo|Cumprindo protocolo & Tira foto, posta no Facebook e acabou... \\
\hline Transcrição E2 revisada & AÇÃO\Campanhas (22)\Marketing amarelo|Cumprindo protocolo & Estamos cumprindo o programa de setembro... \\
\hline Transcrição E2 revisada & AÇÃO\Campanhas (22)\Marketing amarelo\Marketing amarelo & $\begin{array}{l}\text { Tem muitas empresas que são assim, se engajam mas não repassam para os seus } \\
\text { funcionários, os seus colaboradores, aquela importância, dá um papelzinho, dá } \\
\text { uma fitinha para colocar na camisa, mas agora vai... volta a trabalhar então, mas } \\
\text { coloca lá estampado que está dando o apoio, não sei o que lá... mas não, não... } \\
\text { leva um profissional, nada... }\end{array}$ \\
\hline Transcrição E2 revisada & AÇÃo|Campanhas (22)\Marketing amarelo|Campanha sem conscientização & $\begin{array}{l}\text { Tem muitas empresas que são assim, se engajam mas não repassam para os seus } \\
\text { funcionários, os seus colaboradores, aquela importância, dá um papelzinho, dá } \\
\text { uma fitinha para colocar na camisa, mas agora vai... volta a trabalhar então, mas } \\
\text { coloca lá estampado que está dando o apoio, não sei o que lá... mas não, não... } \\
\text { leva um profissional, nada... }\end{array}$ \\
\hline Transcrição E2 revisada & AÇÃO\Campanhas (22)\Marketing amarelo|Marketing amarelo & Marketing que ele vende como conscientização.... uma coisa muito vazia né \\
\hline Transcrição E2 revisada & AÇÃO\Campanhas (22)\Marketing amarelo|Marketing amarelo & Uma ação de marketing com o nome de conscientização \\
\hline Transcrição E2 revisada & AÇÃo|Campanhas (22)\Setembro amarelo|Participando de várias ações do setembro amarelo & $\begin{array}{l}\text { No ano passado no setembro amarelo eu estava trabalhando no CVV, então } \\
\text { houveram várias ações que foram em metrô, escolas e a gente podia trabalhar } \\
\text { como voluntário. }\end{array}$ \\
\hline Transcrição E2 revisada & COMPREENSÃO\Experiência|O viver|Quem viveu (5)\Depois do suicídio|Nosso olhar fica diferente & $\begin{array}{l}\text { Só que é assim, a percepcão que eu tive, foi um pouco do que ela falou. Acho que } \\
\text { foi você que falou, assim, que, quando a gente passa, o nosso olhar fica diferente. }\end{array}$ \\
\hline Transcrição E2 revisada & COMPREENSÃO\Experiência|O viver|Quem viveu (5)\Depois do suicídio|Nosso olhar fica diferente & $\begin{array}{l}\text { Quando a gente está envolvido no assunto, a gente tende a enxergar mais. Quando } \\
\text { a gente não está e aquele assunto é um tabu, no caso, não só a gente não repara } \\
\text { como é um ponto cego }\end{array}$ \\
\hline Transcrição E2 revisada & CONSCIENTIZAÇÃo|Consciência|Complexidade\A exclusão da tristeza|Assuntos ponto cego & $\begin{array}{l}\text { Quando a gente não está e aquele assunto é um tabu, no caso, não só a gente não } \\
\text { repara como é um ponto cego }\end{array}$ \\
\hline Transcrição E2 revisada & COMPREENSÃO\Comunicação|Social\Aumento da comunicação\A mídia já fala mais & A referência que eu uso é que tem coisa que está na mídia, está sendo falada. \\
\hline Transcrição E2 revisada & AÇÃO\Campanhas (22)\Campanha $x$ falar|Relações pessoais ainda não falam mais & Mas a minha vivência nas relações pessoais não é de mais abertura de falar. \\
\hline Transcrição E2 revisada & AÇÃO\Campanhas (22)\Campanha x falar|Não achando ninguém para falar sobre o assunto & $\begin{array}{l}\text { Eu tive muita dificuldade, assim, eu não, eu tive momentos que eu não tinha nem } \\
\text { uma pessoa pra falar sobre o assunto. Nem uma }\end{array}$ \\
\hline
\end{tabular}

Material integrante da pesquisa de doutorado de Karen Scavacini - USP Proibida a reprodução ou utilização sem autorização do autor - 2018 


\begin{tabular}{|c|c|c|}
\hline Transcrição E2 revisada & COMPREENSÃO|Comunicação|Pessoal|Reações|Negativas|Falta de suporte e agressão|Solidão & $\begin{array}{l}\text { Eu tive muita dificuldade, assim, eu não, eu tive momentos que eu não tinha nem } \\
\text { uma pessoa pra falar sobre o assunto. Nem uma. Então, eu mesmo ligava no CVV. } \\
\text { Foi assim que eu acabei virando voluntário. }\end{array}$ \\
\hline Transcrição E2 revisada & COMPREENSÃO\Tabu (1)\Consequências do Tabu\Estigma|Preconceito e estigma em falar do assunto & $\begin{array}{l}\text { Eu acho que assim, muitas campanhas esbarram no estigma, porque falar sobre o } \\
\text { assunto, eu acredito, isso eu percebi, assim né, que a pessoa que toca no assunto, } \\
\text { ela sofre um preconceito de falar à respeito disso. É diferente, por exemplo, sei lá, } \\
\text { falar de infarto, doença do coração. Se você estiver numa roda de amigos, como } \\
\text { você falou, você pode trazer esse assunto e não vai ter preconceito. Ah eu estou } \\
\text { indo em numa academia... agora se você entra no tema do suicídio a pessoa: "Não, } \\
\text { mas você tá pensando..."e aí você... existe um estigma que atrapalha. }\end{array}$ \\
\hline Transcrição E2 revisada & CONSCIENTIZAÇÃO|Consciência|Complexidade\Assunto proibido|Assuntos permitidos & $\begin{array}{l}\text { É diferente, por exemplo, sei lá, falar de infarto, doença do coração. Se você estiver } \\
\text { numa roda de amigos, como você falou, você pode trazer esse assunto e não vai } \\
\text { ter preconceito. Ah eu estou indo em numa academia... }\end{array}$ \\
\hline Transcrição E2 revisada & CONSCIENTIZAÇÃO|ConsciêncialComplexidade\Ditadura da alegria|Efeito Facebook & $\begin{array}{l}\text { eu acho que tem um problema grande, que na minha opinião né, começa assim, } \\
\text { com a tristeza, tem um preconceito que é, falando um pouco do efeito Facebook. } \\
\text { Todo mundo quer aparecer feliz ou parecer feliz. }\end{array}$ \\
\hline Transcrição E2 revisada & 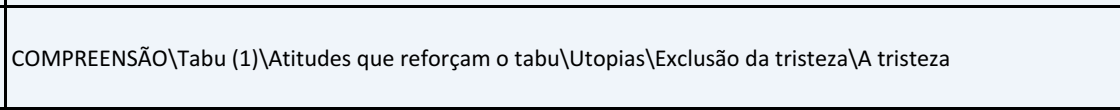 & $\begin{array}{l}\text { eu acho que tem um problema grande, que na minha opinião né, começa assim, } \\
\text { com a tristeza, tem um preconceito que é, falando um pouco do efeito Facebook. } \\
\text { Todo mundo quer aparecer feliz ou parecer feliz. }\end{array}$ \\
\hline Transcrição E2 revisada & CONSCIENTIZAÇÃO|Consciência|Complexidade\A exclusão da tristeza|Preconceito começa na tristeza & $\begin{array}{l}\text { Daí, desse, a tristeza ser preconceito vem a morte, o luto, suicídio... vem tudo } \\
\text { atrelado. Então, qualquer pessoa que começa a trazer o assunto que é considerado } \\
\text { triste... mas isso já é uma coisa interna, acho que da nossa cultura. }\end{array}$ \\
\hline Transcrição E2 revisada & CONSCIENTIZAÇÃO|Consciência|Complexidade|Por onde começar|Sentir tristeza é saudável e normal & $\begin{array}{l}\text { Você acha que começar a abordar, que todo mundo sente tristeza em algum } \\
\text { momento? Tem como alguém... }\end{array}$ \\
\hline Transcrição E2 revisada & CONSCIENTIZAÇão|Consciência|Complexidade|Por onde começar|Sentir tristeza é saudável e normal & Sim, como algo natural, como algo natural. \\
\hline Transcrição E2 revisada & CONSCIENTIZAÇÃO|Consciência|Complexidade|Por onde começar|Sentir tristeza é saudável e normal & $\begin{array}{l}\begin{array}{l}\text { Não já como depressão, mas como: tristeza é uma coisa normal que todos nós } \\
\text { sentimos }\end{array} \\
\end{array}$ \\
\hline Transcrição E2 revisada & CONSCIENTIZAÇÃO|Consciência|Complexidade|Por onde começar|Sentir tristeza é saudável e normal & Isso! Como algo saudável. \\
\hline Transcrição E2 revisada & CONSCIENTIZAÇÃo|Consciência|Complexidade\A exclusão da tristeza|Preconceito começa na tristeza & $\begin{array}{l}\text { Enquanto não tiver isso... então qualquer assunto... vamos supor: se eu chegar } \\
\text { num churrasco, está todo mundo tomando cerveja, e eu falar "Ah, estou indo } \\
\text { numa academia. Poxa, me matriculei eu vou." todo mundo fala numa boa. Mas, se } \\
\text { falar: "Putz, eu ando meio triste, eu ando meio deprimido"... Ihhh, existe o } \\
\text { isolamento... }\end{array}$ \\
\hline Transcrição E2 revisada & CONSCIENTIZAÇÃO|Consciência|Complexidade\Assunto proibido|Assuntos permitidos & $\begin{array}{l}\text { se eu chegar num churrasco, está todo mundo tomando cerveja, e eu falar "Ah, } \\
\text { estou indo numa academia. Poxa, me matriculei eu vou." todo mundo fala numa } \\
\text { boa. }\end{array}$ \\
\hline Transcrição E2 revisada & CONSCIENTIZAÇÃo|Consciência|Complexidade\Assunto proibido & $\begin{array}{l}\text { Mas, se falar: "Putz, eu ando meio triste, eu ando meio deprimido"... Ihhh, existe o } \\
\text { isolamento... }\end{array}$ \\
\hline Transcrição E2 revisada & CONSCIENTIZAÇão|Consciência|Complexidade\A exclusão da tristeza|Tristeza vista como algo negativo & $\begin{array}{l}\text { É visto como uma coisa negativa, né? Aquela coisa do... aquela pessoa ela é } \\
\text { negativa. }\end{array}$ \\
\hline Transcrição E2 revisada & COMPREENSÃO\Tabu (1)\Consequências do Tabu\Estigma|Estigma atrelado a algumas emoções & Eu acho que existe um estigma atrelado a algumas emoções. \\
\hline Transcrição E2 revisada & CONSCIENTIZAÇÃo|Consciência|Complexidade\A exclusão da tristeza\Assuntos ponto cego & $\begin{array}{l}\text { Eu acho que existe um estigma atrelado a algumas emoções. Enquanto a gente não } \\
\text { resolver isso, o assunto em si ficou um ponto cego da sociedade. Aí as campanhas, } \\
\text { também, é o que eu percebi... }\end{array}$ \\
\hline Transcrição E2 revisada & AÇÃOICampanhas (22)\Falhas\Campanhas não surtem efeito em pontos cegos da sociedade & não surtem efeito... (fala junto) \\
\hline Transcrição E2 revisada & AÇÃO|Cuidar|Grupos de apoio (21)〈Livre arbítrio|Pessoas não querendo participar & $\begin{array}{l}\text { eu estava trabalhando no } \mathrm{CVV} \text {, e eu falei com duas pessoas que tiveram, pessoas } \\
\text { que próximas do suicídio... para participarem do (nome de instituição)... }\end{array}$ \\
\hline Transcrição E2 revisada & AÇÃO|Cuidar|Grupos de apoio (21)〈Livre arbítrio\Achando que o que faz bem para mim fará bem para o outro & $\begin{array}{l}\text { eu estava trabalhando no CVV, e eu falei com duas pessoas que tiveram, pessoas } \\
\text { que próximas do suicídio... para participarem do (nome de instituição)... }\end{array}$ \\
\hline
\end{tabular}

Material integrante da pesquisa de doutorado de Karen Scavacini - USP Proibida a reprodução ou utilização sem autorização do autor - 2018 


\begin{tabular}{|c|c|c|}
\hline Transcrição E2 revisada & AÇÃO\Cuidar|Grupos de apoio (21)\Livre arbítrio|Pessoas não querendo participar & ... não conseguiu levar nenhuma... \\
\hline Transcrição E2 revisada & AÇÃO\Cuidar|Grupos de apoio (21)〈Livre arbítrio\Pessoas não querendo participar & ... eu não consegui levar nenhum. \\
\hline Transcrição E2 revisada & COMPREENSÃO\Tabu (1)\Consequências do Tabu\Afastamento|Reaç̃̃es negativas das pessoas & $\begin{array}{l}\text { Um eu não consegui nem terminar a conversa e outra pessoa parou de falar } \\
\text { comigo. }\end{array}$ \\
\hline Transcrição E2 revisada & COMPREENSÃO\Tabu (1)\Consequências do Tabu\O não falar|Dificuldade de falar sobre o suicídio & Porque é uma dificuldade do assunto. \\
\hline Transcrição E2 revisada & CONSCIENTIZAÇÃO|Desafios \Impeditivos (18)\Medo do preconceito & $\begin{array}{l}\text { Então, a pessoa não quer falar que tem esse problema porque ela vai sofrer o } \\
\text { preconceito e ela não quer falar com você também... }\end{array}$ \\
\hline Transcrição E2 revisada & COMPREENSÃO\Tabu (1)\Consequências do Tabu\O não falar|Dificuldade de falar sobre o suicídio & $\begin{array}{l}\text { Então, a pessoa não quer falar que tem esse problema porque ela vai sofrer o } \\
\text { preconceito e ela não quer falar com você também... }\end{array}$ \\
\hline Transcrição E2 revisada & AÇÃO\Diálogo\O falar (23)\O que (MENSAGEM)\Depressão - A mensagem\Funcionaria se falasse sobre depressão & $\begin{array}{l}\text { Na minha opinião ela funciona, por exemplo, a pessoa que tem, ela ou alguém } \\
\text { próximo que tem depressão que aí é socialmente aceito, falar que a pessoa tem } \\
\text { depressão eu acho que aí funciona... }\end{array}$ \\
\hline Transcrição E2 revisada & AÇÃO\Diálogo\O falar (23)\O que (MENSAGEM)\Ensinar como agir & $\begin{array}{l}\text { Pros familiares, quando você está percebendo alguém ou algum amigo, não só um } \\
\text { familiar né, alguém próximo, como agir. Eu acho que deveria ter um pouco mais, } \\
\text { porque muitas vezes, as vezes alguém que quero ajudar mas eu não sabia como } \\
\text { agir. Nem sei se eu sei hoje se alguém chegar pra mim e falar que: "Ai eu não, eu } \\
\text { não quero mais viver"... Eu não sei, eu ainda nem sei se eu sei o que falar. Eu sei } \\
\text { que eu vou querer ajudar. Vou procurar ajuda, vou tentar levar em algum lugar, } \\
\text { mas agora eu não sei se eu mesma sei o que falar... eu acho que pra gente } \\
\text { conseguir tocar quem tá vendo.... }\end{array}$ \\
\hline Transcrição E2 revisada & AÇÃO\Diálogo\O falar (23)\O que (MENSAGEM)\Ensinar como agir|Sem saber como agir & $\begin{array}{l}\text { Eu acho que deveria ter um pouco mais, porque muitas vezes, as vezes alguém que } \\
\text { quero ajudar mas eu não sabia como agir. }\end{array}$ \\
\hline Transcrição E2 revisada & AÇÃO\Diálogo|O falar (23)\O que (MENSAGEM)\Ensinar como agir|Sem saber o que falar para ajudar & $\begin{array}{l}\text { Nem sei se eu sei hoje se alguém chegar pra mim e falar que: "Ai eu não, eu não } \\
\text { quero mais viver"... Eu não sei, eu ainda nem sei se eu sei o que falar. }\end{array}$ \\
\hline Transcrição E2 revisada & AÇÃO\Diálogo\O falar (23)\O que (MENSAGEM)\Ensinar como agir|Sem saber o que falar para ajudar & $\begin{array}{l}\text { Eu sei que eu vou querer ajudar. Vou procurar ajuda, vou tentar levar em algum } \\
\text { lugar, mas agora eu não sei se eu mesma sei o que falar... eu acho que pra gente } \\
\text { conseguir tocar quem tá vendo.... }\end{array}$ \\
\hline Transcrição E2 revisada & CONSCIENTIZAÇão|Consciência|O absurdo do suicídio|Prevenção x Previsão|A pessoa precisa falar & E precisa a pessoa falar, né? Porque a gente perceber é muito difíiil... \\
\hline Transcrição E2 revisada & CONSCIENTIZAÇÃOIConsciência\O absurdo do suicídio|Prevenção x Previsão\Perceber é difícil & E precisa a pessoa falar, né? Porque a gente perceber é muito difícil... \\
\hline Transcrição E2 revisada & 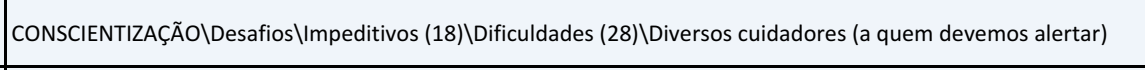 & $\begin{array}{l}\text { é, eu sei lá, alertar ali, mais pais, cuidadores, quem cuida, que hoje em dia nem as } \\
\text { vezes é mais os pais... é avós, tios.... }\end{array}$ \\
\hline Transcrição E2 revisada & AÇÃO\DiálogolO falar (23)\Quem\Adolescentes\Alertar como abordar adolescente & $\begin{array}{l}\text {.. é, ou antes da pessoa, ou se está percebendo... é, eu sei lá, alertar ali, mais pais, } \\
\text { cuidadores, quem cuida, que hoje em dia nem as vezes é mais os pais... é avós, } \\
\text { tios.... mas alertar se tiver alguma coisa como abordar um adolescente, } \\
\text { principalmente acho que adolescente, assim que fica lá mais fechado no quarto, e } \\
\text { tal, mais.. }\end{array}$ \\
\hline Transcrição E2 revisada & 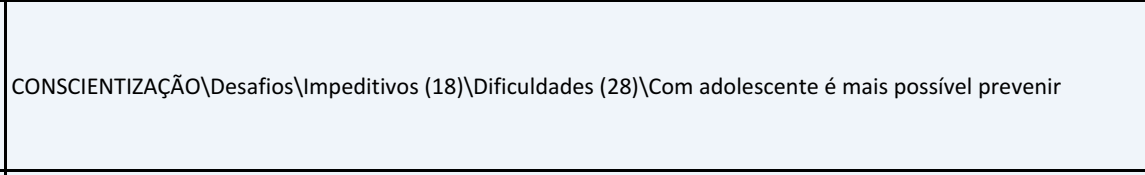 & $\begin{array}{l}\text {.. é, ou antes da pessoa, ou se está percebendo... é, eu sei lá, alertar ali, mais pais, } \\
\text { cuidadores, quem cuida, que hoje em dia nem as vezes é mais os pais... é avós, } \\
\text { tios.... mas alertar se tiver alguma coisa como abordar um adolescente, } \\
\text { principalmente acho que adolescente, assim que fica lá mais fechado no quarto, e } \\
\text { tal, mais.. }\end{array}$ \\
\hline Transcrição E2 revisada & CONSCIENTIZAÇÃO\Consciência\O absurdo do suicídio\O não saber\Adulto camufla mais & $\begin{array}{l}\text { porque o adulto as vezes vai camuflar muito mais, que a gente não precisa nem... } \\
\text { eu acho que quanto mais a idade vai passando, acho que isso aí você não consegue } \\
\text { tirar nada. }\end{array}$ \\
\hline Transcrição E2 revisada & CONSCIENTIZAÇÃO|Consciência|Complexidade|Por onde começar|Dar milhões de passos para traz & $\begin{array}{l}\text { gente tem ainda uma base, um b a bá que a gente tem que dar milhões de passos } \\
\text { pra trás porque assim, pra mim, suicídio é o nível hard, entendeu? }\end{array}$ \\
\hline Transcrição E2 revisada & CONSCIENTIZAÇÃO|Consciência|Complexidade|Onde tudo começa|Suicídio é o final de uma cadeira nivel hard & $\begin{array}{l}\text { gente tem ainda uma base, um b a bá que a gente tem que dar milhões de passos } \\
\text { pra trás porque assim, pra mim, suicídio é o nível hard, entendeu? }\end{array}$ \\
\hline
\end{tabular}




\begin{tabular}{|c|c|c|}
\hline Transcrição E2 revisada & CONSCIENTIZAÇÃO|Consciência|Complexidade|Por onde começar & $\begin{array}{l}\text { E aí, que nem ele estava falando né, da tristeza e tudo. E eu acho que vir muito } \\
\text { ainda, acho que trabalhar muito mais esse tema de tristeza, tal, pra depois chegar } \\
\text { no suicídio }\end{array}$ \\
\hline Transcrição E2 revisada & AÇÃo|Campanhas (22) \Efeito|Campanhas só fazem efeito em quem tem alguma coisa com o tema & \begin{tabular}{|l|} 
E aí eu acho também, que a pessoa, ela só vai passar a se interessar, a campanha \\
só tem efeito naqueles que na essência tem, acho, alguma coisa a ver com o tema.
\end{tabular} \\
\hline Transcrição E2 revisada & AÇÃO\Campanhas (22)\Engajamento\O que me leva a ser engajada no GLBTA & $\begin{array}{l}\text { eu sou envolvida no GLBTA (Gays, lésbicas, Bi, Trans e aliados) e aí assim, quando } \\
\text { eu olho esse grupo, as pessoas que lideram os grupos, normalmente são pessoas } \\
\text { que são ou gays ou lésbicas... no meu caso eu não sou, mas eu estou ainda mais } \\
\text { engajada porque que eu sei que esse é grupo que se suicida. }\end{array}$ \\
\hline Transcrição E2 revisada & AÇÃO|Campanhas (22)\Engajamento|Escondendo o motivo real & $\begin{array}{l}\text { Porque se alguém me perguntar: "Por que você é engajada no (GLBTA)"! Eu falo } \\
\text { que eu quero que cada um possa ser o que ele quer, quero que as pessoas venham } \\
\text { verdadeiramente pra empresa... porque o fato de você não poder ser você, você } \\
\text { deixa o seu você em casa e vem trabalhar. E como eu sei que assim, são várias } \\
\text { pessoas sofrem e cometem suicídio, a verdadeira razão, né, vem um pouco que eu } \\
\text { sei a importância da diversidade, mas pra mim, lá no fim tem a ponta do suicídio. }\end{array}$ \\
\hline Transcrição E2 revisada & AÇÃO\Campanhas (22)\Engajamento\O que me leva a ser engajada no GLBTA & $\begin{array}{l}\text { É que eu acho que cada um, a gente fez um evento na semana passada no } \\
\text { trabalho, e quando eu olho as pessoas que vão, normalmente são pessoas que são } \\
\text { alguma das letras, e o A, que é do aliado, que sou eu, você não vê tantos. }\end{array}$ \\
\hline Transcrição E2 revisada & AÇÃO\Campanhas (22)\Engajamento\Preconceito do engajamento em certo grupo & $\begin{array}{l}\text { Porque aquela coisa de talvez a pessoa pensar: "Ai, vão achar, sei lá, alguma coisa } \\
\text { de mim porque eu estou engajada nesse grupo. }\end{array}$ \\
\hline Transcrição E2 revisada & AÇÃO\Campanhas (22)【Efeito|Campanhas só fazem efeito em quem tem alguma coisa com o tema & $\begin{array}{l}\text { Então eu acho que essa campanha do GLBTA só atinge as pessoas que de alguma } \\
\text { forma se sentem ligadas ao tema. }\end{array}$ \\
\hline Transcrição E2 revisada & AÇÃo|Campanhas (22) \Efeito|Campanhas só fazem efeito em quem tem alguma coisa com o tema & $\begin{array}{l}\text { então, talvez essas campanhas do suicídio, elas só vão atingir quem, na sua } \\
\text { essência, tem alguma ligação com o tema. Se não ela passa desapercebida. }\end{array}$ \\
\hline Transcrição E2 revisada & AÇÃO\Campanhas (22)\Engajamento\Pessoas não querem se engajar em certos temas & $\begin{array}{l}\text { Tanto que a gente fica lá tentando engajar as pessoas pra ir no GLBTA, e assim, tipo } \\
\text { as pessoas não vão. São raras. São raras. }\end{array}$ \\
\hline Transcrição E2 revisada & AÇÃO\Campanhas (22)\Engajamento|Líderes obrigados a se engajarem & $\begin{array}{l}\text { Aí lógico já tem vários líderes que vão porque, tipo, eles tem que ir, eles tem que } \\
\text { liderar pelo exemplo, você tem que ir... então eu não sei se não tivesse talvez um } \\
\text { pouco disso de ser um exemplo, de ter que cumprir com isso, se aquelas pessoas } \\
\text { iriam, }\end{array}$ \\
\hline Transcrição E2 revisada & AÇÃO\Campanhas (22)\Engajamento|Se engaja quem tem proposito & $\begin{array}{l}\text { e aí eu não sei se por exemplo os jovens, por ser um grupo que tem um propósito, } \\
\text { eles acabam se engajando também. }\end{array}$ \\
\hline Transcrição E2 revisada & AÇÃO\Campanhas (22)\Engajamento|Se engaja quem tem proposito & $\begin{array}{l}\text { Então é um fato interessante: eu não sei se eles se engajam porque eles tem a ver } \\
\text { com algumas das letras ou porque na essência tem algo, ali, ou se é porque coisas } \\
\text { com propósitos, e eu vejo que é uma coisa que as novas gerações elas trazem isso }\end{array}$ \\
\hline Transcrição E2 revisada & AÇÃ̃OSSemear|Facilitadores (29)|Busca de proposito & $\begin{array}{l}\text { exemplo os jovens, por ser um grupo que tem um propósito, eles acabam se } \\
\text { engajando também. Então é um fato interessante: eu não sei se eles se engajam } \\
\text { porque eles tem a ver com algumas das letras ou porque na essência tem algo, ali, } \\
\text { ou se é porque coisas com propósitos, e eu vejo que é uma coisa que as novas } \\
\text { gerações elas trazem isso. Que nem, por exemplo, a busca por um emprego que } \\
\text { tenha um propósito maior. }\end{array}$ \\
\hline Transcrição E2 revisada & CONSCIENTIZAÇÃO|Consciência|Complexidade\Por onde começar|Trazer a conexão pelo comum - a tristeza & $\begin{array}{l}\text { Então acho que a questão das campanhas do suicídio é essa: é primeiro eu tenho } \\
\text { que trabalhar lá atrás, né, a questão do sentimento. E talvez, se a gente trouxer } \\
\text { isso através dessa base, as pessoas se conectem mais porque elas vão falar, nossa, } \\
\text { isso que é um assunto que tem a ver comigo. Eu também sinto tristeza. Eu também } \\
\text { às vezes estou triste. }\end{array}$ \\
\hline Transcrição E2 revisada & AÇÃo|Campanhas (22)\Efeito\Efeito pela empatia & Talvez elas surtiriam mais efeito quando você sente a empatia \\
\hline
\end{tabular}

Material integrante da pesquisa de doutorado de Karen Scavacini - USP Proibida a reprodução ou utilização sem autorização do autor - 2018 


\begin{tabular}{|c|c|c|}
\hline Transcrição E2 revisada & AÇÃO\Campanhas (22)\EngajamentolO que leva alguém a se engajar & $\begin{array}{l}\text { porque hoje em grandes campanhas, normalmente, que nem essa do transito, né, } \\
\text { não sei, se as pessoas que perderam alguém, assim são as mais engajadas... O que } \\
\text { leva alguém a se engajar? Eu não sei }\end{array}$ \\
\hline Transcrição E2 revisada & AÇÃo|Campanhas (22) \Identificação|Campanhas que não presto atenção & $\begin{array}{l}\text { Essa do Trânsito pra mim é uma que eu não presto muita a atenção. Sei que ela } \\
\text { existe mas assim, pra mim é X. Também passa desapercebida. Eu não sei se tem } \\
\text { isso, entendeu? }\end{array}$ \\
\hline Transcrição E2 revisada & AÇÃO\Campanhas (22)\Engajamento|Engajamento por motivo pessoal & $\begin{array}{l}\text { De ter que ter algo, assim, pessoal pra você se engajar naquele tema... que é } \\
\text { aquilo: suicídio só passa a ser realidade, você só presta atenção, quando você de } \\
\text { alguma maneira tem a ver com aquilo }\end{array}$ \\
\hline Transcrição E2 revisada & AÇÃO\Campanhas (22) \nfluêncialCampanha bem feita mexe comigo & $\begin{array}{l}\text { Essa campanha do trânsito mexe muito comigo apesar de eu não ter ninguém, mas } \\
\text { tá muito bem feita }\end{array}$ \\
\hline Transcrição E2 revisada & AÇÃo|Campanhas (22)\Temas\Campanha que mexe com a emoção & $\begin{array}{l}\text { É uma moça que ficou paralítica e ela ficou falando do quanto mudou a vida dela } \\
\text { depois desse acidente. É uma coisa muito.. presta a atenção é linda a campanha, } \\
\text { emocionante. Aquilo mexe comigo apesar de eu não ter nada a ver, mas é uma } \\
\text { coisa muito bonita e mexe com as pessoas... }\end{array}$ \\
\hline Transcrição E2 revisada & AÇÃo|Campanhas (22)\Temas\Campanha sendo falada por quem passou & $\begin{array}{l}\text { É uma moça que ficou paralítica e ela ficou falando do quanto mudou a vida dela } \\
\text { depois desse acidente. }\end{array}$ \\
\hline Transcrição E2 revisada & AÇÃO\Diálogo\O falar (23)\O que (MENSAGEM)\Ansiedade\Falar sobre a ansiedade & $\begin{array}{l}\text { Não só a depressão, mas a ansiedade, eu acho que é uma coisa muito pesada, pelo } \\
\text { menos deve ter sido o meu caso. A pessoa não sabe lidar com essa ansiedade. Eu } \\
\text { acho que nem foi depressão, foi ansiedade. É uma coisa que ninguém fala. Eu acho } \\
\text { que nas campanhas deve ser falado pras pessoas se tocarem... o quanto isso } \\
\text { também incomoda. Não só depressão. }\end{array}$ \\
\hline Transcrição E2 revisada & AÇÃO\Diálogo\O falar (23)\O que (MENSAGEM)\Ansiedade\Acho que meu caso foi ansiedade & eu acho que é uma coisa muito pesada, pelo menos deve ter sido o meu caso \\
\hline Transcrição E2 revisada & COMPREENSÃO\Tabu (1)\O tabu em diversas esferas\Transtornos mentais|Ninguém fala sobre ansiedade & É uma coisa que ninguém fala \\
\hline Transcrição E2 revisada & AÇÃO\Campanhas (22)\Identificação\Para quem a campanha funciona & $\begin{array}{l}\text { a minha vivência é que eu percebi que as campanhas, elas funcionam bem pra } \\
\text { quem não tem a informação e tenha uma realidade próxima de depressão. }\end{array}$ \\
\hline Transcrição E2 revisada & AÇÃO\Campanhas (22)\Temas\Campanhas informativas & $\begin{array}{l}\text { Porque aí a pessoa fala: "Puxa, eu não sei como lidar, isso pode levar ao suicídio e } \\
\text { aí não sabia nem que encaminhamento fazer. Não sabia que existia o CVV, não } \\
\text { sabia que as vezes é necessário a medicação, a busca de um profissional. Nisso eu } \\
\text { acho que as campanhas funcionam. Porque a pessoa se identifica. }\end{array}$ \\
\hline Transcrição E2 revisada & AÇÃo|Campanhas (22) \Identificação\A pessoa precisa se identificar com a campanha & $\begin{array}{l}\text { Porque aí a pessoa fala: "Puxa, eu não sei como lidar, isso pode levar ao suicídio e } \\
\text { aí não sabia nem que encaminhamento fazer. Não sabia que existia o CVV, não } \\
\text { sabia que as vezes é necessário a medicação, a busca de um profissional. Nisso eu } \\
\text { acho que as campanhas funcionam. Porque a pessoa se identifica. }\end{array}$ \\
\hline Transcrição E2 revisada & CONSCIENTIZAÇÃO|Consciência|ComplexidadelOnde tudo começa|A soma de pequenas coisas & $\begin{array}{l}\text { Aonde eu acho que elas falham, aí é uma visão minha também de leigo: Eu tenho a } \\
\text { impressão que existem alguns casos, assim, de suicídio, que não tem a ver com } \\
\text { uma depressão caracterizada, que é assim, a soma de um monte de pequenas } \\
\text { coisas: }\end{array}$ \\
\hline Transcrição E2 revisada & CONSCIENTIZAÇÃo|Consciência|Complexidade|Onde tudo começa|A soma de pequenas coisas & $\begin{array}{l}\text { Poxa, assim, ahh, tá com dificuldade no relacionamento na família, aí problema no } \\
\text { trabalho... São essas pequenas coisas somadas que podem levar ao suicídio. }\end{array}$ \\
\hline
\end{tabular}




\begin{tabular}{|c|c|c|}
\hline Transcrição E2 revisada & AÇÃO\Campanhas (22) \IdentificaçãolComo fazer as pessoas se identificarem & $\begin{array}{l}\text { Eu tenho a impressão que existem alguns casos, assim, de suicídio, que não tem a } \\
\text { ver com uma depressão caracterizada, que é assim, a soma de um monte de } \\
\text { pequenas coisas: Poxa, assim, ahh, tá com dificuldade no relacionamento na } \\
\text { família, aí problema no trabalho... São essas pequenas coisas somadas que podem } \\
\text { levar ao suicídio. Aí, esse caso, eu acho que poderia fazer com que qualquer pessoa } \\
\text { se identificasse e dizer assim: "Poxa, se você tem algum problema que você não } \\
\text { consegue lidar ou tem dificuldade em falar. Eu tenho dificuldade de encaminhar e } \\
\text { isso pode chegar nesse ponto, de suicídio. Eu acho que nesse ponto as campanhas } \\
\text { falham porque a impressão que eu tive, como leigo, é de que assim, isso não tem a } \\
\text { ver comigo. }\end{array}$ \\
\hline Transcrição E2 revisada & CONSCIENTIZAÇÃO|Consciência|Complexidade\Onde tudo começa|O suicídio tem relação com as pequenas coisas & $\begin{array}{l}\text { "Poxa, se você tem algum problema que você não consegue lidar ou tem } \\
\text { dificuldade em falar. Eu tenho dificuldade de encaminhar e isso pode chegar nesse } \\
\text { ponto, de suicídio }\end{array}$ \\
\hline Transcrição E2 revisada & AÇÃOICampanhas (22) (Falhas|Sentindo que as campanhas falham & $\begin{array}{l}\text { Eu acho que nesse ponto as campanhas falham porque a impressão que eu tive, } \\
\text { como leigo, é de que assim, isso não tem a ver comigo. }\end{array}$ \\
\hline Transcrição E2 revisada & COMPREENSÃO|Comunicação|Pessoal|Conversando com amigos|Tentando falar com os amigos & $\begin{array}{l}\text { É o que eu sentia com os amigos. Assim, por exemplo, se eu ia falar com eles... não, } \\
\text { na minha família ninguém tem depressão então não tem nada a ver comigo e aí o } \\
\text { assunto morria. }\end{array}$ \\
\hline Transcrição E2 revisada & COMPREENSÃO|Visão|Visão da Sociedade (2)\Depressão\Tabu e depressão\Amigos achando que depressão não tem haver com eles & $\begin{array}{l}\text { É o que eu sentia com os amigos. Assim, por exemplo, se eu ia falar com eles... não, } \\
\text { na minha família ninguém tem depressão então não tem nada a ver comigo e aí o } \\
\text { assunto morria. }\end{array}$ \\
\hline Transcrição E2 revisada & CONSCIENTIZAÇÃO|Desafios\\
mpeditivos (18)\A reação é diferente do esperado pela ação proposta (Avaliação)\Palestras na empresa & $\begin{array}{l}\text { teve uma vez uma moça que foi fazer uma palestra, lá que é daquele, tipo } 0800 \\
\text { para auxiliar os empregados, tal, que tem vários serviços e aí eles tem serviço } \\
\text { jurídico, psicológico, sei lá, e mais outros dois. Eaí, quando ela estava dando } \\
\text { exemplos, aá ela falou assim: Há, porque tem algumas pessoas...que ela falou } \\
\text { assim: o único momento que a gente quebra o sigilo para a empresa desse serviço, } \\
\text { é quando alguém fala que vai se matar. }\end{array}$ \\
\hline Transcrição E2 revisada & COMPREENSÃO\Tabu (1)\Consequências do Tabu\Mitos\Mito de que as pessoas não falam sobre isso & $\begin{array}{l}\text { Há, porque tem algumas pessoas...que ela falou assim: o único momento que a } \\
\text { gente quebra o sigilo para a empresa desse serviço, é quando alguém fala que vai } \\
\text { se matar. As pessoas começaram a dar risada na sala.. "ah é, tipo, até parece que a } \\
\text { pessoa vai"... entendeu? }\end{array}$ \\
\hline Transcrição E2 revisada & COMPREENSÃO\Experiência\O viver|Quem não viveu (6)|Suicídio colocado como do outro e distante & $\begin{array}{l}\text { Há, porque tem algumas pessoas...que ela falou assim: o único momento que a } \\
\text { gente quebra o sigilo para a empresa desse serviço, é quando alguém fala que vai } \\
\text { se matar. As pessoas começaram a dar risada na sala.. "ah é, tipo, até parece que a } \\
\text { pessoa vai"... entendeu? Então assim acho que tem pessoas..., eu também uma vez } \\
\text { estava num almoço com outras pessoas da empresa e falaram que acho que } \\
\text { alguém do prédio do lado tentou, sabe uma coisa assim? "E tipo eles falaram "Ah! } \\
\text { Nossa, que coisa engraçada, tipo, por que não se joga, mesmo" }\end{array}$ \\
\hline Transcrição E2 revisada & COMPREENSÃO|Visão|Causa Mortis (9)|Curiosidade mórbida|Suicídio como espetáculo & $\begin{array}{l}\text { eu também uma vez estava num almoço com outras pessoas da empresa e falaram } \\
\text { que acho que alguém do prédio do lado tentou, sabe uma coisa assim? "E tipo eles } \\
\text { falaram "Ah! Nossa, que coisa engraçada, tipo, por que não se joga, mesmo". }\end{array}$ \\
\hline Transcrição E2 revisada & COMPREENSÃO\Experiência\O viver\Quem não viveu (6)\Outros não entendem o real significado do suicídio & $\begin{array}{l}\text { Então assim, o nível de entendimento das pessoas, a gravidade de que aquilo é } \\
\text { real, não é o suficiente pra realmente a pessoa ir lá ouvir uma campanha. }\end{array}$ \\
\hline Transcrição E2 revisada & COMPREENSÃo\Tabu (1)\Consequências do Tabu\Mitos\Mito de que as pessoas não falam sobre isso & $\begin{array}{l}\text { "Nossa, se viu o formulário da semana da saúde que perguntaram se você tem } \\
\text { vontade de se matar? Isso é pergunta? Se acha que alguém vai falar que tem } \\
\text { vontade? Tipo, sabe? Eles ficaram surpresos de num formulário estar escrito } \\
\text { fazendo essa pergunta. E então falaram: "Duvido que alguém vai escrever que tipo, } \\
\text { sim." }\end{array}$ \\
\hline
\end{tabular}

Material integrante da pesquisa de doutorado de Karen Scavacini - USP Proibida a reprodução ou utilização sem autorização do autor - 2018 


\begin{tabular}{|c|c|c|}
\hline Transcrição E2 revisada & CONSCIENTIZAÇÃo|Desafios\\
mpeditivos (18)\A reação é diferente do esperado pela ação proposta (Avaliação)\O que a empresa faz com & $\begin{array}{l}\text {.ou teve uns que eu já ouvi: "Nossa, se viu o formulário da semana da saúde que } \\
\text { perguntaram se você tem vontade de se matar? Isso é pergunta? Se acha que } \\
\text { alguém vai falar que tem vontade? Tipo, sabe? Eles ficaram surpresos de num } \\
\text { formulário estar escrito fazendo essa pergunta. E então falaram: "Duvido que } \\
\text { alguém vai escrever que tipo, sim." Ou o que a empresa vai fazer? Entendeu? }\end{array}$ \\
\hline Transcrição E2 revisada & CONSCIENTIZAÇÃo|Desafios|Impeditivos (18)\A reação é diferente do esperado pela ação proposta (Avaliação) & $\begin{array}{l}\text { Então assim, existem pequenas ações que às vezes a gente faz, só que a reação } \\
\text { nem sempre é aquela esperada. }\end{array}$ \\
\hline Transcrição E2 revisada & COMPREENSÃO\Experiência\O viver\Quem não viveu (6)\Quem é que vai fazer isso & $\begin{array}{l}\text { Ou essa moça fazendo a palestra falando que era um serviço que eles né, } \\
\text { prestavam, e eles assim, dando risada, achando tipo, ai, quem é que vai fazer isso... }\end{array}$ \\
\hline Transcrição E2 revisada & CONSCIENTIZAÇÃo|Desafios\Impeditivos (18)\A reação é diferente do esperado pela ação proposta (Avaliação)\Outros rindo do serviço o & $\begin{array}{l}\text { Ou essa moça fazendo a palestra falando que era um serviço que eles né, } \\
\text { prestavam, e eles assim, dando risada, achando tipo, ai, quem é que vai fazer isso... }\end{array}$ \\
\hline Transcrição E2 revisada & AÇÃO\Campanhas (22) \nfluência|Sentindo impactada positivamente pelas campanhas suicídio & $\begin{array}{l}\text { Pra mim positivamente, porque eu achei que pelo menos está se fazendo alguma } \\
\text { coisa. }\end{array}$ \\
\hline Transcrição E2 revisada & AÇÃo|Campanhas (22)\É um começo|Sentindo que campanhas são como fazer alguma coisa sobre o assu & $\begin{array}{l}\text { Pra mim positivamente, porque eu achei que pelo menos está se fazendo alguma } \\
\text { coisa. As pessoas estão pensando nisso, no assunto. Começando, pelo menos, tem } \\
\text { que partir de algum ponto }\end{array}$ \\
\hline Transcrição E2 revisada & CONSCIENTIZAÇÃO|Consciência|O absurdo do suicídio|É muita coisa para fazer|Precisa começar de algum lugar & $\begin{array}{l}\text { Começando, pelo menos, tem que partir de algum ponto. E se a gente achar que } \\
\text { nada também vai surtir efeito, a gente vai parar e não vai fazer nada. Então eu } \\
\text { acho que tem que começar, }\end{array}$ \\
\hline Transcrição E2 revisada & AÇÃO\Campanhas (22)\É um começo|As campanhas são um começo & $\begin{array}{l}\text { Então eu acho que tem que começar, fiquei feliz de os programas estarem falando, } \\
\text { pelo menos naquele mês, massivamente abordando, saindo em jornal, matéria } \\
\text { que... tem que começar! }\end{array}$ \\
\hline Transcrição E2 revisada & AÇÃolFazer|Outros tipos de trabalho (24)\Trabalhos científicos são um começo & $\begin{array}{l}\text { E dai tá vendo, né, um trabalho assim, como o seu, e as pessoas se dedicando a } \\
\text { isso pra estar surgindo ideias da gente como abordar. }\end{array}$ \\
\hline Transcrição E2 revisada & COMPREENSÃo|Visão|Visão da Sociedade (2)\Causas do suicídio|Causa e efeito|Causa única & $\begin{array}{l}\text { eu me lembro, que, acho que foi agora, no ano passado, colocaram no Facebook, e } \\
\text { eu até discuti com uma amiga minha porque ela que passou adiante, quando eu vi } \\
\text { aquilo...até o (nome do marido) mandou pra ela tirar na hora... aquele } \\
\text { empresário... aí "Olha o que a Dilma está fazendo com as pessoas. Aí tem uma foto } \\
\text { do empresário que filmaram de manhã, que os empregados chegaram, e ele } \\
\text { tinha... }\end{array}$ \\
\hline Transcrição E2 revisada & COMPREENSÃO|Comunicação|Social|Canais virtuais\O suicídio nas redes sociais\Foto do corpo nas redes sociais & $\begin{array}{l}\text { eu me lembro, que, acho que foi agora, no ano passado, colocaram no Facebook, e } \\
\text { eu até discuti com uma amiga minha porque ela que passou adiante, quando eu vi } \\
\text { aquilo...até o (nome do marido) mandou pra ela tirar na hora... aquele } \\
\text { empresário... ai "Olha o que a Dilma está fazendo com as pessoas. Aí tem uma foto } \\
\text { do empresário que filmaram de manhã, que os empregados chegaram, e ele } \\
\text { tinha... }\end{array}$ \\
\hline Transcrição E2 revisada & CONSCIENTIZAÇÃO|Desafios\Interesses diversos\Uso politico de um suicídio & $\begin{array}{l}\text { eu me lembro, que, acho que foi agora, no ano passado, colocaram no Facebook, e } \\
\text { eu até discuti com uma amiga minha porque ela que passou adiante, quando eu vi } \\
\text { aquilo...até o (nome do marido) mandou pra ela tirar na hora... aquele } \\
\text { empresário... ai "Olha o que a Dilma está fazendo com as pessoas. Aí tem uma foto } \\
\text { do empresário que filmaram de manhã, que os empregados chegaram, e ele } \\
\text { tinha... }\end{array}$ \\
\hline
\end{tabular}

Material integrante da pesquisa de doutorado de Karen Scavacini - USP Proibida a reprodução ou utilização sem autorização do autor - 2018 


\begin{tabular}{|c|c|c|}
\hline Transcrição E2 revisada & COMPREENSÃO|Comunicação|Social|Canais virtuais\Compartilhar sem pensar & $\begin{array}{l}\text { eu me lembro, que, acho que foi agora, no ano passado, colocaram no Facebook, e } \\
\text { eu até discuti com uma amiga minha porque ela que passou adiante, quando eu vi } \\
\text { aquilo...até o (nome do marido) mandou pra ela tirar na hora... aquele } \\
\text { empresário... aí "Olha o que a Dilma está fazendo com as pessoas. Aí tem uma foto } \\
\text { do empresário que filmaram de manhã, que os empregados chegaram, e ele } \\
\text { tinha... }\end{array}$ \\
\hline Transcrição E2 revisada & COMPREENSÃO|Visão|Causa Mortis (9)|Curiosidade mórbida|Suicídio como espetáculo & $\begin{array}{l}\text { Aí tem uma foto do empresário que filmaram de manhã, que os empregados } \\
\text { chegaram, e ele tinha... }\end{array}$ \\
\hline Transcrição E2 revisada & COMPREENSÃO|Comunicação|Social| Canais virtuais $\backslash 0$ suicídio nas redes sociais\Ficando brava com a amiga que divulgou foto & $\begin{array}{l}\text { Eu sei que na hora eu fiquei brava com ela assim, Aí ela: "Não, mas eu quis dizer... } \\
\text { e aí eu disse... "Não, você pode até falar o texto: "Olha o que está acontecendo } \\
\text { com as pessoas que estão, né..." Mas não divulgar a foto. Jamais! }\end{array}$ \\
\hline Transcrição E2 revisada & COMPREENSÃO|Comunicação|Social||Canais virtuais\O suicídio nas redes sociais & $\begin{array}{l}\text { Eu sei que na hora eu fiquei brava com ela assim, Aí ela: "Não, mas eu quis dizer... } \\
\text { e aí eu disse... "Não, você pode até falar o texto: "Olha o que está acontecendo } \\
\text { com as pessoas que estão, né..." Mas não divulgar a foto. Jamais! Você esqueceu } \\
\text { que essa pessoa, pode não estar aqui mas tem família? E aí, eu lembro que eu } \\
\text { briguei muito com ela, né, porque ela queria me mostrar que ela só fez pra que } \\
\text { outras pessoas... Eu falei: "Não, mas as pessoas tem família. Você gostaria de ver } \\
\text { alguém da sua família nisso, exposto no Facebook. Porque alguém fotografou? }\end{array}$ \\
\hline Transcrição E2 revisada & COMPREENSÃO|Comunicação|Social|Canais virtuais\O suicídio nas redes sociais\Outros esquecendo da família de quem se matou & Você esqueceu que essa pessoa, pode não estar aqui mas tem família? \\
\hline Transcrição E2 revisada & COMPREENSÃO|Comunicação|Social|Canais virtuais\Compartilhar sem pensar\O que leva os outros a compartilharem um suicídio & porque ela queria me mostrar que ela só fez pra que outras pessoas... \\
\hline Transcrição E2 revisada & COMPREENSÃO|Comunicação|Social|Canais virtuais\O suicídio nas redes sociais\Outros esquecendo da família de quem se matou & $\begin{array}{l}\text { "Não, mas as pessoas tem família. Você gostaria de ver alguém da sua família } \\
\text { nisso, exposto no Facebook. Porque alguém fotografou? }\end{array}$ \\
\hline Transcrição E2 revisada & COMPREENSÃo|Visão|Causa Mortis (9)\Curiosidade mórbida\A curiosidade das pessoas & $\begin{array}{l}\text { Eu "sinto muito" das pessoas, elas querem saber, quando você conta uma coisa, a } \\
\text { curiosidade não é assim em: A) ter ajudado, como poderia ter ajudado, como } \\
\text { ajudar o outro... eles querem saber como foi, como foi encontrado, o que } \\
\text { aconteceu? Eu sinto muito! Ainda as pessoas querem... }\end{array}$ \\
\hline Transcrição E2 revisada & COMPREENSÃO|Comunicação|Pessoal|Morreu de que \Reação das pessoas a noticia da morte\Como ajudar x curiosidade & $\begin{array}{l}\text { Eu "sinto muito" das pessoas, elas querem saber, quando você conta uma coisa, a } \\
\text { curiosidade não é assim em: A) ter ajudado, como poderia ter ajudado, como } \\
\text { ajudar o outro... eles querem saber como foi, como foi encontrado, o que } \\
\text { aconteceu? Eu sinto muito! Ainda as pessoas querem... }\end{array}$ \\
\hline Transcrição E2 revisada & COMPREENSÃO|Visão|Causa Mortis (9)\Curiosidade mórbidaldetalhes mórbidos & detalhes mórbidos \\
\hline Transcrição E2 revisada & COMPREENSÃO|Visão|Causa Mortis (9)\Curiosidade mórbidaldetalhes mórbidos & Detalhes mórbidos, um filme. Elas querem saber... sabe... você viu? \\
\hline Transcrição E2 revisada & COMPREENSÃO|Visão|Causa Mortis (9)\Curiosidade mórbidaldetalhes mórbidos & Pra depois que souber os detalhes darem opinião... (falatório) \\
\hline Transcrição E2 revisada & COMPREENSÃO\Tabu (1)\Consequências do Tabu|Afastamento|Falta de apoio e ajuda amigos e familiares & $\begin{array}{l}\text { e não é de saber o que a pessoa estava sentindo, ou tipo, nossa, como eu posso... } \\
\text { eu nunca, nunca ninguém me perguntou assim: Como eu posso te ajudar? Você } \\
\text { está pensando nisso? Nunca ninguém me perguntou de amigos ou familiares. O } \\
\text { que você está sentindo com isso? Eu posso te ajudar de que maneira? Isso eu senti. } \\
\text { Nunca ninguém me abordou assim. }\end{array}$ \\
\hline Transcrição E2 revisada & COMPREENSÃO\Comunicação\Pessoal\Morreu de que\Reação das pessoas a noticia da morte\Insensibilidade\Falta de sensibilidade & Falta de sensibilidade né... \\
\hline Transcrição E2 revisada & COMPREENSÃO\Comunicação|Pessoal|Morreu de que\Reação das pessoas a noticia da morte\Insensibilidade)|Falta de sensibilidade & $\begin{array}{l}\text { A abordagem era: Bom, mas como foi? Mas, como era? Como estava? É horrivel, } \\
\text { assim. O caixão foi aberto ou fechado? Sabe, assim, aquilo... }\end{array}$ \\
\hline Transcrição E2 revisada & COMPREENSÃO|Comunicação|Social|Canais virtuais|Compartilhar sem pensar|O que leva os outros a compartilharem um suicídio & \begin{tabular}{|l|} 
É... então eu percebo na internet, casos, as pessoas vão ler pra....saber...como... \\
esse caso eu fiquei chocada, assim, de publicarem e muita gente compartilhar.
\end{tabular} \\
\hline Transcrição E2 revisada & COMPREENSÃO|Comunicação|Social|Canais virtuais\O suicídio nas redes sociais & $\begin{array}{l}\text { É... então eu percebo na internet, casos, as pessoas vão ler pra....saber...como... } \\
\text { esse caso eu fiquei chocada, assim, de publicarem e muita gente compartilhar. }\end{array}$ \\
\hline Transcrição E2 revisada & COMPREENSÃo|Comunicação|Social|Desafios\Baleia azul & $\begin{array}{l}\text { Da baleia azul também, recentemente. Quando as pessoas postavam assim: "Há... } \\
\text { dá uma carteira azul pra ele. Carteira de trabalho... para esse jovem que de } \\
\text { repente isso não vai mais acontecer" }\end{array}$ \\
\hline
\end{tabular}




\begin{tabular}{|c|c|c|}
\hline Transcrição E2 revisada & COMPREENSÃo|Comunicação|Social|Desafios\Baleia azul|Visão de que suicídio ocorre pela falta de trabalho & $\begin{array}{l}\text { Da baleia azul também, recentemente. Quando as pessoas postavam assim: "Há... } \\
\text { dá uma carteira azul pra ele. Carteira de trabalho... para esse jovem que de } \\
\text { repente isso não vai mais acontecer" }\end{array}$ \\
\hline Transcrição E2 revisada & |COMPREENSÃo|Comunicação|Social|Desafios|Baleia azul|Visão simplista e causal & $\begin{array}{l}\text { Eu acho que é uma falta de respeito porque o jovem que entra nessa, está } \\
\text { deprimido, né, uma carteira de trabalho não vai resolver o problema dele. Então } \\
\text { isso... }\end{array}$ \\
\hline Transcrição E2 revisada & COMPREENSÃO\Comunicação|Social\Reportagens\Reportagens que culpabilizam & $\begin{array}{l}\text { o que eu me lembro muito, o que eu acho que também me deixa um pouco } \\
\text { cismada, é que eram reportagens até de colunistas da Folha dizendo que aí, que } \\
\text { isso aí, que essas coisas, que esse suicídio é plenamente evitável, isso é falta de } \\
\text { carinho, falta de amor, falta de não sei o que.... e tipo, eram muitas as reportagens } \\
\text { e a gente vê, que culpabilização todas as pessoas em volta. Como se as pessoas em } \\
\text { volta tivessem negado ou virado as costas, ou não tivessem enxergado... }\end{array}$ \\
\hline Transcrição E2 revisada & COMPREENSÃO|Comunicação|Social|Reportagens|Cobertura irresponsável da morte do piloto|Suicídio piloto avião & $\begin{array}{l}\text { eu acho que eu lembro mais um conjunto de reportagens que saiu acho que } \\
\text { quando... teve aquele suicídio do piloto do avião, né? Que ele jogou... eu me } \\
\text { lembro porque foi assim pouquissimo tempo, foi quase junto com a morte do meu } \\
\text { irmão. }\end{array}$ \\
\hline Transcrição E2 revisada & COMPREENSÃO\Comunicação|Social\Reportagens\Reportagens que culpabilizam & ou não tivesse percebido... \\
\hline Transcrição E2 revisada & CONSCIENTIZAÇÃO|Consciência\O absurdo do suicídio\Limitações\Ajudar também tem limite & É, mas a gente não consegue ficar olhando pros outros também o tempo inteiro \\
\hline Transcrição E2 revisada & COMPREENSÃO\Experiência\O viver\Quem viveu (5)\Depois do suicídio\Analisa diferente depois de passar & $\begin{array}{l}\text { Mas eu lembro também dessa reportagem, também lembro que eu senti...aí } \\
\text { quando você passa aí que você começa analisar de outro jeito. }\end{array}$ \\
\hline Transcrição E2 revisada & COMPREENSÃO\Tabu (1)\Consequências do Tabu\Julgamento\O julgamento do piloto & $\begin{array}{l}\text { Porque eu nem sei se eu não tivesse passado por isso, eu teria falado isso, mas eu } \\
\text { ouvi muitas pessoas falarem assim: "Se queria fazer isso, porque não fez sozinho } \\
\text { em casa? Porque tinha que levar tantas pessoas inocentes e tal?" De repente você } \\
\text { sabe que tá errado mas eu acho que é... }\end{array}$ \\
\hline Transcrição E2 revisada & COMPREENSÃO\Experiência\O viver|Quem viveu (5)\Empatia|Pensando no piloto & $\begin{array}{l}\text { Mas vai saber o que estava passando na cabeça da pessoa, a gente não sabe o que } \\
\text { estava passando na cabeça... }\end{array}$ \\
\hline Transcrição E2 revisada & AÇÃO\Diálogo\O falar (23)\O que (MENSAGEM)\Falar das várias dores (interna e sobreviventes)\Uma dor maior que a minha & $\begin{array}{l}\text { A gente estava tão machucado que a gente começava até a entender...Sei lá. É } \\
\text { exatamente o que a gente falou, que eu penso e falei aquele dia, pra mim, a dor } \\
\text { deles é maior que a minha. }\end{array}$ \\
\hline Transcrição E2 revisada & 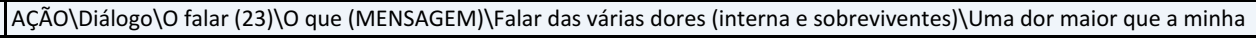 & a pessoa está em outra realidade... \\
\hline Transcrição E2 revisada & 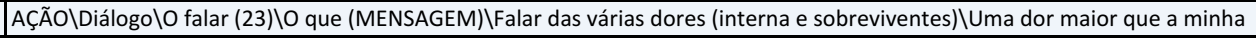 & A dor do (nome do filho) para mim é maior que a minha, a gente chegou a falar. \\
\hline Transcrição E2 revisada & 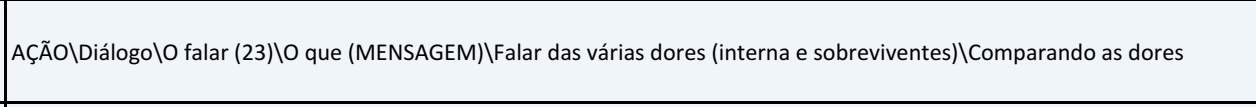 & $\begin{array}{l}\text { Porque se a minha fosse tão a que ele tivesse sentindo, teu também teria então } \\
\text { falado que não quero mais viver. E em nenhum momento eu pensei em fazer isso } \\
\text { comigo. }\end{array}$ \\
\hline Transcrição E2 revisada & 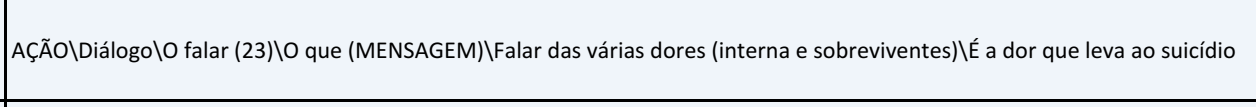 & $\begin{array}{l}\text { Porque se a minha fosse tão a que ele tivesse sentindo, teu também teria então } \\
\text { falado que não quero mais viver. E em nenhum momento eu pensei em fazer isso } \\
\text { comigo. }\end{array}$ \\
\hline Transcrição E2 revisada & AÇÃO\Diálogo\O falar (23)\O que (MENSAGEM)\Falar das várias dores (interna e sobreviventes)\Uma dor maior que a minha & $\begin{array}{l}\text { Então, pra mim, eu não consigo passar assim, o que eles fazem que... no momento, } \\
\text { eu tenho certeza que eles só não pensam na gente porque a dor é tamanha de algo } \\
\text { que nem eu posso imaginar... então, aí que nesse dia que eu comecei também, } \\
\text { desse rapaz com as pessoas julgando }\end{array}$ \\
\hline Transcrição E2 revisada & 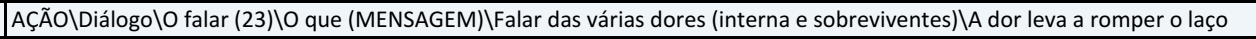 & ... a pessoa já rompeu o laço... \\
\hline Transcrição E2 revisada & COMPREENSÃO\ExperiêncialO viver|Quem viveu (5)\Aprende\Tive uma lição de vida & $\begin{array}{l}\text { a a não julgar mais. Quer dizer, isso para mim foi uma lição de vida, o que } \\
\text { aconteceu comigo. }\end{array}$ \\
\hline Transcrição E2 revisada & COMPREENSÃO\Experiência\O viver|Quem viveu (5)\Antes do suicídio\Também julgava a depressão & $\begin{array}{l}\text { a não julgar mais. Quer dizer, isso para mim foi uma lição de vida, o que aconteceu } \\
\text { comigo. De não julgar. Porque eu também achava que depressão era...a pessoa ah, } \\
\text { não quer, sabe, vai... tem que acordar as } 5 \text { horas da manhã como eu acordava, } \\
\text { então você não tinha tempo para estar deprimido. }\end{array}$ \\
\hline Transcrição E2 revisada & AÇÃO\Campanhas (22)\Temas\Campanha - não julgar & então não julgar eu acho que essas campanhas.... \\
\hline
\end{tabular}

Material integrante da pesquisa de doutorado de Karen Scavacini - USP Proibida a reprodução ou utilização sem autorização do autor - 2018 


\begin{tabular}{|c|c|c|}
\hline Transcrição E2 revisada & AÇÃo|Cuidar|Depressão|Depressão é doença|Sentindo abençoada por não ter depressão & $\begin{array}{l}\text { Hoje eu sinto que eu sou abençoada por eu não sentir nada disso, nem com tudo } \\
\text { que eu passei eu não sinto, é lógico, tristeza é uma coisa, a gente sente em todos } \\
\text { os momentos, mas não sinto, ai, fico com dó de mim, tinha que, nada... eu não } \\
\text { sinto isso, então não julgar eu acho que essas campanhas.... }\end{array}$ \\
\hline Transcrição E2 revisada & AÇÃO\Campanhas (22)\Temas\Campanha - não julgar & é porque eu acho que olhar a outra situação... \\
\hline Transcrição E2 revisada & AÇÃO\Campanhas (22)〈Temas\Campanha - não julgar & tem que olhar com outro olhar que a pessoa está num momento ali... \\
\hline Transcrição E2 revisada & COMPREENSÃO|Comunicação|Social|Reportagens|Cobertura irresponsável da morte do piloto|Mídia e muitas vitimas & $\begin{array}{l}\text { É, eu acho que a mídia, ela trata toda aquela situação dessa forma porque eu acho } \\
\text { que ele tinha levado outras pessoas junto. }\end{array}$ \\
\hline Transcrição E2 revisada & COMPREENSÃO|Comunicação|Social|Reportagens|Cobertura irresponsável da morte do piloto & $\begin{array}{l}\text { Mas a forma como toda a cobertura foi feita, eu achei muito irresponsável. Que } \\
\text { não foi em outras, mas eu acho que naquele momento a cobertura, toda } \\
\text { cobertura...eu acho que gente que começou a falar aleatoriamente sobre o } \\
\text { assunto e eu acho que por ter esse negócio de ter matado outras pessoas, foi } \\
\text { totalmente irresponsável. Eu achei assim. Esse foi o momento que eu achei que os } \\
\text { canais de comunicação foram irresponsáveis no tratamento do assunto, assim de } \\
\text { em nenhum momento mostrar que, meu, o cara já tinha desligado, ele já não } \\
\text { estava...que é quando a pessoa faz isso ela já não está neste plano, ela já não tem } \\
\text { mais, ela já perdeu, cortou os laços com as pessoas. Eu acho que isso que...eu acho } \\
\text { que esse foi o momento que foi irresponsável, né, da cobertura. }\end{array}$ \\
\hline Transcrição E2 revisada & AÇÃO\Diálogo\O falar (23)\O que (MENSAGEM)\Falar das várias dores (interna e sobreviventes)\A dor leva a romper o laço & $\begin{array}{l}\text { o cara já tinha desligado, ele já não estava...que é quando a pessoa faz isso ela já } \\
\text { não está neste plano, ela já não tem mais, ela já perdeu, cortou os laços com as } \\
\text { pessoas. }\end{array}$ \\
\hline Transcrição E2 revisada & AÇÃO\Campanhas (22)\Periodicidade\Durante o ano todo & Não só do setembro, acho que ter mais campanhas durante o ano. \\
\hline Transcrição E2 revisada & AÇÃO\Campanhas (22)\Provedores ou Onde\Ter avisos em mais lugares & Como teve o aviso do cigarro, enfim... entendeu, ter mais. \\
\hline Transcrição E2 revisada & AÇÃO\Campanhas (22) \PeriodicidadelNão concentrar tudo em setembro & $\begin{array}{l}\text { Não ficar esperando tudo, concentrar tudo, porque eu acho que a pessoa nem } \\
\text { assimila. Porque daí ela começa... "Ah, setembro tão falando isso. }\end{array}$ \\
\hline Transcrição E2 revisada & AÇÃO\Campanhas (22)\Periodicidade\As pessoas não assimilam tudo - setembro & $\begin{array}{l}\text { Não ficar esperando tudo, concentrar tudo, porque eu acho que a pessoa nem } \\
\text { assimila. Porque dai ela começa... "Ah, setembro tão falando isso. }\end{array}$ \\
\hline Transcrição E2 revisada & AÇÃOICampanhas (22)\PeriodicidadelCampanhas menores e mais reportagens & $\begin{array}{l}\text { Ter mais coisas menores, campanhas, coisinhas menores, mas, mais reportagens. } \\
\text { Eu acho que a mídia começar a abordar, de uma maneira mais sutil e ir chegando... }\end{array}$ \\
\hline Transcrição E2 revisada & AÇÃO\Campanhas (22)\PeriodicidadelComeçar a abordar o tema sutilmente & $\begin{array}{l}\text { Ter mais coisas menores, campanhas, coisinhas menores, mas, mais reportagens. } \\
\text { Eu acho que a mídia começar a abordar, de uma maneira mais sutil e ir chegando... }\end{array}$ \\
\hline Transcrição E2 revisada & AÇÃO\Campanhas (22)\PeriodicidadelCampanhas menores e mais reportagens & Com mais frequência. \\
\hline Transcrição E2 revisada & AÇÃo|Campanhas (22) \Periodicidade \Não concentrar tudo em setembro & $\begin{array}{l}\text { Não precisa ser tão massivo porque aí as pessoas não prestam mais atenção, só } \\
\text { aquele grupo que vai prestar atenção, que vai se engajar, vai tá ali de camiseta } \\
\text { participando, dando folheto, tentando, mas assim, }\end{array}$ \\
\hline Transcrição E2 revisada & AÇÃO\Campanhas (22)\Temas|Divulgar o CVV & $\begin{array}{l}\text { acho que ter um horário pra divulgar que o CVV está disponível que aí é um órgão } \\
\text { nacional. É uma coisa nacional. Então, ter uns segundos ali na TV... a gente tem } \\
\text { tanto segundos ali gratuitos pra falar de tanta coisa, porque não alertar que o CVV } \\
\text { está aí. Acho que pelo menos a pessoa teria um lugar seguro pra pedir ajuda. }\end{array}$ \\
\hline Transcrição E2 revisada & AÇÃO|Campanhas (22)\Provedores ou Onde\Usar os segundos gratuitos da TV & $\begin{array}{l}\text { acho que ter um horário pra divulgar que o CVV está disponível que aí é um órgão } \\
\text { nacional. É uma coisa nacional. Então, ter uns segundos ali na TV... a gente tem } \\
\text { tanto segundos ali gratuitos pra falar de tanta coisa, porque não alertar que o CVV } \\
\text { está aí. Acho que pelo menos a pessoa teria um lugar seguro pra pedir ajuda. }\end{array}$ \\
\hline Transcrição E2 revisada & AÇÃO\Campanhas (22)\Temas|Divulgar o CVV & 24 horas eu sei, mas que fica o sigilo. \\
\hline Transcrição E2 revisada & AÇÃo\Cuidar\CVV\Dúvida sobre o CVV & $\begin{array}{l}\text { E se a pessoa liga e fala que vai cometer? Pode? É aberto um chamado pra policia, } \\
\text { não? }\end{array}$ \\
\hline
\end{tabular}

Material integrante da pesquisa de doutorado de Karen Scavacini - USP Proibida a reprodução ou utilização sem autorização do autor - 2018 


\begin{tabular}{|c|c|c|}
\hline Transcrição E2 revisada & AÇÃo|Cuidar\CVV\Como funciona o CVV & $\begin{array}{l}\text { A não ser que ela peça ajuda. Se ela falar... eu já fiz o ato e estou precisando de } \\
\text { ajuda. E ela passar o endereço... ai você pode. Se ela falar... pois não tem } \\
\text { identificador de chamada. }\end{array}$ \\
\hline Transcrição E2 revisada & AÇÃO\Cuidar\CVV\Atendimento sigiloso & $\begin{array}{l}\text { A não ser que ela peça ajuda. Se ela falar... eu já fiz o ato e estou precisando de } \\
\text { ajuda. E ela passar o endereço... ai você pode. Se ela falar... pois não tem } \\
\text { identificador de chamada. }\end{array}$ \\
\hline Transcrição E2 revisada & AÇÃO\Campanhas (22)\Provedores ou OndelCampanhas na TV & $\begin{array}{l}\text { Então mas eu acho que uma coisa interessante seria isso, ter espaço, na mídia, } \\
\text { principalmente TV que atinge muita gente, de todas as idades, }\end{array}$ \\
\hline Transcrição E2 revisada & AÇÃO\Campanhas (22)\Provedores ou Onde\Jovens e tevê aberta & $\begin{array}{l}\text { porque a gente está aqui falando se jovens... mas que as vezes não vai ver tevê } \\
\text { aberta tanto }\end{array}$ \\
\hline Transcrição E2 revisada & AÇÃOlCuidar|CVV\Desconhecimento do cVV & $\begin{array}{l}\text { mas a gente está falando de pessoas de mais idade também que está aí sozinha em } \\
\text { casa, pensando, e aparecer, porque eu não sei, mas eu acho que se eu perguntasse } \\
\text { para a minha avó ela não sabe do CVV. }\end{array}$ \\
\hline Transcrição E2 revisada & AÇÃO\Campanhas (22)\Provedores ou Onde\TV comunicando para os idosos & $\begin{array}{l}\text { mas a gente está falando de pessoas de mais idade também que está aí sozinha em } \\
\text { casa, pensando, e aparecer, porque eu não sei, mas eu acho que se eu perguntasse } \\
\text { para a minha avó ela não sabe do CVV. }\end{array}$ \\
\hline Transcrição E2 revisada & AÇÃO\Campanhas (22)\Temas\Divulgar o CVV & $\begin{array}{l}\text { Se ela.. então eu acho que devia ter mais campanhazinhas.. mini coisinhas assim, } \\
\text { com esse número disponivel. }\end{array}$ \\
\hline Transcrição E2 revisada & AÇÃO|Campanhas (22)\Periodicidade \Campanhas menores e mais reportagens & $\begin{array}{l}\text { Se ela.. então eu acho que devia ter mais campanhazinhas.. mini coisinhas assim, } \\
\text { com esse número disponivel. }\end{array}$ \\
\hline Transcrição E2 revisada & AÇÃ̃OCuidar\Tratamento (13)\Acesso a formas de tratamento\O tratamento é caro & $\begin{array}{l}\text { O que eu acho que também poderia ter, faculdades de psicologia que abrisse ao } \\
\text { público porque é muito caro um tratamento, hoje. Um psicólogo, psiquiatra, acho } \\
\text { que poderia ter mais faculdades, aí, atendendo o povo em geral e... Acho que } \\
\text { ajudaria bastante. }\end{array}$ \\
\hline Transcrição E2 revisada & 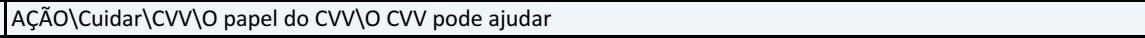 & Procure ajuda... Tem o CVV se a pessoa quer... \\
\hline Transcrição E2 revisada & AÇÃO\Cuidar\CVV\O papel do CVV & Mas o CVV é atendimento só telefônico \\
\hline Transcrição E2 revisada & 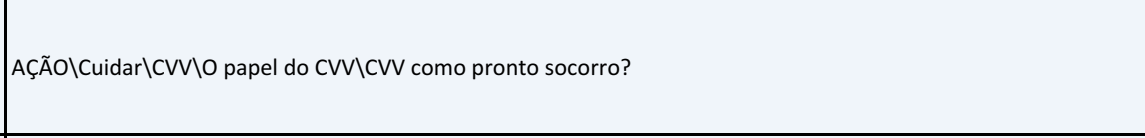 & $\begin{array}{l}\text { Mas pega o urgente, mas ele poderia também... se tivesse mais locais, se a pessoa } \\
\text { pedir ajuda, falando assim: "'Ah mas eu não tenho dinheiro, eu não tenho como ir } \\
\text { ao psiquiatra, eu estou me sentindo mal" Aí ter publicamente um lugar pra } \\
\text { encaminhar. }\end{array}$ \\
\hline Transcrição E2 revisada & AÇÃO|Cuidar\CVV\O papel do CVVICVV não é terapia & $\begin{array}{l}\text { Mas eles tem, o CVV, eles tem atendimento pessoal. Só que ele é pra aquela crise } \\
\text { emocional. Você não pode fazer dele uma terapia. Não tem um acompanhamento } \\
\text { para você ir sempre com a mesma pessoa... a formação é outra, né. }\end{array}$ \\
\hline Transcrição E2 revisada & AÇÃo|Cuidar\Tratamento (13)\Acesso a formas de tratamento\Dificuldade das pessoas pagarem tratamento & $\begin{array}{l}\text { Eu acho que isso seria muito interessante: um lugar onde as pessoas pudessem ser } \\
\text { atendidas porque é muito caro e quantas pessoas podem arcar com isso? }\end{array}$ \\
\hline Transcrição E2 revisada & AÇÃo\Cuidar\Tratamento (13)\Acesso a formas de tratamento|Local onde as pessoas conseguissem ser atendidas & $\begin{array}{l}\text { Eu acho que isso seria muito interessante: um lugar onde as pessoas pudessem ser } \\
\text { atendidas porque é muito caro e quantas pessoas podem arcar com isso? }\end{array}$ \\
\hline Transcrição E2 revisada & AÇÃO|Cuidar\Tratamento (13)\Acesso a formas de tratamento|CAPS são deficientes & Aqueles, é... CAPS, são deficientes né... \\
\hline Transcrição E2 revisada & AÇÃO|Cuidar\Tratamento (13)\Acesso a formas de tratamento|CAPS são deficientes & Não dá conta da demanda... \\
\hline Transcrição E2 revisada & AÇão\Campanhas (22)\Temas\Divulgar o CVV\Divulgação facilita o acesso & $\begin{array}{l}\text { A divulgação do CVV e outros lugares que as pessoas podem buscar ajuda, facilitar } \\
\text { o acesso né, }\end{array}$ \\
\hline Transcrição E2 revisada & AÇÃO|Cuidar|Tratamento (13)\Acesso a formas de tratamento\Tratamentos não acessiveis & facilitar o acesso né, porque muitas soluções são caras, não são acessiveis mas, \\
\hline Transcrição E2 revisada & COMPREENSÃo\Tabu (1)\Consequências do Tabu|Afastamento|Tabu do suicídio e da morte geram afastamento & $\begin{array}{l}\text { toda vez que a gente fala de suicídio, ou morte, existe na nossa cultura, em } \\
\text { particular, um tabu grande. Então gera uma rejeição, gera um afastamento }\end{array}$ \\
\hline Transcrição E2 revisada & 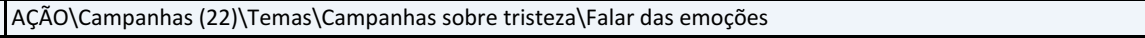 & um caminho que pode ajudar, é a gente falar das emoções, \\
\hline Transcrição E2 revisada & AÇÃo|Campanhas (22)\Temas\Campanhas de capacitação do diálogo|Falta de diálogo & $\begin{array}{l}\text { e que a falta de diálogo, não só assim como você está na crise aí você ligar pro CVV, } \\
\text { mas a falta de você, por exemplo, de poder chegar pra um amigo, ou um parente e } \\
\text { conversar sobre um assunto difícil é que lá na ponta..., vai... é um dos casos de... } \\
\text { não é }\end{array}$ \\
\hline
\end{tabular}

Material integrante da pesquisa de doutorado de Karen Scavacini - USP Proibida a reprodução ou utilização sem autorização do autor - 2018 


\begin{tabular}{|c|c|c|}
\hline Transcrição E2 revisada & AÇão|Campanhas (22)|Temas|Campanhas de capacitação do diálogo|Falta de diálogo & $\begin{array}{l}\text { mas um dos casos é esse, assim, que a pessoa não tem com quem falar e isso acho } \\
\text { que é cultural, eu acho que isso eu acho que tem a ver com prevenção de suicídio e } \\
\text { eu acho que aproxima as pessoas, porque tem a ver com todo mundo, não é só } \\
\text { aquele caso... }\end{array}$ \\
\hline Transcrição E2 revisada & AÇÃO\Campanhas (22) Influência|Influencia da cultura & $\begin{array}{l}\text { mas um dos casos é esse, assim, que a pessoa não tem com quem falar e isso acho } \\
\text { que é cultural, eu acho que isso eu acho que tem a ver com prevenção de suicídio e } \\
\text { eu acho que aproxima as pessoas, porque tem a ver com todo mundo, não é só } \\
\text { aquele caso... }\end{array}$ \\
\hline Transcrição E2 revisada & AÇÃo\Campanhas (22)\Temas\Campanha focada no acolhimento & $\begin{array}{l}\text { Quer dizer, você tem uma campanha, por exemplo, focada em acolhimento, em } \\
\text { diálogo, que a gente estava falando em prevenção em saúde mental, não está } \\
\text { falando exatamente de prevenção do suicídio, mas que automaticamente uma } \\
\text { coisa que vai levar a outra. Você promove saúde mental você diminui o número de } \\
\text { suicídios... }\end{array}$ \\
\hline Transcrição E2 revisada & AÇÃOlCampanhas (22)\Temas\Campanha para capacitar os profissionais & \begin{tabular}{|l|} 
E você capacita os profissionais, né? Que nem a gente vê.... gente já ouviu relato \\
as pessoas que tentaram que eles não tiveram o atendimento adequado, né?
\end{tabular} \\
\hline Transcrição E2 revisada & CONSCIENTIZAÇÃO|Desafios \Impeditivos (18)\Quem deveria acolher não está preparado (Acolhimento) & $\begin{array}{l}\text { Então, acho que assim, nem aquelas pessoas que teriam o papel de acolher não } \\
\text { estão preparadas, imagina outros seres que assim, né? Na profissão, isso não vai } \\
\text { saber mesmo. }\end{array}$ \\
\hline Transcrição E2 revisada & AÇÃO\Campanhas (22)\Temas\Campanha focada no acolhimento & $\begin{array}{l}\text { Então, acho que assim, nem aquelas pessoas que teriam o papel de acolher não } \\
\text { estão preparadas, imagina outros seres que assim, né? Na profissão, isso não vai } \\
\text { saber mesmo. }\end{array}$ \\
\hline Transcrição E2 revisada & AÇÃO|Semear|Facilitadores (29)\Amar as pessoas do meio que convive & $\begin{array}{l}\text { No seu meio, você talvez tente por amar as outras pessoas com quem você } \\
\text { convive, }\end{array}$ \\
\hline Transcrição E2 revisada & AÇÃO\Campanhas (22)\Temas\Campanha para capacitar os profissionais & $\begin{array}{l}\text { a questão de capacitação, que nem, de universitários, mas a questão, tipo, a } \\
\text { policia, os médicos, entendeu? Acho que em vários, assim. Vários profissionais que } \\
\text { precisam estar um pouco mais capacitados para lidar com isso né, então como que } \\
\text { a gente consegue? }\end{array}$ \\
\hline Transcrição E2 revisada & CONSCIENTIZAÇÃOOCConsciência|O absurdo do suicídio|É muita coisa para fazer|Dúvidas de como conseguir & então como que a gente consegue? \\
\hline Transcrição E2 revisada & AÇÃO\Diálogo\O falar (23)\Onde\Começar conscientização pelas faculdades com assuntos relaciona & Eu acho que tem que ir primeiro naqueles que tem o assunto mais relacionado. \\
\hline Transcrição E2 revisada & AÇÃO\Fazer|Outros tipos de trabalho (24)\Disciplina de religião & $\begin{array}{l}\text { Por exemplo, a disciplina religião, sério, no colégio. Todo mundo... tipo, não vai na } \\
\text { aula, trata de qualquer jeito, joga papel no ar, entendeu? Porque nem todo mundo } \\
\text { que tá ali se identifica com o tema. }\end{array}$ \\
\hline Transcrição E2 revisada & AçÃO|DiálogolO falar (23)\Onde\Começar conscientização pelas faculdades com assuntos relacionalComeçar com os cursos que tem rela & \begin{tabular}{|l|} 
Então, por exemplo: talvez se começar com os cursos que tem uma relação, um \\
pouco mais, né? Talvez os médicos, os psicólogos,
\end{tabular} \\
\hline Transcrição E2 revisada & AÇão|Diálogo|O falar (23)\Onde\Começar conscientização pelas faculdades com assuntos relacionalComeçar com os cursos que tem rela & Os recursos humanos... acho que eles tinha que ter mais... \\
\hline Transcrição E2 revisada & AÇão|DiálogolO falar (23)\OndelComeçar conscientização pelas faculdades com assuntos relacionalComeçar com os cursos que tem rela & \begin{tabular}{|l} 
na área de recursos humanos......enfermagem.... assim, você tem uns que \\
teoricamente são os mais..
\end{tabular} \\
\hline Transcrição E2 revisada & 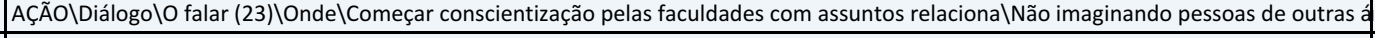 & não tem, imagina uma pessoa de direito, engenharia.... \\
\hline Transcrição E2 revisada & COMPREENSÃO\Experiência\O viver|Quem viveu (5)\Empatia|Só não deixa passar a tristeza do outro quem passou por isso & $\begin{array}{l}\text { Uma pessoa chega lá para você... estou com depressão, estou mal ou estou me } \\
\text { sentindo triste... Se você não tivesse passado por isso ia passar... }\end{array}$ \\
\hline Transcrição E2 revisada & AÇÃO\Diálogo|O falar (23)\Quem|Sobreviventes enlutados\Acreditando ter a chave para derrubar essa barreira & $\begin{array}{l}\text { Sobre essa questão, eu acho também, existe um universo a ser explorado e esse } \\
\text { contingente é que pode ser a chave pra gente derrubar essa barreira. }\end{array}$ \\
\hline Transcrição E2 revisada & COMPREENSÃO|Comunicação|Social|Reportagens\Não se aprofundam na dor dos que ficam & $\begin{array}{l}\text { Eu percebo, até nas recentes reportagens que eles não aprofundam sobre a dor } \\
\text { dos que ficam. Fala do luto, fala da morte, fala do suicídio mas não aprofunda a dor } \\
\text { dos que ficam. }\end{array}$ \\
\hline Transcrição E2 revisada & CONSCIENTIZAÇÃO|Consciência|Epidemiologia (20)\Epidemiologia dos sobreviventes & $\begin{array}{l}\text { E se estatisticamente é uma média mínima de pelo menos } 6 \text { pessoas pra mais, que } \\
\text { é afetada pra cada suicídio. E nós temos suicídio a cada } 40 \text { segundos. Nós temos } \\
\text { um contingente da população expressivo e que certamente são de diversos perfis } \\
\text { socioeconômicos e culturais }\end{array}$ \\
\hline
\end{tabular}

Material integrante da pesquisa de doutorado de Karen Scavacini - USP Proibida a reprodução ou utilização sem autorização do autor - 2018 


\begin{tabular}{|c|c|c|}
\hline Transcrição E2 revisada & AÇÃO\Diálogo\O falar (23)\Quem|Sobreviventes enlutados|Sobreviventes como formadores de opinião & $\begin{array}{l}\text { E se estatisticamente é uma média mínima de pelo menos } 6 \text { pessoas pra mais, que } \\
\text { é afetada pra cada suicídio. E nós temos suicídio a cada } 40 \text { segundos. Nós temos } \\
\text { um contingente da população expressivo e que certamente são de diversos perfis } \\
\text { socioeconômicos e culturais e que cada um atue e dialogue no seu meio e que } \\
\text { poderia ser um grande formador de opinião e poderia ser um grande parceiro pra } \\
\text { desfrutar a consciência afetiva da sociedade como um todo. }\end{array}$ \\
\hline Transcrição E2 revisada & AÇÃO\Diálogo\O falar (23)\Quem|Sobreviventes enlutados|Consciência afetiva & $\begin{array}{l}\text { Nós temos um contingente da população expressivo e que certamente são de } \\
\text { diversos perfis socioeconômicos e culturais e que cada um atue e dialogue no seu } \\
\text { meio e que poderia ser um grande formador de opinião e poderia ser um grande } \\
\text { parceiro pra desfrutar a consciência afetiva da sociedade como um todo. }\end{array}$ \\
\hline Transcrição E2 revisada & 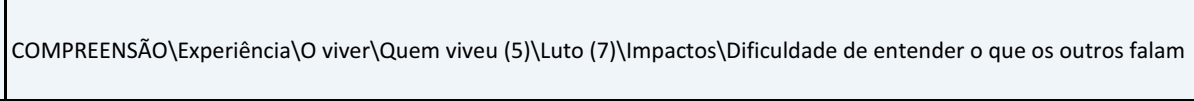 & $\begin{array}{l}\text { Você me desculpe, com o maior respeito mas eu tenho uma dificuldade... eu... eu } \\
\text { fiquei ouvindo pacientemente mas não entendi nada do que você falou, que eu } \\
\text { estou tentando sustentar a ideia...é uma dificuldade. }\end{array}$ \\
\hline Transcrição E2 revisada & 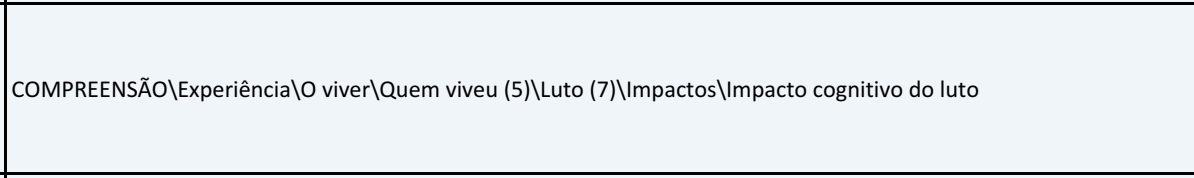 & $\begin{array}{l}\text { Você me desculpe, com o maior respeito mas eu tenho uma dificuldade... eu... eu } \\
\text { fiquei ouvindo pacientemente mas não entendi nada do que você falou, que eu } \\
\text { estou tentando sustentar a ideia...é uma dificuldade. É uma limitação minha. Eu } \\
\text { adquiri isso desde a primeira separação, se agravou na segunda e agora com esse } \\
\text { baque... então, eu não consigo... eu fiquei “mono”. }\end{array}$ \\
\hline Transcrição E2 revisada & CONSCIENTIZAÇÃOIConsciêncialEpidemiologia (20)\Epidemiologia dos sobreviventes & $\begin{array}{l}\text { Mas então, esse contingente, deve ter um percentual, não sei quanto, vamos } \\
\text { chutar 10,20\% de mil, } 2 \text { mil pessoas, } 3 \text { mil pessoas, são milhares de pessoas que } \\
\text { tem um status sociocultural e um perfil, inclusive alguns devem ser psicólogos, } \\
\text { profissionais de saúde, aqui mesmo nós temos profissionais de saúde que são } \\
\text { enlutados, né? }\end{array}$ \\
\hline Transcrição E2 revisada & AÇÃO|Cuidar|Grupos de apoio (21)\Divulgação e conhecimento|Divulgar grupo de apoio & $\begin{array}{l}\text { Enfim, e que somem a esses dados, diferentes faixas etárias em que, se a gente } \\
\text { divulgar, grupos de enlutados de instituições como o CVV, o Vita Alere, etc., parece } \\
\text { que tem outras também. }\end{array}$ \\
\hline Transcrição E2 revisada & AÇÃO|DiálogolO falar (23)\Quem|Sobreviventes enlutados\Pega muitas pessoas & $\begin{array}{l}\text { são milhares de pessoas que tem um status sociocultural e um perfil, inclusive } \\
\text { alguns devem ser psicólogos, profissionais de saúde, aqui mesmo nós temos } \\
\text { profissionais de saúde que são enlutados, né? }\end{array}$ \\
\hline Transcrição E2 revisada & AÇÃO\Campanhas (22)\Periodicidade \Divulgar massivamente & $\begin{array}{l}\text { Que fazem esse trabalho nas diversas cidades, nos conglomerados urbanos } \\
\text { maiores, pelo menos, e procurar fazer parceria com empresa, para atacar } \\
\text { massivamente divulgando. Porque, o que ocorre? Por ser massivo, todo mundo, o } \\
\text { familiar, "Não, olha tem isso aqui." "Tem esse aqui, não sei aonde tem um grupo" }\end{array}$ \\
\hline Transcrição E2 revisada & AÇÃO|Cuidar|Grupos de apoio (21)\Divulgação e conhecimento|Divulgar grupo de apoio & $\begin{array}{l}\text { Fim de semana, durante a semana, vai lá, alguém vai lá, vai procurar saber. Então, } \\
\text { se a gente conseguir manter, não de forma episódica mas, assim, constante, que } \\
\text { existem esses centros, esses grupos que trabalham com a dor dos que ficam. Enão } \\
\text { só dos que ficam, tá? Daqueles que estão lidando com alguém que tá tentando e } \\
\text { ainda não consumou e a pessoa tá sofrendo... ou até mesmo alguém que tentou e } \\
\text { não conseguiu ele mesmo... mas assim, eu acho que se isso for feito, o que vai } \\
\text { ocorrer? }\end{array}$ \\
\hline Transcrição E2 revisada & AÇÃO\O saber (12)\Saber é poder\Informação é poder & Informação é poder \\
\hline Transcrição E2 revisada & AÇÃO|Cuidar|Grupos de apoio (21)|Divulgação e conhecimento|A importância das pessoas saberem dos grupos & $\begin{array}{l}\text { Então, as pessoas sabendo que isso existe... eu mesmo só soube porque alguém } \\
\text { que era enlutado e era psicólogo que soube, tal. }\end{array}$ \\
\hline Transcrição E2 revisada & AÇÃo|Cuidar|Grupos de apoio (21)|Divulgação e conhecimento|Soube através de um enlutado psicólogo & $\begin{array}{l}\text { eu mesmo só soube porque alguém que era enlutado e era psicólogo que soube, } \\
\text { tal. }\end{array}$ \\
\hline Transcrição E2 revisada & AÇÃo|Cuidar|Grupos de apoio (21)〈Divulgação e conhecimento|Se não me falassem ia fica ao deus dará & Mas assim, eu ia ficar ao Deus dará por que... \\
\hline Transcrição E2 revisada & AÇÃOlCuidar|Grupos de apoio (21)\Outros grupos de apoio (AA) & por exemplo, os alcoólicos anônimos tem o Anon para os parentes, o AA. \\
\hline Transcrição E2 revisada & AÇÃO\O saber (12)\Saber é poder \Informação é poder & $\begin{array}{l}\text { Então eu acho que essa passividade de divulgação, informação é poder, eu repito, } \\
\text { eu acho o ponto de partida }\end{array}$ \\
\hline
\end{tabular}

Material integrante da pesquisa de doutorado de Karen Scavacini - USP Proibida a reprodução ou utilização sem autorização do autor - 2018 


\begin{tabular}{|c|c|c|}
\hline Transcrição E2 revisada & AÇÃO\Campanhas (22)\Periodicidade\Divulgar massivamente & $\begin{array}{l}\text { Então eu acho que essa passividade de divulgação, informação é poder, eu repito, } \\
\text { eu acho o ponto de partida }\end{array}$ \\
\hline Transcrição E2 revisada & AÇÃO\Campanhas (22)\Periodicidade\Divulgar massivamente & $\begin{array}{l}\begin{array}{l}\text { Porque a via desse porto seguro pra acolhimento é... e sendo massivamente } \\
\text { divulgado }\end{array} \\
\end{array}$ \\
\hline Transcrição E2 revisada & AÇÃO|Cuidar|Grupos de apoio (21)|Divulgação e conhecimento|Criar protocolo de encaminhar para grupos & $\begin{array}{l}\text { e sendo massivamente divulgado, até mesmo os profissionais de saúde colocar até } \\
\text { como um protocolo, protocolo, encaminhar, ou pelo menos dar as indicações das } \\
\text { opções disponiveis para procurar }\end{array}$ \\
\hline Transcrição E2 revisada & AÇÃo|Cuidar|Grupos de apoio (21)\Livre arbítrio\As pessoas experienciarem se é bom ou não os grupos & $\begin{array}{l}\text { Porque, o que que vai, quando a pessoa chega, ela pode até não continuar, mas ela } \\
\text { já foi e sabe como é, e tal. E ai vai ter um contingente que vai abraçar, de alguma } \\
\text { forma }\end{array}$ \\
\hline Transcrição E2 revisada & COMPREENSÃO\Comunicação|Pessoal\O falar como uma causa/bandeira\nem todos precisam sair do anonimato & $\begin{array}{l}\text { Não digo que vá abrir mão do anonimato, que vai fazer... mas vai fazer pelo menos } \\
\text { isso que ele está fazendo e muito mais. }\end{array}$ \\
\hline Transcrição E2 revisada & AÇÃO\Diálogo\O falar (23)\Como (FORMA)\Formas\Multiplicadores de opinião & $\begin{array}{l}\text { E aí vai ter um contingente que vai abraçar, de alguma forma. Não digo que vá } \\
\text { abrir mão do anonimato, que vai fazer... mas vai fazer pelo menos isso que ele está } \\
\text { fazendo e muito mais. Se o cara é um universitário, ele vai começar a conversar } \\
\text { com pessoas do meio universitário. Se ele é um professor, professor é um grande } \\
\text { formador de opinião, se ele é um profissional de saúde, ou é estudante da área de } \\
\text { saúde, enfim... eu acho que isso seria um grande salto }\end{array}$ \\
\hline Transcrição E2 revisada & AÇÃOlSemear|Facilitadores (29)\Um salto pra mudança & $\begin{array}{l}\text { Se ele é um professor, professor é um grande formador de opinião, se ele é um } \\
\text { profissional de saúde, ou é estudante da área de saúde, enfim... eu acho que isso } \\
\text { seria um grande salto. Um salto pra mudança. Trabalhando com a informação. Eu } \\
\text { acho que aí, as pessoas, cada uma hoje em dia, ainda mais se for mais jovem ou de } \\
\text { meia idade, usa muito a rede social. Então vai impactar. }\end{array}$ \\
\hline Transcrição E2 revisada & COMPREENSÃO|Comunicação|Social|Canais virtuais\Impactar pela rede social & $\begin{array}{l}\text { Eu acho que aí, as pessoas, cada uma hoje em dia, ainda mais se for mais jovem ou } \\
\text { de meia idade, usa muito a rede social. Então vai impactar. }\end{array}$ \\
\hline Transcrição E2 revisada & AÇÃO\Cuidar|Grupos de apoio (21)\Sou acolhido e acolho|Grupo como fonte de apoio habitual & $\begin{array}{l}\text { A pessoa, muitos deles vão fazer disso um habito, um habito mensal, semanal, que } \\
\text { seja e aí de tá indo lá. }\end{array}$ \\
\hline Transcrição E2 revisada & AÇÃO\Cuidar|Grupos de apoio (21)|Vrequência dos grupos\Ter grupos semanais & $\begin{array}{l}\text { E eu acho até que deveria ter, além das reuniões mensais, alguma coisa semanal. } \\
\text { Algum mecanismo de acolhimento, semanal... Porque a pessoa esperar um mês, as } \\
\text { vezes a pessoa já esqueceu. Então, semanal deveria ter. }\end{array}$ \\
\hline Transcrição E2 revisada & AÇÃO\Fazer|Outros tipos de trabalho (24)\Cidadãos fazendo mudança & $\begin{array}{l}\text { Algum mecanismo de acolhimento, semanal... Porque a pessoa esperar um mês, as } \\
\text { vezes a pessoa já esqueceu. Então, semanal deveria ter. Enfim, eu acho que essa } \\
\text { lógica, ela vai nos trazer uma grande parceria. Uma grande parceria de cidadãos } \\
\text { que vão cumprir esse papel de reproduzir as suas realidades, fomentar discussão e } \\
\text { assim fazer a mudança, creio eu. }\end{array}$ \\
\hline Transcrição E2 revisada & CONSCIENTIZAÇÃO|Consciência \O absurdo do suicídio|É muita coisa para fazer|Sentindo que é muita coisa & $\begin{array}{l}\text { Aí a gente esta falando de uma linha de proteção: mídia, polícia que tem que saber } \\
\text { o que fazer na hora } \mathrm{H} \text {, os médicos, psicólogos, psiquiatras, a família... é tanta } \\
\text { coisa... é a demanda que vai aumentar e a gente precisa de pessoas para onde? } \\
\text { Mesmo que elas falem "ok, aceito, preciso de ajuda". A gente faz o que? Tá dando } \\
\text { um nó na minha cabeça. É muita coisa ao mesmo tempo. A gente precisa de muita } \\
\text { gente do lado da gente eu não estou conseguindo entender como é que a gente } \\
\text { vai conseguir amarrar uma coisa à outra e aí... }\end{array}$ \\
\hline Transcrição E2 revisada & AÇÃO\Cuidar\Tratamento (13)\Acesso a formas de tratamento|Aumenta demanda e encaminha para onde? & $\begin{array}{l}\text { é a demanda que vai aumentar e a gente precisa de pessoas para onde? Mesmo } \\
\text { que elas falem "ok, aceito, preciso de ajuda". }\end{array}$ \\
\hline Transcrição E2 revisada & CONSCIENTIZAÇÃO|Consciência \O absurdo do suicídio|É muita coisa para fazer\A gente precisa de muita gente do lado da gente & $\begin{array}{l}\text { A gente faz o que? Tá dando um nó na minha cabeça. É muita coisa ao mesmo } \\
\text { tempo. A gente precisa de muita gente do lado da gente eu não estou conseguindo } \\
\text { entender como é que a gente vai conseguir amarrar uma coisa à outra e aí... }\end{array}$ \\
\hline Transcrição E2 revisada & CONSCIENTIZAÇÃO|Consciência\O absurdo do suicídio|É muita coisa para fazer|Por onde começamos? & Através da mídia? Através do que? \\
\hline
\end{tabular}

Material integrante da pesquisa de doutorado de Karen Scavacini - USP Proibida a reprodução ou utilização sem autorização do autor - 2018 


\begin{tabular}{|c|c|c|}
\hline Transcrição E2 revisada & COMPREENSÃO\Experiência\O viver\Quem viveu (5)\Antes do suicídio\Não tinha ideia sobre o que era o suicídio antes & $\begin{array}{l}\text { mas assim, até a bem pouco tempo a gente não tinha nem ideia sobre o suicídio, } \\
\text { com o que aconteceu com a (nome da filha) }\end{array}$ \\
\hline Transcrição E2 revisada & AÇÃO\Fazer|Outros tipos de trabalho (24)\Usando a dor para ajudar os outros|Criando Instituto para ajudar outros & $\begin{array}{l}\text { mas assim, até a bem pouco tempo a gente não tinha nem ideia sobre o suicídio, } \\
\text { com o que aconteceu com a (nome da filha) a e depois por outros motivos, a gente } \\
\text { criou o instituto, está certo? }\end{array}$ \\
\hline Transcrição E2 revisada & AÇÃO|Fazer\Outros tipos de trabalho (24)\Religião / Espiritualidade\A influência positiva da espiritualidade & $\begin{array}{l}\text { Esse instituto ele já foi traçado através de mensagens para a gente, ele foi traçado } \\
\text { como ele devia trabalhar, inclusive para aquelas pessoas, tanto faz ser da periferia } \\
\text { ou não... que sofrem de depressão }\end{array}$ \\
\hline Transcrição E2 revisada & 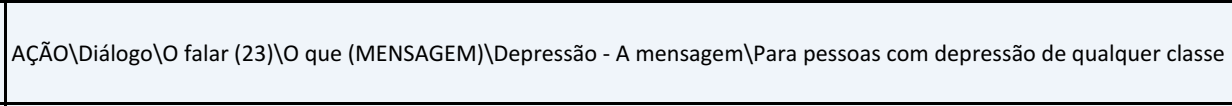 & $\begin{array}{l}\text { Esse instituto ele já foi traçado através de mensagens para a gente, ele foi traçado } \\
\text { como ele devia trabalhar, inclusive para aquelas pessoas, tanto faz ser da periferia } \\
\text { ou não... que sofrem de depressão }\end{array}$ \\
\hline Transcrição E2 revisada & COMPREENSÃO\Comunicação|Social|Área acadêmica e palestras\Montando palestras com psicólogas & $\begin{array}{l}\text { Então a gente montou palestras, a (nome da esposa) montou palestras com as } \\
\text { psicólogas. }\end{array}$ \\
\hline Transcrição E2 revisada & COMPREENSÃO|Comunicação|Social|Área acadêmica e palestras|Dificuldades em achar quem aceitava palestras & E a gente tinha dificuldade em achar uma escola para dar palestras no começo. \\
\hline Transcrição E2 revisada & COMPREENSÃo|Comunicação|Social|Área acadêmica e palestras|Aumento do pedido de palestras & Hoje a gente tá dando 2 as vezes até 3 por semana nas escolas. \\
\hline Transcrição E2 revisada & COMPREENSÃO|Comunicação|Social|Área acadêmica e palestras\As pessoas estão buscando informação por palestras & $\begin{array}{l}\text {. Hoje a gente tá dando } 2 \text { as vezes até } 3 \text { por semana nas escolas. Principalmente na } \\
\text { periferia, as escolas que tem mais dificuldade de ter, de levar o profissional né. }\end{array}$ \\
\hline Transcrição E2 revisada & COMPREENSÃO|Comunicação|Social|Área acadêmica e palestras\Periferia mais aberta para palestras & $\begin{array}{l}\text { Principalmente na periferia, as escolas que tem mais dificuldade de ter, de levar o } \\
\text { profissional né. }\end{array}$ \\
\hline Transcrição E2 revisada & COMPREENSÃo|Comunicação|Social\Área acadêmica e palestras|Tema da palestras & $\begin{array}{l}\text { Essa palestra ela foi passada e mostrada para vários profissionais e tal, é uma } \\
\text { palestra que você fala sobre prevenção do suicídio e a valorização da vida. }\end{array}$ \\
\hline Transcrição E2 revisada & AÇÃO\Diálogo|O falar (23)\Quem\Adolescentes\Ensinando alunos a identificar e a ouvir & $\begin{array}{l}\text { E tenta criar, conscientizar os alunos para perceberem outro amigo seu, varias } \\
\text { situações de risco. Que você possa conversar entre eles, então essa é a filosofia } \\
\text { dessas palestras. É apresentar e tudo, falar da família que necessita e tal, mas } \\
\text { principalmente para que ela possa, sentir nesse amigo alguma coisa. Que ninguém } \\
\text { vai falar mas sempre tem alguém que chega para uma pessoa e fala "hoje eu estou } \\
\text { triste, estou isso, aquilo...". Então a pessoa começa a despertar e saber, pelo } \\
\text { menos, ouvir. Tá certo. Essa é assim, o ponto chave. }\end{array}$ \\
\hline Transcrição E2 revisada & AÇÃo|Cuidar|Tratamento (13)|Acesso a formas de tratamento|Atendimento com demanda grande & $\begin{array}{l}\text { E o outro foi o atendimento, hoje está com } 4 \text { psicólogas porque a demanda é muito } \\
\text { grande, estavam falando que é CAPS, é isso, e você não consegue é efetivamente, } \\
\text { e até o CAPS estaria mandando para lá, porque eles não tem como atender todos, } \\
\text { tal.. e }\end{array}$ \\
\hline Transcrição E2 revisada & AÇÃo|Cuidar|Tratamento (13)\Acesso a formas de tratamento|CAPS enviando para atendimento por não dar conta & $\begin{array}{l}\text { E o outro foi o atendimento, hoje está com } 4 \text { psicólogas porque a demanda é muito } \\
\text { grande, estavam falando que é CAPS, é isso, e você não consegue é efetivamente, } \\
\text { e até o CAPS estaria mandando para lá, porque eles não tem como atender todos, } \\
\text { tal.. e }\end{array}$ \\
\hline Transcrição E2 revisada & CONSCIENTIZAÇÃO|Consciência|O absurdo do suicídio|É muita coisa para fazerla gente faz aquilo que pode & $\begin{array}{l}\text { a gente faz aquilo que pode né, sabemos que precisamos fazer além disso, mas é } \\
\text { um começo, é um focozinho aqui, outro acolá, como ele falou, então se você tem } \\
\text { vários focos desses, percebe, e começa a se expandir, mas tem que começar né, } \\
\text { uma coisa de cada vez. }\end{array}$ \\
\hline Transcrição E2 revisada & AÇÃO\Fazer|Outros tipos de trabalho (24)\Começar com pequenos focos\sabemos que precisamos fazer além disso, & sabemos que precisamos fazer além disso, \\
\hline Transcrição E2 revisada & AÇÃO\Fazer|Outros tipos de trabalho (24)\Começar com pequenos focos & $\begin{array}{l}\text { mas é um começo, é um focozinho aqui, outro acolá, como ele falou, então se você } \\
\text { tem vários focos desses, percebe, e começa a se expandir, mas tem que começar } \\
\text { né, uma coisa de cada vez. }\end{array}$ \\
\hline Transcrição E2 revisada & AÇÃO\Fazer|Outros tipos de trabalho (24)\Era digital & a gente tá indo cada vez mais pra uma era mais digital \\
\hline Transcrição E2 revisada & CONSCIENTIZAÇÃo|Consciência \O absurdo do suicídio|Prevenção x Previsão\Tentando apagar os rastros & $\begin{array}{l}\text { eu pegaram o Laptop do meu irmão, estava lá no google pesquisas, né, de como se } \\
\text { matar, depressão, bipolaridade. Então acho que é assim, só que naquela internet, } \\
\text { black internet, underweb, que ninguém consegue rastrear. }\end{array}$ \\
\hline
\end{tabular}

Material integrante da pesquisa de doutorado de Karen Scavacini - USP Proibida a reprodução ou utilização sem autorização do autor - 2018 


\begin{tabular}{|c|c|c|}
\hline Transcrição E2 revisada & AÇÃO\Fazer\Outros tipos de trabalho (24)\Era digital|Usar a rastreabilidade & $\begin{array}{l}\text { gente abre uma vez por dia o Google, né, é assim como acho que o Google usa as } \\
\text { rastreabilidade de dados pra certas coisas e a gente usa, né, eu acho que a gente } \\
\text { poderia usar talvez pra isso também. }\end{array}$ \\
\hline Transcrição E2 revisada & AÇÃO)Fazer|Outros tipos de trabalho (24)\Era digital|Usar a rastreabilidade & $\begin{array}{l}\text { Por exemplo, quando você vê que tem uma pessoa, um computador, um aplicativo } \\
\text { ou algum celular que tá procurando... Por exemplo, se alguém escreve "como se } \\
\text { matar", não é possivel que a pessoa não está pensando. }\end{array}$ \\
\hline Transcrição E2 revisada & AÇÃO\Fazer\Outros tipos de trabalho (24)\Era digital|Se pesquisou é porque tem alguma ligação com o tema & $\begin{array}{l}\text { Por exemplo, quando você vê que tem uma pessoa, um computador, um aplicativo } \\
\text { ou algum celular que tá procurando... Por exemplo, se alguém escreve "como se } \\
\text { matar", não é possível que a pessoa não está pensando. }\end{array}$ \\
\hline Transcrição E2 revisada & AÇÃO\Fazer|Outros tipos de trabalho (24)\Era digital|Se pesquisou é porque tem alguma ligação com o tema & Talvez não pra ela mas assim...alguma coisa de "como se matar". \\
\hline Transcrição E2 revisada & AÇÃO|Fazer|Outros tipos de trabalho (24)\Era digital(Usar a rastreabilidade & $\begin{array}{l}\text { porque como o meu irmão tinha pesquisado, mas eu pesquisei numa internet } \\
\text { normal, então se fizesse uma intervenção comigo, que eu estava fazendo uma } \\
\text { pesquisa. Então eu acho que essa questão de rastrear o que as pessoas } \\
\text { procuram.... a gente vai rastrear uma bando de idiotice? Que a gente use talvez pra } \\
\text { causas assim, graves mesmo, porque tudo nosso é rastreado, entendeu? Todo } \\
\text { mundo sabe tudo da nossa vida, hoje. Então, será que não tem como a gente usar } \\
\text { as redes pra gente entender e aí pegar algumas palavras chaves de tipo há... ou se } \\
\text { aquele computador, aquele celular vive procurando aquilo. }\end{array}$ \\
\hline Transcrição E2 revisada & AÇÃO\Fazer|Outros tipos de trabalho (24)\Era digital|Não aparecer a resposta para certas buscas na internet & $\begin{array}{l}\text { Ou eu até acho que nem deveria aparecer na internet com a resposta da pergunta } \\
\text { "como se matar", porque existe. Se vocês procurarem... não sei se vocês já } \\
\text { procuraram...entendeu? }\end{array}$ \\
\hline Transcrição E2 revisada & CONSCIENTIZAÇÃO|Consciência\O absurdo do suicídio|Prevenção x Previsão|Underweb & $\begin{array}{l}\begin{array}{l}\text { Tudo bem, nessa internet que não é rastreada, e assim, eu nem sei quem faz a } \\
\text { gestão disso. Acho que é uma coisa que sempre vão burlar e talvez sempre exista }\end{array} \\
\end{array}$ \\
\hline Transcrição E2 revisada & CONSCIENTIZAÇÃOIConsciência \O absurdo do suicídio|Prevenção x Previsão|Underweb & $\begin{array}{l}\text { eu lembro que quando eu pegaram o Laptop do meu irmão, estava lá no google } \\
\text { pesquisas, né, de como se matar, depressão, bipolaridade. Então acho que é assim, } \\
\text { só que naquela internet, black internet, underweb, que ninguém consegue } \\
\text { rastrear. É uma internet que, né? }\end{array}$ \\
\hline Transcrição E2 revisada & AÇÃO\Fazer|Outros tipos de trabalho (24)\Era digital|Não aparecer a resposta para certas buscas na internet & $\begin{array}{l}\text { Ou tipo tomar chumbinho, sabe, acho que tem algumas ideias, que tem na internet } \\
\text { hoje, que eu não vejo necessidade de existir porque não vai gerar nada bom. }\end{array}$ \\
\hline Transcrição E2 revisada & AÇÃO\Fazer|Outros tipos de trabalho (24)\Era digital|Usar a rastreabilidade & $\begin{array}{l}\text { Então acho que a questão disso talvez porque todo mundo vai sempre no Google e } \\
\text { talvez através do Google você é rastreado, eu sei que o Facebook ele começa a } \\
\text { monitorar também o seu comportamento à respeito dos seus posts e tal, e o face } \\
\text { tem algumas coisas que eles começam a monitorar o que a pessoa está fazendo... } \\
\text { então, como hoje a gente está na era bem digital, e todos nós, teoricamente, } \\
\text { temos um celular, que não é todo mundo mas que, enfim, talvez também tenha } \\
\text { que ver por aí né... }\end{array}$ \\
\hline Transcrição E2 revisada & AÇÃO\Fazer|Outros tipos de trabalho (24)\Era digital\Usar o mundo digital a favor da prevenção & $\begin{array}{l}\text { não sei se o mundo digital consegue ajudar a gente, já que também atrapalha, né? } \\
\text { Que a gente use ele de uma forma inteligente pra entender o comportamento } \\
\text { humano, ou conseguir...ou por exemplo, digitou lá "como se matar", que apareça } \\
\text { um negócio por exemplo: O CVV, você está triste, não tente...eu sei lá.... não sei... }\end{array}$ \\
\hline Transcrição E2 revisada & AÇÃO\Fazer|Outros tipos de trabalho (24)\Era digital\Aparecer um aviso de ajuda ao ser rastreado & $\begin{array}{l}\text { não sei se o mundo digital consegue ajudar a gente, já que também atrapalha, né? } \\
\text { Que a gente use ele de uma forma inteligente pra entender o comportamento } \\
\text { humano, ou conseguir...ou por exemplo, digitou lá "como se matar", que apareça } \\
\text { um negócio por exemplo: O CVV, você está triste, não tente...eu sei lá.... não sei... }\end{array}$ \\
\hline Transcrição E2 revisada & AÇÃO\Diálogo\O falar (23)\Como (FORMA)\Formas\Depoimentos de pessoas & $\begin{array}{l}\text { E outras coisas, que eu acho que ajudam, são também depoimentos de pessoas } \\
\text { que passaram por isso, por exemplo, tem aquele Nicki... e eu não sei falar o } \\
\text { sobrenome dele... é um cara que não tem braço e pernas, }\end{array}$ \\
\hline
\end{tabular}




\begin{tabular}{|c|c|c|}
\hline Transcrição E2 revisada & AÇÃO\Diálogo\O falar (23)\Quem|Sobreviventes tentativas\Depoimento de quem já pensou & $\begin{array}{l}\text { ele para mim assim, eu assisto os vídeos dele, acho que semanalmente, o mesmo, } \\
\text { sempre faço isso, porque eu olho a história dele e eu já li vários livros dele e ele } \\
\text { fala que ele já tentou, que ele tinha pensamento suicidas, etc., etc. }\end{array}$ \\
\hline Transcrição E2 revisada & AÇÃO\Campanhas (22)\Temas\Histórias que inspiram para o bem & $\begin{array}{l}\text { Eu acho que histórias que nos inspiram pro bem, talvez ajudariam as pessoas } \\
\text { porque as palestras que ele faz, }\end{array}$ \\
\hline Transcrição E2 revisada & AÇÃO\Campanhas (22)\Temas\Histórias reais e humanas e superação\História que toca e impressiona & $\begin{array}{l}\text { Eu acho que histórias que nos inspiram pro bem, talvez ajudariam as pessoas } \\
\text { porque as palestras que ele faz, por exemplo, em colégio, você vê vários } \\
\text { adolescentes chorando porque com certeza eles se identificam com a história em } \\
\text { algum momento do depoimento, né, que ele faz dos sentimentos, as coisas que ele } \\
\text { viveu, então, assim, a história dele é impressionante. }\end{array}$ \\
\hline Transcrição E2 revisada & AÇÃO|Campanhas (22) \Identificação|Se identificam com a história & $\begin{array}{l}\text { em colégio, você vê vários adolescentes chorando porque com certeza eles se } \\
\text { identificam com a história em algum momento do depoimento, né, }\end{array}$ \\
\hline Transcrição E2 revisada & AÇÃO\Campanhas (22)\Temas\Histórias reais e humanas e superação\Empatia pela história difícil & $\begin{array}{l}\text { Eu acho que o trabalho que ele faz é muito incrível porque ele fala de suicídio e eu } \\
\text { acho que as pessoas acabam tendo um pouco de empatia, pela história difícil que } \\
\text { ele tem }\end{array}$ \\
\hline Transcrição E2 revisada & AÇÃO\Campanhas (22)〈Temas\Histórias reais e humanas e superação & $\begin{array}{l}\text { Então, e se a gente tivesse histórias herói? Heróis, assim, pessoas referencia, sabe, } \\
\text { de superação...e assim, histórias reais e não pro cara ficar famoso e tipo aí, } \\
\text { sabe...eu acho que tem que ser uma coisa humana }\end{array}$ \\
\hline Transcrição E2 revisada & AÇÃo|Campanhas (22)〈Temas\Histórias reais e humanas e superação\Fácil de se identificar com a historia bonita dele & $\begin{array}{l}\text { Pra mim ele é maravilhoso e ele fala muito de suicídio, de bullying e eu tenho } \\
\text { certeza que os adolescentes e as crianças, eu também assim me identifico e é } \\
\text { muito bonita, a história dele. }\end{array}$ \\
\hline Transcrição E2 revisada & AÇÃO\Fazer|Outros tipos de trabalho (24)\Dá para falar de suicídio com adolescentes e crianças & $\begin{array}{l}\text { Pra mim ele é maravilhoso e ele fala muito de suicídio, de bullying e eu tenho } \\
\text { certeza que os adolescentes e as crianças, eu também assim me identifico e é } \\
\text { muito bonita, a história dele. }\end{array}$ \\
\hline Transcrição E2 revisada & AÇÃO\Campanhas (22)\Cuidados\Deus é muito subjetivo & $\begin{array}{l}\text { E aí ele trás a mensagem de Deus. E aí é que Deus é uma coisa muito subjetiva, né, } \\
\text { que cada um... }\end{array}$ \\
\hline Transcrição E2 revisada & AÇÃO\Campanhas (22)\Temas\Histórias que inspiram para o bem & mas eu acho que tem histórias, como a dele, que eu acho que inspiram. \\
\hline Transcrição E2 revisada & AÇÃO\Campanhas (22)\Temas\Histórias reais e humanas e superação\É possivel vencer & $\begin{array}{l}\text { Tipo é possivel vencer, que realmente a história dele é bem... quando ele fala, tem } \\
\text { uma hora que ele fala assim, que ele queria que alguém falasse que ia ficar tudo } \\
\text { bem }\end{array}$ \\
\hline Transcrição E2 revisada & AÇÃO\Campanhas (22)\Temas\Ter exemplos para seguir|Vai ficar tudo bem - ter exemplos & $\begin{array}{l}\text { Tipo é possível vencer, que realmente a história dele é bem... quando ele fala, tem } \\
\text { uma hora que ele fala assim, que ele queria que alguém falasse que ia ficar tudo } \\
\text { bem, mas como, se todo, ele não conhece ninguém que não tenha braços e pernas } \\
\text { na verdade tem mais uma criança que chama Daniel que nasceu depois, né, } \\
\text { quando você se coloca no lugar dele, realmente, não tem um ser humano na face } \\
\text { da terra que passou pelo o que o cara passou pra poder falar "Olha vai ficar tudo } \\
\text { bem" eu sou um exemplo }\end{array}$ \\
\hline Transcrição E2 revisada & AÇÃO\Campanhas (22)\Temas\Ter exemplos para seguir & $\begin{array}{l}\text { Então eu acho que essa questão, ele também procurava um exemplo, entende? } \\
\text { Então eu acho que a questão do exemplo, do tipo as pessoas falarem: "Olha, passei } \\
\text { por isso mas hoje eu estou bem". }\end{array}$ \\
\hline Transcrição E2 revisada & AÇÃO\Diálogo\O falar (23)\Como (FORMA)\Formas\Depoimentos de pessoas & $\begin{array}{l}\text { Ter depoimentos, tanto de pessoas que ficaram da família e que são os enlutados } \\
\text { pra criar empatia de outras famílias, como pessoas que tentaram. Porque você não } \\
\text { vê muito depoimento de pessoas que tentaram. Até no nosso grupo quando } \\
\text { alguém vai, é interessante você ouvir... }\end{array}$ \\
\hline Transcrição E2 revisada & CONSCIENTIZAÇÃO\Desafios\Impeditivos (18)\Difíili depoimentos de pessoas que tentaram & Porque você não vê muito depoimento de pessoas que tentaram. \\
\hline Transcrição E2 revisada & AÇÃO|Semear|Sugestão de entrevistar pessoas que tentaram (16)\Quem tentou não se sente a vontade & Mas a pessoa não sente à vontade... \\
\hline Transcrição E2 revisada & AÇÃO|Semear|Sugestão de entrevistar pessoas que tentaram (16)\Quem tentou não se sente a vontade & Exato porque falar, é só... \\
\hline Transcrição E2 revisada & 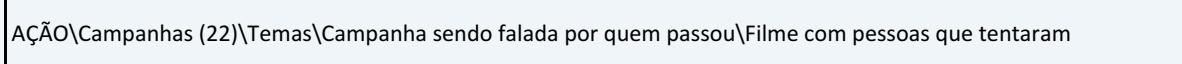 & $\begin{array}{l}\text { Por causa da (nome de canal de televisão). Vai ter } 3 \text { jovens que tentaram o suicídio } \\
\text { que vão participar agora do filme que eu vou estar participando }\end{array}$ \\
\hline
\end{tabular}

Material integrante da pesquisa de doutorado de Karen Scavacini - USP Proibida a reprodução ou utilização sem autorização do autor - 2018 


\begin{tabular}{|c|c|c|}
\hline Transcrição E2 revisada & COMPREENSÃO|Comunicação|Social|Possíveis Causas para o Aumento|Canais de TV investindo no tema & $\begin{array}{l}\text { Vai ter. Por causa da (nome de canal de televisão). Vai ter } 3 \text { jovens que tentaram o } \\
\text { suicídio que vão participar agora do filme que eu vou estar participando. Porque os } \\
\text { produtores me falaram. Eu sou o enlutado mas tem ... jovens, acho que de } 20 \text { e } \\
\text { poucos anos que abriram mão do anonimato, na condição de terem tentado o } \\
\text { suicídio e vão relatar suas histórias. Eu acho que são .... ou vice-versa. Eu não sei } \\
\text { mais detalhes, mas vai ter. Vai ter. }\end{array}$ \\
\hline Transcrição E2 revisada & AÇÃO\Diálogo\O falar (23)\Quem|Sobreviventes tentativas\Depoimento de quem já pensou & $\begin{array}{l}\text { Eu sou o enlutado mas tem ... jovens, acho que de ... que abriram mão do } \\
\text { anonimato, na condição de terem tentado o suicídio e vão relatar suas histórias. Eu } \\
\text { acho que são .... ou vice-versa. Eu não sei mais detalhes, mas vai ter. }\end{array}$ \\
\hline Transcrição E2 revisada & AÇÃO\Campanhas (22)\Temas\Campanha sendo falada por quem passou\Histórias verídicas & Quer dizer, histórias verídicas... \\
\hline Transcrição E2 revisada & AÇÃo\Campanhas (22)\Temas\Campanha sendo falada por quem passou\Histórias verídicas & Verídicas. Reais \\
\hline Transcrição E2 revisada & AÇÃO\Campanhas (22)\Temas\Campanhas voltadas para todos & $\begin{array}{l}\text { Sim, eu acho que uma coisa que ajudaria, seria se as campanhas fossem voltadas } \\
\text { para pessoas comuns, todo mundo, para capacitar a pessoa pra melhorar o diálogo } \\
\text { e falar de momentos de tristeza. }\end{array}$ \\
\hline Transcrição E2 revisada & AÇÃo\Campanhas (22)\Temas\Campanhas de capacitação do diálogo & $\begin{array}{l}\text { Sim, eu acho que uma coisa que ajudaria, seria se as campanhas fossem voltadas } \\
\text { para pessoas comuns, todo mundo, para capacitar a pessoa pra melhorar o diálogo } \\
\text { e falar de momentos de tristeza. }\end{array}$ \\
\hline Transcrição E2 revisada & AÇÃO\Campanhas (22)\Temas\Campanhas sobre tristeza & $\begin{array}{l}\text { Sim, eu acho que uma coisa que ajudaria, seria se as campanhas fossem voltadas } \\
\text { para pessoas comuns, todo mundo, para capacitar a pessoa pra melhorar o diálogo } \\
\text { e falar de momentos de tristeza. }\end{array}$ \\
\hline Transcrição E2 revisada & AÇÃO\Campanhas (22)\Temas \Informação da hora de procurar ajuda profissional & $\begin{array}{l}\text { Ao mesmo tempo, passar informação de que tem um certo ponto de que aí eu ? e } \\
\text { vou amigo. Já foge da minha alçada, puxa será que já não é hora de... podia } \\
\text { procurar o CVV, um psicólogo, será que não é hora de tomar medicação... se isso } \\
\text { fosse parte do diálogo comum, eu acho que assim, é, elas teriam um alcance } \\
\text { maior. }\end{array}$ \\
\hline Transcrição E2 revisada & AÇÃo|Campanhas (22)\Temas\Passar a informação de que tem um limite & $\begin{array}{l}\text { Ao mesmo tempo, passar informação de que tem um certo ponto de que aí eu ? e } \\
\text { vou amigo. Já foge da minha alçada, puxa será que já não é hora de... podia } \\
\text { procurar o CVV, um psicólogo, será que não é hora de tomar medicação... se isso } \\
\text { fosse parte do diálogo comum, eu acho que assim, é, elas teriam um alcance } \\
\text { maior. }\end{array}$ \\
\hline Transcrição E2 revisada & AÇÃO\Campanhas (22) \dentificação\AS pessoas não se identificam com as outras que falam & $\begin{array}{l}\text { Que a campanha não fosse voltada pra.... o que eu sinto de grande dificuldade é } \\
\text { que as pessoas não se identificam com as outras quando falam... a não ser quem } \\
\text { passou. }\end{array}$ \\
\hline Transcrição E2 revisada & AÇÃo|Campanhas (22) \Identificação|Só se identifica quem passou & $\begin{array}{l}\text { Que a campanha não fosse voltada pra.... o que eu sinto de grande dificuldade é } \\
\text { que as pessoas não se identificam com as outras quando falam... a não ser quem } \\
\text { passou. }\end{array}$ \\
\hline Transcrição E2 revisada & AÇÃO\Campanhas (22)\Temas \Campanhas sobre tristeza & $\begin{array}{l}\text { a maneira de evitar esse impacto, né, nós estamos falando de um tema que na } \\
\text { nossa cultura é tabu, seria assim, falar sobre a emoção da tristeza e da importância } \\
\text { de você poder conversar com o seu amigo, com a sua família quando você está } \\
\text { triste. }\end{array}$ \\
\hline Transcrição E2 revisada & AÇÃO\Campanhas (22)\Temas\Campanhas de capacitação do diálogo & $\begin{array}{l}\text { a maneira de evitar esse impacto, né, nós estamos falando de um tema que na } \\
\text { nossa cultura é tabu, seria assim, falar sobre a emoção da tristeza e da importância } \\
\text { de você poder conversar com o seu amigo, com a sua familia quando você está } \\
\text { triste. }\end{array}$ \\
\hline Transcrição E2 revisada & AÇÃo|DiálogolOuvir|Pessoas não tem com quem conversar & $\begin{array}{l}\text { E aí eu acho que uma boa parte, isso é a minha referência, quando eu estava no } \\
\text { CVV, uma boa parte das ligações que eu recebi, era isso. Só que elas vão se } \\
\text { somando ate chegar naquela gota d'água. A pessoa nunca tem com quem falar } \\
\text { sobre nada, quando ela está triste, e um dos casos é isso da gota d'água. }\end{array}$ \\
\hline Transcrição E2 revisada & AÇÃO|Fazer|Prevenção (30)\Multifatores|Saúde mental & Outros não. Existe um problema de saúde mental. \\
\hline
\end{tabular}

Material integrante da pesquisa de doutorado de Karen Scavacini - USP Proibida a reprodução ou utilização sem autorização do autor - 2018 


\begin{tabular}{|c|c|c|}
\hline Transcrição E2 revisada & AçÃo|Campanhas (22)\Temas|Campanhas de capacitação do diálogo & $\begin{array}{l}\text { Mas eu acho que se todo mundo fosse mais preparado pra conversar, no cotidiano, } \\
\text { sobre assuntos de tristeza, }\end{array}$ \\
\hline Transcrição E2 revisada & AÇÃo|Campanhas (22)\Temas|Campanhas sobre tristeza & $\begin{array}{l}\text { Mas eu acho que se todo mundo fosse mais preparado pra conversar, no cotidiano, } \\
\text { sobre assuntos de tristeza, }\end{array}$ \\
\hline Transcrição E2 revisada & AÇÃO\Campanhas (22)\Temas\Informação da hora de procurar ajuda profissional & $\begin{array}{l}\text { "Bom, até aqui, eu posso ir como amigo. A partir daqui seria legal, talvez, você } \\
\text { procurar um profissional, ligar pro CVV..." }\end{array}$ \\
\hline Transcrição E2 revisada & AÇÃo|Campanhas (22)\Temas|Passar a informação de que tem um limite\Tirar toda a carga de uma pessoa só & $\begin{array}{l}\text { "Bom, até aqui, eu posso ir como amigo. A partir daqui seria legal, talvez, você } \\
\text { procurar um profissional, ligar pro CVV..." Eu acho que a gente iria pra um lado que } \\
\text { aproxima mais e cria menos resistência. }\end{array}$ \\
\hline Transcrição E2 revisada & AÇÃO\Fazer\Outros tipos de trabalho (24)\Religião / Espiritualidade\Procurando ajuda com o padre & Eu a muito tempo estava com uma tristeza muito grande e fui procurar um padre. \\
\hline Transcrição E2 revisada & AÇÃO\Fazer|Outros tipos de trabalho (24)\Religião / Espiritualidade\Não sendo acolhida pelo padre & $\begin{array}{l}\text { Por incrível que pareça, não fui acolhida: "Olha você vai me desculpar mas eu não } \\
\text { tenho tempo. Eu só posso confessar tal hora, se você quiser." Você vai ter } 5 \\
\text { minutos para se confessar, né? Isso é igreja católica. }\end{array}$ \\
\hline Transcrição E2 revisada & AÇÃO\Fazer\Outros tipos de trabalho (24)\Religião / Espiritualidadel|greja evangélica acolhe bem & $\begin{array}{l}\text { Na igreja evangélica eu não sei como é que está, pelo jeito eles acolhem muito } \\
\text { bem, }\end{array}$ \\
\hline Transcrição E2 revisada & AÇÃO\Fazer\Outros tipos de trabalho (24)\Religião / Espiritualidade\Frequentava a igreja católica & $\begin{array}{l}\text { mas a igreja católica, eu tive essa experiência e era uma pessoa fervorosa, } \\
\text { frequentava... }\end{array}$ \\
\hline Transcrição E2 revisada & AÇÃO\Fazer|Outros tipos de trabalho (24)\Religião / Espiritualidade/Se decepcionando com o padre & $\begin{array}{l}\text { Aquilo me decepcionou tanto, que eu continuei praticando, mas essa decepção é } \\
\text { quanto aos padres. Acredito que não sejam todos mas me decepcionei muito. }\end{array}$ \\
\hline Transcrição E2 revisada & AÇÃO\Fazer\Outros tipos de trabalho (24)\Religião / Espiritualidade \Profissionais a disposição (cvv católico?) & $\begin{array}{l}\text { Então eu acho que isso seria uma grande ajuda você encontrar uma psicóloga, } \\
\text { psiquiatra, um padre eu acho que a grande ajuda é essa. São profissionais que } \\
\text { estariam ali à disposição pra isso. }\end{array}$ \\
\hline Transcrição E2 revisada & AÇÃO\Fazer\Outros tipos de trabalho (24)\Religião / Espiritualidade\Profissionais a disposição (cvv católico?) & Os líderes religiosos, de repente... \\
\hline Transcrição E2 revisada & AÇÃO\Fazer|Outros tipos de trabalho (24)\Religião / Espiritualidade\Acreditando que a religião previne suicídio & $\begin{array}{l}\text { Os líderes religiosos, porque eu acho que a única coisa que prende pra você não } \\
\text { cometer o suicídio é a religião. Você fala: "Não... não é nem pensando na família, é } \\
\text { pensando na religião. }\end{array}$ \\
\hline Transcrição E2 revisada & AÇÃO\Campanhas (22)\Temas\Campanha de psicofobia pelo cfp & $\begin{array}{l}\text { O conselho de psicologia devia fazer uma divulgação na, assim, acho que a gente } \\
\text { falou isso na vez passada, que se você vai procurar um psicólogo já pensa que é, tá } \\
\text { doente, que a pessoa é louca... }\end{array}$ \\
\hline Transcrição E2 revisada & AÇÃO\Campanhas (22)\Temas/Campanha de psicofobia pelo cfp & Que é louca \\
\hline Transcrição E2 revisada & AÇÃO\Campanhas (22)\Temas\Campanha de psicofobia pelo cfp & então é tirar esse né, acho que o conselho de psicologia devia fazer campanha... \\
\hline Transcrição E2 revisada & AÇÃO\Campanhas (22)\Temas\Campanha de psicofobia pelo cfp & psicofobia... \\
\hline Transcrição E2 revisada & AÇÃO\O saber (12)\Falta de formaçãolPessoas que se acham psicólogas & $\begin{array}{l}\text { as pessoas que acham que todo mundo é psicólogo. Também tem essa também. } \\
\text { Eu acho que aí tem, eu ouço tantas coisas, assim, das pessoas. A pessoa leu algum } \\
\text { folheto, alguma coisa... tem isso também. }\end{array}$ \\
\hline Transcrição E2 revisada & AÇÃo|Campanhas (22)\Temas|Passar a informação de que tem um limite & $\begin{array}{l}\text { Tem aquilo que pode ser acolhido por amigos e tem a gente saber detectar o } \\
\text { momento que.. olha... que a gente precisa... aqui a gente já não dá conta e precisa } \\
\text { ajudar aquela pessoa a saber a quem procurar... acho que isso é importante... }\end{array}$ \\
\hline Transcrição E2 revisada & AÇÃO\Campanhas (22)\Temas\Informar quem eles podem procurar & $\begin{array}{l}\text { Tem aquilo que pode ser acolhido por amigos e tem a gente saber detectar o } \\
\text { momento que.. olha... que a gente precisa... aqui a gente já não dá conta e precisa } \\
\text { ajudar aquela pessoa a saber a quem procurar... acho que isso é importante... }\end{array}$ \\
\hline Transcrição E2 revisada & AÇÃO\Campanhas (22)\Temas\Informar quem eles podem procurar & Principalmente a pessoa próxima... que pode ajudar essa família... \\
\hline Transcrição E2 revisada & AÇÃo|Campanhas (22)\Temas|Passar a informação de que tem um limite\Porque não damos conta de tudo & $\begin{array}{l}\text { Porque a gente também não dá conta de tudo... as vezes a gente nem dá conta da } \\
\text { gente... }\end{array}$ \\
\hline Transcrição E2 revisada & AÇÃOlCampanhas (22)\Provedores ou OndelCampanhas de conselhos nacionais & $\begin{array}{l}\text { Igual o conselho de engenharia faz campanha, de arquitetura, e assim vai, né... de } \\
\text { enfermagem, de... eu vi até a pouco tempo, de terapia ocupacional, tudo... } \\
\text { fisioterapia, }\end{array}$ \\
\hline Transcrição E2 revisada & AÇÃO|Campanhas (22)\Provedores ou Onde \Campanha do conselho de psicologia & e o conselho de psicologia poderia também entrar nessa né, está sempre, agora... \\
\hline
\end{tabular}

Material integrante da pesquisa de doutorado de Karen Scavacini - USP Proibida a reprodução ou utilização sem autorização do autor - 2018 


\begin{tabular}{|c|c|c|}
\hline Transcrição E2 revisada & AÇÃ̃OCCampanhas (22)\Provedores ou OndelCampanhas de conselhos nacionais & $\begin{array}{l}\text { acho que foi no Fantástico, né... aquele que... não se faz uma obra sem consultar } \\
\text { um profissional, né, o que que acontece... não tem um quadro assim... a porta que } \\
\text { não abre, sei lá... }\end{array}$ \\
\hline Transcrição E2 revisada & AÇã̃O|Campanhas (22) \Provedores ou OndelCampanha do conselho de psicologia & $\begin{array}{l}\text { então fazer uma campanha numa área que fale sobre procurar o profissional } \\
\text { adequado né... e acho que a psicologia poderia também entrar nessa de... }\end{array}$ \\
\hline Transcrição E2 revisada & AÇÃO\Campanhas (22)\Temas/Campanha de psicofobia pelo cfp & existe um estigma de quem procura um psicólogo tem algum problema, \\
\hline Transcrição E2 revisada & AÇÃo\Campanhas (22)\Temas\Campanha de psicofobia pelo cfp\Terapia também como autoconhecimento & $\begin{array}{l}\text { mas eu acho que tem um lado que podia ser explorado porque eu já vejo também, } \\
\text { em algumas situações que a pessoa entende, assim, procurar uma terapia como } \\
\text { autoconhecimento. }\end{array}$ \\
\hline Transcrição E2 revisada & AÇÃo\Campanhas (22)\Temas\Campanha de psicofobia pelo cfp\Terapia também como autoconhecimento & $\begin{array}{l}\text { é pequeno mas acho que... existe esse outro lado que é um lado positivo, saudável. } \\
\text { Acho que poderia ser mais divulgado, isso. }\end{array}$ \\
\hline Transcrição E2 revisada & AÇãolSemear|Facilitadores (29)\Cursos auto ajuda & $\begin{array}{l}\text { Mas tem isso pode haver uma autoajuda, curso de psicólogos, palestra } \\
\text { motivacional, cursos onde as pessoas vão para não sei aonde, passar o final de } \\
\text { semana pra ficar sozinho e encontrar o seu eu, meditação, Yoga... A humanidade } \\
\text { está passando por isso. }\end{array}$ \\
\hline Transcrição E2 revisada & AÇÃO\Semear\Facilitadores (29)\Achando que as pessoas se perderam do seu eu & Eu acho que a gente se perdeu e a gente tá tentando resgatar o EU \\
\hline Transcrição E2 revisada & AÇÃO|Semear|Facilitadores (29)\Pessoas mais humanas e preocupadas & $\begin{array}{l}\text { Eu acho que a gente se perdeu e a gente tá tentando resgatar o EU, e talvez } \\
\text { quando a gente voltar a ser mais humano, se importar um pouco mais em como a } \\
\text { gente se relaciona, talvez ajude, né, }\end{array}$ \\
\hline Transcrição E2 revisada & AÇÃO|Semear|Facilitadores (29)|Demonstração de cuidado & $\begin{array}{l}\text { se importar um pouco mais em como a gente se relaciona, talvez ajude, né, } \\
\text { porque, as vezes só um: "Oi, tudo bem?", um "Obrigada", ou um "Como você está } \\
\text { hoje?" Às vezes isso, pronto, já fez o seu dia, né? Ou alguém te manda uma } \\
\text { mensagem você fala: "Ah! É por isso que vale à pena viver", entendeu. }\end{array}$ \\
\hline Transcrição E2 revisada & AÇão|Semear|Facilitadores (29)|Sentindo-se amada por outros & $\begin{array}{l}\text { e importar um pouco mais em como a gente se relaciona, talvez ajude, né, porque, } \\
\text { as vezes só um: "Oi, tudo bem?", um "Obrigada", ou um "Como você está hoje?" Às } \\
\text { vezes isso, pronto, já fez o seu dia, né? Ou alguém te manda uma mensagem você } \\
\text { fala: "Ah! É por isso que vale à pena viver", entendeu. São as diversas formas de } \\
\text { amor. }\end{array}$ \\
\hline Transcrição E2 revisada & AÇÃO|Semear|Facilitadores (29)\Resgate do eu & Então, eu acho que quando a gente voltar a resgatar o eu, talvez isso, né, \\
\hline Transcrição E2 revisada & AÇÃolSemear|Facilitadores (29)\Relações saudáveis e acolhedoras & $\begin{array}{l}\text { Então, eu acho que quando a gente voltar a resgatar o eu, talvez isso, né, ajude a } \\
\text { gente acolher as pessoas porque acho que não vai ter profissional pra todo mundo } \\
\text { todos os dias mas, se cada um fizer um pouquinho e ter boas relações e aí é assim, } \\
\text { é difíill, a gente trabalha com isso todo dia isso vai ajudar, também... }\end{array}$ \\
\hline Transcrição E2 revisada & 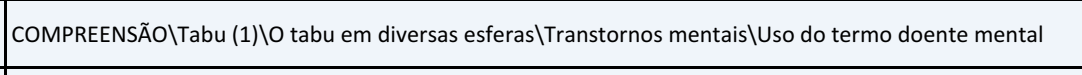 & $\begin{array}{l}\text { Aí a pessoa fala: "Nossa, então eu sou doente mental" Não como mudar, suavizar } \\
\text { esse conceito? Esse termo? Porque a pessoa aí não aceita esse termo porque... }\end{array}$ \\
\hline Transcrição E2 revisada & COMPREENSÃO\Tabu (1)\Consequências do Tabu\Estigma\Estigma da doença mental & $\begin{array}{l}\text { E o estigma de "Doença mental". Que quando a gente fala em doença mental entra } \\
\text { depressão, ansiedade, entra tudo isso. Aí a pessoa fala: "Nossa, então eu sou } \\
\text { doente mental" Não como mudar, suavizar esse conceito? Esse termo? Porque a } \\
\text { pessoa aí não aceita esse termo porque... }\end{array}$ \\
\hline Transcrição E2 revisada & COMPREENSÃO\Tabu (1)\Consequências do Tabu\Estigma\Estigma da doença mental & Transtorno? Chamar de transtorno... \\
\hline Transcrição E2 revisada & 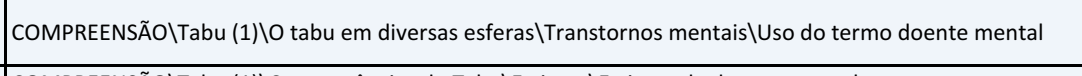 & $\begin{array}{l}\text { Não sei. Mas assim... Doença mental? Meu Deus, eu sou um doente mental? Não! } \\
\text { É difícil a pessoa... para a pessoa assumir... }\end{array}$ \\
\hline Transcrição E2 revisada & COMPREENSÃO\Tabu (1)\Consequências do Tabu\Estigma\Estigma da doença mental & Transtorno, talvez. A palavra mais suave... \\
\hline Transcrição E2 revisada & AÇÃO\Diálogo\O falar (23)\O que (MENSAGEM)\Desmistificar|Suavizar o termo & $\begin{array}{l}\text { Não como mudar, suavizar esse conceito? Esse termo? Porque a pessoa aí não } \\
\text { aceita esse termo porque... }\end{array}$ \\
\hline Transcrição E2 revisada & 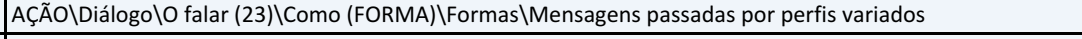 & Variado... \\
\hline Transcrição E2 revisada & 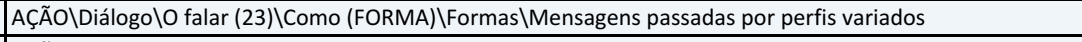 & Vários perfis... \\
\hline Transcrição E2 revisada & AÇÃO|DiálogolO falar (23)\Como (FORMA)\Formas\Mensagens passadas por perfis variados & Diversidade... tem que refletir a sociedade... \\
\hline
\end{tabular}




\begin{tabular}{|c|c|c|}
\hline Transcrição E2 revisada & AÇÃO\Diálogo|O falar (23)\Quem\Profissionais|Sem ser professoral & $\begin{array}{l}\text { E não pode ser professoral, não pode... porque por exemplo, se for um profissional } \\
\text { de saúde categorizado vai ficar professoral... Você, por exemplo, impõe, impõe } \\
\text { autoridade. Eaí sim... para o segmento, (risos). Autoridade... sim, porque você tem } \\
\text { um título...tem um reconhecimento e tal. }\end{array}$ \\
\hline Transcrição E2 revisada & AÇÃo|DiálogolO falar (23)\Quem\Profissionais|Autoridade no assunto para aqueles que buscam isso & $\begin{array}{l}\text { Autoridade... sim, porque você tem um título...tem um reconhecimento e tal. } \\
\text { Então, quando vai falar, aí, é pra aquele contingente que busca uma informação e } \\
\text { quer ouvir uma autoridade no assunto. Então ele vai, então serve a esse fim, }\end{array}$ \\
\hline Transcrição E2 revisada & AÇÃO\DiálogolO falar (23)\Quem|De um par|Ouvir uma pessoa como ele & $\begin{array}{l}\text { existe um outro contingente que não quer ouvir, é, quer ouvir, as vezes, uma } \\
\text { pessoa como ele, esse.. }\end{array}$ \\
\hline Transcrição E2 revisada & 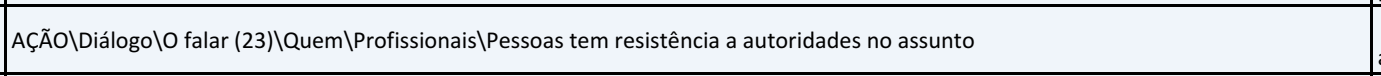 & $\begin{array}{l}\text { então aquela resistência que muita gente vai ter à pessoa que é autoridade do } \\
\text { assunto. }\end{array}$ \\
\hline Transcrição E2 revisada & AÇÃO\Diálogo\O falar (23)\Quem|Sobreviventes tentativas\Ouvir de quem passou & $\begin{array}{l}\text { eu também já vi alguns dele, esse que não tem os braços e pernas, esse camarada, } \\
\text { ele até pode ter o tom profissional também mas acontece que ele vive a realidade, }\end{array}$ \\
\hline Transcrição E2 revisada & AÇÃO\Diálogo\O falar (23)\Quem\De um par|Ouvir de um par & $\begin{array}{l}\text { Porque a pessoa, ela, na fragilidade dela ela precisa, as vezes, de ver outra pessoa } \\
\text { frágil, uma outra pessoa que chora, que dói, que fica com a palavra embargada } \\
\text { pela dor que está sentindo...então que é um igual, que é um par... }\end{array}$ \\
\hline Transcrição E2 revisada & AÇÃo|DiálogolO falar (23)\Quem \De um parlOuvir de um par & Parecido com ela, um par.... \\
\hline Transcrição E2 revisada & AÇÃo|Semear|Sugestão de entrevistar pessoas que tentaram (16)\Perguntar para quem tentou & $\begin{array}{l}\text { E essa eu acho que é uma pergunta para se fazer para pessoas que já tentaram, } \\
\text { porque assim: porque elas desistiram ou quem são referencias para elas, ou por } \\
\text { exemplo, quem elas ouvem. }\end{array}$ \\
\hline Transcrição E2 revisada & AÇÃO|Semear|Sugestão de entrevistar pessoas que tentaram (16)\Quem as pessoas que tentaram ouvem & $\begin{array}{l}\text { porque elas desistiram ou quem são referencias para elas, ou por exemplo, quem } \\
\text { elas ouvem. }\end{array}$ \\
\hline Transcrição E2 revisada & AÇÃO|Semear|Sugestão de entrevistar pessoas que tentaram (16)|Perguntar para quem tentou & Muito bom isso \\
\hline Transcrição E2 revisada & AÇÃO|Semear|Sugestão de entrevistar pessoas que tentaram (16)\Perguntar para quem tentou & $\begin{array}{l}\text { Entendeu? Acho que pessoas que já tentaram são excelentes pessoas pra } \\
\text { responder, assim: O que te ajuda, aonde você vai, quais são as mídias que te } \\
\text { atingem, o que você ouve, o que você acha do tipo "ah, isso é uma porcaria, só tão } \\
\text { falando porque tão cumprindo o protocolo"... então acho que eles podem } \\
\text { responder essa pergunta, melhor ainda... }\end{array}$ \\
\hline Transcrição E2 revisada & AÇÃO|Semear|Sugestão de entrevistar pessoas que tentaram (16)\Quem as pessoas que tentaram ouvem & $\begin{array}{l}\text { O que te ajuda, aonde você vai, quais são as mídias que te atingem, o que você } \\
\text { ouve, o que você acha do tipo "ah, isso é uma porcaria, só tão falando porque tão } \\
\text { cumprindo o protocolo"... então acho que eles podem responder essa pergunta, } \\
\text { melhor ainda... }\end{array}$ \\
\hline Transcrição E2 revisada & AÇÃO|Diálogo\O falar (23)\Quem\Profissionais\Resistência se for de profissional & $\begin{array}{l}\text { E uma pessoa dessas, por exemplo, talvez não tenha um coração aberto para ouvir } \\
\text { alguma autoridade sobre o assunto, um psicólogo, alguém institucional, }\end{array}$ \\
\hline Transcrição E2 revisada & AÇÃo|DiálogolO falar (23)\Quem\De um par|Ouvir de um par & $\begin{array}{l}\text { mas, não vai ter a resistência se vier um de nós, assim, alguém que não é nada de } \\
\text { mais, e que é o um como ele, que também tá sofrendo e que até também pensou } \\
\text { em suicídio, e que de repente tá... na mesma faixa etária, ou alguma coisa assim, } \\
\text { né, então aí, é isso. }\end{array}$ \\
\hline Transcrição E2 revisada & AÇÃO\DiálogolO falar (23)\Quem\De um par|De quem ele se vê e se identifica & $\begin{array}{l}\text { mas, não vai ter a resistência se vier um de nós, assim, alguém que não é nada de } \\
\text { mais, e que é o um como ele, que também tá sofrendo e que até também pensou } \\
\text { em suicídio, e que de repente tá... na mesma faixa etária, ou alguma coisa assim, } \\
\text { né, então aí, é isso. }\end{array}$ \\
\hline Transcrição E2 revisada & CONSCIENTIZAÇão|Consciência|Aumento da Consciência (19)\Condição|Consciência publica influencia individual & Não tem como \\
\hline Transcrição E2 revisada & CONSCIENTIZAÇãO\Consciência|Aumento da Consciência (19)\Condição|Consciência publica influencia individual & Sim \\
\hline Transcrição E2 revisada & CONSCIENTIZAÇÃO|Consciência|Aumento da Consciência (19)|Condição|Quase não existe consciência individual & $\begin{array}{l}\text { É que a consciência individual, quase não existe, eu acho na minha opinião. Acho } \\
\text { que os seres, a gente não tem uma consciência, assim...a gente nem se conhece } \\
\text { pra poder assim, não se deixar influenciar. }\end{array}$ \\
\hline Transcrição E2 revisada & CONSCIENTIZAÇÃO|Consciência|Aumento da Consciência (19)\Condição\A cegueira individual influencia as outras\As consciências são jur| & Eu acho que é uma coisa assim, uhu, tudo junto... \\
\hline Transcrição E2 revisada & CONSCIENTIZAÇÃO\Consciência|Aumento da Consciência (19)\Condição\A cegueira individual influencia as outras\As consciências são jur| & Mas é que não é uma coisa que vai ser $100 \% \ldots$ \\
\hline
\end{tabular}

Material integrante da pesquisa de doutorado de Karen Scavacini - USP Proibida a reprodução ou utilização sem autorização do autor - 2018 


\begin{tabular}{|c|c|c|}
\hline Transcrição E2 revisada & CONSCIENTIZAÇÃO|Consciência\Aumento da Consciência (19)\Condição\A cegueira individual influencia as outras\As consciências são jur & Não, nada vai ser $100 \%$ mas eu acho que... \\
\hline Transcrição E2 revisada & CONSCIENTIZAÇÃO\Consciência\Aumento da Consciência (19)\Condição|Somos influenciados por tendências & Tendências né, nós somos influenciados por tendências, modas e etc. \\
\hline Transcrição E2 revisada & CONSCIENTIZAÇÃO|Consciência\Aumento da Consciência (19)\Condição|Somos influenciados por tendências & $\begin{array}{l}\text { Quer dizer, a gente acha que é indivíduo mas uma boa parte de nós é acomodação } \\
\text { com outras coisas que outras pessoas também aceitam. Que é a tendência, a } \\
\text { moda...então eu aceito que eu tenho que usar calça, camisa, enfim, essa coisa, } \\
\text { então de repente, isso não é uma decisão minha mas é a forma de como eu vou ser } \\
\text { aceito. }\end{array}$ \\
\hline Transcrição E2 revisada & CONSCIENTIZAÇÃo|Consciência|Aumento da Consciência (19)|Condição|Forma de ser aceito & $\begin{array}{l}\text { Que é a tendência, a moda...então eu aceito que eu tenho que usar calça, camisa, } \\
\text { enfim, essa coisa, então de repente, isso não é uma decisão minha mas é a forma } \\
\text { de como eu vou ser aceito. }\end{array}$ \\
\hline Transcrição E2 revisada & COMPREENSÃO|Comunicação|Pessoal|Falando abertamente na sociedadelFalando sobre o suicídio para outros & Eu pego e falo... \\
\hline Transcrição E2 revisada & COMPREENSÃO|Comunicação|Pessoal|Falando abertamente na sociedade\Falando sobre o suicídio para outros & A gente também já não esconde mais... \\
\hline Transcrição E2 revisada & COMPREENSÃO|Comunicação|Pessoal|Se preparando para falar|No início é difícil de falar & Mas eu acho que pra quem tá ainda no início... \\
\hline Transcrição E2 revisada & COMPREENSÃO|Comunicação|Pessoal|Se preparando para falar|Pergunta sobre se ele fala logo no inicio & Você fala no início, no primeiro instante? \\
\hline Transcrição E2 revisada & COMPREENSÃo|Comunicação|Pessoal\Morreu de que\Mudando a causa da morte\Precisando negar a forma de morte\Para uns sim, out & $\begin{array}{l}\text { Eu falo pra algumas pessoas pra outras não, assim como eu falo que uma pessoa } \\
\text { querida que morreu de câncer, eu falo pra uns e não falo pra outros... quer dizer, } \\
\text { eu falo para quem... }\end{array}$ \\
\hline Transcrição E2 revisada & COMPREENSÃOVVisão|Visão da Sociedade (2)\Visão do suicídio hoje no brasil|Suicida é fraco e covarde\لá ouvi falarem que quem se mat & Tem uns que falam isso para mim... \\
\hline Transcrição E2 revisada & COMPREENSÃo|Visão|Visão da Sociedade (2)\Visão do suicídio hoje no brasil|Suicida é fraco e covarde|Reações ao quem se mata é fraco & $\begin{array}{l}\text { Eu se hoje em dia estiver em uma eu falo.. Porque, você já passou por isso? Como } \\
\text { é? Qual é a experiência que você tem? Como você sabe? Aí eu vou partir já até } \\
\text { pra... }\end{array}$ \\
\hline Transcrição E2 revisada & COMPREENSÃo|Visão|Visão da Sociedade (2)\Visão do suicídio hoje no brasil|Suicida é fraco e covarde|Reações ao quem se mata é fraco & Para a defesa né... \\
\hline Transcrição E2 revisada & COMPREENSÃO|Comunicação|Pessoal|Se preparando para falar|No começo não dá para falar - sensível & $\begin{array}{l}\text { É... mas em outras épocas não. No primeiro momento eu acho que você fica muito } \\
\text { sensivel, que você não sabe nem que tem que falar, né? }\end{array}$ \\
\hline Transcrição E2 revisada & COMPREENSÃO|Comunicação|Pessoal|Se preparando para falar|Dá para falar depois de um tempo & Mas depois... você começa né... \\
\hline Transcrição E2 revisada & CONSCIENTIZAÇão|Consciência|Aumento da Consciência (19)〈Consequência & Machuca! \\
\hline Transcrição E2 revisada & CONSCIENTIZAÇÃOIConsciência|Aumento da Consciência (19)\Consequência & nossa! Eu passei muito. De perder amizades... \\
\hline Transcrição E2 revisada & CONSCIENTIZAÇÃOIConsciência\Aumento da Consciência (19)\Consequência\Perdi amizades pela falta de consciência & Nossa! Eu passei muito. De perder amizades... \\
\hline Transcrição E2 revisada & COMPREENSÃO|Comunicação|Pessoal|Falando abertamente na sociedade)|Falando sobre o suicídio para outros & $\begin{array}{l}\text { O fotógrafo que foi lá apresentar os trabalhos de formatura da minha filha, a que } \\
\text { está viva né... mas aí no final ele disse "Mas e então, a formatura da outra, tem } \\
\text { aqui... mas cadê ela?" Aí eu olhei.. Minha filha? Morreu. E ele: "ah! morreu, é? Do } \\
\text { que ela morreu?" Minha filha se suicidou. }\end{array}$ \\
\hline Transcrição E2 revisada & COMPREENSÃO|Comunicação|Pessoal\Morreu de que\Reação das pessoas a noticia da morte\Insensibilidade\Outros sendo inconvenien & $\begin{array}{l}\text { E ele, ele é tipo japonês, eu não sei, talvez pela formação e tudo, "Ah, mas suicídio, } \\
\text { a pessoa, ela... tem religião até que ela não é nem enterrado junto." Aí começou } \\
\text { então a falar... meu deus que inconveniente, e eu olhava para a minha filha, e eu } \\
\text { fiquei olhando para ele, e olhava para a minha filha. Até uma hora ele viu que não } \\
\text { estava fazendo "feedback" né. }\end{array}$ \\
\hline Transcrição E2 revisada & COMPREENSÃO\Comunicação|Pessoal|Morreu de que \Reação das pessoas a noticia da morte\Insensibilidade\Pessoas não pensam no qu & $\begin{array}{l}\text { quer dizer então as pessoas recebem o impacto e começam a botar para fora } \\
\text { qualquer coisa e né, não pensa no que está falando... }\end{array}$ \\
\hline Transcrição E2 revisada & COMPREENSÃO\Comunicação|Pessoal\Morreu de que\Reação das pessoas a noticia da morte\Insensibilidade\Pessoas não pensam no qu & Mas isso eu acho que é pra qualquer tipo de morte. Não sei.. \\
\hline Transcrição E2 revisada & COMPREENSÃO|Comunicação\Pessoal\Morreu de que\Reação das pessoas a noticia da mortelOutras mortes são acolhidas & Acho que não... Eles acolhem tanto todos tipos de morte, sabe? \\
\hline Transcrição E2 revisada & COMPREENSÃo|Comunicação|Pessoal|Morreu de que\Mudando a causa da morte|Tia falando outra causa de morte & $\begin{array}{l}\text { Eu tive essa situação de por exemplo a minha tia sair dizendo que o meu irmão } \\
\text { morreu de um ataque fulminante. Um ataque cardíaco. }\end{array}$ \\
\hline Transcrição E2 revisada & COMPREENSÃO|Visão|Causa Mortis (9)|Curiosidade mórbida|Curiosidade da morte & $\begin{array}{l}\text { Eu tive essa situação de por exemplo a minha tia sair dizendo que o meu irmão } \\
\text { morreu de um ataque fulminante. Um ataque cardíaco. E eu sentei numa mesa de } \\
\text { uma pessoa que eu não via ha tempo e ela virou assim : "AH! É o seu irmão morreu } \\
\text { de um ataque cardíaco fulminante, né?" Eu olhei pra ela e falei assim: "Ah sei lá, } \\
\text { né. Se te falaram isso deve ser, né? }\end{array}$ \\
\hline
\end{tabular}




\begin{tabular}{|c|c|c|}
\hline Transcrição E2 revisada & COMPREENSÃO\Comunicação|Pessoal\Morreu de que \Reação das pessoas a noticia da morte\Insensibilidade \Pessoas começam a contar & $\begin{array}{l}\text { Aí ela começou a rir e me contou de umas } 5 \text { pessoas que tinham morrido de } \\
\text { ataque cardíaco fulminante com } 10 \text { anos, com } 20 \text { anos, com } 60 \text { anos... e as pessoas } \\
\text { fazem isso.... }\end{array}$ \\
\hline Transcrição E2 revisada & COMPREENSÃO|Comunicação|Pessoal|Morreu de que\Mudando a causa da morte\Mas não julgaram o seu irmão... & Mas não julgaram o seu irmão... \\
\hline Transcrição E2 revisada & COMPREENSÃO|Comunicação|Pessoal\Morreu de que\Mudando a causa da morte\Mas não julgaram o seu irmão... & Mas ele não morreu de ataque cardíaco... \\
\hline Transcrição E2 revisada & COMPREENSÃO\Comunicação|Pessoal\Morreu de que\Reação das pessoas a noticia da morte \Insensibilidade\As pessoas falam qualquer & S Sim, mas as pessoas falam coisas. Elas falam qualquer coisa. \\
\hline Transcrição E2 revisada & COMPREENSÃO\Comunicação|Pessoal\Morreu de que\Reação das pessoas a noticia da morte\Insensibilidade \Pessoas começam a contar & $\begin{array}{l}\text { De quando eu estou com a minha mãe no cartório pra registrar o óbito o cara fala } \\
\text { assim: "Ah, sabe que morreu também essa semana? }\end{array}$ \\
\hline Transcrição E2 revisada & COMPREENSÃO\Comunicação|Pessoal\Morreu de que\Reação das pessoas a noticia da morte\Insensibilidade\Pessoas sem noção & $\begin{array}{l}\text { Um dia depois que o meu irmão morreu falaram isso pra minha mãe. As pessoas } \\
\text { são completamente sem noção. }\end{array}$ \\
\hline Transcrição E2 revisada & COMPREENSÃO\Comunicação|Pessoal\Morreu de que\Reação das pessoas a noticia da morte\Pessoas ficam sem ação ao saberem de su & $\begin{array}{l}\text { Eu acho que no suicídio talvez as pessoas ficam, eu não sei se julgam ou ficam mais } \\
\text { sem saber o que fazer e fica falando... }\end{array}$ \\
\hline Transcrição E2 revisada & COMPREENSÃo|Comunicação|Pessoal\Morreu de que\Reação das pessoas a noticia da morte\Pessoas ficam sem ação ao saberem de su & Sem saber o que fazer é uma reação normal... \\
\hline Transcrição E2 revisada & COMPREENSÃo|Comunicação|Pessoal\Morreu de que\Reação das pessoas a noticia da morte\Pessoas ficam sem ação ao saberem de su & $\begin{array}{l}\text { eu já vi reações, as vezes a pessoa vai perguntando, ah e tal... morreu, e você fala e } \\
\text { a pessoa, bum. Fica todo mundo sem ação. }\end{array}$ \\
\hline Transcrição E2 revisada & COMPREENSÃO\Comunicação|Pessoal\Morreu de que\Reação das pessoas a noticia da morte\Insensibilidade\Pessoas começam a contar & $\begin{array}{l}\text { É que com outros tipos de morte a pessoa sabe o que fazer porque conhece } \\
\text { alguém, porque não sei o que...aí eles começam a falar essas coisas, de... uma } \\
\text { coisa que leu, lá, e começam a falar essas coisas como falaram pra você. }\end{array}$ \\
\hline Transcrição E2 revisada & COMPREENSÃO\Comunicação|Pessoal\Morreu de que\Reação das pessoas a noticia da morte\Insensibilidade\As pessoas falam bobagen & As pessoas falam muita bobagem... \\
\hline Transcrição E2 revisada & COMPREENSÃOIVisão|Visão da Sociedade (2) Visão do suicídio hoje no brasil|Suicida é fraco e covarde \á ouvi que quem se suicida é cov & $\begin{array}{l}\text { Isso que você comentou, né, que quem se suicida é covarde, é o que eu ouvi, } \\
\text { assim. }\end{array}$ \\
\hline Transcrição E2 revisada & COMPREENSÃO|Comunicação|Pessoal|Reações\Negativas|Falta de suporte e agressão|Ficando sem entender o porque da reação & $\begin{array}{l}\text { De uma pessoa próxima, então eu tive essa experiência e aí eu tive assim, primeiro } \\
\text { eu fiquei sem entender porque, a reação, uma reação agressiva da pessoa, de } \\
\text { ofender mesmo. }\end{array}$ \\
\hline Transcrição E2 revisada & |COMPREENSÃO|Comunicação|Pessoal|Reações\Negativas\Pessoas tendo reações agressivas sobre suicídio & $\begin{array}{l}\text { De uma pessoa próxima, então eu tive essa experiência e aí eu tive assim, primeiro } \\
\text { eu fiquei sem entender porque, a reação, uma reação agressiva da pessoa, de } \\
\text { ofender mesmo. }\end{array}$ \\
\hline Transcrição E2 revisada & COMPREENSÃO|Comunicação|Pessoal|Reações\Negativas\Pessoas tendo reações agressivas sobre suicídio & Ela teve a intenção de ofender? \\
\hline Transcrição E2 revisada & COMPREENSÃO\Comunicação|Pessoal|Reações/Negativas\Pessoas tendo reações agressivas sobre suicídio & Começou a levantar a voz, falou que eu acho você um indivíduo... \\
\hline Transcrição E2 revisada & AÇÃO|Cuidar|Grupos de apoio (21)\Falando que vai em grupo de suporte & e eu falei, não, eu estou indo em um grupo de suporte... \\
\hline Transcrição E2 revisada & AÇÃo|Cuidar|Grupos de apoio (21)\Falando que vai em grupo de suporte\Amigo falando para ele não se envolver em grupo de suporte & $\begin{array}{l}\text { você não devia se envolver com essas coisas... uma pessoa próxima, assim, que eu } \\
\text { conheço ha muitos anos }\end{array}$ \\
\hline Transcrição E2 revisada & COMPREENSÃo|Comunicação|Pessoal \Reações\Negativas\Falta de suporte e agressão\Entendendo a agressão como mecanismo de defe & $\begin{array}{l}\text { Eu acabei me afastando, eu levei um tempo pra processar isso. E aí, depois é que } \\
\text { eu fui entender que é um mecanismo, nesse caso em particular, de defesa dela e } \\
\text { da família inteira dela. É a esposa de um amigo meu que tem dificuldade de lidar } \\
\text { com qualquer tema que é morte ou doença grave, o jeito da pessoa cortar o } \\
\text { assunto é agredindo. }\end{array}$ \\
\hline Transcrição E2 revisada & COMPREENSÃO|Comunicação|Pessoal|Reações/Negativas|Falta de suporte e agressão|Não tendo o suporte do amigo & $\begin{array}{l}\text { É então, eu, é lógico que é doído, assim. Naquele momento que você vai procurar } \\
\text { suporte de um amigo... E assim, o curioso é que é o mesmo amigo que falou do } \\
\text { "divertidamente", o filme, e que ele comprou pras filhas e falou que todas as } \\
\text { emoções, mas na mesma família tem isso. }\end{array}$ \\
\hline Transcrição E2 revisada & COMPREENSÃO\Comunicação|Pessoal|(Conversando com amigos\Filme $x$ experiência pessoal & $\begin{array}{l}\text { E assim, o curioso é que é o mesmo amigo que falou do "divertidamente", o filme, } \\
\text { e que ele comprou pras filhas e falou que todas as emoções, mas na mesma família } \\
\text { tem isso. }\end{array}$ \\
\hline Transcrição E2 revisada & 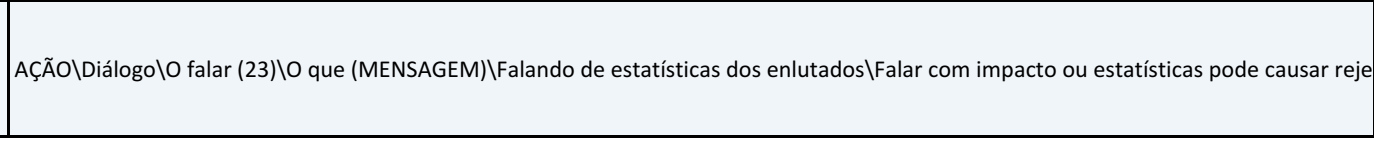 & $\begin{array}{l}\text { Então, dessa experiência que eu trouxe, assim, que as vezes chegar nesse tema, } \\
\text { assim, meio tipo, as vezes eu vejo algumas informações serem passadas com } \\
\text { impacto, né, de estatísticas, eu percebo que pra pessoa que já tem dificuldade, } \\
\text { cria, talvez uma rejeição, }\end{array}$ \\
\hline
\end{tabular}




\begin{tabular}{|c|c|c|}
\hline Transcrição E2 revisada & AÇÃO\Diálogo\O falar (23)\O que (MENSAGEM)\Emoções\Menor resistência se falar de emoções & $\begin{array}{l}\text { talvez uma maneira de falar das emoções... que a tristeza faz parte, que o luto faz } \\
\text { parte... talvez tenha uma resistência menor. }\end{array}$ \\
\hline Transcrição E2 revisada & CONSCIENTIZAÇÃO|Consciência|Aumento da Consciência (19)\Consequência|Seria mais fácil se a sociedade aceitasse melhor essa morte & Sim, mais fácil. \\
\hline Transcrição E2 revisada & COMPREENSÃO\Experiência\O viver|Quem viveu (5)(Luto (7)〈Lidei com duas coisas em relação a morte & $\begin{array}{l}\text { Porque a gente lida com duas coisas, a gente falava muito isso no grupo, são duas, } \\
\text { e eu passei muito por isso.. }\end{array}$ \\
\hline Transcrição E2 revisada & 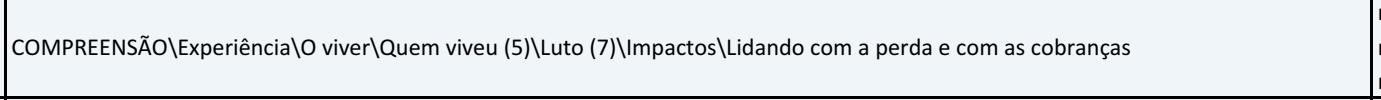 & $\begin{array}{l}\text { não dois, é lida com a perda, com o luto e da maneira que foi... muitas cobranças, } \\
\text { muitos "por quês", muitas pessoas querendo saber por que. Eu tinha que dar uma } \\
\text { resposta, né! }\end{array}$ \\
\hline Transcrição E2 revisada & COMPREENSÃOIVisão|Visão da Sociedade (2)\Causas do suicídio|Causa e efeito\Pessoas (e psiquiatras) procurando razão única|Pessoas & $\begin{array}{l}\text { Em um caso do meu filho que era jovem era, a pergunta era, ou droga, de namorar, } \\
\text { assim, a opção sexual eles não tinham dúvidas, porque eles tinham até namorada, } \\
\text { mas se não tivesse, seria uma outra pergunta... mas meu filho era drogas, por } \\
\text { causa da idade, nunca, assim, pessoas que viram ele, que ele estava deprimido, } \\
\text { que ele estava ruim e vinham perguntar, "há, mas ele estava envolvido com } \\
\text { alguma coisa, mas ele estava envolvido com drogas?" }\end{array}$ \\
\hline Transcrição E2 revisada & COMPREENSÃO\Experiência\O viver|Quem viveu (5)\Luto (7)\Sentimentos|Sentindo raiva ao pegar o atestado de óbito & $\begin{array}{l}\text { Eu tive, eu tive, eu tive a sensação de raiva no dia em que eu peguei o atestado de } \\
\text { óbito, eu tirei uma cópia e pedi pra minha tia entregar pra um primo meu que } \\
\text { tinha falado.. }\end{array}$ \\
\hline Transcrição E2 revisada & COMPREENSÃolVisãolVisão da Sociedade (2)\Causas do suicídio\Causa e efeito\Pessoas (e psiquiatras) procurando razão única|Provand & $\begin{array}{l}\text { eu tirei uma cópia e pedi pra minha tia entregar pra um primo meu que tinha } \\
\text { falado... porque lá constava que não constava nada de álcool e nem de nenhum } \\
\text { medicamento, que ele estava, na verdade, que na verdade a primeira reação eu } \\
\text { achei que ele tinha tomado todo o medicamento. Eaí dava negativo dos dois. Eu } \\
\text { naquele momento, dois meses depois, que veio o laudo, eu fiz questão de } \\
\text { mostrar... hoje eu não faria mais isso, entendeu? }\end{array}$ \\
\hline Transcrição E2 revisada & CONSCIENTIZAÇÃO|Desafios\Burocracia (11)\Atestado de óbito\A importância do laudo & $\begin{array}{l}\text { na verdade, que na verdade a primeira reação eu achei que ele tinha tomado todo } \\
\text { o medicamento }\end{array}$ \\
\hline Transcrição E2 revisada & COMPREENSÃO\Experiência\O viver|Quem viveu (5)\Depois do suicídio\Hoje já penso diferente em relação ao laudo & hoje eu não faria mais isso, entendeu? Já passou. \\
\hline Transcrição E2 revisada & COMPREENSÃO\Experiência\O viver\Quem viveu (5)\Aprende〈Hoje não preciso provar nada a ninguém & $\begin{array}{l}\text { Eu naquele momento, dois meses depois, que veio o laudo, eu fiz questão de } \\
\text { mostrar... hoje eu não faria mais isso, entendeu? Já passou. Mas naquele momento } \\
\text { a pressão era tanto, deles falarem, que eu queria, assim, ser mal educada mesmo, } \\
\text { eu queria calar boca deles, então eu queria assim, eu falei pra minha tia, pega esse } \\
\text { papel, mas você faz assim, você esfrega na cara do seu filho, como a minha tia } \\
\text { amava o meu filho com se fosse o filho dela, essa minha tia, e esse meu primo é, } \\
\text { trabalha com ela, é afilhado dela... trabalha dentro da empresa dela, ela entregou } \\
\text { para ele. }\end{array}$ \\
\hline Transcrição E2 revisada & COMPREENSÃolVisão|Visão da Sociedade (2)\Causas do suicídio|Causa e efeito\Pessoas (e psiquiatras) procurando razão única|Provand & $\begin{array}{l}\text { Mas naquele momento a pressão era tanto, deles falarem, que eu queria, assim, } \\
\text { ser mal educada mesmo, eu queria calar boca deles, então eu queria assim, eu falei } \\
\text { pra minha tia, pega esse papel, mas você faz assim, você esfrega na cara do seu } \\
\text { filho, }\end{array}$ \\
\hline Transcrição E2 revisada & 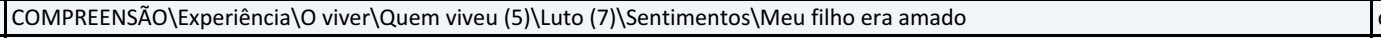 & como a minha tia amava o meu filho com se fosse o filho dela, \\
\hline Transcrição E2 revisada & CONSCIENTIZAÇÃO|Consciência|Aumento da Consciência (19)|Prevenção|Falar para diminuir preconceito e aumentar conhecimento & $\begin{array}{l}\text { Acho que quanto mais a gente tiver esse assunto, talvez, mais presente, mais } \\
\text { comum, mais falado, talvez até as pessoas parem de ter pré-julgamentos porque } \\
\text { elas vão aumentar o conhecimento a respeito do tema. }\end{array}$ \\
\hline Transcrição E2 revisada & CONSCIENTIZAÇÃO\Consciência|Aumento da Consciência (19)\Prevenção\Formas\A importância da formação & Formação é importante... \\
\hline Transcrição E2 revisada & CONSCIENTIZAÇão|Consciência\Aumento da Consciência (19)\Prevenção|Falar para diminuir preconceito e aumentar conhecimento & Então elas vão talvez julgar menos \\
\hline Transcrição E2 revisada & COMPREENSÃO\Experiência|O viver|Quem viveu (5)\Crenças (27)\O vale dos suicidas & $\begin{array}{l}\text { E sinceramente, por exemplo, no centro espírita fala que tem o vale, esqueci o } \\
\text { nome }\end{array}$ \\
\hline Transcrição E2 revisada & COMPREENSÃO\Experiência|O viver|Quem viveu (5)\Crenças (27)\O vale dos suicidas & $\begin{array}{l}\text { O vale dos suicidas, então, em alguns lugares, né, no centro que eu vou, eles dão a } \\
\text { palestra e fala sobre isso. }\end{array}$ \\
\hline
\end{tabular}




\begin{tabular}{|c|c|c|}
\hline Transcrição E2 revisada & COMPREENSÃO\Experiência\O viver\Quem viveu (5)\Crenças (27)\O vale dos suicidas\Respeito a opinião dos outros em relação ao vale d & $\begin{array}{l}\text { as eu não levanto e saio correndo, porque para mim aquilo é uma opinião, e eu } \\
\text { respeito. Se ele acha que é aquilo, se ele acredita naquilo, ele tem o direito de } \\
\text { acreditar que existe um vale, etc., etc. Eu tenho outra opinião. }\end{array}$ \\
\hline Transcrição E2 revisada & COMPREENSÃO\Experiência\O viver|Quem viveu (5)\Crenças (27)\Para ser respeitado precisa respeitar outras opiniões & $\begin{array}{l}\text { Assim como acho que cada um de nós, a gente também quer que esse assunto seja } \\
\text { respeitado, a gente também tem que respeitar se alguém acha..., né? }\end{array}$ \\
\hline Transcrição E2 revisada & CONSCIENTIZAÇão|Consciência|O absurdo do suicídio|O não saber|Nunca saberemos porque ocorreram os casos & $\begin{array}{l}\text { Então, e talvez tenha alguém que tenha se suicidado porque foi covarde naquele } \\
\text { momento, talvez sim, mas gente nunca vai saber, quais foram os casos que foram } \\
\text { por covardia, outros porque são valentes, outros. }\end{array}$ \\
\hline Transcrição E2 revisada & COMPREENSÃO\Experiência\O viver\Quem viveu (5)\Crenças (27)\Para ser respeitado precisa respeitar outras opiniões & $\begin{array}{l}\text { então assim, muitas coisas são opiniões e cada um tem a sua. Eu, quando ouço } \\
\text { essas coisas, eu respeito. }\end{array}$ \\
\hline Transcrição E2 revisada & COMPREENSÃO\Experiência\O viver\Quem viveu (5)\Aprende\A opinião é embasada no que a pessoa viveu & Eu falo: essa é a opinião da pessoa, embasada no que ela sabe, no que ela viveu. \\
\hline Transcrição E2 revisada & COMPREENSÃO\Experiência|O viver|Quem viveu (5)\Crenças (27)\Do motivo do suicídio\Pessoas dando opiniões sem saber & $\begin{array}{l}\text { Muita gente nem viveu o suicídio e vai ter uma opinião e ela vai se dar opinião } \\
\text { sobre diversos outros temas sem saber. }\end{array}$ \\
\hline Transcrição E2 revisada & |COMPREENSÃO\Experiência|O viver|Quem viveu (5)|Depois do suicídio|Dando opinião porque viveu & $\begin{array}{l}\text { Eu tento dar opinião daquilo que eu vivo. Né, então, por exemplo, hoje tem } \\
\text { algumas situações que quando eu vejo eu falo: olha, eu não sei te falar porque eu } \\
\text { não sei como, assim, fazer com isso. }\end{array}$ \\
\hline Transcrição E2 revisada & COMPREENSÃO\Experiência\O viver|Quem viveu (5)\Crenças (27)\Para ser respeitado precisa respeitar outras opiniões & $\begin{array}{l}\text { Então eu acho que as pessoas, elas vão dar opinião sim, vão continuar dando e a } \\
\text { gente tem que respeitar, se tem pessoas que acham, sei lá o quê elas acham, como } \\
\text { eu não quero ser agredida quando eu por dar a minha opinião a respeito do } \\
\text { assunto do suicídio né }\end{array}$ \\
\hline Transcrição E2 revisada & COMPREENSÃO\Experiência|O viver|Quem viveu (5)\Crenças (27)\Do motivo do suicídio\Pessoas dando opiniões sem saber & $\begin{array}{l}\text { Então eu acho que as pessoas, elas vão dar opinião sim, vão continuar dando e a } \\
\text { gente tem que respeitar, se tem pessoas que acham, sei lá o quê elas acham, como } \\
\text { eu não quero ser agredida quando eu por dar a minha opinião a respeito do } \\
\text { assunto do suicídio né }\end{array}$ \\
\hline Transcrição E2 revisada & COMPREENSÃO\Experiência|O viver|Quem viveu (5)\Crenças (27)\Do motivo do suicídio\Os motivos do suicídio só cabem a quem se mat & então assim, os motivos que levaram à ele, à se suicidar, só cabe à ele \\
\hline Transcrição E2 revisada & 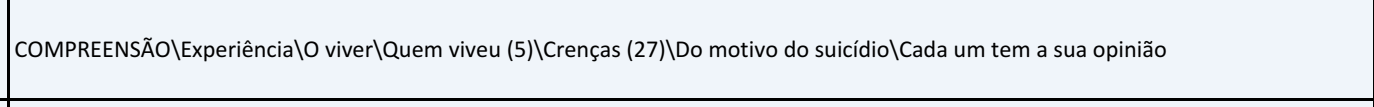 & $\begin{array}{l}\text { eu conheço meu irmão, né, e eu... então assim, os motivos que levaram à ele, à se } \\
\text { suicidar, só cabe à ele e eu tenho uma opinião à respeito. Eu sei os porquês mas é } \\
\text { uma opinião íntima minha. Não sei explicar, olha, foi por A né? }\end{array}$ \\
\hline Transcrição E2 revisada & COMPREENSÃO\Experiência\O viver\Quem viveu (5)\Crenças (27)\Do motivo do suicídio\Tenho minha opinião intima do suicídio do meu & $\begin{array}{l}\text { eu conheço meu irmão, né, e eu... então assim, os motivos que levaram à ele, à se } \\
\text { suicidar, só cabe à ele e eu tenho uma opinião à respeito. Eu sei os porquês mas é } \\
\text { uma opinião íntima minha. Não sei explicar, olha, foi por A né? }\end{array}$ \\
\hline Transcrição E2 revisada & 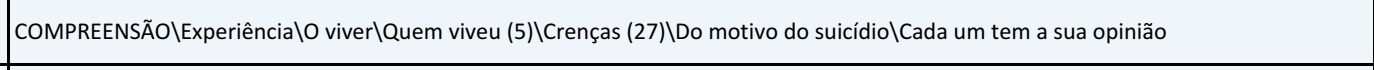 & $\begin{array}{l}\text { Assim como meu pai deve ter uma opinião, minha mãe, cada um tem uma opinião, } \\
\text { então... Eu acho que mesmo que.. }\end{array}$ \\
\hline Transcrição E2 revisada & COMPREENSÃO\Experiência\O viver|Quem viveu (5)\Crenças (27)\Saber onde vai para não se machucar & $\begin{array}{l}\text { É, eu acho que machuca e por saber que machuca, acho que a gente tem que saber } \\
\text { onde a gente vai... }\end{array}$ \\
\hline Transcrição E2 revisada & COMPREENSÃO\Experiência\O viver\Quem viveu (5)\Crenças (27)\A importância de ter liberdade de opinião na religião\Tenho a liberdad & $\begin{array}{l}\text { Eu posso não ir mais no centro espírita porque eles tem essa opinião mas cabe a } \\
\text { mim decidir se eu quero continuar ir, mas sabendo que pode ser que eu chegue } \\
\text { um dia lá e que a palestra vai ser falando que tem o vale que as pessoas ficam lá } \\
\text { sofrendo... }\end{array}$ \\
\hline Transcrição E2 revisada & COMPREENSÃO|Experiência|O viver|Quem viveu (5)\Crenças (27)\O vale dos suicidas & $\begin{array}{l}\text { Eu posso não ir mais no centro espírita porque eles tem essa opinião mas cabe a } \\
\text { mim decidir se eu quero continuar ir, mas sabendo que pode ser que eu chegue } \\
\text { um dia lá e que a palestra vai ser falando que tem o vale que as pessoas ficam lá } \\
\text { sofrendo... }\end{array}$ \\
\hline Transcrição E2 revisada & 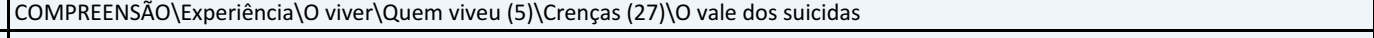 & Então pra eles, ninguém mais fala desse vale... \\
\hline Transcrição E2 revisada & COMPREENSÃO\Experiência|O viver|Quem viveu (5)\Crenças (27)\O vale dos suicidas & $\begin{array}{l}\text { É talvez tenham algumas linhas que sim, talvez seja pelo nível de informação, olha } \\
\text { só, talvez não seja geral, }\end{array}$ \\
\hline Transcrição E2 revisada & COMPREENSÃO\ExperiêncialO viver|Quem viveu (5)\Crenças (27)\O vale dos suicidas|Centros espíritas que reviram seus conceitos do val & $\begin{array}{l}\text { talvez os centros espíritas, hoje, olha que legal, depois de um tempo a mais lidando } \\
\text { com o assunto, tenha outras opiniões, que foram outros, não sei, onde que eles se } \\
\text { basearam. }\end{array}$ \\
\hline
\end{tabular}

Material integrante da pesquisa de doutorado de Karen Scavacini - USP Proibida a reprodução ou utilização sem autorização do autor - 2018 


\begin{tabular}{|c|c|c|}
\hline Transcrição E2 revisada & AÇÃO\O saber (12)\Saber é poderlQuanto mais informação melhor o embasamento em relação ao suíça & $\begin{array}{l}\text { Então acho que é muito isso. Acho que quanto mais informação tiver aí, as pessoas } \\
\text { vão se embasar um pouco melhor }\end{array}$ \\
\hline Transcrição E2 revisada & COMPREENSÃO\Experiência\O viver|Quem viveu (5)\Crenças (27)\Do motivo do suicídio|Pessoas dando opiniões sem saber & $\begin{array}{l}\text { E tem outras que vão se embasar mesmo sem saber e vão achar que é aquilo e } \\
\text { cada um acredita no que quer... }\end{array}$ \\
\hline Transcrição E2 revisada & COMPREENSÃO\ExperiêncialO viver|Quem viveu (5)\Crenças (27)\A importância de ter liberdade de opinião na religião|Cada um acredit & $\begin{array}{l}\text { E tem outras que vão se embasar mesmo sem saber e vão achar que é aquilo e } \\
\text { cada um acredita no que quer... }\end{array}$ \\
\hline Transcrição E2 revisada & 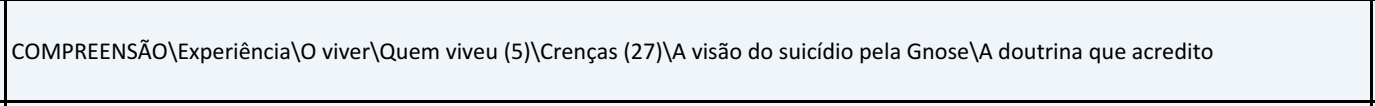 & $\begin{array}{l}\text { No meu meio que eu frequento religioso que é a Gnose, a questão é digamos, mais } \\
\text { ou menos, dogmática que parte do princípio da sabedoria do mestre. E o que ele } \\
\text { fala, que está registrado nos livros e é o que a gente aceita como doutrina, }\end{array}$ \\
\hline Transcrição E2 revisada & COMPREENSÃO\Experiência\O viver\Quem viveu (5)\Crenças (27)\A visão do suicídio pela Gnose & $\begin{array}{l}\text { é que quando a pessoa, quando ela se mata, comete o suicídio, ela volta, vive a } \\
\text { vida normalmente conforme o seu carma e darma, conforme o que já tinha, né, } \\
\text { mas toda a vida dela vai ser estruturada, e ele vai viver, e na hora em que ele } \\
\text { estiver mais feliz e querendo viver, ele vai morrer. Então, por exemplo: aquela } \\
\text { pessoa que está prestes a casar, então está na festa de casamento morre aí. Que } \\
\text { conseguiu conquistar tudo e vai gozar e morre ali, na hora. Quer dizer, na hora em } \\
\text { que ela mais esta querendo viver a vida lhe é tirada. }\end{array}$ \\
\hline Transcrição E2 revisada & 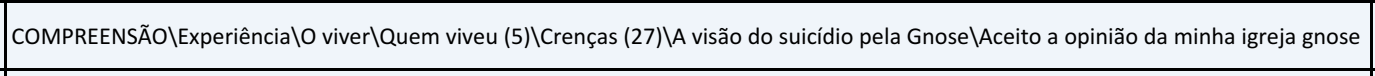 & $\begin{array}{l}\text { Daí a gente aceita. A gente não fica com raiva. Eu, pelo menos, eu aceito, eu não } \\
\text { dei a minha opinião....esse caso eu aceito }\end{array}$ \\
\hline Transcrição E2 revisada & 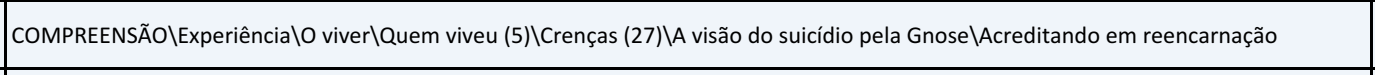 & $\begin{array}{l}\text { Eu entendo que isso é lógico, até porque o que eu falei aqui, a sua vida vai seguir } \\
\text { adiante, a sua outra existência, continuarão sendo normal, como qualquer outra. }\end{array}$ \\
\hline Transcrição E2 revisada & 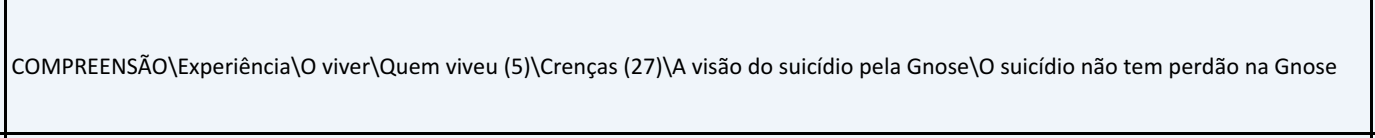 & $\begin{array}{l}\text { Mas essa é uma coisa que não tem perdão. Não dá para negociar na existência } \\
\text { seguinte, pra ela não morrer na hora que ela mais quiser viver. Isso aí tem que } \\
\text { acontecer pra que ela fique tão impactada a ponto de nunca mais fazer isso na } \\
\text { sequencia das outras existências. }\end{array}$ \\
\hline Transcrição E2 revisada & COMPREENSÃo\Experiência\O viver\Quem viveu (5)\Crenças (27)\A visão do suicídio pela Gnose\A consequência do suicídio pela gnose & $\begin{array}{l}\text { Mas essa é uma coisa que não tem perdão. Não dá para negociar na existência } \\
\text { seguinte, pra ela não morrer na hora que ela mais quiser viver. Isso aí tem que } \\
\text { acontecer pra que ela fique tão impactada a ponto de nunca mais fazer isso na } \\
\text { sequencia das outras existências. }\end{array}$ \\
\hline Transcrição E2 revisada & 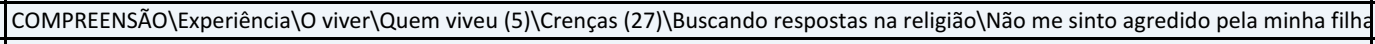 & Quer dizer, pela lógica que ela contem, ela não me agrediu \\
\hline Transcrição E2 revisada & COMPREENSÃO\Experiência\O viver\Quem viveu (5)\Crenças (27)\A visão do suicídio pela Gnose\Eu continuo aceitando & $\begin{array}{l}\text { A gente não fica com raiva. Eu, pelo menos, eu aceito, eu não dei a minha } \\
\text { opinião....esse caso eu aceito. Eu entendo que isso é lógico, até porque o que eu } \\
\text { falei aqui, a sua vida vai seguir adiante, a sua outra existência, continuarão sendo } \\
\text { normal, como qualquer outra. Mas essa é uma coisa que não tem perdão. Não dá } \\
\text { para negociar na existência seguinte, pra ela não morrer na hora que ela mais } \\
\text { quiser viver. Isso aí tem que acontecer pra que ela fique tão impactada a ponto de } \\
\text { nunca mais fazer isso na sequencia das outras existências. Quer dizer, pela lógica } \\
\text { que ela contem, ela não me agrediu. Eu continuo aceitando }\end{array}$ \\
\hline Transcrição E2 revisada & COMPREENSÃO\Experiência\O viver|Quem viveu (5)\Crenças (27)\A visão do suicídio pela Gnose\Dando exemplos de famosos que morre & $\begin{array}{l}\text { Por exemplo, os Mamonas Assassinas, aquele grupo, estava no auge do seu } \\
\text { sucesso. Bum, morreram todos. Quando mais queriam viver. Quando a vida Ihe } \\
\text { sorria e tem outros exemplos, né? Quer dizer, exemplos famosos, né? }\end{array}$ \\
\hline Transcrição E2 revisada & COMPREENSÃO\Experiência\O viver|Quem viveu (5)\Crenças (27)\Buscando respostas na religião\Aceito em paz o que diz minha religião & E pra mim, na minha religião, eu aceito isso em paz... \\
\hline Transcrição E2 revisada & COMPREENSÃO\ExperiêncialO viver|Quem viveu (5)\Crenças (27)\A importância de ter liberdade de opinião na religião|Direito de seguir & $\begin{array}{l}\text { Acho que é aquilo, acho que cada um aceita, né, ou você pode aceitar tudo de uma } \\
\text { religião e aquele ponto não. Acho que é nosso direito. A gente fala: Ah, eu sigo } \\
50 \% \text { dessa, } 1 \% \text { daquela.... }\end{array}$ \\
\hline Transcrição E2 revisada & COMPREENSÃO\Experiência\O viver|Quem viveu (5)\Crenças (27)\Buscando respostas na religião\Aceito em paz o que diz minha religião & $\begin{array}{l}\text { Pode ser. É que no meu caso, esse ponto que fala do suicídio, pra mim foi pacífico. } \\
\text { Pra mim e pra minha família. }\end{array}$ \\
\hline Transcrição E2 revisada & 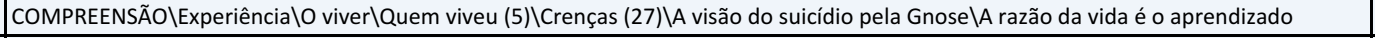 & Porque é tão lógico, porque eu acho que a razão de ser da vida é o aprendizado. \\
\hline Transcrição E2 revisada & 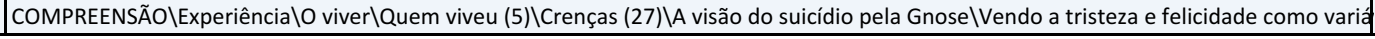 & O ser feliz ou o ser triste é uma variável... \\
\hline
\end{tabular}

Material integrante da pesquisa de doutorado de Karen Scavacini - USP Proibida a reprodução ou utilização sem autorização do autor - 2018 


\begin{tabular}{|c|c|c|}
\hline Transcrição E2 revisada & 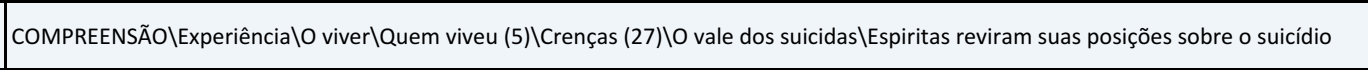 & $\begin{array}{l}\text { Nós fizemos uma discussão sobre isso e hoje é considerado, assim, primeiro que na } \\
\text { verdade eles estudam que já não é mais aquilo }\end{array}$ \\
\hline Transcrição E2 revisada & 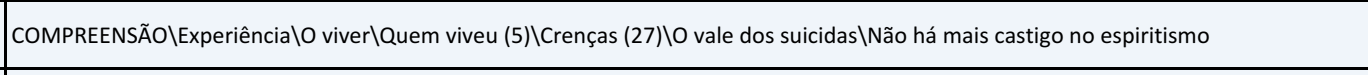 & $\begin{array}{l}\text { há, então você morreu de suicídio com um tiro na cabeça você vai vir com } \\
\text { problemas mentais. Não é mais essa ligação. }\end{array}$ \\
\hline Transcrição E2 revisada & 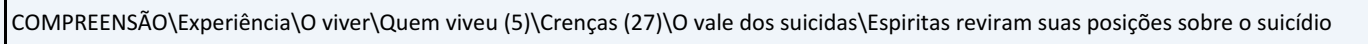 & Eles foram estudando e vendo que as coisas não são assim. Pode ser, pode não ser. \\
\hline Transcrição E2 revisada & |COMPREENSÃO|Experiência\O viver|Quem viveu (5)\Crenças (27)\O vale dos suicidas\Espiritas reviram suas posições sobre o suicídio & $\begin{array}{l}\text { Muitas vezes pode vir um médico, um psiquiatra, alguém que vai ligar, que vai } \\
\text { trabalhar com isso. Porque ele já vai vir com algo dentro dele sabendo, entendeu, } \\
\text { como lidar com a situação. Então vai ser aproveitado de uma maneira benéfica, } \\
\text { não necessariamente vai vir debilitado, então, tem enes maneiras de voltar. }\end{array}$ \\
\hline Transcrição E2 revisada & 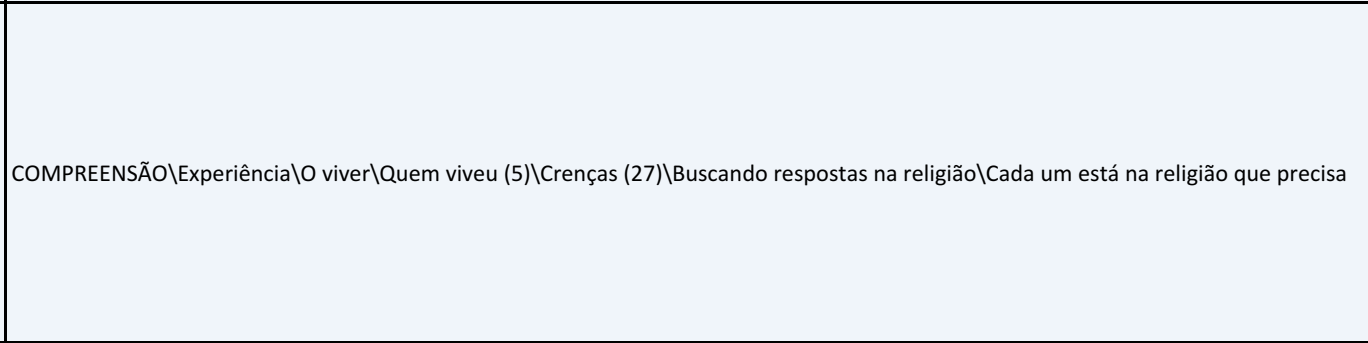 & $\begin{array}{l}\text { Exatamente, talvez a religião que a pessoa, que não é o caso da minha, mas vamos } \\
\text { dizer que uma pessoa, daquela religião, a gente aprende muito isso: cada um está, } \\
\text { as vezes, na religião certa e quando não está, não é o momento mais, vai procurar } \\
\text { uma outra. Porque muitas vezes a pessoa que estava na igreja evangélica, e } \\
\text { aprende, porque é necessário, porque eles tem tantas... de acreditar, é necessário } \\
\text { as vezes ainda, porque as vezes lá seguram, um pai de família que está bebendo e } \\
\text { as vezes vai lá e por temor a Deus, que na nossa já não é o temor, mas por temor a } \\
\text { Deus, para de beber, não bate na mulher, entendeu? Se modifica. Então, são } \\
\text { necessárias, depende do grau que você vá buscando. Você vai buscando mais, } \\
\text { mais, vai questionando... }\end{array}$ \\
\hline Transcrição E2 revisada & 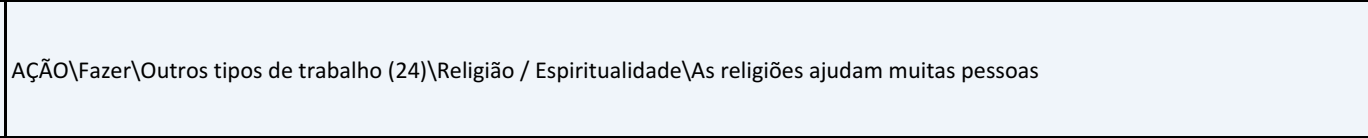 & $\begin{array}{l}\text { porque as vezes lá seguram, um pai de família que está bebendo e as vezes vai lá e } \\
\text { por temor a Deus, que na nossa já não é o temor, mas por temor a Deus, para de } \\
\text { beber, não bate na mulher, entendeu? Se modifica. Então, são necessárias, } \\
\text { depende do grau que você vá buscando }\end{array}$ \\
\hline Transcrição E2 revisada & AÇÃO\Fazer\Outros tipos de trabalho (24)\Religião / Espiritualidade\As religiões ajudam muitas pessoas & Eles conseguem, inclusive nas cadeias, recuperam tanta gente... \\
\hline Transcrição E2 revisada & AÇÃO\Fazer\Outros tipos de trabalho (24)\Religião / Espiritualidade\As religiões ajudam muitas pessoas & Tem, tem seu mérito, todas elas tem, na essência um mérito bom... \\
\hline Transcrição E2 revisada & COMPREENSÃO\Experiência|O viver|Quem viveu (5)\Crenças (27)\Saber onde vai para não se machucar|Quem prejudica as religiões são & $\begin{array}{l}\text { O que as vezes prejudica uma religião ou outra somos nós mesmos, seres humanos } \\
\text { que estamos administrando. }\end{array}$ \\
\hline Transcrição E2 revisada & COMPREENSÃO\Experiência|O viver|Quem viveu (5)\Crenças (27)\A importância de ter liberdade de opinião na religião & $\begin{array}{l}\text { Acho que religião, eu acho que é importante, mas é importante frisar a liberdade } \\
\text { de cada um ter opinião diferente. }\end{array}$ \\
\hline Transcrição E2 revisada & COMPREENSÃO\Experiência\O viver|Quem viveu (5)\Crenças (27)\A importância de ter liberdade de opinião na religião & Até de não ter religião \\
\hline Transcrição E2 revisada & COMPREENSÃO|Experiência\O viver|Quem viveu (5)\Crenças (27)\A importância de ter liberdade de opinião na religião & $\begin{array}{l}\text { Porque nunca se crê em coisas conflitantes, não é? E aí poder, assim, ter a } \\
\text { liberdade de conversar e se abrir, e falar, não, eu penso diferente na minha } \\
\text { religião.... }\end{array}$ \\
\hline Transcrição E2 revisada & 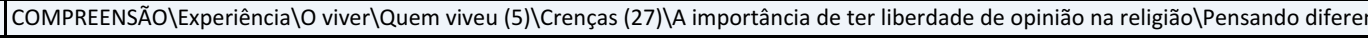 & eu penso diferente na minha religião.... \\
\hline Transcrição E2 revisada & 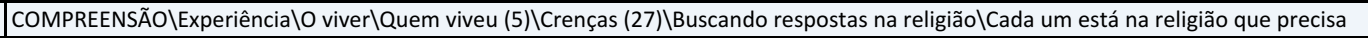 & Porque nunca se crê em coisas conflitantes, não é? \\
\hline Transcrição E2 revisada & 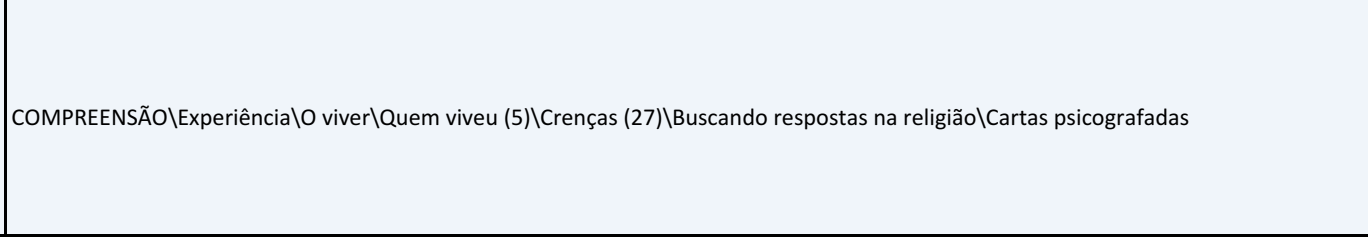 & $\begin{array}{l}\text { Meu filho escreveu muitas cartas, e nas cartas pela religião dele, que ele } \\
\text { frequentava ele falava o que ele sabia, que simplesmente ele não sabia qual era o } \\
\text { local dele neste mundo. Mas... que ele sabia que ele teria que voltar algum dia e, } \\
\text { ele não usa pagar por isso, mas ele fala, resgatar o que ele fez... mas que aqui } \\
\text { neste momento ele não estava pronto, que o mundo era um lugar muito escuro } \\
\text { pra ele, que ele não sabia qual era a posição que ele tinha que tomar. Então assim, } \\
\text { na verdade é dele, não são cartas psicografadas, é dele né? }\end{array}$ \\
\hline Transcrição E2 revisada & COMPREENSÃO\Experiência\O viver|Quem viveu (5)\Crenças (27)\Buscando respostas na religião & $\begin{array}{l}\text { A sensação era maior do que a educação que ele teve de desde os } 5 \text { anos de } \\
\text { evangelização espírta. Então ele sabia que tinha outra coisa? Eu questionei muito } \\
\text { isso, na época. Como então? Mas como? Se a pessoa comete o ato achando que lá } \\
\text { não tem mais nada, então eu vou tirar a minha dor, como que meu filho fez isso } \\
\text { sabendo que tinha alguma coisa? Eu fui pesquisar muito isso na doutrina, } \\
\text { conversar com muita gente... ler muito... }\end{array}$ \\
\hline
\end{tabular}

Material integrante da pesquisa de doutorado de Karen Scavacini - USP Proibida a reprodução ou utilização sem autorização do autor - 2018 


\begin{tabular}{|c|c|c|}
\hline Transcrição E2 revisada & CONSCIENTIZAÇão|Consciência\O absurdo do suicídio|Prevenção x Previsão|Questionando a religião como fator de proteção & $\begin{array}{l}\text { A sensação era maior do que a educação que ele teve de desde os } 5 \text { anos de } \\
\text { evangelização espírta. Então ele sabia que tinha outra coisa? Eu questionei muito } \\
\text { isso, na época. Como então? Mas como? Se a pessoa comete o ato achando que lá } \\
\text { não tem mais nada, então eu vou tirar a minha dor, como que meu filho fez isso } \\
\text { sabendo que tinha alguma coisa? Eu fui pesquisar muito isso na doutrina, } \\
\text { conversar com muita gente... ler muito... }\end{array}$ \\
\hline Transcrição E2 revisada & 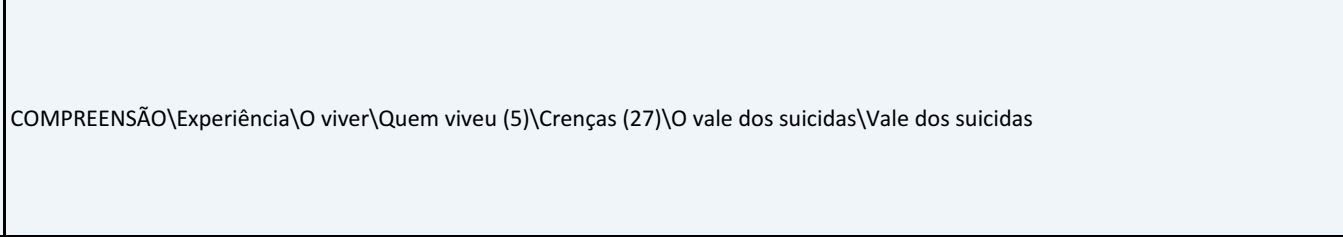 & $\begin{array}{l}\text { por isso que eu sei que assim, só os livros muito antigos, os mais antigos que não } \\
\text { vão lá continuar estudando, lendo, que ainda revê esse vale dos suicidas, porque } \\
\text { falaram isso pra (nome de uma amiga), e ela ligou para mim em desespero, ela } \\
\text { chegou pra um senhor e falou: "Como o senhor acha que está meu filho?" Ele } \\
\text { falou: " Como você acha? Está no vale dos suicidas. Vai ficar lá até o tempo que ele } \\
\text { deveria estar aqui". Ela entrou em desespero então, é um ser humano, a pessoa, } \\
\text { você não dá pra falar que aquilo, você falar em nome, né? }\end{array}$ \\
\hline Transcrição E2 revisada & 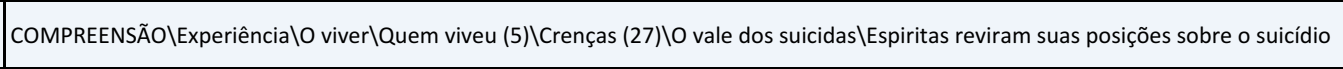 & $\begin{array}{l}\text { por isso que eu sei que assim, só os livros muito antigos, os mais antigos que não } \\
\text { vão lá continuar estudando, lendo, que ainda revê esse vale dos suicidas, }\end{array}$ \\
\hline Transcrição E2 revisada & 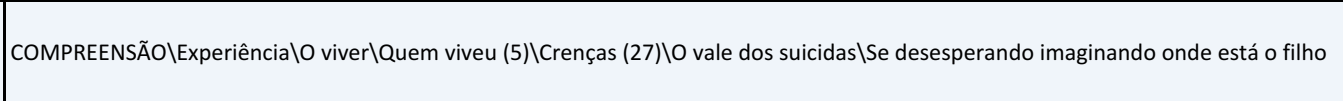 & $\begin{array}{l}\text { ela chegou pra um senhor e falou: "Como o senhor acha que está meu filho?" Ele } \\
\text { falou: " Como você acha? Está no vale dos suicidas. Vai ficar lá até o tempo que ele } \\
\text { deveria estar aqui". Ela entrou em desespero }\end{array}$ \\
\hline Transcrição E2 revisada & COMPREENSÃO\Tabu (1)\O tabu em diversas esferas\Religião\Falta de sensibilidade de religiosos & $\begin{array}{l}\text { Ela entrou em desespero então, é um ser humano, a pessoa, você não dá pra falar } \\
\text { que aquilo, você falar em nome, né? }\end{array}$ \\
\hline Transcrição E2 revisada & 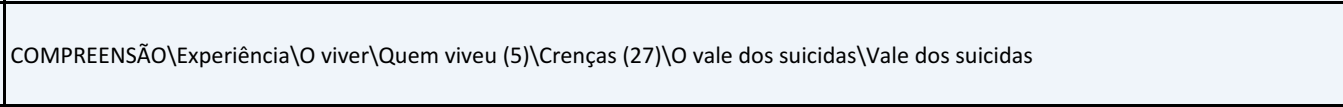 & $\begin{array}{l}\text { Uma colega nossa chegou lá para a (nome da esposa), com um panfleto sobre uma } \\
\text { palestra, do vale dos suicidas e disse, Dona (nome da esposa), a senhora não pode } \\
\text { perder essa palestra, porque a (nome da filha) está lá, }\end{array}$ \\
\hline Transcrição E2 revisada & 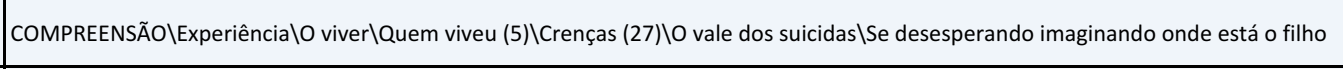 & $\begin{array}{l}\text { porque a (nome da filha) está lá, ela ficou assim no desespero né, ficou tal, e foi } \\
\text { sair e disse, não deixa de ir não... }\end{array}$ \\
\hline Transcrição E2 revisada & 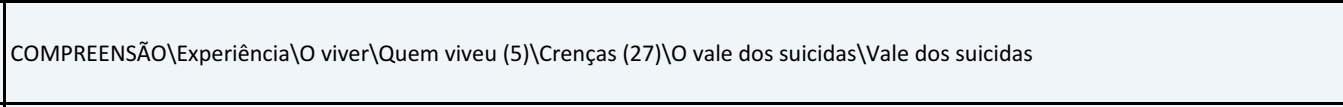 & $\begin{array}{l}\text { ela pegou o carro e ia, aí no meio do caminho ela disse: " não vou, minha filha não } \\
\text { está lá" aí voltou pra casa. Quando foi a própria carta que ela recebeu, ela começa: } \\
\text { "Mãe, eu estou falando de um vale, não do vale suicidas." (Risos) }\end{array}$ \\
\hline Transcrição E2 revisada & COMPREENSÃO\Experiência\O viver|Quem viveu (5)\Crenças (27)\Buscando respostas na religião|Cartas psicografadas & $\begin{array}{l}\text { Quando foi a própria carta que ela recebeu, ela começa: "Mãe, eu estou falando de } \\
\text { um vale, não do vale suicidas." (Risos) }\end{array}$ \\
\hline Transcrição E2 revisada & COMPREENSÃO\Experiência\O viver|Quem viveu (5)\Crenças (27)\Buscando respostas na religião\Cartas psicografadas & A gente ouve cada coisa que as pessoas acham que a gente é maluco... \\
\hline Transcrição E2 revisada & 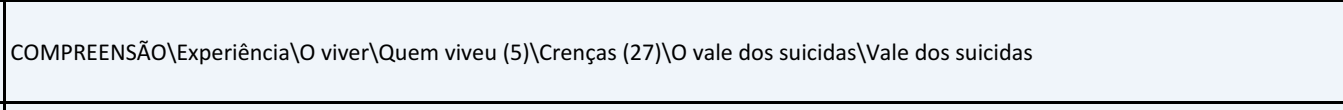 & $\begin{array}{l}\text { Aí ela ficou assim, ela não falou isso para ninguém né... pois é... nem eu sabia, } \\
\text { fiquei sabendo depois, que a menina tinha dado para ela, que ia ter uma palestra } \\
\text { sobre o vale dos suicidas. }\end{array}$ \\
\hline Transcrição E2 revisada & 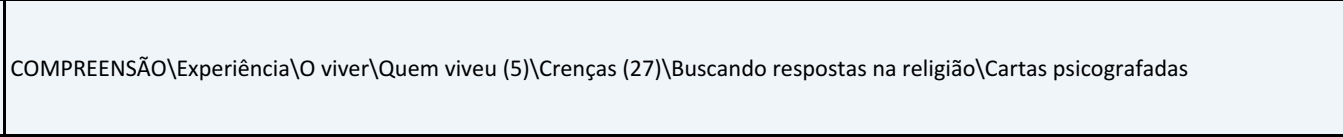 & $\begin{array}{l}\text { Eu fiz uma boa pergunta, é, muito, assim, mentalmente também, assistindo a um } \\
\text { filme, na outra carta o meu filho respondeu... Não, aqui nós temos obrigações } \\
\text { diárias de afinidades, não de namorados. Eu tinha feito uma pergunta, em casa } \\
\text { né... }\end{array}$ \\
\hline Transcrição E2 revisada & COMPREENSÃO|Comunicação|Pessoal|Falando abertamente na família|Falando sobre o suicídio & Agora só... de 2 anos para cá... \\
\hline Transcrição E2 revisada & COMPREENSÃO|Comunicação|Pessoal|Falando abertamente na família|Falando sobre o suicídio & Com a família sim, mas com a família não, com os amigos sim. \\
\hline Transcrição E2 revisada & COMPREENSÃO|Comunicação|Pessoal|Falando abertamente na família|Falando sobre o suicídio & Eu agora na família eu falo, de 2 anos para cá, \\
\hline Transcrição E2 revisada & AÇÃO\Fazer|Outros tipos de trabalho (24)\Começar com pequenos focos\Pessoas buscando ajuda com eles & $\begin{array}{l}\text { aliás as pessoas agora, sentindo que eu estou melhor, me procuram pra quando } \\
\text { sabe, por exemplo, uma amiga minha, que era uma das que me pressionaram } \\
\text { muito, mas por que?... a sobrinha dela está com problemas e se está falando pra } \\
\text { mãe, ela toma medicamentos, sérios problemas e ela agora começou a falar pra } \\
\text { mãe que não quer mais viver. Já deu muitos problemas. Ela foi convidada a se } \\
\text { retirar da escola, uma escola muito boa, aqui em São Paulo. la com saia muito } \\
\text { curta, você entendeu... só que agora está.. e essa minha amiga, outro dia, veio me } \\
\text { procurar. }\end{array}$ \\
\hline
\end{tabular}

Material integrante da pesquisa de doutorado de Karen Scavacini - USP Proibida a reprodução ou utilização sem autorização do autor - 2018 


\begin{tabular}{|c|c|c|}
\hline Transcrição E2 revisada & |CONSCIENTIZAÇÃO|Desafios\Impeditivos (18)\Psicofobia & $\begin{array}{l}\text { Inclusive pensei em indica-la para a mãe, mas a mãe está restrições de mandar ela } \\
\text { pra uma terapia. O psiquiatra tá falando que ela tem que ir. }\end{array}$ \\
\hline Transcrição E2 revisada & AÇÃO\Fazer|Outros tipos de trabalho (24)\Começar com pequenos focos\Pessoas buscando ajuda com eles & $\begin{array}{l}\text { Então ela veio me procurar: "Ah, preciso te contar uma coisa..." Porque ela se } \\
\text { sentiu à vontade de me contar e que eu... "Não porque...sei que você né? Tem } \\
\text { vários lugares... o que eu posso indicar para a minha cunhada, eu falei, eu acho que } \\
\text { terapia, acho que dá para ficar em cima com ela para ela tomar o medicamento, vê } \\
\text { o resultado do medicamento... então assim, agora as pessoas estão perguntando. }\end{array}$ \\
\hline Transcrição E2 revisada & AÇÃO\Fazer|Outros tipos de trabalho (24) Ussando a dor para ajudar os outros|Se sentindo a vontade para ajudar outros & $\begin{array}{l}\text { Então ela veio me procurar: "Ah, preciso te contar uma coisa..." Porque ela se } \\
\text { sentiu à vontade de me contar e que eu... "Não porque...sei que você né? Tem } \\
\text { vários lugares... o que eu posso indicar para a minha cunhada, eu falei, eu acho que } \\
\text { terapia, acho que dá para ficar em cima com ela para ela tomar o medicamento, vê } \\
\text { o resultado do medicamento... então assim, agora as pessoas estão perguntando. }\end{array}$ \\
\hline Transcrição E2 revisada & AÇÃO\Fazer|Outros tipos de trabalho (24)\Usando a dor para ajudar os outros\Ao se abrir outros buscam ajuda & $\begin{array}{l}\text { Porque estão vendo que eu estou levando adiante, eu estou falando sobre o } \\
\text { assunto }\end{array}$ \\
\hline Transcrição E2 revisada & COMPREENSÃO|Comunicação|Pessoal|Falando abertamente na familia|Falando sobre o suicídio & $\begin{array}{l}\begin{array}{l}\text { Porque estão vendo que eu estou levando adiante, eu estou falando sobre o } \\
\text { assunto }\end{array} \\
\end{array}$ \\
\hline Transcrição E2 revisada & COMPREENSÃO|Comunicação|Pessoal|Falando abertamente na família|Conversando sobre suicídio na família & $\begin{array}{l}\text { Então eu falo abertamente com o (nome do filho do marido) que mora comigo, } \\
\text { que é filho do P5, né, o mais novo que era como irmão do (nome do filho), então a } \\
\text { gente fala, quando a gente ficou preocupado com o meio irmão dele a gente } \\
\text { conversa sobre isso. Então, a gente conversa. }\end{array}$ \\
\hline Transcrição E2 revisada & COMPREENSÃO|Comunicação|Pessoal|Dificuldades comunicação familiar|Filhos com dificuldade de tocar no assunto & $\begin{array}{l}\text { Tenho um filho que nunca tocou no assunto. Falou uma vez só mas acho que } \\
\text { porque eu perguntei. }\end{array}$ \\
\hline Transcrição E2 revisada & COMPREENSÃO|Comunicação|Pessoal|Dificuldades comunicação familiar|Filhos com dificuldade de tocar no assunto & $\begin{array}{l}\text { O outro toca no assunto quando eu quero falar. Mas ele mais me escuta do que ele } \\
\text { mesmo fala }\end{array}$ \\
\hline Transcrição E2 revisada & COMPREENSÃO|Comunicação|Pessoal|Dificuldades comunicação familiar|Achando que machuca os filhos ao falar & Então eu sinto que aquilo machuca...eu procuro evitar. \\
\hline Transcrição E2 revisada & COMPREENSÃO\Comunicação|Pessoal|Conversando com amigos\Os de fora tem receio de falar & $\begin{array}{l}\text { Não, não. As pessoas tem esse receio. Não sabem como tocar... como eu também } \\
\text { não falo. }\end{array}$ \\
\hline Transcrição E2 revisada & COMPREENSÃO|Comunicação|Pessoal\Escolhendo com quem falar|Se sentindo a vontade de falar com prima psicóloga & $\begin{array}{l}\text { Eu tenho uma prima que é psicóloga. Com essa eu converso muito mas fora isso } \\
\text { não. }\end{array}$ \\
\hline Transcrição E2 revisada & COMPREENSÃO|Comunicação|Pessoal|Conversando com amigos & Com amigos, muito \\
\hline Transcrição E2 revisada & COMPREENSÃO\Comunicação|Pessoal|Conversando com amigos|Conversando pouco com colegas & Com colegas, pouco. \\
\hline Transcrição E2 revisada & COMPREENSÃO|Comunicação|Pessoal|Falando abertamente na família|Com cada parte da família é diferente a conversa & Com uma parte da familia, muito e outra parte quase nada. \\
\hline Transcrição E2 revisada & COMPREENSÃO|Comunicação|Pessoal|Escolhendo com quem falar|Com quem não gosto de falar & $\begin{array}{l}\text { Porque a minha sogra, por exemplo, começa com as lamúrias dela e aí eu já tenho } \\
\text { que dar uma cortada, "aí, porque ele não me leva também..", aí começa com } \\
\text { drama. Aí, porque sempre foi difícil, eu queria ficar com o meu neto. Aí aquilo } \\
\text { começa a me dar um desgaste né, aí eu falo “Ai, por favor... não... para com isso". } \\
\text { Aí já vou logo para frente. Mas é isso. }\end{array}$ \\
\hline Transcrição E2 revisada & COMPREENSÃO\Comunicação|Pessoal|Escolhendo com quem falar|Com que gosto de falar & Agora em casa com o marido falo bastante. \\
\hline Transcrição E2 revisada & COMPREENSÃo|Comunicação|Pessoal|Falando abertamente na família|Sempre conversamos sobre suicídio em família & $\begin{array}{l}\text { Eu acho que em casa a gente sempre falou, mesmo antes. Sempre foi uma } \\
\text { discussão, acho que do ponto de vista intelectual, sempre se conversou um pouco } \\
\text { sobre isso. }\end{array}$ \\
\hline Transcrição E2 revisada & COMPREENSÃo|Comunicação|Pessoal|Falando abertamente na família|Conversando sobre doenças criticas com a família & $\begin{array}{l}\text { Até por questões de...por exemplo, de ter algumas doenças na família que são } \\
\text { muito críticas, a gente sempre conversou: "E se a gente for diagnosticado com isso, } \\
\text { o que você faria?" A gente fazia esse exercício, um pouco, porque é complicado } \\
\text { também }\end{array}$ \\
\hline Transcrição E2 revisada & COMPREENSÃO\Comunicação|Pessoal\Conversando com amigos/Não falando com amigos & É... depois com os amigos não. \\
\hline
\end{tabular}

Material integrante da pesquisa de doutorado de Karen Scavacini - USP Proibida a reprodução ou utilização sem autorização do autor - 2018 


\begin{tabular}{|c|c|c|}
\hline Transcrição E2 revisada & COMPREENSÃO|Comunicação|Pessoal|Conversando com amigos\Conversando sobre suicídio com amigos & $\begin{array}{l}\text { É... depois com os amigos não. Mas depois do que aconteceu com alguns amigos } \\
\text { eu converso sobre isso, falava as vezes alguma coisa mas pouca coisa. Depois do } \\
\text { acontecido eu acho que eu tive...eu tenho a sorte talvez de ter muitas pessoas que } \\
\text { conseguem conversar isso bem, pessoas que se revelaram bons amigos, depois } \\
\text { disso e hoje a gente fala, ainda fala mas a gente não fala do meu irmão mas a } \\
\text { gente fala do assunto. Meu irmão ainda....acho que a cicatriz... gente ainda não } \\
\text { conversa sobre ele mas a gente fala sobre o assunto. }\end{array}$ \\
\hline Transcrição E2 revisada & COMPREENSÃo|Comunicação|Pessoal\Conversando com amigos|Dificuldade de falar sobre a morte do irmão com amigos & $\begin{array}{l}\text { pessoas que se revelaram bons amigos, depois disso e hoje a gente fala, ainda fala } \\
\text { mas a gente não fala do meu irmão mas a gente fala do assunto. Meu irmão } \\
\text { ainda... acho que a cicatriz.... gente ainda não conversa sobre ele mas a gente fala } \\
\text { sobre o assunto. }\end{array}$ \\
\hline Transcrição E2 revisada & COMPREENSÃo|Comunicação\Pessoal\Conversando com amigos\Conversando sobre suicídio com amigos & $\begin{array}{l}\text { Até por questão de ser uma situação presente pra outras pessoas, eu tenho um } \\
\text { primo que esta passando por um depressão profunda e minha irmã está tentando } \\
\text { ajudar a minha tia... }\end{array}$ \\
\hline Transcrição E2 revisada & COMPREENSÃO|Comunicação|Pessoal|Conversando com amigos|Dificuldade de falar sobre a morte do irmão com amigos & Então fala-se, mas a gente não fala do meu irmão, ainda. \\
\hline Transcrição E2 revisada & COMPREENSÃO|Comunicação|Pessoal\O falar como uma causa/bandeira|Falam muito porque trabalham com isso & A gente fala o tempo todinho né, porque a gente trabalha com isso né... \\
\hline Transcrição E2 revisada & COMPREENSÃO|Comunicação|Pessoal|Conversando com amigos/Conversando sobre suicídio com amigos & $\begin{array}{l}\text { Mas assim eu ainda sinto, assim, receio de amigos quando falo no assunto. Mas } \\
\text { por outro lado, tem já alguns amigos que eles procuram...já é bastante casos de } \\
\text { amigos deles, pra gente ver se pode dar uma ajuda e tal, quer dizer, se ele vem é } \\
\text { porque, é porque ele tem uma certa vontade que é de gente conversar. }\end{array}$ \\
\hline Transcrição E2 revisada & COMPREENSÃO|Comunicação|Pessoal|Conversando com amigos|Sentindo receio de falar com alguns amigos & Mas assim eu ainda sinto, assim, receio de amigos quando falo no assunto. \\
\hline Transcrição E2 revisada & COMPREENSÃo|Comunicação|Pessoal|Reações\Positivas|Sendo procurado por alguns amigos para falar sobre suicídio & $\begin{array}{l}\text { Mas por outro lado, tem já alguns amigos que eles procuram...já é bastante casos } \\
\text { de amigos deles, pra gente ver se pode dar uma ajuda e tal, quer dizer, se ele vem } \\
\text { é porque, é porque ele tem uma certa vontade que é de gente conversar. }\end{array}$ \\
\hline Transcrição E2 revisada & COMPREENSÃO\Comunicação|Pessoal|Dificuldades comunicação familiar|Familia mais geral fala sobre instituto não sobre a filha que m & $\begin{array}{l}\text { Na família, fora a família mais íntima né, quer dizer eu, a (nome da esposa) e a } \\
\text { (nome da outra filha), não se fala né, fala muito do instituto né, muitas coisas, mas } \\
\text { assim fala mais de modo geral... }\end{array}$ \\
\hline Transcrição E2 revisada & COMPREENSÃO|Comunicação|Pessoal|Dificuldades comunicação familiar|Família mais geral fala sobre instituto não sobre a filha que $\mathrm{m}$ & É, do suicídio da (nome da filha) não \\
\hline Transcrição E2 revisada & COMPREENSÃO\Comunicação|Pessoal|Falando abertamente na família\Para a família é transparente falar do suicídio da filha & Mas não é assim tão, assim, para a gente, é transparente... \\
\hline Transcrição E2 revisada & 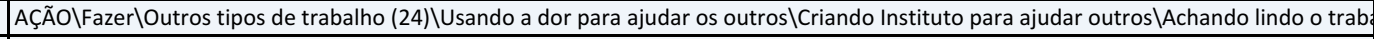 & Isso é lindo, que vocês fazem, de usar essa dor, para ajudar os outros. \\
\hline Transcrição E2 revisada & AÇÃO\Fazer\Outros tipos de trabalho (24)\Usando a dor para ajudar os outros & Isso é lindo, que vocês fazem, de usar essa dor, para ajudar os outros. \\
\hline Transcrição E2 revisada & AÇÃO\Fazer\Outros tipos de trabalho (24)\Usando a dor para ajudar os outros & Exato, entendem É isso! \\
\hline Transcrição E2 revisada & COMPREENSÃO|Comunicação|Pessoal|Escolhendo com quem falar|Com quem eu falo sobre o suicídio & $\begin{array}{l}\text { Eu falo com minha mãe e meu pai, minha avó, com uma tia e com duas amigas, } \\
\text { mas é porque as pessoas não sabem }\end{array}$ \\
\hline Transcrição E2 revisada & COMPREENSÃO\Comunicação|Pessoal\Morreu de que\Mudando a causa da mortelPrecisando negar a forma de morte\Escondendo o mo & $\begin{array}{l}\text { mas é porque as pessoas não sabem. A gente não falou que foi suicídio, só dentro } \\
\text { da família. }\end{array}$ \\
\hline Transcrição E2 revisada & COMPREENSÃO\Comunicação|Pessoal|Morreu de que\Mudando a causa da morte\Precisando negar a forma de morte\Escondendo o mo & $\begin{array}{l}\text { Meus amigos, teoricamente se eles sabem não foi porque eu contei, não sei se } \\
\text { ficaram sabendo e não falaram....Então...nem na empresa, em nenhum lugar as } \\
\text { pessoas, eu não falo com ninguém porque eu não falei que foi suicídio }\end{array}$ \\
\hline Transcrição E2 revisada & COMPREENSÃO|Comunicação|Pessoal|Escolhendo com quem falar|Fala da perda do irmão para os amigos & Eu falo da perda do meu irmão. Isso eu falo. Mas não falo do motivo. \\
\hline Transcrição E2 revisada & COMPREENSÃO|Comunicação|Pessoal|Escolhendo com quem falar|Com quem eu falo sobre o suicídio & $\begin{array}{l}\text { E na minha família só com as pessoas que são realmente mais próximas, né? Meus } \\
\text { pais, a minha avó, essa minha tia... A minha melhor amiga sabe, }\end{array}$ \\
\hline Transcrição E2 revisada & CONSCIENTIZAÇÃO|Consciência\O absurdo do suicídio|Proximidade de suicídios/Casos na família da melhor amiga & $\begin{array}{l}\text { A minha melhor amiga sabe, inclusive na família dela também tiveram alguns } \\
\text { casos. }\end{array}$ \\
\hline Transcrição E2 revisada & COMPREENSÃO|Comunicação|Pessoal|Escolhendo com quem falar|Escolhendo não falar sobre o suicídio do irmão na sociedade & $\begin{array}{l}\text { Então mais assim. Mas na sociedade, ninguém, né, assim é coisa que eu não falo } \\
\text { então eu não tenho assim muito... eu não falo com ninguém mas é por escolha. }\end{array}$ \\
\hline Transcrição E2 revisada & COMPREENSÃo|Comunicação|Pessoal|Escolhendo com quem falar|Escolhendo não falar sobre o suicídio do irmão na sociedade & $\begin{array}{l}\text { Se eu quisesse falar que foi suicídio eu poderia falar e assumir mas eu não contei, } \\
\text { talvez um dia, enfim... }\end{array}$ \\
\hline
\end{tabular}




\begin{tabular}{|c|c|c|}
\hline Transcrição E2 revisada & COMPREENSÃO\Comunicação|Pessoal|Se preparando para falar\Talvez um dia eu conte para os outros que foi suicídio & $\begin{array}{l}\text { Se eu quisesse falar que foi suicídio eu poderia falar e assumir mas eu não contei, } \\
\text { talvez um dia, enfim... }\end{array}$ \\
\hline Transcrição E2 revisada & COMPREENSÃO|Comunicação|Pessoal|Dificuldades comunicação familiar|Família não quer conversar sobre o assunto & Com a família, a gente não fala porque já sabe que não quer falar sobre o assunto. \\
\hline Transcrição E2 revisada & COMPREENSÃo|Comunicação|Social|Aumento da comunicação|Mídia incluindo os sobreviventes\Família dando depoimento na televisã & $\begin{array}{l}\text { A única exceção que eles participaram de alguma coisa foi na (nome de um canal } \\
\text { de televisão) que deram um breve depoimento, a mãe, e a (nome da filha do } \\
\text { meio), o meu filho menor não. }\end{array}$ \\
\hline Transcrição E2 revisada & COMPREENSÃO|Comunicação|Pessoal|Dificuldades comunicação familiar|Família não gosta de conversar sobre o assunto & $\begin{array}{l}\text { Mas eles não gostam e quando eu estou conversando com alguém eles se afastam } \\
\text { se o tema entra nesse assunto, né? }\end{array}$ \\
\hline Transcrição E2 revisada & COMPREENSÃo|Comunicação|Pessoal|Dificuldades comunicação familiar|Família não gosta de conversar sobre o assunto & $\begin{array}{l}\text { Então, eles ficam constrangidos, não querem conversar sobre o assunto, é uma } \\
\text { forma de eles lidarem... }\end{array}$ \\
\hline Transcrição E2 revisada & COMPREENSÃO|Comunicação|Pessoal|Conversando com amigos & agora, os amigos não. Com os amigos eu converso... \\
\hline Transcrição E2 revisada & COMPREENSÃO\Comunicação|Pessoal|Reações\Positivas\Amigos ficam tocados com a conversa & $\begin{array}{l}\text { Com os amigos eu converso... mas é porque está embutido na conversa com os } \\
\text { amigos, e uma parte deles é militante, batalhador que nem eu, então eles até se } \\
\text { identificaram, ficaram meio tocados. }\end{array}$ \\
\hline Transcrição E2 revisada & COMPREENSÃO\Experiência\O viver|Quem viveu (5)\Luto (7)\Luta\Amigos militantes como ele & $\begin{array}{l}\text { Com os amigos eu converso... mas é porque está embutido na conversa com os } \\
\text { amigos, e uma parte deles é militante, batalhador que nem eu, então eles até se } \\
\text { identificaram, ficaram meio tocados. Você tá sempre lutando e abraçou mais essa } \\
\text { luta, é isso aí, tal. Essa feição de luta, de coisa, como é algo que a sociedade } \\
\text { assimila legal, no caso, o cara está fazendo uma luta por as outras pessoas, então } \\
\text { permite as pessoas, acho que, por causa desse viés, elas conseguem conversar. }\end{array}$ \\
\hline Transcrição E2 revisada & COMPREENSÃO\Experiência\O viver|Quem viveu (5)〈Luto (7)\Luta|Sendo militante da prevenção do suicídio & $\begin{array}{l}\text { Você tá sempre lutando e abraçou mais essa luta, é isso aí, tal. Essa feição de luta, } \\
\text { de coisa, como é algo que a sociedade assimila legal, no caso, o cara está fazendo } \\
\text { uma luta por as outras pessoas, então permite as pessoas, acho que, por causa } \\
\text { desse viés, elas conseguem conversar. Porque elas não ficam aprofundando a } \\
\text { questão do suicídio, mas a luta que tá fazendo. }\end{array}$ \\
\hline Transcrição E2 revisada & 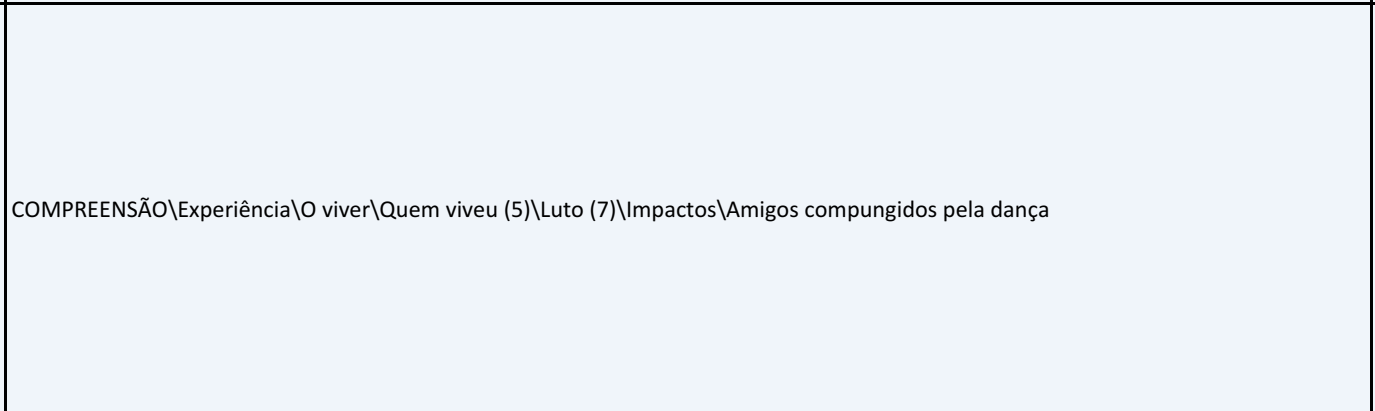 & $\begin{array}{l}\text { Agora, o impacto que está causando, principalmente entre os profissionais da área, } \\
\text { que me conhecem de longa data e alguns são da dança, os profissionais de dança, } \\
\text { é que eles não se conformam com essa impossibilidade que eu adquiri de dançar, } \\
\text { né? Então eles... eu sinto que alguns até ficam compungidos. Profissionais } \\
\text { principalmente, muito compungidos. É como se tivessem perdido com que o } \\
\text { dançarino morreu, né? É onde eu sinto assim mais uma carga emocional, por mim. } \\
\text { Quer dizer, não se conformam com fato de eu não dançar e como eu já eu ouvi em } \\
\text { alguns casos, alguns apelos de algumas parceiras do passado, de que um dia eu } \\
\text { gostaria voltar a dançar comigo... Eu acho que as pessoas, elas falam P7, você, tem } \\
\text { direito a ser feliz, você tem que voltar a dançar porque quem dança é mais } \\
\text { feliz...Ainda mais eu que defendia, eu abracei essa bandeira da dança, sabe, é uma } \\
\text { bandeira que eu abracei. }\end{array}$ \\
\hline Transcrição E2 revisada & COMPREENSÃO\Experiência\O viver|Quem viveu (5)(Luto (7)\Luta\E se eu abandonar a luta pela prevenção do suicídio & $\begin{array}{l}\text { Imagina eu amanhã eu abandonar a luta pelo suicídio, a luta pela prevenção ao } \\
\text { suicídio.; Como vocês vão se sentir? Se eu abandonar essa luta? E não participar? }\end{array}$ \\
\hline Transcrição E2 revisada & 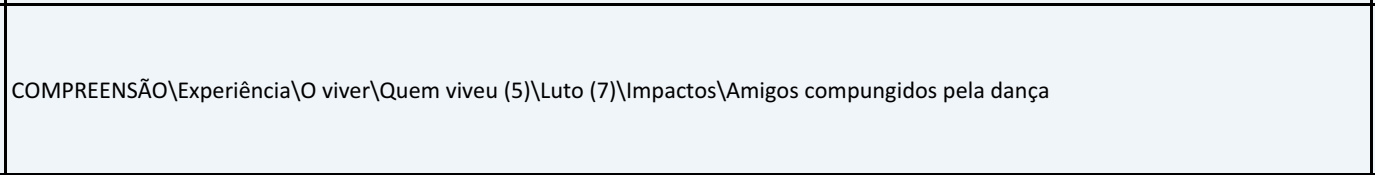 & $\begin{array}{l}\text { É o que eles estão sentindo porque eu era um grande divulgador, os profissionais } \\
\text { de dança ficaram muito agradecidos porque eu ajudava e tal... e onde eu vivo hoje } \\
\text { em dia quase não tem mais jantar dançante... eu fiquei espantado, P7, a dança } \\
\text { morreu aqui em (nome de uma cidade), Quer dizer então que eu era a } \\
\text { chama...então nesse ambiente o impacto é maior. }\end{array}$ \\
\hline Transcrição E2 revisada & 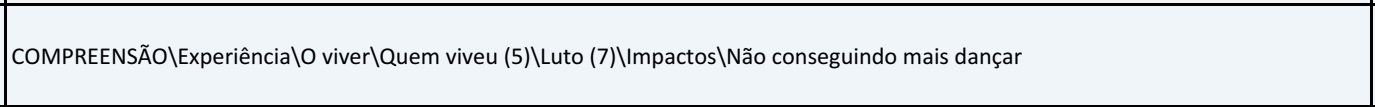 & $\begin{array}{l}\text { Mas eu falo: "Gente, eu não danço porque eu não quero. Eu não consigo." Aí hoje } \\
\text { eu encontrei uma..., hoje não, ha pouco tempo, eu encontrei uma figura, um } \\
\text { exemplo, para poder as pessoas entender o que é }\end{array}$ \\
\hline Transcrição E2 revisada & 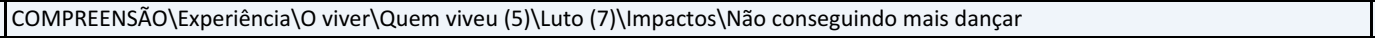 & eles não se conformam com essa impossibilidade que eu adquiri de dançar, né? \\
\hline
\end{tabular}

Material integrante da pesquisa de doutorado de Karen Scavacini - USP Proibida a reprodução ou utilização sem autorização do autor - 2018 


\begin{tabular}{|c|c|c|}
\hline Transcrição E2 revisada & 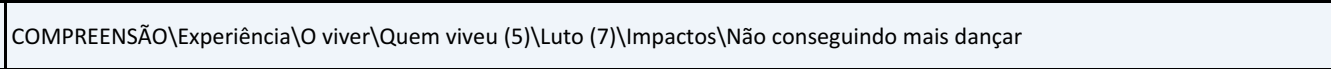 & $\begin{array}{l}\text { É como se tivessem perdido com que o dançarino morreu, né? É onde eu sinto } \\
\text { assim mais uma carga emocional }\end{array}$ \\
\hline Transcrição E2 revisada & 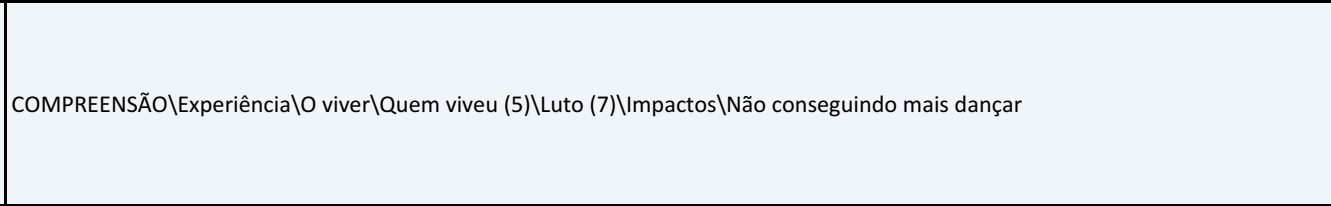 & $\begin{array}{l}\text { Imagina você ter que fazer sexo com alguém, sem vontade, apenas pra agradar } \\
\text { essa pessoa. Não dá. Não vou conseguir. Então, eu não consigo dançar porque tem } \\
\text { que ter emoção, assim como no sexo tem que ter o desejo, a vontade, o impulso, é } \\
\text { o sagrado, é o que gera a vida, é o que desenvolve o amor enfim, né? E você vai } \\
\text { fazer uma coisa mecânica. Então, é a mesma coisa a dança. Então, esse } \\
\text { contingente está seriamente impactado. }\end{array}$ \\
\hline Transcrição E2 revisada & 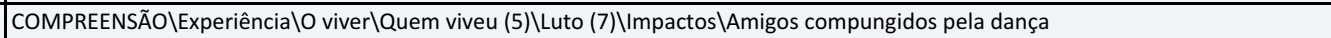 & Então, esse contingente está seriamente impactado. \\
\hline Transcrição E2 revisada & COMPREENSÃO\Comunicação|Pessoal\O falar como uma causa/bandeira \Me imponho falar por causa da bandeira que abracei & $\begin{array}{l}\text { Mas eu converso, mesmo, com eles. Eu me imponho começar a falar, mesmo que } \\
\text { dói, eu me imponho, por causa dessa bandeira que eu abracei... }\end{array}$ \\
\hline Transcrição E2 revisada & COMPREENSÃO\Comunicação|Pessoal|Conversando com amigos\Conversando com poucas pessoas & Eu converso com poucas pessoas. \\
\hline Transcrição E2 revisada & COMPREENSÃo|Comunicação|Pessoal|Reações|Positivas|Pessoas ficando interessadas no tema & $\begin{array}{l}\text { Acho que teve uma pessoa que eu falei sobre o tema e ela e a pessoa falou: "Nossa } \\
\text { que interessante!" Perguntou mais coisas. }\end{array}$ \\
\hline Transcrição E2 revisada & COMPREENSÃO\Comunicação|Pessoal|Se preparando para falar\Explorar primeiro para depois falar & $\begin{array}{l}\text { Aí eu tive experiências ruins, então hoje o que eu percebo, assim, não falo sobre, } \\
\text { primeiro que dou uma explorada pra ver como é a visão dela em relação a morte, } \\
\text { pra saber se eu posso entrar no assunto. }\end{array}$ \\
\hline Transcrição E2 revisada & COMPREENSÃO|Comunicação|Pessoal|Se preparando para falar|Sendo preventivo para falar & $\begin{array}{l}\text { Aí eu tive experiências ruins, então hoje o que eu percebo, assim, não falo sobre, } \\
\text { primeiro que dou uma explorada pra ver como é a visão dela em relação a morte, } \\
\text { pra saber se eu posso entrar no assunto. }\end{array}$ \\
\hline Transcrição E2 revisada & COMPREENSÃO|Comunicação|Pessoal|Se preparando para falar|Sendo preventivo para falar & Você faz um teste. \\
\hline Transcrição E2 revisada & COMPREENSÃO\Comunicação|Pessoal|Se preparando para falar|Sendo preventivo para falar & É, é, por experiência prática. \\
\hline Transcrição E2 revisada & COMPREENSÃo|Comunicação|Pessoal|Reações\Negativas|Reação negativa do amigo & $\begin{array}{l}\text { Então, até desses amigos, tinha essa, que eu recebi uma reação bem negativa, eles } \\
\text { têm duas filhas. }\end{array}$ \\
\hline Transcrição E2 revisada & COMPREENSÃO|Comunicação|Pessoal|Reações|Negativas|Sofrendo resistência por compartilhar informação & $\begin{array}{l}\text { Então, tinha um certo conflito, uma angustia, de eu ter muita informação e querer } \\
\text { compartilhar e sofrer essa resistência. }\end{array}$ \\
\hline Transcrição E2 revisada & COMPREENSÃO|Comunicação|Pessoal|Se preparando para falar|Hoje pergunto antes de falar & \begin{tabular}{|l|} 
Então hoje eu consegui assim, ligar e falar assim: "Posso te falar sobre tal, tal, \\
coisa? "E aí, o meu amigo disse, ok... aí de vez enquanto eu passo a informação.
\end{tabular} \\
\hline Transcrição E2 revisada & COMPREENSÃo|Comunicação|Pessoal|Reações\Negativas\Tema criando afastamento com amigo & Mas criou um afastamento. 0 tema criou um afastamento. \\
\hline Transcrição E2 revisada & COMPREENSÃO|Comunicação|Pessoal\O falar como uma causa/bandeira|Poucas pessoas conseguem compartilhar essa experiência & $\begin{array}{l}\text { Então, eu encontrei...Apesar de ter tido esse tempo no CVV, eu tive poucas } \\
\text { pessoas com quem eu pude compartilhar a experiência. Isso é uma coisa que pra } \\
\text { mim entristece bastante. }\end{array}$ \\
\hline Transcrição E2 revisada & COMPREENSÃO|Comunicação|Pessoal \O falar como uma causa/bandeira|Se entristecendo por não poder compartilhar mais & $\begin{array}{l}\text { Então, eu encontrei...Apesar de ter tido esse tempo no CVV, eu tive poucas } \\
\text { pessoas com quem eu pude compartilhar a experiência. Isso é uma coisa que pra } \\
\text { mim entristece bastante. }\end{array}$ \\
\hline Transcrição E2 revisada & COMPREENSÃO|Comunicação|Pessoal\O falar como uma causa/bandeira|Se entristecendo por não poder compartilhar mais & Alguém tem alguma outra observação, quer falar mais alguma coisa? \\
\hline Transcrição E2 revisada & AÇÃOlCuidar|Sobre os encontros (25)\Ficando tocado na reunião anterior & $\begin{array}{l}\text { Da reunião passada, por exemplo, uma coisa que me tocou e foi o que eu fiquei } \\
\text { refletindo né. Quando a P2 falou: "Poxa, eu tenho uma pessoa com depressão mas } \\
\text { eu não consigo..." E falou com esse sofrimento. }\end{array}$ \\
\hline Transcrição E2 revisada & CONSCIENTIZAÇão|Consciência\O absurdo do suicídio|Limitações|Sendo difícil reconhecer seu limite na ajuda & $\begin{array}{l}\text { Então, é a mesma coisa que eu sinto, e é um conflito meu, quando falam assim: } \\
\text { "Existe algo que eu posso fazer mas eu tenho que conseguir saber reconhecer o } \\
\text { meu limite até onde eu consigo ir. Isso é difícil. }\end{array}$ \\
\hline Transcrição E2 revisada & AÇÃO|Cuidar|Grupos de apoio (21)\Sendo difícil participar de grupos & $\begin{array}{l}\text { Pra mim participar do grupo foi difícil, assim, porque eu sabia que teriam opiniões } \\
\text { diferentes né? }\end{array}$ \\
\hline Transcrição E2 revisada & AÇÃO|Cuidar|Grupos de apoio (21)\Sendo difícil participar de grupos\Sabendo que ia encontrar opiniões diferentes & $\begin{array}{l}\text { Pra mim participar do grupo foi difícil, assim, porque eu sabia que teriam opiniões } \\
\text { diferentes né? }\end{array}$ \\
\hline Transcrição E2 revisada & AÇÃO|Cuidar|Grupos de apoio (21)|Sendo difícil participar de grupos|Comparando a história dos outros & $\begin{array}{l}\text { E algumas coisas que a gente fala como a história do outro é diferente, às vezes } \\
\text { chega, né, de uma maneira dolorosa }\end{array}$ \\
\hline
\end{tabular}




\begin{tabular}{|c|c|c|}
\hline Transcrição E2 revisada & AÇÃo|Cuidar|Grupos de apoio (21)\Sendo difícil participar de grupos\Vivendo um conflito no grupo & $\begin{array}{l}\text { Puxa mas então, eu devia fazer algo e será que eu não fiz? É o meu conflito que eu } \\
\text { fiquei. Então, tenho algo para acrescentar? }\end{array}$ \\
\hline Transcrição E2 revisada & CONSCIENTIZAÇÃo|Consciência \O absurdo do suicídio|É muita coisa para fazer|Sentindo que devia fazer algo diferente & $\begin{array}{l}\text { Puxa mas então, eu devia fazer algo e será que eu não fiz? É o meu conflito que eu } \\
\text { fiquei. Então, tenho algo para acrescentar? }\end{array}$ \\
\hline Transcrição E2 revisada & CONSCIENTIZAÇÃO|Consciência \O absurdo do suicídio|Prevenção x Previsão|Duvidando que poderia ajudar & $\begin{array}{l}\text { Puxa mas então, eu devia fazer algo e será que eu não fiz? É o meu conflito que eu } \\
\text { fiquei. Então, tenho algo para acrescentar? }\end{array}$ \\
\hline Transcrição E2 revisada & COMPREENSÃo\Experiência\O viver\Quem viveu (5)\Depois do suicídio\A experiência de perder um amigo para o suicídio & $\begin{array}{l}\text { uma experiência que eu particularmente vivi, que foi a perda de um amigo, foi o } \\
\text { que muita gente relatou do processo, né, é do atestado de óbito, da polícia e tal. }\end{array}$ \\
\hline Transcrição E2 revisada & CONSCIENTIZAÇão|Consciência\Aumento da Consciência (19)\Condição\A cegueira individual influencia as outras & $\begin{array}{l}\text { Uma das coisas que eu percebo, assim, toda a cegueira que a gente tem individual } \\
\text { vai pra cultura. Isso também vai pra cultura das organizações. Então, o sistema de } \\
\text { saúde, hospital e plano de saúde ele vai de alguma maneira refletir a dificuldade } \\
\text { que cada um individualmente tem com o tema. O tabu que tem, né? É um reflexo. }\end{array}$ \\
\hline Transcrição E2 revisada & COMPREENSÃO\Tabu (1)\O tabu em diversas esferas\Tabu piorando o tratamentolO hospital reflete as dificuldades individuais com o ten & $\begin{array}{l}\text { Então, o sistema de saúde, hospital e plano de saúde ele vai de alguma maneira } \\
\text { refletir a dificuldade que cada um individualmente tem com o tema. O tabu que } \\
\text { tem, né? É um reflexo }\end{array}$ \\
\hline Transcrição E2 revisada & COMPREENSÃO\Tabu (1)\O tabu em diversas esferas\Tabu piorando o tratamento|Reflexo do tabu individual & $\begin{array}{l}\text { O tabu que tem, né? É um reflexo. Então, tanto o sistema de saúde quanto a policia } \\
\text { vai ser um reflexo disso }\end{array}$ \\
\hline Transcrição E2 revisada & COMPREENSÃO\Experiência|O sentir|Sentimentos (8)\Dor|De quem fica|Ficando tocado com a dor do processo & $\begin{array}{l}\text { Aí me tocou bastante, assim, alguns depoimentos do como é doloroso esse } \\
\text { processo... }\end{array}$ \\
\hline Transcrição E2 revisada & COMPREENSÃO\Experiência\O viver|Quem viveu (5)\Sendo bem cuidada (polícia e médicos)\Médicos também cuidam bem & Um relato bonito que eu ouvi de uma médica é o cuidado que ela tem. \\
\hline Transcrição E2 revisada & 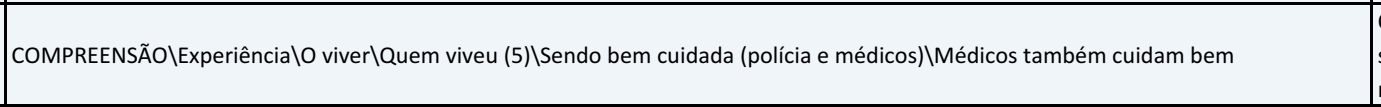 & $\begin{array}{l}\text { Quando vai tratar alguns assuntos com a família, ela falava, ela falava assim: "Eu } \\
\text { sei que vai ser um momento que aquela família, aquela pessoas vão levar para o } \\
\text { resto da vida }\end{array}$ \\
\hline Transcrição E2 revisada & AÇãolFazer\Outros tipos de trabalho (24)\Cuidado na informação e comunicação com os enlutados $\backslash 0$ momento da comunicação é impo & $\begin{array}{l}\text { Quando vai tratar alguns assuntos com a família, ela falava, ela falava assim: "Eu } \\
\text { sei que vai ser um momento que aquela família, aquela pessoas vão levar para o } \\
\text { resto da vida }\end{array}$ \\
\hline Transcrição E2 revisada & COMPREENSÃO\Experiência\O viver\Quem viveu (5)\Sendo bem cuidada (polícia e médicos)\A forma da comunicação influencia os enlut & $\begin{array}{l}\text { Então, o que eu ouvi de depoimentos é que eu também já passei em situações } \\
\text { diferentes com uma notícia, ou uma comunicação entre o profissional de saúde, } \\
\text { não tive com a policia mas isso é uma dor a mais que se soma à aquela que o } \\
\text { enlutado já está passando. }\end{array}$ \\
\hline Transcrição E2 revisada & AÇÃO|Fazer|Outros tipos de trabalho (24)\Cuidado na informação e comunicação com os enlutados & $\begin{array}{l}\text { Então, uma sugestão, né, que eu acho que seria importante para vários } \\
\text { profissionais. Eu não sou da administração da área de saúde mas, essa discussão, } \\
\text { esse cuidado na informação, na comunicação dessas organizações com os } \\
\text { enlutados, eu acho que poderia diminuir o risco. }\end{array}$ \\
\hline Transcrição E2 revisada & AÇÃo|Cuidar\Tratamento (13)\Dificuldade de achar apoio adequado\Buracos que ninguém se responsabiliza & $\begin{array}{l}\text { Então, eu acho que tem alguns meandros que talvez, assim, vamos supor, o } \\
\text { profissional de saúde atua...esse é o trabalho deles. O policial tem, esse é o } \\
\text { trabalho dele. Mas talvez tenham buracos que ninguém, não tem ninguém, } \\
\text { digamos, responsável, né? E que a pessoa enlutada, as vezes ela passa e não tem } \\
\text { ninguém... fica um buraco... }\end{array}$ \\
\hline Transcrição E2 revisada & COMPREENSÃO\Tabu (1)\O tabu em diversas esferas\Seguro de vida & $\begin{array}{l}\text { Falando eu lembrei que o preconceito já começa quando você tem um seguro de } \\
\text { vida e não pode o suicídio. }\end{array}$ \\
\hline Transcrição E2 revisada & COMPREENSÃO\Tabu (1)\O tabu em diversas esferas|Seguro de vida|Seguro de vida que não cobre suicídio & $\begin{array}{l}\text { Falando eu lembrei que o preconceito já começa quando você tem um seguro de } \\
\text { vida e não pode o suicídio. }\end{array}$ \\
\hline Transcrição E2 revisada & COMPREENSÃO\Tabu (1)\O tabu em diversas esferas\Seguro de vida|Seguro de vida que não cobre suicídio & $\begin{array}{l}\text { Porque o (nome do filho), tinha comprado um carro fazia pouco tempo e estava } \\
\text { financiado uma parte e a gente fez automaticamente um seguro de vida }\end{array}$ \\
\hline Transcrição E2 revisada & COMPREENSÃO\Tabu (1)\O tabu em diversas esferas\Seguro de vida|Seguro de vida que não cobre suicídio & $\begin{array}{l}\text { "Olha, no fim de semana retrasado, eu nem falei para a P4, no seguro de vida, não } \\
\text { cobriu, deu negativo. }\end{array}$ \\
\hline
\end{tabular}




\begin{tabular}{|c|c|c|}
\hline Transcrição E2 revisada & COMPREENSÃO\Tabu (1)\O tabu em diversas esferas $\backslash$ Seguro de vida \Entrando com processo para ter direito ao seguro de vida & \begin{tabular}{|l|} 
Depois por o (nome do filho) estar trabalhando com uma grande amiga que era \\
que nem mãe dele né, ela pegou e falou, me dá aqui, meu filho acabou de se \\
formar, que era irmão do grande amigo do (nome do filho), vai ser a primeira causa \\
dele, ela conseguiu no (seguradora) com alguns casos que já tinham acontecido de \\
depressão, ela levou todo o histórico dele dos médicos, ela levou os remédios que \\
ele estava tomando, tudo, fez um processo. Demorou 2 anos \\
\end{tabular} \\
\hline Transcrição E2 revisada & COMPREENSÃO\Tabu (1)\O tabu em diversas esferas $\mid$ Seguro de vida|Dinheiro do seguro para um fundo de ajuda & \begin{tabular}{|l|} 
e ela sabia que eu não ia usar esse dinheiro... eu queria esse dinheiro não para \\
mim, eu queria deixar esse dinheiro num fundo pra ajudar as coisas.
\end{tabular} \\
\hline Transcrição E2 revisada & COMPREENSÃO\Tabu (1)\O tabu em diversas esferas|Seguro de vida\Entrando com processo para ter direito ao seguro de vida & $\begin{array}{l}\text { Ela conseguiu no * mas foi assim, uma briga, o da (nome de amiga) tinha e o } \\
\text { advogado não conseguiu. Etambém não quis brigar. Eu também não queria brigar } \\
\text { por isso. Eu tinha deixado. Faltavam } 5 \text { dias pra expirar o prazo, porque tem um ano } \\
\text { só pra entrar. Já tinha vindo uma negativa. Eu só comentei com ela que eu ia entrar } \\
\text { aí ela falou assim: "Me da aqui que eu entrego...." }\end{array}$ \\
\hline Transcrição E2 revisada & COMPREENSÃO\Tabu (1)\O tabu em diversas esferas\Seguro de vida\Pessoas que não conseguiram o seguro de vida & $\begin{array}{l}\text { o da (nome de amiga) tinha e o advogado não conseguiu. E também não quis } \\
\text { brigar. }\end{array}$ \\
\hline Transcrição E2 revisada & COMPREENSÃO\Experiência\O viver\Quem viveu (5)\Sendo bem cuidada (polícia e médicos)\Sendo bem tratada pela policia & $\begin{array}{l}\text { Eu queria só acrescentar que eu fiquei muito surpresa com o tratamento que eu } \\
\text { tive pela policia. }\end{array}$ \\
\hline Transcrição E2 revisada & COMPREENSÃO\Experiência\O viver\Quem viveu (5)\Sendo bem cuidada (polícia e médicos)\Esperando um tratamento hostil da policia & Eu não esperava né. Esperava realmente um tratamento meio hostil \\
\hline Transcrição E2 revisada & COMPREENSÃO\Experiência\O viver|Quem viveu (5)\Sendo bem cuidada (polícia e médicos)\Sendo bem tratada pela policia & $\begin{array}{l}\text { les não foram em nenhum momento. Desde a delegada, todos que foram... os } \\
\text { peritos, todos eles foram tão acolhedores que eu precisei voltar depois pra } \\
\text { agradecer, sabe? }\end{array}$ \\
\hline Transcrição E2 revisada & COMPREENSÃO\Experiência|O viver|Quem viveu (5)\Sendo bem cuidada (polícia e médicos)\Delegada dando acolhimento & $\begin{array}{l}\text { Eu estava em frangalhos, eu não conseguia nem se manter em pé e a delegada } \\
\text { conversou muito comigo, me acalmou e eu perguntei para ela se ela poderia falar } \\
\text { essas mesmas palavras para o meu marido. Ela saiu da delegacia, foi até ele e falou } \\
\text { tudo aquilo com uma calma, uma mansidão, }\end{array}$ \\
\hline Transcrição E2 revisada & COMPREENSÃO\Experiência\O viver\Quem viveu (5)\Sendo bem cuidada (polícia e médicos)\Sendo bem tratada pela policia & \begin{tabular}{|l|} 
e todos eles de um respeito que eu fiquei muito surpresa e aí eu tive que \\
desconstruir toda a imagem negativa que eu tinha da polícia naquele momento....
\end{tabular} \\
\hline Transcrição E2 revisada & COMPREENSÃO\Experiência\O viver\Quem viveu (5)\Sendo bem cuidada (polícia e médicos)\Descontruindo a imagem negativa da policia & $\begin{array}{l}\text { e aí eu tive que desconstruir toda a imagem negativa que eu tinha da polícia } \\
\text { naquele momento.... }\end{array}$ \\
\hline Transcrição E2 revisada & COMPREENSÃO\Experiência|O viver|Quem viveu (5)\Sendo bem cuidada (polícia e médicos)\Delegada dando acolhimento & $\begin{array}{l}\text { Para mim foi também a mesma coisa. Foi uma delegada, era bem mocinha ela, uns } \\
30 \text { e poucos anos, me tratou assim, uma maravilha, nossa, foi uma das pessoas que } \\
\text { mais me consolou. Foi assim maravilhoso. }\end{array}$ \\
\hline Transcrição E2 revisada & COMPREENSÃO\Experiência\O viver|Quem viveu (5)\Sendo bem cuidada (polícia e médicos)\Sendo bem tratada pela policia & $\begin{array}{l}\text { Para mim foi também a mesma coisa. Foi uma delegada, era bem mocinha ela, uns } \\
30 \text { e poucos anos, me tratou assim, uma maravilha, nossa, foi uma das pessoas que } \\
\text { mais me consolou. Foi assim maravilhoso. }\end{array}$ \\
\hline Transcrição E2 revisada & COMPREENSÃO\Experiência\O viver\Quem viveu (5)\Sendo bem cuidada (polícia e médicos)\Achando difícil ter muitos policiais acolhedo & Quer dizer, são raros mas existem né enfim, \\
\hline Transcrição E2 revisada & AÇÃO|Cuidar|Sobre os encontros (25)\Gente, a gente vai precisar parar... & Gente, a gente vai precisar parar... \\
\hline Transcrição E2 revisada & AÇÃO|Semear|Sugestão de entrevistar pessoas que tentaram (16) & $\begin{array}{l}\text { Eu acho que esse estudo teria que perguntar também para as pessoas que } \\
\text { tentaram, tudo isso porque eu acho que ele tem respostas de uma perspectiva } \\
\text { bem, talvez, assertiva, né, com relação a muitos dos pontos. }\end{array}$ \\
\hline Transcrição E2 revisada & COMPREENSÃO|Comunicação|Social|Aumento da comunicação|Mídia incluindo os sobreviventes\Informando sobre um programa que & $\begin{array}{l}\text { Eu tenho um informe a dar, um informe a dar. É...eu.... fui entrevistado pela (nome } \\
\text { de canal de televisão) essa semana, eles foram lá em casa né. Eles fizeram vários } \\
\text { registros, tal e disseram que é o programa (nome do programa) de toda (data e } \\
\text { horário do programa). Dura } 50 \text { min. (nome de canal de televisão e nome do } \\
\text { programa). Vai ser provavelmente na (dia da semana) feira dia * sem ser a } \\
\text { próxima, a outra. }\end{array}$ \\
\hline
\end{tabular}




\begin{tabular}{|c|c|c|}
\hline Transcrição E2 revisada & AÇÃO|Fazer|Outros tipos de trabalho (24)\Planos de saúde\Implantar prevenção em planos de saúde & $\begin{array}{l}\text { Só uma observação, você falou de locais para atuar, eu tive uma ideia, assim, } \\
\text { pensando no lado de administração, assim por exemplo, os planos de saúde eu já } \\
\text { participei, tem programas de prevenção, cardíaco, tal, e sim, muitas vezes } \\
\text { infelizmente não é por uma consciência, uma conscientização mas é por causa dos } \\
\text { custos, mas até por isso, talvez, a partir de alguns dados possa se implantar dentro } \\
\text { do programa de saúde, um programa de prevenção nessa linha, né? }\end{array}$ \\
\hline Transcrição E2 revisada & AÇÃO|Fazer|Outros tipos de trabalho (24)\Planos de saúde\Interesse dos planos de saúde nos custos & $\begin{array}{l}\text { em programas de prevenção, cardíaco, tal, e sim, muitas vezes infelizmente não é } \\
\text { por uma consciência, uma conscientização mas é por causa dos custos, mas até por } \\
\text { isso, talvez, a partir de alguns dados possa se implantar dentro do programa de } \\
\text { saúde }\end{array}$ \\
\hline Transcrição E2 revisada & AÇÃO\Cuidar|Sobre os encontros (25)\Agradecendo por participarem do trabalho & Karen acho que nós todos aqui estamos agradecidos com esse trabalho \\
\hline Transcrição E2 revisada & AÇÃO|Cuidar|Sobre os encontros (25)\Agradecendo por participarem do trabalho & É o mínimo, imagina, você também nos acolhe. \\
\hline Transcrição E2 revisada & AÇÃO|Cuidar|Sobre os encontros (25)\Agradecendo por participarem do trabalho & $\begin{array}{l}\begin{array}{l}\text { Nós estamos aqui porque temos uma causa, você está.. tudo bem, você é } \\
\text { profissional, mas é para ajudar, então, para evitar, então nós que agradecemos. }\end{array} \\
\end{array}$ \\
\hline Transcrição E2 revisada & AÇÃO|Cuidar|Sobre os encontros (25)\Agradecendo por participarem do trabalho & Desabafar é uma coisa que ajuda muito. \\
\hline Transcrição E2 revisada & AÇÃO|Cuidar|Sobre os encontros (25)\Sentindo-se bem ao desabafar & Desabafar é uma coisa que ajuda muito. \\
\hline $\begin{array}{l}\text { Transcrição E1 } \\
\text { revisada_para maxqda }\end{array}$ & COMPREENSÃO\Tabu (1)\Consequências do Tabu & $\begin{array}{l}\text { A internet mesmo a gente vê, pessoas que se suicidam, o funcionário chega mais } \\
\text { cedo na empresa, vê, tira foto, posta e daqui a pouco aquilo se espalha de uma tal } \\
\text { maneira e todo mundo vê, então eu vejo que o problema é a questão do tabu, é o } \\
\text { preconceito né?! }\end{array}$ \\
\hline \begin{tabular}{|l} 
Transcrição E1 \\
revisada_para maxqda
\end{tabular} & COMPREENSÃo|Visão|Visão da Sociedade (2)\Causas do suicídio|Suicídio e orgulho & Orgulho... \\
\hline Transcrição E2 revisada & COMPREENSÃO\Comunicação|Social|Possiveis Causas para o Aumento & o que tem de palestra em que a moda do tema é falar sobre o suicídio \\
\hline Transcrição E2 revisada & COMPREENSÃO|Comunicação|Social|Canais virtuais|Redes sociais & e tem as redes sociais... \\
\hline Transcrição E2 revisada & COMPREENSÃO\Experiência\O viver|Quem não viveu (6)\Suicídio como espetáculo & $\begin{array}{l}\text { eu também uma vez estava num almoço com outras pessoas da empresa e falaram } \\
\text { que acho que alguém do prédio do lado tentou, sabe uma coisa assim? "E tipo eles } \\
\text { falaram "Ah! Nossa, que coisa engraçada, tipo, por que não se joga, mesmo". }\end{array}$ \\
\hline Transcrição E2 revisada & COMPREENSÃO\Experiência\O viver|Quem não viveu (6)\Suicídio como espetáculo & $\begin{array}{l}\text { Aí tem uma foto do empresário que filmaram de manhã, que os empregados } \\
\text { chegaram, e ele tinha... }\end{array}$ \\
\hline $\begin{array}{l}\text { Transcrição E1 } \\
\text { revisada_para maxqda }\end{array}$ & COMPREENSÃo|Visão|Visão da Sociedade (2)\Depressão|Tabu e depressão & não é isso, então... então, o problema tá nisso, no tabu, é depressão. \\
\hline $\begin{array}{l}\text { Transcrição E1 } \\
\text { revisada_para maxqda }\end{array}$ & AÇÃO\Diálogo\O falar (23)\O que (MENSAGEM)\Depressão - A mensagem & $\begin{array}{l}\text { acho que ainda as pessoas ficam têm essa coisa de "não vai acontecer comigo } \\
\text { porque eu estou bem, minha vida é ótima", e então mais a vida pode ser ótima e } \\
\text { pode acontecer, é isso! }\end{array}$ \\
\hline Transcrição E2 revisada & AÇÃO\Campanhas (22)|Setembro amarelo & $\begin{array}{l}\text { Então ele já começou a fazer isso, e assim, começam os movimentos né, é, estão } \\
\text { começando e foi muito assim, difícil, porque a gente participou muito então a } \\
\text { gente acaba, nosso dever público é tão bom que você acaba engajado né, mas eu } \\
\text { acho que esse também vai ser, assim, já começou né.. }\end{array}$ \\
\hline Transcrição E2 revisada & AÇÃOICampanhas (22) \Alcance & $\begin{array}{l}\text { Isso, se a gente procura a gente acha coisa e acha coisa muito interessante, agora, } \\
\text { não é uma coisa que chega em você. } V\end{array}$ \\
\hline Transcrição E2 revisada & AÇÃO\Campanhas (22)\Alcance & $\begin{array}{l}\text { assim, aquele repórter da Globo, o André Trigueiro... ele tem uma palestra desde } \\
\text { 2012, que eu vi, outro dia eu fui numa palestra dele, que ele veio em São Paulo, foi } \\
\text { ótimo, mas ele tem, desde } 2012 \text { que ele fala sobre o tema e eu não sabia, quer } \\
\text { dizer, foi pesquisando na internet, você vê, uma pessoa da globo e ninguém } \\
\text { comenta nada, e ninguém faz isso fora o André Trigueiro. Uma palestra excelente } \\
\text { dele. }\end{array}$ \\
\hline $\begin{array}{l}\text { Transcrição E1 } \\
\text { revisada_para maxqda }\end{array}$ & AÇÃO\Diálogo|O falar (23)\Quem \De um par & mas vai ter gente que vai pensar mais vezes... \\
\hline
\end{tabular}

Material integrante da pesquisa de doutorado de Karen Scavacini - USP Proibida a reprodução ou utilização sem autorização do autor - 2018 


\begin{tabular}{|c|c|c|}
\hline $\begin{array}{l}\text { Transcrição E1 } \\
\text { revisada_para maxqda }\end{array}$ & COMPREENSÃO\Comunicação\Pessoal|Reações\Não falar como respeito a dor & $\begin{array}{l}\text { Elas sabem a gravidade do assunto ... tem dificuldade em falar, que eles sabem } \\
\text { que aquilo é tão doloroso pra quem tá passando, e ela não imagina que aquilo } \\
\text { possa chegar até ela de tão doloroso que é, então as pessoas evitam de falar, } \\
\text { porque não tem o que falar e sabem o quanto é doloroso, eu já entendo diferente } \\
\text { aqui de todo mundo, eu acho que não falam porque, por pena, e porque sabem o } \\
\text { quanto aquilo é doloroso. }\end{array}$ \\
\hline $\begin{array}{l}\text { Transcrição E1 } \\
\text { revisada_para maxqda }\end{array}$ & COMPREENSÃO|Comunicação|Social|Aumento da comunicação & vocês estão falando que hoje já se fala mais do que falava antes! \\
\hline $\begin{array}{l}\text { Transcrição E1 } \\
\text { revisada_para maxqda }\end{array}$ & COMPREENSÃO\Experiência\O viver\Quem viveu (5)\Antes do suicídio\Suicídio como ficção & \begin{tabular}{|l|}
$\begin{array}{l}\text { Então você vê um filme você fala "é uma ficção, não existe na vida real, comigo } \\
\text { jamais vai acontecer" }\end{array}$ \\
\end{tabular} \\
\hline $\begin{array}{l}\text { Transcrição E1 } \\
\text { revisada_para maxqda }\end{array}$ & COMPREENSÃO|Comunicação|Pessoal|Falar pode machucar (a si mesmo) & $\begin{array}{l}\text { por ser uma coisa que parece que as pessoas querem achar um culpado, querem } \\
\text { achar um motivo, tem que ter uma razão né, então quanto mais você fala, mais } \\
\text { vão te cutucar, mais vão te machucar, mais vão né, as vezes sem querer mesmo né, } \\
\text { mas acabam te deixando mal. }\end{array}$ \\
\hline \begin{tabular}{|l|} 
Transcrição E1 \\
revisada_para maxqda
\end{tabular} & COMPREENSÃO\Tabu (1)\Consequências do Tabu\O não falar|Não ter que falar & $\begin{array}{l}\text { quando você tem a oportunidade de falar né, as pessoas já cortam logo o assunto } \\
\text { pra não ter que falar... }\end{array}$ \\
\hline \begin{tabular}{|l|l} 
\\
Transcrição E1 \\
revisada_para maxqda
\end{tabular} & AÇÃO\Campanhas (22)\Outras cores & $\begin{array}{l}\text { eu creio que isso tá aumentando e eu tenho esperança que isso seja tão comum } \\
\text { como hoje é falado da prevenção do câncer de mama, próstata, enfim... }\end{array}$ \\
\hline $\begin{array}{l}\text { Transcrição E1 } \\
\text { revisada_para maxqda }\end{array}$ & |CONSCIENTIZAÇÃ̃O|Desafios\Impeditivos (18)\Necessidade de profissionais capacitados (Capacitação) & mas tem profissionais capacitados, é o outro lado né que tá... \\
\hline \begin{tabular}{|l|} 
Roteiro de \\
perguntas_eduardo_maxqd \\
a
\end{tabular} & COMPREENSÃolVisãolVisão da Sociedade (2)\Visão do suicídio hoje no brasil & $\begin{array}{l}\text { De forma geral acho que o suicídio é visto com muito preconceito, e como casos } \\
\text { isolados e não na proporção que realmente acontecem }\end{array}$ \\
\hline \begin{tabular}{|l|} 
Roteiro de \\
perguntas_eduardo_maxqd \\
a
\end{tabular} & COMPREENSÃO\Tabu (1)\O tabu está no suicídio & $\begin{array}{l}\text { acredito que é uma das facetas mais difíceis do tema relacionado ao morte, luto e } \\
\text { tristeza }\end{array}$ \\
\hline \begin{tabular}{|l|} 
Roteiro de \\
perguntas_eduardo_maxqd \\
a
\end{tabular} & COMPREENSÃO\Tabu (1)\Atitudes que reforçam o tabu\Utopias\Exclusão da tristeza & $\begin{array}{l}\text { Acredito que a origem disso vem da visão equivocada de que felicidade é ausência } \\
\text { de tristeza, perdas e luto. Como consequência todos essas emoções são reprimidas } \\
\text { e se tornam um tabu. }\end{array}$ \\
\hline \begin{tabular}{|l|} 
Roteiro de \\
perguntas_eduardo_maxqd \\
a
\end{tabular} & COMPREENSÃO\Tabu (1)\Atitudes que reforçam o tabu\Aonde o tabu começa & $\begin{array}{l}\text { Com a crença de que falar no assunto relacionado a morte, suicídio ou doenças, } \\
\text { "atraem" o fato. Evitar falar no assunto é como se fosse uma forma de evitar que } \\
\text { isso exista ou aconteça. }\end{array}$ \\
\hline $\begin{array}{l}z \text { Roteiro de } \\
\text { perguntas_eduardo_maxqd } \\
\text { a }\end{array}$ & CONSCIENTIZAÇÃO\Consciência\Aumento da Consciência (19) & $\begin{array}{l}\text { Acho muito importante, pois a minha impressão sobre o tema é de que a grande } \\
\text { maioria das pessoas só entra em contato com o assunto depois de ter passado por } \\
\text { uma perda de alguém próximo. Através da conscientização percebo que a } \\
\text { prevenção seria possivel, já que é nas relações e nos vínculos entre as pessoas que } \\
\text { temos a possibilidade de prevenir. }\end{array}$ \\
\hline $\begin{array}{l}z \text { Roteiro de } \\
\text { perguntas_eduardo_maxqd } \\
\text { a }\end{array}$ & CONSCIENTIZAÇÃO|Consciência\Aumento da Consciência (19)|Prevenção|Formas & $\begin{array}{l}\text { Depende do publico direcionado e da forma como o assunto é abordado. Para } \\
\text { grupos diferentes é acredito que é necessária uma abordagem especifica. Para } \\
\text { profissionais da área de saúde, de psicologia e psiquiatria, uma abordagem mais } \\
\text { direta com todas as informações disponiveis e um diálogo aberto e franco. Para o } \\
\text { publico leigo em geral é necessária uma abordagem diferente e que leve em conta } \\
\text { o tabu e que cria resistência, e pode criar até em alguns casos aversão ao tema. } \\
\text { Pude observar isso, através de experiências pessoais, e pelos depoimentos que } \\
\text { tenho ouvido de pessoas enlutadas por suicídio. }\end{array}$ \\
\hline $\begin{array}{l}z \text { Roteiro de } \\
\text { perguntas_eduardo_maxqd } \\
\text { a }\end{array}$ & CONSCIENTIZAÇÃO|Consciência\Aumento da Consciência (19))Prevenção|Formas & $\begin{array}{l}\text { Primeiro como algo que não é distante. A minha própria experiência e pelo } \\
\text { compartilhar de outras pessoas que também passaram por suicídio de alguém } \\
\text { próximo, é de que até aquele momento, o suicídio era um assunto distante. Que } \\
\text { nunca aconteceria com alguém próximo. }\end{array}$ \\
\hline
\end{tabular}

Material integrante da pesquisa de doutorado de Karen Scavacini - USP Proibida a reprodução ou utilização sem autorização do autor - 2018 


\begin{tabular}{|c|c|c|}
\hline $\begin{array}{l}z \text { Roteiro de } \\
\text { perguntas_eduardo_maxqd } \\
\text { a }\end{array}$ & COMPREENSÃO\Tabu (1)\Consequências do Tabu\Afastamento & $\begin{array}{l}\text { Acho que estamos despreparados de forma geral para reconhecer os elementos } \\
\text { que podem levar ao suicídio nos aspectos que fazem parte da vida de qualquer } \\
\text { pessoa. Sim, existem os casos em que ele é decorrência de um transtorno mental } \\
\text { mais severo. Mas de forma geral acho que esta ideia afasta o tema das pessoas. A } \\
\text { associação apenas com estes casos, faz com que em primeiro momento nem se } \\
\text { queira falar no assunto pois significaria que a pessoa tem nela ou em alguém } \\
\text { próximo um transtorno mais grave. }\end{array}$ \\
\hline $\begin{array}{l}\text { z Roteiro de } \\
\text { perguntas_eduardo_maxqd } \\
\text { a }\end{array}$ & AÇÃO\Diálogo\O falar (23)\O que (MENSAGEM)\Temas & $\begin{array}{l}\text { Mas pelo que vi, todas as pessoas podem ter num certo grau, elementos que a } \\
\text { colocam num grupo de risco e que a coincidência de fatores e eventos da vida } \\
\text { podem se somar para que a pessoa chegue ao ato do suicídio. Esta percepção de } \\
\text { que isto pode acontecer com qualquer pessoa, e dentro de qualquer família, } \\
\text { aproxima o tema. Pode trazer o interesse para a prevenção e para o diálogo sobre } \\
\text { o assunto. }\end{array}$ \\
\hline $\begin{array}{l}z \text { Roteiro de } \\
\text { perguntas_eduardo_maxqd } \\
\text { a }\end{array}$ & COMPREENSÃO\Tabu (1)\Consequências do Tabu\O não falar & $\begin{array}{l}\text { Ainda assim, vejo a barreira do preconceito sobre o que comumente são chamados } \\
\text { de assuntos "negativos", como suicídio, morte, doenças. Isto também cria uma } \\
\text { repulsa da discussão e do diálogo sobre o tema. }\end{array}$ \\
\hline $\begin{array}{l}z \text { Roteiro de } \\
\text { perguntas_eduardo_maxqd } \\
\text { a }\end{array}$ & COMPREENSÃO\Comunicação\Pessoal & $\begin{array}{l}\text { Na ocasião do Setembro amarelo passado em } 2016 \text {, eu estava trabalhando como } \\
\text { voluntário do CVV. É com tristeza que relato que não encontrei abertura para falar } \\
\text { da campanha com ninguém da família e com a maioria dos amigos mais próximos. }\end{array}$ \\
\hline $\begin{array}{l}z \text { Roteiro de } \\
\text { perguntas_eduardo_maxqd } \\
\text { a }\end{array}$ & COMPREENSÃOIComunicação|Pessoal & $\begin{array}{l}\text { Nas pessoas mais próximas, não consigo ainda hoje entrar no tema do suicídio sem } \\
\text { notar um impacto de estranhamento e desconforto nas pessoas }\end{array}$ \\
\hline $\begin{array}{l}z \text { Roteiro de } \\
\text { perguntas_eduardo_maxqd } \\
\text { a }\end{array}$ & COMPREENSÃO\Comunicação|Pessoal|Conversando com amigos & $\begin{array}{l}\text { Nas pessoas mais próximas, não consigo ainda hoje entrar no tema do suicídio sem } \\
\text { notar um impacto de estranhamento e desconforto nas pessoas. Falar no tema é } \\
\text { encarado como mau agouro, ou então percebo o preconceito na causa e até um } \\
\text { afastamento e perda de alguns vínculos de amizade. Alguns mais descontraídos } \\
\text { brincam sobre ser um assunto negro, e apesar de ser de forma mais educada, } \\
\text { desviam-se do tema. }\end{array}$ \\
\hline $\begin{array}{l}z \text { Roteiro de } \\
\text { perguntas_eduardo_maxqd } \\
\text { a }\end{array}$ & COMPREENSÃO|Comunicação|Pessoal|Falando abertamente na família & $\begin{array}{l}\text { Tive apenas uma pessoa da familia que achou interessante e quis saber um pouco } \\
\text { mais sobre o tema }\end{array}$ \\
\hline $\begin{array}{l}z \text { Roteiro de } \\
\text { perguntas_eduardo_maxqd } \\
\text { a }\end{array}$ & COMPREENSÃO\Tabu (1)\Consequências do Tabu\Afastamento & $\begin{array}{l}\text { Mas de forma geral, o fato de eu tocar no assunto sendo apenas leigo, faz com que } \\
\text { algumas pessoas me olhem como se eu fosse um problema. Muitas acabam } \\
\text { reagindo ou se afastando. }\end{array}$ \\
\hline $\begin{array}{l}z \text { Roteiro de } \\
\text { perguntas_eduardo_maxqd } \\
\text { a }\end{array}$ & AÇÃO\Campanhas (22)\Temas|Divulgar o CVV & $\begin{array}{l}\text { Lembro de uma campanha de tevê muito antiga do CVV, aonde um homem pede } \\
\text { dinheiro na rua, e ao receber uma moeda entra num bar. Tudo dá a entender que } \\
\text { ele vai comprar bebida alcoólica. Mas ele compra uma ficha e vai a um telefone } \\
\text { publico dentro do bar e efetua uma ligação. Do outro lado da linha uma voz diz: } \\
\text { "CVV boa noite", e eles começam a conversar. Esta campanha antiga, me marcou a } \\
\text { respeito da imagem do CVV e que seria um lugar aonde se pode conversar. Acho } \\
\text { uma campanha extremamente positiva e que nos aproxima. A ideia de que ao } \\
\text { passar uma situação difíiil, o CVV é um lugar aonde se pode conversar e ser } \\
\text { ouvido. Acho que a campanha vai exatamente no ponto que é necessário a } \\
\text { respeito do assunto. Abordando de forma prática um canal para o diálogo e a } \\
\text { empatia, e que estaria disponível para todos. }\end{array}$ \\
\hline $\begin{array}{l}z \text { Roteiro de } \\
\text { perguntas_eduardo_maxqd } \\
\text { a }\end{array}$ & AÇÃO\Campanhas (22)\Cuidados & $\begin{array}{l}\text { Hoje questiono a abordagem do impacto dos números do suicídio, e falar de forma } \\
\text { chocante sobre a morte para todos os grupos. Para o público em geral no Brasil, } \\
\text { que tem um grande preconceito com o tabu e o preconceito com a morte, acho } \\
\text { que pode reforçar uma postura de fechamento e retração. }\end{array}$ \\
\hline
\end{tabular}

Material integrante da pesquisa de doutorado de Karen Scavacini - USP Proibida a reprodução ou utilização sem autorização do autor - 2018 


\begin{tabular}{|c|c|c|}
\hline $\begin{array}{l}z \text { Roteiro de } \\
\text { perguntas_eduardo_maxqd } \\
\text { a }\end{array}$ & AÇÃO\DiálogolO falar (23)\O que (MENSAGEM)\Temas\Criar empatia|Empatia & $\begin{array}{l}\text { Mas para o público em geral, acho que é necessária uma abordagem diferente, } \\
\text { elaborada em conjunto com profissionais da área, levando em conta que nossa } \\
\text { cultura tem hoje uma aversão aos temas ligados a morte, e a depressão. Acho que } \\
\text { uma campanha que foca na empatia em momentos de tristeza, que são comuns a } \\
\text { qualquer pessoa, teria um impacto positivo e uma aceitação maior. }\end{array}$ \\
\hline $\begin{array}{l}z \text { Roteiro de } \\
\text { perguntas_eduardo_maxqd } \\
\text { a }\end{array}$ & AÇÃo\DiálogolO falar (23)\Quem & $\begin{array}{l}\text { Refletindo bastante, acredito que a conscientização no Brasil, ainda requer uma } \\
\text { abordagem totalmente diferente para o público. A abordagem que hoje tenho } \\
\text { visto sobre o tema do suicídio, acho extremamente adequada para profissionais da } \\
\text { área ou para pessoas que já tem uma abertura e interesse no tema. Seja por } \\
\text { motivos profissionais ou pessoais (quando viveram algum caso próximo). Para este } \\
\text { grupo, informações mais detalhadas que incluem estatísticas e dados mais } \\
\text { específicos considero extremamente úteis. }\end{array}$ \\
\hline $\begin{array}{l}\text { z Roteiro de } \\
\text { perguntas_eduardo_maxqd } \\
\text { a }\end{array}$ & AÇÃO\Diálogo\O falar (23)\Quem & $\begin{array}{l}\text { Dividiria num primeiro momento a abordagem em três grupos: } 1 \text { - Com } \\
\text { profissionais da área, uma abordagem direta com estatísticas e com pesquisas } \\
\text { sobre o tema. } 2 \text { - Para enlutados e sobreviventes do suicídio, uma abordagem de } \\
\text { acolhimento como o que tenho observado no Vita Alere. Friso por exemplo que } \\
\text { observo, o como a informação de que } 9 \text { entre } 10 \text { suicídios podem ser prevenidos, } \\
\text { acentua para algumas pessoas enlutadas, um sentimento de culpa. } 3 \text { - Para o } \\
\text { publico em geral, acho que o tema do diálogo e da empatia nos momentos difíceis } \\
\text { que todos nós passamos, teria uma eficácia muito grande na prevenção. Dentro da } \\
\text { família, no trabalho, nas amizades e nos relacionamentos de casal. O que acho que } \\
\text { nos impede de falar sobre o tema é de forma geral, algo que está na cultura } \\
\text { brasileira, que tem muito forte a ideia de ser um país da alegria, da festa. Acho que } \\
\text { isto cria uma sombra, e reprime aspectos naturais da tristeza e das perdas que } \\
\text { todos nós passamos. Observo que parte da nossa etnia, vem dos portugueses e } \\
\text { curiosamente soube que Portugal é a terra aonde se tem uma certa apreciação } \\
\text { pela tristeza ou melancolia (joy in sadness). O fado, uma musica tradicional } \\
\text { portuguesa, é uma música que traduz isso. Talvez sejamos o outro lado da mesma } \\
\text { moeda. }\end{array}$ \\
\hline $\begin{array}{l}\text { z Roteiro de } \\
\text { perguntas_eduardo_maxqd } \\
\text { a }\end{array}$ & AÇÃo\Diálogo\O falar (23)\O que (MENSAGEM)\Temas & $\begin{array}{l}\text { Acho que seria interessante ter como foco num primeiro momento nos suicídios } \\
\text { que ocorrem da somatória de pequenos fatores, e que todos estamos expostos. } \\
\text { Trazer o tema de que as tristezas e perdas cotidianas, quando não elaboradas e } \\
\text { quando não encontramos espaço para poder dialogar sobre elas com as pessoas } \\
\text { próximas, podem se somar e levar até ao suicídio. Mas focar mais nas atitudes } \\
\text { preventivas, que seriam empatia, diálogo, aprender a lidar com as perdas. Evitar } \\
\text { uma abordagem muito direta dos temas mais tabus. }\end{array}$ \\
\hline $\begin{array}{l}\text { z Roteiro de } \\
\text { perguntas_eduardo_maxqd } \\
\text { a }\end{array}$ & AÇÃO\DiálogolO falar (23)\Onde & $\begin{array}{l}\text { Falar sobre a empatia e o diálogo, a aceitação da tristeza e seu papel pode ocorrer } \\
\text { dentro de vários locais. Dentro da escola, na família, no trabalho, dentro de grupos } \\
\text { religiosos. Informações mais diretas sobre o tema suicídio e o que está } \\
\text { diretamente relacionado (morte, luto, doenças terminais, depressão), dentro de } \\
\text { grupos específicos de profissionais de saúde (Psicologia, psiquiatria, medicina, } \\
\text { enfermagem). }\end{array}$ \\
\hline
\end{tabular}




\begin{tabular}{|c|c|c|}
\hline $\begin{array}{l}z \text { Roteiro de } \\
\text { perguntas_eduardo_maxqd } \\
\text { a }\end{array}$ & AÇÃO\Diálogo\O falar (23)\Como (FORMA) & \begin{tabular}{|l|} 
Iniciaria a discussão com profissionais de saúde, enlutados e sobreviventes. A \\
partir desta visão geral elegeria as principais causas e quais os fatores que podem \\
ajudar na prevenção. Nesta discussão também incluiria profissionais da área de \\
comunicação. Para a elaboração das aç̃̃es necessárias, vejo que além da área de \\
saúde, estamos falando de comunicação. Para profissionais da área, uma \\
abordagem mais profunda e técnica sobre o assunto. Para enlutados, informações \\
sobre como elaborar o luto e trabalhar a culpa. Bem como dar alternativas e \\
informações de suporte (CVV, grupos de sobreviventes, terapeutas), além de como \\
uma pessoa que não tem acesso a estas formas de suporte (seja pela localidade, ou \\
por condições financeiras), pode criar seu próprio grupo de apoio através da \\
família, amigos, religião. Para o público em geral, teria uma abordagem a partir \\
da empatia nos momentos difíceis. Talvez o espírto mais acolhedor e fraterno \\
brasileiro seja receptivo a temas como solidariedade e empatia, e que pode ser \\
uma forma prática de agir na prevenção. Campanhas que promovam o diálogo e a \\
solidariedade em momentos difíceis, acredito que teriam uma aceitação melhor do \\
que campanhas que falem diretamente do suicídio, morte e luto. Abordar algumas \\
causas como bullying, rompimentos afetivos, perda de trabalho, dificuldades \\
financeiras, problemas de saúde, sob a ótica de que a empatia e o diálogo nestes \\
momentos, pode ter uma eficácia maior. Os profissionais da área saberiam que \\
estão atuando dentro do tema do suicídio, mas o público em geral creio que seja \\
mais receptivo a uma abordagem indireta. Acho que os efeitos a longo prazo \\
seriam mais duradouros.
\end{tabular} \\
\hline $\begin{array}{l}z \text { Roteiro de } \\
\text { perguntas_eduardo_maxqd } \\
\text { a }\end{array}$ & CONSCIENTIZAÇÃO|Consciência|Aumento da Consciência (19) & $\begin{array}{l}\text { P: Vocês acham que a consciência publica influencia a consciência individual, de } \\
\text { que forma? } \\
\text { R: Acho que elas se influenciam mutuamente. Estão interligadas. }\end{array}$ \\
\hline $\begin{array}{l}z \text { Roteiro de } \\
\text { perguntas_eduardo_maxqd } \\
\text { a }\end{array}$ & CONSCIENTIZAÇÃo|Consciência|Aumento da Consciência (19)|Prevenção & $\begin{array}{l}\text { P: Vocês acham que a falta de consciência pública pode ter influenciado o suicídio } \\
\text { da pessoa que perderam? } \\
\text { R: Sim, alguns no caso da pessoa que perdi, a exclusão social, bullying, acredito que } \\
\text { teve uma influência direta. Naquele momento, não havia uma discussão sobre } \\
\text { estes assuntos publicamente como há hoje. }\end{array}$ \\
\hline $\begin{array}{l}\text { z Roteiro de } \\
\text { perguntas_eduardo_maxqd } \\
\text { a }\end{array}$ & COMPREENSÃO|Comunicação|Pessoal & $\begin{array}{l}\text { Para mim, é um tema importante e que requer uma ação imediata, mas que apesar } \\
\text { da gravidade e da urgência, não encontro muitas oportunidades e pessoas com } \\
\text { quem conversar a respeito. }\end{array}$ \\
\hline $\begin{array}{l}z \text { Roteiro de } \\
\text { perguntas_eduardo_maxqd } \\
\text { a }\end{array}$ & COMPREENSÃO\Tabu (1)\Consequências do Tabu\Preconceito & $\begin{array}{l}\text { P: A forma como a sociedade e as pessoas encaram o suicídio te toca? R: } \\
\text { Bastante, pois sinto que há uma preconceito muito grande. Pois a visão atual só } \\
\text { tende a colaborar que isso continue ocorrendo. }\end{array}$ \\
\hline $\begin{array}{l}z \text { Roteiro de } \\
\text { perguntas_eduardo_maxqd } \\
\text { a }\end{array}$ & COMPREENSÃO\Tabu (1)\Consequências do Tabu\Preconceito & $\begin{array}{l}\text { Sim, passei por várias situações de falta de consciência sobre o suicídio. Desde a } \\
\text { pessoa que disse que "quem se suicida é um covarde", que soube depois que era } \\
\text { uma forma dela cortar o assunto, pois dentro de toda a família dela, falar em } \\
\text { morte e doenças graves, "atrai"... Palavras fortes e com muito julgamento, que } \\
\text { hoje entendo que foram uma forma de defesa da pessoa que disse. Uma } \\
\text { dificuldade da própria pessoa em lidar com o tema. Também ao me abrir com um } \\
\text { amigo, sobre meu processo de luto, sofri preconceito e afastamento, como se eu a } \\
\text { tristeza não fosse parte de um processo natural. Pois para ele, o estado de uma } \\
\text { pessoa saudável é de apenas alegria. }\end{array}$ \\
\hline $\begin{array}{l}\text { z Roteiro de } \\
\text { perguntas_eduardo_maxqd } \\
\text { a }\end{array}$ & COMPREENSÃO|Comunicação|Pessoal|Morreu de que & $\begin{array}{l}\text { Meu amigo se suicidou com um tiro na cabeça com um revolver do tio. Para mim, } \\
\text { hoje é mais natural, mas como não tive muitas oportunidades de falar no assunto } \\
\text { com quase ninguém, ainda sinto um certo estranhamento e uma certa dificuldade. }\end{array}$ \\
\hline
\end{tabular}




\begin{tabular}{|c|c|c|}
\hline \begin{tabular}{|l|} 
Roteiro de \\
perguntas_eduardo_maxqd \\
a
\end{tabular} & COMPREENSÃO\Comunicação|Pessoal\Dificuldades comunicação familiar & $\begin{array}{l}\text { Na família nunca, e em poucas tentativas não fui bem recebido. Muito raramente } \\
\text { com uns poucos amigos muito próximos. Geralmente apenas dentro de grupos de } \\
\text { sobreviventes ou ligando para o CVV. }\end{array}$ \\
\hline \begin{tabular}{|l|} 
Roteiro de \\
perguntas_eduardo_maxqd \\
\end{tabular} & COMPREENSÃO\ExperiêncialO viverlQuem viveu (5)\Entende & $\begin{array}{l}\text { A comunicação é mais fácil apenas quando a outra pessoa já passou por isso e } \\
\text { também está aberta a conversar sobre o tema. Com pessoas que não tiveram um } \\
\text { caso próximo, acho de forma geral muito difícil essa comunicação. }\end{array}$ \\
\hline $\begin{array}{l}z \text { Roteiro de } \\
\text { perguntas_eduardo_maxqd } \\
\text { a }\end{array}$ & COMPREENSÃO|Experiência\O viver|Quem viveu (5)\Depois do suicídio & $\begin{array}{l}\text { Sim, houve uma mudança muito grande após elaborar melhor o luto e conhecer } \\
\text { um pouco mais do assunto. Percebi que a falta de espaço para as pessoas } \\
\text { dialogarem sobre suas dificuldades cotidianas, suas tristezas e perdas e também } \\
\text { em muitos casos o fato da pessoa saber que não pode falar de algum assunto ou } \\
\text { problema que a aflige com as pessoas próximas, agrava seu sofrimento. } \\
\text { Participando do Vita Alere, a partir do compartilhamento e da possibilidade de me } \\
\text { abrir e acessar emoções guardadas, pude enfim, realizar meu processo de luto. } \\
\text { Dentro do grupo também percebi que alguns sentimentos como a culpa, e a } \\
\text { dificuldade de encontrar pessoas para dialogar, eram comuns a outros enlutados. } \\
\text { Ao trabalhar no CVV como voluntário, um outro tema que não citei e que era } \\
\text { muito recorrente na busca de apoio, era a solidão em diversas formas. As vezes } \\
\text { para uma pessoa idosa, ou aposentada porque a família se distanciou e porque a } \\
\text { pessoas não se sente mais inserida na sociedade através do trabalho, as vezes } \\
\text { porque uma doença mais séria a debilita e a impede de ter a liberdade em } \\
\text { atividades cotidianas. Outras vezes porque dentro de uma família há muitos } \\
\text { conflitos e discussões. Outras vezes porque dentro de um casal, um deles passa por } \\
\text { um problema que não pode compartilhar com o cônjuge e sofre porque não } \\
\text { consegue resolver sozinho, mas não pode pedir ajuda. Todos estes elementos } \\
\text { cotidianos podem gerar um sofrimento tão grande que podem levar uma pessoa } \\
\text { ao suicídio, num dia aonde muitos fatores se somam. }\end{array}$ \\
\hline $\begin{array}{l}z \text { Roteiro de } \\
\text { perguntas_eduardo_maxqd } \\
\text { a }\end{array}$ & COMPREENSÃO\Experiência\O viver \Quem viveu (5)\O que gostaria de ter tido & $\begin{array}{l}\text { Eu gostaria de ter tido mais informações sobre como lidar com a culpa, algo que } \\
\text { apenas recentemente através do Vita Alere, estou tendo. Gostaria de saber que o } \\
\text { suicídio é também em muitos casos uma somatória de fatores que todos nós } \\
\text { estamos expostos. Gostaria de ter tido uma educação emocional que incluísse a } \\
\text { tristeza, o luto e a perda como algo natural e saudável da vida. }\end{array}$ \\
\hline $\begin{array}{l}z \text { Roteiro de } \\
\text { perguntas_eduardo_maxqd } \\
\text { a }\end{array}$ & COMPREENSÃO\Experiência\O viverlQuem viveu (5)\O que gostaria de ter tido & $\begin{array}{l}\text { P: O que gostaria que tivesse disponível em termos de ajuda e/ou conhecimento } \\
\text { para você no luto e para pessoa que faleceu? } \\
\text { R: Gostaria de poder ter uma forma de que fosse possível encontrar pessoas que } \\
\text { tem abertura e disponibilidade para conversar sobre o assunto. Com relação ao } \\
\text { grupo de suporte, tem sido uma lugar de acolhimento importante em momentos } \\
\text { mais difíceis do processo. Sei que a viabilização é fruto da doação do trabalho e do } \\
\text { tempo de muitas pessoas, bem como a infraestrutura de espaço para os eventos } \\
\text { acontecerem. Gostaria de que outros espaços como o do Vita Alere estivessem } \\
\text { disponíveis para mais pessoas. Para a pessoa que faleceu, gostaria de que ela } \\
\text { tivesse encontrado ao seu redor mais oportunidades de compartilhar sua dor, suas } \\
\text { tristezas, de se abrir e ser bem recebido. Acredito que isso poderia ter evitado o } \\
\text { suicídio. }\end{array}$ \\
\hline $\begin{array}{l}z \text { Roteiro de } \\
\text { perguntas_eduardo_maxqd } \\
\text { a }\end{array}$ & AÇ̄̃olFazer|Outros tipos de trabalho (24)\Planos de saúde & $\begin{array}{l}\text { Talvez os planos de saúde possam ser um dos canais de entrada. Talvez, mostrando } \\
\text { que atividades de prevenção podem uma influência direta na saúde dos segurados } \\
\text { e por consequência na redução dos custos do plano. Indo por este caminho, } \\
\text { acredito que é possível uma abertura para um fator multiplicador de ações, com } \\
\text { recursos vindos dos próprios planos e com benefício para muitas pessoas }\end{array}$ \\
\hline
\end{tabular}




\begin{tabular}{|c|c|c|}
\hline $\begin{array}{l}\text { z Roteiro de } \\
\text { perguntas_eduardo_maxqd } \\
\text { a }\end{array}$ & AÇÃO\DiálogolO falar (23)\Como (FORMA)\Prevenir através de falar do cotidiano\Cotidiano & $\begin{array}{l}\text { Uma abordagem mais indireta para o público em geral, e mais direta para os } \\
\text { profissionais de saúde. Focar na comunicação e ações de prevenção diretamente } \\
\text { nas causas cotidianas, abordando assuntos que tem mais aceitação e menos } \\
\text { resistência por tabus. }\end{array}$ \\
\hline $\begin{array}{l}\text { z Roteiro de } \\
\text { perguntas_eduardo_maxqd } \\
\text { a }\end{array}$ & AÇ̧̃o|Diálogo\O falar (23)\O que (MENSAGEM)\Emoç̃̃es & $\begin{array}{l}\text { Abordar de que o sentimento de tristeza é natural e parte de uma vida emocional } \\
\text { saudável, e de que para vivenciar plenamente a alegria é preciso estar aberto a } \\
\text { todas as outras emoções. Enfim, uma educação emocional direcionada ao público } \\
\text { em geral, mas com o foco no diálogo e empatia entre as pessoas para acolhimento } \\
\text { nos momentos de adversidade. }\end{array}$ \\
\hline $\begin{array}{l}\text { z Roteiro de } \\
\text { perguntas_eduardo_maxqd } \\
\text { a }\end{array}$ & AÇÃO|DiálogolO falar (23)\O que (MENSAGEM)\Ensinar como agirlO acesso & $\begin{array}{l}\text { Tudo isso tendo como objetivo ações concretas para a prevenção do suicídio, } \\
\text { levando em conta as resistências e tabus que existem no Brasil. A partir do } \\
\text { momento que há uma abertura de alguém para falar sobre o tema, percebo que a } \\
\text { pergunta que surge a seguir é: "o que eu posso fazer por alguém?". Ao me fazer } \\
\text { esta pergunta muitas vezes, percebi que é num primeiro momento estar aberto } \\
\text { para ouvir o outro e acolher diante de uma dor que a pessoa passa. E saber até } \\
\text { aonde posso ir, e quando está além do meu alcance. Esta informação não está } \\
\text { disponivel para a maioria das pessoas e só consegui elaborar através da } \\
\text { participação dos grupos e do auxílio de profissionais. Gostaria que este } \\
\text { conhecimento em essência, pudesse ser traduzida numa forma de informação que } \\
\text { estivesse disponível para as pessoas em geral. }\end{array}$ \\
\hline $\begin{array}{l}\text { z Roteiro de } \\
\text { perguntas_eduardo_maxqd } \\
\text { a }\end{array}$ & AÇÃOlCuidar|Sobre os encontros (25) & $\begin{array}{l}\text { Me coloco a disposição para ajudar no que mais estiver ao meu alcance. Sobre as } \\
\text { respostas do questionário, fico a disposição para conversar por celular ou } \\
\text { pessoalmente. Agradeço muito todo o apoio e acolhimento que tenho recebido } \\
\text { através do trabalho do Vita Alere durante meu processo de elaboração do luto. } \\
\text { Tem sido um processo transformador poder colocar um pouco de luz num tema } \\
\text { que para mim foi tão difíiil por tanto tempo. Fico feliz em poder retribuir uma } \\
\text { fração de tudo o que recebi. }\end{array}$ \\
\hline Roteiro de perguntas TL & COMPREENSÃo|Visão|Visão da Sociedade (2)\Visão do suicídio hoje no brasil & $\begin{array}{l}\text { O tema suicídio ainda é assunto velado e carregado de preconceito. As discussões } \\
\text { ainda geram temor e a maioria das pessoas prefere não olhar para um problema } \\
\text { que afeta praticamente a todos. }\end{array}$ \\
\hline Roteiro de perguntas $\mathrm{TL}$ & COMPREENSÃO\Tabu (1)\Consequências do Tabu\O não falar & $\begin{array}{l}\text { Ainda é um assunto pouco discutido e muitas vezes evitado até por pessoas que } \\
\text { passaram por situação de suicídio na família. Muitas pessoas tem vergonha de ter } \\
\text { tentado ou mesmo de ter alguém na família que fez tentativa ou morreu por } \\
\text { suicídio. Geralmente o assunto fica velado, por temer o estigma, o julgamento, } \\
\text { enfim, o preconceito da sociedade. }\end{array}$ \\
\hline Roteiro de perguntas TL & COMPREENSÃO\Tabu (1)\O tabu em diversas esferas\Religião & $\begin{array}{l}\text { Acredito que esse tabu é decorrente de um processo social cultural atrelado a } \\
\text { dogmas religiosos, a partir da condenação ao pecado mortal a pessoa que comete } \\
\text { suicídio, estendendo as punições também à família. }\end{array}$ \\
\hline Roteiro de perguntas TL & COMPREENSÃo|Tabu (1)\Consequências do Tabu\Um assunto proibido & $\begin{array}{l}\text { Assim como tudo que nos causa sofrimento e medo, o suicídio foi ao longo do } \\
\text { tempo se tornando assunto proibido na sociedade. Tudo isso, contribuiu de forma } \\
\text { significativa para que o problema tomasse dimensão de uma epidemia. }\end{array}$ \\
\hline Roteiro de perguntas TL & COMPREENSÃO\Tabu (1)\Atitudes que reforçam o tabu\Aonde o tabu começa & $\begin{array}{l}\text { Na família, quando na tentativa de proteger o seu núcleo, os pais evitar comentar } \\
\text { sobre o assunto. Geralmente, assuntos de suicídio e morte são proibidos nas } \\
\text { discussões familiares. Nos nossos grupos sociais quando não se permite falar sobre } \\
\text { suicídio, porque é assunto pesado e normalmente as pessoas consideram que } \\
\text { naquele grupo não tem ninguém com ideação suicida. Na igreja, quando condena a } \\
\text { pessoa com comportamento suicídio ao pecado mortal. }\end{array}$ \\
\hline
\end{tabular}




\begin{tabular}{|c|c|c|}
\hline Roteiro de perguntas TL & CONSCIENTIZAÇÃOIConsciência\Aumento da Consciência (19) & $\begin{array}{l}\text { Importante e necessária. A falta de informação pode ser considerada como um } \\
\text { fator que contribui para o crescimento dos índices de tentativas e de mortes por } \\
\text { suicídio. Por falta de informação as pessoas deixam de tomar conhecimento sofre } \\
\text { os fatores de risco, sobre os sinais que uma pessoa com ideação suicida apresenta } \\
\text { e ainda sobre o que fazer quando alguém faz uma tentativa de suicídio, quais as } \\
\text { posturas corretas, como a família deve cuidar desta pessoa e principalmente onde } \\
\text { e como a família a deve buscar orientação. }\end{array}$ \\
\hline Roteiro de perguntas TL & CONSCIENTIZAÇÃO|Consciência|Aumento da Consciência (19)\Prevenção|Formas & $\begin{array}{l}\text { A conscientização deve ser feita de forma que contemple toda a população. O que } \\
\text { se percebe atualmente é que algumas pessoas já buscam informação, entretanto, } \\
\text { há que se preparar a sociedade para a discussão sobre o assunto, através de } \\
\text { estratégias que mostrem a importância da divulgação das campanhas de } \\
\text { prevenção e que o suicídio é um problema de saúde pública, é como tal, a } \\
\text { população precisa se envolver de forma consciente, como tem se envolvido em } \\
\text { outras campanha de promoção de saúde e prevenção de doenças. }\end{array}$ \\
\hline Roteiro de perguntas $\mathrm{TL}$ & CONSCIENTIZAÇÃO\Desafios\Impeditivos (18) & $\begin{array}{l}\text { Sim. Desde que de forma respeitosa e consciente, evitando o senso comum, } \\
\text { desmistificando os tabus e desconstruindo o preconceito em torno do tema. É } \\
\text { importante informar sobre as formas de prevenção, sobre os fatores de riscos, } \\
\text { sobre os fatores protetivos e sobre a importância de buscar ajuda. }\end{array}$ \\
\hline Roteiro de perguntas $\mathrm{TL}$ & CONSCIENTIZAÇÃO\Consciência\Aumento da Consciência (19)\Condição & $\begin{array}{l}\text { A possibilidade de discutir o assunto abre espaço para que as pessoas possam se } \\
\text { refletir sobre o tema. Posam mudar de postura. Possam se perceber e perceber o } \\
\text { outro. }\end{array}$ \\
\hline Roteiro de perguntas TL & AÇÃO\Semear\O que gostariam / Desejos (17) & $\begin{array}{l}\text { Gostaria que fosse tratado como um problema de saúde que potencialmente afeta } \\
\text { a população, independente da condição social. Gostaria que fosse tratado como } \\
\text { causa decorrente de doença, e não como um ato individual de coragem ou de } \\
\text { covardia. Gostaria que fosse tratado com humanidade, compreensão e respeito, no } \\
\text { sentido de que, se troque o julgamento pela reflexão do que cada pessoas pode } \\
\text { fazer a respeito, partindo do lugar comum para uma mudança de atitude. }\end{array}$ \\
\hline Roteiro de perguntas TL & AÇÃO\Campanhas (22)|Setembro amarelo & $\begin{array}{l}\text { R. Eu tomei conhecimento da Campanha Setembro Amarelo em 2015. Foi a } \\
\text { primeira vez que participei de um evento público. O impacto é positivo uma vez } \\
\text { que consegue sensibilizar um grande número de pessoas. }\end{array}$ \\
\hline Roteiro de perguntas TL & AÇÃO\Campanhas (22)|Setembro amarelo & $\begin{array}{l}\text { R. A Campanha Setembro Amarelo, em 2016, foi divulgada nos meios de } \\
\text { comunicação de massa e nas redes sociais. Muitas ações foram noticiadas nas } \\
\text { principais emissoras de televisão e rádio do país. }\end{array}$ \\
\hline Roteiro de perguntas TL & AÇÃO\Diálogo\O falar (23)\Onde & $\begin{array}{l}\text { Através de um programa regular de palestras, fóruns e seminários nas escolhas de } \\
\text { ensino fundamental, médio e nas universidades. Através da divulgação de } \\
\text { informações nos meios de comunicação. Através de peças e filmes que abordem o } \\
\text { assunto. }\end{array}$ \\
\hline Roteiro de perguntas TL & AÇÃO\Diálogo\O falar (23)\Como (FORMA) & $\begin{array}{l}\text { Podemos começar falando sobre prevenção do suicídio, sobre a relação do suicídio } \\
\text { com a saúde mental, sobre a importância de discutir o tema para que as pessoas } \\
\text { possam buscar ajuda, nos nosso grupos sociais mais próximos, na família, na igreja, } \\
\text { no trabalho. }\end{array}$ \\
\hline Roteiro de perguntas TL & AÇÃO\Diálogo\O falar (23)\Como (FORMA) & $\begin{array}{l}\text { Podemos falar quando alguém abordar o assunto de forma preconceituosa, ou } \\
\text { quando julga a pessoa que comete suicídio como um a pessoa "corajosa" ou } \\
\text { "covarde" ou mesmo uma pessoa que não tem amor pela vida e não pensa nos } \\
\text { familiares. Essas, são oportunidades particulares que podem ser aproveitadas para } \\
\text { conscientização. }\end{array}$ \\
\hline
\end{tabular}




\begin{tabular}{|c|c|c|}
\hline Roteiro de perguntas $\mathrm{TL}$ & AÇÃOlCampanhas (22)\Provedores ou Onde & $\begin{array}{l}\text { Seriam importantes campanhas de prevenção do suicídio veiculadas nos meios de } \\
\text { comunicação, promovida pelo Ministério da Saúde e pelas Secretarias de Saúde } \\
\text { dos estados, a exemplo de outras campanhas que são promovidas quando } \\
\text { identificas epidemias ou o avanço de certas doenças. }\end{array}$ \\
\hline Roteiro de perguntas $\mathrm{TL}$ & AÇÃO\Diálogo\O falar (23)\Onde & $\begin{array}{l}\text { Geralmente estes temas tem uma discussão mais ampla através de fóruns, } \\
\text { simpósios e congressos, entretanto as discussões ficam mais no meio acadêmico e } \\
\text { técnico, o que é importante mas não abrange um grande contingente. As } \\
\text { informações devem chegar a sociedade em geral através de palestras nas escolas e } \\
\text { nas universidades, organização de grupos de estudos sobre o tema, formação de } \\
\text { rodas de conversas mediadas por alguém que já estude o tema }\end{array}$ \\
\hline Roteiro de perguntas $\mathrm{TL}$ & AÇãO\DiálogolO falar (23)\Como (FORMA) & $\begin{array}{l}\text { Acredito que o tema deve ser abordado da mesma forma que são abordados os } \\
\text { problemas de saúde pública, as epidemias, as questões que afetam a sociedade; } \\
\text { com de forma esclarecedora, informativa, com uma linguagem simples e acessivel } \\
\text { a todas as pessoas. }\end{array}$ \\
\hline Roteiro de perguntas TL & AÇÃO|Diálogo\O falar (23)\Onde & $\begin{array}{l}\text { Devem ser promovidas palestras e oficinas para adolescentes através das escolas, } \\
\text { com o objetivo não só de falar sobre o suicídio, mas também de como lidar com os } \\
\text { sentimentos, se perceber e perceber o outro, e ainda como e onde buscar ajuda. }\end{array}$ \\
\hline Roteiro de perguntas $\mathrm{TL}$ & AÇÃO\DiálogolO falar (23)\Quem & $\begin{array}{l}\text { Acredito que deverão ser oferecidos programas de conscientização para } \\
\text { professores, pais, e cuidadores, com o fim de levar a informação sobre a prevenção } \\
\text { do suicídio e como tomar uma atitude ou como buscar ajuda. }\end{array}$ \\
\hline Roteiro de perguntas $\mathrm{TL}$ & AÇÃO\Diálogo\O falar (23)\O que (MENSAGEM) & $\begin{array}{l}\text { Devem ser passadas mensagens de que o suicídio pode ser prevenido, que o } \\
\text { suicídio na maioria das vezes está relacionado a uma doença mental, que as } \\
\text { pessoas que estão com ideação suicida devem buscar ajuda. }\end{array}$ \\
\hline Roteiro de perguntas TL & COMPREENSÃO\Comunicação\Pessoal|\Falando abertamente na sociedade & $\begin{array}{l}\text { Já foi muito difícil. Nos primeiros anos evitava falar a palavra suicídio (ou termos } \\
\text { associados como se matou, tirou a própria vida). Atualmente é um assunto que flui } \\
\text { tranquilamente, sem preconceito. Todas as vezes que tenho a oportunidade falo } \\
\text { sobre as formas de prevenção, sobre como podem ser percebidos sinais, sobre } \\
\text { como os preconceitos devem ser descontruídos. }\end{array}$ \\
\hline Roteiro de perguntas $\mathrm{TL}$ & COMPREENSÃO|Comunicação|Pessoal|Reaç̃ões & $\begin{array}{l}\text { Ah, sim. Principalmente pela falta de informação. Pela falta de humanidade e de } \\
\text { empatia de entender o sofrimento do outros. O julgamento que grande parte da } \\
\text { sociedade faz, ainda é baseado em dogmas religiosos; na questão do pecado. Por } \\
\text { outro lado, percebe-se claramente como a sociedade fica perplexa diante de um } \\
\text { suicídio e como esta mesma sociedade silencia a morte por suicídio. }\end{array}$ \\
\hline Roteiro de perguntas TL & COMPREENSÃO|Comunicação|Pessoal|Reações & $\begin{array}{l}\text { Sim, já passei por várias situaç̃es, que envolveram falta de consciência individual e } \\
\text { pública. Primeiro, a busca de um porque, é uma necessidade que angustia a } \\
\text { sociedade. Se a família, ainda em choque com o suicídio não consegue encontrar } \\
\text { um motivo, a sociedade se encarrega de encontrar um porque, e surge uma lista } \\
\text { de porquês, desde coisas mais simples até motivos absurdos. A sociedade faz um } \\
\text { julgamento. Os amigos e familiares também fazem seus julgamentos: julgamento } \\
\text { de que a família não foi presente; julgamento de que suicídio entre adolescentes } \\
\text { ocorrem em famílias desestruturadas; julgamento de que quem comete suicídio é } \\
\text { um egoísta, entre outros. }\end{array}$ \\
\hline Roteiro de perguntas $\mathrm{TL}$ & COMPREENSÃO|Comunicação|Pessoal|Falar pode machucar (a si mesmo) & $\begin{array}{l}\text { Ainda é difícil, mas necessário falar; não pelo fato da morte por suicídio, mas pela } \\
\text { questão afetiva, pela saudade, pelos planos interrompidos, pelo que ficou no meio } \\
\text { do caminho... }\end{array}$ \\
\hline
\end{tabular}




\begin{tabular}{|c|c|c|}
\hline Roteiro de perguntas TL & |COMPREENSÃO|Comunicação|Pessoal \O falar como uma causa/bandeira & $\begin{array}{l}\text { Atualmente falo com o intuito de informar, mas também procuro mostrar que não } \\
\text { tem porque ter preconceito ou vergonha. Sempre esclareço que a causa foi morte } \\
\text { por suicídio. Muitas vezes essa fala choca as pessoas e o assunto se encerra, até } \\
\text { como certo pedido de desculpas de quem escuta. Entretanto, se a pessoa ou o } \\
\text { grupo der uma abertura para continuidade do assunto, continuamos a conversa, } \\
\text { sem constrangimentos. Falar é preciso. Falar é necessário. }\end{array}$ \\
\hline Roteiro de perguntas TL & COMPREENSÃO\Experiência\O viver|Quem viveu (5)\Antes do suicídio & $\begin{array}{l}\text { Antes do suicídio, nunca se falou sobre o tema suicídio como algo que pusesse } \\
\text { fazer parte da nossa vida. O assunto morte também não se discutia em família. }\end{array}$ \\
\hline Roteiro de perguntas TL & COMPREENSÃO\Experiência\O viver|Quem viveu (5)\Depois do suicídio & $\begin{array}{l}\text { Após o fato, passamos a falar no tema morte, vida após a morte em família e } \\
\text { inevitavelmente sobre o "morrer por suicídio", mas numa visão muito particular, } \\
\text { sobre o que nos afetava, sobre como e como a sociedade julgava o suicídio. Nos } \\
\text { primeiros anos este assunto ficou muito restrito a família e amigos próximos. } \\
\text { Posteriormente, quando decidimos buscar informaç̃es, livros, vídeos, } \\
\text { documentários a respeitos do assunto, passamos a discutir o assunto de forma } \\
\text { mais aberta e consciente. Atualmente falamos sobre o tema com conhecidos e } \\
\text { desconhecidos, através de palestras, rodas de conversas, em pequenos grupos. }\end{array}$ \\
\hline Roteiro de perguntas TL & COMPREENSÃO|Comunicação|Pessoal|Se preparando para falar & $\begin{array}{l}\text { É uma discussão necessária, entretanto, deve ser conduzida com muito cuidado em } \\
\text { qualquer momento, porque depende muito dos fatores emocionais, dos conceitos } \\
\text { de cada um a respeito do tema, dos laços de afetividades estabelecidos do tempo } \\
\text { decorrido. }\end{array}$ \\
\hline Roteiro de perguntas TL & COMPREENSÃO\Experiência\O viver|Quem viveu (5)\Depois do suicídio & $\begin{array}{l}\text { Sim, significativa. Antes eu não julgava, mas também não comentava. Entretanto, } \\
\text { sempre que sabia que algum tinha morrido por suicídio tinha uma angústia em } \\
\text { imaginar como esta pessoa se sentia desamparada, desesperada ou vazia de si e do } \\
\text { mundo naquele momento. Este sentimento eu ainda carrego. Atualmente, eu } \\
\text { comento sobre o que já li e ouvi sobre o suicídio e procuro desmistificar o ato, } \\
\text { minimizar os atos de tabus e preconceitos. Atualmente procuro conscientizar sobre } \\
\text { o assunto. }\end{array}$ \\
\hline Roteiro de perguntas TL & COMPREENSÃO\Experiência\O viver\Quem viveu (5)\O que gostaria de ter tido & $\begin{array}{l}\text { O tema suicídio para que não vivenciou uma situação, é um tema que dá medo, e, } \\
\text { tudo que nos apavora, queremos distância; assim era com o tema suicídio. } \\
\text { Gostaria de ter sido mais aberto para falar sobre o assunto e saber que a pessoa } \\
\text { que está com pensamento suicida dá sinais, pede socorro de uma forma implíitia, } \\
\text { que somente quem está atento percebe. Gostaria de saber tudo que sei hoje, } \\
\text { antes. Certamente eu teria tido uma atitude diferente. Talvez eu pudesse ter } \\
\text { mudado a história... }\end{array}$ \\
\hline Roteiro de perguntas TL & COMPREENSÃO\ExperiêncialO viver|Quem viveu (5)\O que gostaria de ter tido & $\begin{array}{l}\text { Para mim, um local para falar sobre o que aconteceu, sobre como estava me } \\
\text { sentindo, ver como outras pessoas foram sobrevivendo, e, principalmente falar } \\
\text { sobre a minha filha, como ela vivia, sem julgamentos. Para a família sobrevivente } \\
\text { este lugar de fala, em uma sociedade que ainda é muito preconceituosa com a } \\
\text { pessoa que morre por suicídio e com a família, é muito importante. Para a pessoa } \\
\text { que faleceu, um lugar de fala por ela, poder falar sobre sua vida, suas memórias, } \\
\text { suas histórias, seus projetos de vida, sobre seus sonhos. }\end{array}$ \\
\hline Roteiro de perguntas TL & AÇÃO\Cuidar\Grupos de apoio (21)\O mundo dos sobreviventes\Um lugar para falar e honrar a memória & $\begin{array}{l}\text { Para mim, um local para falar sobre o que aconteceu, sobre como estava me } \\
\text { sentindo, ver como outras pessoas foram sobrevivendo, e, principalmente falar } \\
\text { sobre a minha filha, como ela vivia, sem julgamentos. Para a família sobrevivente } \\
\text { este lugar de fala, em uma sociedade que ainda é muito preconceituosa com a } \\
\text { pessoa que morre por suicídio e com a família, é muito importante. Para a pessoa } \\
\text { que faleceu, um lugar de fala por ela, poder falar sobre sua vida, suas memórias, } \\
\text { suas histórias, seus projetos de vida, sobre seus sonhos. }\end{array}$ \\
\hline
\end{tabular}




\begin{tabular}{|c|c|c|}
\hline Roteiro de perguntas TL & AÇÃO|Semear\O que gostariam / Desejos (17)\Esperança em aumentar as falas de prev do suicídio & $\begin{array}{l}\text { As sugestões são que o tema seja cada vez mais estudado e discutido, no intuído } \\
\text { de desconstruir tabus e estigma e que seja focando no esclarecimento, na } \\
\text { informação sobre as formas de prevenção e conscientização. }\end{array}$ \\
\hline Roteiro de perguntas $\mathrm{TL}$ & AÇÃOlCuidar|Sobre os encontros (25) & $\begin{array}{l}\text { Somente agradece pela oportunidade de falar sobre a temática suicídio e torcer } \\
\text { por você para que tenha uma excelente Tese de Doutorado, e que venha a ajudar } \\
\text { para desmitificar essa temática. }\end{array}$ \\
\hline Transcrição E2 revisada & COMPREENSÃO\Tabu (1)\O tabu em diversas esferas \Tabu sobre falar de sentimentos & $\begin{array}{l}\text { Então assim, é, a maneira de evitar esse impacto, né, nós estamos falando de um } \\
\text { tema que na nossa cultura é tabu, seria assim, falar sobre a emoção da tristeza e } \\
\text { da importância de você poder conversar com o seu amigo, com a sua família } \\
\text { quando você está triste. }\end{array}$ \\
\hline $\begin{array}{l}\text { Transcrição E1 } \\
\text { revisada_para maxqda }\end{array}$ & AÇÃO\Fazer|Outros tipos de trabalho (24) & $\begin{array}{l}\text { quando a gente vai dar palestra de prevenção, de informação em escola infantil. } \\
\text { "Mas como vocês vai fazer prevenção de suicídio em escola infantil?" A gente } \\
\text { ensina as crianças a nomearem os sentimentos, a gente trabalha aqueles } \\
\text { bonequinhos do filme "Divertidamente" pra que a criança saiba nomear o que está } \\
\text { sentindo: "Ah, olha, hoje eu estou triste ok?" Tudo bem, é normal ficar triste de vez } \\
\text { em quando né, mas hoje as pessoas não sabem nomear o que elas sentem, elas } \\
\text { não conseguem dar nome, elas não conseguem explicar, mas não conseguem } \\
\text { pessoas que também as escutem, em sua grande maioria. As pessoas estão muito } \\
\text { ocupadas, né. Elas não tem tempo pra ouvir... }\end{array}$ \\
\hline \begin{tabular}{|l|} 
Roteiro de \\
perguntas_eduardo_maxqd \\
a
\end{tabular} & COMPREENSÃO\Tabu (1)\Atitudes que reforçam o tabu\Educação emocional pobre & \begin{tabular}{|l} 
E não de que para vivenciarmos plenamente as emoções como alegria, é \\
necessário também estar aberto para sentir a tristeza. Que não é possivel \\
anestesiar apenas uma das emoções sem se anestesiar para as outras.
\end{tabular} \\
\hline \begin{tabular}{|l|} 
Transcrição E1 \\
revisada_para maxqda
\end{tabular} & COMPREENSÃO\Tabu (1)\O tabu em diversas esferas\Tabu Escolar & Acho que isso é mais uma questão do tabu em si... é o tabu mesmo... \\
\hline Transcrição E2 revisada & COMPREENSÃO|Visão|Causa Mortis (9)\Curiosidade mórbida & $\begin{array}{l}\text { É! A curiosidade é tanta de saber, e não é de saber o que a pessoa estava sentindo, } \\
\text { ou tipo, nossa, como eu posso... eu nunca, nunca ninguém me perguntou assim: } \\
\text { Como eu posso te ajudar? Você está pensando nisso? Nunca ninguém me } \\
\text { perguntou de amigos ou familiares. O que você está sentindo com isso? Eu posso } \\
\text { te ajudar de que maneira? Isso eu senti. Nunca ninguém me abordou assim. A } \\
\text { abordagem era: Bom, mas como foi? Mas, como era? Como estava? É horrivel, } \\
\text { assim. O caixão foi aberto ou fechado? Sabe, assim, aquilo... }\end{array}$ \\
\hline \begin{tabular}{|l|} 
Transcrição E1 \\
revisada_para maxqda
\end{tabular} & COMPREENSÃO|Comunicação|Social|Canais virtuais|A fantasia das redes sociais & $\begin{array}{l}\text { eu fui demitida em janeiro e uma das coisas que usaram foram as minhas fotos, } \\
\text { depois da morte do meu sobrinho. Só que eu conversei com o meu chefe e ele me } \\
\text { autorizou a ficar em casa e aí ele depois se juntou lá e me mandou embora. Eu } \\
\text { achei uma covardia, uma coisa assim, que você acha que pode contar com as } \\
\text { pessoas mas você não pode. Você acha que estão te apoiando, quando na verdade } \\
\text { estão criando, às vezes, alguma coisa pra usar contra você. Então isso pra mim foi } \\
\text { terrível... foi... eu achei muito cruel, entendeu? Podiam me mandar embora por } \\
\text { qualquer outro motivo, mas por aquelas fotos...eu pedi férias e não me deu. Ele } \\
\text { me mandou ficar em casa né, então... mas isso não é fato... }\end{array}$ \\
\hline
\end{tabular}




\begin{tabular}{|c|c|c|}
\hline \begin{tabular}{|l} 
Transcrição E1 \\
revisada_para maxqda
\end{tabular} & COMPREENSÃO|Comunicação|Social|Canais virtuais\A fantasia das redes sociais & $\begin{array}{l}\text { uma obrigação hoje em dia, por conta das redes sociais também isso que a P10 } \\
\text { estava falando. Que todo mundo só compartilha momentos bons, comida boa, } \\
\text { lugar bom... ninguém compartilha, né P10, a visão do metrô lotado, então eu acho } \\
\text { que quem não tem, principalmente os jovens né, eles se sentem muito cobrados, e } \\
\text { muito... "poxa, mas todo mundo é feliz menos eu?", "poxa, mas fulano est } \\
\text { viajando, o outro tá rico...o outro...E ninguém tá, a grande verdade, quando você } \\
\text { pegar essas pessoas, é que ninguém tá. Ninguém leva a vida que compartilha ali, } \\
\text { são pouquíssimas pessoas que realmente têm uma vida maravilhosa todos os dias, } \\
\text { aliás acho que né, não sei quantas, mas não conheço né, não conheço, então tem } \\
\text { isso também de, você não pode falar que tá triste, você não pode falar que não tá } \\
\text { legal, né, então, se você chorou você é fraco, e se você não está be }\end{array}$ \\
\hline Roteiro de perguntas $\mathrm{TL}$ & CONSCIENTIZAÇÃOIConsciência|Aumento da Consciência (19) & $\begin{array}{l}\text { R. Ah, sim. Principalmente pela falta de informação. Pela falta de humanidade e de } \\
\text { empatia de entender o sofrimento do outros. O julgamento que grande parte da } \\
\text { sociedade faz, ainda é baseado em dogmas religiosos; na questão do pecado. Por } \\
\text { outro lado, percebe-se claramente como a sociedade fica perplexa diante de um } \\
\text { suicídio e como esta mesma sociedade silencia a morte por suicídio. } \\
\text { - Você já passou por alguma situação que envolvesse a falta ou não de consciência } \\
\text { pública e individual em relação ao suicídio? } \\
\text { R. Sim, já passei por várias situações, que envolveram falta de consciência } \\
\text { individual e pública. Primeiro, a busca de um porque, é uma necessidade que } \\
\text { angustia a sociedade. Se a família, ainda em choque com o suicídio não consegue } \\
\text { encontrar um motivo, a sociedade se encarrega de encontrar um porque, e surge } \\
\text { uma lista de porquês, desde coisas mais simples até motivos absurdos. A sociedade } \\
\text { faz um julgamento. Os amigos e familiares também fazem seus julgamentos: } \\
\text { julgamento de que a família não foi presente; julgamento de que suicídio entre } \\
\text { adolescentes ocorrem em famílias desestruturadas; julgamento de que quem } \\
\text { comete suicídio é um egoísta, entre outros. }\end{array}$ \\
\hline $\begin{array}{l}\text { z Roteiro de } \\
\text { perguntas_eduardo_maxqd } \\
\text { a }\end{array}$ & CONSCIENTIZAÇÃOIConsciência & $\begin{array}{l}\text { Lembro de uma campanha de tevê muito antiga do CVV, aonde um homem pede } \\
\text { dinheiro na rua, e ao receber uma moeda entra num bar. Tudo dá a entender que } \\
\text { ele vai comprar bebida alcoólica. Mas ele compra uma ficha e vai a um telefone } \\
\text { publico dentro do bar e efetua uma ligação. Do outro lado da linha uma voz diz: } \\
\text { "CVV boa noite", e eles começam a conversar. Esta campanha antiga, me marcou a } \\
\text { respeito da imagem do CVV e que seria um lugar aonde se pode conversar. Acho } \\
\text { uma campanha extremamente positiva e que nos aproxima. A ideia de que ao } \\
\text { passar uma situação difíili, o CVV é um lugar aonde se pode conversar e ser } \\
\text { ouvido. Acho que a campanha vai exatamente no ponto que é necessário a } \\
\text { respeito do assunto. Abordando de forma prática um canal para o diálogo e a } \\
\text { empatia, e que estaria disponivel para todos. Hoje questiono a abordagem do } \\
\text { impacto dos números do suicídio, e falar de forma chocante sobre a morte para } \\
\text { todos os grupos. Para o público em geral no Brasil, que tem um grande preconceito } \\
\text { com o tabu e o preconceito com a morte, acho que pode reforçar uma postura de } \\
\text { fechamento e retração. }\end{array}$ \\
\hline
\end{tabular}




\begin{tabular}{|c|c|c|}
\hline $\begin{array}{l}\text { z Roteiro de } \\
\text { perguntas_eduardo_maxqd } \\
\text { a }\end{array}$ & AÇÃO\Cuidar\CVV & $\begin{array}{l}\text { Lembro de uma campanha de tevê muito antiga do CVV, aonde um homem pede } \\
\text { dinheiro na rua, e ao receber uma moeda entra num bar. Tudo dá a entender que } \\
\text { ele vai comprar bebida alcoólica. Mas ele compra uma ficha e vai a um telefone } \\
\text { publico dentro do bar e efetua uma ligação. Do outro lado da linha uma voz diz: } \\
\text { "CVV boa noite", e eles começam a conversar. Esta campanha antiga, me marcou a } \\
\text { respeito da imagem do CVV e que seria um lugar aonde se pode conversar. Acho } \\
\text { uma campanha extremamente positiva e que nos aproxima. A ideia de que ao } \\
\text { passar uma situação difíiil, o CVV é um lugar aonde se pode conversar e ser } \\
\text { ouvido. Acho que a campanha vai exatamente no ponto que é necessário a } \\
\text { respeito do assunto. Abordando de forma prática um canal para o diálogo e a } \\
\text { empatia, e que estaria disponível para todos. Hoje questiono a abordagem do } \\
\text { impacto dos números do suicídio, e falar de forma chocante sobre a morte para } \\
\text { todos os grupos. Para o público em geral no Brasil, que tem um grande preconceito } \\
\text { com o tabu e o preconceito com a morte, acho que pode reforçar uma postura de } \\
\text { fechamento e retração. }\end{array}$ \\
\hline
\end{tabular}

Material integrante da pesquisa de doutorado de Karen Scavacini

Proibida a reprodução ou utilização sem autorização do autor 2018 


\section{Anexo Q - Colaboradores}

\begin{tabular}{|c|c|c|c|c|c|c|c|c|}
\hline Nome & Idade & Sexo & Estado civil & Estado de SP & Quem perdeu & Há quanto tempo & Idade da pessoa na época & Idade do colaborador na época \\
\hline P1 & 59 & M & Casado & Não & Filha & 8 anos e 10 meses & 13 & 54 \\
\hline P2 & 51 & F & casada & Sim & Filho & 2 anos e 4 meses & 24 & 49 \\
\hline P3 & 73 & F & viúva & Sim & marido & 3 anos & 71 & 70 \\
\hline P4 & 48 & F & Casado & Sim & Filho & 4 anos e 6 meses & 22 & 44 \\
\hline P5 & 59 & M & Casado & Sim & Filho & 4 anos & 22 & 55 \\
\hline P6 & 39 & F & Casado & Sim & Paciente & 1 ano e 3 meses & 63 & 38 \\
\hline P7 & 58 & M & Divorciado & Sim & Filha & 3 anos e 1 mês & 18 & 55 \\
\hline P8 & 40 & F & solteira & Sim & Irmão & 2 anos e 2 meses & 40 & 38 \\
\hline P9 & 51 & M & Solteiro & Sim & Amigo & 36 anos & 15 & 15 \\
\hline P10 & 28 & F & Solteiro & Sim & Irmão & 1 ano e 9 meses & 21 & 16 \\
\hline P11 & 35 & F & Solteiro & Sim & Sobrinho & 7 meses & 16 & 34 \\
\hline
\end{tabular}

Material integrante da pesquisa de doutorado de Karen Scavacini - USP

Proibida a reprodução ou utilização sem autorização do autor - 2018 


\begin{tabular}{|c|c|c|c|c|c|c|c|}
\hline Há quanto tempo participa de grupos de apoio & Tratam psicológico & Quanto tempo & Decorrente da perda & Tratamento psiquiátrico & Quanto tempo & Decorrente da perda & Total terapia \\
\hline 1 ano & não & & & não & & & \\
\hline 2 anos & $\operatorname{sim}$ & 2 anos & $\operatorname{sim}$ & não & & & \\
\hline 10 meses & $\operatorname{sim}$ & 2 anos & $\operatorname{sim}$ & não & & & \\
\hline 2 anos e 6 meses & $\operatorname{sim}(\mathrm{fez})$ & 2 anos & $\operatorname{sim}$ & não & & & \\
\hline 3 anos & não & & & não & & & \\
\hline 1 ano & não & & & não & & & \\
\hline 3 anos & $\operatorname{sim}$ & alguns meses & $\operatorname{sim}$ & não & & & \\
\hline 4 meses & $\operatorname{sim}$ & 10 meses & $\operatorname{sim}$ & $\operatorname{sim}$ & 16 anos & não & 10 anos \\
\hline 3 anos & $\operatorname{sim}$ & 15 anos & não & $\operatorname{sim}$ & 1 ano & $\operatorname{sim}$ & \\
\hline 1 ano e 6 meses & $\mathrm{Sim}$ & anos & $\operatorname{sim}$ & não & & & \\
\hline 5 meses & agora não & & não & agora não & & não & \\
\hline
\end{tabular}

Material integrante da pesquisa de doutorado de Karen Scavacini - SP

Proibida a reprodução ou utilização sem autorização do autor 2018 - SP 


\section{USP- INSTITUTO DE \\ PSICOLOGIA DA \\ UNIVERSIDADE DE SÃO}

\section{PARECER CONSUBSTANCIADO DO CEP}

\section{DADOS DO PROJETO DE PESQUISA}

Título da Pesquisa: Comunicação sobre suicídio. Prevenção e posvenção do suicídio no Brasil

Pesquisador: Karen Scavacini

Área Temática:

Versão: 2

CAAE: 54657616.3 .0000 .5561

Instituição Proponente: UNIVERSIDADE DE SAO PAULO

Patrocinador Principal: UNIVERSIDADE DE SAO PAULO

\section{DADOS DO PARECER}

Número do Parecer: 2.065.567

\section{Apresentação do Projeto:}

O presente projeto de pesquisa busca compreender como a consciência pública sobre o suicídio pode ser desenvolvida no Brasil; através de um estudo qualitativo, exploratório, descritivo e explicativo, a partir da análise documental e coleta de dados por meio de entrevistas e observação, sendo que os participantes serão especialistas da área, estudantes e profissionais das áreas da saúde e publicidade, leigos e pessoas que tentaram o suicídio há algum tempo e sobreviventes enlutados que tenham disponibilidade para compartilhar sua experiência; apresenta o TCLE; mostra-se relevante dentro do campo da Psicologia; e toma os cuidados éticos necessários.

\section{Objetivo da Pesquisa:}

O objetivo da pesquisa é relevante e claramente explicitado e busca compreender como a consciência pública sobre o suicídio pode ser desenvolvida no Brasil, ou seja, de que forma é possível falar sobre o suicídio e aumentar a consciência pública do tema no Brasil, de modo a colaborar com a prevenção e a posvenção do suicídio.

\section{Avaliação dos Riscos e Benefícios:}

O projeto de pesquisa apresenta claramente descrito os benefícios e os riscos inerente à pesquisa trará mais benefícios do que riscos, principalmente ajudar na compreensão de como aumentar a consciência pública em relação ao suicídio e suas influências na sua prevenção e posvenção. Caso algum desconforto seja gerado ao/à participante por despertar lembranças que possam causar

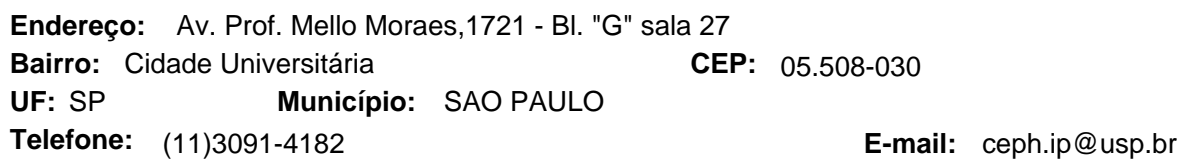




\section{USP- INSTITUTO DE \\ PSICOLOGIA DA \\ UNIVERSIDADE DE SÃO}

Patoserome

Continuação do Parecer: 2.065.567

sofrimento, ele/a será acolhido/a pela pesquisadora e referido à serviço de suporte psicológico, se necessário, principalmente nos casos de pessoas que tenham tentado cometer suicídio. Além disso, o/a participante poderá não responder a perguntas que não queira.

Com relação aos cuidados éticos apontados em parecer anterior, a pesquisadora relata: "houve uma alteração nos participantes da pesquisa. Serão incluídas somente pessoas enlutadas pelo suicídio que tenham participado ou participem de grupos de apoio aos enlutados pelo suicídio. Ao escolher participantes de grupo de apoio, há a suposição que são pessoas que já conseguem falar sobre o suicídio em situação de grupo e já tenham sido acolhidas após a perda de seu familiar por suicídio".

\section{Comentários e Considerações sobre a Pesquisa:}

O presente projeto de pesquisa apresenta referencial teórico pertinente, metodologia qualitativa adequada, indica o processo de recrutamento e os critérios de inclusão dos participantes, apresenta o TCLE e se mostra relevante dentro do campo da Psicologia. Foram feitas as alterações sugeridas em parecer anterior, conforme mencionado.

\section{Considerações sobre os Termos de apresentação obrigatória:}

O TCLE deixa claro os objetivos e procedimentos que serão adotados; oferece um contato do pesquisador e do Comitê de Ética para eventuais dúvidas e esclarecimentos adicionais e o pesquisador; deixa claro que haverá anonimato e a garantia do sigilo dos participantes quando da divulgação dos dados; e que os participantes poderão pedir os esclarecimentos que desejarem e/ou deixar a pesquisa a qualquer momento, retirando seu consentimento, sem quaisquer consequências, penalizações ou prejuízos; indica que as entrevistas serão gravadas e onde ficarão armazenadas as gravações.

\section{Recomendações:}

Sem recomendações.

\section{Conclusões ou Pendências e Lista de Inadequações:}

Sem pendências ou inadequações.

\section{Considerações Finais a critério do CEP:}

Se o projeto prevê aplicação de TCLE, todas as páginas do documento deverão ser rubricadas pelo pesquisador e pelo voluntário e a última página assinada por ambos, conforme Carta Circular no 003/2011 da CONEP/CNS.

Salientamos que o pesquisador deve desenvolver a pesquisa conforme delineada no protocolo aprovado.

Endereço: Av. Prof. Mello Moraes,1721 - BI. "G" sala 27

Bairro: Cidade Universitária

CEP: $05.508-030$

UF: SP Município: SAO PAULO

Telefone: (11)3091-4182

E-mail: ceph.ip@usp.br 


\section{USP- INSTITUTO DE \\ PSICOLOGIA DA \\ UNIVERSIDADE DE SÃO}

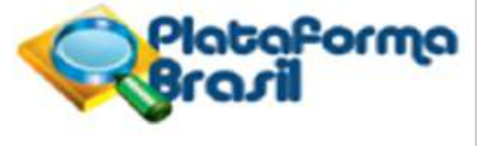

Continuação do Parecer: 2.065.567

Eventuais modificações ou emendas ao protocolo devem ser apresentadas ao CEPH de forma clara e sucinta, identificando a parte do protocolo a ser modificada e suas justificativas. Lembramos que esta modificação necessitará de aprovação ética do CEPH antes de ser implementada. De acordo com a Res. CNS 466/12, o pesquisador deve apresentar a este CEP/SMS o relatório final do projeto desenvolvido, conforme preenchimento de Protocolo disponível na página do Comitê de Ética em Pesquisa com Seres Humanos do IPUSP, do site do IPUSP. Em seguida, o protocolo preenchido deverá ser enviado ao $\mathrm{CEPH}$ pela Plataforma Brasil, ícone Notificação, logo que o mesmo estiver concluído.

Este parecer foi elaborado baseado nos documentos abaixo relacionados:

\begin{tabular}{|c|c|c|c|c|}
\hline Tipo Documento & Arquivo & Postagem & Autor & Situação \\
\hline $\begin{array}{l}\text { Informações Básicas } \\
\text { do Projeto }\end{array}$ & $\begin{array}{l}\text { PB_INFORMAÇÕES_BÁSICAS_DO_P } \\
\text { ROJETO 608430.pdf }\end{array}$ & $\begin{array}{c}04 / 05 / 2017 \\
22: 26: 23\end{array}$ & & Aceito \\
\hline Outros & Autorizacao_Vita_Alere.pdf & $\begin{array}{c}04 / 05 / 2017 \\
22: 25: 58\end{array}$ & Karen Scavacini & Aceito \\
\hline $\begin{array}{l}\text { Recurso Anexado } \\
\text { pelo Pesquisador }\end{array}$ & Carta_CEPH4.docx & $\begin{array}{c}04 / 05 / 2017 \\
22: 20: 57\end{array}$ & Karen Scavacini & Aceito \\
\hline $\begin{array}{l}\text { TCLE / Termos de } \\
\text { Assentimento / } \\
\text { Justificativa de } \\
\text { Ausência }\end{array}$ & $\begin{array}{l}\text { Termo_de_consentimento_revisado2.do } \\
\text { c }\end{array}$ & $\begin{array}{c}04 / 05 / 2017 \\
22: 20: 40\end{array}$ & Karen Scavacini & Aceito \\
\hline $\begin{array}{l}\text { Projeto Detalhado / } \\
\text { Brochura } \\
\text { Investigador }\end{array}$ & Projeto_detalhado_revisado_3.docx & $\begin{array}{c}04 / 05 / 2017 \\
22: 20: 06\end{array}$ & Karen Scavacini & Aceito \\
\hline $\begin{array}{l}\text { Declaração de } \\
\text { Pesquisadores }\end{array}$ & Compromisso_do_pesquisador.docx & $\begin{array}{c}24 / 03 / 2016 \\
17: 02: 19\end{array}$ & Karen Scavacini & Aceito \\
\hline $\begin{array}{l}\text { Declaração de } \\
\text { Instituição e } \\
\text { Infraestrutura }\end{array}$ & Termo_infraestrutura.pdf & $\begin{array}{c}24 / 03 / 2016 \\
16: 56: 12\end{array}$ & Karen Scavacini & Aceito \\
\hline Folha de Rosto & Folha_de_rosto_p1.pdf & $\begin{array}{c}24 / 03 / 2016 \\
16: 54: 59\end{array}$ & Karen Scavacini & Aceito \\
\hline
\end{tabular}

Situação do Parecer:

Aprovado

Necessita Apreciação da CONEP:

Não

Endereço: Av. Prof. Mello Moraes,1721 - BI. "G" sala 27

Bairro: Cidade Universitária

CEP: $05.508-030$

UF: SP

Município: SAO PAULO

Telefone: (11)3091-4182

E-mail: ceph.ip@usp.br 


\section{USP- INSTITUTO DE \\ PSICOLOGIA DA \\ UNIVERSIDADE DE SÃO}

Continuação do Parecer: 2.065.567

SAO PAULO, 16 de Maio de 2017

\section{Assinado por: \\ Helena Rinaldi Rosa}

(Coordenador)

Endereço: Av. Prof. Mello Moraes,1721 - Bl. "G" sala 27

Bairro: Cidade Universitária

CEP: $05.508-030$

UF: SP

Município: SAO PAULO

Telefone: (11)3091-4182

E-mail: ceph.ip@usp.br 